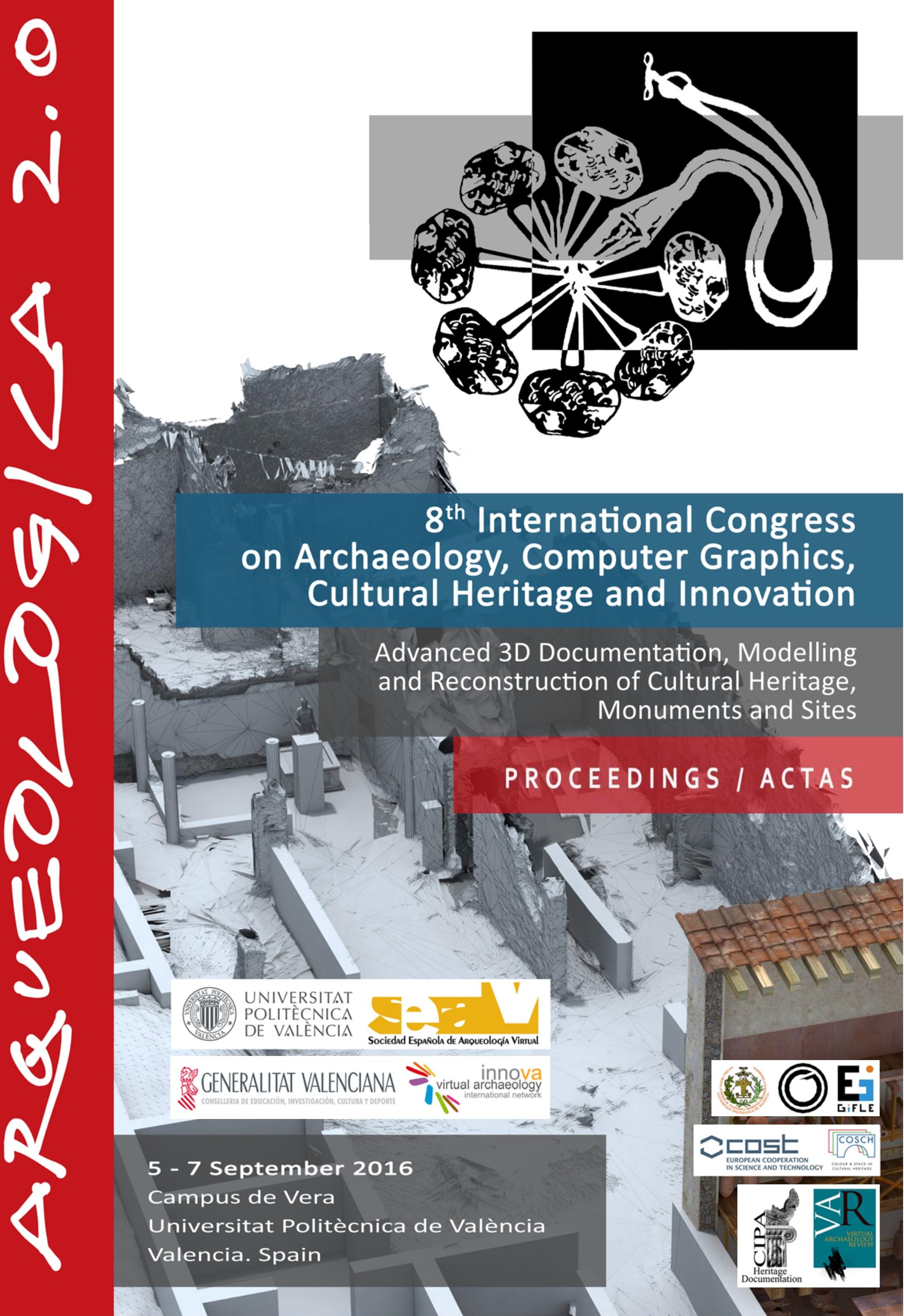




\section{Congress UPV}

Proceedings of the ARQUEOLÓGICA 2.0 - 8th International Congress on Archaeology, Computer Graphics, Cultural Heritage and Innovation

Lemma: Advanced 3D documentation, modelling and reconstruction of cultural heritage objects, monuments and sites.

ARQUEOLÓGICA 2.0 - $8^{\circ}$ Congreso Internacional de Arqueología e Informática Gráfica, Patrimonio e Innovación Lema: Documentación 3D avanzada, modelado y reconstrucción de objetos patrimoniales, monumentos y sitios.

The contents of this publication have been evaluated by the Scientific Committee which it relates and the procedure set out http://ocs.editorial.upv.es/index.php/arqueologica20/arqueologica8/about/organizingTeam

\section{Scientific Editors}

\section{J. L. Lerma}

M. Cabrelles

(C) of the texts: authors

(C) 2016, Editorial Universitat Politècnica de València www.lalibreria.upv.es / Ref.: 6283_01_01_01

ISBN: 978-84-9048-455-5 (print version)

Print on-demand

DOI: http://dx.doi.org/10.4995/arqueologica8.2016.4479

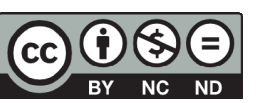

Proceedings of the ARQUEOLÓGICA 2.0 - 8th International Congress on Archaeology, Computer Graphics, Cultural Heritage and Innovation.

This book is licensed under a Creative Commons Atribution-NonCommercial-NonDetivates-4.0 International license Editorial Universitat Politècnica de València http://ocs.editorial.upv.es/index.php/arqueologica20/arqueologica8 


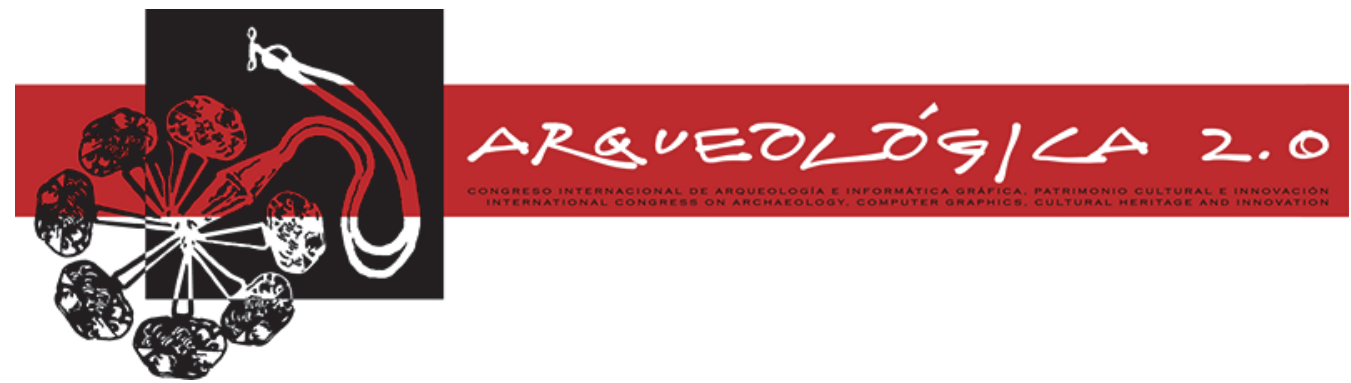

Proceedings of the 8th International Congress on Archaeology, Computer Graphics, Cultural Heritage and Innovation 'ARQUEOLÓGICA 2.0 in Valencia (Spain), Sept. 5-7, 2016

\section{Conference Committee}

\section{Congress director:}

$\checkmark$ José Luis Lerma

\section{Organising Committee:}

$\checkmark$ Ana Belén Anquela

$\checkmark$ Matilde Balaguer

$\checkmark$ Miriam Cabrelles

$\checkmark$ Lourdes García-Cerezuela

$\checkmark$ Alfredo Grande

$\checkmark$ Ángeles Hernández-Barahona

$\checkmark \quad$ José Luis Lerma

$\checkmark \quad$ Víctor Manuel López-Menchero

$\checkmark$ Ángel Marqués-Mateu

$\checkmark$ Jorge Padín

$\checkmark$ Matthew Vincent

\section{Scientific committee:}

\begin{tabular}{|c|c|c|c|c|}
\hline$\checkmark$ & Ester Alba & Spain & $\checkmark$ & Thomas E. Levy \\
\hline$\checkmark$ & Ana Almagro & Spain & $\checkmark$ & Minna Lonnqvist \\
\hline$\checkmark$ & Arivaldo Leao de Amorim & Brazil & $\checkmark$ & Víctor Manuel López-Menchero \\
\hline$\checkmark$ & Matilde Balaguer & Spain & $\checkmark$ & Ángel Marqués-Mateu \\
\hline$\checkmark$ & Juan Antonio Barceló & Spain & $\checkmark$ & Jorge Onrubia \\
\hline$\checkmark$ & Frank Boochs & Germany & $\checkmark$ & Petros Patias \\
\hline$\checkmark$ & Miriam Cabrelles & Spain & $\checkmark$ & Robert Sablatnig \\
\hline$\checkmark$ & José Juan De Sanjosé & Spain & $\checkmark$ & Mario Santana \\
\hline$\checkmark$ & Michael Doneus & Austria & $\checkmark$ & Sebastián Ramallo \\
\hline$\checkmark$ & Rand Eppich & USA & $\checkmark$ & José Ignacio Rojas-Sola \\
\hline$\checkmark$ & Mercedes Farjas & Spain & $\checkmark$ & Efstratios Stylianidis \\
\hline$\checkmark$ & Andreas Georgopoulos & Greece & $\checkmark$ & Jin Shang \\
\hline$\checkmark$ & Diego González-Aguilera & Spain & $\checkmark$ & Clifford Leslie Ogleby \\
\hline$\checkmark$ & Alfredo Grande & Spain & $\checkmark$ & Daniel Pletinckx \\
\hline 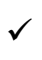 & Pierre Grussenmeyer & France & $\checkmark$ & Fulvio Rinaudo \\
\hline 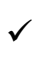 & Marinos loannides & Cyprus & $\checkmark$ & Fabio Remondino \\
\hline$\checkmark$ & José Luis Jiménez & Spain & $\checkmark$ & Pablo Rodriguez-Navarro \\
\hline$\checkmark$ & Klaus Hanke & Austria & $\checkmark$ & Grazia Tucci \\
\hline$\checkmark$ & Raphaële Heno & France & $\checkmark$ & Geert Verhoeven \\
\hline$\checkmark$ & Luis Hernández & Spain & $\checkmark$ & Matthew Vincent \\
\hline & David Hernández-López & Spain & $\checkmark$ & Alex Yen \\
\hline 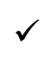 & José Luis Lerma & Spain & & \\
\hline
\end{tabular}

USA

Finland

Spain

Spain

Spain

Greece

Austria

Canada

Spain

Spain

Greece

China

Australia

Belgium

Italy

Italy

Spain

Italy

Austria

USA

China 


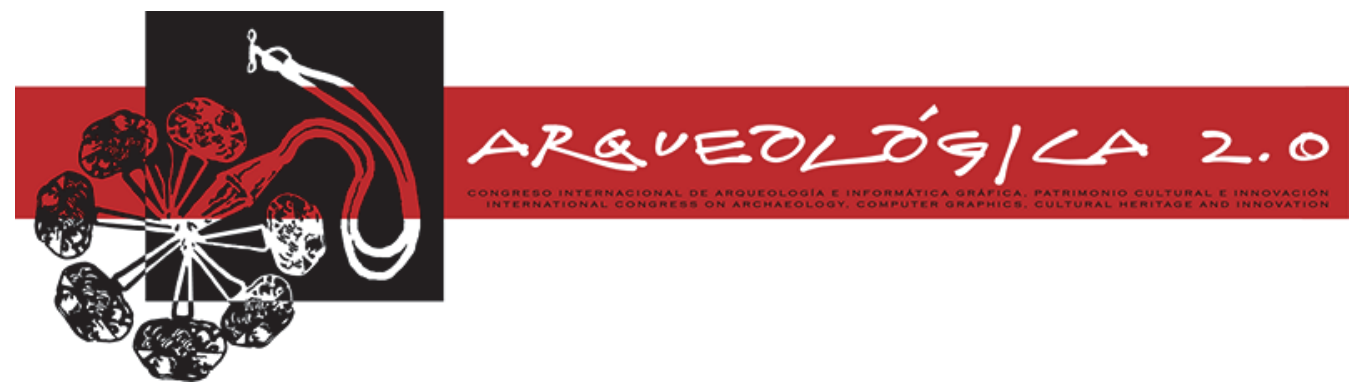

Proceedings of the 8th International Congress on Archaeology, Computer Graphics, Cultural Heritage and Innovation 'ARQUEOLÓGICA 2.0' in Valencia (Spain), Sept. 5-7, 2016

\section{Supporters:}

$\checkmark$ Universitat Politècnica de València

$\checkmark$ Spanish Society of Virtual Archaeology (SEAV)

$\checkmark$ Conselleria d'Educació, Investigació, Cultura i Esport de la Generalitat Valenciana (AORG/2016/062)

\section{Collaborators:}

$\checkmark$ CIPA Heritage Documentation

$\checkmark$ Virtual Archaeology International Network (INNOVA)

$\checkmark$ Virtual Archaeology Review (VAR)

$\checkmark$ School of Engineering in Geodesy, Cartography and Surveying

$\checkmark$ Dept. of Cartographic Engineering, Geodesy and Photogrammetry

$\checkmark \quad$ Photogrammetry \& Laser Scanning Research Group (GIFLE)

$\checkmark$ COST European Cooperation in Science and Technology

$\checkmark \mathrm{COSCH}$ Colour and Space In Cultural Heritage 


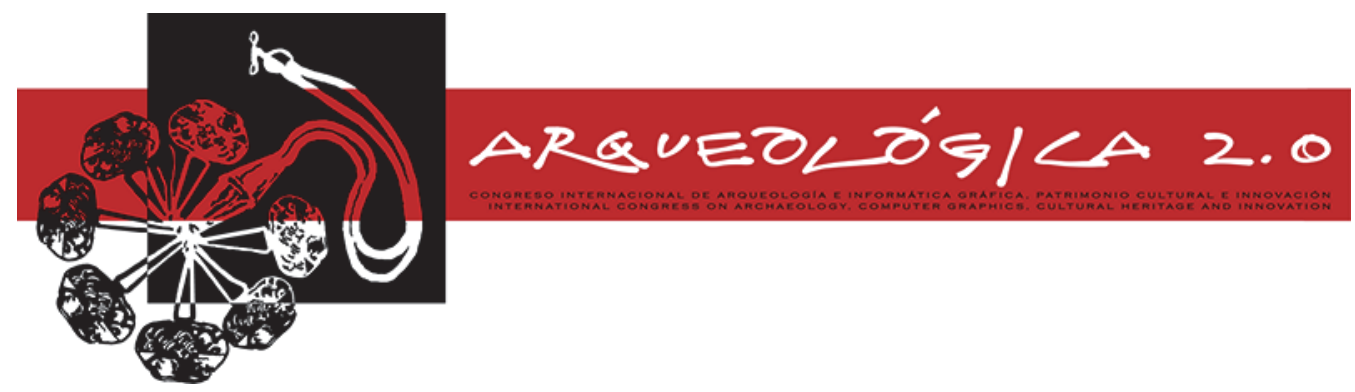

Proceedings of the 8 th International Congress on Archaeology, Computer Graphics, Cultural Heritage and Innovation 'ARQUEOLÓGICA 2.0' in Valencia (Spain), Sept. 5-7, 2016

\section{Preface}

This book comprises the proceedings of ARQUEOLÓGICA 2.0 - 8th International Congress on Archaeology, Computer Graphics, Cultural Heritage and Innovation at the Universitat Politècnica de València (UPV), Valencia, Spain, on 5-7 September, 2016. ARQUEOLÓGICA 2.0 discusses both the present and future of documentation, reconstruction and computer aided rendering techniques, applied to the field of Cultural Heritage. ARQUEOLÓGICA 2.0 - 8th invited authors to submit original and unpublished work in applied and innovative digital heritage areas such as documentation of cultural heritage, high-end digitisation and 3D modelling of objects, monuments and sites, virtual conservation/restoration, virtual archaeology, virtual museums, virtual exhibitions, cultural heritage gaming, collaborative environments and internet technologies and social media in archaeology. The main aim was to offer an updated overview about the Heritage of the 21st century applying new and innovative techniques and methodologies. The lemma of the present edition was: Advanced 3D documentation, modelling and reconstruction of cultural heritage objects, monuments and sites. The Scientific Committee carried out a great peer-reviewing task selecting the papers that are presented in the form of long scientific papers and works in progress (short papers). The former constitute the first part of the book; the latter the second part. Some selected contributions from both the long and the short scientific papers are in the process of being published in the Virtual Archaeology Review (VAR).

ARQUEOLÓGICA 2.0 - 8th International Congress was organised by the Spanish Society of Virtual Archaeology (SEAV), the Virtual Archaeology International Network (INNOVA), and the Universitat Politècnica de València (School of Engineering in Geodesy, Cartography and Surveying, ETSIGCT; Dept. of Cartographic Engineering, Geodesy and Photogrammetry, DICGF; Photogrammetry \& Laser Scanning Research Group, GIFLE) in cooperation with CIPA Heritage Documentation, European Cooperation in Science and Technology (COST) and COST-Action TD 1201: Colour and Space in Cultural Heritage $(\mathrm{COSCH})$.

Let me thank, on behalf of the Organising Committee, to all the contributors, collaborators (namely the Scientific Committee and anonymous reviewers) and sponsors/media partners. The sponsorship of the Conselleria d'Educació, Investigació, Cultura i Esport, Generalitat Valenciana, to the grant AORG/2016/062 is highly appreciated.

Prof. José Luis Lerma

Congress Director

ARQUEOLÓGICA 2.0 - 8th International Congress 


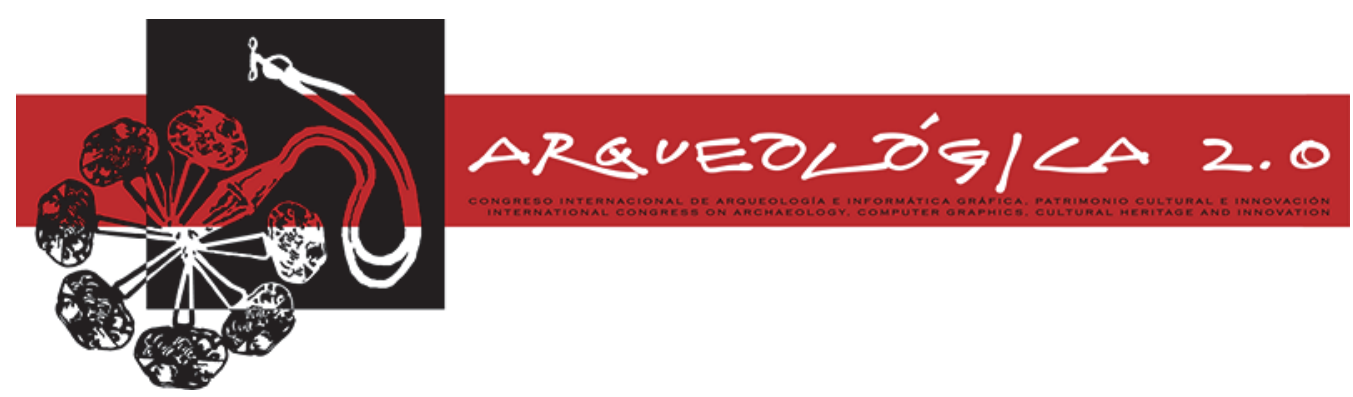

Proceedings of the 8 th International Congress on Archaeology, Computer Graphics, Cultural Heritage and Innovation 'ARQUEOLÓGICA 2.0' in Valencia (Spain), Sept. 5-7, 2016

\section{Contents}

\section{Long scientific papers}

COMPARISON OF 3D REALITY CAPTURE TECHNOLOGIES FOR THE SURVEY OF STONE WALLS.

E. Valero, A. Forster, F. Bosché, L. Wilson, A. Leslie

RECUPERACIÓN GRÁFICA DE LA MÁQUINA EÓLICA PARA DESAGUAR TERRENOS PANTANOSOS DE

AGUSTÍN DE BETANCOURT Y MOLINA: MODELADO TRIDIMENSIONAL Y DOCUMENTACIÓN

GEOMÉTRICA CON SOLID EDGE.

J.I. Rojas-Sola, L. García-Ruesgas, J. Porras-Galán

APLICACIÓN DE TÉCNICAS DE INGENIERÍA INVERSA PARA LADOCUMENTACIÓN GRÁFICA Y

GEOMÉTRICA DEL PATRIMONIO EN UNPROYECTO DE REALIDAD AUMENTADA: UN

PRODUCTOMUSEOGRÁFICO PARA LA CATEDRAL DE LA SEO DE ZARAGOZA

J. Monzón

DIGITAL RECONSTRUCTIONS - A METHODOLOGY FOR THE STUDY, PRESERVATION AND DISSEMINATION

OF ARCHITECTURALHERITAGE

A. Gil

DOCUMENTACIÓN Y ANÁLISIS DE PIEZAS ARQUEOLÓGICAS DEL MUSEO DE BURRIANA MEDIANTE EL

USO DE RX DIGITAL

J.A. Madrid, J.M. Melchor

DOCUMENTACION DIGITAL APLICADA A LA VILLA ROMANA DE SANT GREGORI (BURRIANA, ESPAÑA). 64

J.M. Melchor, J. Benedito, J.J. Ferrer, J. Ricart, R. Ayora

3D DIGITAL TECHNOLOGIES TO RECORD EXCAVATION DATA: THE CASE OF THE CATACOMBS OF ST.

LUCY (SIRACUSA, SICILY)

I. Gradante, M. Sgarlata, D. Tanasi

LA VIRTUALIZACIÓN EN EL MUSEO ARQUEOLÓGICO DE BURRIANA (CASTELLÓN - ESPAÑA) 78

J.M. Melchor, J. Martínez, C. Bonafe, A. Cabrera

DIGITAL DOCUMENTATION OF INDUSTRIAL HERITAGE AT RISK: THE CASE OF PALATAKI AND THE OLD MINING COMPLEX AT LIMENARIA OF THASSOS (GREECE)

N. Lianos, A. Stamnas

A RECORDING AND DOCUMENTATION SYSTEM OF BUILDING STOCK: THE CASE OF PENTALOFOS

SETTLEMENT IN KOZANI (GREECE)

N. Lianos, A. Stamnas

PHOTOGRAMMETRIC SURVEY AND 3D MODELING OF THE FUNERARY URN DEPICTING THE MYTH OF OENOMAUS, FOUND INSIDE THE TOMB OF THE ETRUSCAN FAMILY OF CACNI IN PERUGIA (III-I CENTURY BC). 95

D. Calisi 


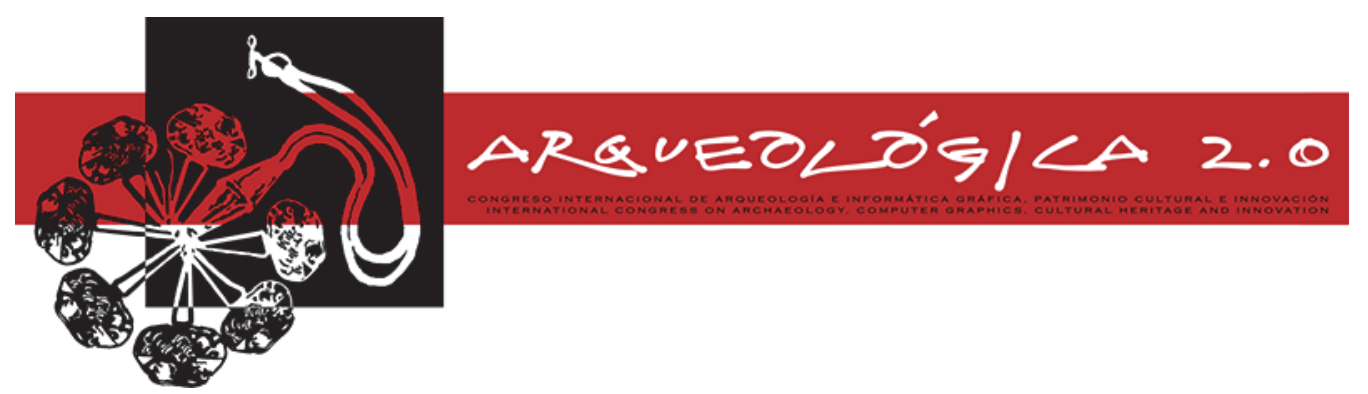

Proceedings of the 8th International Congress on Archaeology, Computer Graphics, Cultural Heritage and Innovation 'ARQUEOLÓGICA 2.0' in Valencia (Spain), Sept. 5-7, 2016

PARAMETERIZATION OF COMPLEX CULTURAL HERITAGE SHAPES FOR ONLINE VIEWING AND INTERACTIVE PRESENTATION AND PROCESSING. 105

M. Ćurković, D. Vučina

METODOLOGÍA Y APLICACION PRÁCTICA PARA LA DIGITALIZACIÓN DE PATRIMONIO COFRADE

MEDIANTE LA FUSION DE DATOS DE LÁSER ESCANER Y FOTOGRAMÉTRICOS

C. Colomo, J.L. Pérez, J.M. Gómez, F.J. Rosales

TRATAMIENTO DE DATOS TLS MEDIANTE EL EMPLEO DE IMÁGENES ESFÉRICAS: APLICACIÓN A LA

DOCUMENTACIÓN DE LA SALA CAPITULAR DE LA CATEDRAL DE JAÉN. 118

J.M. Gómez-López, J.L. Pérez-García, C. Colomo, J. Cardenal, E. Mata

PROPUESTA DE REUBICACIÓN MEDIANTE RECONSTRUCCIÓN VIRTUAL. CASO DE ESTUDIO: RETABLO

MAYOR DE SAN FRANCISCO DE SAN ESTEBAN DE GORMAZ (SORIA)

M. Sánchez

SELF-EXPLAINING VIDEOS FOR THE MUSEO EGIZIO IN TURIN. 132

F. Gabellone, I. Ferrari, F. Giuri, M. Chiffi

DEVELOPMENT OF AN EFFICIENT APPROACH OF ARCHAEOLOGICAL HERITAGE IN THE INTERTIDAL

ZONE OF THE BELGIAN NORTH SEA.

M. Decock, C. Stal, S. Van Ackere, A. Vandenbulcke, P. De Maeyer, A. De Wulf

INTEGRATED METHODOLOGIES FOR A NEW RECONSTRUCTIVE PROPOSAL OF THE AMPHITHEATRE OF

CATANIA. 146

D. Malfitana, F. Gabellone, G. Leucci, G. Cacciaguerra, I. Ferrari, F. Giuri, L. De Giorgi, C. Pantellaro CRITICAL READING OF SURVIVING STRUCTURES STARTING FROM OLD STUDIES FOR NEW

RECONSTRUCTIVE PROPOSAL OF THE ROMAN THEATRE OF CATANIA 155

D. Malfitana, F. Gabellone, G. Cacciaguerra, I. Ferrari, F. Giuri, C. Pantellaro

THE SURVEY, THE REPRESENTATION AND THE STRUCTURAL MODELING OF A DATED BRIDGE. 162

S. Artese, J.L. Lerma, G. Zagari, R. Zinno

DIGITAL IMAGE ANALYSIS OF THE VISIBLE REGION THROUGH SIMULATION OF ROCK ART PAINTINGS...... 169

B. Carrión-Ruiz, S. Blanco-Pons, J.L. Lerma

REVIEW OF AUGMENTED REALITY AND VIRTUAL REALITY TECHNIQUES IN ROCK ART 176

S. Blanco-Pons, B. Carrión-Ruiz, J.L. Lerma

MODELIZACIÓN Y SIMULACION DE LAS POSIBLES POSICIONES DE LAS ATALAYAS DE LA FORTALEZA DE

LA MOTA EN ALCALA LA REAL, MEDIANTE TECNICAS DE ANALISIS VISUAL

F.J. Rosales, J.L. Pérez-García, C. Colomo, J.M. Gómez-López, M.A. Ureña

SIMULACIÓN 3D CON INTERFACES HÁPTICAS PARA LA RECUPERACION DEL PATRIMONIO CULTURAL

DEL TREN EN RIOBAMBA. 191

M. Duque, F. Proaño, R. Santos

EXPLOTACIONES MINERAS EN PATRIMONIO INDUSTRIAL: UN CASO DE USO DE DOCUMENTACIÓN Y SIMULACIÓN. 197

D. Marcos, J. Martínez, F.J. Delgado, J. Finat 


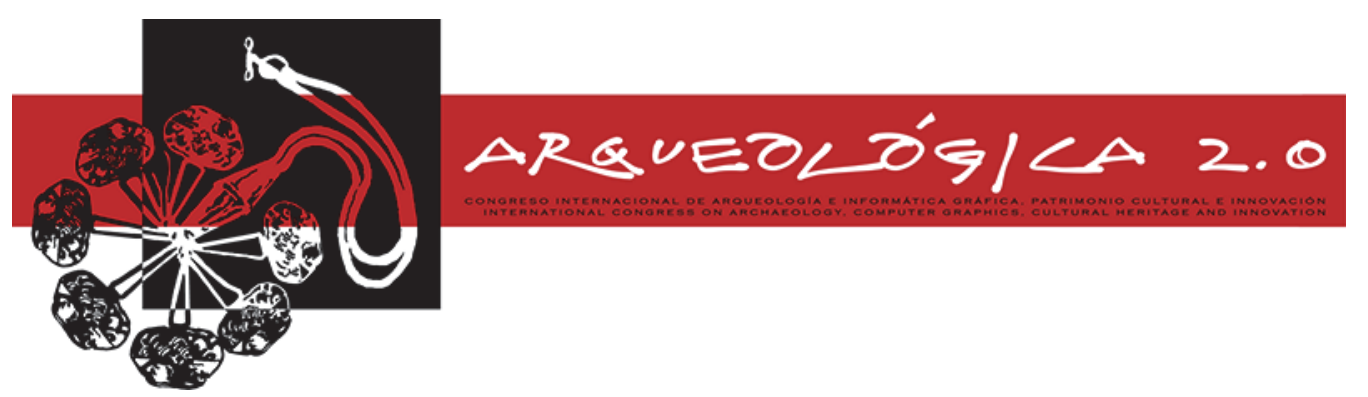

Proceedings of the 8th International Congress on Archaeology, Computer Graphics, Cultural Heritage and Innovation 'ARQUEOLÓGICA 2.0' in Valencia (Spain), Sept. 5-7, 2016

KUÉLAP VIRTUAL: VIRTUALIZACIÓN DE UNA CIUDADELA PREINCA EN LOS ANDES AMAZÓNICOS DEL

PERÚ MEDIANTE FOTOGRAFÍA ESFÉRICA, MODELADO 3D E IMPRESIÓN 3D.

E. Ribera

CONSERVATION MODEL FOR BASILICA OF SMYRNA AS AN THEORETICAL INTENTION. 215

T. Saricaoglu

LA APLICACIÓN DE NUEVAS TECNOLOGÍAS EN LA DOCUMENTACIÓN ARQUEOLÓGICA DE LA VILLA

ROMANA DE NOHEDA Y SU PROYECCIÓN TURÍSTICA DIGITAL

M.Á. Valero, N. Huete

VIRTUAL RECONSTRUCTION APPLIED TO THE RECOVERY AND HERITAGE DISCLOSURE OF THE OLD

VILLAGE OF BELCHITE 231

A. Alfaro, M.P. Biel, D. Gutiérrez

BIG DATA IN LANDSCAPE ARCHAEOLOGICAL PROSPECTION 238

J. Torrejón, M. Wallner, I. Trinks, M. Kucera, N. Luznik, K. Löcker, W. Neubauer

CASTLE4D: AN ARCHAEOLOGICAL INFORMATION SYSTEM BASED ON 3D POINT CLOUDS 247

A. Luczfalvy, B. Jonlet, P. Hallot, F. Poux, P. Hoffsummer, R. Billen

\section{Works in progress}

BETWEEN LANDSCAPE AND ARCHITECTURE: ENVISIONING CAPPADOCIAN RUPESTRIAN MONASTERY

THROUGH COLORFUL CONTOUR LINES.

F. Colonnese, M. Carpiceci, C. Inglese

MODELADO TRIDIMENSIONAL DE LA PALEOTOGRAFÍA DE CARTAGENA.

J. García-León, M.M. Ros, A. García, M. Torres, F. Cerezo, S.F. Ramallo

RECUPERACIÓN GRÁFICA DE LA MÁQUINA PARA CORTAR LA HIERBA DE LOS CANALES NAVEGABLES

DE AGUSTÍN DE BETANCOURT Y MOLINA: MODELADO TRIDIMENSIONAL Y DOCUMENTACIÓN

GEOMÉTRICA CON SOLID EDGE.

J.I. Rojas-Sola, J. Porras-Galán, L. García-Ruesgas

A PERSPECTIVE ON PROCEDURAL MODELING BASED ON STRUCTURAL ANALYSIS. 264

J.L. Fita, G. Besuievsky, G.A. Patow

3D VISIBILITY ANALYSIS AS A MEAN TO VALIDATE ANCIENT THEATRE'S RECONSTRUCTIONS..... 267

Maria Cristina Manzetti

ALGUNOS APUNTES SOBRE LA DIGITALIZACIÓN Y LA RECONSTRUCCIÓN VIRTUAL DEL CASTRO DE SAN

CHUIS (ALLANDE, ASTURIAS, ESPAÑA)

J. Molina, J.F. Jordá

ESQUINA MULTIMEDIA - MUSEUM EXHIBITION FOR THE VISUALIZATION OF CHAN CHAN

ARCHAEOLOGICAL SITE

R. Pierdicca, E. S. Malinverni, E. Frontoni, F. Colosi, R. Orazi

3D GIS TOOLS FOR SUBSOIL MANAGEMENT. 277

M. Herrador, A. Graciano, F.R. Feito, L. Ortega 


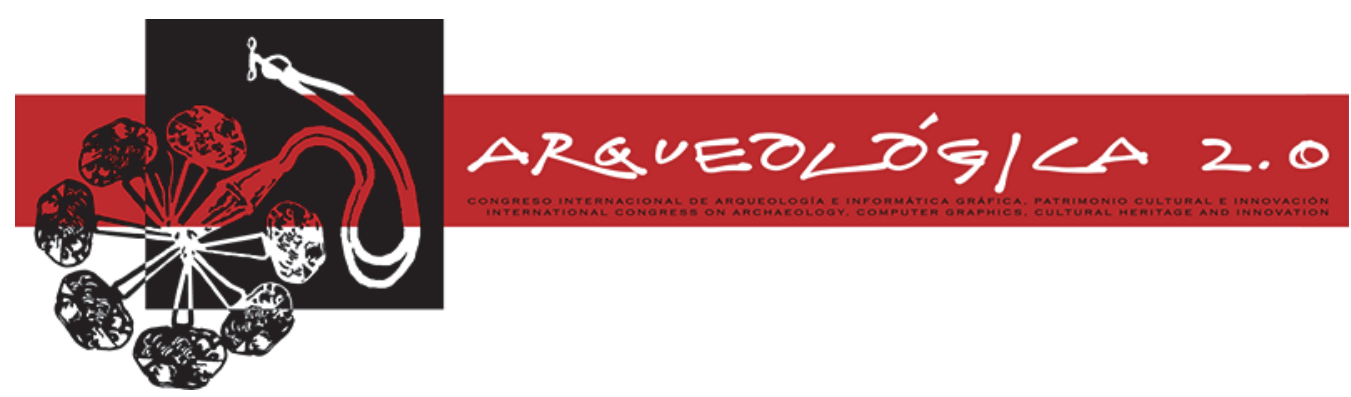

Proceedings of the 8th International Congress on Archaeology, Computer Graphics, Cultural Heritage and Innovation 'ARQUEOLÓGICA 2.0' in Valencia (Spain), Sept. 5-7, 2016

VIRTUAL TOURS OF HISTORICAL AND ARTISTIC HERITAGE IN THE PROVINCE OF CACERES 281

J.M. Naranjo, M.Á. Parrilla, M. Sanchez

NATURAL GESTURE INTERACTION IN ARCHAEOLOGICAL VIRTUAL ENVIRONMENTS: WORK IN PROGRESS 284

N. Albertini, A. Brogni, B. Caramiaux, M. Gillies, R. Olivito, E. Taccola

HISTORICAL TRACES' INTERPRETATION AND VIRTUAL RECONSTRUCTION - THE CASE OF

ACROCORINTH CASTLE. 288

D. Athanasoulis, X. Simou, T. Zirogianni

THE DOCUMENTATION OF CULTURAL HERITAGE WITH BIM OPEN SOURCE SOFTWARE .... 291

S. Logothetis, E. Stylianidis

UNVEILING DAMNATIO MEMORIAE. THE USE OF 3D DIGITAL TECHNOLOGIES FOR THE VIRTUAL

RECONSTRUCTION OF ARCHAEOLOGICAL FINDS AND ARTEFACTS. 295

A.M. Manferdini, S. Gasperoni, F. Guidi, M. Marchesi

THE ROLE OF VIRTUAL ARCHITECTURE: PHENOMENOLOGICAL PERSPECTIVE 298

H.J. Lee

REGISTRO TRIDIMENSIONAL DEL EDIFICIO “E” DEL SITIO ARQUEOLÓGICO EL HUARCO-CERRO AZUL,

CAÑETE, PERÚ

G.M. Quiroga, G. Marcone

UN REGRESO VIRTUAL: RECREACIÓN DE LA APARIENCIA ORIGINAL DEL CORO DEL CONVENTO DE

SANTA CLARA DE TORO (ZAMORA) CON SUS PINTURAS MURALES MEDIEVALES, EN LA ACTUALIDAD

ARRANCADAS Y DESPLAZADAS 305

F. Gutiérrez, F.M. Morillo, J.I. San José, J.J. Fernández

PROSPECCIÓN GEOFÍSICA EN EL SECTOR PÚBLICO CENTRAL DEL SITIO ARQUEOLÓGICO EL HUARCO -

CERRO AZUL 2016

G.M. Quiroga, G. Marcone, N.M. Castillo

UN PROCEDIMIENTO DE SEGMENTACIÓN DE MALLAS 3D DE EDIFICIOS HISTÓRICOS 311

B.J. Herráez, E. Vendrell

ARCHAEOBIM: AN INNOVATIVE METHOD FOR ARCHAEOLOGICAL ANALYSIS OF AN ETRUSCAN TEMPLE

IN MARZABOTTO

S. Garagnani, A. Gaucci, B. Gruška

VIRTUAL PALMYRA: 3D RECONSTRUCTION OF THE LOST REALITY OF "THE BRIDE OF THE DESERT"

\section{A. Denker}

LA HISTORIA EN EL PAISAJE: DIFERENTES LUGARES Y ANÁLOGAS REPRESENTACIONES. ANÁLISIS E INTERPRETACIÓN CON LAS NUEVAS TECNOLOGÍAS DE MODELIZACIÓN VIRTUAL 321

X. Otero, M. Farjas, M. Santos

DOCUMENTACIÓN GEOMÉTRICA DE LA TORRE VALLFEROSA DE TORÀ 324

R. Tortosa, J. Blasco, O. Aparicio, L. Gimeno, A. Vilaplana, J. Menchón 


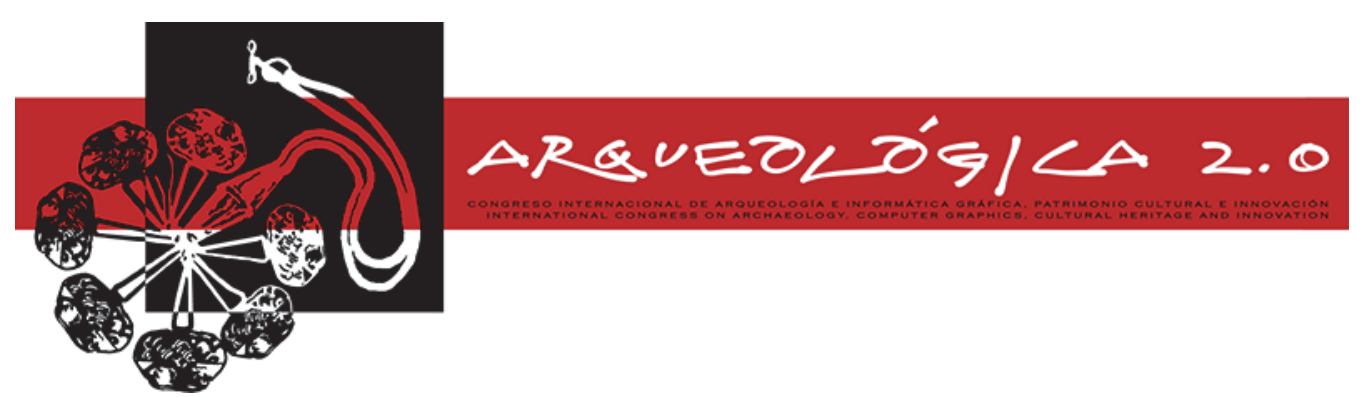

Proceedings of the 8th International Congress on Archaeology, Computer Graphics, Cultural Heritage and Innovation 'ARQUEOLÓGICA 2.0' in Valencia (Spain), Sept. 5-7, 2016

CATÁLOGACIÓN DIGITAL 3D DE MACROÚTILES LÍTICOS PROCEDENTES DE COVES DE SANTA MAIRA Y CUEVA DE NERJA

R. Tortosa, J. Blasco, O.A. González, L. Gimeno, A. Vilaplana, J.E. Aura

RESTAURACIÓN DE VIDRIO ARQUEOLÓGICO: RECONSTRUCCIÓN DE, FRAGMENTOS FALTANTES

MEDIANTE MODELADO E IMPRESIÓN 3D.

C. Díaz-Marín, E. Aura-Castro

DEVELOPMENT OF A GEOREFERENCED ARCHAEOLOGICAL INFORMATION DATA BASE FOR

ELEUTHERNA IN CRETE. 333

S. Tapinaki, A. Georgopoulos, C. Ioannidis, E. Frentzos, N. Stampolidis, N. Maragoudakis

A NEW METHODOLOGY FOR THE 3D PHOTOREALISTIC VIRTUAL RECONSTRUCTION OF THE

ARCHAEOLOGICAL SITE "CASTELLET DE BERNABÉ" (LLÍRIA, SPAIN) 337

C. Portalés, P. Alonso-Monasterio, M.J. Viñals

DIFUSIÓN DE PROYECTOS DE PATRIMONIO CULTURAL EN ENTORNOS WEB. PRIMERAS EXPERIENCIAS

CON LA LIBRERÍA THREE-JS 340

J. Palomar-Vázquez, M.J. Viñals-Blasco

PRELIMINARY EVALUATION OF HDR TONE MAPPING OPERATORS FOR CULTURAL HERITAGE.

R. Suma, G. Stavropoulou, E.K. Stathopoulou, L. van Gool, A. Georgopoulos, A. Chalmers

3D MODELLING FROM UAV DATA IN HIERAPOLIS OF PHRIGIA (TK) .

F. Chiabrando, F. D'Andria, G. Sammartano, A. Spanò

UAV OBLIQUE DATA AND LASER SCANNING IN AN EXCAVATED AREA

F. Chiabrando, A. Spanò, G. Sammartano, L. Teppati

REPORT ON THE DIGITAL RECONSTRUCTION OF THE 4TH CENTURY SUSA (WORK IN PROGRESS) 354

F. Chiabrando, L. Dezzani, A. Prencipe, A. Spanò

UN NUEVO ESPACIO TERMAL DE ÉPOCA ROMANA ANEXO A LA VILLA DEL CASALE (PIAZZA ARMERINA, SICILIA): PROPUESTA DE RECONSTRUCCIÓN VIRTUAL DE SUS AMBIENTES FRÍOS A LA LUZ DE LOS HALLAZGOS ARQUEOLÓGICOS

\section{J. Atienza}

GEORRADAR Y TOMOGRAFÍA ELÉCTRICA PARA LA CARACTERIZACIÓN DE UN YACIMIENTO

ARQUEOLÓGICO MEDIEVAL, (CONJUNTO ARQUEOLÓGICO CASTILLO DE LA ESTRELLA, MONTIEL).

J.L. Sánchez, D. Gallego, J. Molero, J. Sánchez, Ó. Merlo

PRIMEROS RESULTADOS DE LA RECONSTRUCCIÓN VIRTUAL DEL CASTILLO DE TURÍS (TURÍS,

VALENCIA, ESPAÑA) 365

J.L. Jiménez, E. Díes, J. Tierno

COMUNICACIÓN ESTRATÉGICA APLICADA AL DESTINO TURÍSTICOCULTURAL DE CARTAGENA (MURCIAESPAÑA). 369

M.D. Teruel-Serrano, M.J. Viñals-Blasco 


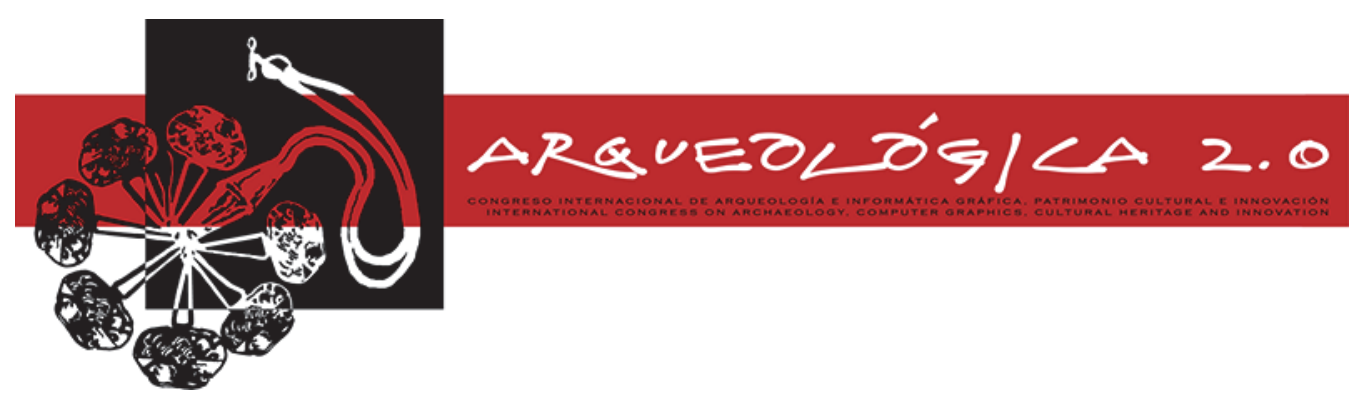

Proceedings of the 8th International Congress on Archaeology, Computer Graphics, Cultural Heritage and Innovation 'ARQUEOLÓGICA 2.0' in Valencia (Spain), Sept. 5-7, 2016

RAPID MAPPING AND VISUAL NOISE: RECORDING FOR THE VISITOR, RESIDENT, PILGRIM AND TOURIST;

AJMER, INDIA (WORK IN, PROGRESS)

O. Prizeman, A. Hardy

EDETA 360: VIRTUAL TOUR FOR VISITING THE HERITAGE OF LLÍRIA, (SPAIN). 376

J.M. Maícas, M.J. Viñals

PROPUESTA DE PROTOCOLO GIS Y DE UTILIZACIÓN DE UN, ENTORNO 3D PARA LA INTERVENCIÓN

ARQUEOLÓGICA 2015 EN,CUEVA DE LA COCINA (DOS AGUAS, VALENCIA).....

A. Díez, A. Cortell, O. García, P. Escribá

IMAGING AND VISUALIZING MAYA CAVE SHRINES IN NORTHERN, QUINTANA ROO, MEXICO. 382

D. Rissolo, M.R. Hess, A.R. Hoff, D. Meyer, F.E. Amador, A. Velázquez, V. Petrovic, F. Kuester DEL REGISTRO MANUAL AL DIGITAL: APLICACIÓN DE GRÁFICOS, VECTORIALES EN ESTUDIOS

ARQUEOLÓGICOS. 385

A. Papú, L.M. Berisso, D. Bozzuto

FOTOGRAMETRÍA AÉREA Y TERRESTRE PARA LA DOCUMENTACIÓN, 3D DEL CASTILLO DE BARXELL

(ALCOI, ALICANTE, ESPAÑA) 388

N. Segura, E.A. Paredes, J.D. Busquier

3D IMAGING ANALYSIS AND DIGITAL STORYTELLING FOR, PROMOTION OF CULTURAL HERITAGE: THE

SCHOOL OUTREACH,PROJECT OF REALMONTE

E. Bonacini, D. Gulli, D. Tanasi

RECONSTRUCCIÓN FOTOGRAMÉTRICA DE LA TORRE GÓTICA DE LA, IGLESIA DE SANTA MARIA DE

ALCAÑIZ 396

L. Agustín, A. Fernández-Morales

BUILDING A VIRTUAL TIME MACHINE FOR THE ANCIENT RUINS OF, JIAOHE 400

B. Lonneville, N. Vanhaeren, A. Vandenbulcke, A. De Wulf, P. De Maeyer

PIXEL-LEVEL IMAGE FUSION FOR ARCHAEOLOGICAL, INTERPRETATIVE MAPPING 404

G. Verhoeven, M. Nowak, R. Nowak

USING 3D MODELLING IN THE VALLEY OF TURU ALTY (SIBERIA, RUSSIA) FOR RESEARCH AND CONSERVATIONAL PURPOSES. 408

A. Vandenbulcke, C. Stal, B. Lonneville, J. Bourgeois, A. De Wulf

LA PUNTA DEL ICEBERG: ARQUEOLOGIA ANTÁRTICA EN LA ERA, DIGITAL 412

F. Codevilla, J. Cruz, G. Radicchi, A. Zarankin

RECUPERANDO EL PALACIO VISIGODO DE PLA DE NADAL (RIBAROJA, DE TÚRIA, VALENCIA) 416

A. Ribera, I. Escrivà, J.M. Macias, J.J. Marín, J. Morín, J.M. Puche, M. Rosselló, I. Sánchez, A.

Santonja, C. Silvestre

PHOTOGRAMMETRIC SURVEY IN THE LATRINES OF CHAMBORD 419

P. Antoine, S. Bryant 


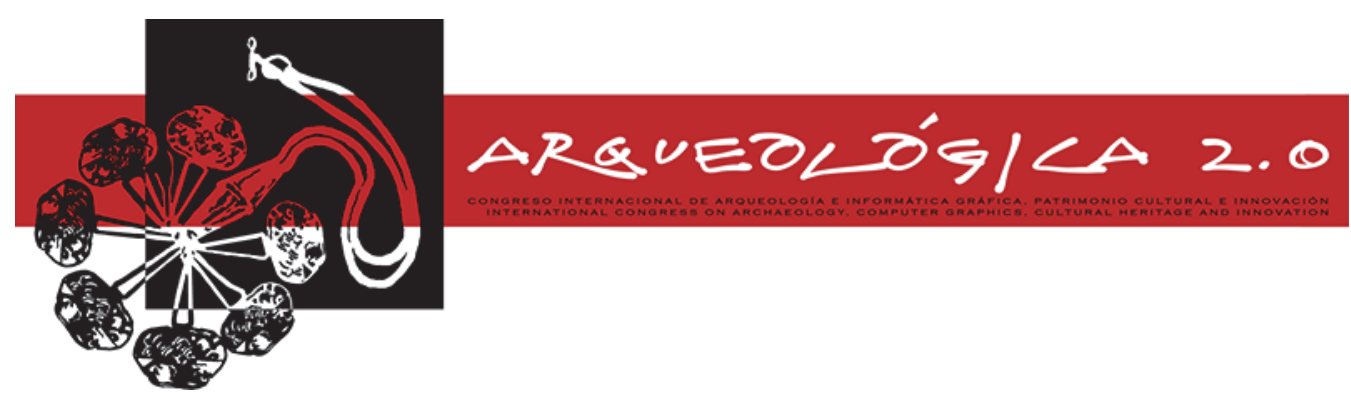

Proceedings of the 8th International Congress on Archaeology, Computer Graphics, Cultural Heritage and Innovation 'ARQUEOLÓGICA 2.0' in Valencia (Spain), Sept. 5-7, 2016

SITUACIÓN EN EL ESPACIO E INVERSIÓN DE TRABAJO DE LAS,CONSTRUCCIONES MEGALÍTICAS A

PARTIR DE LOS SISTEMAS 3D, IMÁGENES PANORÁMICAS Y $360^{\circ}$.....

E. López

COMPLEX 3D HERITAGE ARCHITECTURES ACCESSIBLE ON THE WEB 426

M.M. Ramos, D. Bellido, N. Carboni, M. Domajnko, E.K. Stathopoulou, G. Stavropoulou, D. Morabito,

F. Remondino

A PILOT PROJECT AERIAL STREET VIEW TOUR AT THE VALLEY OF, THE TEMPLES (AGRIGENTO)..... 430

E. Bonacini

COMMUNICATING THE CUTURAL HERITAGE THROUGH THE USE OF, DRONES, 3D MODELS AND APP.

CASE OF STUDY: "FERRAN3DINA"

A. Pecci

3D DIGITISATION AND RECONSTRUCTION OF A CAPITAL IN NORTHWESTERN, GAUL: INTERIM RESULTS

ON THE CITY OF ALET.

Y. Bernard, J.B. Barreau, C. Bizien-Jaglin, L. Quesnel, L. Langouët, M.Y. Daire

THE ROLE OF TANGIBLE INTERACTION FOR COMMUNICATING, QUALITATIVE INFORMATION OF BUILT

HERITAGE

E. Nofal, V. Boschloos, H. Hameeuw, A. Vande Moere

TRAZANDO RUTAS EN LA EDAD DEL BRONCE TUROLENSE: PERSPECTIVAS DE TRABAJO 445

J. Jiménez, T. Orozco, A. Diez

PUTTING 3D MODELS INTO CONTEXT - THE SCHACHERMEYR, POTTERY COLLECTION AND THE DEFC APP

S. Štuhec, E. Aspöck, A. Masur, P. Andorfer, K. Zaytseva

PORTUS LUPIAE. 3D MODELING AND VISUAL NARRATIVE FOR, RECONSTRUCTING A LONG MARITIME HISTORY

I. Ferrari, A. Quarta, M. Sammarco, A. Carpentieri, A. Di Tondo, R. Leone

3D MODELING AND VIRTUAL APPLICATIONS FOR THE VALORIZATION, OF HISTORICAL HERITAGE 456

E. Farella, F. Menna, F. Remondino, M. Campi

TRABAJOS 3D REALIZADOS EN LA PUERTA 1 DEL COMPLEJO, ARQUEOLÓGICO DE PERDIGÕES

(PORTUGAL): ESTADO DE LA,CUESTIÓN. 460

J.L. Caro

3D SURVEY AND HBIM FOR THE KNOWLEDGE AND VALORIZATION OF, ARCHEOLOGICAL HERITAGE. THE

CASE STUDIES OF THE CAPUA, AND TELESIA AMPHITHEATRES 464

D. lovane, V. Cera

NUEVAS PUERTAS VIRTUALES AL MUNDO DE LA PRESERVACIÓN Y DIFUSIÓN DEL PATRIMONIO HISTÓRICO MILITAR. UN COMPROMISO POR EL FUTURO DE LA INVESTIGACIÓN Y

EL CONOCIMIENTO 468

M. Gil-Melitón, J.L. Lerma 


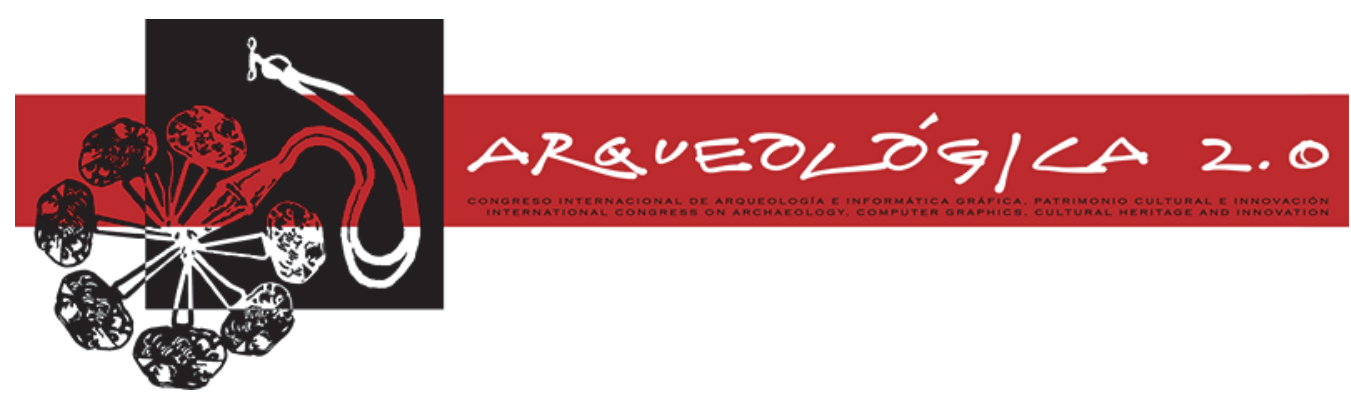

Proceedings of the 8 th International Congress on Archaeology, Computer Graphics, Cultural Heritage and Innovation 'ARQUEOLÓGICA 2.0' in Valencia (Spain), Sept. 5-7, 2016

PHILANTHROPIC FOUNTAIN OF KORNAROU SQUARE: USING SFM TO CALCULATE THE FOUNTAIN'S GEOMETRIC CHARACTERISTICS IN ORDER TO DETERMINE ITS INELASTIC DYNAMIC RESPONSE 472

A. Lyratzakis, P. Parthenios, M. Stavroulaki

COMBINING STRUCTURE FROM MOTION TECHNIQUES WITH LOW COST EQUIPMENT FOR A COMPLETE

3D RECONSTRUCTION OF A 13TH CENTURY CHURCH

P. Parthenios, T. Androulaki, E. Gereoudaki, G. Vidalis

THE SOUTH AFRICAN HERITAGE RESOURCES INFORMATION SYSTEM (SAHRIS): DEVELOPMENT AND

CHALLENGES THROUGH MANAGEMENT OF CULTURAL HERITAGE RESOURCES THROUGH AN

INTEGRATED WEB-BASED PLATFORM

C. Jackson, R. Redelstorff

AUTHENTICITIES AND VIRTUAL REALITY THE CASE STUDIES JUPITER COLUMN AND KALEIDOPHONIC

DOG

J. Muñoz, F. Schaaf, R.H. Schneider, C.Y. Robertson-von Trotha

SURVEYING DAMAGE TO HISTORIC BUILDINGS IN MEINONG EARTHQUAKE 488

R.Z. Wang, H.C. Chang, M.C. Lee

ESTRATEGIAS PASIVAS EN EDIFICIOS ECLESIÁSTICOS CANARIOS CONSTRUIDOS ENTRE LOS SIGLOS XVYXVI 492

S. Pérez

DISCRETE AND CONTINUOUS MONITORING TO CHARACTERISED THE THERMO-HYGROMETRIC STATE

OF WALL-BUILDING MATERIALS IN OSTIA ANTICA ARCHEOLOGICAL SITE

F.J. García-Diego, C. Scatigno, P. Merello

VIRTUAL CITIES INHABITED BY AUTONOMOUS CHARACTERS: A PIPELINE FOR THEIR PRODUCTION 500

A.P. Cláudio, M.B. Carmo, A.A. de Carvalho, W. Xavier, R.F. Antunes

PRELIMINARY DATA OF CFD MODELING TO ASSESS THE VENTILATION IN AN ARCHAEOLOGICAL

BUILDING.

F.J. García-Diego, C. Scatigno, P. Merello, E. Bustamante

THE CIRCUS MAXIMUS: DIACHRONIC RECONSTRUCTION THROUGH THE APPLICATIONOF NEW

TECHNOLOGIES 508

D. Dininno

APLICACIÓN DE DIVERSAS TÉCNICAS DE DOCUMENTACIÓN PATRIMONIAL ARQUITECTÓNICA EN LA

ALQUERÍA 'MAS DEL NOI'. 511

J.P. Carbonell-Rivera, D. Montalvá-España, J.L. Lerma

EL PALACIO DE LOS NIÑOS DE DON GOME (ANDÚJAR, JAÉN), GESTIONADO DESDE UN PROYECTO H-BIM

Á. García, E. Nieto, J.J. Moyano

THE WESTERN HIGH GATE OF MEDINET HABU: PHOTOGRAMMETRIC 3D MODELLING

\& DOCUMENTATION .520

O. Murray, H. McDonald, J.L.Kimpton 


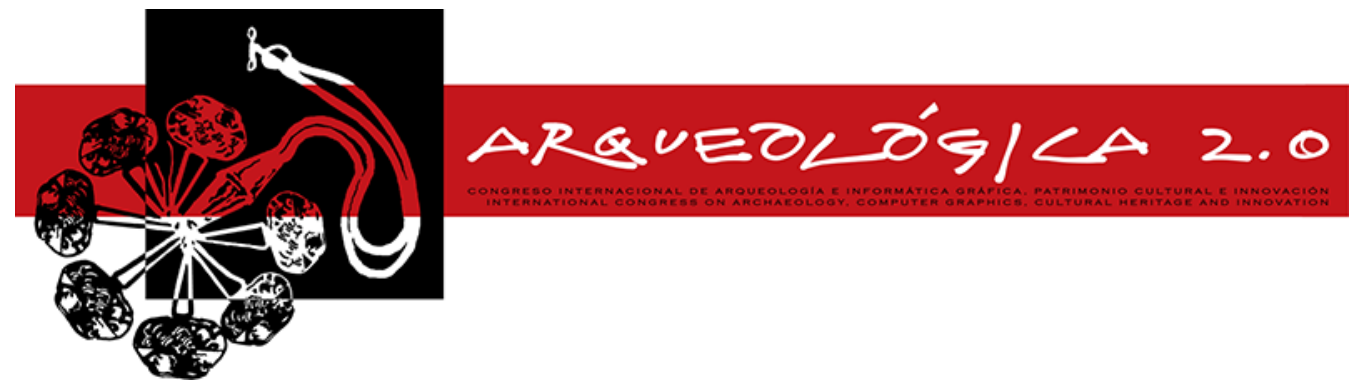

Proceedings of the 8th International Congress on Archaeology, Computer Graphics, Cultural Heritage and Innovation 'ARQUEOLÓGICA 2.0' in Valencia (Spain), Sept. 5-7, 2016

PROPUESTA DE ANÁLISIS TRIDIMENSIONAL APLICADO A LA INTEGRACIÓN DE LAS DIFERENTES ACTUACIONES ARQUEOLÓGICAS REALIZADAS EN CUEVA DE LA COCINA (DOS AGUAS, VALENCIA) 524

A. Diez, O. García, M. Basile, A. Cortell, N. Tsa

TRABAJOS DE DOCUMENTACIÓN DIGITAL DE GRABADOS RUPESTRES EN EL TÉRMINO MUNICIPAL DE ALCÁZAR DE SAN JUAN (CIUDAD REAL, ESPAÑA) 528

V.M. López-Menchero, Á. Marchante, M.L. Vincent, Á.J. Cárdenas, J. Onrubia EXTRACTING SPATIAL INFORMATION OF HERITAGE GARDENS FROM BOUNDARY PAINTINGS BASED ON 3D MAPPING TECHNOLOGIES 531

C. Yang 


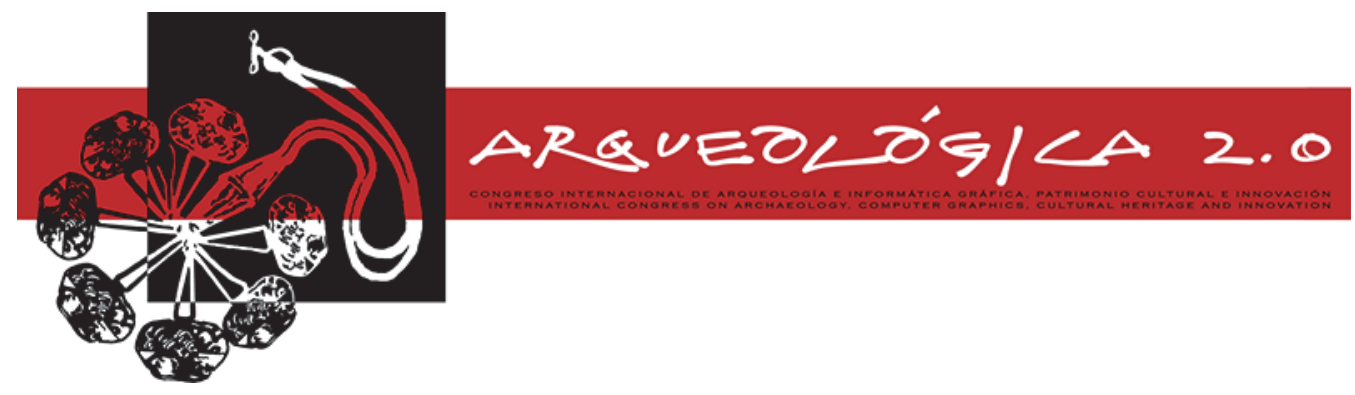

Proceedings of the 8th International Congress on Archaeology, Computer Graphics, Cultural Heritage and Innovation 'ARQUEOLÓGICA 2.0' in Valencia (Spain), Sept. 5-7, 2016

\section{Long scientific papers}




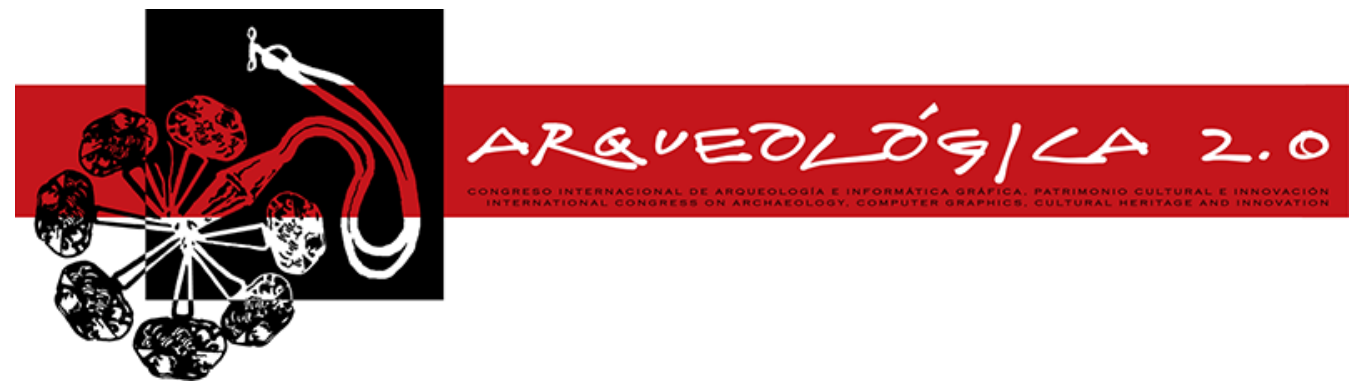

Proceedings of the $8^{\text {th }}$ International Congress

on Archaeology,

Computer Graphics,

Cultural Heritage and Innovation

'ARQUEOLÓGICA 2.0'

in Valencia (Spain),

Sept. 5-7, 2016

DOI: http://dx.doi.org/10.4995/arqueologica8.2016.2582

Received: 26/01/2016

Accepted: 18/05/2016

\title{
COMPARISON OF 3D REALITY CAPTURE TECHNOLOGIES FOR THE SURVEY OF STONE WALLS
}

\author{
COMPARATIVA DE TECNOLOGÍAS 3D PARA LA INSPECCIÓN DE MUROS DE PIEDRA \\ Enrique Valero ${ }^{\mathrm{a},{ }^{,},}$, Alan Forster ${ }^{\mathrm{a}}$, Frédéric Bosché ${ }^{\mathrm{a}}$, Lyn Wilson ${ }^{\mathrm{b}}$, Alick Leslie $^{\mathrm{b}}$ \\ ${ }^{a}$ Royal Academy of Engineering Centre of Excellence in Sustainable Building Design, Heriot-Watt University, EH14 4AS, Edinburgh, \\ UK. e.valero@hw.ac.uk; a.m.forster@hw.ac.uk; f.n.bosche@hw.ac.uk \\ ${ }^{b}$ South Gyle Conservation Centre, Historic Environment Scotland, EH12 9EB, Edinburgh, UK. lyn.wilson@gov.scot \\ alick.leslie@gov.scot
}

\begin{abstract}
:
The maintenance of the external fabric of historic buildings constitutes a large portion of overall building life cycle costs. Advanced reality capture and data processing technologies have the potential to transform existing survey practice, providing surveyors with objective data pertaining to building fabric, in a more rapid (frequent), safe and cost-effective manner. In this paper, we present a unique evaluation of several Terrestrial Laser Scanning (TLS) and photogrammetric (PG) systems that assess their relative strengths for the survey of stone walls. The assessment is conducted using an historic building selected for its representativeness of form, fabric and condition. The work considers performance in terms of data accuracy and precision, data completeness, and process efficiency. The results show that, while TLS provides good geometric data to generate accurate and valuable 3D models, the quality of PG reconstructions can be also be sufficient in such contexts. And considering the relatively low-cost and portability of modern digital cameras compared to laser scanners, photogrammetry can constitute a realistic alternative to TLS. In addition, mounting a camera on a UAV could further solve access issues, preventing the need for any additional infrastructure (e.g. scaffolding), which would be required when employing TLS. However, a lesson drawn from this work is that effective acquisition of photogrammetric data requires careful planning to select the appropriate camera settings and picture density (and locations) to ensure accurate and reliable photogrammetric reconstruction. This process may be referred to as: Planning for Photogrammetry (P4P).
\end{abstract}

Key words: virtual archaeology, historic buildings, cultural heritage, documentation, survey, 3D reconstruction, laser scanning, photogrammetry

\section{Resumen:}

Las labores de mantenimiento de la estructura externa de edificios históricos constituyen una gran parte de los costes asociados al ciclo de vida de estos. Las tecnologías empleadas para la adquisición de datos estructurales y su procesamiento tienen el potencial de transformar, en gran medida, las tareas de inspección tradicionales, proporcionando información relativa al edificio de una manera más rápida, segura y económica. En este trabajo, se evalúan escáneres láser y sistemas basados en fotogrametría, demostrando su solidez para la inspección de paredes de piedra. Esta evaluación se ha llevado a cabo en un edificio histórico representativo y en un buen estado de conservación. En el artículo, se compara la actuación de los diferentes dispositivos en términos de precisión, repetibilidad, densidad de datos y eficiencia del proceso. Los resultados muestran que, mientras que los escáneres proporcionan buena información geométrica y permiten la generación de modelos tridimensionales precisos, la calidad de las reconstrucciones a partir de fotogrametría también pueden ser suficientes en determinados contextos. Considerando, además, el relativo bajo coste y la portabilidad de las cámaras digitales modernas en comparación con los escáneres láser, la fotogrametría puede constituir una alternativa real a estos últimos. Además, la instalación de cámaras en vehículos aéreos no tripulados (drones) puede resolver problemas de accesibilidad y minimizar el uso de infraestructuras adicionales (como andamiajes), las cuales son empleadas en la digitalización mediante escáneres. Sin embargo, una lección que se desprende de estos experimentos es que para conseguir una efectiva adquisición de datos fotogramétricos se requiere una cuidada planificación y una selección apropiada de los ajustes de la cámara, así como su correcto posicionamiento en la escena, con el objetivo de conseguir una adecuada densidad de imágenes y obtener una reconstrucción 3D precisa. Este proceso se denomina Planificación para la Fotogrametría.

"Corresponding Author: Enrique Valero, e.valero@hw.ac.uk 
Palabras clave: arqueología virtual, edificios históricos, patrimonio, documentación, inspección, reconstrucción 3D, escáneres láser, fotogrametría

\section{Introduction}

The maintenance of the external fabric of historic buildings constitutes a large portion of overall building life cycle costs. In Scotland alone, it is estimated that there are approximately 400,000 traditional (pre 1919) buildings representing $20 \%$ of building stock and constituting an important portion of construction spendings (Mueller et al. 2014). "Repair, maintenance and improvement accounts for approximately $46 \%$ of the total construction industry output, of which one third relates directly to pre 1919 buildings (accounting for approximately $£ 1.2$ billion)" (Historic Scotland 2011).

Environmental climatic conditions and associated weathering act as 'agencies of materials change', that lead to the deterioration of building fabric. Arresting this deterioration requires regular, appropriate maintenance. This operation is becoming more onerous due to climate change and more specifically increased incidence of extreme rainfall in Scotland. Practically, higher levels of moisture can be correlated with accelerated deterioration in porous building materials. Prevalent decay mechanism in masonry include increased severity and frequency in freeze-thaw cycling and spalling events, and biological growth associated with long term saturation of fabric. Logically, increased aggressivity of environmental conditions requires higher frequency evaluation of condition of the external evelope of buildings.

Maintenance decisions are made following detailed surveys of fabric. Advanced reality capture and data processing technologies have the potential to transform existing survey practice, providing surveyors with objective data pertaining to building fabric, in a more rapid (frequent), safe and cost-effective manner. In particular, greater volume and better accuracy of information can support surveyors in ensuring objectivity and consistency when assessing condition. This is paramount as these surveys are utilised to develop repair strategies.

Surveying building fabric encompasses many disparate and interconnected components that require the acquisition of various types of data. Principally, amongst information is construction form and materials. Both of these first order survey objectives rely upon specific data including the dimensions/geometry and texture of the fabric components. Advanced three-dimensional and visual reality capture technologies have been developed in the last few decades to acquire such data. These technologies mainly include: photogrammetry and laser scanning. Both can deliver dense 3D point clouds of scenes, possibly augmented with colour information. Photogrammetric systems are based on the use of cameras and the principle of stereo vision, while laser scanning is a more recent technology that is based on the controlled command of laser beams and time-offlight principles to determine the distance to an object.

Despite the quality of the data delivered by laser scanners, their use is limited by the need to set up the scanner on the ground or a stable platform at multiple locations that produce a complete $3 \mathrm{D}$ model when individual scans are registered together. Photogrammetric systems have shown great potential to resolve access-related issues but their performance can be significantly limited by the texture and/or type of material being scanned. Another limitation of photogrammetric systems is that the $3 D$ data they provide has unknown scale; control networks or known dimensions in the data are necessary to convert the data to metric scale, which inevitably introduces additional error.

The different strengths and weaknesses of both systems have led researchers to determine which solution is most appropriate in various contexts. In this paper, we present a unique evaluation of several Terrestrial Laser Scanning (TLS) and photogrammetric (PG) systems that are compared to assess their relative strengths for the survey of stone walls. The assessment is conducted using an historic building selected for its representativeness of form, fabric and condition. The work considers performance in terms of data accuracy and precision, data completeness, and process efficiency.

This paper is structured as follows: Section 2 contains a review of prior works on the use of laser scanning and photogrammetry for the survey of historic buildings, leading to the identification of the knowledge gap that this research contributes to fill. Section 3 describes the technologies assessed and the methodology followed to compare them. Section 4 presents the on-site data acquisition and reconstruction steps. Section 5 reports and analyses the results on the comparison of the data obtained for the different systems. Finally, Section 6 presents the conclusions and future works.

\section{Background}

Laser scanning is a relatively recent technology that constitutes a revolution in land and building surveying. Within the context of historic monument survey, noteworthy examples of the use of TLS include the work of Wilson et al. (2013) who illustrate the advantages of TLS for the survey of large and complex historic monuments via case studies of UNESCO World Heritage Sites. Cardaci et al. (2011) show that TLS provides significant value compared to traditional manual survey. They also show how CAD models generated from the data can be successfully used for structural analysis using the Finite Element Method (FEM). Nettley et al. (2013) use TLS and light Detection and Ranging (LiDAR) - i.e. aerial laser scanning - to obtain a photorealistic geospatial model of the historic quayside at Cotehele Quay integrated in an accurate Digital Elevation Map (DEM) in order to assess the potential impact of rising sea levels resulting from climate change. Temizer et al. (2013) show the value of TLS to survey underground structures like the Byzantine cistern situated beneath the court of the Sarnicli Han building. They also investigate the impact of various levels of point filtering on the accuracy of the mesh produced from the data. 
Photogrammetry is another well-established method for obtaining 3D records of historic monuments as the review of Ogleby (1995) for example shows. Its use outdates that of TLS by decades, almost a century (Schermerhorn 1940). However, significant progress has been made in the last two decades, both in terms of hardware and software, that has enabled significant automation of $P G$ data acquisition and processing for 3D model reconstruction. The development of robust automated feature detection and matching in digital images, (e.g. SIFT (Lowe 1999) or SURF (Bay et al. 2006) features), as well as dense matching approaches (Strecha et al. 2003) have dramatically improved, even automated the image processing stage. Furthermore, high-resolution and portable digital cameras are now widely available at a relatively low cost, meaning that photogrammetry can be easily deployed to produce dense textured $3 \mathrm{D}$ point clouds and meshes. Thanks to the light weight of modern cameras, single-camera photogrammetry has also shown great potential to resolve access-related constraints.

Regarding the field of historic monument survey, remarkable examples of the use of photogrammetry include the work of Cappellini et al. (CAPELLINI, V., STEFANI, C., NONY, N. and DE LUCA, L., 2012) who apply it to produce $3 D$ models of monuments that are used to generate $2.5 \mathrm{D}$ orthophotos of walls. Using the example of Roman walls, these orthophotos are employed to conduct the semantic annotation of the opus of different sections of the wall. Lerma and Muir (2014) present a comparison of laser scanning with photogrammetry, reconstructing a 3D model by means of Visual Structure for Motion (VSfM) and Patch or Cluster based Multi View Stereo Software (PMVS/CMVS), and concluded that for accurate documentation of carved detailing on stone, photogrammetric techniques provided the greatest level of flexibility and reliability, although the two techniques used in combination may provide the best results.

However, PG systems also have limitations. For example, they are not robust to varying lighting conditions and texture-poor or reflective materials (Thornbush and Viles 2008). Furthermore, their precision quickly drops with the distance of the camera to the target scene when compared to TLS (Rasztovits and Dorninger 2013). Also, single-camera PG systems provide $3 \mathrm{D}$ reconstructions only up to scale, and require the user to use survey networks or extract known dimensions in the images to adequately scale the reconstructions (Skarlatos and Kiparissi 2012).

With regard to access provision, PG and TLS systems can both be mounted on poles or extendable tripods that enable positioning them at heights up to approximately $5 \mathrm{~m}$. For greater heights, aerial solutions can then be considered. In fact, aerial photogrammetry and LiDAR (i.e. aerial laser scanning) systems have long been conducted using planes or helicopters with the sensors mounted under them. However, these solutions do not allow the acquisition of images at close distances, which limits the accuracy and density of the resulting 3D reconstructions. Recent and rapid developments of Unmanned Aerial Vehicles (UAVs), in particular helicopter-type UAVs, offer new platforms that are particularly suited to light-weight $P G$ systems. PG cameras mounted on helicopter UAV enable the acquisition of images at close ranges at any height, providing a serious advantage over laser scanning systems in terms of access provision. It should be noted that there are attempts to mount laser scanning systems on helicopter UAVs but the weight of the scanners requires very large UAVs and ensuring that the acquired data has high precision and accuracy remains a great challenge.

UAVs have already been considered for use in the application of photogrammetry in the context of historic monuments. For example, Püschel et al. (2008) propose the use of terrestrial and UAV pictures to create an accurate 3D model of Castle Landenberg. Remondino et al. (2011) review the different stages of data acquisition and processing, such as: planning, camera calibration, 3D reconstruction and applications; and Remondino (2011) provides an extensive review of devices and software for recording and modelling oriented towards cultural heritage. Lately, Koutsoudis et al. (2014) proposed a PG system combining UAV and terrestrial pictures and compared the resulting reconstruction with that obtained with TLS, reporting promising results. In constrast, Xu et al. (2014) actually combined 3D data from TLS and a UAV-mounted camera for the reconstruction of a historical monument in Fujian, China. TLS point clouds are used to model the façades and photogrammetric information is used to complete the roof area (not completely visible by the TLS system located on the ground).

Despite the greater effort invested into investigating the potential of TLS and PG for the survey of historic monuments, we found that further studies were still necessary to compare the quality of the data delivered by these technologies in the specific but common case of stone walls recording. In particular, the team wished to assess whether UAV-based photogrammetry could be used as a reliable means to obtain sufficiently accurate textured 3D models of masonry walls for their survey and maintenance, as such solution would considerably reduce the need for and therefore the cost and safety risks associated with traditional solutions for access provision (e.g. scaffolding, abseiling).

\section{Methodology}

The comparison of $3 D$ reality capture technology was conducted experimentally in the field using an actual historic monument as test site. The study considered: two terrestrial laser scanners employing different measurement principles; a hand-held/pole-mounted single-camera PG system; and a UAV-mounted singlecamera PG system.

This section first presents the characteristics and settings of the tested systems (Section 3.1). The test site and the reasons for its selection are described in Section 3.2. Finally, the criteria defined to compare the performances of the different systems are presented in Section 3.3.

\subsection{Systems}

The two TLS devices considered are the Leica ScanStation P40 and the Faro Focus 3D. The Leica ScanStation P40 (hereafter TLS-1) is the latest time-offlight (TOF) scanner produced by Leica. It can scan objects up to $270 \mathrm{~m}$ away, with an accuracy of $3 \mathrm{~mm}$ at 
$50 \mathrm{~m}$ and up to 1 million points are recorded per second (Leica Geosystems 2015). In contrast, the Faro Focus 3D (TLS-2) is a phase-based scanner. Its advertised performance (Faro 2011) characteristics show that this scanner can measure distances up to $120 \mathrm{~m}$, with slightly lower but still good single point precision $(2 \mathrm{~mm}$ at $25 \mathrm{~m})$ and can scan up to 1 million points per second. An additional important advantage of the Faro Focus 3D scanner is that it is significantly smaller and lighter weight than scanners such as the Leica ScanStation P40, which makes it more portable.

The first single-camera PG system considered (hereafter $P G-1)$ is a digital single-lens reflex (DSLR) Nikon D810 camera equipped with a $14 \mathrm{~mm}$ lens that is operated manually hand-held or mounted on an extendable pole. This camera can acquire 36 megapixel (MPx) pictures and the system allows the acquisition of high-quality data with the camera raised at heights up to $5 \mathrm{~m}$ (the pole height). The second single-camera photogrammetric system considered (hereafter PG-2) is a DSLR Sony $\alpha-7 R$ camera equipped with a $35 \mathrm{~mm}$ lens that is mounted on a UAV and operated remotely. This camera can also obtain 36MPx pictures. The UAV on which the camera is mounted is an Asctec Falcon 8 Multi-rotor that can fly at significant distances and heights - although the pilot should continuously maintain eye contact, and Civil Aviation Authority regulations actually prevent flying such UAVs at heights above 120 metres.

\subsection{Test Site}

The East garden of the medieval Craigmillar Castle, in Edinburgh, Scotland, was selected as test site. This castle was built in the $14^{\text {th }}$ century and is currently managed and maintained by Historic Environment Scotland. Within the East garden, the rampart wall (facing East; see Figure 1) was selected for the following reasons:

1. Complexity: The area of wall was selected due to its relative complexity and more specifically: the random nature of the stonework; variation in width and depth of mortar joint; planar and curved surfaces; stone soiling and associate colour and texture variation.

2. Sufficient height: It is important to study the performance of the chosen technologies at increasing heights; the rampart wall is approximately $10 \mathrm{~m}$ high, which seemed sufficient to challenge certain technologies, in particular the ground-based TLS devices.

3. Wind protection: The UAV can only be operated in conditions with low wind (to prevent collision with the monument and ensure good quality pictures). To enhance the chances of being able to operated the UAV on the selected day for data acquisition, the East-facing wall was found best due to the predominantly western winds in Edinburgh;

4. Accessibility: There should not be trees or other occlusions preventing the safe use of the UAV and occluding the surveyed scene. The East-gardern does not include any trees.

\subsection{Performance Assessment Criteria}

The performances of the four $3 D$ reality capture systems for the recording of the 3D geometry of stone walls were assessed and compared using several quantitative and qualitative criteria.

Data Completeness: this is measured by the density and uniformity of data across the acquired surface.

Efficiency: this is measused by the time required for acquiring and pre-processing the data to obtain a unified geo-referenced dense 3D point cloud.

Data Accuracy and Precision: taking the most accurate and precise TLS data as 'ground truth', data accuracy and precision is measured by the 'distance' of the other datasets to this ground-truth dataset. It is proposed to measure the 'distance' between two point clouds using the Hausdorff distance metric (Huttenlocher et al. 1993). For this, the volume containing the wall data is divided in voxels (i.e cuboids); we use voxels of size $1 \mathrm{~cm} \times 1 \mathrm{~cm} \times 10 \mathrm{~cm}$. The larger voxel side corresponds to the depth (perpendicular to the wall plane); it is set large to ensure matching points are found despite possible global misalignments. Note that the Hausdorff distance differs from the standard point-to-point distance that simply considers the closest points in the two point clouds. In constrast, the Hausdorff distance is based on the study of minimal and maximal distances between point clouds within each voxel, which makes it more sensitive to noisy data. Interestingly, it also makes it sensitive to variations in the uniformity of the cloud point density.

\section{Data Acquisition and Reconstruction Stages}

A survey network, composed of three geo-referenced tie points set with $150 \mathrm{~mm}$ circular targets, was established within the East garden site for geo-referencing the TLS data. Unfortunately, such survey network cannot be used for the geo-referencing of PG data. This is due to the inability of the surveyors (and the technologies employed) to simultaneously focus the camera on the wall and the tie point targets located in the garden. Therefore, a second survey network based on a different set of geo-referenced targets had to be established with $17 \mathrm{~cm}$ checkerboard patterns fixed to the walls. Both survey networks are shown in Figure 1. All measurements for the establishment of the networks were conducted using a Leica MS50 multistation.

To ensure a full coverage of the garden, three laser scans were acquired with TLS- 1 , with a resolution of $1.6 \mathrm{~mm}$ at a range of $10 \mathrm{~m}$. The three scans were then aligned using the TLS survey network, resulting in a unified clean point cloud containing 374 million points, including 180 million points from the rampart wall.

The same procedure was applied for the data acquisition using TLS-2, with three scans acquired at similar locations and with a resolution of $3 \mathrm{~mm}$ at $10 \mathrm{~m}$. The final unified point cloud contained 87 million points overall, and 51 million points for the rampart wall section. In this case, colour information has also been acquired using the Faro Focus 3D internal camera. 


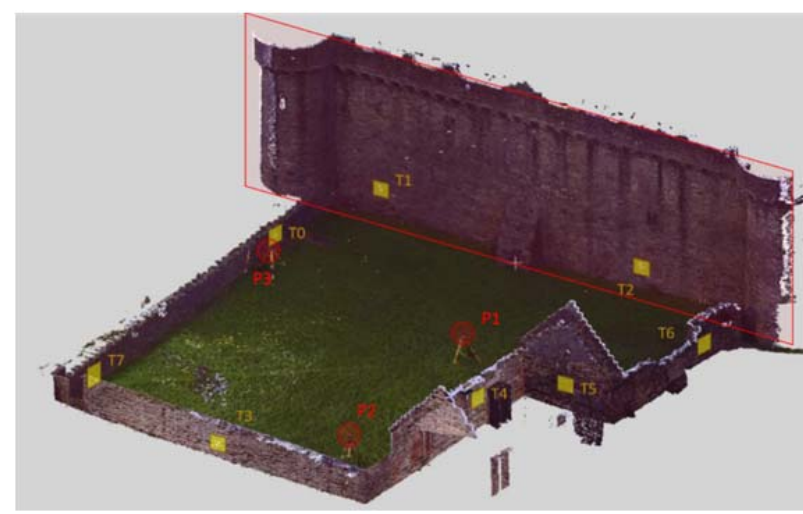

Figure 1: Point cloud of the East garden of Craigmillar Castle. The rampart wall is marked in red. The TLS survey network is illustrated in red, and the PG network in yellow.

Using the PG-1 system, 260 pictures were taken from many locations around the garden and with different orientation. The distance of the camera to the walls was kept to approximately $5 \mathrm{~m}$, with a few additional pictures taken at further distances. While some of the images were acquired with the camera hand-held, other images (specifically for the rampart wall) were acquired with the camera mounted on the pole and triggered using a mobile phone app. An overlap of $40-50 \%$ between adjacent photos was aimed for. The $3 D$ reconstruction was conducted using Agisoft PhotoScan v.1.1.6, delivering a dense point cloud containing 79 million points overall, including 51 million points for the rampart wall section. The PG-1 point cloud was scaled and georeferencing using the $P G$ survey network.

Using the PG-2 system, 460 pictures were acquired at similar distances to the walls. The pictures were then processed using the exact same procedures as for the PG-1 system, delivering a geo-referenced and scaled dense point cloud containing 34 million points overall, including 20 million points for the rampart wall section. The reconstruction process used for both photogrammetric reconstructions (PG-1 and PG-2) integrates the optimisation of the camera internal calibration, and this process is carried out using as initial values those provided by the manufacturers (EXIF information).

The point clouds corresponding to the rampart wall for all these reconstructions are shown in Figure 2. Note that the colour information was acquired with the TLS-2 system but not TLS-1 system. Nonetheless, colour information appears of significantly better quality for the PG systems.

\section{Results}

\subsection{Data Precision and Accuracy}

For the reporting and analysis of the results on the accuracy and precision of the systems, we focus on three areas of the rampart wall that we found were representative in highlighting the strengths and limitations of the different survey technologies regarding accuracy and precision. These areas are shown in Figure 3. Area 1 is an upper part of the wall, at 5 meters height and its dimensions are $4 \mathrm{~m} \times 2 \mathrm{~m}$. Area 2 is located just below at human height and has similar dimensions.
Finally, Area 3 covers a vertical region, with dimensions $2 \mathrm{~m} \times 6 \mathrm{~m}$.
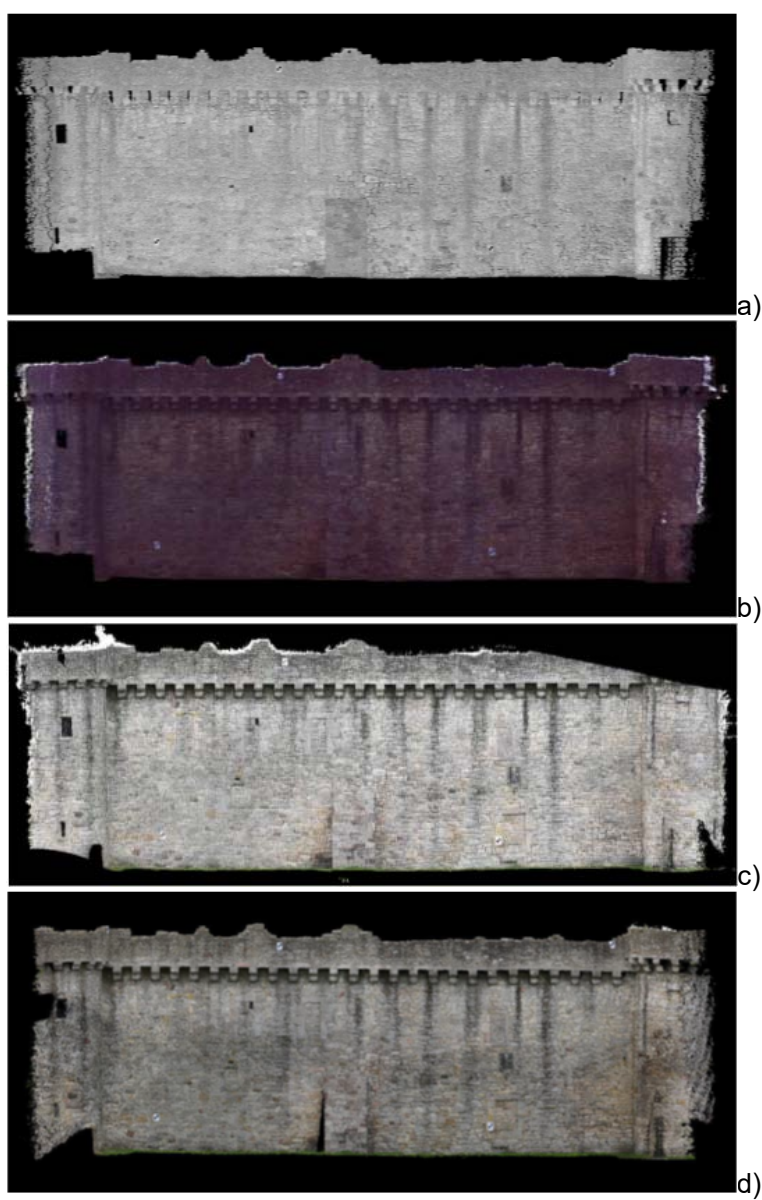

Figure 2: Wall reconstruction for the employed systems. (a) TLS-1, (b) TLS-2, (c) PG-1, (d) PG-2.

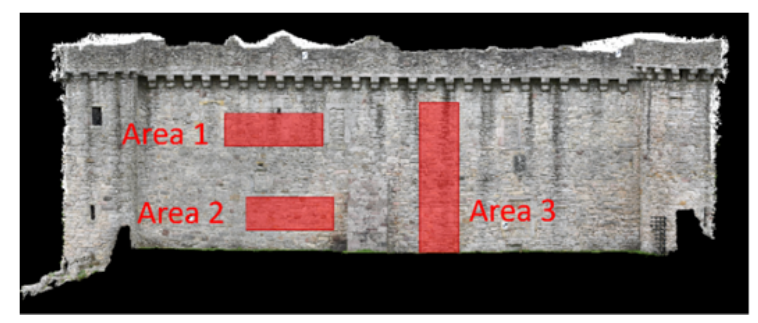

Figure 3: The three areas within the East rampart wall that are used for the assessment of performance in terms of accuracy and precision.

As previously mentioned, all the datasets were georeferenced by means of survey networks. Given the matches between the tie points in the survey networks and the corresponding points in the acquired point clouds, the geo-referencing errors are calculated for all devices and summarised in Table 1.

These results, together with the better specifications of the TLS-1 device in comparison with TLS-2, lead to the conclusion that TLS-1 indeed provides the data with the highest quality overall and so can be used as ground truth against which all other datasets can be compared. 
Table 1: Mean residual errors for the geo-referencing of the different devices.

\begin{tabular}{c|c} 
Device & Value (inch) \\
\hline TLS-1 & 1.53 \\
TLS-2 & 3.73 \\
PG-1 & 19.8 \\
PG-2 & 18.1
\end{tabular}

Figure 4 illustrates the results of the Hausdorff distance calculations for the three selected areas of the rampart wall, and Table 1 summarizes the mean and standard deviations of the Hausdorff distance for each case. As can be seen, the Hausdorff distances are smaller for the Faro TLS with a mean below $5 \mathrm{~mm}$ in both Areas 1 and 2. The mean distance for the PG-1 point cloud is only slightly higher and is thus remarkably good. In contrast, the results are disappointing for the PG-2 point cloud, with a mean between 10 and $20 \mathrm{~mm}$. The results are particularly poor for Area 1. But, we identified that this was due to the insufficient amount of overlap between neighbouring pictures acquired by the PG-2 system. The reasons for the poor performance of PG-2 are discussed further in Section 5.4 .

Area 3 was selected to assess the variation of the accuracy and precision with height for the different systems. It is interesting to note the relative uniformity of the Hausdorff distances along the height of the wall for the PG-2 data which highlights the advantage of UAV in terms of access, thereby ensuring consistent results. For the pole-mounted PG-1 system, the distances increase more significantly at the bottom, because fewer images were taken of the lower parts - the operator was focused on the coverage of the upper part of the wall that is less accessible and did not realise that an insufficient number of images would be taken for the lower part (e.g. taking pictures while on their knees). However, the height of the wall $(10 \mathrm{~m})$ seemed not to have been quite sufficient to show a similar pattern in the top part of the wall resulting from the limited extension of the pole. This suggests that even with a $5 \mathrm{~m}$ pole, good-quality data can still be obtained up to almost twice that height.

Overall, these results confirm that TLS devices provide more precise and accurate results than photogrammetric systems. But, the cheaper pole-mounted PG-1 system demonstrated comparatively good results, meaning that such a system can certainly be considered as a reliable alternative for the survey of stone walls.

Table 2: Mean $\left(\mu_{H}\right)$ and standard deviation $\left(\sigma_{H}\right)$ of the Hausdorff distance of the TLS-2, PG-1 and PG-2 point clouds against the TLS-1 point cloud, for the three selected Areas of the rampart wall.

\begin{tabular}{c|cc|cc|cc} 
Device & \multicolumn{2}{|c|}{ Area 1 $(\mathrm{mm})$} & \multicolumn{2}{c|}{ Area 2 $(\mathrm{mm})$} & \multicolumn{2}{|c}{ Area 3 $(\mathrm{mm})$} \\
& $\mu_{H}$ & $\sigma_{H}$ & $\mu_{H}$ & $\sigma_{H}$ & $\mu_{H}$ & $\sigma_{H}$ \\
\hline TLS-2 & 3.67 & 1.06 & 4.29 & 0.99 & 5.23 & 1.66 \\
PG-1 & 4.36 & 1.60 & 5.09 & 1.95 & 6.14 & 2.8 \\
PG-2 & 17.62 & 10.18 & 10.79 & 5.62 & 7.76 & 3.04
\end{tabular}

\subsection{Data Completeness}

Performance cannot be solely judged on data precision and accuracy. Another important criterion is data completeness, that assesses data point density and its uniformity. Table 3 summarizes the point density in the point clouds obtained for the entire rampart wall by means of the four different systems. Point density is calculated by projecting the reconstructed points on the wall plane and then calculating the density of points within that plane. As can be seen, the density is higher for the laser scanners, but again we note that the difference between the TLS-2 and PG-1 systems is really not that significant, which further confirms the potential of PG-1 system as an alternative 3D reality capture technology.

Table 3: The maximum density $\left(\operatorname{Max}_{D}\right)$, mean density $\left(\mu_{D}\right)$ and standard deviation $\left(\sigma_{D}\right)$ for the point clouds of the entire rampart wall obtained by the four reality capture systems.

\begin{tabular}{c|c|c|c} 
Device & MaxD $\left(p t s / \mathrm{cm}^{2}\right)$ & $\mu D\left(p t s / \mathrm{cm}^{2}\right)$ & $\sigma D\left(p t s / \mathrm{cm}^{2}\right)$ \\
\hline TLS-1 & 164 & 75.94 & 11.67 \\
TLS-2 & 49 & 22.99 & 3.88 \\
PG-1 & 31 & 16.09 & 3.05 \\
PG-2 & 23 & 7.54 & 2.29
\end{tabular}

\subsection{Process Efficiency}

An additional criterion for comparing performance between TLS and PG systems is efficiency. This is defined as the time required for acquiring and processing the data to obtain a unified geo-referenced dense 3D point cloud. Acquisition time comprises the positioning of the devices around the garden and the acquisition of points clouds (for TLS devices) or pictures (for PG systems). Processing includes data transfer, registration/geo-referencing, colourisation and data cleaning (removing spurious data).

Table 5 shows the approximate time recorded for each task for each survey system. Note that the processing operations have all been undertaken on the same computer (i7 $3.60 \mathrm{GHz}$ processor and $12 \mathrm{~GB}$ RAM). Regarding the acquisition stage, the scanning time appears significantly shorter for the TLS-1 than for the TLS-2. But, this is essentially due to the fact that no colour information was acquired during the TLS-1 scanning. If colour acquisition had been conducted, the acquisition times would likely have been similar. An important difference is noticeable between PG-1 and $P G-2$. This is due to two factors. First, the longer focal length selected for the PG 2 system led to the need to acquire many more images with the PG-2 system (to ensure sufficient overlap between neighbouring images). Then, the UAV could only work for 10-minute periods at a time, after which the UAV had to be landed to change its battery before resuming works. Combined, these two factors resulted in a significantly longer acquisition time than expected for the PG-2 system. The analysis of the performance of the PG-2 system is further discussed in Section 5.4 . 


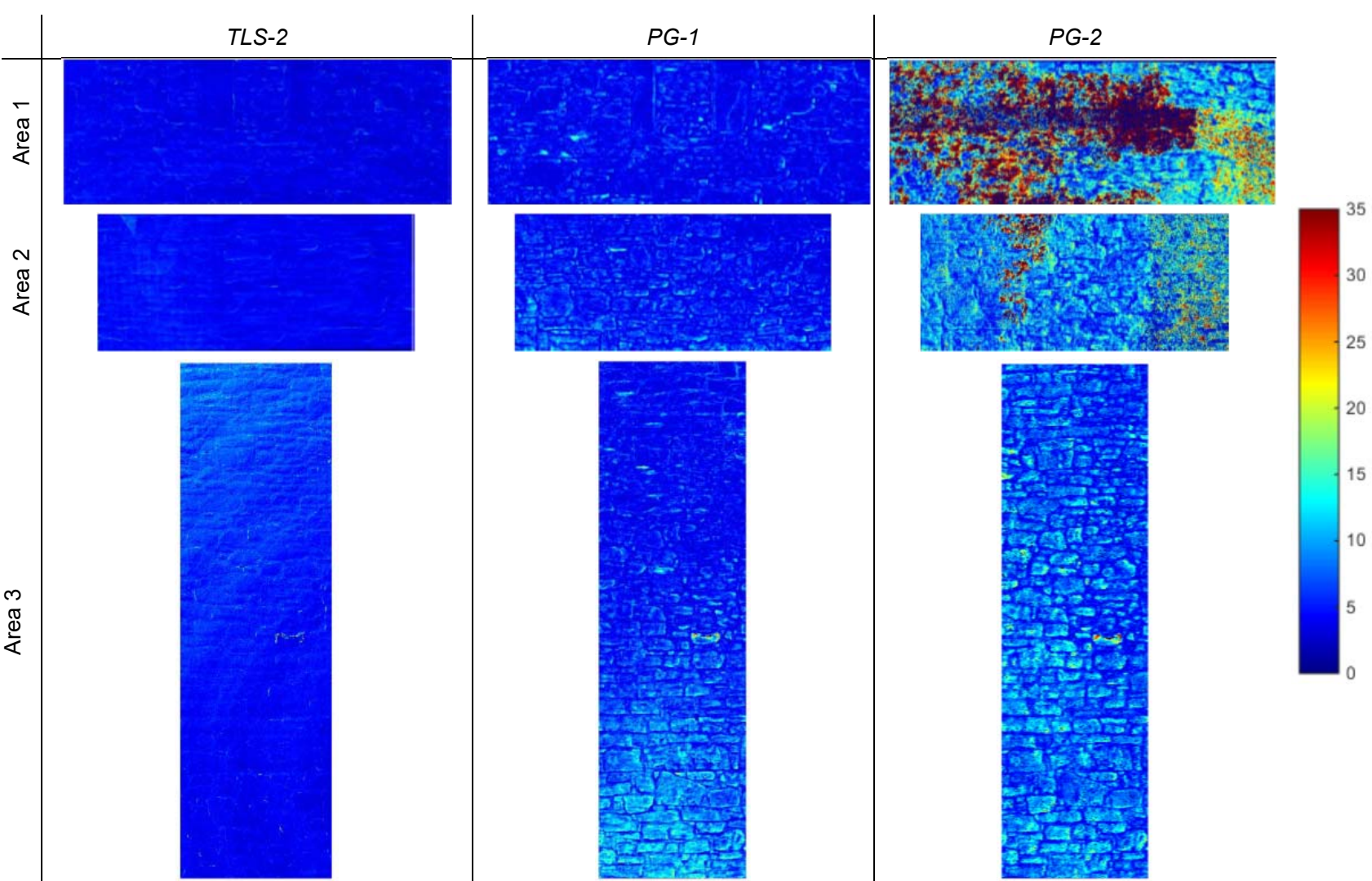

Figure 4: Hausdorff distance between Leica ScanStation P40 point cloud and the point clouds of Faro (left), Nikon (middle) and Sony (right) for the three selected Areas of the rampart wall.

Processing times are similar for all systems, despite the fact that they require different processing steps. The main observation is that processing times are in this case study often more than double the acquisition times, despite the use of a high-performance computer.

Table 4: Acquisition and pre-processing times for TLS and PG systems.

\begin{tabular}{|c|c|c|c|}
\hline & Acquisition & Processing & Total \\
\hline TLS-1 & $40^{\prime}$ & $3 \mathrm{~h}$ & 3h 40' \\
\hline TLS-2 & $1 \mathrm{~h} 30^{\prime}$ & 2 h $30^{\prime}$ & $4 \mathrm{~h}$ \\
\hline PG-1 & $30^{\prime}$ & 3 h $15^{\prime}$ & 3 h $45^{\prime}$ \\
\hline PG-2 & 1h $30^{\prime}$ & 3 h $15^{\prime}$ & 4 h $45^{\prime}$ \\
\hline
\end{tabular}

\subsection{Discussion of the Performance of the UAV-based PG System (PG-2)}

Reasonably good quality results were achieved with the PG-1 system, suggesting that in such contexts photogrammetric systems can be considered as viable alternatives to TLS. It was hoped that similar results would also be achieved with the PG-2 system that would have demonstrated its additional advantage in terms of access provision. Yet, the results achieved with the PG2 system were comparatively very poor and disappointing overall. It must however be qualified that, in some areas of the wall, the results obtained with the PG-2 system were as good (if not better) than those obtained with the PG-1 system. This section aims to discuss the reasons for these poor results observed in certain areas, highlighting the factors that contributed to getting those poor results, and how they could in fact have been obviated. This shall demonstrate that UAVbased PG systems do have great potential for the survey of stone walls, as long as the identified factors are adequately managed.

The local variability in the quality of the reconstruction obtained with the PG-2 has highlighted that (1) camera locations, and (2) camera properties and settings can signficantly impact the performance of those systems. PG-1 and PG-2 actually used different camera setups and camera positioning methods, which we believe altogether explain the poorer results achieved by PG-2.

Firstly, Table 5 shows that the camera settings of PG-1 and PG-2 differed in several ways. The PG-2 system did not use entirely manual settings, which led to images with varying ISO and F-stop values. But, an important difference is noticed in the lens's focal length. The focal length of PG-2 is three times larger than that of PG-1, which implies that the wall area covered by each picture taken by the PG-2 system was significantly smaller. The ground sampling distance (GSD) for each system can be obtained from the parameters presented in Table 5. For $P G-1, G S D=2 \mathrm{~mm}$; for PG-2, GSD=0.5mm. To ensure a sufficient amount of overlap between pictures, a significantly larger number of images was thus necessary. Although twice more pictures were indeed acquired using the PG-2 system compared to PG-1, this number appears to still have been insufficient. Indeed, the poor quality of the reconstructions achieved in the local areas of the rampart wall Area 1 and Area 2 visible in Figure 4 appears to directly correlate with a lower overlap between images acquired with the UAV in these areas, as can be seen in Figure 5. 
Table 5: Properties and settings of the cameras used in the two PG systems.

\begin{tabular}{c|c|c} 
Settings & $P G-1$ & $P G-2$ \\
\hline Size $(\mathrm{px})$ & $7360 \times 4912$ & $7360 \times 4912$ \\
Sensor (mm) & $35.9 \times 24$ & $35.9 \times 24$ \\
Focal length (mm) & 14 & 35 \\
F-stop & $\mathrm{f} / 8$ & $\mathrm{f} 4-\mathrm{f} / 8$ \\
ISO & 250 & $100-400$ \\
Shutter (s) & $1 / 125$ & $1 / 500$ \\
Number of pictures & 260 & 460 \\
Area of wall covered by the \\
camera at $5 \mathrm{~m}(\mathrm{~m})$
\end{tabular}

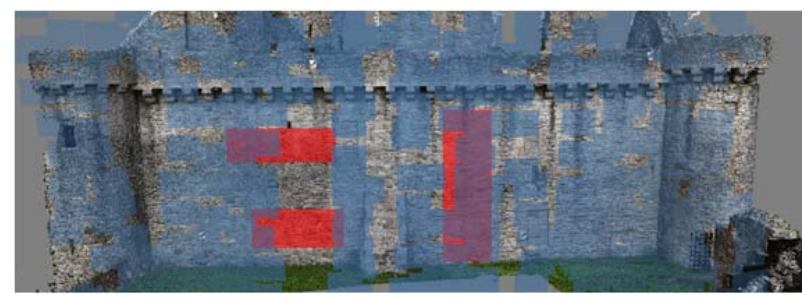

Figure 5: Camera locations (in blue) for the acquisition of data with the PG-2 system. The three areas of the wall used for the performance assessment are shown in red.

The PG 2 system operators may have expected that, by acquiring more images with a lens having a longer focal length, better results would be produced. But, they underestimated the full impact of a longer focal length on the number of images needed to be acquired. In this case, it seems that they should probably have acquired twice more pictures than they actually have (which would have further negatively influenced the acquisition time). Naturally, other factors may have influenced the results, such as the variable F-stop and ISO values. But, we found the PG-2 pictures to be of quality similar to that of the PG-1 system. This suggests that, thanks to their modern gimbals, UAVs can provide a reliable platform for the acquisition of images for photogrammetric purposes.

Overall, we believe that significantly better results (at least as good as PG-1) would have been obtained by using a lens with short focal length $(14-16 \mathrm{~mm})$ on the UAV-mounted camera (PG-2). A more general lesson drawn from this work is that careful planning should be considered to select the appropriate camera settings and picture density (and locations) to ensure accurate and reliable photogrammetric reconstruction. This process may be referred to as: Planning for Photogrammetry (P4P).

\section{Conclusions}

Terrestrial laser scanning and photogrammetry are increasingly used for building surveying, providing dense textured 3D point clouds (and meshes). In terms of geometry, data from TLS was found particularly accurate. While this was expected (since it had been shown by previous researchers), in the case study considered here the Faro Focus 3D scanner point clouds were close to the Leica ScanStation P40 ones. This similarity is interesting, although it must be remembered that these results are obtained at rather short ranges (maximum 10m) and the performance of the Faro scanner would be expected to deteriorate faster at larger distances.

While TLS clearly provides good geometric data to generate accurate and valuable $3 \mathrm{D}$ models, it also has three important limitations. First, TLS devices remain relatively expensive (tens of thousands of pounds per unit). Also, the cameras embedded within the scanners do not produce good quality colour information compared to what is achieved with common DSLR cameras. And finally, but still very importantly, current TLS devices have to be operated from stable positions, which reduces their mobility and the range of contexts within which they can be reliably employed.

In contrast, modern digital cameras are relatively cheap and very portable, making them suitable in a wider range of contexts. However, their main limitation is their variable performance depending on the level of texture in the scene being reconstructed. Nonetheless, we have shown that scenes like stone walls present great textures for the application of photogrammetry. In such contexts, photogrammetry can constitute a realistic alternative to TLS.

Mounting a camera on a UAV can further solve access issues. A copter-type UAV can fly around close to buildings and take pictures from different viewpoints without the need for any additional infrastructure (e.g. scaffolding). This theoretically extends the applicability of photogrammetry to significantly more contexts (e.g. without occluded areas, as was experienced with TLS). Unfortunately, this research was not able to fully demonstrate this. However, the analysis of the factors that led to the disappointing results obtained with the UAV-mounted PG system were 'simply' an inappropriate selection of lens and a correspondingly insufficient number of images acquired. The results showed the need for photogrammetric survey teams to have a good understanding of the photogrammetric process to establish effective data acquisition procedures. This suggests the need to establish robuts methods for Planning for Photogrammetry (P4P), which should be the focus of future investigations. But, the results reported here should not deter professionals from considering this otherwise valuable technology that could significantly reduce the cost and safety risks associated with access provision, in comparison with current solutions used for manual survey as well as the use of TLS systems.

Beyond the technical conclusions provided, this work also highlights that mixed adoption of technologies or specific technologies utilised for survey are potentially required. Their selection will depend upon weighted considerations for data precision, acquisition and processing efficiency, and health and safety grounds. The work shows that it is important that surveyors attempt to better understand the pros and cons of technologies adopted and realise that some will perform better than others in different contexts. It stresses that better dialogue between traditional surveyors and architects and specialist technologically-oriented survey operatives is required so that better understanding of expectations can be achieved by both parties. 


\section{Acknowledgements}

The writers are grateful to Historic Environment Scotland (HES) for funding this project, and Cyberhawk Innovations Ltd. for conducting the UAV-based survey.

\section{References}

BAY H., TUYTELAARS, T and VAN GOOL, L., 2006. SURF: Speeded Up Robust Features, Proceedings of the $9^{\text {th }}$ European Conference on Computer Vision, Part I, Graz, Austria, pp. 404-417.

CAPELLINI, V., STEFANI, C., NONY, N. and DE LUCA, L., 2012 Surveying Masonry Structures by Semantically Enriched 2.5D Textures: A New Approach. In M. IOANNIDES, D. FRITSCH, J. LEISSNER, R. DAVIES, F. REMONDINO and R. CAFFO, eds, Progress in Cultural Heritage Preservation, Vol. 7616 of Lecture Notes in Computer Science, Springer Berlin Heidelberg, pp. 729-737. DOI; 10.1007/978-3-642-34234-9_77

CARDACI, A., ROBERTI, G. M. and VERSACI, A., 2011. From the Continuous to the Discrete Model: a Laser Scanning Application to Conservation Projects. In Proceedings of the Congress of the International Society for Photogrammetry and Remote Sensing (ISPRS) 2011, Trento, Italy, pp. 437-444.

FARO, 2011. Faro Focus 3D 120 Specifications. Available: http://www.faro.com/products/3d-surveying/laser-scannerfaro-focus-3d [1/26, 2016].

HISTORIC SCOTLAND, 2011. Scottish Traditional Building Skills. Audit Scoping Exercise. Technical report, Historic Scotland.

HUTTENLOCHER, D., KLANDERMAN, G. and RUCKLIDGE, W., 1993. Comparing Images Using the Hausdorff Distance. IEEE Transactions on Pattern Analysis and Machine Intelligence 15(9), pp. 850-863. DOI: 10.1109/34.232073.

KOUTSOUDIS, A., VIDMAR, B., IOANNAKIS, G., ARNAOUTOGLOU, F., PAVLIDIS, G. and CHAMZAS, C., 2014. MultiImage 3D Reconstruction Data Evaluation. Journal of Cultural Heritage 15, pp. 73-79. DOI: doi:10.1016/j.culher.2012.12.003.

LEICA GEOSYSTEMS, 2015. Leica ScanStation P30/P40 Specifications. Available: http://w3.leicageosystems.com/downloads123/hds/hds/general/brochures-datasheet/Leica ScanStation P30P40 Plant DS en.pdf $[1 / 26,2016]$.

LERMA, J. and MUIR, C., 2014. Evaluating the 3D Documentation of an Early Christian Upright Stone with Carvings from Scotland with Multiples Images. Journal of Archaeological Science 46, pp.311-318. DOI: doi:10.1016/j.jas.2014.02.026.

LOWE, D., 1999. Object Recognition from Local Scale-Invariant Features. In Proceedings of the Seventh International Conference on Computer Vision, 1999, Kerkyra, Greece, Vol. 2, pp. 1150-1157.

MUELLER, G., ROBERTSON, J., LEADBETTER, C., LAING, N., MCMENEMY, M. and KYRIAKOU, A., 2014. Scottish House Conditions Survey 2013. Key Findings. Technical report, Directorate for Housing, Regeneration and Welfare. Scottish Government.

NETTLEY, A., ANDERSON, K., DESILVEY, C. and CASELDINE, C., 2011. Using Terrestrial Laser Scanning and LIDAR Data for Photo-Realistic Visualization of Climate Impacts at Heritage Sites. International Archives of Photogrammetry, Remote Sensing and Spatial Information Sciences, 38, pp. 223-229. DOI: 10.5194/isprsarchives-XXXVIII-5-W16223-2011.

OGLEBY, C. L., 1995. Advances in the Digital Recording of Cultural Monuments. ISPRS Journal of Photogrammetry and Remote Sensing 50(3), 8 - 19. DOI:10.1016/0924-2716(95)91286-S.

PUSCHEL, H., SAUERBIER, M. and EISENBEISS, H., 2008. A 3D Model of Castle Landenberg (CH) from Combined Photogrammetric Processing of Terrestrial and UAV-Based Images. International Archives of the Photogrammetry, Remote Sensing and Spatial Information Sciences, 37, pp. 93-98.

RASZTOVITS, S. and DORNINGER, P., 2013. Comparison of 3d Reconstruction Services and Terrestrial Laser Scanning for Cultural Heritage Documentation. XVI International CIPA Symposium, 2013, Strasbourg, France, Vol. 1, pp. 513-518.

REMONDINO, F., 2011. Heritage Recording and 3D Modeling with Photogrammetry and 3D Scanning. Remote Sensing 3, pp. 1104-1138. DOI: 10.3390/rs3061104.

REMONDINO, F., BARAZZETI, L., NEX, F., SCAIONI, M. and SARAZZI, D., 2011. UAV Photogrammetry for Mapping and 3D Modeling - Current Status and Future Perspectives. International Archives of the Photogrammetry, Remote Sensing and Spatial Information Sciences, 38, pp. 25-31.

SCHERMERHORN, W., 1940. Draft for an International Bibliography of Photogrammetry, Photogrammetria 3(3), pp. 116 - 119. DOI: 10.1016/S0031-8663(40)80036-7. 
SKARLATOS, D. and KIPARISSI, S., 2012. Comparison of Laser Scanning, Photogrammetry and Sfm-Mvs Pipeline Applied in Structures and Artificial Surfaces. ISPRS Annals of Photogrammetry, Remote Sensing and Spatial Information Sciences, Vol. I-3, pp. 299-304.

STRECHA, C., TYUTELAARS, T. and VAN GOOL, L., 2003. Dense Matching of Multiple Wide-baseline Views. In Proceedings of International Conference on Computer Vision, ICCV 2003, Nice, France, Vol. 2, pp. 1194 - 1201.

TEMIZER, T., NEMLI, G., EKIZCE, E., EKIZCE, A., DEMIR, S., BAYRAM, A., COBANOGLU, A. V. and YILMAZ, H. F., 2013. 3D Documentation of a Historic Monument Using Terrestrial Laser Scanning Case Study: Byzantine Water Cistern, Istanbul. In XXIV International CIPA Symposium, 2013, Strasbourg, France, pp. 623-628.

THORNBUSH, M. J. and VILES, H., 2008. Photographic Monitoring of Soiling and Decay of Roadside Walls in Central Oxford, England, Environmental Geology 56(3-4), pp. 777-787. DOI: 10.1007/s00254-008-1311-3.

WILSON, L., RAWLINSON, A., MITCHELL, D., MCGREGOR, H. and PARSONS, R., 2013. The Scottish Ten Project: Collaborative Heritage Documentation. In XXIV International CIPA Symposium, Strasbourg, France, pp. 685-690.

XU, Z., WU, L., SHEN, Y., LI, F., WANG, Q. and WANG, R., 2014. Tridimensional Reconstruction Applied to Cultural Heritage with the Use of Camera-Equipped UAV and Terrestrial Laser Scanner. Remote Sensing 6, pp. 1041310434. DOI: $10.3390 /$ rs61110413. 


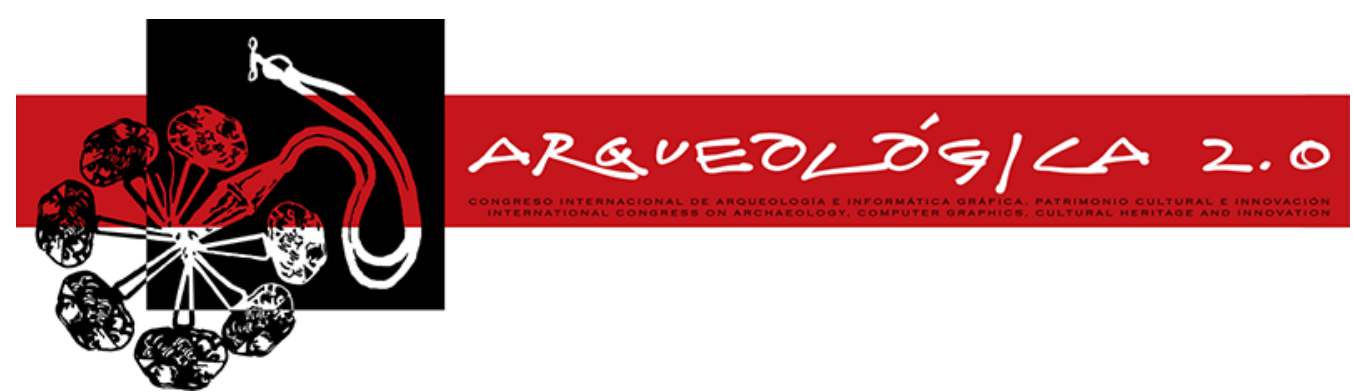

Proceedings of the $8^{\text {th }}$ International Congress

on Archaeology,

Computer Graphics,

Cultural Heritage and Innovation

'ARQUEOLÓGICA 2.0'

in Valencia (Spain),

Sept. $5-7,2016$

DOI: http://dx.doi.org/10.4995/arqueologica8.2016.2950

Received: $16 / 02 / 2016$

Accepted: 05/04/2016

\title{
RECUPERACIÓN GRÁFICA DE LA MÁQUINA EÓLICA PARA DESAGUAR TERRENOS PANTANOSOS DE AGUSTÍN DE BETANCOURT Y MOLINA: MODELADO TRIDIMENSIONAL Y DOCUMENTACIÓN GEOMÉTRICA CON SOLID EDGE
}

\author{
GRAPHICAL RECOVERY OF THE AGUSTIN DE BETANCOURT'S WIND MACHINE TO DRAIN MARSHY \\ GROUNDS: 3D MODELING AND GEOMETRIC DOCUMENTATION WITH SOLID EDGE \\ José Ignacio Rojas-Sola ${ }^{a,}{ }^{,}$, Laura García-Ruesgas ${ }^{b}$, José Porras-Galán ${ }^{c}$ \\ a Departamento de Ingeniería Gráfica, Diseño y Proyectos, Universidad de Jaén, Campus de las Lagunillas s/n, 23071 Jaén, España. \\ jirojas@ujaen.es \\ ${ }^{\mathrm{b}}$ Departamento de Ingeniería Gráfica, Universidad de Sevilla, Isla de la Cartuja, Camino de los Descubrimientos s/n, 41092 Sevilla, \\ España. lauragr@us.es \\ ${ }^{\text {c }}$ Departamento de Ingeniería Mecánica, Universidad Pontificia Comillas, Alberto Aguilera 23, 28015 Madrid, España. \\ iporras@icai.comillas.edu
}

\begin{abstract}
:
Agustín de Betancourt and Molina was one of the most distinguished engineers of the eighteenth and nineteenth century with numerous contributions to various fields of engineering, including civil engineering. This research shows the process followed in the documentation of the cultural heritage of that canary engineer, especially in the geometric documentation of the wind machine to drain marshy grounds designed in 1789. The baseline information has been recovered from the Canary Orotava Foundation of History of Science who has spent years collecting information about the Project Betancourt, in particular, planimetric information as well as a small report on its operation and description of parts of machine. From this information, we have obtained its 3D reconstruction using CAD techniques with the cooperation of Solid Edge ST7 parametric software, which has enabled to obtain the 3D model as well as different detail plans and exploded views.
\end{abstract}

Key words: cultural heritage, geometric documentation, 3D reconstruction, Agustín de Betancourt y Molina, wind machine to drain marshy grounds

\section{Resumen:}

Agustín de Betancourt y Molina fue uno de los más ilustres ingenieros del siglo XVIII y XIX, siendo muy numerosas sus aportaciones a diferentes ámbitos de la ingeniería, en particular a la ingeniería civil. La presente investigación muestra el proceso seguido en la documentación del patrimonio cultural del citado ingeniero canario, en particular, en la documentación geométrica de la máquina eólica para desaguar terrenos pantanosos que diseñó en 1789. La información de partida se ha podido rescatar de la Fundación Canaria Orotava de Historia de la Ciencia que lleva años recopilando información sobre el Proyecto Betancourt, en concreto, se ha dispuesto de información planimétrica así como de una pequeña memoria sobre su funcionamiento y descripción de las partes del ingenio. A partir de dicha información, se ha obtenido su reconstrucción 3D, mediante técnicas CAD gracias al uso del software paramétrico Solid Edge ST7, lo que ha posibilitado la obtención del modelo 3D así diferentes planos de detalle y perspectivas estalladas.

Palabras clave: patrimonio cultural, documentación geométrica, reconstrucción 3D, Agustín de Betancourt y Molina, máquina eólica para desaguar terrenos pantanosos

`Corresponding Author: José Ignacio Rojas-Sola, jirojas@ujaen.es 


\section{Introducción}

\subsection{Breve reseña biográfica}

Muchas son las publicaciones relacionadas con Agustín de Betancourt y Molina que presentan una visión global de su biografía y obra (AA.VV 1996, 2009; Bogoliúbov 1969, 1973; Cioranescu 1965; Martin 2006; Muñoz 2008; Padrón 1958), permitiendo realizar una breve reseña biográfica.

Agustín de Betancourt y Molina fué un celebre ingeniero canario nacido en la población tinerfeña del Puerto de la Cruz en 1758 y fallecido en la ciudad rusa de San Petersburgo en 1824. Sus aportaciones a diferentes ámbitos de la ingeniería han sido muy numerosas, destacando aquellas que tienen que ver con la ingeniería civil.

Su comienzo como inventor se produce en 1778 con el diseño de una máquina epicilíndrica para entorchar seda, presentada en la Sociedad Económica de la Laguna. En ese año, parte a Madrid para estudiar en los Reales Estudios de San Isidro. Ya en 1783 recibe diversos encargos para la Corona, como la inspección del Canal Imperial de Aragón o el estudio de las Minas de Almadén.

En 1784 marcha a la Escuela de Puentes y Caminos de París para realizar estudios de hidráulica y mecánica y a diseñar máquinas para el Real Gabinete de Máquinas cuya creación se produjo en Madrid en 1792. Mientras tanto, en 1788 viaja a Inglaterra para observar la máquina de vapor de doble efecto, y a su vuelta a París en 1789 escribe la memoria sobre una máquina de vapor de doble efecto mejorada, comenzando su época más productiva. Así pues, desarrolla un telar mecánico, la máquina para desaguar terrenos pantanosos, y escribe la memoria sobre la fuerza expansiva del vapor de agua, el estudio sobre la manera de fundir y barrenar cañones de hierro o la memoria sobre una draga mecánica.

En 1792 se inaugura el Real Gabinete de Máquinas del que es nombrado Director, publicando el primer catálogo de modelos, planos y manuscritos que contiene 270 máquinas, 358 planos y más de 100 memorias con 92 gráficos, diseñados todos ellos en su estancia en París. Posteriormente, en 1795 presenta en Inglaterra el diseño de la máquina para cortar la hierba de los canales navegables, en 1796 el prototipo y los planos de un telégrafo óptico junto a Breguet, y en 1797 patenta una prensa hidráulica para uso industrial junto a Perier.

De regreso a España, es nombrado Director General de Puertos y Caminos, y en 1802 se crea la primera Escuela de Ingenieros de la que fue su primer Director. En 1803 escribe junto a José María Lanz el ensayo sobre la composición de las máquinas, viajando posteriormente a París para presentar en la Academia de Ciencias la memoria sobre un nuevo sistema de navegación interior que incluía el diseño de una nueva esclusa de émbolo buzo, así como el diseño de un termómetro metálico junto a Breguet.

Ya en 1807 viaja a San Petersburgo por invitación del Zar Alejandro I siendo nombrado Mariscal quedando adscrito al Consejo Asesor del Departamento de Vías de Comunicación, y posteriormente es nombrado Inspector del Instituto del Cuerpo de Ingenieros, y en 1819,
Director del Departamento de Vías de Comunicación. En esta última etapa de su vida, desarrolla una intensa labor como ingeniero de caminos con obras como el puente sobre el río Nevka, la fábrica de armas de Tula, la fábrica de cañones de Kazan, la draga mecánica del puerto de Krondstadt, la columna de Alejandro I, el canal Betancourt de San Petersburgo, la fábrica de papel moneda, la navegación a vapor en el Volga, o diferentes sistemas de abastecimiento de aguas o ferrocarriles, entre obras públicas.

\subsection{Objetivos}

La investigación presentada en esta comunicación es el principio de una más completa en el que se abordarán otros aspectos relacionados como la realización de una recreación virtual y el análisis estático realizado sobre el modelo 3D con herramientas de ingeniería asistida por ordenador, mostrando en estudios previos la estructura a seguir (Villar-Ribera et al. 2011).

Por ello, el objetivo principal de esta comunicación es la restitución digital de un modelo $3 \mathrm{D}$ preciso así como la documentación geométrica del ingenio desarrollado, obteniendo diversas perspectivas de cada uno de los subsistemas considerados, sobre los que poder obtener resultados fidedignos de los aspectos antes mencionados.

\section{Material y métodos}

El material de partida ha sido únicamente la información disponible en el Proyecto digital Agustín de Betancourt de la Fundación Canaria Orotava de Historia de la Ciencia promovido por el Centro de Estudios Históricos de Obras Públicas y Urbanismo (CEHOPU), el Centro de Estudios y Experimentación de Obras Públicas (CEDEX), el Ministerio de Fomento y la Fundación Juanelo Turriano (Proyecto Digital Betancourt 2016).

El objetivo del mismo es la recuperación, digitalización y puesta en Internet de su obra, tales como memorias, informes, publicaciones, dibujos, planos, cartas personales o reproducciones de maquetas de máquinas o edificios de su autoría.

En particular, la presente investigación se ha realizado apoyándose en el material que aparece en dicho sitio web (Expediente de la máquina eólica para desaguar terrenos pantanosos 2016)

En dicha web, se muestra la información relacionada con dicho expediente titulado 'Sur le nouveau moulin à vent', datado de 1789 y con el número de manuscrito 1487.

Toda la información de dicho expediente fue cedida para su digitalización por la Escuela Nacional de Puentes y Caminos de la Universidad ParisTech.

En realidad, dicho manuscrito es una carpeta que contiene documentos de Gaspard Riche de Prony, aunque examinando la misma, se encuentran dos dibujos y un texto titulado 'Troisième note sur les moulins à vent' de Monsieur Menault del que se desconoce su relación con la obra de Betancourt.

Sin embargo, en la lámina 5 del 'Essai sur la composition des machines', la figura M 7' coincide con la vista frontal de dicha máquina que corresponde con el 
segundo dibujo de este manuscrito. Por otro lado, en el Catálogo del Real Gabinete de Máquinas, el modelo 153 dice lo siguiente "...de una maquina movida por el viento (cuyas aspas son verticales) para sacar agua de un pozo por medio de dos cántaros que suben y bajan alternativamente. Inventada por Don Agustín de Betancourt".

Esto demostraría que efectivamente el autor de este invento fue el ingeniero canario.

La Figura 1 muestra una serie de vistas principales de dicha máquina (alzado, perfil y perspectiva caballera) junto a otros detalles que son mostrados más claramente en la Figura 2, concretamente una vista superior del sistema de rotación vertical y una perspectiva caballera del regulador de llenado de las artesas.

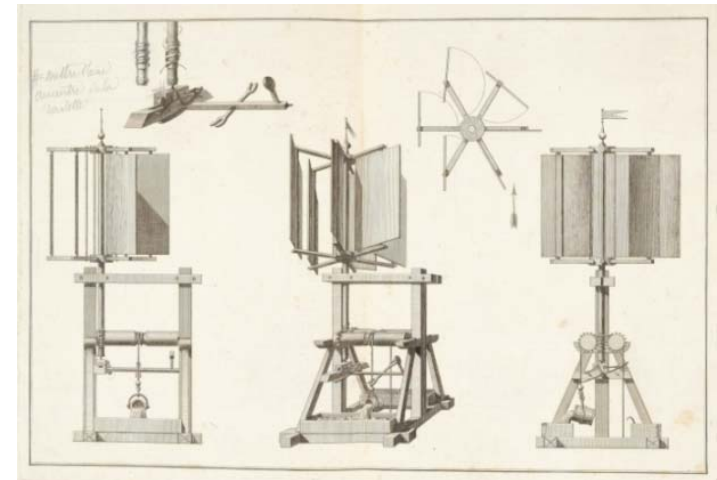

Figura 1: Vistas de alzado, perfil y perspectiva de las máquina. Imagen de la "Fundación Canaria Orotava de Historia de la Ciencia".

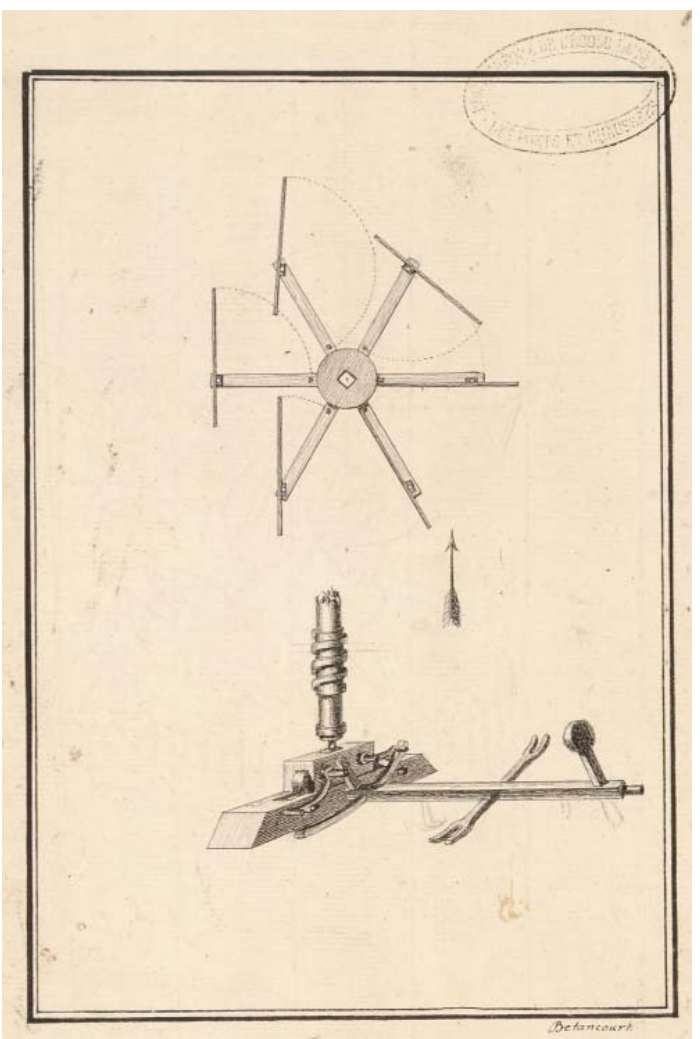

Figura 2: Vista superior del sistema de rotación vertical y perspectiva del regulador de llenado de las artesas. Imagen de la "Fundación Canaria Orotava de Historia de la Ciencia".
Sin embargo, el texto de dicho expediente corresponde a otra invención diferente que la objeto de estudio en esta comunicación, por lo que sólo se dispone de las dos láminas sin escala mostradas en la misma (Figs. 1 y 2).

Esta situación hará necesario el establecimiento de diversas suposiciones tanto de geometría como de funcionamiento de los diversos elementos que componen dicha máquina eólica, que se explicarán detalladamente en el siguiente apartado.

La metodología empleada ha sido la restitución digital del modelo 3D utilizando como herramienta Solid Edge ST7, software paramétrico de diseño asistido por ordenador desarrollado por Siemens AG, y cuya última versión estable data de julio de 2014 (Tickoo 2015).

Su kernel de modelado geométrico era inicialmente ACIS, pero fue cambiado a Parasolid desarrollado por Siemens PLM Software, y es utilizado como motor geométrico de otras muchas herramientas de CAD (del inglés, Computer-Aided Design).

A continuación, se describe con detalle el proceso de modelado de cada una de las piezas de la máquina, así como el proceso de ensamblado de las mismas para formar el conjunto, con explicación de las restricciones aplicadas, y las ventajas, inconvenientes y dificultades obtenidas en dicho proceso.

\section{Resultados y discusión}

\subsection{Consideraciones generales}

Para llevar a cabo el modelado tridimensional del mecanismo en estudio se han tenido en cuenta una serie de consideraciones generales que se especifican en los siguientes párrafos.

Dado que la información inicial de la que se ha partido no cumple los estándares modernos, no resulta factible considerar los documentos disponibles como planos de fabricación actuales, tal y como se interpretan hoy en día. Hay que tener en cuenta además, que en aquella época no existía normativa alguna. Cada ingeniero representaba sus invenciones como consideraba más adecuado, intentando plasmar el concepto de diseño fundamentalmente, quedando sin resolver por completo los problemas de fabricación y funcionamiento. Por esta razón, las dimensiones de algunos elementos presentan pequeñas incongruencias en algunas de las representaciones.

Por este motivo, al representar la geometría de este mecanismo ha resultado necesario efectuar alguna hipótesis dimensional basada en cómo se podría fabricar y cómo podría funcionar en aquella época. Queda abierta la posibilidad de efectuar un estudio en mayor profundidad sobre la relación existente entre las técnicas de fabricación de entonces y el diseño detallado de las piezas.

El modelado de este mecanismo se ha dividido en tres partes: la estructura soporte del mecanismo, el sistema de rotación vertical, y el mecanismo regulador de llenado de las artesas.

En el estudio de las uniones entre piezas se han considerado básicamente las uniones fijas (ajuste con 
aprieto) y móviles (ajuste móvil) que permiten el giro. Las dimensiones de éstas se han calculado a partir de los valores tomados directamente de las láminas, buscando minimizar la variedad de los mismos en todo el conjunto. No se han modelado las roscas de estas uniones puesto que en aquella época no había ni tornillos ni tuercas iguales, ya que eran fabricados de forma artesanal y variaban tanto en tamaño como en diámetro de la rosca, así como en la separación de la misma.

Tampoco se han considerado las tolerancias de montaje entre cada una de las distintas piezas porque la fabricación artesanal de este mecanismo obliga a que sea el propio artesano quien realice los ajustes necesarios durante el proceso de fabricación.

\subsection{Modelado de la estructura soporte del mecanismo}

La estructura soporte de toda la maquinaria se muestra en la Figura 3. Esta estructura, fabricada completamente con madera y modelada como una pieza única, consta de una base aproximadamente rectangular sobre la que se asientan dos pilares verticales más cuatro pilares inclinados que permiten reforzar el conjunto. Sobre los pilares verticales, se sitúan dos vástagos horizontales cuya función es hacer de guía al eje del sistema de rotación vertical.

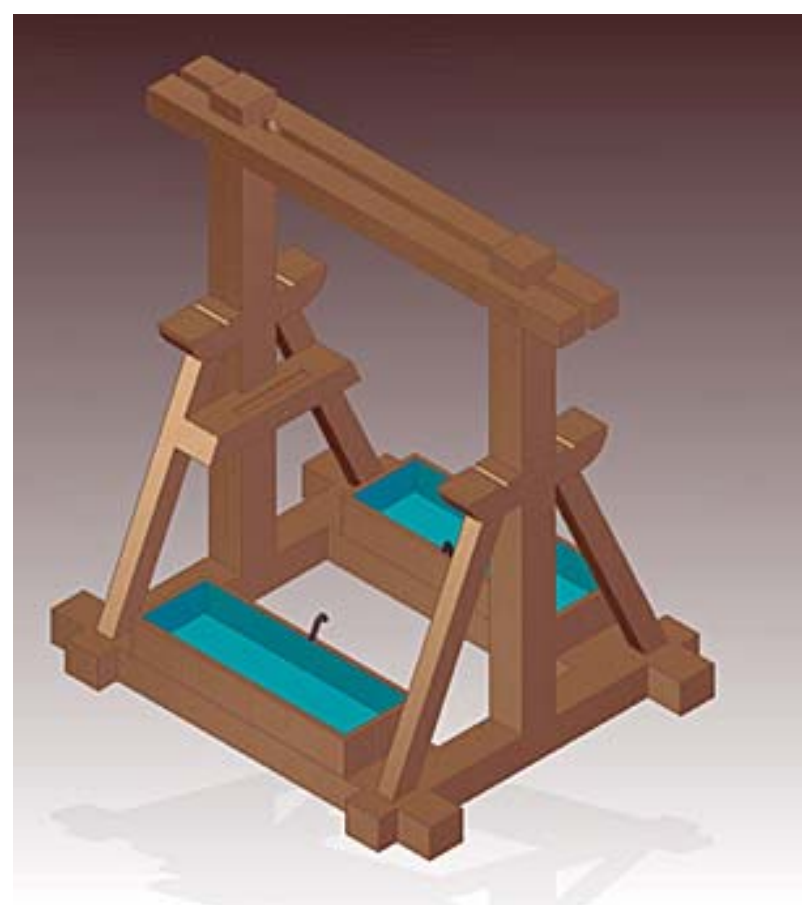

Figura 3: Vista general de la estructura soporte de la máquina.

Asimismo, se han añadido a esta estructura algunos elementos, que por su simplicidad y porque no son determinantes en el funcionamiento de la máquina, se consideran parte de la misma. Estos son: dos artesas que permiten almacenar el agua recogida y dos elementos con forma de gancho que facilitan que el movimiento de traslación de los cántaros se transforme en un giro, permitiendo así verter el agua dentro de las artesas.
Además esta estructura contiene dos elementos con forma de bañera (Fig. 4) que sirven de soporte para los dos tambores cilíndricos, fundamentales en el funcionamiento de esta invención. Por último, se ha considerado también como parte de esta estructura, un elemento con forma trapezoidal (Fig. 4), dispuesto horizontalmente que sirve de base de uno de los elementos imprescindibles del regulador de llenado de las artesas. Toda la estructura de este mecanismo es de madera.

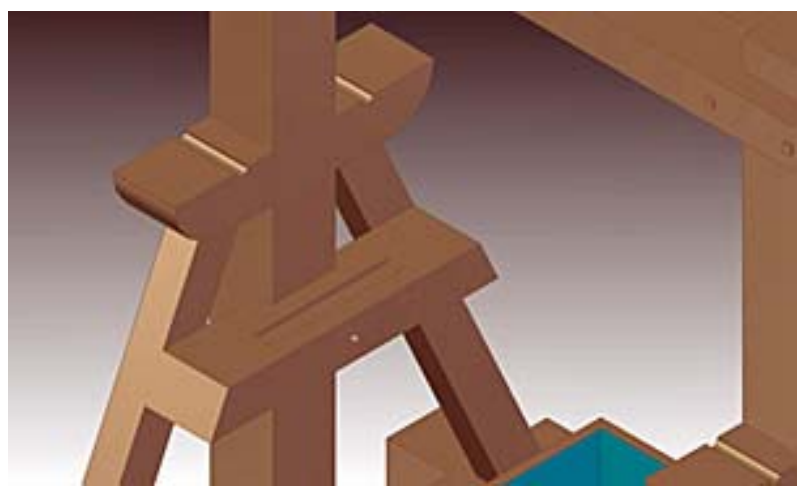

Figura 4: Detalle de base de leva y soporte de tambor cilíndrico.

\subsection{Modelado del sistema de rotación vertical}

Las piezas que componen este sistema (Fig. 5) comprenden un eje vertical con un tornillo solidario en su parte inferior en el que encajan dos estructuras cilíndricas rodeadas de seis vástagos cada una de ellas a modo de aspa y que se han modelado como una única pieza. En el interior de cada uno de los vástagos con agujeros en los dos extremos, se acoplan seis varillas cilíndricas también en sus extremos y seis paneles (a semejanza de las aspas de un molino) respectivamente.

Los paneles se han modelado como elementos rectangulares que presentan un saliente con forma prismática de sección también rectangular y con un cilindro en cada extremo (Fig. 6).

El conjunto se completa con un detalle decorativo constituido por superficies cilíndricas, cónicas y esféricas, además de un elemento con forma de embudo y una bandera. Todos los elementos de este sistema son de madera, excepto el tornillo de la parte inferior del eje que debe ser de un material más resistente al desgaste, por ejemplo de hierro fundido, ya que engrana con una corona mientras funciona la máquina eólica.

Por otro lado, el eje debe ser flexible, es decir, debe permitir un cierto pandeo, por lo que es imprescindible que se fabrique con una madera flexible. Asimismo, la función de las varillas es impedir un giro libre de los paneles, de forma que estos se accionan con la energía eólica obtenida del viento y comienzan a girar hasta que se encuentran con la varilla como obstáculo, haciendo girar de esta manera al eje vertical. Por otra parte, la estructura cilíndrica superior es solidaria al eje, girando ambos al mismo tiempo, ya que encajan a través de un agujero con forma cuadrada, siendo lógicamente el ajuste entre ambos, un ajuste con aprieto. 


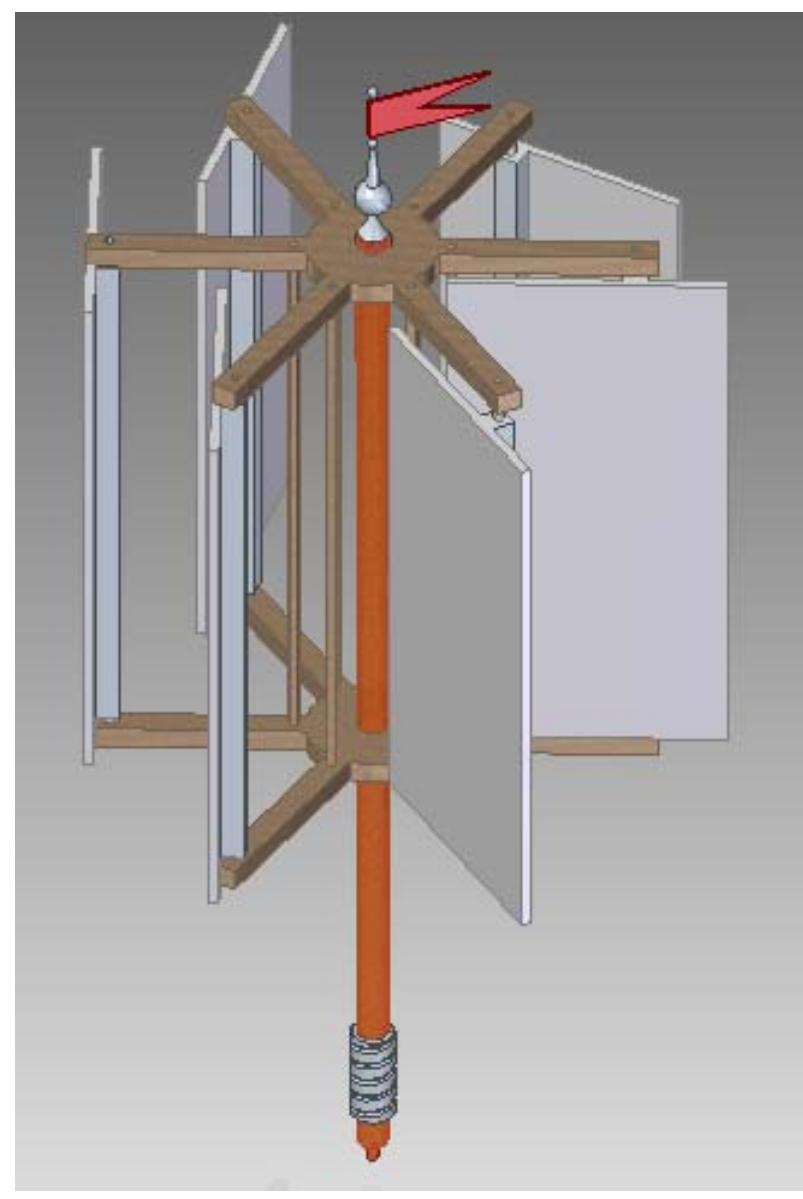

Figura 5: Sistema de rotación vertical de la máquina eólica.

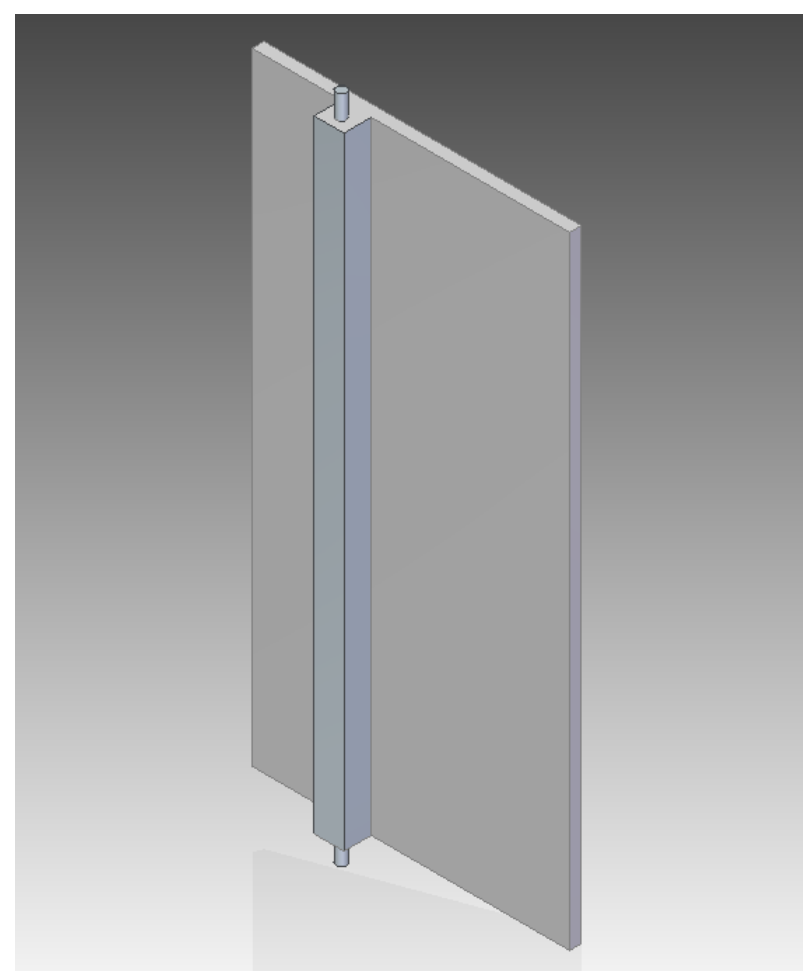

Figura 6: Panel del sistema de rotación vertical.
En la Figura 7 se muestra una representación en planta de este sistema observándose la posición que ocupan los paneles a medida que van girando.

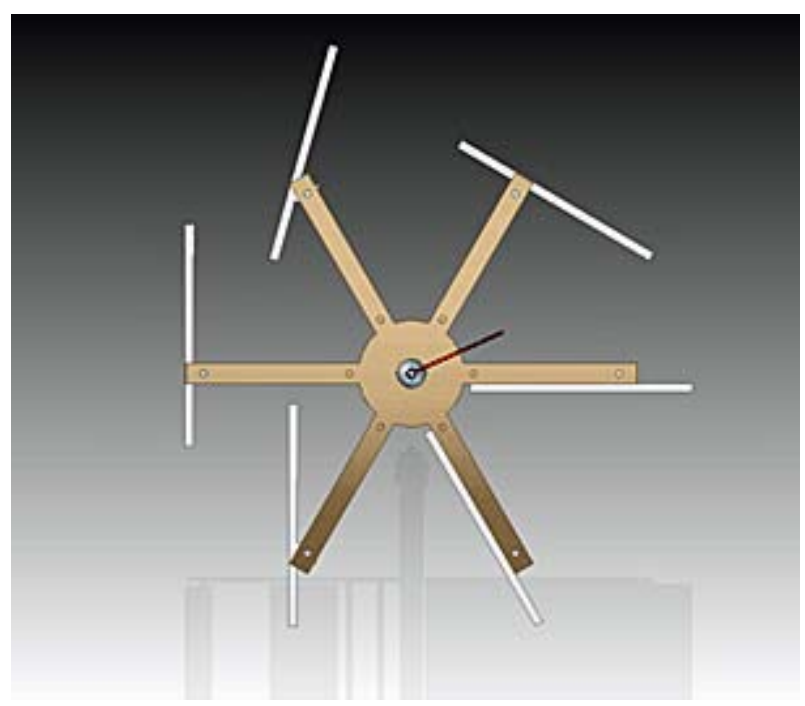

Figura 7: Representación en planta del sistema de rotación vertical.

\subsection{Modelado del mecanismo regulador de llenado de las artesas}

La Figura 8 muestra una perspectiva axonométrica dimétrica del mecanismo regualdor de llenado de las artesas, y en la Figura 9 se muestra una vista de alzado del mismo. Dicho mecanismo está compuesto principalmente por dos tambores cilíndricos que poseen una rueda dentada solidaria en uno de sus extremos (corona), engranando los mismos con el tornillo vertical mencionado en el apartado 3.3, y realizando las funciones propias del mecanismo de un tornillo sinfín y corona (Fig. 10).

Al igual que ocurre con el tornillo, la corona también sería de hierro fundido para evitar un desgaste excesivo. Por otro lado, el dentado se ha modelado de forma aproximada, ya que por el momento no se ha planteado realizar una simulación exacta del comportamiento de los dientes al carecer de información geométrica detallada de los mismos.

Estos elementos se utilizan para transmitir movimiento entre dos ejes perpendiculares, de forma que cuando el tornillo gira, también lo hace la rueda que engrana con él. En este caso, por cada vuelta que da la rueda, el tornillo da dieciséis vueltas, tantas como dientes tiene la rueda, siendo este mecanismo irreversible porque sólo el tornillo puede mover a la rueda. Por tanto, la rotación de la rueda provoca el desplazamiento vertical de los cántaros unidos a una cuerda enrollada alrededor de los tambores, de forma que cuando un cántaro sube, el otro baja.

Debajo de los tambores, y solidario a la estructura, se ubica un eje de sección cuadrada y extremos cilíndricos (Fig. 11) que presenta tres cavidades, también de sección cuadrada, en las que se alojan dos elementos con forma de tenedor, y uno a modo de péndulo. En el extremo opuesto al péndulo, se sitúa un elemento con forma muy similar a la de una chaveta que ejerce las funciones de tope y dos piezas con forma de arco. 


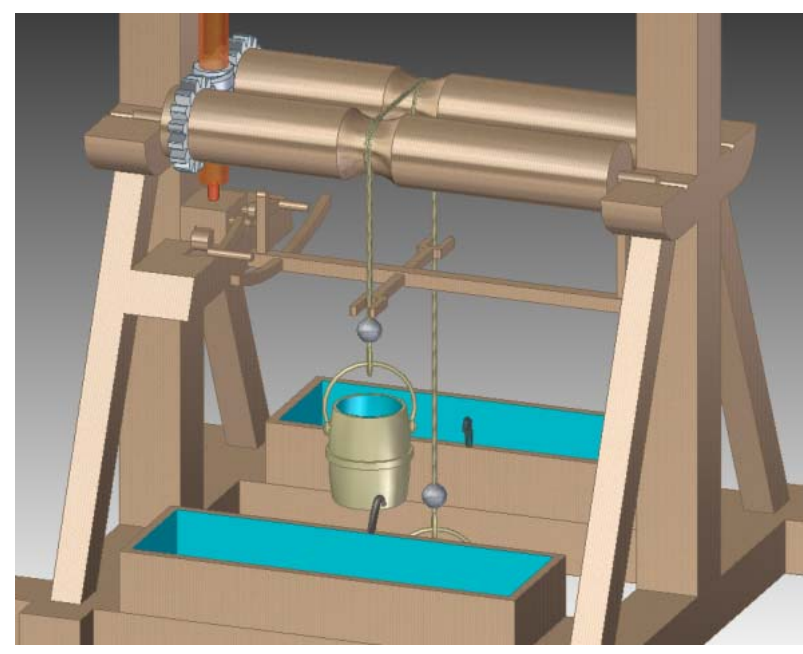

Figura 8: Perspectiva axonométrica dimétrica del regulador.

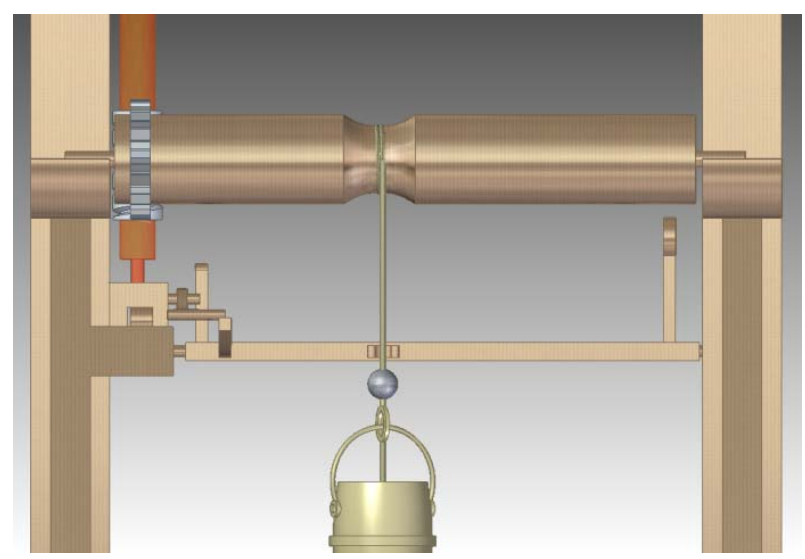

Figura 9: Vista de alzado del regulador.

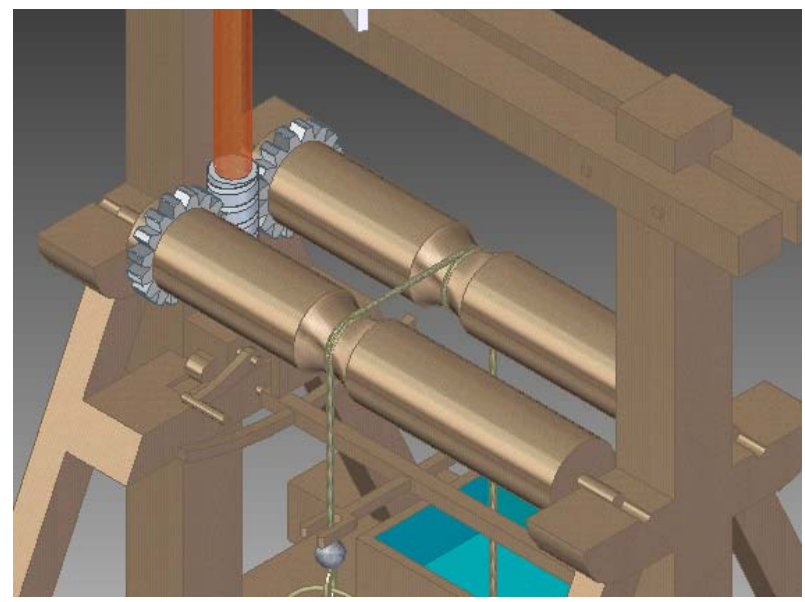

Figura 10: Vista del tornillo sinfín, corona y tambores.

El extremo cilíndrico permite unir el eje a la estructura por medio de un ajuste móvil. Los elementos con forma de tenedor actúan como tope del movimiento lineal de la bola solidaria con el cántaro, de modo que cuando la bola contacta con el elemento con forma de tenedor, éste hace girar al eje, y por tanto, a las dos piezas con forma de arco solidarias al mismo. Cuando una de estas dos últimas piezas contacta con la leva, ésta gira y a su vez fuerza el desplazamiento del cajón superior hasta que se encuentra con el tope, momento en el que el tornillo sinfín engrana con la corona opuesta invirtiéndose así el sentido de rotación (Fig. 12). Esto hará que los cántaros se muevan en direcciones opuestas, consiguiendo así que un movimiento de giro se transforme en un movimiento de rotación, semejante al funcionamiento de una leva.

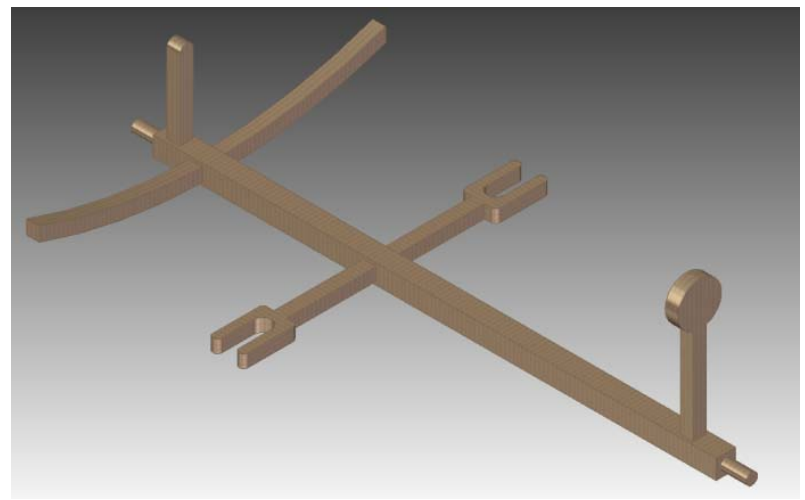

Figura 11: Vista del eje del regulador.

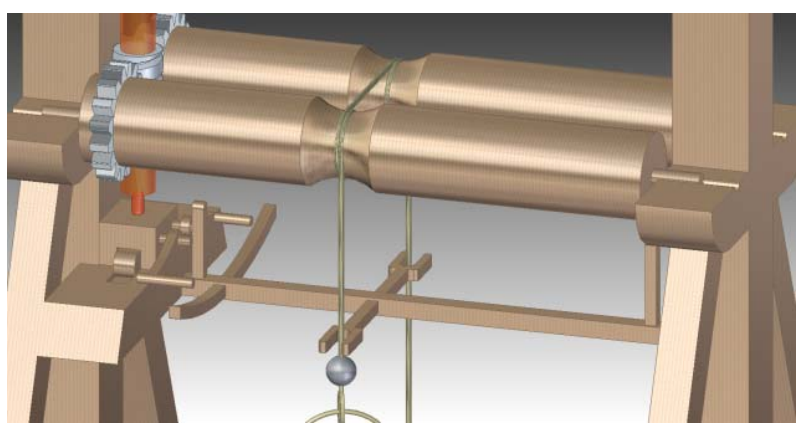

Figura 12: Detalle del mecanismo de leva.

Como se acaba de exponer, cuando el cántaro que sube alcanza la posición en la que la bola toca al elemento con forma de tenedor, se produce la conmutación del movimiento, es decir, el movimiento ascendente del cántaro sumergido y el descendente del cántaro vacío. Asimismo, el gancho solidario a cada una de las artesas provoca el giro del cántaro al chocar el primero contra la parte superior del último, consiguiendo de esta forma recoger en la artesa el agua contenida en el mismo.

Cuando el eje vertical de rotación se encuentra entre los dos tambores (posición internedia) no acciona ninguno de ellos, y por tanto, la máquina no funciona. En este caso, es la propia inercia del péndulo, que actúa como contrapeso, la que fuerza a que el eje vuelva a accionar uno de los dos tambores.

\subsection{Ensamblaje del conjunto}

La Figura 13 muestra una imagen fotorrealista del conjunto ensamblado, realizado gracias al uso del software Keyshot 5.

Para realizar el ensamblaje del sistema de rotación vertical, se partió del eje vertical con tornillo solidario como pieza inicial. Sobre éste se insertaron las dos estructuras cilíndricas con forma de aspa, asegurando la alineación de ejes entre piezas y garantizando que las aspas mantengan su posición utilizando para ello, la relación de coincidencia de caras entre las caras planas 
del vaciado cuadrado del aspa superior y las caras, también cuadradas, del eje en su parte superior (Fig. 5).

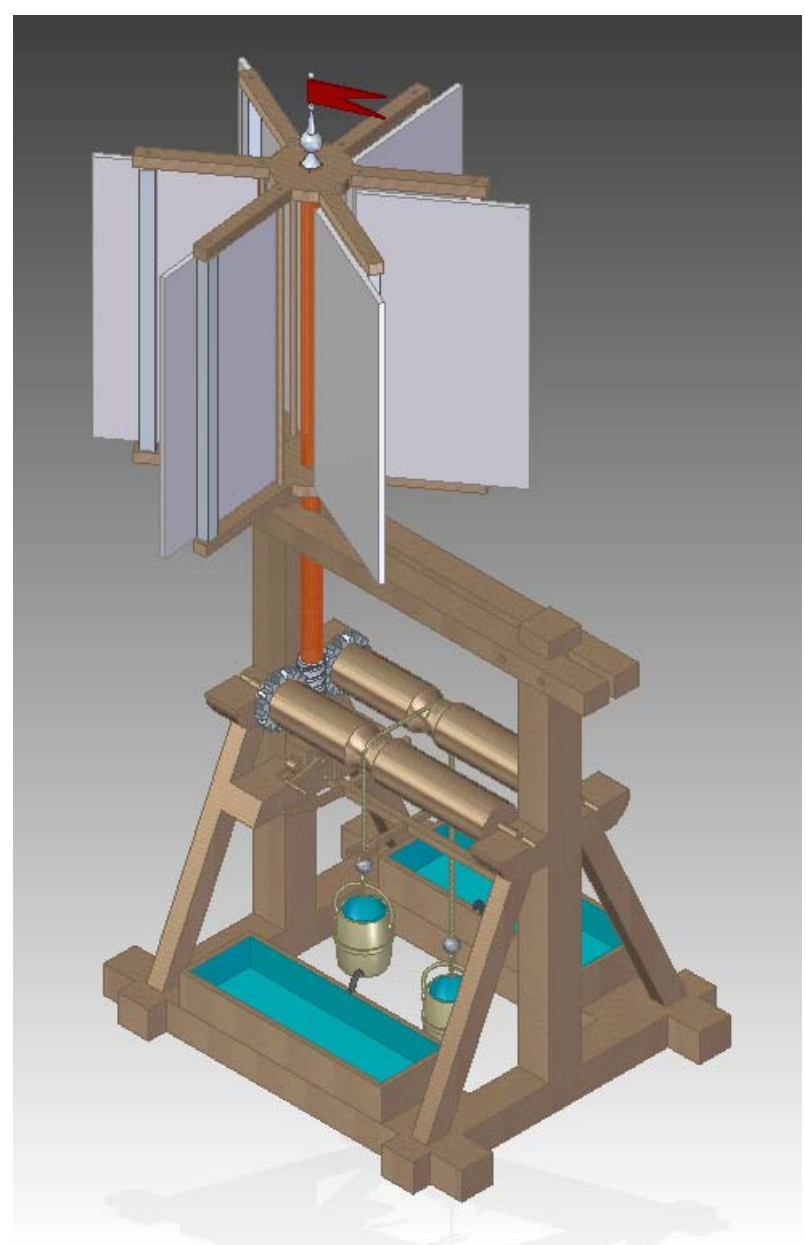

Figura 13: Imagen fotorrealista del modelo de la máquina.

Los paneles y varillas se unen a las aspas a través de uniones con ajustes con aprieto y móviles, garantizando la alineación de sus ejes con los ejes de los agujeros de las aspas. Las varillas permanecen fijas por lo que se restringen todos sus grados de libertad, mientras que los paneles conservan el grado de libertad del giro alrededor de su eje vertical (Fig. 6)

El ensamblado del mecanismo regulador de llenado de las artesas se ha realizado de la siguiente manera: el tornillo sinfín se aloja dentro del cajón superior de la leva siendo su único movimiento posible el giro alrededor de su eje vertical, garantizándose la alineación de los ejes del tornillo y el agujero de la parte superior del cajón (Fig. 8).

En cuanto al eje de sección cuadrada, éste se une a la estructura soporte de forma que su único grado de libertad es el giro alrededor de su eje. Los elementos con forma de tenedor, el péndulo, y demás elementos solidarios con este eje, presentan restringidos todos sus grados de libertad (Fig. 11).

El cajón superior de la leva y la guía que hay en su interior, tienen como único grado de libertad la traslación en dirección perpendicular al eje. Asimismo, se ha asegurado que el plano inferior del cajón superior y el plano superior de la base de la leva mantengan contacto a través de una alineación plana. Se trata de un elemento que además de girar alrededor del eje de su agujero puede desplazarse en dirección perpendicular al eje de sección cuadrada, presentando por tanto, dos grados de libertad, un giro y una traslación. Además, se han alineado el eje del agujero de la leva con el eje del extremo cilíndrico del cajón superior de leva. En lo que respecta a los tambores cilíndricos, el único movimiento que presentan es el giro alrededor de su eje, quedando restringidos todos los grados de libertad restantes (Fig. 12).

La gran ventaja de este mecanismo es que la mayor parte de sus elementos son simples, y por tanto, relativamente sencillos de modelar y fabricar.

Por el contrario, el gran inconveniente que presenta es que es un mecanismo de grandes dimensiones, no apto para ubicarlo en cualquier lugar, y fundamentalmente que su velocidad de trabajo es lenta, no resultando útil en circunstancias en las que se requiera rapidez.

\section{Conclusiones}

Se ha obtenido el modelado tridimensional y la documentación geométrica de la máquina eólica para desaguar terrenos pantanosos de Agustín de Betancourt y Molina mediante el uso del software paramétrico Solid Edge ST7.

Asimismo, en el proceso de modelado, ha sido necesario introducir algunas hipótesis dimensionales, pues dicha información no aparece reflejada en las láminas del expediente que ha sido la única información disponible, tratándose siempre de obtener elementos que respetaran la proporcionalidad o fueran homotéticos con los representados. A partir de la documentación geométrica 3D de dicha máquina, se podrá realizar una recreación virtual de su funcionamiento, y estudiar con herramientas CAE (del inglés, Computer-Aided Engineering), su comportamiento funcional realizando un análisis estático de la misma, analizando tensiones de von Mises, desplazamientos y coeficiente de seguridad, así como en su caso, utilizar la ingeniería clásica a modo de comprobación.

A modo de conclusión, se podría decir que esta invención puede considerarse innovadora y muy útil en aquella época puesto que, pese a su baja velocidad de funcionamiento, resuelve el problema de desaguar un terreno inundado con una máquina cuyo mecanismo es simple pero muy eficaz, sobretodo con escasez de mano de obra ya que el funcionamiento simultáneo de varios de estos mecanismos sólo requeriría de una persona encargada de su mantenimiento en caso de avería, aunque evidentemente, hoy en día no tendría ninguna aplicación, puesto que usar una bomba resulta entre otras cosas, mucho más práctico y eficaz.

\section{Agradecimientos}

Este trabajo se ha desarrollado en el seno del proyecto de investigación titulado: "El patrimonio histórico de Agustín de Betancourt: estudio integral de las aportaciones a la ingeniería civil desde la ingeniería gráfica para su puesta en valor y difusión" (HAR201563503-P), financiado por el Ministerio de Economía y Competitividad, dentro del Programa Estatal de Fomento de la Investigación Científica y Técnica de Excelencia, Subprograma Estatal de Generación del 
Conocimiento, en el marco del Plan Estatal de Investigación Científica y Técnica y de Innovación 20132016, y por el Fondo Europeo de Desarrollo Regional (FEDER).

Asimismo, los autores agradecen muy sinceramente a la Fundación Canaria Orotava de Historia de la Ciencia, su disponibilidad y autorización a utilizar el material de su web, en la persona del que fue su Director, Sergio Toledo Prats, así como en la persona de María Rodríguez Hernández que ha sido la persona que ha gestionado toda la información necesaria.

\section{Referencias}

AA.VV., 1996. Betancourt: Los inicios de la ingeniería moderna en Europa. Catálogo de la Exposición del Centro de Estudios Históricos de Obras Públicas y Urbanismo (CEHOPU). Dirección a cargo de Ignacio González Tascón. Madrid: Ministerio de Obras Públicas, Transportes y Medio Ambiente. 373 páginas.

AA.VV., 2009. Agustín de Betancourt y Molina (1754-1824). Barcelona: Escuela Técnica Superior de Ingenieros Industriales. 448 páginas.

BOGOLIÚBOV, A.N., 1969. Agustín de Betancourt. Moscú: Ciencia. 152 páginas.

BOGOLIÚBOV, A.N., 1973. Agustín de Betancourt: un héroe español del progreso. Madrid: Seminarios y Ediciones. 188 páginas.

CIORANESCU, A., 1965. Agustín de Betancourt: su obra técnica y científica. La Laguna de Tenerife: Instituto de Estudios Canarios. 199 páginas.

EXPEDIENTE DE LA MÁQUINA EÓLICA PARA DESAGUAR TERRENOS PANTANOSOS, 2016. Disponible en: http://fundacionorotava.es/pynakes/lise/betan mouli fr 01 18XX [07/02, 2016].

MARTÍN, A., 2006. Agustín de Betancourt y Molina. Madrid: Dykinson. 189 páginas.

MUÑOZ, J., 2008. Biografía cronológica de Don Agustín de Betancourt y Molina en el 250 aniversario de su nacimiento. Murcia: Acciona Infraestructuras. 323 páginas.

PADRÓN, S., 1958. El ingeniero Agustín de Béthencourt y Molina. Lalaguna de Tenerife: Instituto de Estudios Canarios. 50 páginas.

PROYECTO DIGITAL BETANCOURT, 2016. Disponible en: http://fundacionorotava.es/betancourt [07/02, 2016].

VILLAR-RIBERA, R., HERNÁNDEZ-ABAD, F., ROJAS-SOLA, J.I. y HERNÁNDEZ-DÍAZ, D., 2011. Agustin de Betancourt's telegraph: Study and virtual reconstruction. Mechanism and Machine Theory, 46(6), pp. 820-830. DOI: 10.1016/j.mechmachtheory.2011.01.008.

TICKOO, S. 2015. Solid Edge ST7 for designers. Lafayette (Indiana, EE.UU): Purdue University Calumet. 752 páginas. 


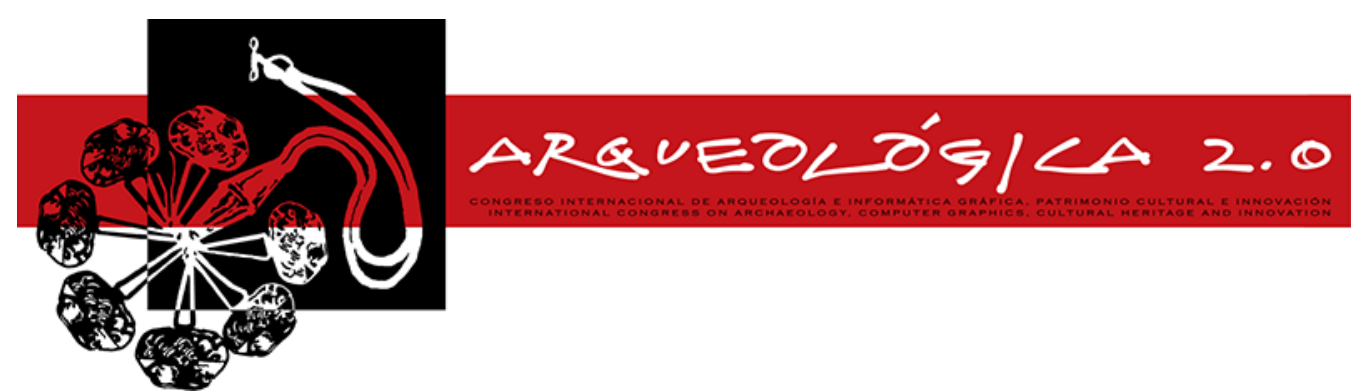

Proceedings of the $8^{\text {th }}$ International Congress

on Archaeology,

Computer Graphics,

Cultural Heritage and Innovation

'ARQUEOLÓGICA 2.0'

in Valencia (Spain),

Sept. $5-7,2016$

DOI: http://dx.doi.org/10.4995/arqueologica8.2016.2976

Received: $11 / 02 / 2016$

Accepted: 01/04/2016

\title{
APLICACIÓN DE TÉCNICAS DE INGENIERÍA INVERSA PARA LA DOCUMENTACIÓN GRÁFICA Y GEOMÉTRICA DEL PATRIMONIO EN UN PROYECTO DE REALIDAD AUMENTADA: UN PRODUCTO MUSEOGRÁFICO PARA LA CATEDRAL DE LA SEO DE ZARAGOZA
}

\author{
APPLICATION OF INVERSE ENGINEERING TECHNIQUES BASED ON GRAPHICAL AND GEOMETRICAL \\ DOCUMENTATION OF HERITAGE TO AN AUGMENTED REALITY PROJECT: A MUSEOLOGICAL PRODUCT FOR \\ LA SEO CATHEDRAL OF ZARAGOZA
}

\author{
Juan Monzón
}

Departamento de Ingeniería de Diseño y Fabricación, Centro Politécnico Superior, Universidad de Zaragoza, María de Luna 3, 50018 Zaragoza, España. jmonzongasca@gmail.com

\begin{abstract}
:
This article addresses a project aimed to the diffusion of the Capilla de San Marcos cultural heritage. The project for this chapel, also called Capilla del Monumento de la Catedral del Salvador de Zaragoza, is based on augmented reality. After studying its history and researching on this cultural object, metric and graphic digitization were carried out by using reverse engineering, laser scanner and photogrammetry techniques. Processing that information thanks to new technologies has allowed generating methodological conclusions that focus on the creation of a museographic product about this singular place that will be helpful to understand the monument's historical and artistical context and, of course, to contribute to the Spanish heritage diffusion.
\end{abstract}

Key words: Heritage, laser scanner, reverse engineering augmented reality, 3D printing, museographic product.

\section{Resumen:}

El presente artículo muestra un proyecto de difusión de patrimonio cultural para la Capilla de San Marcos o también denominada Capilla del Monumento de la Catedral del Salvador de Zaragoza basado en la realidad aumentada. Tras una revisión histórica e investigación del bien cultural, se procedió mediante técnicas de ingeniería inversa, escáner láser y fotogrametría, a su digitalización métrica y gráfica. El procesamiento de esta información gracias a las nuevas tecnologías, ha permitido generar unas conclusiones metodológicas enfocadas a la creación de un producto museográfico de este espacio tan singular que sirva para la comprensión histórico-artística del monumento y por supuesto, para la difusión del patrimonio español.

Palabras clave: Patrimonio, escáner láser, ingeniería inversa, realidad aumentada, impresión 3D, producto museográfico.

\section{Introducción}

La necesidad de documentar el patrimonio históricoartístico ha sido una constante a lo largo del tiempo, con el fin de poder estudiar y conservar los bienes culturales. Las técnicas empleadas han variado a lo largo de las épocas perfeccionándose hasta la actualidad, en que se hace imprescindible el uso de las nuevas tecnologías para documentar y explicar correctamente los bienes culturales.

El presente proyecto consiste en primer lugar, en documentar gráfica y geométricamente la capilla de San Marcos, también denominada Capilla del Monumento, mediante técnicas de ingeniería inversa. En segundo lugar, el proyecto trata de procesar esa información, para generar unas conclusiones metodológicas que conlleven la creación de un producto museográfico para la capilla, que sirva para la comprensión históricoartística del monumento y por supuesto, para la difusión del patrimonio aragonés.

La metodología llevada a cabo consta de tres partes fundamentales. Comenzamos con un estado de la cuestión, revisando las fuentes bibliográficas de lo general a lo particular, desde los monumentos de Semana Santa en Aragón a las descripciones específicas de la capilla del Monumento. En cuanto a las 
fuentes documentales, aunque no son muy numerosas, nos han permitido reconstruir "el escenario del Monumento" o la empaliada de tapices y pasillo solemne que perduró hasta la década de los 70 del siglo XX. En una segunda parte, analizamos detalladamente los aspectos técnicos derivados del uso de la ingeniería inversa, destinados a la documentación de bienes culturales. Para la medición de estos datos, en el trabajo de campo se han utilizado técnicas de digitalización de grandes volúmenes, como láser escáner terrestre y fotogrametría. Por último, tras la toma e interpretación de estos datos, se ha procedido al diseño de un producto museográfico basado en técnicas de realidad aumentada (videomapping), para entender el estado ideal de la capilla y su funcionamiento.

\section{Estado de la cuestión de la Capilla del Monumento o Capilla de San Marcos}

Desde principios del siglo XVI hasta finales del siglo XVIII, la arquitectura efímera desempeñó un papel primordial en los ámbitos sociales, políticos y artísticos hispánicos. Estas construcciones realizadas en materiales maleables y de escasa consistencia (maderas, cañas, estopa, telas, cartón, papeles, cal y escayola), eran levantadas con la intención de crear un vistoso escenario que durase únicamente durante el corto tiempo de las ceremonias para las que habían sido concebidas. Estas arquitecturas efímeras pretendían buscar efecto y causar admiración en aquéllos que las contemplasen. En el caso de la monarquía, eran símbolos de demostración de poder, así como muestra de esplendor victorioso para la Iglesia Católica en festividades señaladas.

En el ámbito religioso estas estructuras (arcos de triunfo, pórticos, pabellones, edículos...) se construían para eventos tales como canonizaciones de santos, consagraciones de templos o capillas singulares, procesiones y otras ceremonias y festividades como el Corpus Christi. Por similitud formal y funcional caben destacar los monumentos de Semana Santa, máquinas a mitad efímeras y temporales, que sólo se montaban en el interior de las iglesias el día del Jueves de Pasión, guardándose sus piezas en un almacén durante todo el resto del año (Bonet 1993).

De cualquier modo, para el tema que nos ocupa, nos centramos en el día de Jueves Santo, que abre el Triduo Pascual, día en que Jesús instituyó la Eucaristía en el marco de la Cena Pascual. Es el sacramento como expresión permanente de Cristo hasta la Parusía.

Como dicen en su trabajo Calvo y Lozano (2004), los denominados "monumentos de Semana Santa" o "monumentos pascuales" son una singularidad dentro de las arquitecturas provisionales, también nombradas en las fuentes como "arte de las tramoyas" (debido a su marcado componente escenográfico) o "arte para el caso" (por su uso coyuntural y esporádico). Parece ser que el origen de estas construcciones se remonta a las ceremonias paralitúrgicas bajomedievales relacionadas con la Pasión de Cristo, para alcanzar su máximo esplendor durante el Barroco, debido al reforzamiento que el misterio eucarístico experimentó a raíz del Concilio de Trento y al consiguiente auge de las festividades del Jueves Santo y del Corpus Christi.
Se considera que los monumentos de Semana Santa comenzaron a plantearse como estructuras arquitectónicas independientes en los albores del siglo XVI (Morte 1986). En Aragón se conservan ejemplos desde el siglo XVII, entre ellos podemos destacar los de Ateca, Bolea, Carenas, Ibdes o el de Fuentes de Ebro. No obstante la escasa calidad de los materiales con los que se realizaban, los daños infligidos durante la instalación y desmantelamiento, así como los gustos artísticos de cada momento que obligaban a reformarlos o sustituirlos, han impedido que lleguen hasta nuestros días. Afortunadamente para nuestro patrimonio histórico-artístico, en el siglo XVII y sobre todo en el XVIII, los monumentos comenzarán a dejarse instalados de forma permanente en espacios concretos (generalmente capillas), que cerradas mediante puertas o telones, preservarán su naturaleza hasta la actualidad (Ibáñez 2006).

En concreto, en el caso de Aragón, uno de los ejemplos más notables de monumentos levantados de forma permanente, es el que se encuentra en una de las capillas de la catedral del Salvador de Zaragoza. Existen varias descripciones acerca de la capilla de San Marcos o también denominada del Monumento (Gascón de Gotor 1939) (Fig. 1). La gran síntesis y descripción que de ella hace Esteban (1977) y en la que nos basaremos en los próximos párrafos, nos permite acercarnos a este espacio singular de forma fidedigna con el objetivo de entender sus aspectos formales y funcionales:

"La capilla de San Marcos, cuyo retablo oculta el Monumento de Semana Santa (Fig. 2), es la primera del lateral del Evangelio del templo de La Seo, entrando por la puerta de la Pabostría, a los pies de la iglesia. Es un recinto cuadrado, cubierto por una cúpula semiesférica montada sobre pechinas y coronada por una linterna [...]. El retablo es un gran lienzo que ocupa toda la pared (Fig. 3): simula con gran habilidad pictórica un retablo de madera de grandes proporciones, de un solo cuerpo con remate; su aparente estructura es convergente, formada por dos pares de columnas, [...]. Las paredes de los laterales las cubren dos grandes lienzos atribuidos a Pablo Raviella hijo, en los que se representa la entrada triunfal de Jesús en Jerusalén, y el beso de Judas". Dichas pinturas barrocas han sido objeto de estudio por parte del profesor Lozano (2010).

Continuando con la descripción de Esteban Lorente: " $L a$ magnífica portada, esculpida en yeso, desarrolla un programa simbólico en torno a la pasión y exaltación de Cristo como víctima propiciatoria [...]. Para el montaje del escenario del monumento de Semana Santa es preciso descender el gran lienzo del retablo que, por medio de unas carruchas, un gran torno y unas sogas, se oculta en una caja del subterráneo del trasaltar de la capilla; así, tras montar una tarima elevada y unas gradas de acceso, se nos patentiza la nueva función del recinto" (Fig. 4).

Este lienzo, actualmente en paradero desconocido, se encontraba sobre un gran soporte de madera compuesto de dos partes: Una es rectangular mientras que la otra tiene la forma semicircular del arco que cierra ocultando la escalinata. Estas dos partes están unidas por una serie de bisagras que permiten plegar la parte superior (semicircular) sobre la inferior para ocultarlo en el foso situado en el sótano, haciéndolo 
descender por un carril de madera situado a ambos lados a modo de guía (Fig. 5). Por debajo del soporte del telón discurren dos sogas que en un extremo estan ancladas a la pared del foso mientras que en el extremo opuesto se enroscan sobre un torno simple oculto en el sótano (Fig. 6). Este mecanismo tensa la cuerda haciendo ascender el telón.

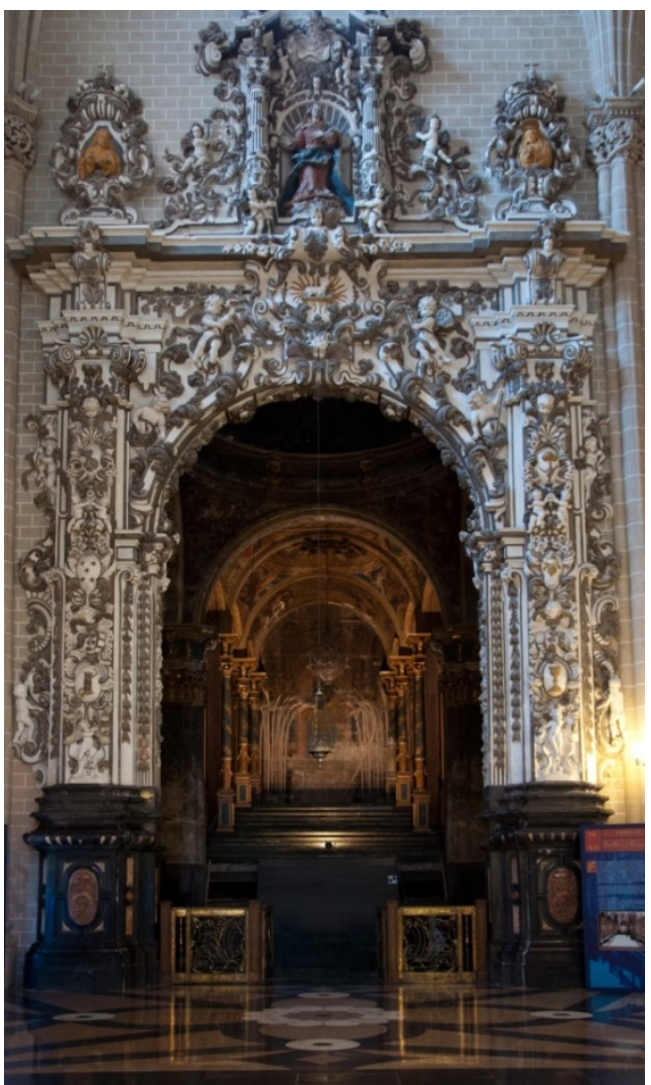

Figura 1: Vista exterior de la capilla de San Marcos (Capilla del Monumento). Catedral del Salvador de Zaragoza.

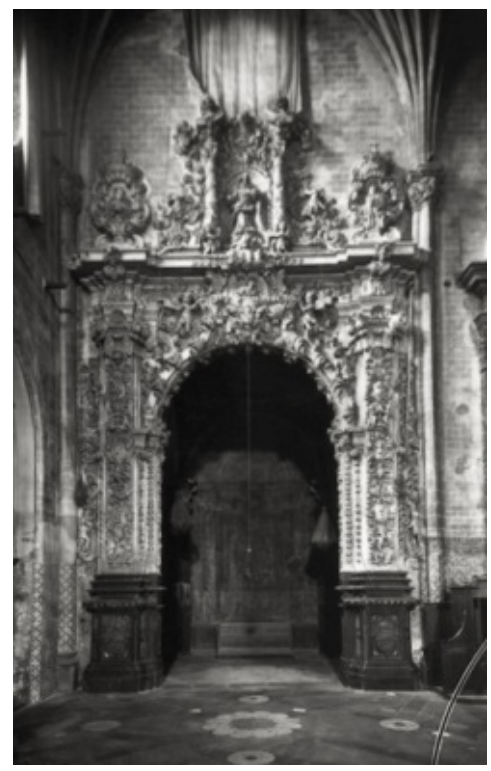

Figura 2: Fotografía antigua de la capilla de San Marcos con el telón cerrado. Fuente: Archivo Histórico Provincial Zaragoza-

Archivo Arte Aragonés. ES/AHPZ-MF/MORA/001734-

"Zaragoza, La Seo. Capilla de San Marcos. Estilo: Barroco." Juan Mora Insa.

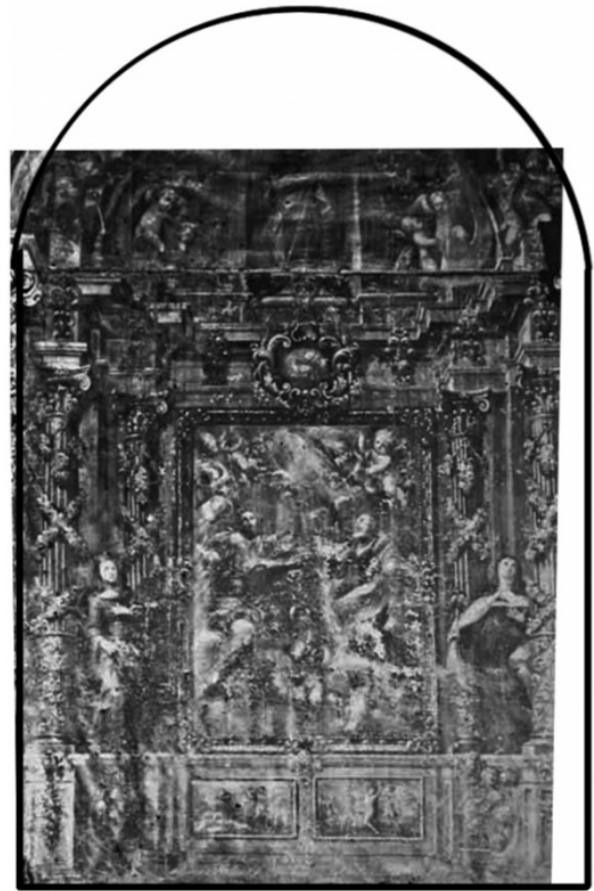

Figura 3: Reconstrucción esquemática sobre fotografía de archivo del telón original de la capilla de San Marcos.

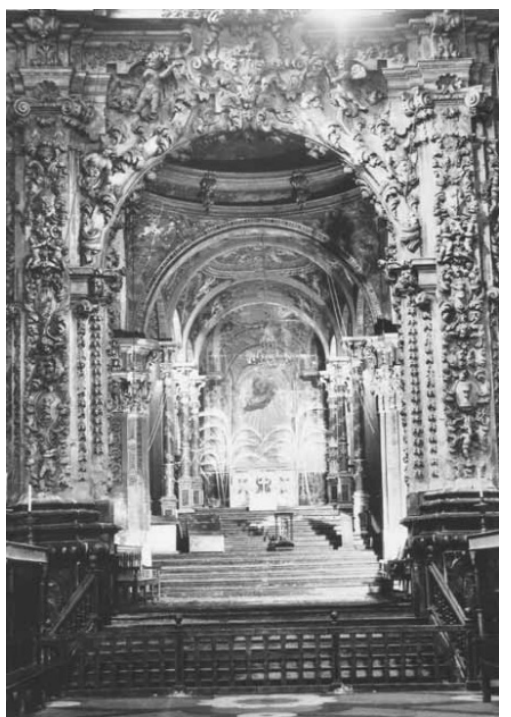

Figura 4: Capilla del Monumento montada. Fuente: Esteban Lorente, Juan Francisco, Op. Cit. 1977 p. 99.

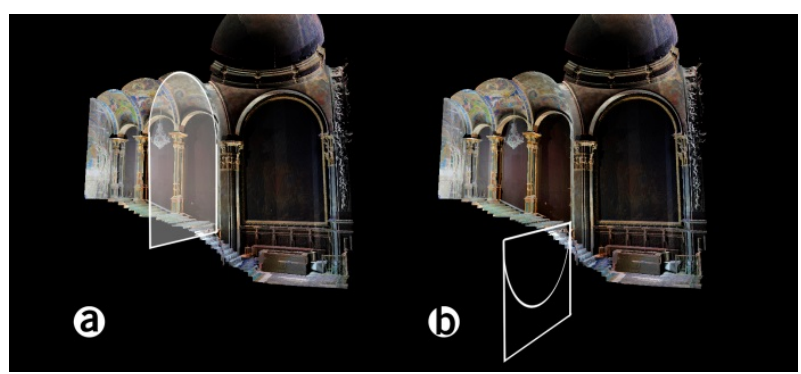

Figura 5: a) Esquema del telón ocultando la escalinata del Monumento de la capilla de San Marcos. b) Esquema del telón recogido dejando a la vista la escalinata del Monumento, en la que se puede apreciar las dos partes que lo forman. 


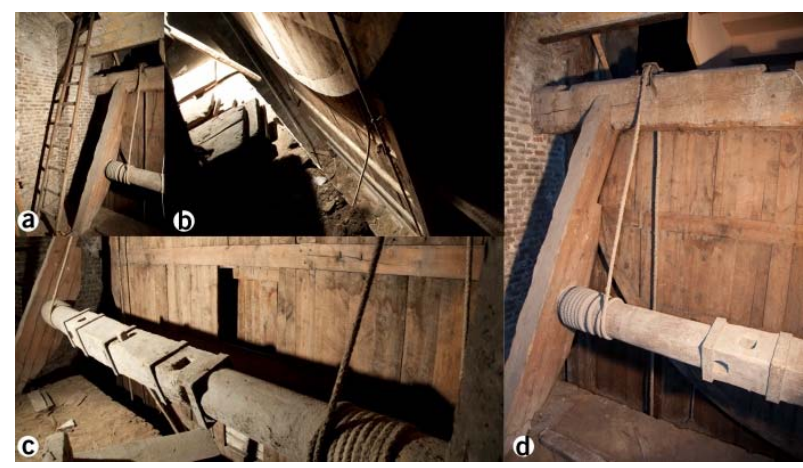

Figura 6: a) Escalera de acceso al sótano de la capilla del Monumento. b) Vista interior del foso en la que se distinguen las dos cuerdas cuerdas y la parte semicircular plegada sobre la rectangular. c) Mecanismo de elevación del telón por medio de un torno simple. d) Torno, soga y polea del mecanismo. Soporte del telón plegado.

Como dice la descripción del profesor J.F. Esteban (1977): "El monumento de Semana Santa es todo él, un auténtico escenario de madera, incluyendo las bóvedas; una verdadera arquitectura provisional que nos ha llegado hasta hoy con la misma función que cuando se concibió. Su estructura general es convergente. Tras una grada de nueve peldaños, se flanquea la rica portada de la capilla que sirve de maravilloso marco al conjunto, penetrando así en el primer espacio, el de la capilla de San Marcos, acondicionada ahora a modo de escenario teatral con una plataforma desnivelada situada algo más alta de la mitad de su zócalo; [...]. Sucede a esta plataforma, en un precipitado ritmo, una gradería de tres tramos flanqueada de columnas ricamente decorada en las bóvedas, todo convergente hacia el altar, y en el muro del fondo aún se ha simulado la continuación de tres tramos más de esta estructura, y un cuarto, que forma cabecera recta, y del que avanza la figura del Padre Eterno; así, ilusionísticamente, a mitad mismo de este largo espacio, se ha colocado un altar de rocalla, que, con espejos, simula plata bruñida y es el que sirve de pedestal a la urna del Monumento" (Fig. 7)

Este frontal de altar (Fig. 8) está realizado íntegramente en madera, cuyas dimensiones son $183 \mathrm{~cm}$ de largo por $103 \mathrm{~cm}$ de alto, sin contar los añadidos de aproximadamente $30 \mathrm{~cm}$ de ancho. La parte delantera está dividida en tres partes de madera cuya ornamentación calada deja a la vista el espejo posterior. En el centro, sobre el espejo (que está roto) hay una cruz y dos palos que partiendo y apoyados en la parte baja, llegan hasta el extremo de los brazos de la misma, donde terminan el de la derecha en una esponja y el de la izquierda en la lanza. En el centro de la cruz y debajo de INRI, aparece la corona de espinas. En la parte derecha del frontal se representan la escalera, el martillo, los clavos y las tenazas. A la izquierda la columna, los azotes, palma y mano de la bofetada. Siendo todos estos elementos de la Pasión de Cristo. Enmarcando éstos y sujetando los espejos, tallado en la madera, hay un conjunto de ornamentación barroca en forma de $S$ en la parte alta y de $C$ en la baja. Las formas de la izquierda son normales, las de la derecha son las letras invertidas. El resto del frontal está lleno de decoración de volutas, ramas, hojas esquematizadas, y espejos, completando todas estas formas en pintura plateada.

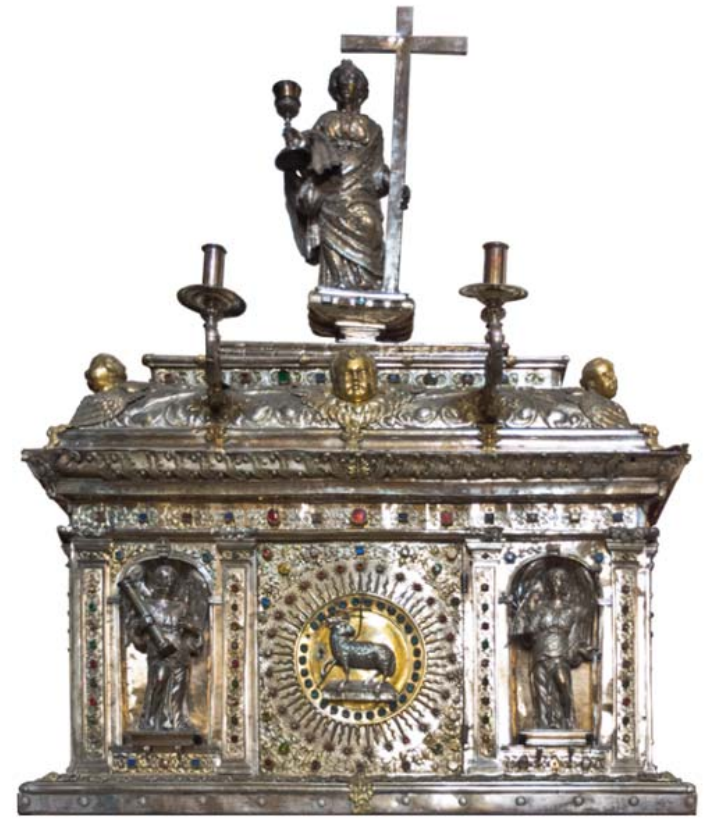

Figura 7: Arca del Monumento. Catedral del Salvador de Zaragoza.

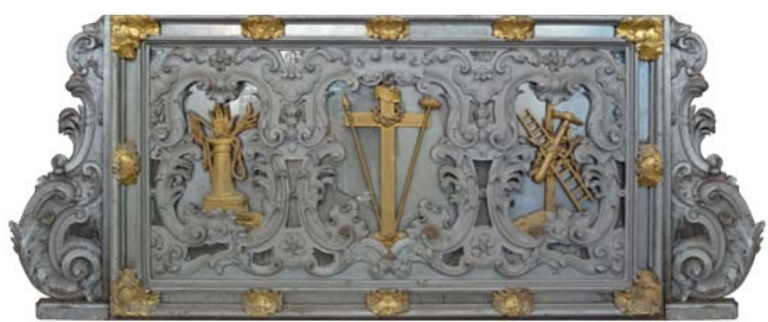

Figura 8: Frontal de altar para la capilla del Monumento. Catedral del Salvador de Zaragoza.

Todo el frontal está enmarcado, como si fuera un cuadro, con listones donde hay colocados, entre espejo y espejo, unos adornos: en la parte inferior y superior tres y en los laterales uno, en las esquinas cuatro florones también pintados en dorado como sucede con los elementos pasionarios.

Finalizamos la descripción del frontal de altar de nuevo con las palabras del profesor Esteban Lorente: "[...] La decoración pictórica de las bóvedas es de gran logro ilusionista, y se ve apoyada por la creciente luz hacia el fondo. No hay que olvidar el inestimable recurso que supone delimitar la nave situada en su frente por medio de ricos tapices -creando un impresionante recinto abocinado-, [...]".

En cuanto a las fuentes documentales, el Inventario del Archivo Capitular de la Catedral del Salvador (1906), detalla cuáles eran los tapices de la colección que se utilizaban:12 tapices de raz grandes que representan los doce meses del año; 8 paños de raz que representan la Historia de Moisés; 10 paños de raz grandes: 6 azules y 4 colorados, con vestuarios muy antiguos; 2 paños de raz con la historia de San Juan; 2 paños de raz en forma de reposteros y 5 paños de raz de distintas historias.

Según los diferentes documentos y fotografías que han aparecido en la investigación realizada en este trabajo, la empaliada estaba compuesta en primer lugar por una estructura a modo de pasillo, formada por una serie de 
columnas y travesaños de madera ornamentada que delimitaban el recorrido desde la fachada de la epístola, a la altura de la capilla Santa Elena, hasta la capilla del Monumento. Estas columnas se encajaban en un orificio sobre un pie de madera apoyado en el suelo. En su parte superior acaban en forma de $T$ dónde descansan los travesaños que las unen, y sobre los cuales se insertan hachones para cirios a lo largo de todo el recorrido. En segundo lugar los tapices eran sujetados a un largero de madera por su parte posterior y suspendidos del techo de la catedral mediante cuerdas por un sistema de poleas, colocándolos por encima de la estructura de madera anteriormente explicada, dejando libre la parte inferior para el tránsito de los fieles. Un ejemplo similar de este sistema lo encontramos en las explicaciones que da De la SalaValdés (1933) sobre el Monumento de Semana Santa de la Iglesia de San Pablo de Zaragoza y las fotografías de Juan Mora Ínsa (1905-1954) y de Manuel Coyne (1954) del Archivo Histórico Provincial de Zaragoza.

La disposición de los tapices de La Seo de Zaragoza debió de cambiar a lo largo de su existencia puesto que los documentos que constan del pasado siglo nos ofrecen diferentes puntos de vista de su montaje. En la lámina 51 del libro "Zaragoza Monumental" (Magaña 1919) que data de 1919 se observa como la empaliada constaba de dos alturas de tapices a ambos lados del pasillo (Fig. 9), mientras que en la fotografía de 1962 del Boletín Municipal (Beltrán 1962), en la que se aprecia el Monumento ya montado en Semana Santa con la candelería encendida, figura solamente una única altura de tapices (Fig. 10). El acceso a este recinto se realizaba al final del lado de la Epístola a la altura de la capilla de Santa Elena, donde la fila de tapices quedaba interrumpida. En la fotografía de 1976 del profesor Esteban Lorente aparecen dos tapices reposteros con el escudo del Duque de Calabria en el lado opuesto a la portada del Monumento. El resto de tapices que se colocaban se conocen por el inventario de 1906, pero no se dispone de ningún documento que nos aclare el orden de su colocación.

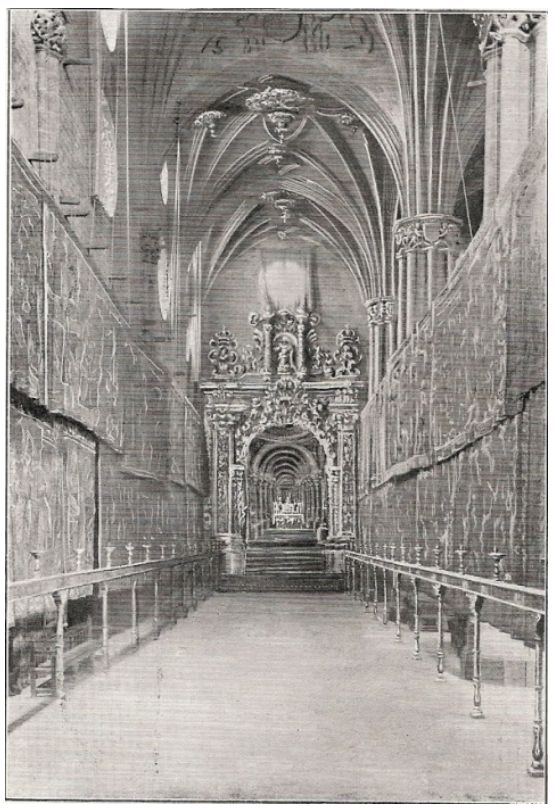

Figura 9: Empaliada con dos filas de tapices (1919). Fuente: "Zaragoza Monumental", lámina 51.

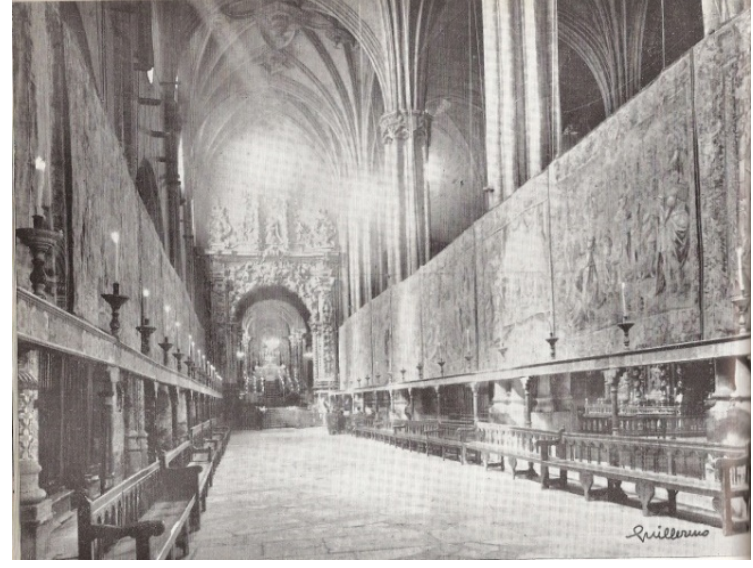

Figura 10: Empaliada con una fila de tapices (1962). Fuente: Boletín Municipal de Zaragoza, p.24.

A partir de esta interesante noticia documental, podemos reconstruir visualmente la empaliada que cumplía la función de pasillo solemne para la procesión al Monumento y que perduró hasta que se declaró la Catedral de La Seo en estado de ruina a finales del siglo XX, (Fig. 11 y 12).

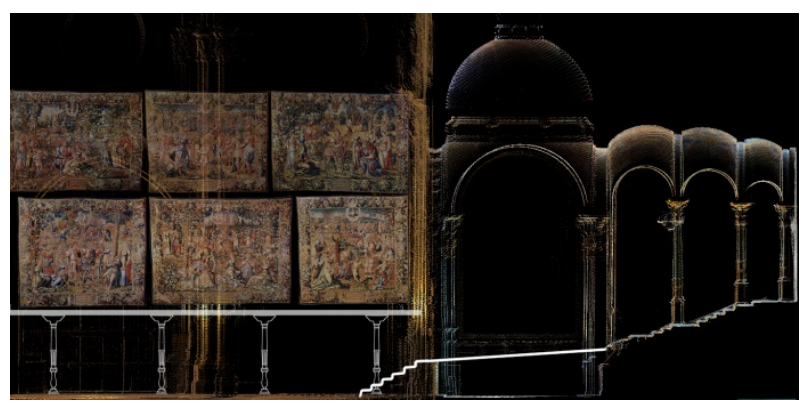

Figura 11: Reconstrucción digital de la empaliada original sobre nube de puntos de la sección transversal de la capilla de

San Marcos. Basado en fotografía de la empaliada de 1919.

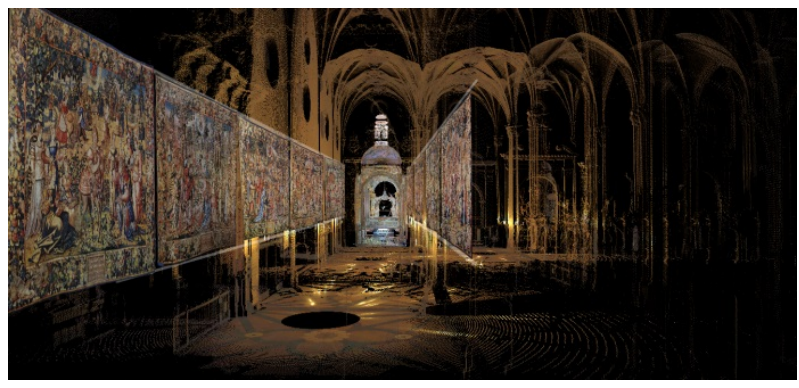

Figura 12: Reconstrucción digital de la empaliada original sobre nube de puntos de la vista frontal de la capilla de San

Marcos. Basado en fotografía de la empaliada de 1962.

El último elemento que nos queda por describir de la Capilla del Monumento, es su portada de ingreso. Está realizada en yeso y descansa sobre dos pedestales tallados en piedra negra de Calatorao en la que figuran esculpidas en jaspe rojo las armas heráldico-religiosas del Arzobispo Crespo-Agüero; letra "Y" surmontada de corona real cerrada y flanqueada por una estrella de seis puntas a cada lado. Sin lugar a duda, la descripción que mejor documenta el resto del arco de ingreso es la de la Dra. Boloqui Larraya (Fatás 2008): "La portada de ingreso [...], es obra del escultor José Serra en el año 1711. Su estructura arquitectónica, de carácter 
churrigueresco, parece derivar de la de Santo Dominguito de Val, situada en el lado de la Epístola. Novedad interesantísima respecto a su modelo es la sustitución de las pilastras del ático por columnas de fuste estriado enguirnaldadas, las primeras documentadas en Zaragoza. Todo el frontis, incluido el intradós del arco, va decorado con profusa talla de hojas carnosas, cabezas de angelitos y tarjetones con los símbolos de la Pasión. En medio de la gran cartela del arco aparece el Cordero místico sobre el libro de los siete sellos, flanqueado por ángeles portadores de Las Armas de Cristo o instrumentos de su Pasión. Sobre el entablamento, en la hornacina central, se localiza la alegoría de la Iglesia, arrodillada y suplicante, a la que escoltan cabezas de serafines, con nuevos símbolos de la Pasión (Fig. 13). A los lados, hay dispuestos sendos tarjetones conteniendo respectivamente, un jarrón, símbolo de la Redención por el Bautismo, y una linterna que significa el poder de la Gracia. En los extremos, dentro de cartelas recortadas, están los bustos de María y Juan Evangelista; como coronamiento, la imagen del Padre Eterno entre algodonosas nubes".

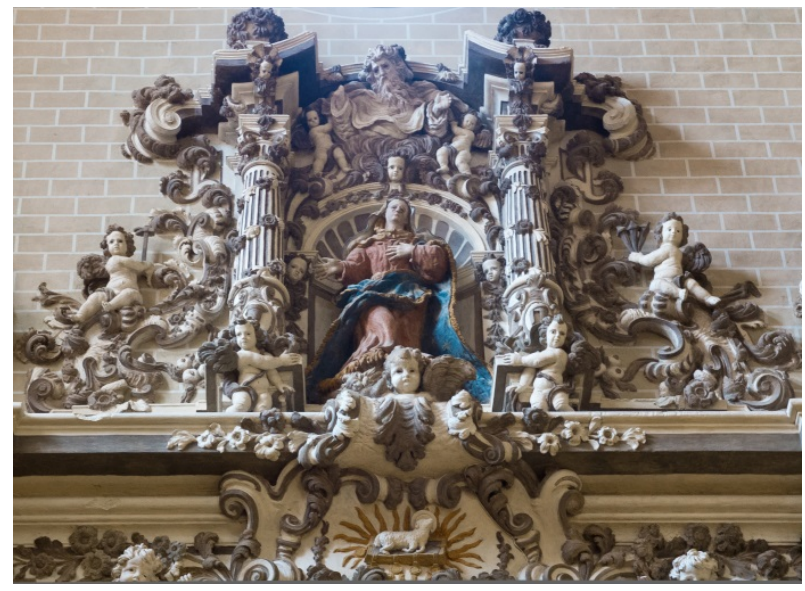

Figura 13: Detalle de la portada de ingreso. Hornacina central con la alegoría de la Iglesia y representación del Padre Eterno.

De este sucinto estado de la cuestión, se desprende la importancia que tiene la documentación del patrimonio a la hora de estudiar y conservar los bienes culturales. En la actualidad gracias a las nuevas tecnologías, partiendo del rigor documental y bibliográfico, contamos con recursos que nos permiten abordar este tema con nuevas y refrescantes perspectivas.

\section{Aspectos técnicos del proyecto: utilización de la ingeniería inversa para la documentación de la Capilla de San Marcos}

El término "documentación" puede definirse como el procesamiento y registro de información que proporciona un compendio de datos con un fin determinado. Cada trabajo de documentación es distinto y los resultados que se obtienen son únicos para cada caso. Esto implica que los métodos y equipos empleados a la hora de documentar el patrimonio, se adecúen a las finalidades deseadas y a las precisiones prefijadas.

Al hablar de documentación del patrimonio, basándonos en la clasificación del profesor Lodeiro (1995), podemos diferenciar dos grupos de documentos ("métricos" o "no métricos"), que implican distintas labores de actuación.

La documentación no métrica, generalmente está destinada a labores divulgativas y didácticas, en su gran mayoría museos en los que se incluyen modelos en tres dimensiones o representaciones virtuales $360^{\circ}$ de un objeto. Los métodos más comunes basados en esta técnica son las descripciones y el uso de fotografías e imágenes, fotos panorámicas o modelos virtuales, que sirven para trazar un plan de actuación en una posible restauración, o imágenes radiográficas y reflectográficas que permiten desvelar información subyacente de una obra pictórica, utilizando una cámara sensible en la zona del infrarrojo.

Hasta la fecha, la documentación que consta de la capilla de San Marcos, es exclusivamente de carácter "no métrico": descripciones por parte de diversos autores, fotografías, gráficos esquemáticos y documentos escritos de archivos particulares, así como fuentes directas o testimonios verbales. Además de las fotografías ya comentadas en este artículo, podemos citar una serie de plantas, alzados y secciones de 1919 del Arquitecto Julio Bravo (1919); un recibo de 1920 del taller de pintura Hijos de Silvestre Gracia (1920) para reparar la capilla y los esquemas gráficos y fotografías del profesor Esteban (1970). A partir de estos datos resultaría muy complicado dejar correctamente documentada la capilla desde el punto de vista gráfico y geométrico. Ni siquiera las fotografías que constan, nos darían la información suficiente para recuperar pinturas o elementos arquitectónicos en el caso de que éstos se perdieran; de ahí la importancia de utilizar formas de documentación más precisas y completas.

Por otro lado, la documentación métrica permite un registro exacto del bien, lo que implica definir su geometría en un momento determinado, obteniendo alzados, secciones, perfiles y mapas de daños. Además, si se realiza en distintos momentos, se puede obtener un estudio temporal que permitiría elaborar un seguimiento de los movimientos, deformaciones o volumen de la materia perdida. Las medidas con cinta, topografía y rectificación son métodos muy comunes, mientras que el escáner láser y la fotogrametría, son técnicas menos empleadas debido a su reciente aplicación.

El escáner láser es una técnica de ingeniería inversa, que permite obtener un modelo tridimensional en el que se cuenta con una documentación tanto geométrica como gráfica del patrimonio. (Angás 2010) Gracias a esta tecnología, somos capaces de registrar datos que por otros métodos serían imposibles de definir. La gran desventaja es el tratamiento de la nube de puntos obtenida, ya que el software de procesado es complejo y caro. Con esta técnica no se toca el bien cultural, por lo que no se introducen deterioros adicionales. Es por ello que se ha escogido esta técnica no destructiva para trabajar en la capilla de San Marcos, ya que es la más conveniente para desarrollar el producto museográfico. La toma de datos se llevó a cabo en dos sesiones diferentes: por un lado se procedió a escanear el interior de la capilla, mientras que por otro, se escanearon la portada y las naves de la catedral.

En cuanto a la capilla de San Marcos se dispusieron en la parte baja de la misma y en las escaleras ascendentes, tres luminarias (luz fluorescente) de modo 
que quedasen iluminados los dos lienzos laterales y el interior del recinto. Más tarde, se procedió a colocar un conjunto de siete dianas circulares, con un patrón en blanco y negro, que sirvieron para unir un total de tres escaneados permitiendo documentar la capilla geométricamente en su totalidad (Fig. 14). Una vez dispuestos estos adhesivos, se continuó con el montaje del escáner láser de diferencia de fase Leica HDS 6100 (LINK http://hds.leicageosystems.com/downloads123/hds/hds/HDS6000/broc hures-datasheet/HDS6100 Datasheet us.pdf ) sobre un trípode que descansa en una estrella de apoyo. Después de su calibrado, procedimos al escaneo por control remoto desde un ordenador portátil, realizando en primer lugar un barrido láser que registró todos los puntos de la capilla a una resolución preestablecida obteniendo una nube de puntos. Posteriormente se realizaron escaneados parciales a mayor resolución de los puntos diana. Estos puntos o localizaciones comunes, permitieron la unión de diferentes escaneados con mayor facilidad. Mediante este proceso la geometría de la capilla queda registrada, tras lo cual, sin mover el trípode, se procedió a fotografiar la capilla, sustituyendo el escáner láser por una cámara fotográfica, de modo que la lente quedase ajustada con su mismo eje. Las fotos tomadas (ocho fotografías por cada escaneado), deberán ajustarse a la nube de puntos para generar tres imágenes equirrectangulares que documentan la capilla gráficamente por completo (Fig. 15).

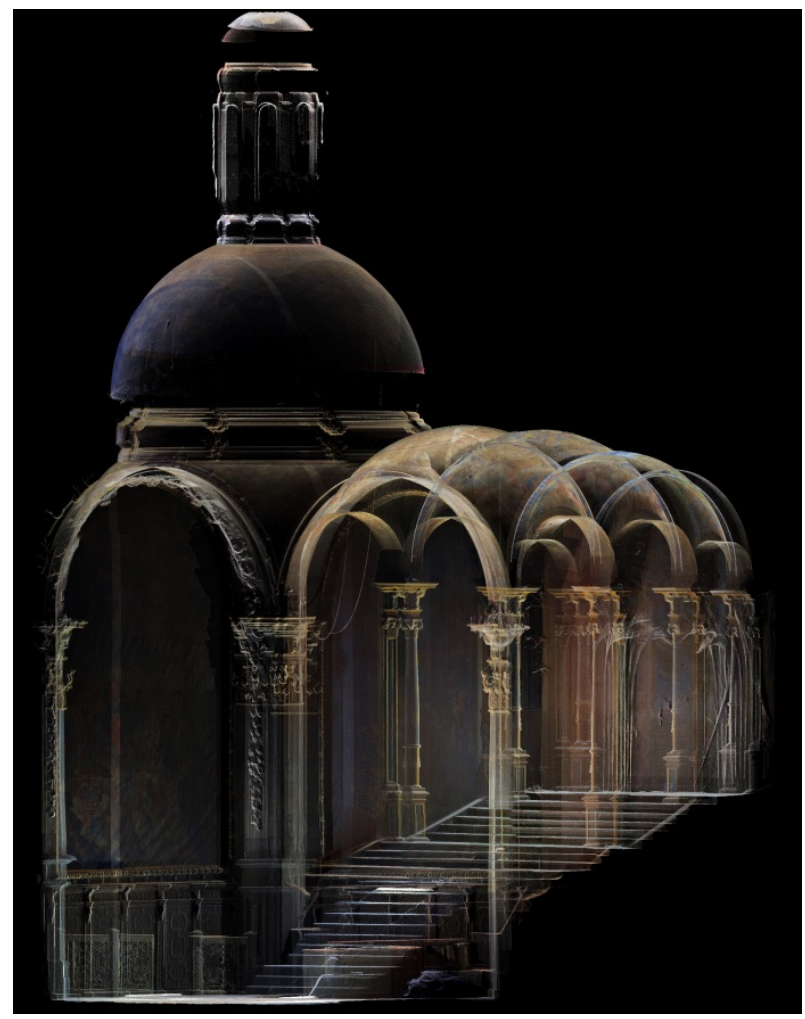

Figura 14: Nube de puntos que documenta geométricamente la capilla.

Para digitalizar la portada de la capilla y las naves de la catedral, la forma de proceder fue muy similar a la que se cita en el párrafo previo. Aunque en este caso, a fin de comparar métodos de trabajo y resultados con respecto al escáner anterior, se optó por utilizar un escáner de tiempo de vuelo Leica C10 (Fig. 16) (LINK http://hds.leica-

geosystems.com/downloads $123 /$ hds/hds/ScanStation $\% 2$ 0C10/brochures-

datasheet/Leica ScanStation C10 DS en.pdf ) que registró datos geométricos y gráficos en el mismo proceso. Este escáner consta de una memoria interna y es independiente de un ordenador externo que lo controle. Una vez que fueron configurados los parámetros deseados, el escáner tardó 40 minutos en completar cada uno de los tres barridos que fueron necesarios para registrar el exterior de la capilla (Fig. 17).

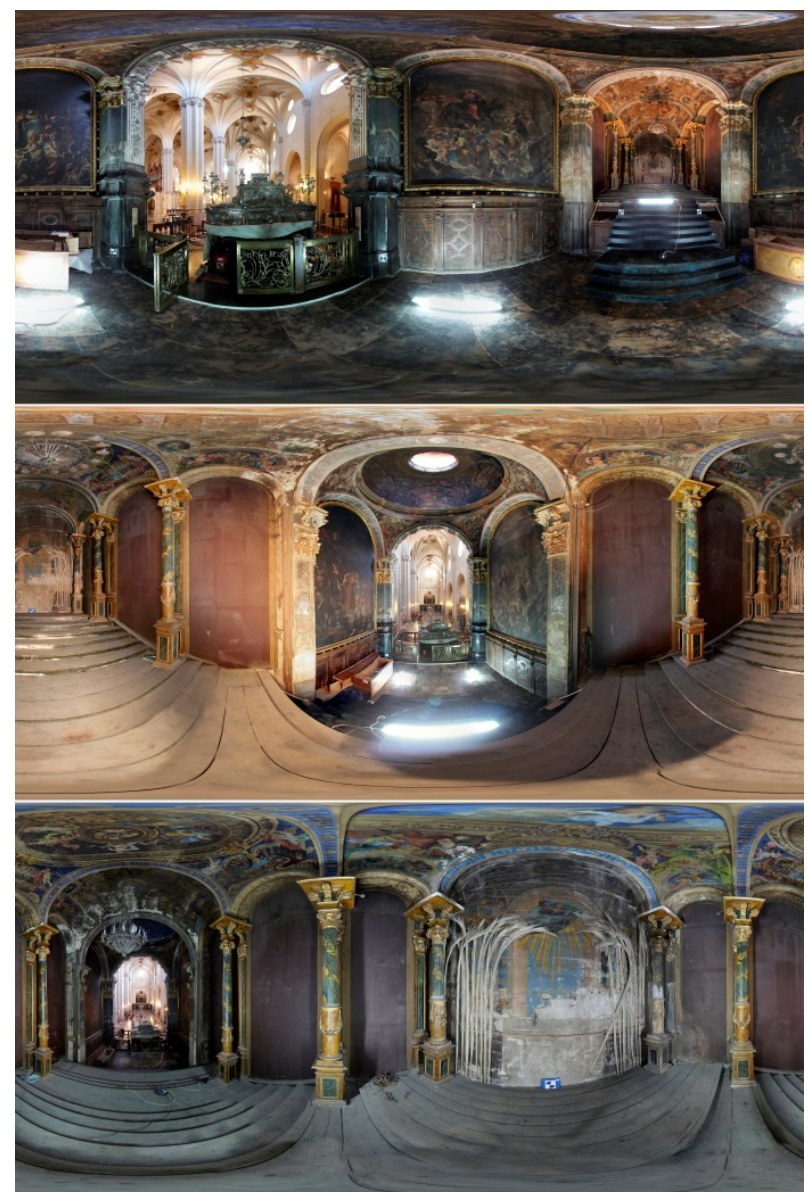

Figura 15: Conjunto de imágenes equirrectangulares que documentan gráficamente la capilla.

Tras la toma de datos y escaneos necesarios para registrar en su totalidad todos los puntos que se necesitaban, se procedió al tratamiento de los mismos mediante el programa Leica Cyclone (LINK http://survey.crkennedy.com.au/sites/default/files/downlo ads/Leica\%20Cyclone\%20Basic\%20User\%20Manual\%2 0-\%20January\%202015.pdf ), para seleccionar aquéllos destinados al diseño del producto museográfico. Para el manejo de la nube de puntos de la portada de la capilla de San Marcos, fue necesario utilizar una serie de software específicos para cada una de las tareas, con el objetivo de imprimir la portada en tres dimensiones, mediante técnicas de prototipado rápido para su posterior uso en una maqueta a escala. 


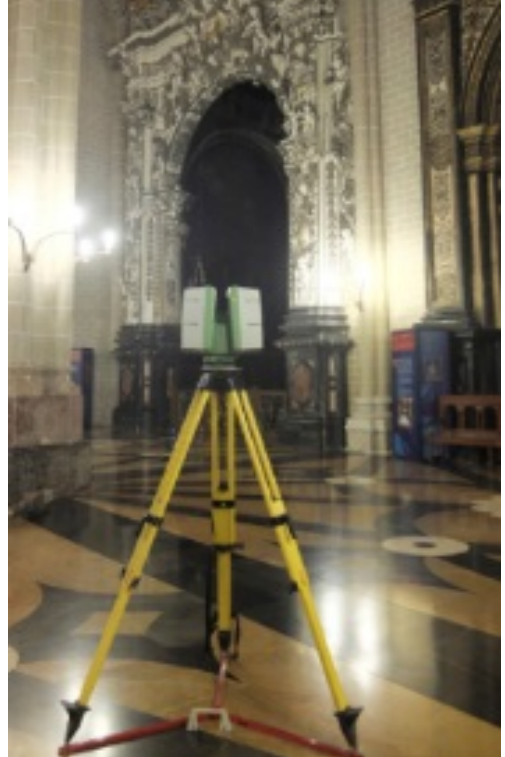

Figura 16: Escáner Leica $\mathrm{C} 10$ en las naves de la catedral del Salvador de Zaragoza.

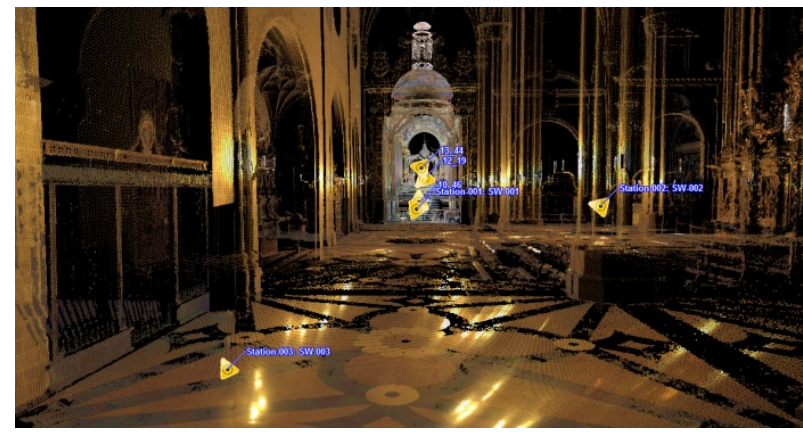

Figura 17: Estaciones de escaneo para el registro de datos exterior a la capilla.

El tratamiento general consistió, mediante el software Geomagic Studio12 (LINK http://www.dirdim.com/pdfs/DDI Geomagic Studio Wra p 2012.pdf ), en triangular las nubes registradas con el fin de obtener una superficie (malla de polígonos altamente refinados), ya que al tratarse de una portada libre y de gran complejidad, no se necesitaba grado de parametrización, por lo que no era necesario realizar un modelo CAD (Fig. 18).

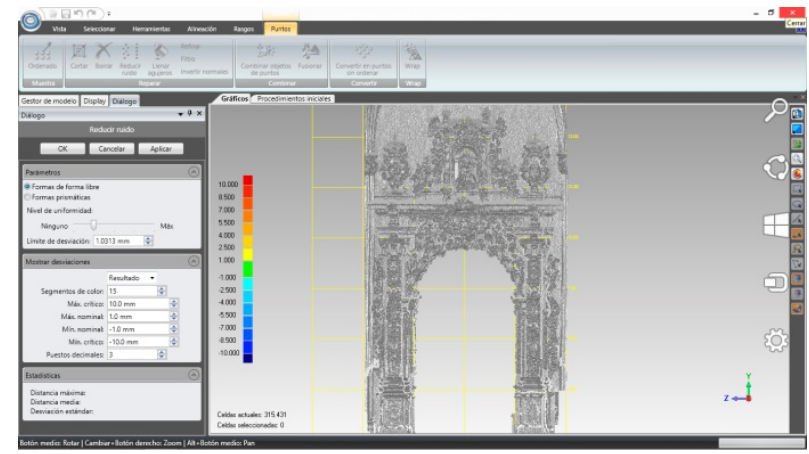

Figura 18: Captura de pantalla del programa Geomagic Studio $12^{\text {TM }}$

Debido a la gran cantidad de detalles de la portada, fue necesario exportar la malla de polígonos altamente refinados a un software de modelado $3 D$ denominado Zbrush $4 R 6 \quad$ (LINK http://pixologic.com/zbrush/downloadcenter/documentati on/ ). Gracias a este software, se pulieron las superficies de forma más sutil que con Geomagic Studio12. Además, se reconstruyeron parte de los ángeles y detalles de la portada reajustando la geometría para hacerla lo más fiel a la realidad, disminuyendo el ruido y consiguiendo una imagen más nítida (Fig. 19).

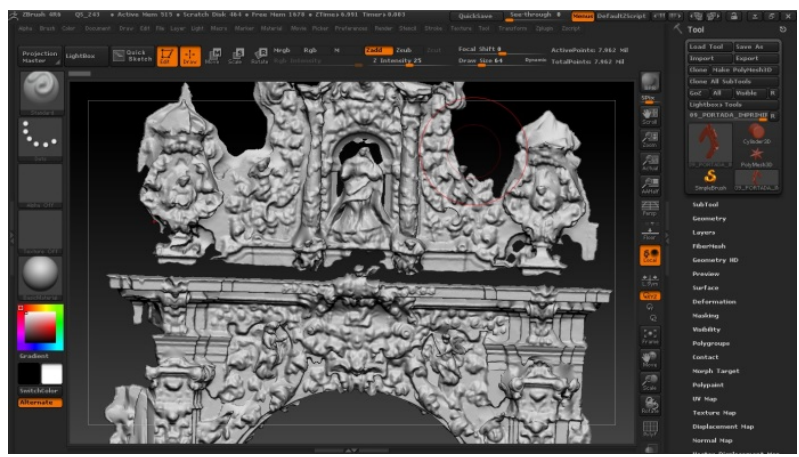

Figura 19: Captura de pantalla del programa Zbrush $4 R 6$.

Como se puede apreciar, la ingeniería inversa permite la digitalización y el posterior tratamiento de objetos físicos mediante programas (Geomagic, Polyworks, Zbrush, ...). En nuestro caso se trabajó con la nube de puntos y se realizó un modelado escultórico de ajuste preparándolo en formato .OBJ para la impresión me diante técnicas de prototipado rápido.

Se entiende como prototipado rápido el proceso de fabricar artículos mediante la adición de capas ya sean de metal, plástico, cerámica u otros materiales. La impresión 3D puede ser utilizada en distintos ámbitos, desde la medicina, el prototipado, la aeronáutica, hasta aplicaciones en el ámbito doméstico. En este caso la tecnología de adición de capas ha sido utilizada con fines museográficos, imprimiendo la portada de ingreso para realizar una maqueta a escala 1:50 de la capilla (Fig. 20).

Para la impresión fue necesario convertir el archivo .OBJ al estándar .STL (Standard Triangulation Languange). Este formato es una discretización de la pieza mediante triángulos, los cuales vienen referenciados por las coordenadas de sus ejes y un vector normal en la superficie. De esta manera el programa reconoce las caras interiores y exteriores. Cuantos más puntos posea el STL más triángulos habrá y más fiel será el archivo. Para continuar con la impresión, se necesita preparar el archivo STL importándolo a un programa de slicing que divida al modelo $3 \mathrm{D}$ en capas y genere las trayectorias que más tarde interpretará la impresora.

El software de la impresora Object EDEN $350 \mathrm{~V}$ (Stratasys Inc.) (LINK http://www.3dvision.com/pdf/3Dprinting/design-series/Objet-Eden350 350V.pdf

utilizada en este proyecto permite gestionar diferentes puntos clave en la impresión, como son la orientación y distribución de la pieza, las estructuras de soporte, la generación de capas y la trayectoria del cabezal para imprimir la portada. Esta acción, es un proceso automático desatendido que tiene una duración variable en función del tamaño del objeto a imprimir. Consiste en la adición de capas (entre 16 y $30 \mu \mathrm{m}$ ) de un polímero 
acrílico líquido, polimerizado por radiación ultravioleta tras ser depositado por el cabezal. Tras la fabricación de la portada de ingreso, se realizó el postproceso de la pieza, eliminando el material de soporte y realizando tratamientos para mejorar la calidad superficial así como sus propiedades físicas.

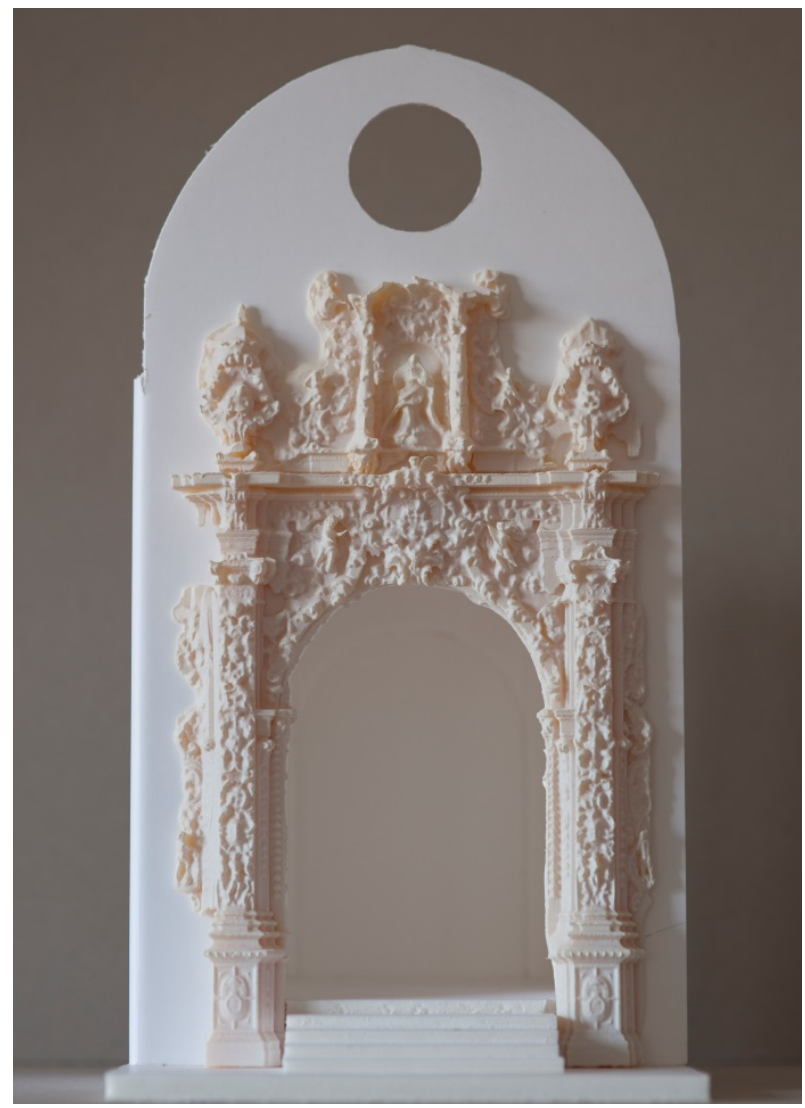

Figura 20: Maqueta a escala de la capilla de San Marcos con la portada impresa mediante técnicas de prototipado rápido $(30 \mathrm{~cm} \times 20 \mathrm{~cm})$.

\section{Propuesta museográfica para la capilla del Monumento: El uso de técnicas de realidad aumentada}

Después de haber analizado los aspectos técnicos, queda patente la utilidad de la ingeniería inversa en la documentación de bienes culturales y la importancia que tiene a la hora de ser empleada en productos museográficos que permitan la difusión del patrimonio (Ruiz 2010).

Hasta hace un tiempo, la museografía se había sostenido en métodos tradicionales en los que no había interacción entre el usuario y el bien cultural. Pero desde hace unos años, se está comenzando a tener en cuenta este aspecto, llegando a soluciones como la utilización de recursos tecnológicos acordes a nuestro tiempo, que mejoran la experiencia del usuario con técnicas como por ejemplo la realidad aumentada.

El videomapping es una técnica audiovisual de realidad aumentada que consiste en la proyección de luz sobre un objeto tridimensional del espacio real que permite proyectar imágenes, texturas o vídeos, con el objetivo de crear en el espectador un estímulo sensorial en la percepción.
Uno de los ejemplos museográficos más destacados a nivel nacional donde se ha empleado esta técnica es el de la iglesia románica de San Clemente de Tahull (LINK https://vimeo.com/87102885 ). Esta iglesia que fue construida entre los siglos XI-XII y fue declarada Patrimonio Mundial por la Unesco en el año 2000. Consta de una proyección audiovisual animada que mediante 6 proyectores de alta definición reproduce virtual y fielmente las pinturas originales del ábside mayor (Fig. 21). Las pinturas del ábside que había hasta ahora (que eran una reproducción de las originales hecha en 1960 por Ramon Millet) se conservan ahora en un museo anexo en la misma zona. Los frescos originales se conservan en el Museo Nacional de Arte de Cataluña en Barcelona.

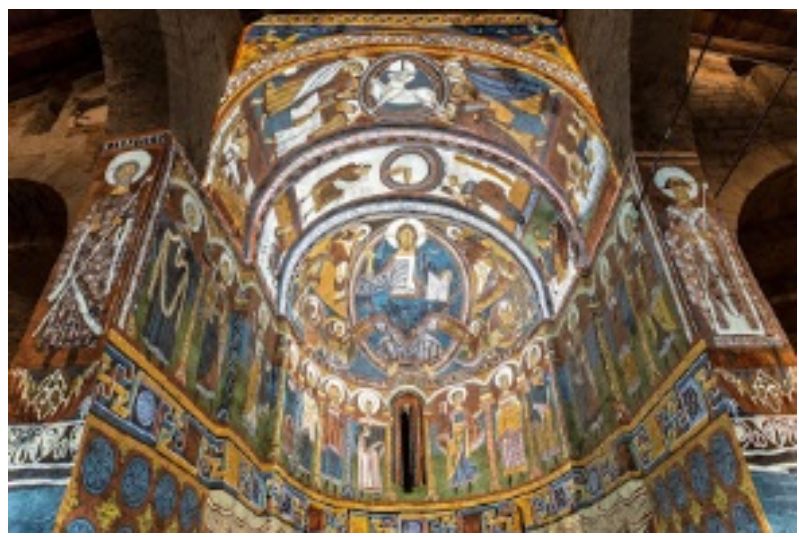

Figura 21: Reconstrucción mediante videoproyección de los frescos románicos de San Clemente de Tahull. Lérida

A continuación abordaremos los elementos fundamentales que constituyen la técnica del videomapping con la intención de diseñar un producto museográfico para la capilla de San Marcos. El sistema de proyección, la superficie proyectada, los puntos de visualización y los contenidos, son los aspectos a tener en cuenta.

Un sistema de proyección consta de diferentes características que afectan de forma directa en la proyección final. El sistema óptico influye en el proceso de calibración del mapeado, ya que determina el frustum o cono de proyección del proyector. Este sistema está formado por: el ratio que indica la relación entre la distancia del foco y el ancho del área de proyección; el shift que representa el desplazamiento del eje óptico y el focal, la longitud del sistema óptico. El resto de elementos que forman el sistema de proyección son la relación de aspecto, luminosidad, definición, contraste y parámetros intrínsecos y extrínsecos del proyector.

Las superficies donde se puede videoproyectar son continuas o discontinuas. Las continuas son aquellas superficies lisas o curvas como cúpulas, columnas o esferas, mientras que las discontinuas tienen geometrías más complejas, ya que constan de diferentes planos de proyección. Ambas son independientes del material sobre el que se proyecte.

Un proyecto de videomapping puede llevarse a cabo de diferentes formas. El objetivo final siempre trata de adaptar una proyección a una superficie del espacio real para ser vista desde un punto de visualización concreto. Cada técnica tiene sus ventajas y sus inconvenientes, que generalmente tienen que ver con la 
espectacularidad de la proyección y la complejidad del montaje. Para realizar el set up es necesario comprender el montaje desde tres elementos diferentes: objeto, proyector y espectador. El punto de visualización donde se coloca el espectador influye de forma decisiva en la percepción de la videoproyección, cuestión que se ha tenido en cuenta a la hora generar los contenidos para el producto museográfico para la capilla de San Marcos. En la mayoría de los casos este problema se soluciona ubicando a los espectadores y el sistema óptico en el mismo lugar. Es por este motivo que cuando la perspectiva del contenido no coincide con la del espectador, el efecto 3D no es coherente.

Existen varias formas a la hora de videoproyectar y ajustar la proyección al espacio real. La primera de ellas es el pintado directo, útil para casos simples. Éste no requiere de calibración ni necesita un programa de edición de imagen. Es imprescindible no mover ni el proyector ni el objeto sobre el cual proyectamos, ya que el efecto 3D solo se aprecia desde un único punto de vista. Por el contrario, MeshWarping (QuadWarpingHomografía) se utilizan para geometrías más complejas, ya que precisan de un mallado previo de la proyección, que posteriormente se ajusta a la superficie del espacio real. El resto de formas precisan de un modelado $3 D$ de la escena, ya que son sistemas complejos basados en visión por computador que utilizan una imagen real y un mapa de profundidad para modelos de interactividad.

La generación de contenidos es el último elemento que constituye la técnica de videomapping. Como ya hemos dicho, una de las principales características de esta tecnología es la adaptación de los contenidos a la superficie de proyección, para lo cual es necesario realizar un estudio previo del espacio sobre el cual se quiere proyectar. Una vez estudiada la superficie se puede proceder de dos formas: bien proyectar a partir de un modelado 3D como se ha hecho para el caso de la capilla de San Marcos, o bien proyectar a partir de una plantilla 0 foto generada a través de un procedimiento fotográfico, en el que es necesario contar con una óptica similar a la de proyección.

Antes de abordar el desarrollo del producto museográfico sobre la capilla de San Marcos se realizaron diferentes pruebas en la catedral. Una de ellas se llevó a cabo en el trascoro, tomando una imagen que posteriormente fue procesada coloreando sus distintas partes. Después se proyectó la imagen mallándola y ajustándola a la superficie original (Fig. 22).

De la singularidad de esta capilla surge la necesidad de diseñar un producto museográfico específico para la difusión del patrimonio histórico-artístico de Aragón, basado en técnicas de realidad aumentada; en este caso videomapping. Gracias a esta técnica se puede realizar una fiel reconstrucción del estado original y funcionamiento de la capilla, además de utilizar elementos ficticios estimulando la imaginación del espectador. En caso de llevar a cabo este proyecto se podría diseñar un producto museográfico para ser utilizado en futuras exposiciones en la catedral del Salvador, con una función didáctica, arqueológica y restaurativa, que sirva de referente y motivo para atraer visitantes.

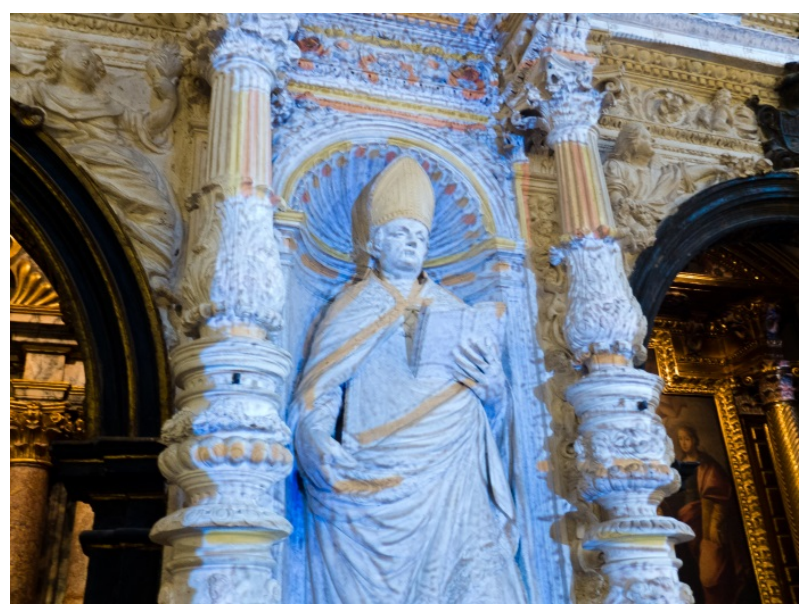

Figura 22: Ejemplo de proyección en realidad aumentada sobre el trascoro de la catedral del Salvador de Zaragoza.

Desde el punto de vista museográfico se procede a estudiar el espacio dando lugar a tres posibles soluciones acordes a los recursos de que se dispone, teniendo en cuenta la aplicabilidad, el coste y la funcionalidad. En la primera opción se decide proyectar sobre toda la superficie que forma la capilla, independientemente de la dificultad de la geometría: en la albanega de la fachada exterior utilizando el ojo de buey que hay en lo alto, así como en el interior de capilla, tanto en la escalinata sobre todas las columnas, como en el lienzo del fondo. En una segunda opción, se puede optar por proyectar únicamente sobre la portada de ingreso, jugando con todos los elementos decorativos que la forman. En último lugar, sería posible proyectar tanto sobre la portada de ingreso como sobre una lona, justo en el sitio donde originalmente estaba situado el telón con el altar fingido (Fig. 23). Además, como función extra, se podría disponer de dos pantallas laterales que cerraran y enmarcaran el espacio de la portada, permitiendo que se puedan proyectar imágenes de los tapices de la colección del Cabildo para simular la empaliada (Fig. 24). a)
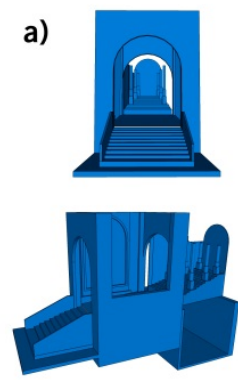

b)
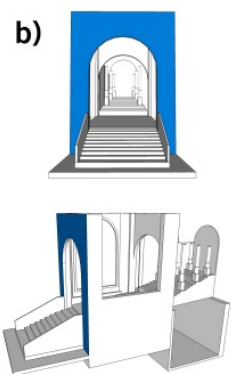

c)
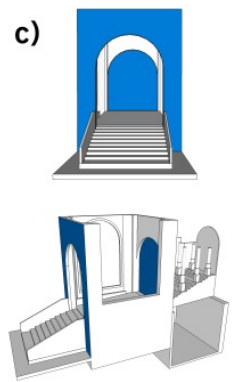

Figura 23: a) esquema del diseño de la proyección sobre todo el espacio, b) únicamente sobre la portada, c) sobre la portada y lona situada en el espacio del telón.

Después de las alternativas anteriormente citadas y tras la evaluación de las mismas, se decide elegir la tercera opción. Esta solución funciona muy bien a nivel compositivo, permitiendo jugar con dos planos a diferentes profundidades de modo que el espectadorusuario pueda entender el espacio en el que se encuentra. De esta forma, al proyectar sobre la lona situada en el interior de la capilla se puede simular el 
uso del antiguo telón, mientras que al hacerlo sobre la fachada de ingreso podemos generar contenidos de mayor libertad visual, minimizando los recursos y aumentando la espectacularidad.

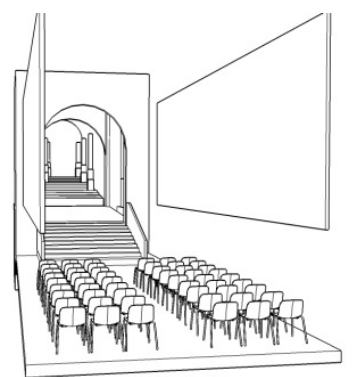

Figure 24: Esquema de dos pantallas opcionales para recrear la empaliada de tapices.

Los contenidos son el conjunto de imágenes, texturas y videos que podrían proyectarse a la hora de diseñar el producto museográfico, permitiendo la recreación del estado original de la capilla, su evolución histórica, su restauración, el proceso de construcción de las perspectivas fingidas, así como el montaje del Monumento de Semana Santa para la ceremonia del Jueves Santo y los elementos que lo componían en el pasado.

Para poner en práctica esta técnica de realidad aumentada se procedió a proyectar diferentes contenidos sobre una maqueta a escala de la capilla, ya que resulta práctico y económico, quedando patente el papel relevante de las nuevas tecnologías en lo que a la documentación y difusión del patrimonio se refiere (Fig. 25).

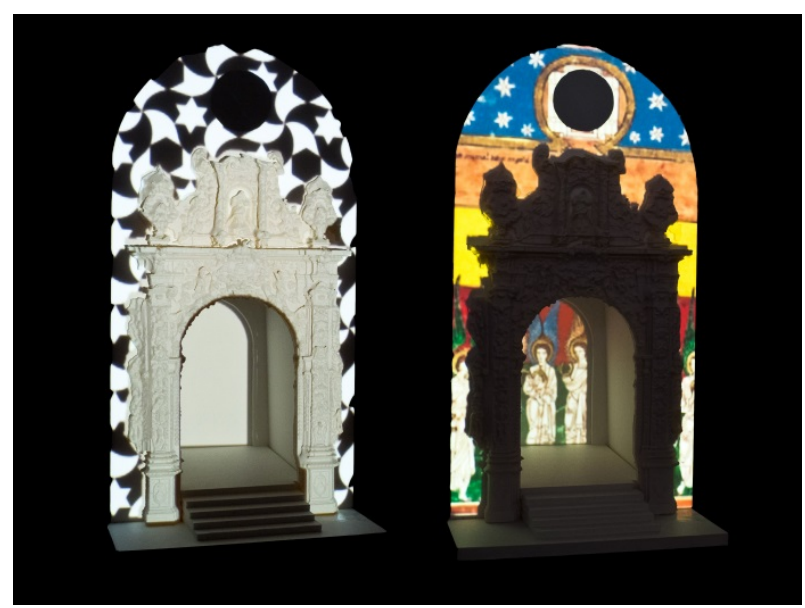

Figura 25: Ejemplos de proyección en la maqueta sobre el alzado de la capilla y el telón

\section{Conclusiones del proyecto}

La elaboración de un producto museográfico para un espacio singular, como es el de la capilla de San Marcos o del Monumento de la catedral del Salvador de Zaragoza, requiere ante todo de un exhaustivo estudio previo documental para el posterior diseño de un producto que permita su difusión. Con el fin de poder estudiar y conservar los bienes culturales, las técnicas de documentación han ido perfeccionándose hasta la actualidad, donde las nuevas tecnologías, en su gran mayoría de carácter métrico como es el caso de la ingeniería inversa, han resultado fundamentales.

Desde hace unos años, se ha comenzado a cuestionar la museografía tradicional, llegando a soluciones en las que se usan recursos tecnológicos acordes a nuestro tiempo. Estas soluciones mejoran la experiencia del usuario, con técnicas como por ejemplo la realidad aumentada y que permiten la interacción con el bien cultural hasta ahora impensable. Es así como se ha dotado de ficción e irrealidad a un espacio que de por sí ya resulta curioso para darle mayor reconocimiento, e ir un poco más allá generando valor añadido mediante la unión de arte e ingeniería.

Hemos visto como el prototipado nos permite restituir piezas del patrimonio. Las técnicas de impresión 3D ayudan a elaborar representaciones a escala con gran precisión, para trazar líneas de actuación y comprobar resultados. El resultado final es un producto museográfico (Fig. 26) basado en técnicas de realidad aumentada, en las que mediante el videomapping se ha conseguido recrear el estado original de la capilla, su evolución histórica, su restauración, el proceso de construcción de las perspectivas fingidas, así como el montaje del Monumento de Semana Santa para la ceremonia del Jueves Santo y los elementos que lo compusieron en el pasado.

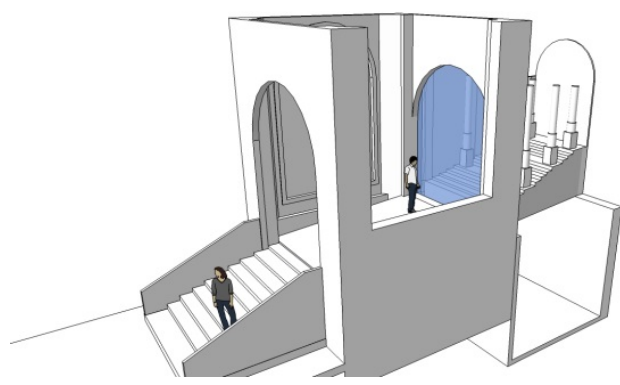

Figura 26: Producto final. Esquema de interacción usuarioproducto. En color azul se muestra la lona retroproyectada.

\section{Referencias}

ANGÁS, J., 2010. Valorización, difusión y estandarización de la documentación geométrica del patrimonio. In Secretaría general técnica de Publicaciones, Información y Documentación. Documentación gráfica del Patrimonio ( $1^{\text {a }}$ Ed. pp.154-163.). Madrid: MEC. Gob España.

BELTRÁN, A., 1962. Los museos de Zaragoza. Zaragoza: Boletín Municipal de Zaragoza, Año 3, №8, página 24, a pie de foto: "Tapicerías colgadas en Semana Santa".

BONET, A., 1993. La arquitectura efímera del Barroco en España. Revista de Arte, n¹3, pp.23-70.

BRAVO, J., 1919. Planos arquitectónicos, №15, documentos 1 y 2 . Archivo Capitular de La Seo de Zaragoza. 
CALVO, J. I. y LOZANO, J.C., 2004. Los monumentos de Semana Santa en Aragón (Siglos XVII-XVIII). Artigrama, núm. 19, pp. 95-137.

DE LA SALA-VALDÉS, M., 1933. Estudios históricos y artísticos de Zaragoza. Zaragoza: Imprenta del Hospicio Provincial. 293 pages.

ESTEBAN, J.F., 1977. La capilla de San Marcos y el Monumento de Semana Santa de La Seo de Zaragoza. Seminario Arte Aragonés, XXII-XXIII-XXIV, pp. 175-180.

ESTUDIO COYNE, 1954. Tapiz de "La Predicación de San Pablo". Archivo Histórico Provincial Zaragoza- Catedral de San Salvador, ES/AHPZ-MF/COYNE/000722-000729. Retrieved May 28, 2016, from http://dara.aragon.es/opac/app/item/arfo?vm=nv\&q=tapiz+manuel+coyne+1954\&p=4\&i=368473

FATÁS, G., 2008. Guía histórico artística de Zaragoza. Zaragoza: Institución Fernando el Católico.

GASCÓN DE GOTOR, A., 1939. La Seo de Zaragoza. Estudio histórico-arqueológico, col. "Arte Aragonés". Barcelona: Ed. Luis Miracle.

IBÁÑEZ, J., 2006. Los decorados de Semana Santa en Aragón en la Edad Moderna en Monuments et décors de la Semaine Sainte en Méditerranée: art, rituels, liturgies, Actes des premières rencontres méditerranéennes sur les décors de la Semaine Sainte. Art et rituels autour des Monuments, Université de Toulouse-Le Mirail. Perpignan, 2325 nov. pp. 45-132.

LODEIRO, J.M., 1995. Aplicaciones de la topografía en la documentación arquitectónica y monumental. Madrid: colegio oficial de ingenieros técnicos en topografía.

LOZANO, J.C., 2010. La pintura barroca en La Seo de Zaragoza: viejos problemas, nuevas visiones, in M. C. Lacarra Ducay. El barroco en las catedrales españolas. Zaragoza: Institución Fernando el Católico.

MAGAÑA, A., 1919. Zaragoza Monumental. Vol 1. Edificios Religiosos. Zaragoza: Artes Gráficas Gregorio Casañal, página 18, Lámina 51, a pie de foto: "Perspectiva del monumento de Jueves Santo".

MORA, J., 1905-1954. Zaragoza, S. Pablo. Tapiz. Estilo: Renacimiento. Rafael Sancio de Urbino. Archivo Histórico Provincial Zaragoza- Archivo Arte Aragonés. ES/AHPZ-MF/MORA/001837-001843. Retrieved May 28, 2016, from http://dara.aragon.es/opac/app/item/arfo?vm=nv\&q=tapiz+renacimiento+rafael+urbino\&p=0\&i=199926

MORTE, M.C., 1986. Monumentos de Semana Santa en Aragón en el siglo XVI. Artigrama: Revista del Departamento de Historia del Arte de la Universidad de Zaragoza, 3, pp 195-214.

RUIZ, J., 2010. ImaginArte. Aplicación de tecnologías 3D en museos y espacios singulares. In Secretaría general técnica de Publicaciones, Información y Documentación. Documentación gráfica del Patrimonio, 1ª Ed. pp.144-153. Madrid: MEC. Gob España.

SILVESTRE, H., 1920. Culto y fábrica. Recibos año 1920. Pinturas Capilla Monumento. Archivo Capitular de La Seo de Zaragoza. 


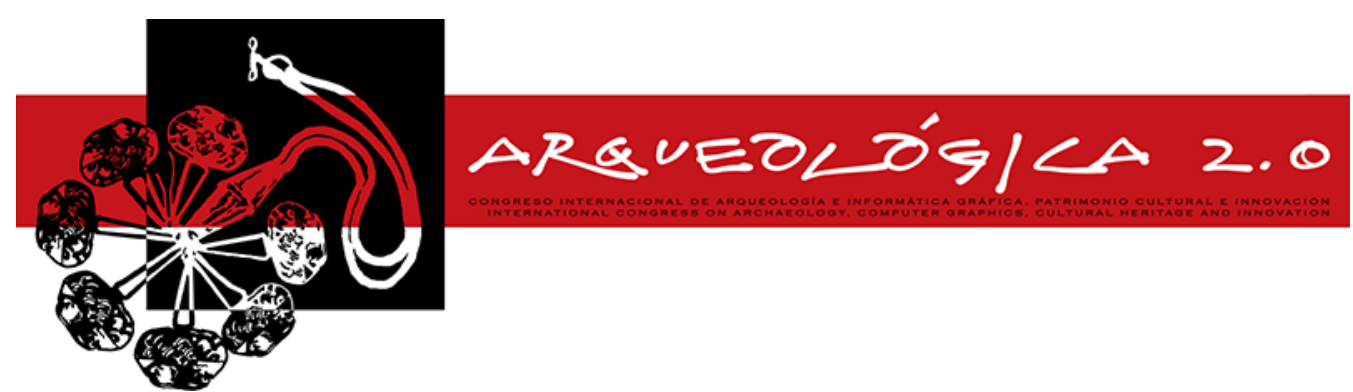

Proceedings of the $8^{\text {th }}$ International Congress

on Archaeology,

Computer Graphics,

Cultural Heritage and Innovation

'ARQUEOLÓGICA 2.0'

in Valencia (Spain),

Sept. $5-7,2016$

DOI: http://dx.doi.org/10.4995/arqueologica8.2016.2982

Received: 02/03/2016

Accepted: 09/04/2016

\title{
DIGITAL RECONSTRUCTIONS - A METHODOLOGY FOR THE STUDY, PRESERVATION AND DISSEMINATION OF ARCHITECTURAL HERITAGE
}

\author{
RECONSTRUCCIONES DIGITALES - UNA METODOLOGÍA PARA EL ESTUDIO, CONSERVACIÓN Y \\ DIVULGACIÓN DEL PATRIMONIO ARQUITECTÓNICO
}

Ana Gil

CERIS, DECivil, Instituto Superior Técnico, University of Lisbon, Avenida Rovisco Pais, 1049-001 Lisbon, Portugal. ana.c.gil@tecnico.ulisboa.pt

\begin{abstract}
:
The architectural heritage is a particular case from the immaterial and material assets, movable or immovable, constituents of the cultural heritage. It is presented as a complex system with a continuous historical process, which can not be dissociated from its surroundings (Brusaporci 2015).

In order to study, preserve and disseminate the past and present reality of this type of heritage, it was developed a digital recostruction methodology, able to adapt to each specific case, both in the object nature and in the representation objectives. This is only possible due to the last decade technological advances, that, alongside with the hardware and software development, led to the digital heritage definition.

In order to disclose and discuss the proposed methodology, is presented digital reconstructions of monuments that have marked and still mark the image of the city of Lisbon. European city, capital of Portugal, country of aqueducts, rich in religious and military architecture. To cover their specific needs, taking into account their different natures, is presented the following case studies: 1) particular case of an extensive monument - the Águas Livres Aqueduct - and the case of territory circumscribed monuments in different preservation states (demolished, remains or existent). This last includes three representative convents of Lisbon's religious houses: the Nossa Senhora da Piedade da Esperança Convent, the Santíssima Trindade Convent and the Santo Antão-o-Velho College.

The developed digital reconstructions were based on the London's Charter and Principles of Seville, in order to ensure the intellectual and technical rigor, as well as the methodological computer-methods visualization work sturdiness. Thus, the developed methodology is scientific, cyclical and flexible based on the creation of digital models with associative and parametric geometry - BIM models (Building Information Model) - intended to include the architectural heritage study, conservation and dissemination.
\end{abstract}

Key words: Heritage architectural, virtual reconstructions, Digital Heritage, London Charter, Seville Principles, BIM

\section{Resumen:}

El patrimonio arquitectónico es un caso particular entre los bienes inmateriales y materiales, muebles e inmuebles constituyentes del patrimonio cultural. Se presenta como un proceso histórico continuo que no puede ser descotextualizado de su entorno (Brusaporci 2015).

Con la intención de estudiar, preservar y divulgar la realidad pasada y presente de este tipo de patrimonio, fue desarrolada una metodología de reconstrucción digital capaz de adaptarse a cada caso concreto, tanto por la naturaleza del objeto estudiado como por el objetivo final de su representación que apenas es posible por los avances tecnológicos de la última década que llevarán al nacimiento del concepto de património digital y, paralelamente la innovación y/o perfeccionamiento del hardware y software próprio.

La manera de exponer y discutir una metodólogia desarrollada que muestra las reconstruccines digitales de los monumentos que marcan la imagen de la ciudad de Lisboa. Por la forma de cubrir sus necesidades específicas y teniendo en cuenta sus distintas naturalezas será mostrado el caso particular de un monumento en concreto, el Acueducto de las Águas Livres, el caso de monumentos circunscritos en el territorio de los distintos estados de conservación con tres conventos representativos del universo de los conventos de Lisboa: El convento de nuestra señora de la Piedad de la Esperanza, el convento de la Santísima Trinidad y el colegio de San Antonio Viejo. 
Las reconstrucciones virtuales elaboradas tuvieron como base la Carta de Atenas y los principios de Sevilla como forma de asegurar el rigor intelectual y técnico así como la solided metodológica del trabajo de visualización informatizada. De este modo, la metodología desarrolada, científica de manera cíclica y flexible basada en la creación de los modelos digitales de geometría asociativa y paramétrica. Modelos BIM (Building Information Model) pretende abarcar las vertientes del estudio, conservación y divulgación del patrimonio arquitectónico.

Palabras clave: Patrimonio Arquitectónico, reconstrucciones virtuales, Patrimonio digital, Carta de Londres, Principios de Sevilla, BIM

\section{Introduction}

The responsibility for the cultural heritage belongs to us all, whether in the community, the city, the region or country and we must ensure that it is preserved as a legacy for future generations. This paper aims to present, discuss and validate the established methodology, for architectural heritage study, preservation and dissemination through digital reconstruction. It is intended to be:

- Scientific, where the created models can be considered scientific models, based on solid sources, originating well documented and accurate results. Thus, fulfilling all Principles of Seville, guiding, in a general way, the flow of information between people, software, files and formats, and where the developed elements are easily integrated into the project chain, enabling its access, through the dissemination platform, to all users.

- Cyclic, where the developed models have the ability to be corrected at any time, without the obligation to rebuild them, enabling the results dissemination and their subsequent correction without losing the technical rigor and without depriving the general public of continued disclosure. Making it possible, at any stage, to interrupt and start, allowing an expeditious disclosure of the available data.

- Flexible, adapting to the final objectives, allowing, first, to skip unnecessary steps and disclose the results at any stage, if necessary, and, secondly, to incorporate more appropriate tools to the objectives and to integrate new software or hardware. It is intended that each case is a case, as it is not the model that depends on the methodology but the methodology that depends on the model, establishing guiding lines.

Initially, the extensive monuments issue appeared, since the size and the wide extent territory occupation hindered the survey and subsequent maintenance, as well as studies and dissemination. In this sense, is presented the Águas Livres Aqueduct, the largest extensive monument of Lisbon metropolitan area, in which only small sections are well known to population (Gil 2011; Rua and Gil 2014).

EPAL (Empresa Portuguesa das Águas Livres), the entity responsible for the management and maintenance, did not have enough accurate information about it, and the one they had was not in digital format. This was an opportunity to generate useful data for its management and maintenance, as well as allowing it to be studied and disclosed in its totality. Thus, the main premises were:

- To study the aqueduct main section and its branches (secondary aqueducts), in order to acquire expeditiously geocoded data, as well as the constituent geometry shapes. Data that could be integrated into the company's geographical and alphanumerical database system, in order to optimize the monument management and maintenance.

- To develop digital model's by-products that enables future studies or analysis, and consequent storage in the company's database.

- To develop digital model's by-products in order to assist its dissemination, through its incorporation into the Water Museum exhibition content.

In a second stage, there was a concern to adapt the methodology used in the aqueduct to all kind of monuments, supporting the work of technicians and non-technicians.

In this context, the LxConventos research project (PTDC/CPC HAT/4703/2012) appears with the aim of studying, in a systematic and integrated way, the impact of the religious orders extinction in the development, function and image of the city of Lisbon (Mégre and Silva 2014). The project's study area is limited to the current Lisbon city area and as case study all existing convents (81 convents) until extinction date (1834). Were selected three convents as representative cases of Lisbon's religious houses: the Nossa Senhora da Piedade da Esperança Convent, the Santíssima Trindade Convent and the Santo Antão-o-Velho College, in different preservation states (demolished, remains or existent), respectively, all with different needs.

Because of the size and complexity of the study universe, the project goals accomplishment was only possible through a coordinated multidisciplinary work. Also, the use of technologies, equipment and programs to inventory, analyse, generate results and represent information, became inevitable due to the data project quantity and diversity. So, to compile all the information and to make it available to general public, it was used two main databases: 1) the Inpatrimonium for alphanumeric data, bibliographic, graphic and image repository; 2) ArcGIS - as Desktop platform (ArcMap) for geocoding, spatial analysis and map generation. This information was disclosed through the project website (http://lxconventos.cm-lisboa.pt/), through ArcGISserver - as an integrating storage and spatial data platform availability, web services and webmapping features creations and InWeb, for Inpatrimonium content broadcast (Fig. 1). 


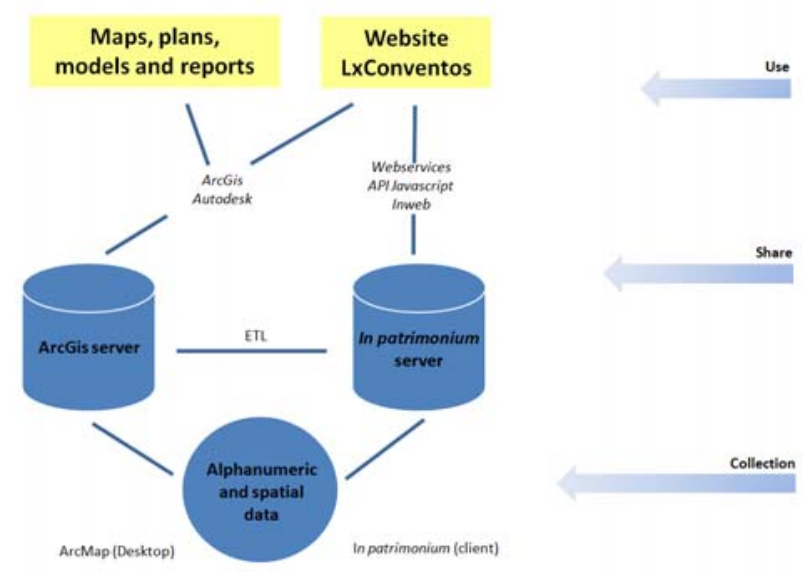

Figure 1: The project information system scheme.

Thus, regarding the selected case studies graphical data production, the main aims were:

- To geotag constituent elements (church, convent, and ground convent) at the extinction and current date, so that it could be studied the impact on an urban scale.

- To study the architectural evolution of the convents at the time of extinction and what has persisted to the present day, with digital reconstruction of three emblematic cases.

- To generate models and data able to integrate the project database, with subsequent availability by an easy and intuitive disclosure in the project's site.

This article is organized in four parts. The first part exposes the acquired importance of today's digital heritage in the cultural heritage field. The second part presents the methodology developed to achieve the stated objectives. In the third, the case studies are presented and analysed. And lastly, the final conclusion is made and future developments are identified.

\section{From the heritage records to computer-methods visualization}

Heritage is understood as part of man's work, in which a community recognizes values and identifies with it. Memory, in turn, is a testimony of past generations heritage and leads to cultural identity consciousness, where the assimilation by the community has a key-role in its preservation and protection through education, research, science and tourism.

The earliest known examples of concern with objects of the past appears in antiquity, but it's with the humanists, in the Renaissance, that is born the awareness of the past's true distance through literary collections, historiographical investigations and graphic surveys of ancient Rome architectural traces.

Following these concerns, a bit all over Europe, throughout the nineteenth century, national heritage protection laws were introduced and entities responsible for the protection and preservation of architectural and / or archaeological heritage were created. In 1931, Athens Charter is written as first normative act exclusively dedicated to heritage. This sets out the need of each country to publish an inventory of the existent heritage, as well as archives creation, with all documents related to historical monuments.

Since then, there have been outlined new concepts and concerns in cultural heritage field, through charters, recommendations and international conventions by UNESCO, COE and ICOMOS. It stands out: the historical monument definition and the importance given to its surroundings (Athens' Charter in 1931); definitions of architectural heritage (European Charter of Architetural Heritage in 1975), historical gardens (Florence Charter on the protection of Historic Gardens in 1981), historical towns and the inhabitants recognition of their importance in the participation and involvement for successful heritage protection (Washington's Charter in 1987); Archeological heritage definition (International Charter on the Archaeological Heritage Protection and Management 1990 corrected by ICOMOS in the International Charter on Underwater Cultural Heritage Protection and Management in 1996); And the cultural tourism recognition as a benefit to the cultural heritage (International Charter on Cultural Tourism in 1999).

With the digital Era, the paradigm changed. ICT (Information and Communication Technologies), combined with the new means of communication, the World Wide Web, have originated a new kind of heritage - digital heritage - recognized by UNESCO in 2003, by the Charter on the Preservation of Digital Heritage. It was clear the importance of heritage information production and distribution through digital means, with easy access, to ensure its transmission to future generations. However it is recognized the weak support, from software and hardware, and it is given to each nation the responsibility for data production and archive, including libraries, archives, museums and public heritage institutions, fomenting education, research and experiences exchange.

With the technological evolution occurred in the last thirty years, the humanities (history, archaeology and architecture) were able to enhance the heritage study and dissemination through the introduction of three-dimensional digital models as main form of visualization. It has appeared substantial three-dimensional modeling software, file formats, working methods and developed models increased potential (Frisher 2008).

In 2009, the London Charter "defines principles for the use of computer-based visualization methods in relation to intellectual integrity, reliability, documentation, sustainability and access. (...) The Charter therefore does not seek to prescribe specific aims or methods, but rather establishes those broad principles for the use, in the research and communication of cultural heritage, of computer-based visualization upon which the intellectual integrity of such method and outcomes depend" (UNESCO 2009).

In 2012, The Principles of Seville intend to increase the applicability of the London's Charter on a cultural heritage specific field: archaeological heritage. Eight fundamental principles are presented: Interdisciplinarity, purpose, complementarity, authenticity, historical rigor, efficiency, scientific transparency, education and evaluation (SEAV 2012). 
The Principles of Seville came to define three categories in which the created scientific three-dimensional models must be built for: dissemination, study and maintenance. In turn, regarding the historical rigor, it highlights the importance of a strong research and documentation, stating photogrammetry and laser scanning as techniques that increase the quality of scientific data. Also, expressing scale evidence (Aparicio and Figueiredo 2010) to distinguish the different accuracy levels of the developed model.

This evolution allowed Humanities to adopt AEC industry (Architecture, Engineering and Construction) BIM methodology (Eastman et al. 2011), in the preparation of architectural heritage scientific three-dimensional models. Thus, the developed models altered from simple nurbs to three-dimensional parametric models with associated databases.

The HBIM (Historical Building Information Modeling) is a BIM feature associated to historic buildings and an attempt to automate architectural canons reproduction (Murphy et al. 2011).

In a general way, BIM came to offer new forms of knowledge management for architectural heritage regarding its documentation, preservation, maintenance (Fai et al. 2013) and disclosure, enhanced by the libraries creation of historical architectural elements and surveys integration by photogrammetry and laser scanning (Santagati 2005) (Garagnani and Manferdini 2013). This type of survey has undergone significant advances, in terms of hardware and software, making expeditious and low-cost surveys, hence multiplying its use among experts in the field.

In Portugal, the first steps in BIM have begun with groups like BIMForum Portugal, BIMClub (BIMForum Portugal 2014) and technnical commission CT197. Regarding computer-methods visualization applied to architectural heritage, there are not known examples that allow to simultaneously potentiate its preservation, dissemination and study. As the closest examples, there are projects such as: City and Entertainment: $A$ view of Pre-earthquake Lisbon, which aims to virtually recreate the memory of the destroyed city caused by November 1th, 1755 earthquake, using Second Life virtual world technology for disclosure (Murteira and Rodrigues 2014); Olisipo Reconstitution and a corbita type Roman ship a past reproduction and interpretation, based on archeology scientific illustration methods, that seeks to represent how ancient Lisbon would have been, disclosed by a documentary "Roman anchorage in Olisipo". These models are only applied to the disclosure category. However, since they are not constituted by parametric and associative elements based on an associated database, it hinders the process of incorporating new data of more complex studies, or its adaptation to maintenance situations where structure still exist.

In this context, it is highlighted $L x$ Conventos project role, which through a multidisciplinary team dedicated to the architectural heritage specific characteristics, generates Lisbon's Convents useful data, used in its study, dissemination and preservation, all stored and available to the community in digital format.

\section{Digital reconstructions - a methodology}

Nowadays, the development of scientific $3 \mathrm{~d}$ models has increased rapidly, as well as the methodologies and tools used by the purpose for which they are intended to, as stated by the previous section.

The developed methodology (Fig. 2) is scientific, cyclical and flexible as explained before, based on as-built digital models creation with associative geometry and parametric - BIM models - intended to be used, simultaneously, for study, preservation and dissemination of architectural heritage.

According to this, the data goes through three main stages: 1) Acquisition, made by research and survey, 2) Interpretation and treatment, and finally, 3) Communication, made by modeling and visualization. It is possible to make studies and analysis in any stage, more common in stage 2 and 3.

Follows a brief description of each of these phases.

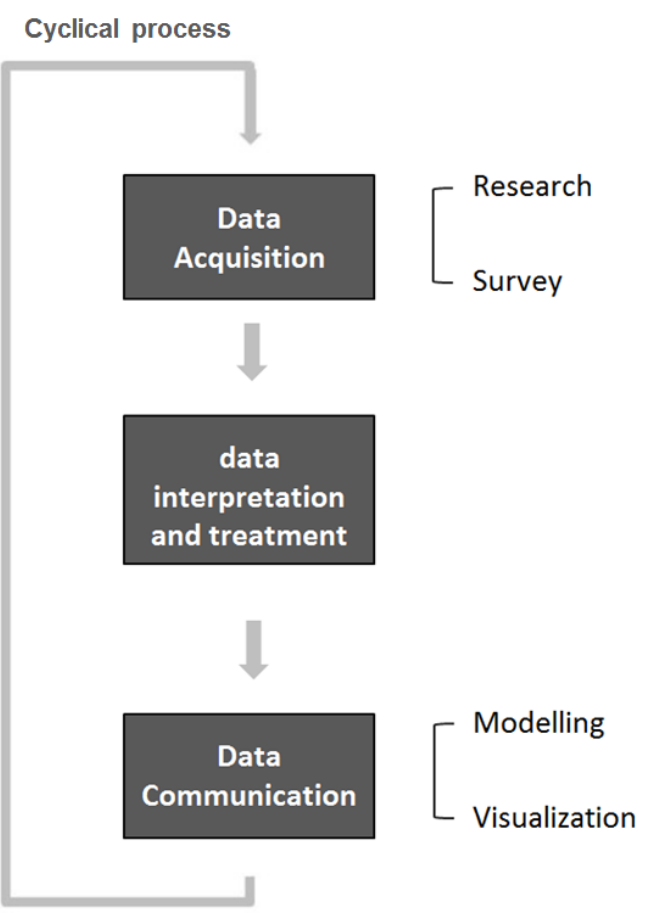

Figure 2: Developed methodology for the development of architectural heritage virtual reconstruction.

\subsection{Research}

At this stage it is highlighted interdisciplinarity, where historians, archaeologists, architects, among others, research, dialogue and share information. Consists in, gathering research and information in digital archive files and libraries, regarding the monument in study: written documents, old photographs, iconography, cartography and levels.

It is necessary to make a first geographical approach to the monument, be it in extension or territory limited, punctual approach done by photo-interpretation and using geocoding program. 


\subsection{Survey}

Based on the research stage gathered data, field work is done to verify the studied architectural element current state. Depending on the initial data quantity and quality, in the presence of visible architectural structures, it is carried out the intended survey or just field data confirmation. The methodology at the survey stage, allows for direct and indirect methods (Manual measurement with the aid of measure tape and distancemeters) and indirect (laser scanning and / or photogrammetric).

The choice of method will depend from case to case. On one hand, by the type of monument and its conservation state and, on the other hand, by the final model required level of detail, always having in mind that the surveyd data will be modeled in a BIM modeling tool.

To monuments where it is required milimeter surveying, it is advised to use laser scanning. It is now possible to go to milimiter accuracy, even in adverse wheather conditions (with Leica Geosystems P40), in case of specific monuments, and in case of monuments in extension, it is possible to use laser scanner mobile devices producing little or no cloud noise. In the case of roof surveys, it is advised the use of a drone with a photographic machine, to complement the laser scanning cloud.

This being an extreme and ideal case, it is not sustainable to do an exhaustive indirect survey of all building elements. In this case the most common solution is, based on existing drawings or in a first draft made after photo interpretation, the survey to be initiated by direct methods using manual measurement (with the help of tape measure and distancemeters) for main dimensions (length, width, height and position of elements, such as doors and windows) complemented by a photographic survey and, in some specific cases, by laser scanning and/or photogrammetric survey.

The laser scanning is made for large areas where you need to collect countless types of detail, such as cloisters, that consist in several elements like columns, arches, vaults, gaps and floor levels. It is possible to systematically make a complete survey of all necessary data without a huge effort, pre or post survey.

The photogrammetric survey, currently being used to cover large areas to only small details (depending on the desired accuracy), for these situations it is only used in individual elements in which is necessary to have rigorous survey, such as columns and statues. It is a more economical and expeditious process.

Regarding indirect surveys, we must highlight the operator role. Although it being an expeditious process with easy data treatment where exists a reverse modeling process, where the data analysis and treatment is mostly made after its acquisition, the subsequent modeling is dependent on the survey quality. An experienced operator does all the difference in terms of results and time spent before, during and after the survey.

Regarding the choice of equipment, it points out:

- Manual survey - laser distancemeters are preferred in expedited measurements at the expense of sound distancemeters, especially if it is outdoor measurements or are non-homogeneous surfaces.

- Laser scanner Survey - The main factors for laser scanner equipment choice are: the intended rigor alongside the type of surveyed monument (as stated before), software support to process all the collected data with easy integration in the work process and technical support.

- Photogrammetry - a wide-agle lens camera it is a good choice, since it will be used only for singular objects survey of the studied monument. The operator is essential in the whole process and has to consider: orientation, restitution, design and photo execution, number and shots position.

\subsection{Interpretation and data treatment}

Intermediate stage that allows to develop macro and micro scale relevant work, which contributes to the comprehension and consequent final architectural representation - Digital reconstruction.

At the macro scale, there is a city scale geocoding and cartographic development analysis, in GIS software (Geographic information System) supported by CAD (Computer aided Design) and sometimes by alphanumerical database, that allow us to have the correct studied architectural set location and its evolution over time.

In turn, at micro scale, we have a building's scale analysis. On one hand, with architectural rules systematization and architectural evolution, in CAD software, and on the other hand, the intermediate elements development based on laser scanner or photogrammetry cloud point, each with its particular software.

The used software and the reasons for their selection were:

- GIS - for expedite works that are not part of an extensive work chain, it is possible at an early stage to use Google Earth. However, already exists specific freeware with good functionality and practical use, as is the case of Qgis, open source software. In these cases it is advisable for its accuracy and available features. In general, in the present methodology, for most cases, it is used ArcMap, because it is interoperable with CAD software and BIM, CIM (City Information Model) modeling software since it has good data sharing capabilities both locally or through web services for global dissemination via internet, thus enhancing both the modeling and dissemination stage.

- CAD - highly effective support software, usually Autocad, despite other existent freeware softwares that in some cases can satisfy the needs. In general, AutoCad, of all, it is the one that has more functionality and potential, because there is always the possibility to automate procedures using its own programming language (VLISP). 
- Laser scanning - since it was chosen Leica Geosystems hardware, it is preferred the use of LeicaCyclone, software that lets you make the correct cloud point treatment and its preparation for the ultimate modeling software import. It is also available the CloudWorx Revit plug-in that allows direct cloud modeling. However it is not excluded the existence of other softwares that enables cloud treatment, surface generation and even BIM software plug-ins. These two are the selected ones taking into account all of the methodology proposed premises.

- Photogrammetry (structured for motion) - Photoscan was choosen by allowing photo integration from different equipment's, demonstrating to be expeditious and rigorous software.

Regarding the stage analysis, it is given emphasis to recent developments that allows the inclusion of a quantitative method of urban analysis - Space Syntaxe (Hillier and Hanson, 1984) - within GIS software. This possibility has been increasing the number of analysis variables and consequent study types, since it may resort to both cartographic data as to GIS software database existing parameters (Gil et al. 2015).

Thus, at city scale, it is possible, in QGIS, to analyse the surroundings in an integrated way with the plug-in 'Space Syntax Toolkit' (SST) which integrates depthmapX software in QGIS environment. This GIS software is not preferred, but it easily imports and exports in an effective way the ArcMap developed data.

\subsection{Modeling}

The survey stage and data processing allows the knowledge acquisition of the studied building, concerning its elements features and nearby surroundings. After that, modeling can start. It is the first communication stage.

At this stage, the elements are modeled according to the desired LoD (level of detail), however you can use the same model for future works that need a different LoD.

To accomplish this, it's used BIM software, the methodology main component, which allows the methodology to be cyclic. Because it allows to apply characteristics elements with an identity in the project, rather than only solids or surfaces, devoided of information. These softwares also have associated databases that allow to manage the entire project and its elements in an effective way.

It is possible, at this stage, to use colour scale to determine the epoch constructive elements, by using the phase software. Regarding the colour different veracity levels used by archaeologists, it is also possible, but it is not usually used in architecture.

In the carried out modeling, it was decided not to use a colour scale to represent the different veracity levels, as suggested by The Principles of Seville, since the elements are only modeled upon the existence of sources that justify it. Thus, the LoD of each modeled element depends on the detail of the origin source level.

The chosen modeling software was Revit, since this:
- Allows laser scanning integration in a quickly and expeditiously way, in particular, point clouds that originated from Leica Geosystems laser scanner, through Leica CloudWorx for Revit, as well as different types of files, such as CAD and GIS software, like Autocad and ArcMap, thus ensuring the developed models intellectual and technical rigor and scientific features.

- Possesses parametric and associative properties that allow elements parameterization - families (Fig. 3) - and development of associated database. The elements can be corrected at any time, and be in constant disclosure, without interfering with the research work.

- Allows to generate technical data and information to the general public, easily adding the models in the project chain, which will be described in next stage.

Regarding modeling sets / sites, for the surrounding case study, preference is given to City Engine, CIM software (city Information Model).

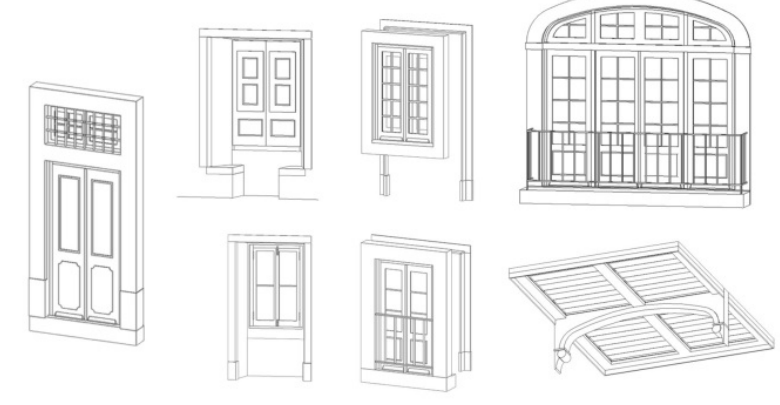

Figure 3: Santo Antão-o-Velho College: exemple of the main developed families.

\subsection{Visualization}

The final results may be, as first observed in The Principles of Seville, to study, preserve and disseminate. The present methodology does not intend to exclude any possibility, in other words, you can generate visualization forms mainly aimed for technicians, for studies and preservation, or to the general public, as a way of disclosure.

As visualization methods for technicians, are available: Revit models (with all stages and associated tables), point clouds and GIS file format (ArcMap). In turn, to the general public, it is possible to produce different file types in different formats, such as renders and videos (produced in LeicaCyclone or Revit), which are the easiest to understand, and technical drawings (sections and levels) and 3D pdf, a little more complex, but more complete in its content. In neither case, the average user needs to install any specific viewing software.

At this stage, in addition to elements that can be directly developed from previous stages software, highlight is given to serious games, game engines or educational game development, with a variety of goals with easy and expeditious use. Blender and Unity are suggested. Blender is freeware and has an active community, both in support as in new applications, and features development. Unity, in turn, integrates more satisfactorily 
in the present methodology, since it has a greater interoperability between modeling software due to already existent well-defined paths, regarding web deployment and mobile applications.

\section{Case Studies}

"At micro-scale level it is possible to find subtle metamorphosed architectural remains in ancient convents places given as demolished" (Sequeira 1939).

Without heritage presence awareness it is not possible to exist a common will to preserve. A watchful eye can always awaken the collective memory. It is the technician's role to take the first step towards enhancing this memory through reliable disclosures.

Therefore, the present case studies were chosen due to their partial or total ignorance by part of the general population, by its specificities as an extensive monument and by punctual monuments. They have different types and existent documentary information quantity, different preservation states and consequently, different needs. Therefore, it is intended to disseminate the architectural heritage, and at the same time, to be used as case study to the methodology improvement, so it can be applied in a broader range of monuments.

The Águas Livres Aqueduct construction, Portuguese National monument, started on May 16th 1731, and concluded at the year of 1748. The aqueduct, its branches and its distribution gallerys, have a $58 \mathrm{~km}$ extension total. The main section has $14.20 \mathrm{~km}$ of length, and includes about $8 \mathrm{~km}$ of trenches, $4.2 \mathrm{~km}$ of tunnels, and $2 \mathrm{~km}$ of arches, where $0.941 \mathrm{~km}$ are in Alcântara valley. This section was bridged by building 35 arches, 14 of them ogee and the largest is $65 \mathrm{~m}$ tall and $29 \mathrm{~m}$ wide. The distribution structure remained operational until the mid-twentieth century, but it has been merely ancillary since 1880 .

The Lisbon Convents are city's symbolic landmarks. It is composed by grounds and church, each possessing specific types accordingly to its religious order.

The 1834 religious order extinction was decisive to nineteenth century Lisbon's urban development, where around 130 religious houses were disaffected, received profane occupations, demolished or changed.

At present time, a new cycle begins, with government sale, of nationalized heritage. Efforts have been made to give accurate studies that allow well thought decisions that safekeep the existing heritage values, linking them with new social, cultural and tourism needs.

For this work it were choosed three Lisbon's Convents:

- Nossa Senhora da Piedade da Esperança Convent, Santa Clara religious feminine order convent, was constructed in 1527, only remains exist at the present date.

- Santíssima Trindade de Lisboa Convent, Trindade, Santíssima Trindade para a Redenção dos Cativos religious feminine order convent, was funded in 1218 , and is partially demolished at the present day.

- Santo Antão-o-Velho College, Coleginho, companhia de Jesus masculine order college, was constructed in 1542 and still exists at the present day.
Next, will be presented the obtained main data for each case study, taking into account the methodology stages and respective digital reconstructions results. Results that are intended to serve both the technical and the general public in an effort to keep the identity and collective memory.

\subsection{Aguas Livres Aqueduct}

The Águas Livres Aqueduct, regarding existing documentation, it had topographic data (military charts at 1: 25,000 and Lisbon chart at 1: 1000) and the main section plan and longitudinal profiles from all aqueduct and subsidiaries, with bailing slope values, angle and length between vertices, gutter fund quota, distance from the origin and mileage.

Based on this documentation, it was necessary to carry out geocoding and local survey of some unidentified points, as well as, an element of each turret type to proceed to its parameterization, taking into account their main features.

The whole process is described in the Table 1, such as stages, data types, needed software types and used software.

Given that it was intended a low-cost process, freeware software was used whenever possible. However, the used methodology was optimized in three stages by replacing some software.

In the acquisition and data processing, by the replacement of Google Earth by ArcMap, and Excel database for Access, allowing to remove the Autocad use and Scheme programming. The geocoding would be made directly into ArcMap, associated with an Access table. ArcMap file could then be easily linked to Revit to be used as modeling basis.

In data communication, replacing the Blender by Unity, removes the 3DMax conversion formats. It would facilitate the cyclical process in future changes.

This case study was used to prove the expeditiously methodology application on extensive monuments, where there aren't many representative examples.

\subsection{Convents}

Each three convents existent documents and current state, varied from case to case. This caused the survey process to be different in each case, as well as part of the data processing. As a disclosure method, in a general way, there is a Revit model and its $3 \mathrm{D}$ pdf, technical drawings and renders.

It is possible, in the Table 2, to observe the synthesize stages, data types, software required types and used software.

Therefore, the methodology has presented itself to be flexible and cyclic, allowing to adapt to existing data in every situation and allowing to incorporate new data at any time.

It will be briefly described each of the three convents, in different situations, so that it is possible to understand what kind of data was attainable to collect before and which elements were created after, based on the same methodology. 


\subsubsection{Santo Antão-o-Velho College}

Santo Antão-o-Velho College, Coleginho, did not have sufficient documentation to ensure an accurate digital reconstruction. However, since it remained nearly intact until the present day, it was possible to obtain an accurate model based on the entire building direct survey, and indirectly, by laser scanning of the cloister, an area of more detail.

Thus, it was possible to parameterize its characteristic elements (Revit families) with high LoD, including: ceilings, windows, doors (indoor and outdoor), columns and arches.

To disclosure, beyond model Revit (Fig. 4), 3D pdf, technical drawings and renders (Fig. 5), it was possible to produce videos based on the point cloud.

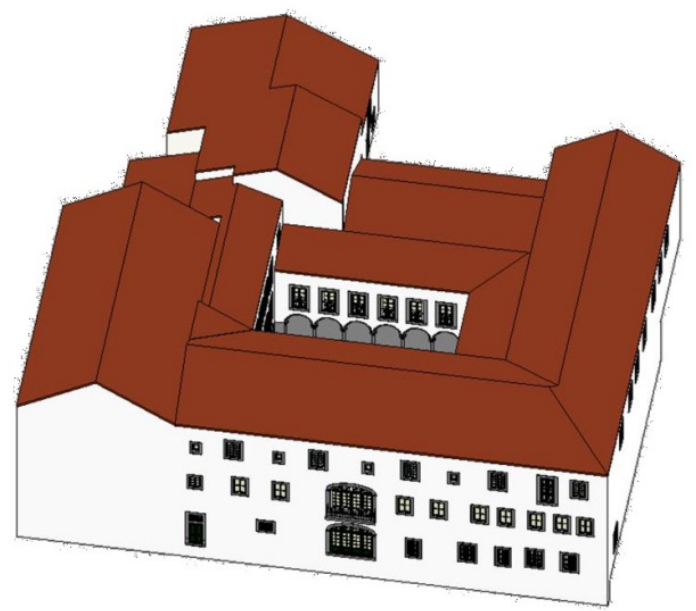

Figure 4: Coleginho - Revit model.

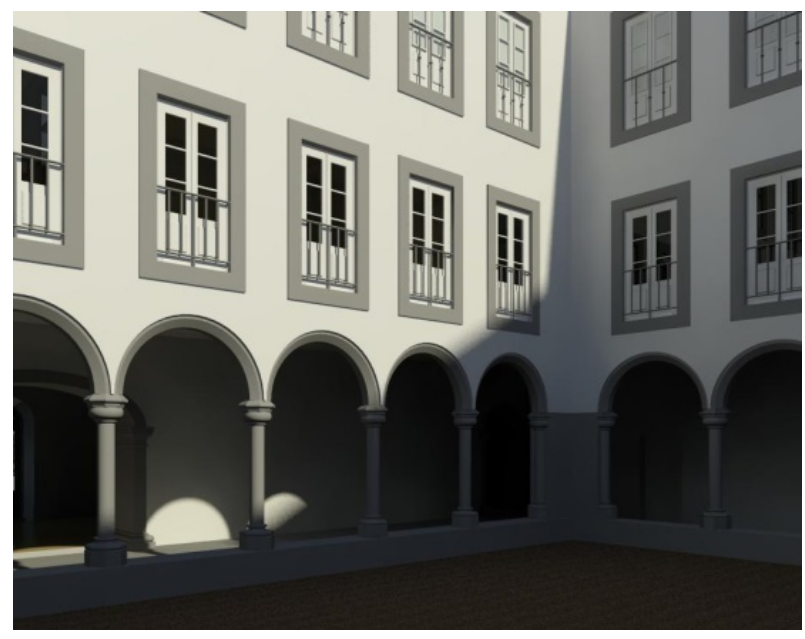

Figure 5: Coleginho cloister - Revit render.

\subsubsection{Nossa Senhora da Piedade da Esperança Convent}

The Esperança Convent, unlike Coleginho, was demolished almost in its entirety, and only remained archway traces of one of the cloister wings that was reattached to the new buildings.

An epoch document together with the extinction process existing plants, were vital in the convent's digital recreation (Fig. 6), since they had descriptions of the convent spaces as well as strict dimensions.

Thus, the archway rigorous survey along with the existing plants allowed not only a rigorous cloister reconstruction (Fig. 7) but also to assign the correct height floor, and therefore rebuild all convent, with planimetric and altimetry accuracy.

However, it should be noted that there are still some uncertainties and low visible LoD in the model, including in the developed families due to missing plans and sections.

Alongside the model digital reconstruction, it was possible to incorporate the space syntax analysis to the convent grounds urban area, and nearby surroundings, in an attempt to comprehend the central urban system relation, which progressed with the city's transformation after the religious order extinction.

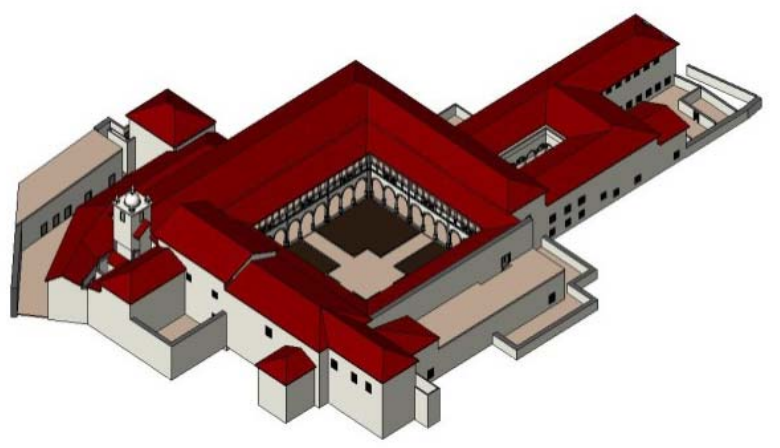

Figure 6: Esperança - Revit model.

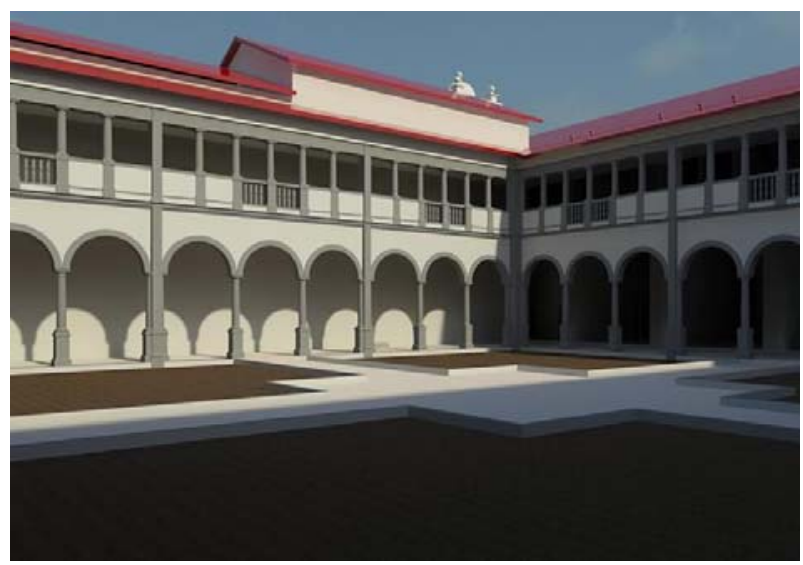

Figure 7: Esperança cloister - Revit render.

\subsubsection{Santíssima Trindade de Lisboa Convent}

The Santíssima Trindade de Lisboa Convent, Trindade, presented itself as the most richest and complex example, due to both high physically and documentary information.

In this way it was possible to do its pre-earthquake representation (although with low LoD), extinction and current date representations, which has a significantly different implementation of both the convent building as to the 1834 existing church (Fig. 8). 


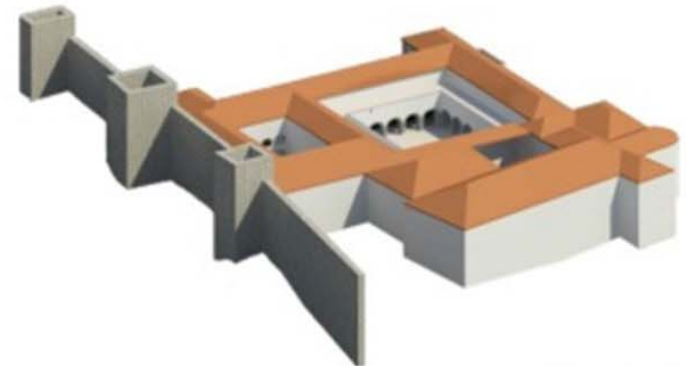

(a)

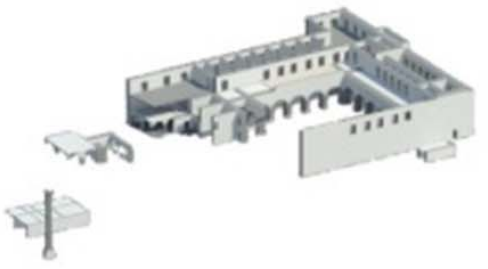

(c)

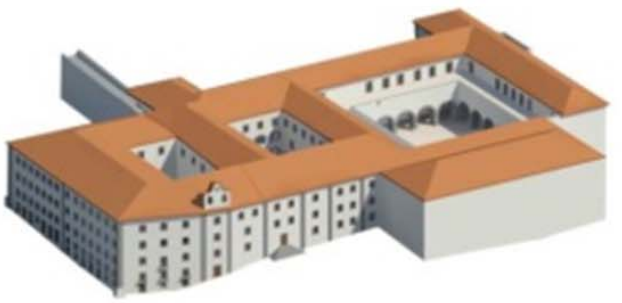

(b)

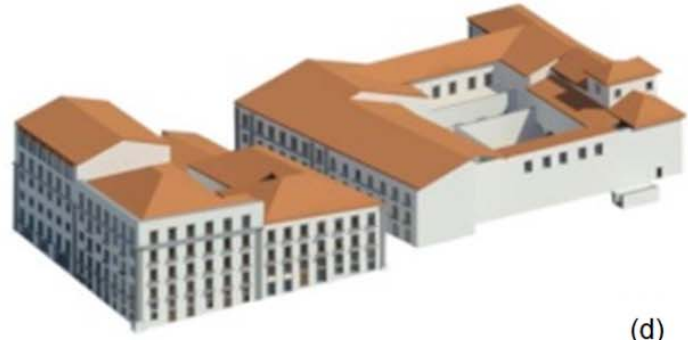

(d)

Figure 8: Santíssima Trindade de Lisboa convent - architectural evolution: a) Pre-earthquake; b) Extinction (1834); c) Conventual architectural remains (2015); d) 2015

Since it was found plenty preexistence, it was necessary to understand the whole planimetry and altimetry, to be able to make associations from present to the past. The site was visited several times and it was conducted a thorough investigation of all documents of the two blocks that corresponded to the convent implementation to extinction date. Reciprocal information existed. On one hand, based on the first floor plan, included in the extinction process, it was possible to discover preexistence in the current buildings. On the other hand, based on visits to the site and documentation, it was possible to draw conclusions of how would the stores area should be like (west part of the monastery on the two floors beneath first pavement), since there was no drawings of these, only descriptions that corroborated the drawings and found geometries. It was interesting to note that the past helped present and the present helped the past in the digital reconstruction of this convent.

Regarding uncertainties and low LoD, the situation was similar to Esperança convent. The same question exists in the middle floor definition between the first and the second floor, adding the existing doubts of the second floor level since the existing plant is only partial. As well as the families low LoD due to lack of sections and plans. In this case, the iconography of the convent and church main façade was determinant to define the modeled elements.

\section{Conclusion and future developments}

"By the moment the London Charter is the most important document approved by the international community in the field of cultural heritage and new technologies, and is, therefore, a consultation document required for all researchers who in one way or another working in this field." (SEAV 2012)

In heritage preservation and disclose work is essential to follow guidelines that allow to create rigorous models through consistent procedures. Thus, the London's
Charter guidelines, as well as The Principles of Seville, are fundamental.

Regarding general principles, multidisciplinary, is an essential topic to obtain and disseminate more and better results. In this case, the $L x$ Conventos project is an example, whose final results are due to the architects, historians, geographers, restoration and computer technics, joint work.

However, can be suggested some adaptations to the principles taking into account the architectural heritage specificities in relation to archaeological heritage. An example is the relevance of colour scale use to represent different construction periods (when there are more than two identified periods), rather than the scale used by archaeologists (Historical/Archaeology Evidence Scale) to represent the different veracity levels, which is not so important in these cases.

Regarding architectural heritage digital reconstruction, in general, it is possible to point out some important future developments:

- Architectural heritage recreations and digital reconstructions general principles conception, different from The Principles of Seville, taking into account its specificities;

- Ontologies definition;

- Technical and theoretical multidisciplinary work. That will allow interests and efforts convergence, enabling more analysis and parallel studies, alongside each individual work, based on the same data;

- Disseminate methods, management and data storage processes, in order to correctly preserve it.

- GIS and its databases development in order to incorporate architectural heritage digital models without subsequently data loss;

- BIM models use in a general way; 
- BIM modeling standardization and automation, through families creation directly from the cloud point, already happenning in the AEC industry or HBIM approaches.

It is possible to conclude that the three fundamental elements to a good end result are the people, the method and the software / hardware. The technician has a major role in the method and software/hardware choice, in an interoperable way, more suitable for the entirety work development.

Regarding the used methodology, as originally proposed, it aimed to follow guidelines, and proved to be scientific, flexible and cyclical. It stands out:

- Model development and its disclosure, without all available data. In the case of the aqueduct, there was only an initial fast survey that allowed its early disclosure, followed by its on-going improvement. In the case of the convents, especially in the Trindade Convent, there was a constant data acquisition for both in site new physical discoveries or new documentation, which did not interrupt the constant model enhancement and disclosure.

- New incorporation techniques in the methodological process without losing its cyclical nature and general public commitment, i.e. disclose easily editable models. It was incorporated: laser scanning, photogrammetry and space syntax analyse. The laser scanning survey integration came to fill the lack of documentation, in the case of still existing structures, such as the Coleginho, allowing a quick, expeditious and rigorous survey of its main characteristic, giving detail and rigor to developed model, and potentiating new disclosure ways. The photogrammetry integration for some specific surveys, allowed to generate non editable models of some particular details. In turn, the space syntax analyse incorporation at urban area level, allowed to understand the local city dynamics.

In order to improve the methodology, the following developments are underway:

- The photogrammetry survey integration in specific non-parameterized architectural details.

- Colours and textures incorporation to create more realistic models, ensuring data integrity in conversion process (rvt, ifc, pdf).

- Colour scale integration to identify different construction periods, simplifying, in an easier and more intuitive way, access to technical data.
- Methodology expansion to virtual recreations by incorporating experiences, i.e. user interactions in virtual space, in order to disclose, in an intuitive way, the different space uses and appropriations, through mobile augmented reality.

- Application of digital models in management and maintenance of existent architectural heritage.

Regarding the four mentioned case studies digital reconstructions, presents itself as technically rigorous, taking into account the existing data and applied methodology (Table 1 and 2). However, it is possible to state the following future developments:

- Águas Livres Aqueduct - developing digital reconstruction and subsequent digital recreation of the aqueduct in its entirety: general section, branches and its Lisbon distribution, including galleries and fountains.

- Coleginho - more broad modeling of its surroundings, aiming to the grounds evolution perception.

- Esperança - historical documentation research continuation in order to be able to correct the model and address the existing representation errors in some specific locations.

- Trindade - a broader modeling of its surroundings, as suggested in Coleginho, and historical documentation research continuation, as suggested in Esperança. It highlights the importance of archaeological data incorporation. This could be relevant in the old church area, contributing to significant pre-earthquake representation developments.

In conclusion, the developed models expose an integrated form of heritage representation and disclosure to technical and non-technical, thus, introducing new dynamic processes. In this particular case, it was disclosed Lisbon's forgotten, or given as demolished, heritage.

Therefore, the present work aims to generalize the presented multidisciplinary and cyclical methodology, through systematic application in architectural heritage study, disclosure and management. It aims to a global notion of cultural identity, which inevitably generates collective memory and consequent desire to preserve.

\section{Acknowledgements}

This work was supported by EPAL (Empresa Portuguesa das Águas Livres); and FCT (Fundação para a Ciência e Tecnoogia) under Grant (PTDC/CPC HAT/4703/2012) to the LxConventos project. 
Table 1: Aguas Livres acqueduct - types of programs / equipments recommended to use in each stage of the digital reconstructions methodology.

\begin{tabular}{|c|c|c|c|}
\hline & & Type of software/equipment & software/equipment used \\
\hline \multirow[t]{2}{*}{ Data acquisition } & $\begin{array}{l}\text { Data collection } \\
\text { (Sources: cartography, project, } \\
\text { photograph e photo-interpretation) }\end{array}$ & Geocoding software & Google Earth \\
\hline & Architectural survey & GPS & portable GPS \\
\hline \multirow{3}{*}{ Data treatment } & Data base development & $\begin{array}{l}\text { database program with programming } \\
\text { language associated }\end{array}$ & Excel + Scheme \\
\hline & Director axle model generation & $\begin{array}{l}\text { CAD program with programming } \\
\text { language associated }\end{array}$ & AutoCad + Scheme \\
\hline & Data to generate the environment & $\begin{array}{l}\text { Gis and CAD programs with } \\
\text { programming language associated }\end{array}$ & ArcGis e Autocad + Scheme \\
\hline \multirow{3}{*}{ Data Communication } & Digital modeling & $\begin{array}{l}\text { BIM program with associative and } \\
\text { parametric geometry }\end{array}$ & Revit \\
\hline & Format conversion & $\begin{array}{l}\text { Program compatible with modeling } \\
\text { softwares }\end{array}$ & 3DMax \\
\hline & Virtual modeling & $\begin{array}{l}\text { Visualization and three-dimensional } \\
\text { interaction program }\end{array}$ & Blender \\
\hline
\end{tabular}

Table 2: Convents - types of programs / equipments recommended to use in each stage of the digital reconstructions methodology.

\begin{tabular}{|c|c|c|c|}
\hline & & Type of software/equipment & software/equipment used \\
\hline \multirow{2}{*}{ Data acquisition } & Data collection & Geocoding software & ArcGis \\
\hline & Architectural survey & $\begin{array}{l}\text { Manual survey equipment and laser } \\
\text { scanning }\end{array}$ & $\begin{array}{l}\text { Tape measure, distanciometer, } \\
\text { laser scanner Leica P20 }\end{array}$ \\
\hline \multirow{2}{*}{ Data treatment } & $\begin{array}{l}\text { database and primary drawings } \\
\text { development }\end{array}$ & Data base, GIS and Cad softwares & Acess, ArcGis e Autocad \\
\hline & Point cloud treatment & $\begin{array}{l}\text { Cloud points and photography } \\
\text { processing programs }\end{array}$ & Leica Ciclone e Photoscan \\
\hline \multirow[b]{2}{*}{ Data Communication } & Modelling & $\begin{array}{l}\text { BIM software able to easily incorporate } \\
\text { cloud points }\end{array}$ & Revit e Cloud Worx \\
\hline & Visualization & $\begin{array}{l}\text { current softwares of data visualization } \\
\text { (video, technical drawings and } 3 D \\
\text { models viewers) }\end{array}$ & $\begin{array}{l}\text { Adobe Reader and media } \\
\text { player }\end{array}$ \\
\hline
\end{tabular}

\section{References}

APARÍCIO, P. and FIGEIRIEDO, C., 2010. Escala de evindencias. Available: http://www.mediafire.com/view/vcl26cuwc66b5m3/Escala Evidencias.pdf [2/29, 2016].

BIMFORUM PORTUGAL, 2014. Building Information Modeling: A new constrution paradigma. 1st BIM International Conference. Porto: BIMForum Portugal. Available: http://www.bimmi.net/index.php/pt/other-editions [2/29,2016].

BRUSAPORCI, S., 2015. Handbook of Research on Emerging Digital Tools for Architectural Surveying, Modeling, and Representation, IGI Global, Hershey. doi:10.4018/978-1-4666-8379-2 Available: http://www.igiglobal.com/book/handbook-research-emerging-digital-tools/123121 [2/29, 2016].

EASTMAN, C., TEICHOLZ, P., SACKS, R. and LISTON, K., 2011. BIM handbook: a guide to building information modeling for owners, managers, designers, engineers and contractors. Second Edition. New Jersey: Wiley.

FAI, S., FILIPPI, M. and PALIAGA, S., 2013. Parametric modeling (BIM) for the documentation of vernacular construction methods: a BIM model for the commissariat building, Ottawa, Canada. ISPRS Annals of the Photogrammetry, Remote Sensing and Spatial Information Sciences, Volume II-5/W1, 2013 XXIV International CIPA Symposium, 2 - 6 September 2013, Strasbourg, France.

FRISHER, B., 2008. The Rome Reborn Project. How Technology is Helping Us to Study History. University of Virginia, OPEd. Available: http://www.romereborn.virginia.edu/rome reborn 2 documents/papers/Frischer OpEd final2.pdf [2/29, 2016].

GARAGNANI, S. and MANFERDINI, A., 2013. Parametric accuracy: Building Information Modeling process applied to the cultural heritage preservation. International Archives of the Photogrammetry, Remote Sensing and Spatial Information Sciences, Volume XL-5/W1, 3D-ARCH 2013 - 3D Virtual Reconstruction and Visualization of Complex Architectures, 25 - 26 February 2013, Trento, Italy.

GIL, A., 2011. Modelos Digitais - Geometria associativa: particularidade da musealização de monumentos em extensão. O Aqueduto das Águas Livres como caso de estudo. Universidade Técnica de Lisboa - Instituto Superior Técnico.

GIL, J., KARIMI, K., PENN, A. and VAROUDIS, T., 2015. The space syntax toolkit: Integrating depthmapX and exploratory spatial analysis workflows in QGIS, 10th International Space Syntax Symposium, London. 
HILLIER, B. and HANSON, J., 1984. The Social Logic of Space, Cambridge University Press, Cambridge.

MÉGRE, R. and SILVA, H., 2014. "Os Conventos na imagem urbana de Lisboa". Monastic architeture and the city, Debates, $n^{\circ} 6$. Coimbra: cescontexto, pp.108-124.

MURPHY, M., MCGOVERNA, E. and PAVIA, S., 2011. Historic Building Information Modeling - adding intelligence to laser and image based surveys. International Archives of the Photogrammetry, Remote Sensing and Spatial Information Sciences, vol.XXXVIII-5/W16, ISPRS Trento 2011 Workshop, 2-4 March, Trento, Italy.

MURTEIRA, H. and RODRIGUES, P., 2014. "Lisbon 31st October 1755: the city imaginary museum". THE CITY AS A VIRTUAL MUSEUM RECONSTRUCTING THE PAST TO LIVE IN THE PRESENT, Lisboa, ISCTE - IUL - Escola de Sociologia e Politicas Publicas.

RUA, H. and GIL, A., 2014. Automation in heritage - Parametric and associative design strategies to model inaccessible monuments: The case-study of eighteenth-century Lisbon Águas Livres Aqueduct. Digital Applications in Archaeology and Cultural Heritage. Available: http://dx.doi.org/10.1016/j.daach.2014.06.002i [2/29, 2016].

SANTAGATI, C., 2005. 3D laser scanner aimed to architectural heritage survey: From the point's cloud to the geometrical genesis determination. International Society Of Photogrammetry And Remote Sensing, Volume XXXVI, Part 5/W17, 3D-ARCH 2005: Virtual Reconstruction and Visualization of Complex Architectures, 22-24 August, 2005, Mestre-Venice, Italy.

SEAV, 2012. Principlies of Seville. Available: http://www.arqueologiavirtual.com/carta/?page id=189 [2/29, 2016].

SEQUEIRA, M., 1939. O Carmo e a Trindade. Lisboa: Câmara Municipal de Lisboa, Volume III.

UNESCO, 2009. The London Charter. For the computer-based visualisation of cultural heritage. Available: http://www.londoncharter.org/ [2/29, 2016]. 


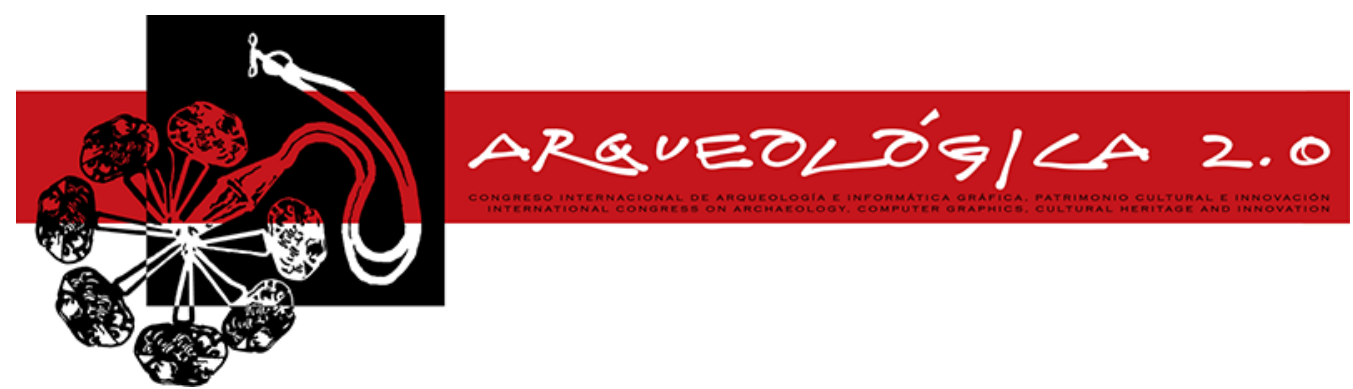

Proceedings of the $8^{\text {th }}$ International Congress

on Archaeology,

Computer Graphics,

Cultural Heritage and Innovation

'ARQUEOLÓGICA 2.0'

in Valencia (Spain),

Sept. 5-7, 2016

DOI: http://dx.doi.org/10.4995/arqueologica8.2016.2987

Received: 04/03/2016

Accepted: 04/04/2016

\title{
DOCUMENTACIÓN Y ANÁLISIS DE PIEZAS ARQUEOLÓGICAS DEL MUSEO DE BURRIANA MEDIANTE EL USO DE RX DIGITAL
}

\author{
RECORDING AND ANALYSIS OF ARCHAEOLOGICAL ARTEFACTS OF BURRIANA MUSEUM BY USING \\ DIGITAL RX \\ Jose A. Madrid ${ }^{\mathrm{a},}$, Jose Manuel Melchor ${ }^{\mathrm{b}}$ \\ a Instituto Universitario para la Restauración del Patrimonio, Universidad Politécnica de Valencia, Camino de Vera s/n, 46022 Valencia, \\ España. imadrid@crbc.upv.es \\ ${ }^{\mathrm{b}}$ Departamento de Geografia, Historia y Arte, Universitat Jaume I de Castelló, Av. Vicente SosBaynat s/n, 12071 Castellón, España. \\ melchor@uji.es
}

\begin{abstract}
:
This paper is the result of the research conducted on more than 200 archaeological artefacts from the Museum of Burriana as a result of 6 years of scientific collaboration between the Museum and the Instituto Universitario para la Restauración del Patrimonio of the Universitat Politècnica de València. Digital X-rays Technology has been used on these artefacts. This technique has allowed achieving valuable information in different aspects of the artefacts: from its content (in the case of well-preserved specimens) to technical manufacturing, or analysis of evidence of previous restoration interventions. The application of Digital X-ray Technology has shown a number of important benefits; not only at the economic level and data manipulation, but also allowing as data collectors that can be further processed and thereby obtain outcome. These results can be used into different 2D or 3D formats.
\end{abstract}

Key words: digital X-ray, digital archaeology, pieces, restoration, documentation, Burriana.

\section{Resumen:}

Este trabajo es fruto de la investigación llevada a cabo en más de 200 piezas arqueológicas del Museo de Burriana como resultado de los 6 años de colaboración científica entre el Museo y el Instituto Universitario para la Restauración del Patrimonio de la Universitat Politècnica de València. Usando en éste la tecnología digital en los registros radiográficos. Esta técnica ha permitido lograr una valiosa información en diferentes aspectos de las piezas: a partir de su contenido (en el caso de objetos bien conservados) para la comprensión en sus métodos de fabricación, o el análisis de la evidencia de anteriores intervenciones de restauración. La aplicación de la tecnología de digital en la radiografía ha demostrado una serie de importantes beneficios; no sólo en el nivel de la manipulación del registro y de tipo económico, sino que también permite que los datos obtenidos que se pueden procesar mejor y así poder conseguir el mejor resultado. $Y$ estos pueden ser utilizados en la formación de imágenes tanto 2D como 3D.

Palabras clave: arqueología virtual, arqueología digital, ciber-arqueología, patrimonio cultural, documentación, reconstrucción 3D

\section{Introducción}

Desde 2010, el Instituto Universitario para la Restauración del Patrimonio de la Universitat Politècnica de València y el Museo Arqueológico Municipal de Burriana vienen colaborando en la aplicación de los Rayos $\mathrm{X}$ en soporte digital a piezas arqueológicas. Fruto de esta cooperación ha sido el análisis de más de un centenar de artefactos (básicamente de tipo cerámico y de metal) actualmente depositados en el citado museo, tanto en sus almacenes, como en su exposición permanente.

El objetivo de esta investigación ha consistido en la documentación de materiales arqueológicos buscando el establecimiento de un protocolo de aplicación genérico a este tipo de piezas, cuyo resultado sea la obtención de resultados científicos que no se podrían obtener por otros medios de análisis físico no invasivo (Madrid y Ramírez 2011).

*Corresponding Author: Jose A. Madrid, jmadrid@crbc.upv.es 
En este caso concreto, la gran ventaja que presenta el uso de la radiografía en soporte digital es la facilidad de manipulación, consulta y archivo de las imágenes obtenidas, además de la posibilidad que ofrecen en futuros tratamientos digitales e informáticos sobre los datos actualmente obtenidos, y que ampliarán el espectro de futuros estudios.

\section{Los yacimientos arqueológicos}

Los trabajos se han llevado a cabo sobre diversos yacimientos (Fig. 1) y a continuación haremos una breve descripción de cada uno de ellos.

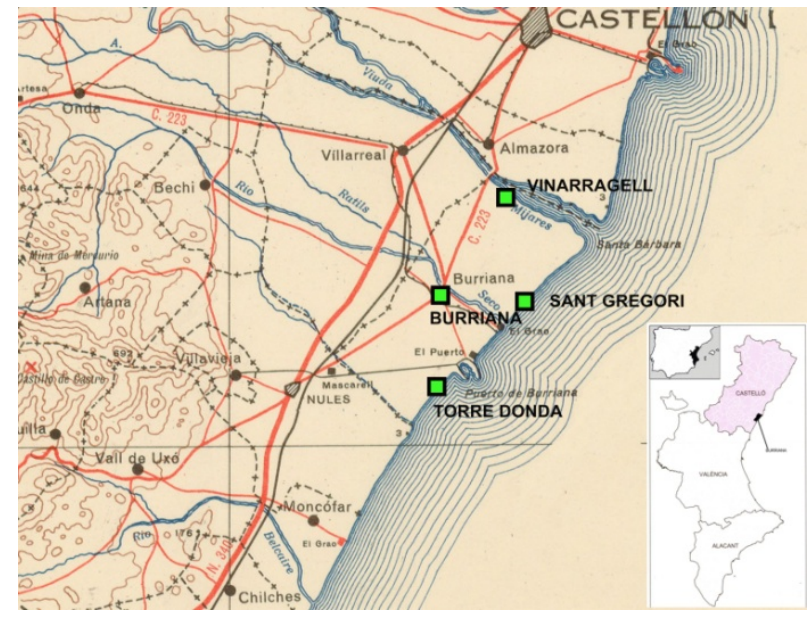

Figura 1: Plano de situación de los yacimientos citados en el texto.

\subsection{Centro Histórico de Burriana}

La ciudad de Burriana tiene su origen en época musulmana, y aparece reflejada en las escasas crónicas árabes que describían las ciudades a lo largo del camino, siendo la más antigua conocida la del historiador cordobés Ahmad ibn Muhammad al-Razi (887 - 955 d.C.). Sin embargo, no podemos hablar de Burriana como enclave urbano y fortificado con certeza hasta el siglo $\mathrm{XI}$, cuando empieza un largo periodo de inestabilidad con las invasiones almorávides y los ataques del Cid; además la propia técnica constructiva de la muralla musulmana apunta a una influencia del norte de África. La ciudad es conquista en el año 1233 por el monarca aragonés Jaume I, lo que produjo importantes cambios en la ciudad, que finalmente llevaron a un lento e inexorable proceso de decadencia que culminaría en el siglo XVII (Melchor 2011).

La arqueología urbana se desarrolló de forma esporádica desde principio del siglo XX entre el coleccionismo y el interés de aficionados, hasta que a finales de la misma centuria se amplía de forma muy importante la cantidad de excavaciones. Eso permitió al Museo Arqueológico Municipal de Burriana contar con un importante acervo de piezas medievales tanto en su depósito como en sus vitrinas.

\subsection{Villa romana de SantGregori}

Se trata de una villa romana situada en el término municipal de Burriana. La intervención desarrollada en Sant Gregori, en una colaboración entre la Universitat Jaume I, el Museo de Burriana y la Universitat
Politècnica de València, prosigue en la actualidad en la parte residencial de la villa situada en su extremo noreste, que ocupa la parte más cercana al agua (aproximadamente a $80 \mathrm{~m}$ de la costa actual) y que llegaría a contactar originalmente con el mar. La villa se desarrolla mediante un peristilo, con un gran estanque rectangular con orientación Norte-Sur y paralelo a la costa. Alrededor de él aparecen una serie de habitaciones con pavimento de opus caementicium, pero presuponemos que originariamente sería un pequeño espacio abierto ajardinado (Melchor 2013).

Hasta el momento, y a falta de futuras campañas de excavación, la intervención actual muestra una riqueza material considerable, pues además de una gran cantidad de mármol de muy distintas variedades, lapis specularis, agujas de hueso, vidrio, útiles de pesca, teselas, pintura mural, etc. se está recuperando un amplio conjunto de restos cerámicos. Todo ello apuntaría al momento de auge del asentamiento, entre el final o mediado del siglo I d. C., y una reforma y reutilización de parte de sus estructuras, quizá alrededor del siglo II d. C. Aún no podemos señalar el momento de abandono de la villa, pero los materiales encontrados por ahora hablan de una ocupación intensa por lo menos hasta mediado el siglo III d. C. y algunos indicios apuntan a una pervivencia hasta el siglo IV d. C. (Ferrer et al. 2013)

\subsection{Poblado ibero-romano de Torre d'Onda}

Este yacimiento se encuentra en la costa de Burriana y sus primeros hallazgos se remontan a principios del siglo $X X$, pero no fue hasta la década de los 80 , de ese mismo siglo, cuando empezó a ser objeto de excavaciones arqueológicas y que no tuvieron continuidad hasta el siguiente. En ellas se detectaron la existencia de calles, departamentos y muros de contención de un poblado de raíces iberas, con importante presencia de materiales itálicos y púnicos.

Lamentablemente buena parte del yacimiento se encuentra bajo construcciones actuales. Fruto de las intervenciones es una abundante colección de elementos cerámicos, y en menor cantidad de otro tipo de materiales. Probablemente nos encontremos ante un importante yacimiento dedicado prioritariamente al comercio marítimo, que tuvo su auge entre el siglo III a.C. y el cambio de Era (Melchor 2013).

\subsection{Poblado protohistórico de Vinarragell}

El yacimiento protohistórico de Vinarragell, incoado Bien de Interés Cultural por su extraordinaria contribución para conocer el proceso de iberización en tierras valencianas, situado en la ribera derecha del río Mijares a $80 \mathrm{~m}$ de su cauce actual y a $3,5 \mathrm{Km}$. de su desembocadura. Se trata de un pequeño montículo de cerca de $3,5 \mathrm{~m}$ de altura de forma irregular, con un diámetro entre 80 y $60 \mathrm{~m}$.

Se trata de un yacimiento de excepcional importancia para el conocimiento del periodo protohistórico, y por ello es Monumento Histórico Artístico del año 1985. Las excavaciones arqueológicas no se iniciaron hasta la década de 1960 , si bien el yacimiento ya era conocido de antiguo. Tras diversas campañas de excavación en Vinarragell, se sistematizan sus diversos horizontes culturales y de hábitat del siguiente modo: Hierro I, 
Cultura Ibérica, Romanización y Edad Media (Mesado 1988). No se realiza ninguna publicación con nuevos datos desde 1988, aunque con motivo de las obras del gasoducto Castellón-Valencia en 1991 y en 2008 se realizan intervenciones arqueológicas que indican que el yacimiento se extendería hasta el cauce del río Mijares y contaría con una necrópolis musulmana en su espacio inmediato (Melchor 2013).

Ya desde el año 2014 se han retomado los trabajos en el yacimiento mediante un equipo multidisciplinar formado por el Área de Historia Antigua de la Universitat Jaume I, el Museo de Burriana y el Servicio de Investigaciones Arqueológicas y Prehistóricas de la Diputación de Castellón.

\section{Marco de la investigación}

Los objetivos marcados en un primer momento consistían en el análisis de algunos aspectos genéricos de los materiales, tanto de forma individual como en su conjunto. Estos los podemos unir en los siguientes apartados, destacado en cada uno los casos más significativos detectados hasta el momento:

\subsection{Materiales sin intervenir}

Este grupo está formado por aquellos materiales extraídos del yacimiento y sobre los cuales se obtiene la imagen radiográfica sin haber recibido ningún tratamiento previo, ni tan siquiera la limpieza de los mismos.

En estos casos se ha podido apreciar claramente el interior de la pieza y su contenido. En algunos ejemplos como la lucerna romana del dextrarum iunctio (Fig. 2) extraída en el yacimiento de Sant Gregori en la campaña del año 2011 (Ferrer y Benedito 2012), se obtuvo una importante información de los depósitos de tierra en su interior, ya que la pieza apareció prácticamente intacta, pero en un contexto de las zanjas del siglo XVIII que afectaban buena parte del yacimiento (Melchor 2013).

Mediante los Rx se pudo observar cual había sido el proceso de colmatación por sedimentos del interior de la pieza, y se constató que originariamente se encontraba boca abajo al ser abandonada en época romana, lo que sumado al impacto que presentaba en la piquera (único daño reseñable) podemos suponer que sufrió una caída desde una superficie poco elevada, quedando en posición invertida sobre el suelo de la habitación de la villa, desde donde fue posteriormente extraída por las zanjas realizadas en época Moderna.

Otros casos, ya más habituales en la investigación arqueológica, como es el análisis de materiales férreos extraídos de la misma excavación de Sant Gregori (Fig. 3). En este caso los Rx fueron sin duda una importante herramienta, ya que permitieron, mediante el claro discernimiento entre el óxido y el núcleo metálico, hacer una selección de los materiales que presentaban un mejor estado de conservación, cara a proceder a su limpieza y consolidación, permitiendo reducir costes y obtener una mayor rentabilidad museográfica, pues se aseguraba intervenir sobre piezas importantes.

Pero además se obtuvo una valiosa información científica, ya que los resultados de los Rx permitieron clasificar piezas sin tener que proceder a su limpieza, lo cual no solo evitaba riegos para su integridad, sino que además aportaba una imagen mucho más aproximada a lo que había sido el original.
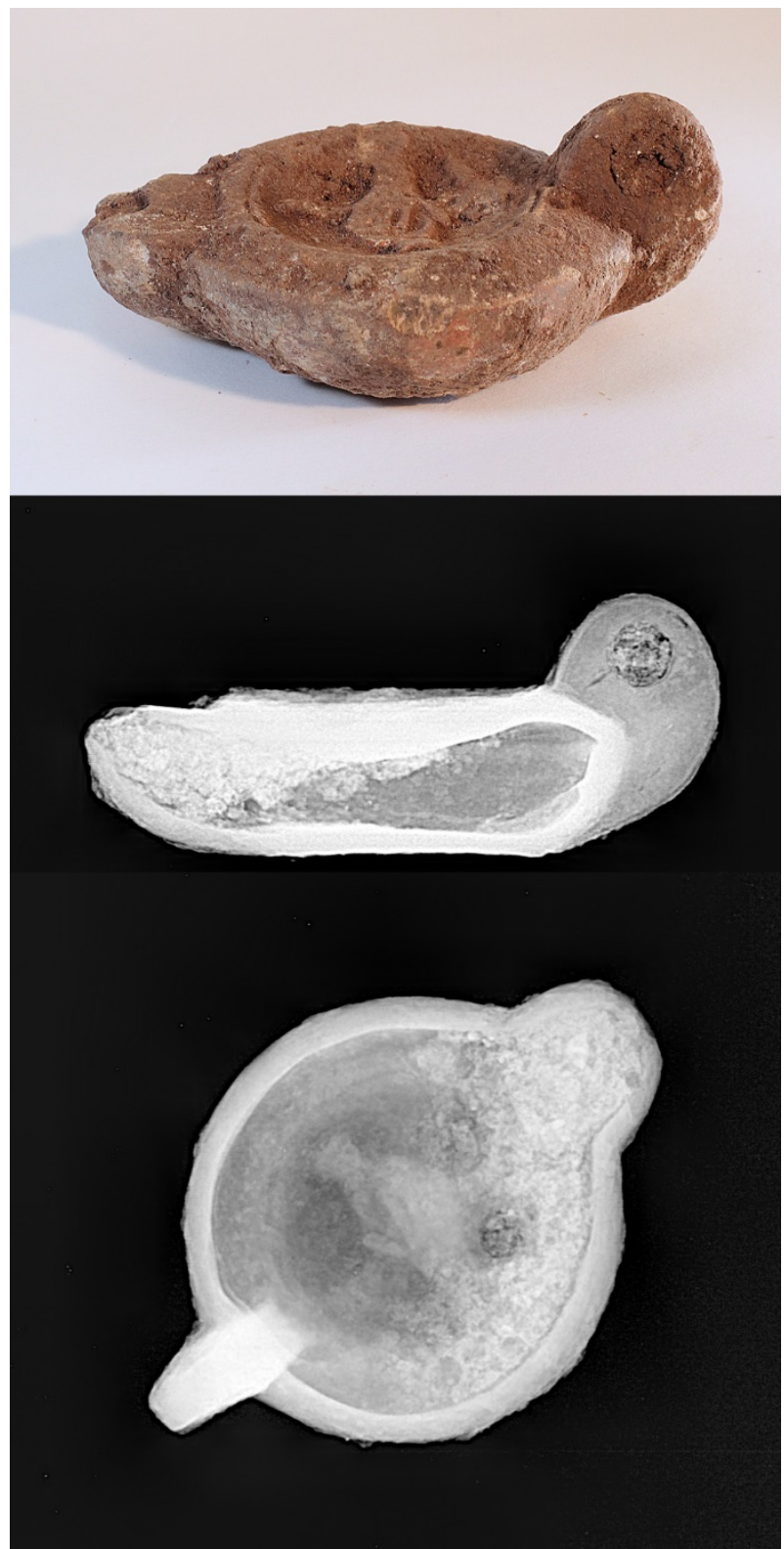

Figura 2: Lucerna romana del dextrarum iunctio y su Rx.

\subsection{Antiguas intervenciones}

Al tratarse de un museo con una larga trayectoria, las piezas que posee en sus fondos antiguos han sufrido distintas intervenciones de consolidación y restauración a lo largo de los años, no todas documentadas al uso y muchas con criterios hoy antiguos (Pasíes et al. 2011) actualmente poco acordes con los razonamientos museográficos recientes.

Como resultado de ello en el museo nos encontramos con piezas que han sufrido intervenciones antiguas importantes, que enmascaran y confunden los fragmentos originales y las reintegraciones. A la hora de tomar decisiones respecto a recuperar estas piezas con criterios nuevos y museográficamente más aceptables, la imagen radiográfica se muestra como una 
herramienta fundamental, ya que permiten diferenciar claramente que porcentaje de original tiene la pieza, además de su estado de conservación y cohesión.

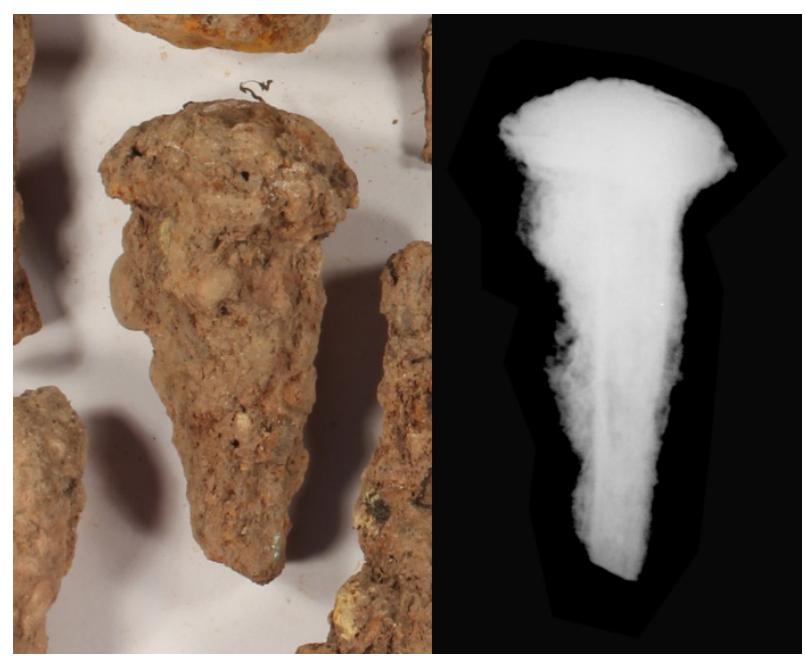

Figura 3: Material férreo del yacimiento de Sant Gregori.

El ejemplo más claro lo tenemos en una pieza de vajilla Campaniense B del yacimiento de Torre d'Onda, concretamente una forma Lamboglia 1 (Arasa y Mesado 1997) recuperada en los años 70 del siglo XX. Esta, además de abundantemente reintegrada con fragmentos que a veces revestían el original, fue cubierta por una pintura negra mate que en algunos casos impedía distinguir donde empezaba el original y donde acababa la reintegración (Fig. 4).

Otro aspecto importante de este apartado de la investigación es el análisis de antiguas restauraciones (en el caso de que se traten de intervenciones completamente miméticas, las incluimos en otro aparato de estudio), como es el tema de la jarra romana de cerámica común oxidante y probablemente de cronología entre los siglos I y III d. C., procedente de Mérida. Lamentablemente no existe información sobre cómo esta pieza llega al museo de Burriana, pero suponemos que vendría en el mismo contexto de los años 70 del siglo $X X$ en que también fueron traídos más materiales de origen extremeño, como ungüentarios de vidrio, cerámicas de paredes finas o una estatua de mármol, entre otras (Fig. 5).

En este caso se pudo comprobar el uso de alambres, cómo elemento sustentante de las reintegraciones, elementos que sería imposible documentar de forma correcta si no fuera mediante el uso de los Rx.

Esta información sin duda es muy valiosa a la hora de aportar datos a futuros estudios de analicen la evolución y la historia de las intervenciones de restauraciónconservación en España, ya que en este caso desconocemos si la pieza fue intervenida en origen.

\subsection{Material con intervenciones miméticas}

Como ya ha citado en el apartado de antiguas intervenciones, existen algunos casos en las que las piezas son objeto de restauraciones que intentan mimetizar el original y pasar desapercibidas. Este es otro de los temas en que los Rx aportan información esencial.
El primero de los casos es un ánfora tipo Dressel 1 del yacimiento de Torre d'Onda (Fig. 6), fruto de un hallazgo subacuático fortuito que ya se conocía desde principio del siglo XX. En su representación gráfica más antigua ya se observaba (Roca 1932:32) claramente que había sufrido una restauración. Sin embargo, en la actualidad prácticamente no se podía diferenciar ninguna intervención en esta pieza exhibida en el museo.

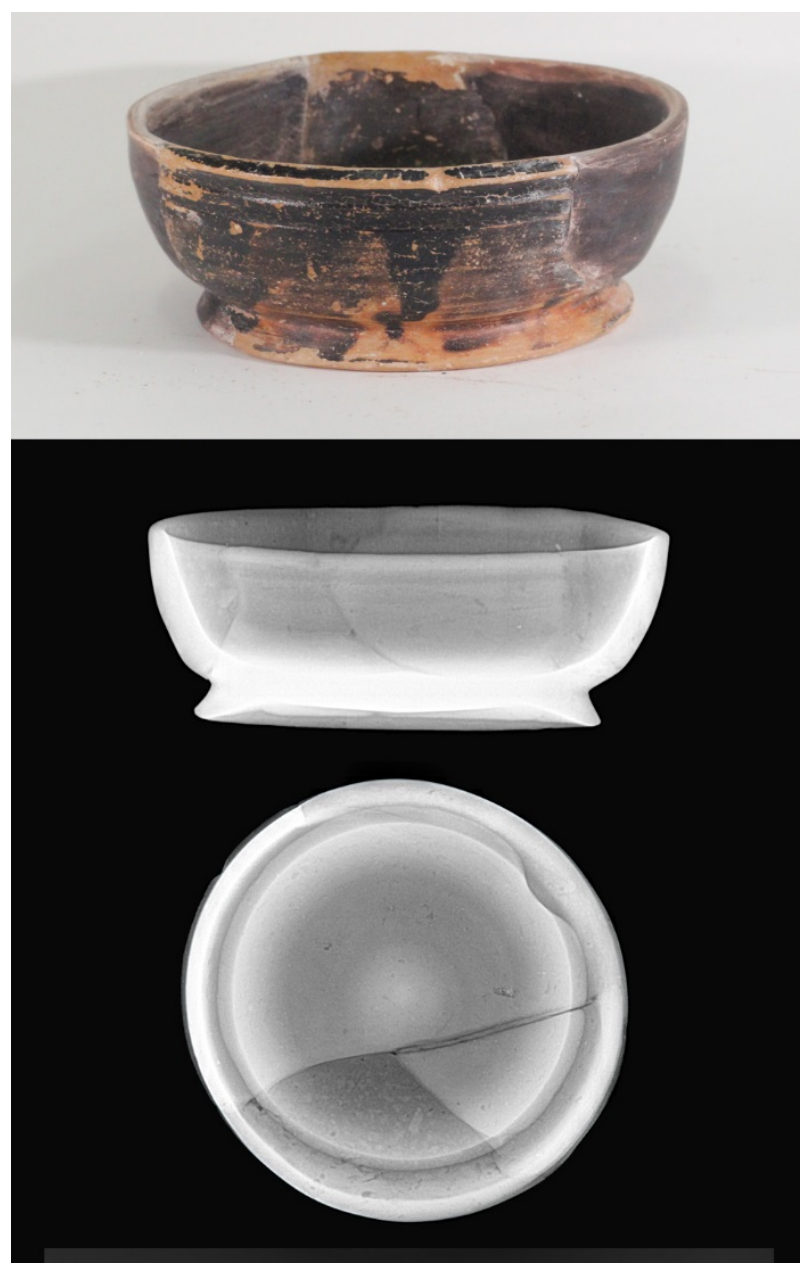

Figura 4: Campaniense B forma Lamboglia 1 de Torre d'Onda y su Rx.

Gracias al estudio radiográfico, no solamente se pudo documentar uno de los procesos más antiguos de restauración que se conservaban en el museo, sino que además se encontraron muchas más antiguas intervenciones en la pieza de las que no se tenía documentación, en parte por tratarse de una restauración muy antigua que podemos fechar aproximadamente en la primera década del siglo XX.

Otro caso destacado es la fíbula de bronce del yacimiento de Vinarragell (Fig. 7), perteneciente al periodo del Hierro I (Mesado 1988), de la cual no se tenía ninguna noticia sobre algún tipo de intervención sobre la pieza en los archivos del Museo de Burriana y que en una inspección visual aparentaba ser una pieza homogénea.

Pero a través de los $\mathrm{Rx}$ se comprobó que contaba con importantes intervenciones en buena parte del cuerpo original del artefacto, además de los añadidos de partes postizas. 
En ambos casos, como ya citamos anteriormente, no contamos con datos sobre las obras que se realizaron sobre las piezas, pero podemos suponer que las más recientes se ejecutaron a principio de la década de los 90 del siglo $\mathrm{XX}$, ya que fue el último periodo en que se llevaron a cabo de gran cantidad de intervenciones en material arqueológico.

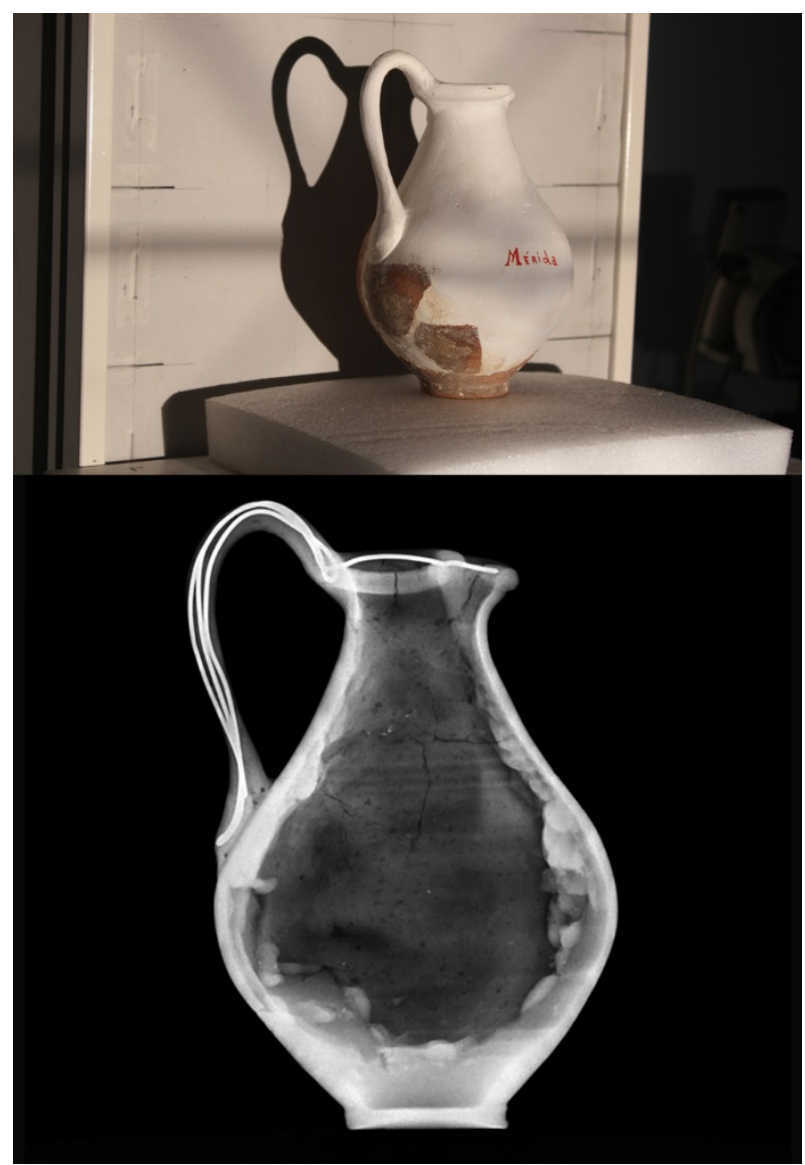

Figura 5: Jarra romana de Mérida del Museo de Burriana, vista frontal a través de su radiografía.

\subsection{Análisis de componentes y tecnología}

Entre los elementos analizados mediante Rx también tenemos interesantes ejemplos de materiales que ofrecieron significativos datos sobre sus componentes y tecnología de fabricación.

En la intervención desarrollada en la villa romana de Sant Gregori (Burriana), surgió la problemática de la identificación cronológica de materiales férreos (principalmente clavos y alcayatas) que se encontraban en fosas y zanjas que mezclaban materiales romanos y postmedievales. Gracias a la aplicación de Rx en estos materiales, la clasificación de los mismos fue bastante sencillas ya que la característica fabricación de estos elementos con núcleo hueco en época romana se diferenciaba claramente de los artefactos macizos de épocas más recientes (Fig. 8).

En el caso de los elementos cerámicos, tenemos la referencia de los materiales medievales del centro histórico de Burriana (Madrid y Ramírez 2011). Los Rx han permitido revelar con claridad la presencia de elementos metálicos en la decoración musulmana de las jarritas de cuerda seca o en los barnices cubrientes de otras piezas, además de importantes datos sobre la técnica de su fabricación, como por ejemplo el añadido de asas. (Fig. 9).

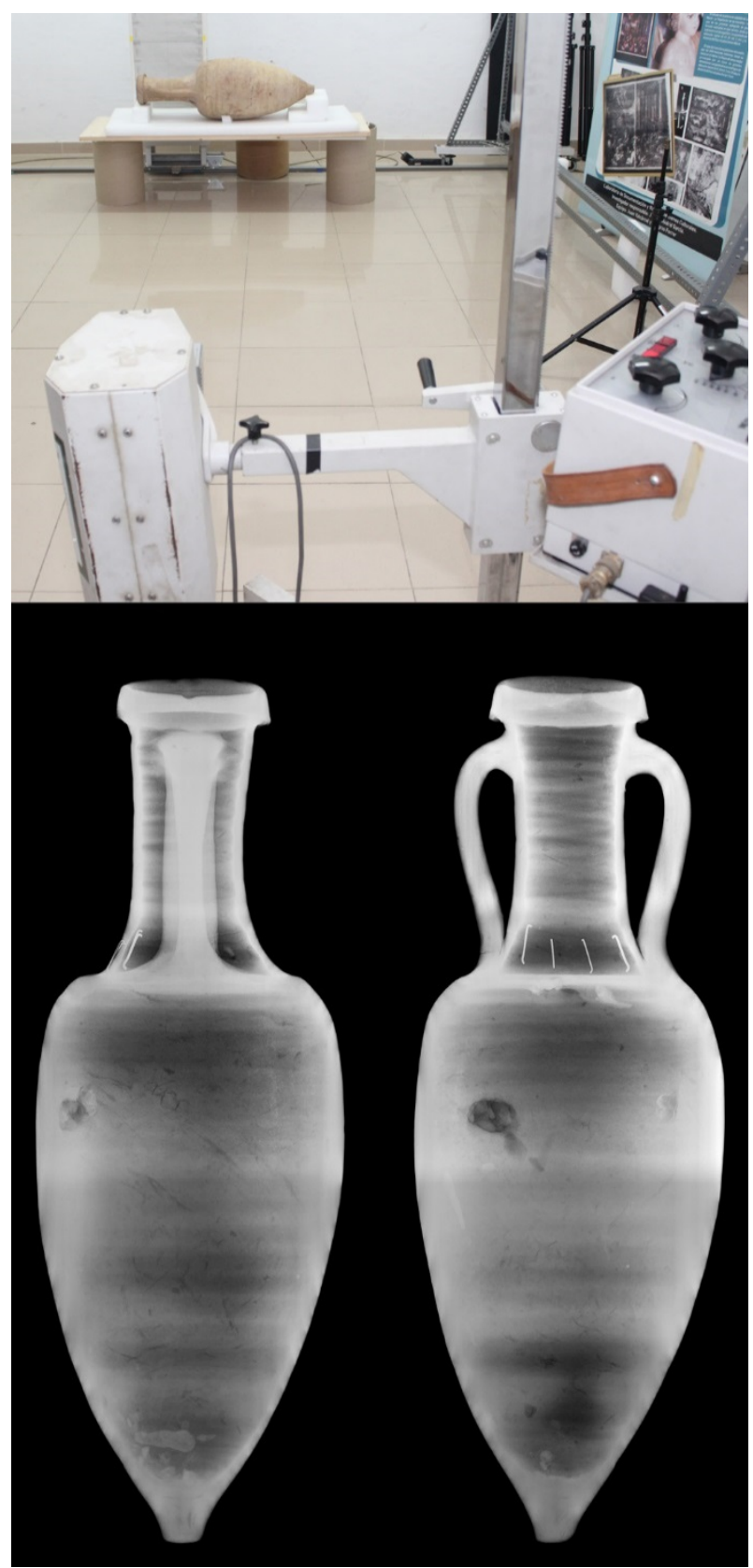

Figura 6: Ánfora Dressel 1 de Torre d'Onda y su Rx, a) ejecucción de la RX, b) vistas frontales en RX.

Este mismo procedimiento aportó información en el caso del aplique cerámico helenístico del yacimiento de Torre d'Onda (Fig. 10). En él se comprobó que se trataba de una cabeza de arcilla maciza, fabricada a molde, la cual se aplicó sobre la vasija y posteriormente se le añadió en su parte superior un asa trenzada.

Esto lleva a pensar que se utilizó un molde de la cabeza de una divinidad (probablemente la diosa Deméter) utilizada también en la fabricación de estatuillas de terracota conocidas como tanagrinas relacionadas con el culto, muy típicas del periodo helenístico; con lo cual nos encontraríamos con una pieza de excepcional interés en el contexto valenciano. 


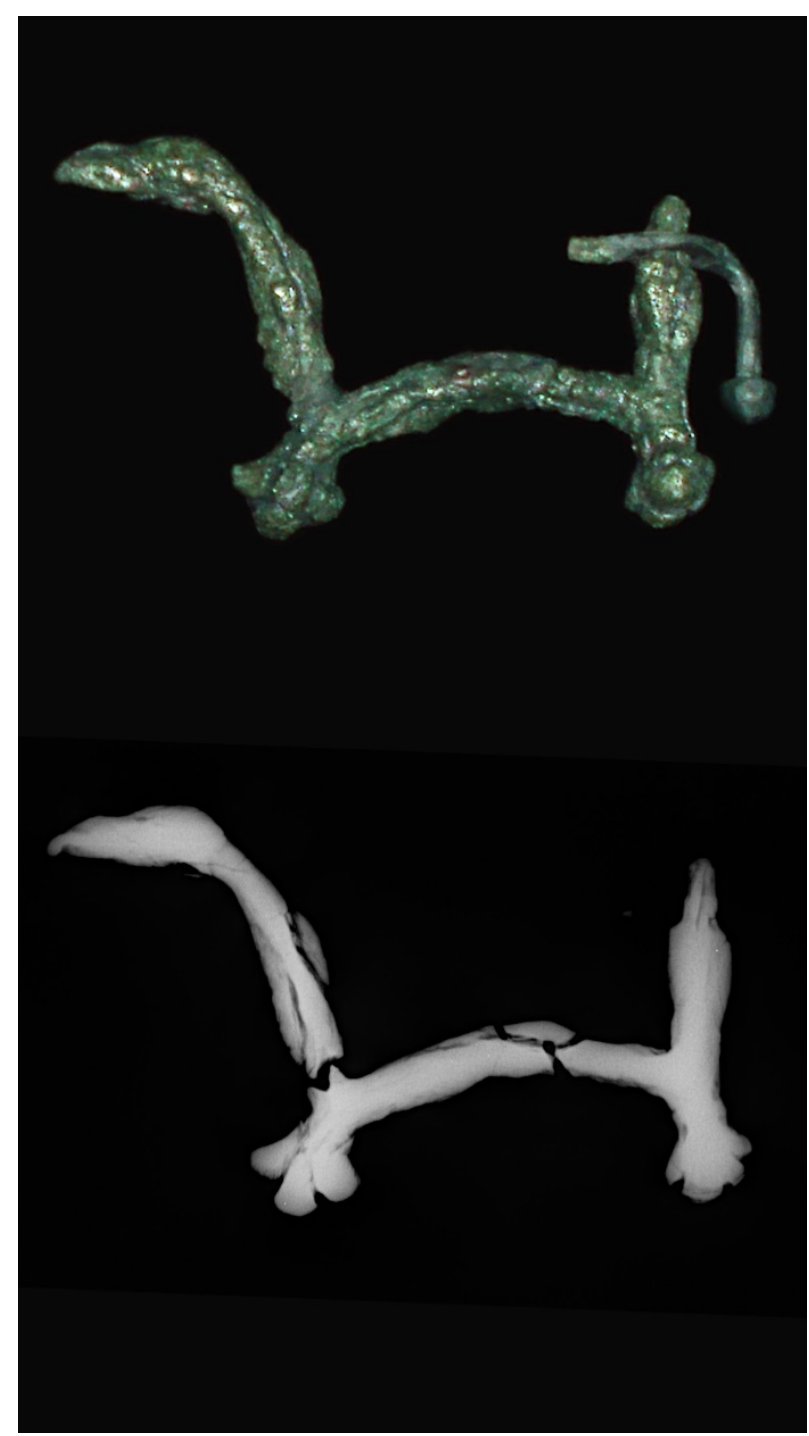

Figura 7: Fíbula del yacimiento de Vinarragell y su Rx.

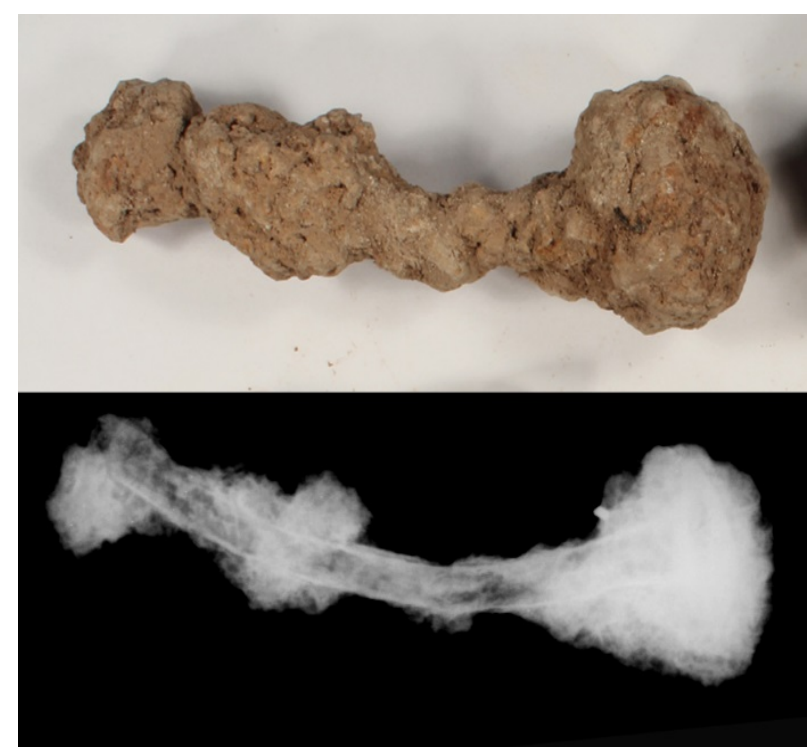

Figura 8: Material férreo romano y moderno de Sant Gregori.

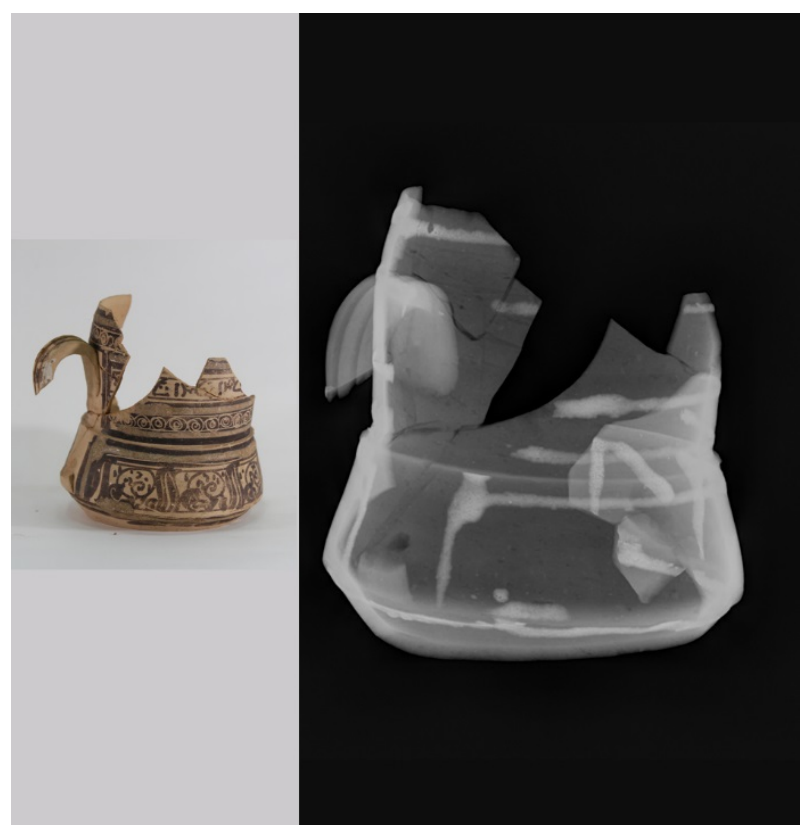

Figura 9: Material cerámico del centro histórico de Burriana.

\section{Tecnología de Rx aplicada a la investigación arqueológica}

La incorporación de la tecnología digital al estudio de rayos $X$ de bienes culturales está suponiendo en estos últimos años una pequeña revolución, sobre todo en los estudios arqueológicos. La tecnología del soporte digital en Rx ofrece solución a ciertas barreras propias del uso de los antiguos sistemas analógicos, como son los costes o la imposibilidad de ofrecer en muchos casos un registro adecuado. (Madrid 2014)

Con todo lo expuesto hemos podido constatar que poder implicar el uso de esta técnica en cualquier fase del estudio de una pieza, ya desde el mismo yacimiento o de su posterior tratamiento en taller, son ya un hecho. Ofreciendo en cada uno de esas etapas información relevante, tanto para su conservación, almacenaje o exposición.

\section{Proceso de la aplicación de los Rx en los artefactos arqueológicos}

En el presente estudio se ha empleado una fuente de rayos X TRANSXPORTIX 50尺, de la empresa General Electric, un detector de cámara de ionización y sistema de autorango, Ram Ion ${ }^{\circledR}$ de la empresa Rotem, más una procesadora automática de tipo $\mathrm{CR}$ de la empresa AGFA®. (Madrid 2006)

La procesadora es una estación de trabajo CR de radiografía indirecta $C R 30-X$ de la empresa $A G F A \otimes$. Este dispositivo se combina con el programa de identificación de imágenes y control de calidad AGFA® NX. La estación procesa las imágenes digitales obtenidas a través de los chasis CR MDT4.0T, también de $A G F A 囚$, con un formato de $35 \times 43 \mathrm{~cm}$ y un tamaño de matriz de pixel de $3480 \times 4248$.

Los parámetros usados para la obtención de las radiografías del estudio, como son voltaje $(\mathrm{kV})$ e intensidad ( $\mathrm{mA}$ ), se han ido adaptando a cada caso de estudio. Para ello se ha empleado el monitor de 
ionización, gracias al cual se establece la dosis (microSv) adecuada, dosis que marcara los valores de voltaje $(\mathrm{kV})$, intensidad $(\mathrm{mA})$ y tiempo de exposición más adecuados.

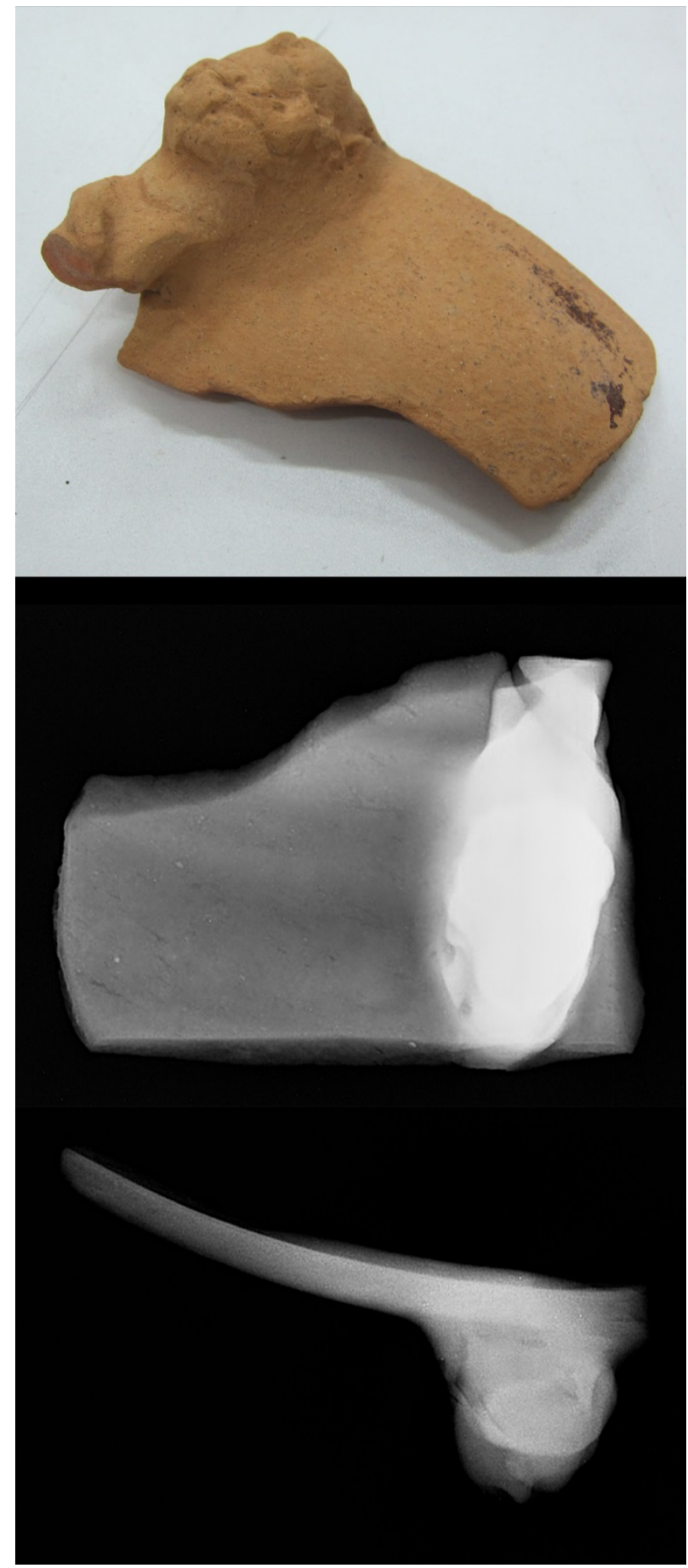

Figura 10: a) Aplique cerámico helenístico de Torre d'Onda, b) vista frontal en $R x, c)$ vista cenital en $R X$.

En el caso de Lucerna romana del dextrarum iunctio (Fig. 2) los parámetros fueron de $45 \mathrm{kV}, 20 \mathrm{~mA}$, con 3" de exposición, colocando la pieza a $100 \mathrm{~cm}$. La radiografía permite ver el estado en que se encuentra la orla y la representación de las dos manos derechas juntas sosteniendo un caduceo alado. Relieve que presentaba una gran cantidad de depósitos, debido a que la pieza no había sido intervenida, como se ha indicado.

El trabajo de estudio realizado para el conjunto de piezas del yacimiento de Sant Gregori fue más complejo. Fueron más de 40 placas radiográficas, con composiciones que oscilaban de 1 a 20 piezas en cada una de ellas. Nuestro objetivo fue hacer una selección objetiva de aquellas piezas que tenían más interés para su estudio o tratamiento posterior. Los parámetros se mantuvieron en un margen de voltaje que oscilo entre $50 \mathrm{kV}$ y $76 \mathrm{kV}$. En todos los casos se mantuvo constante la intensidad en $20 \mathrm{~mA}$, la exposición en 3" y la distancia entre foco e imagen de $100 \mathrm{~cm}$. (Fig. 3 y 8)

El estudio Campaniense B forma Lamboglia 1 de Torre d'Onda necesitó tan solo de $35 \mathrm{kV}, 20 \mathrm{~mA}$, con 3" de exposición en cada una de sus vistas, tanto frontal como cenital, colocando la pieza a $100 \mathrm{~cm}$. (Fig. 4)

El estudio realizado a la Jarra romana de Mérida (Fig. 5) sirvió de pretexto para realizar un estudio en un cuerpo de revolución. Para ello se obtuvieron las cuatro vistas de su eje sagital, más la referencia de su vista cenital. De esta forma los artefactos propios de la pieza no interfieren en la lectura de la misma. Todos los disparos se realizaron a la misma distancia de $100 \mathrm{~cm}$, con 42kV, 20 mA y 3" de exposición.

En el caso del Ánfora Dressel 1 de Torre d'Onda (Fig. 6) las medidas obtenidas a través del monitor de ionización (12,40 microSv por exposición) fueron fundamentales (Madrid 2011), debido a las dimensiones de la pieza $(85 \times 28 \times 28 \mathrm{~cm})$ lo que obligaba a colocar la fuente a $320 \mathrm{~cm}$ de distancia. La radiografía completa se construye a partir de 5 placas y los parámetros de las mismas fueron $72 \mathrm{kV}, 20 \mathrm{~mA}$ y 5 " de exposición.

La Fíbula del yacimiento de Vinarragell (Fig. 7), desde el punto de vista técnico también presenta un reto debido a la densidad del material constitutivo frente al empleado en las reconstrucciones posteriores. Los parámetros en este caso fueron $72 \mathrm{kV}, 20 \mathrm{~mA}$ y 5 " de exposición.

Para la jarra musulmana con decoración de cuerda seca (Fig. 9), como ejemplo de material cerámica del centro histórico de Burriana, los parámetros fueron $45 \mathrm{kV}, 20$ $\mathrm{mA}$ y 3 " de exposición manteniendo una distancia entre el objeto y el foco de $100 \mathrm{~cm}$.

Caso curioso fue el Aplique cerámico helenístico de Torre d'Onda (Fig. 10), pues siendo una pieza de terracota se tuvo que emplear un voltaje un tanto elevado, de $72 \mathrm{kV}$, para la obtención de un registro óptimo. El resto de parámetros fueron $20 \mathrm{~mA}$ y 3 " de exposición.

\section{Conclusiones}

En la actualidad, las ventajas de la aplicación de la radiografía digital en el campo de la arqueología son más que evidentes. Por un lado, está la vertiente puramente crematística, pues representa un menor coste económico respecto a la analógica, debido a que necesita una menor cantidad de soporte material y permite una mayor facilidad a la hora de analizar digitalmente los resultados, más la inmediatez en su obtención

Pero además es una herramienta muy valiosa para el análisis de materiales arqueológicos, pues permite 
reducir costes y agilizar el proceso de decisión a la hora de limpiar y restaurar piezas donde un examen visual no permite calibrar su verdadero estado, como en el ejemplo que exponemos referido a piezas con abundante cubierta de óxido.

La otra vertiente importante es la investigación científica de los materiales constituyentes de las piezas, ya que la manejabilidad de la radiografía digital permite clasificar objetos no visibles (por ejemplo los que se encuentran dentro de núcleos de óxido), obteniendo resultados a nivel de componentes, tanto en los casos donde los materiales estén compuesto por elementos metálicos ( $p$. e. la decoración en cuerda seca de época musulmana), como a nivel de unidades que presenten distinta respuestas a los $\mathrm{Rx}$, en este caso hablamos de los componentes de la pasta de cerámica con la superficie cubierta completamente por engobe, pintura, vidriado, etc. o de las partes de restauraciones antiguas no documentadas.

Finalmente debemos hablar del análisis de elementos estructurales, en la composición de piezas, que pueden aportar datos interesantes respecto a la tecnología cerámica, como es el montaje de las piezas o el uso de elementos añadidos y apliques, que, en algunos casos, como el ejemplo expuesto de la cabeza cerámica de Deméter, pueden ayudar al análisis estilístico y cronológico de la pieza.

Pero somos conscientes de que queda mucho camino por recorrer y que las posibilidades con la radiografía digital son muchas. Máxime si incorporamos la tecnología 3D y la posibilidad de la impresión de piezas.

Son ya algunos ejemplos los que estamos obtenido con la mezcla de la visualización en tres dimensiones de la pieza, más la incorporación de la imagen radiográfica. Imágenes que están facilitado la compresión de los objetos estudiados.

Como objetivo y líneas de futuro queremos indagar más en las posibilidades que estas técnicas nos pueden ofrecer, intentado que se lleguen a entender como referentes a la hora de la investigación, estudio y muselización de estos objetos.

\section{Referencias}

ARASA, F. y MESADO, N., 1997. La cerámica d'importació del jaciment ibéric de Torre d'Onda (Borriana - La Plana Baixa). Archivo de Prehistoria Levantina, XXII, pp. 375-408.

FERRER, J.J. y BENEDITO, J., 2012. La dextrarum iunctio y su representación en el registro arqueológico romano: la lucerna de Sant Gregori (Burriana - España). Millars, XXXV, pp.25-48. DOI:dx.doi.org/10.6035/Millars.

FERRER, J.J., MELCHOR, J.M. y BENEDITO, J., 2013. Sant Gregori. Un complejo arquitectónico de época romana en la costa de Burriana (España). Millars, XXXVI, pp.129-233. DOI:dx.doi.org/10.6035/Millars.

MADRID, J.A., 2006. Aplicación de la técnica radiográfica en la Conservación y Restauración de bienes culturales. Valencia. Universitat Politècnica de València.

MADRID, J.A., 2013. "Use of telemetry X-ray techniques in large-size pictorial works”. En Ge-conservación. n 5. pp 101109.

MADRID, J.A., 2014. Dos décadas de inspección radiográfica en España: retrospectiva y horizontes en un contexto de cambio tecnológico. Intervención. Revista Internacional de Conservación, Restauración y Museología, Escuela Nacional de Conservación, Restauración y Museografía-INAH. Año 5. Núm. 10, Julio-diciembre de 2014. pp. 8593.

MADRID, J.A. y RAMÍREZ, A.M., 2011. Radiografía digital en el estudio de piezas cerámicas. Estudio e interpretación de cerámica medieval procedentes del Museo Arqueológico Municipal de Burriana. En: J.M. MELCHOR, J. BENEDITO y T. PASIES, eds, La arqueología de la Buriyyana islámica a la Borrianacristiana. Conselleria de Governació de la Generalitat Valenciana, pp. 153-172.

MELCHOR, J.M., 2011. La arqueología como fuente de estudio para la Burriana medieval. En: J.M. MELCHOR, J. BENEDITO y T. PASIES, eds, La arqueología de la Buriyyana islámica a la Borriana cristiana. Conselleria de Governació de la Generalitat Valenciana, pp. 11-48.

MELCHOR, J.M., 2013. Diez años del Servicios Arqueológico Municipal de Burriana, Ayuntamiento de Burriana. 160 páginas.

MESADO, N., 1988. Nuevos materiales arqueológicos en el Pozo I del yacimiento de Vinarragell (Burriana, Castellón). Archivo de Prehistoria Levantina, XVIII Tomo II, pp. 287-328.

PASIES, T., PEIRÓ, M.A. y TEJERINA, D., 2011. La conservación-restauración en arqueología. Trabajos en el laboratorio del Museo Arqueológico de Burriana. En: J.M. MELCHOR, J. BENEDITO y T. PASIES, eds, La arqueología de la Buriyyana islámica a la Borriana cristiana. Conselleria de Governació de la Generalitat Valenciana, pp. 137-152.

ROCA, F., 1932. Historia de Burriana. Imprenta Hijos de Armengot. Castellón. 562 páginas 


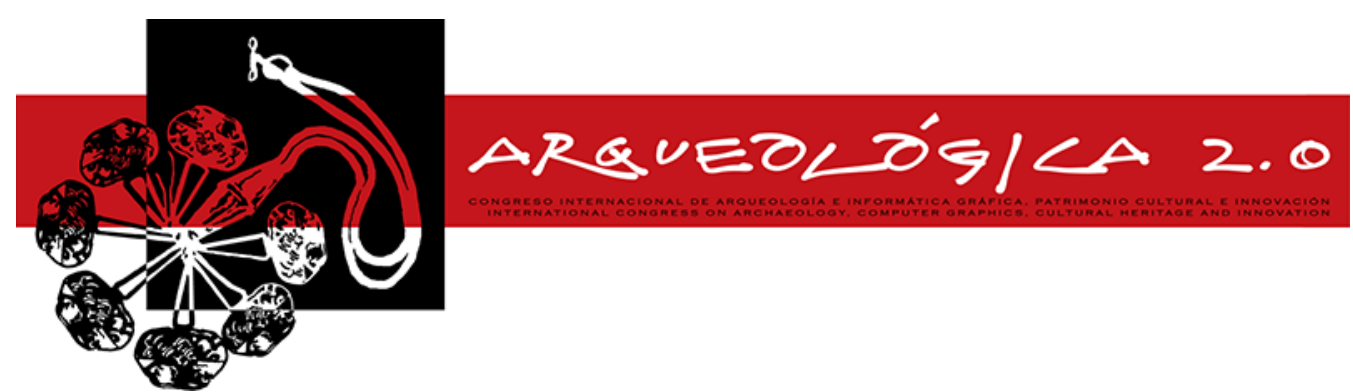

Proceedings of the $8^{\text {th }}$ International Congress on Archaeology, Computer Graphics, Cultural Heritage and Innovation 'ARQUEOLÓGICA 2.0'

in Valencia (Spain), Sept. $5-7,2016$

DOI: http://dx.doi.org/10.4995/arqueologica8.2016.2993

\title{
DOCUMENTACION DIGITAL APLICADA A LA VILLA ROMANA DE SANT GREGORI (BURRIANA, ESPAÑA)
}

\author{
DIGITAL DOCUMENTATION APPLIED TO THE ROMAN VILLA SANT GREGORI (BURRIANA, SPAIN) \\ José Manuel Melchor ${ }^{\mathrm{a},{ }^{*},}$, Josep Benedito ${ }^{\mathrm{b}}$, Juan José Ferrer ${ }^{\mathrm{a}}$, José Ricart ${ }^{\mathrm{c}}$, Rafael Ayora ${ }^{\mathrm{c}}$ \\ ${ }^{a}$ Departament d'Història, Geografia i Art, Universitat Jaume I, Av. Sos Baynat s/n, 12071 Castellón, España. melchor@uji.es; \\ jerrer@uji.es \\ ${ }^{\mathrm{b}}$ Departament d'Història de l'Antiguitat i de la Cultura Escrita, Universitat de València, Av. Blasco Ibáñez 28, 46010 Valencia, España. \\ Josep.Benedito@uv.es \\ 'SIGMA SCAN SC, San Blas 66, planta 3, pta. 1, 12500 Vinaròs, Castellón, España. info@sigma-scan.es
}

\begin{abstract}
:
In this paper we aim at presenting the digitalization process done on the archaeological site at San Gregori a villa a mare from the Early Roman Empire found in Burriana, a Mediterranean coastal village of Spain. The archaeological work is part of a joint research project carried out by Universitat Jaume I in Castellón and the Archaeological Museum of Burriana. To date, the residential part of the villa in the northeast corner of the settlement has been excavated; this area is situated about 100 meters from the waterfront. The villa has been dated around the change of Era and IV c. A. D.; however, some Roman republican and Iberian materials have also been registered. The last phase of the work consisted on the development of a $3 \mathrm{D}$ laser scanning to complete the graphical work for the archaeological documentation of the site.
\end{abstract}

Key words: Roman villa, digital archaeology, Burriana, scanner, documentation, planimetry

\section{Resumen:}

En este artículo se presentan los trabajos de digitalización realizados sobre los restos arqueológicos del yacimiento de Sant Gregori, una villa marítima de época romana alto imperial situada en la costa de Burriana. Los trabajos arqueológicos forman parte de un proyecto de investigación desarrollado por la Universitat Jaume I de Castellón y el Museo de Burriana. Hasta la fecha se ha excavado la parte residencial de la villa, localizada en el extremo noreste del asentamiento, aproximadamente a $100 \mathrm{~m}$ de la línea de costa. La villa se ha datado entre el cambio de Era y el siglo IV d. C., aunque también se han registrado materiales de época romano republicana e ibérica. La última fase de los trabajos ha consistido en realizar un escáner láser 3D, que completa los trabajos gráficos de documentación del yacimiento.

Palabras clave: villa romana, arqueología digital, Burriana, laser escáner, documentación, planimetría.

\section{El yacimiento}

Los restos romanos de Sant Gregori fueron descubiertos por N. Mesado en la década de 1970 (Verdegal et al. 1990), quien llevó a cabo dos efímeras campañas de excavación. La primera intervención se realizó en 1978 , un sondeo en la parcela situada en primera línea de playa, en el que se salieron a la luz algunos muros, fragmentos de mármol y cerámica. En 1987 se efectuó una nueva campaña en la que se descubrieron varias habitaciones de planta cuadrangular y fragmentos de revestimiento de mortero con pintura mural, que indican que algunas paredes debieron estar pintadas. Los pavimentos eran de mortero de cal y ladrillos. También se registró una gran cantidad de teselas de color blanco y negro, lo que sugiere que en el yacimiento debía existir un mosaico bicromo. De estas primeras intervenciones sólo se conservan en el Museo Arqueológico memorias incompletas y algunas fotografías, tampoco se realizó ningún trabajo de clasificación de los hallazgos.

En el año 2003 se llevó a cabo una prospección arqueológica en los terrenos de la villa. Años después, en el 2009 se realizó una prospección electromagnética

*Corresponding Author: Josep Benedito, Josep.Benedito@uv.es 
que reveló importantes diferencias en la consistencia del subsuelo. El sistema de georradar confirmó la existencia de una apreciable zona de contacto entre la arena de aportación marina y una serie de estructuras y vertidos romanos. Como complemento de esta intervención se llevó a cabo en el año 2010 una campaña de sondeos arqueológicos con el objeto de delimitar el perímetro de la villa.

Desde el año 2011 se han llevado a cabo cinco campañas anuales de excavación arqueológica a cargo del Museo Arqueológico Municipal de Burriana en colaboración con la Universitat Jaume I de Castellón. Desde entonces, los trabajos han permitido sacar a la luz un conjunto de estructuras arquitectónicas muy interesantes de la única villa costera de época romana excavada hasta la fecha en la provincia de Castellón.

Sant Gregori se halla en la costa norte de Burriana, una franja litoral baja, rectilínea y estrecha, formada por una sucesión de abanicos aluviales (Fig. 1). En época romana era un área lagunar junto a la desembocadura del río Anna y el antiguo barranc de l'Hospital. La villa se ha datado entre el cambio de Era y el siglo IV aunque tiene lugar una notable obra de reforma entre el siglo II y III. El buen estado de conservación de los pavimentos no permitió continuar la excavación, pues hubiera supuesto la destrucción de estos restos (Fig. 2). Con todo, en época Moderna algunos sectores de la pars urbana de la villa sufrieron la excavación de zanjas y fosas con el objeto de extraer material constructivo, que tal vez trasladarían a las salinas medievales, que sabemos que fueron rehabilitadas entre 1570 y 1580 . En estos rellenos se registraron importaciones de cerámica itálica y cerámica campaniense A, B e ibérica. Estos materiales podrían sugerir que el lugar ya fue ocupado entre los siglos III y I a. C., en un momento anterior a la construcción de la villa. Por otro lado, en el último de los niveles de la excavación, que se ha hallado en contacto con la capa freática, se encontró cerámica de la Edad del Bronce y del Hierro antiguo, así como algún fragmento de ática. Sin embargo, estas cerámicas no se asocian a niveles estratigráficos claros y solo los futuros trabajos permitirán aclarar qué hacen ahí estos artefactos (Melchor et al. 2014).

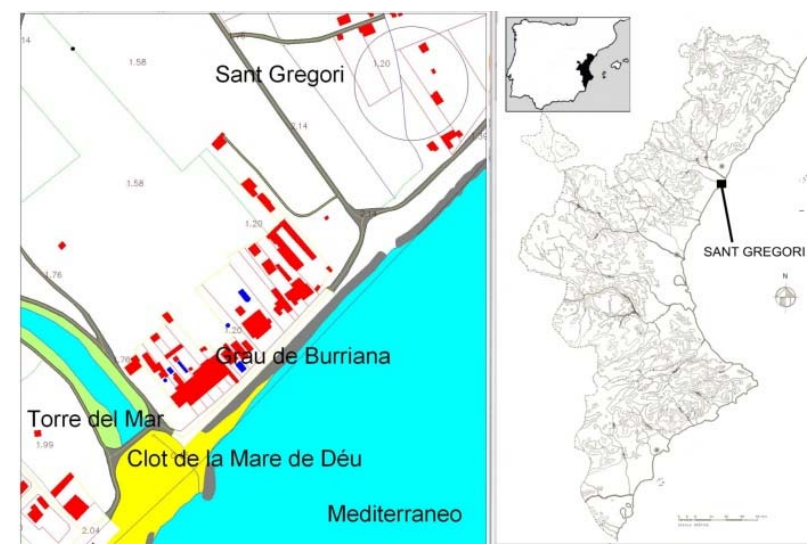

Figura 1: Plano de situación de la villa romana de Sant Gregori.

Los hallazgos más relevantes realizados hasta el momento a nivel arquitectónico, corresponden a un peristilo orientado de norte a sur datado en el siglo I, que constaría de un espacio ajardinado alrededor de un impluvium rectangular, de 9,80 por $1,75 \mathrm{~m}$ y cimientos de $95 \mathrm{~cm}$ de ancho, revestido de opus signinum y aristas acabadas con juntas de cuarto de bocel, además cuenta con una tubería de plomo, a través de la cual el agua se decantaría probablemente hacia el hortus de la villa. Este espacio ajardinado se amortizó posteriormente con una serie de pavimentos de opus caementicium (Ferrer et al. 2013) y a un monumento funerario, probablemente un columbario familiar, de 4,25 $\mathrm{m}$ de lado, situado en una esquina exterior del peristilo, la estructura es de morfología cuadrangular y pavimento de cantos rodados. En los rellenos de colmatación se encontraron fragmentos de placas y molduras de mármol, que pudieron formar parte de su decoración arquitectónica.

Este espacio fue profundamente transformado en el siglo II para crear un área de almacenes, pues se recuperaron dos dolia (Ferrer et al. 2014) registrándose en líneas generales una disminución de la riqueza del enclave.

Respecto a los hallazgos muebles, se han recuperado sigillatas itálicas, hispánicas y sudgálicas, engobe rojo pompeyano y paredes finas, que se fechan desde finales del siglo I a. C. y durante todo el siglo I d. C. En el Alto Imperio la villa muestra una notable riqueza: mármoles, vidrio, lapis specularis y un amplio muestrario de fragmentos de pintura mural decorados, indicios de un mosaico en opus tesselatum y un opus sectile.

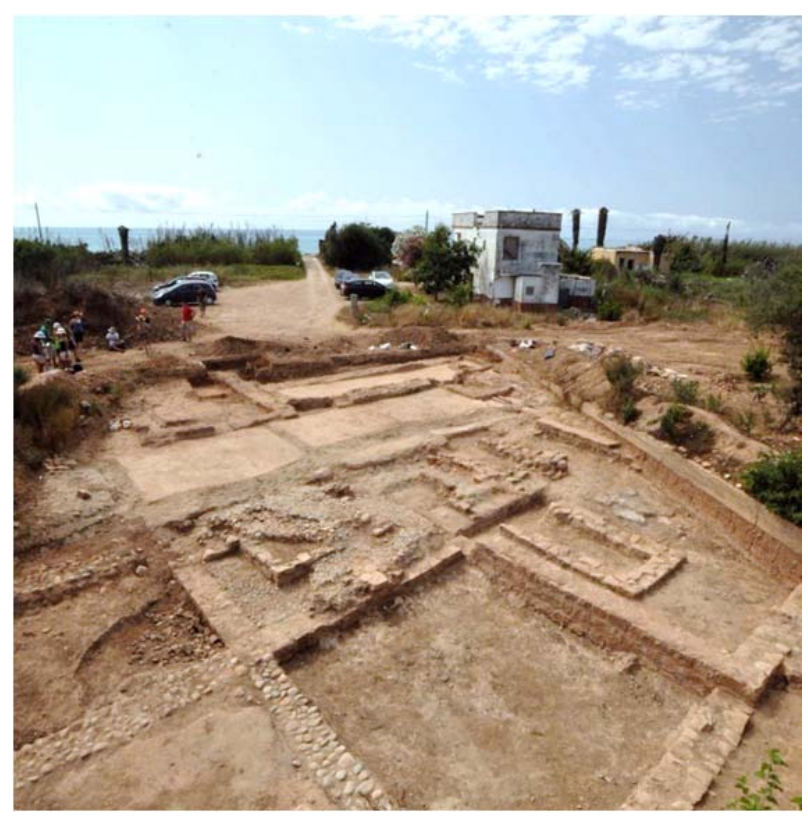

Figura 2: Proceso de excavación de la villa.

\section{La villa y su contexto histórico}

Sant Gregori podría tratarse de un tipo de villa marítima polifuncional, similar a otras localizadas en la costa peninsular, sin embargo averiguar las funciones que podría haber ejercido este asentamiento es una cuestión que todavía se nos escapa. Por un lado, el fundus de estas instalaciones se hallaría en medio de una zona de marjales, como ya citamos anteriormente, por lo que su explotación agrícola no sería fácil. Debemos examinar la relación que tiene Sant Gregori con los yacimientos del Marjalet (Melchor 2013) y del Palau (Melchor y 
Benedito 2000), localizados a 1,7 y $3,5 \quad \mathrm{~km}$ respectivamente.

Otra cuestión está relacionada con el límite norte del territorium saguntino que se ha situado en el río Millars. Este enclave es el último yacimiento costero excavado que se localiza al sur del citado río, por lo que su emplazamiento debería tener cierta relevancia (Ferrer et al. 2013).

Las evidencias materiales sugieren que se trata de un enclave utilizado para servir de punto de apoyo al transporte de mercancías y controlar el paso de una vía (Fig. 3). Sant Gregori encajaría así en un panorama rural en el que el sistema de uillae e incluso de uici, serviría para vigilar caminos y campos, utilizarse como almacenes y ocasionalmente servir de alojamiento (Ferrer et al. 2013).

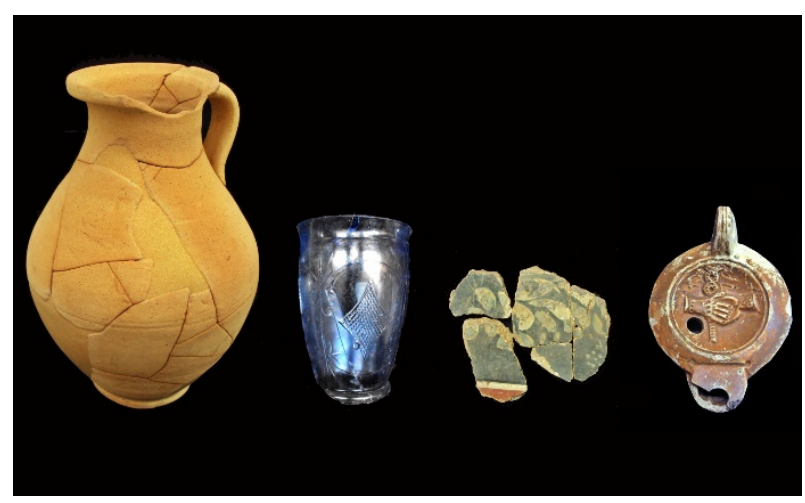

Figura 3: Materiales arqueológicos de la villa de Sant Gregori.

\section{El proceso de documentación digital de la villa}

El siguiente paso en la ejecución del proyecto de investigación fue realizar un escaneado mediante láser de todo el yacimiento. Para ello se ha contado con la colaboración de SIGMA SCAN, empresa ubicada en la provincia de Castellón especialista en el campo de la topografía, escaneado láser terrestre y geomática. Su misión ha sido llevar a cabo los trabajos de escaneado y posterior procesado de los datos para dotar al proyecto de una nueva dimensión en la documentación del yacimiento arqueológico.

Hasta la fecha, los yacimientos se documentaban a través de levantamientos topográficos, croquizados de detalle y fotografías. Gracias al desarrollo tecnológico experimentado en los últimos años en el campo de los equipos topográficos y la informática, se han incorporado a estas técnicas clásicas de registro los escaneados láser 3D, modelos virtuales y demás disciplinas que permiten el tratamiento de los datos en sus tres dimensiones.

\subsection{Descripción de los medios técnicos}

El gran avance de la tecnología de escaneado láser, nos permite aprovechar su inmenso potencial en el campo de la documentación arqueológica y conservación del patrimonio, entre otros ámbitos. Con la tecnología láser escáner 3D, se pueden generar imágenes tridimensionales de geometría y entornos complejos. Es una metodología de captura masiva de datos mediante la que se obtienen grandes nubes de millones de puntos que reflejan de manera fidedigna los objetos y entornos deseados con la posibilidad de dotar a dichos puntos de niveles de intensidad y colores reales, lo que nos lleva a alcanzar una representación fotorrealista.

Es una metodología emergente y en constante evolución. Existen principalmente dos clases de técnicas de medición en el campo del láser escáner: 1) Tiempo de vuelo (TOF - Time of Flight) que se basa en la medición del tiempo de transmisión del láser en su trayectoria de ida y vuelta desde el emisor-receptor hasta el objeto escaneado. 2) Diferencia de Fase (Phase Shift) basado en el cálculo de la diferencia de fase entre el láser emitido y el recibido.

Ambas tecnologías presentan valores de precisión similares (3-4 mm), siendo la velocidad de toma datos mucho mayor la de los equipos de diferencia de fase (1 millón puntos/seg) frente a los de tiempo de vuelo (100.000 puntos/seg). Todas estas prestaciones son mejoradas continuamente por los distintos fabricantes que dotan a sus equipos de mayor velocidad, superior alcance y mejor precisión a un ritmo formidable.

Prácticamente todos los modelos están provistos de cámaras digitales que permiten realizar fotografías del entorno escaneado $y$, de este modo, dotar a la infinidad de puntos obtenidos, del color capturado en las imágenes. Ello permite obtener una nube de puntos coloreada con una mejor representación de realidad.

Un factor fundamental en esta tecnología es la gestión de los datos en gabinete, ya que es esta tarea la que requiere de mayor especialización por parte del equipo técnico y supone cerca de un $80 \%$ del tiempo invertido en el proyecto. Los programas informáticos van avanzando en la automatización de procesos, como el registro de las distintas estaciones y la limpieza de las nubes de puntos brutas, aunque siempre es de suma importancia la experiencia y buen hacer del técnico para obtener unos resultados óptimos.

En nuestro caso, se optó por un modelo de escáner de 'tiempo de vuelo', en concreto se utilizó el escáner C10 de la casa Leica. Un instrumento que nos permitía llevar a cabo el registro de campo con una calidad y tiempos de captación de datos óptima para las características que presenta nuestro yacimiento.

El proyecto ejecutado en Sant Gregori se ha gestionado con el software 'Cyclone', también de la casa Leica, con el que se han realizado las tareas de registro de estacionamientos, limpieza de nubes de puntos, digitalización de elementos principales y creación de material divulgativo (videos, fotogramas, etc.). Todo ello con el objetivo de obtener la mejor calidad posible en la documentación técnica que sería utilizada en el estudio arqueológico.

\subsection{Trabajos de escaneado y tratamiento de los resultados}

Los trabajos de escaneado consisten principalmente es la toma de datos desde diferentes puntos de manera que se cubran con suficiente densidad y calidad de puntos todo el ámbito de estudio. 


\subsubsection{Planificación}

El primer paso en los trabajos de escaneado ha sido llevar a cabo una exhaustiva programación de las estaciones que posteriormente se realizarían en campo. Estos trabajos de planificación son de gran importancia para minimizar los futuros problemas en la gestión de las nubes de puntos escaneadas. En el caso de realizar insuficientes escaneados, tenemos el inconveniente de la falta de información, siendo habitual presentar espacios de sombra en los que, al no disponer de las necesarias referencias para generar el modelo, no se podrán analizar sus características. Si nos encontramos en la circunstancia contraria, con la presencia de excesiva cantidad de datos registrados, nos veremos con el obstáculo de gestión de los mismos, algo que, debido a la gran dimensión de los archivos generados con esta técnica, puede ser un gran problema para alcanzar los objetivos del proyecto, ya que esta situación puede dificultar mucho la tarea de limpieza inicial para eliminar el ruido generado en cada escaneado.

Antes de iniciar cada proceso de escaneado, se tomaron una serie de dianas distribuidas a lo largo del ámbito de estudio con el objetivo de asegurar y facilitar el registro de los diferentes estacionamientos (Fig. 4). La ubicación de cada una de estas dianas también se ha tenido en cuenta en el proceso de planificación que estudia el posicionamiento de las estaciones. Siendo suficientes dos dianas comunes entre escaneados sucesivos para el registro automático, la situación ideal sería aquella en la que nos encontráramos tres o más dianas.

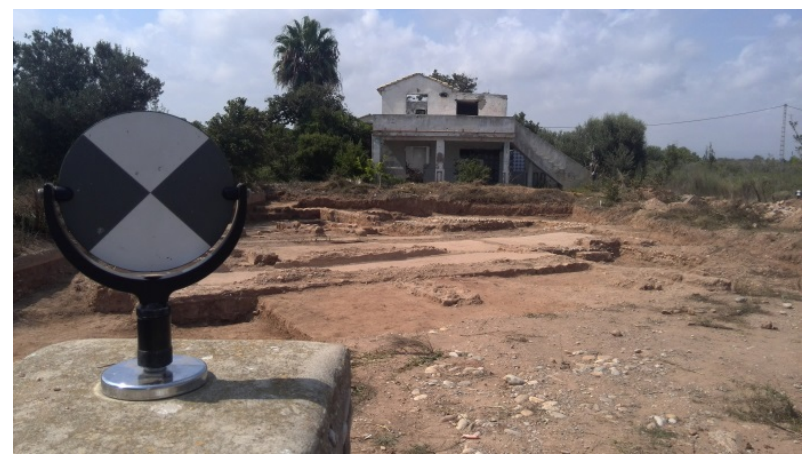

Figura 4: Diana de registro y vista general del yacimiento.

\subsubsection{Escaneado}

Por último, se llevaron a cabo 16 escaneados, obteniendo tras su procesado un modelo cercano a los 112 millones de puntos (Fig. 5).

También se realizaron fotografías desde la cámara digital propia del instrumento. Podremos generar así las nubes de puntos con el color verdadero procedente de dichas fotografías, creando de este modo visuales con una alta percepción de la realidad.

Como complemento a las labores de escaneado, se realizó el levantamiento por medio de observaciones GPS-GNSS de puntos significativos del ámbito de actuación que nos permitieron georreferenciar el trabajo.

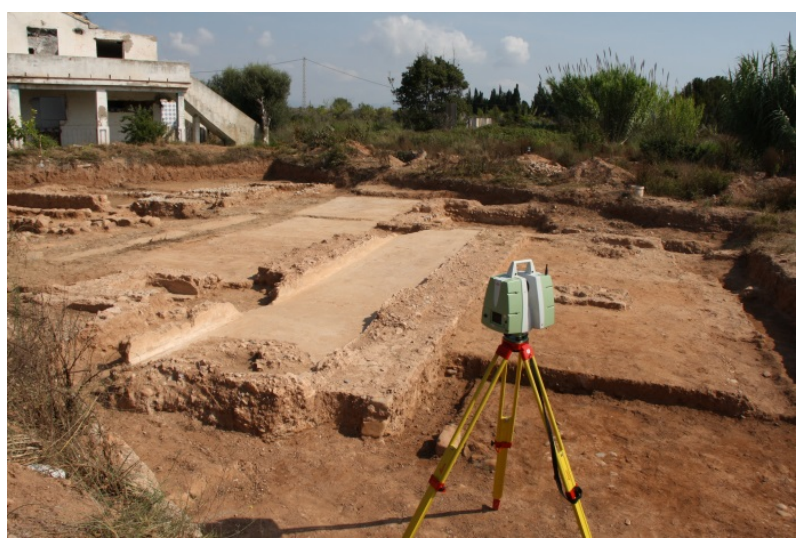

Figura 5: Vista general del yacimiento y el escáner C10 Leica.

\subsubsection{Procesado}

El primero de los trabajos de gabinete fue el registro automático de los distintos escaneados, utilizando para ello la composición de los pares de dianas comunes entre estaciones. Desechadas de la ecuación de ajuste las dos combinaciones con mayor residuo, se alcanza la solución de ensamble definitivo en la que los residuales obtenidos se encuentran dentro de los parámetros establecidos con anterioridad al inicio del proyecto. Los resultados ofrecieron residuales óptimos, con valores de entre $1-3 \mathrm{~mm}$ y valor máximo de $4 \mathrm{~mm}$.

Seguidamente comenzó el arduo trabajo de limpieza de las nubes de puntos de cada uno de los escaneados (Fig. 6). Se trata del proceso más delicado y minuciosos del proyecto en el que se analiza el conjunto de nubes de manera pormenorizada, eliminando el ruido y elementos registrados ajenos al estudio. Cuanto más cuidado y riguroso sea este proceso, mayor será la calidad de los datos presentados en el resultado final.

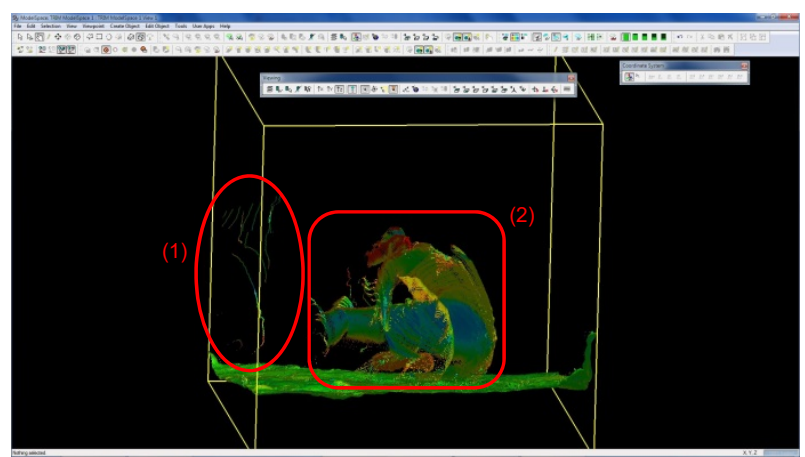

Figura 6: Ejemplo del proceso de limpieza de la nube de puntos.

En la Figura 6 puede observarse un ejemplo muy representativo del proceso de limpieza. En él se puede distinguir el ruido generado por la interrupción del escaneado, como puede ser el paso de alguna persona u objeto por el campo de exploración del escáner (1) y también el registro de elementos que no forman parte del ámbito de estudio, como en este caso es la figura de un colaborador en los trabajos de excavación (2).

Finalmente se digitalizaron los elementos principales de manera que nos permitiera obtener el plano de planta a escala del yacimiento. Con la clasificación de cada uno de estos elementos, se logra tener un mapa cronológico de las estructuras. 
Al mismo tiempo, se elaboraron una serie de los perfiles más representativos que nos permitían tener una visión en alzado.

\subsubsection{Resultados}

La base de los resultados obtenidos tras la gestión de la información escaneada es la nube de puntos procesada (Fig. 7)

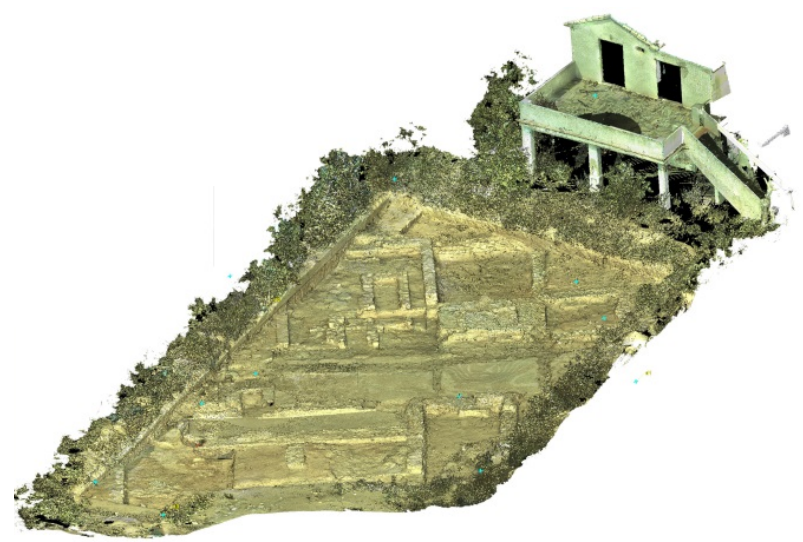

Figura 7: Vista general de la nube de puntos procesada.

La documentación final se divide en varios grupos: planos, ortofotos, fotogramas, visor TruView y videos divulgativos.

Los planos producto de los trabajos de digitalización corresponden a la planta y perfiles longitudinales más representativos. Presentamos a continuación alguno de estos ejemplos (Figs. 8, 9)

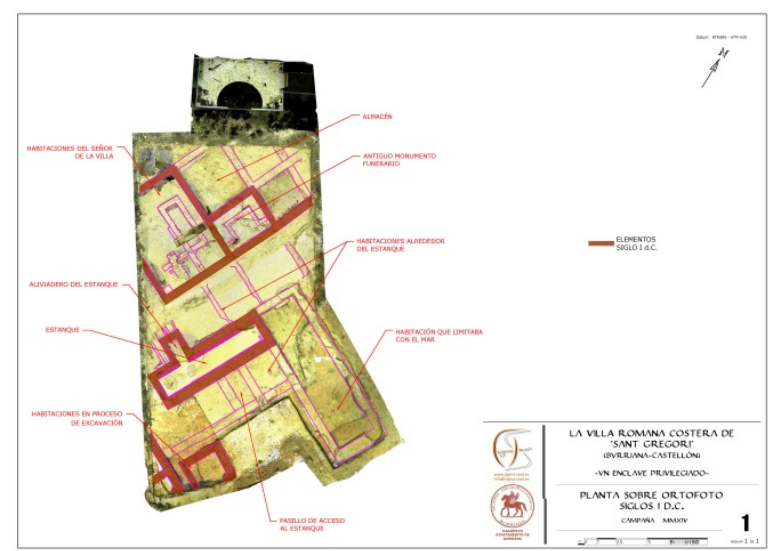

Figura 8: Plano de planta del sector excavado perteneciente al siglo I d.C.

Otro de los productos finales son las ortofotografías. Se trata de fotografías cenitales a escala sobre las que podemos realizar mediciones y observar los elementos en su verdadera magnitude (Fig. 10).

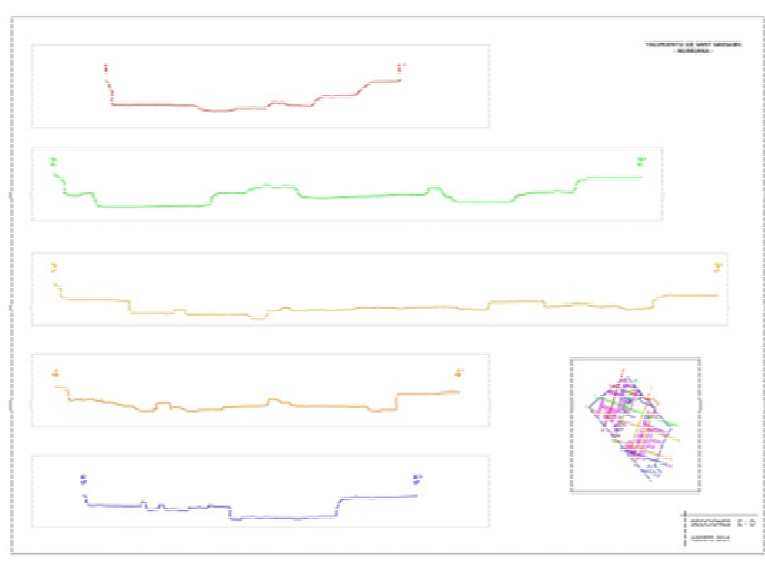

Figura 9: Plano de perfiles.

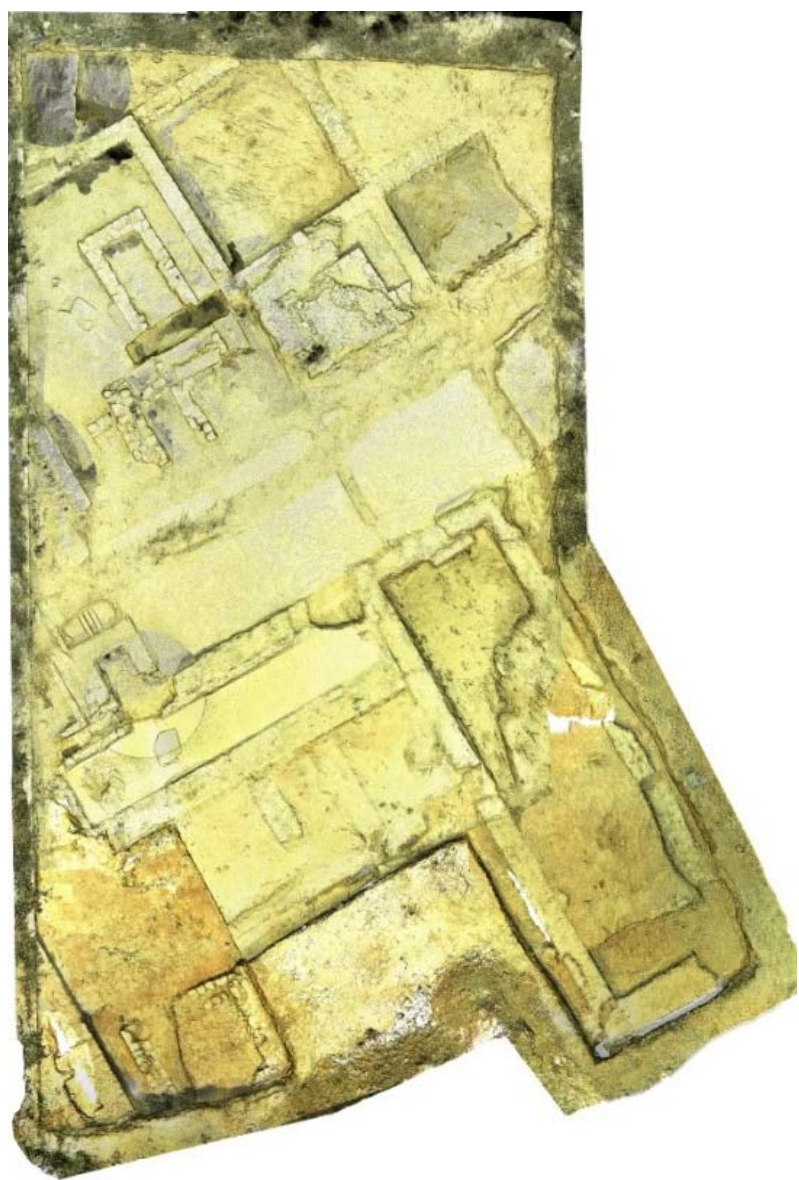

Figura 10: Ortofotografía del yacimiento.

Existe también la posibilidad de obtener ortofotos con las distintas visualizaciones (color verdadero, intensidades, color por estaciones, etc.), lo que nos permite resaltar ciertos aspectos de los objetos escaneados, apreciándose distintos detalles según la configuración elegida. El software utilizado en estos trabajos 'Cyclone' tiene una configuración particular llamada 'Silhouette' que resalta la concentración de puntos contenidos en el plano vertical. Esto es muy útil a la hora de estudiar e identificar elementos como muros y zanjas. Un ejemplo de esta visualización se puede observar en la siguiente Figura 11. 


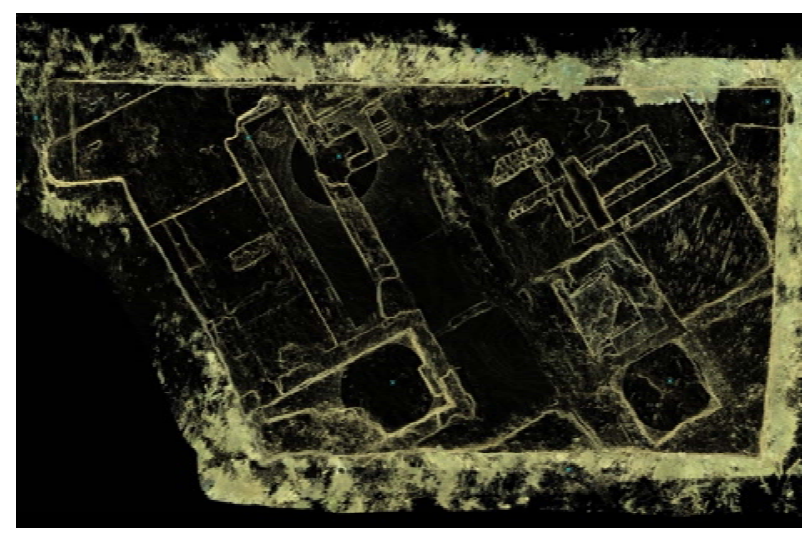

Figura 11: Visualización 'Silhouette'.

También son interesantes los distintos fotogramas extraídos de los detalles del yacimiento observados desde distintas perspectivas, que nos han ayudado a tener una mejor composición espacial del entorno (Figs. 12 y 13$)$.

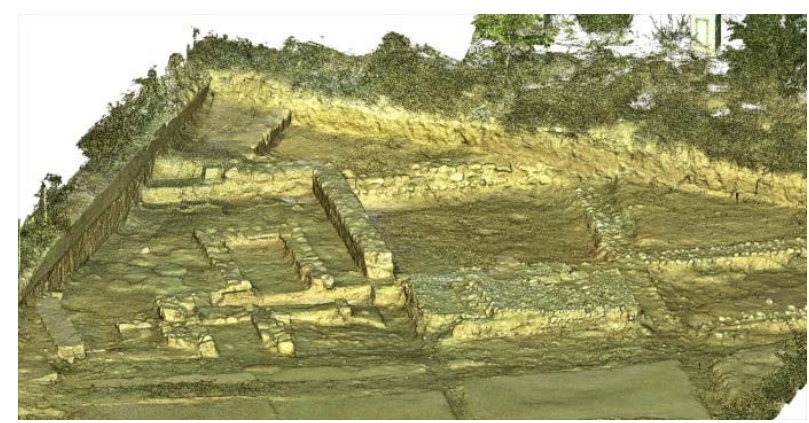

Figura 12: Nube de puntos.

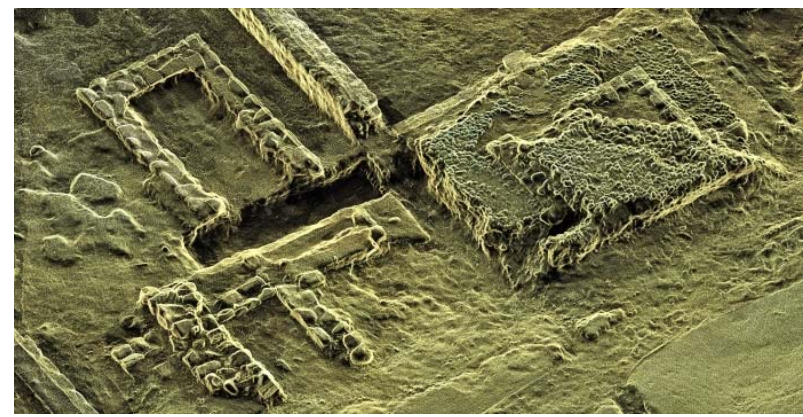

Figura 13: Nube de puntos en visualización 'Silhouette'.

Uno de los productos más interesantes para llevar a cabo el estudio arqueológico es el llamado 'TruView'. Se trata de un visor de los escaneados, el cual nos permite la observación del yacimiento desde el punto de vista del escáner. Al mismo tiempo que se visualizan los detalles, es posible realizar mediciones, anotaciones, extraer imágenes e incluso introducir enlaces a la documentación auxiliar (Figs. 14, 15 y 16).

Por último, en el marco de la documentación divulgativa, se llevó a cabo la edición de un video presentación del escaneado 3D del yacimiento de Sant Gregori en el que se muestran los resultados obtenidos.

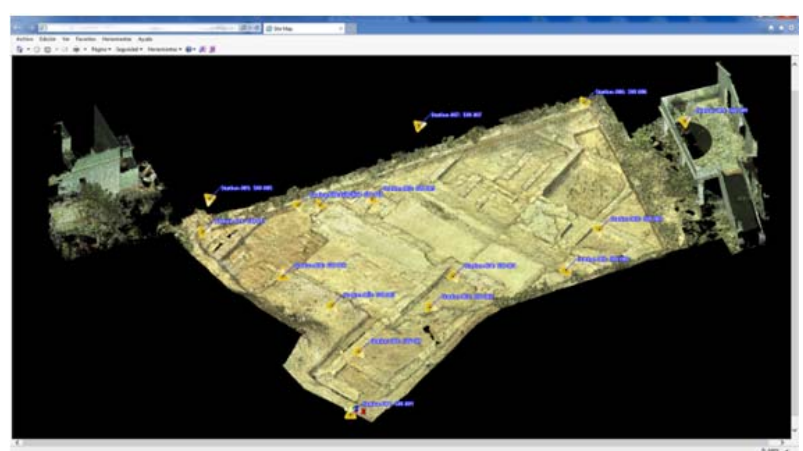

Figura 14: Pantalla de mapa de estaciones TruView.

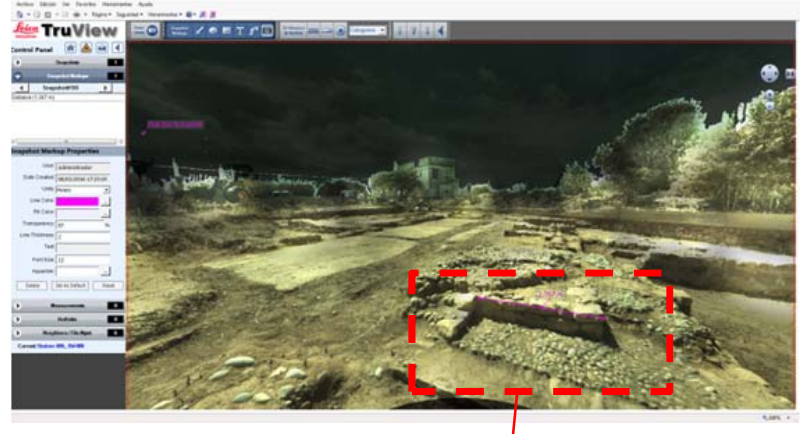

Figura 15: Vista de yacimiento desde estación en TruView.

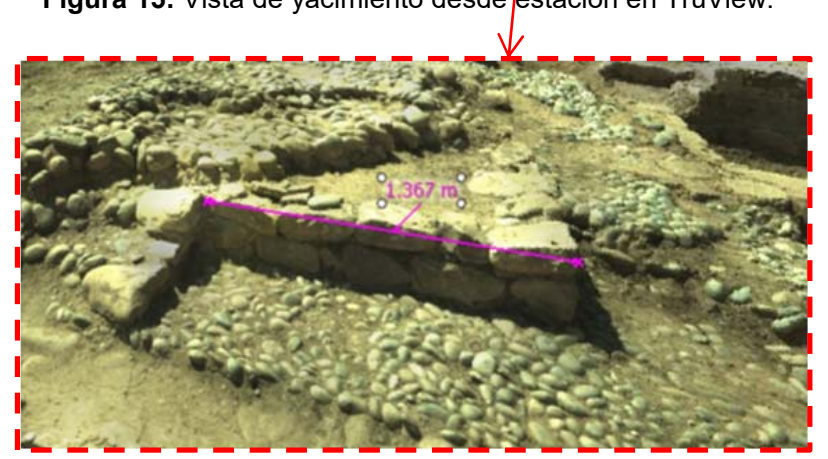

Figura 16: Detalle acotación de muro en TruView.

\section{Futuros trabajos a desarrollar: moldeado y SIG del yacimiento}

A partir de los resultados obtenidos en los trabajos de escaneado 3D, se ha planteado desarrollar nuevos productos.

\subsection{Modelado}

En el ámbito de la documentación divulgativa, se llevará a cabo el modelado virtual de la villa tomando como base la nube de puntos del escaneado. Estos trabajos requerirán la participación de un equipo técnico multidisciplinar. Con el estudio inicial del equipo arqueológico director del proyecto como base del trabajo y la colaboración de técnicos especialistas en gestión de datos de escaneado 3D, modelado virtual, texturización y ambientación, se recreará un escenario fidedigno de cómo eran las instalaciones de la villa romana en su época de esplendor.

Todo esto podrá ser culminado con la elaboración de una maqueta a escala que permita transmitir al público general las conclusiones de los trabajos arqueológicos 
realizados en la villa a lo largo de las distintas campañas de excavación.

\subsection{Modelado Sistema de Información Geográfica}

Debido a su potencial tanto científico como divulgativo, están en auge en los últimos tiempos los llamados Sistemas de Información Geográfica (SIG o GIS en inglés). Esta tecnología permite dotar de información adicional a la representación gráfica de cualquier elemento susceptible de ser grafiado, convirtiéndose así en una herramienta fundamental para el estudio del patrimonio cultural.

Se trata de una potente herramienta analítica que nos permite el estudio, catalogación, reconstrucción y análisis de toda la información recopilada desde cualquier tipo fuente, a la vez que nos posibilita la creación de documentación temática de gran valor divulgativo.

La elaboración de un SIG sobre el yacimiento de Sant Gregori, nos permitirá coordinar toda la información registrada hasta la fecha, ofreciendo la posibilidad de analizarla en todo su contexto, al igual que nos facilitará un mejor estudio sobre futuros trabajos arqueológicos.

\section{Tratamiento arqueológico de los resultados}

\subsection{Análisis cronológico del yacimiento}

Este artículo nos ha permitido poner sobre la mesa gran parte de las posibilidades que nos ofrece la documentación $3 \mathrm{D}$ que se ha realizado durante estas primeras cinco campañas de excavación en la villa romana de Sant Gregori (Burriana, España). A partir de este proyecto se nos abre también la posibilidad de aumentar la capacidad de investigación del yacimiento, contrastando los diferentes estados de conservación de los restos constructivos que se han registrado en la parte excavada y proyectar con ello la posterior restauración de los mismos (Fig. 17).

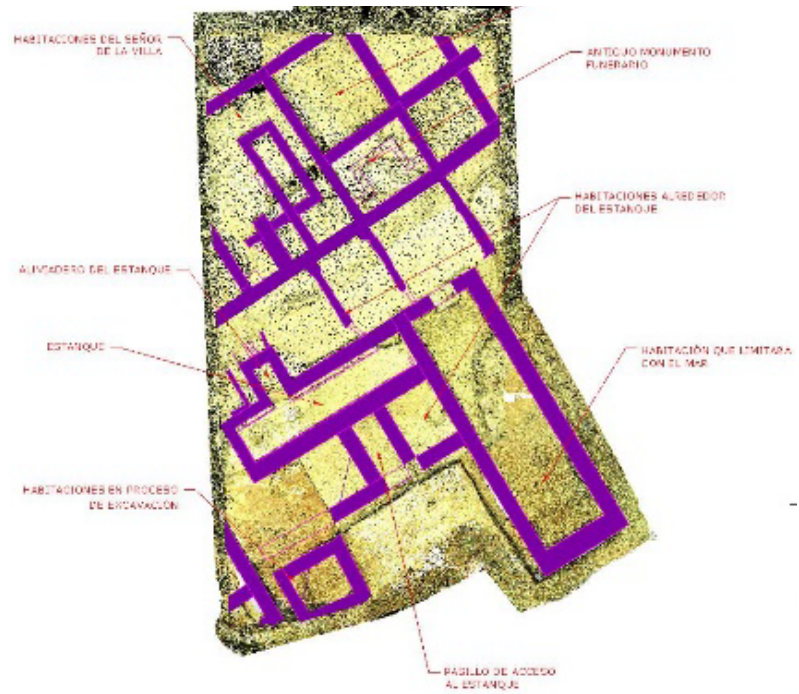

Figura 17: Plano del sector excavado perteneciente al siglo II.

La versatilidad de la herramienta 3D también nos ha permitido obtener planimetrías sincrónicas, por lo que refiere a usos y ambientes relacionados con las estructuras, y diacrónicas, que por otro lado reflejan las distintas etapas cronológicas que se sucedieron en el yacimiento.

\section{Referencias}

FERRER, J.J., MELCHOR, J.M. y BENEDITO, J., 2013. Sant Gregori. Un complejo arquitectónico de época romana en la costa de Burriana (España). Millars, XXXVI, pp.199-223. http://dx.doi.org/10.6035/Millars

FERRER, J.J., MELCHOR, J.M. y BENEDITO, J., 2014. El complejo arquitectónico de Sant Gregori en la costa de Burriana. Actas XVIII Congreso Internacional de Arqueología Clásica, J. M. ÁLVAREZ, T. NOGALES, I. RODÀ (eds.): Centre and periphery in the ancient world. Mérida, pp. 1143-1145.

MELCHOR, J.M., 2013. Diez años del Servicios Arqueológico Municipal de Burriana. Burriana.

MELCHOR, J.M. y BENEDITO, J., 2000. Campaña de excavaciones arqueológicas en los yacimientos de El Palau (Burriana, Castellón). Cuadernos de Prehistoria y Arqueología Castellonenses, 21. pp. 303-319.

MELCHOR, J.M. FERRER, J.J. y BENEDITO, J., 2014. Les excavacions arqueològiques en la vil·la romana de Sant Gregori: una porta oberta al coneixement de la badia de Borriana (Castelló) entre els segles I al IV. Quaderns dels Museus Municipals de València, 3, actuacions sobre el patrimoni arqueològic de la Comunitat Valenciana, actes de les I Jornades d'Arqueologia de la Comunitat Valenciana, pp. 101-112.

VERDEGAL, V., MESADO, N. y ARASA, F., 1990. Sant Gregori. Borriana, la Plana Baixa. Memòries Arqueològiques de la Comunitat Valenciana 1984-1988. Intervencions rurals. Generalitat Valenciana, pp. 115-117. 


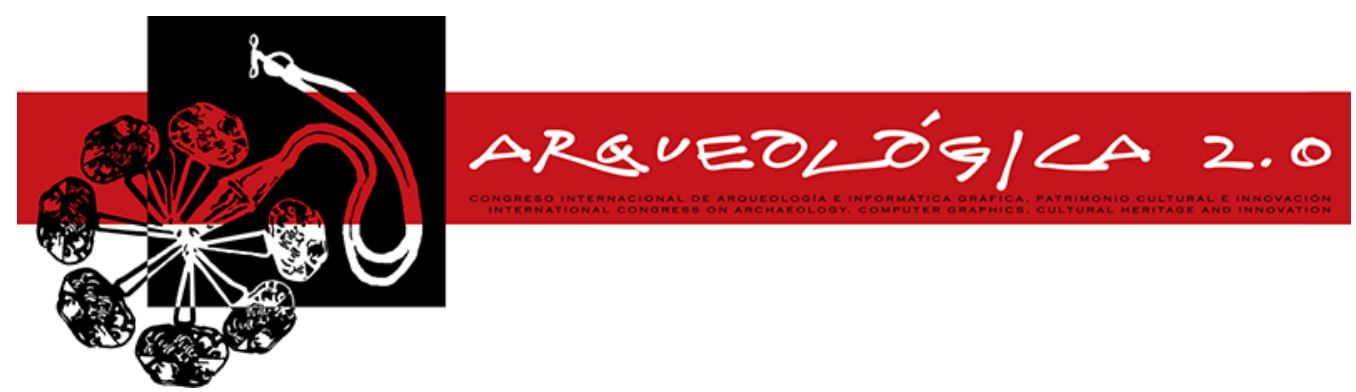

Proceedings of the $8^{\text {th }}$ International Congress

on Archaeology,

Computer Graphics,

Cultural Heritage and Innovation

'AROUEOLÓGICA 2.0'

in Valencia (Spain),

Sept. $5-7,2016$

DOI: http://dx.doi.org/10.4995/arqueologica8.2016.3002

Received: 04/03/2016

Accepted: 05/04/2016

\title{
3D DIGITAL TECHNOLOGIES TO RECORD EXCAVATION DATA: THE CASE OF THE CATACOMBS OF ST. LUCY (SIRACUSA, SICILY)
}

\section{TECNOLOGÍA DIGITAL 3-D PARA REGISTRAR DATOS DE EXCAVACIÓN: EL CASO DE LAS CATACUMBAS DE SANTA LUCÍA (SIRACUSA, ITALIA)}

\author{
Ilenia Gradante ${ }^{a}$, Mariarita Sgarlata ${ }^{a}$, Davide Tanasi ${ }^{\mathrm{b},{ }^{,}}$ \\ ${ }^{a}$ Römisches Institut der Görres-Gesellschaft, Campo Santo Teutonico, 00120 Città del Vaticano. ileniag@hotmail.com \\ b Università di Catania, Dipartimento di Scienze Umanistiche, Piazza Dante 32, 95124 Catania, Italia. m.sgarlata@unict.it \\ c University of South Florida, Center for Virtualization and Applied Spatial Technologies (CVAST) \& Department of History, 4202 E \\ Fowler Ave, Tampa, FL 33620, USA. dtanasi@usf.edu
}

\begin{abstract}
:
Between 2013 and 2015, Arcadia University in partnership with the Pontifical Commission for Sacred Archaeology and the University of Catania undertook new excavation campaigns in the Catacombs of St. Lucy at Siracusa. The research focuses on some very problematic parts of Region C of the complex, including Oratory C, the so-called Pagan Shrine and Crypt VI. These areas document most effectively the long life of this Christian hypogeum, which incorporated previous structures and artefacts related to the Greek period and continued to be used until the Middle Ages. During the excavation an array of 3D digital techniques (3D scanning, 3d Modelling, Image-based 3D modelling) was used for the daily recording of the archaeological units, but also to create high-resolution virtual replicas of certain districts of the catacombs. Furthermore, the same techniques were applied to support the study of certain classes of materials, such as frescoes and marble architectural elements that could otherwise only be studied in the dark environment of the catacombs, making the visual analysis of such complex artifacts difficult and sometimes misleading, not to mention that the frequent use of strong sources of light for study can also endanger them. The virtual archaeology research undertaken at the Catacombs of St. Lucy represents the first systematic application of 3D digital technologies to the study of such a special archaeological context in Sicily.
\end{abstract}

Key words: Christian catacombs, Sicily, virtual archaeology, 3D scanning, 3D modelling, Image-based 3D modelling, Open source

\section{Resumen:}

Entre los años 2013 hasta 2015, La Universidad de Arcadia conjunto con la Comisión Pontifical para Arqueología Sagrada y la Universidad de Catania se comprometieron a hacer nuevas excavaciones en las catacumbas de Santa Lucia en Siracusa. La investigación se enfoca en unas de las partes mas problemáticas de la región C del complejo, como la oratoria C, los dos así llamados santuarios paganos y la cripta VI. Estas áreas documentan la larga historia del hipogeo cristiano mejor que otras lo cual incorporó previas estructuras y artefactos relacionados con el periodo griego y siguió ser usado hasta el Medioevo. Durante la excavación, un despliegue de técnicos digitales en 3D (el escaneo 3D, el modelado en 3D hecho a mano, el modelado 3D basado en la imagen) fueron usados para la registro diario de las unidades arquitectónicas, pero también para crear replicas virtuales de alta resolución de ciertas regiones de las catacumbas. Además, las mismas técnicas fueron aplicadas para apoyar el estudio de ciertas clases de materiales, como frescos y elementos arquitectónicos de mármol, los cuales sólo se puede estudiar en la oscuridad de las catacumbas que lo hace difícil y a veces engaña el análisis visual de esos objetos tan complejos, por no hablar del uso frecuente de fuentes fuertes de luz para investigar los objetos que también puede ponerlos en peligro. La investigación arqueológica virtual que aconteció en las catacumbas de Santa Lucia representa la primera aplicación sistémica de tecnologías digitales en 3D para la investigación de un contexto arqueológico tan peculiar en Sicilia.

Palabras clave: catacumbas cristianas, Sicilia, arqueología virtual, escaneo 3D, modelado 3D, modelado 3D basado en imagen, código abierto

*Corresponding Author: Davide Tanasi, dtanasi@usf.edu 


\section{Introduction}

The growing popularity of virtual archaeology has substantially changed the perspective of archaeologists towards the object of their study, conditioning their field strategies and directing their research perspectives (Stanco and Tanasi 2011; Hugget 2013; Economou 2015). The application of certain 3D imaging solutions turned out to be extremely helpful for the analysis of peculiar archaeological contexts, such as the Christian catacombs, characterized by a multi-faceted architectural history and by dark restricted environments (Zimmermann 2008).

In the framework of the excavation project undertaken by the Pontifical Commission of Sacred Archaeology, Arcadia University and the University of Catania at the Catacombs of St. Lucy at Siracusa (Fig. 1), one of the most important Late Roman cultural complexes of Sicily (Sgarlata and Salvo 2006; Sgarlata 2007), an array of different 3D Digital Imaging techniques were used to record excavation data. The scientific exercises were carried out by American undergraduate students previously trained in the use of open-source software for data-processing and low-cost 3D scanning devices such as Microsoft Kinect and Occipital Structure. In some cases, triangulation 3D scanning and image-based 3D modelling were also used. The combination of archaeological excavation with the phase of digital recording represents a very important educative experiment in the field of digital archaeology. With regards to the areas of intervention, as well as the areas of Oratory C and Crypt $\mathrm{VI}$, a successful research exercise was carried out in the 'Pagan Shrine'.

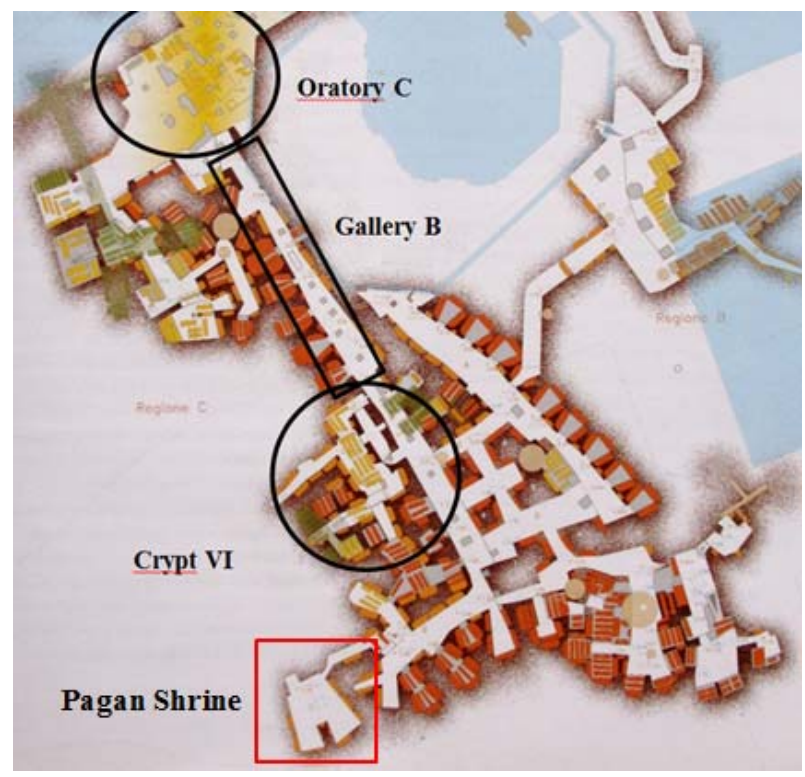

Figure 1: Plan of Region C of the Catacombs of St. Lucy, indicating the areas where 3D digital technologies for data recording were applied.

The enormous amount of digital data acquired in the different tasks was processed using the workstations of the Arcadia Virtual Archaeology Laboratory at Siracusa and the open-source software Meshlab (Cignoni et al. 2008) for the mesh processing, and Blender (Delli Ponti et al. 2011) for the 3D modelling integration.

\section{Oratory C}

Region $\mathrm{C}$ of the catacombs, certainly dated to postConstantinian times (4th century $A D$ ) and used for funerary purposes until the end of the 5th century AD, offers significant evidence for the Medieval phase of use. After the cemetery falls into disuse for burial, the catacombs undergo a series of architectural and monumental transformations that turn it into a true place of martyrial worship: in particular, the so-called "Oratory C" (Fig. 2). The walls are entirely covered with frescoes which in places overlap to form four layers on top of each other (called palimpsests), ranging in chronology from Byzantine times to the Norman period. The frescocycle consists of panels painted with figures of saints, two of which are clearly distinguished by the presence of captions in Latin. The most significant palimpsest is on the eastern wall of Room I, traditionally known as the "Fresco of the Little Commissioner", due to the figure of an old man with outstretched hands as if in prayer to the great saints to his right, on the left corner of the panel (Fig. 3). The characteristics of the oratory and in particular of the Fresco of the Little Commissioner are the writing and graphic testimonials left by pilgrims who visited the hypogeum, attracted to the venerated resting place of the body of St. Lucy nearby up until the 11th century.

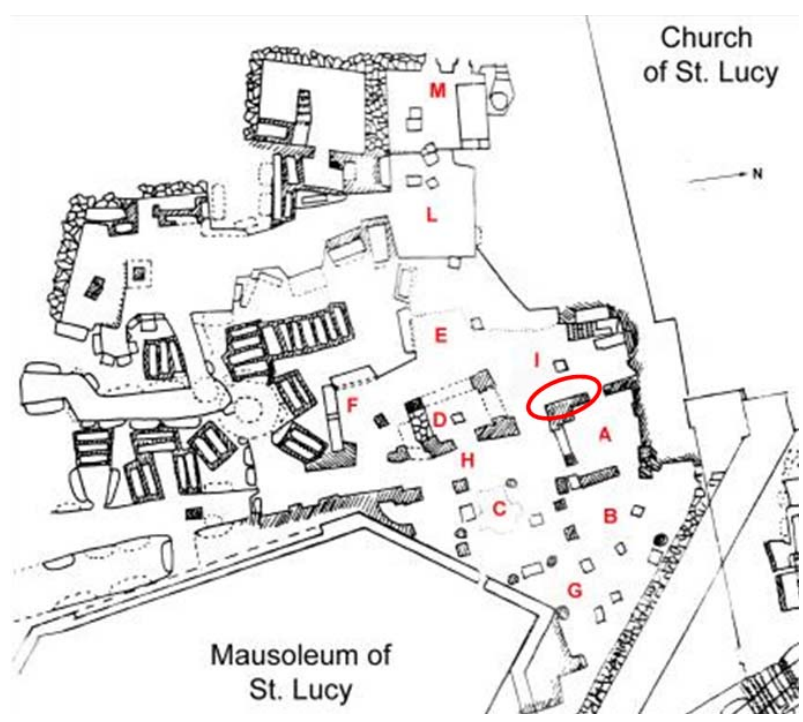

Figure 2: Plan of Oratory $C$ with indication of the location of the Fresco of the Little Commissioner.
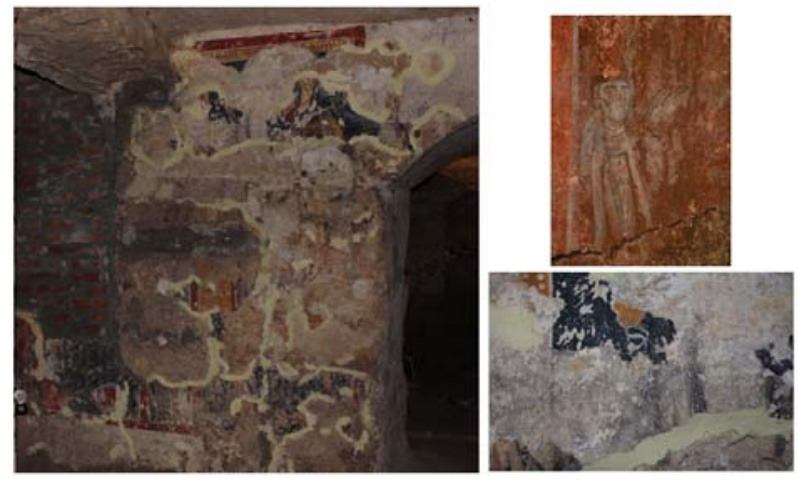

Figure 3: Eastern wall of Room I (Oratory C, Region C): Fresco of the Little Commissioner. 


\subsection{The 3D laser scanning of the Fresco of the Little Commissioner}

Considering the total lack of monitoring for the natural decay of the fresco and the extreme environmental conditions of the catacombs, it was decided to produce a virtual replica of the fresco using 3D laser scanning. The virtual model would provide a unalterable 3D image of the artefact, and properly manipulated, would improve the readability of the writings.

The 3D laser scanning (Fig. 4) was carried out with a NextEngine triangulation 3D scanner in macro setting. Due to the high level of details of the artefact - different strata of paint and multiple layers of graffiti -, it was decided to rely on macro scans, acquiring sections of the surface of $5.1 \times 3.8 \mathrm{~cm}$ at a time, for a total of 75 scans organized on vertical strips. Coded targets were applied on the fresco in order to create a reference grid to facilitate the alignment of the scanned portions.
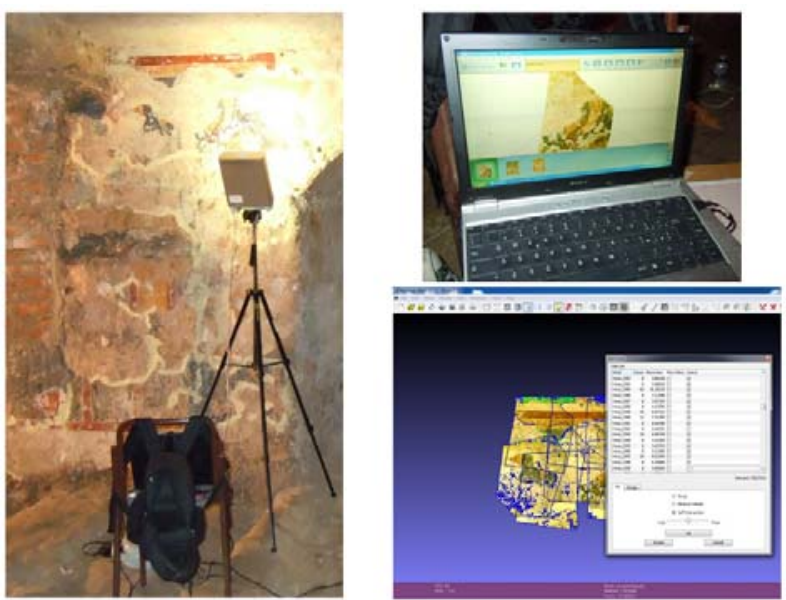

Figure 4: Acquisition via triangulation laser scanner of the fresco and initial data processing.

During data processing, the open-source software Meshlab was used for alignment and for filling gaps and removing noise and the coded targets. The 3D model resulting from the alignment of three main portions, showed circa $46 \mathrm{M}$ vertices and $95 \mathrm{M}$ faces, and the portions of it bearing graffiti turned out to be significantly more readable than they were on the digital pictures (Figs. 5, 6).

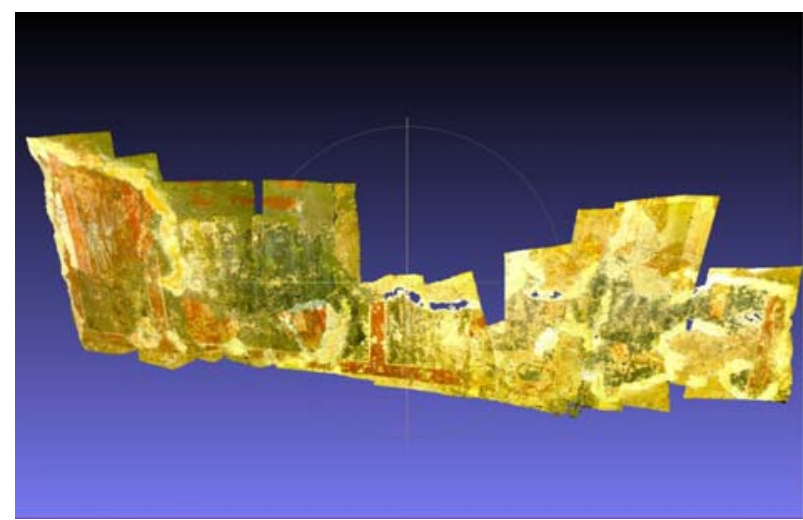

Figura 5: High quality 3D model of the lower part of the fresco.

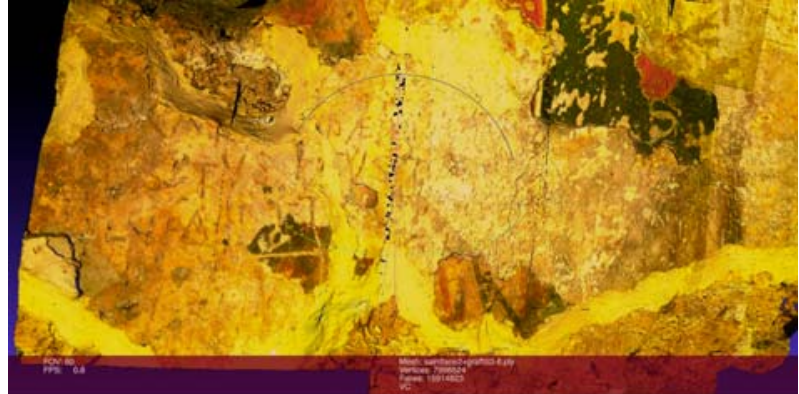

Figura 6: High quality 3D model of the lower part of the fresco, details of the graffiti.

\subsection{The 3D digital documentation of the trench in Room A}

The restricted space provided by Room A represented the best environment in which to use 3D scanning to document the progress in the excavation of the formae opened on the floor. In particular, in the case of tombs $2043,2044,2045$, showing a complex stratigraphy characterized by later phases of reuse, this method turned out to be particularly useful.

In order to not slow down the excavation work, the 3D scans were carried out using an infrared light structured portable scanner (Occipital Structure), providing high detail models in a short time (Fig. 7). Simultaneously the scanner was used to produce the 3D model of the four internal walls of Room $A$, characterized by several different types of masonry and old restoration interventions.

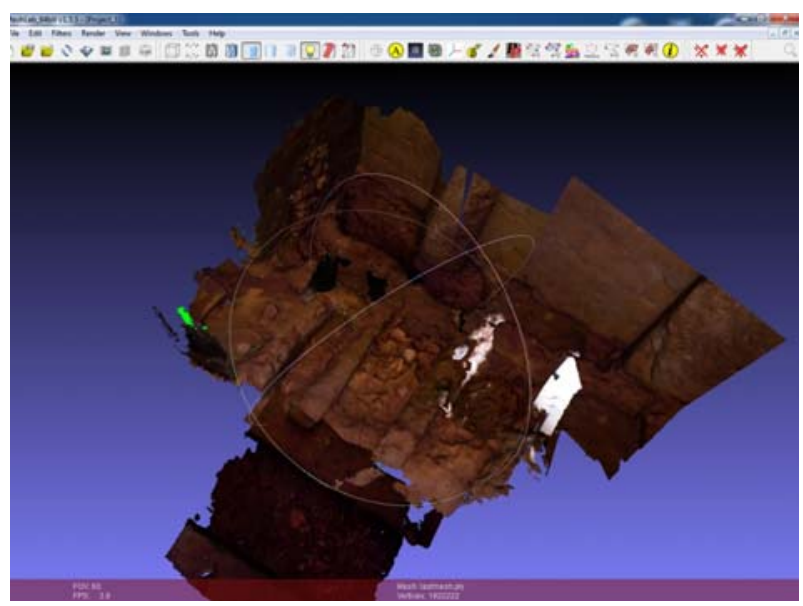

Figure 7: 3D model of Room A of Oratory $C$ acquired after the exploration of tombs 2045, 2046 and 2047.

\subsection{The 3D digital documentation of tomb 2174 in Room F}

The excavation of tomb 2174 , in the north-eastern corner of Room $\mathrm{F}$, required particular care in the data recording. The presence of multiple burials and the possibility that the tomb had been ransacked but still held several findings, especially bronze coins, suggested that we employ the NextEngine triangulation 3D laser scanner in macro setting (Fig. 8). Five scans for each of the four stratigraphic units identified were carried out for a total of twenty scans organized in vertical strips. During data processing the open-source software Meshlab was used for the alignment and for the filling of 
gaps and removing noise. The four 3D models resulting from the alignment of the sets of five parts, showed approximately $7 \mathrm{M}$ vertices.

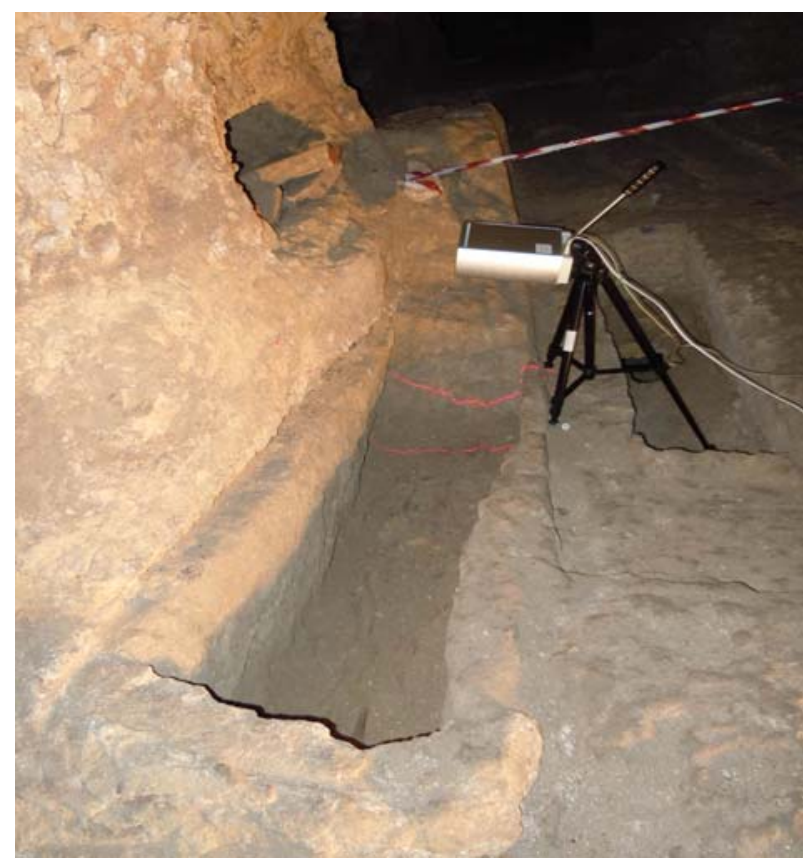

Figure 8: Acquisition via triangulation laser scanner of skeletal remains of tomb 2174

\subsection{The 3D digital documentation of the architectural disiecta membra from old excavations}

Due to a decision taken by the Pontifical Commission for Sacred Archaeology, which supervises every scientific enterprise undertaken in the catacombs of St. Lucy, a number of architectural elements that were discovered during the excavation of the 50 s in nearly every room of the oratory $\mathrm{C}$, were not moved to the storeroom but left near their places of discovery. Preliminarily discussed in the scientific literature, they were never properly catalogued and documented. Twenty-two pieces (SL01SL22), mostly related to the later phase of use of the oratory, including portions of parapets, columns, capitals, inscriptions and stone vessels, were collected and studied and their find-spots recorded (Fig. 9).

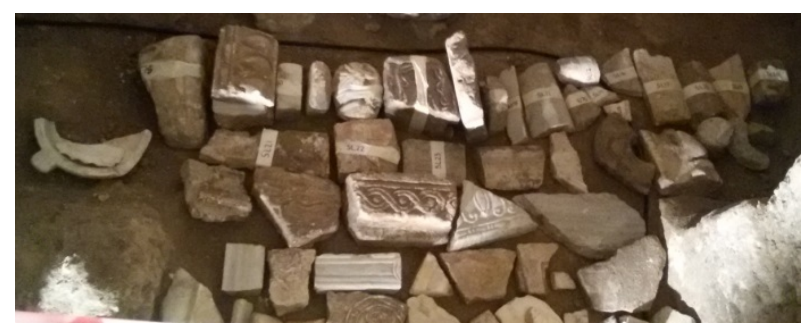

Figure 9: Architectural elements from old excavations at Oratory C.

The tight working schedule led us to carry out the 3D documentation of the pieces via Image Based 3D Modelling (Olson and Placchetti 2015) in order to speed up the digitization process. The artefacts were set on a wooden turntable and photographed with a Nikon D3300 with 24.2 MP, producing a data-set of 40-70 pictures for every object (Fig. 10). Subsequently, the processing occurred via Agisoft Photoscan on the workstation of the Arcadia Virtual Archaeology Lab (Fig. 11). The semiautomatic reconstruction process took intermittently three weeks due to the high number of visual sources (slightly less than 1.500 high quality pictures). The final results represented by the high quality $3 D$ models of the disiecta membra surpass every other alternative documentation method (Fig. 12).

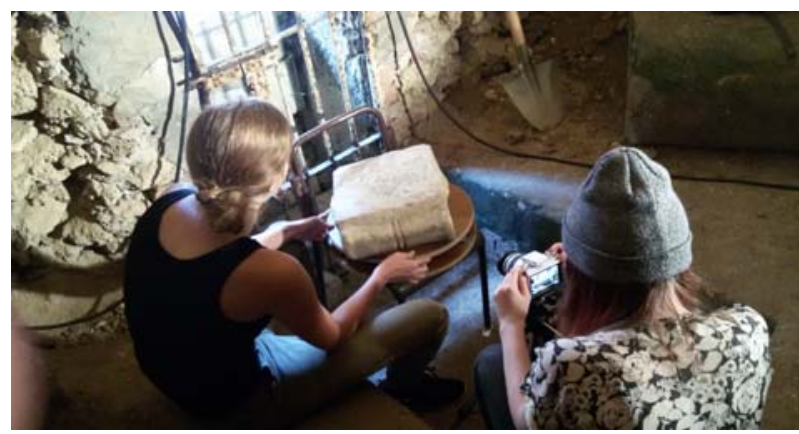

Figure 10: Arcadia University students acquiring the data set of pictures.

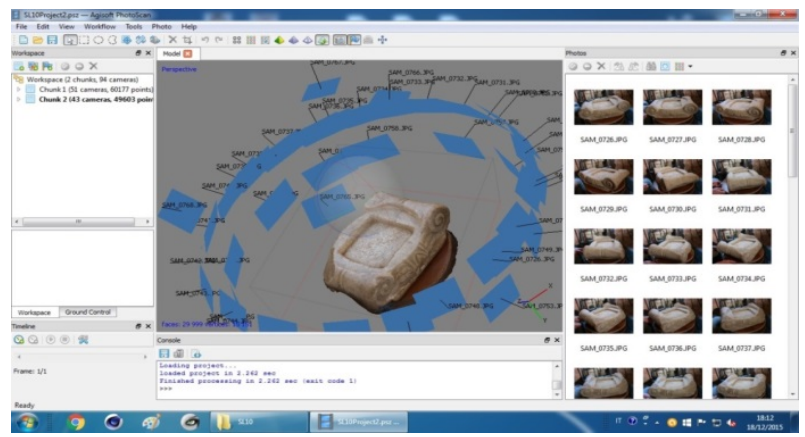

Figure 11: Processing of the 3D model of piece SL10 via Image Based 3D Modeling technique with a data set of 90 pictures.
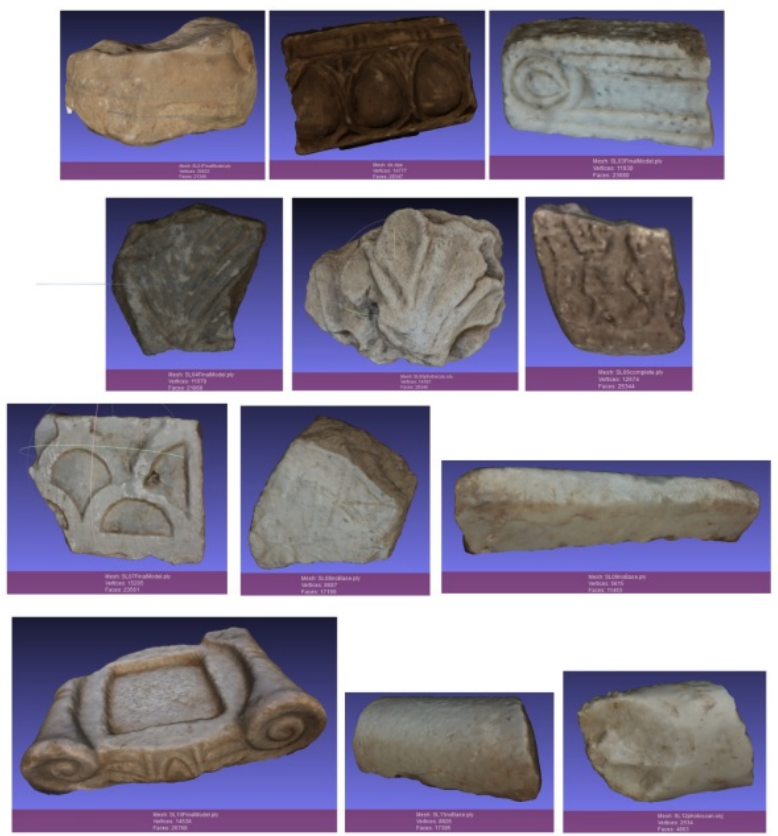

Figure 12: 3D models of architectural elements SL01-SL12 from old excavations at Oratory C, Region C. 


\subsection{The 3D digital documentation of the trench of tombs 2006-2009 in Room L}

The complex stratigraphic deposit represented by the three tombs 2006-2009, set in the south-eastern side of Room L, was a perfect case-study for the application of $3 \mathrm{D}$ digital imaging to record excavation data. In fact, the series of architectural transformations that the three tombs underwent during several phases of reuse was particular. It was also important to document as best as possible the relationship between the three tombs and the others nearby. The data was acquired using an infrared light structured portable scanner (Occipital Structure) to create an untextured high quality $3 \mathrm{D}$ model to represent in detail stratigraphic relations (Figs. 13, 14).

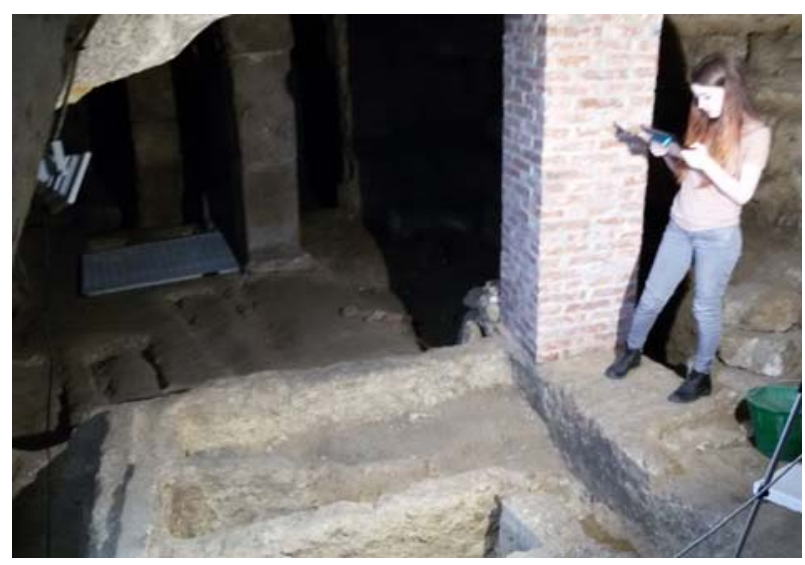

Figure 13: Room E, Oratory C: data set acquisition via a portable infrared light structured 3D scanner (Occipital Structure) of the area of tombs 2006-2009.

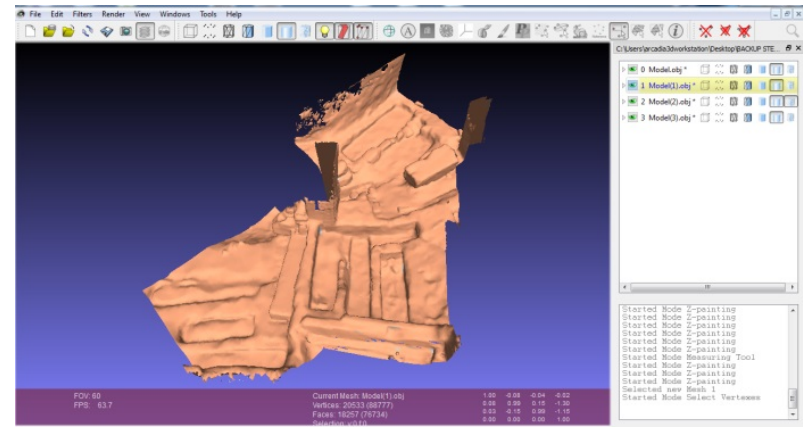

Figure 14: Room E, Oratory C: 3D models of the tombs 20062009 and of the nearby clusters of burials.

\section{Pagan Shrine}

The so called 'Pagan Shrine' in the south-western corner of Regio $C$ is certainly the most important structure predating the foundation of the communal cemetery. With its complex of frescoes with mundane themes and pagan deities, dated between the 1st century $B C$ and $1 \mathrm{st}$ century $A D$, this hypogeal Pagan Shrine, later encompassed in the catacombs without any damage caused to the paintings, still has a central place in the academic dispute.

Located in the less accessible and rather dangerous part of the Region $\mathrm{C}$, it has always been closed to the public and accessible just to a few scholars in the past decades. Seeing as all the necessary equipment was being deployed in Region $C$ for the digital recording of excavation data, it was decided to attempt the acquisition of the complex in order to produce a virtual replica of the Pagan Shrine for the first time.

Due to dimensions of the chamber, the technique of Image Based 3D Modelling was applied, using coded targets set on the walls in order to create a reference system for the alignment phase. A data-set of 310 pictures was produced using a Nikon D3300 with 24.2 $\mathrm{MP}$, covering every spot of the surfaces of the chamber (Fig. 15).

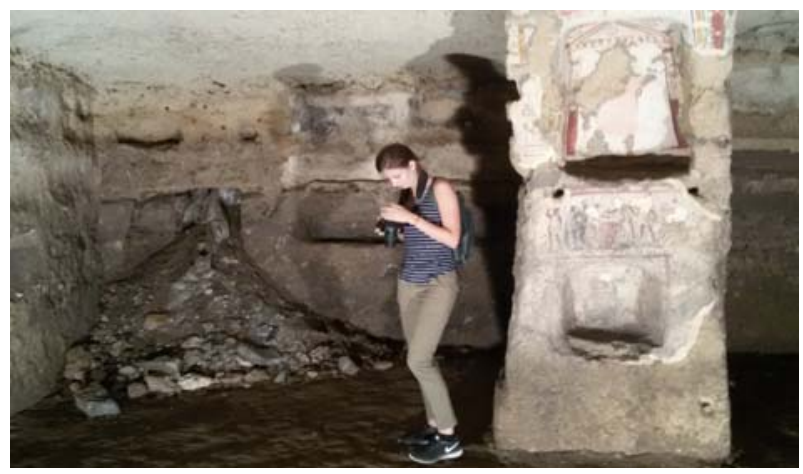

Figure 15: Data set acquisition at the Pagan Shrine.

Subsequently, the processing occurred via Agisoft Photoscan on the workstation of the Arcadia Virtual Archaeology Lab (Fig. 16). The semi-automatic reconstruction process took 27 hours and produced a flawless high quality 3D model of the Pagan Shrine. The model was later exported in the Game Engine of Blender in order to create an interface for the interactive model (Oikarinen 2016) (Fig. 17). In this way, it is now possible for everyone to explore the Pagan Shrine virtually.

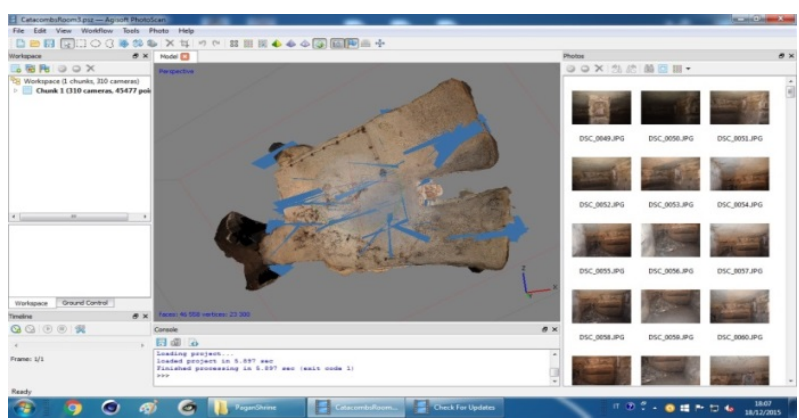

Figure 16: Data processing of the 3D model of the Pagan Shrine via Image Based 3D Modeling technique with a data set of 310 pictures.

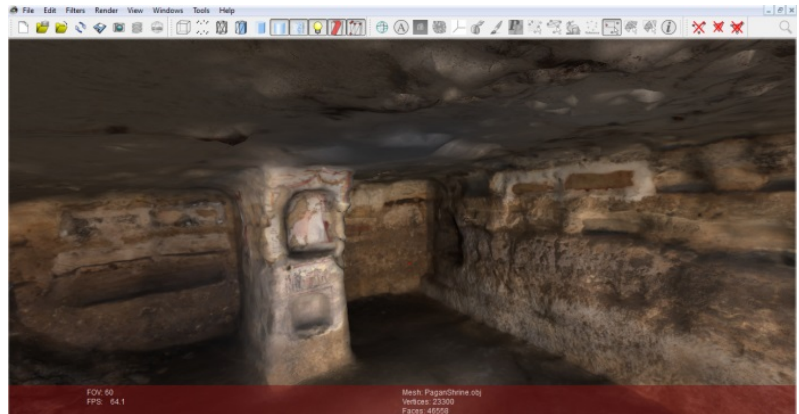

Figure 17: High quality interactive 3D model of the Pagan Shrine. 


\section{Crypt VI}

The hardest but also the most rewarding task regarding the application of 3D digital imaging of the entire excavation campaign was the 3D scanning of the entirety of Crypt VI, a complex about which the available graphic documentation is outdated and incomplete (Fig. 18). The operation was meticulously prepared, taking into consideration the complex plan of the crypt, with three main corridors (B1, B2, B3) and two lower levels (east and west) partly flooded with water coming from an underground spring. The data acquisition project included 16 points of scanning to cover every part of the crypt and a number of markers in strategic spots to be used to link the digital portions.

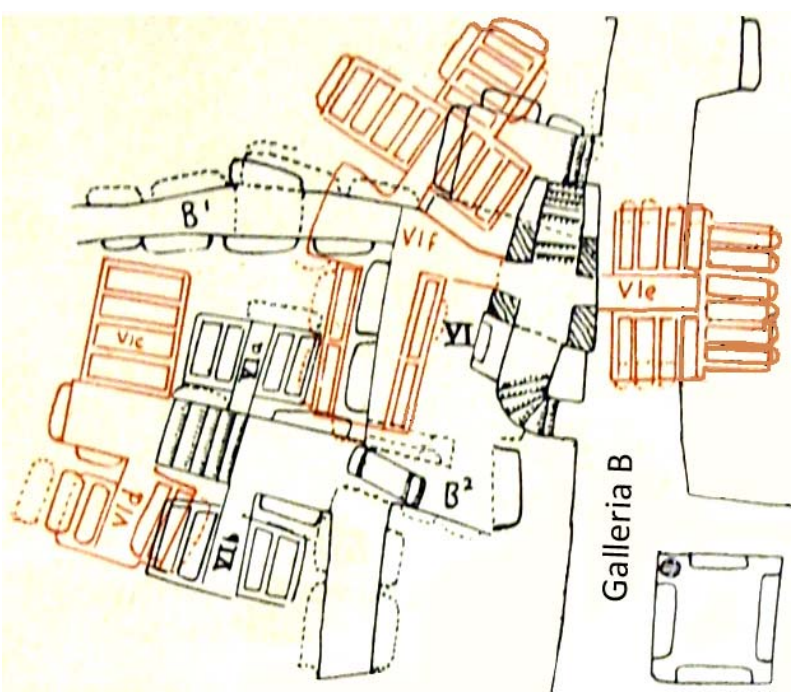

Figure 18: Plan of the Crypy VI.

Considering the unstable power system, the presence of water, the poor light conditions and the very real chance for the digital equipment to be damaged, it was decided to use a low-cost infrared light structured portable 3D scanner (Microsoft Kinect) connected with one of the workstations of the Arcadia Virtual Archaeology Laboratory. Well aware of the limits that the Kinect has as a 3D scanner, especially in consideration of the structural complexity of Crypt $\mathrm{VI}$, it was decided nonetheless to attempt the scan of it. In fact, the educative importance of the task, in this case, would have been higher than the accuracy of the outcome.

The 3D scanning that took place alternated with the excavation works throughout the 4 weeks of excavations. 127 coded targets were applied on the wall of Crypt VI in order to facilitate the subsequent alignment of all the portions.

The huge mass of data acquired in the field took a long time to be processed but ultimately a point cloud 3D model, counting 8.9991.369 faces and resulting from the combination of the 16 scans, was obtained (Fig. 19).

As the 3D model includes both floors and ceilings, it needs to be elaborated in order to get section views and plans and this part of the processing work is still ongoing. The complexity of the $3 \mathrm{D}$ model is such that any further elaboration has to be carried out on the untextured model (Fig. 20). The scans included Corridor B1, never documented before, and the western flooded area, in which it was possible to capture the floor surface for the first time thanks to a particular low level of water (Fig. 21). Unfortunately it was not possible to acquire the two chambers of the eastern flooded area, containing the sarcophagi and accessible through a staircase from a monumental landing, as the level of the water was consistently at $0,50-0,60 \mathrm{~cm}$ of height and covering them. However the structure and complex plan of the landing itself was documented in detail and it is currently under processing. With all its limits, coming from the use of the Microsoft Kinect as scanner, the outcome represents the best documentation of Crypt VI available so far and its 3D model can be certainly used to plan the overall 3D scanning of the complex with a time-of-flight $3 d$ scanner which has been already scheduled.

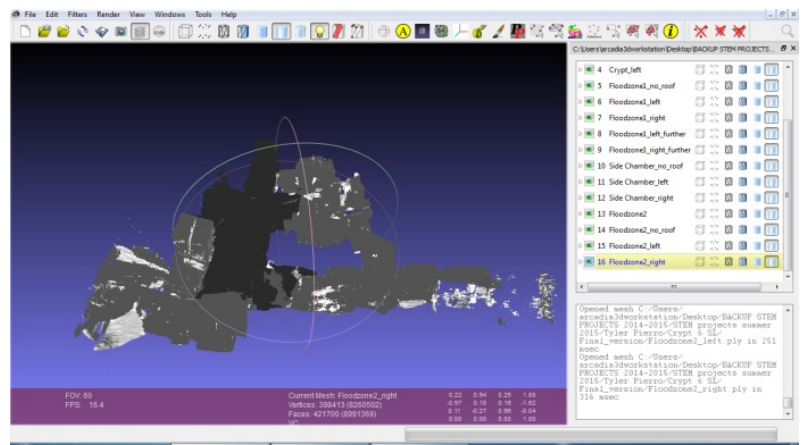

Figure 19: General point cloud 3D model of the entire complex of Crypt $\mathrm{VI}$ (upper and lower levels) obtained by the combination of 16 scans (8.991.369 faces).

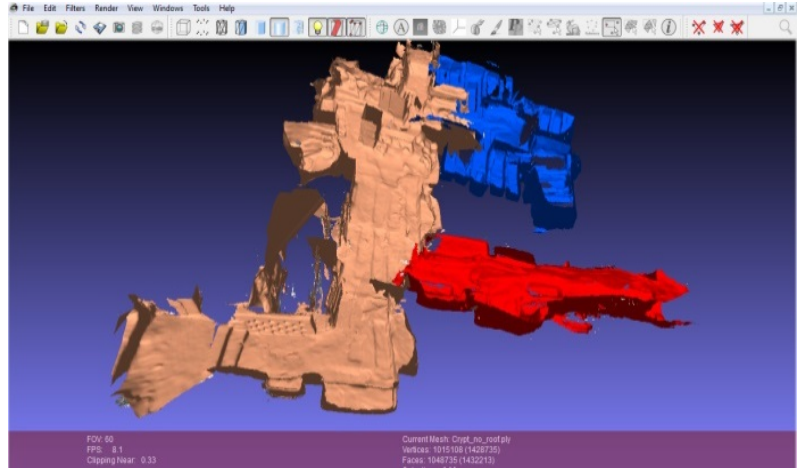

Figure 20: Untextured section view of the 3D model of Crypt $\mathrm{VI}$ (in pink corridor B2, in blue corridor B3 and related lower level, in red corridor B1).

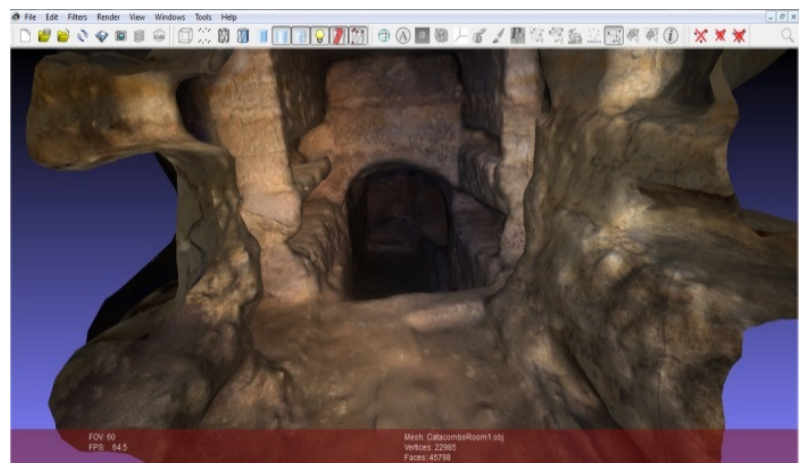

Figure 21: Textured 3D model of the corridor $\mathrm{B} 3$ and the staircase to the west lower level. 


\section{Final remarks}

This contribution has set out the results of the application of an ensemble of 3D digital imaging techniques to record the excavation data of 2013-2015 explorations in the catacombs of St. Lucy at Siracusa. Although the applications of such techniques is quite customary, in this specific case study the production of 3D models of areas of the complex usually not accessible to public has contributed to its popularization (Ferdani and Bianchi 2016).
The 3D data will certainly be helpful for the postexcavation studies, considering that the catacombs are hardly accessible outside of the fieldwork periods. But the most important result achieved is represented by the full involvement of undergraduate students in a firsthand experience in digital archaeology. Students have, in fact, learned new, innovative and affordable methods to record and process excavation data. This alternative approach to the subject of their study - the catacombs combined with the immersive experience that the excavation itself grants has provided important learning outcomes (Healey and Jenkins 2009).

\section{References}

CIGNONI, P. CALLIERI, M., CORSINI, M., DELLEPIANE, M., GANOVELLI, F. and RANZUGLIA, G., 2008. MeshLab: an Open-Source Mesh Processing Tool, in V. SCARANO, R. DE CHIARA, U. ERRA, eds, Proceedings of Eurographics Italian Chapter Conference, pp. 1-8.

DELLI PONTI, F., GUIDAZZOLI, A., LIGUORI, M.C. and IMBODEN, S., 2011. A Blender Open Pipeline for a 3D Animated Historical Short Film, in Proceedings of the 12th International Symposium on Virtual Reality, Archaeology and Cultural Heritage, VAST 2011, pp. 81-90.

ECONOMOU, M., 2015. Heritage in the Digital Age. In: W. LOGAN, M. N. CRAITH AND U. KOCKEL, eds, A Companion to Heritage Studies. New York: John Wiley \& Sons 2015, pp. 215-228.

FERDANI, D. and BIANCHI, G., 2016. Recording, preserving and interpreting a Medieval Archaeological Site by Integrating Different 3D tehcnologies. In In S. CAMPANA, R: SCOPIGNO, G. CARPENTIERO, M. CIRILLO, eds, CAA 2015. Proceedings of the 43rd Annual Conference on Computer Applications and Quantitive Methods in Archaeology, Oxford: Archaeopress, pp. 213-225.

HEALEY, M. and JENKINS, A., 2009. Developing undergraduate research and inquiry. The Higher Education Academy 2009, pp. 1-151.

HUGGET, J., 2013. Disciplinary Issues: Challenging the Research and Practice of Computer Applications in Archaeology. In: E. GRAEME, T. SLY, A. CHRYSANTHI, P. MURRIETA-FLORES, C. PAPADOPOULOS, I. ROMANOWSKA AND D. WHEATLEY, eds, Archaeology in the Digital Era, Papers from the 40th Annual Conference of Computer Applications and Quantitative Methods in Archaeology (CAA), Southampton, 26-29 March 2012. Amsterdam: Amsterdam University Press.

OIKARINEN, T., 2016. Utilisation of Game Engine for Archaeological Visualization. In S. CAMPANA, R: SCOPIGNO, G. CARPENTIERO, M. CIRILLO, eds, CAA 2015. Proceedings of the 43rd Annual Conference on Computer Applications and Quantitive Methods in Archaeology, Oxford: Archaeopress, pp. 27-34.

OLSON, B.R. and PLACCHETTI, R.A., 2015. A Discussion of the Analytical Benefits of Image Based Modeling in Archaeology. In: B. R. OLSON, W. R. CARAHER, eds, 3D Imagining in Mediterranean Archaeology. Fargo: The Digital Press at The University of North Dakota 2015, pp. 17-26.

SGARLATA, M. and SALVO, G., 2006. La Catacomba di Santa Lucia e l'Oratorio dei Quaranta Martiri. Siracusa: Pontificia Commissione di Archeologia Sacra.

STANCO, F. and TANASI, D., 2011. Experiencing the Past. Computer Graphics in Archaeology. In: F. STANCO, S. BATTIATO, G. GALLO, eds, Digital Imaging for Cultural Heritage: Analysis, Restoration and Reconstruction of Ancient Artifacts. Boca Raton: CRC Press, pp. 1-37.

SGARLATA, M., 2007. La catacomba di S. Lucia a Siracusa: origini e trasformazioni. In: R. M. BONACASA CARRA, E. VITALE, eds, La cristianizzazione in Italia tra Tardoantico e Altomedioevo. Atti del IX Congresso Nazionale di Archeologia Cristiana. Agrigento, 20-25 novembre 2004, Palermo: Carlo Saladino Editore pp. 1565-1588.

ZIMMERMANN, N. and EßER G., 2008. Showing the invisible - documentation and research on the Roman Domitilla catacomb, based on image laser scanning and 3D modelling. In: A. POSLUSCHNY, K. LAMBERS, I. HERZOG, eds, Layers of Perception. Proceedings of the 35th International Conference on Computer Applications and Quantitative Methods in Archaeology (CAA), Berlin, 2-6. April 2007. Bonn: Koll. Vor- u. Frühgesch, pp. 58-64. 


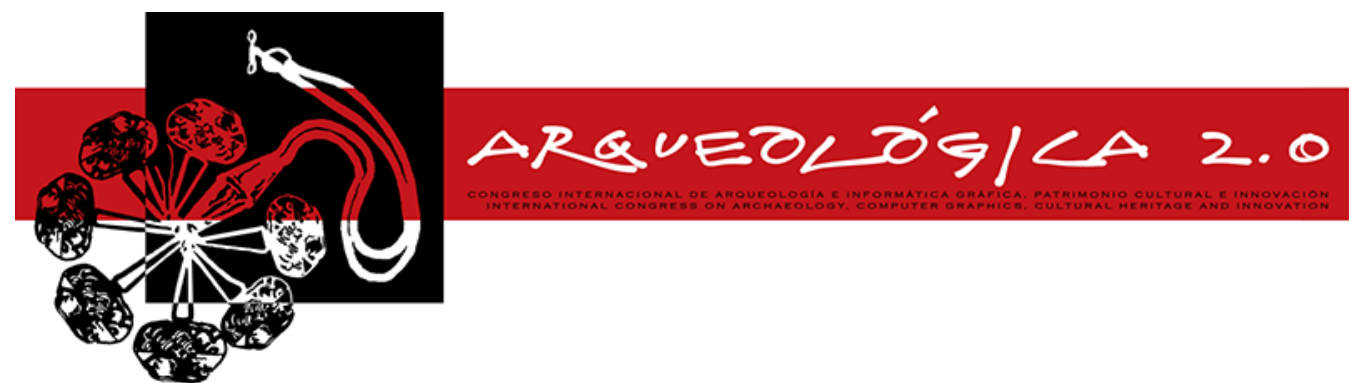

Proceedings of the $8^{\text {th }}$ International Congress

on Archaeology,

Computer Graphics,

Cultural Heritage and Innovation

'ARQUEOLÓGICA 2.0'

in Valencia (Spain),

Sept. 5-7, 2016

DOI: http://dx.doi.org/10.4995/arqueologica8.2016.3036

Received: $14 / 02 / 2016$

Accepted: 01/06/2016

\title{
LA VIRTUALIZACIÓN EN EL MUSEO ARQUEOLÓGICO DE BURRIANA (CASTELLÓN - ESPAÑA)
}

\author{
VIRTUALIZATION IN THE ARCHAEOLOGICAL MUSEUM OF BURRIANA(CASTELLÓN - SPAIN) \\ José Manuel Melchor ${ }^{\mathrm{a},{ }^{,},}$Jose Martínez ${ }^{\mathrm{b}}$, Carlos Bonafe ${ }^{\mathrm{b}}$, Alicia Cabrera ${ }^{\mathrm{b}}$ \\ ${ }^{a}$ Museo Arqueológico Municipal de Burriana, Plaza de la Merced s/n, 12530 Burriana, España. arqueologo@burriana.es \\ ${ }^{\mathrm{b}}$ Photocad-Fablabvlc, Camino de Vera, Edificio 8L 1, 46022 Valencia, España. fablabvalencia@gmail.com
}

\begin{abstract}
:
The Municipal Archaeological Museum of Burriana began the virtualization of parts and elements of cultural heritage and historic buildings in the early years of this century. Tangible results showed up from 2010. Regarding to archaeological artifacts two basic lines of action have been explored; on the one hand, literal documentation of pieces for later exhibition in augmented reality displays. Secondly, the research in the virtual recreation of missing elements or in the reconstruction of pieces. About the issue of cultural heritage we are currently in the documentation of buildings and archaeological excavations for augmented reality or didactic stage. We will also briefly discuss the prospects in the current virtualization works.
\end{abstract}

Key words: virtual archeology, museum, Burriana, cultural heritage, documentation, 3D reconstruction

\section{Resumen:}

La virtualización de piezas, elementos del patrimonio cultural y edificios de valor histórico empezó a desarrollarse en el Museo Arqueológico Municipal de Burriana desde los primeros años del siglo XXI, aunque los resultados tangibles empiezan a mostrarse a partir del año 2010. En la vertiente de los artefactos arqueológicos se han buscado dos líneas básicas de actuación; por un lado la documentación de literal de piezas para su posterior exhibición en montajes de realidad aumentada, y por otro la investigación en la recreación virtual de elementos faltantes o reconstrucción de piezas. En el aspecto del patrimonio inmueble por el momento solamente se ha procedido a la documentación de edificios y excavaciones arqueológicas para fines de realidad aumentada o de didáctica. También expondremos brevemente las perspectivas de futuro en los actuales trabajos de virtualización.

Palabras clave: arqueología virtual, museo, Burriana, patrimonio cultural, documentación, reconstrucción 3D

\section{Antecedentes de la cuestión}

El Museo Arqueológico Municipal de Burriana tiene sus antecedentes en las colecciones de principio del siglo $\mathrm{XX}$ que existían en el municipio, sin embargo, su origen más directo se debe a su refundación en el año 1967. Con la entrada de un nuevo equipo directivo en el año 2005 empieza un largo proceso de cambio museológico y museográfico. Desde el año 2010 se está llevado a cabo la introducción en el Museo Arqueológico Municipal de Burriana de nuevas tecnologías asociadas con la arqueología y el patrimonio cultural; estas discurren por dos líneas básicas: la divulgación expositiva y la investigación arqueológica.

Los primeros trabajos se centraron en la reconstrucción de elementos cerámicos de época musulmana (Pasíes et al. 2011), dentro de la línea de rehacer los faltantes en las piezas (incluida la decoración) sin tener que recurrir a una actuación física directa sobre el artefacto arqueológico (Fig. 1). Otro ejemplo fue la actuación sobre una moneda romana del yacimiento de Sant Gregori (Ferrer et al. 2013), que gracias a su virtualización y una animación básica, permitía al visitante del museo observar el anverso y el reverso de la moneda.

Al mismo tiempo se realizaron experimentos a nivel de reconstrucción en 3D de los restos arquitectónicos de la villa romana de Sant Gregori (Melchor 2013), concretamente se actuó sobre la balsa del peristilo (uno de los elementos mejor conservados detectados en la excavación), la cual, mediante el análisis de los restos conservados, pudo ser reconstruida virtualmente sobre

*Corresponding Author: Jose Manuel Melchor, arqueologo@burriana.es 
la actual hipótesis de trabajo, obtenida gracias a los fragmentos recuperados en la intervención, tanto a nivel del cromatismo de la pintura que la recubría, como de restitución del nivel de agua de su interior (Fig. 2).

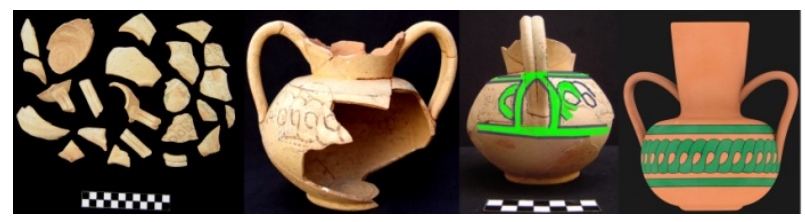

Figura 1: Restauración, documentación y reconstrucción digital de una jarrita musulmana.

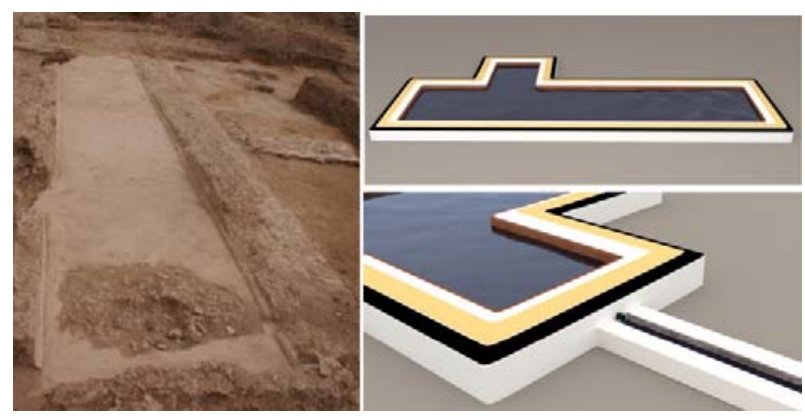

Figura 2: Excavación de la balsa del peristilo de Sant Gregori y su reconstrucción virtual.

En la actualidad ninguno de estos ejemplos se encuentra expuesto en las vitrinas del Museo Arqueológico de Burriana, ya que sus salas cuentan con ejemplos más avanzados, tanto tecnológicamente como a nivel de investigación arqueológica. Sin embargo, los casos citados si han servido como importantes herramientas de análisis en los campos de la arqueología y la conservación-restauración de piezas.

\section{La documentación virtual de restos arquitectónicos}

Una de las vertientes de las nuevas tecnologías introducidas en las estancias del Museo Arqueológico de Burriana es la reproducción de edificios históricos del municipio, de tal forma que en las pantallas de determinadas salas se pueden observar reproducciones de los mismos, obtenidas mediante fotogrametría y técnicas de modelado 3D paramétrico.

En los propios monumentos que no se encuentran permanentemente abiertos al público, se ha insertado un código QR en sus fachadas, que permite acceder a los videos expuestos en el Museo Arqueológico de Burriana mediante páginas web municipales.

En las representaciones, actualmente visualizadas mediante videos, se ha buscado dar a conocer la globalidad de los edificios, no solamente mediante vistas de todos sus paramentos y salas, sino que también por secciones que permitan ver su disposición interior (Fig. 3). También se han añadido textos explicativos relativos a los inmuebles, tanto en lo concerniente a sus datos históricos, como a su funcionalidad.

Lo citado más arriba es lo que actualmente se encuentra accesible al público o en la red, pero existen modelos interactivos, que permiten al visitante organizar su propio recorrido.
Hasta el momento se han realizado trabajos sobre cuatro edificios emblemáticos de Burriana: la torre de Carabona del siglo XVI (Melchor 2013), la torre del Mar de época Moderna (Melchor 2015), los depósitos de agua potable decimonónicos y la iglesia medieval del Salvador (Melchor 2011).

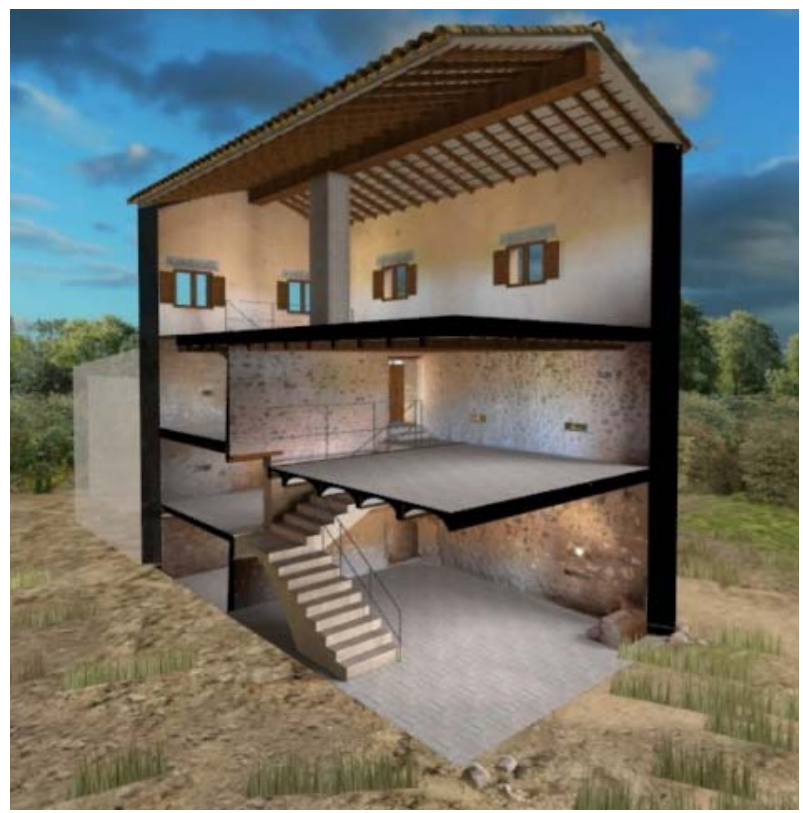

Figura 3: Sección virtual de la Torre de Carabona.

Lo citado más arriba es lo que actualmente se encuentra accesible al público o en la red, pero existen modelos interactivos, que permiten al visitante organizar su propio recorrido.

Hasta el momento se han realizado trabajos sobre cuatro edificios emblemáticos de Burriana: la torre de Carabona del siglo XVI (Melchor 2013), la torre del Mar de época Moderna (Melchor 2015), los depósitos de agua potable decimonónicos y la iglesia medieval del Salvador (Melchor 2011).

Queremos hacer hincapié en el último de estos ejemplos, ya que aquí también se han documentado los restos de la excavación arqueológica de la nueva casa abadía del Salvador, donde aparecieron relevantes estructuras medievales (Melchor 2011). Tal era la importancia de las mismas que se modificó el proyecto original de cimentación para realizar una losa que salvaguardara los restos. Lamentablemente no hubo acuerdo con la propiedad ni recursos económicos para poner en valor esos restos que actualmente permanecen ocultos, pero gracias a su documentación mediante fotogrametría, ahora existe la posibilidad de visualizarlos de una forma mucho más completa y dinámica (Fig. 4) que mediante una serie de fotos fijas.

\section{La documentación virtual de piezas}

Para el montaje de una vitrina del Museo Arqueológico de Burriana que emplea la realidad aumentada (esta vitrina se creó en el año 2014) se han empleado dos técnicas (fotogrametría y laser escáner) sobre piezas del museo. El objetivo del uso de realidad aumentada es permitir al visitante visualizar varios ángulos de una pieza que no son observables desde la vitrina donde se 
encuentra, como es el caso de la cratera griega de Orleyl (Melchor et al. 2010), pieza en la que se permite observar virtualmente no solamente toda su decoración exterior, sino que además se accede a una vista de su interior.

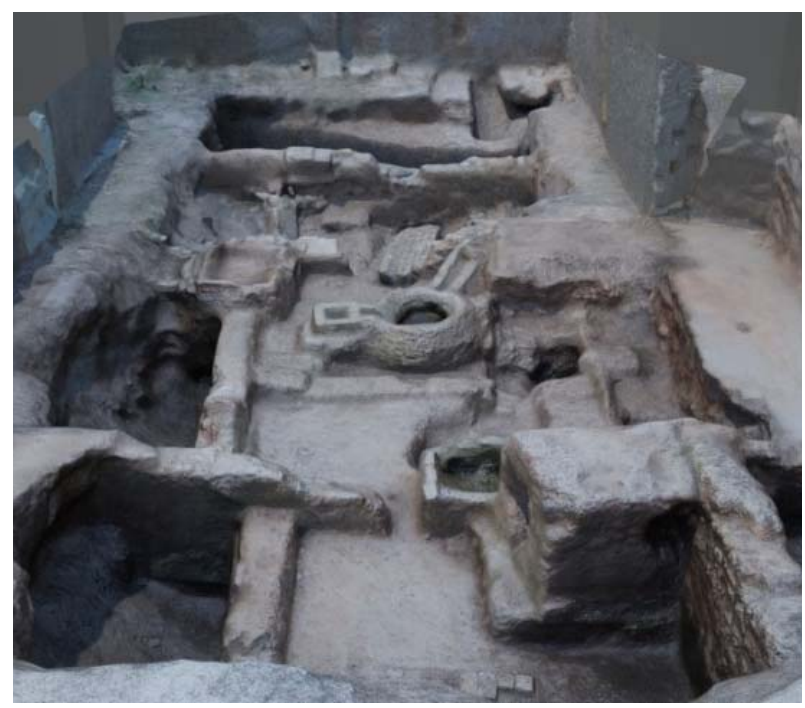

Figura 4: Reproducción virtual de la excavación de la casa abadía del Salvador.

Lo mismo sucede con el aplique cerámico helenístico con cabeza de Deméter del yacimiento de Torre d'Onda (Burriana) y el cráneo calcolítico del Argilagar de Morella (Mesado y Andrés 1999). En otros casos como la estatuilla de bronce romana del Hermes de Xilxes (Mesado 1971) y el candil medieval judío de Burriana (Utrilla 1966), también se exponen hipótesis interpretativas plasmadas en el resultado final de la realidad aumentada y que explicaremos con detalle en el siguiente apartado.

\section{La virtualización y la investigación arqueológica}

Las herramientas informáticas nos han permitido avanzar en la investigación de determinadas piezas, sin tener que actuar físicamente sobre ellas. Esto, en nuestra opinión, significa un gran avance desde el punto de vista de la conservación de las mismas, pues evita que la presentación al público del aspecto original de estas piezas, implique en tratamientos agresivos hacia ellas, como por ejemplo: reintegraciones, limpiezas o prótesis (sean miméticas o no), en la búsqueda de alcanzar una aspecto visual actual más cercano al antiguo.

También desde el punto de vista de los trabajos de documentación arqueológica significa una importante herramienta de apoyo, pues prácticamente elimina el uso de elementos como los calcos, dibujos, etc.; lo que sin duda agiliza y abarata estos trabajos (Fig. 5).

\subsection{Candil judío}

Se trata de un lámpara de aceite de seis picos con cubierta vítrea y decorada en azul cobalto con motivos geométricos y vegetales; tiene una cronología de alrededor del siglo XIV y fue recuperada en la excavación del año 1965 que se llevó a cabo en la iglesia de la Sangre, situada en la antigua judería de Burriana (Utrilla 1966), de la que lamentablemente se conserva muy poca información.

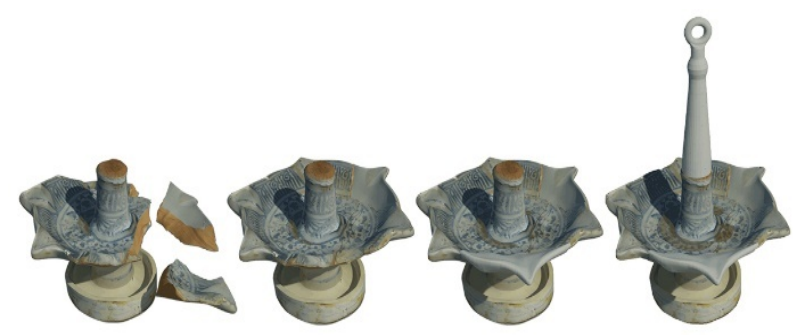

Figura 5: Proceso de análisis del candil judío.

Hasta hoy en día no se realizó ninguna intervención sobre la pieza, excepto la reintegración en escayola de parte de sus picos que se hizo al poco tiempo de su descubrimiento.

Durante el proceso actual de estudio de la pieza, localizamos un paralelo formalmente exacto de la misma en el museo del Tinell de Barcelona, sobre esta base se realizó la restitución virtual de la partes faltantes; en ellas se optó por no incluir decoración y mantener un color blanco que transmite un aspecto neutro y que sirve para diferenciar claramente las partes que son fruto de la interpretación arqueológica y las que son reales.

Pasaremos a describir brevemente el proceso seguido en cada uno de los elementos.

Para el proceso de documentación se realizó una toma de datos mediante escaneado fotogramétrico, con el cual se generó una nube de puntos de gran densidad que sirvió de base para el posterior tratamiento y virtualización 3D

Una vez obtenido el resultado deseado, o sea una reproducción virtual en 3D de la pieza, se decidió acrecentar un recurso de realidad aumentada cara a su exposición en el museo, consistente en añadir mechas encendidas y aceite en la cazoleta (Fig. 6), siendo que aquellas podían ser apagadas virtualmente con un gesto de la mano.

\subsection{Estatua de Hermes}

Se trata de una estatua de bronce macizo de pequeño tamaño que representa al dios Hermes (Fig. 7), y que fue encontrada alrededor del año 1966 por unos obreros, durante los trabajos de desfonde que arrasaron parte de la villa romana del Alter, en el municipio de Xilxes (Castellón), siendo posteriormente adquirida por el Museo Arqueológico Municipal de Burriana (Mesado 1971).

Esta pieza se encontraría originariamente en uno de los pequeños oratorios de la villa, los llamados lararios, que son habituales en las viviendas romanas de la época y es, por su calidad estilística, uno de los mejores ejemplos de la Comunidad Valencia de escultura romana en bronce de época romana altoimperial.

Desde su hallazgo la pieza sufrió un proceso de limpieza, se le añadió un anacrónico bastoncillo dorado en su mano izquierda y finalmente se pegó a una base cuadrangular maciza de mármol. Posteriormente, y 
obedeciendo a criterios museográficos mas actuales, en el año 2007, se retiró el bastoncillo y la base de mármol.

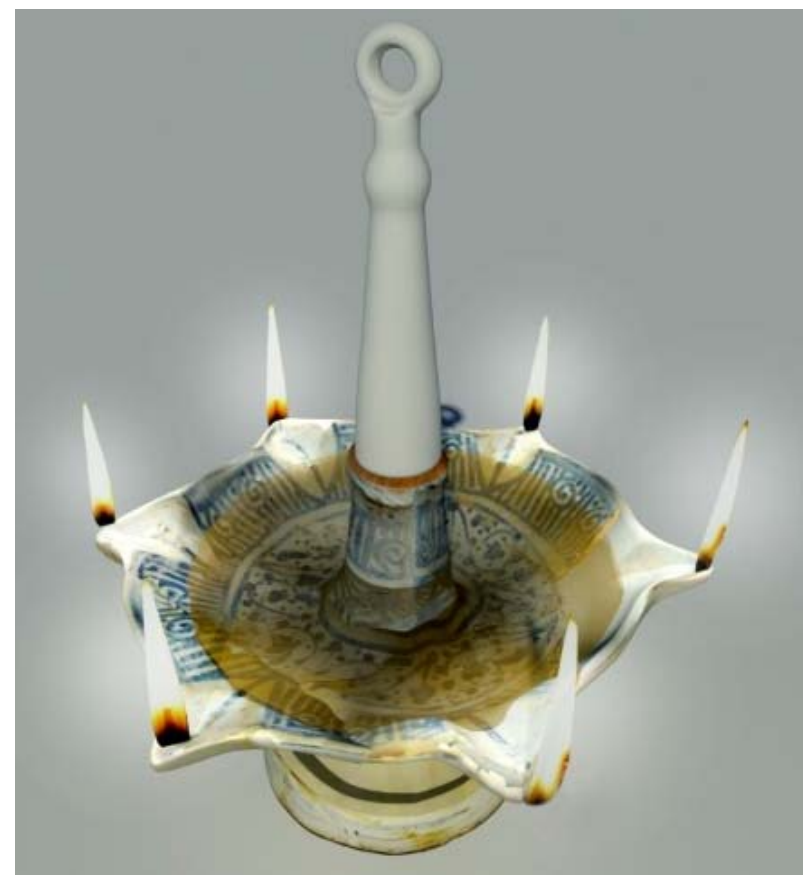

Figura 6: Reconstrucción virtual del candil judío.

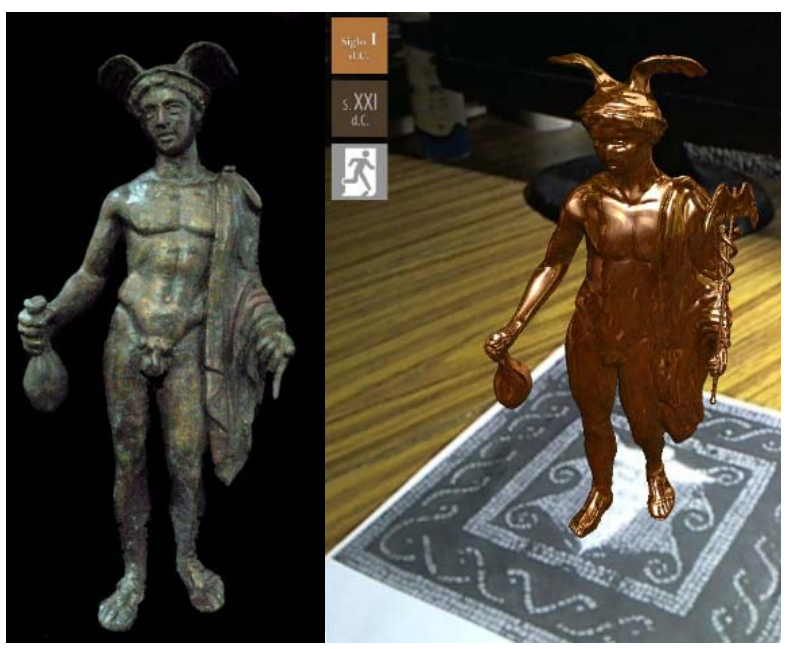

Figura 7: Hermes de Xilxes y su recreación virtual.

Para el proceso de documentación se realizó una toma de datos fotogramétrica y escaneado a pequeña escala de la pieza, consiguiendo precisiones inferiores al milímetro.

Por paralelos en otras estatuillas similares se estableció la hipótesis de que esta originariamente debería llevar un caduceo en su mano izquierda, ya que la posición de la misma es la propia para llevar este artefacto, que además es uno de los emblemas característicos de la divinidad.

Así pues, mediante un modelado virtual y reconstrucción 3D se añadió un caduceo a una escala aproximada a la que debería tener el original y posteriormente se reprodujo el tono del bronce recién fundido (sin patina y sin oxidación) para que el visitante al museo pueda tener una idea de su apariencia original (Fig. 8).
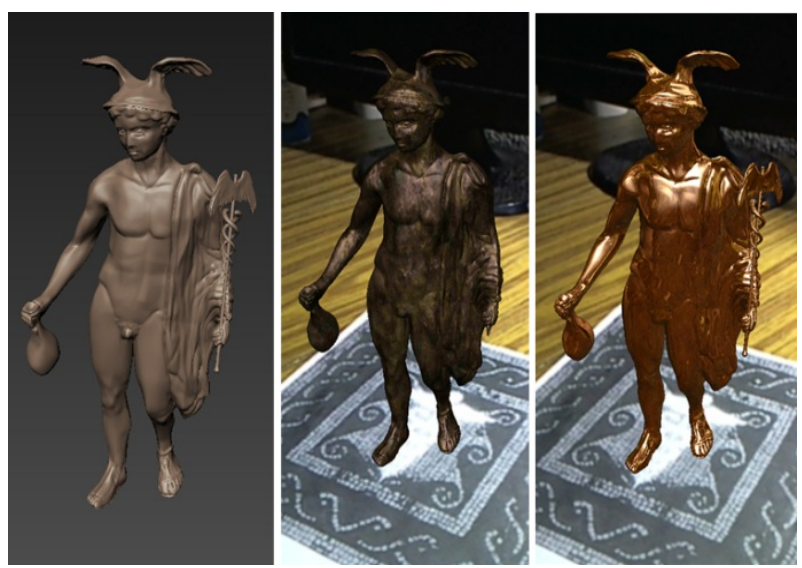

Figura 8: Proceso de trabajo del Hermes de Xilxes.

\subsection{Estatua de Livia}

Es una estatua de mármol blanco a tamaño natural de un mujer romana vestida con chitón, a la que le faltan todas las extremidades. Se trata de una pieza de una cierta calidad artística.

Fue traída al Museo Arqueológico Municipal de Burriana en los años 70 desde Talavera de la Reina (Mesado 1971), dentro de un contexto de otros materiales arqueológicos varios traídos de esta misma zona geográfica en aquel periodo.

La imagen aparentemente apareció en el derribo de un edificio de época moderna, donde había sido reutilizada como material constructivo, del cual aun conservaba restos de mortero y pintura en su superficie.

Desde que se incorporó al museo fue trasladada a varios sitios, hasta que finalmente en el año 2010 fue rescatada desde su ubicación en un soporte volado en la segunda planta de la Casa de Cultura de Burriana (donde había sido emplazada en el año 1991), y se le practicó la primera limpieza desde su descubrimiento. Posteriormente se le realizó una peana y desde entonces forma parte de la exposición permanente del museo en un lugar destacado de la misma.

Debido al tamaño de la pieza, el proceso de documentación se realizó exclusivamente mediante fotogrametría, consiguiendo excelentes resultados desde el modelo extraído en la propia toma, sin casi necesidad de postprocesado (Fig. 9).

La labor de documentación de paralelos fue compleja debido a la variedad de la estatuaria romana y se acotó a efigies de Livia, esposa del emperador Augusto, con las cuales coincidía cronológica y estilísticamente la pieza talaverana.

Finalmente la posición de lo que restaba de las cuatro extremidades nos llevó a inclinarnos por interpretar la estatua como similar a una imagen de Livia divinizada, en este caso portando una cornucopia en la mano izquierda y una patera en la derecha; en estos casos es frecuente que la imagen tenga la cabeza cubierta por un velo como parte del ritual. Se trata de un modelo bastante usual en este periodo del imperio romano

Con estos datos realizamos dos propuestas de restitución: una canónica, añadiendo virtualmente las extremidades faltantes y diferenciando las texturas del 
original y los añadidos, simulando que la pieza hubiera sido objeto de una reintegración real, y otra opción donde proponemos el aspecto original de la estatua (Fig. 10).
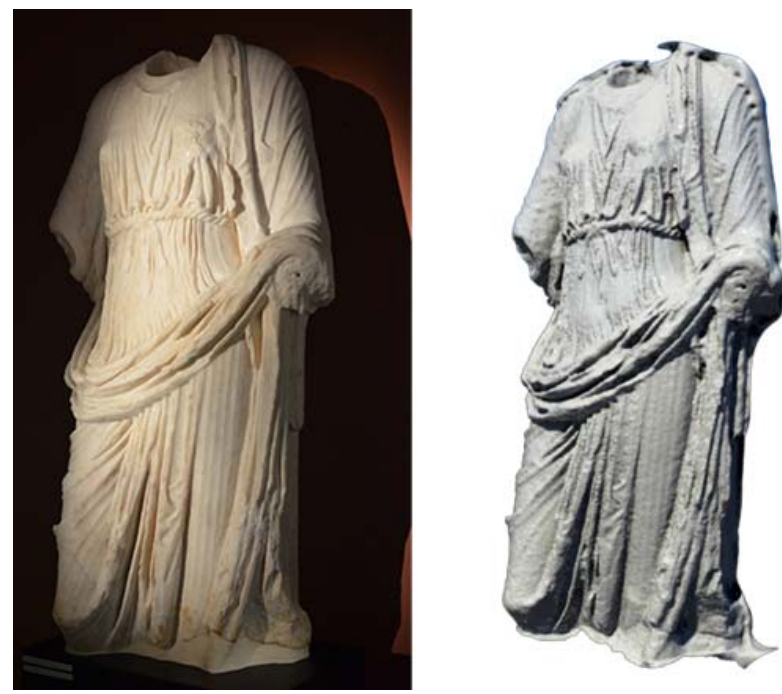

Figura 9: Estatua de Livia y su modelo virtual.
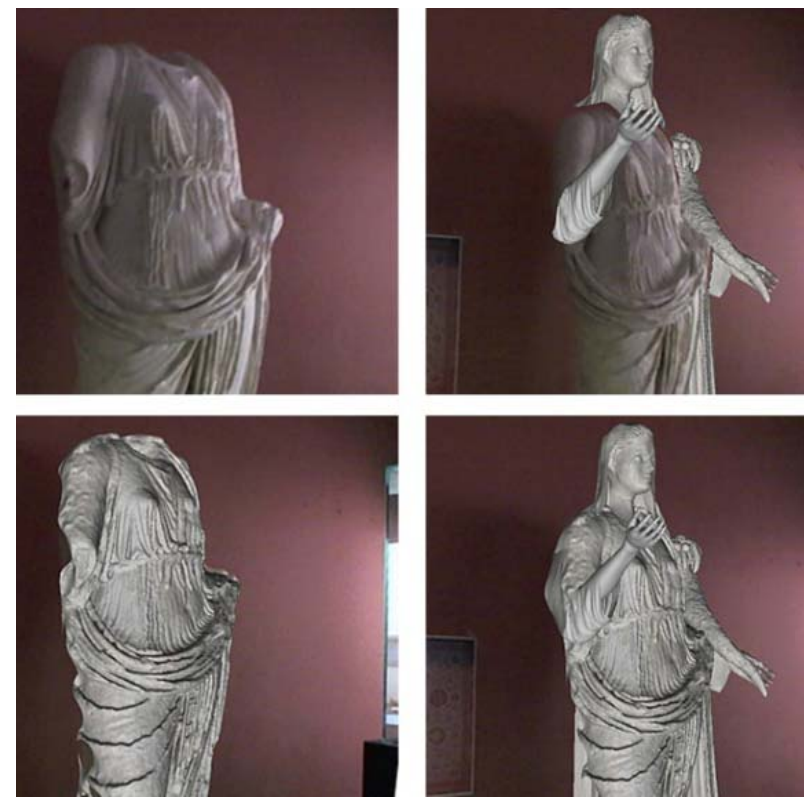

Figura 10: Estatua de Livia y su recreación virtual en el museo.

\subsection{Aplique cerámico de Deméter}

Se trata de un aplique cerámico helenístico del yacimiento ibero-romano de Torre d'Onda (Mesado et al. 1991) formado por una cabeza de arcilla maciza (probablemente la diosa Deméter), fabricada a molde, la cual se aplicó sobre la vasija y sobre ella se pegó una asa trenzada. Por su calidad y origen se trata de una pieza de excepcional interés en el contexto valenciano, donde además este tipo de piezas son muy escasas.

En este caso el procedimiento utilizado fue captación fotogramétrica a pequeña escala (Fig. 11). Con este procedimiento se buscó documentar más aspectos físicos de la pieza (arcilla, textura, superficies, etc.) debido a su excepcionalidad. Así también fue posible documentar no solo la existencia de restos de pintura, si no las propias características morfológicas de la pieza.

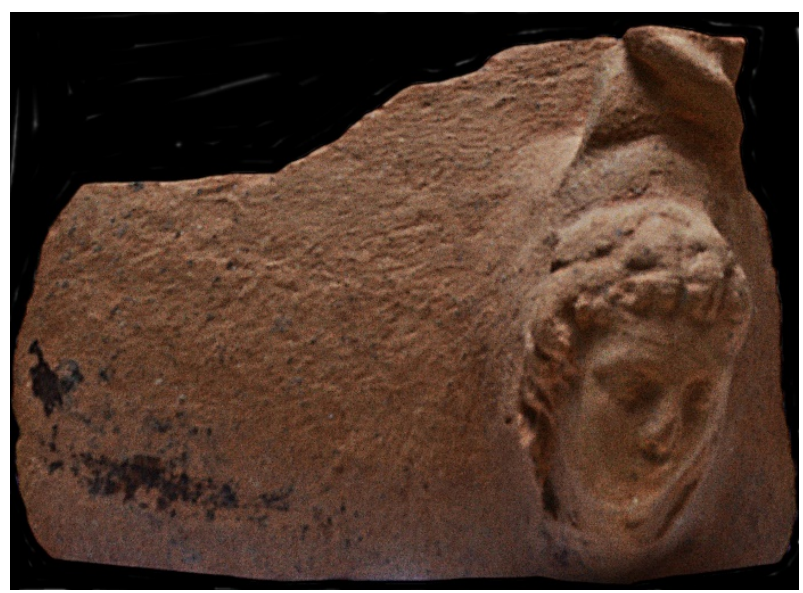

Figura 11: Escaneado de la cabeza cerámica de Deméter.

\section{Estado actual y propuestas de virtualización del museo}

Actualmente la disposición dentro del discurso museográfico de las piezas reales que han sido virtualizadas es bastante dispersa.

Las estatuas de Livia divinizada y Hermes, además del aplique de Deméter, ocupan un espacio diferenciado dedicado a las divinidades en la sala de la cultura romana del Museo Arqueológico Municipal de Burriana.

El candil judío se encuentra en la vitrina que tiene por temática a las tres culturas (musulmana, judía y cristiana) de la Burriana medieval. Junto a esta parece la pantalla donde se muestran los videos de dos de los edificios históricos virtualizados ya citados en este artículo (Torre de Carabona y Torre del Mar). La cratera griega de Orleyl está ubicada en una vitrina dedicada exclusivamente a la necrópolis ibérica donde apareció, en el espacio del museo dedicado a la arqueología de la muerte.

Los artefactos virtualizados se muestran justo en la entrada del museo, entre sus primeras vitrinas dedicadas a la metodología arqueológica y la restauración. Allí tenemos una pantalla dedicada a la realidad aumentada; donde aparecen la cratera de Orley, Hermes de Xilxes, cráneo del Argilagar de Morella y candil judío de Burriana (Fig. 12).

Gracias a la línea de investigación arqueológica y museológica que se está siguiendo desde el Museo Arqueológico Municipal de Burriana, sumada al constante proceso de aplicación de nuevas tecnologías, está previsto implementar en el museo otro tipo de interacciones, además de ampliar las ya existentes.

En estos momentos se está trabajando en instalaciones de videomapping, realidad aumentada con base en tecnología móvil, y visitas virtuales $360^{\circ}$ relacionadas con piezas y salas del museo. 


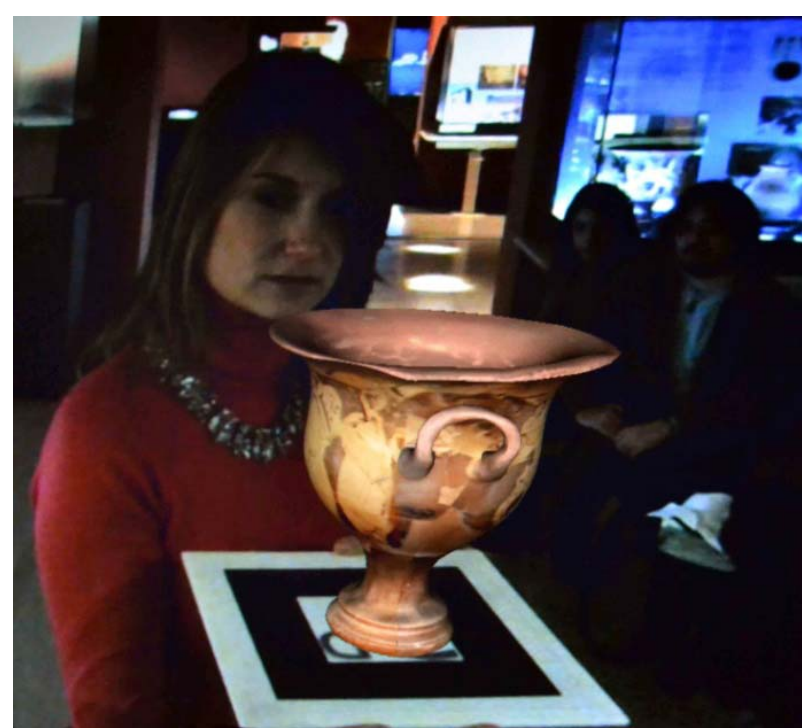

Figura 12: Vitrina de realidad aumentada del Museo de Burriana con una vista de la cratera de Orleyl.

\section{Conclusión}

La aplicación de estas nuevas tecnologías permite crear un espacio virtual dentro del museo que admite exhibir inmuebles o piezas que seria imposible introducir en las salas por motivos obvios.

Pero no solo eso, también permite enseñar a los visitantes propuestas de reintegración o reconstrucción de piezas que no solo mantienen inalterado el artefacto, si no que permiten su modificación y modernización constante.

\section{Referencias}

FERRER, J.J., MELCHOR, J.M. y BENEDITO, J., 2013. Sant Gregori. Un complejo arquitectónico de época romana en la costa de Burriana (España). Millars, XXXVI, pp. 129-233. DOI:dx.doi.org/10.6035/Millars.

MELCHOR, J.M., 2011. La arqueología como fuente de estudio para la Burriana medieval. En: J.M. MELCHOR, J. BENEDITO y T. PASIES, eds, La arqueología de la Buriyyana islámica a la Borriana cristiana. Conselleria de Governació de la Generalitat Valenciana, pp. 11-48.

MELCHOR, J.M., 2013. Diez años del Servicio Arqueológico Municipal de Burriana, Ayuntamiento de Burriana. 160 páginas.

MELCHOR, J.M., 2015. Datos históricos sobre la Torre del Mar (Burriana - Castellón), en Defensive Architecture of the Mediterranean. XV to XVIII centuries, Vol I, P. Rodríguez-Navarro (ed.), Universidad Politécnica de Valencia, pp. 113-116. DOI: 10.4995/FORTMED2015.2015.1678.

MELCHOR, J.M., FERRER, J.J. y BENEDITO, J., 2010. El enterramiento ibérico de la "Cratera de la Grifomaquia" de Orleyl, Millars, XXXIII, pp. 39-54. DOI:dx.doi.org/10.6035/Millars

MESADO, N., 1971. Estatua femenina y mercurio del Museo de Burriana (Castellón). AEspArq. 123-24. Pp. $169-71$.

MESADO, N. y ANDRÉS, J., 1999. La necrópolis megalítica del Argilagar del Mas de García (Morella, Castellón). Archivo de Prehistoria Levantina, XXIII. Pp. 85-156

MESADO, N., GIL, J.L. y RUFINO, A., 1991. El Museo Histórico Municipal de Burriana, Ayuntamiento de Burriana. 107 paginas.

PASIES, T., PEIRÓ, M.A. y TEJERINA, D., 2011. La conservación-restauración en arqueología. Trabajos en el laboratorio del Museo Arqueológico de Burriana. En: J.M. MELCHOR, J. BENEDITO y T. PASIES, eds, La arqueología de la Buriyyana islámica a la Borriana cristiana. Conselleria de Governació de la Generalitat Valenciana, pp. 137-152.

UTRILLA, T., 1966. Sobre los orígenes de Burriana. Su sinagoga e iglesia de la Sangre, BurisAna. 99. pp. 10-13. 


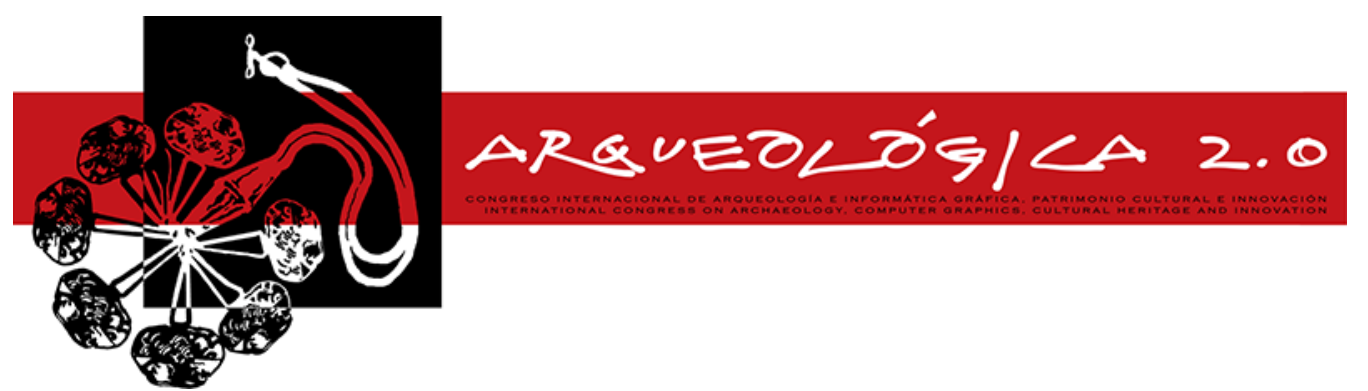

Proceedings of the $8^{\text {th }}$ International Congress on Archaeology, Computer Graphics, Cultural Heritage and Innovation

'ARQUEOLÓGICA 2.0 '

in Valencia (Spain),

Sept. $5-7,2016$

\title{
DIGITAL DOCUMENTATION OF INDUSTRIAL HERITAGE AT RISK: THE CASE OF PALATAKI AND THE OLD MINING COMPLEX AT LIMENARIA OF THASSOS (GREECE)
}

\author{
Nikolaos Lianos ${ }^{*}$, Anastasios Stamnas \\ Faculty of Architecture, Democritus University of Thrace, Greece. nlianos@arch.duth.gr
}

\begin{abstract}
:
Following completion of the 1st Workshop of Digital Documentation of Monuments Using 3d Laser Scanner organized by the Laboratory of Architectural Theory of Forms and Preservation Studies, Faculty of Architecture, DUTh, the present study was undertaken mainly to focus on the application of advanced techniques, such as the $3 \mathrm{~d}$ laser scanner, for the geometric documentation of the mining complex at the town of Limenaria of the island of Thassos, an abandoned and discredited monument for almost half a century. The key purpose of the laboratory work was the instruction of new technologies in surveying and documentation and their contribution to preservation, protection and restoration of monuments. The Field of practice was the former Speidel headquarters, known as "Palataki", and the abandoned mining complex at Limenaria, a unique example of industrial heritage at risk. The main objective of the laboratory was the documentation and the recording of this monument in order to protect it and highlight its historical value and cultural significance to the public.
\end{abstract}

Key words: cultural heritage, documentation, GIS, laser scanning, 3D modeling

\section{Introduction}

Industrial heritage refers to the physical remains of the history of technology and industry, such as manufacturing and mining sites, as well as power and transportation infrastructure. The industrial heritage of a region is an aspect of its cultural heritage. The international organization dedicated to the study and preservation of such heritage is The International Committee for the Conservation of the Industrial Heritage, known as $\mathrm{TICCIH}$. TICCIH has been ICOMOS's specialist adviser on industrial heritage since 2000 and assesses industrial sites for the World Heritage List.

According to $\mathrm{TICCIH}$ principles, the industrial heritage is highly vulnerable and often at risk to be lost for lack of awareness, documentation, recognition or protection, but also because of changing economic trends, negative perceptions, environmental issues or its sheer size and complexity (Lianos 2012). The first step to ensure effective protection and conservation of the industrial heritage structures, sites, areas and landscapes requires an up-to-date precise documentation and recording (context analysis, study at different scales, inventory of component parts and of impact, history of the town and its phases of evolution, etc.) (ICOMOS, The Dublin Principles, 2011). Moreover, as already stated by the
Nizhny Tagil Charter for the Industrial Heritage (2003), "recording is a fundamental part of the study of industrial heritage and a full record of the physical features and condition of a site should be made and placed in a public archive before any interventions are made".

Nowadays, technology has radically changed matters in documentation and promises to continue to bring more changes rapidly (Lerma et al. 2008). In contrast to other available techniques of documentation such as nonphotographic (graphic documentation, hand measuring and tachometry) and photographic (photography, rectified photography, computer-rectified photography, photogrammetry) techniques, $3 \mathrm{~d}$ laser scanning represents today the most advanced technology available for measuring and documenting objects, structures and landscapes (Patias et al. 2008, 2013). 3d laser scanners produce a huge number of $3 \mathrm{~d}$ points and the resulting three dimensional color point cloud can be used to extract CAD elements or to create a $3 d$ surface model (Remondino 2011). 3d laser scanners are widely used in the field of architectural and archaeological surveying and documentation of monuments thereby bringing new perspectives, and can satisfy most requirements of those types of applications (Haddad 2011).

In this context, the Laboratory of Architectural Theory of Forms and Preservation Studies, Faculty of Architecture, 
Democritus University of Thrace, Greece, organized the 1st Workshop of Digital Documentation of Monuments Using a 3d Laser Scanner at Limenaria of Thassos (Fig. 1) on May 2014. The main purpose was the instruction of new technologies in surveying and documentation, and their contribution to preservation, protection and restoration of monuments. The Field of practice was the former Speidel headquarters, known as "Palataki", and the entire abandoned mining complex at Limenaria, a unique example of industrial heritage at risk. The main objective of the laboratory was the documentation and recording of the monument in order to protect it and highlight its historical value and cultural significance to the public.

a)

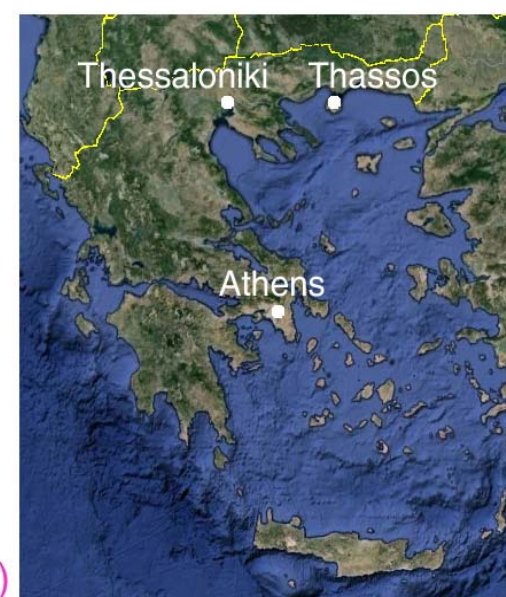

b)

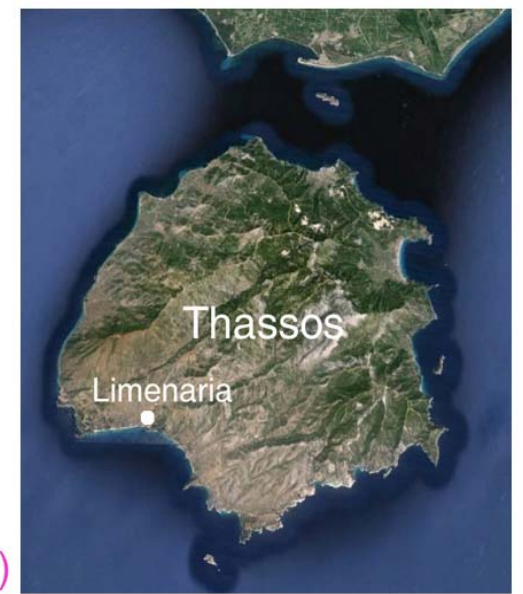

Figure 1: Map of Greece and the location of Thassos island (a) The location of Limenaria of Thassos (b) (Source: Gougle Earth).

\section{Case study: "Palataki" and the old mining complex}

\subsection{Brief mining history of Limenaria}

"Palataki" and the old mining complex (Fig. 2) are located at Limenaria of Thassos, a Greek island in the northern Aegean Sea, close to the coast of Thrace and the plain of the river Nestos, geographically part of Macedonia. Thassos possesses mineral wealth and mining activities for basic and precious metals dating as far back as the 7th century B.C. with the Phoenicians, followed in the 4th century by the Greeks and then the Romans.

In the early 20th century, mining companies such as "Speidel-Pforzeheim" (1905-1912) and "Veille Montagne \& Société Hellenique Metallurgique et Miniere" (19251930 ) exploited the island's Zinc-lead rich calamine ores. In 1905 a metallurgical plant was erected at Limenaria, the second largest town of the island, for the calcination of the calamines in vertical and Oxland furnaces to produce ZnO. Later (1926) the calcination plant was rebuilt by Vieille Montagne with Waelz system rotary furnaces. Iron ore mining became important during the years 1954-1964. Several mining companies (SchmidtKrupp and Apostolopoulos A.E., Chondrodimos S.A.) exploited the iron ore deposits of the island. It is estimated that total mineral production during the period 1905-1964 was about 2 million tonnes of calamine (12\% $\mathrm{Zn}+\mathrm{Pb})$ and 3 million tonnes of iron ore $(44 \% \mathrm{Fe})$. Since 1964 there has been no mining activity on the island.

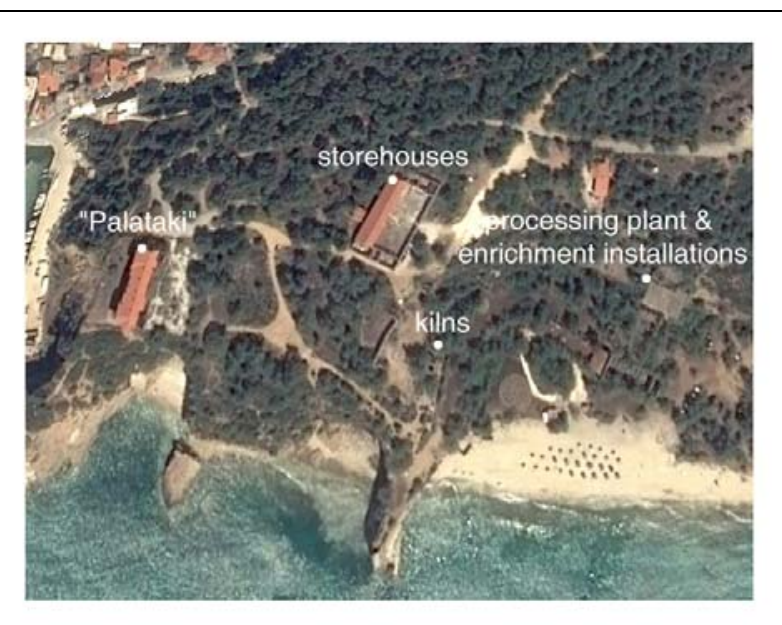

Figure 2: Map of the mining complex of Limenaria (Source: Google Earth).

\subsection{Analysis of the mining complex}

The impressive "Palataki" dominates the rocky cape where it stands just at the end of the Limenaria harbour (Fig. 3). It is a two-storey building, rectangular, with two small towers on its narrow facets. As a vivid example of eclectic architecture, it is characterized by a strict geometry and influenced from central European adherents. It was built between 1903 and 1904 to house the administration of Speidel, the German company which by then was exploiting the Thassos mines. In 1963 though, it stopped being used since the industrial installations were deserted.

Near "Palataki" there are the remains of the old storehouses, currently used as a makeshift folk-art museum. At the foot of the hill where "Palataki" stands, there is the picturesque beach of "Metalia" (Mines) where the old ore-enrichment installations lie. The old buildings cover the slope and, along with a heap of old rust dominate the scenery. The floors and walls are left naked, since all metal parts and machinery have been looted and sold as scrap.

The only installations preserved are the kilns (furnaces), part of the ore process, which in the early 1900s was performed by the company "Speidel-Pforzeheim" and 
later by its successor "Veille Montagne" (Fig. 4). After the 1930s recession, ore-processing was stopped and the great furnace-ramp was used only for hauling unprocessed ore to barges. Several other buildings complete the set of installations around the Limenaria area.

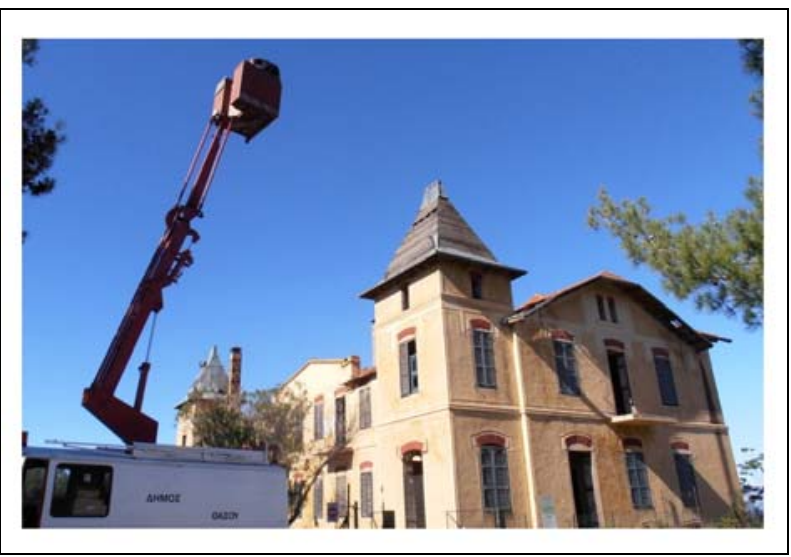

Figure 3: "Palataki" during data acquisition process.

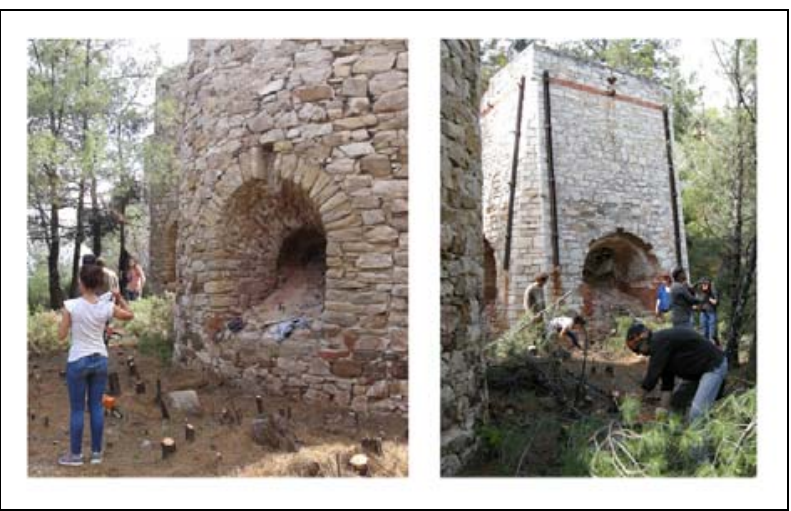

Figure 4: The kilns during vegetation removal.

\subsection{The importance of documentating the mining complex}

"Palataki" and the mining complex of Limenaria, including buildings, facilities, mining galleries and the surrounding landscape, is one of the most important industrial-mining complexes which are preserved intact in their original historical form in the Eastern Mediterranean.

According to the ICOMOS international charters, the International Charter for the Industrial Heritage of Nizhny Tagil, signed in 2003, and the specifications of $\mathrm{TICClH}$ (The International Committee for the Conservation of the Industrial Heritage), the mining complex of Limenaria constitutes a complete monument worthy of rescue and protection, in regards to integrity, authenticity and uniqueness.

Today, the obsolescence of this monument became an unfortunate reality. The monument has been at risk, abandoned and discredited for almost half a century, and there is no doubt that the first step towards ensuring its protection is the documentation of the whole mining complex. Therefore, everyone can easily understand that a complete documentation of the mining complex, using advanced technologies such as the $3 d$ laser scanner, can guarantee the basis for planning and execution of preservation and conservation works and a viable reuse of the monument.

\section{Organizing the workshop of digital documentation}

\subsection{Structure and goals of the workshop}

The focus of the $1^{\text {st }}$ Workshop of Digital Documentation of Monuments Using 3d Laser Scanning was organized at Limenaria of Thassos on May 2014 by the Laboratory of Architectural Theory of Forms and Preservation Studies (Faculty of Architecture, Democritus University of Thrace, Greece), and was targeted towards: a) the education and training on use of advanced technologies available for measuring and documenting objects, and the contribution of these technologies to the protection and restoration of monuments, and b) the digital documentation of the mining complex of Limenaria of Thassos in order to protect it and highlight its cultural value. To achieve these goals, the Worskshop began with the selection of buildings and sites to be captured using the $3 \mathrm{~d}$ laser scanner and, afterwards, the organization of field work and office work. To this end, the use of a work diary was considered an essential tool to manage the documentation work.

\subsection{Selection of buildings and sites}

The selection of buildings and site to be scanned was made on the basis of two factors: (i) the importance and the state of risk of each building, and (ii) the duration of the Workshop (six days). Thus, the selected buildings and sites (Fig. 5) to be scanned were as follows: (a) "Palataki" and the kilns (furnaces), (b) the platform above the kilns, (c) the road that connects "Palataki" and the platform, (d) the road that connects kilns (furnaces), and (e) the factory (processing plant and enrichment installations). Initially, the area around "Palataki" and the kilns was cleaned and a bunch of trees was removed in order to capture the selected buildings.

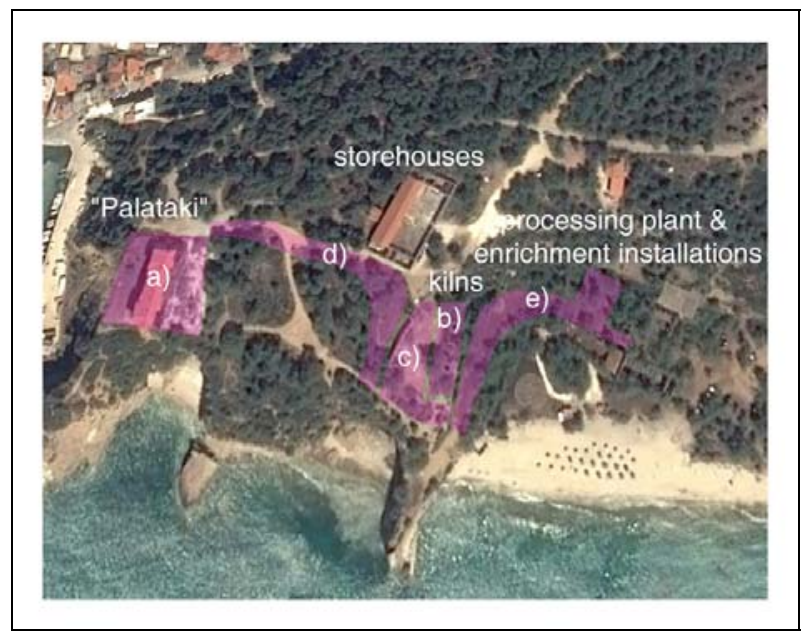

Figure 5: The selected buildings and sites to be scanned.

\subsection{Analysis of field measurements}

During data acquisition process, the "Faro focus $3 \mathrm{~d} X$ 120" laser scanner (Table. 1) was used for DSM collection and a significant number of 71 measurements 
were realized in order to capture the selected buildings and sites of the mining complex of Limenaria of Thassos.

Table 1: Technical details of the equipment

\begin{tabular}{c|c} 
Laser scanner & Faro focus $3 d \times 120$ \\
\hline Distance accuracy & up to $\pm 2 \mathrm{~mm}$ \\
Dynamic range & from $0.6 \mathrm{~m}$ up to $130 \mathrm{~m}$ \\
Noise reduction & $50,00 \%$
\end{tabular}

The Data acquisition process lasted for five days during the Workshop and while trying to organize field measurements and establish a methodology for conducting field works, certain steps were followed:

1. Delimitation of scan area.

2. Designing of sketches illustrating the positioning of the $3 \mathrm{~d}$ laser scanner and the location of ground control points (Fig. 6).

3. Selection of initial settings of the $3 d$ laser scanner (quality of scanning, scan resolution, scanning in color or in black-and-white etc.)

4. Placement of Bullets and targets (uniformly distributed over all scanned areas) in order to be used as homologous points to merge the different scans.

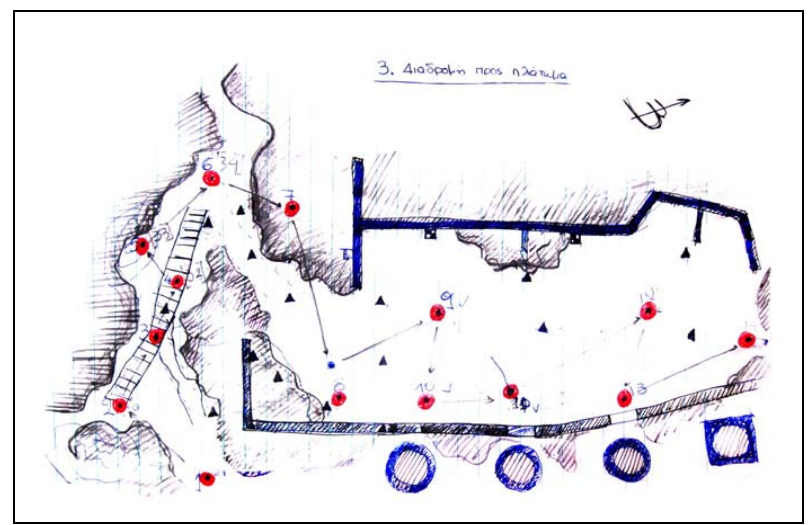

Figure 6: Design sketch illustrating the positioning of the 3d laser scanner and the location of ground control points during field work.

\subsection{Data processing}

Data processing lasted for four days using 4 powerful workstation PCs. Each workstation PC was used to merge a group of 17 stations and each merged group was copied into one workstation PC for the final merging of all stations. The point clouds of all stations (71) were merged using the FARO SCENE software specifically designed for the FARO laser scanner. During the registration stage, at least 3 pairs of homologous points were selected for each overlapping pair of point clouds. The images taken with the internal camera of the laser scanner were used for the coloring of the 3D points (Fig. 7 ). Then the model was exported from the faro scene software to the Bentley Pointools software in order to remove noise and areas of no interest. Finally, the model was used to create a high resolution animated video of the whole area scanned. The finalized "noise-free' model consisted of 5 billion points.

a)

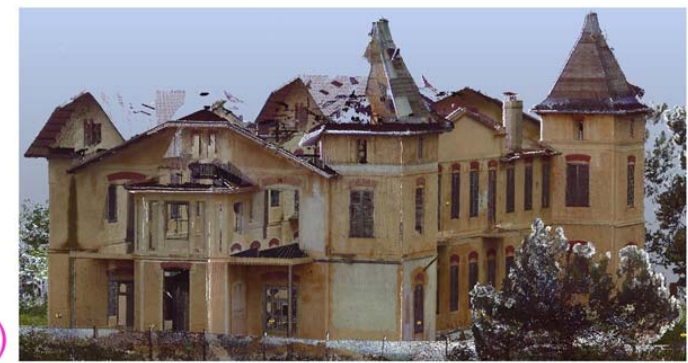

b)

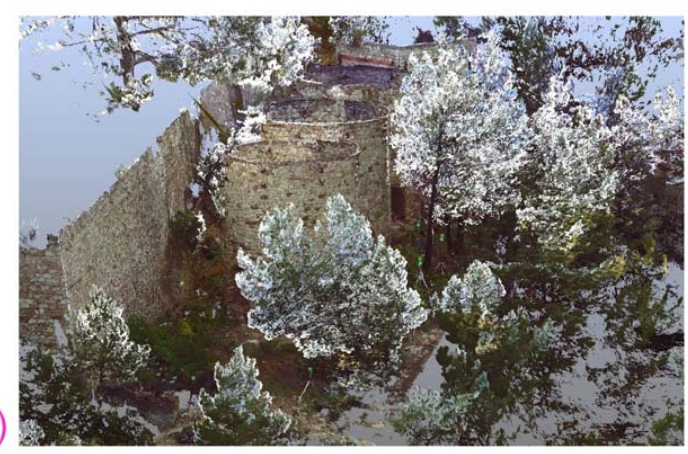

Figure 7: The colored point cloud of "Palataki" (a) and the kilns (b).

\section{Conclusions and future work}

3D laser scanning technology is a powerful tool not only to record historical sites and objects, but also for preservation purposes, for scientific research and environmental applications. Today, more than ever before, the application of 3D laser scanning to reconstruct and conserve heritage buildings, monuments and/or archaeological sites, is generally accepted as a method of choice to document cultural heritage owing to its accurate and fast characteristics. Thus, during the period of the current economic crisis when other laborrequiring approaches are not possible, accurate digital documentation of the present state of our cultural heritage, especially the one at particularly high risk, is very important as a reference and as a record for future generations.

In this context, the Laboratory of Architectural Theory of Forms and Preservation Studies, Faculty of Architecture, Democritus University of Thrace, intend to extend the activities of the Workshop of digital documentation of monuments using $3 \mathrm{~d}$ laser scaning in order to protect monuments at risk, such as the mining complex of Limenaria of Thassos, and highlight their historical value and cultural significance to the public.

\section{Acknowledgements}

We would like to express our sincere thanks and appreciation to Giorgos Agelis, Giorgos Vasilakis, Nikos Karagiannis, Ioanna Mpalioti, Ioannis Mourthos, Anna Boutou, Panagiota Spuropoulou, Eirini Tsetine and Maria loanna Photopoulou who attended the Workshop and helped with field measurements and data acquisition and processing. 


\section{References}

HADDAD N. A., 2011, From ground surveying to 3D laser scanner: A review of techniques used for spatial documentation of historic sites, Journal of King Saud University - Engineering Sciences, Volume 23, Issue, 2, pp. $109-118$.

LIANOS, N., 2012, “The Economic Crisis: Is the Protection of a Nation's Cultural Heritage Still Possible? The significance and the role of an accurate 3D documentation". From past experience to new approaches and synergies: the Future of Protection Heritage Management for Archaeological Heritage in Times of Economic Crisis, Athens, New Acropolis Museum, Nikos Lianos: LIMENARIA THASOS MINING COMPLEX, https://www.youtube.com/watch?v=dkJrnUxcnYs, https://www.youtube.com/watch?v=TEjIME7w3B4.

LERMA, J.L., VAN GENECHTEN, B., HEINE, E., SANTANA, M., 2008, 3D Risk Mapping. Theory and Practice on Terrestrial Laser Scanning, Training Material Based on Practical Applications, Universidad Politécnica de Valencia, Spain.

PATIAS, P., GEOGOULA, O., KAIMARIS, D., GEORGIADIS, CH., STYLIANIDIS, S., STAMNAS, A., 2008, 3D Mapping using Model Helicopter and Laser Scanning: case study activities of the laboratory of Photogrammetry and Remote Sensing, AUTh, 14th International Conference on Virtual Systems and Multimedia (VSMM) dedicated to Cultural Heritage, Nicosia, Cyprus, pp.1-5.

PATIAS, P., KAIMARIS, D., GEORGIADIS, CH., STAMNAS, A., ANTONIADIS, D., PAPADIMITRAKIS D., 2013, 3d mapping of cultural heritage: special problems and best practices in extreme case-studies, ISPRS Annals of the Photogrammetry, Remote Sensing and Spatial Information Sciences, Volume II-5/W1, 2013, XXIV International CIPA Symposium, Strasbourg, France, pp. 223-228.

REMONDINO F., 2011, Heritage Recording and 3D Modeling with Photogrammetry and 3D Scanning. Remote Sensing $3(1)$, pp. 1104-1138, doi:10.3390/rs3061104. 


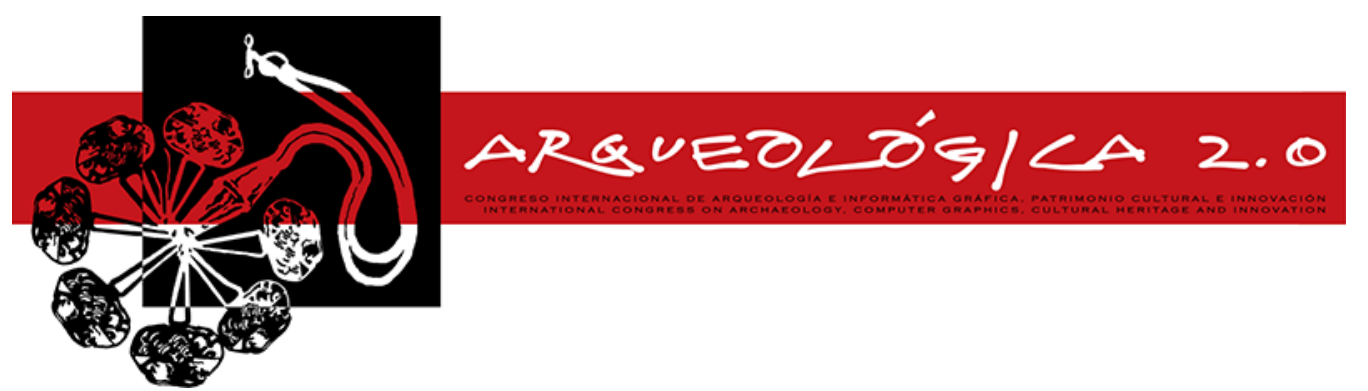

Proceedings of the $8^{\text {th }}$ International Congress on Archaeology, Computer Graphics, Cultural Heritage and Innovation

'ARQUEOLÓGICA 2.0'

in Valencia (Spain),

Sept. $5-7,2016$

DOI: http://dx.doi.org/10.4995/arqueologica8.2016.3262

\title{
A RECORDING AND DOCUMENTATION SYSTEM OF BUILDING STOCK: THE CASE OF PENTALOFOS SETTLEMENT IN KOZANI (GREECE)
}

\author{
Nikolaos Lianos, Anastasios Stamnas \\ Faculty of Architecture, Democritus University of Thrace, Greece. nlianos@arch.duth.gr
}

\begin{abstract}
:
Facing the need for effective and efficient integration of spatial and descriptive information related to the documentation of the cultural heritage, the primary aim of this project is the production of a dynamic geodatabase in order to collect, record and organize cartographic and architectural data as well as morphological and typological features of Pentalofos settlement into a GIS application. For this purpose, the project is meant, among other things, to complete a thorough research on the evolution of the settlement and its context, create the necessary geographic background for the documentation of the area of interest and to record building's technical features among others (year of construction, property status, structure, morphology, typology, description of current condition, pathology etc) by implementing traditional and up-to-date as well architectural documentation methods.
\end{abstract}

Key words: cultural heritage, documentation, GIS, laser scanning

\section{Introduction}

Innovative use of technology on the promotion of cultural information and cultural project management by applying exclusively new digital technologies, such as the internet, multimedia applications, three-dimensional computer graphics, virtual reality and Geographic Information System (GIS) applications, are nowadays objects of study for a significant number of scientists. Similar issues and problems are now addressed to a wide range of public, not only within the education and research community, but also to different professional specialties such as information technology, museology, media, history and archaeology, arts, architecture etc.

Applications of special scientific interest and the combination of different methods and techniques, such as laser scanning technology and GIS, act as a catalyst for the promotion and the management of cultural monuments and archaeological sites. Up-to-date methods and surveying equipment combined with the capabilities of GIS allow the processing of huge amount of data, acquired during the surveying and documentation process, and the creation of digital cultural heritage multimedia applications.

On the one hand, the creation of geographical index lists, dynamic maps and three-dimensional representations of cultural monuments as well, and, on the other hand, the detection of properties and the state of maintenance of monuments using the latest technology available, contribute decisively to reveal pathological causes and provide practical guidelines on rehabilitation interventions.

In this context, this project aims to exploit the potential of digital technologies by applying traditional and up-todate architectural documentation methods in order to create a recording and documentation system of building stock of Pentalofos settlement in Kozani (Fig. 1). Basis of this project was the systematic recording of a significant number of buildings during the past four "Workshops in the Conservation of Historical and Vernacular Architectural Buildings in Mastorochoria in the Prefecture of Kozani”, organized by the Laboratory of Architectural Theory of Forms and Preservation Studies, Faculty of Architecture, Democritus University of Thrace, in collaboration with the "Literature and Arts Association of Kozani Prefecture".

\section{Case study: Pentalofos settlement in Kozani}

\subsection{General information and brief history of the settlement}

Pentalofos settlement is part of Kozani regional unit, West Macedonia, Greece. It istands at about $1060 \mathrm{~m}$. a.s.I. at the foot of Voio Mountain (Fig. 2). Since the 2011 local government structural reform, Pentalofos is a municipal unit of the Voio Municipality and the population of the municipal unit for the year 2011 was 620 people.

“Corresponding Author: Nikolaos Lianos, nlianos@arch.duth.gr 
a)

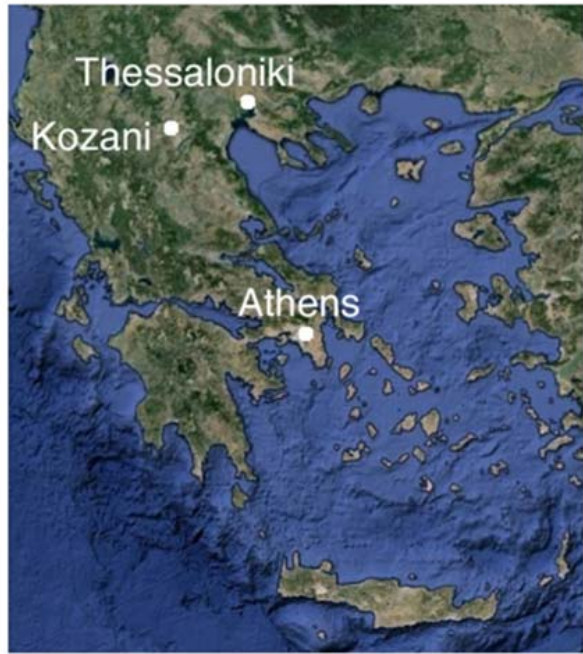

b)

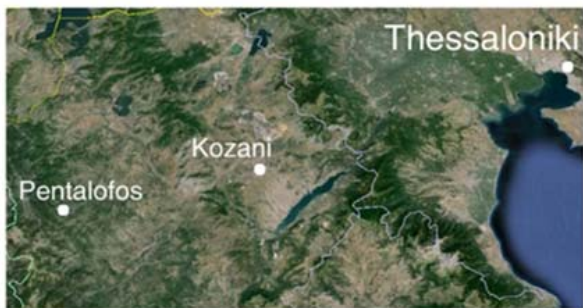

Figure 1: Map of Greece and the location of Kozani (a). The location of Pentalofos settlement (b) (Source: Gougle Earth).

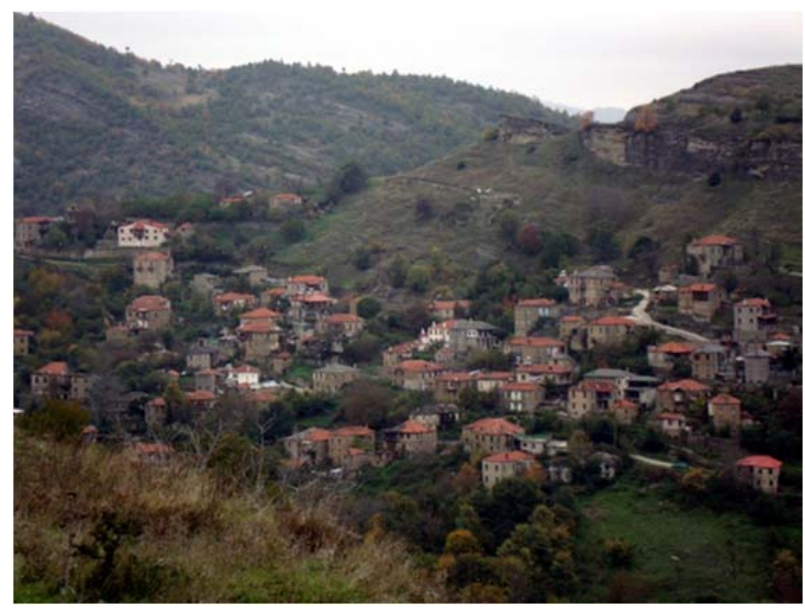

Figure 2: Panoramic view of Pentalofos (June 2014).

The first nuclei of Pentalofos settlement (Fig. 3) were formed about 1427 A.D. and then populated purely by Greek speakers from other regions of Voio and Epirus. During the Byzantine era and then the Othoman rule in Greece, the invasion by several barbaric tribes from the North continued: Celts, Gauls, Goths, Huns, Normans, Franks, Slavs and Bulgarians.

The province of Voio released and joined Greece in October 1912 A.D. During the Second World War, Pentalofos used to be a military base of the Greek army. From there, women of Pindos Mountains, loaded with ammunition, went ahead the war front and carried injured men on their return to the village. The village was bombed several times and then suffered the consequences of the Grrek Civil War. A period of poverty and abandonment followed while skilled stone and wood craftsmen migrated across and beyond Greece.

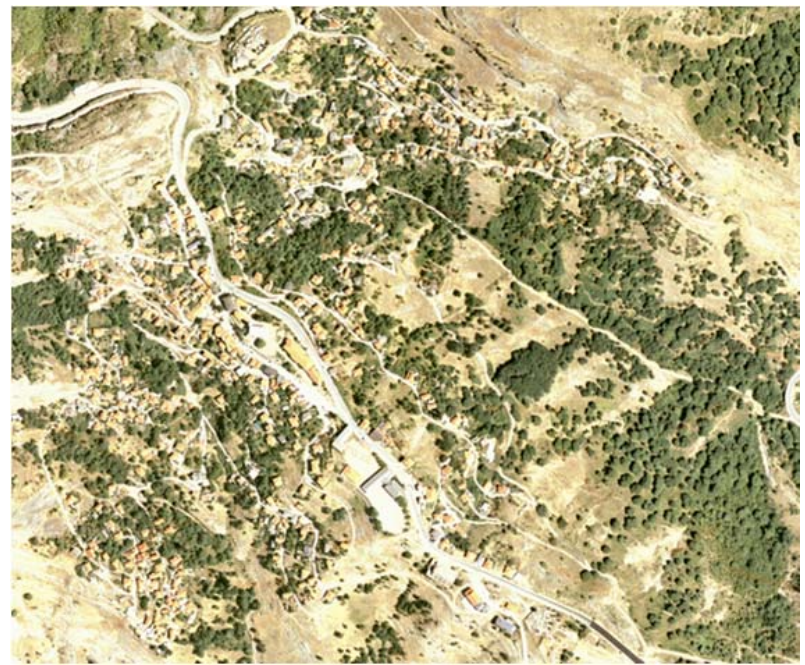

Figure 3: Aerial photo of Pentalofos (2007).

\subsection{Analysis of the settlement}

In order to understand and portray the structure of Pentalofos settlement, a large amount of data and systems, the historic settlement is comprised of, should be noted, systematically recorded and evaluated. This analysis includes the structure of neighborhoods and building plots, the organization of public and private open spaces, the arrangement of traffic network and grid road system, the system of land distribution, organization of building volumes and street fronts and the type and location of individual buildings contributing to the tissue of the village.

The systems of the urban tissue of Pentalofos settlement are as follows (Fig. 4): the system of building plots (a), the road system (b), the system of built-up and unbuilt areas (c) and the system of monuments and other significant buildings of the settlement (d).

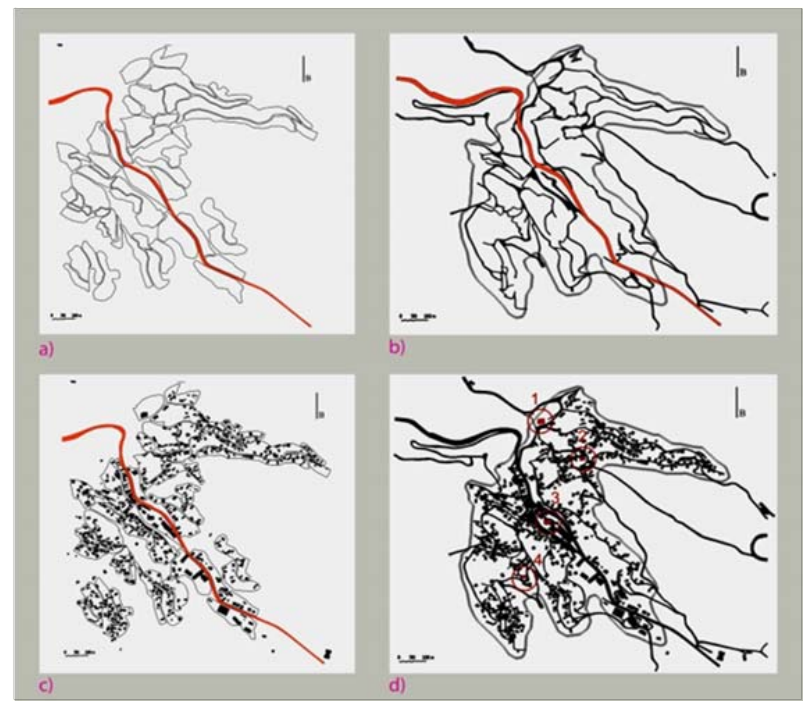

Figure 4: The structure of the urban tissue of Pentalofos. 
The arrangement of rural building plots of the settlement obeys mainly the natural geomorphologic characteristics (Fig. 5) and the natural development of the rural family as well, and it manifests as an element of diversity and picturesqueness of the vernacular architecture. The road system of the settlement is the result of extended configurations and illustrates in an obvious manner the relationships and the importance of linkages between the village and the surrounding area. In this configuration, both the topography and the location of the core functions of the settlement, the presence of significant elements of the built environment, such as religious and public buildings, have played a key role (Fig. 4d).

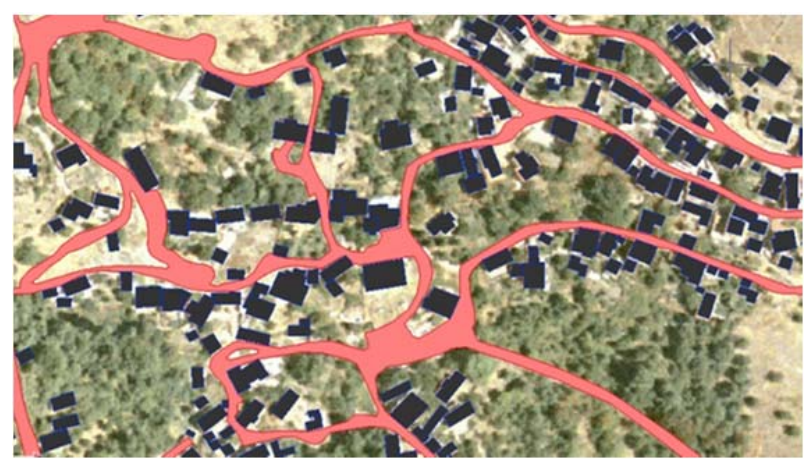

Figure 5: The system of roads and the structure of built-up areas of the down district of Pentalofos.

The system of built-up areas presents itself in varying degrees of continuity and discontinuity, arising from the location of buildings on the plot and the relations between them. Similarly, free unstructured areas are closely bound up with the built environment, as it is not possible to define a free area without comparing it with other structures. Therefore, the organization of unbuilt areas is expressed as the negative of built-up areas.

The whole number of monuments and significant buildings of the settlement represents isolated buildings and not a coherent system of buildings with a continuous form. Their presence (Fig. 6), however, is particularly important for the general structure of the settlement in spite of the changes and the transformations of their role and importance through the years.
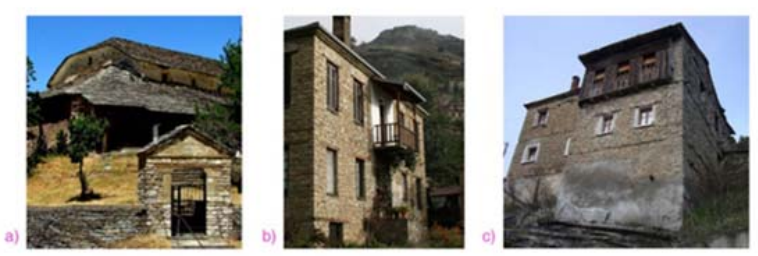

Figure 6: Saint Achilles church (a) and indicative buildings of the down district of Pentalofos (b) and (c).

\subsection{The importance of documentating the settlement}

Today, more than ever before, international committees that work for the protection of cultural heritage places such as the ICOMOS, a non-governmental international organisation dedicated to the conservation of the world's monuments and sites, or the International World Heritage Programme administered by the United Nations
Educational, Scientific and Cultural Organization (UNESCO) and charters presenting the general principles and doctrines relating to the protection of monuments such as the Athens Charter for the Restoration of Historic Monuments, adopted at the First International Congress of Architects and Technicians of Historic Monuments (Carta del Restauro, Athens 1931), the International Charter for the Conservation and Restoration of Monuments and Sites (The Venice Charter, 1964) and the Declaration of Amsterdam (The Congress of Amsterdam, 1975) express the opinion that the architectural heritage includes not only individual buildings of exceptional quality and their surroundings, but also all areas of towns or villages of historic or cultural interest.

In this context, the study of Pentalofos settlement is proposed as an instrument for the reading of its history, natural and cultural, for the understanding of its timeless progression and for the diagnosis of management perspectives towards sustainable development. For this purpose, the study is meant, among other things, to complete a thorough research on the evolution of the settlement and its context, create the necessary geographic background for the documentation of the area of interest and to record building's technical features among others (year of construction, property status, structure, morphology, typology, description of current condition, pathology etc) by applying traditional and up-to-date as well architectural documentation methods.

\section{Organizing a recording and documentation system of building stock of Pentalofos}

\subsection{Structure of the system}

The focus of this study was targeted towards, on the one hand, the production of the necessary cartographic background for the documentation of Pentalofos settlement (aerial photos and cartographic maps) and the creation of a dynamic geodatabase in order to collect, record and organizes architectural and technical features of its building stock, and on the other hand, the implementation of architectural documentation methods and the integration of all the above recordings and information of the settlement into a GIS application where all the geographic and thematic information can be stored, edited, integrated, analyzed and finally displayed in maps, each one of them portraying and highlighting a unique urban feature of Pentalofos settlement.

\subsection{Cartographic background and registration bulletins}

Aerial photos and cartographic maps (Fig. 7), provided by the Hellenic Military Geographical Service and the Lands and Mapping Service of Greece of The Ministry of Environment, were used as the necessary cartographic background for the recording, the analysis and the documentation of the settlement. After their geographical reference using the appropriate softwares (e.g. ERDAS Imagine), these maps gave a complete picture of the evolution of the settlement and its context through years. 


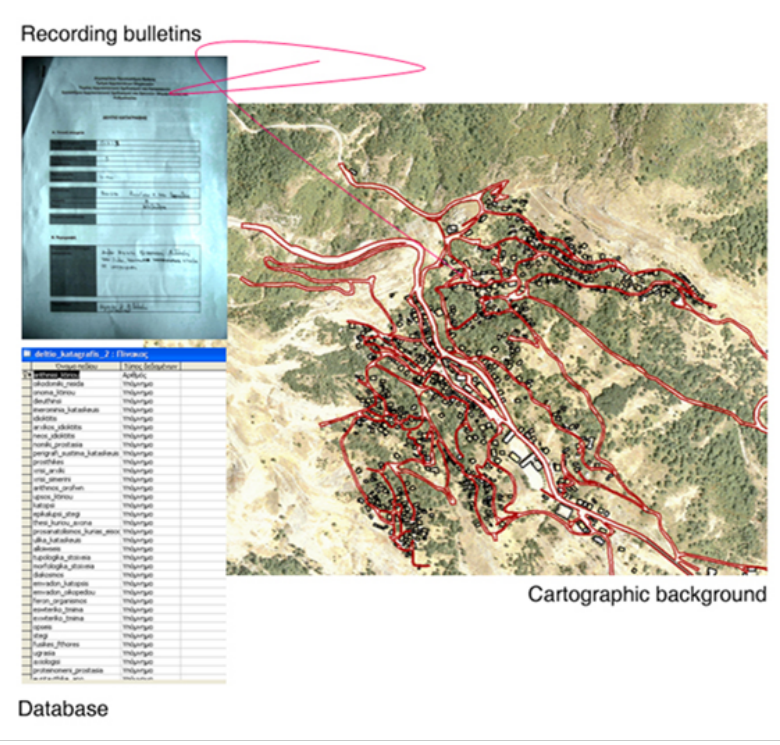

Figure 7: Cartographic background, registration bulletins and database used for the documentation of the building stock of Pentalofos settlement.

A thorough and systematic documentation of the building stock of Pentalofos was followed using registration bulletins (Fig. 7), specially designed for this purpose. As a result, a great number of important features of the buildings (total number: 38) were recorded. These features concern the chronology, the property, the morphology, the typology, the construction, the history and other information about the building stock of the settlement. For instance, these characteristics can de divided into two main groups:

A. The building code, the building plot, the building name, the region code, the construction date, the owner (original or new), the constitutional protection, the type of use (original or current) etc.

B. The construction system, the ground plan, the façades, the roof, the interior and the exterior parts, the number of floors, the total building height, the state of conservation, the protection grade etc.

Afterwards, all the features described above were properly and accurately organized and registered into a database (Fig. 7).

\subsection{Architectural documentation methods}

Heritage recording is the capturing of graphic and photographic information describing the physical configuration, evolution, and condition of a heritage place. Today, due to rapid technological development in the field of measured survey techniques, a broad range of recording techniques can be applied and the measured survey tool (or combination of tools) that will best match project requirements can be chosen. In this context, traditional and up-to-date as well architectural documentation methods were implemented in order to record the building stock of Pentalofos settlement. The three main types of documentation, applied for this purpose, were as follows:

A. Photographic documentation and detailed measured drawings.
B. Topographic and photogrammetric techniques.

C. 3D laser scanning techniques.

The first type of documentation involved baseline measurements (plans, roofs, cross sections and façades) and photographic recording of each building (Fig. 8). This procedure helped to get a preliminary understanding of the current condition of the buildings, the way they were built, their arrangement etc. Along with photographs, measured drawings were actually key components of the heritage record of the settlement. Their production, taken hand in hand with a series of dimensional, topographic, and structural analyses, was an indispensable part of the process of understanding the building stock of the settlement.

a)
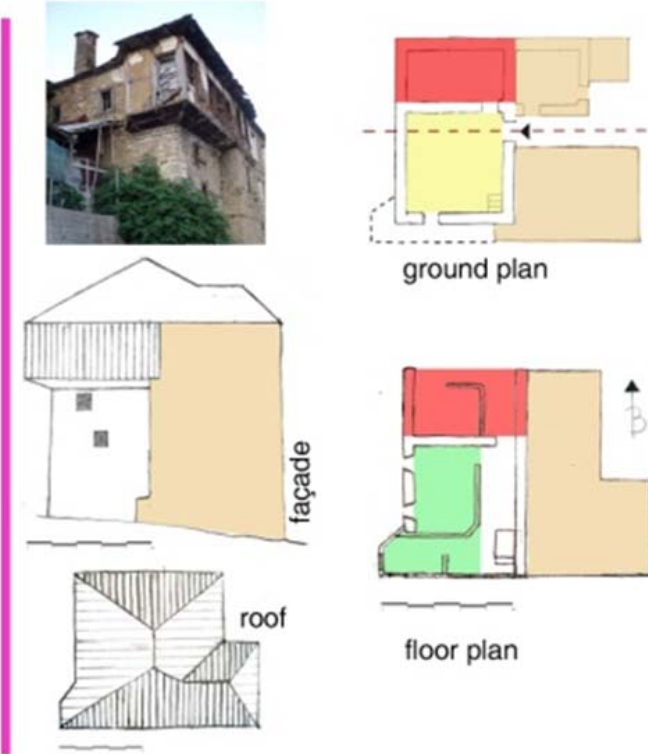

ground plan

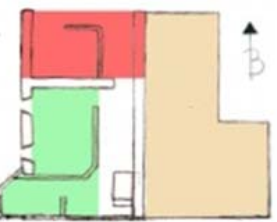

floor plan
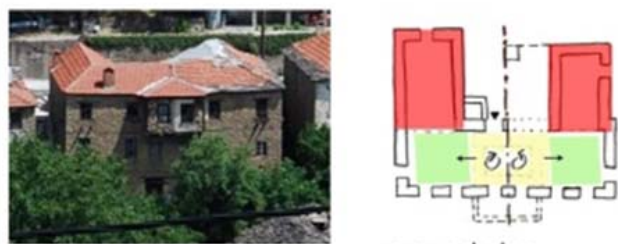

ground plan
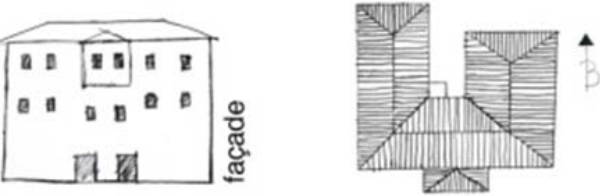

roo

b)

Figure 8: Photographic documentation and schematic drawings of three buildings of Pentalofos settlement.

Topographic and photogrammetric techniques were used as well for the documentation of a small number of selected buildings of the settlement. Control points were 
measured using survey instruments (total stations) and photogrammetric images were rectified and scaled in order to produce digital photographic base map of the building façades (Fig. 9).

The four byzantine monuments of the settlement, Saint Athanasius church (Fig. 10), Saint Achilles church, Saint George's church and Saint Barbara's church, were recorded using 3D laser scanning techniques that made it possible to create high-resolution $3-D$ models and accurate and reliable drawings of the monuments, such as plans, cross sections and façades.

The implementation of the above methods made it clear that, even though the work that is in direct contact with the object is crucial, new technologies, such as laser scanning, can better fulfill the requirement of documentation. In this regard, the correlation of manual measured drawings that have a clear advantage with mechanized methods, such as photogrammetry or laser scanning, clarifies most questions concerning the documentation of a monument.
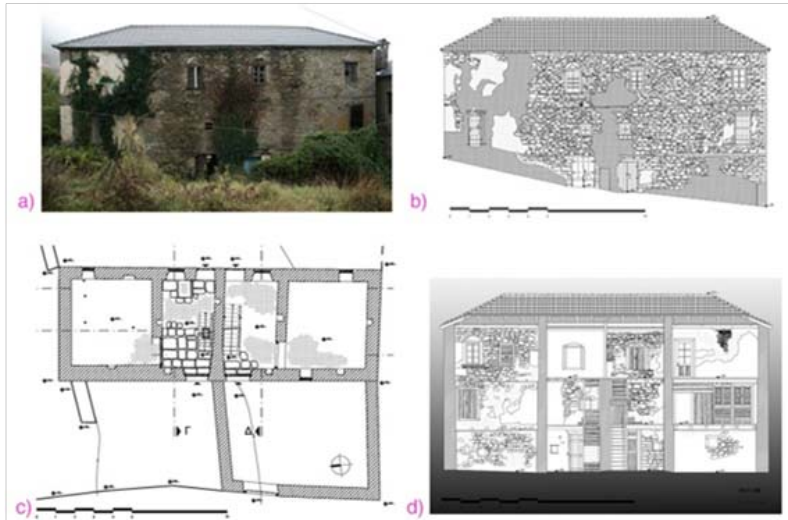

Figure 9: Photographic documentation: (a) and detailed drawings of a building, façade; (b) ground plan; (c) and cross section; (d) using topographic and photogrammetric techniques.

a)

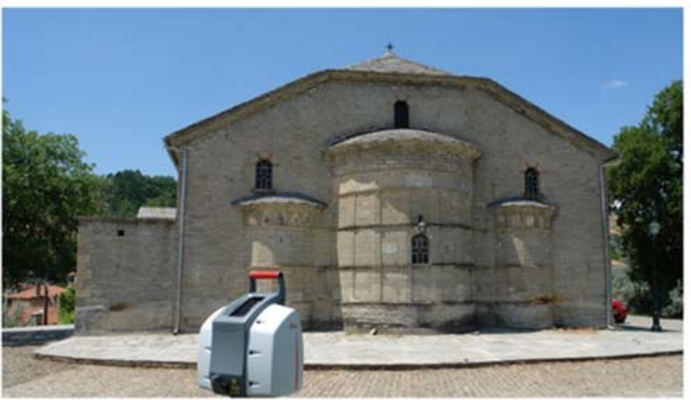

b)

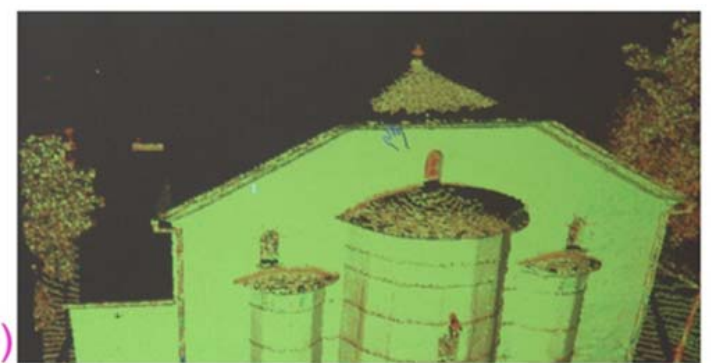

Figure 10: Laser Scanning: (a) and 3D data processing; (b) of Saint Athanasius church.

\subsection{GIS application}

This part of the project derives from the conjunction of the previous ones. It focuses on the creation of a geodatabase in which cartographic background, registration bulletins, drawings and documentation are related using a GIS application (Fig. 11). So all the above recordings and information of the settlement converge and join with the available spatial information of the area of interest.

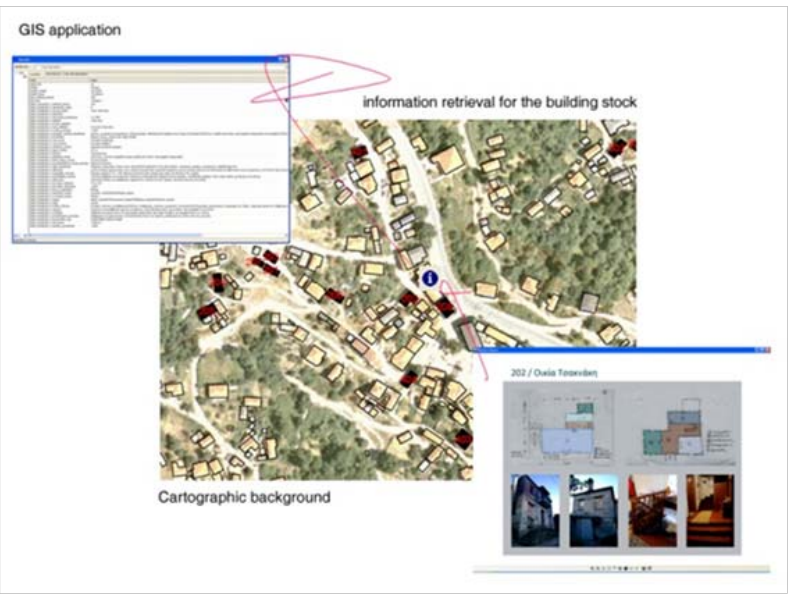

Figure 11: GIS application for the building stock of Pentalofos settlement.

The GIS can be described as a computer system capable of integrating, storing, editing, analyzing, displaying, and sharing geographically referenced information. In general, GIS applications are tools that allow users to create interactive queries, analyze spatial information, edit data, maps, and present the results of all these operations. In this case study, all the geographic information was stored, edited, integrated, analyzed and finally displayed in thematic maps. Appropriate data analysis and processing provided a significant number of thematic maps, each one portraying and highlighting the unique architectural, morphological and typological features of Pentalofos.

\section{Conclusions and future work}

The detailed recording of the architectural, morphological, typological, etc. characteristics of the building stock of Pentalofos settlement provided a better understanding of the examined heritage in terms of values, condition and relationship to the urban context.

Like all research activities, architectural survey needs careful project design and the choice of methodologies depends on case-specific factors. All recording operations must be carefully documented and the outputs (graphic representations, photographs, archival documentation etc) must be examined critically.

As far as the documentation of the building stock of Pentalofos is concerned, the integration of different techniques has proved to be indispensable. The GIS application for the record, analysis and documentation of the settlement played a key role in the whole project. Such a GIS application can be a useful tool for its institutional protection. Thus recording of the current situation of the settlement can be particularly useful as a substratum for restoration works. Alongside the detailed 
recording may help in further analysis and the export of many important findings concerning our cultural heritage.

\section{Acknowledgements}

We would like to express our sincere thanks and appreciation to those who attended the past four "Workshops in the Conservation of Historical and
Vernacular Architectural Buildings in Mastorochoria in the Prefecture of Kozani", organized by the Laboratory of Architectural Theory of Forms and Preservation Studies, Faculty of Architecture, Democritus University of Thrace, in collaboration with the "Literature and Arts Association of Kozani Prefecture" and helped with field measurements and data acquisition and processing as well.

\section{References}

AGAPIOU, A., GEORGOPOULOS, A., IOANNIDES, M. and IOANNIDIS, Ch., 2008. A Web Based GIS for the Byzantine Churches of Cyprus, Conference on Virtual Systems and MultiMedia Dedicated to Digital Heritage, Project Paper Volume pp. 148-151.

HADDAD N.A., 2011. From ground surveying to 3D laser scanner: A review of Techniques Used for Spatial Documentation of Historic Sites, Journal of King Saud University - Engineering Sciences, Volume 23, Issue, 2, pp. 109-118.

HERAS V., STEENBERGHEN T., ZÚÑIGA M., CARDOSO F., SANTANA M. and VAN BALEN K., 2012. An Information System for Heritage Documentation Management of Cuencacity, Ecuador, MASKANA, Revista semestral de DIUC, Vol. 3, No. 1.

LETELLIER R., SCHMID W. and LEBLANC F, 2007. Recording, Documentation, and Information Management for the Conservation of Heritage Places: Guiding Principles, The Getty Conservation Institute.

MAISTROU H. and PSYCHOGYIOS D., 2006. Presentation of an Integrated System for the Recording and Documentation of the Cultural Heritage of a Historic City. Digital Registry for the Historic Centre of Nafplion, The 7th International Symposium on Virtual Reality, Archeology and Cultural Heritage, VAST.

PAPPA K., GEORGOULA O., STAMOU A., STAMNAS A. and KAFKOULA K., 2009. Record, Analysis and Documentation Using GIS Applications for the Institutional Protection of Enoria Settlement in Greece, 22nd CIPA Symposium, Kyoto, Japan.

PATIAS P., STAMNAS A., GEORGIADIS CH., STYLIANIDIS E. and KAIMARIS D., 2011. Mapping of Buildings Facades' at the Historical Centre of Nicosia and Creating a Preservation Information System, XXIII CIPA Symposium, Prague, Czech Republic.

REMONDINO F., 2011. Heritage Recording and 3D Modeling with Photogrammetry and 3D Scanning. Remote Sensing 3(1), pp. 1104-1138, doi:10.3390/rs3061104. 


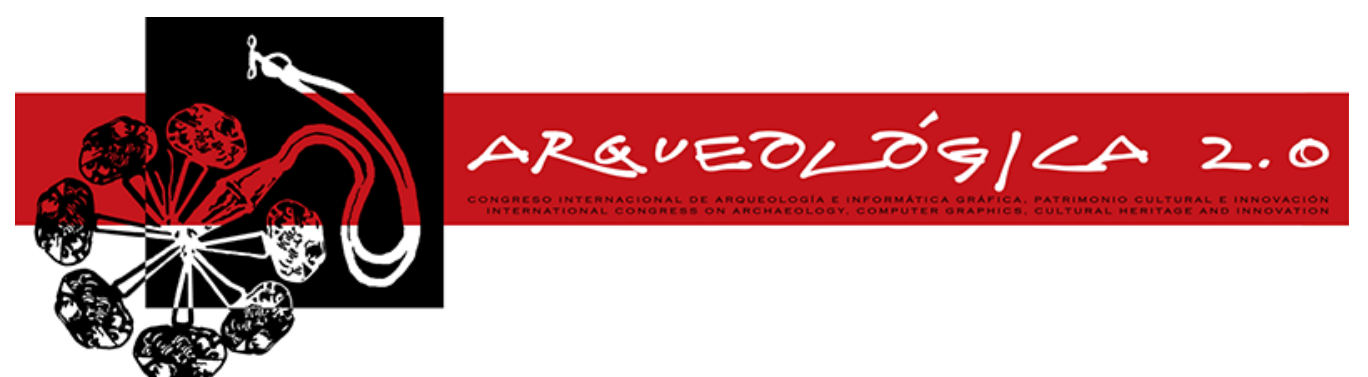

Proceedings of the $8^{\text {th }}$ International Congress

on Archaeology,

Computer Graphics,

Cultural Heritage and Innovation

'AROUEOLÓGICA 2.0'

in Valencia (Spain),

Sept. 5-7, 2016

DOI: http://dx.doi.org/10.4995/arqueologica8.2016.3318

\title{
PHOTOGRAMMETRIC SURVEY AND 3D MODELING OF THE FUNERARY URN DEPICTING THE MYTH OF OENOMAUS, FOUND INSIDE THE TOMB OF THE ETRUSCAN FAMILY OF CACNI IN PERUGIA (III-I CENTURY BC)
}

\author{
LEVANTAMIENTO FOTOGRAMÉTRICO Y MODELADO 3D DE LA URNA FUNERARIA QUE REPRESENTA EL \\ MITO DE ENOMAO, ENCONTRADA EN LA TUMBA DE LA FAMILIA DE LOS ETRUSCOS CACTOS EN PERUGIA \\ (III-I AC) \\ Daniele Calisi
}

Dipartimento di Architettura, Università degli studi G. D’Annunzio Chieti Pescara, Viale Pindaro, 65127 Pescara, Italy. d.calisi@gmail.com

\begin{abstract}
:
The urn, recovered in 2013 by the Cultural Heritage's Police Command along with other 21 and with the funeral set of the tomb of the Cacni family at Perugia, was exhibited at the Quirinale and then moved to Perugia, at the National Archaeological Museum of Umbria. 2014. After a first attempt to survey the laser scanner, the survey, aimed at the graphic documentation and implementation of a virtual model for the study and dissemination, has been performed with photographic processed with software modeling structure from motion.

3D model in mesh made with the appropriate software has been cleaned of all its impurities: holes, tips, noise and rough surfaces. To conclude the process, the mapping from photography, with high resolution textures, giving the mesh the appearance next to the real funerary urn. The survey work on the urn of Oenomaus is a case in point, both for research of best practices in the surveys of archaeological objects, both in the ultimate goal of the relief: not only cataloging and knowledge, but also of divulging to a wider public.
\end{abstract}

Key words: virtual archaeology, digital archaeology, 3D reconstruction, etruscan funerary art, photogrammetry, photomodelling, texturing, Mesh managing

\section{Resumen:}

La urna, recuperada en 2013 por el Comando de Policía del patrimonio cultural, junto con otros 21 y con el conjunto funerario de la tumba de la familia Cacni en Perugia, fue exhibida en el Quirinale y luego se trasladó a Perugia, en el Museo Arqueológico Nacional de Umbría. 2014. Después de un primer intento de estudiar el escáner láser, el levantamiento, dirigido a la documentación gráfica e implementación de un modelo virtual para el estudio y la difusión, se ha realizado con procesado fotográfico con software de modelado structure for motion.

La malla 3D realizada con el software adecuado se ha limpiado de todas sus impurezas: agujeros, las extremidades, el ruido y superficies rugosas. Para finalizar el proceso, el mapeo de la fotografía, con texturas de alta resolución, dando la malla la apariencia de la urna funeraria real. El trabajo de investigación en la urna de Enomao es un ejemplo emblemático, tanto para la investigación de las mejores prácticas en levantamiento de objetos arqueológicos, tanto en el objetivo final del relieve: no sólo la catalogación y el conocimiento, sino también el difundir a un público más amplio.

Palabras clave: arqueología virtual, arqueología digital, reconstrucción 3D, arte funerario etrusco, fotogrametría, fotomodelado, texturizado, malla de gestión

\section{Introduction and study cases}

In recent years the use of laser scanners and photographic modeling has increased significantly. They are now essential tools especially in the surveying and knowledge of the built. However, it is the archeology sector that lately is mainly using these tools. Particularly in the excavations, it is essential to document and save the data of each stratification: no instrument can be today more useful to for scanning the layer of which we have to build the digital surface. No more photographs to witness the excavation but three-dimensional models "layered". Personally, I experienced both technologies and practice allows us to understand and analyze the methodologies that become experimentation and then sap for research in the field. 
One of the first work performed with the software PhotoScan, was an assignment for the survey and photogrammetric survey of the Lodge of the Rector's Palace in Dubrovnik designed by Onofrio della Cava. Photografic campaign aimed at creating a 3D mesh model with software structure for motion of the engraved capitals by Pietro di Martino da Milano.

We performed a $3 \mathrm{D}$ modeling, high resolution texturing and profiling of the capitals of the porch (consultancy related to the Recovery Plan of the urban space promoted by the Municipality of Ragusa. 2013/2014).

Among the capitals finely chiseled, one in particular has special prestige for the shapes and the executive detail. The point cloud and 3D mesh model were realized through a detailed photographic campaign (Calisi 2014). The distance of the mesh points is less, in some cases, than $1 \mathrm{~mm}$, ensuring a very faithful reproduction of the original. In addition, the high-resolution texture allows also to better appreciate the 3D display.

A second case study, following the Croatian experience, is in Rome: the church of Santa Maria di Loreto in the Forum of Trajan. An entire building, no longer a portion of it. In this case, the data provided by the photographic restitution are less detailed, because it is obviously less close up the photographic campaign. Having to frame the entire building is at the expense of details capitals or moldings. However, the analysis of the point cloud and mesh model, the comparison with the original design or with later surveys, have provided interesting and innovative conclusions on the seventeenth-century church (Calisi and Cianci 2014).

The use of photographic modeling in this case study is one consistent for the reconstruction of the basement floor, attributed to Antonio da Sangallo, the verification of the measures and proportions and the search for the basic module, however measured in palms (Fig. 1).

I leave to the reader the desire to better understand the topic by reading the article inserted in the bibliography.

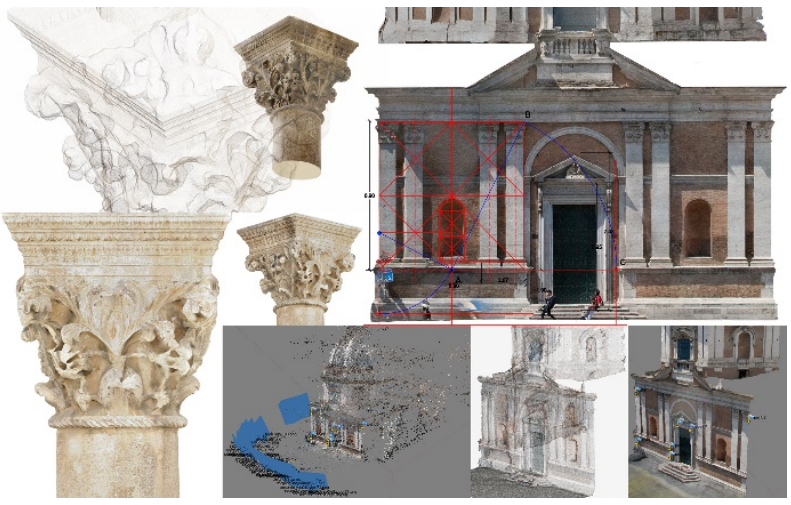

Figure 1: Two case of study: the capital Lodge of the Rector's Palace in Dubrovnik; Santa Maria di Loreto in Rome. 3D

modeling, high resolution texturing. Analysis and comparison of data.

For this paper, however, I present another job followed with Margherita Caputo and Luisa Bogliolo, which is inherent to the archeology theme, it is a wonderful Etruscan urn. In the last months of 2013, the engineers of the Central Institute of Restoration were engaged in the restoration of 21 Etruscan urns and a lid sarcophagus and their kit, retrieved by the Police after a long detective investigation (Godart 2014).

The choice of the urn to detect fell on the one depicting the myth of Oenomaus, dated between the late third and early second century $\mathrm{BC}$, for different reasons: a) the plasticity of the high relief; b) the narrative succession masterfully recounted; c) the richness and detail of the figures and decorative elements; d) the rests of gilding surface that emphasize the narrative elements of the composition; e) the traces of blue that highlight the bottom part while the red color defines the hairstyles.

An urn that has a unique artistic importance. Moreover, all the elements described provided the opportunity to make a virtual model for the study and dissemination, as well as the production of orthophotos and 2D graphics for documentation of techniques of execution, of the conservation status and restoration interventions.

On the basis of the objectives pursued it was decided to perform a three-dimensional survay of precision, enabling a high-resolution digital modeling that can also be used for the possible reproduction of the object as well as for the more traditional 2D drawings (Fig. 2).

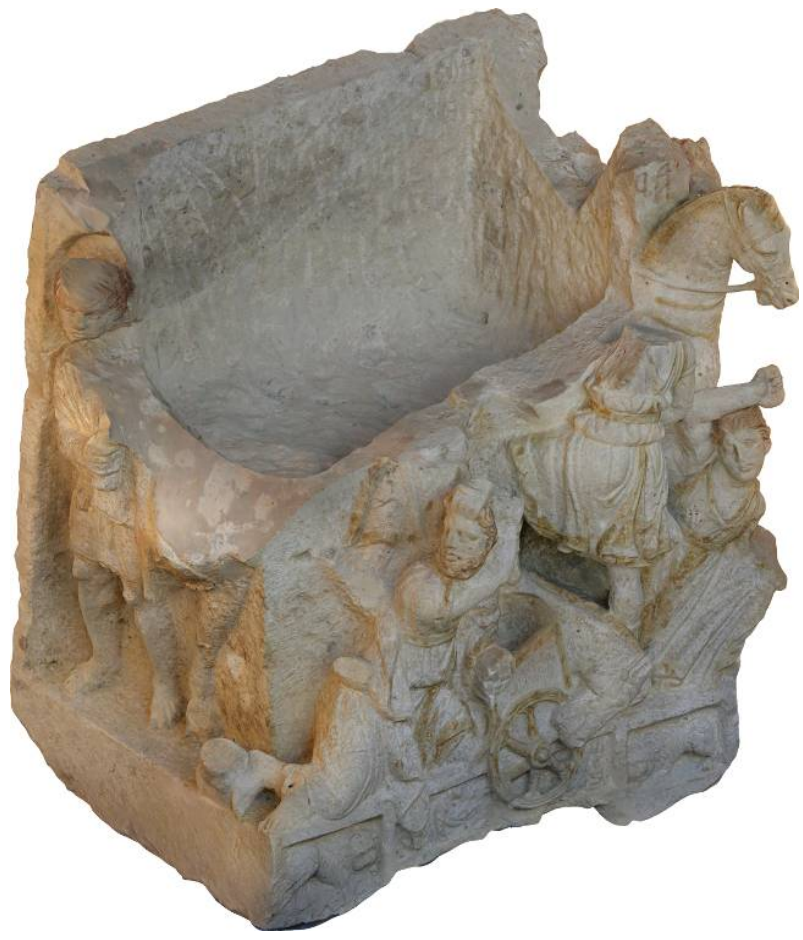

Figure 2: Orthophoto in isometric view (parallel projection), made by PhotoScan. the 3D model is mapped directly from the photos with textures of 16,000 pixels per side. Two of the three sculpted sides are shown.

The choice of technology to be used has been affected by both the instrumentation used both by time, limited, for the acquisition and data processing. We had the availability of a laser scanner Leica HDS 6200 phase shift detection, useful for application to architectural scale, but little effective for close-ups and for the appreciation of details below $1 \mathrm{~mm}$.

But finally, it was decided to experiment with digital photogrammetry that, starting from a set of twodimensional images and making use of algorithms SFM (Structure from Motion) complemented by stereo 
matching algorithms that allows to obtain photo-realistic 3D models that contain all the information (geometry and texture) quickly with use of hardware and software solutions low cost or open source and without renouncing to accuracy and quality of the result.

According to the camera that is used is also possible to determine the scale of representation in which it is possible to show the detected object, so that details are not lost. To calculate it takes advantage of the GSD, ground sample distance, which identifies the smallest element of real space that can be represented in the digital image, taking into account the sensor pixel size.

It is obviously useful when the survey design, to determine the distances of the shooting points from the object. However it is just as useful, if you were bound to cramped conditions or impossibility, instead, the closeups, to understand to what scale of representation you can push in the final communication.

The proportional relationship between the shooting characteristics are:

Focal Lenght: Pixel size of the sensor $=$ Distance camera object: GSD

The focal lenght is determined by the distance of the sensor from the projection center. The size of the pixels of the sensor is a given by the DigiCams factory. The unknowns at this point, in this equation, can be or the shooting distance, or the GSD, that is the minimum recordable detail.

In the case study, instead, the GSD is the equation's unknown: because of the reduced physical space, all shooting was done at an average distance of about 2 meters, with a EOS 5D Camera, with a pixel size of $2 \mu \mathrm{m}$, with a $24 \mathrm{~mm}$ focal length. Then:

GSD $=(D \times$ pixel $) / f$

GSD $=(2000 \times 0,0082) / 24$ (all in $\mathrm{mm})$

GSD is $0,683 \mathrm{~mm}$, which means that from this distance it is possible to represent less than one millimeter without having representation errors. Which of course it makes me realize that the detail of the 3D model that I will get will have a very high resolution, with a consequent heaviness of the file, and management difficulties.

However, the team has preferred to work, during shooting, ensuring the highest possible resolution, also in view of possible future technological developments and provide for the decimation of the mesh in the second phase, preserving in a separate file the original mesh.

The relief has always been a necessary tool for the analysis and knowledge of an object, but in recent years it is possible to perform surveys with a high level of detail thanks, in particular, to the use of photogrammetry systems based on images processed by algorithms of automation of Computer Vision. The results that can be achieved with these new technological applications are of great interest especially in the fields of application of the Architectural and Archaeological Heritage.

In photogrammetry, the techniques used for orientation, as the collinearity equations, ensured greater accuracy. However, the ever-greater accuracy in Computer Vision and reliability of the result have called, in a sense, in the discussion the rules of photogrammetric. In the image based modeling shall apply different algorithms and linear mathematical models for calculating the orientation and searching of the homologous points, in a more simple but at the same time more efficient way.

One of the expedients which allows a better calibration of the orientation of the camera is definitely to have a major characterization of the surfaces of the objects to be detected: a uniform and white stone hardly lead to the realization of a three-dimensional model, but it doesn't happens for the urn of Oenomaus, where we find a porous travertine (with holes of different sizes), painted in different areas and in which there are also evident light and shadow zones.

\section{Analysis of photogrammetric survay}

The funerary urn of Oenomaus was likely to be placed against a wall, or with one side not visible. However, the particular archaeological discovery, isolated from the context, gives great importance to each his portion: for this reason it was decided to proceed with a photo campaign aimed to the survey and the creation of a three-dimensional model that embraced each side of the urn, except for the basement of support.

Five out of six sides therefore have been the subject of a photographic campaign that would allow to shoot the work in its entirety.

It is possible to recover the spatial coordinates of a point, using the rules of photogrammetry, using at least a pair of photographs from two different points of view, in which, of course, the point of unknown coordinates is visible. The two frames are placed in relative position but such as to respect the position of the shoot (exploiting some intrinsic parameters of the camera and extrinsic ones of the environment) (De Luca 2011).

For each real point $\mathrm{P}$ there are two homologous points $\mathrm{P} 1$ and $\mathrm{P} 2$ on the respective frames and for each one there is a visual ray which start from the relative point of view, intercept the homologous points and should intersect in space in one and only one point (P) (Fig. 3).

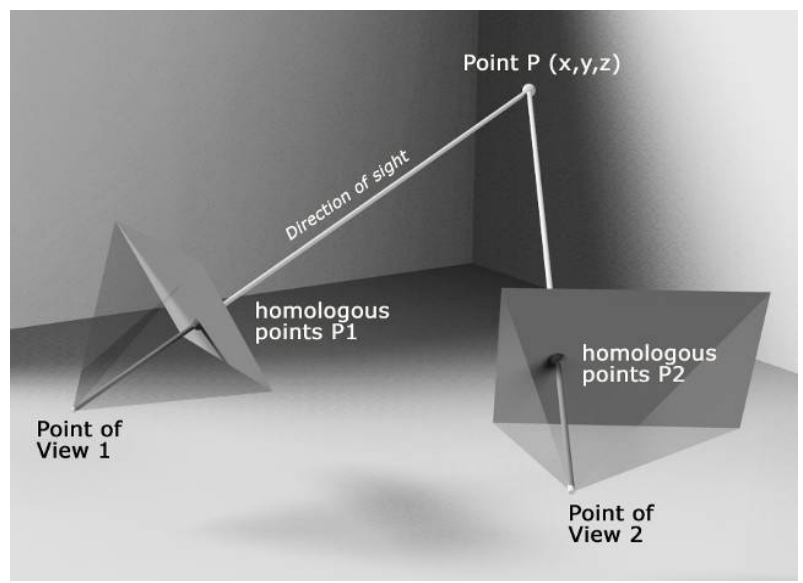

Figure 3: Scheme of reconstruction of the ordinates of a point $\mathrm{P}$, given two photographs randomly oriented in space and sighting the same point.

The 3D image is defined as a set of points in space, a cloud of points, corresponding to the respective homologues in the photos, from which we can start for 
the realization of a real three-dimensional model in mesh (De Luca et al. 2011).

Some modern software, such as Agisoft Photoscan, allows creating mesh models that can be scaled, in which set some points called target, and on which take any measures that are needed, without having to perform a direct survey.

However, the realization of the $3 \mathrm{D}$ model is a complex process and requires good knowledge of shooting and photographic technique, and knowledge of the software used.

In our case, the camera was placed in about one hundred and forty different positions, following meridians and parallels of an ideal sphere that envelopes the urn itself.

Even the orientation of the camera changed by position, basically following the normal to the sphere at the point of station: in a central location we sight the equator; in a lower position looks upward and vice versa for the upper position (Fig. 4).

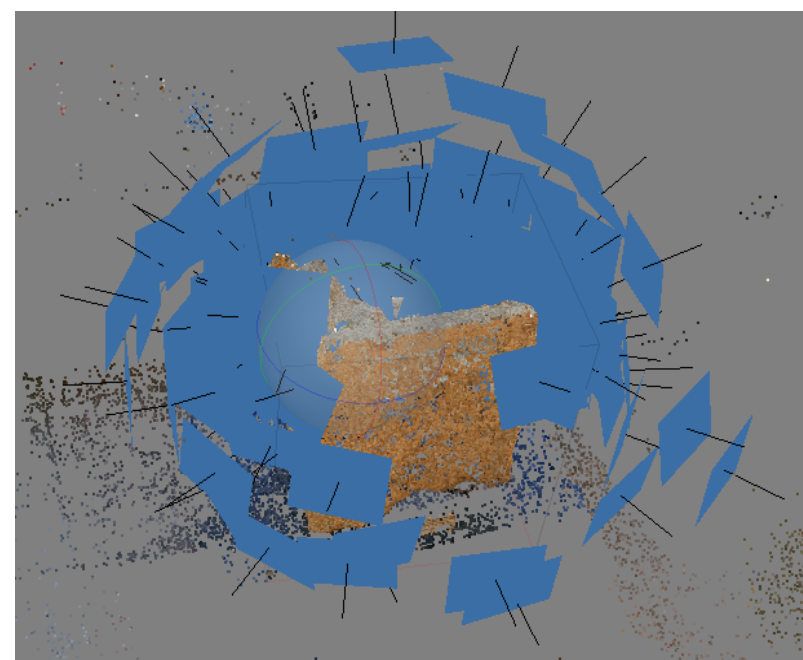

Figure 4: Alignment of the 138 positions of the camera, from which we photographed the urn, according to a virtual sphere divided into meridians and parallels.

The density of shooting has allowed to cover virtually with photos every portion of the urn, which is essential for the posthumous realization of a high-resolution textures.

Moreover the pictures are at full resolution of the camera and, considering the need to have perfectly clear shoots, was used a Canon EOS $5 \mathrm{D}$ with $24 \mathrm{~mm}$ lens, a diaphragm rather closed (the large windows in front of the urn provided enough light) to $f$ / 16 which would widen the depth of field and have each point of the urn in focus within the photograph.

This is in reality a necessary condition for the success of the three-dimensional reconstruction: in fact, if the software identifies the orientation of the cameras even through the matching of homologous points recognized in two or more frames, it is evident that the more the image will be in focus the more precise will be the calibration.
Recognition of points inside of the pictures is essential and it is necessary to use all the tricks to be able to get the highest possible number of pairs.

For this purpose, the areas not reached by direct light of the window were illuminated using auxiliary lights, artificial and with rather large diffusers to simulate an area light, completely analogous to that of the main glass window.

The use of artificial lights that blend with the natural light, however, causes chromatic effects less than optimal: the urn appears to be in part under cold temperature color of lighting and partly under a different color temperature, of a warmer tone. The particular location and reduced space does not, unfortunately, have allowed a similar type of homogenous illumination all around the urn: the window was being totally binding from this point of view.

However, despite being a negative factor from the purely chromatic point of view, this anomaly has also allowed a more accurate recognition of the positions of the cameras.

In fact, thanks to the colder colors areas due to natural light and to those warmer due to artificial light, the software has organized better the spherical grid that envelope the model, and the recognized better the orientation of the camera.

The color problem was solved in the next step, after the positive result in the creation of three-dimensional model (Fig. 5).

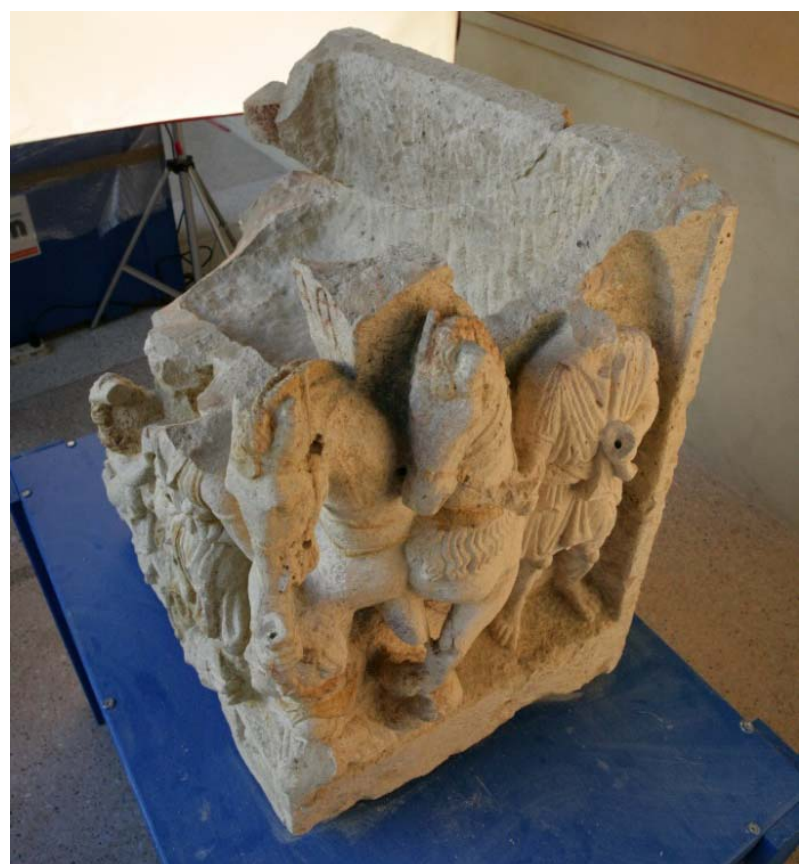

Figure 5: The funerary urn of Oenomaus, placed over a large wooden base, and artificially lit for backs. The mixture of natural and artificial light, has caused some color effects useful to the recognition of homologous points: the main front is subjected to natural light with cold tone; the two side faces are exposed to cold tones and warm tones (caused by artificial lighting); the back face has only warm tones because it is almost completely illuminated by artificial lights. 


\section{Analysis of the mesh obtained: problems of open holes and heaviness of the file}

The software used for the construction of the model was Agisoft PhotoScan. The algorithm used is that at the basis of normal photogrammetry: recognition (no more manual but systematic) of corresponding points (homologous) in at least two shots, identification of the points of view on the basis of internal parameters of the cameras, and finally tracking of two visual rays which depart from the point of view, pass through the homologous points and intersect in space recreating the original spatial coordinates. This process is, however, carried out not more for only two frames, but for a much larger amount (138 in this case).

The first step therefore is to align all the photographs taken. In this phase, the software examines only some homologous points to create a grid, a point cloud discreet and lightened. In this case, for example, of approximately three hundred and eighteen thousand points, which are obviously a considerable amount, that is to envisage a three-dimensional mesh model very detailed. The internal parameters of the camera are essential for the recognition of spatial positions: focal length, orientation, features of the body of the camera and the targets used, are stored in the metafile of every shot.

The parameters for the alignment of the camera in PhotoScan have been set to the maximum. Very high accuracy, because in this way there is greater accuracy and the software works with full-size images. Lowering this value we downscale image size to a quarter (half each side) and subsequently of $1 / 16$. Pair preselection is set to Generic preselection mode: in this way the overlapping pairs of photos are selected by matching photos using lower accuracy setting first (Fig. 6).

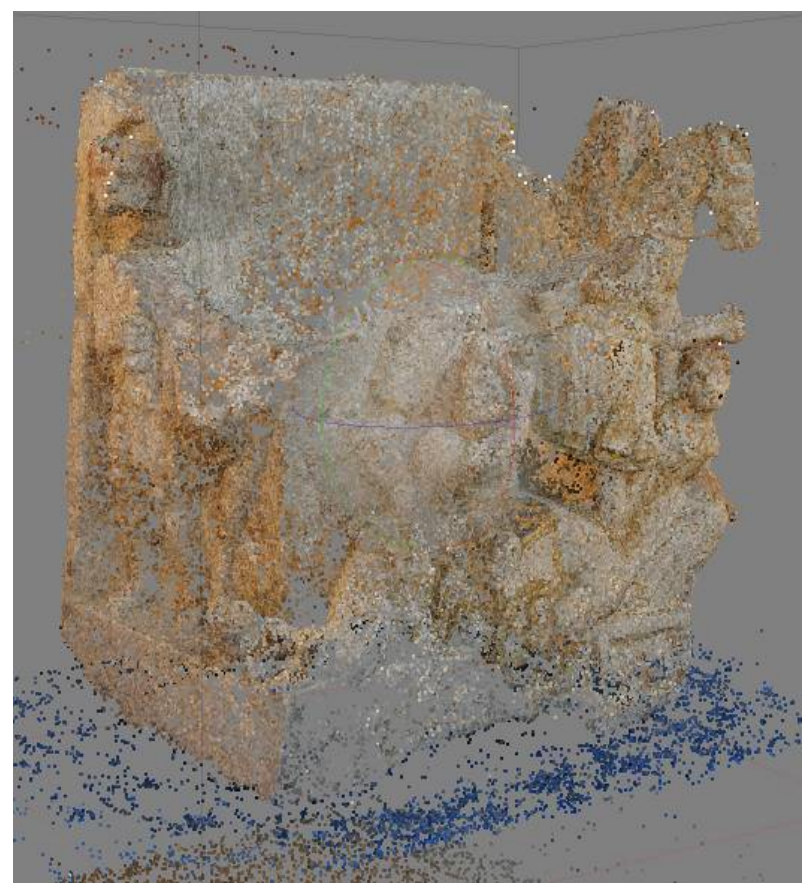

Figure 6: Synthetic cloud of homologous points generated by the software following the first alignment of the positions of the camera.
The second step involves an increase of detail through the recognition of many more points within the grid of characteristic homologous points of the beginning. Than create the geometry, ie the mesh, in triangular surfaces (sometimes square, quad) whose vertices has placed on points of the dense cloud.

The parameters set for the creation of the geometry primarily concern the type of object, which in this case is arbitrary, that is, a generic object and amorphous rather than planar as a ground. The geometry is set to sharp, to avoid that the software would combine arbitrarily holes that are inevitably create. Quality target was set at medium in definitiva.purtroppo a high value not allowed to get a result because of PC crash.

The density of the points is sometimes really impressive: in the case proposed vertices are about ten and a half million, with a distance between the points, at times, of less than a millimeter.

A mesh that is so dense unfortunately, at least with normal hardware instrumentation, is even impossible to navigate. Each operation on the mesh is inevitably fatal to the stability of the processes of the PC, so as to lock the system constantly.

Unfortunately this is a common problem now with modern instruments: increasing amounts of information (captured with a laser scanner or through photomodeling) have no equivalent and constant development of hardware.

Even also by an analysis of the obtained mesh (requireing more work in post processing), that is dense but with dirty areas or holes in the surface, we felt it was necessary and inevitable to provide for a gradual decimation of mesh. This is a simplification by elimination of triangles, trying to find an appropriate solution between the density made to the model by the software and the manageability of the same with the appropriate software.

The decimation made was rather significant, from twenty million faces to five million faces. However, this strong decimation did not alter the formal characteristics of the digital urn and with the creation of a high resolution textures applied to the mesh seems almost that there are no differences in definition.

Moreover, as already mentioned, the surface presented of open holes, voids, essentially caused by two reasons: a problem of shooting, and a poor lighting in much hidden areas. The first reason is depended on local conditions: the urn placed on a large wooden base that however hid shots that should have made from the ground, aiming upwards. Therefore, some areas were not fully covered by the photographs, especially the lower portions of protrusions in the low end of the urn. The second reason, instead, it depends on the inability of the software to recognize homologous points in dark areas, where there is a strong contrast. Therefore, in those areas, the algorithm is not able to complete the surfaces.

Agisoft PhotoScan is not a program dedicated to the management of the mesh, therefore in order to refine the obtained model we had to export in OBJ format to be able to manage with other platforms like MeshLab, or, in our case, with Geomagic (Fig. 7 -8). 


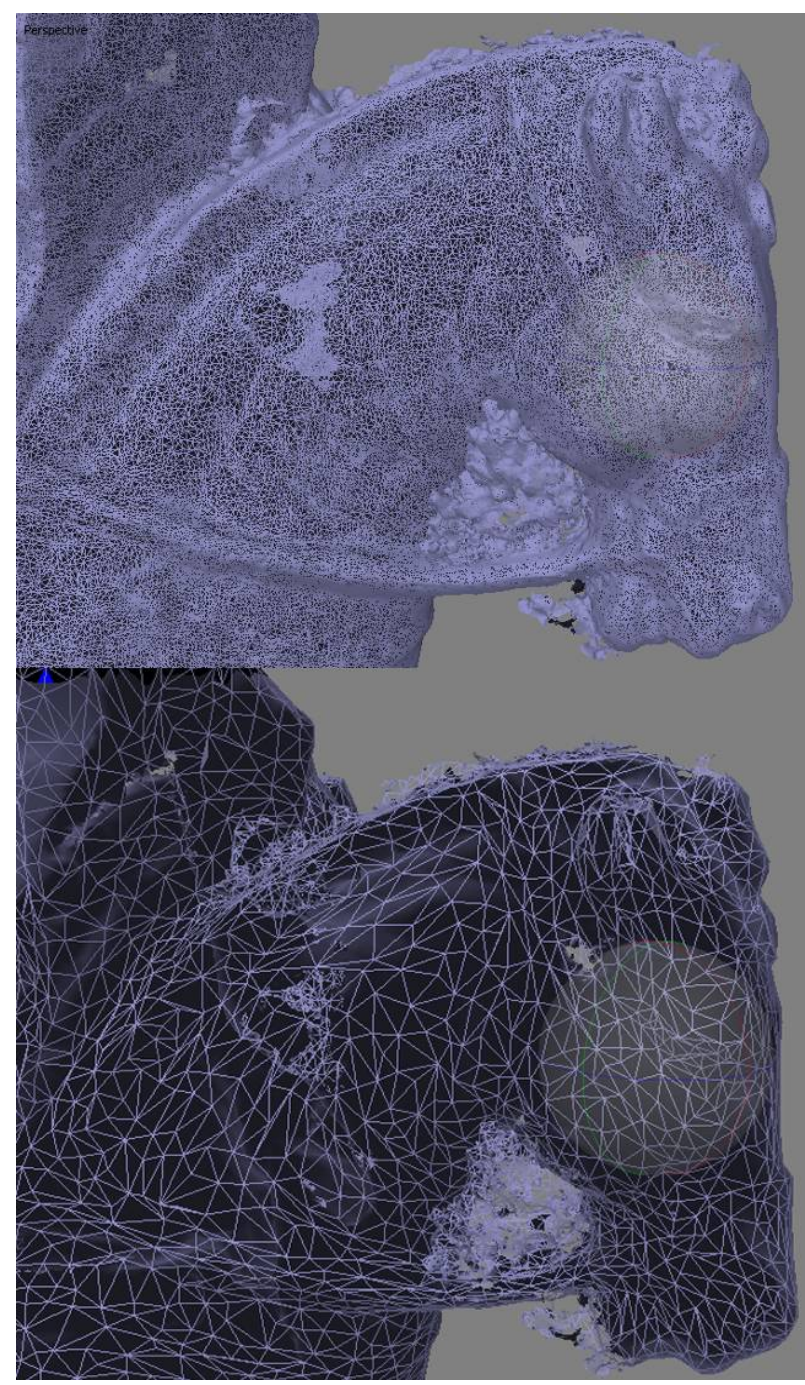

Figure 7: Decimation of the mesh: loss of detail, but the shape is consistent with the original. Unfortunately, the inability to manage the model mesh ten and a half million vertices, led us to having to make such extreme decimation. The mesh obtained, seven hundred thousand vertices, is definitely less detailed, but manageable. The high-resolution textures, however, will compensate the loss of detail in the model.

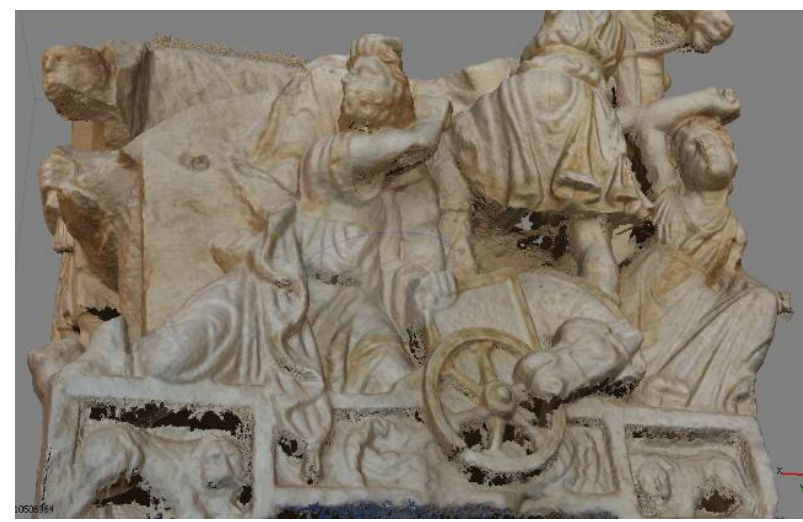

Figure 8: The model presents dirtying and holes especially in the lower parts respect to protrusions.

\section{Open or dirty mesh: closing the holes and cleaning the mesh}

Cleaning the dirty mesh is fundamental and needs the right tools to be able to get a good result: Geomegic allows a wide range of solutions to problems.

First, the cleaning of all those small portions of the mesh "shredded", that is, at corners where the separation between the object to be modeled and the background is not clear. In these areas are always present small portions of mesh partially connected with the mother mesh because of errors of assessment. These areas must be removed automatically (they can be highlighted with a gradual selection and then deleted all together if they are detached from the mesh) or manually (one by one, making sure, then, to close the holes created).

In other areas it is possible that, although there are no particular outgrowths, the mesh is still very rough and crude so much that needs to be polished with the necessary tools, to eliminate spikes and noise (rounding the sharp corners), or repair the normal to the surface. The mesh can also be carved as if it were a real piece of clay.

Furthermore, closing of the holes of the mesh are difficult operations to perform. For some holes, it is possible to perform an automatic closing simply by setting the type of curvature to be used for the patches to be applied, but in other cases, where the hole is more extended, the reconstruction must be reasoned.

Often it must proceed to subsequent steps. First recreating some bridges between the meshes, which also have a certain curvature and take account of the tangents to the extreme edges of mesh triangles: in this way, the bridge will be tangent to the existing surface and will have a greater or lesser curvature, set by the user and consistent with the reconstruction.

When the holes are too large and are of very inhomogeneous areas, the software is not able to reconstruct the mesh in the hole because is not able to exploit the tangent to the surface of each mesh edge of the hole. It is therefore necessary to manually creating more bridges in sequence and finally close the holes. In some cases, it is also necessary to clean the hole itself, eliminating ragged mesh, prominent tips, or malformations of the surface: the aim is to get a clean hole with smooth edges.

The closing of the holes is finally also, as for bridges, regulated by a curvature at the discretion of the user: if we are in flat surfaces can also be setted at zero, otherwise we could increase the camber. However, in most cases it is appropriate to leave the curvature not setted. In fact, this does not correspond to achieve flat surfaces, but to avoid interpretations: the software always takes into account the tangents to the edges of the hole, and create an area to cover the hole that interpolates all tangents without adding additional curvatures (Fig. 9). 

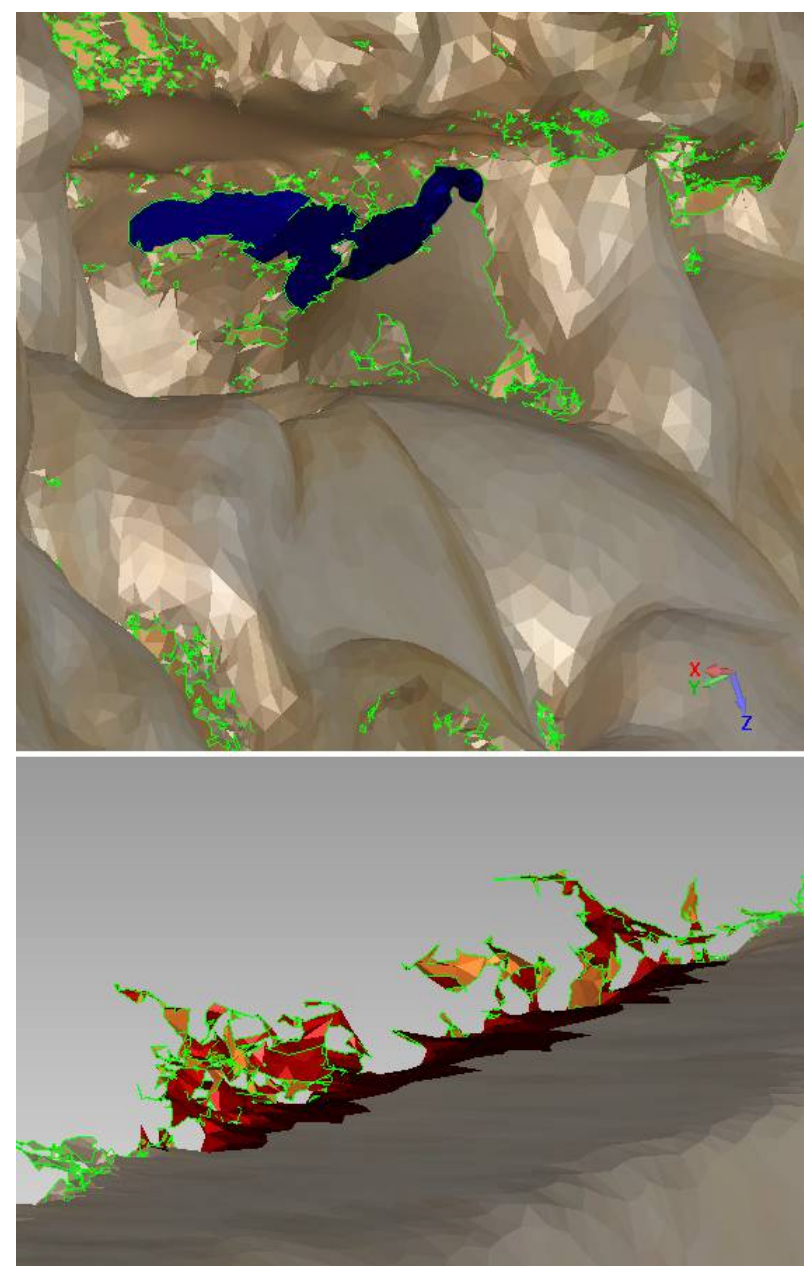

Figure 9: Cleaning of the mesh. In order to close the holes very large, it is necessary to build bridges at variable curvature which link very distant parts of the mesh. In some cases, instead, it is necessary to clean the ragged surfaces at the edges of the mesh.

\section{Mesh processing and photographic postproduction}

The cleaning of the mesh is certainly very accurate in Geomegic and the underlying result is very good and accurate. However, we must be careful not to move the model in the digital space to avoid problems in the next phase of re-importing into PhotoScan: the closed and corrected mesh, in fact, can be reported in the source software, taking the same position as the original. Nevertheless, we have to avoid problems of slipping of anchor with the original locations of the cameras which had created the first 3D mesh model.

This step is in fact necessary in order to achieve, in the last phase of the process, the high-resolution textures, to apply to the mesh, which is created starting precisely from original photographs through a rather complex process.

The algorithm used provides for the View-Dependent Texture Mapping, which is a kind of mapping of the mesh that affords for the calculation of the normal to the surface and mapping from partial picture: it extrapolate from the pic only the portions that are as parallel as possible to the mesh destination.
The procedure performed for all the photos of the model. Therefore, to create a texture composed of the hundred and thirty-eight pictures in which every part is very sharp with no aberration.

Therefore, in a zone of strong curvature software will map the mesh using each time those portions of photographs that will become more parallel to the surface at a given point.

The user can choose the resolution of the texture also depending on final use: VRML for Web, textured orthophoto, exporting the model with mesh texture for film postproduction and so on.

However, as already described at the beginning, in the case study there was a problem of lack of homogeneity of the light, and some photographs were tacking toward cool tones, while other ones to warm tones.

Therefore, we considered to make the correction of the images in postproduction, before the implementation of the final texture. So that, for proceeding efficiently to the replacement of the images, however, we must applied a trick: do not change the folder source nor the names of files, otherwise we could lose the alignment of the cameras, but also the geometry created and re-imported in Photoscan.

It is therefore good practice to copy the originals in a subfolder before proceeding to their modification. At this point, we could keep on to postproduction and saving the file to overwrite.

The color balance of the photo was made with Adobe Lightroom, a digital darkroom. We imposed to the images a white balance set manually (with the eyedropper tool) on some white sheets placed on the wood basement: imposing what were the white absolute point and the software initiates the color change of the whole picture as a function of it.

In this way, we eliminated the hot component in the images artificially lit, and the component too cold in the images in which the natural light is greater. A uniform set of images was such performed (Fig. 10).

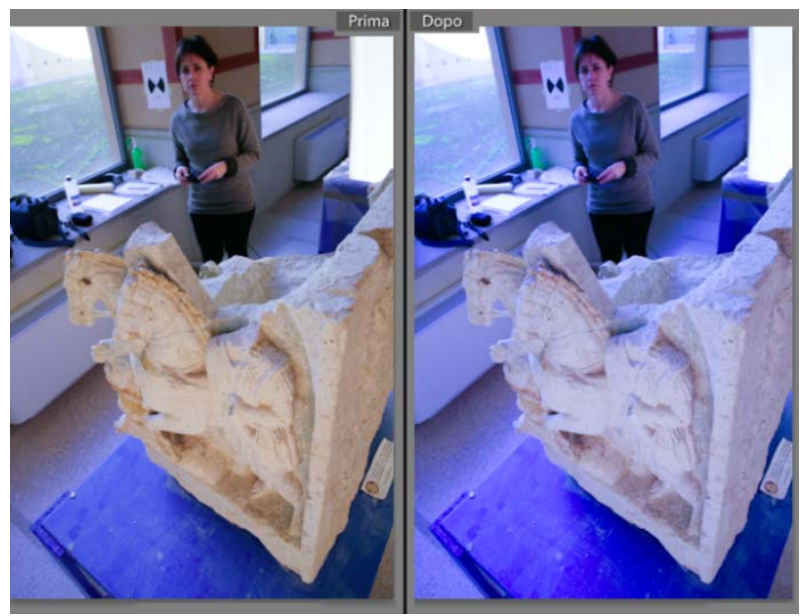

Figure 10: White balance in post production. All pictures (lighted with daylight or artificial light) were tacking, imposing the absolute white point by some paper sheets over the wood basement. In this way it was possible to standardize the photo set to obtain a more realistic texture. 
The software will recognize the changes saved to the original images, but without going to affect the mesh model, and then it will be possible to start the realization of a high-resolution mesh, 16.000 pixels (each side), that will wrap the closed mesh (Fig. 11).
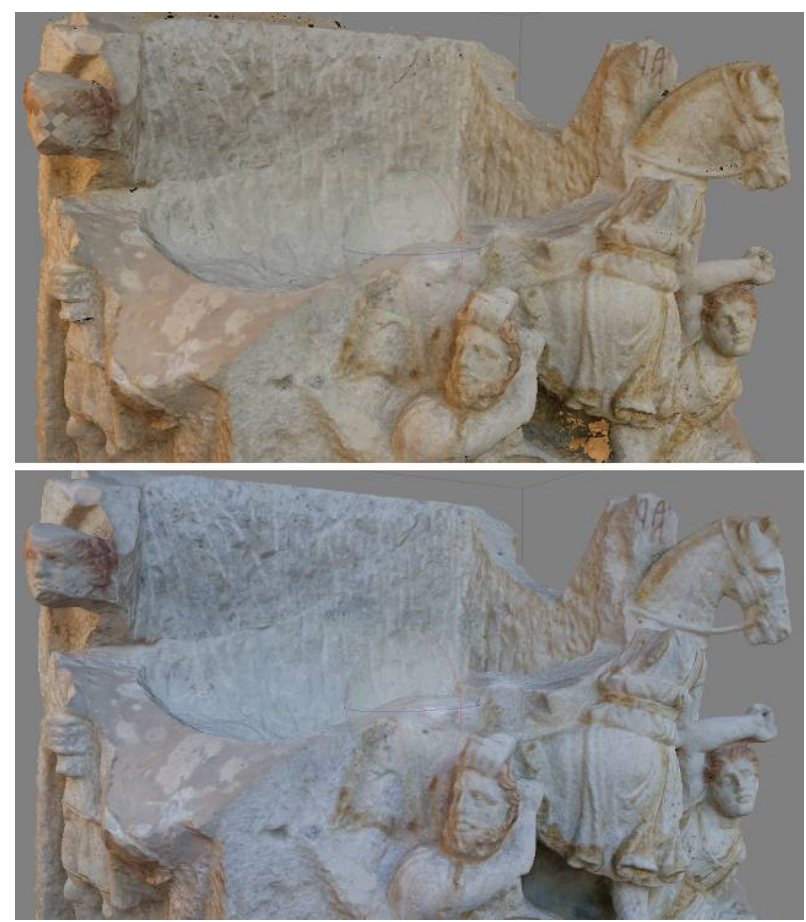

Figure 11: The mesh model without texture in comparison with the clean model, imported back into PhotoScan, and textured with toned pictures.

The softwares allow the direct creation of orthophotos from the 3D model, that is, high-resolution views in orthogonal or isometric depending on the projection plane and the point of view considered (Pierrot Deseilligny et al. 2011).

In this way, we can create accurate and faithful elevations of the object that would not have been possible to create with the original Etruscan.

To do that it need to fix the target points, characteristic points selected in the photos, which allow us to impose the $\mathrm{X}$-axis and $\mathrm{Y}$-axis of the projection plane. Furthermore, the targets are also useful to permit the scaling of the model through one known measurement.

Then we could pick any distance in the model to find out the exact real measure.

At least, we could take advantage of the orthophoto of front elevations and put them in the appropriate scales of reduction, for reproductions of work and for display panels for any exhibitions, where the aspect ratio is definitely essential.

The work was carried out thanks to the availability and logistical support of the Carabinieri for the Protection of Cultural Heritage which has hosted in the headquarters of Trastevere where the urns were in custody during the restoration.

The Etruscan Museum of Perugia, where now is the urn found (along with all the others), plans to make an exhibition video which goes to explain the myth of Oenomaus and morphological characteristics of the urn.

Therefore, following the definition of the 3D model, one of the works carried out has been precisely to recreate, in Cinema 4D software, a movie set of lighting and shooting video.

The digital urn was illuminated with effect's lights and sliding to highlight the chiaroscuro with sharp shadows, and dark background. In this way, the figures seem to emerge from urn so marked by darkness, as after the archaeological find (Fig. 12).
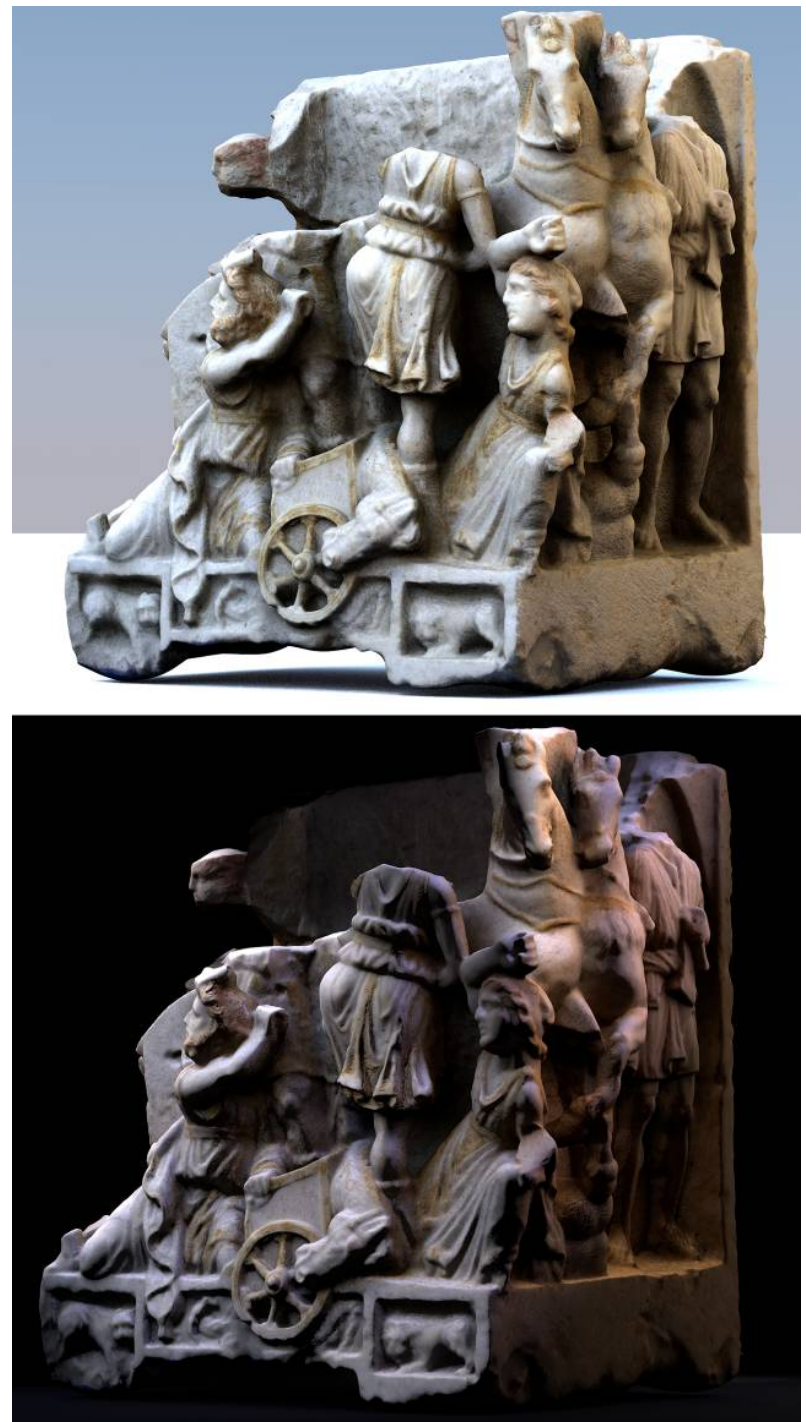

Figure 12: The 3D model obj exported and imported into Cinema 4D, then illuminated by sunlight (with its shadows) or subject to set of lights at night to give greater emphasis to the digital urn.

An emphasis of forms allows to better represent the myth and make the story more dramaturgy appealing.

\section{Conclusion}

The modern instruments for surveying are always a source of renewable solutions and new open to future developments. We must grapple with these instruments, know them, understand them and know what might be the application fields. 
In this example the use of the laser scanner was totally unnecessary given the considerable problems of the shadow zones, and it was unthinkable to join together 138 shots by laser scanner.

Instead, the photo modelling has led to a result of considerable precision and to the possibility of more various uses.

Exploiting the 3D mesh model to create photorealistic video of the urn is certainly both a way to divulge the importance of a priceless artistic heritage, and a way, at the same time, to preserve the original object. All the operations of setting, lighting, recovery are totally on the digital platform and performed on a copy almost perfect of the real artistic work (Fig. 13) (Debevec 2004). (Debevec et al. 2002).

We believe that the proposed case study, is an excellent example of what today would be the relationship with art and the artistic and cultural heritage that abounds in Italy: protection and preservation but at the same time divulging and research.

The experiments and research until now personally conducted showed some characteristics of the photographic modeling. Currently it is quite complicated to be able to get accurate meshed model in all its parts for large architectures: in the case of the church of Santa Maria di Loreto, the 3D model obtained is certainly very useful but has large gaps in precision ornaments, capitals or moldings; they require more detailed elaboration with detailed photographs.

However, PhotoScan and photographic modeling, produce excellent results for items that are not constructed geometrically. Statues, bas-reliefs, archaeological excavations and ruins in general are certainly very noticeable with the tools presented in this paper.

\section{Acknowledgements}

A special thanks to Marshal of the Carabinieri Sebastian Antoci, which allowed the execution of the survey. The photogrammetric survey was performed by Margherita Caputo and Luisa Bogliolo. Thanks to Roberto de Paolis to take the pictures on the site. The 3D model, animations and graphics processing were performed by Daniel Calisi.
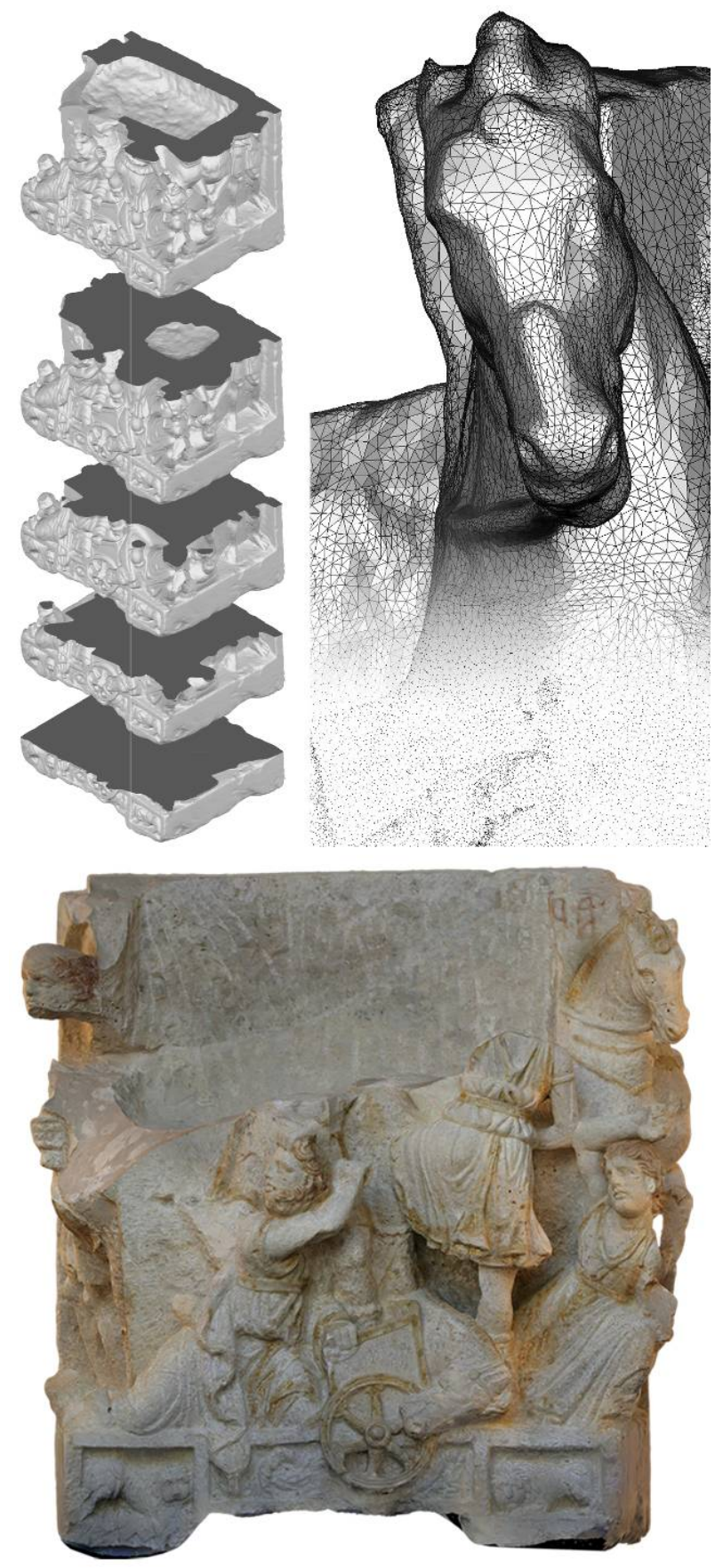

Figure 13: Composition of some of the processing on the 3D model. Axonometric view with some horizontal sections of relevance. Render of the mesh network and overlap with the point cloud. Down, orthophotos of the main front, rendered as an orthogonal projection in high resolution.

\section{References}

AA.VV., 2014. Catalogo della mostra "La memoria ritrovata. Tesori recuperati dall'Arma dei Carabinieri". Roma, Palazzo del Quirinale, 23 gennaio - 16 marzo 2014, a cura di Louis Godart, CIVITA.

CALISI, D., and AA. VV., 2014. Schede di rilievi in "Italian Survey, National and International Portfolio". ISBN 978-88548-7508-1

CALISI, D. and CIANCI, M.G., 2014. Storia e contemporaneità nella ricostruzione della Chiesa di Santa Maria di Loreto, In: XXXVI Convegno Internazionale dei Docenti della Rappresentazione "Italian Survey and International Experience" - UID 2014. ISBN 978-88492-2915-8 
DEBEVEC, P., 2004. Postproduction Re-Illumination of Live Action Using Time-Multiplexed Lighting. In: ICT Technical Report. DOI: 10.1145/1186415.1186470

DEBEVEC, P., WENGER, A., TCHOU, C., GARDNER, A., WAESE, J. and HAWKINS, T., 2002. A Lighting Reproduction Approach to Live-Action Compositing. SIGGRAPH 2002 (August). DOI: 10.1145/566570.566614

DE LUCA, L., 2011. La Fotomodellazione Architettonica. Palermo, Italy. Dario Flaccovio Editore, 2011. ISBN:978-88579-0070-4

DE LUCA, L., BUSARAYAT, C., STEFANI, C., VERON, P. and FLORENZANO, M., 2011. A semantic-based platform for the digital analysis of the architectural heritage, Computers \& Graphics. Volume 35, Issue 2, April 2011, Elsevier. Pages 227-241. DOI: 10.1016/j.cag.2010.11.009

PIERROT-DESEILLIGNY, M., DE LUCA, L. and REMONDINO, F., 2011. Automated ImageBased Procedures for Accurate Artifacts 3D Modeling and Orthoimage, Proceedings of XXIIIrd International CIPA Symposium, Prague, Czech Republic, September 12 - 16. DOI: http://dx.doi.org/10.14311/gi.6.36 


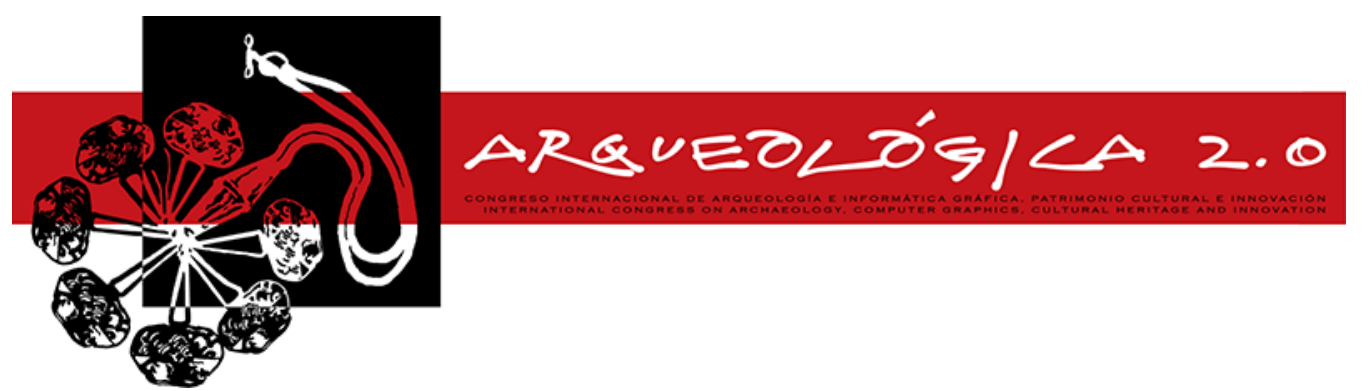

Proceedings of the $8^{\text {th }}$ International Congress on Archaeology,

Computer Graphics,

Cultural Heritage and Innovation

'ARQUEOLÓGICA 2.0'

in Valencia (Spain),

Sept. 5-7, 2016

DOI: http://dx.doi.org/10.4995/arqueologica8.2016.3510

\title{
PARAMETERIZATION OF COMPLEX CULTURAL HERITAGE SHAPES FOR ONLINE VIEWING AND INTERACTIVE PRESENTATION AND PROCESSING
}

\author{
Milan Ćurković*, Damir Vučina \\ FESB, Faculty of Electrical Engineering, Mechanical Engineering and Naval Architecture, University of Split, R. Boskovica 32, 21000 \\ Split, Croatia. milan.curkovic@fesb.hr; damir.vucina@fesb.hr
}

\begin{abstract}
:
We have developed algorithms and programs capable of efficiently parameterizing complex cultural heritage shapes including texture, which significantly reduces the data-set size. This is potentially significant for online viewing and interactive presentation and processing. The proposed approach is based on Non-uniform rational B-splines (NURBS) mathematical model which is also by itself suitable for analysis, especially of different artistic techniques.
\end{abstract}

Key words: virtual archaeology, digital archaeology, cultural heritage, documentation, 3D reconstruction, NURBS parameterization

\section{Introduction}

In recent times the cultural heritage worldwide becomes one of the main subjects in the field of information and communications technology (ICT). That way, cultural heritage is becoming available to all enthusiasts of culture and history for reviewing, learning and analysing, and all that over the web. The Virtual Museum (VM) will be a place for the critical personal preview before a possible visit to the museum and a place where people can renew their memories. But, implementing a virtual museum with all expected possibilities is a very demanding task. The main problem is to get the shape of cultural heritage objects in the form which does not take a lot of memory space and which provides real-time data transmission adequacy. That form should also be suitable for display and for shape analysis. This is not easy by using standard systems because the records of geometry and textures are too large for easy redistribution and dynamic display, and any analysis of them is almost impossible, especially in real-time.

We present enhanced single-patch NURBS parameterization based on fitting parameter values as a mathematical model which may also be considered as an approximation or as an initial solution for piecewise NURBS and T- spline parameterization (RiffnallerSchiefer et al. 2016; Dimitri et al. 2014). It relies on papers (Ćurković and Vučina 2014; Vučina et al. 2014) which outline a parameterization based on fitting parameter values and classification of 3D shape deviation using feature recognition operating on parameterization control points. The proposed approach should be considered as an interactive and adaptive compression of the shape and texture with the aim of visualization in real-time and also efficient analysis. The initial form of the 3D objects is a 3D point cloud obtained by a high resolution digitizing system, and the texture is a set of images.

The advantages of such a form is a very small number of parameters needed to display the shape. That way the transfer and archiving of such data becomes trivial.

In addition, the mere analysis of 3D objects using such a form is much easier because of the possibility of applying different mathematical functions (filters) in order to get the character of the shape.

\section{Data acquisition}

The equipment we have used in this paper is the ATOS system which consists of a projector and two cameras (GOM GmbH, 2012), that include stereophotogrammetry and triangulation (Peng and Gupta, 2007; Cyganek and Siebert, 2009), and which provides for efficient 3D scanning with high resolution and accuracy (Fig. 1). It is an optical system based on triangulation and stereo-photogrammetry which applies structured light patterns projection and uses time-based coding for addressing the positions of individual points. High resolution and high accuracy 3D optical scanning results in high density point clouds, typically in the range beyond 108 points. At present there is no ICT which is capable of providing efficient functionality based on such

*Corresponding Author: Milan Ćurković, milan.curkovic@fesb.hr 
initial 3D scanning results. That is the reason why we have started the development of a parametric model which adequate describes cultural heritage objects. In the following, we provide examples that represent a spectrum of heritage objects and demonstrate the robustness of our approach. The first sample shows two heads from the Cathedral of St. James in Sibenik (Fig. 1 ), Croatia and the second one represents the missing stone block from wall of Diocletian's Palace in Split, Croatia (Fig. 2).

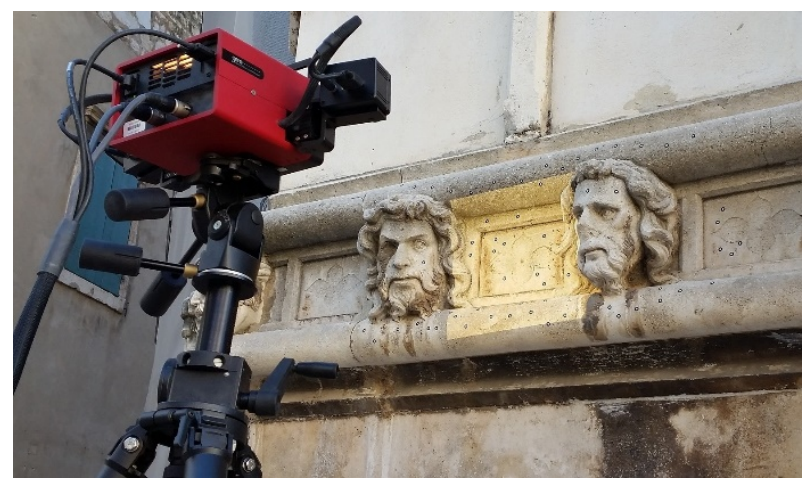

Figure 1: The scanning process of two heads from the Cathedral of St. James in Sibenik, Croatia.

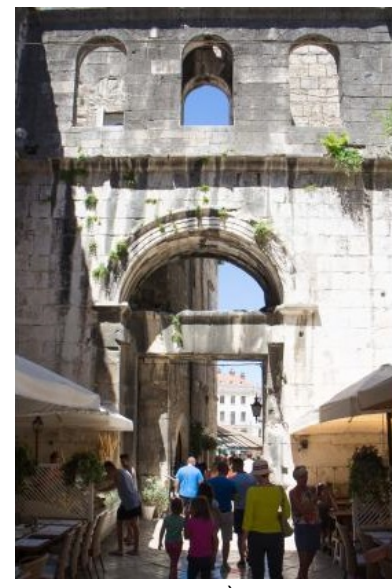

a)

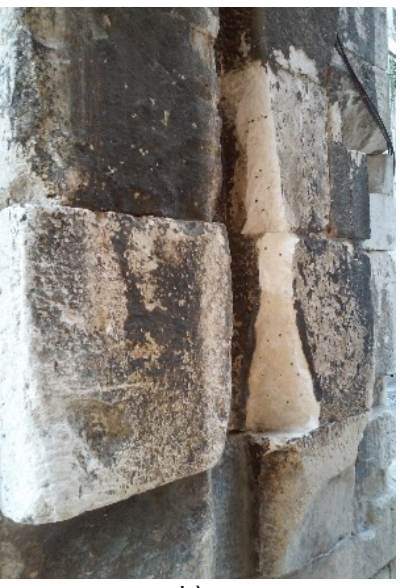

b)

$$
\boldsymbol{C}(u, v)=\frac{\sum_{i_{0}=0}^{n_{0}} \sum_{i_{1}=0}^{n_{1}} N_{i_{0}, p_{u}}(u) N_{i_{1}, p_{v}}(v) w_{i_{0} i_{1}} \boldsymbol{Q}_{i_{0} i_{1}}}{\sum_{i_{0}=0}^{n_{0}} \sum_{\substack{i_{1}=0 \\ n_{1}}} N_{i_{0}, p_{u}}(u) N_{i_{1}, p_{v}}(v) w_{i_{0} i_{1}}}
$$

where $\mathrm{n}_{0}, \mathrm{n}_{1}$ are the numbers of the control points, $\mathrm{N}_{\mathrm{i}_{0}, \mathrm{p}_{\mathrm{u}}}(\mathrm{u})$ and $\mathrm{N}_{\mathrm{i}_{1}, \mathrm{p}_{\mathrm{v}}}(\mathrm{v})$ are the basic B-spline functions of degrees $\mathrm{p}_{\mathrm{u}}, \mathrm{p}_{\mathrm{v}} \in \mathbb{N}$ defined by

$$
\begin{gathered}
N_{i, 0}(u)=\left\{\begin{array}{l}
1, \bar{u}_{i} \leq u \leq \bar{u}_{i+1}, \\
0, \text { else }
\end{array}\right. \\
N_{i, p}(u)=\frac{u-\bar{u}_{i}}{\bar{u}_{i+p}-\bar{u}_{i}} N_{i, p-1}(u)+\frac{\bar{u}_{i+p+1}-u}{\bar{u}_{i+p+1}-\bar{u}_{i+1}} N_{i+1, p-1}(u) .
\end{gathered}
$$

The knots $\bar{u}_{i} \in[0,1]$ as part of the basic B-spline functions we set as

$$
\overline{\boldsymbol{u}}=\{\underbrace{0, \ldots 00}_{p+1}, \bar{u}_{i+p}, \ldots, \bar{u}_{n-p-1}, \underbrace{1, \ldots 1}_{p+1}\},\left\{\bar{u}_{i}=\frac{i}{n}\right\}_{i=p+1}^{n-p-1},
$$

and they are fixed during the parameterization process. The matrix

$$
\boldsymbol{W}=\left[\begin{array}{ccc}
w_{00} & \cdots & w_{0 n_{1}} \\
\vdots & \ddots & \vdots \\
w_{n_{0} 0} & \cdots & w_{n_{0} n_{1}}
\end{array}\right]
$$

denotes the weight factors which we all set as 1 for the initial solution.

To fit the NURBS model to a given shape, the proposed approach uses the section matrix $P \in \mathbb{R}^{3\left(m_{0}+1\right) \times\left(m_{1}+1\right)}$ from the shape by applying parallel sections instead of using the original unstructured shape. During the fitting procedure, each point $\mathrm{P}_{\mathrm{j}_{0} \mathrm{j}_{1}}$ is assigned a pair of parameter values $\mathrm{u}_{\mathrm{i}_{0} \mathrm{j}_{1}}$ and $\mathrm{v}_{\mathrm{j}_{0} \mathrm{j}_{1}} \in\left[\begin{array}{ll}0 & 1\end{array}\right]$ given according to

$$
\left\{u_{j_{0} 0}=u_{j_{0} 1}=\cdots=u_{j_{0} m_{1}}:=\frac{j_{0}}{m_{0}}\right\}_{j_{0}=0}^{m_{0}}
$$

and

Figure 2: Diocletian's Palace in Split, Croatia: a) The Iron Gate (http://www.visitsplit.com/en/523/the-iron-gate); b) The missing stone block from wall.

\section{NURBS model construction}

The aim of construction of a NURBS surface is to get a small (typically in range less than 100 kilobytes) parameter data set which faithfully describes the object shape instead of the initial high density 3D scanned point cloud (often measured in gigabytes). In the following examples (the small points in Figure 4 and Figure 8) the main part of the NURBS model is shown, the set of the control points. The additional part of the NURBS surface, the set of weighted parameters used for the additional quality, is hidden from the users.

The NURBS surface is defined by its control points, weight factors, degrees of polynomials and the set of knots,

$$
\left\{v_{0 j_{1}}=v_{1 j_{1}}=\cdots=v_{m_{0} j_{1}}:=\frac{j_{1}}{m_{1}}\right\}_{j_{1}=0}^{m_{1}} .
$$

The NURBS surface which represents the geometry of the sections matrix $P$ must minimize the error function

$$
\begin{aligned}
& \boldsymbol{E}(\boldsymbol{U}, \boldsymbol{V}, \boldsymbol{Q}, \boldsymbol{W})= \\
& =\frac{1}{2} \sum_{j_{0}=0}^{m_{0}} \sum_{j_{1}=0}^{m_{1}}\left\|\boldsymbol{C}\left(u_{j_{0} j_{1}}, v_{j_{0} j_{1}}\right)-\boldsymbol{P}_{j_{0} j_{1}}\right\|^{2}
\end{aligned}
$$

which constitutes a least-squares problem. Minimizing the error function (5) reduces the cumulative sum of distances between the geometry $\mathrm{P}_{\mathrm{j}_{0} \mathrm{j}_{1}}$ and the corresponding points on the NURBS surface

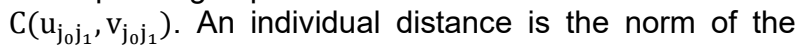
individual error vector.

The result of this numerical method is the desired set of the control points and their associated weight factors which together form the small input data for the Virtual Museum. Since the proposed method is non-linear, as 
the initial solution it uses the solution of linear best-fitting of B-spline surfaces to data-sets acquired by measurement and numerically generated surfaces (Eberly, 2010). It is realistic to expect that the users of the virtual museum, while previewing some object would like to zoom in and see specific details. To make this possible, it is necessary to construct one detailed parametric model with a larger number of parameters or one simple model with an additional series of small simple parametric models that individually describe only certain parts of the object. While zooming, these are being superimposed on the initial simple parametric model.

The above example (Fig. 3) presents one of the results of the 3D scanning process of the two-head set from the Cathedral of St. James in Sibenik, Croatia, as a standard example from the cultural heritage. The original 3D scanned size is about $1.5 \mathrm{~GB}$ and its thinned (CAD) version is about $100 \mathrm{MB}$.

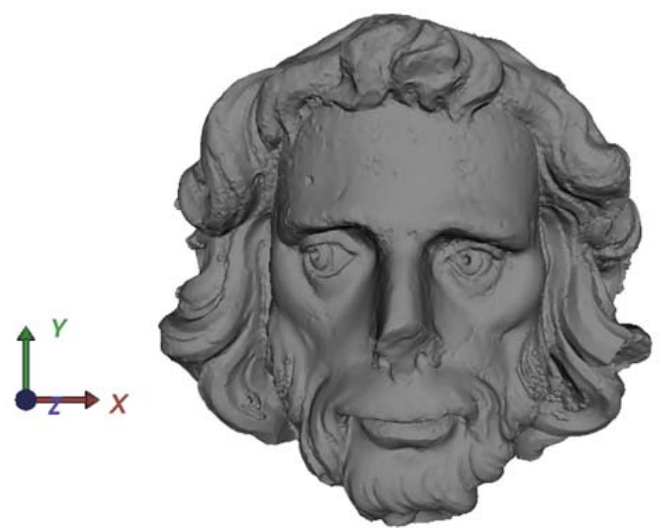

Figure 3: One of the results of the 3D scanning process of the two head set from the Cathedral of St. James in Sibenik, Croatia.

Although its thinned version is reduced by 15 -times, it is still too big for fluid manipulation. The next sample (Fig. 4) presents the proposed NURBS model of the above example. The model consists of a $40 \times 40$ control points grid and $40 \times 40$ weight factors grid which take up $54 \mathrm{~KB}$ of memory.

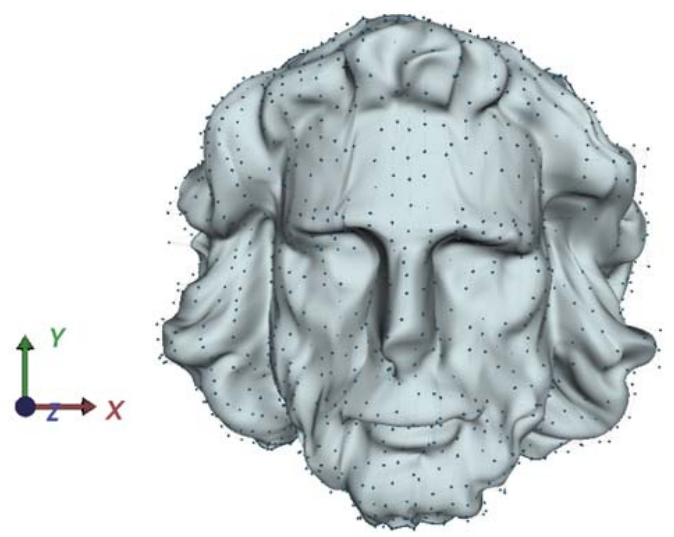

Figure 4: The single-patch NURBS surface as a result of the parameterization process, $40 \times 40$ control points, the degree of B-spline functions is 2 .
The distribution of the geometric error between the original scanned surface (Fig. 3) and the NURBS model (Fig. 4) is shown in Figure 5.

The geometric error is relevant for possibly improved fitting by the proposed method or towards selection of some other methods that are based on the proposed method for further fitting. The criterion could be the cumulative geometric error or it could be the error obtained by using mathematical filters in areas with geometric features (peaks, edges, ...).

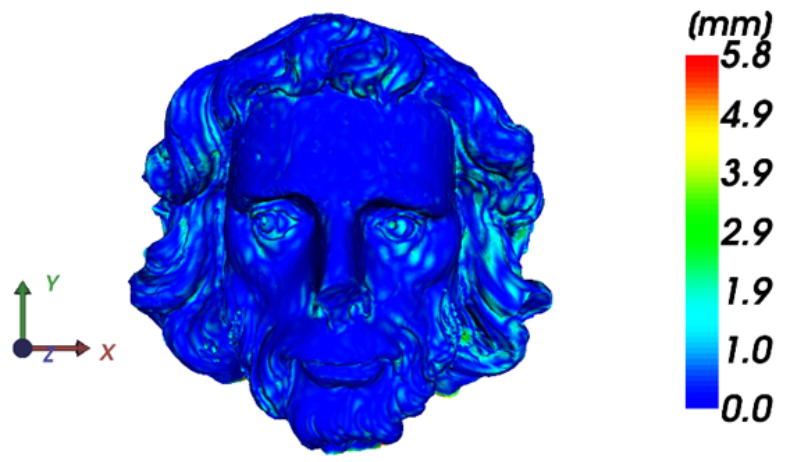

Figure 5: The distribution of the geometric error between original scanned surface (Fig. 3) and NURBS model (Fig. 4).

As preparation for the proposed method, we have used the projection of the initial object's shape into a rectangular domain and that way we are able to employ the proposed method on non-rectangular patches (Fig. 6 ). This is very important in terms of multi-patch NURBS parameterization because it is not necessary to have a rectangular subdivision of shape, and it is posible to have nature borders of the patches.

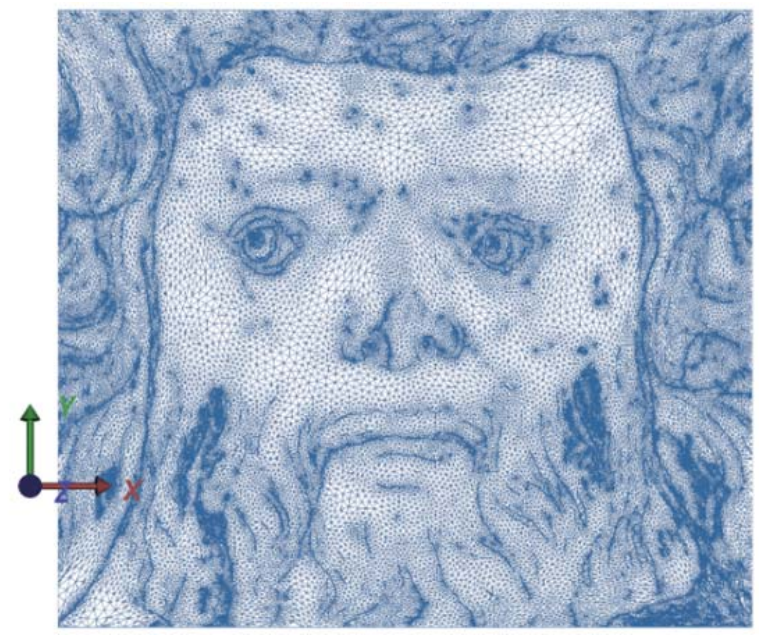

Figure 6: Projection into rectangular domain of thinned surface (Fig. 3).

The other preparation method we have applied is remeshing of the original shape in order to achieve higher density of the shape points in areas with significant geometric features. The method results in a better global fitting solution and more accuracy in the mentioned areas. We detect areas with significant geometric features by applying the Principal component analysis (PCA) method, where the ratio of eigen-values identifies the geometric feature. For a local sub-set of the point cloud, the variance measures the spread of 
data along a single dimension in the data set, and the covariance measures the mutual dependence of any two dimensions of the data-set

$$
\operatorname{var}(x)=\frac{\sum_{i=1}^{n}\left(x_{i}-\bar{x}\right)^{2}}{n-1}
$$

and

$$
\operatorname{cov}(x)=\frac{\sum_{i=1}^{n}\left(x_{i}-\bar{x}\right)\left(y_{i}-\bar{y}\right)}{n-1}
$$

For example, while positive covariance in a local point cloud sub-set indicates the two dimensions which increase or decrease together, low covariance implies mutually independent dimensions in the sub-set. Principal component analysis can be very useful with this regard as it may assist in identifying features contained in the data set by transforming correlated variables into new variables with less correlation. Accordingly, principal component analysis can identify the variables responsible for the majority of variation in the local point cloud sub-set.

The proposed approach we also applied on the missing stone block from wall from the Diocletian's Palace in Split (Fig. 7). The original 3D scanned size is about 2.9 $\mathrm{GB}$ and its thinned (CAD) version is about $160 \mathrm{MB}$.

The missing stone block is an excellent example for applying of a mathematical model such as the proposed NURBS model. In addition to the reduction of the number of parameters needed to describe the geometry and facilitated reviewing within the Virtual Museum, it represents a classic example of a damaged object which should be numerically analyzed and faithfully replicated.

These mentioned numerical procedures are significantly facilitated by the existence of a parametric model. This is because the topological structure is included by itself in the parametric model which enables the application of integral filters.

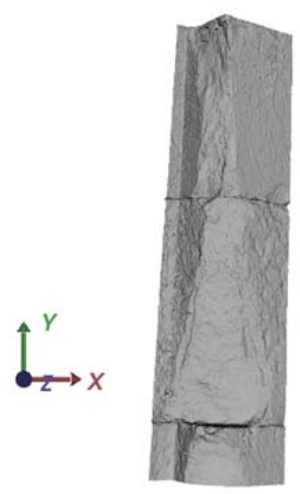

a)

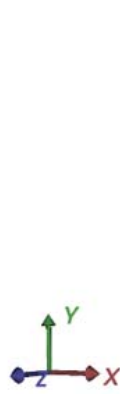

b)

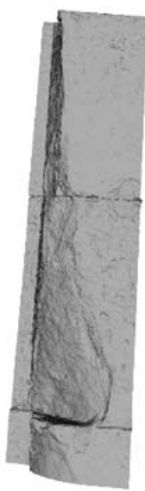

Figure 7: Two views of the result of the 3D scanning process of the wall from the Diocletian's Palace in Split.

The next sample (Fig. 8) presents the proposed NURBS model of the sample (Fig. 7). The model consists of a $20 \times 20$ control points grid and a $40 \times 20$ weight factors grid which take up $14 \mathrm{~KB}$ of memory.

The distribution of the geometric error between the original scanned surface (Fig. 7) and the NURBS model
(Fig. 8) is shown in Figure 9. The geometric error in this example has a micro character which confirms the quality of the initial parametric model. Further improvements related to the texture that can be part of a separate parametric model.

In terms of replacing the missing parts of a cultural heritage object, the geometric difference (texture) shown in Figure 9 should be minimized as much as possible since the process of replacing the missing part should include the texture from the surrounding area to substitute the original texture. To achieve that requirement the proposed parametric model should be capable to present texture also. That is possible with an additional parameterization model which will be superimposed on the initial parametric model (Fig. 8). Converting texture into a separate parametric model and superimposing it onto the basic parameterization model is generally an extensive and demanding topic and hence a subject of future work, only outlined in this paper.

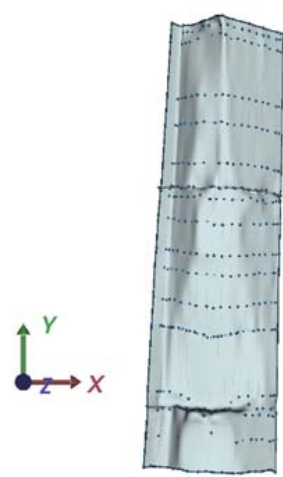

a)

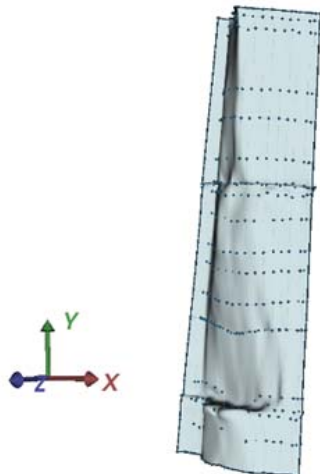

b)
Figure 8: Two views of the single-patch NURBS surface as a result of the parameterization process, $20 \times 20$ control points, the degree of B-spline functions is 2 .

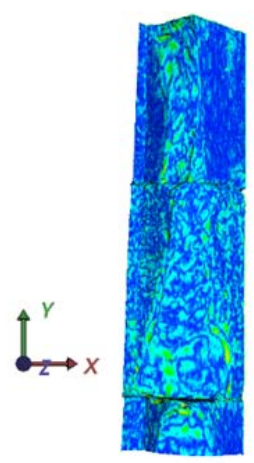

a)
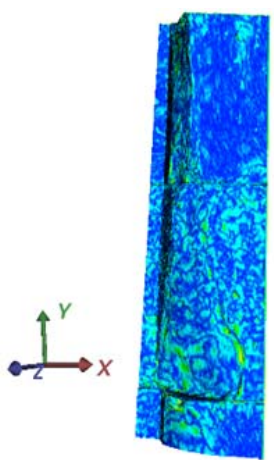

b)

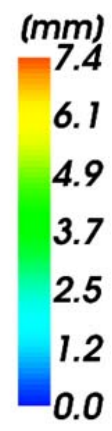

6.1
Figure 9: Two views of the distribution of the geometric error between original scanned surface (Fig. 7) and NURBS model (Fig. 8).

\section{Conclusion}

As a dynamic preparation method, the proposed approach goes hand in hand with tools such as the 3D HOP (http://3dhop.net/). The shape of the object is presented as two superimposed models. The basic NURBS model applies to the global geometry and the other model to texture. During previewing by means of a Virtual Museum based on tools such as 3D HOP, it could 
be converted to one of the supported data formats (ply, ...). All the necessary steps for the conversion could be performed on the client side in real time.

\section{Acknowledgements}

This work was supported by the Croatian Science Foundation [grant number IP-2014-09-6130]

\section{References}

ĆURKOVIĆ, M. and VUČINA, D., 2014. 3D shape acquisition and integral compact representation using optical scanning and enhanced shape parameterization, Advanced Engineering Informatics, 28(2), pp. 111-126.

DIMITRI, R., DE LORENZIS, L., SCOTT, M.A., WRIGGERS, P., TAYLOR, R.L. and ZAVARISE, G., 2014. Isogeometric large deformation frictionless contact using T-splines, Comput. Methods Appl. Mech. Engrg. 269, pp. 394-414.

DIMITRI, R., DE LORENZIS, L., WRIGGERS, P. and ZAVARISE, G., 2014. NURBS- and T-spline-based isogeometric cohesive zone modelingof interface debonding, Computational Mechanics, 54(2), pp. 369-388.

EBERLY, D., 2010. Least-Squares Fitting of Data with B-Spline Curves. Available: http://www.geometrictools.com [1/1, 2010].

GOM GmbH, 2012. Available: http://www.gom.com/metrology-systems/system-overview/atos.html [2/7, 2012].

LI, X. and SCOTT, M.A., 2013. Analysis-suitable T-splines: characterization, refineability, and approximation, submitted for publication, arXiv: 1211.5669 [CS.GR]

NGUYEN, V.P., KERFRIDEN, P., BRINO, M., BORDAS, S.P.A. and BONISOLI, E., 2013. Nitsche's method for two and three dimensional NURBS patch coupling, Computational Mechanics, 53(6), pp. 1163-1182.

PENG, T. and GUPTA, S.K., 2007. Model and algorithms for point cloud construction using digital projection patterns, ASME Journal of Computing and Information Science in Engineering, 7(4), pp. 372-381.

VUČINA, D., ĆURKOVIĆ, M. and NOVKOVIĆ, T., 2014. Classification of 3D shape deviation using feature recognition operating on parametrization control points, Computers in industry, 65(6), pp. 1018-1031.

CYGANEK, B. and SIEBERT, J.P., 2009. An Introduction to 3D Computer Vision Techniques and Algorithms, John Wiley \& Sons, Chichester.

RIFFNALLER-SCHIEFER, A., AUGSDÖRF, U.H. and FELLNER D.W., 2016. Isogeometric shell analysis with NURBS compatible subdivision surfaces. Applied Mathematics and Computation, 272, pp. 139-147. 


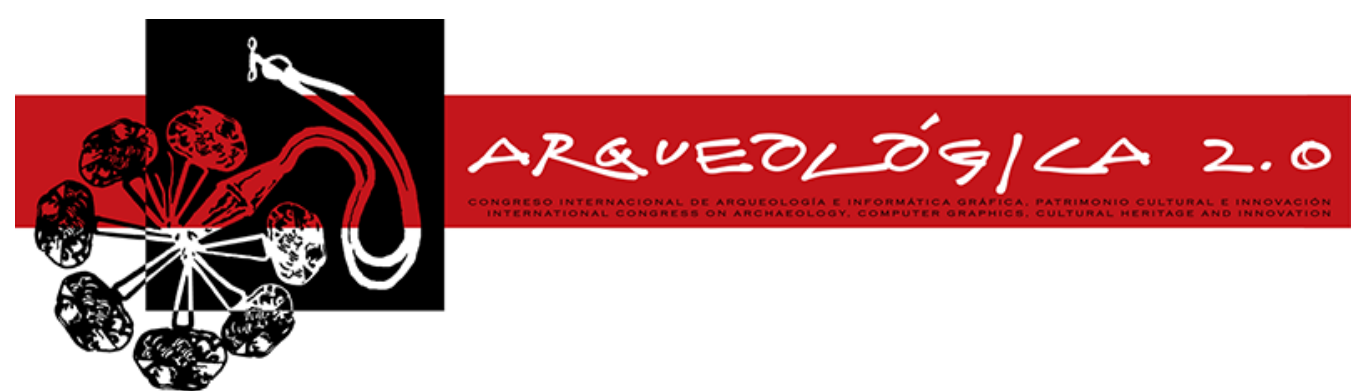

Proceedings of the $8^{\text {th }}$ International Congress

on Archaeology,

Computer Graphics,

Cultural Heritage and Innovation

'ARQUEOLÓGICA 2.0'

in Valencia (Spain),

Sept. $5-7,2016$

DOI: http://dx.doi.org/10.4995/arqueologica8.2016.3517

\title{
METODOLOGÍA Y APLICACION PRÁCTICA PARA LA DIGITALIZACIÓN DE PATRIMONIO COFRADE MEDIANTE LA FUSION DE DATOS DE LÁSER ESCANER Y FOTOGRAMÉTRICOS
}

\author{
METHODOLOGY AND PRACTICAL APPLICATION FOR RELIGIOUS HERITAGE DIGITALIZATION USING \\ SCANNER LASER AND PHOTOGRAMMETRIC DATA
}

\author{
Carlos Colomo*, José Luis Pérez, José Miguel Gómez, Francisco Javier Rosales
}

Dpto. de Ingeniería Cartográfica, Geodésica y Fotogrametría, Escuela Politécnica Superior de Jaén, Campus de las Lagunillas, Universidad de Jaén s/n, 23071 Jaén, España. cmcj0002@red.ujaen.es; ilperez@ujaen.es; iglopez@ujaen.es; fjra0004@red.ujaen.es

\begin{abstract}
:
This paper describes the methodology used to capture information from a religious sculpture. The study also shows the results obtained in using free software and fusion of data from laser scanner and photographs. In this sense, one of the problems that can occur when Heritage documentation is made, is the impossibility of move the object of study from other places with appropriates environment conditions to capture data. This problem is especially important in the case of sculptures found upright with certain height, where many upper portions are hidden by the inability to locate safely locate the instruments. This paper show a case of study with this problem and provides the solution to capture data in cenital position with laser scanner. Finally, the overall results are showed and some considerations in terms of conservation and diffusion of the cultural heritage.
\end{abstract}

Key words: cultural heritage, 3D documentation, instrumentation, data fusion

\section{Resumen:}

En este trabajo se presenta la metodología empleada para la captura de información de una imagen cofrade objeto de estudio, así como los resultados obtenidos en su modelado haciendo uso de software libre y la fusión de datos procedentes de escáner láser y de tomas fotográficas. En este sentido, uno de los problemas que pueden existir a la hora de la documentación tridimensional del patrimonio cultural es la imposibilidad de su desplazamiento a zonas de trabajo donde las condiciones y entorno de trabajo sean los idóneos para llevar a cabo la captura de los datos. Este problema es especialmente importante en el caso de imágenes o esculturas que se encuentran en posición vertical con cierta altura, donde muchas partes superiores se quedan ocultas por la imposibilidad de situar de manera segura el instrumental que suele ser pesado, sobre el objeto a digitalizar. En este trabajo, se presenta un caso de estudio donde aparece esta problemática y la solución aportada para realizar capturas de tipo cenital con láser escáner. Finalmente, se muestran los resultados generales obtenidos, así como algunas consideraciones de los mismos en cuanto a los resultados en cuanto a la conservación como la difusión del objeto modelizado.

Palabras clave: patrimonio cultural, documentación 3D, instrumentación, fusión de datos

\section{Introducción}

El modelado tridimensional se podría describir como la descripción numérica de una superficie a partir de un conjunto de puntos medidos por diferentes técnicas. De esta forma, a partir de datos discretos, se idealiza una superficie matemática a partir de distintos algoritmos de reconstrucción superficial, como son los métodos de Poisson, Ball Pivoting o el VCG (Berger et al. 2014).
En cuanto a las principales técnicas para la obtención de esta información discreta del objeto, podemos diferenciar dos grandes grupos. En un primer lugar, las técnicas fotogramétricas, las cuales basan la obtención de la geometría del objeto de estudio en la reconstrucción de la posición de la fotografías y en la detección de puntos homólogos, de manera que se reconstruye su posición tridimensional a partir de información bidimensional de las imágenes. Por otro lado tenemos los sistemas de escaneado 3D, entre las

"Corresponding Author: Carlos Colomo, cmcj0002@red.ujaen.es 
que destacan dos tipologías diferenciadas; en primer lugar los sistemas de luz estructurada, los cuales basan la reconstrucción geométrica del objeto en la proyección de un patrón de luz sobre el mismo y su registro en un sistema de adquisición. $Y$ por otro lado, los sistemas de escáner de barrido, que proyectan un haz láser que es registrado por el Sistema de visión del escáner. (Sansoni et al. 2009)

Analizando las principales características de los sistemas de captura mediante fotogrametría y sistemas de escáner 3D, así como los resultados obtenidos mediante su uso, se podrían plantear algunas consideraciones:

- Los sistemas de escáner 3D presentan precisiones mayores que las obtenidas por fotogrametría, y obtienen información mediante observación directa sobre el objeto frente a la fotogrametría que la obtiene mediante la interpretación de la información capturada en imágenes.

- El coste de los sistemas de escaneado es mayor que los sistemas necesarios para llevar a cabo estudios fotogramétricos.

- El texturizado mediante fotogrametría tiene una mayor calidad que el que proporcionan algunos sistemas láser.

Por otra parte, sería importante comentar la gran importancia que está teniendo en estos últimos años la irrupción de plataformas de software libre, como MeshLab o Bundler SFM, así como de sistemas de adquisición de datos tridimensionales de bajo coste, aunque es cierto que aunque ofrecen resultados muy visuales, no llegan en ocasiones a conseguir las precisiones y terminaciones obtenidas a partir de otros sistemas comerciales.

\subsection{Técnicas $3 \mathrm{D}$ en el duplicado artístico}

El campo de la reproducción artística, aplicado a la obtención de copias de seguridad, es algo que ha existido desde hace muchos siglos, modificándose los procedimientos utilizados a lo largo del tiempo. Así, ya se tiene constancia del uso del método de la cuadrícula utilizada por los egipcios, evolucionando estas técnicas hasta las ampliadoras, reductoras y máquinas de puntos de finales del siglo pasado. Sin embargo, gracias a la tecnología se ha logrado dar un paso más allá, y a día de hoy es posible la realización de una copia sin intervenir en la imagen para obtener un vaciado, como sí era necesario en las técnicas anteriormente nombradas.

El proceso de obtención de reproducciones exactas o copias de seguridad tridimensionales se considera como la realización de un molde virtual que captura por completo la superficie de la imagen, con una resolución tal que cualquier detalle de la misma queda registrado para su posterior uso o análisis.

El digitalizado tridimensional de imaginería cofrade es una técnica que consiste en la "obtención de modelos digitales" de objetos tridimensionales normalmente a partir del uso de un escáner 3D combinando en algunos casos con imágenes fotográficas. De este modo, y tras el procesado y edición de los datos, se obtienen copias de seguridad en 3D de esculturas, que son un fiel reflejo de la realidad en formato digital, resultado de un meticuloso y laborioso proceso de digitalización 3D con resoluciones inferiores al milímetro.

La implementación de las técnicas digitales para la obtención de copias de seguridad, se debe principalmente a las ventajas que éstas presentan respecto las técnicas de replicado tradicionales de copiado por puntos o usando mascarillas de silicona, entre las que destacan:

- Es inocuo para la talla, ya que en ningún momento existe contacto con la obra de arte.

- Facilidad de custodia, ya que no requiere de un espacio físico como en el caso de las copias tradicionales, por tratarse de un archivo digital.

- Además de no ser necesaria la presencia del objeto en el momento de hacer la copia, dado que una vez digitalizada se podrá hacer la copia en cualquier momento y lugar. Esto es una gran ventaja frente a otros métodos tradicionales donde suele ser necesario que exista el objeto original.

Por otra parte, los resultados obtenidos, aparte de ser muy útiles para la conservación del patrimonio histórico, también constituyen una herramienta de gran potencial para la difusión y puesta en valor del patrimonio que ha sido digitalizado.

\subsection{Objeto de estudio}

La imagen del Santísimo Cristo Yacente (Fig. 1), objeto de estudio, realizada en 1959 por el escultor Constantino Unghuetti, está inspirado en las proporciones del cuerpo de la Sabana Santa de Turín, motivo por el cual mide 1,83 metros. Está realizada en pino de Flandes, policromada en un principio por Francisco Cerezo y en 1961 por Juan Abascal, policromía que ha mantenido hasta su restauración en el año 2005 por Francisco Romero Zafra.

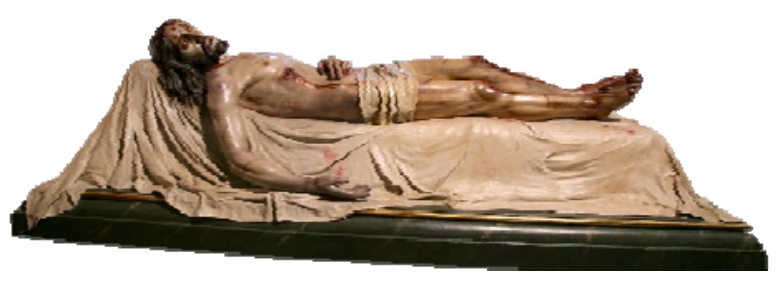

Figura 1: Imagen Objeto de estudio.

\section{Material}

A continuación se presenta el instrumental utilizado para la captura de la información geométrica, así como para la información de la textura del objeto estudiado.

\subsection{Minolta V 910}

Para la realización de este trabajo se ha utilizado el escáner láser Konica Minolta VIVID 910 (Fig. 2). Se trata de un instrumento para digitalización 3D sin contacto, del tipo de triangulación capaz de capturar 300,000 puntos en una única toma. Se trata de un equipo que presenta un volumen variable de escaneo (entre $100 \times 80 \times 40 \mathrm{~mm}$ y $1200 \times 900 \times 400 \mathrm{~mm}$ ) manteniendo la precisión gracias a su sistema de lentes 
intercambiables. Las principales especificaciones técnicas del instrumento se encuentran descritas en la Tabla 1.

Tabla 1: Características Konica Minolta VIVID 910

\begin{tabular}{|c|c|}
\hline Konica Minolta & Características \\
\hline \multirow[t]{3}{*}{ Lentes } & TELE: Distancia Focal $\mathrm{f}=25 \mathrm{~mm}$ \\
\hline & MIDDLE: Distancia Focal $\mathrm{f}=14 \mathrm{~mm}$ \\
\hline & WIDE: Distancia Focal $\mathrm{f}=8 \mathrm{~mm}$ \\
\hline Rango de trabajo & Entre 0.6 y $1.2 \mathrm{~m}$ \\
\hline Clase de láser & $\begin{array}{c}\text { Láser de Clase } 2 \text { (IEC 60825-1), "Seguro } \\
\text { para la vista ", Class } 1 \text { (FDA) }\end{array}$ \\
\hline $\begin{array}{l}\text { Método de } \\
\text { barrido del láser }\end{array}$ & Espejo rotatorio \\
\hline Precisión & $X: \pm 0.22 \mathrm{~mm}, Y: \pm 0.16 \mathrm{~mm}, \mathrm{Z}: \pm 0.10 \mathrm{~mm}$ \\
\hline
\end{tabular}

El sistema presenta la posibilidad de capturar imágenes equivalentes a una cámara de 24 bits de color, sin embargo en la práctica, los resultados obtenidos no son los adecuados. Por otro lado, aunque según las especificaciones técnicas el escáner funciona bien en condiciones lumínicas de una oficina en tono a $500 \mathrm{~lx} o$ menos, se ha comprobado que trabaja mejor en condiciones de penumbra u oscuridad, condiciones que afectan negativamente a la captura de la textura. Además, la captura del color con este instrumento presenta muchas irregularidades, ya que se ve muy afectado por las condiciones de luz, el ángulo con el que el haz incide sobre el objeto, variando el tono en función de donde se capture el objeto Por ese motivo, se propone separar la captura del color de la captura de la geometría haciendo uso de cámaras digitales.

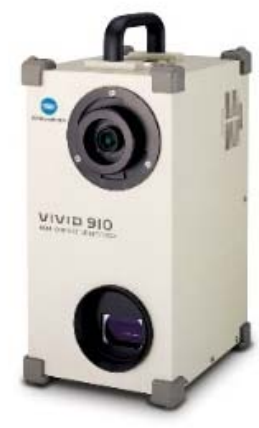

Figura 2: Minolta V910.

\subsection{Cámaras digitales}

Para la captura de la información de la textura del objeto de estudio se han utilizado 2 cámaras digitales, por un lado una cámara compacta Fujifilm finepix F660 EXR y por otro lugar, una cámara tipo bridge Panasonic DMCFZ45, cuyas características aparecen en la Tabla2:

Tabla 2: Características de las cámaras usadas

\begin{tabular}{c|c|c} 
Cámara & Finepix F660 EXR & DMC-FZ45 \\
\hline Tamaño Pixel (mm) & 0.0013 & 0.0014 \\
Focal (mm) & 4.4 & 4.5 \\
Tamaño sensor (pix) & $4608 \times 3456$ & $4320 \times 3240$ \\
Tipo Sensor & CMOS & CCD
\end{tabular}

\section{Proceso de trabajo}

\subsection{Captura de la geometría}

Tal como se ha comentado, el objeto de estudio se trata de una imagen escultórica que representa un cristo yacente. Las principales dificultades encontradas a la hora de realizar la toma de datos son, en primer lugar la distancia existente entre el suelo y la parte más alta de la imagen, y por otro la distancia entre los extremos de la talla y el centro de la misma, al tener la escultura una base de considerable anchura. Estos dos factores, unidos al peso del equipo, que ronda los 11 kilos, y al tipo de trípode disponible, impedían una captura de datos completa de la imagen utilizando únicamente el trípode convencional, apareciendo dos problemas a la hora de realizar la toma. Por un lado la parte más central de la escultura, la correspondiente al esternón, la parte alta de la cabeza o la zona de sombra por la posición de las piernas, no era posible su adquisición debido a la falta de visión por parte del láser al no poder subir lo suficiente el instrumental y darle la inclinación necesaria dentro de unos límites de seguridad para la imagen (Figs. 3 y 4). Por otra parte, además de las zonas que no eran capturadas en la zona del esternón, la zona del pecho, estaba capturada en gran medida con ángulos muy sesgados entre el láser y el objeto de estudio, lo que obligo a la creación de un prototipo de un trípode de captura cenital, con el que se pretendía resolver ambos inconvenientes, descrito en el apartado 3.1.1.

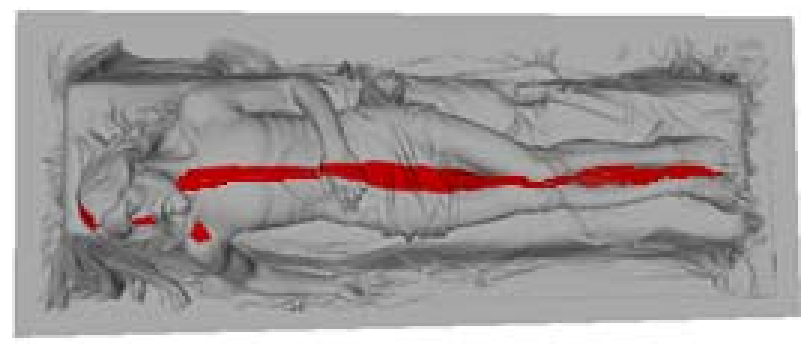

Figura 3: Zonas ocultas con el trípode convencional.

La captura de la información con el escáner ha sido realizada con el objetivo medio, de manera que la planificación para la ejecución del trabajo es de medio metro respecto el objeto. En cuanto a la captura de datos mediante el trípode tradicional alrededor del objeto, se procura que el solape entre las tomas perpendiculares al objeto de estudio sea mínimo del $30 \%$ con los escaneos vecinos para asegurarse un recubrimiento completo y una mayor facilidad para el registro entre escaneos, tanto de manera manual como para un mejor trabajo por parte de los algoritmos automáticos.

Además de la realización de una toma perpendicular hacia el objeto de estudio, desde cada punto de escaneo se realizan dos tomas adicionales con un giro de $45^{\circ}$ a izquierda y derecha, simulando de esta manera tomas convergentes, de manera que se mejora notablemente la captura de zonas de difícil medición con la toma perpendicular minimizando de esta manera zonas ocultas (Fig. 5). Así se tiene una metodología ordenada de trabajo, con una alta redundancia de datos, lo cual facilita en gran medida el trabajo en gabinete y 
reduciendo el riesgo de vuelta al lugar de trabajo por la existencia de zonas sin registrar.

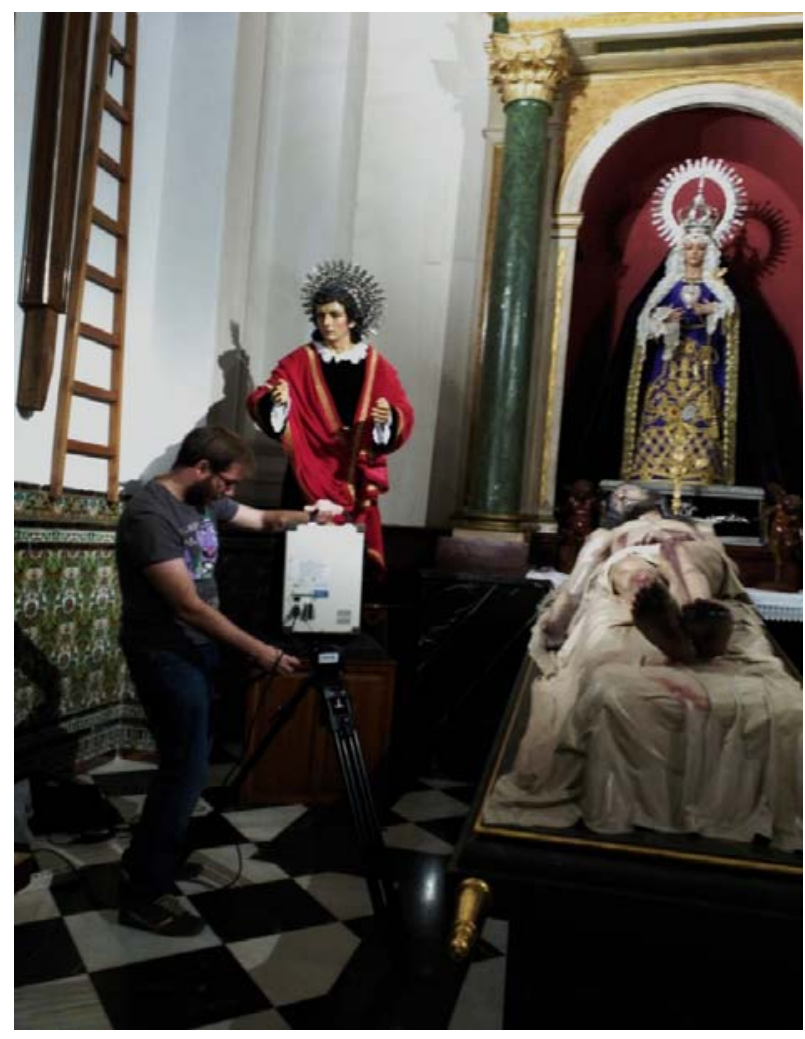

Figura 4: Trabajo Trípode convencional.

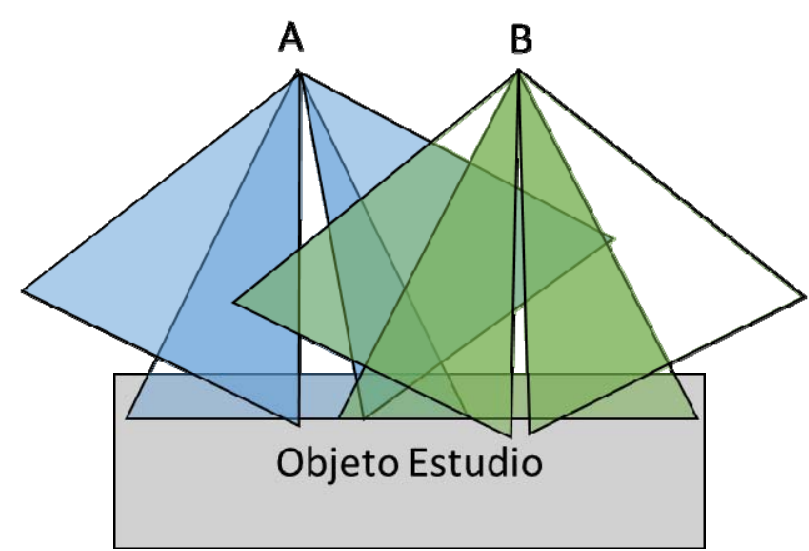

Figura 5: Tomas convergentes con el escáner.

\subsubsection{Prototipo de captura cenital}

La realización de un prototipo para la captura de datos cenitales, debía cubrir la necesidad planteada, y por otro lado deberá ser de fácil montaje y desmontaje, aparte de ser estable para soportar el peso del equipo con total seguridad para la imagen objeto de estudio. Para satisfacer todas estas necesidades se opta por la creación de una estructura dividida a su vez en dos partes funcionales distintas (Fig. 6).

La primera de las partes se trata de una estructura en aluminio de 2 metros de altura, 0.5 metros de largo y 2 metros de ancho que conforma el esqueleto, da rigidez al sistema y sobre la que se apoyará la segunda parte del prototipo. Esta estructura de dos metros se encuentra apoyada en sus cuatro patas por ruedas, dos de ellas equipadas con freno para bloquear el avance de la estructura. Por otra parte, la estructura se encuentra dividida en pasos para la modificación de la altura cada 5 centímetros, de manera que sobre estos pasos se anclará la segunda estructura en función de la altura de trabajo a la que se quiera trabajar. De esta forma queda solucionado el problema del desplazamiento a lo largo del objeto de estudio desde cierta altura en cenital.

La segunda estructura, que se encuentra anclada al esqueleto del prototipo, es aquella que situada a la altura deseada en el armazón nos permitirá desplazar el instrumental transversalmente al objeto de estudio. Para ello, esta estructura de aluminio hace el trabajo de carril sobre el cual se desliza una pieza de conglomerado de 5 centímetros de grosor y con el tamaño del instrumento, con una apertura centrar para la introducción del sistema de medida del escáner. Con este riel se permite el movimiento transversal del escáner a lo ancho del objeto de estudio.

Una vez diseñado, se realiza el montaje y pruebas de carga para comprobar la estabilidad y seguridad que ofrece este nuevo sistema. Para el montaje del prototipo es necesario aproximadamente 10 minutos para el montaje y el chequeo de la correcta colocación de los elementos con una sola persona. Por otra parte, para comprobar la estabilidad y seguridad del sistema se realizó una prueba de carga durante 10 horas, en donde se cargó en la zona diseñada para colocar el escáner un total de 25 kilos, a una altura de 1,75 metros del suelo, dando por superada dicha prueba de carga.

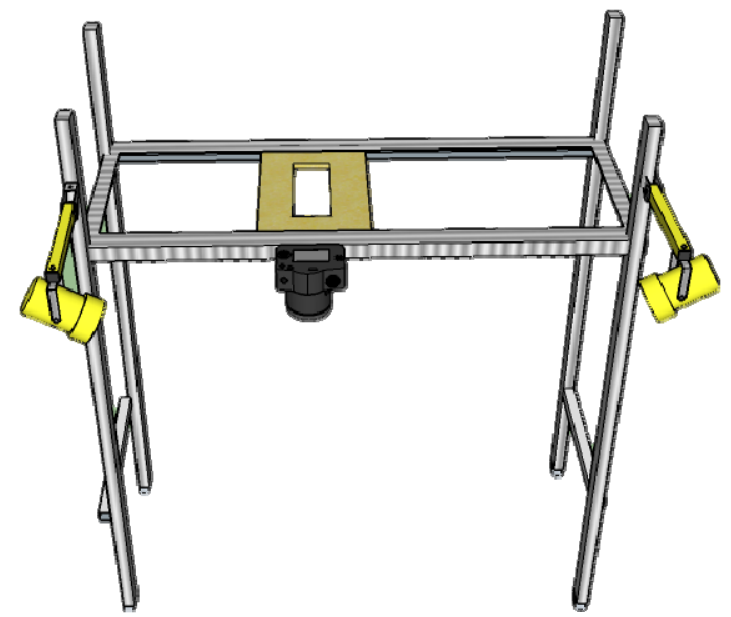

Figura 6: Esquema Prototipo fabricado.

Una vez puesta en funcionamiento en el lugar de trabajo, se comprueba unas más que destacable reducción del tiempo de captura y fatiga del operador al ser los desplazamientos del instrumentar más cómodos para éste, que no tiene que cargar en peso con el escáner y trípode (Fig. 7). Además queda demostrada la eficacia del sistema a la hora de capturar tomas cenitales, ya que además de resolver los problemas que existían a la hora de capturar alguna información, al simular un proyecto de vuelo fotogramétrico, la organización de los datos es óptima para el trabajo posterior de procesado de los mismos (Fig. 8). 


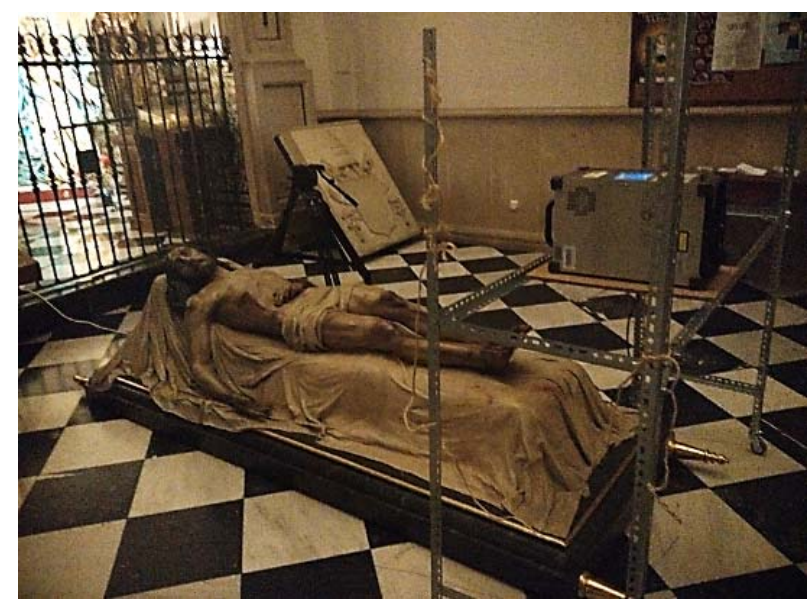

Figura 7: Puesta en funcionamiento prototipo.

Por lo tanto, podemos asegurar que esta estructura permite un mejor flujo de trabajo en este tipo de estudios, al permitir simultáneamente el movimiento longitudinal y transversal a lo largo del objeto mientras se realizan tomas cenitales del mismo muy adecuadas para el estudio de esculturas donde el objeto se encuentre en posición tumbada, pero aplicable también a otro tipos de elementos, como pueden ser mosaicos, los cuales podrían ser estudiados con láser escáner desde una posición cenital sin necesidad de apoyarse sobre el mismo.

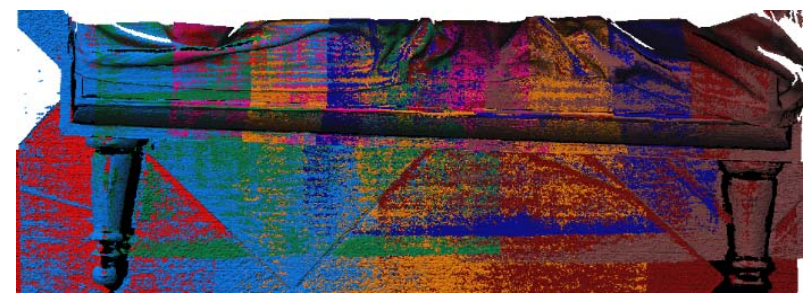

Figura 8: Tomas superpuestas.

Al primer prototipo para captura de tomas cenitales con láser escáner, al comprobar la escasa calidad de las texturas que ofrece el instrumento, se ha realizado una modificación en la cual se ha incorporado a la base de conglomerado un adaptador para situar una cámara fotográfica, la cual se moverá solidaria al escáner, de manera que permita la captura de tomas cenitales, o si se desea la captura de tomas convergentes inclinando la posición de la cámara en función de su posición respecto el objeto.

Este sistema de anclaje de una cámara fotográfica se complementa con la introducción de dos puntos de luz difusa en ambos laterales de la estructura de manera que tengamos totalmente controladas las condiciones lumínicas, mejorando los resultados si realizamos estudios fotogramétricos con software de SfM, los cuales se ven muy afectados con la aparición de reflejos en las imágenes en la realización de los modelos. De esta forma, se podrá trabajar en penumbra, donde el sistema de captura del escáner presenta mejores resultados, al realizar la captura de información geométrica y sin cambiar las condiciones de iluminación ambiental, con este sistema de iluminación difusa obtener las condiciones lumínicas óptimas para la captura fotográfica.

\subsubsection{Reconstrucción de la geometría}

Antes del procesado de los datos del escáner se utiliza primero el software del equipo para transformar el formato nativo .CDM al formato.PLY para llevar a cabo el registro y orientación de las distintas tomas del escáner y modelado de la nube de puntos posterior.

Todos los procesos de alineado manual, ajuste global del alineado, así como el la modelización a partir de la nube de puntos reconstruyendo la superficie ha sido realizado con el software libre MeshLab. De esta manera se pretendía comprobar si era factible con un software libre un flujo de trabajo similar a otros softwares propietarios, con un gran volumen de puntos.

En primer lugar, se han ido relacionando los distintos escaneos a partir de puntos homólogos entre escaneos así con todos los escaneos.

A continuación, una vez pre orientados, se procede a una fase de un nuevo ajuste, de manera que todos los bloques se ajustan simultáneamente minimizando los posibles errores encadenados en los sucesivos alineados de las tomas, ya que al cerrar el objeto tridimensionalmente podemos ajustar el error de cierre.

Una vez la nube completa se ha ajustado, es posible realizar la reconstrucción de la superficie del objeto de estudio, para ello se hizo uso del algoritmo de Poisson, con un total de 18,3 millones de puntos, dando como resultado un modelo de la superficie de la imagen de más de 15,5 millones de polígonos (Figs. 9 y 10).

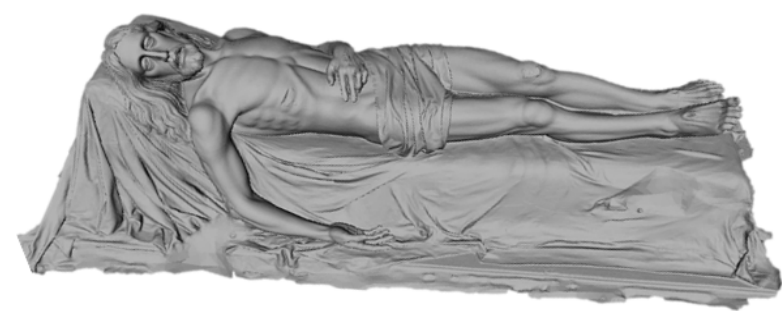

Figura 9: Malla final completa.

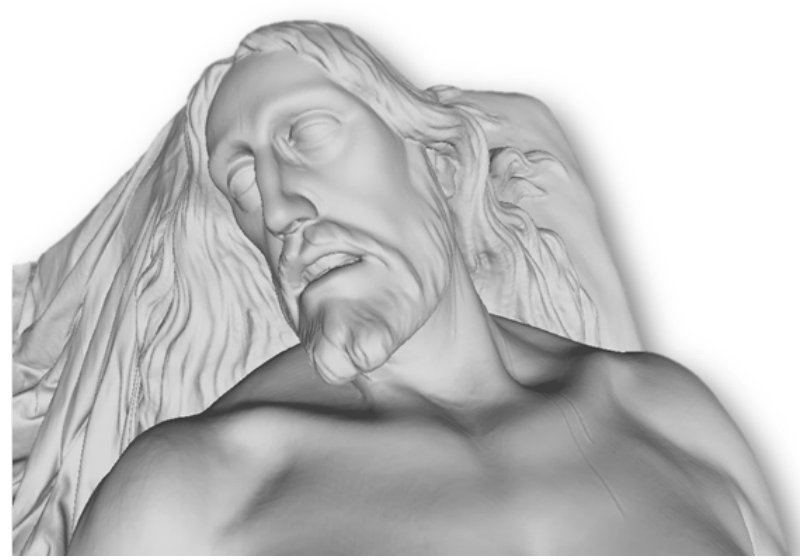

Figura 10: Detalle de la malla, donde se aprecian detalles de la policromía.

\subsection{Captura información de la textura}

En un primer lugar se establece una captura de la información fotográfica únicamente como fuente de estudio complementaria sin pretender realizar modelos 
fotogramétricos, por lo que la geometría de la toma no fue considerada como algo fundamental en el proceso del mismo.

Tal como se ha indicado, la principal función que presentaba el estudio fotográfico era el de servir de guía visual para la relación entre las diversas capturas del láser escáner, el cual puede ser un trabajo complicado si no tenemos información complementaria adicional. Sin embargo,una vez realizado todo el proceso de captura de datos y sin posibilidad de volver a la zona de trabajo, se procede a la obtención de un modelo de la talla mediante fotogrametría, aunque las tomas no habían sido planeadas ni realizadas con suficiente rigor para llevar a cabo un estudio fotogramétrico completo. Debido a esta circunstancia los resultados no son adecuados. El principal inconveniente que aparece es que las imágenes correspondientes a las zonas izquierda y derecha de la escultura no se pueden orientar en un mismo bloque, ya que la zona central de la misma presenta poco solape entre los bloques tomados en cada uno de los extremos. Esto imposibilita en un primer instante la realización de un modelo fotogramétrico completo de la imagen objeto de estudio, de manera que para la obtención de un modelo texturizado completo será necesario la fusión de los datos fotogramétricos y de escáner.

\subsection{Fusión de los datos}

Se parte por un lado de un modelo geométrico de muy alta resolución sin textura, y por otro lado, una fuente importante de información de la policromía que será necesario fusionar para obtener el modelo virtual con textura (Fig. 11).

Con este fin, se realiza la extracción de puntos comunes reconocibles en ambos sistemas y así poder unificar toda la información en un solo sistema, posibilitando la obtención del modelo texturizado. Para la fusión de los datos capturados por el escáner y los datos de imágenes, el proceso llevado a cabo ha sido:

- Extracción de puntos de control en la geometría

- Medición de puntos de control en las imágenes

- Fusión de los bloques independientes

- Combinación del modelo e imagines

- Texturizado

\subsubsection{Extracción de puntos de control modelo}

En primer lugar, para poder combinar dos sistemas de referencia, es fundamental la medición de puntos comunes que hagan de puntos de control de un sistema de referencia a otro. Para ello, el dato que se usa como Sistema de referencia sobre el que trabajar será el modelo triangulado de alta resolución medido con el escáner. Para ello, se han ido extrayendo de manera manual aquellos detalles que podrían ser observables en las imagines fotográficas, como elementos anatómicos de la imagen fácilmente reconocibles como pueden ser heridas, o uñas, pero también han sido medidos elementos de la policromía que han sido capturados por el Sistema de captura geométrica, como son los surcos generados por la sangre (ver Fig. 11).
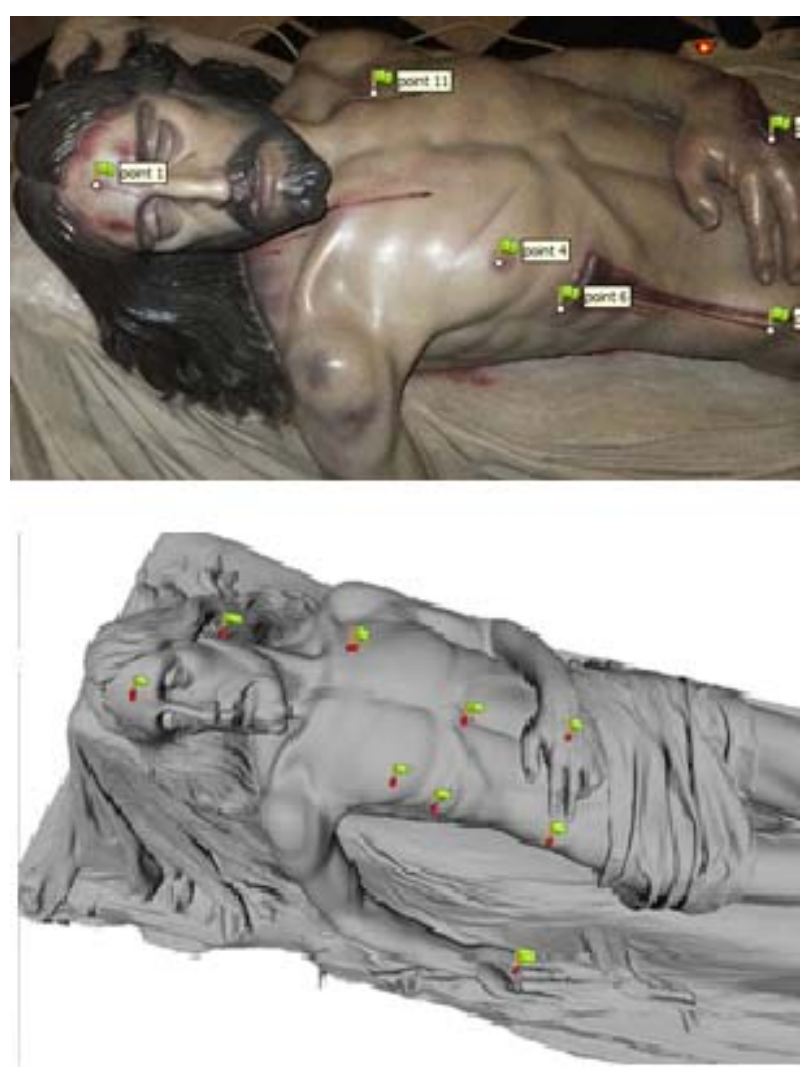

Figura 11: Puntos de control sobre imagen (arriba) y modelo (abajo).

\subsubsection{Medición de puntos de control y fusión de bloques}

Una vez extraídos los puntos de control, se realiza la medición de los mismos en las imágenes correspondientes a los dos bloques fotogramétricos previamente creados. De manera que el problema existente de falta de solape suficiente entre estos dos bloques queda solventado mediante la orientación independiente de cada uno de ellos.

En este punto, se estaría en disposición de poder reconstruir la geometría completa de la talla mediante fotogrametría. Aun así la calidad obtenida realizando el modelado con las imágenes es muy inferior a la obtenida con el láser escáner, por lo que se descarta usar el modelo fotogramétrico.

\subsubsection{Combinación modelo-fotografías}

La filosofía del método es usar la fuente de mayor calidad que tengamos para cada fase del proyecto, por lo que en el caso de la texturización de la malla se utilizará la superficie obtenida a partir del escáner y las imágenes fotogramétricas una vez orientado todo en el mismo sistema de referencia, descartando el uso de la malla obtenida con fotogrametría como base para ser texturizado. De este modo importamos el modelo del escáner en el software fotogramétrico, de manera que también este software nos permite la reducción de la malla en función del uso que se le dará al modelo texturizado (Fig. 12). 


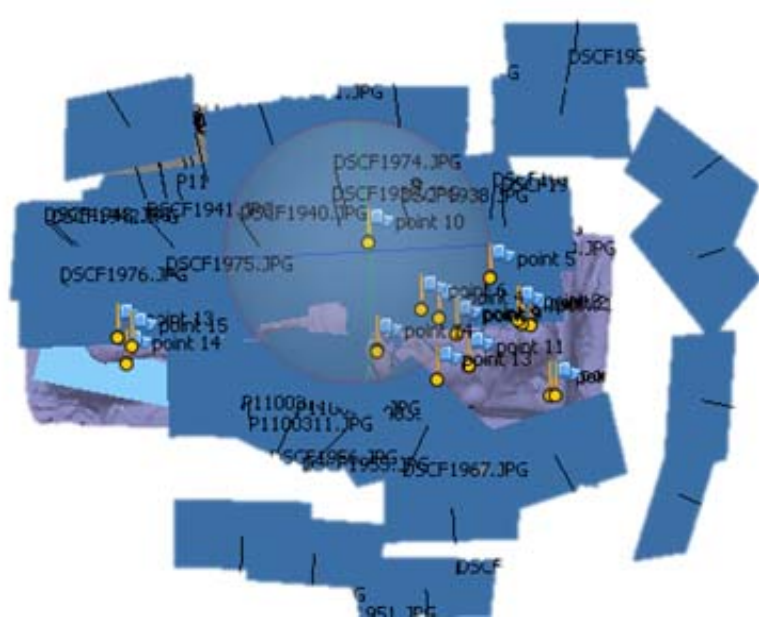

Figura 12: Situación de las imágenes y modelo de alta resolución.

\section{Resultados}

En cuanto a los resultados obtenidos, podemos destacar que con este tipo de técnicas se permite un paso de lo físico a lo virtual mediante las técnicas de adquisición de datos, pero también el proceso contrario, es posible un paso de lo virtual a lo físico en caso de necesidad, con los variados sistemas que existen en el mercado, como son las máquinas de mecanizado o las impresoras 3D. En función de la utilidad con la que se utilicen los datos obtenidos, podemos diferenciar aplicaciones destinadas a la conservación del patrimonio, o aplicaciones de difusión del mismo.

\subsection{Resultados de conservación}

Para los productos de conservación del patrimonio hacienda uso de técnicas geométricas y de imagen, generalmente se hará uso de los productos obtenidos con la máxima precisión en el flujo de trabajo, es decir, los productos brutos ya procesados. En cuanto a las principales aplicaciones que presenta, se podría destacar la realización de copias de seguridad del mismo, de manera que se pueda realizar una reproducción exacta de elementos dañados o de la talla completa en caso de necesidad. Otra aplicación muy recurrente son los estudios multitemporales de manera que se puede estudiar el comportamiento y evolución de los diferentes bloques estructurales que componen estas esculturas, así como multitud de estudios científicos-artísticos de estudio de proporciones.

\subsection{Resultados de difusión}

En cuanto a los resultados destinados a la difusión, se podrían considerar como productos derivados del resultado inicial, de manera que pueden sufrir un proceso de simplificación o transformación a otros resultados. Así los productos derivados para la difusión del patrimonio consisten en reproducciones a diferentes escales y materiales, gracias a las impresoras 3D, publicación en formatos digitales, como son el pdf3D, visores Web, así como aplicaciones de realidad aumentada, virtualizaciones o vídeos de promoción (Figs. 13 y 14).

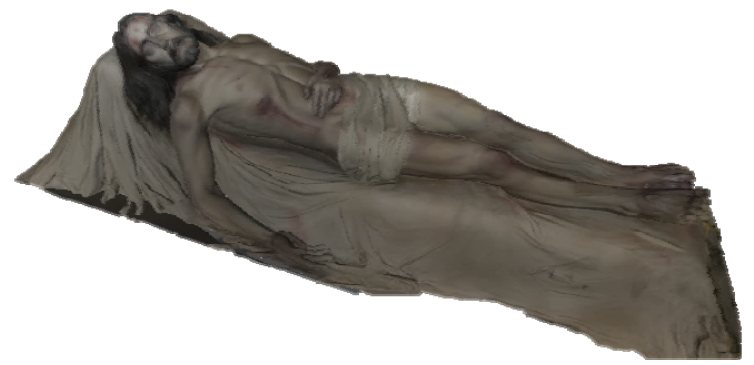

Figura 13: Modelo Texturizado para visor WEB.

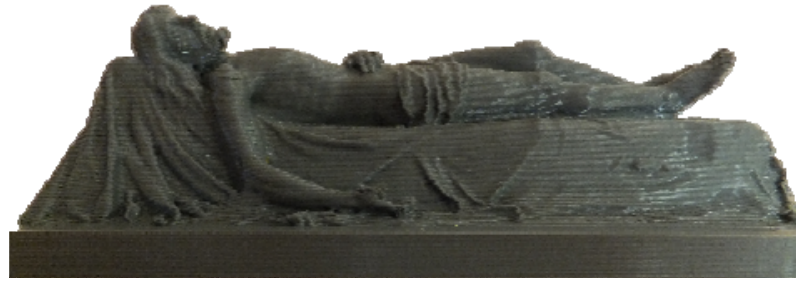

Figura 14: Impresión 3D.

Como conclusiones finales, destacar los resultados satisfactorios obtenidos en cada una de las fases comentadas, de manera que se han obtenidos productos de muy alta resolución geométrica y radiométrica haciendo uso de la fusión de datos. Además el uso del prototipo ha cumplido las expectativas, al agilizar el flujo de trabajo $y$ disminuyendo la fatiga y dificultades del operador y por último recalcar que la posibilidad que permite este tipo de técnicas a la hora de la realización de reproducciones exactas del patrimonio analizado, sin la necesidad de que la imagen sufra contacto alguno ni necesidad de desplazamiento de su lugar habitual.

\section{Agradecimientos}

Agradecimientos al departamento de Ingeniería Cartográfica, Geodésica y Fotogrametría y al Grupo de Investigación Sistemas Fotogramétricos y Topométricos, por facilitar el material para la realización del presente trabajo, así como por el uso de la impresora 3D.

Agradecer también a la Pontificia y Real Cofradía del Stmo. Cristo Yacente y Siervos de Ntra. Sra. De la Soledad por permitir la difusión de los resultados finales.

\section{Referencias}

BERger, M., TAGLIASACCHI, A., SEVERSKY, L., ALLIEZ, P., LEVINE, J., SHARF, A. y SILVA, C., 2014. State of the art in surface reconstruction from point clouds. In EUROGRAPHICS star reports Vol. 1, No. 1, pp. 161-185. DOI:10.2312/egst.20141040

LEVOY, M., PULLI, K., CURLESS, B., RUSINKIEWICZ, S., KOLLER, D., PEREIRA, L. y SHADE, J., 2000. The digital Michelangelo project: 3D scanning of large statues. In Proceedings of the 27th annual conference on Computer 
graphics and interactive techniques, pp. 131-144. ACM Press/Addison-Wesley Publishing Co. doi:10.1145/344779.344849

LOPEZ-MENCHERO, V.M., GRANDE, A., 2011. The principles of the Seville charter. In CIPA symposium proceedings Vol. 2011, pp. 2-6.

SANSONI, G., TREBESCHI, M. y DOCCHIO, F., 2009. "State-Of-The-Art and Applications of 3D Imaging Sensors in Industry, Cultural Heritage, Medicine, and Criminal Investigation" en Sensors, $n^{\circ}$ 9. Multidisciplinary Digital Publishing Institute. Págs: 568-601. DOI:10.3390/s90100568 


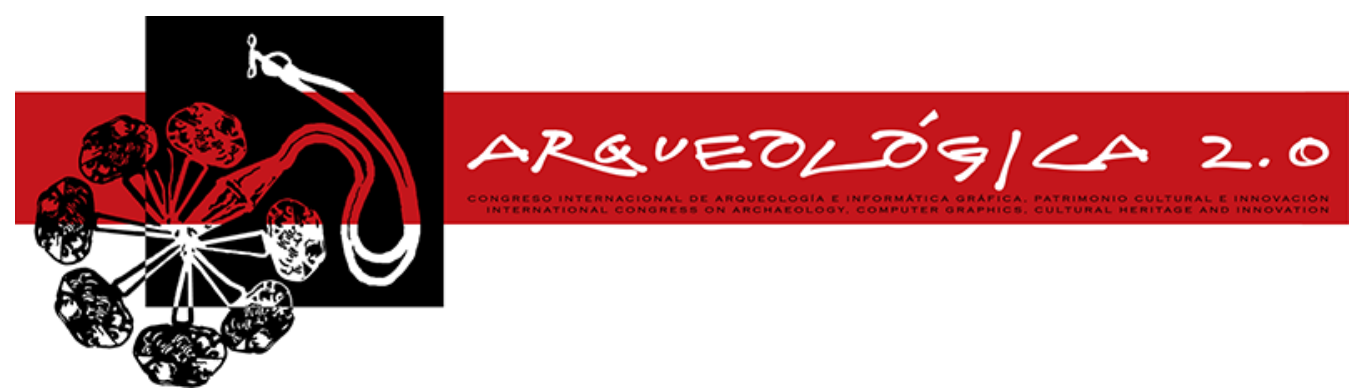

Proceedings of the $8^{\text {th }}$ International Congress on Archaeology, Computer Graphics, Cultural Heritage and Innovation

'ARQUEOLÓGICA 2.0'

in Valencia (Spain), Sept. $5-7,2016$

DOI: $\mathrm{http}: / / \mathrm{dx}$. doi.org/10.4995/arqueologica8.2016.3535

\title{
TRATAMIENTO DE DATOS TLS MEDIANTE EL EMPLEO DE IMÁGENES ESFÉRICAS: APLICACIÓN A LA DOCUMENTACIÓN DE LA SALA CAPITULAR DE LA CATEDRAL DE JAÉN
}

\author{
TLS DATA PROCESSING USING SPHERICAL IMAGES: APPLICATION TO THE CHAPTERHOUSE OF THE \\ CATHEDRAL OF JAEN
}

\author{
José M. Gómez-López , José L. Pérez-García, Carlos Colomo, Javier Cardenal, Emilio Mata
}

Dpto. Ingeniería Cartográfica, Geodésica y Fotogrametría, Escuela Politécnica Superior, Campus Las Lagunillas, Universidad de Jaén, 23071 Jaén, España. jglopez@ujaen.es; ilperez@ujaen.es; cmcj0002@red.ujaen.es; icardena@ujaen.es; emata@ujaen.es

\begin{abstract}
:
Nowadays, one of the techniques more used for documentation of cultural heritage is terrestrial laser scanner (TLS). This kind of instrumental has become essential in this kind of heritage projects. However, in many projects, the captured information by these systems are excessive, which hinders its data processing and information extraction. But when the documentation purpose is limited to the visualization or dissemination, the final products can be simpler than those obtained from the dense point clouds and the resulting detailed models. In this paper it is presented an approach based on TLS data processed with spherical images algorithms. TLS point clouds are used to simulate spherical images allowing the storage, processing, visualization and dissemination of both data and products. This approach has been applied to a real study case in the documentation of the chapterhouse of the Cathedral of Jaén.
\end{abstract}

Key words: spherical images, terrestrial laser scanner, spherical photogrammetry, cultural heritage documentation

Resumen:

En la actualidad, una de las técnicas más utilizadas para la documentación del patrimonio cultural es el escáner láser terrestre, instrumental que se ha convertido en imprescindible en cualquier empresa que se dedique a estos fines. Sin embargo, en muchos casos la información capturada por estos sistemas es excesiva, lo que dificulta su procesado y la posterior extracción de información. Por otro lado, cuando el fin es solo la visualización o la divulgación del monumento, los productos necesarios son más simples que la nube de puntos densa o una modelización de gran precisión obtenida a partir de esta nube. En este trabajo se presenta una filosofía de trabajo con datos TLS basada en el uso de imágenes esféricas obtenidas a partir de las nubes de puntos provenientes del escaneado, que facilita su almacenamiento, procesado, visualización y divulgación. Finalmente se presenta la metodología llevada a cabo y los resultados obtenidos en un caso de estudio real, más concretamente en la documentación de la Sala Capitular de la Catedral de Jaén.

Palabras clave: imágenes esféricas, escáner láser terrestre, fotogrametría esférica, documentación del patrimonio cultural

\section{Introducción}

En todo trabajo de documentación del patrimonio mediante técnicas basadas en escáner láser terrestre, el objetivo principal de la fase inicial de captura, es aprovechar la información capturada de manera masiva, de tal forma, que estos datos no sean insuficientes ni excesivamente redundantes. En definitiva, que estos datos sean lo suficientemente densos para cumplir el propósito para el que son capturados, pero que no se produzca una innecesaria captura de información no útil que pueda suponer un sobrecoste en los tiempos y en el presupuesto destinado al trabajo de documentación planteado.

Este objetivo se plantea porque uno de los principales problemas, cuando se trabaja con esta tecnología, es la alta densidad de información que se obtiene. De hecho, hoy en día resulta más útil y eficaz obtener toda la geometría del entorno de trabajo en la fase de medición, para luego, en oficina, decidir cuál será la información que se extrae o se aprovecha puntualmente. Este hecho implica dos problemas. Por un lado, se generan archivos digitales de gran volumen, teniendo en mayor o menor

`Corresponding Author: José M. Gómez-López, jglopez@ujaen.es 
medida un problema de almacenamiento de información, y por otro lado, un post-proceso de los datos para extraer la información relevante que requiere bastante tiempo y recursos informáticos. Es por esto, que el tratamiento de los datos escáner láser terrestre sea un tema de gran interés en la comunidad científica relacionada con esta área de trabajo.

Por otro lado, son muy numerosos los artículos y trabajos publicados cada año, donde se utiliza esta técnica en combinación con otras técnicas como la fotogrametría aérea (UAV), la fotogrametría de objetos cercanos o la videogrametría, para aplicaciones de reconstrucción, modelado $3 \mathrm{D}$, etc.

La metodología que aquí se plantea, trata de conseguir un enfoque distinto al habitual de tratamiento y aprovechamiento de los datos de escáner láser presente en la mayoría de las aplicaciones informáticas desarrolladas para este fin, para agilizar los procesos de almacenamiento, procesado, extracción de información relevante y la fusión con datos procedentes de otras técnicas o instrumentos.

Para explicar el fundamento de este planteamiento, podríamos apoyarnos en dos definiciones propuestas por Mills y Barber (2003). Por un lado, se define escáner láser terrestre como "un dispositivo fijo en tierra que utiliza un láser para medir las coordenadas tridimensionales de una región determinada de una superficie de un objeto, en un orden sistemático a un velocidad alta en tiempo real". Por otro lado, también se define la nube de puntos como, "una colección de coordenadas $\mathrm{XYZ}$ en un sistema de referencia común que representa al observador, una comprensión de la distribución espacial de un objeto o lugar, que también puede incluir información adicional como la intensidad o el valor RGB". Teniendo en cuenta estas definiciones, se podría deducir que:

- Se dispone de un instrumento que hace medidas puntuales en un orden sistemático.

- El producto que genera, es una estructura sin ningún orden, sin ninguna relación implícita o explícita entre elementos.

- El propósito seria entonces reconstruir ese orden, para obtener un producto con una estructura topológica, que facilite las operaciones. Esto se podría traducir en convertir esa colección de coordenadas, en una estructura de almacenamiento de tipo ráster.

Se puede encontrar numerosa bibliografía del empleo de esta estructura para solventar los problemas de registro o de extracción de elementos. Por ejemplo, en Chen et al. (1998) se propone un método para determinar las tres mejores homologías entre dos imágenes de distancia. El algoritmo line-based planteado por Stamos y Leordean (2003) está basado en la segmentación de las imágenes de distancia y la extracción de segmentos rectos y planos. Por otro lado, Moldovan et al. (2009) utiliza la información de la intensidad y el operador SIFT para obtener puntos comunes. Siguiendo esta línea, Theiler y Schindler (2012) determina puntos comunes a varios escaneados, a partir de la intersección de tres planos encontrados en los escaneados, ya que estos puntos tienen geometría más estable, aplicando el operador RANSAC a la pirámide de imágenes generadas a partir de las imágenes correspondiente a cada escaneado o un ejemplo más curioso de utilización de estas imágenes lo podemos encontrar en Nüchter et al. (2011), que consiste en un método de registro automático de escenas $360^{\circ}$ en ciudades, a partir de la obtención del borde o línea que genera los edificios con el cielo (Skyline) en cada toma e identificar características comunes sobre estas líneas.

\section{Metodología}

El trabajo que se presenta está estructurado en una serie de fases que permiten la definición e implementación de la metodología propuesta:

- Generación de imágenes esféricas a partir de la nube de puntos.

- Registro de la nube de puntos a partir de las imágenes esféricas utilizando modelos fotogramétricos adaptados.

- Extracción de puntos de control a partir de las imágenes esféricas para la fusión con imágenes procedentes de cámaras fotográficas y proceso de orientación fotogramétrica.

- Aplicación de la metodología en un caso de estudio real, validación y generación de productos asociados.

\section{Generación de las Imágenes esféricas}

Como se definió en el apartado anterior, el escáner láser terrestre realiza una medición en un orden sistemático, esto se traduce en un barrido horizontal y vertical del objeto, midiendo la distancia respecto a éste en cada punto, es decir, las observaciones que realiza este instrumento están basadas en un sistema esférico (Fig. 1).

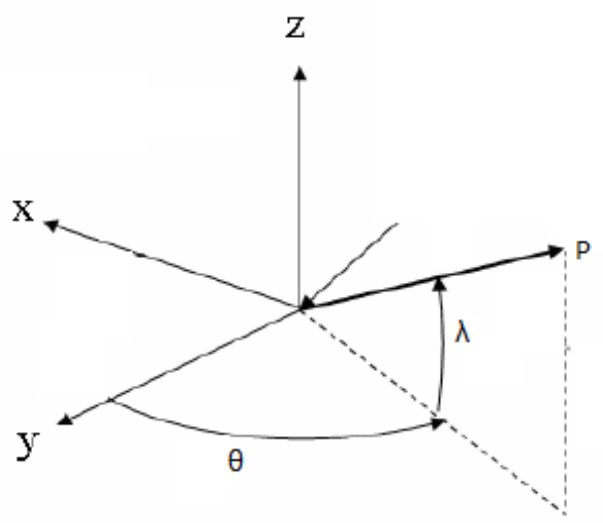

Figura 1: Sistema Cartesiano y Esférico

El primer paso para la generación de las imágenes, sería transformar las coordenadas $X Y Z$ obtenidas, en coordenadas esféricas $\theta, \lambda, D$, Eq. (1):

$$
\theta=\operatorname{atg}\left(\frac{y}{x}\right) ; \lambda=\operatorname{acos}\left(\frac{z}{D}\right) ; D=\sqrt{x^{2}+y^{2}+z^{2}}
$$


A partir de aquí, se obtiene la estructura ráster. En primer lugar se calculan los extremos de los ángulos ( $\theta$ min, $\lambda$ max, $\theta \max , \lambda \min )$, definiendo así la superficie esférica que se ha escaneado, y posteriormente una vez calculado el paso angular o resolución del escáner utilizada a partir de los datos, se añadirán a dicha estructura ráster los puntos capturados en dicho escaneo.

Por último, queda elegir las ecuaciones proyectivas que permitan pasar de la esfera a la proyección y definir el tamaño de la imagen resultante. En Houshiar et al. (2015) se hace un estudio de las proyecciones para mejorar la extracción de elementos y descriptores, para posteriormente hacer un registro automático. En este trabajo se ha elegido por defecto la proyección equirectangular o de Plate Carrée.

Esta proyección tiene una pequeña desventaja, como es la deformación que se produce a partir de latitudes por encima de $80^{\circ}$, lo que hace que se dificulte la visualización de datos que se encuentran en estas zonas. Para solucionar esto, se ha recurrido a otras proyecciones, de tipo gnomónica para la visualización de estos datos (Fig. 2).

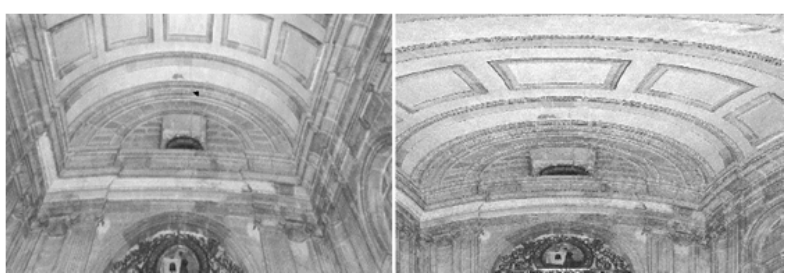

Figura 2: Izquierda: proyección Gnomónica. Derecha: proyección Equirectangular

Según lo comentado anteriormente, el tamaño de la imagen queda definido por, Eq. (2):

$$
\mathrm{f}=\frac{\lambda_{\max }-\lambda_{\min }}{\delta \alpha} ; \mathrm{c}=\frac{\theta_{\max }-\theta_{\min }}{\delta \alpha}
$$

donde:

$$
\begin{aligned}
& \text { - } \quad f y c \text { son el número de filas y de columnas } \\
& \text { - } \quad \delta \alpha \text { es la resolución espacial. }
\end{aligned}
$$

Para completar la conversión entre estructuras de almacenamiento, quedaría asignar a cada celda, o pixel de la imagen, el valor de la distancia con respecto al origen del escáner. Así, cada posición de la imagen define dos ángulos, horizontal y vertical, y el valor de esa celda tiene almacenada la distancia del punto o los puntos que se encuentren dentro de esta.

En este momento surge el primer inconveniente de esta conversión, como es la interpolación, o la conversión de entidades puntuales en entidades zonales, y como eso puede afectar a la posterior recuperación de la estructura inicial de nube de puntos. Dado que la nube de puntos no es una estructura regular con densidad y espaciado angular constante y el ráster si lo es, dado que tiene tamaño de celda fijo y sólo almacena un dato por celda, habrá que tener en cuenta algunas consideraciones. En primer lugar, existirán celdas donde aparecerán varios puntos y habrá que seleccionar que valor representará al de la celda correspondiente. En este sentido, se puede optar, en función de la aplicación o las necesidades planteadas, por seleccionar el punto más cercano al escáner, el último, el más centrado, o el promedio de todos. Por otro lado, los puntos encerrados en cada celda no tienen por qué encontrarse en el centro de la misma, posición que representa a dicha celda, por lo tanto si se desea recuperar la posición real de los datos habrá que almacenar el offset del punto respecto al centro de la celda (Fig. 3). Este offset es guardado en la misma estructura de almacenamiento.

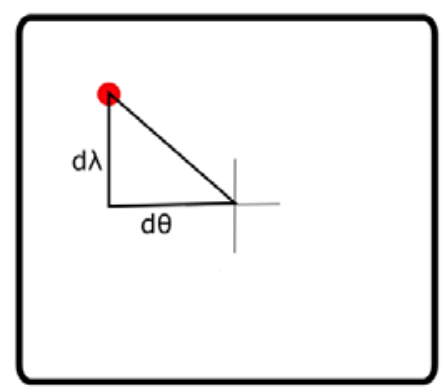

Figura 3: Offset del punto respecto al centro de la celda

Otro aspecto a tener en cuenta en la generación de la estructura ráster, es que en la mayoría de las ocasiones, se va a disponer de información adicional a la distancia de cada uno de los puntos como es la intensidad o el color. En este sentido, el almacenado de esta información se llevará a cabo en la misma estructura creada para la distancia, bien como una capa más o bien como imágenes independientes.

Una vez creada la estructura ráster que representa a la nube de puntos, habría que analizar algunas de las ventajas que esta aporta sobre la estructura original de $X Y Z$. Por un lado, se facilitan todas las operaciones de almacenamiento y recuperación de la información, así como todas las operaciones basadas en la vecindad de los puntos. Por otro lado, esta estructura va a permitir el uso sobre los datos de algoritmos de procesamiento digital de imágenes para generar nuevas imágenes derivadas de distinta información, útiles para la extracción de elementos o características de forma automática.

Por último, se podría también destacar una ventaja evidente respecto al almacenamiento de la información en disco, ya que la conversión entre estructuras significa reducir considerablemente el tamaño de los archivos originales. Por ejemplo, un archivo ASCII de 4 millones de puntos $X Y Z$ tiene un tamaño en disco de alrededor de $200 \mathrm{MB}$, sin embargo, almacenado en imagen esférica en formato TIFF, el tamaño es de $\sim 14 \mathrm{MB}$. En Houshiar y Nuchter (2015), aplican los metodos convencionales de comprensión de imágenes, a las imágenes panorámicas de distancias, color e intensidad para reducir el espacio de almacenamiento, asi como para estudiar los efectos que producen en los datos.

\section{Registro u orientación de las nubes de puntos a partir de modelos fotogramétricos adaptados}

Una de las ventajas de la utilización de las imágenes esféricas, es la fácil adaptación de los modelos propios de orientación fotogramétrica a los datos procedentes de escáner láser terrestre.

En este caso, se implementa un modelo matemático basado en la condición de colinealidad. Por tanto, el 
vector de posición en la esfera $(r)$ y su correspondiente en el sistema de referencia $(R)$ deberán estar alineados en el espacio (Fig. 4). Para ello, habrá que rotar el sistema esférico, y ajustarlo en escala si fuese necesario.

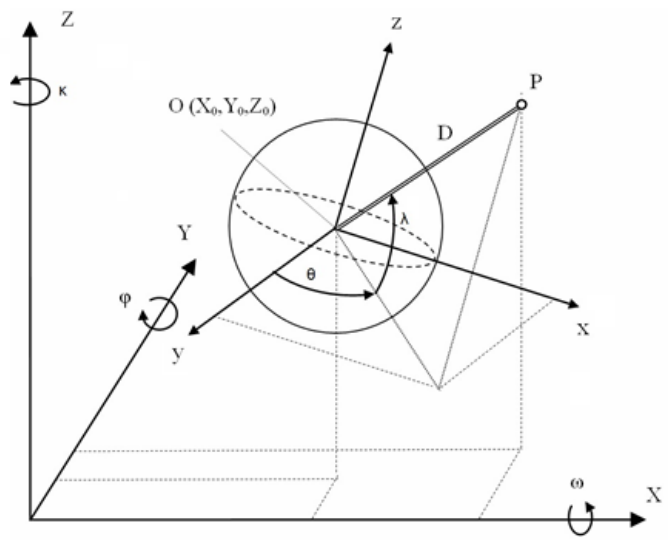

Figura 4: Esquema del modelo de colinealidad adaptado para esféricas

Las matrices que definen esta condición quedarán de la siguiente manera, Eqs. (3, 4, 5 y 6):

$$
\begin{gathered}
\vec{r}=\left[\begin{array}{c}
D \operatorname{sen}(\theta) \cos (\lambda) \\
D \cos (\theta) \cos (\lambda) \\
D \operatorname{sen}(\lambda)
\end{array}\right] ; \vec{R}=\left[\begin{array}{c}
X_{p}-X_{0} \\
Y_{p}-Y_{0} \\
Z_{p}-Z_{0}
\end{array}\right] \\
{\left[\begin{array}{c}
D \cos (\theta) \operatorname{sen}(\lambda) \\
D \cos (\theta) \cos (\lambda) \\
D \operatorname{sen}(\lambda)
\end{array}\right]=K[M(\omega, \varphi, \mathrm{\xi})]\left[\begin{array}{c}
X_{p}-X_{0} \\
Y_{p}-Y_{0} \\
Z_{p}-Z_{0}
\end{array}\right]}
\end{gathered}
$$

Analíticamente seria:

$$
\begin{aligned}
& x S=\frac{\operatorname{sen}(\theta) \cos (\lambda)}{\operatorname{sen}(\lambda)}=\frac{m_{11}\left(X_{P}-X_{0}\right)+m_{12}\left(Y_{P}-Y_{0}\right)+m_{13}\left(Z_{P}-Z_{0}\right)}{m_{31}\left(X_{P}-X_{0}\right)+m_{32}\left(Y_{P}-Y_{0}\right)+m_{33}\left(Z_{P}-Z_{0}\right)} \\
& y S=\frac{\cos (\theta) \cos (\lambda)}{\operatorname{sen}(\lambda)}=\frac{m_{21}\left(X_{P}-X_{0}\right)+m_{22}\left(Y_{P}-Y_{0}\right)+m_{23}\left(Z_{P}-Z_{0}\right)}{m_{31}\left(X_{P}-X_{0}\right)+m_{32}\left(Y_{P}-Y_{0}\right)+m_{33}\left(Z_{P}-Z_{0}\right)}
\end{aligned}
$$

donde:

$$
\begin{aligned}
& \text { - } \quad x s, y s \text { son las fotocoordenadas esféricas. } \\
& \text { - } \quad \theta, \lambda \text { coordenadas esféricas } \\
& \text { - } \quad \mathrm{m}_{\mathrm{nn}} \text { los elementos de la matriz de rotación. }
\end{aligned}
$$

Las incógnitas a resolver son parámetros de orientación externa $(X O, Y O, Z O, \omega, \varphi, \varkappa)$. Este modelo linealizado, será utilizado como una ecuación de observación en el modelo de ajustes de haces.

\section{Fusión con otros datos}

Tal y como se comentó con anterioridad, esta estructura ráster facilita la fusión de datos de distinto tipo. En este sentido, el proceso de fusión de datos láser escáner con datos de imágenes fotográficas tomadas con cámaras convencionales, se ha resuelto extrayendo puntos comunes entre ambos conjuntos de puntos, y utilizándolos como puntos de apoyo para la orientación fotogramétrica de las fotografías.

Cuando se trabaja en proyectos de documentación geométrica del patrimonio cultural, con fines de virtualización de la realidad, puede ocurrir que la utilización de targets o puntos artificiales para la materialización de puntos de apoyo, oculte detalles del objeto o la escena a documentar, o que la colocación de los mismos suponga un problema para el propio objeto o por lo inaccesible de este. Es por esto, que en ocasiones se tenga que recurrir a utilizar detalles o puntos característicos de la escena, que sean identificables en el conjunto de observaciones realizadas.

En este sentido, se puede obtener el apoyo fotogramétrico a partir de la nube de puntos, si esta tiene una resolución espacial equiparable a la de las fotografías. La utilización de las imágenes esféricas, en lugar de la nube de puntos, agiliza mucho el proceso de búsqueda de puntos característicos, obteniendo buenos resultados tras el ajuste fotogramétrico (Fig. 5). Facilitando de esta manera la fusión de datos fotogramétricos y de escáner láser terrestre sin la necesidad de la preseñalización de puntos de control ni de la medida de los mismos mediante técnicas topográficas.

\section{Caso de Estudio: Sala Capitular de la Catedral de Jaén}

La sala capitular (Fig. 6), también llamada Capilla de San Pedro de Osma fue construida en 1556 por Andrés de Vandelvira. Es de planta rectangular de medidas muy proporcionadas, de $14 \mathrm{~m}$ por $7 \mathrm{~m}$, y está adornada por pilastras jónicas, veinticuatro nichos y tres grandes ventanales orientados al oeste. Al frente hay un retablo del siglo XVI de Pedro Machuca, discípulo de Miguel Ángel, siendo la única decoración de la estancia. Está formado por 13 tablas simétricamente distribuidas en torno al motivo central de San Pedro de Osma.

La documentación geométrica se realizó empleando un escáner láser terrestre Leica ScanStation C10, y una cámara réflex Canon EOS D5 MKII. Las características de ambos se especifican en la Tabla 1.

Tabla 1: Características Instrumental

\begin{tabular}{c|c} 
Leica ScanStation C10 & Canon EOS D5 MKII \\
\hline 50,000 puntos $/ \mathrm{seg}$ & $5616 \times 3744$ \\
Alcance hasta $150 \mathrm{~m}$ & $24 \mathrm{~mm}$ y $35 \mathrm{~mm}$ de focal \\
Precisión distancia $6 \mathrm{~mm} / 50 \mathrm{~m}$ & $6.5 \mu \mathrm{m}$ tamaño de pixel \\
Campo de visión $360^{\circ} \times 270^{\circ}$ & \\
Cámara digital $4 \mathrm{Mpx}$ & \\
Compensador doble eje &
\end{tabular}

Para la toma de algunas de las imágenes, se utilizó un mástil telescópico con trípode (Fig. 7).

En total, se realizaron tres escaneos de resolución $1 \mathrm{~cm}$. a $10 \mathrm{~m}$. y 120 imágenes fotográficas con distintas distancias de disparo. 


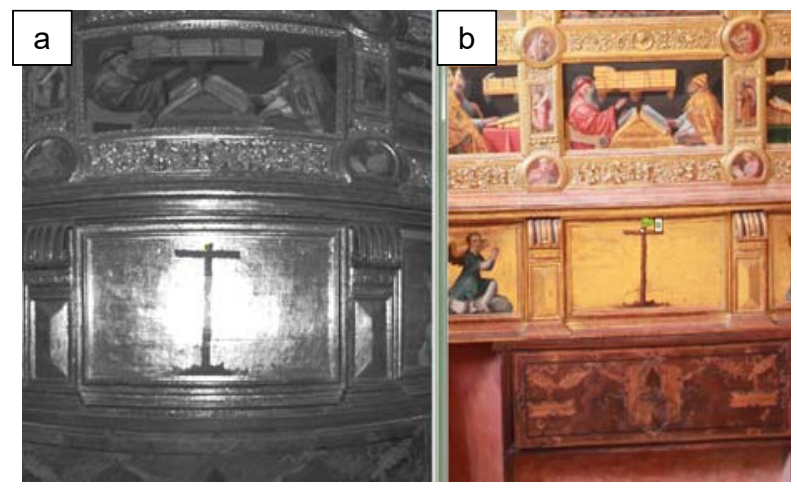

Figura 5: a) Imagen esférica de Intensidades; b) Imagen fotográfica

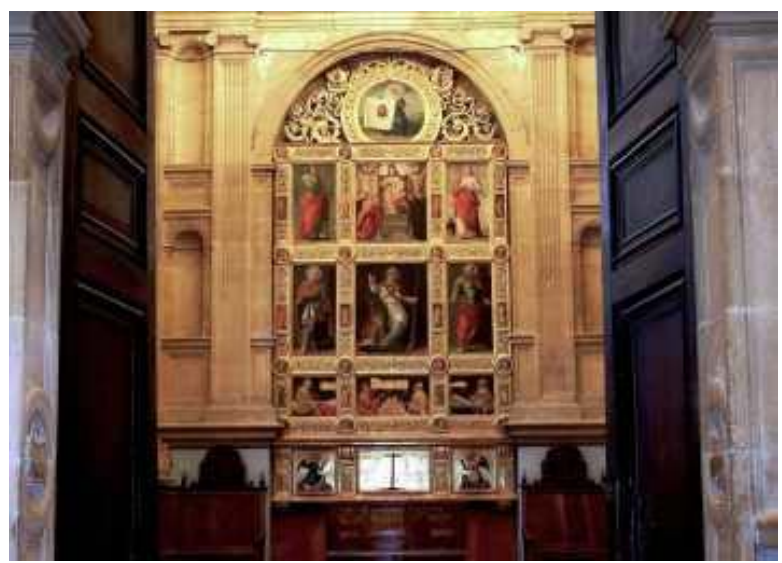

Figura 6: Sala Capitular, Catedral de Jaén

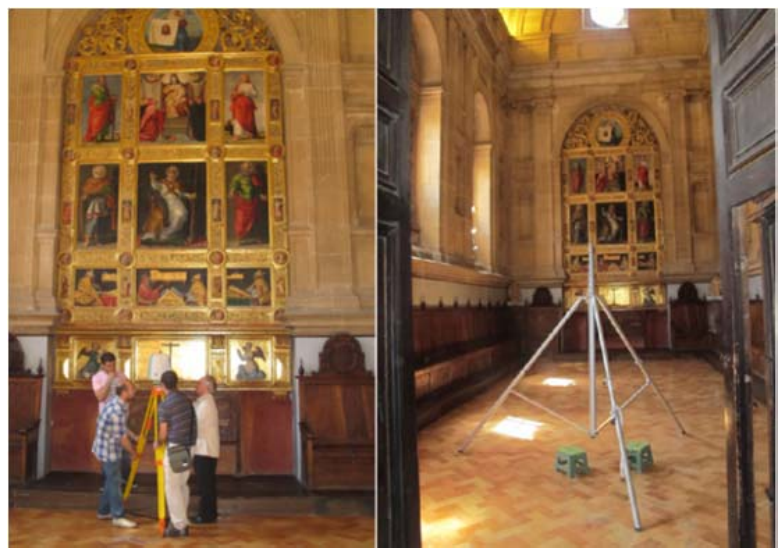

Figura 7: Instrumental empleado

Para aplicar y verificar la metodología propuesta, se implementó una aplicación en Java (Fig. 8) que principalmente permite:

- Abrir/importar nubes de puntos procedentes de escáner láser terrestre.

- Generación, visualización y manipulación de las imágenes esféricas.

- Realización de mediadas manuales y semiautomática de puntos sobre las imágenes.

- Implementación del modelo fotogramétrico propuesto para el cálculo de los parámetros de orientación externa de los escaneos.

- Salida de resultados.

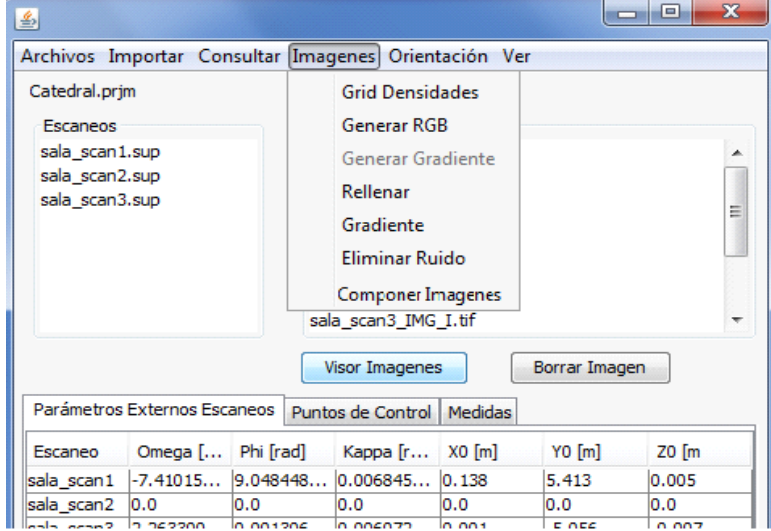

Figura 8: Software LaserScan

Para la orientación de las imágenes se ha utilizado el software Agisoft PhotoScan.

\subsection{Generación de las imágenes y proceso de registro}

En las tres medidas llevadas a cabo con el escáner láser terrestre, se captura a parte de las coordenadas de los puntos, la intensidad y el color como información adicional. De esta forma, se generan 3 imágenes por cada escaneo para guardar la totalidad de la información capturada (Fig. 9).
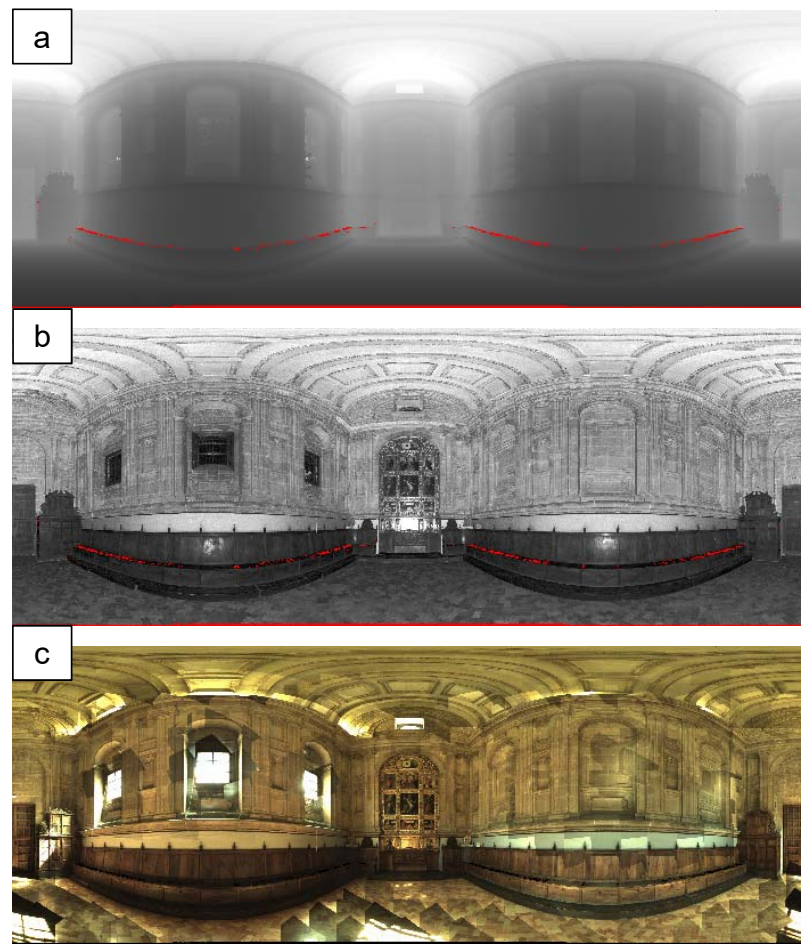

Figura 9: a) distancias; b) intensidad; c) RGB

Una vez generadas estas imágenes, se procede a la orientación de las tres nubes mediante el modelo matemático antes mencionado $y$ de los puntos implicados, obteniendo resultados satisfactorios, con residuos medios en los puntos de control considerados en el ajuste, por debajo de los $5 \mathrm{~mm}$. 


\subsection{Orientación Fotogramétrica}

Para el proceso de orientación fotogramétrica se extraen, a partir de las imágenes esféricas, puntos de control distribuidos por toda la escena de forma manual. Con estos puntos y las imágenes, se procesa todo el bloque mediante el software photoScan, obteniendo como resultado del ajuste, un residuo medio de $6.6 \mathrm{~mm}$ y un error máximo de $7.1 \mathrm{~mm}$ (Fig. 10).

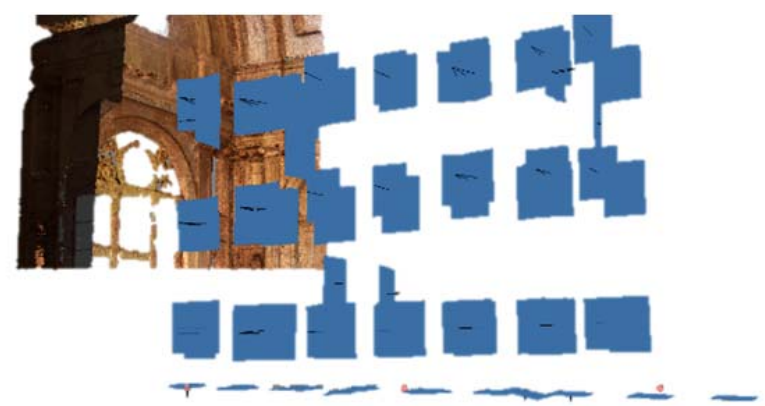

Figura 10: Resultado visual de la orientación de la imágenes y del escáner láser terrestre. Los puntos de color rosado, es la posición de los escaneos

\subsection{Generación de productos}

Los productos que se han generado a partir de los datos obtenidos y procesados son (Fig. 11):

- Nubes de puntos registradas, orientadas o alineadas.

- Modelo 3D foto-realístico a partir la nube y texturizado con las imágenes fotográficas

- Orto-Imágenes considerando diferentes planos.
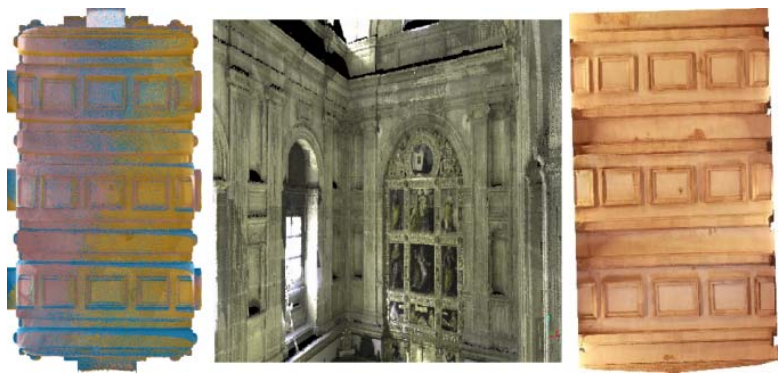

Figura 11: Productos generados

Además se han obtenido otros productos derivados de las propias imágenes esféricas como (Fig. 11):

- Imágenes de inclinación de la normal, donde se pueden apreciar rugosidades con detalle.

- Segmentación de normales en puntos, para extracción de planos específicos para la rectificación de imágenes.

- Extracción de bordes, para la vectorización semiautomática de líneas de ruptura o cambio de dirección de la normal

- Visualización de imágenes esféricas para aplicaciones web utilizando la librería Three.js
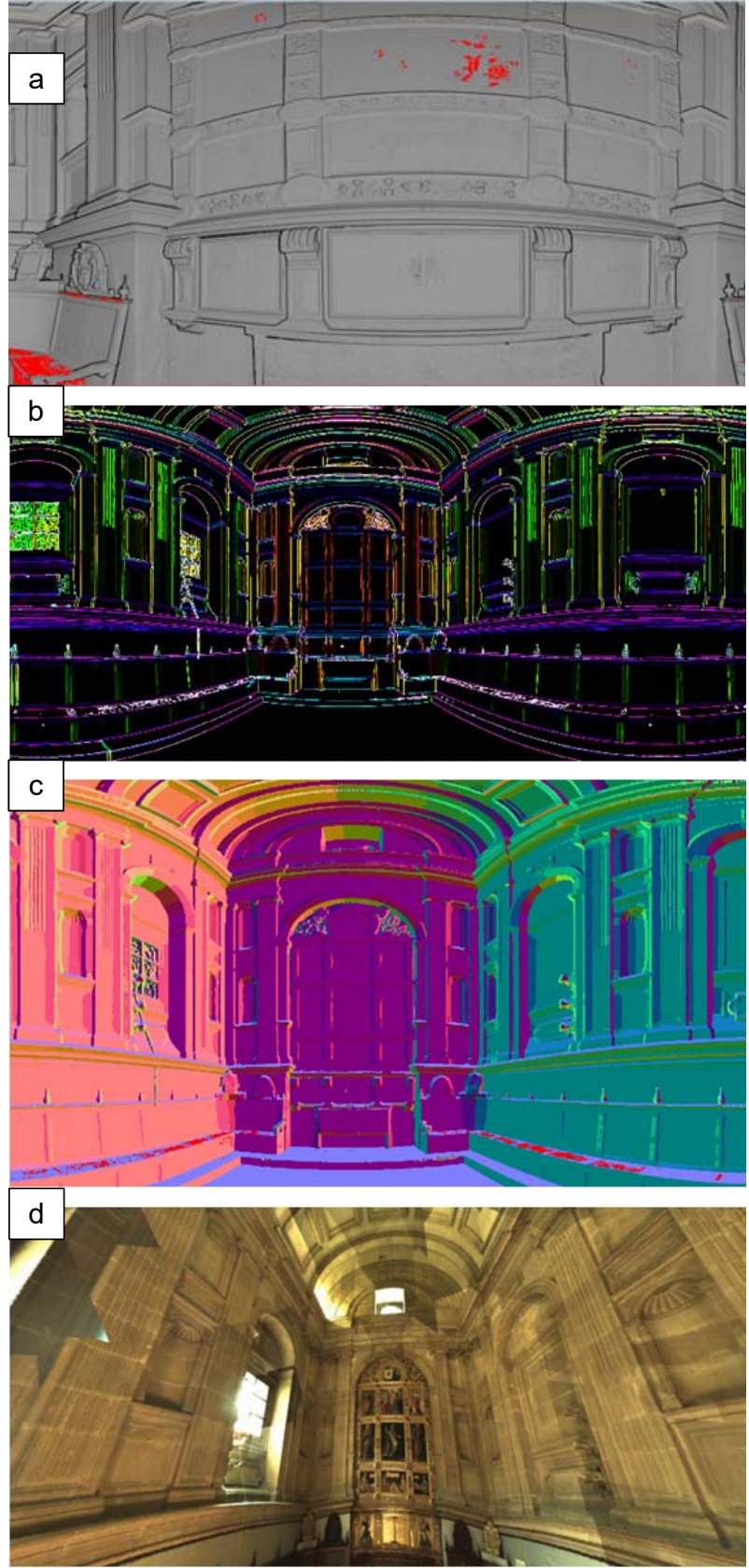

Figura 12: a) Imágenes gradiente; b) imagen extracción líneas; c) imagen segmentación normal; d) imagen RGB

\section{Conclusiones}

Con la metodología de tratamiento de datos TLS propuesta, se consigue el objetivo principal del este trabajo, que era el de obtener el máximo rendimiento a los datos capturados a través de esta técnica. No sólo se mejora la eficiencia en cuanto al almacenamiento y procesamiento de la información, sino que además, la puesta en marcha de esta metodología sobre datos reales, ha sido desencadenante de nuevos planteamientos y productos para la difusión y la documentación de patrimonio histórico cultural.

\section{Agradecimientos}

Agradecimientos al departamento Ingeniería Cartográfica, Geodésica y Fotogrametría y al Grupo de 
Investigación Sistemas Fotogramétricos y Topométricos, por facilitar el material para la realización del presente trabajo.

\section{Referencias}

CHEN, CHU-SONG, HUNG, YI-PING, CHENG y JEN-BO, 1998. A fast automatic method for registration of partiallyoverlapping range images. En Computer Vision, 1998. Sixth International Conference on. IEEE, 1998, pp. $242-248$. DOI: 10.1109/ICCV.1998.710725

HOUSHIAR, H., ELSEBERG, J., BORRMANN, D. y NÜCHTER, A., 2015. A study of projections for key point based registration of panoramic terrestrial 3D laser scan. Geo-spatial Information Science, 18(1), pp. 11-31. DOI: $10.1080 / 10095020.2015 .1017913$

HOUSHIAR, H. y NUCHTER, A., 2015. 3D point cloud compression using conventional image compression for efficient data transmission. En Information, Communication and Automation Technologies (ICAT), 2015 XXV International Conference on. IEEE, 2015. pp. 1-8. DOI: 10.1109/ICAT.2015.7340499

MILLS, J. y BARBER, D., 2003. An Addendum to the Metric Survey Specifications for English Heritage-the collection and archiving of point cloud data obtained by terrestrial laser scanning or other methods. Version 11/12/2003. Available: http://archive.cyark.org/temp/EH3DHeritageaddendum2006.pdf.

MOLDOVAN, D., YANO, S. y INOUE, N., 2009. Automatic registration of multiple range views based on feature matching and feature-depth correspondences. In Intelligent Computer Communication and Processing, 2009. IEEE 5th International Conference on. IEEE, 2009, pp. 169-172. DOI: 10.1109/ICCP.2009.5284767

NÜCHTER, A., GUTEV, S., BORRMANN, D. y ELSEBERG, J., 2011. Skyline-based registration of 3D laser scans. Geospatial Information Science, 14(2), pp. 85-90. DOI: 10.1007/s11806-011-0449-4

STAMOS, I. y LEORDEAN, M., 2003. Automated feature-based range registration of urban scenes of large scale. En Computer Vision and Pattern Recognition, 2003. Proceedings. 2003 IEEE Computer Society Conference on. IEEE, 2003 vol. 2, pp.555-561. DOI: 10.1109/CVPR.2003.1211516

THEILER, P. W. y SCHINDLER, K., 2012. Automatic registration of terrestrial laser scanner point clouds using natural planar surfaces. ISPRS Annals of Photogrammetry, Remote Sensing and Spatial Information Sciences, 2012, vol. 3, pp. 173-178. 


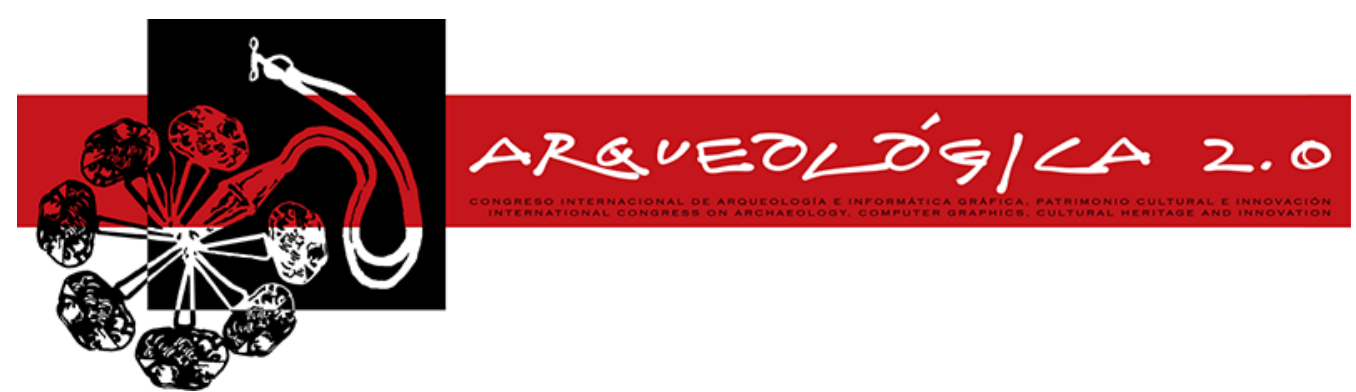

Proceedings of the $8^{\text {th }}$ International Congress

on Archaeology,

Computer Graphics,

Cultural Heritage and Innovation

'ARQUEOLÓGICA 2.0'

in Valencia (Spain),

Sept. $5-7,2016$

DOI: http://dx.doi.org/10.4995/arqueologica8.2016.3537

Received: 01/03/2016

Accepted: 10/04/2016

\title{
PROPUESTA DE REUBICACIÓN MEDIANTE RECONSTRUCCIÓN VIRTUAL. CASO DE ESTUDIO: RETABLO MAYOR DE SAN FRANCISCO DE SAN ESTEBAN DE GORMAZ (SORIA)
}

\author{
REUBICATION PROPOSAL THROUGH VIRTUAL RECONSTRUCTION. CASE STUDY: MAYOR ALTARPIECE OF \\ SAN FRANCISCO OF SAN ESTEBAN DE GORMAZ (SORIA)
}

\section{Mónica Sánchez}

Patrimonio Virtual, Universidad de Alicante, Campus de San Vicente, S/N, 03690 Alicante, España. msanchezy2015@gmail.com

\begin{abstract}
:
This paper briefly shows the skills acquired not only in the field of Conservation-Restoration, but also in Virtual Restoration as applied to Cultrual Heritage. The work under consideration is the Mayor Altarpiece of the old Convent of San Francsico, today Church of San Esteban Protomartir in San Esteban de Gormaz, Soria. Built in 1628 in one of the most important workshops of the Diocese, in 1985 renovation works and refurbishment of the church had uncovered wall paintings in advocation to the founder of the Order behind the wooden reredos, one of the few examples of pictorial altarpieces preserved in Spain that forced the transfer of the wooden altarpiece to a shrine in the same locality where it is currently disassembled.

This Cultural Property is a great example of heritage on which to apply the techniques of 3D modeling for virtual restoration and reconstruction of the environment as well, which aims to attempt visual recovery and potential unit without counyerfeiting, as methods of conservation, restoration and dissemination of Cultural Heritage.
\end{abstract}

Key words: conservation-Restoration, polychrome wood altarpiece, 3D modeling, virtualr restoration, virtual reconstruction, virtual architecture

\section{Resumen:}

En este artículo se muestran brevemente las competencias adquiridas no sólo en el ámbito de la ConservaciónRestauración, sino también en el de la Restauración Virtual aplicada al Patrimonio Cultural. La obra objeto de estudio es el Retablo Mayor del antiguo Convento de San Francisco, actual Iglesia Parroquial de San Esteban Protomártir de San Esteban de Gormaz, Soria. Construido en 1628 en uno de los talleres más importantes de la Diócesis, en 1985 unas obras de remodelación de la iglesia dejaron al descubierto unas pinturas murales en advocación al santo fundador de la Orden tras el conjunto de madera, uno de los escasos ejemplos de retablos pictóricos que se conservan en la España, que obligaron al traslado del retablo de madera a una ermita de la misma localidad donde se encuentra desmontado actualmente.

Este Bien Cultural es un gran ejemplo de Patrimonio sobre el que aplicar las nuevas tecnologías a través del modelado 3D realizando la restauración y reconstrucción virtuales tanto del entorno como de la obra, basadas en el intento de recuperación visual y de la unidad potencial sin llegar a la falsificación, a expensas de su posterior aplicación física valorando los múltiples factores que intervienen siendo, además, métodos de conservación, restauración y difusión de Patrimonio.

Palabras clave: conservación-Restauración, retablo madera policromada, modelado 3D, restauración virtual, reconstrucción virtual, arquitectura virtual

\section{Introducción}

El retablo de San Francisco es un gran ejemplo de patrimonio sobre el que aplicar las nuevas tecnologías como métodos de conservación, restauración y difusión a generaciones futuras.
La importancia de este conjunto viene dada, en primer lugar, por constituirse como una de las manifestaciones artísticas más importantes del patrimonio cultural, destacando de un modo más singular por sus dimensiones de escala monumental, así como por haberse construido en uno de los talleres oxomensessorianos más importantes del Renacimiento sacro (Fig. 
1). Datado en 1628 (Arranz 1985), responde a la tipología de retablo romanista sujeto en su arquitectura y decoración a un ritmo evolutivo correspondiente a la primera mitad del siglo XVII, una etapa más romanista que muestra la raíz del clasicismo, con la peculiaridad de instituirse como una de las escasas muestras que incorporan columnas mixtas, entorchadas y estriadas o la interposición de frontones curvos y partidos, matices que distinguen la línea estilística de la obra.

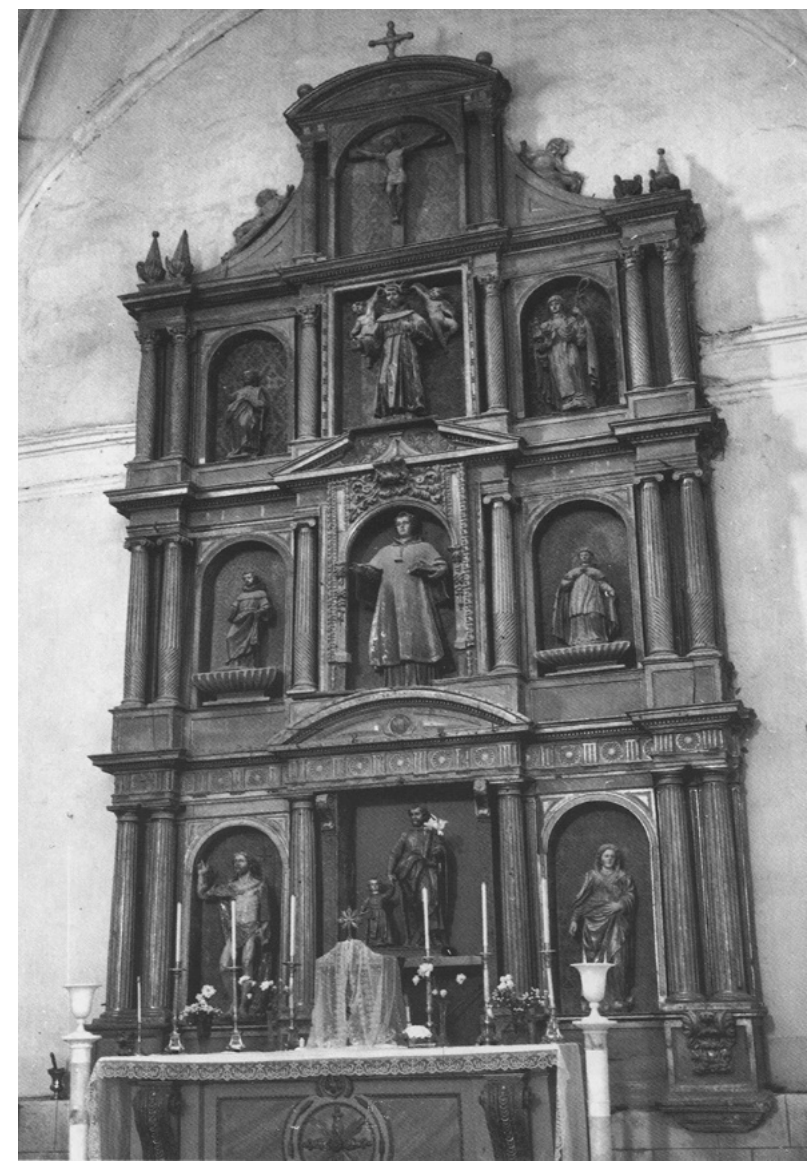

Figura 1: Imagen de "La escultura romanista en la Diócesis de Osma-Soria" de D. José Arranz Arranz (1986): retablo de San ubicación original.

La peculiaridad de esta estructura ornamental construida en "ad hoc" con indiferencia de un esquema iconográfico y escultórico- se debe a su historia material y cultural. Ubicado en el interior del antiguo Convento de San Francisco (Fig. 2), en la capilla de la actual iglesia parroquial de San Esteban Protomártir (Antón 2013), unas obras realizadas entre los años 1982 y 1985 dejaron al descubierto un retablo de pintura mural de mediados del siglo XVI oculto tras el de madera policromada, donde la conservación de las pinturas predominó, por su calidad y cronología, sobre el conjunto retablístico, el cual se llevó a la ermita de San Roque (Fig. 3), situada a escasos metros de la iglesia, donde permanece desmontado a día de hoy.

Es indudable que el proceso de deterioro de la obra ha evolucionado negativamente durante los últimos treinta años debido al sistema constructivo de baja calidad del inmueble (Carrasón 2008) en el que se ampara, así como por la agresión de la humedad, viéndose reflejado directamente en el retablo a través de indicadores patológicos (Fig. 4) que permiten analizar el precario estado de conservación que presenta.
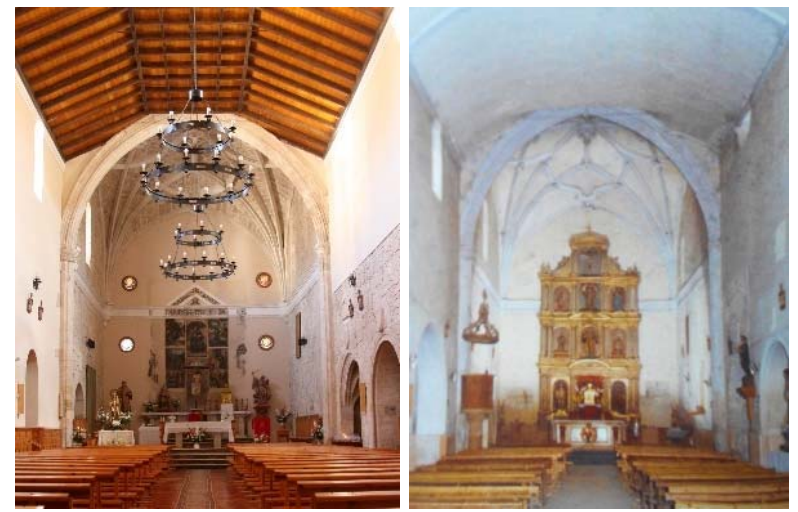

Figura 2: a) Imagen cedida por D. Fortunato Antón Nuño: retablo de San Francisco en ubicación original; b) pinturas murales de San Francisco restauradas.

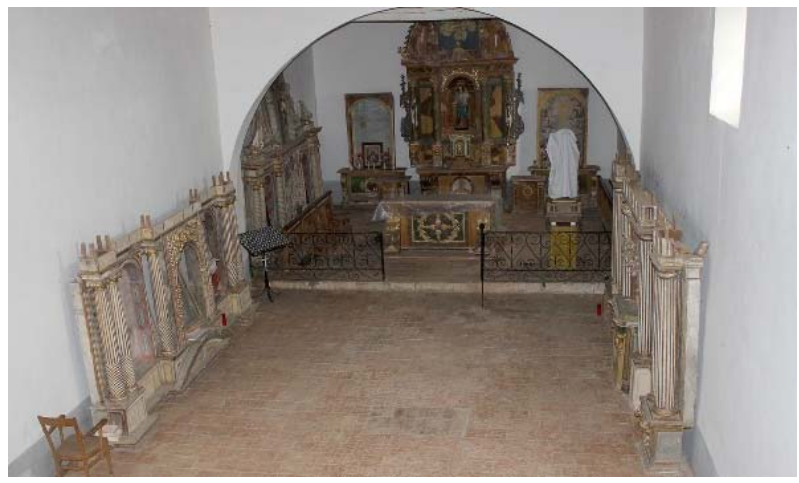

Figura 3: Disposición de los cuerpos del retablo de San Francisco en el interior de la ermita de San Roque.

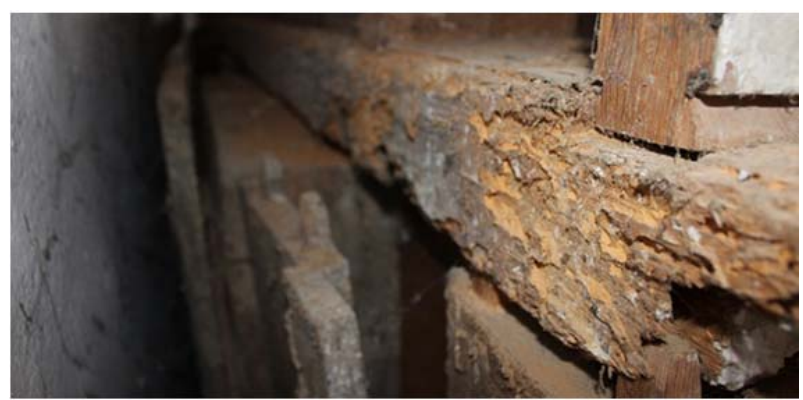

Figura 4: Detalle de alteraciones localizadas en el conjunto: ataque de xilófagos.

Atendiendo a la imposibilidad de una intervención próxima, es destacable la sinergia entre las disciplinas que abarcan las nuevas tecnologías y el patrimonio cultural, permitiendo utilizar distintas técnicas virtuales sobre piezas de estas características y mostrar la aplicación de las mismas a este tipo de obras.

\section{Documentación y modelado 3D}

\subsection{Preparación del material para la toma de imágenes}

La primera visita permitió analizar in situ las ventajas e inconvenientes que pudieran interferir positiva o negativamente en la fase de documentación. 
En cuanto a lo que se refiere al objeto a documentar, las dimensiones y disposición no hacían accesible el conjunto, especialmente a la trasera. Respecto al entorno, en el interior de la ermita se disponían numerosos obstáculos que entorpecerían el campo de visión. En lo que atañe a la iluminación, sólo se contaba con la luz natural que entraba por los ventanucos laterales, pues en el interior del inmueble no hay corriente eléctrica (Fig. 5).

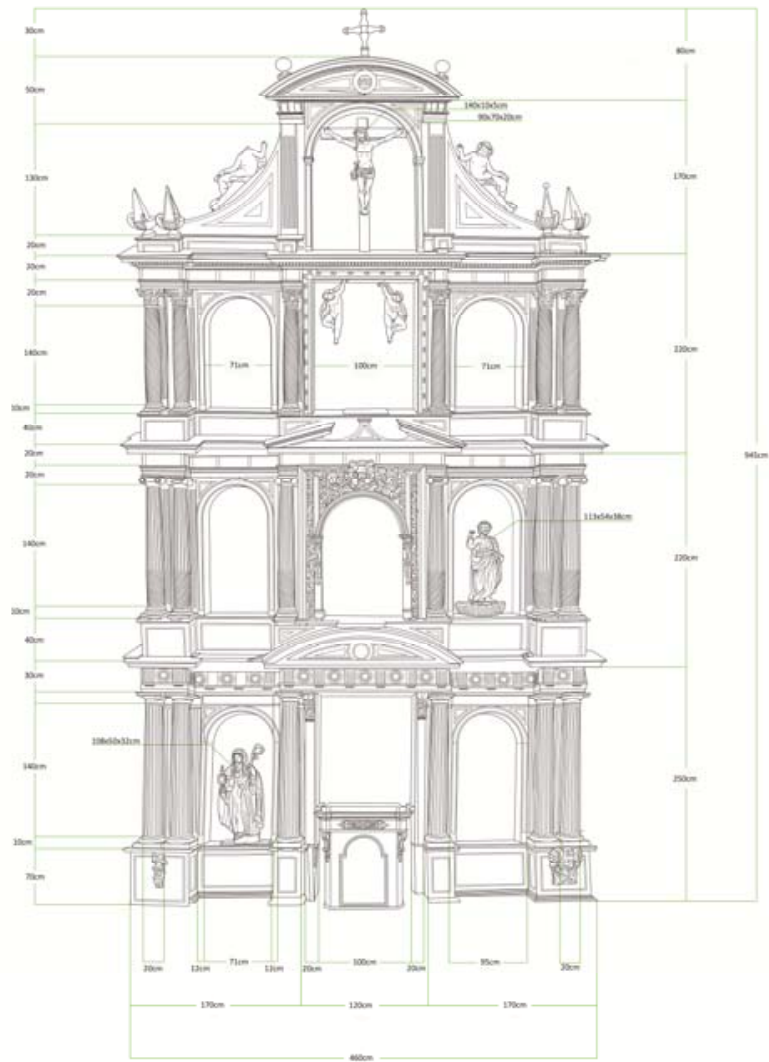

Figura 5: Habilitación del espacio de trabajo y muestra del equipo empleado.

El equipo de trabajo empleado estaba compuesto por:

- Dos cámaras digitales réflex: Canon EOS 450D y Canon EOS 600D.

- Dos trípodes: Manfrotto (1,80 metros), Velbon CX200 (1,50 metros).

- Dos focos LED: Creé.

\subsection{Toma de medidas}

Para poder respetar al máximo la integridad de la obra como de su contexto en la generación del modelo 3D, se procedió a la toma de medidas de la ermita y la iglesia mediante un metro láser preciso de 50 metros de alcance. Por su parte, las mediciones del retablo fueron las siguientes (Fig. 6):

\subsection{Construcción del modelo 3D}

El software utilizado es Blender, orientado al modelado de objetos y equipado con un conjunto de herramientas que permite trabajar en todas las fases que puede llegar a plantear un proyecto de infografía 3D.
En el modelo 3D únicamente se ha mostrado la arquitectura del retablo, excluyendo las esculturas debido a su distribución heterogénea e imposibilidad de documentación de todas ellas.

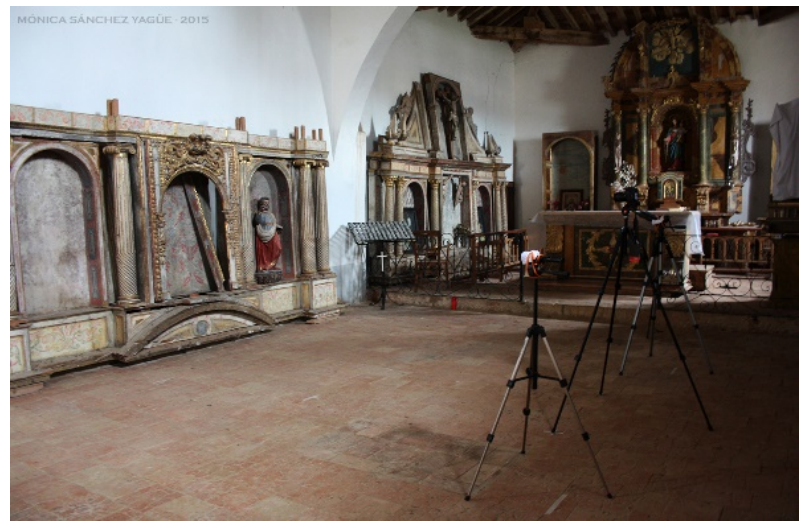

Figura 6: croquis de mediciones.

A partir de un rectángulo como estructura principal del retablo, se fue dividiendo en las diferentes partes que conforman las calles que lo conforman, junto con los entrantes y salientes o decoración correspondiente al entablamento (Fig. 7). Los cuerpos se fueron construyendo y colocando ordenadamente con el fin de reconstruir y restaurar virtualmente mediante la superposición y ensambles realizando el montaje del conjunto hasta finalizar el modelo $3 \mathrm{D}$ con el frontón curvo que remata el ático.

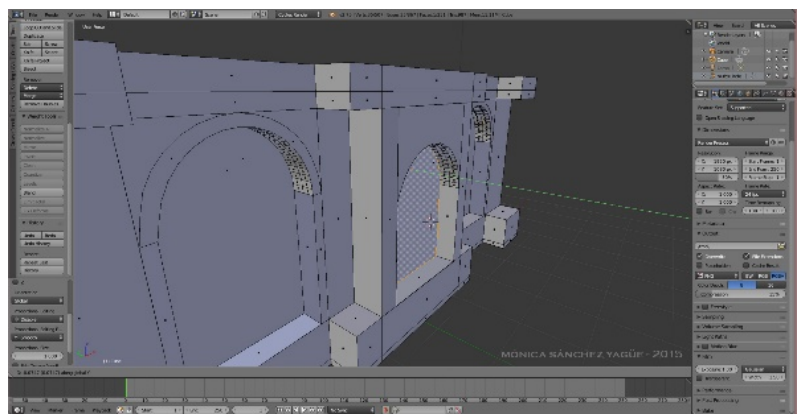

Figura 7: Captura de pantalla de Blender: creación de las hornacinas mediante la extrusión de caras.

Elementos como los remates piramidales situados en los laterales del tercer cuerpo se construyeron en su totalidad realizando la restauración al encontrarse pérdidas volumétricas, como sucede con las esferas que culminan los elementos piramidales (Fig. 8).

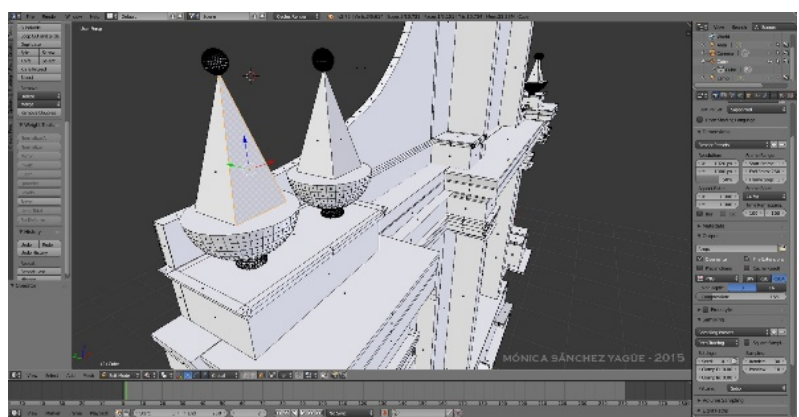

Figura 8: Captura de pantalla de Blender: reintegración volumétrica de elementos decorativos. 
Por último, elementos arquitectónicos y decorativos como columnas y capiteles se crearon tomando como referencia documentación gráfica para generar a partir de cilindros las distintas torsiones correspondientes a los cuatro órdenes clásicos presentes en los cuatro cuerpos del retablo (Fig. 9).

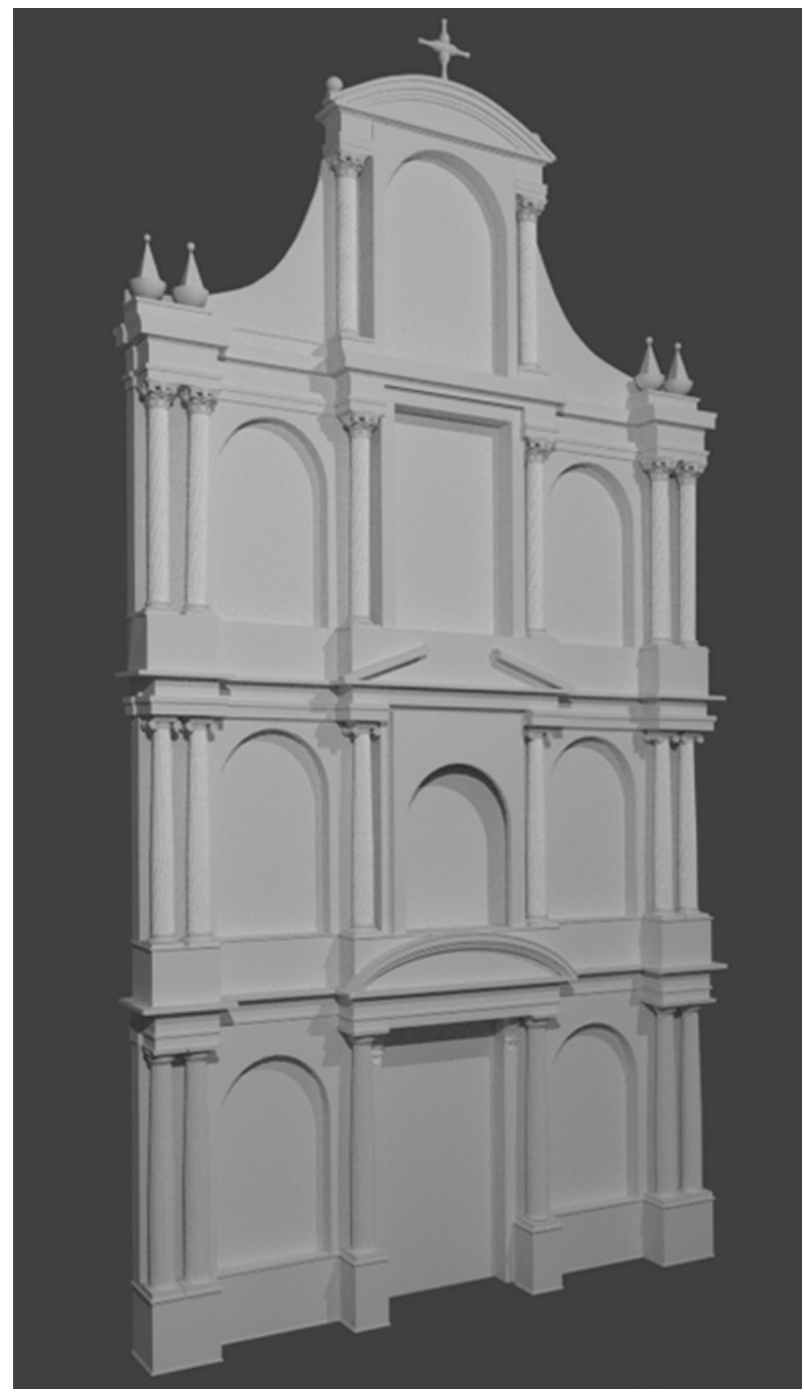

Figura 9: Maqueta 3D del montaje de los cuerpos del retablo.

Para la construcción de la iglesia (Fig. 10) se siguió la misma metodología de trabajo a través del modelado 3D.

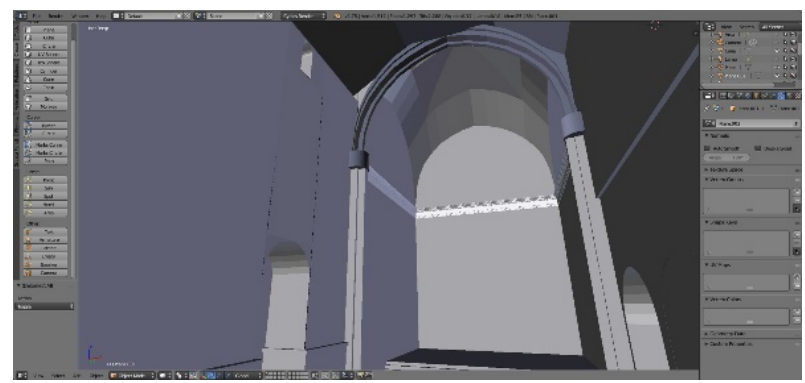

Figura 10: Captura de pantalla de Blender: construcción de las cubiertas de la iglesia.

\subsection{Aplicación de texturas}

Se constituye como una fase fundamental para dar realismo al modelo tridimensional mediante la aplicación de texturas procedentes de la fase de documentación fotográfica (Fig. 11).

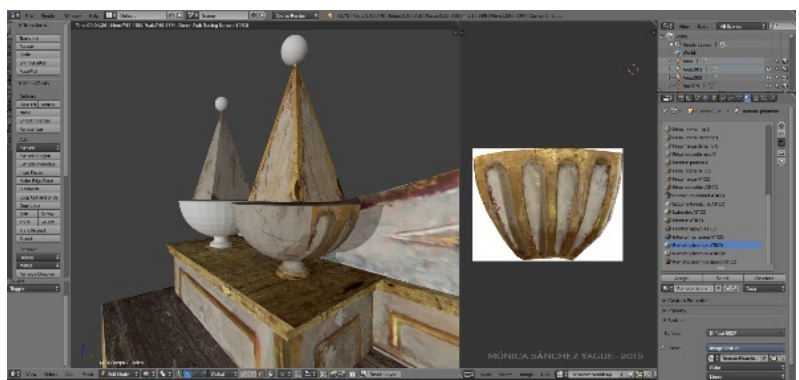

Figura 11: Captura de pantalla de Blender: aplicación de texturas en los distintos cuerpos y elementos del retablo.

El manejo de las texturas en numerosos casos requirió un procesado previo modificando con Photoshop los factores de niveles o curvas y brillo o contraste, adaptándolas posteriormente en Blender.

Por su parte, para contextualizar la iglesia y recrear su estado original incorporé texturas adicionales para crear visualmente el paso del tiempo sobre el inmueble.

\subsection{Obtención del modelo 3D: renderizado y animación 3D}

Los modelos finales se completaron mediante la inclusión de distintas fuentes de iluminación, obteniendo finalmente una serie de renderizados que permiten observar los modelos con detalle.

\subsubsection{Renderizado}

\subsubsection{Retablo montado}

Se puede observar la restauración virtual mediante el montaje y la reintegración de elementos perdidos (Figs. 12 y 13).

\subsubsection{Retablo en ubicación origina}

El segundo renderizado sirve como introducción y narración visual que complementa el estudio históricoartístico (Fig. 14). En este caso se muestra la localización original del retablo, atendiendo a su disposición física dentro de la iglesia parroquial, observando a su vez el margen de espacio del retablo respecto a la altura de la pared ya que no es el mismo que el de las paredes laterales de la posible nueva ubicación.

\subsubsection{Propuesta de reubicación I: No válida}

En el tercer renderizado se muestra la primera propuesta de reubicación con el fin de demostrar que no es posible por dos razones: en primer lugar, siguiendo la historia de este bien cultural, el no haberse montado de nuevo es debido a que prevaleció mantener visibles las pinturas murales que aparecieron tras él (Fig. 15). En segundo lugar, el espacio disponible entre la cabecera, el presbiterio y el altar es insuficiente para colocar el 
retablo paralelo a las pinturas manteniendo ambos una distancia mínima de 1,50 metros (Fig. 16).

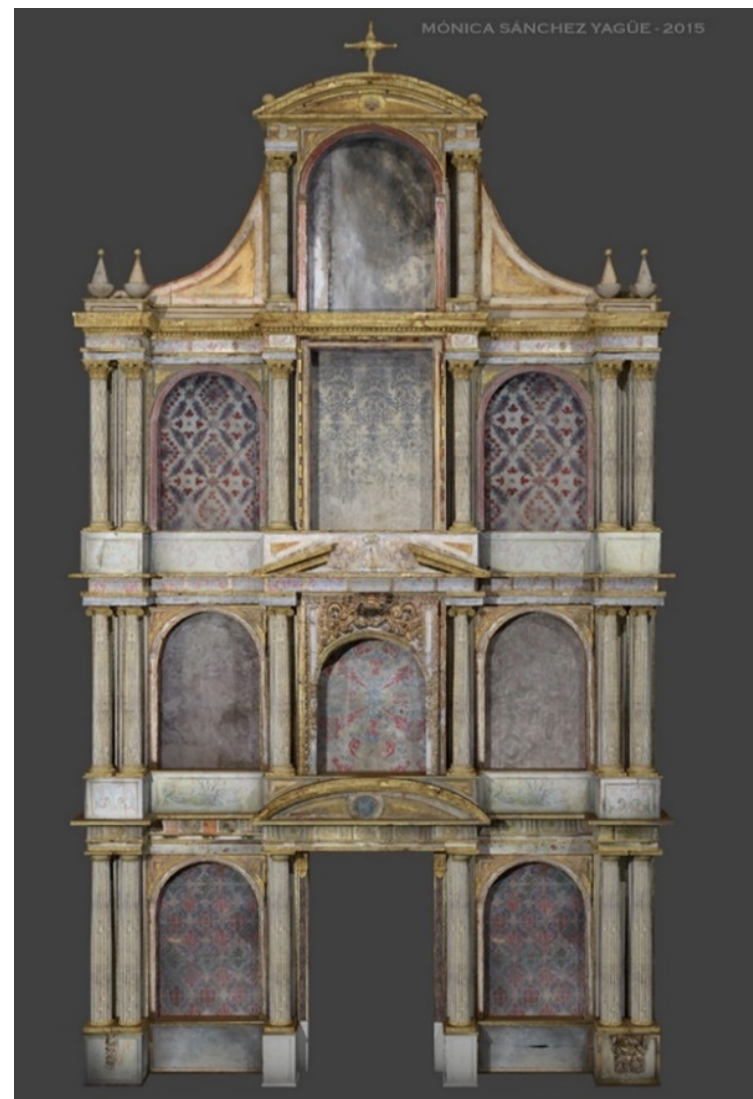

Figura 12: Renderizado del retablo montado. Vista frontal.

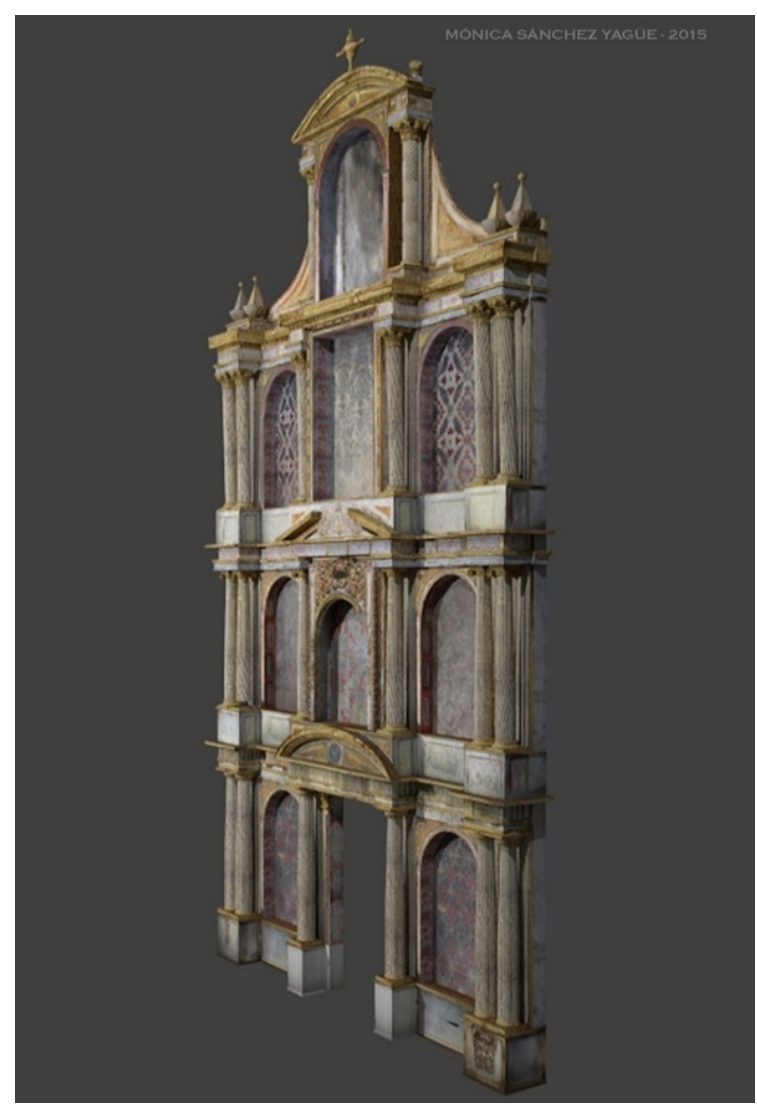

Figura 13: Renderizado del retablo montado. Vista lateral.

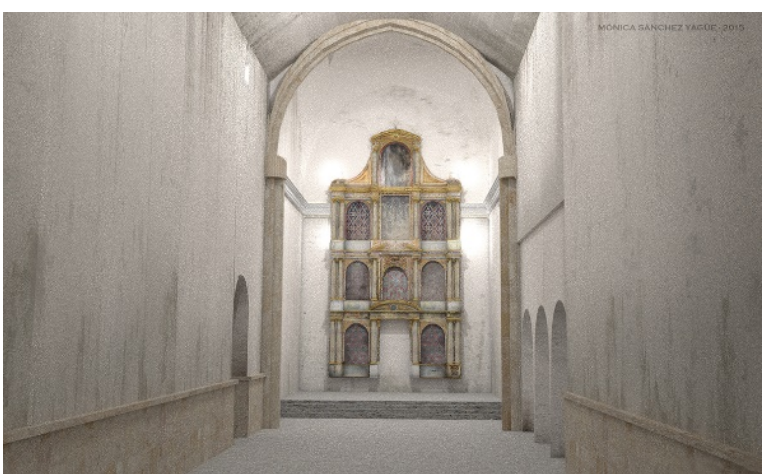

Figura 14: Renderizado del retablo en ubicación original.

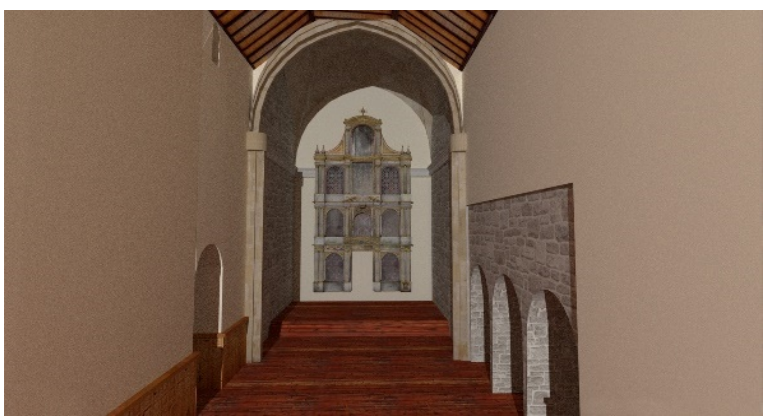

Figura 15: Renderizado I. Propuesta de reubicación I: No válida.

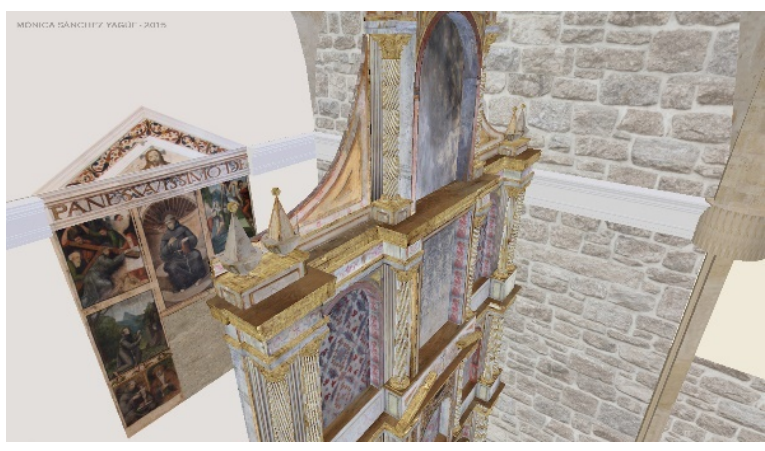

Figura 16: Detalle del retablo en paralelo a las pinturas murales.

\subsubsection{Propuestas de reubicación II y III: ¿Válidas?}

Como segunda y tercera propuesta de reubicación, se ha seguido la idea principal planteada por el Delegado de Patrimonio de la Diócesis de Osma-Soria y párroco de la localidad de San Esteban de Gormaz (Figs. 17 y 19).

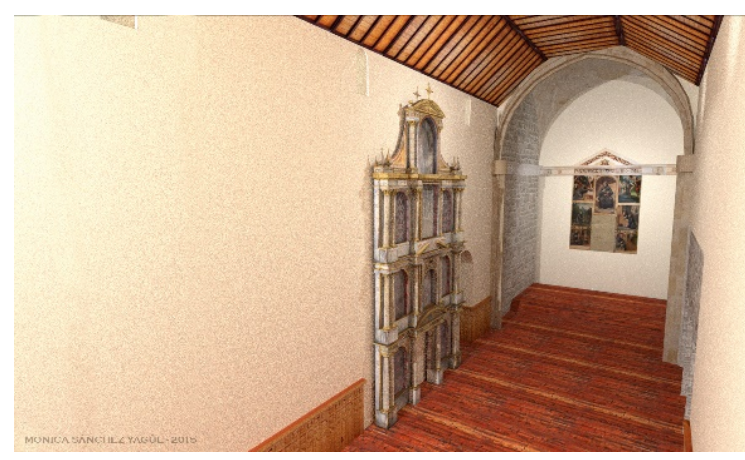

Figura 17: Renderizado II. Propuestas de reubicación II y III: ¿Válidas?. 


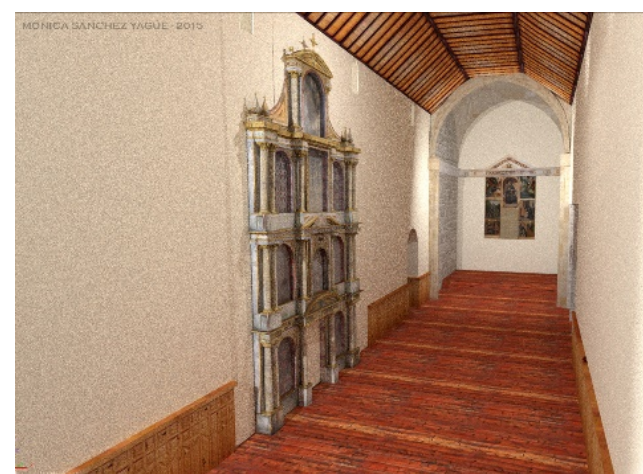

Figura 18: Renderizado III. Propuestas de reubicación II y III: ¿Válidas?.

Son opciones no descartadas pero el problema primordial reside en la altura disponible de la pared lateral, pues mide aproximadamente 9,7 metros mientras que el retablo alcanza los 9,4 metros, de manera que el espacio intermedio entre el retablo y la cubierta es muy reducido. Además, esto impediría la colocación de una bancada de piedra como se pretendía antes de la aparición de las pinturas murales en la cabecera.

En ambos casos debería incorporarse un panel explicativo con el fin de difundir la historia del bien cultural y la restauración para preservarlas en la historia.

\subsubsection{Animación 3D}

Como último paso, se ha propuesto la realización de una breve animación de aproximadamente 20 segundos de duración en Blender, cuyo fin es mostrar un recorrido virtual en el interior de la iglesia comenzando por el retablo de arriba abajo continuando hasta la cabecera donde poder apreciar las pinturas murales medievales, otorgando valor a las dos obras de arte (Figs. 19 y 20).

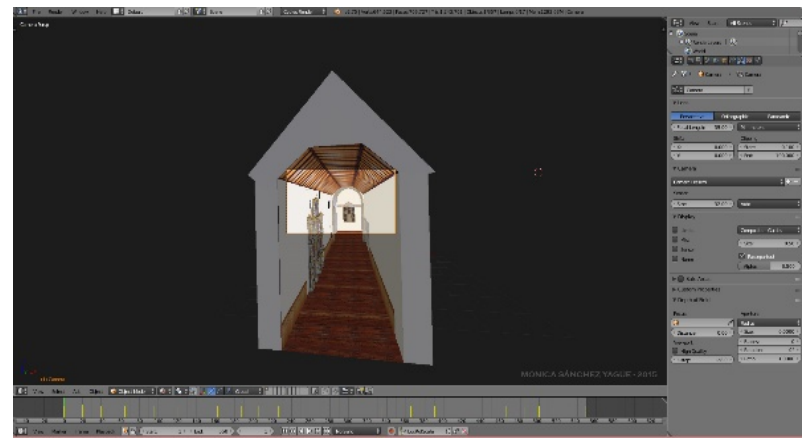

Figura 19: Posición de la cámara para comenzar la animación.

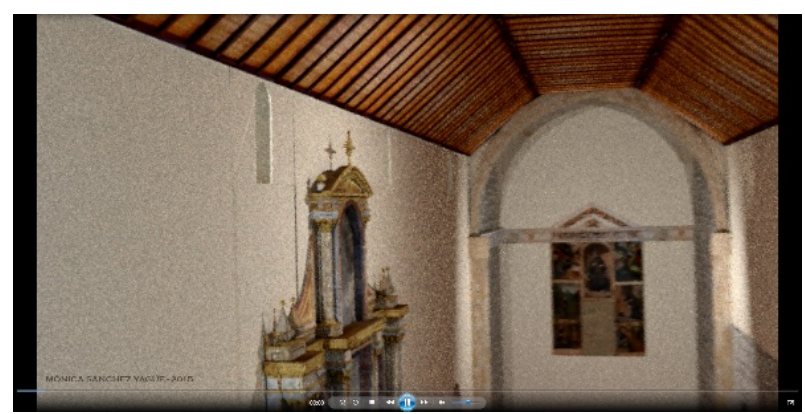

Figura 20: Visualización de la animación en el reproductor de video.

\section{Resultados}

Se optó por la elaboración de un modelo 3D con resultados lo más fieles posibles a la realidad, y la contextualización de la obra a través de la reconstrucción virtual del inmueble en el que se situaba en origen así como futura ubicación. Esta segunda fase ha permitido visualizar de una forma muy directa las distintas ubicaciones que se tienen en cuenta actualmente en el momento en el que se lleve a cabo la restauración, el traslado y montaje del retablo.

Con esto me refiero a que, una vez estudiadas las distintas propuestas de reubicación por los responsables de la Diócesis, fuimos conscientes de los inconvenientes reales que existen y que han de tenerse muy presentes en el momento de la reubicación, ya que actualmente se están tomando nuevas medidas de rehabilitación del inmueble para colocar el retablo de madera y, que de otra forma no habría sido posible averiguar.

De esta manera, se han desarrollado varias alternativas justificando cada una de las intervenciones.

Ante las posibles propuestas de reubicación, se ha seleccionado una de ellas sobre la que se ha realizado una animación 3D mostrando brevemente un recorrido desde la entrada de la iglesia hasta las pinturas murales que aparecieron tras el retablo de madera, simulando así cómo el espectador admiraría la obra en primera persona.

\section{Conclusiones}

Este retablo es un magnífico ejemplo de divulgación de patrimonio cultural sobre el que desarrollar la información apropiada para la puesta en valor de la obra, que va a mejorar la capacidad de transmisión y su accesibilidad. Se pretende, además, desarrollar el trabajo realizado de forma práctica, colocando un panel explicativo al lado del retablo con un fin didáctico, explicando y justificando la intervención.

Las nuevas tecnologías son las que tomen el papel más importante, como se ha demostrado previamente, para la difusión y desarrollo de los distintos aspectos de la restauración y la conservación preventiva. Es por ello que la reconstrucción y restauración virtuales desarrolladas anteriormente supondrán una parte fundamental de la conservación de la obra ya que virtualmente se podrá observar por parte del público tanto el paso de la historia como el trabajo del conservador-restaurador en la actualidad por las generaciones venideras.

En este artículo se recoge una de las partes que han conformado este proyecto. La labor de investigación ha permitido ir más allá en el ámbito de la ConservaciónRestauración, pudiendo así realizar un estudio en profundidad de la obra buscando las vías más adecuadas de actuación a través de distintas técnicas virtuales, obteniendo como resultado una infinidad de posibilidades para devolver la unidad potencial a las obras, observándose proyectos como los que se presentan en esta revista. 


\section{Referencias}

ANTÓN, F., 2013. El Románico de San Esteban de Gormaz. El año de la Fe. Soria, pp. 17-23.

ARRANZ, J., 1985. La escultura romanista en la Diócesis de Osma-Soria. Navarra, pp. 173-398.

ARRANZ, J., 1986. El Renacimiento sacro en la Diócesis de Osma-Soria. Navarra, pp. 256-262.

CARRASÓN, A., 2008. Algunas consideraciones sobre la conservación preventiva de retablos. Madrid: IPCE, 178 páginas. 


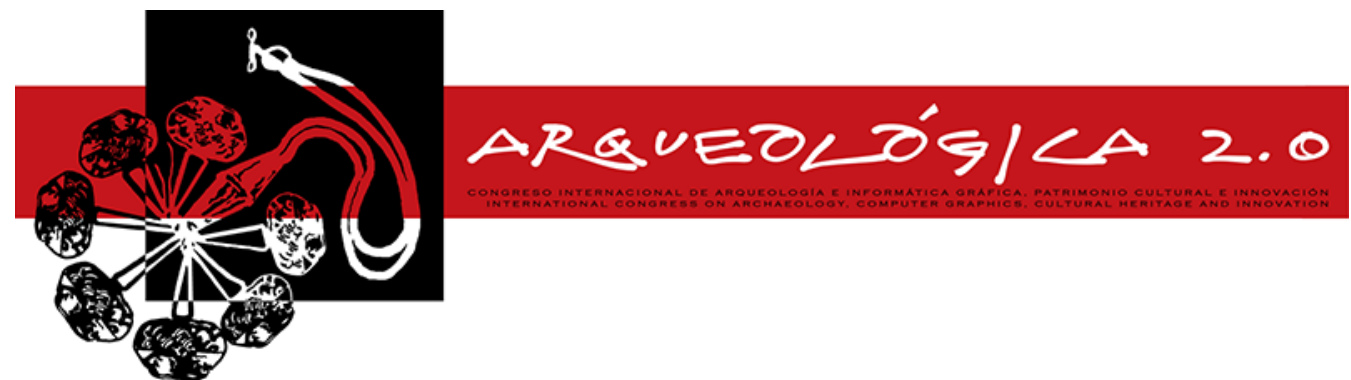

Proceedings of the $8^{\text {th }}$ International Congress

on Archaeology,

Computer Graphics,

Cultural Heritage and Innovation

'ARQUEOLÓGICA 2.0'

in Valencia (Spain),

Sept. 5-7, 2016

DOI: http://dx.doi.org/10.4995/arqueologica8.2016.3550

Received: 01/03/2016

Accepted: 25/05/2016

\title{
SELF-EXPLAINING VIDEOS FOR THE MUSEO EGIZIO IN TURIN
}

\author{
VIDEOS AUTOEXPLICATIVOS PARA EL MUSEO EGIPCIO DE TURÍN

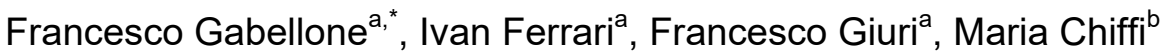 \\ ${ }^{a}$ CNR - IBAM (Istituto per i Beni Archeologici e Monumentali), Via prov.le Monteroni, 73100 Lecce, Italy. f.gabellone@ibam.cnr.it; \\ itlab.ferrari@ibam.cnr.it; itlab.giuri@ibam.cnr.it \\ ${ }^{\text {b } A r k e m a t i c a ~ s . r . I ., ~ C o n t r a d a ~ S o v a r e t t e ~ S o t t a n e, ~ 40 / 41, ~} 87040$ Cosenza, Italy. maria.chiffi@libero.it
}

\begin{abstract}
:
In the present project for the setting of the new Museo Egizio of Turin the "cultural message" has been charged to make a few specific 3D computer graphic (CG) movies, and aims to introduce the topics dealt with the rooms dedicated to queen Nefertari, the chapel of the painter Maia and the tomb of Kha, respectively. In these movies, the passivity of viewing is counteracted with an emotional approach that involves the visitor within an informative path where, despite of the inactive kind of interaction, the viewer is somehow involved in the events because he or she is emotionally invested in them. Thanks to this passive and "self-explaining" approach, the visitor will be enabled to understand the relations between different objects, some of which are not directly visible. Moreover, the visitor will be able to virtually insert the tombs within their original context and above all will have the possibility to visit them as they appeared at the moment of their discovery. This has been made possible thanks the use of integrated technologies of representation, able to enhance the virtualization process to a verisimilar level allowing a hyper-realistic and "participative" vision. The high level of realism of the virtual reconstruction, the visual effects and the cinematographic representation, with added emotions to the scientific contents, positively contribute to the "dreamlike displacement" of the visitor between the real and the virtual dimensions.
\end{abstract}

Key words: virtual archaeology, digital archaeology, Museo Egizio, 3D reconstruction, 3D image based

\section{Resumen:}

En este proyecto para la construcción del nuevo Museo Egipcio de Turín el mensaje cultural fue dado a tres películas específicas en gráficos 3D, destinados a la introducción de los temas tratados en las salas dedicadas a la reina Nefertari, la capilla del pintor Maia y la tumba de Kha. En estas películas, la pasividad de la visión se ve compensado por un enfoque emocional que implica el visitante en un trayecto de información en el que, a pesar de la falta de actividad de disfrute, él es en realidad participante, porque emocionalmente involucrado. Gracias a este método, pasivo y "autoexplicativa" el visitante puede comprender las relaciones entre diferentes objetos, algunos no directamente visibles, como la momia de Kha y su esposa Merit, a ser posible reconstruir las tumbas en su contexto original, pero sobre todo la posibilidad de visitar, gracias a las técnicas de la arqueología virtuales, tales contextos como aparecieron en el momento de su descubrimiento. Todo esto es posible gracias a la utilización de tecnologías integradas para el estudio y la representación, capaz de llevar el proceso de virtualización a un grado de verosimilitud hiperrealista y "participativa". El alto grado de realismo de las reconstrucciones virtuales, efectos visuales y técnicas de representación cinematográfica, añadiendo emoción al contenido científico, contribuyen positivamente a la "pérdida" del visitante entre el real y el tamaño dimensión virtual.

Palabras clave: arqueología virtual, arqueología digital, Museo Egizio, reconstrucción 3D, 3D image based

\section{Overview about active and passive presentation}

Multi-modal information and dynamic narratives have really changed the exhibition methods in modern museums and, at the same time, enable an efficient reading of cultural contents by the public. The impulse of new technologies has powerfully imposed new forms of communication, based above all on digital content. From recent studies it is clear that all the museums that have characterized their cultural offerings through digital technologies and the active participation of the public have achieved the greatest success in terms of number

*Corresponding Author: Francesco Gabellone, f.gabellone@ibam.cnr.it 
of visitors and, probably, a greater understanding of cultural information by the public. In this context, our proposal of communication for the Egyptian Museum of Turin which uses three-dimensional technologies for survey, reconstruction and computer animation, is useful in order to accelerate and enhance the cognitive capabilities of the visitor. It has the perspective to offer a medium capable of efficiently generating "virtuous processes" of learning.

Our idea is to evoke the ideas of the past and to inform the visitors through a modern approach that is efficient but above all philologically correct. The message that is developed to be communicated through the use of technologies of three-dimensional representation becomes an important component of the process of musealization, by way of imagining the cultural communication that puts new museums in the wake of the current dynamics of social communication. In this specific case we have not adopted communication solutions based on interactivity or immersivity, which would require the active participation of the visitor, as requested by the most common modern technological scenarios.

This choice was motivated by the need to avoid prolonged stops of the visitors within some thematic rooms, but also because the concerned spaces, due to the organization and distribution of exhibits, were not set up to accommodate large groups of people forming queues. So, the main rules to be followed were two: to produce easily understood content that could be seen quickly. Another important element is related to the ability to manage informatical tools. In effect, all active systems require from the public a certain expertise and this, no matter its perceived simplicity, is not always easy to find in certain age groups, or even more problematic, in visitors with cultural backgrounds that are reluctant to use interactive solutions. The last consideration regards the number of visitors that, at the same time, view digital content. Although it is true that in recent times multi-user applications are considered a rapidly growing sector, it is generally true that an interactive system can be managed by only one person at a time, or at best by two or three people simultaneously. All this is only possible with complex systems, which in our recent experience of other museum installations, have shown a certain weakness in garnering intensive use, requiring continuous interventions of software and hardware settings.

While not informed about these our reflections concerning our experience about the usability of active systems, the museum management has deemed it appropriate to entrust the entire communication process to passive animated narratives, orsimple movies. These introduce the basic themes of the topics dealt in the rooms and lead the visitor on a fascinating journey that evokes spaces, objects and historic The tomb of Kha ures involved in the discoveries. All in according with scenographic settings, narrative paths and informational approaches designed to produce an effective transmission of a cultural message, without any hint to forms of dramatization that do not produce new information, compared to pure vision of real objects exposed in the rooms.

\section{The reconstruction of the discovery}

Three specific movies based on 3D computer graphics were created for the transmission of cultural content, designed to introduce the topics covered in the rooms dedicated to Queen Nefertari, the chapel of the painter Maia and the Tomb of Kha. These are archaeological contexts of extraordinary importance for the study and knowledge of the art and culture of ancient Egypt, all of which were discovered by the Italian Egyptologist Ernesto Schiaparelli in the early years of the twentieth century. In the production of the film the presentation of narrated comments was deliberately omitted, choosing to present only bilingual textual infographics (Italian / English). Such textual information was reduced to a minimum, assuming the role of quick captions that strengthen the main message assigned to the images in sequence. In fact, the reading over the display of the text, done in accordance to this simple scheme, shifts the focus of the narrative and on the communicative power of computer graphics animations. In this way it can represent the reconstructed scenarios using unusual patterns, in animated section, in orthogonal view or with shots impossible in the real world. We found great utility in the original photographic documentation, a rare example of a modern approach to archaeological excavation itself. Many photos were made in stereoscopic mode, a well-known technique at the time of the discovery, which represent an important tool to document even in the third dimension and are also useful for the survey purposes.

\section{The emotional approach}

Through means of expression offered by computer animation one can re-read and re-create the single identity of "place", generated by time and by human activity, to present it again in forms of communication which can bring a high degree of knowledge with multidisciplinary content. It is undeniable the role and impact of the emotional narrative every time they treat themes related to the re-evocation of the ancient, with its forms, its awesomeness, its colours and the lost atmosphere that we are called to represent. Only through accurate scientific reconstructions (Figs. 1, 2 and 3) can we create engaging stories guiding the visitor in an information path in which, despite the lack of enjoyment, can feel in part emotionally involved. A high degree of realism in virtual reconstructions, visual effects and techniques of cinematic representation, adds emotional content to the scientific content, contributing positively to the "loss" of the visitor's differentiation between the real dimension and the virtual dimension. In this sense, it may be acceptable to note the philosophical position of Heidegger on the concept of the presence of the "Being" - Dasein - that does not indicate a mere spatial location, but something more ambiguous and complex, or the way in which the Being concretely (in a phenomenological way) is "present" in a history, as part of humanity. Developing this "sense of presence" and emotional involvement, is a well known purpose of three-dimensional representation as part of an internal and essential language of Virtual Reality: developing a dematerialization of the object, but with the need to make it "comprehensible", present, and almost real. 


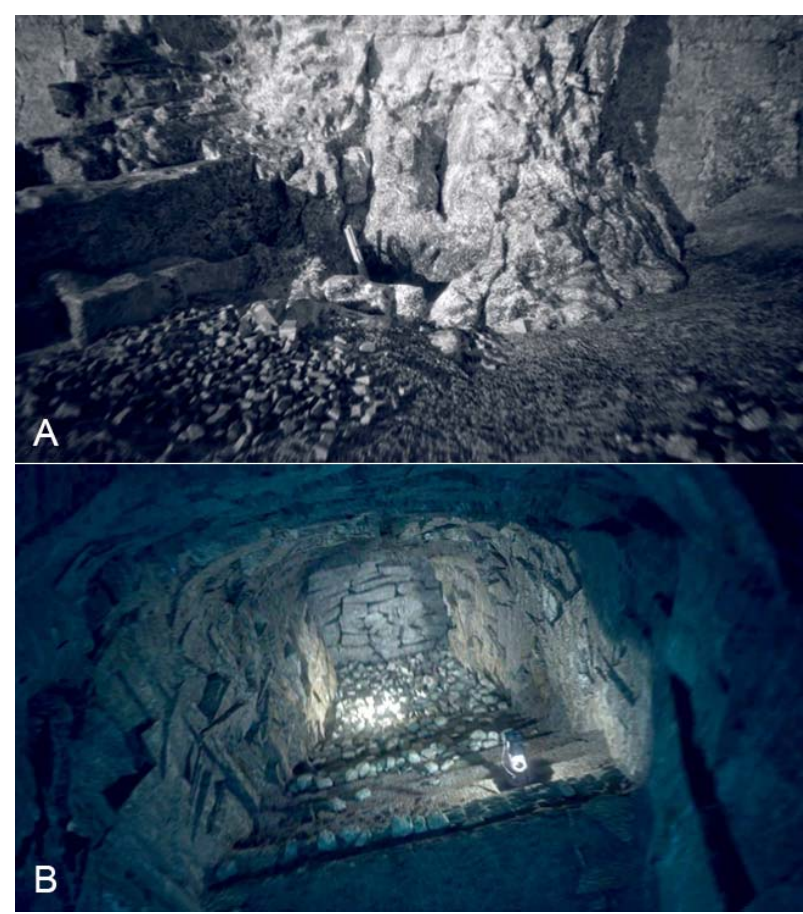

Figure 1: Reconstruction of the tomb of Kha: the entrance pit (A) the entrance corridor (B).

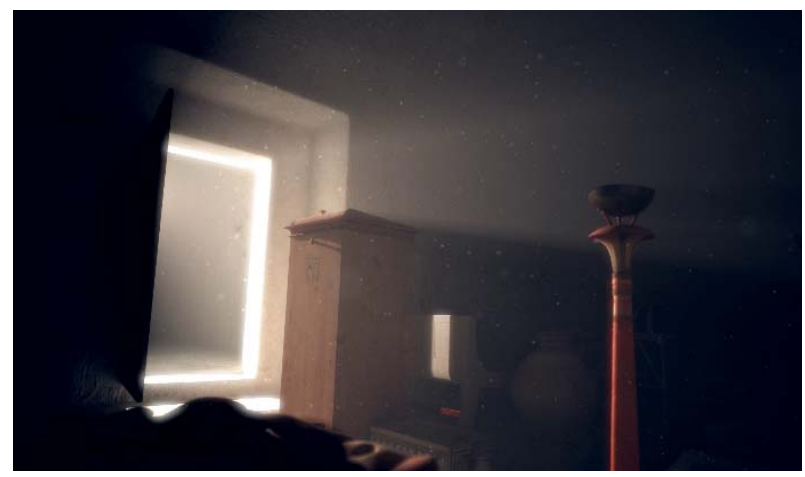

Figure 2: Tomb of Kha, reconstruction of the discovery.

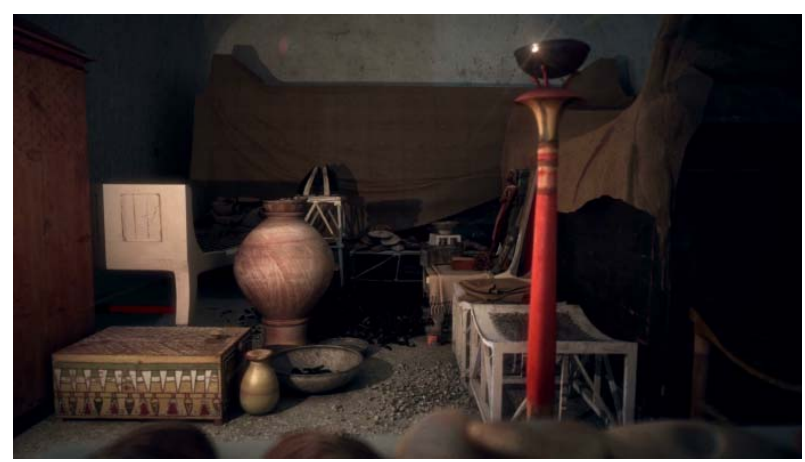

Figure 3: Reconstruction of Tomb of Kha, using 3D ImageBased and NURBS models.

\section{Techniques and methods for 3D reconstruction}

All of these reasons form the basis for continuous research into the best rendering quality in conjunction with philological approaches. Using the most recent achievements in 3D image-based survey, we restitute in three dimensions almost one hundred objects of the tomb of Kha, then virtually recollected them in their original context to become the basic elements of a narrative. Thanks to the passive "self-explaining" approach described above, the visitor will understand the relationships between different objects, some not directly visible in the museum room, such as the mummy of Kha and his wife, Merit. Ideally, the visitor can rebuild the finds in their original context, but especially moreimportantly be able to visit these contexts as they appeared at the time of their discovery, thanks to the techniques of virtual archaeology.

As the entire project was completed in just three months, we used only rapid survey technologies in an effort to keep the metrical data under control, considering that the final goal is not the survey itself, but the representation and the contextualization of all finds. From an operative and technical point of view we used two different technologies: the objects characterized by a rather simple geometry were modelled with NURBS techniques using frontal photos that were orthorectified with the help of direct measurements (Fig. 4). More complex objects, such as sarcophagi, statues and the mask of Merit, were recognized using Agisoft PhotoScan, a well known program that uses algorithms such as SfM (Structure from Motion) for the generation of 3D models complete with textures (Fig. 5). Diverging from normal operational practice, after the generation of the mesh, every model was temporarily exported (in obj format) into software for 3D sculpting in order to manually manage some small anomalies over the surface and to apply a smoothing algorithm to eliminate the $3 \mathrm{D}$ noise caused by high ISO and by the uncertainty of some measurements, due to the poor lighting and the low surface characterization of some parts. The acquisition of 3D models in environments with low light is a significant problem, especially when it is impossible, as it was in this case, to set up a professional still-life with additional lights to reduce the high ISO. Later, the models were re-imported into PhotoScan (in the same obj format) for the definitive computing of the textures, typically with a resolution of $10000 \times 10000$ pixels.

The virtualization of the tomb allows us to understand the exact position and morphology of the burial assemblage, as well as that which was discovered and documented in detail through the excavation journals and photographs of E. Schiaparelli. (Figs. 6 and 7). As said previously, this instrument was used by the Italian as a real form of documentation of excavation and thanks to these old photos it was possible to reconstruct the entire discovery, from the opening of the entrance pit until the opening of burial chamber. His images have been reused in these movies and reprocessed with matte painting and camera mapping techniques in order to offer the visitor the exact feeling of the discovery. The metrically accurate $3 \mathrm{D}$ scenes have been used to superimpose archival images with a colour representation of the tomb, where the individual objects viewable in the museum return to life in the background. The vision of the movie prepares the visitor to visit the museum rooms, but it is also a moment of study and reading of the whole information of context, reconnected to the votive chapel and to the site of Deir-el-Medina. The tomb of Kha was represented with different techniques and methods, including sections in perspective view and continuous camera movements 
giving direct information in a simple way without mediation or excessive fragmentation of the communicated message. The narrative proceeds without emphases given by special effects, but just provide information and points of view that allow for understanding everything in a dynamic and sequential way, with a scale that begins from the village of Deir-elMedina and continues down to the smallest objects.

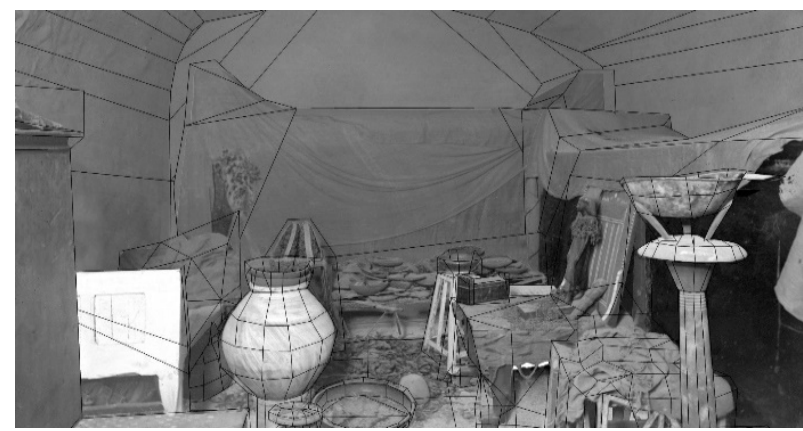

Figure 4: Camera Mapping of old real photo.

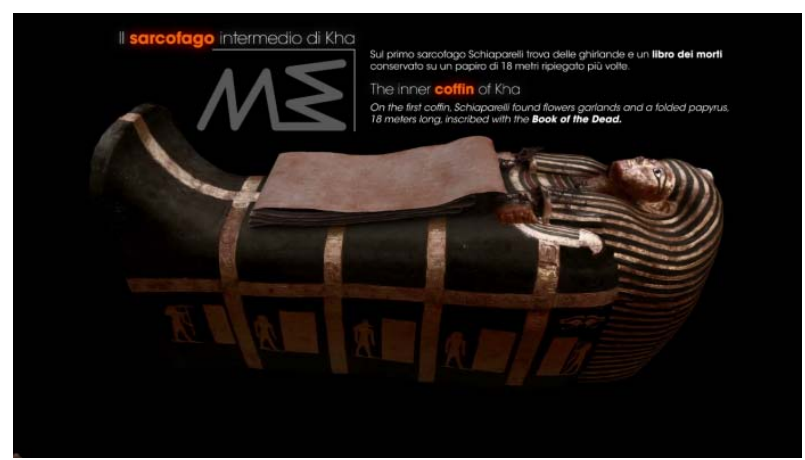

Figure 5: 3D model of inner coffin of Kha, obtained with IB techniques.

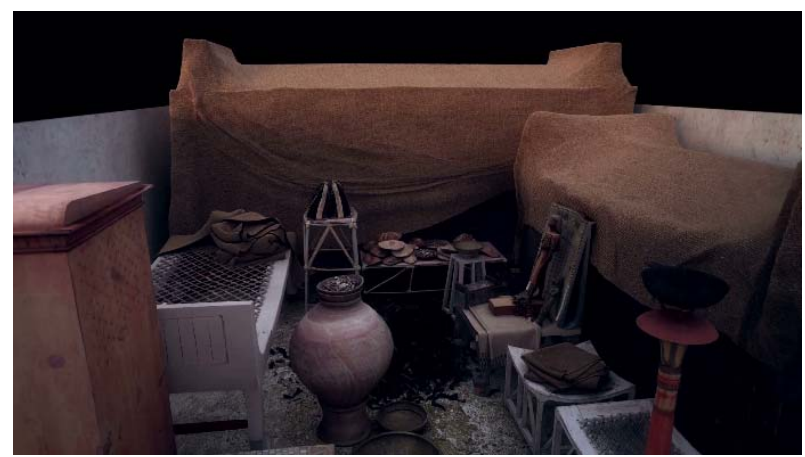

Figure 6: Tomb of Kha, screenshot of the reconstructed interiors.

The second film regards the chapel of Maia, the already mentioned painter that worked in the necropolis of Deirel-Medina. His frescoes that were "detached" from the original walls are currently exhibited in the museum. In this setting, a virtual reconstruction of the small building with the fragments of paintings appropriately integrated with outline drawings has been proposed. All this would be done in order to clarify the complex reading of all registers (Fig. 8).

Even here, the historical images properly reconstructed in $3 \mathrm{D}$ using the techniques described above serve as support for the description of the funerary ritual represented in the paintings. The overall view describes the contents of the registers in the order of reading and allows one to observe the ritual procession horizontally, in accordance with its natural development. Increased zoom over the figures allows one to appreciate the features and stylistic details, with additions of reconstructive drawings that complete, as far as possible, the description of the ritual.

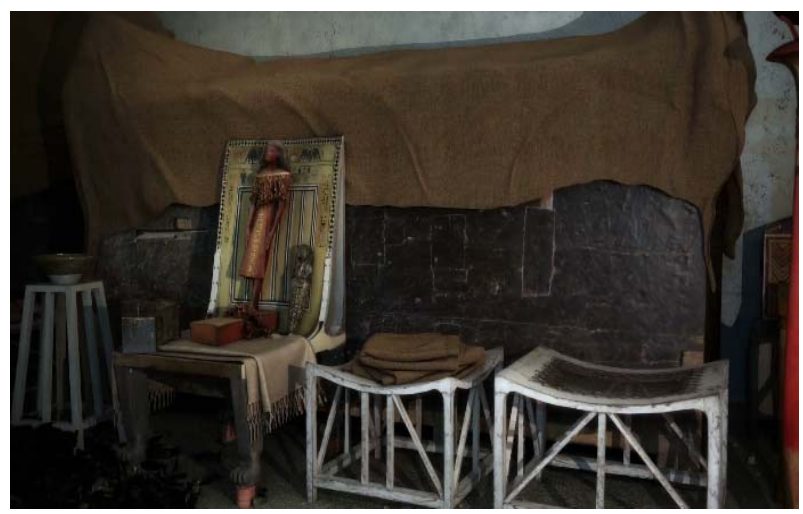

Figure 7: Tomb of Kha, screenshots of the reconstructed interiors.

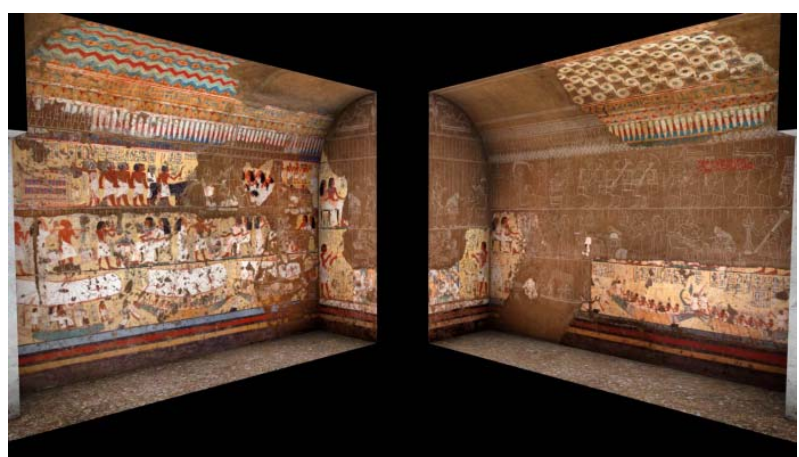

Figure 8: Reconstruction of Chapel of Maia.

Even here, the historical images properly reconstructed in 3D using the techniques described above serve as support for the description of the funerary ritual represented in the paintings. The overall view describes the contents of the registers in the order of reading and allows one to observe the ritual procession horizontally, in accordance with its natural development. Increased zoom over the figures allows one to appreciate the features and stylistic details, with additions of reconstructive drawings that complete, as far as possible, the description of the ritual.

The third film concerns the cycle of paintings that decorates the hypogean tomb of Nefertari, one of the most complete and important of the New Kingdom. This vast tomb discovered in 1904 by the Egyptologist Ernesto Schiaparelli, unfortunately looted and deprived of the mummy, is located on the northern slope of the Valley of the Queens and has a highly articulated plan. It is in fact different from the tombs of other queens (usually more simple, with only one burial chamber) and was rather inspired by the pharaonic tombs of the nearby Valley of the Kings. The paintings reach the acme of quality in Egyptian funerary art especially for their richness in colours (green, Egyptian blue, red, yellow ocher, white and black) and detail, while the themes and content respect the information supplied in 
the Book of the Dead. The images describe the journey to the afterlife of Nefertari, during which she plays the Senet, and enters the underground world where she encounters many gods such as Osiris and Isis.

At the end of the cycle of paintings, Nefertari triumphs and turns into Osiris (god of the dead), with the consequent, advocated reaching of immortality and eternal peace. The museum keeps the sarcophagus of Queen Nefertari and a wooden maquette of the entire royal tomb accompanied by pictorial decorations, meticulously replicated when discovered. A document of considerable interest for a complete view of a cycle is now no longer legible in its entierety. The context was restituted in 3D (Fig. 9) in order to illustrate the path of solarisation and deification of the Queen after death, which involve the visitor in a virtual and emotional journey within the underworld, among the Egyptian gods, having as a point of connection just the real objects exposed in the museum room.

This process of historical re-evocation is developed in accordance with a cinematographic approach, which integrates the techniques of synoptic representation of the paints used for the chapel of Maia and combines the animation of 3D wooden model displayed in the museum. The narratives allow us to understand the figurative themes and the dynamic development of the path of deification and the spatiality of the tomb, one of the most beautiful of the Valley of the Queens.

\section{Conclusions}

The virtualization of the three contexts described in this paper allows visitors to the Museo Egizio in Turin to better recognise the characteristics of the objects exposed in the rooms, but at the same time enable the visitor to contextualize and understand the relationships between them. Many objects not directly visible in the rooms are described adequately in the video e.g. the organization of three coffins of Kha and the correct view of smaller finds originally contained in the boxes. Image- based technologies and NURBS modeling based on orthophotos made it possible to restitute nearly 100 funerary objects, which were used to complete the reading of funerary contexts. In this work there is also the precise attempt to compensate the passivity of the vision through an emotional approach which involves the visitor on an information path in which, despite the inactivity of vision, he or she is emotionally involved.

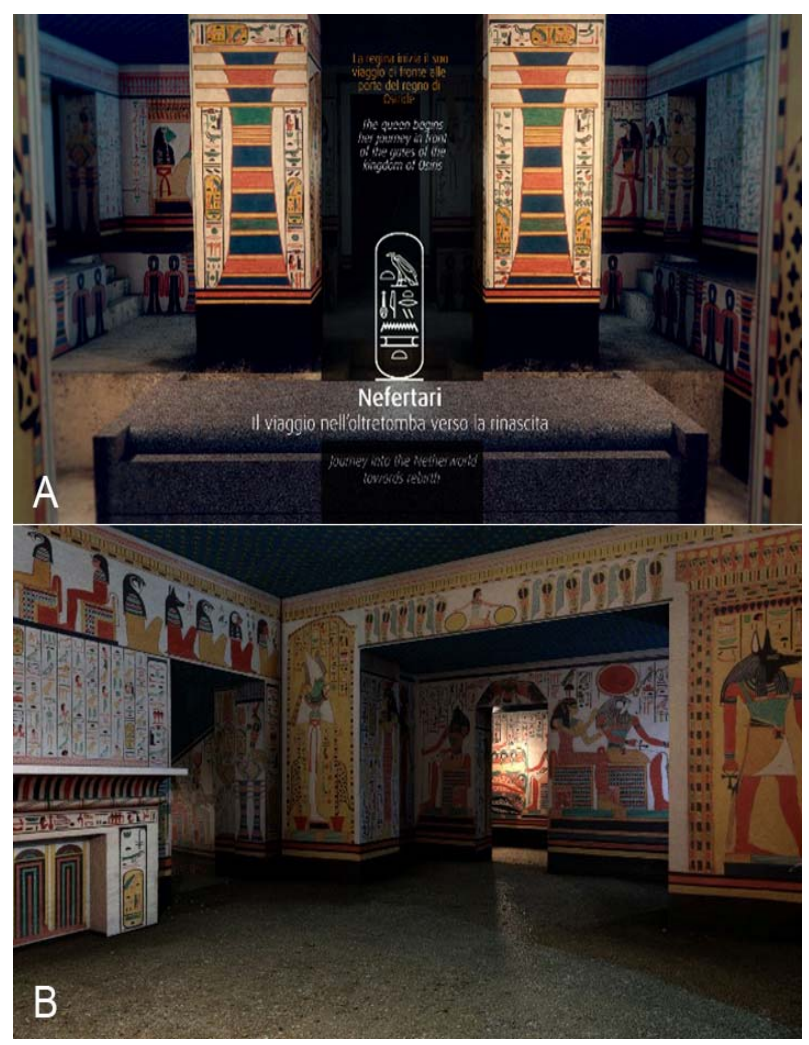

Figure 9: Reconstruction of tomb of Nefertari, starting by Schiaparelli wooden maquette: the sarcophagus hall $(A)$, the entrance hall $(B)$

\section{References}

The full video of "The tomb of Kha" is available here: https://www.youtube.com/watch?v=S7QElbjfT4w

Nefertari trailer is available here: https://www.youtube.com/watch?v=5bY-XjS5uec

CHIODI, P., 1976. Essere e tempo, Milano.

D'AMICONE, E., 2007. Nefer: la donna dell'Antico Egitto, Milano.

DONEUS, M., VERHOEVEN, G., FERA, M., BRIESE, CH., KUCERA, M. and NEUBAUER, W., 2011. From deposit to point cloud - A study of low-cost Computer Vision approaches for the straightforward documentation of archaeological excavations, in: Geoinformatics CTU FCE, pp. 81-88.

GABELLONE, F., FERRARI, I. and GIURI F., 2015. Digital restoration using Image-Based 3D models, in: Proceedings of the1st International Conference on Metrology for Archaeology Benevento- Italy, October 21-23, 2015, Benevento, pp. 478- 482.

MOISO, B., 2008. Ernesto Schiaparelli e la tomba di Kha, Torino.

NASR, M. and TOSI M., 1997. La tomba di Nefertari, Firenze.

NORBERG-SCHULZ, C., 1992. Genius Loci. Paesaggio, ambiente, architettura, Documenti di architettura, Milano.

PATIAS, P., 2007. Cultural heritage documentation, in: Fryer J., Mitchell H., Chandler J. (eds.), Application of 3D measurement from images, 59(3), pp. 225-257, Dunbeath.

POLLEFEYS, M., VERGAUWEN, M. and VAN GOOL, L., 2000. Automatic 3D modeling from image sequences, in: International Archive of Photogrammetry and Remote Sensing, Vol. XXXIII, part B5, pp. 619-626. 
REMONDINO, F. and EL-HAKIM, S., 2006. Image-based 3D modelling: a review, in: The Photogrammetric Record, 21(115), (September 2006), pp. 269-291.

VERHOEVEN, G., DONEUS, M., BRIESE, CH. and VERMEULEN, F., 2012. Mapping by matching: a computer visionbased approach to fast and accurate georeferencing of archaeological aerial photographs, in: Journal of Archaeological Science, 39, pp. 2060-2070. 


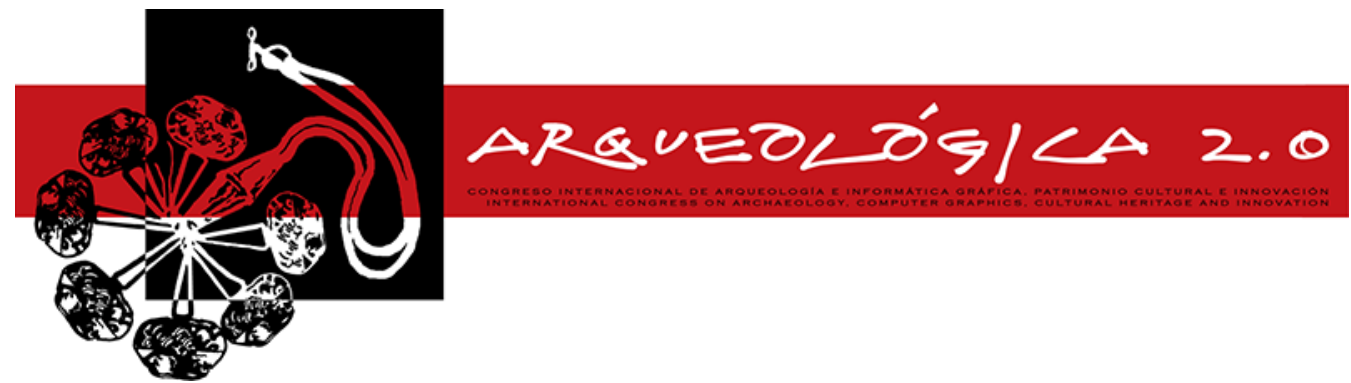

Proceedings of the $8^{\text {th }}$ International Congress

on Archaeology,

Computer Graphics,

Cultural Heritage and Innovation

'ARQUEOLÓGICA 2.0'

in Valencia (Spain),

Sept. 5-7, 2016

DOI: http://dx.doi.org/10.4995/arqueologica8.2016.3554

Received: 01/03/2016

Accepted: 25/06/2016

\title{
DEVELOPMENT OF AN EFFICIENT APPROACH OF ARCHAEOLOGICAL HERITAGE IN THE INTERTIDAL ZONE OF THE BELGIAN NORTH SEA
}

\author{
Michiel Decock ${ }^{a}{ }^{,}$, Cornelis Stal ${ }^{a, b}$, Samuel Van Ackere ${ }^{a}$, Annelies Vandenbulcke ${ }^{a}$, Philippe De \\ Maeyer ${ }^{\mathrm{a}}$, Alain De Wulf ${ }^{\mathrm{a}}$

\begin{abstract}
a Department of Geography, Ghent University, Krijgslaan 281 (building S8), Ghent, Belgium. Michiel.Decock@Ugent.be; Alain.Dewulf@Ugent.be
\end{abstract} \\ Cornelis.Stal@Ugent.be; Samuel.Vanackere@Ugent.be; Annelies.Vandenbulcke@Ugent.be; Philippe.Demaeyer@Ugent.be; \\ ${ }^{\mathrm{b}}$ Department of Real Estate and Land Surveying, University College Ghent, Valentin Vaerwyckweg 1 (building P), Ghent, Belgium.
} Cornelis.Stal@HoGent.be

\begin{abstract}
The knowledge of the submerged cultural heritage in the North Sea is rather limited. The Belgian North Sea is being used for a lot of different purposes, such as fishing, aggregate extraction, wind farms, dredging, etc. Due to these increasing economic activities, the underwater archive is in danger. In the context of the UNESCO Convention on the Protection of the Underwater Cultural Heritage of 2001, gathering more information about the submerged cultural heritage in the intertidal zones of the North Sea is one of the main objectives of the Belgian scientific project 'SeArch'. It will give a clearer picture of the broader cultural and archaeological heritage in the region and it can be used as a basis for a sustainable management by government agencies. The Department of Geography (Ghent University, Belgium) contributes to the SeArch project in two ways. First, an innovative survey methodology has been developed which allows an accurate and cost-efficient evaluation of the archaeological potential in the intertidal zones of the Belgian beaches. Secondly, the Department of Geography is developing an interactive webGIS platform, which makes it possible to share, integrate and visualize the gathered archaeological and environmental data and information in a user-friendly way. Hereby, the total potential of this project is fully exploited in a time-efficient manner. To create an interactive webGIS platform, a good structured spatial database is needed. It enables manipulation of a wide variety of georeferenced information in both raster and vector formats. This paper provides more information about the configuration and application of the spatial database. Moreover, it focusses on the development of a fully functional Spatial Data Infrastructure (SDI) using the most reliable, powerful and state-of-the-art technological components. Besides, a new way of collecting geomatic data in a fast and accurate manner will be discussed. Some processing results will show the possibilities for detecting and visualizing underground structures and archaeological objects.
\end{abstract}

Key words: North Sea, submerged cultural heritage, 3D data acquisition, Spatial Data Infrastructure, Geo Web-Service

\section{Introduction}

During the last glacial period (approx. 110,000 to 12,000 years ago, also called the Weichselien), a vast amount of water crystallized. This resulted in much lower sea levels. At those times, the level of the North Sea was even $130 \mathrm{~m}$ below the current one. As a result, many regions in the current North Sea were suitable for terrestrial organisms to live, such as mammoths, sabertoothed cats and pre-historic men. When the temperatures on Earth started to rise, the ice poles melted, causing the flooding of those regions. This is the reason why so many archaeologic artefacts and structures are found in the bottom layers of the North Sea. Because the water bulk acts as a protection layer against natural degradation processes, the finds are mostly well preserved.

The knowledge of the underwater cultural heritage in the Belgian part of the North Sea (Fig. 1) is rather limited. Nevertheless, this submerged heritage forms an important aspect of our cultural heritage and offers huge possibilities for scientific and (inter-)cultural purposes. Due to an increasing number of economic activities at sea (aggregate extractions, fishing, dredging, wind farms, etc.), this unique underwater archive is in danger. But this is not the only threat. Due to the very complex state structure of Belgium, a solid regulation regarding underwater cultural heritage is still lacking, notwithstanding the awareness of the need to take responsibility for this heritage in danger at the political level. According to the UNESCO (2001) Convention on

`Corresponding Author: Michiel Decock, Michiel.Decock@Ugent.be 
the Protection of the Underwater Cultural Heritage, the mapping and preservation of archaeological finds is even mandatory, as well as promoting the public awareness and the exchange of information. The multidisciplinary 'SeArch' project (Archaeological Heritage in the North Sea, www.sea-arch.be) offers solutions to these challenges through the development of an efficient assessment methodology and an approach towards a sustainable management policy and legal framework. Apart from the Department of Geography of Ghent University (www.geoweb.ugent.be), there are several other collaborating partners, each specialized in their own discipline (archaeologists, lawyers, geologists, marine specialists): Flanders Marine Institute (VLIZ, www.vliz.be), Flemish Heritage Agency (FHA, www.onroerenderfgoed.be), Deltares (Department of Geology and Geophysics, The Netherlands, www.deltares.nl), Renard Centre of Marine Geology (Ghent University Department of Geology, www.rcmg.ugent.be ) and the Maritime Institute (Ghent University Department of European, Public and International Law, www.ugent.be/re/epir/en/research groups/public-international-law/department/maritime institute/maritimeinstitute.htm).

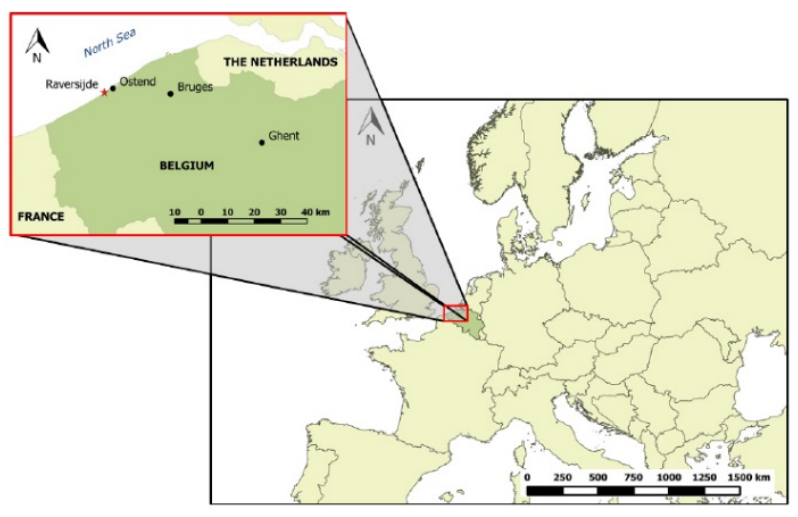

Figure 1: Geographic location of Belgium in Europe with detail map focused on the survey region of Raversijde

The contribution of the Department of Geography, Ghent University, comprises two aspects. First, there was an urgent need for an innovative survey methodology which allows an accurate and cost-efficient evaluation of the archaeological potential in the intertidal zones of the Belgian coast line. Conventional topographic and bathymetric surface modelling methodologies are not sufficient for these areas and new surveying approaches are required. This paper describes a new way for collecting geomatic data on beaches. This will be followed by some data processing, showing the great possibilities for detecting and visualizing underground structures and archaeological objects.

Secondly, the archaeological and environmental data resulting from the surveys within this project, as well as already existing data, have to be investigated using a Spatial Data Infrastructure (SDI). The objective of this SDI is to increase the accessibility and interoperability of spatial data for a wide range of users. A web-based Geographical Information System/Service (webGIS), as part of the SDI, will allow an efficient integration and visualization of the data in a user-friendly way in accordance with clearly defined protocols. The interface is useful for dissemination of information and for support of decision makers. One of the major challenges for spatial data users is the integration of multi-source spatial data. Within the framework of this project, datasets come from different actors, which are operated by different institutions. Consequently, there are many heterogeneities and inconsistencies in the technical and non-technical aspects of the different (spatial) datasets. In spite of the heterogeneity of the datasets, the use of a SDI facilitates the data integration and interoperability. The SDI provides a holistic platform for users to interact with spatial data through technical and non-technical tools (Mohammadi et al. 2008). This paper will explain the advantages of storing archaeological data purely based on their specific characteristics. In this way, different objects with similar characteristics can be linked to one another and adjustments of existing data can be easily done.

\section{Methodology}

\subsection{Data acquisition}

At first sight, Airborne Laser Scanning (ALS) seemed to be the most appropriate data acquisition technique for measuring the intertidal zone. However, there are some reasons why this is not the case. The most obvious one is that airborne methods are very expensive for measuring only a relatively small region. More important though is the fact that airborne methods are not accurate enough for the scope of this project. Objects not too deep below the surface have an influence on the microrelief of sandy beach structures. In this way, knowledge of possible micro-ripples on a temporal base offers the possibility to detect archaeological findings; if certain micro-ripples at a specific place are existent at different times, this indicates an object might be beneath the surface. As the local stockpiling of sand grains is of the order of a few millimetres, there is a need to distinguish sub-centimetre height variations. Airborne methods only have an accuracy of about one decimetre (Middleton et al. 2013).

Solely relying on ALS for detecting small sub-soil finds in the intertidal zone is not sufficient. This has been confirmed based on ALS measurements of the Flemish Hydrography (http://www.vlaamsehydrografie.be), which scans the Belgian coast twice a year and after each storm. Based on those data, no small archaeological objects have yet been found. However, ALS can be used to detect interesting archaeological sites, as was extensively done in e.g. Baden Württemberg (Hesse 2010).

To deliver the necessary vertical accuracy of about 1 $\mathrm{mm}$, a range of terrestrial solutions was considered. A short description of each of these techniques is given below, as well as their respective advantages and limitations.

\subsubsection{Robotic Total Station}

Recent developments towards robotic total stations made it possible to perform reflectorless distance measurements (EDM) by only one operator, significantly increasing the performance of total station measurements. The use of such a total station for surface mapping may result in an accuracy of about 1 to $2 \mathrm{~cm}$, although sub-centimetre single point precisions can be reached. Another interesting development is the 
integration of total stations with imaging sensors. An important drawback is the low point density due to the slower measurement speed (in comparison with laser scanners) and the higher degree of manual intervention by the operator.

\subsubsection{Real-Time Kinematic GNSS}

Until a few years, it was very difficult and expensive to measure single points with $\mathrm{cm}$ accuracy. Moreover, these measurements were extremely time-consuming. The ability to use data connections over mobile networks have sped up the development of Real-Time Kinematic (RTK) GNSS measurements with $\mathrm{cm}$ accuracy. The Flemish Positioning Service (FLEPOS) is the implementation of such a system in Flanders, consisting of a network of 40 permanent reference stations. Users can use this FLEPOS service by downloading real-time correction messages for their own GNSS measurements. By using FLEPOS, point precisions between $2 \mathrm{~cm}$ in planimetry and $4 \mathrm{~cm}(67 \%$ or 1 sigma) in altimetry can be reached. This easy access to very accurate GNSS measurements has opened a lot of possibilities to use GNSS for the fast and accurate generation of Digital Surface Models (DSM). The technique is still limited by the achievable resolution of the measurements. Assuming a mobile vehicle equipped solely with RTK-GNSS but without inertial system and laser scanning, extra error sources are introduced by the sinking of the wheels into the sand surface and the inclination of the GNSS pole.

\subsubsection{Static Terrestrial Laser Scanning}

Static Terrestrial Laser Scanning (STLS) is a technique where a huge amount of accurate detail points is acquired from a fixed laser scanner position. STLS is frequently used to model objects of limited size or at a limited distance from the scanner. The type of application and the range is in this context mainly related to the type of distance measurement (i.e. phase-based with a range up to $100 \mathrm{~m}$ or pulse-based with a range up to $1 \mathrm{~km}$ ). Its main advantage consists of the high scanning rate of up to $1 \mathrm{GHz}$, which leads to an accurate $3 \mathrm{D}$ model which offers a point based representation of the object or site.

The technique can be used for topographic surface modelling, but it is obvious that STLS suffers from some important drawbacks for intertidal zone mapping. The number of scans is related to the size of the area that has to be scanned. Because of the lack of topographic variability of the terrain, a target based registration is required. Since each target, or materialized reference point, has to be positioned in a coordinate system, large campaigns are very time consuming. Another drawback of static measurements is the fact that on flat terrains, the angles of incidence will be very large and the range limited. The scanner is placed on a tripod (Fig. 2), meaning that the scanning height is around 1.50 to 2.00 $\mathrm{m}$. Even with a range of $8.50 \mathrm{~m}$, there will be an incidence angle of 80 degrees, resulting in weak reflection and large beam spots. Thereupon, lower signal to noise ratios will occur and lower point accuracies will be reached. Summarizing, it can be concluded that STLS will be very useful for the detailed modelling of small surfaces, but limited on speed, coverage and accuracy for the mapping of larger areas.

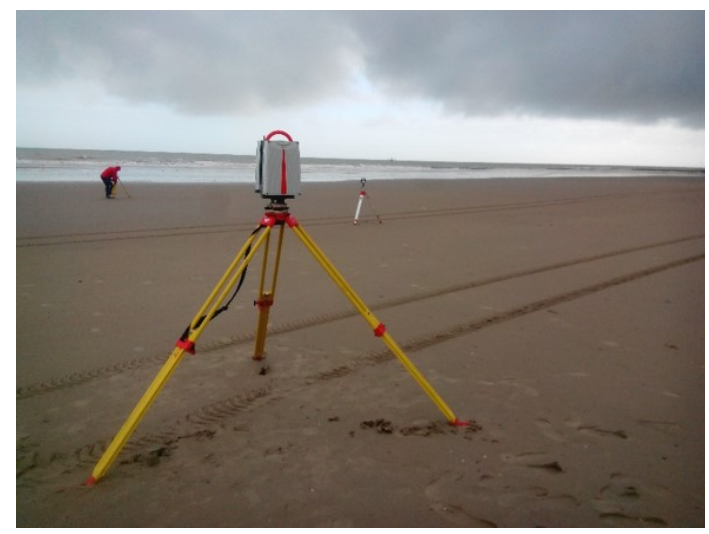

Figure 2: STLS at Raversijde

\subsubsection{Photogrammetry or image based modelling}

Photogrammetry or image based modelling is frequently executed by means of an airborne laser scanner, but next to this classic mapping technique, Kite Aerial Photogrammetry (KAP) is a promising alternative (Fig. 3). KAP can be used to create DSMs in a fast and accurate way for mapping and monitoring sand dunes and particular areas of interest situated directly along the coastline. The resulting models can be used after a storm surge, to assess the need of beach nourishment, to evaluate coastal erosion or when new constructions need to be placed along the coastline.

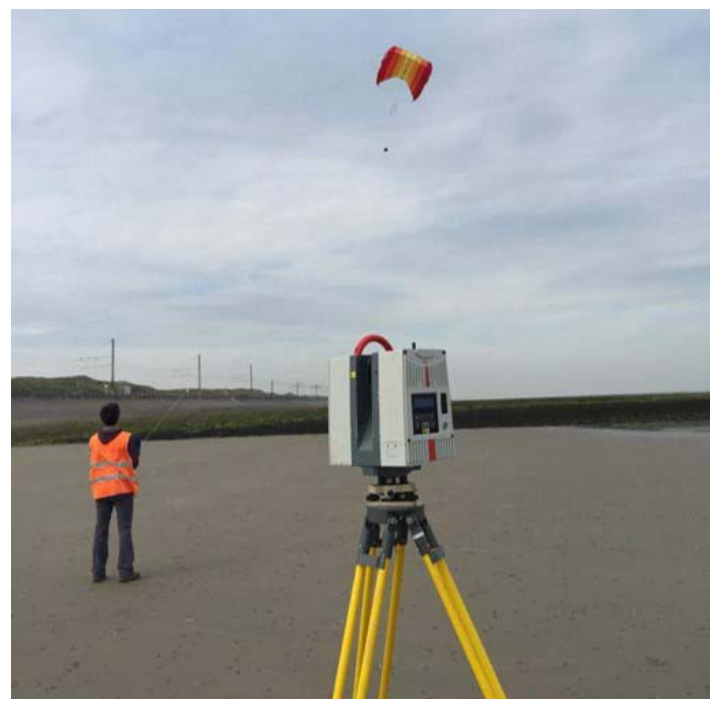

Figure 3: Image based modelling using a kite (KAP)

The principle of KAP is similar to that of conventional airborne campaigns. An important factor consists of the weather conditions. The kite system can be used in conditions from 2 (light breeze) to 6 (fresh breeze) on the Beaufort scale. This in contrast to the use of Unmanned Aerial Vehicles (UAV), which need to operate in less windy conditions (2-3 Beaufort). The procedure involves the kite operator walking around the beach, on which ground control points (GCPs) have been placed as black-and-white targets. To achieve the best positional accuracy, GCPs are surveyed with a total station. The kite has a working altitude of 10 to 20 meters above ground level. The kite carries a shock- and waterproof, non-metric compact camera with a smallsize 12 till 20 Megapixel sensor. This camera makes it 
possible to acquire images with a ground resolution of less than $5 \mathrm{~cm}$. Afterwards, photogrammetric processing is used to combine the photographs into a mosaic. The aerial triangulation with camera calibration and subsequent model generation is mostly an automated process. The photomosaic is georeferenced and orthorectified using the GCPs. In one day, an area of up to 10 ha can be surveyed and processed to produce digital height maps and orthorectified images. Kite systems can be used as an addition to classic topographic surveys and aircraft-based surveys, with considerable gains in the cost of the data acquisition.

\subsubsection{Mobile Terrestrial Laser Scanning}

Considering the drawback of the aforementioned techniques (accuracy, speed, coverage), a Mobile Terrestrial Laser Scanning (MTLS) system was considered to survey the intertidal zones. The system configuration of the used MTLS is very similar to an ALS set-up. The main components consist of a laser scanner, an Inertial Navigation System (INS) and a Global Navigation Satellite System (GNSS), depicted in Figure 4. These instruments were mounted on a moving platform: an 8 wheeled vehicle called ARGO (Fig. 5). As in airborne applications, the combination of GNSS and INS measurements with the Position and Orientation measurement System (POS) provides highly accurate positioning. In turn, the laser scanner produces a very precise point cloud. The accurate determination of the calibration parameters is also essential for the correct use of MTLS (Skaloud and Lichti 2006). This state-ofthe-art survey method was developed by Prof. Dr. Nicolas Seube (Seube et al. 2012) and his research team of ENSTA Bretagne, Brest (École Nationale Supérieure de Techniques Avancées, http://www.enstabretagne.fr), who also cooperated with the field campaigns.

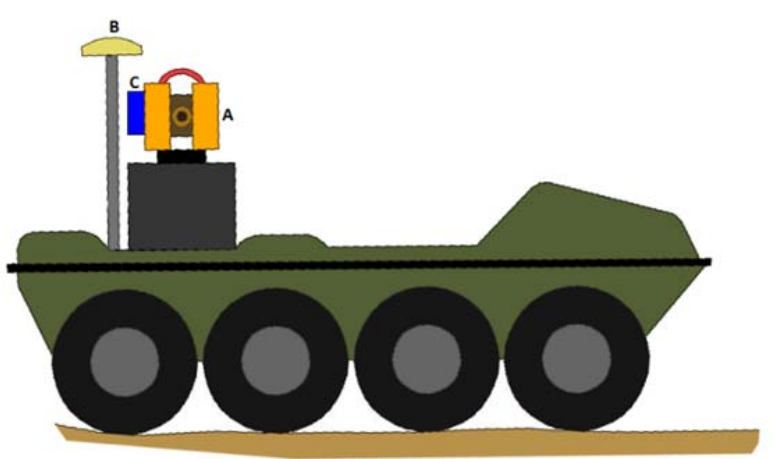

Figure 4: Illustration of the set-up of the survey main components: A) laser scanner, B) GNSS and C) INS

Using laser scanning, the distance between an object and the sensor is derived using a beam of monochromatic light. A large number of distance and angular measurements will result in a very dense point cloud within a limited time frame; for each beach strip (approx. $150 \mathrm{~m}$ by $300 \mathrm{~m}$ ) the scanning time was only about 45 minutes. However, most part of the time is spent on the calibration procedure (about half a day). All types of laser scanning systems use active, optical, reflection based and contact-free scanning methods. Here, the used laser scanning device (Leica HDS6100) determines the distance based on the calculation of the phase difference between the emitted and reflected continuous wave with a maximum scan rate of 508,000 points/s. Hereby, the used electromagnetic radiation has a wavelength of approx. $650 \mathrm{~nm}$.

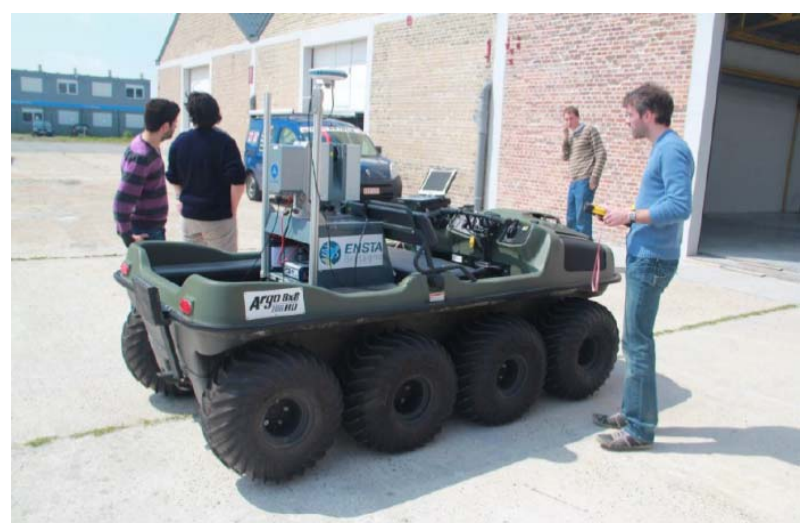

Figure 5: The used amphibious vehicle ARGO with equipment

To verify and analyse the accuracy of the DEMs created using the MTLS technique, a theoretical and practical comparison of the various other described survey methods was made (robotic total station, Real-Time Kinematic (RTK) GNSS, STLS and conventional photogrammetry).

\subsection{WebGIS platform}

Another contribution of the Department of Geography to the SeArch project is the development of a new and specific Spatial Data Infrastructure (SDI) of the archaeological and geologic/geophysical data. Its main purpose is to maximally integrate those data and to visualize them in a user-friendly way. A SDI encompasses organizational or institutional arrangements and policies, as well as the desired technology, which is needed to make geographical data available. SDI components are amongst others: geographic data, metadata, technical specifications and standards, procedures for the coordination of the infrastructure, arrangements for the availability and use of geographic data, etc.

Figure 6 depicts the use of the web-based Geographic Information System (webGIS) for both the deliverance and request of archaeological information. Hereby, solely open-source software is used. By means of QGIS (www.qgis.org), the administrator puts archaeologic and geologic/geophysical data in a spatial database (arrow 1). PostGIS (www.postgis.net) adds extra elements to the object related database, such as geometry, geography and the creation of a raster. With the aid of open standards, data from the database can be published (arrow 2). The end user is able to view those data in a web browser, where they are visualized on a map (arrow 3). This is done by means of an open-source server written in Java, GeoServer (geoserver.org), which generates cartographic products of the data. GeoServer is designed for interoperability, such that any major geospatial data source can be published, based on the open standards set forth by the Open Geospatial Consortium (OGC, www.opengeospatial.org). In turn, OpenLayers (www.openlayers.org) is a public JavaScript library for showing geo-data in a web browser. The usage of pre-rendered maps (tiles) is necessary for a 
fast visualization of the maps. GeoWebCache (www.geowebcache.org) accelerates the output of tiles from GeoServer (arrow 4).

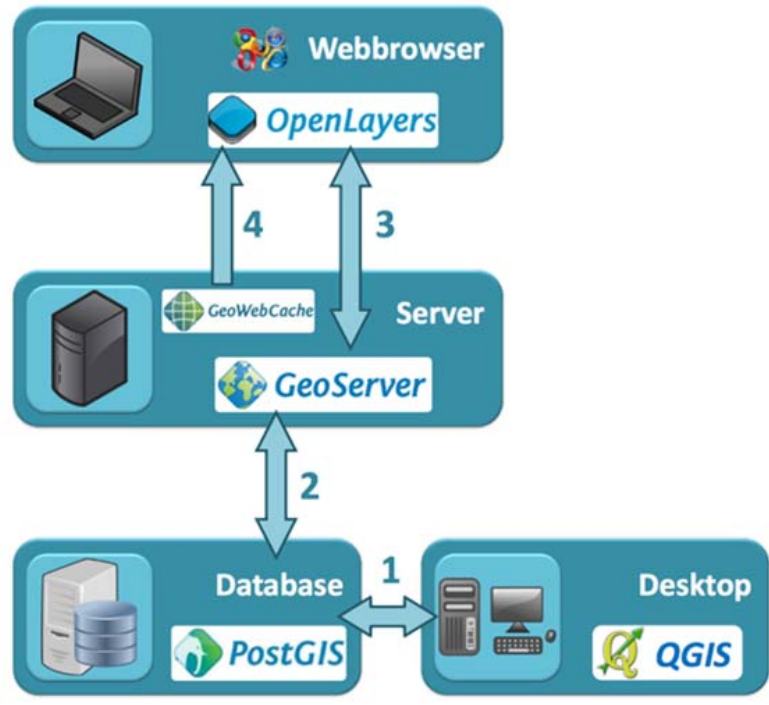

Figure 6: Schematic overview of the webGIS

The SeArch web application is based on a flexible and linkable data structure. It mainly consists of nodes with properties and relations between them. In this way, no rigid structure has to be followed by archaeological organizations for the huge variety of archaeological objects. For example, a Roman amphora has totally different characteristics (material, height, location, preservation condition, etc.) compared to a $20^{\text {th }}$ century warship. Consequently, no tables with large amounts of empty cells or default values exist in the database. Moreover, this data structure is suitable for different application domains of archaeology and cultural heritage, from research to conservation management.

Figure 7 is an example of the used data structure. Nodes form the main concept and correspond to the archaeological object (e.g. 3 blade propeller, plane wreck, bayonet). The nodes can have relations between them. Their type is designated in the data structure by the concept property, for example the location or kind of material. To each property there is a value assigned (e.g. wood for material, $50^{\circ} \mathrm{N} 10^{\circ} \mathrm{E}$ for location) and together they build up the relation vertex.

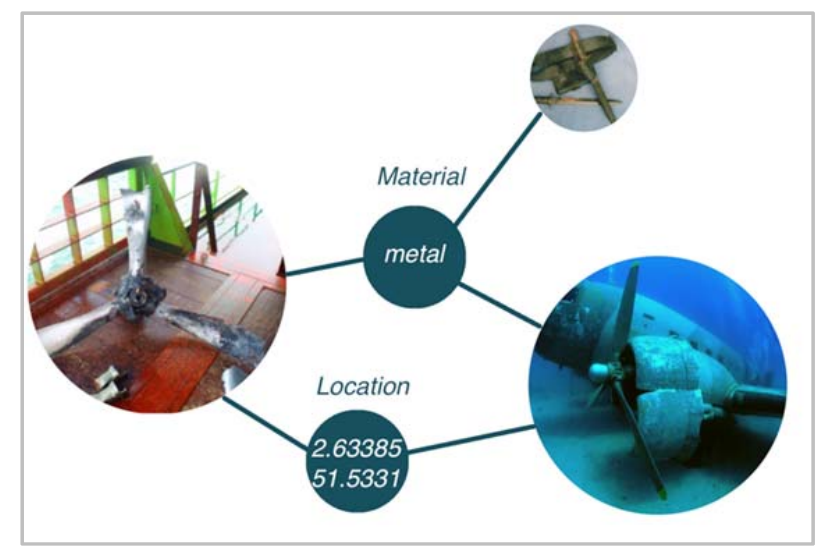

Figure 7: Example of the data structure
Building a web-based application on this data structure enables dissemination of information, collaboration and discussion on the data and their interpretation, quickly acquiring and editing information, etc. Due to the geographical nature of most archaeological data, a geodatabase is used for the storage of the data and information. In this way, an archaeological data infrastructure is set up, which serves as a web-based GIS and can function as a shared virtual workspace. This approach, therefore, agrees with the ideas proposed by Snow et al. (2006) regarding cyber tools for archaeology.

Figure 8 is an example of the kind of maps which can be found on the webGIS platform (www.sea-arch.be). It shows the currently found shipwrecks in the Belgian part of the North Sea, altogether with the present shallow zones. In this way, knowledge of the spots of the shipwrecks and the local height of the sea level can be linked to one another, which are totally different kinds of data. Apart from archaeological object related maps, the website also contains a large number of maps depicting natural structures, such as soil layers of pre-historical eras.

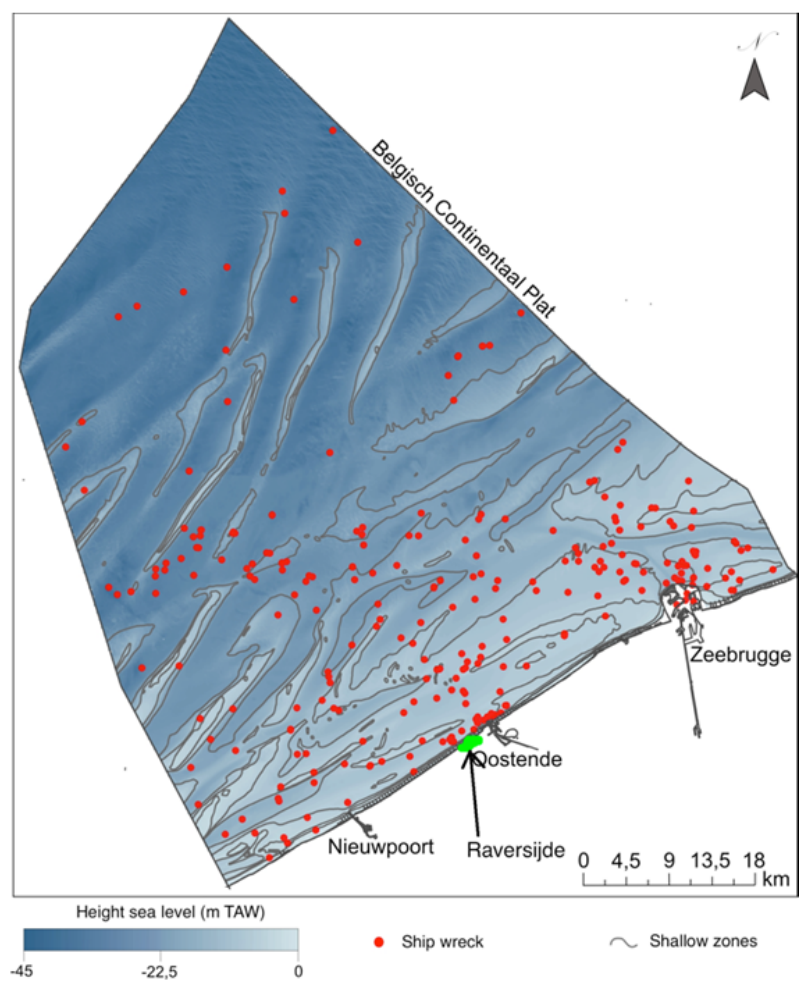

Figure 8: Shallow zones and locations of shipwrecks in the Belgian part of the North Sea

\section{Data acquisition and processing results}

To collect the data on site, several surveys were organized at the beach of Raversijde, Belgium (June 2013, May 2015 and May 2016). As illustrated in Figure 9 , the beach is totally covered with sand and it was selected based on its high archaeological potential (Ervynck et al. 1999). The submerged village of 'Walravenside' is situated in the intertidal zone of the beach and some archaeological features appeared during neap tide a few decades ago. The detection of these finds using micro-topographical enhancement techniques is one of the goals of this project. The 
measured sections are separated by breakwaters and are represented by hashed lines in Figure 10.

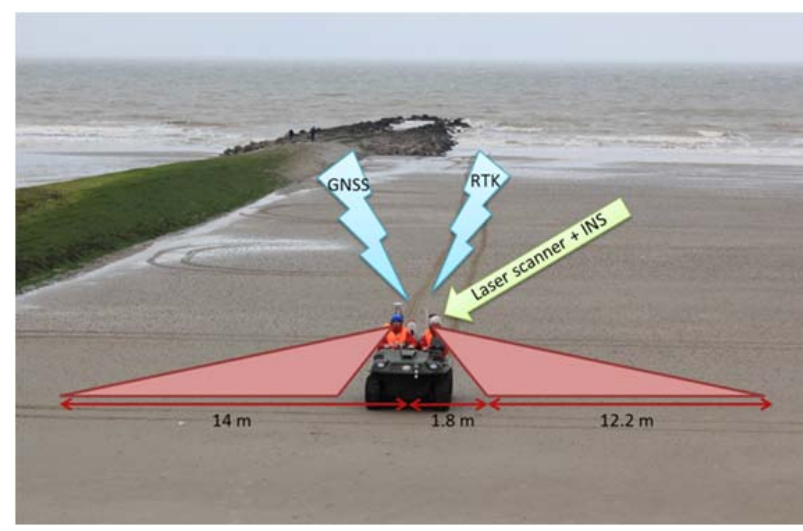

Figure 9: The ARGO at work on the beach of Raversijde, Belgium

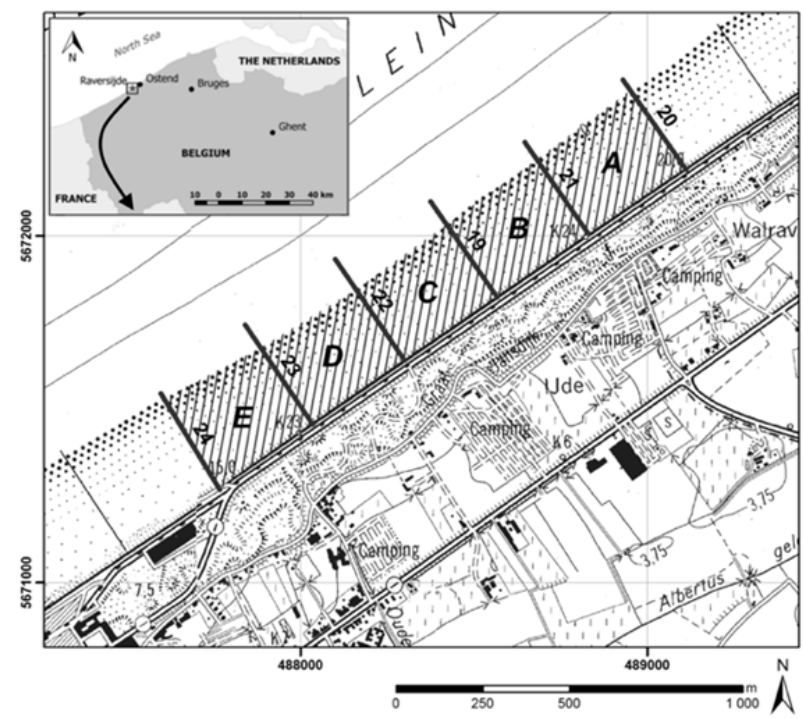

Figure 10: Overview of the study area in Raversijde, Belgium. The five test areas are indexed from $A$ to $E$ (source background map: NGI)

The survey zones $A$ till $E$ in Raversijde can be approximated by a surface with an inclination of $1.7 \%$. The breakwaters are spaced by approx. $300 \mathrm{~m}$. Incoul et al. (2014) have demonstrated that a maximal range of 14 $\mathrm{m}$ can be accepted for topographic surface modelling under these conditions, with a typical scanning height of $1.60 \mathrm{~m}$. Various parallel lines were driven with an overlap between consecutive strips. This overlap allowed a quality assessment, as well as removing the blind spot underneath the vehicle. A series of STLS measurements was also executed on the beach to perform an extra quality assessment on the data, where the STLS point clouds were georeferenced using a target-based registration.

Adjacent strips have a certain amount of overlap. A study of the height variations in the common region of two overlapping strips has been made. One strip was measured parallel to the dyke (red dots in Fig. 11), the other one perpendicular to it (blue dots in Fig. 11). Figure 11 depicts the local height of two cross sections in an overlapping zone. Table 1 contains the height differences between the two cross sections of the strips and this for five different samples. For example sample 1 contains the first $1 / 5$ elements of each cross section. As the local height variations are everywhere approx. $9 \mathrm{~mm}$, no systematic errors are present. In other words, the transversal strip lies approximately $1 \mathrm{~cm}$ above the longitudinal one. Although for different strips only an accuracy of $1 \mathrm{~cm}$ is attained relatively to each other, the accuracy in each separate layer is a factor 10 higher.

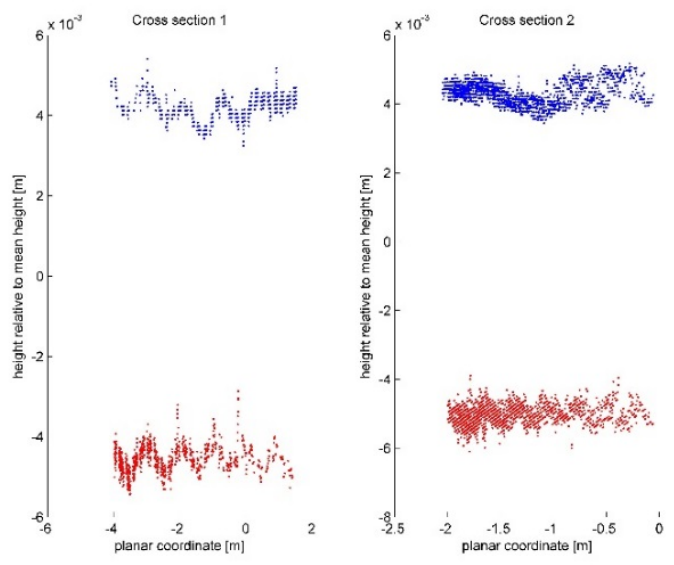

Figure 11: Height difference between longitudinal and transversal MTLS scan of the same region

Table 1: Vertical differences $(\mathrm{mm})$ between longitudinal and transversal strips covering a common region

\begin{tabular}{c|c|c|c|c|c} 
& $\begin{array}{c}\text { Sample } \\
1\end{array}$ & $\begin{array}{c}\text { Sample } \\
2\end{array}$ & $\begin{array}{c}\text { Sample } \\
3\end{array}$ & $\begin{array}{c}\text { Sample } \\
4\end{array}$ & $\begin{array}{c}\text { Sample } \\
5\end{array}$ \\
\hline $\begin{array}{c}\text { Cross } \\
\text { section } \\
1\end{array}$ & 9.0 & 9.1 & 8.8 & 8.4 & 8.6 \\
$\begin{array}{c}\text { Cross } \\
\text { section } \\
2\end{array}$ & 9.4 & 8.9 & 9.3 & 9.5 & 9.5 \\
& & & & &
\end{tabular}

Next to the influence of the system calibration, the quality of the MTLS-based point clouds is heavily depending on the measured distance, the incidence angle and the speed of the platform. Therefore, the speed was limited to $6 \mathrm{~km} / \mathrm{h}$ and the cross section measurement frequency was $20 \mathrm{~Hz}$, resulting in a longitudinal point spacing of approx. $8 \mathrm{~cm}$. The scanner was set to a lateral point spacing of $1 \mathrm{mrad}$, resulting in a distance of $0.5 \mathrm{~cm}$ near the scanning line, to $4.5 \mathrm{~cm}$ at the limits. Erroneous points were manually removed from the data and an Inverse Distance Weight (IDW) interpolation was performed for the calculation of an equidistant grid.

As visible in Figure 12, the point density decreases away from the scan lines. Moreover, a non-linear relation between the measured distance and the point reflection strength appears. This property is used for the adjustment of the intensity values, which represent the received backscatter of the emitted signal. 


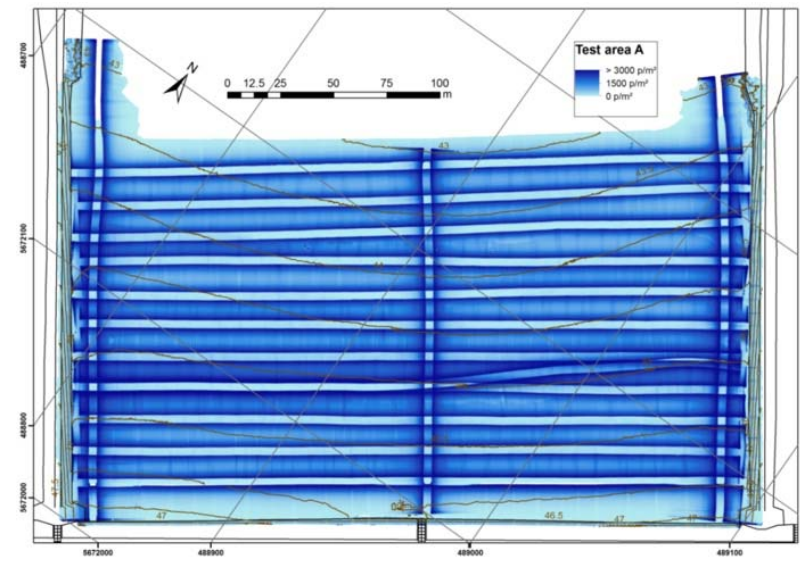

Figure 12: Point density in test area A calculated from the MTLS data (points/m2)

An empirical experiment on the determination of the relation between the intensity value on the one hand and the measured distance, incidence angle and surface properties on the other hand was presented by Voegtle et al. (2009). Under assumption of extended targets with Lambertian reflection, ignorance of the atmospheric transmission factor and a constant power emission, the laser range equation is simplified as (Pfeifer et al. 2007):

$$
I=C \rho \eta_{\text {sys }} \frac{\cos \alpha}{r^{2}}
$$

where

$$
\begin{gathered}
I=\text { intensity } \\
C=\text { constant factor } \\
\rho=\text { surface properties } \\
\alpha=\text { incidence angle } \\
r=\text { measured distance }
\end{gathered}
$$$$
\eta_{\text {sys }}=\text { (non-constant) system transmission factor }
$$

The definition of the incidence angle $\alpha$ and the measured distance $r$ is illustrated in Figure 13.

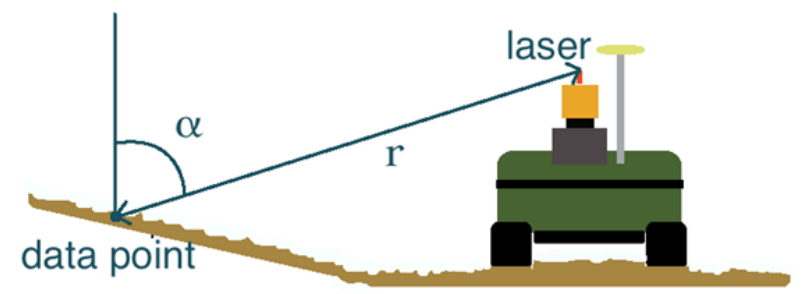

Figure 13: Definition of the distance $r$ and the incidence angle

To show the potential of the MTLS method, the intensity based filter has been applied on a survey line in zone $A$ (Fig. 14). The combination of the Digital Surface Model (DSM) with the reflection strength model provides an improved topography of the area. Intensity variations unveil a change in the surface properties based on which archaeological features or structures can be discovered (Fig. 15) that are not directly observed at the site. In the case of Figure 14, where the intensity values were adjusted using formula (1), the location of a former gully can be observed. It is expected that smaller objects, such as amphorae and flint stones, could be detected with the MTLS method. Further measurements will give a decisive answer.

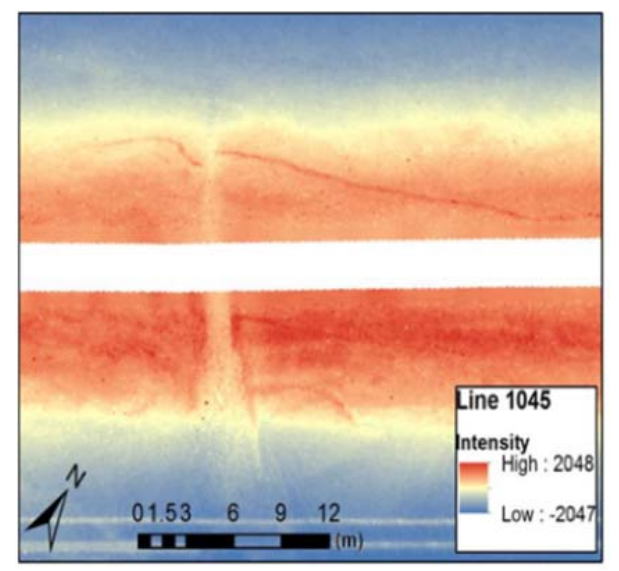

Figure 14: Intensity map acquired from a track line in test area A

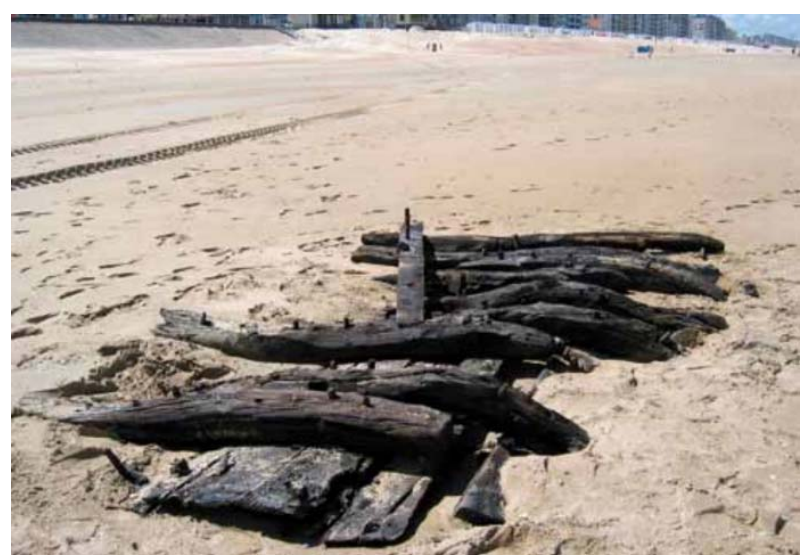

Figure 15: Remains of a wooden shipwreck washed ashore at Sint-Idesbald, Belgium (Pieters et al. 2010).

\section{Conclusion}

The use of MTLS has shown promising results for the construction of DEMs of beaches. Near the laser, a lateral point spacing of $0.5 \mathrm{~cm}$ has been reached. Together with a longitudinal point spacing of $8 \mathrm{~cm}$, this results in very dense point clouds. The suggested work flow of detecting archaeological finds in an efficient manner is as follows: first, ALS can be used to scan larger regions, such that archaeologically interesting zones can be distinguished. Next, MTLS with a horizontal accuracy of a few $\mathrm{cm}$ and vertical accuracy on the millimetre scale is performed. Finally, at zones where micro-ripples indicate a sub-soil object is possibly present, another MTLS measurement can be performed, but with a scanning direction perpendicular to the first MTLS measurement. This will drastically increase the local point density.

Besides attaining high point densities, the used configuration reduces considerably the surveying time; a beach strip of about $150 \mathrm{~m}$ by $300 \mathrm{~m}$ was measured in 45 minutes. The combination of GNSS, INS and a laser scanner definitely improved the accuracy for measuring heights, which is primordial for the measurement of the micro-relief of intertidal areas. Next to the use of this system for DEM reconstruction, the usefulness of the 
measured intensity values has been assessed. In this contribution, a methodology was presented to eliminate the influence of the measured distance and the incidence angle on the intensity values. Indeed, the new intensity values, seen in Figure 14, are independent from the distance and incidence angle after correction. Aberrations in these values are most likely to be caused by differences in sand structure, humidity, or by other features in the sand. Consequently, the proposed procedures can be used as an object recognition technique, allowing micro-morphological feature extraction.

To create an interactive webGIS platform, a good structured spatial database is needed. The presented innovative way for structuring a database offers the advantage of linking archaeological, geophysical and geologic data, solely based on specific characteristics, such as material, location and preservation condition. In this way, no rigid structure has to be followed by archaeological organizations for the huge variety of archaeological objects.

\section{Acknowledgements}

Because the mapping of a cultural heritage is a huge amount of work where a knowledge of different disciplines is required, the SeArch project consists of several specialized research groups. Many thanks go to the project partners of SeArch, who make it possible that our cultural heritage will not be lost forever: Flanders Marine Institute (VLIZ), Flemish Heritage Agency (FHA), Deltares (Department of Geology and Geophysics) and Ghent University (Renard Centre of Marine Geology, Maritime Institute). Special thanks to Prof. Dr. N. Seube and his research team of ENSTA Bretagne for the development of a very reliable, accurate and innovative way for doing mobile terrestrial laser scanning surveys. The authors also wish to thank Clement Aubry and Pierre Simon for their practical assistance during the measurement campaigns and to the Flemish Positioning Service for offering the technology for delivering precise point positions.

\section{References}

ERVYNCK, A., BAETEMAN, C., DEMIDDELE, H., HOLlEVOET, Y., PIETERS, M., SCHELVIS, J., TYS, D., VAN STRYDONCK, M. and VERHAEGHE, F., 1999. Human occupation because of a regression, or the cause of a transgression. A critical review of the interaction between geological events and human occupation in the Belgian coastal plain during the first millennium AD. Probleme der Küstenforschung im südlichen Nordseegebiet, 26, pp. 97121.

HESSE, R., 2010. LIDAR-derived Local Relief Models - a new tool for archaeological prospection. Archaeological Prospection, 17, pp. 67-72. DOI: 10.1002/arp.374

INCOUL, A., NUTTENS, T., DE MAEYER, P., SEUBE, N., STAL, C., TOUZÉ, T. and DE WULF, A. 2014. Mobile laser scanning of intertidal zones of beaches using an amphibious vehicle. 6th International conference on Engineering Surveying (INGEO 2014), Bratislava, Slovakia: Slovenská Technická Univerzita v Bratislave. Stavebná Fakulta. pp. 87-92.

MIDDLETON, J.H., COOKE, C.G., KEARNEY, E.T., MUMFORD, P.J., MOLE, M.A., NIPPARD, G.J., RIZOS, C., SPLINTER, K.D. and TURNER, I.L., 2013. Resolution and accuracy of an airborne scanning laser system for beach surveys. Journal of Atmospheric and Oceanic Technology, 30, pp. 2452-2464. DOI: 10.1175/jtech-d-12-00174.1

MOHAMMADI, H., RAJABIFARD, A. and WILLAMSON, I.P., 2008. Spatial data integrability and interoperability in the context of SDI. In: L. Bernard, A. Friis-Christensen and H. Pundt, eds, Lecture Notes in Geoinformation and Cartography. The European Information Society, pp. 401-413. DOI: 10.1007/978-3-540-78946-8_21.

PFEIFER, N., DORNINGER, P., HARING, A. and FAN, H., 2007. Investigating terrestrial laser scanning intensity data: Quality and functional relations. 8th Conference on Optical 3D Measurement Techniques, 9-12 July 2007, ETH Zurich, Switzerland, pp. 328-337.

PIETERS, M., DEMERRE, I., LENAERTS, T., ZEEBROEK, I., DE BIE, M., DE ClERCQ, W., DICKINSON, B. and MONSIEUR, P., 2010. De Noordzee: een waardevol archief onder water. Meer dan 100 jaar onderzoek van strandvondsten en vondsten uit zee in België: een overzicht. Relicta, 6, pp. 177-218.

SEUBE, N., PICARD, A., TOUZÉ, T., NISTAD, J.G. and RONDEAU, M., 2012. Calibration of vessel mounted LiDAR. Paper presented at the Hydrographic Society Benelux conference Hydro12 - Taking care of the sea, 13-15 November 2012, Rotterdam, The Netherlands.

SKALOUD, J. and LICHTI, D., 2006. Rigorous approach to bore-sight self-calibration in airborne laser scanning. ISPRS Journal of Photogrammetry and Remote Sensing, 61(1), pp. 47-59. DOI:10.1016/j.isprsjprs.2006.07.003.

SNOW, D. R., GAHEGAN, M., GILES, C. L., HIRTH, K. G., MILNER, G. R., MITRA, P. and WANG, J. Z., 2006. Cybertools and archaeology. SCIENCE, 311(5763), pp. 958-959. DOI: 10.1126/science.1121556.

UNESCO, 2001. Text of the 2001 Convention - Convention on the Protection of the Underwater Cultural Heritage. Available: http://www.unesco.org/new/en/culture/themes/underwater-cultural-heritage/2001-convention/ [03/01, 2016]

VOEGTLE, T. and WAKALUK, S., 2009. Effect on the measurement of the terrestrial laser scanner HDS 6000 (Leica) caused by different object materials. International Archives of Photogrammetry and Remote Sensing, 38(3), pp. 6874. 


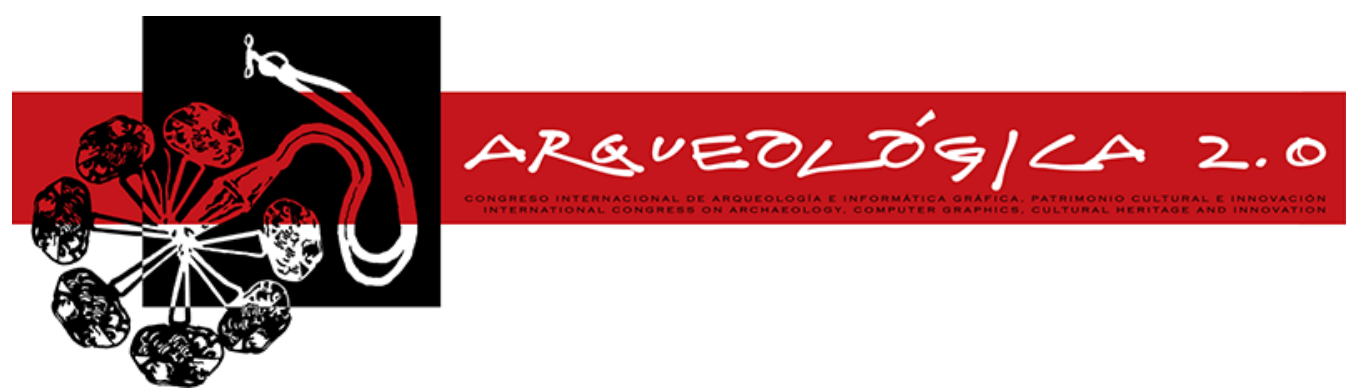

Proceedings of the $8^{\text {th }}$ International Congress

on Archaeology,

Computer Graphics,

Cultural Heritage and Innovation

'ARQUEOLÓGICA 2.0'

in Valencia (Spain),

Sept. $5-7,2016$

DOI: http://dx.doi.org/10.4995/arqueologica8.2016.3555

Received: 01/03/2016

Accepted: 10/04/2016

\title{
INTEGRATED METHODOLOGIES FOR A NEW RECONSTRUCTIVE PROPOSAL OF THE AMPHITHEATRE OF CATANIA
}

\author{
METODOLOGÍAS INTEGRADAS PARA UNA NUEVA PROPUESTA RECONSTRUCTIVA DEL ANFITEATRO DE \\ CATANIA
}

\author{
Daniele Malfitana, Francesco Gabellone*, Giovanni Leucci, Giuseppe Cacciaguerra, Ivan Ferrari, \\ Francesco Giuri, Lara De Giorgi, Claudia Pantellaro
}

CNR - IBAM (Istituto per i Beni Archeologici e Monumentali), Via prov.le Monteroni, 73100 Lecce, Italy. d.malfitana@ibam.cnr.it; f.gabellone@ibam.cnr.it; g.leucci@ibam.cnr.it; g.cacciaguerra@ibam.cnr.it; i.ferrari@ibam.cnr.it; f.giuri@ibam.cnr.it; I.degiorgi@ibam.cnr.it; c.pantellaro@ibam.cnr.it

\begin{abstract}
:
The roman amphitheatre of Catania stands in a very complex and interesting area where settlement dynamics and transformations have profoundly marked its urban landscape. Over the centuries, the urban and architectural histories together with the formation of the archaeological deposits have led to the complete obliteration of the monument and restricted knowledge of its plan and architectural development. Therefore, it constitutes an interesting context in which to experiment methods and techniques for architectural representation and the three-dimensional reconstruction of the monument.
\end{abstract}

Key words: virtual archaeology, digital archaeology, integrated technologies, 3D reconstruction, amphitheatre

\section{Resumen:}

El anfiteatro romano de Catania se encuentra en una zona compleja e interesante donde la dinámica de asentamiento y transformaciones han marcado profundamente su paisaje urbano. A través de los siglos, las historias urbanas y arquitectónicas, junto con la formación de los depósitos arqueológicos han dado lugar a la destrucción completa del monumento y el conocimiento de su plan de desarrollo arquitectónico. Por lo tanto, constituye un contexto interesante en el que experimentar métodos y técnicas para la representación de la arquitectura y la reconstrucción tridimensional del monumento.

Palabras clave: arqueología virtual, arqueología digital, tecnologías integradas, reconstrucción 3D, anfiteatro

\section{The Roman amphitheatre: research to date}

The Roman amphitheatre was built in the early imperial period on the northern edge of the ancient city. There are few references to the amphitheatre in the sources and there is no mention of it before the $6^{\text {th }}$ century A.D. when Cassiodorus mentions the concession granted by Theodoric to the people of Catania allowing them to reuse stone blocks from the Roman monument for the construction of the city walls (Cassiodorus, Variae III, 49). From the $16^{\text {th }}$ century the amphitheatre is cited and described several times by scholars and corographers and represented in numerous historical views and maps that give its exact position within the urban fabric of the modern city (Fig. 1), documenting the material and architectural substance of its structures (Fazello 1558;
Spannocchi 1578; Hogenberg 1598; De Grossis 164247; Carrera 1639; Negro 1640).

However, the amphitheatre's structures were definitively buried when the structures were razed in 1618 (D'Arcangelo 1621, III, p. 11). Although well-known by the townspeople, the structures were completely obliterated and no longer considered within the reconstruction plan that followed the 1693 earthquake and subsequent construction expansion that took place in the area between the mid $18^{\text {th }}$ and the $19^{\text {th }}$ centuries (Boscarino 1981; Oteri 2002, p. 45).

However, during the $18^{\text {th }}$ century Ignazio Paternò Castello V, Prince of Biscari, renewed study of the amphitheatre. He excavated the buried structures, uncovering large sections of the ground floor. At the same time, J-P. Houel and other French (Ducros 1778)

*Corresponding Author: Francesco Gabellone, f.gabellone@ibam.cnr.it 
and Dutch travellers described and drew the amphitheatre providing us with details of the visible portions of the monument and hypothetical reconstructions.

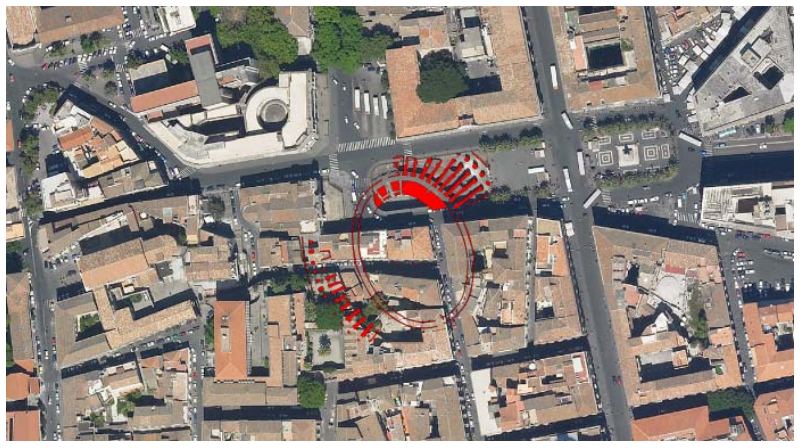

Figure 1: The structure of the amphitheatre over the actual city.

Between 1904 and 1905, an invasive excavation undertaken in Piazza Stesicoro by the engineer $F$. Fichera brought to light a portion of the area and the northernmost sectors of the structure (Fichera 1904; Fichera 1905). However, the absence of excavation records means that this intervention did not improve knowledge of the monument. In particular, the excavations identified part of the ima cavea in the northeastern sector, with a service corridor and podium wall that still preserved parts of its marble facing. An "unusual" praecintio was identified, about $6 \mathrm{~m}$ wide built on top of the internal walkway. He imagined the structure to be crowned by a portico with a colonnade of Ionic columns. At the end of the excavations the entire route of the first walkway was opened up and part of the first two sectors of seating tiers with the underlying radial spaces delimited by a peripheral corridor were visible.

Therefore, at the end of the 1990s a systematic study had still not been made of Catania's amphitheatre and it remained largely unpublished (Wilson 1990). Between 2006 and 2007, the data acquired during research undertaken by the German Institute of Archaeology in collaboration with the Superintendency of Catania provided a better understanding of some structural and architectural aspects of the Roman amphitheatre and identified the phases of construction and enlargement (Beste et al. 2007).Two different construction phases were documented. In the first, dated to the early imperial period (contra Buscemi 2012), the amphitheatre was much smaller. The second is attributable to the Antonine period, suggested by the use of opus africanum for the facing of the radial dividing walls and, above all by the structural discontinuity documenting interventions to enlarge the entire building. This involved the extension of the existing sectors by the creation of a wide external walkway with a façade ornamented with pilasters. This operation led to the choice of complex architectural and engineering solutions such as the partial excavation of the hillside and the creation of entrances on upper levels directly from the hill of Montevirgine. Thus, the amphitheatre became one of the city's cardinal points, situated on its outskirts in an area linking the city centre with the suburbs.

Furthermore, recent archaeological investigations, carried out to the west and north of the monument, documented evidence about the context in which it stood. In fact, they provided useful elements suggesting the presence of a residential district in this sector of the city in the Republican period (Branciforti 2003, pp. 113114; Branciforti 2005, pp. 186-187; Branciforti 2010, pp. 221-222), with quite wealthy domus, the result of an important phase of urban development which also effected other parts of the city. The building of the amphitheatre in the early imperial period was probably a "traumatic" intervention leading to the reorganisation of the urban layout in this sector of the roman city that perhaps determined the demolition of a part of the preexisting residential quarter. (DM, GC, CP).

\section{The reconstruction of the discovery}

The research undertaken by IBAM-CNR between 2014 and 2015 aimed towards obtaining a three-dimensional reconstruction of the monument by combining diverse methods of data acquisition and processing. This made it possible to acquire important data for the creation of an exact reproduction of the parts of the monument that are still hidden and provide a faithful reconstruction of the entire architectural structure.

\subsection{The integrated archaeological and geophysical investigations}

The integration of the archaeological data with that acquired by the geophysical surveys (ERT and GPR) improved knowledge of the monument within its actual topographical position in relation to the context of the Roman city and made it possible to reconstruct the relationship with the Montevergine hill. In addition, a number of hypotheses formulated in the past were confirmed and new important data acquired regarding the architectural development of several parts of the monument. From the model of the resistivity distribution is evident the presence of a heterogeneous subsoil with an area of regular shape. The area allows to know the development of the amphitheatre below the city. The data processing has enabled us to reconstruct the 3D development of the amphitheatre and, using the results of the geoelectric survey, it was possible to reconstruct the probable ancient walking surface in Roman times. The research also made it possible to state that the arena was partially excavated in the rock within what was the geological basis (Fig. 2).
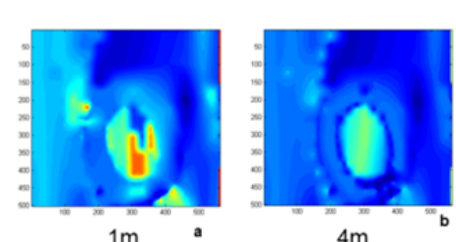

$4 \mathrm{~m}$

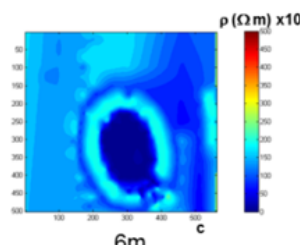

$6 \mathrm{~m}$
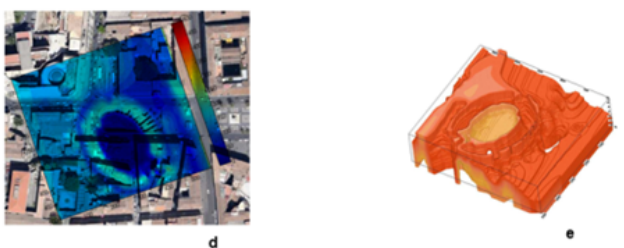

Figure 2: Geophysical prospection indicate the overall dimensions of the building.

The data on the relationship with the hill slope offered a new important evidence. Recent excavations carried out 
in the area of Sant'Agata al Carcere had identified a small temple on a podium, dating to the $2^{\text {nd }}$ century A.D. It was aligned on an east-west axis and standing on the summit of a short stretch of supporting wall decorated with three deep niches (Arcifa 2010; Patanè et al. 2010; Malfitana et al. 2015). However, although associated with the amphitheatre, its exact topographic and architectural relationship had not been explained. The geophysical investigations, combined with an analysis of the ancient and present levels, made it possible to identify an anomaly situated along the same axis as the three niches at the base of the small imperial temple. Therefore, it is compatible with a long structure that supported a great terrace on which the small cult building stood in the imperial period. A large open space developed below it, perhaps on a slight slope, which facilitated and served the entrance to the amphitheatre on an upper level, confirming what was already suggested by earlier research (Beste et al. 2007). (GL, LDG, GC, CP).

\subsection{The survey and graphic rendering of the amphitheatre of Catania}

The metric analysis of the survey, reveals, between hypotheses and confirmations, the morphological aspects and the stratigraphy of the structure, an absolute necessity for any formulation of a hypothetical reconstruction. Every context constitutes a separate case, which presents different questions and peculiarities, which make the use of 3D survey indispensible for the basic documentation and analysis of an architectural organism.

In this process, the contribution of the 3D modelling software is not limited to the pure generation and manipulation of the polygons in the space, but is outstanding in its capacity to facilitate the interpretative processes. In the limited time available to many projects, it would certainly be impossible to examine numerous considerations regarding equilibrium of the proportions, the juxtaposition of the volumes, the application of the laws of statics, neither would it be easy to examine such questions on a vast scale using traditional drawing methods. It is therefore fundamental to recognise 3D modelling software's substantial contribution to the study of ancient monuments. The greater three-dimensional awareness of an architectural organism provided by the modelling environment makes it possible to go into greater detail and have more control over the different reconstruction phases, with a notable increase in precision, productivity and capacity to respond to specific problems imposed by the observation and study of monuments within a space. It would be mistaken and restrictive to consider $3 \mathrm{D}$ modelling as merely one of the new representational tools that simply replace the drafting pen or pencil. The role of the virtual archaeology specialist is closely connected to the dialectic relationship between classical studies and the possibilities offered by these tools for 3D modelling and simulation. Only through constant checks in 3D of technical and construction, dimensional and spatial aspects is it possible to validate the hypotheses that are formed from the philological study of the sources, archaeological data, and contemporary parallels. Many original results achieved by mixed teams of classical scholars and specialists in virtual archaeology have been possible thanks to the verification and study of the monuments in the 3D environment. This is because only a minimal part of the proposed reconstruction is revealed to be plausible and compatible with the functional logic and construction and stylistic principles used by a particular civilisation, in a precise historical period.

In the case of Catania's Roman amphitheatre the decision was made to combine different methods and tools in order to obtain an exhaustive representation of the architectural geometry and its specific materiality, beginning with a numerical model of the state of preservation of the surviving structures. Two separate indirect survey methods were employed using both active sensors and passive sensors for different purposes.

A Leica ScanStation 2 laser scanner was used to survey the part of the amphitheatre situated in Piazza Stesicoro and part of the rooms that are known but cannot be entered situated underneath Villa Cerami. The parts of the city surrounding the monument were also surveyed (Figs. 3, 4b).

In addition to the laser scanner, it was possible, although only for the part of the amphitheatre in Piazza Stesicoro, to use 3D rendering techniques from photographs, able to provide a digital model with a high level of detail, geometric accuracy, photorealism, and portability. In particular, the elevated photorealism of the surfaces that could be reached using these techniques overcomes the limitations of the camera combined with the laser scanner and is indispensible in the study and identification of materials, construction techniques and phases. These systems, using SfM (Structure from Motion) algorithms completed by stereo matching operations, are the result of the convergence of different disciplines, on the one hand Computer Vision for automatism in the generation of 3D models, on the other hand photogrammetry for the measurable documentation of the object.

The entire photographic campaign (c. 350 photos) was carried out using a full frame digital reflex camera (Canon 5D Mark II-21 MPix). Care was taken to maintain the focal length $(24 \mathrm{~mm})$ and width of sampling constant in order to cover the entire surface of the objects and guarantee sufficient overlapping of the images, which is indispensible for the identification and association of corresponding points. The photographs were taken in environmental conditions that guaranteed diffused luminosity without excessive contrast between zones in light or in shade. Subsequently, all the photographs were processed using Photoscan by Agisoft, proceeding with the alignment of the shots, the creation of the points cloud (c. $88 \mathrm{mln}$ ), the mesh, and processing of the textures at a resolution of $15000 \times 15000 \mathrm{px}$. The model created has a high level of metric accuracy, equal to that of the laser scanner, with the advantage of also having the surface colour that is vital for the study of building techniques and materials. Elements which, thanks to the availability of a complete texture model, can be perfectly identified and measured (Fig. 5). 


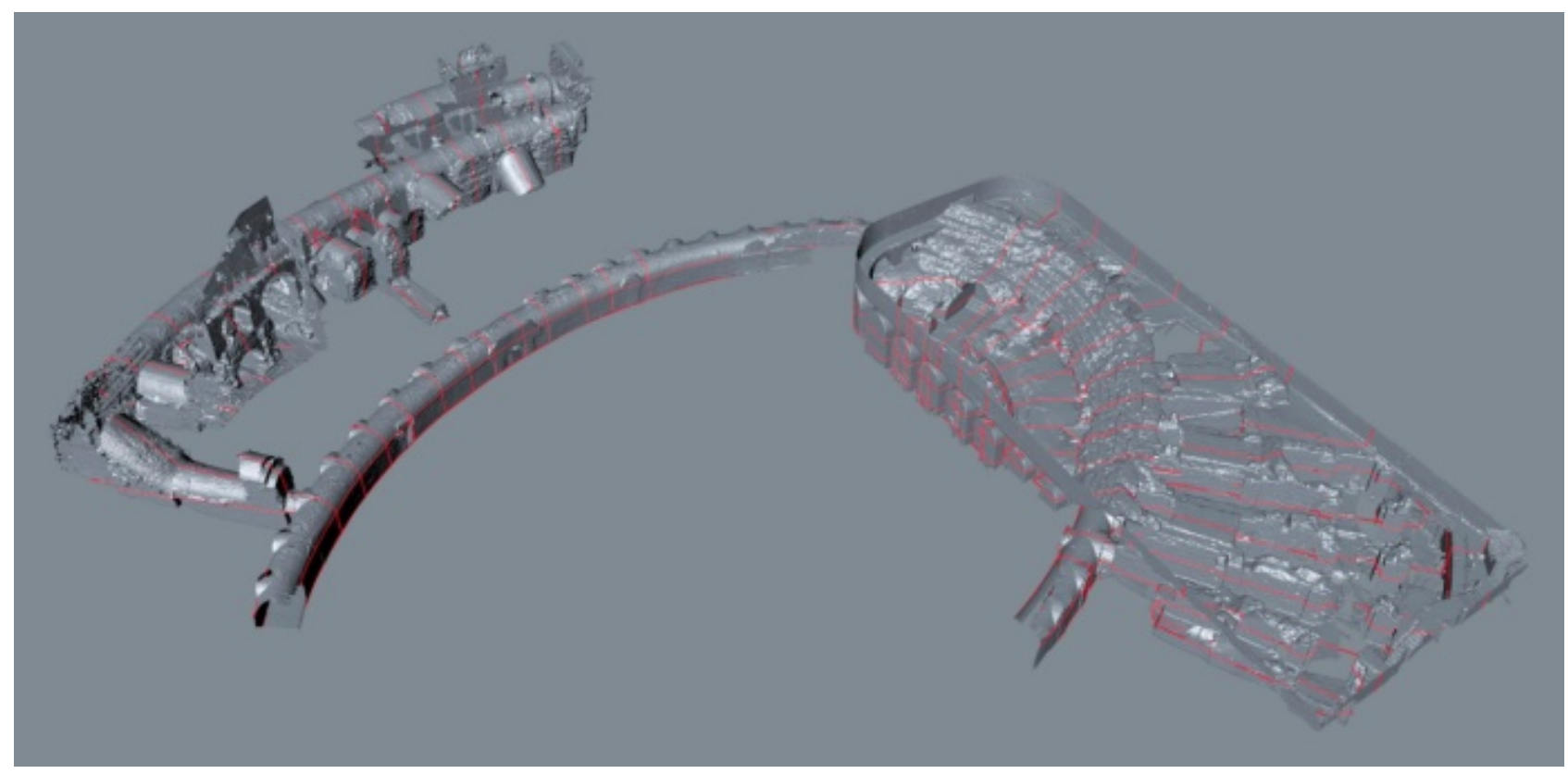

Figure 3: Laser scanner survey with the sections line used for the 3D reconstructive study.

A

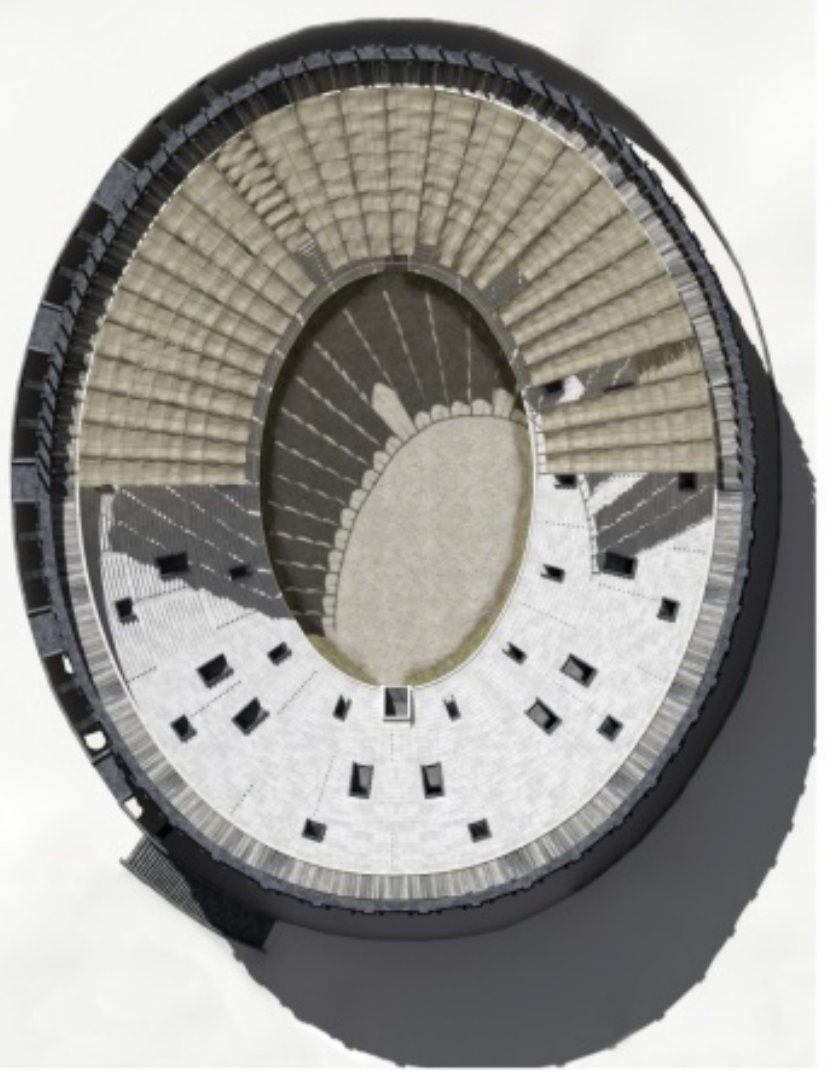

B

Figure 4: Reconstructive hypothesis of the second phase (A) and 3D survey of accessible sectors (B).

The processing of the data from the combined techniques of laser scanning and photogrammetry have been used for the production of the planimetric sections. Indeed, the methodological rigour and uniformity of the data produced by the laser instrumentation and structure from motion systems made it possible to manage the entire mass of information within the same 3D workspace. Two identical models are used, predisposed to provide all the information, about both geometry and colour, that is far more complete, much faster and with a far superior level of accuracy than information accessible via the traditional techniques of direct survey. The combination of these technologies demonstrates how the characteristics of the individual tools have a level of complementarity that renders a combined system more performing and flexible, able to produce a much better 
result in absolute terms and able to adapt to the individual morphology of the various subjects contained within the surveyed scene. The result is a cognitive digital model, in other words a container of various levels of information, which through comparison with known examples of coeval amphitheatres makes it possible to investigate analogies for the building techniques in use during the construction period, but above all to examine the particular construction solutions adopted for this monument. (FGa, IF, FGi).

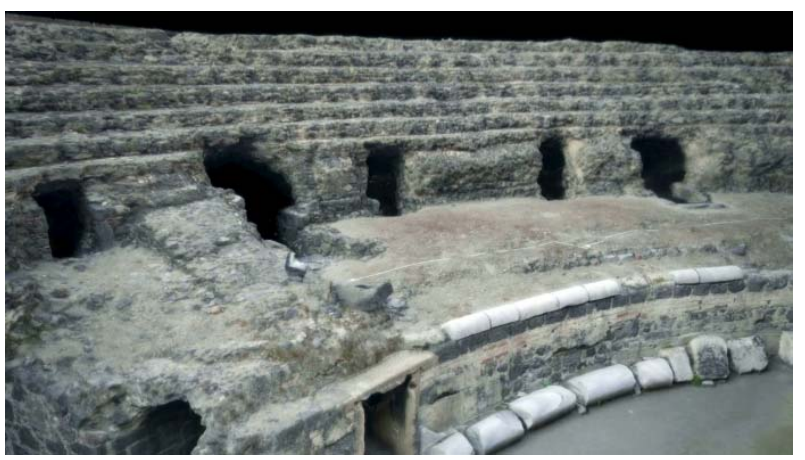

Figure 5: Image-Based survey useful for the detailed study.

\section{The 3D Reconstruction of Amphitheatre}

During the processing of a hypothetical reconstruction of Catania's Roman amphitheatre, it was necessary to deal with a series of construction questions highlighted by the analysis of the most recent survey, which led, at least in some specific aspects, to original interpretative solutions.

Hypothetical reconstruction of phase 1 . The important contribution provided by the German Archaeological Institute in 2006 and 2007 (Beste et al. 2007), verified the existence of two distinct construction phases, the first constituted by a structure datable to the early imperial period that was smaller than the later monument that was enlarged probably during the Antonine period.

At first, the structure's plan presumably formed an oval with the maximum dimensions of c. $80 \mathrm{~m}$. by $100 \mathrm{~m}$. The size of the arena was more or less the same as the present one (c. $40 \times 60 \mathrm{~m}$.) and was accessed via the two main entrances, situated on the main axis, with two small lateral entrances. The only walkway presents in this phase developed concentrically around the arena at about $6 \mathrm{~m}$ from it, was $3 \mathrm{~m}$ wide and its floor surface was about $1 \mathrm{~m}$ higher. Originally, the radial dividing walls were no more than $10.5 \mathrm{~m}$ in length and are still recognizable by their different construction technique and the presence of an offset that constituted the external head of the wall. An overall look at the plan highlights an important fact, the imperfect symmetry of the monument whose axes are just one degree off being perfectly orthogonal. For the sake of convenience, one quarter of the structure was analysed. Fourteen radial walls are present, delimiting corridors that flare towards the exterior, sometimes interconnected by openings, topped by the oblique vaults in opus caementicium that supported the cavea. Arched passageways linked the radial corridors to the walkway, from which three separate flights of steps were reached, two situated close to the main axes and a third in an intermediate position, which led into the three vomitoria providing access to the imacavea. However, the problem of access to the summa cavea remains, perhaps resolved by the creation of external ramps, which via openings in the upper crowning wall, made it possible to reach the annular passageway of the summa cavea. This arrangement finds parallels with other typologically similar structures present in other Roman cities, for example the amphitheatre at Pompeii, perhaps coeval with the one in Catania. This solution could have been adopted later between the $2^{\text {nd }}$ and $3^{\text {rd }}$ centuries A.D. in Catania's Roman theatre.

Hypothetical reconstruction of phase 2. The desire to increase the capacity of the structure, but at the same time exploit what already existed, can be clearly perceived in this phase. It is possible to distinguish several elements that differ in construction technique and morphology. The enlargement of the cavea can be seen in the elongation of the individual radial walls and the creation of two superimposed annular walkways, supported externally by a series of pillars in opus quadratum with a cruciform section, on the same axes as the individual walls. Pairs of corbels inserted in the side of the pillars support the brick-built arched lintels that distinguish the two orders of the amphitheatre, which particularly in proximity to the main axis become segmental arches, in order to adapt to the wider bays between the dividing walls (Fig. 4).

Regarding the slope of the cavea, the suggestion that there was a large praecentio immediately abutting the area is no longer considered viable, a doubt already expressed by R. Wilson and F. Buscemi (Wilson 1990; Buscemi 2012). These observations are based on the fact that the profile of the seating tiers, highlighted in the sections, must necessarily have been further forward due to the presence of blocks that must originally have faced the conglomerate. In the second place, it can be seen how the conglomerate partly continues the oblique profile, in particular on the sides of the entrance to the arena in correspondence with the main axis, and the absence of a jump in height noted. The space remaining between the last step of the cavea (as visible today) and the arena's parapet would thus determine a continuous descending profile, terminating in a praecentio of reduced dimensions but large enough to allow the flow of spectators.

The vomitoria from phase one were kept to allow access to the ima cavea, while the problem of access to the media and summa cavea remained to be solved. The absence of stairs providing a link from the first order to the second also justifies the absence of an intermediate walkway situated between the inner one abutting the arena and the superimposed outer ones. This is a peculiarity of the amphitheatre in Catania that probably derives from the topographical context and urban layout in which the structure was built, immediately abutting a rocky slope that was then cut in order to enlarge it. This means that, in the western sector, all of the first order of the second phase was situated below the ground level of the ancient city (Arcifa 2010; Patanè et al. 2010). This resulted in an extremely unusual distribution system that resolved access to the building via passageways on an upper level running above the corridor abutting the rock face and leading directly into the outer walkway. In this sense, it is likely that following the structure's enlargement, the greatest flow of spectators must have 
been concentrated in the point of easiest access to the city, precisely on the western side. This would explain how the only access points to the ima and summa cavea led out from this walkway. As regards the link from the upper external walkway to the media cavea, when the structure was enlarged the construction of barrel vaults with a flat extrados was planned (fig. $4 \mathrm{~b}$, sector 46 ). These were built on and supported by the dividing walls that were partly reinforced by thickening their width (this is clearly visible in the different construction technique), with a downward sloping diagonal line in the first portion to support a flight of steps. At the end of this ramp, a flat part is visible, at the end of which another short flight of steps must have led to the vomitoria situated on an intermediate diazoma in the cavea.

As can be noted by observing sector 39 , a diagonal vault, also beginning from the upper external walkway but this time ascending, must have supported another flight of steps that provided access to the vomitoria in the summa cavea. Using the survey data, an attempt has been made to understand the distribution of these passageways and therefore the distribution of the diverse vomitoria, which in the three-dimensional reconstruction tend to assume a particular distribution, probably as a consequence of the compromise deriving from the fusion and adaptation of the old project with the new and more capacious structure (Fig. 6).

The top of the cavea was probably crowned by a portico of Ionic columns, with regular pairs of corbels incorporated into the external face of the rear wall, some of which still present among the amphitheatre's structures. The corbels would have supported the velarium and there must have been two orders, the first and lower one to support the vertical weight of the masts, the second, and upper ones had a square socket into which the which the wooden mast was inserted (Fig. 7). Unlike other and larger structures such as the Colosseum, where the entire awning system was anchored by ropes, a self-supporting system was presumably used in the amphitheatre at Catania, a suggestion justified by the smaller awnings, the notable radial space to be covered and by the morphology of the terrain surrounding the building, which presented substantial variations in height.

This element introduces another important consideration that emerged from the contextualisation of the monument within the urban topography of ancient Catania. In fact, contrary to the western area where the entrances are on an upper level, in the portion in front of the area south of the amphitheatre in correspondence with the main axis, excavations have shown that the ground level of the Roman city must have been more or less at the level of the first order (Beste et al. 2007; Arcifa 2010; Patanè et al. 2010; Malfitana et al. 2015). This would suggest that precisely in this point there was an entrance on this level into the amphitheatre (Fig. 8). Therefore, a substantial difference in height must have distinguished the two access areas, very probably linked by ramps or steps. Today, a containing wall is visible in the north-eastern sector in Piazza Stesicoro, which indicates that in this part the rock face tends to rise, presumably to then join with the level of the terrace on which the entrances in the second order were situated (Fig. 9). (FGa, IF, FGi)
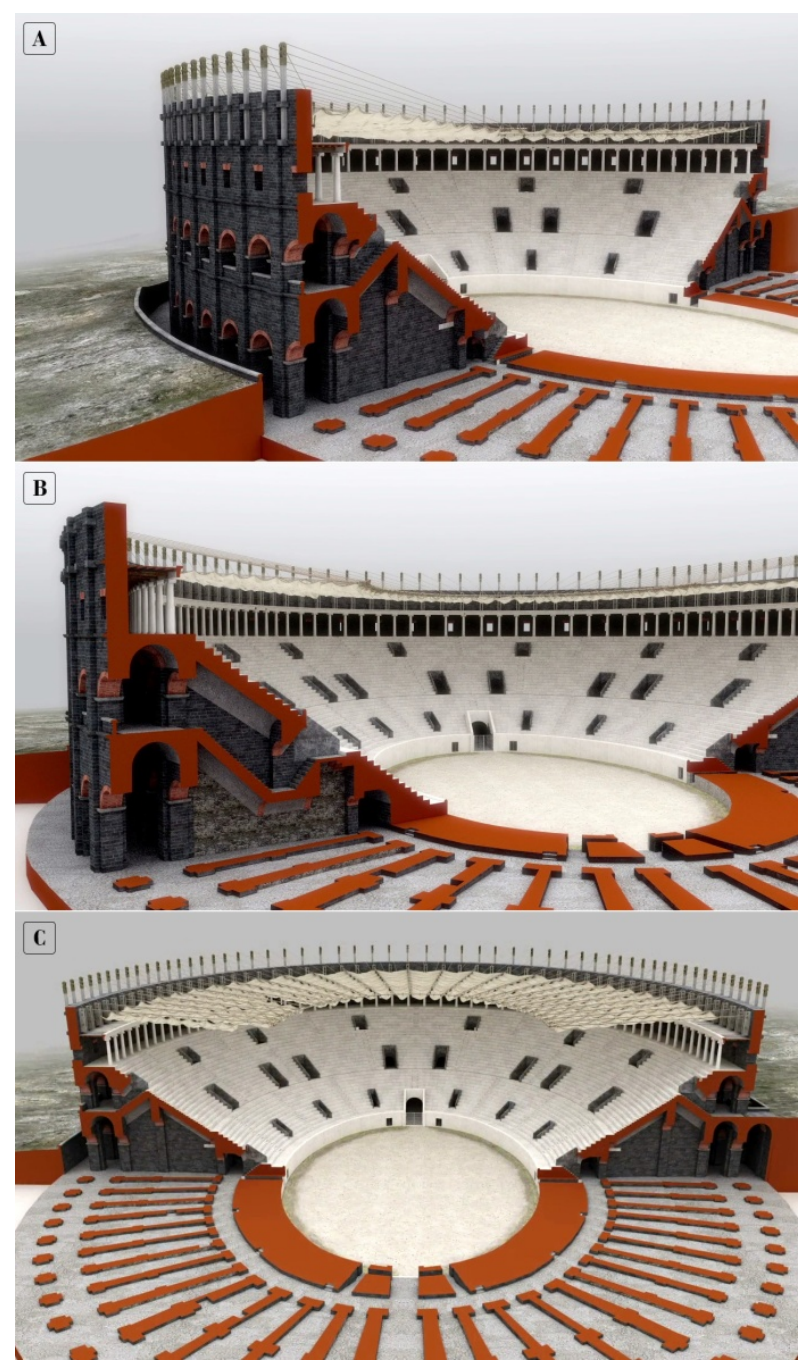

Figure 6: Several sections of the amphitheatre shows internal distribution paths of the hypothetical reconstruction of the second phase.

This element introduces another important consideration that emerged from the contextualisation of the monument within the urban topography of ancient Catania. In fact, contrary to the western area where the entrances are on an upper level, in the portion in front of the area south of the amphitheatre in correspondence with the main axis, excavations have shown that the ground level of the Roman city must have been more or less at the level of the first order (Beste et al. 2007; Arcifa 2010; Patanè et al. 2010; Malfitana et al. 2015). This would suggest that precisely in this point there was an entrance on this level into the amphitheatre (Fig. 8). Therefore, a substantial difference in height must have distinguished the two access areas, very probably linked by ramps or steps. Today, a containing wall is visible in the north-eastern sector in Piazza Stesicoro, which indicates that in this part the rock face tends to rise, presumably to then join with the level of the terrace on which the entrances in the second order were situated (Fig. 9). (FGa, IF, FGi) 
$\mathbf{A}$

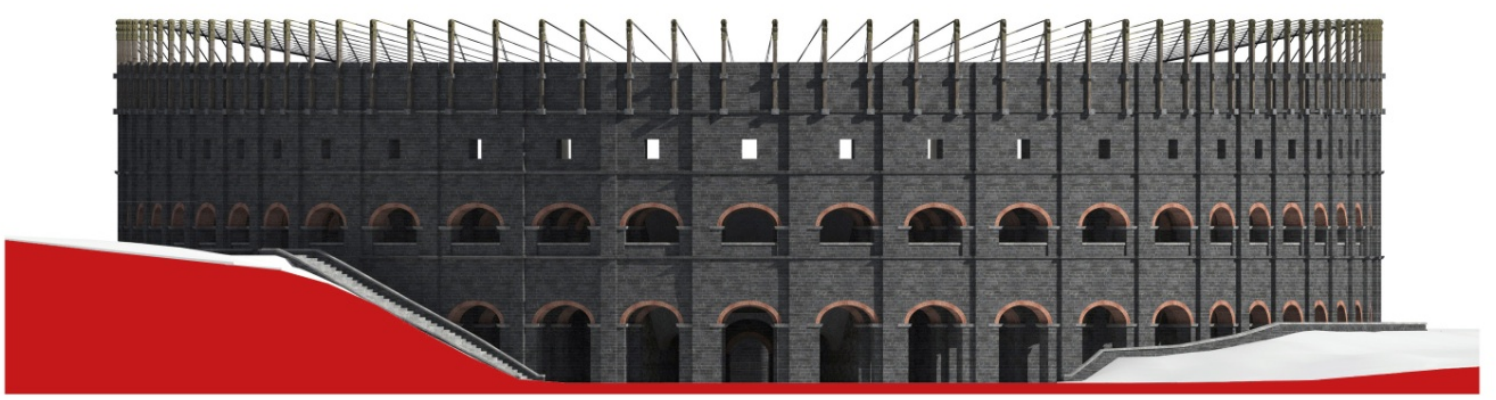

B
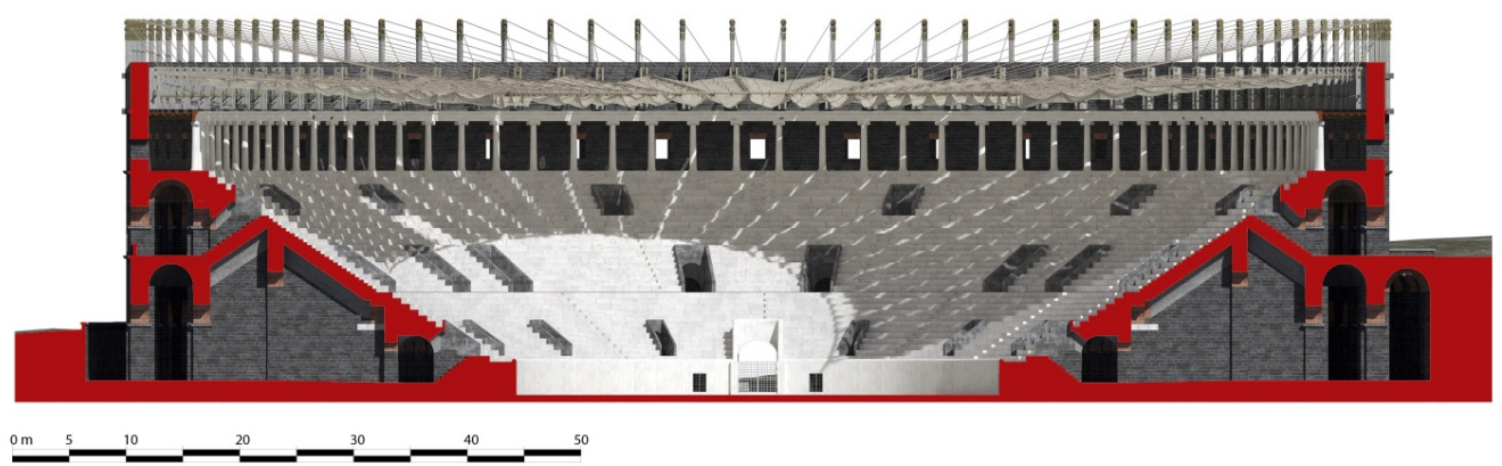

Figure 7: Reconstructive hypothesis of the second phase: front view (A) and section in correspondence of the minor axis (B).

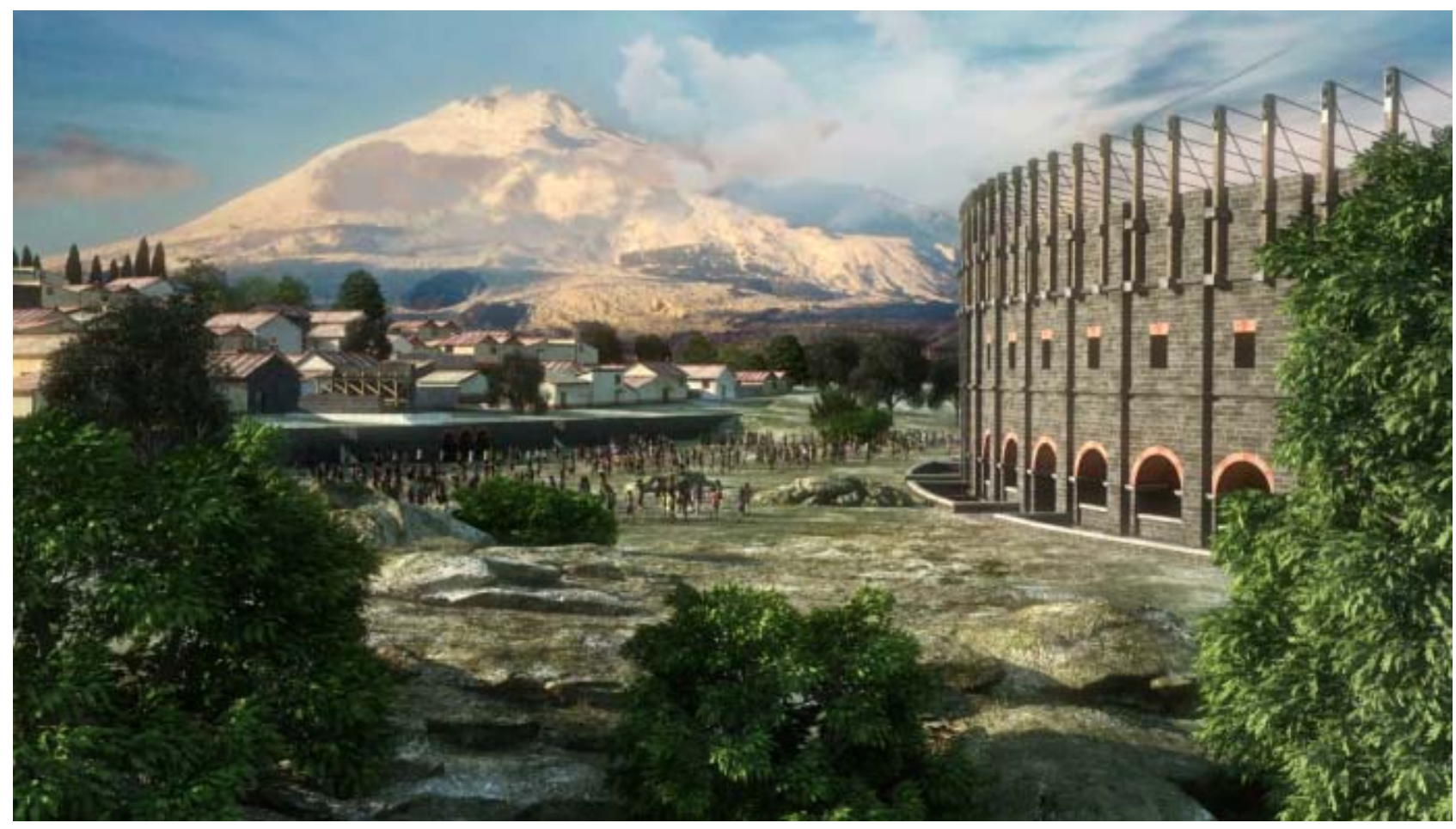

Figure 8: Screen shot of informative movie. The access to the building via passageways from the terrace level in the last phase.

\section{Conclusion}

In the last years the amphitheatre of Catania has been the focus of several studies, especially with the aimed to identify the different chronological phases and to interpret the different structural features. This work, entirely done with methods and techniques of Virtual Archaeology, aims to provide new interpretations of some structural phases that outline the salient features of an extremely unusual monument. The threedimensional study of the status quo, traced with the aid of laser scanning, has clarified the entire morphology and the 3D representation of those hidden parts located below the modern buildings. The integration of relief with the archaeological data made it possible to reconstruct a probable architectural development of the building, with its tight integration with the surrounding orography. The system of accesses at different altitude and the use of 
the lava stone denote an identity with strong colour accents combined with a distribution solution of great interest, that the movie reconstruction for public dissemination of the results tells a simple and effective language.

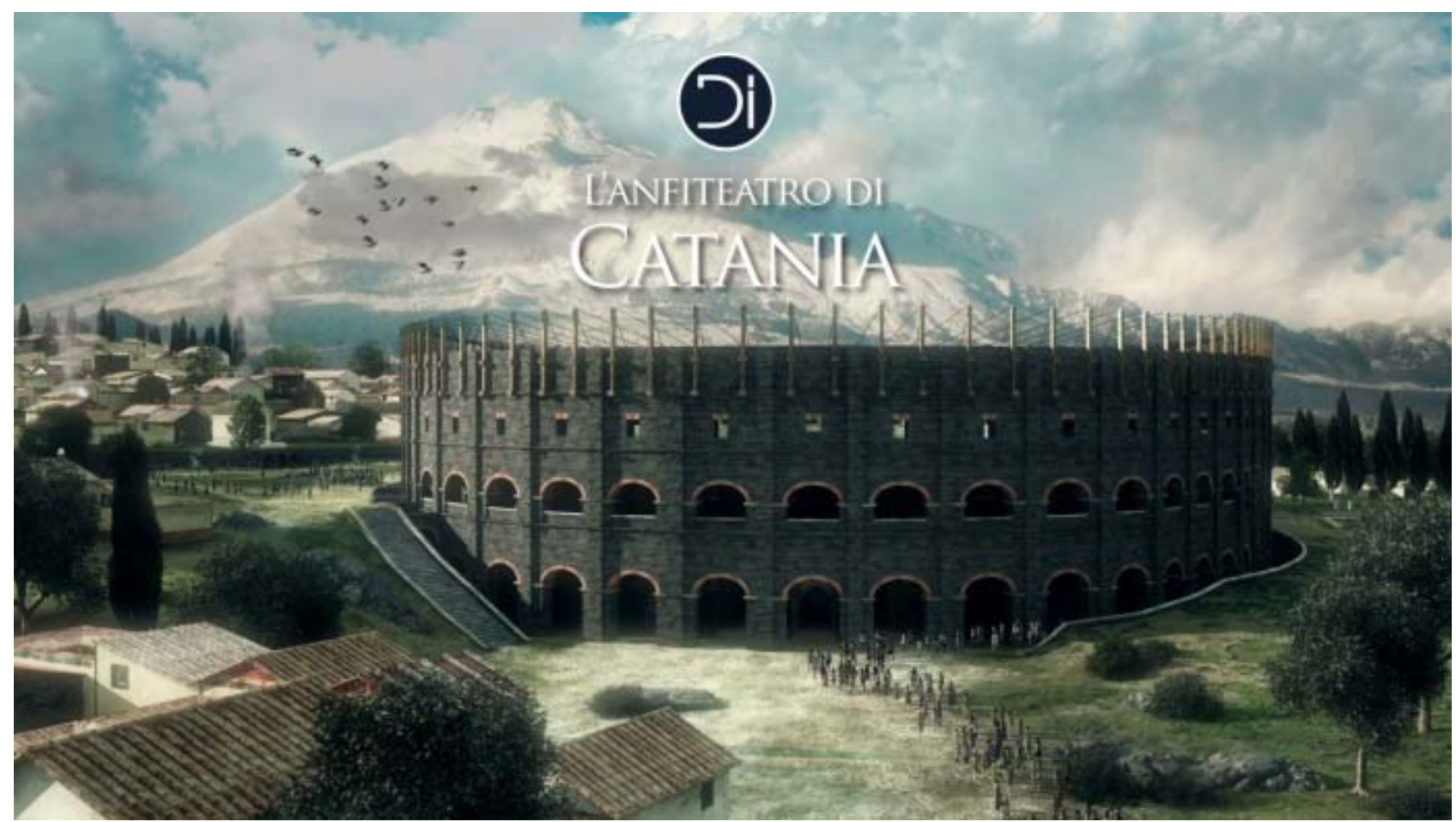

Figure 9: Reconstructive hypothesis with the various access from the city.

\section{References}

ARCIFA, L., 2010. Da Agata al liotru: la costruzione dell'identità urbana nell'alto Medioevo, in: M.G. Branciforti, V. La Rosa (eds.), Tra lava e mare. Contributi all'archaiologia di Catania, Catania, pp. 355-386.

BESTE, H.J., BECKER, F., SPIGO, U. 2007. Studio e rilievo sull'anfiteatro romano di Catania, in: Mitteilungendes Deutschen Archaologischen Instituts - Romische Abteilung, 113, pp. 595-613.

BRANCIFORTI, M.G. 2003. Quartieri di età ellenistica e romana a Catania, in: G. Fiorentini, M. Caltabiano, A. Calderone (eds.), Archeologia del Mediterraneo. Studi in onore di Ernesto De Miro, Roma, pp. 95-120.

BRANCIFORTI, M.G. 2005. Catania. Dalla preistoria al Medioevo, in Dall'Alcantara agli Iblei. La ricerca archeologica in provincia di Catania, in: F. Privitera, U. Spigo (eds.), Palermo, pp. 175-200.

BRANCIFORTI, M.G., 2010. Da Katane a Catina, in: M.G. Branciforti, V. La Rosa (eds.), Tra lava e mare. Contributi all'archaiologia di Catania, Catania, pp. 183-209.

BUSCEMI, F., 2012. Architettura e romanizzazione della Sicilia di età imperiale: gli edifici per spettacoli. Palermo.

FICHERA, F., 1904. Scavi dello Anfiteatro, in: Archivio Storico per la Sicilia orientale, pp. 119-120.

FICHERA, F., 1905. Per lo anfiteatro di Catania, in: Archivio Storico per la Sicilia orientale, pp. 66-72.

GABELLONE, F., 2012. La trasparenza scientifica in archeologia virtuale. Una lettura critica al Principio N.7 della Carta di Siviglia, in: CASPUR CIBER Publishing SCIRES-IT, SClentific RESearch and Information Technology, vol. 2, Issue 2 (2012), pp. 99-124.

GABELLONE, F., FERRARI, I., GIURI, F., 2015. Digital restoration using Image-Based 3D models, in: Proceedings of the 1st International Conference on Metrology for Archaeology, Benevento - Italy, October 21-23, 2015, Benevento, pp. 534- 538.

GABELLONE, F., FERRARI, I., GIURI, F., CHIFFI, M., 2015. The contribution of the 3D study for new reconstructive proposals of Lecce in Roman age, in: Proceedings of the 1st International Conference on Metrology for Archaeology, Benevento - Italy, October 21-23, 2015, Benevento, pp. 534-538.

MALFitANA, D., CACciaguerRA, G., BARONE, S., MAZZAGLIA, A., NOTI, V., LEUCCI, G., DE GIORGI, L., CANNATA, A., PANTELLARO, C., SCROFANI, M.L., 2015. OPENCiTy Project: un progetto per l'archeologia urbana, la pianificazione lo sviluppo sostenibile di Catania. La valutazione del potenziale archeologico: primi dati, in: $F$. Anichini, G. Gattiglia, M.L. Gualandieds., MAPPA Data Book 1. I dati dell'archeologia urbana italiana, Roma, pp. 1738. 
OTERI, A.M., 2002. Riparo, conservazione, restauro nella Sicilia orientale o del "diffinitivo assetto" 1860-1902, Roma.

PATANĖ, A., TANASI, D., CALÌ, D., 2010. Indagini archeologiche a Sant'Agata la Vetere e Sant'Agata al Carcere, in: M.G. Branciforti, V. La Rosa (eds.), Tra lava e mare. Contributi all'archaiologia di Catania, Catania, pp. 337-354.

WILSON, R.J.A., 1990. Sicily under the Roman Empire. The archaeology of a Roman province. 36 B.C. - A.D. 535 , Warminster. 


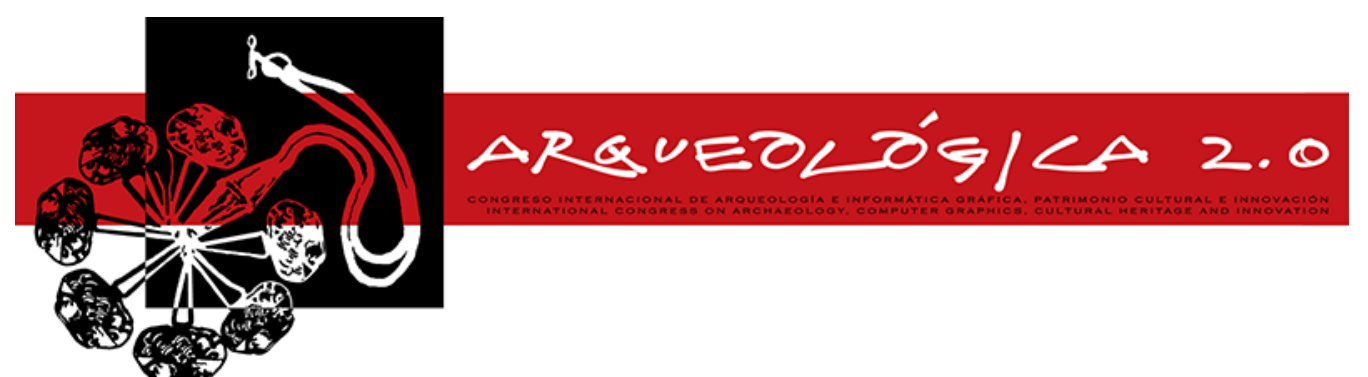

Proceedings of the $8^{\text {th }}$ International Congress on Archaeology, Computer Graphics, Cultural Heritage and Innovation

'ARQUEOLÓGICA 2.0'

in Valencia (Spain),

Sept. $5-7,2016$

DOI: http://dx.doi.org/10.4995/arqueologica8.2016.3556

Received: 01/03/2016

Accepted: 11/04/2016

\title{
CRITICAL READING OF SURVIVING STRUCTURES STARTING FROM OLD STUDIES FOR NEW RECONSTRUCTIVE PROPOSAL OF THE ROMAN THEATRE OF CATANIA
}

\author{
LECTURA CRITICA DE ESTRUCTURAS SUPERVIVIENTES A PARTIR DE ANTIGUOS ESTUDIOS PARA UNA \\ NUEVA PROPUESTA RECONSTRUCTIVA DEL TEATRO ROMANO DE CATANIA \\ Daniele Malfitana, Francesco Gabellone*, Giuseppe Cacciaguerra, Ivan Ferrari, Francesco Giuri, \\ Claudia Pantellaro
}

CNR - IBAM (Istituto per i Beni Archeologici e Monumentali), Via prov.le Monteroni, 73100 Lecce, Italy. d.malfitana@ibam.cnr.it; f.gabellone@ibam.cnr.it; g.cacciaguerra@ibam.cnr.it; i.ferrari@ibam.cnr.it; f.giuri@ibam.cnr.it; c.pantellaro@ibam.cnr.it

\begin{abstract}
:
The Graeco-Roman theatre of Catania stands in the heart of the historic centre, on the south-eastern slopes of the hill of Montevergine. The building visible today was built during the Julio-Claudian period as part of a programme that saw the rebuilding of the monument, which probably used structures and materials from the earlier Greek theatre. The work undertaken over more than fifty years, involving expropriation, demolition, excavation, and restoration, has, on the whole, made it possible to bring to light the surviving parts of the theatre, improving the comprehension of this monument, despite the fact that some sectors have been irreparably compromised.
\end{abstract}

Key words: virtual archaeology, digital archaeology, integrated technologies, 3D reconstruction, roman theatre

\section{Resumen:}

El teatro greco-romano de Catania se encuentra en el corazón del centro histórico, en las laderas del sureste de la colina de Montevergine. Visibles en la actualidad el edificio fue construido durante el período Julio-Claudia como parte de un programa que vio la reconstrucción del monumento, lo que probablemente utiliza estructuras y materiales del teatro griego anterior. El trabajo realizado durante más de cincuenta años, la participación de la expropiación, demolición, excavación y restauración, tiene, en general, hecho posible sacar a la luz las partes sobrevivientes del teatro, la mejora de la comprensión de este monumento, a pesar del hecho de que algunos sectores han sido irremediablemente comprometido.

Palabras clave: arqueología virtual, arqueología digital, tecnologías integradas, reconstrucción 3D, teatro romano

\section{The Roman theatre: research to date}

The Graeco-Roman theatre of Catania stands in the heart of the historic centre, on the south-eastern slopes of the hill of Montevergine, within an area that played a central role in the dynamics of the city's urban development. The original structure seems to date to the Greek period, as suggested by the remains of the walls in limestone blocks identified in several sectors of the monument. These elements make it possible to consider that a theatre, with a horseshoe-shaped cavea, already existed in the 4th century B.C. (Branciforti and Pagnano 2008, pp. 78-79; Branciforti 2010, pp. 192-196; Taormina 2015, p. 322; Buda 2015, p. 272).
The building visible today was built during the JulioClaudian period as part of a programme that saw the rebuilding of the monument, which probably used structures and materials from the earlier Greek theatre (Buda 2015, pp. 274-275). Between the Antonine and Severan periods, the structure was extended and underwent transformations that gave the entire complex monumental aspect (Fig. 1) (Branciforti and Pagnano 2008, Branciforti 2010, Buscemi 2012). The stage building was substantially modified by the insertion of curving exedra into the rear wall of the side doors and the enrichment of the decorative scheme, while the cavea was enlarged by the addition of the third walkway and creation of a new seating tier. The theatre was decorated with marble columns, statues, and decorative reliefs celebrating public events associated with

*Corresponding Author: Francesco Gabellone, f.gabellone@ibam.cnr.it 
mythological themes. During the final period of use, datable to around the 4th century A.D. (Branciforti and Pagnano 2008, p. 71; Branciforti 2010, pp. 198-199), the building was probably adapted for aquatic shows, with the creation of channels and systems for filling it and draining water (Buda 2015, pp. 275-277), work which also involved the repaving of the orchestra (Branciforti 2004, p. 92; Branciforti and Pagnano 2008, pp. 70-71; Branciforti 2010, pp. 198-199; Buda 2015, p. 277).

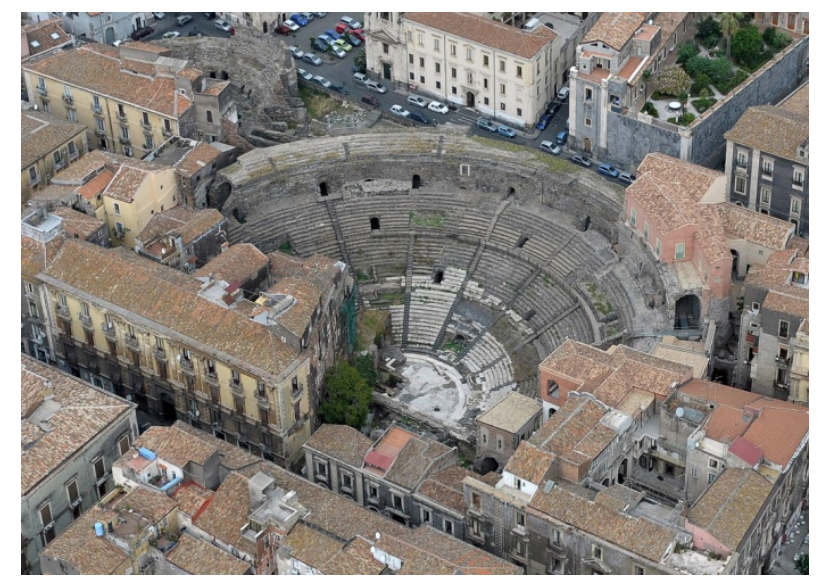

Figure 1: The monument over the actual city.

Between the 5th and 6th centuries A.D., the theatre lost its original function, as attested by the building of structures in the orchestra and gradual filling of the monument's lower part (Arcifa 2010, p. 356; Branciforti and Pagnano 2008, p. 71). From this moment onwards, the building slowly deteriorated beginning with the robbing that took place throughout the medieval period (Holm and Libertini 1925, p. 43) and then with the gradual obliteration of the ancient structures caused by the unstoppable building activity, which between the late medieval and modern periods determined the formation of a residential quarter known as "Grotte" in the theatre area (Policastro 1952, pp. 176-177; Pagnano 2010, pp. 427-438).

From the 16th century onwards many sources describe the ancient remains of theatre (Fazello 1573, pp. 93-94; Carrera 1639, pp. 83-85; De Grossis 1642, pp. 179-181). Real interest in this building began in the 18th century thanks to excavations carried out by Ignazio Paternò Castello V, Prince of Biscari (Biscari 1781, pp. 29-30). His research, begun in 1770 with the consensus of the nobles who lived in the palaces built on the Roman structure, brought to light part of the scaena and the pulpitum (Ferrara 1829, p. 275). In this phase, a large quantity of decorative elements were recovered, which once decorated the stage building, including statues of Hercules and Apollo, two Muses, a plinth with the relief of a dolphin, another Hercules, a frieze showing a gigantomachia and a large sculptured plinth (Libertini 1930, pp. 66-67; Wilson 1996, p. 158).

Subsequently, the excavations were continued by $F$. Ferrara, M. Musumeci and S. Sciuto-Patti (Ferrara 1829, p. 285; Sciuto Patti 1913, p. 312), but these were partial interventions on the cavea and in the walkways. It was only in the mid 20th century that work aimed at uncovering the theatre began. Most of the buildings built on top of it were expropriated and demolished and the exposed structures were reconstructed. In the 1960s, the architect I. Gismondi, roughly following the lines of intervention traced by G. Libertini (Libertini 1946-1947, pp. 134-141), began the work to expose the surviving parts of the cavea (Bernabò 1972-1973, p. 168). At the same time, the Archaeological Superintendency for Eastern Sicily began the excavation of the scaena and orchestra, thus promoting the first regular campaign of archaeological investigations (Rizza 1980-1981, pp. 769770). Indeed, these investigations continued in the 1980 s and 90s with the exploration of new sections of the monument, above all on the eastern side, thanks to the acquisition of the modern buildings that stood on top of it (Branciforti and Pagnano 2008, pp. 37-42). In depth excavations took place in 1998-2001, 2004-2008, and 2014-2015 (Branciforti 2006, pp. 145-154; Branciforti and Pagnano 2008; Branciforti 2010, pp. 183-209; Buda 2015, pp. 247-280; Taormina 2015, pp. 281-350). This cycle of interventions not only provided extremely interesting new evidence regarding the theatre's construction phases, but also achieved the almost complete exposure of the building, enhancing most of its structures.

The work undertaken over more than fifty years, involving expropriation, demolition, excavation, and restoration, has, on the whole, made it possible to bring to light the surviving parts of the theatre, improving the comprehension of this monument, despite the fact that some sectors have been irreparably compromised. (DM, $\mathrm{GC}, \mathrm{CP}$ )

\section{The surveying and reconstruction of the Roman theatre in Catania}

The Roman theatre of Catania is certainly one of the best-preserved examples of this type of Roman architecture, whose characteristics represent peculiarities that have still to be fully documented. The problem faced by an interpretative and reconstructive study essentially lies in the absence of accurate and up to date graphic documentation. To remedy this lacuna, it was decided to undertake a survey campaign using a laser scanner. The work in situ was set up with the aim of covering the entire complex, which due to its substantial size required the planning of a series of stations that would cover the entire external perimeter, the cavea and each individual walkway including the single flight of steps connecting them and those of the vomitoria. The coverage of all wall surfaces required the use of 39 stations, each set at a resolution of $6 \mathrm{~mm}$ on a dome of $10 \mathrm{~m}$. Due to the quantity of data in the fusion process for each individual scan in a single points cloud, (about 3 billion points - 100 giga .pts) per extrapolation of the mesh, it was necessary to subdivide the files into four parts and work on each one separately. In this way, it was possible to generate a three- dimensional model that for practical reasons had to undergo a polygonal decimation, which however facilitated the extrapolation of a series of sections then put together in technical images, which then represent the base for the process of interpreting the monument and its three-dimensional reconstruction. A first and important phase was the study and definition of the cavea's slope and exact positioning of the heights of the floor levels relating to the walkways and intermediate passageways (Figs. 2, 3 and 4). No less important was the understanding of the levels at which the spectator access points from the exterior to 
interior were positioned, and this in an urban morphological context where, precisely in the area of the Roman theatre, there are considerable differences in height. A third and just as important element was the graphic reproduction of some representative decorative architectural elements such as capitals, columns, cornices, pedestals, friezes, and statues, present within the structure, using an Image Based 3D survey with algorithms from Structure from Motion.

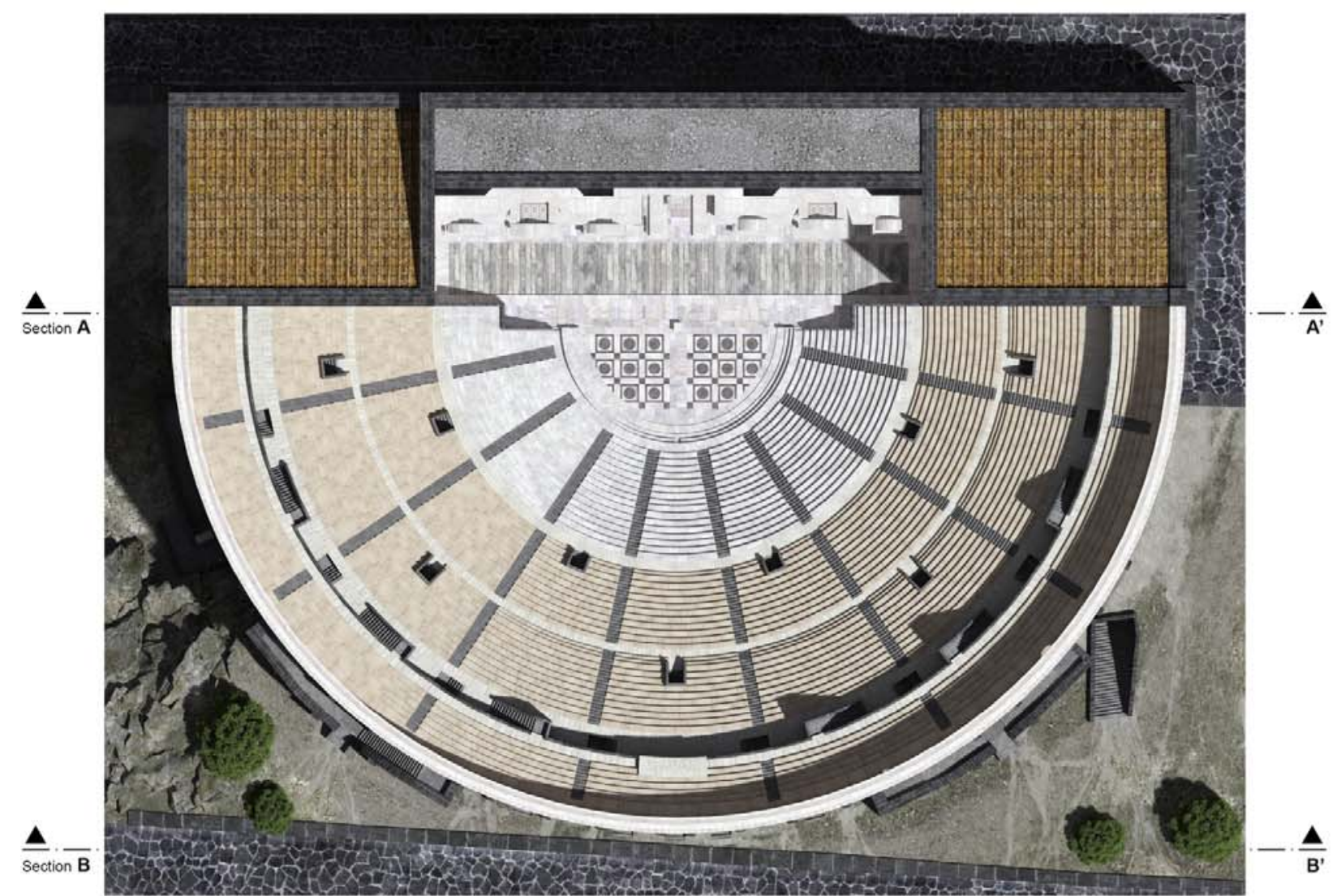

A Orthographic projection: top view

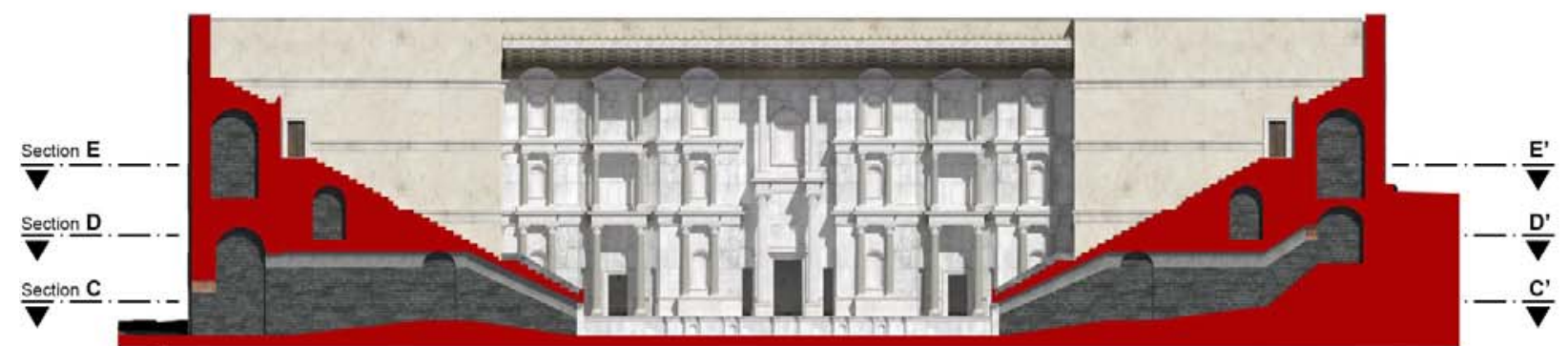

B Section A-A'

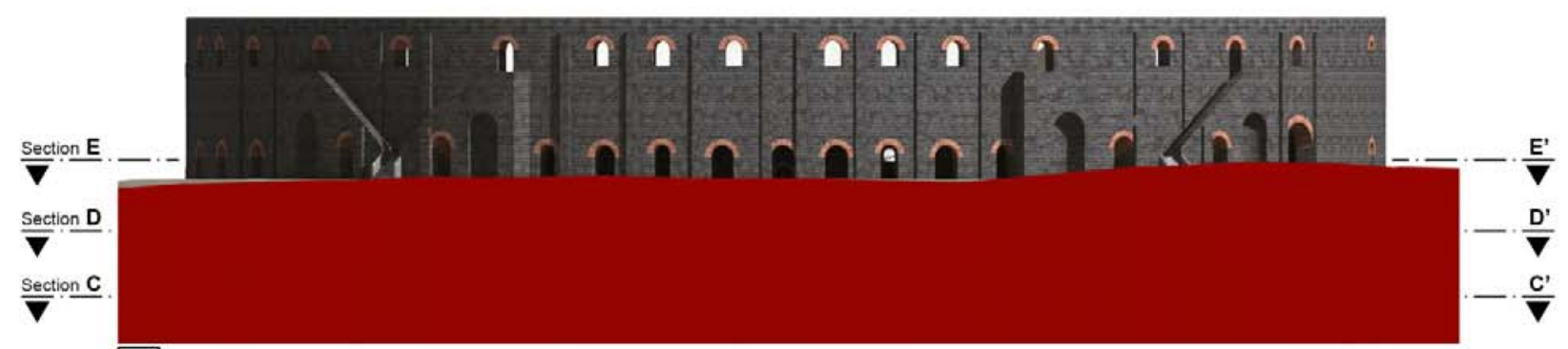

C. Section B-B'

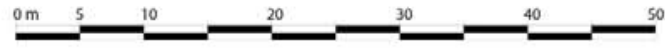

Figure 2: 3D model of the hypothetical reconstruction of the Roman theatre of Catania: Orthographic views $(A)$ and sections (B, C). 

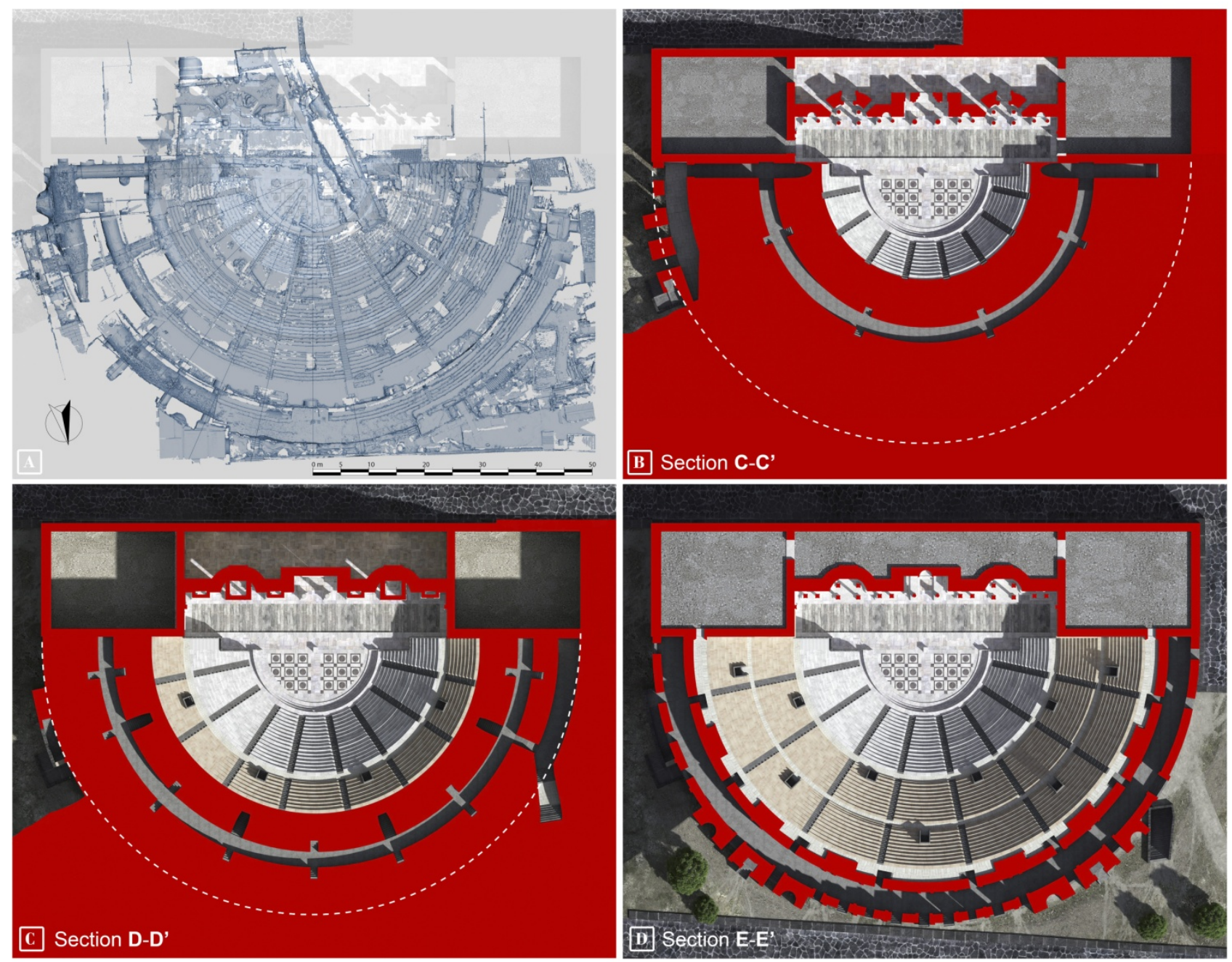

Figure 3: Orthographic views of the laser survey $(A)$ and planar sections of the Roman theatre 3D model $(B, C, D)$.

Once the metric characteristics were acquired, and the data cross-checked with the published material, it was thought opportune to link the hypothetical reconstruction to one of the monument's most interesting phases, its most monumental and richly decorated one. This construction phase has been dated to within a relatively ong period, which began in the Antonine period and probably continued until the Severan period (Pensabene 2005, p. 200; Branciforti 2010, p. 208; Buscemi 2012, p. 128). During this phase, the theatre underwent radical restoration involving the enlargement of the entire structure with the building of the third walkway and creation of a new external façade. Given the monuments' technical characteristics, with the cavea abutting the hill slope behind it, the new annular walkway could only exploit the natural support provided by the slope in its central part, making it necessary to create two different substructures that from the two sides of the scaena, supported the walkway as far as its central section. This intervention necessitated the modification of one side and a series of interventions on the other side to make the complex comply with Roman architectural canons. In fact, the rebuilding of the cavea, attested by the superimposition of the limestone blocks of the first diazoma on an earlier diazoma presumably dating to the Julio-Claudian period (Buda 2015, p. 269), was probably a direct consequence of the theatre's enlargement. The creation of a new scaenae frons, narrower than the preceding one, and a new third seating tier above the pre-existing ones, was probably part of the same restoration project (Fig. 5). Based on the archaeological data, the intervention modified the opening of the lateral doors through the creation of a curved exedra interrupted by two narrow radial corridors communicating with the rear of the stage (Branciforti and Pagnano 2008, p. 61; Branciforti 2010, p. 204). As regards the decorative elements, the repertory was notably enriched by the insertion of statues, decorative friezes, and columns in different marbles (Pensabene 2005, pp. 193-212; Branciforti and Pagnano 2008, p. 56 ), which gave the entire complex a monumental aspect.

The laser scan revealed the presence of a semicircular cavea with a maximum width of $97 \mathrm{~m}$, depth of $51 \mathrm{~m}$ and overall height that from the orchestra must presumably have reached $26 \mathrm{~m}$, with the seating tiers subdivided into nine cunei (wedge-shaped divisions) with eight radial flights of steps. Access to the seating tiers was provided by three orders of vomitoria, whose flights of steps departed from the three annular walkways that distributed the flow of spectators within the structure. Another of the problems to emerge during the reconstruction process was that relating to the points of access to the theatre, strictly related to the various external ground levels. It has emerged from the 3D study 
that most of the spectators must have entered from the north side. In fact, there was direct access from here to the external walkway via a series of arched openings each with a short flight of steps. The summa cavea could also be entered from this side thanks to the presence of two distinct masonry-built foreparts abutting the structure, each with a double flight of steps, symmetrically divergent, able to overcome a difference in height of about $8 \mathrm{~m}$. The existence of a third entrance is attested by the presence of a large flight of steps in the north-western sector, providing access to the second walkway (Fig. 6).
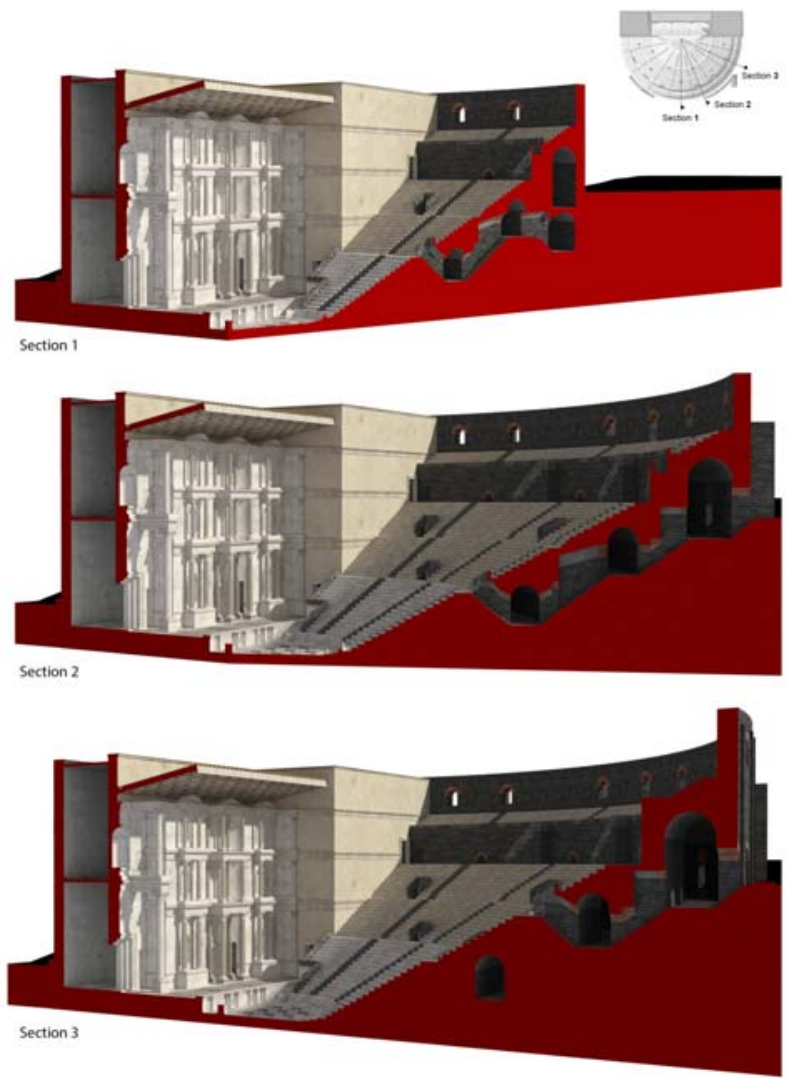

Figure 4: Vertical sections of the 3D model hypothetical reconstruction.

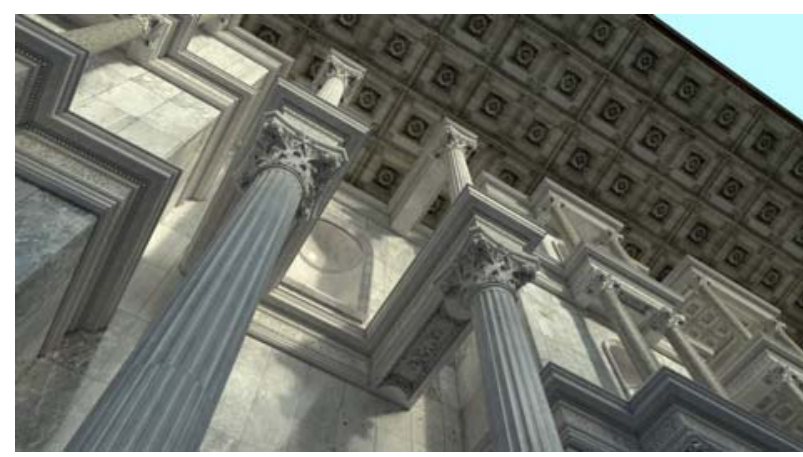

Figure 5: Detail of the scaenae frons 3D reconstruction.

There was further access to the theatre in the eastern sector, at a notably lower level, $13 \mathrm{~m}$, than those described above. The flow of spectators from the eastern part of the theatre had another external forepart available to it that covered a jump in height of about 11 $\mathrm{m}$ to lead into the third walkway. Alternatively, a number of arched passageways led directly into the so-called eastern atrium on the same level. This in turn was linked via a radial passageway directly to the eastern aditon for access to the orchestra floor, crossed in the central portion of the lower walkway.

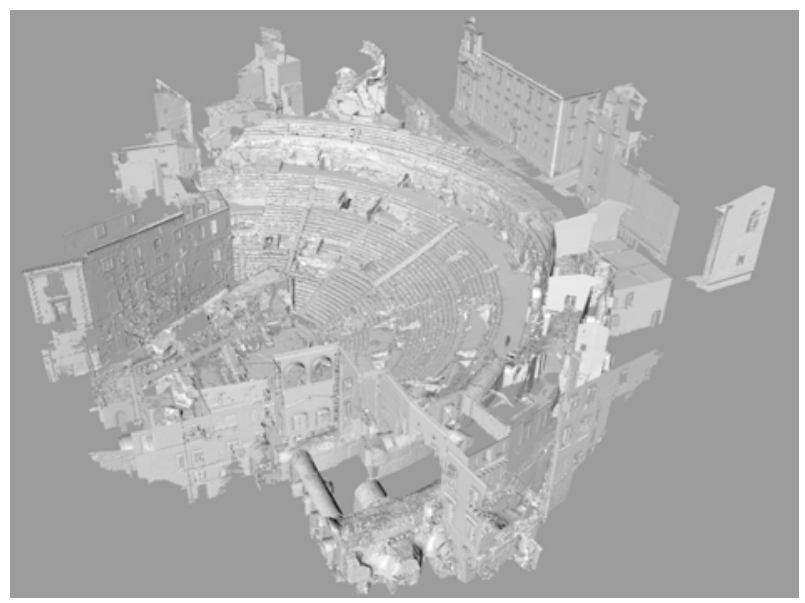

Figure 6: Laser survey of the theatre.

Particular attention was paid to the reconstruction of the stage building, of which only the eastern part is preserved, while the western side remains unexplored as an imposing $19^{\text {th }}$ century palace stands on top of it (Branciforti and Pagnano 2008, p. 56). In the proposed three-dimensional hypothesis - based on the AntonineSeveran period - the foreparts with short longitudinal flights of steps that from the orchestra led up onto the stage have been omitted as they belonged to a later phase. The orchestra has been re-proposed with its original flooring of bi-chrome marble slabs, shaped to create geometric motifs with inscribed circles inside squares. The study also included the recontextualization of the Roman theatre within the urban fabric also characterized by the presence of the Odeon, another Roman building of considerable importance whose remains are still visible in the west area of the theatre (Fig. 7). (FGa, IF, FGi)

\section{Conclusions}

This study provides an unpublished hypothetical reconstruction of the Roman theatre of Catania, aimed at the dissemination of cultural content also immediately understandable by non-experts, in an urban environment that has been modified over the centuries. The survey with Laser Scanner has been useful to rectify the weaknesses of the graphic documentation available today and has been the starting point for the development of a three-dimensional model which incorporates all the historical archaeological and architectural information available for the structure. The hypothesis proposed is the result of a study that uses direct analysis of the remains, integrated by the important contribution offered by the availability of an enhanced observation in a virtual environment. The many information gaps on archaeological and historical level has been supplemented by a comparative study with other contemporary structures. This contribution is taken as a starting point for further studies and investigations that they can better redefine the different stages of this monument, also in the light of the observations and considerations emerged following the availability of 3D models presented here. 


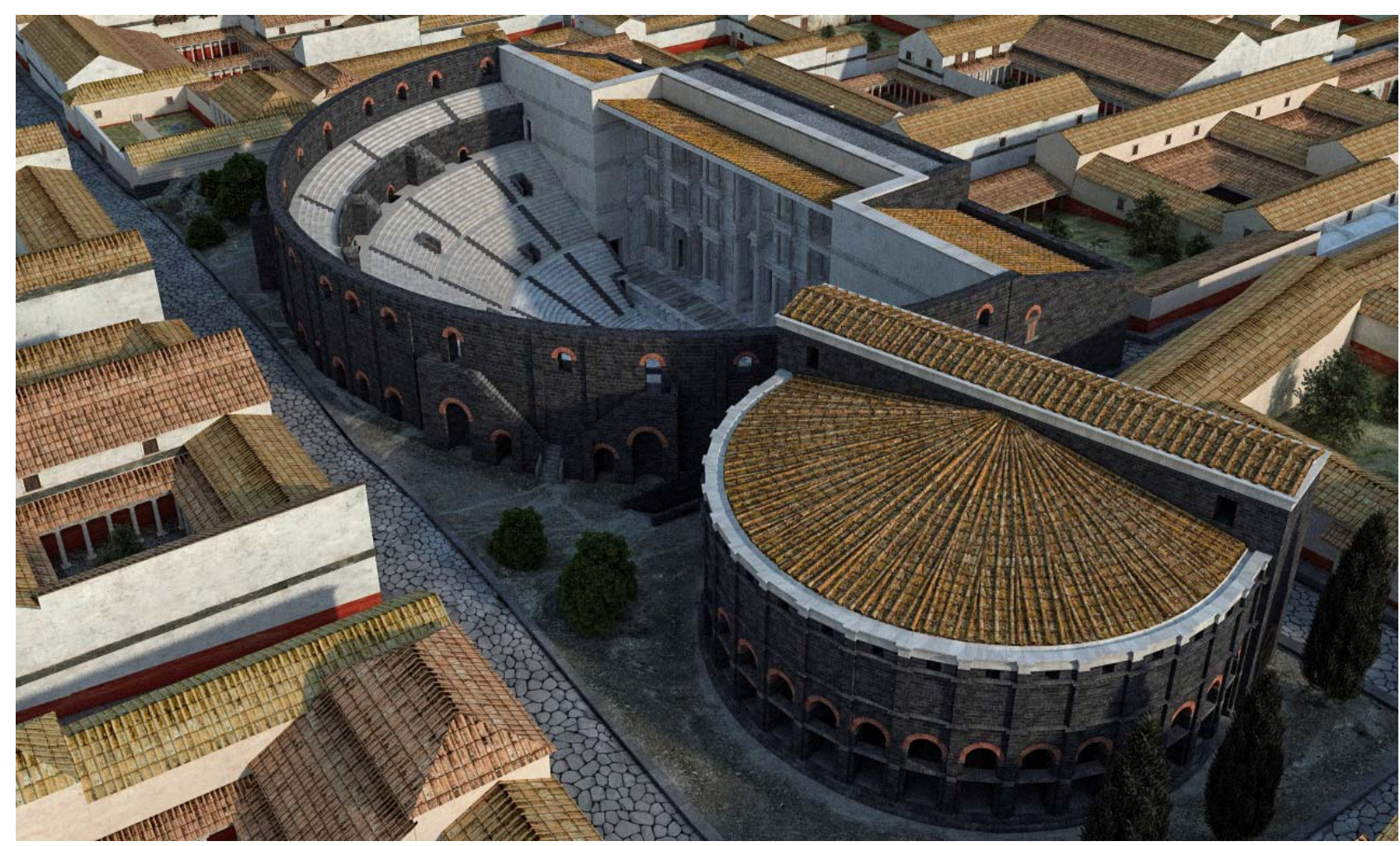

Figure 7: 3D reconstruction of the ancient Roman city of Catania: panoramic view of the theatre and Odeon.

\section{References}

ARCIFA, L., 2010. Da Agata al liotru: la costruzione dell'identità urbana nell'alto Medioevo, in: V. La Rosa, M.G. Branciforti (eds.), Tra lava e mare. Contributi all'archaiologhia di Catania, Catania 2010, pp. 355-386.

BERNABÒ, L., 1972-73. Attività della Soprintendenza alle Antichità per la Sicilia Orientale, in: Kokalos XVIII-XIX, Palermo, pp. 161-192.

BRANCIFORTI, M.G., 2004. Pavimenti in opus sectile di Catania, in: AA.VV., Apparati musivi antichi nell'area del Mediterraneo. Atti del $1^{\circ}$ Convegno Internazionale di Studi, Piazza Armerina, 9-13 Aprile 2003, Palermo, pp. 90-109.

BRANCIFORTI, M.G., 2006. II Teatro Romano di Catania, in: AA.VV., Teatri antichi nell'area del Mediterraneo. Conservazione programmata e fruizione sostenibile. Contributi analitici alla Carta del Rischio. Atti del II Convegno internazionale di studi "La materia e i segni della storia", Siracusa 13-17 ottobre 2004, Palermo, pp. 145-154.

BRANCIFORTI, M.G., 2010. Da Katane a Catina, in: M.G. Branciforti, V. La Rosa (eds.), Tra lava e mare. Contributi all'archaiologhia di Catania, Catania, pp. 183-209.

BRANCIFORTI, M.G. and PAGNANO G., 2008. II complesso archeologico del Teatro e dell'Odeon di Catania, Palermo.

BUDA, G., 2015. Teatro antico di Catania. Lavori tra il 2014 e il 2015. In: F. Nicoletti (ed.), Catania antica. Nuove prospettive di ricerca, Palermo, pp. 247-279.

BUSCEMI, F., 2012. Architettura e romanizzazione della Sicilia di età imperiale: gli edifici per spettacoli, Palermo.

CARRERA, P., 1639. Delle memorie historiche della città di Catania, Catania.

DE GROSSIS, J.B., 1642. Catanense decacordon, sive novissima sacrae Catanensis ecclesiae notitia quam tum ecclesiastica, tum secularis Catanensis politiae status universus intenta signatur, I-II, Catania.

FAZELLO, T., 1573. Le due deche dell'Historia di Sicilia (trad. R. Nannini), Venezia.

FERRARA, F., 1829. Storia di Catania fino alla fine del XVIII secolo, Catania.

GABELLONE, F., FERRARI, I. and GIURI, F., 2015. Digital restoration using Image-Based 3D models, in: Proceedings of the 1st International Conference on Metrology for Archaeology, Benevento - Italy, October 21-23, 2015, Benevento, pp. 534- 538. 
GABELLONE, F., FERRARI, I., GIURI, F. and CHIFFI M., 2015. The contribution of the 3D study for new reconstructive proposals of Lecce in Roman age, in: Proceedings of the 1st International Conference on Metrology for Archaeology, Benevento - Italy, October 21-23, Benevento, pp. 534-538.

GABELLONE, F., 2012. La trasparenza scientifica in archeologia virtuale. Una lettura critica al Principio N.7 della Carta di Siviglia, in: CASPUR CIBER Publishing SCIRES-IT, SClentific RESearch and Information Technology, vol. 2, Issue 2, pp. 99-124.

HOLM, A. and LIBERTINI G., 1925. Catania Antica, Catania.

LIBERTINI, G., 1930. II Museo Biscari. Milano-Roma.

LIBERTINI, G., 1946-1947. Due piccole sculture rinvenute nel Teatro di Catania, in: Bollettino Storico Catanese, XI-XII, pp. $134-141$

PATERNÒ, I., 1781. Viaggio per tutte le antichità della Sicilia descritto da Ignazio Paternò Principe di Biscari, Napoli.

PENSABENE, P., 2005. La decorazione architettonica del Teatro di Catania, in: R. Gigli (ed.), Megalai Nesoi. Studi dedicati a Giovanni Rizza per il suo ottantesimo compleanno, Catania, pp. 187-211.

POLICASTRO, G., 1952. Catania prima del 1693, Torino.

RIZZA, G., 1980-1981. Attività dell'Istituto di Archeologia dell'Università di Catania. Scavi e ricerche negli anni $1976-$ 1979, in: Kokalos XXVI-XXVII, II.1, pp. 746-747.

SCIUTO, S., 1913. I recenti restauri dei Monumenti antichi di Catania: I'Odeon, l'Anfiteatro romano, il Teatro greco, il Foro, in: Archivio Storico per la Sicilia Orientale, I, pp. 312-315.

TAORMINA, A., 2015. Nuove ricerche archeologiche nel teatro antico di Catania, in: F. Nicoletti (ed.), Catania antica. Nuove prospettive di ricerca, Palermo, pp. 281-349.

WILSON, R.J.A., 1996. La topografia della Catania romana, in: B. Gentili (ed.), Catania Antica. Atti del convegno della SISAC, Catania 23-24 Maggio 1992, Pisa-Roma, pp. 157-163. 


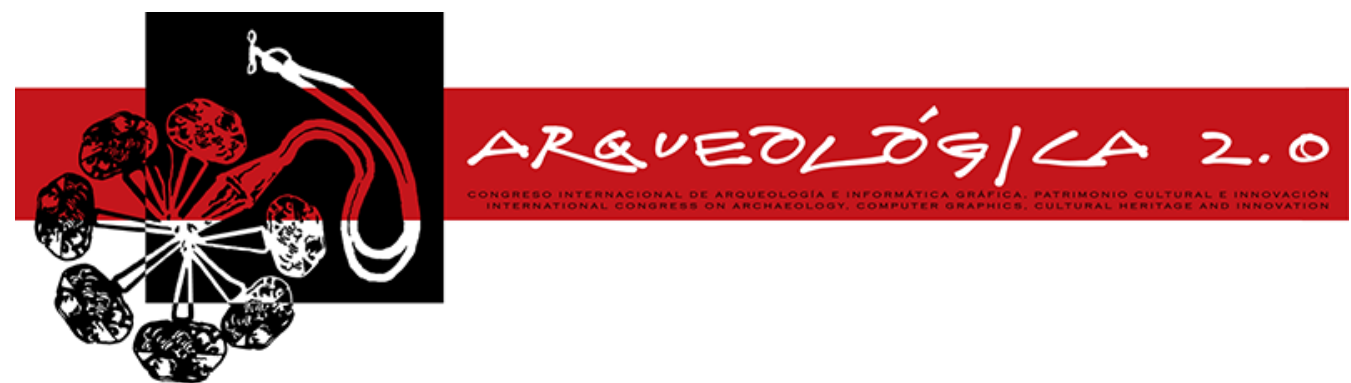

Proceedings of the $8^{\text {th }}$ International Congress

on Archaeology,

Computer Graphics,

Cultural Heritage and Innovation

'ARQUEOLÓGICA 2.0'

in Valencia (Spain),

Sept. 5-7, 2016

DOI: http://dx.doi.org/10.4995/arqueologica8.2016.3559

Received: 01/03/2016

Accepted: 11/04/2016

\title{
THE SURVEY, THE REPRESENTATION AND THE STRUCTURAL MODELING OF A DATED BRIDGE
}

\author{
EL LEVANTAMIENTO, LA REPRESENTACIÓN Y EL MODELADO ESTRUCTURAL DE UN PUENTE ANTICUADO \\ Serena Artese ${ }^{\mathrm{a},{ }^{,},}$, José Luis Lerma ${ }^{\mathrm{b}}$, Giuseppe Zagari ${ }^{\mathrm{a}}$, Raffaele Zinno ${ }^{\mathrm{a}}$ \\ ${ }^{a}$ Department of Informatics, Modeling, Electronics and System (DIMES), University of Calabria, Cubo 39/C, Via Ponte Pietro Bucci, \\ 87036 Rende (CS), Italy. serena.artese@unical.it; giuseppe.zagari@unical.it; raffaele.zinno@unical.it \\ ${ }^{\mathrm{b}}$ Photogrammetry \& Laser Scanner Research Group (GIFLE), Department of Cartographic Engineering, Geodesy and Photogrammetry, \\ Universitat Politècnica de València, Valencia, Spain. jllerma@cgf.upv.es
}

\begin{abstract}
:
The in opera concrete bridges characterize often the landscapes crossed by old roads and railways. In particular the arch bridges represent a product of human genius and, in some cases, of his art. In the last few years, at the SmartLab laboratory of the University of Calabria, there were developed activities in the field of surveying, monitoring and representation of structures. In the framework of these activities, Geomatics techniques for the surveying of bridges are widely used since 2014. The results of the measurements are used for documentation and representation purposes, as well as for the reconstruction of the constructive procedures. The finite element modeling of the structures has been obtained to simulate their behavior in case of earthquake. This article describes the activities relating to a bridge dated back to the 50s of the twentieth century: it is an arch bridge made of reinforced concrete. The surveying is aimed to determine the exact reconstruction of the geometry, the identification of the foundation settlement as well as the Finite Element Modeling (FEM) in order to allow structural identification and reverse engineering process. The instruments and techniques used for surveying and modeling operations, along with the deviations between models and "as built" are described.
\end{abstract}

Key words: laser scanning, cultural heritage, 3D reconstruction, reverse engineering, bridge, FEM model, vibration modes, structural identification

\section{Resumen:}

Los puentes de hormigón in opera caracterizan a menudo los paisajes atravesados por los antiguos caminos y las vías férreas. En particular, los puentes de arco, representan un producto del ingenio humano y, en algunos casos, de su arte. En los últimos años, en el laboratorio SmartLab de la Universidad de Calabria, se desarrollaron actividades en el campo de la topografia, el monitoreo y la representación de estructuras. En el marco de estas actividades, las técnicas geomáticas relativas al levantamiento de puentes se utilizan ampliamente desde 2014. Se utilizan los resultados de las mediciones con fines de documentación y de representación, así como para la reconstrucción de los procedimientos constructivos. La modelización mediante elementos finitos de la estructura se ha obtenido para simular su comportamiento en caso de terremoto. El artículo describe las actividades relativas a un puente que data de los años 50 del siglo XX: es un puente en arco de hormigón armado. El levantamiento está dirigido a la reconstrucción exacta de la geometría, la identificación de asentamiento de la cimentación y el modelado de elementos finitos que permiten la identificación de estructuras y el proceso de ingeniería inversa. Se describen las herramientas y las técnicas utilizadas durante el levantamiento con escéner làser y las operaciones de modelado, junto con las desviaciones entre los modelos y el como fue construido "as built".

Palabras clave: láser escáner, patrimonio cultural, reconstrucción 3D, ingeniería inversa, puente, modelo de elementos finitos, modos de vibración, identificación estructural

*Corresponding Author: Serena Artese, serena.artese@unical.it 


\section{Introduction}

Several reinforced concrete arch bridges cast in situ have been realized during 19th and 20th centuries. The use of precast elements, of prestressed concrete and the increase of the mechanical properties of materials has made so that this technique, involving the use of arch frames typically fabricated from wooden timbers and boards, was gradually abandoned.

Still today, the "in opera" concrete bridges characterize often the landscapes crossed by old roads and railways. In particular the arch bridges represent a product of human genius and, in some cases, of his art. For this reasons, the in opera concrete bridges belong to cultural heritage and deserve to be investigated. Furthermore, several reinforced concrete arch bridges are still used and controls are needed, for evaluating their suitability to withstand the loads to which they are subjected daily.

In the last few years, at the SmartLab laboratory at the University of Calabria, activities were developed in the field of surveying, monitoring and representation of structures. In the framework of these activities, geomatics techniques have been used widely for the surveying of bridges since 2014 .

The authorities in charge of maintenance of the road structures (ANAS - National Agency for Roads, Regions, Provinces) have to face different problems for both new and dated structures.

In the first case, the working plans and the design drawings are used, so the goal of the surveys is to get the as built, to be compared with the project, for testing activities and accounting of work performed, as well as for documentation purposes (Fuchs et al. 2004, Zogg and Ingensand, 2008).

In the case of dated structures, very often it is not possible to obtain the design documents, so the survey is also used to reconstruct the manner of execution and disassemble the organism into the structural elements that were considered and dimensioned during the design phase (Lubowiecka et al. 2009). The results of the measurements are used for documentation and representation purposes, as well as for the reconstruction of the constructive procedures. The finite element modeling of the structures is widely used to simulate their behaviour in case of earthquake. The analysis of the calculation results allows us to identify the critical parts of the structures, possibly to be reinforced, and which present the maximum stress.

The surveys and representations are used also for the identification of degraded areas, detachments of bar coverage, on which we must intervene with actions of recovery and restoration.

An accurate finite element model is used, finally, for the identification of the vibration modes of the structure independently from external stresses, necessary for predicting its behavior under dynamic loads.

The following describes the operations performed for surveying and modeling of a bridge located on a road managed by the Province of Cosenza, Italy. The bridge dates back to the 50s of the last century: it is an arch bridge made of reinforced concrete. The survey is aimed at the exact reconstruction of its geometry, the identification of foundation settlement and finite element modeling, to simulate the behavior of the structure under seismic conditions.

\section{Instruments and methodology}

It was decided to use laser scanner technology, with an integrated camera, and a GPS for the georeferencing, in order to acquire large amounts of geometric and photographic data in a short period. The choice of the laser scanner to perform a survey in a satisfactory manner, with adequate precision and completeness of representation, must take into account, in addition to the mandatory considerations about the accuracy and the flow rate, some other practical-operational features (Ĉapo et al. 2011; Deruyter et al. 2009; Lerma et al. 2008; Tang and Akinci 2011). Fundamental to this is the evaluation of the number of scans necessary for the complete visibility of all parts of the object to be surveyed, and the conditions in which it must operate to perform the survey.

The laser scanner RIEGL VZ 1000 was used, with the following characteristics:

- Accuracy of single point: $\pm 8 \mathrm{~mm}$.

- Range: from $1 \mathrm{~m}$ to $1400 \mathrm{~m}$.

- Sampling frequency: until 122.000 points/sec.

- Field of view: $100^{\circ}$ (Vertical) - $360^{\circ}$ (Horizontal).

- Leveler and magnetometer.

- GPS receiver.

- Nikon D610 Camera with a 20 mm calibrated lens.

- Acquisition of pulse waveform return.

This last characteristic allows us to discriminate the terrain or an object from the vegetation that covers it. The processing of data from the laser scanner was performed with the RiscanPro ${ }^{\circledR}$ and Geomagic $₫$ software.

It must be noted that the laser scanner is equipped with a GNSS receiver which allows just an approximate positioning of the station (single point positioning) with the use of the code and the method of pseudoranges, whereby, to obtain an accurate geo-referencing, we used a Leica Viva dual-frequency receiver, capable of receiving the signals from GPS and GLONASS constellations. For the data processing of satellite measurements in differential mode, we made use of data acquired by the permanent station GNSS positioned at the Laboratory of Geomatics, Department of Civil Engineering - University of Calabria, which captures data at a frequency of one $\mathrm{Hz}$. The processing of the acquired data, performed with the Leica Geo Office $®$ software, provided the coordinates of the station points with centimeter accuracy.

\section{The survey of Caprovidi bridge}

The Caprovidi bridge, in place at S. Angelo, at the town of Cetraro (CS), is located at km $1+900$ of Provincial Road number 26. It is a reinforced concrete arch bridge, cast in place, with two frame piers convergent with the plinths of the supporting arch (Fig. 1).

The VZ 1000, used with the compensator, equipped with the external Nikon D610 camera and the GNSS receiver, was configured with a resolution of $0.08^{\circ} / \mathrm{pt}$, 
corresponding to 7 points per meter at a distance of 100 $\mathrm{m}$, and a scan rate of 120,000 points per second.

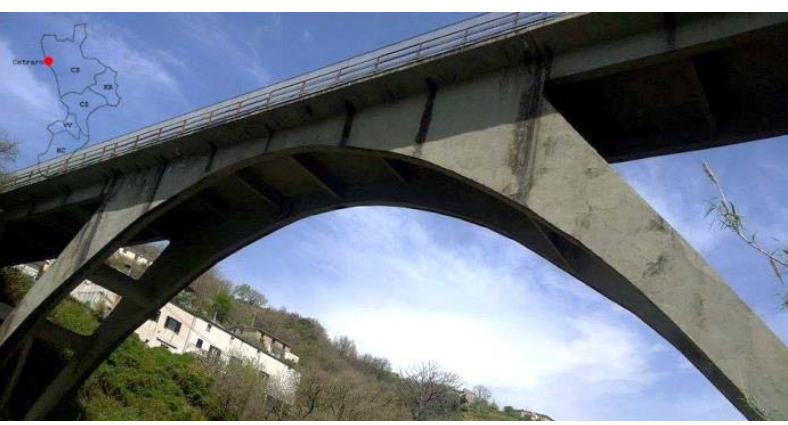

Figure 1: The Caprovidi bridge.

Some details of the bridge were scanned with a resolution of $0.007^{\circ} / \mathrm{pt}$, corresponding to 82 points per meter at a distance of $100 \mathrm{~m}$, in order to reconstruct their geometry in a more accurate way. For georeferencing, the station coordinates obtained by GNSS were used, combined with indications of the magnetometer which is fitted to the laser scanner. Three scans were used (Fig. 2). Due to the topographic situation, in fact, it was not possible to obtain access to the area on the hydraulic right side of the river, for which some parts were not visible; the thick vegetation was also an obstacle which prevented scanning of some parts of the bridge abutments. Lastly, the support bases of the arch and of the $\mathrm{Y}$ piers are covered by backfill terrain. For each scan, a partial spatial overlap with the adjacent ones was planned.
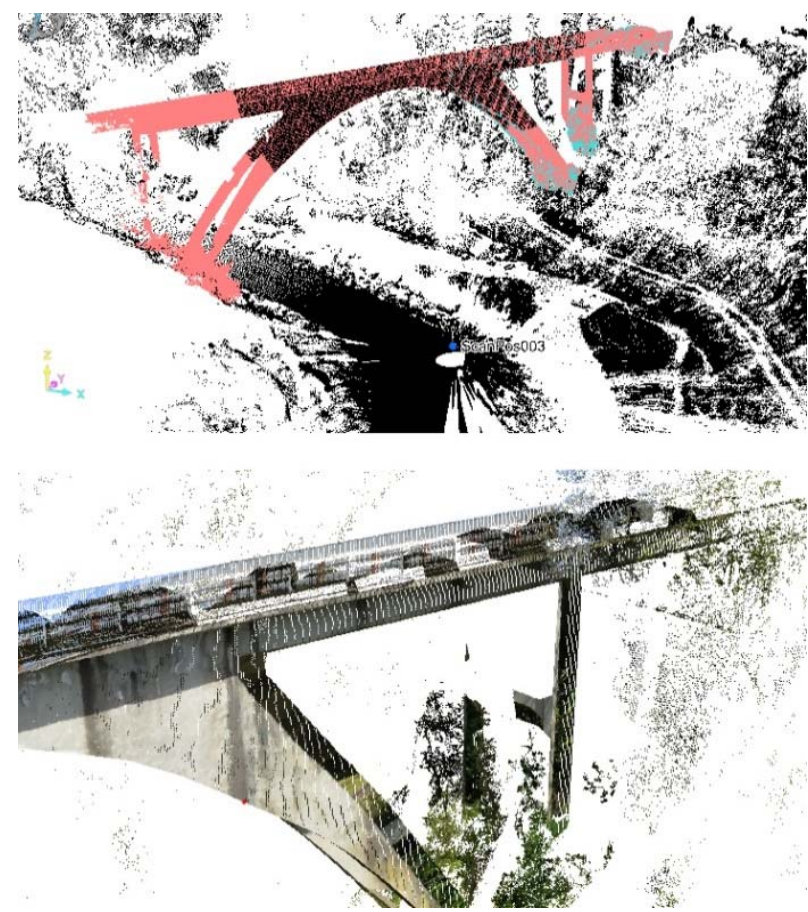

Figure 2: Top: Union of scans. Bottom: detail of a colored point cloud.

Two scans were performed from the two sides of the bridge; for the third acquisition, performed under the deck, the instrument was positioned with an inclination of $90^{\circ}$. Also in this case, some details of the bridge were scanned with more definition. Cylindrical targets were positioned, having a diameter of $14 \mathrm{~cm}$, to facilitate the alignment of the scans in the data processing.

The reference system of the first station was used also for the subsequent ones. The targets, having reflecting surface, were positioned in such a way as to be easily and clearly visible in the scans. For accurate georeferencing, acquisitions were performed with a dualfrequency GNSS receiver, post-processed along with the data collected from the fixed permanent station. The filtering and the reduction of the point clouds were particularly delicated. While having the possibility of discriminating the return pulses, a thorough job on the part of the operator was necessary, since the automatic procedures were influenced by the vegetation and the geometry of the work. In the absence of the project drawings, the survey was aimed at the reconstruction of the structure, but also at obtaining the initial design (reverse engineering). For this reason, two 3D models were created: the first was obtained directly from the mesh generated after the steps of registration, filtering and decimation; the second one is the geometrically regular model, which should constitute the project work. The first model can be used for documentation, while the second is used as a basis for structural modeling. Recent applications aim at obtaining the finite element model directly from the point cloud (Castellazzi et al. 2015; Vosselman et al. 2004). In Figure 3, the mesh obtained after the elimination of the vegetation is shown. There is an evident lack of information, especially in the areas surrounding the foundations.

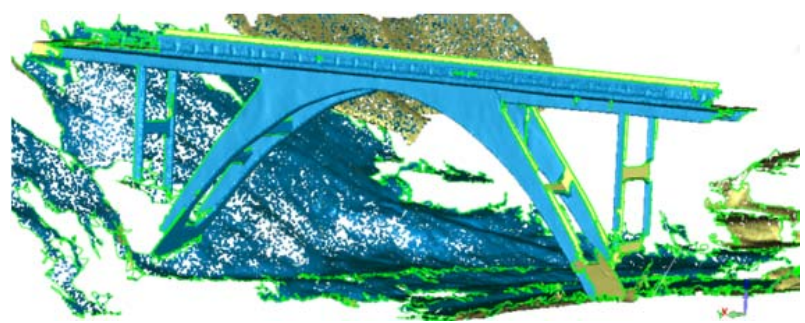

Figure 3: Mesh without vegetation.

The on-site research and detailed measurements allowed us to integrate the results of the laser scanner survey and to develop the likely geometric model of the project, shown in Figure 4 with the main structural elements highlighted in different colors.

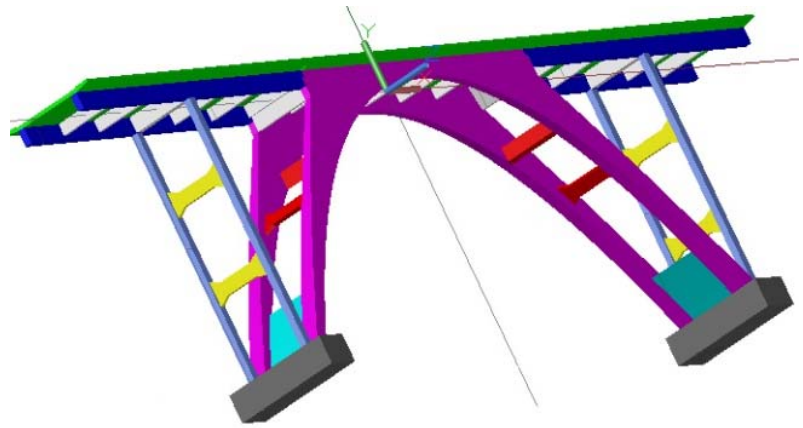

Figure 4: The geometric model.

The red and blue areas identify irregularities generally due to detachment of material. The very high values of the maximum and minimum deviations are due to the presence of some unfiltered points, automatically assigned by the software to a wrong surface. 
Figures 5 and 6 show the deviations between the ideal geometric model and the point cloud. It can be observed that the deviations are typically of centimetric order, within the manufacturing tolerances for this kind of structure (cast on site).

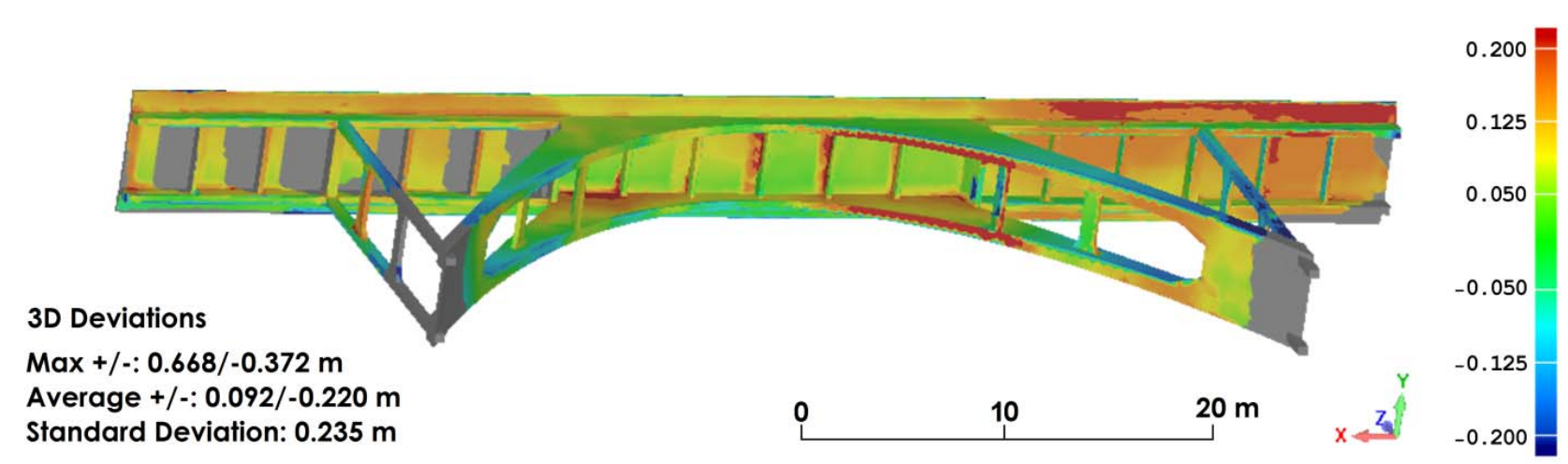

Figure 5: Deviations points-model.

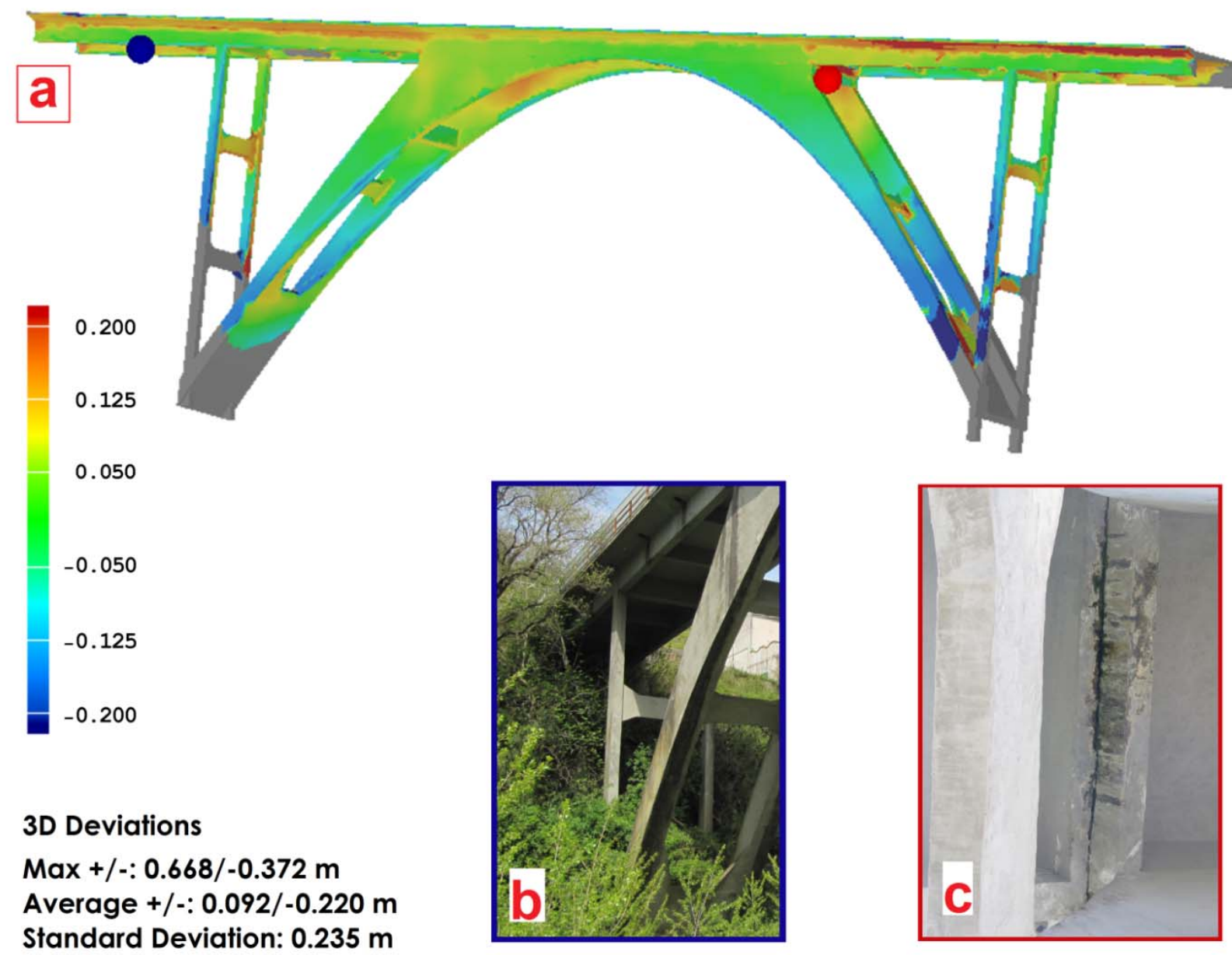

Figure 6: Deviations points-model (a) in correspondence to vegetation (b, blue) and deteriorated areas (c, red).

During vectorization, we proceeded to eliminate eventual interference between the various simple solids that form the overall volume.

\section{The FEM Analysis}

The model so obtained, in this case, was used for the dynamic identification, a very useful procedure also for detecting possible damage to the structure.
The geometrical model was converted into the finite element model (FEM) and analysed using the Abaqus ${ }^{\circledR}$ (ABAQUS 2014), structural analysis software which through automatic procedures imports the vectorized graphic model and converts it into a finite element mesh, in this case 4-node tetrahedral elements with only 3 degrees of freedom per node (Ux, Uy, Uz) 
This type of element was mainly used to generate the structure and the regular mesh, without losing accuracy, even in zones with variable thickness (Figs. 7 and 8).

The outputs of the structural calculations performed on the finite element model, were compared with those obtained through in situ measurements, obtained by positioning a minimal set of 8 piezo electric unidirectional transducers with a sensitivity equal to $10 \mathrm{~V} / \mathrm{g}$ (Volt per standard gravity) arranged in a suitable way in order to catch the main aspects of the structural dynamics of the bridge. These sensors identified the real vibration modes of the structure subjected to ambient noise and uncontrolled stress, by using the Frequency Domain Decomposition (FDD) technique (Brincker et al. 2000, Gentile, 2006).

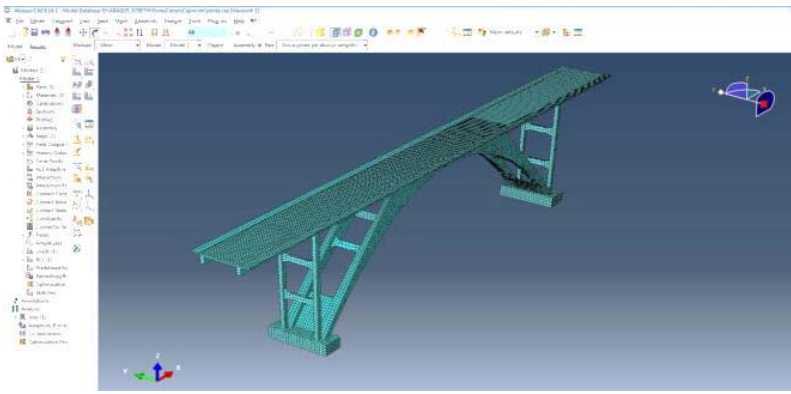

Figure 7: FEM model generated automatically from the CAD model.

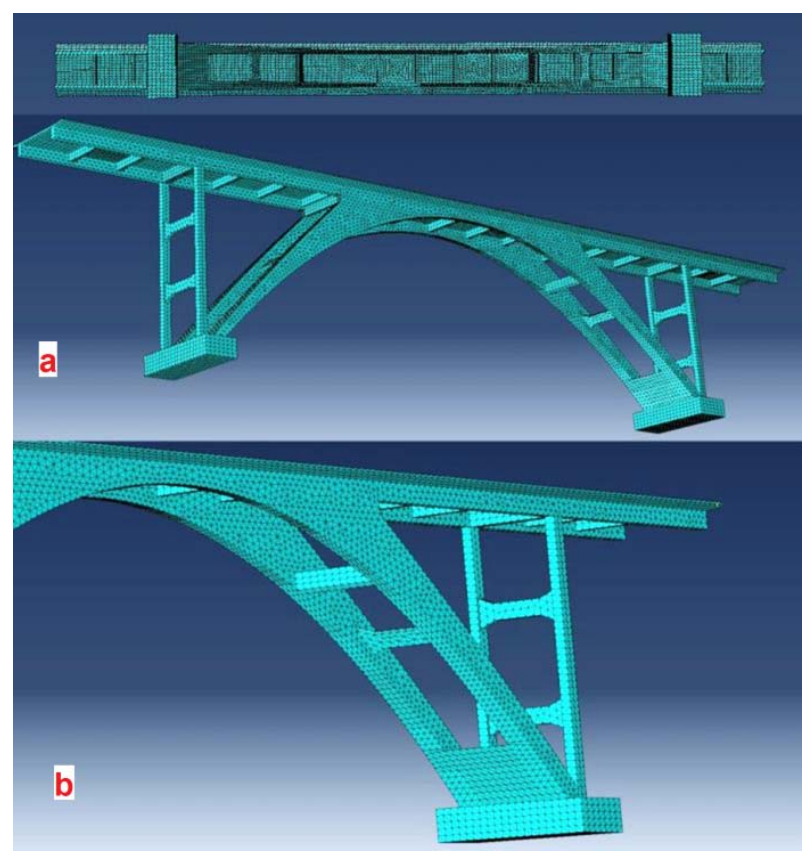

Figure 8: a) bottom views of the FEM model. b) enlargement.

For seismic analysis, a bridge is treated as an oscillating system. The way an oscillating system moves can be decomposed in several patterns of motion, called normal modes. Generally, the first modes are sufficient to describe the behavior of the structure. In our case, the first three modes have been represented in the Figures 9 and 10 . The first mode is characterized by movements in horizontal direction, the second one in vertical direction, the third one by a torsional movement.
The analysis results are in agreement with the measurements in situ and specific procedures were not necessary for updating the identification of the mechanical characteristics of the structure (Artese et al. 2015).
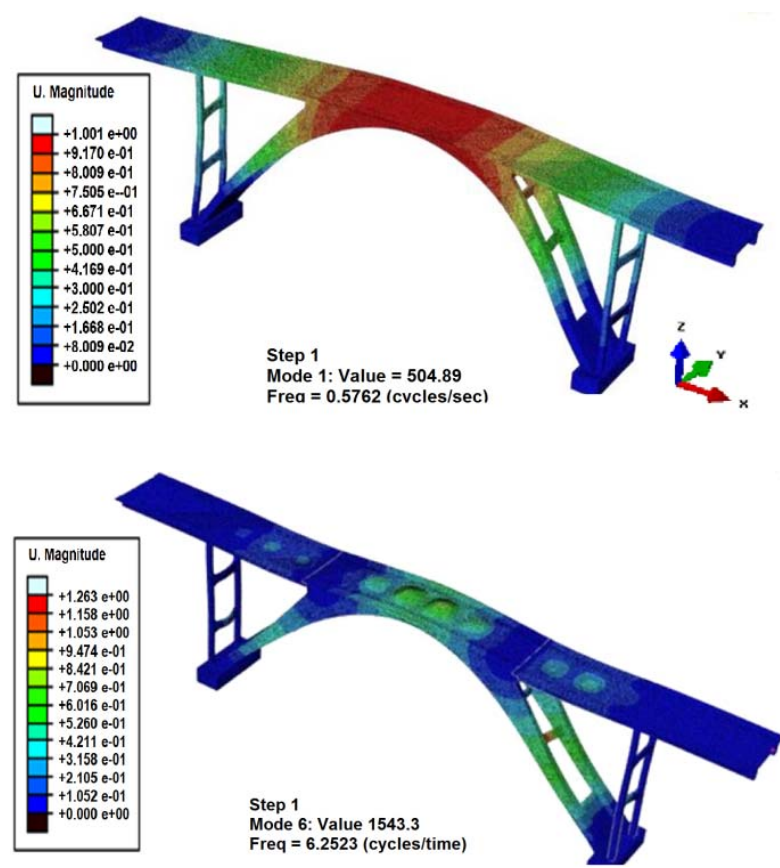

Figure 9: Top: $1^{\text {st }}$ vibration mode. Bottom: $2^{\text {nd }}$ vibration mode.

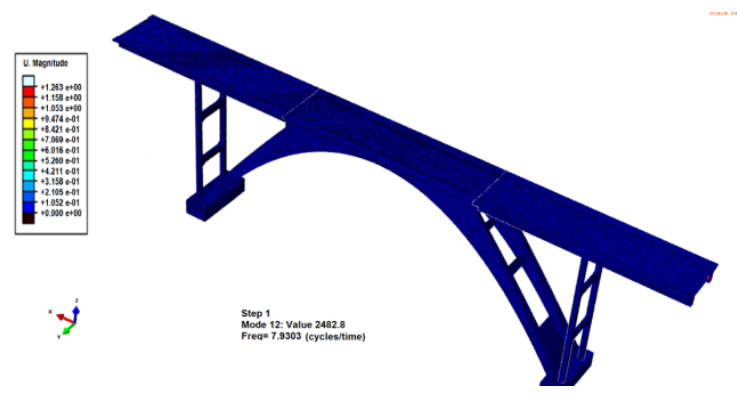

Figure 10: $3^{\text {rd }}$ vibration mode

\section{Future activities}

Another activity regards the ancient constructions in brick masonry and stones, which present special problems, and several examples of which are present and still used along the roads (Riveiro et al. 2011).

A very interesting construction is the Sant'Angelo Bridge, also known as the Hannibal Bridge.

It is a Roman bridge dating from the $2^{\text {nd }}$ century B.C., located between the towns of Altilia and Scigliano, in the Province of Cosenza, Italy (Fig. 11).

The scans of the construction were performed, while the building of the model is still in progress.

Like in the previous case, the activities of survey (Fig. 12) were carried out with two techniques: Riegl VZ 1000 terrestrial time of flight laser scanner to acquire the geometric characteristics, and GNSS receiver for georeferencing. 
To scan the bridge in its entirety, five stations were chosen. The scans carried out provided very high density point clouds (Figs. 13 and 14), which describe the surface of the object with extreme detail. For the connection of individual scans cylindrical target were used, and common points (tie points).

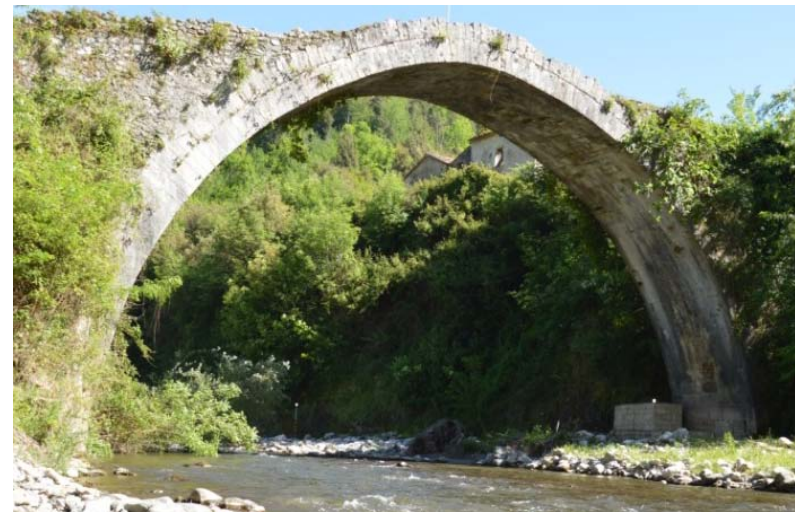

Figure 11: The Hannibal Bridge.
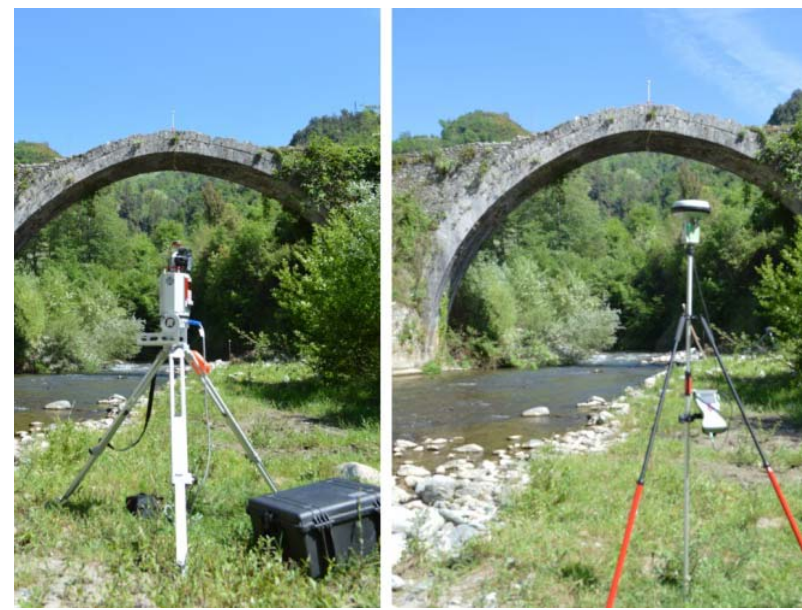

Figure 12: Survey of the Hannibal Bridge with Laser Scanner and GNSS receiver.

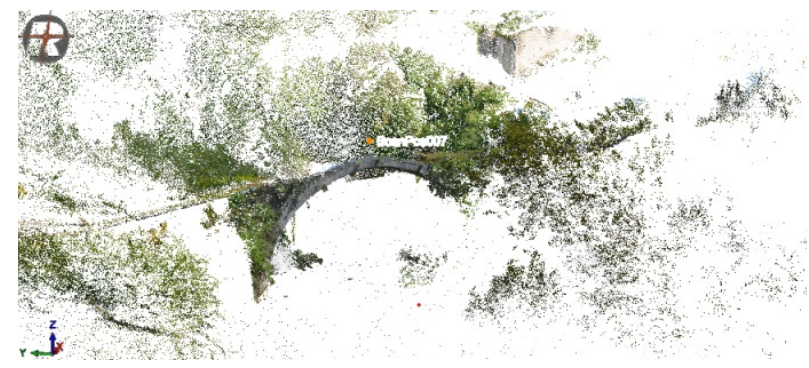

Figure 13: The union of the scans of Hannibal Bridge and Savuto Valley.

The aim of the future activities is to obtain the model of the bridge inserted in the surrounding landscape. This study will be performed in the framework of a research regarding the ancient Roman road "Via Annia", whose path followed the valley of the Savuto river.

\section{Conclusions}

The activities of surveying and modelling of a reinforced concrete arch bridge, cast in place, have been described. The aim was the documentation and the representation of the manufact, as well the reconstruction of the constructive procedures.

The data processing allowed to create two 3D models: the first was obtained directly from the mesh generated; the second one is the geometrically regular model, obtained through interpolating planes, which should constitute the project work.

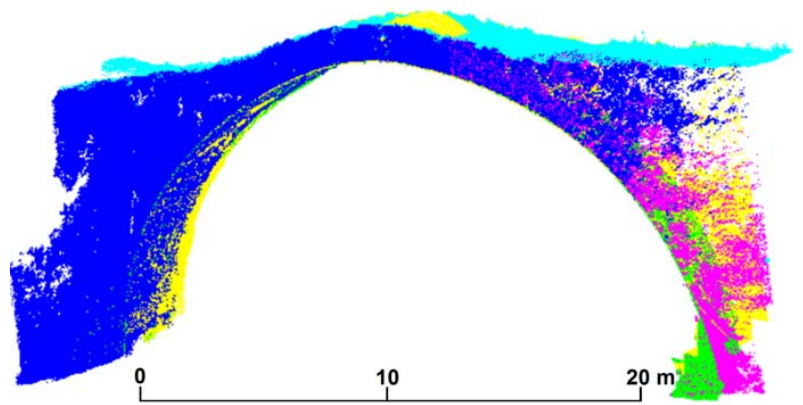

Figure 14: The union of the scans of Hannibal Bridge.

The deviations between the ideal geometric model and the point cloud were typically of centimetric order, within the manufacturing tolerances for this kind of structure (cast on site). The achieved accuracy fits the requirement for a reliable structural analysis. In this case, indeed, the finite elements used to describe the structure and perform the structural analysis, have dimensions of few decimeters, so a few centimeter accuracy is quite sufficient.

The geometrically regular model allowed us to build a finite element model (FEM) of the bridge, in order to obtain the vibration modes and to simulate their behavior in case of earthquake, or when the object is subjected to dynamic changes.

The outputs of the structural calculations performed on the FEM were in agreement with those obtained through in situ measurements

The results obtained confirm the usefulness of geomatics techniques both for the documentation and for the structural modeling of modern bridges.

\section{Acknowledgements}

The authors are thankful to SMARTLab (Structural Monitoring, Structural Advanced Materials, Structural Rehabilitation, Structural Testing) at the University of Calabria, for the technical and scientific support as well as Ing. Angela Miceli, Ing. Paolo Talarico, and Ing. Assunta Venneri for the collaboration during the survey of the bridges.

\section{References}

ABAQUS 6.14. Analysis User's Manual. Online Documentation Help: Dassault Systèmes. 
ARTESE, S., MICELI, A., TALARICO, P., VENNERI, A., ZAGARI, G. and ZINNO, R., 2015. Ponti antichi e moderni: utilizzo di tecniche geomatiche per il rilievo, la rappresentazione e la modellazione strutturale. Atti 19a Conferenza Nazionale ASITA, 29-30 Settembre - 1 ottobre 2015, Lecco - Polo di Lecco del Politecnico di Milano - ISBN 978-88941232-2-7.

BRINCKER, R., ZHANG, L.M. and ANDERSEN, P., 2000. Modal identification from ambient response using Frequency Domain Decomposition. Proc. $18^{\text {th }}$ Int. Modal Analysis Conference (IMAC), San Antonio, 2000.

ĈAPO, A., BABIÜ, L., and PRIBIPEVIÜ, B., 2011. Application of a 3D terrestrial laser scanner in a survey of a railway bridge" Sava Jakuševac". In5th International Conference on Engineering Surveying.

CASTELLAZZI, G., D'ALTRI, A.M., BITELLI, G., SELVAGGI, I. and LAMBERTINI, A., 2015. From laser scanning to finite element analysis of complex buildings by using a semi-automatic procedure. Sensors, 15(8), 18360-18380; doi:10.3390/s150818360

DERUYTER, G., HENNAU, M., DE WOLF, V. and DEWULF, N., 2009. Approach for comparing design and as built models based on data acquisition using a 3D terrestrial laser scanner, a case study. In 4th International workshop on 3D Geo-information, pp. 101-116.

FUCHS, P.A., WASHER, G.A., CHASE, S.B., and MOORE, M., 2004. Applications of Laser-Based Instrumentation for Highway Bridges, Journal of Bridge Engineering , ASCE, November/December, pp. 541-549.

GENTILE, C., 2006. Modal and structural identification of a RC arch bridge. Structural engineering and mechanics.Vol 22, n.1, pp 53-70.

LERMA, J.L., VAN GENECHTEN, B., HEINE, E., and SANTANA, M., 2008. Theory and practice on Terrestrial Laser Scanning. Editorial de la Universidad Politécnica de Valencia, Valencia.

LUBOWIECKA, I., ARMESTO, J., ARIAS, P. and LORENZO, H., 2009. Historic bridge modelling using laser scanning, ground penetrating radar and finite element methods in the context of structural dynamics. Engineering Structures, 31, 2667-2676.

RIVEIRO, B., MORER, P., ARIAS, P. and DE ARTEAGA, I., 2011. Terrestrial laser scanning and limit analysis of masonry arch bridges. Construction and building materials, 25(4), 1726-1735.

TANG, P., and AKINCI, B., 2012. Automatic execution of workflows on laser-scanned data for extracting bridge surveying goals. Advanced Engineering Informatics, 26(4), 889-903.

VOSSELMAN, G., GORTE, B. G., SITHOLE, G. and RABBANI, T., 2004. Recognising structure in laser scanner point clouds. International archives of photogrammetry, remote sensing and spatial information sciences, 46(8), 33-38.

ZOGG, H.M., and INGENSAND, H., 2008. Terrestrial Laser Scanning for Deformation Monitoring -Load Tests on the Felsenau Viaduct $(\mathrm{CH})$. The International Archives of the Photogrammetry, Remote Sensing and Spatial Information Sciences, Volume XXXVII, Part B5, pp. 555-562. 


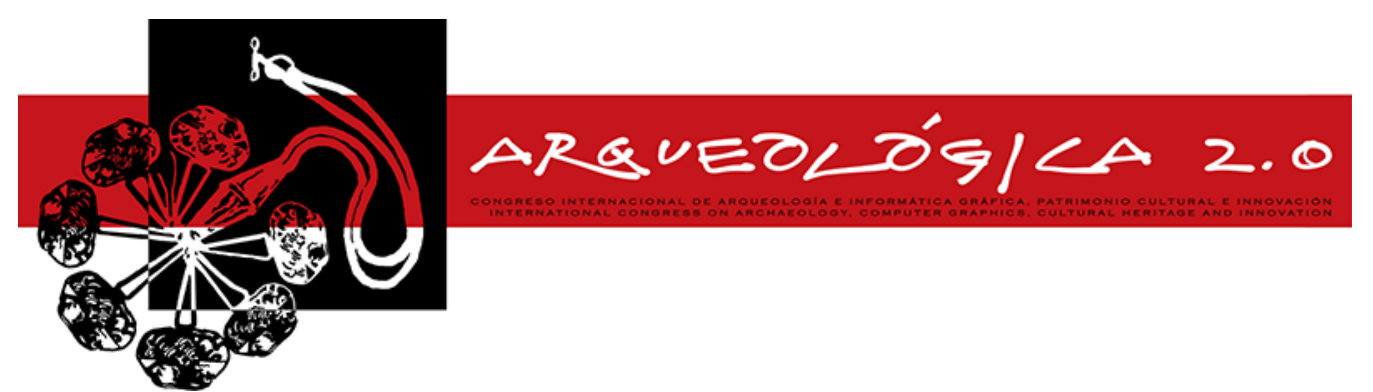

Proceedings of the $8^{\text {th }}$ International Congress

on Archaeology,

Computer Graphics,

Cultural Heritage and Innovation

'ARQUEOLÓGICA 2.0'

in Valencia (Spain),

Sept. 5-7, 2016

DOI: http://dx.doi.org/10.4995/arqueologica8.2016.3560

Received: $07 / 03 / 2016$

Accepted: $11 / 04 / 2016$

\title{
DIGITAL IMAGE ANALYSIS OF THE VISIBLE REGION THROUGH SIMULATION OF ROCK ART PAINTINGS
}

\section{ÁNALISIS DE IMAGEN DIGITAL DE LA REGIÓN VISIBLE MEDIANTE SIMULACIÓN DE PINTURAS DE ARTE RUPESTRE}

\author{
Berta Carrión-Ruiz*, Silvia Blanco-Pons, José Luis Lerma
}

Photogrammetry \& Laser Scanning Research Group (GIFLE), Department of Cartographic Engineering, Geodesy and Photogrammetry, Universitat Politècnica de València, 46022 Valencia, Spain. bercarru@doctor.upv.es; silblapo@doctor.upv.es; illerma@cgf.upv.es

\begin{abstract}
:
Non-destructive rock art recording techniques are getting special attention in the last years, opening new research lines in order to improve the level of documentation and understanding of our rich legacy. This paper applies the principal component analysis (PCA) technique in images that include wavelengths between 400-700 nm (visible range). Our approach is focused on determining the difference provided by the image processing of the visible region through four spectral images versus an image that encompasses the entire visible spectrum. The images were taken by means of optical filters that take specific wavelengths and exclude parts of the spectrum. Simulation of rock art is prepared in laboratory. For this purpose, three different pigments were made simulating the material composition of rock art paintings. The advantages of studying the visible spectrum in separate images are analysed. In addition, PCA is applied to each of the images to reduce redundant data. Finally, PCA is applied to the image that contains the entire visible spectrum and is compared with previous results. Through the results of the four visible spectral images one can begin to draw conclusions about constituent painting materials without using decorrelation techniques.
\end{abstract}

Key words: digital archaeology, cultural heritage, documentation, rock art, decorrelation techniques, digital analysis.

\section{Resumen:}

Las técnicas documentación no destructivas de arte rupestre están recibiendo especial atención en los últimos años, abriendo nuevas líneas de investigación para la mejora del nivel de documentación y comprensión de nuestro patrimonio. Este artículo aplica la técnica de análisis de componentes principales (ACP) en imágenes de longitudes de onda entre 400-700 nm (rango visible). Nuestro enfoque se centra en determinar las diferencias proporcionadas por el procesamiento de imágenes de la región del visible a través de cuatro imágenes espectrales y una imagen que abarca el espectro visible completo. Las imágenes se tomaron con filtros ópticos que recogen longitudes de onda determinadas y excluyen parte del espectro.Se preparó una simulación de pigmentos de arte ruprestre en laboratorio. Para ello se hicieron tres tipos de pigmentos diferentes simulando la composición del material de las pinturas rupestres. Se analizaron las ventajas de estudiar el espectro visible en imágenes separadas. Además, se aplicó ACP a cada una de las imágenes para reducir la información redundante. Finalmente, se realizó ACP a la imagen que abarca todo el espectro visible y se comparó con los resultados anteriores. A través de los resultados de las cuatro imágenes espectrales del visible se pueden sacar conclusiones sobre los materiales que constituyen la pintura sin aplicar técnicas de decorrelación.

Palabras clave: arqueología digital, patrimonio cultural, documentación, arte rupestre, técnicas de decorrelación, análisis digital

\section{Introduction}

Rock art is constantly exposed to natural weathering, threatening and degrading the art. There are many natural and human agents that affect the integrity of cultural sites. Independently of the level of the attacks, the different agents are steadily altering the main features conditions of the archaeological sites. Levantine rock art is located in areas exposed to direct light. Therefore, rock art recording is necessary for the longterm preservation of the fragile archaeological heritage.

"Corresponding Author: Berta Carrión-Ruiz, bercarru@doctor.upv.es 
Combining controlled photographic techniques and digital image processing techniques allow users to get ordered matrices of quantitative data, that collect the variability of certain physical properties (e.g. digital number, distribution and variability of pigments), and this variability is accessible to quantitative analysis methods (Alcalde et al. 1998).

Nowadays the analysis of rock art with digital images is considered an indirect technique essential (Brady and Gunn 2012; Cerrillo-Cuenca and Sepúlveda 2015; Clogg et al. 2000; Mark and Billo 2006). Current digital cameras are easy to use and offer high quality imagery. These devices are able to acquire the objects' reflected radiation in three visible spectral bands (Red $(R)$, Green $(\mathrm{G})$ and Blue (B)) highly correlated.

On the other hand, current digital image processing techniques are based on remote sensing techniques. (Alcalde et al. 1998) reports controlled transposition of concepts, methods and techniques from the field of remote sensing to the rock art context. These techniques are non-invasive, and they can be used to enhance paintings that cannot be easily distinguished (Mark and Billo 2006; Rogerio-Candelera 2015). This is one of the central research lines today. These concepts provide the scientific exploitation and promote the dissemination of rock art knowledge.

One of the most popular techniques used in the remote sensing field is principal components analysis (PCA). PCA is a very useful technique to achieve the decorrelation of digital image levels. Due to a high correlation between visible bands, decorrelations algorithms are used to reduce the redundant data. Thus differences between spectral bands are highlighted.

Many references can be found in which digital image processing was undertaking with these decorrelation techniques. (Rogerio-Candelera et al. 2011) examined through a laboratory test the meaning of each of the principal components obtained in PCA. (Mark and Billo 2002) applied the decorrelation strech (DS) technique to enhance rock art paintings. Furthermore, (Le Quellec et al. 2015) reported the advantage of recording deteriorated figures that would have been missed.

Using decorrelation image techniques can automate part of the image analysis. Therefore motif identification is improved and the process is accelerated in most cases (Díaz-Andreu et al. 2006; Domingo et al. 2015; Gunn et al. 2010; Rogerio-Candelera et al. 2011).

This paper applies the PCA technique in images that include wavelengths between $400-700 \mathrm{~nm}$ (visible range). Our approach is focussed on determining the difference provided by the image processing of the visible region through four images that divide the visible spectrum with a multiband image versus an image that encompasses the entire visible spectrum. The advantages of studying the visible spectrum in separate images are analysed. In addition, PCA is applied to the multiband image. Finally, PCA is performed to the image that contains the entire visible spectrum and is compared with the previous results.

\section{Nature of light}

Humans perceive objects' colour by the reflection of light. That light travels in the form of electromagnetic waves (EM) and the wavelength $(\lambda)$ is the most important characteristic of EM radiation.

Humans and visible imaging sensors such as digital cameras only can capture a portion of visible EM radiation. This range contains wavelengths between 380 $\mathrm{nm}$ and $750 \mathrm{~nm}$ (Fig. 1).

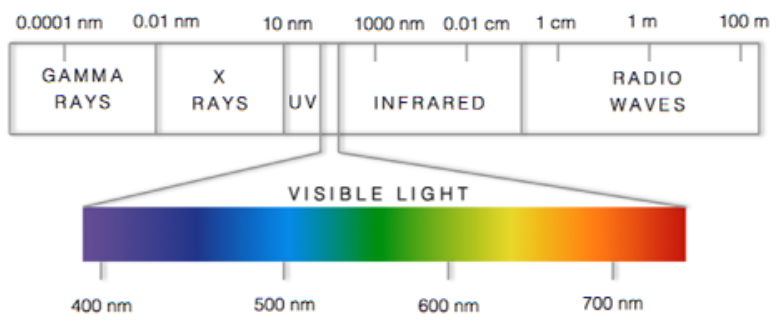

Figure 1: The Electromagnetic spectrum.

The imaging sensors receive the reflected radiation off from a scene. Nevertheless, these devices usually incorporate filters that divide the incoming EM radiation in three visible spectral bands (RGB). As (Verhoeven 2008) describes, digital cameras use a Bayer pattern with photodiodes in groups of four. In each group there are two green filters (summing up $50 \%$ of the incoming light), one red filter (summing up $25 \%$ of the incoming light) and one blue filter (summing up $25 \%$ of the incoming light).

As (Domingo et al., 2015) reported, the RGB bands are most of the times highly correlated, yielding little differences between spectral bands. This aligns with the application of decorrelations algorithms.

\section{Principal component analysis (pca)}

PCA is a multivariate analysis technique that allows the reassignation of digital number (DN) values in a new non-correlated reference system without losing information. As Cerrillo-Cuenca and Sepúlveda (2015) noted, PCA is efficient in the treatment of multiband images (RGB colour images and multispectral images).

The result of this technique is a group of non-correlated images that are the principal components. The number of principal components depends on the number of input image bands. In these components the original image information is divided.

(Rogerio-Candelera et al. 2011) reported that the second component (PC2) and the third component (PC3) can be useful to create a new colour image. Occasionally, the last component PC3 only has residual information and in some cases it allows users to detect invisible features (Cerrillo-Cuenca and Sepúlveda 2015; RogerioCandelera et al. 2011).

\section{Laboratory simulation and test}

For the simulation of rock art in laboratory we made three different pigments and simulated rock art paintings in laboratory. Manganese and charcoal were used to reproduce mineral and organic black pigments, respectively, and iron oxide was used to emulate either red or reddish colours. Some photographs were taken afterwards the pigments were painted on a stone. 
Our approach is based on the possibility to analyse motifs in rock art by means of visible images. For the testing, we analyse four images that divide the visible spectrum, each of the images contains a portion (wavelength range) of the visible region. It allows us to treat each visible spectral wavelength range separately. On the other hand we analyse the image that covers the entire visible range.

\subsection{Pigments simulation}

For the simulation of rock art paintings in laboratory, the sketches were painted based on the procedures developed by several authors (López-Montalvo et al. 2014; Vicent et al. 1996). In that way three different pigments were made:

- To reproduce mineral black pigments found in black features in Levantine rock art, manganese was used.

- To emulate organic black pigments, we used charcoal of burned pine branches.

- To emulate red or reddish colours we used iron oxide, one of the most used materials for elaborating red figures.

The technique consists in a mix of the pigment with water and animal fat. These mixes are applied on sandstone of approximately $4 \times 4 \times 0.5 \mathrm{~cm}$ and over it simple motifs were painted with a feather (Fig. 2).

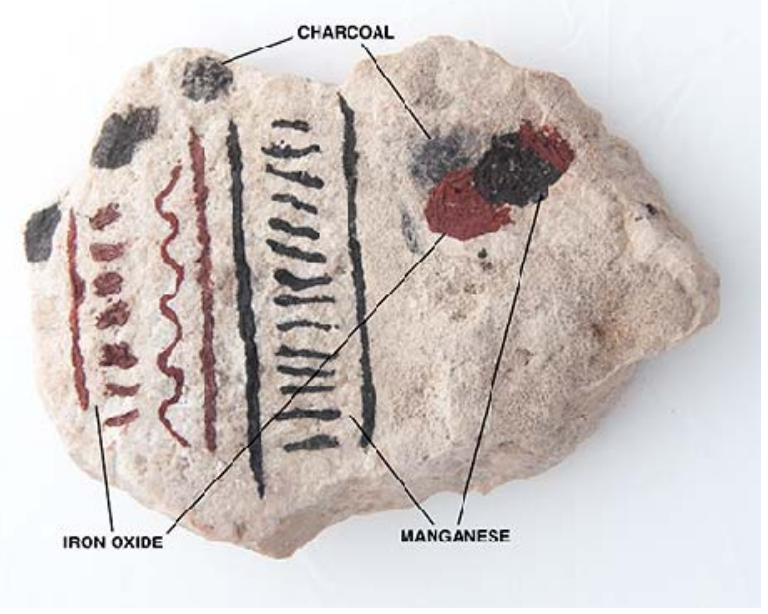

Figure 2: Simulation of rock art paintings.

\subsection{Recording}

All of the images were taken with a Fujifilm Finepix IS Pro camera with a camera lens of $60 \mathrm{~mm}$ focal length, $\mathrm{f} / 8$, ISO 100 and variable exposure time depending on the wavelength. Optical filters were required to take specific wavelengths and exclude parts of the spectrum. The filters selected were bandpass filters spanning the visible electromagnetic spectrum. These types of filters reflect unwanted wavelengths. Trying to recreate the illumination conditions of the rock art locations, the paintings were photographed with sunlight

We used five different filters of Midwest Optical Systems Inc (Midopt, 2016), Fig. 3:
- BP-550 (Near-IR/UV Block-Visible Bandpass Filter): Passes all visible light (useful range 410-690 nm).

- BP-470 (Blue Band pass Filter): This filter has a spectral bandwidth in the blue range (useful range 425-495 nm).

- BP-525 (Light Green Bandpass Filter): This filter passes the green range (useful range 500-555 nm).

- BP590 (Orange Bandpass Filter): This filter has a spectral bandwidth in the orange range (useful range 560-600 $\mathrm{nm}$ ).

- BP635 (Light Red Bandpass Filter): This filter has a spectral bandwidth in the red range (useful range 615-645 $\mathrm{nm}$ ).

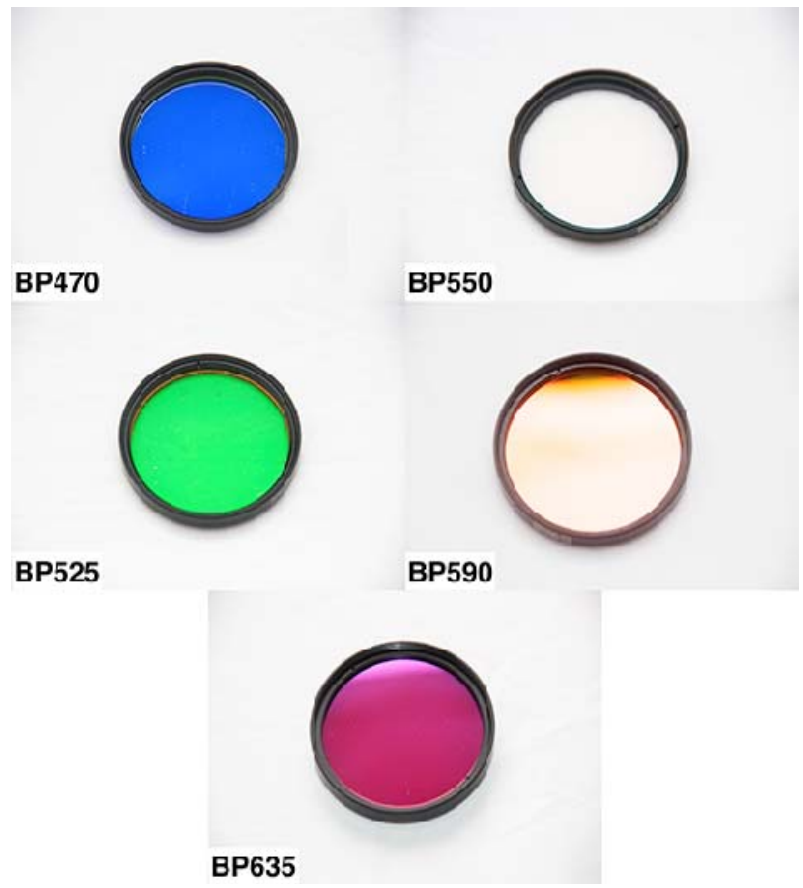

Figure 3: Five bandpass filters used for the testing. The number of MidOpt filter is pointed out in each image.

Conventional digital cameras convert the reflected radiation off from the objects in three bands: Red $(R)$, Green (G) and Blue (B). The results after interchanging the filters were five images of three-bands each one (Fig. 4), stored in RAW format, which creates files with higher colour depth and allow users to correct the exposure (Verhoeven and Schmitt 2010).

\subsection{Digital image analysis}

Images taken are analysed individually first and then jointly: 1) BP470, (blue image); 2) BP525 (green image); 3) BP590 (orange image); 4) BP635 (red image); and 5) BP550 (entire visible spectrum image).

Figure 5 shows the workflow of the digital image analysis.

\subsubsection{Greyscale Visualization}

According to (Brady and Gunn, 2012) monochrome images are easiest to deal with as only one colour needs 
to be adjusted. Therefore, each band is converted to greyscale getting monochrome images. In these images the division of pigments can be seen much more clearly (Fig. 6).

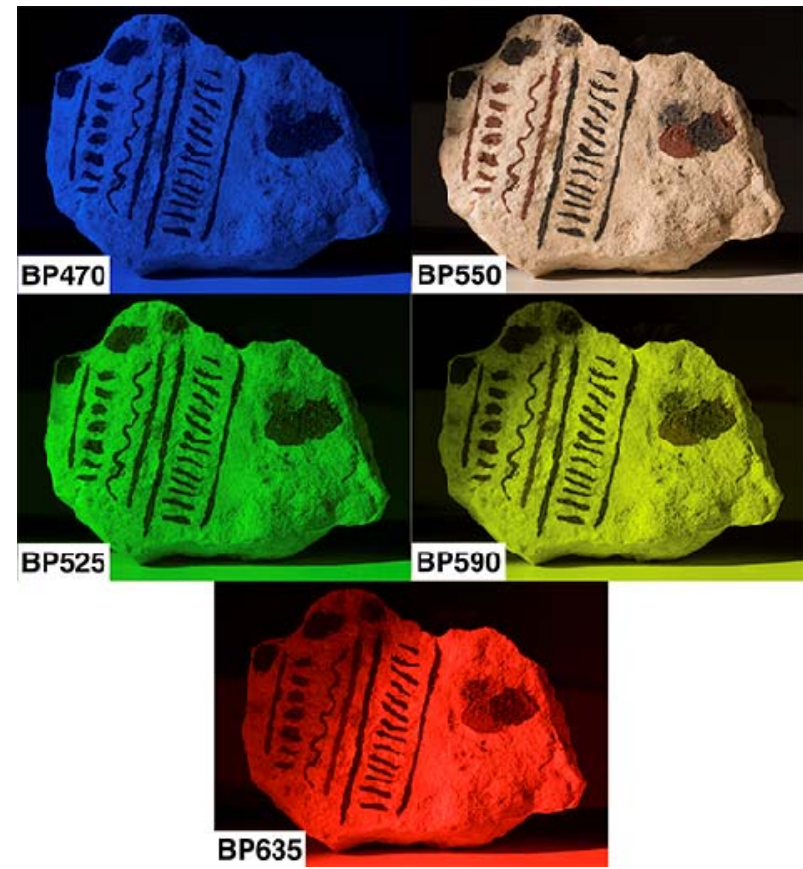

Figure 4: Output images after blocking the light with the five bandpass filters. The number of the filter used is pointed out in each image.

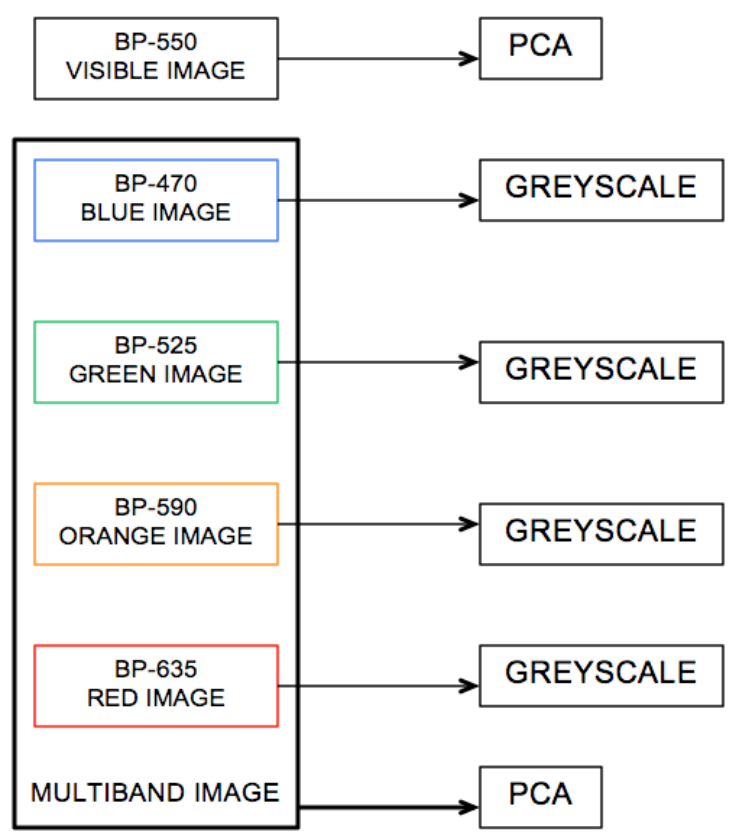

Figure 5: Digital image analysis workflow.

The three types of pigments are observed in the greyscale images. In the orange image the differentiation between iron oxide and manganese pigment is seen. Furthermore, the iron oxide pigment and the charcoal pigment with the same colour are seen (Fig. 6c). That is, there are differences between red and black pigments, but there are not differences between black pigments. In both the blue and the green images there are not differences between pigments (Figs. $6 a$ and $6 b$ ). Finally the red image shows a differentiation of the three pigments (Fig. 6d). Hence, in this case differences between these simulated pigments are seen as recorded wavelength increases.

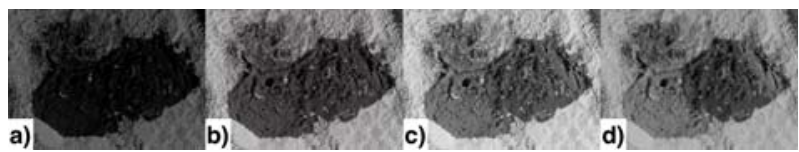

Figure 6: Detail of paintings in greyscale after bandass filter photography: a) blue, b) green, c) orange, d) red.

\subsubsection{Multiband image PCA}

To reduce redundant data, $\mathrm{PCA}$ is applied to a multiband image composed by blue, green, orange and red images. For this multiband image, four components are obtained.

Analysing the components obtained, it is observed that the lighting conditions are an important factor. Lighting should be as homogeneous as possible, avoiding areas of sun-shade. In this case the light is not homogeneous and this affects the principal component analysis.

We are going to analyse the second, third and fourth principal component (PC) due to fact that reflect hardly visible information.

The first component PC1 shows all the paintings in detail although without differentiation between pigments (Fig. $6)$.

In the PC2 the iron oxide pigment is enhanced in black; black manganese pigments are enhanced in light grey and charcoal is almost imperceptible (Fig. 7).

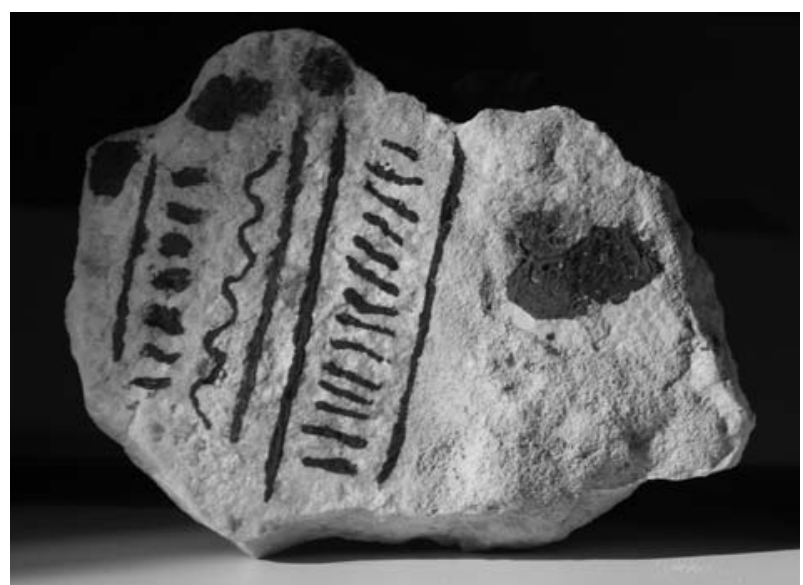

Figure 6: Principal component 1 (PC1) from the multiband image.

The third component PC3 (Fig. 8) reveals a differentiation between red pigment and black pigments. However if PC2, and PC3 are compared it is observed that the information provided is similar.

Finally in PC4 all pigments are displayed in the same colour, charcoal pigment is included (Fig. 9) although this component contains much noise and makes difficult the visualization.

\subsubsection{BP-550 PCA}

In this image, three components are obtained. After the analysis of principal components, PC2 shows that the 
paintings are divided in two tonalities, pigment composed by iron oxide is displayed in light grey/white colour and pigments composed by charcoal and manganese are visualised in dark grey (Fig. 10). Therefore manganese and charcoal pigments are not divided. In PC3 charcoal disappears remaining manganese very attenuated and iron oxide in black (Fig. 11).

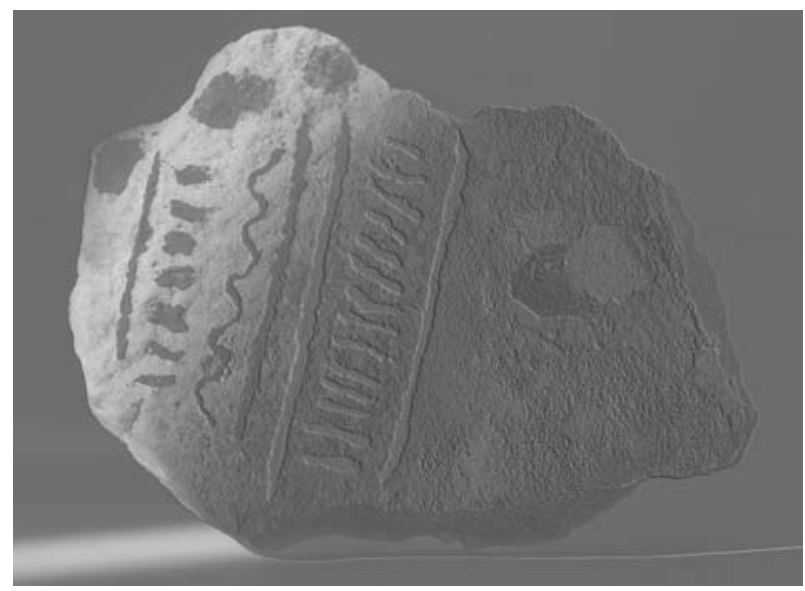

Figure 7: PC2 from the multiband image.

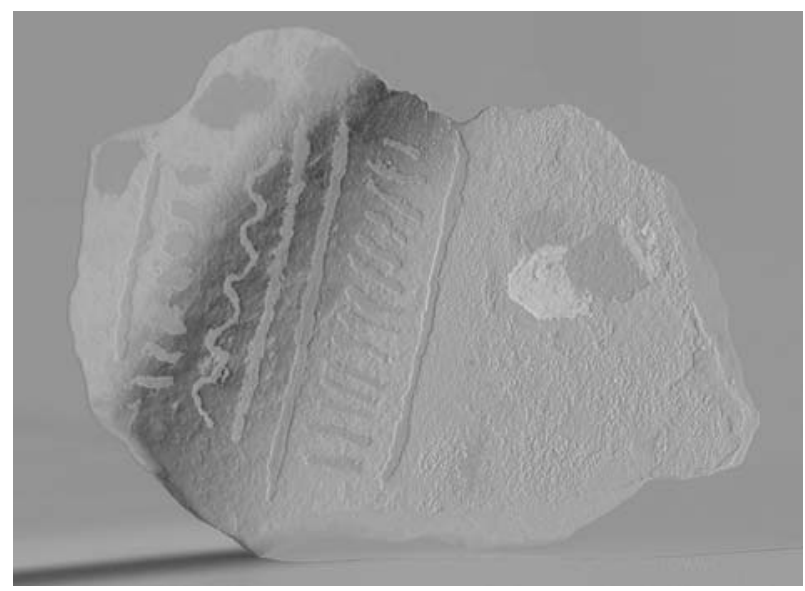

Figure 8: $\mathrm{PC} 3$ from the multiband image.

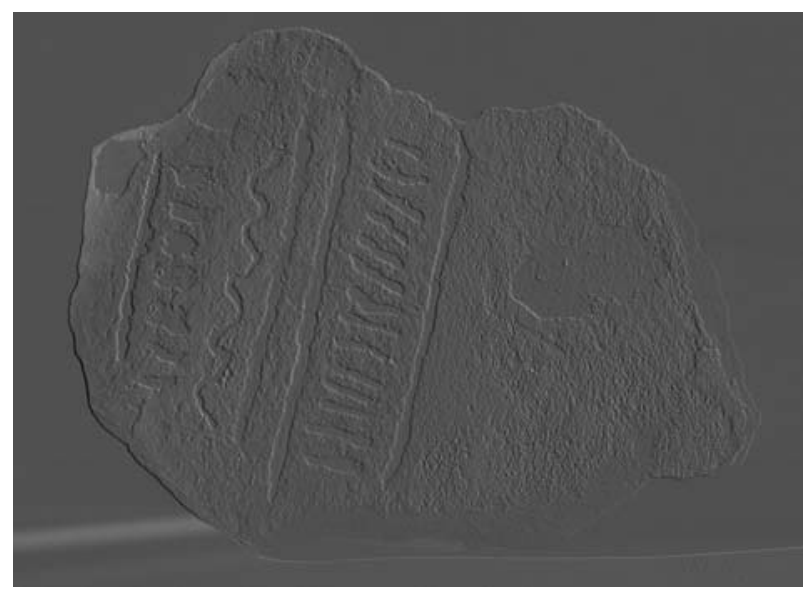

Figure 9: PC4 from the multiband image.

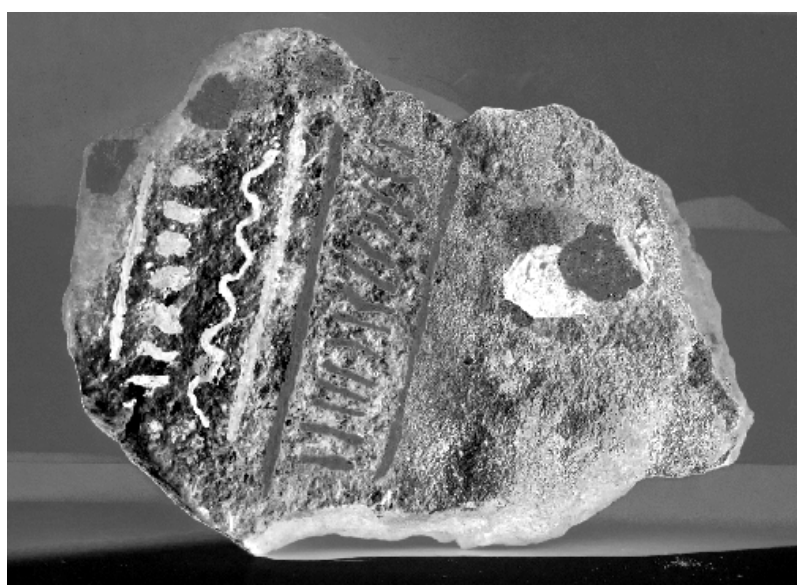

Figure 10: $\mathrm{PC} 2$ of the $\mathrm{BP}-550$ image.

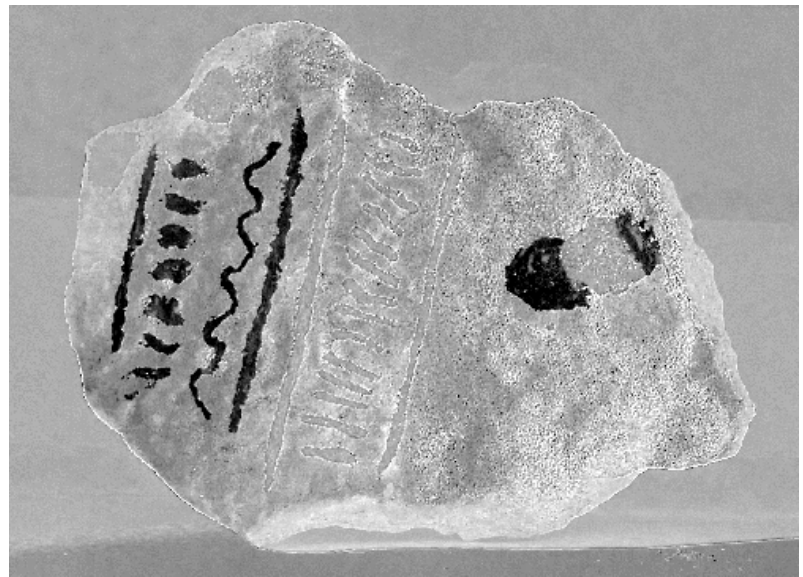

Figure 11: $\mathrm{PC} 3$ of the $\mathrm{BP}-550$ image.

\subsection{Discussion of results}

In BP-550 image, PC2 shows an iron oxide well separated from the rest of the pigments. Besides, the distinction between the pigments and the stone basis is clear. PC3 shows that the charcoal disappears, remaining manganese, what means that these two pigments are also differentiated so that they are different pigments. Hence photographing visible spectrum without splitting into bands is useful, especially when the aim is to separate either the pigment from the stone basis or separate different types of pigment. Nevertheless, it is necessary an image processing with decorrelation techniques to obtain good results.

On the other hand, with images of partial parts of the visible spectrum, one can begin to draw conclusions without applying decorrelation techniques as long as the theory that supports these images is known. The analysis of greyscale images shows that in the blue image, there are not differences between any pigments, pigments reflect the same amount of light therefore the pigments can not be differentiated. This indicates that the pigments in the blue image have a different behaviour than the rest of the images. It is necessary to ask whether this behaviour is due to its chemical composition. So, if we know the spectral behaviour of the pigments, an image that partly differentiates the visible spectrum can be very useful. 
The red image shows a differentiation of the three pigments. In order to differentiate the pigments used, the red filter is essential. Thus, the differences between these three pigments are seen as far as the recorded wavelength increases.

Therefore, in this case the division of the visible range helps users to understand the behaviour of the absorption/reflection of light in the constituent pigment materials as increases/decreases the wavelength.

Analysing the PCs of the multiband image, we can observe that charcoal disappears or attenuates in some of the principal components. PCA interprets it as a different data type. It is necessary to ask whether this is due to its chemical composition or to the pigment density on the stone. It is no possible at the moment to give the right answer. The information about the spectral response of the pigments in the visible spectrum is needed to dismiss any of the proposed options.

By comparing the results of the analysis between the greyscale images and the PCs of the multiband image, it is observed that PCA complements the analysis of the greyscale images, as it allows a higher enhancement of the pigments. Even it helps to separate painted pigments from the stone basis.

In this case both PCA (BP550 and multiband image) show detailed information about the different pigments.

\section{Conclusion}

As we have presented in this paper, digital image processing gives users the opportunity to record and analyse simulated/experimental rock art paintings in detail. The test discussed highlights the value of relatively inexpensive digital technology in recording rock art. The utilization of digital images in short wavelength ranges and the interpretation of these images related with the reflectance of the materials, allows users to establish new methodologies that might help to discover parameters such as the chemical composition of the materials.

The use of many multispectral bands (eventually hyperspectral images) can be very useful to discriminate constituent materials. The more spectral bands we consider, the more information about the pigments behaviour to light will be drawn. Nowadays, there exist a wide variety of filters available, even outside the visible region for the ultraviolet and the near infrared regions. These regions offer valuable information in the field of rock art documentation.

After the simulation and experimental analysis, more research will be devoted to contrast whether or not the results presented herein can be extrapolated to real Levantine rock art motifs composed by similar pigments and stones. Future research is devoted to analyse the behaviour of the pigments less concentrated on overlaying areas under controled lighting conditions.

\section{Acknowledgements}

The authors gratefully acknowledge the support from the Spanish Ministerio de Economía y Competitividad to the project HAR2014-59873-R.

\section{References}

ALCALDE, A.L.R., MANUEL, J., GARCÍA, V., and BERROCAL, M. C., 1998. Técnicas digitales para la elaboración de calcos de arte rupestre. Trabajos de Prehistoria, 55(1), pp. 155-169.

BRADY, L.M., \& GUNN, R.G., 2012. Digital Enhancement of Deteriorated and Superimposed Pigment Art. In Rock Art in the Digital Age, pp. 627-643.

CERRILLO-CUENCA, E., and SEPÚLVEDA, M., 2015. An assessment of methods for the digital enhancement of rock paintings: The rock art from the precordillera of Arica (Chile) as a case study. Journal of Archaeological Science, 55, pp. 197-208. DOI: 10.1016/j.jas.2015.01.006

CLOGG, P., DÍAZ-ANDREU, M., and LARKMAN, B., 2000. Digital Image Processing and the Recording of Rock Art. Journal of Archaeological Science, 27(9), pp. 837-843. DOI: 10.1006/jasc.1999.0522

DÍAZ-ANDREU, M., BROOKE, C., RAINSBURY, M., and ROSSER, N., 2006. The spiral that vanished: the application of non-contact recording techniques to an elusive rock art motif at Castlerigg stone circle in Cumbria. Journal of Archaeological Science, 33(11), pp. 1580-1587. DOI: 10.1016/j.jas.2006.02.010

DOMINGO, I., CARRIÓN, B., BLANCO, S., and LERMA, J.L., 2015. Evaluating conventional and advanced visible image enhancement solutions to produce digital tracings at el Carche rock art shelter. Digital Imaging Techniques for the Study of Prehistoric Rock Art, 2(2-3), pp. 79-88. DOI: 10.1016/j.daach.2015.01.001

GUNN, R.G., OGLEBY, C.L., LEE, D., and WHEAR, R.L., 2010. A method to visually rationalise superimposed pigment motifs. Rock Art Research, 27(2), pp. 131-136.

LE QUELLEC, J.L., DUQUESNOY, F., and DEFRASNE, C., 2015. Digital image enhancement with DStretch: Is complexity always necessary for efficiency? Digital Applications in Archaeology and Cultural Heritage, 2(2-3), pp. 5567. DOI: 10.1016/j.daach.2015.01.003

LÓPEZ-MONTALVO, E., VILLAVERDE, V., ROLDÁN, C., MURCIA, S., and BADAL, E., 2014. An approximation to the study of black pigments in Cova Remigia (Castellón, Spain). Technical and cultural assessments of the use of carbon-based black pigments in Spanish Levantine Rock Art. Journal of Archaeological Science, 52, pp. 535-545. DOI: 10.1016/j.jas.2014.09.017

MARK, R., and BILLO, E., 2002. Application of Digital Image Enhancement in Rock Art Recording. American Indian Rock Art, 28, pp. 121-128. 
MARK, R., and BILLO, E., 2006. also an increased awareness of the that several sites have been inscribed in the Robert Mark and Evelyn Billo. Mosaic A Journal For The Interdisciplinary Study Of Literature, (11), pp. 10-14.

MIDOPT., 2016. Bandpass Filters | MidOpt, Available: http://midopt.com/filters/bandpass/ [02/29, 2016]

ROGERIO-CANDELERA, M.A., 2015. Digital image analysis based study, recording, and protection of painted rock art. Some Iberian experiences. Digital Applications in Archaeology and Cultural Heritage, 2(2-3), pp. 68-78. DOI: 10.1016/j.daach.2014.11.001

ROGERIO-CANDELERA, M.A., JURADO, V., LAIZ, L., and SAIZ-JIMENEZ, C., 2011. Laboratory and in situ assays of digital image analysis based protocols for biodeteriorated rock and mural paintings recording. Journal of Archaeological Science, 38(10), pp. 2571-2578. DOI: 10.1016/j.jas.2011.04.020

VERHOEVEN, G., 2008. Imaging the invisible using modified digital still cameras for straightforward and low-cost archaeological near-infrared photography. Journal of Archaeological Science, 35(12), pp. 3087-3100. DOI: 10.1016/j.jas.2008.06.012

VERHOEVEN, G.J., and SCHMITT, K.D., 2010. An attempt to push back frontiers - digital near-ultraviolet aerial archaeology. Journal of Archaeological Science, 37(4), pp. 833-845. DOI: 10.1016/j.jas.2009.11.013

VICENT, J.M., MONTERO, I., RODRÍGUEZ, Á.L., MARTíNEZ, MAI., and CHAPA, T., 1996. Aplicación de la imagen multiespectral al estudio y conservación del arte rupestre postpaleolítico. Trabajos de Prehistoria, 53(2), pp. 19-35. 


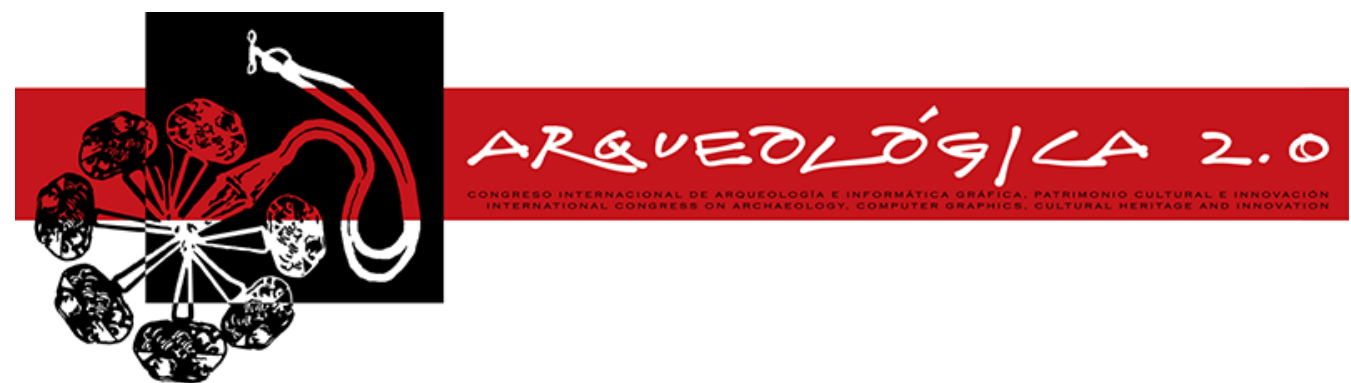

Proceedings of the $8^{\text {th }}$ International Congress

on Archaeology,

Computer Graphics,

Cultural Heritage and Innovation

'ARQUEOLÓGICA 2.0'

in Valencia (Spain),

Sept. $5-7,2016$

DOI: http://dx.doi.org/10.4995/arqueologica8.2016.3561

Received: $07 / 03 / 2016$

Accepted: 07/05/2016

\title{
REVIEW OF AUGMENTED REALITY AND VIRTUAL REALITY TECHNIQUES IN ROCK ART
}

\author{
REVISIÓN DE LAS TÉCNICAS DE REALIDAD AUMENTADA Y REALIDAD VIRTUAL EN EL ARTE RUPESTRE \\ Silvia Blanco-Pons*, Berta Carrión-Ruiz, José Luis Lerma \\ Photogrammetry \& Laser Scanning Research Group (GIFLE), Department of Cartographic Engineering, Geodesy and Photogrammetry, \\ Universitat Politècnica de València, 46022 Valencia, Spain. silblapo@doctor.upv.es; bercarru@doctor.upv.es; illerma@cgf.upv.es
}

\begin{abstract}
:
The usage of augmented reality (AR) and virtual reality (VR) technologies began to grow when smartphones appeared. Until then, the number of portable devices capable of incorporating these technologies was reduced. Video games are the main field where these technologies are applied, but in other fields such as in archaeology, these technologies can offer many advantages. Ruins reconstruction, ancient life simulation, highly detailed 3D models visualisation of valuable objects from the past or even user free movement in missing places are just some examples found in literature.

This paper reviews the latest visualisation technologies and their applicability to the rock art field. The main purpose is to disseminate rock art paintings through AR and VR applications. After the image-based three-dimensional (3D) modelling is obtained, an interactive visit to a shelter for displaying rock art paintings is presented. This is one of examples developed in this paper that pretends to apply the revised AR and VR techniques. In addition, an example of AR is developed that can be easily adapted to further applications displaying rock art paintings.
\end{abstract}

Key words: augmented reality, virtual reality, 3D reconstruction, cultural heritage, Oculus Rift, Unity, rock art paintings

\section{Resumen:}

El uso de las tecnologías de realidad virtual (RV) y realidad aumentada (RA) comenzó a crecer con la aparición de los teléfonos inteligentes. Hasta entonces, había pocos dispositivos portátiles capaces de incorporar estas tecnologías. Principalmente estas tecnologías se aplican en la creación de videojuegos, aunque en otros campos como la arqueología, estas tecnologías tienen mucho que ofrecer. Con estas tecnologías es posible mostrar la reconstrucción de ruinas, la simulación de otra época, modelos 3D altamente detallados de objetos de valor del pasado o incluso trasladar al usuario a lugares que ya no existen.

Este trabajo presenta una revisión de las últimas tecnologías de visualización y su aplicabilidad en el campo del arte rupestre, con el objetivo de divulgar las pinturas rupestres a través de aplicaciones de RA y RV. Después del modelado 3D basado en imágenes, se presenta una visita interactiva a un refugio para la visualización de las pinturas rupestres. Este es uno de los ejemplos desarrollados en este trabajo que pretende aplicar las técnicas revisadas de RA y RV. Además, se detalla un sencillo ejemplo de RA que puede fácilmente adaptarse a otras aplicaciones que muestren pinturas rupestres.

Palabras clave: realidad aumentada, realidad virtual, reconstrucción 3D, patrimonio cultural, Oculus Rift, Unity, pinturas rupestres

\section{Introduction}

The International Council on Monuments and Sites (ICOMOS) defines cultural heritage as follows:

"Cultural Heritage is an expression of the ways of living developed by a community and passed on from generation to generation, including customs, practices, places, objects, artistic expression and values. Cultural Heritage is often expressed as either Intangible or Tangible Cultural Heritage"(ICOMOS 2002).

Tangible cultural heritage is formed by features such as buildings, structures, art works, documents, artefacts and rock art paintings. It is everyone's responsibility to understand, appreciate and conserve the cultural heritage. For this purpose, this paper describes new

`Corresponding Author: Silvia Blanco-Pons, silblapo@doctor.upv.es 
ways to understand and disseminate the cultural heritage, and specifically, rock art paintings, based on the fast development of both augmented reality (AR) and virtual reality (VR) technologies. These new technologies allow users to show highly accurate 3D models of tangible cultural heritage through realistic immersive environments.

$A R$ is a visualisation technique in which virtual contents such as 3D models, text, video and other multimedia formats, are placed on top of the real world camera view (Kounavis et al. 2012). The user simultaneously can perceive the real environment and virtual elements overlaid in real time. AR technology provides a new way to show the cultural heritage. An example of this is Archeoguide (Vlahakis et al. 2002). It offers AR tours of archaeological sites and uses this technique to enhance information presentation, reconstruct ruined sites and simulate ancient life.

Nowadays, AR technology is used in many fields, such as entertainment, education or medicine but, it is also used in the tourism sector to enrich and enhance the user experience. There are several examples making use of this approach. An AR museum guide is presented by Miyashita et al. (2008). This AR guide provides the visitor a basic knowledge of some artworks and drives the visitor through the exhibition. Another example is described by Gutierrez et al. (2015) who presented an AR application to release information about historical graffiti in the Temple of Debod.

VR technology immerses completely users in a virtual world, a world created by computers. The difference between these two technologies is that while AR technology combines the virtual world with the real world, VR only shows virtual elements. VR offers the possibility to visit inaccessible sites or sites that no longer exist. The visualization process of the generated VR is carried out through head-mounted displays (HMD). These HMD have dramatically improved and nowadays are lightweight glasses. An example of this is the virtual reality glasses Oculus Rift, developed by Oculus VR. Although this last generation of HMD is focused on the field of gaming and entertainment, its application in other fields is worth mentioning. Specifically in the field of medicine, Draganov and Boumbarov (2015) investigate a medical assistive system for motor disabled patients through an Oculus Rift VR Display. Other research is focused on disseminating the cultural heritage content through the virtual reconstruction of a typical theatre of the time (Valtolina et al. 2005) or through a 3D virtual museum tour of the Santa Maria Della Scala using the Oculus Rift (Fineschi and Pozzebon 2015).

Both 3D visualisation techniques are quite similar. VR users go into a completely immersive virtual world outside of the real world, meanwhile AR users stay in a semi-immersive environment where they can interact with virtual objects around them in the real world.

In the 1950s appeared the first VR system, but until recently these technologies were rarely used. The user had to carry a computer and a HMD as well as a GPS, webcam, wireless LAN and other components. This hardware was complex and heavy. Besides hardly accessible for the majority of users. Nowadays, the breakthrough in mobile technologies and information technology (IT) infrastructure has allowed the growth of these technologies, especially with smartphone development. A smartphone is a small computer that is fully equipped with a variety of devices such as GPS, wireless internet, Bluetooth, high resolution video camera, accelerometers, gyroscopes, digital compass, barometer, proximity sensors, and other components. Due to hardware features, the smartphones have emerged as potential platforms for implementing mobile AR and VR (Kim et al., 2014). The user is acquainted with the use of a smartphone as a tool for its daily tasks. Furthermore, it is a friendly and portable device. For all these reasons, the smartphone is a perfect tool to implement these kinds of visualization technologies.

The following sections describe AR and VR technologies in detail, and also the current 3D frameworks and processes to develop an application. To test these solutions a smartphone app is developed that aims to teach and disseminate rock art paintings located in an inaccessible shelter.

\section{AR technology}

In the first AR systems, the user used to carry a computer and a HMD, and this entailed many limitations. Firstly, the hardware was uncomfortable and not very portable. Secondly, the HMD used to interrupt the user's natural view and prone to cause discomfort such as nausea or dizziness. Finally, AR systems implementation for that particular hardware required much time and effort from the developers (Kim et al. 2014).

These limitations were improved with the appearance and fast evolution of the smartphones. Nowadays there are powerful smartphones on the market which work as a computer and HMD. As a consequence, the user does not have to carry special hardware and improves users' mobility. Therefore, at present there are many mobile AR applications (apps) on the market.

A mobile AR app consists in overlaying digital information onto the real world. The digital information is shown through the smartphone camera and is placed in a specific position. There are different ways to position information, such as mobile location. All current smartphones are equipped with GNSS localization systems and orientation sensors, among others.

The orientation sensor obtains information by processing the raw sensor data from the accelerometer and the geomagnetic field sensor. The orientation sensor provides the azimuth (degrees of rotation around the $z$ axis), pitch (degrees of rotation around the $x$ axis) and roll (degrees of rotation around the $y$ axis) values. These values set out the direction of the device.

When a smartphone is placed in a location with known coordinates and orientation, the digital information is visualised on the camera. The disadvantage of this method is the accuracy of the GNSS positioning. In areas with tall buildings or with many trees, the signal bounces off and accuracy decreases. If it occurs, the digital information will be badly placed. Besides, this system does not work inside buildings.

Another way of showing the digital information is through the use of markers. A marker is a square frame made up of a light coloured usually white, surrounded by a dark coloured, usually black. Each marker is formed by a 
different pattern which makes them unique. For example, in the Vuforia markers the unique ID is encoded into a binary pattern along the border of the marker image (Fig. 1). In marker recognition process, first smartphone camera collects and processes the images in real time with aim of finding a pattern known. The image recognition techniques are based on finding patterns of known shapes, colour detection, geometries and repeated patterns. When a maker is detected, the virtual information overlaps on the camera.

Finally, using images or objects instead of markers is possible. This is known as Natural Feature Tracking (NFT). NFT allows users to recognise and track natural features on images and objects. This is very useful because it can be used for example, in advertising to augment the images of a brochure.

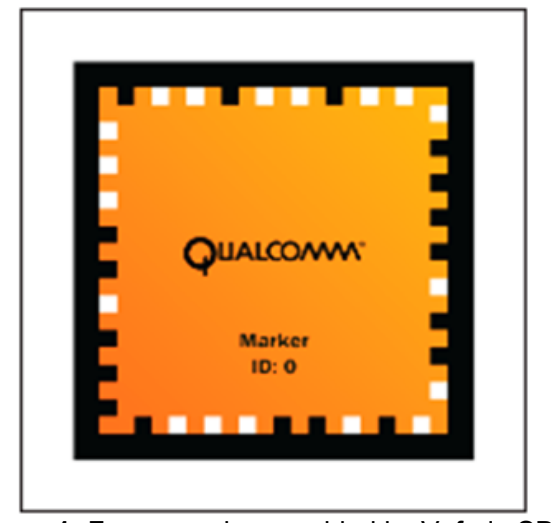

Figure 1: Frame marker provided by Vuforia SDK.

The digital information can be of any type, such as $2 \mathrm{D}$ images, 3D models, text, animation, video, music, etc. This opens up the possibility of creating many and varied applications. Carmigniani et al. (2011) review the main AR apps. In advertising, it is used to promote new products online. In entertainment and education, AR is applied to develop cultural learning games, which are games with educational purposes. In medicine, AR apps are utilized to assist surgery achieving thus, a minimum invasive surgery with improved precision, dexterity, and visualisation.

Nowadays, AR development apps is easier than some years ago. An advantage is that everybody is able to create apps for the same hardware (smartphone). This enables to advance towards best app development due to large number growth of software frameworks. A framework generally provides some base functionality which can be used and extend to make more complex applications from. The main advantages for using frameworks are: they provide an overall application structure, they facilitate the collaboration between developers, and there are many available tools and libraries adapted to frameworks.

At present, there are many available frameworks to develop easily AR applications. The choice of one or another depends on application functionality and eventually the OS used. Kounavis et al. (2012) show some of the publicly available frameworks. In this paper, current free solutions have been analysed and are presented below:

- ARToolkit is an open source AR library for iOS, Android, Linux, Windows, Mac OS $X$ and it has a plug-in for Unity3D. Includes OpenGL ES2.x support, integration with GPS and compass, and automatic camera calibration utilities. It offers marker detection, multimarker tracking and natural feature tracking (NFT). Furthermore it features extensive documentation, examples and tutorials. Includes development for Smart Glasses (ARToolKit 2016).

- $\quad$ BeyondAR is an open source AR framework based on mobile location for Android (BeyondAR 2016).

- DroidAR is an open source AR framework for Android only, it features location based $A R$ and recognition markers (DroidAR 2016).

- Mixare is an open-source AR engine for Android and iPhone, which displays Wikipedia points of interest (POIs) of the surroundings and lets you add your own POls database (Mixare 2016).

- Vuforia is an AR software development kit (SDK) for Android and iOS as well as digital eyewear, and it also offers an extension for Unity3d. Vuforia provides great recognition capabilities as recognises objects, images, cylinders, text, boxes and frame markers. Also includes background effects, video playback, virtual buttons and occlusion management. Actually, Vuforia has free and commercial license (Vuforia 2016).

Table 1 summarizes current free features on AR frameworks. This list changes very fast since many frameworks stop being maintained and are outdated quickly or end up being bought by big companies such as Metaio SDK recently acquired by Apple. The most complete and easy to use tools are Vuforia and ARToolKit but if the goal is to make a location based app will have to choose another frameworks presented.

Table 1: Summary of AR frameworks.

\begin{tabular}{|c|c|c|c|c|}
\hline & Operating System & $\begin{array}{l}\text { Location } \\
\text { Based }\end{array}$ & $\begin{array}{l}\text { Marker } \\
\text { Based }\end{array}$ & $N F T$ \\
\hline ARToolkit & $\begin{array}{l}\text { iOS, Android, } \\
\text { Linux, Windows, } \\
\text { Mac OS X and } \\
\text { Unity 3D }\end{array}$ & & $X$ & $x$ \\
\hline BeyondAR & Android & $x$ & & \\
\hline DroidAR & Android & $x$ & $x$ & \\
\hline Mixare & $\begin{array}{l}\text { Android and } \\
\text { iPhone }\end{array}$ & $x$ & & \\
\hline Vuforia & $\begin{array}{c}\text { Android, iOS and } \\
\text { Unity 3D }\end{array}$ & & $x$ & $\mathrm{X}$ \\
\hline
\end{tabular}

Finally, and to conclude, AR apps are experiencing rapid development and their applications are endless. In addition, these enhance reality users' perception and surrounding environment. In this way, information becomes interactive and easily manipulated digitally.

\section{VR technology}

Although $A R$ and $V R$ are quite similar technologies, both represent different realities. While AR adds elements to the reality, VR creates a new reality that does not exist. VR is an artificial environment created with software and 
presented to the user such as a real environment. The VR is represented in a 3D image that can be explored interactively, by means of gloves with sensors, controls such as a game console or a computer mouse so that image content moves in any direction or zooms in/out.

The VR applications (apps) require using a HMD, such as glasses, to visualise the virtual environment. The first systems of VR needed a complex HMD and the graphics quality was very low. Nowadays, thanks to the technological advances, the HMD has evolved considerably and there are currently powerful solutions in the market such as Oculus Rift (Oculus Rift 2016). The Oculus Rift is a VR HMD developed by Oculus VR. Its operation is based on the stereoscopic vision (imitating natural vision). The stereoscopic vision is any technique capable of collecting 3D visual information and creates the illusion of depth in an image.

In the natural stereo vision, the eyes, due to their separation (interpupillary distance), obtained two images with small differences between them. These differences are processed in the brain to produce depth perception.

The HMD projects a stereoscopic vision. The screen displays two images side by side, one for each eye. A small controller on the basis of the display is used to adjust the interpupillary distance. The eyes separation varies between individuals and is an important element to give a realistic sense of stereoscopic vision. The HMD feature a virtual surround sound system and sensors that control the movements of the user's head and adjust the picture accordingly. For the time being, this device is intended to connect the computer and the smartphone.

This type of totally immersive 3D vision makes some users experience effects such as motion sickness and headaches. To avoid this, it is necessary to adjust the lens to each person vision, but even so, prolonged use might cause discomfort.

Visualising the VR with a HMD is sometimes a bit annoying. However, it is possible to create a semiimmersive app where the $3 \mathrm{D}$ model is shown in the mobile display and the user can interact with it through the touch screen.

There are some frameworks that allow users to load 3D models and interact with them. These frameworks are useful to create simple semi-immersive apps. However, the best solution is a game engine in order to work with 3D models and for rendering, creating animations, and so on. A game engine is a software framework designed for the creation and development of video games ready to be used on multiple platforms. The engine primary components are rendering, loading, animation, collision detection between objects, physics, inputs, GUI (Graphic User Interface) and Al (Artificial Intelligence). Besides, the game engine has other tools that make the actual game: characters and terrains, real world object behaviors, etc. (Paul et al. 2012). The game engine includes all the required tools to create a virtual reality app. In addition, many game engines incorporate stereoscopic vision.

\section{Some frameworks that handle 3D models are:}

Mind3d is a lightweight 3D library/framework for Android based on OpenGL ES v1.0/1.1. It provides the tools to load an .obj, .m2d and .3ds files and add functionality. Nowadays it is not maintained.
- Rajawali is a 3D framework for Android based on OpenGL ES 2.0/3.0. Compatible with the Google Cardboard SDK v0.6.0 and includes full documentation and tutorials.

The disadvantage is that these before-mentioned frameworks are only compatible with Android and it is difficult to develop apps for inexperienced programmers. On the other hand, the game engine is the best solution to create a virtual environment and develop basic functionality.

Currently, the most popular game engines are Unity, Unreal Engine 4 and CryENGINE. These game engines are extremely powerful and each one has its advantages and disadvantages, but all are compatible with VR glasses. Unity (Unity Manual 2016) is the easiest to use and is compatible with all mobile platforms, but the graphics quality is inferior and does not allow real-time modeling. Unreal Engine 4 (Unreal-Engine 2016) has incredible graphics capabilities, allows hyper-realistic scenes generation and it is simple to use but it is only compatible with iOS and Android. Finally, CryENGINE (CryEngine 2016) is more suitable for expert developers as the learning curve of this engine is elevated but graphics quality is very high. Table 2 summarizes the principal features of these game engines.

Table 2: Summary of game engines.

\begin{tabular}{|c|c|c|c|}
\hline & $\begin{array}{c}\text { Mobile } \\
\text { platforms }\end{array}$ & Other platform & $\begin{array}{l}\text { Language } \\
\text { Support }\end{array}$ \\
\hline CryENGINE & & $\begin{array}{c}\text { PC, PlayStation, } \\
\text { Xbox, VR }\end{array}$ & $\begin{array}{l}\text { C++, Lua, } \\
\text { C\#. }\end{array}$ \\
\hline Unity & $\begin{array}{l}\text { Android, } \\
\text { iOS, } \\
\text { Windows }\end{array}$ & $\begin{array}{l}\text { PC, PlayStation, } \\
\text { Xbox, Wii, 3DS, } \\
\text { VR, TV, Web }\end{array}$ & $\begin{array}{l}\text { JavaScript, } \\
\text { C \# and Boo }\end{array}$ \\
\hline $\begin{array}{c}\text { Unreal } \\
\text { Engine } 4\end{array}$ & $\begin{array}{l}\text { Android, } \\
\text { iOS, }\end{array}$ & $\begin{array}{l}\text { PC, PlayStation, } \\
\text { Xbox, VR }\end{array}$ & $\mathrm{C}++$ \\
\hline
\end{tabular}

\subsection{Process to develop a VR app}

The process of creating a virtual world requires more time than for one AR app as a complete environment must be created by the computer.

The process followed in this paper is divided into three phases: 1) Modelling and texturing the virtual element; 2) Environment creation; and 3) Interactive scripting. Unity was chosen to carry out these phases due to its compatibility with multiple platforms. Unity is a crossplatform used to develop games and interactive worlds in $3 \mathrm{D}$ and $2 \mathrm{D}$ for PC, consoles, mobile devices, VR and websites.

The main features of the Unity game engine are:

- $\quad$ Dedicated tools for creating 2D and 3D content.

- Importation of models and animations made with other 3D applications such as Blender, Maya, 3DS Max and Cinema 4D.

- Easy programming through a variety of scripting languages and a comprehensive documentation.

- The inclusion of a physics engine which enables users to create a convincing physical behaviour. In this way, the objects in the scene will be affected by collisions, gravity and other forces. 
Although Unity is focussed in the design and development of video games, it is a complete tool to create interactive $3 \mathrm{D}$ environments and smartphone apps.

\subsubsection{Modelling and texturing the virtual elements}

Any application that requires showing a real environment as a virtual tour, involves the generation of a realistic 3D model. Typical examples are ruins reconstruction (Vlahakis et al. 2002), the museum interior (Fineschi and Pozzebon 2015; Miyashita et al. 2008), an interesting cultural monuments or shelters rock art paintings. In order to create an accurate and detailed 3D model, it is recommended to use photogrammetry or terrestrial laser scanning techniques (Pavlidis et al. 2007).

Photogrammetry enables accurate measurements and 2D and 3D reconstructions of all types of existing objects using images at different scales. Through structure from motion (SfM) algorithms, it is possible to obtain accurate $3 \mathrm{D}$ models quickly and easily. Only overlapping images from multiple perspectives are needed and dense 3D point clouds with real texture are generated automatically in a few minutes (Furukawa and Ponce 2010; Micheletti et al. 2015).

Laser scanning is an efficient, high-precision and ultrafast active remote sensing technique used to acquire dense 3D point clouds (Lerma et al. 2008). These instruments can generate quickly vast amounts of $3 \mathrm{D}$ data. The usage of laser scanner is justified mainly for objects, monuments and sites with complex geometry.

Both photogrammetry and laser scanning techniques can be used to generate dense $3 \mathrm{D}$ point clouds from which real texture can be draped. In order to use these data in apps, it is necessary to convert the point clouds into more practical triangular meshes. This is possible with commercial as well as with open source software.

Another possibility to generate a simple $3 D$ model is through CAD tools. CAD software is recommended in order to create simple 3D models since planar features are requested for simplified 3D modelling. The planes are imported into the software and all surfaces must be converted to solid objects as far as the extrusion command is available. Finally, a texture must be added to the surface of the object.

\subsubsection{Environment creation}

Once the 3D model is generated it should be placed in a real environment to add more realism. Unity includes several tools for this purpose such as terrains on which positioning the object, different lights to illuminate the scene, skyboxes and atmospheric effects.

\subsubsection{Interactive scripting}

In order to create an interactive scene, Unity provides programing scripts in either C\#, JavaScript or Boo. In this phase, physical properties should be added to the objects with Unity physics engine tools. The most important is the "Mesh Colliders". This property ensures the player will not be able to walk through the created walls. Besides, the interaction with the elements of the scene (e.g. opening a door, moving an object...) must be developed through scripts.

\section{Case studies}

Two simple apps are developed in order to test both AR and VR technologies. In example 1, an AR app is developed to show an augmented globe. The goal is to know the steps to perform a complete AR app that might be expanded to disseminate rock art. In example 2, an interactive app is developed with the aim to show through a virtual tour, rock art paintings located in areas with limited access.

\subsection{Example 1: The Augmented Globe}

The application was developed using Vuforia SDK for Unity. The process followed to create an AR app is very simple. First, a frame marker is added to the scene. The app will use it to place the elements of AR. Then, the virtual elements (augmented elements) are added. On this application is used a simple object such as a globe. The object geometry is very simple (a sphere); it can be created in Unity. Creating complex models with other image-based, range-based or CAD software and import the results into Unity is also possible. In order to improve the realism effect on the object, a texture is projected onto it. Finally, to visualize the object, a light is added to the scene. Furthermore, a simple script is developed to make the sphere turning around. With these steps, it is possible to visualise an object through smartphone camera pointing towards a frame marker (Fig. 2a) and then the augmented globe will be displayed (Fig $2 b$ ).

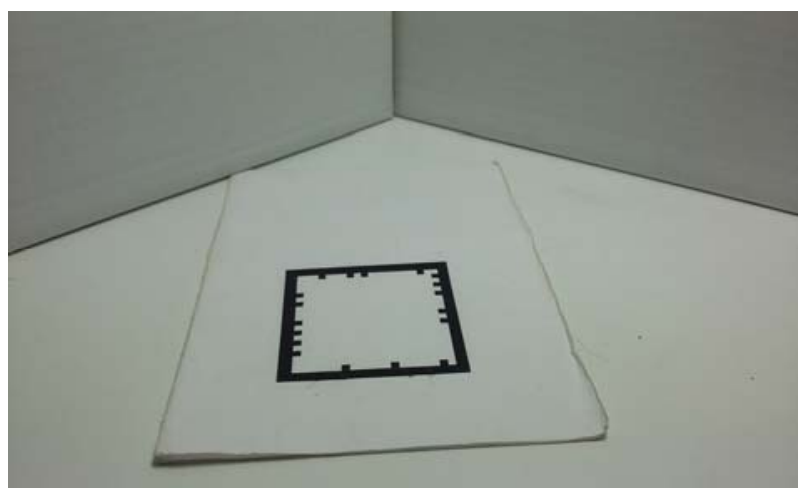

a)

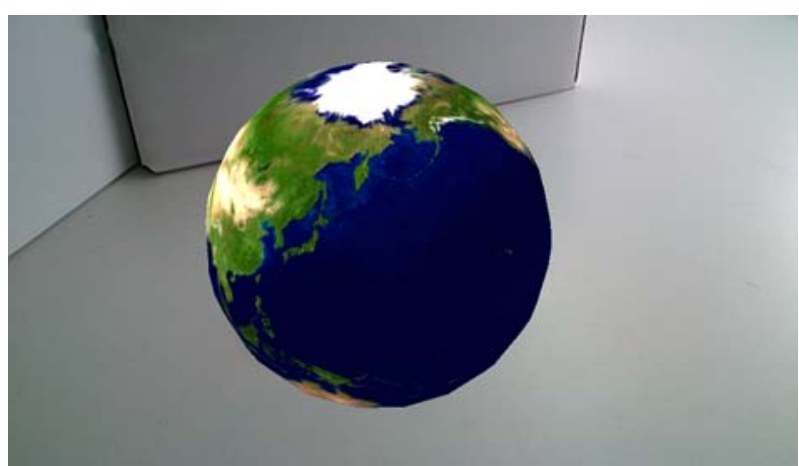

b)

Figure 2: Smartphone screenshots: a) screenshot before the augmented globe; b) screenshot with the augmented globe.

Using Vuforia SDK and Unity software, the steps to develop AR apps are pretty simple. This AR app can be adapted to another project after changing the virtual object to be shown. 
In the rock art field, an app of this type can be used to teach and disseminate rock art paintings. This simple example can be used to create an application that, instead of displaying a 3D object, displays e.g. 2D images of rock art motifs. Through a smartphone camera, the rock art motifs can be projected onto a wall in real size. This app makes possible to show in a comfortable way, rock art paintings that cannot be visited, or that are hardly visible.

\subsection{Example 2: Interactive visit to a rock art shelter}

Many interesting rock art paintings are located in rugged mountains and access to the public is either difficult or limited. In other cases, the rock art sites are closed to the public for protection and conservation, and the visitors are not allowed to visit them. For this reason, the aim of this example is to create an app where the user can make a complete virtual visit to a site.

For this example were tested two different frameworks: Unity game engine and min3d. Each can be used for a different purpose as already explained. In both cases, the first part of the process involves obtaining the 3D model.

The 3D model of a shelter was obtained from multiple images by means of SfM approaches. A point cloud of low density was created (Fig. 3a). Obtaining the 3D model using CAD tools is impossible due to complexity of its shape. On the other hand, the laser scanning is ruled out as it generates point clouds too big for a mobile application. An important limitation in this type of application is the generated 3D model size. Most of the times, it will be necessary to simplify the $3 D$ model to reduce its size.

The triangular mesh has been created using MeshLab. First normal vectors associated with each vertex are determined. Using the original point cloud with the computed normals, a surface reconstruction at the highest resolution is created. Finally, the texture from the colour images is generated after draping the images onto the 3D model. Following this way, a photorealistic 3D model of great detail and with texture is achieved (Fig. 3b).

The 3D model is imported to Unity to create a surrounding environment. The shelter is located on a rugged terrain on the hillside of a mountain. In Unity, with terrain tool, a similar terrain is created and the scene is illuminated with some lights. Finally, to give greater realism to the scene a sky is added through the skybox tool. The skybox is a complete wrapper around the scene which can be edited for changing the colour, exposure, adding clouds, etc.

The user has to move around the scene for the virtual tour. Unity has a standard asset (3D object motion script) for first person characters. Once added the first character into the scene, a person is be able to move in all directions within the project. It is possible to obtain the stereoscopic vision using the Oculus Rift SDK for Unity.

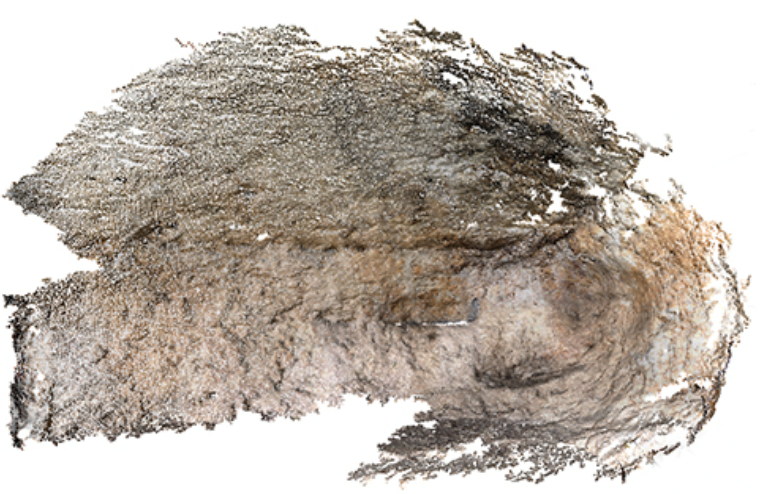

a)

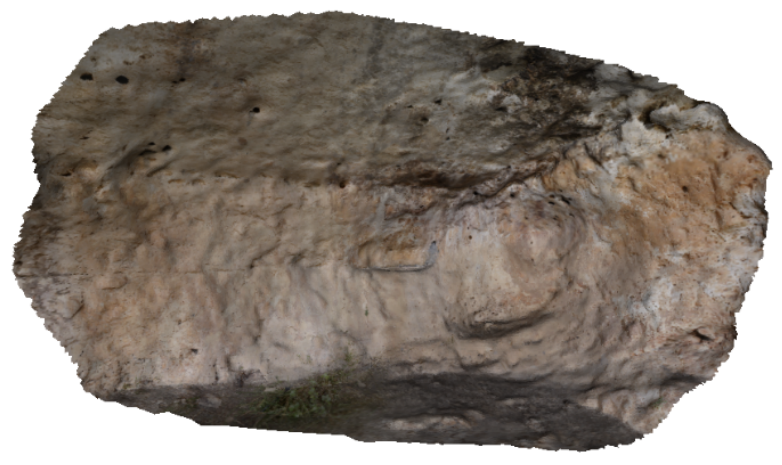

b)

Figure 3: The interior of a shelter: a) 3D point cloud; b) photorealistic 3D model.

Since not everyone has virtual reality glasses, a version for smartphones has been created through mind3d framework. In this version, the user will see on the smartphone screen the shelter 3D model and the rock art paintings. Besides the user is able to move in all directions and zoom with touching gestures. Figure 4 shows a app screenshot where the photorealistic model is visualised. The icon home returns home, and two icons allow users to zoom in/out. Additional icons are presented in other scenes to localise and how to reach the site, to get historical values as well as neat depictions of the rock art paintings.

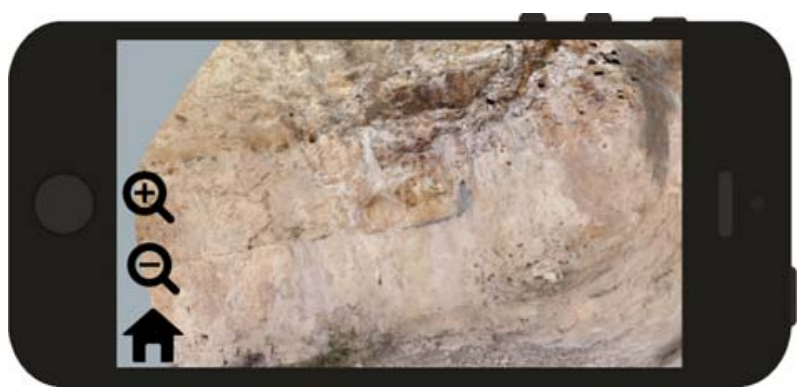

Figure 4: Smartphone screenshot.

\section{Conclusions}

This paper reviews the latest technologies for 3D models visualisation. These technologies provide the user real and enriching experiences for the visualisation of 3D objects. Besides, the amount of possible fields that can benefit from these technologies is very great. 
Specifically, these technologies have been applied in the rock art field.

In future research, the user response to this type of applications will be discussed. These apps, particularly those involving the use of a VR glasses, can cause discomfort and inconvenience to some users. Therefore, some users may either prefer AR apps or display 3D models using the mobile screen.

On the other hand, the creation of photorealistic 3D model is just the first step. Creating complex and/or very large models can be approached with image-based photogrammetric techniques. Nevertheless, the point clouds obtained are so big that the hardware of a mobile phone does not support them. Therefore, optimisation of 3D models is crucial to create photorealistic models for smartphone apps. Enriching the apps with additional user friendly tools is a step that will be developed in the new future.

\section{Acknowledgements}

The authors gratefully acknowledge the support from the Spanish Ministerio de Economía y Competitividad to the project HAR2014-59873-R.

\section{References}

ARTOOLKIT, 2016. Open source augmented reality sdk | Artoolkit.org, [online] Available from: http://artoolkit.org/ (Accessed 26 May 2016).

BEYONDAR, 2016. Home | Beyondar, [online] Available from: http://beyondar.com/ (Accessed 26 May 2016).

CARMIGNIANI, J., FURHT, B., ANISETTI, M., CERAVOLO, P., DAMIANI, E. and IVKOVIC, M., 2011. Augmented reality technologies, systems and applications. Multimedia Tools and Applications, 51(1), pp. 341-377.

CRYENGINE, 2016. Cryengine, [online] Available from: https://www.cryengine.com/features (Accessed 26 May 2016).

DRAGANOV, I. R. and BOUMBAROV, O. L., 2015. Investigating Oculus Rift Virtual Reality Display Applicability to Medical Assistive System for Motor Disabled Patients. The 8th IEEE International Conference on Intelligent Data Acquisition and Advanced Computing Systems: Technology and Applications, pp. 751-754.

DROIDAR, 2016. DroidAR by bitstars, [online] Available from: https://bitstars.github.io/droidar/ (Accessed 26 May 2016)

FINESCHI, A. and POZZEBON, A., 2015. A 3d virtual tour of the santa maria della scala museum complex in siena. Italy , based on the use of oculus rift hmd in 3D Imaging (IC3D), 2015 International Conference on, no, pp. 1-5.

FURUKAWA, Y. and PONCE, J., 2010. Accurate, Dense, and Robust Multiview Stereopsis. Pattern Analysis and Machine Intelligence, IEEE Transactions on, 32(8), pp. 1362-1376.

GUTIERREZ, J. M., MOLINERO, M. A., SOTO-MARTíN, O. and MEDINA, C. R., 2015. Augmented Reality Technology Spreads Information about Historical Graffiti in Temple of Debod. Procedia Computer Science, 75(Vare), pp. 390397, [online] Available from: http://www.sciencedirect.com/science/article/pii/S1877050915037230.

ICOMOS, 2002. ICOMOS International Cultural Tourism Charter: Principles And Guidelines For Managing Tourism At Places Of Cultural And Heritage Significance. ICOMOS International Cultural Tourism Committee.

KIM, S. L., SUK, H. J., KANG, J. H., JUNG, J. M., LAINE, T. H. AND WESTLIN, J., 2014. Using Unity 3D to facilitate mobile augmented reality game development. Internet of Things (WF-loT), 2014 IEEE World Forum on, pp. 21-26.

KOUNAVIS, C. D., KASIMATI, A. E. and ZAMANI, E. D., 2012. Enhancing the tourism experience through mobile augmented reality: Challenges and prospects. International Journal of Engineering Business Management, 4(1), pp. 1-6, [online] Available from: http://www.scopus.com/inward/record.url?eid=2-s2.084867603283\&partnerID=40\&md5=8becc612102fd33899bf0a52ead7ae38.

LERMA, J. L., SANTANA, M., HEINE, E. and GENECHTEN, B. VAN, 2008. Theory and practice on terrestrial laser scanning. Training material bases on practical applications. Lerma García, J. L., Santana Quintero, M., Heine, E., and Genechten, B. Van (eds.), Valencia, Editorial Universitat Politècnica de València.

MICHELETTI, N., CHANDLER, J. H. and LANE, S. N., 2015. Structure from Motion ( SfM ) Photogrammetry. Geomorphological Techniques, 2, pp. 1-12.

MIXARE, 2016. Mixare | Free Open Source Augmented Reality Engine, [online] Available from: http://www.mixare.org/ (Accessed 26 May 2016).

MIYASHITA, T., MEIER, P., TACHIKAWA, T., ORLIC, S., EBLE, T., SCHOLZ, V., GAPEL, A., GERL, O., ARNAUDOV, S. and LIEBERKNECHT, S., 2008. An augmented reality museum guide. Proceedings - 7th IEEE International Symposium on Mixed and Augmented Reality 2008, ISMAR 2008, pp. 103-106.

OCULUS-RIFT, 2016. Oculus Rift, [online] Available from: https://www.oculus.com/en-us/rift/ (Accessed 26 May 2016 ).

PAUL, P. S., GOON, S. and BHATTACHARYA, A., 2012. History and comparative study of modern game engines. International Journal of Advanced Computed and Mathematical Sciences, 3(2), pp. 245-249.

PAVLIDIS, G., KOUTSOUDIS, A., ARNAOUTOGLOU, F., TSIOUKAS, V. and CHAMZAS, C., 2007. Methods for 3D digitization of Cultural Heritage. Journal of Cultural Heritage, 8(1), pp. 93-98, [online] Available from: http://www.sciencedirect.com/science/article/pii/S129620740600121X. 
UNITY-MANUAL: UNITY MANUAL, 2016. Unity-Manual: Unity Manual, [online] Available from: http://docs.unity3d.com/Manual/UnityManual.html (Accessed 24 February 2016).

UNREAL-ENGINE, 2016. Unreal Engine Technology | Home [online] Available from: https://www.unrealengine.com/blog (Accessed 26 May 2016).

VALTOLINA, S., FRANZONI, S., MAZZOLENI, P. and BERTINO, E., 2005. Dissemination of Cultural Heritage Content through Virtual Reality and Multimedia Techniques: A Case Study. 11th International Multimedia Modelling Conference, $\quad$ pp. 214-221, [online] http://ieeexplore.ieee.org/lpdocs/epic03/wrapper.htm?arnumber=1385994.

VLAHAKIS, V., IOANNIDIS, N., KARIGIANNIS, J., TSOTROS, M., GOUNARIS, M., STRICKER, D., GLEUE, T., DAEHNE, P. and ALMEIDA, L., 2002. Archeoguide: An augmented reality guide for archaeolog sites. IEEE Computer Graphics and Applications, 22(5), pp. 52-60.

VUFORIA, 2016. Home | Vuforia, [online] Available from: http://www.vuforia.com/ (Accessed 26 May 2016). 


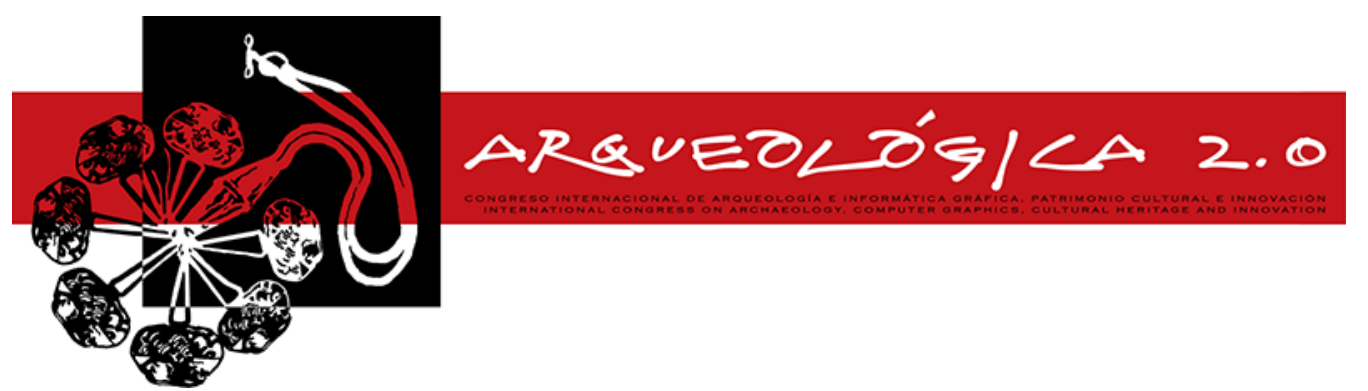

Proceedings of the $8^{\text {th }}$ International Congress

on Archaeology,

Computer Graphics,

Cultural Heritage and Innovation

'ARQUEOLÓGICA 2.0'

in Valencia (Spain),

Sept. 5-7, 2016

DOI: $\underline{\text { http://dx.doi.org/10.4995/arqueologica8.2016.3562 }}$

\title{
MODELIZACIÓN Y SIMULACION DE LAS POSIBLES POSICIONES DE LAS ATALAYAS DE LA FORTALEZA DE LA MOTA EN ALCALA LA REAL, MEDIANTE TECNICAS DE ANALISIS VISUAL
}

\section{MODELING AND SIMULATION OF POSSIBLE POSITIONS OF THE WATCHTOWER NETWORK OF THE MOTA FORTRESS IN ALCALA LA REAL, USING VISUAL ANALYSIS TECHNIQUES}

\author{
Francisco J. Rosales ${ }^{*}$ José Luis Pérez-García, Carlos Colomo, José M. Gómez-López, Manuel A. \\ Ureña
}

Departamento de Ingeniería Cartográfica, Geodésica y Fotogrametría, Escuela Politécnica Superior de Jaén, Campus de las Lagunillas, Universidad de Jaén s/n, 23071 Jaén, España. fira0004@red.ujaen.es, ilperez@ujaen.es; cmcj0002@red.ujaen.es; iglopez@ujaen.es; maurena@ujaen,es

\begin{abstract}
:
The cultural heritage plays a very important role in the Smart management of an area, and geospatial technologies are a perfect tool for the heritage knowledge, management and analysis. Photogrammetry, UAV systems and geographic information systems, can help in cataloguing the cultural heritage of a city. The main turistic value for Alcalá la Real, is the Monumental Group of the Fortress of La Mota and their related monuments.

As the principal objetive of the Project, an analysis and the calculation of the optimal location of the watchtower network is made. To achieve this, on the one hand photogrammetry technics are used to get the geometric information of the studied area. On the other hand, photogrammetry through UAV systems is used to obtain the 3D model of one of the watchtowers, which is better preserved than others. Finally, programming tools are applied over GIS for the analysis and calculation of the optimal location of this watchtower network.
\end{abstract}

Key words: virtual archaeology, visibility, GIS, cultural heritage, watchtower

\section{Resumen:}

El patrimonio cultural juega un papel importante en la gestión inteligente de un territorio, y las técnicas geoespaciales son una perfecta herramienta para el conocimiento, gestión y análisis de dicho patrimonio. Elementos como la fotogrametría, los sistemas UAV y los sistemas de información geográfica, pueden contribuir en gran medida a la catalogación y puesta en valor del patrimonio de una ciudad. Alcalá la Real tiene al Conjunto Monumental de la Fortaleza de la Mota y elementos relacionados como motor principal del atractivo turístico de la ciudad. Motivo por el que se plantea utilizar diversas técnicas geoespaciales para el estudio y análisis de parte de ese patrimonio.

Concretamente, como objetivo principal del trabajo, se plantea el análisis y la determinación de la ubicación óptima de la red de atalayas. Para ello se utilizan técnicas fotogramétricas para obtener la información geométrica de la zona de estudio a partir de imágenes de un vuelo fotogramétrico. Por otro lado, para el conocimiento de las características de las atalayas, se realiza el modelado de una de las mejor conservadas, mediante fotogrametría con sistemas UAV. Finalmente, se utilizan herramientas de programación sobre sistemas de información geográfica para el análisis y la determinación de la ubicación óptima de la red de atalayas.

Palabras clave: arqueología virtual, visibilidad, SIG, patrimonio cultural, atalaya

\section{Introducción}

El patrimonio cultural juega un papel importante en la gestión inteligente de un territorio, siendo las técnicas geoespaciales una perfecta herramienta para el conocimiento, gestión y análisis de dicho patrimonio (Torres et al. 2012). El uso de técnicas como la fotogrametría, los sistemas UAV o los SIG, contribuyen en gran medida a la catalogación y puesta en valor del patrimonio de una zona (Zamora et al. 2012.). 
El objetivo principal del presente trabajo es el análisis y determinación de la ubicación óptima de la red de atalayas, a partir de procesos de simulación en un entorno SIG. Para ello, se hace uso de datos digitales de carácter geográfico facilitados por el Centro Nacional de Información Geográfica (CNIG), para la elaboración de una cartografía base, así como, datos capturados por sistemas UAVs para la modelización y parametrización de las atalayas que aún se conservan.

\subsection{Contexto Histórico}

Alcalá la Real fue un enclave de gran importancia estratégica en el sur de la Península Ibérica. Este hecho, y en especial el carácter de frontera que tuvo en el pasado han determinado el devenir histórico de la ciudad. Está presidida por el Conjunto Monumental de la Fortaleza de la Mota, declarada de Bien Cultural de Andalucía junto a sus murallas, Torre de Alcazaba y su red de atalayas.

La estrategia militar en la Edad Media daba gran importancia a las torres vigía. Estas servían como posiciones avanzadas que informaban de los movimientos del enemigo y de sus posibles ataques.

En torno a Alcalá la Real se configuró un amplio dispositivo de atalayas cristianas y musulmanas, como llave del sistema fronterizo en la Baja Edad Media, poniendo en contacto castillos y ciudades como Alcaudete, Moclín y la propia Alhambra. Hoy día, muchas de esas atalayas han desaparecido o se han visto deterioradas, la disposición de las mejor conservadas se muestra en la Figura 1.

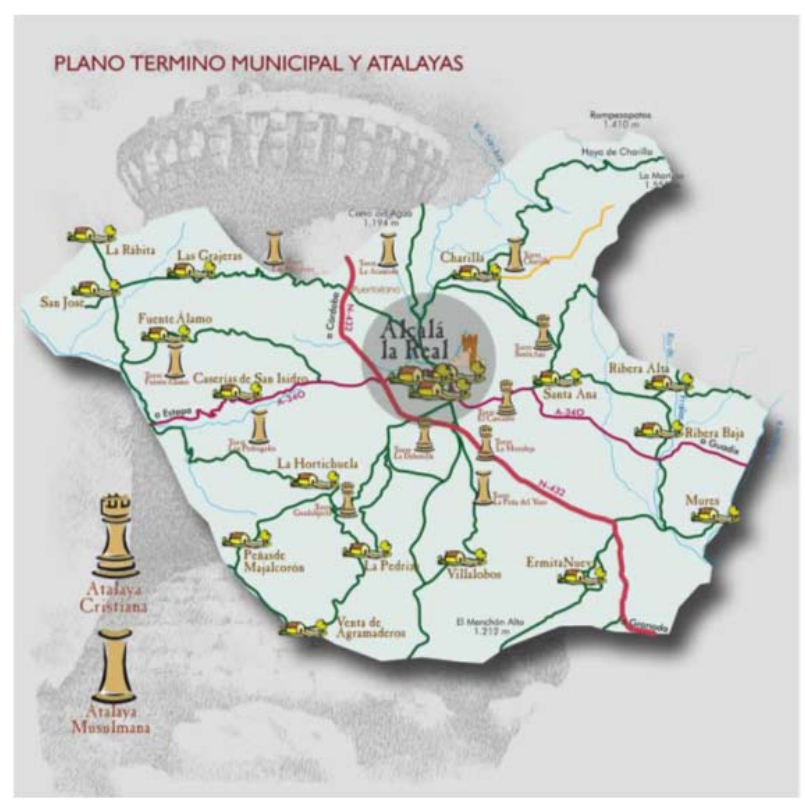

Figura 1: Red de atalayas existentes

\subsection{Análisis de visibilidad}

De entre la gran cantidad de las posibilidades de análisis que presentan los Sistemas de Información Geográfica, las capacidades de análisis de visibilidad abren un amplio campo de posibilidades en trabajos de arqueología virtual. La idea que presentan estos análisis son la de evaluar aquellos lugares que son visibles desde otros (Villanueva 2012).
Dada una superficie del terreno y un punto de vista, el problema clásico de la visibilidad es detectar la porción de terreno visible desde dicho punto, esto es, la cuenca visual. Diversas aéreas de conocimiento utilizan esta técnica como herramienta de análisis.

La morfología de una superficie de terreno afecta en gran medida qué partes de la superficie puede ver un observador desde en un punto determinado. Estos análisis, gracias a la alta capacidad de procesamiento de los ordenadores actuales, se postulan como herramientas imprescindibles en otras áreas de estudio y son utilizados de manera extensa en áreas de estudio como el planeamiento territorial, geomarketing.

El objetivo es determinar la visibilidad de punto a punto a lo largo de una línea de visión determinada o a través de una superficie en una cuenta visual.

\subsubsection{Cuencas Visuales}

Los análisis de cuencas visuales pretenden identificar las zonas visibles que pueden observarse desde una 0 más ubicaciones de observación. Este tipo de análisis requiere de una serie de datos de entrada, siendo estos:

- Modelo Digital del Terreno: La visibilidad es calculada atendiendo a la geometría del terreno, de manera que este dato es fundamental en el estudio, siendo a su vez un factor muy importante, dado que su calidad determinará en gran medida la calidad de los resultados obtenidos.

- Punto/s Observador: ubicación de la cual se desea saber su cuenca visual, puede ser uno o varios puntos. Pudiendo encontrarse estos observadores sobre el terreno, o sobre algún elemento que le permita situarse a cierta altura del mismo.

Con estos datos, el proceso de cálculo de la cuenca visual se desarrolla a partir de anillos concéntricos desde el punto observador.

El procedimiento es en realidad bastante simple computacionalmente, y se parece en esencia al cálculo de la proximidad efectiva. Podemos imaginarlo como una serie de "olas de distancia" que se originan en el punto considerado y se van radiando hacia afuera, como si hubiéramos arrojado una piedra en un estanque (véase la Figura 2). A medida que las olas se propagan, se calculan la distancia desde la celda de observación inicial (denominada celda "run") y la diferencia de elevación con cada una de las celdas que forman el anillo concéntrico de una ola (denominadas celdas "rise"). Si el coeficiente rise/run es mayor que cualquiera de los coeficientes de los anillos concéntricos previos, la celda en cuestión para la que estemos analizando el valor será catalogada como vista. Si por el contrario dicho coeficiente es menor, la celda pasará a ser marcada como no vista.

\subsubsection{Líneas de visión 3D}

Mediante este análisis obtenemos una línea entre dos puntos que muestra las partes de la superficie a lo largo de dicha línea que son visibles o que están ocultas para el observador. Determinando así si un punto es visible desde otro punto. Si el terreno oculta el punto de destino, puede ver dónde se encuentra la obstrucción y qué más puede verse o está oculto a lo largo de la línea 
de visión. En la Figura 3, los segmentos visibles se muestran en verde y los segmentos ocultos se muestran en rojo. Un punto negro al inicio de la línea representa la ubicación del observador. Un punto azul representa el punto de obstrucción desde el observador al destino. Un punto rojo al final de la línea representa la ubicación de destino.

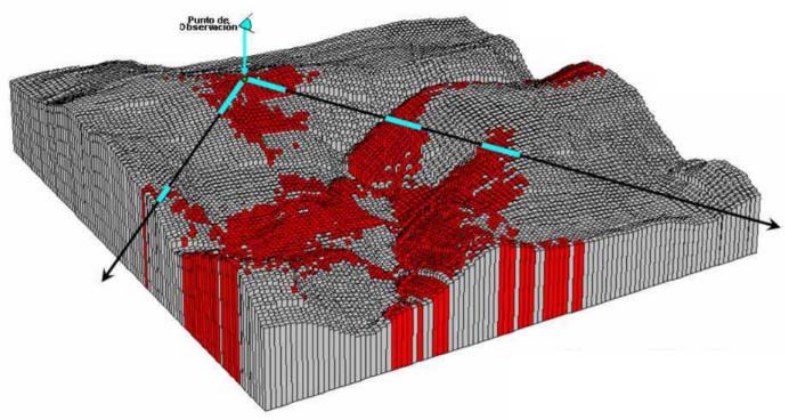

Figura 2: Cuenca Visual

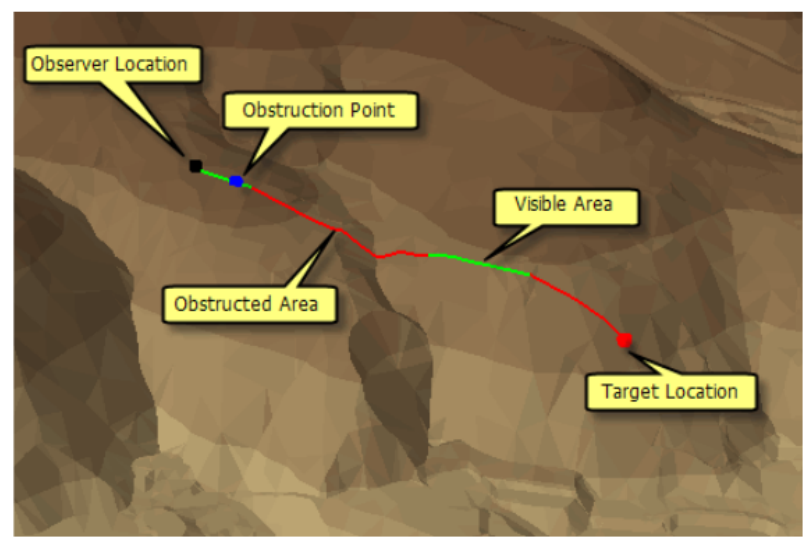

Figura 3: Líneas de visión

\subsection{Programación entorno SIG}

Las herramientas propias del software SIG nos permiten realizar tareas de manera básica e intuitiva por medio de la interfaz propia de cada herramienta. Para realizar análisis más complejos con flujos de trabajo, procesado de datos por lotes, automatización y optimización de estos análisis, se puede hacer uso de lenguajes de programación para la creación de scripts que contengan las órdenes a llevar a cabo por el software SIG. El software utilizado ArcGIS, contiene el módulo ArcPy que permite la creación y ejecución de estos scripts.

A modo de resumen se presenta en la Figura 4 un diagrama con el esquema general del proceso de simulación de la red de atalayas en el entorno de la fortaleza de la Mota. Este esquema general tiene sus particularidades a la hora de calcular la posición de las distintas torres en función del método de simulación seleccionado.

El proceso se realiza de manera totalmente automatizada, se ejecuta externamente al software GIS ejecutando el script diseñado. Solo requiere de los datos de entrada correspondientes, en este caso el modelo digital del terreno y el punto observador principal, es decir, la posición geográfica de la Fortaleza de la Mota.

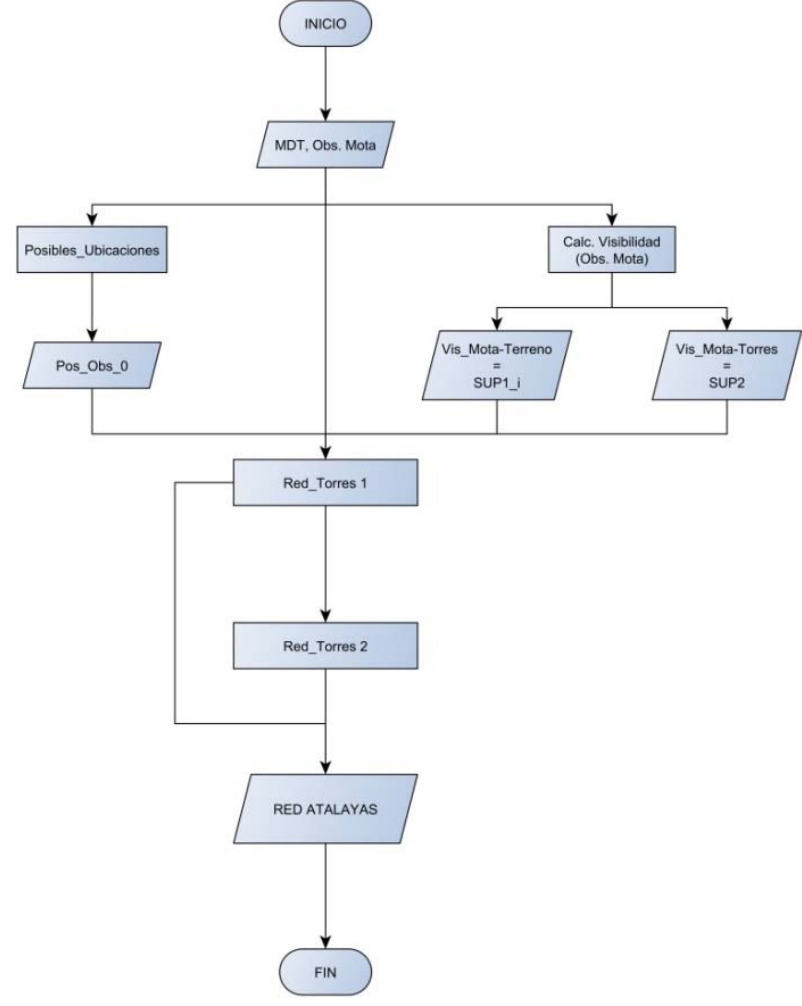

Figura 4: Flujo de Trabajo

\section{Datos de entrada}

\subsection{Modelo Digital del Terreno}

Para la realización de los estudios de visibilidad sobre el Sistema de Información Geográfica, es necesario disponer de un Modelo Digital del Terreno que sirva de base para los diferentes estudios, para ello se utiliza información libre descargada del Centro Nacional de Información Geográfica del IGN, en concreto el "MDT05", que contienen el modelo digital del terreno con paso de malla de $5 \mathrm{~m}$, con la misma distribución de hojas que el MTN50 (véase la Figura 5).

El formato archivo utilizado es ARC-GRID de ESRI. EI sistema geodésico de referencia de la información es ETRS89 y la proyección UTM en huso 30 para este caso.

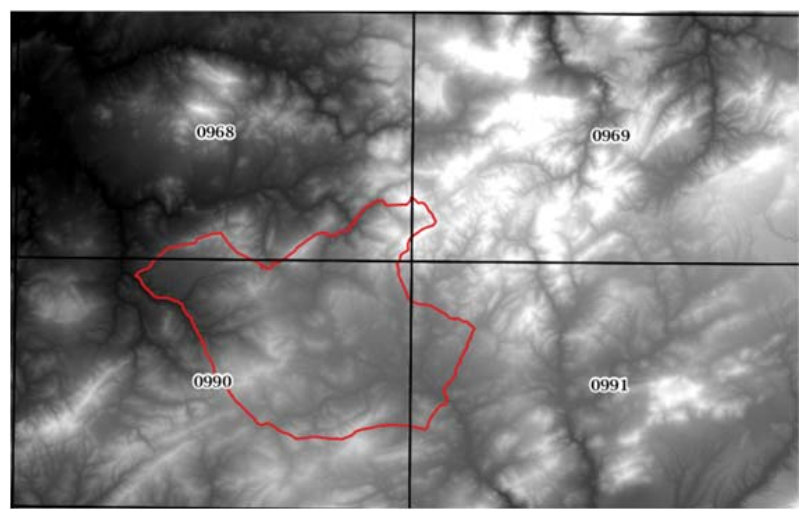

Figura 5: Hojas de MDT utilizadas 


\subsection{Posición de las atalayas existentes}

La posición teórica de las atalayas existentes se obtiene a partir de información proporcionada por el Excmo. Ayuntamiento de Alcalá la Real, el cual proporciona información en formato CAD de la situación de las atalayas que hoy día se encuentran en mejor o peor estado de conservación.

\subsection{Modelo 3D de atalaya}

Con el fin de conocer las características geométricas de las atalayas y de realizar una virtualización y extraer información geométrica de las mismas, se realiza la obtención del modelo 3D de dos de estas atalayas mediante fotogrametría con UAV.

La elección de las atalayas a modelizar se realiza teniendo en cuenta el estado de conservación de las existentes. En la Figura 6, se puede observar una de las seleccionadas denominada "Torre de la Moraleja".

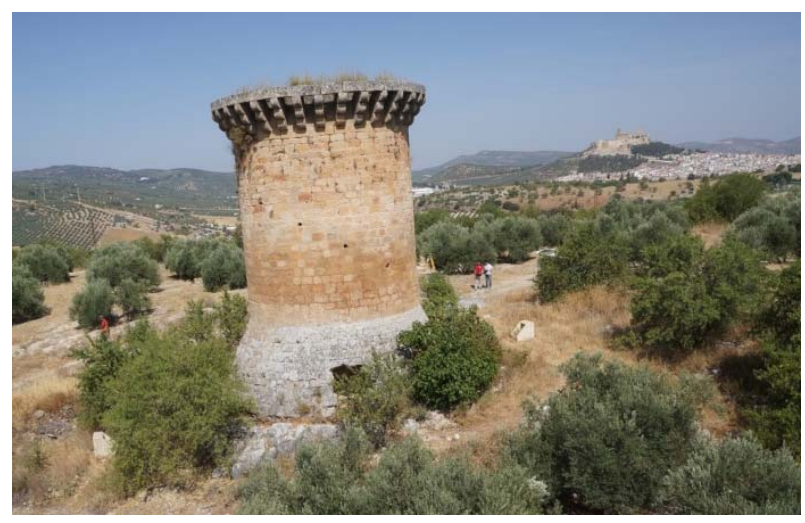

Figura 6: Torre de la Moraleja

Para la obtención del modelo se realizan varios vuelos (cenitales y convergentes) mediante UAV con cámara compacta no métrica. A partir de técnicas fotogramétricas se realiza la virtualización de la atalaya, obteniendo un modelo 3D de la misma, utilizando el software Photoscan.

\section{Propuesta metodológica}

\subsection{Consideraciones previas}

Para la realización de los diferentes estudios, se deben tener en cuenta varios parámetros que afectan al análisis de visibilidad, los cuales se deben establecer a priori. Estos son los siguientes:

\subsubsection{Parametrización de atalaya}

Viene definida tras el conocimiento de las características geométricas de la atalaya objeto de estudio a partir del modelo 3D obtenido mediante fotogrametría con UAV. A efectos de análisis se establece como altura estándar de las atalayas el valor de $10 \mathrm{~m}$ (véase la Figura 7).

\subsubsection{Rango de visibilidad}

Se debe establecer el parámetro de límite máximo de visibilidad, puesto que si no se especifica dicho valor, el software lo considera por defecto como infinito. El límite de visibilidad del ojo humano es difícil de establecer, puesto que depende de condiciones externas, como meteorología, elementos de ayuda a la visión, diferentes señales de alerta. Debido a esto se realiza un análisis de la distancia media entre la Fortaleza y las atalayas, ya que se conoce que la Fortaleza no tiene conectividad visual con todas ellas, se establece como límite máximo de visibilidad una aproximación a la media de estas distancias. A efectos de realización de los estudios, se establece un límite máximo de visibilidad de $6000 \mathrm{~m}$.

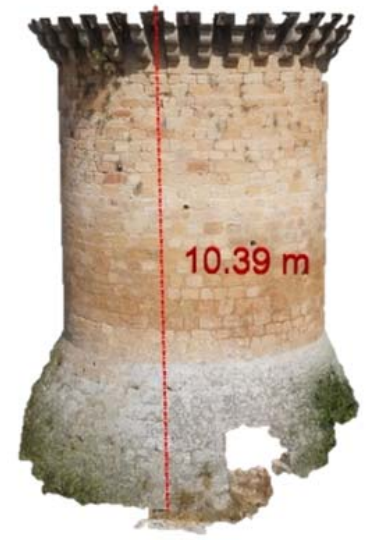

Figura 7: Modelo con dimensiones de atalaya

\subsection{Determinación de posibles ubicaciones}

Las posibles ubicaciones de la red de atalayas dependen directamente del modelo digital del terreno. En principio, se podría plantear que cualquier posición de este modelo digital podría ser una potencial situación de una atalaya. Sin embargo, dado que lo más lógico es que se situaran en lugares localmente elevados, y para disminuir los tiempos de procesamiento, realizando una búsqueda más optimizada, se lleva a cabo una extracción y filtrado de máximos locales en dicho modelo.

Los máximos locales se definen como puntos, que son máximos en relación a sus puntos vecinos analizados. Con este análisis se consigue reducir el número de posibles ubicaciones para atalayas, de un total de 20 millones iniciales a 500 puntos destacados (véase Figura 8).

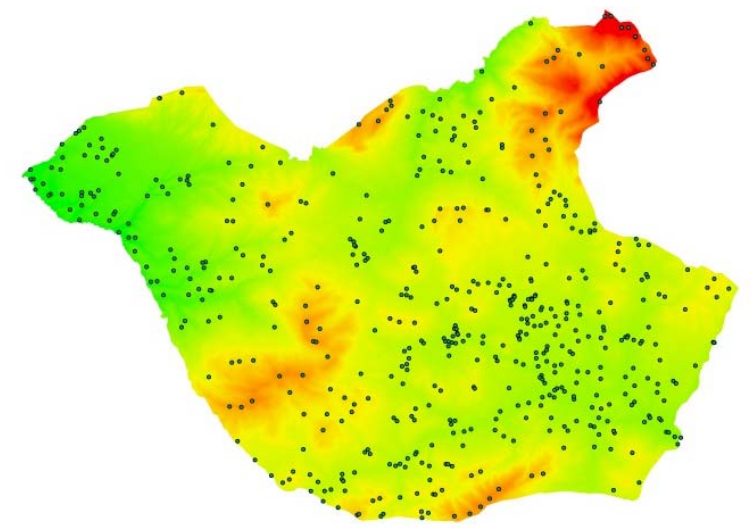

Figura 8: MDT con posibles ubicaciones

Una vez se realiza este proceso, se tendrían todos los datos de entrada para las simulaciones, los cuales son:

- Información geográfica de la Fortaleza de la Mota 
- Modelo digital del terreno.

- Máximos locales como ubicaciones posibles de la red de atalayas.

\subsection{Simulaciones}

Este apartado contiene la descripción de los procesos seguidos para la determinación de la ubicación óptima de la red de atalayas de la Fortaleza de la Mota. El cálculo de la ubicación óptima viene precedido de la imposición de algunos factores que determinan el modo de realizar el proceso y el resultado final. Es por esto, por lo que este proceso se ha realizado de dos maneras diferentes. Se han seleccionado estos tras analizar las posibles hipótesis defensivas que manejan los arqueólogos municipales responsables, a partir de estudios previos.

\subsubsection{Red de anillos concéntricos}

Con esta simulación se pretende obtener la ubicación de la red de atalayas de manera que formen una red de anillos concéntricos respecto a la Fortaleza de la Mota. De esta forma se minimiza el número de comunicaciones a realizar entre atalayas para alertar a la Fortaleza de cualquier incidencia (véase la Figura 9).

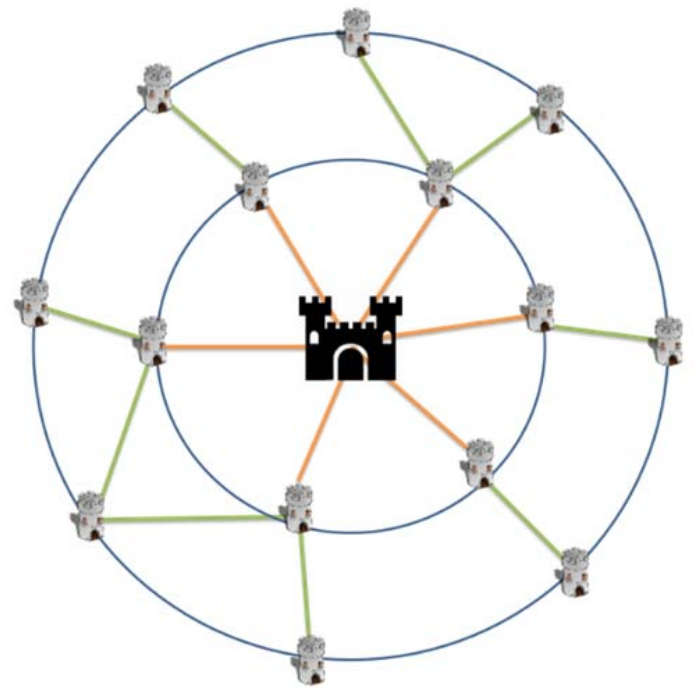

Figura 9: Esquema simulación de red de anillos concéntricos

Así, la Fortaleza tendría comunicación visual con el primer anillo de atalayas y viceversa, pero a su vez el primer anillo tendría comunicación visual con el segundo anillo de atalayas, estableciendo como mínimo una comunicación uno a uno.

\subsubsection{Red ramificada}

Con esta simulación se obtiene la ubicación de la red de atalayas de manera que formen una red lineal, en la que cada elemento se comunique con otro en una relación como mínimo de uno a uno.

Según esta metodología, cada elemento de la red, incluida la Fortaleza, no necesariamente tiene conectividad visual con más de un elemento, de manera que existe menos redundancia de visibilidad entre atalayas (Véase la Figura 10).

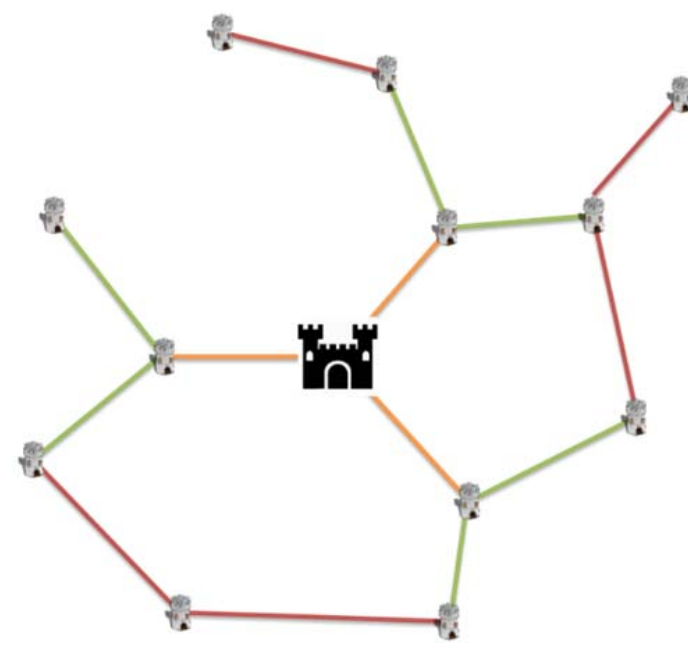

Figura 10: Esquema simulación de red ramificada

\section{Resultados}

\subsection{Determinación de ubicación óptima}

\subsubsection{Simulación 1 - Red de anillos}

A continuación se exponen los resultados obtenidos para la simulación a partir del método de anillos concéntricos. Con esta técnica obtenemos un total de 27 atalayas, 14 situadas en el anillo más cercano a la Fortaleza y 13 en el anillo externo.

A partir de la situación de las atalayas mediante esta simulación y sus respectivas cuencas visuales, se realiza un estudio del comportamiento de la superficie visible por la red (véase la Figura 11).

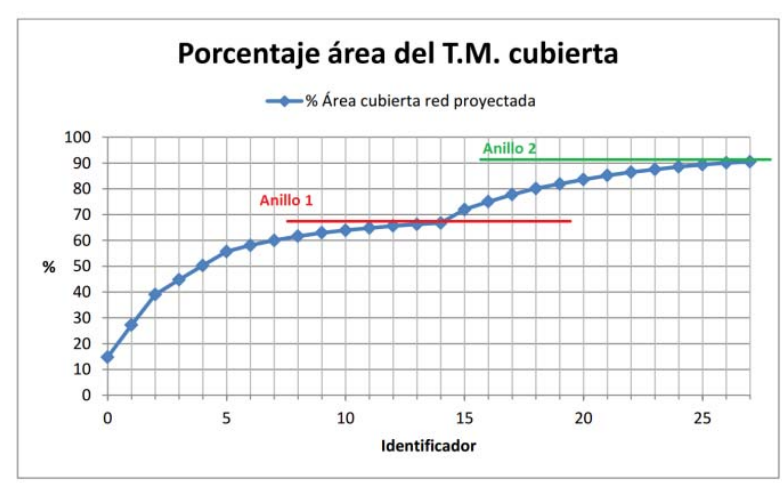

Figura 11: Porcentaje de área visible red de anillos concéntricos

Tal y como se puede ver en la Figura 12, teniendo en cuenta el porcentaje de área visible conseguido, para el primer anillo con la inserción de la torre 14 este porcentaje se estabiliza, de la misma manera que se estabiliza dicho porcentaje en el anillo 2 con la inserción de la torre 27.

\subsubsection{Simulación 2 - Red ramificada}

A continuación se exponen los resultados obtenidos para la simulación a partir del método de red ramificada. Con esta técnica se obtienen un total de 24 atalayas (véase la Figura 13). 


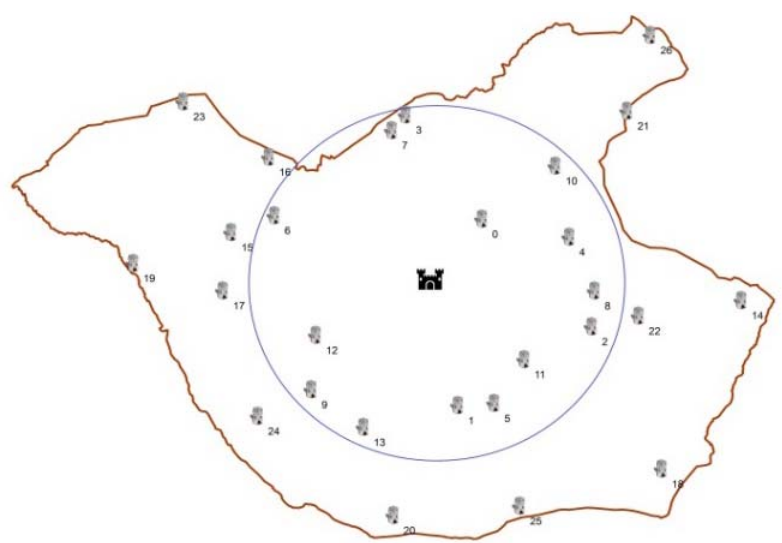

Figura 12: Ubicación atalayas a partir de simulación de red de anillos concéntricos

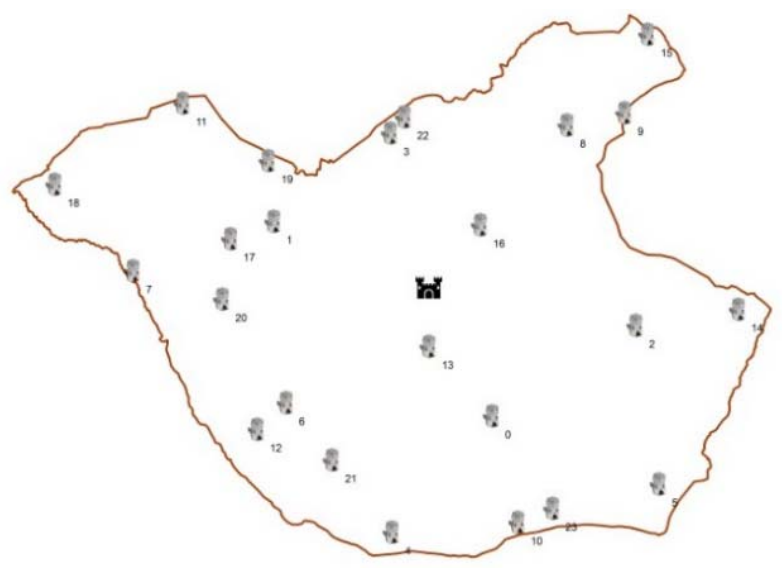

Figura 13: Ubicación atalayas a partir de simulación de red ramificada

A partir de la situación de las atalayas mediante esta simulación y sus respectivas cuencas visuales, se realiza un estudio del comportamiento de la superficie visible por la red.

Tal y como se puede ver en la Figura 14, se observa el comportamiento de la red según esta metodología. El porcentaje de área visible es similar a la conseguida mediante el método de anillos concéntricos pero con un número inferior de elementos.

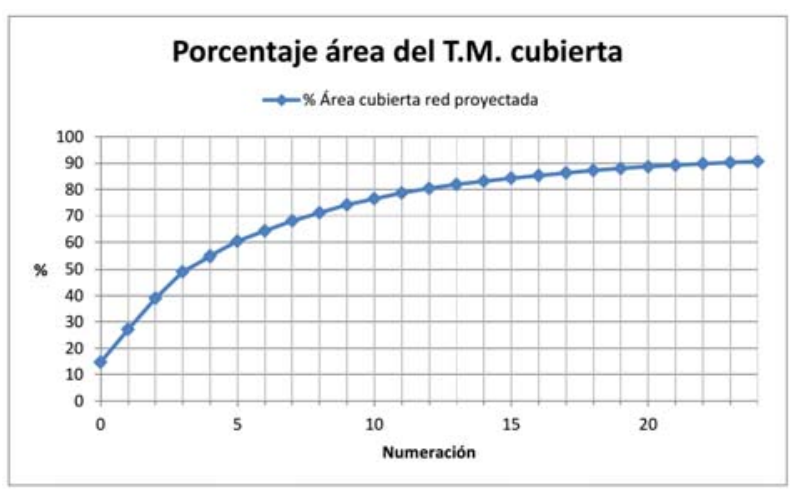

Figura 14: Porcentaje de área visible red ramificada

\subsection{Comparativa entre la red existente y las simuladas}

\subsubsection{Red existente - Red de anillos concéntricos}

A continuación se exponen de manera simultánea la ubicación de las atalayas pertenecientes a la red existente y las obtenidas en la simulación de anillos concéntricos.

Como se puede apreciar en la Figura 15, existen varias coincidencias posicionales entre las atalayas existentes y las simuladas.

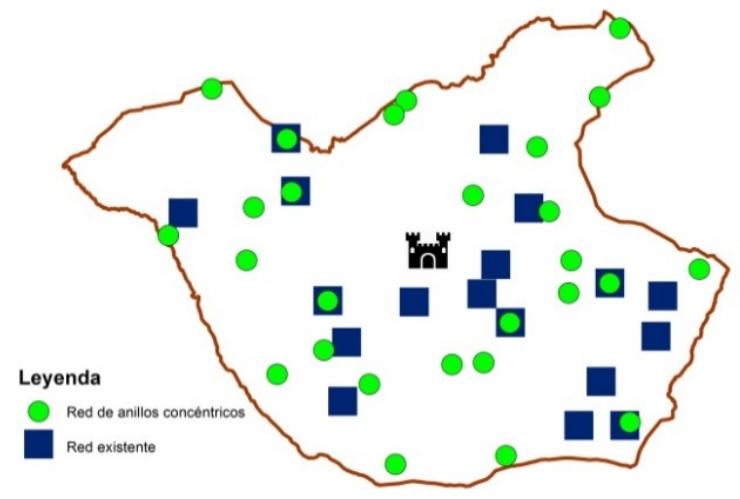

Figura 15: Comparativa entre red existente y red simulada mediante método de red de anillos concéntricos

\subsubsection{Red existente - Red ramificada.}

De la misma manera se exponen superpuestas las ubicaciones de las atalayas pertenecientes a la red existente y las obtenidas en la simulación de red ramificada.

De manera similar a los resultados obtenidos en la simulación de red de anillos concéntricos, existen varias coincidencias posicionales entre atalayas existentes y simuladas (véase la Figura 16).

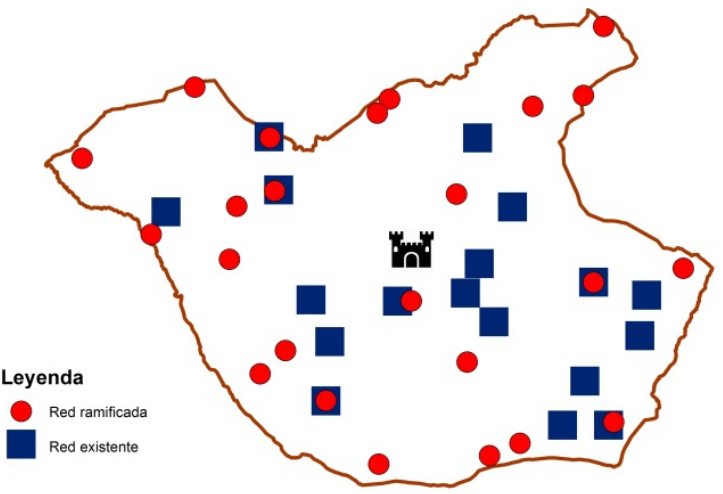

Figura 16: Comparativa entre red existente y red simulada mediante método de red ramificada

\section{Conclusiones}

Destacar el aumento de potencial que se produce utilizando los sistemas de información geográfica y sus herramientas a través de programación, ya que posibilitan la realización de análisis más complejos, además de reutilizar la metodología de la herramienta diseñada en proyectos similares. Los lenguajes de programación nos permiten interactuar con el sistema 
de información geográfica de manera mucho más directa que con la propia interfaz del software.

Por otro lado, la importancia de la fotogrametría en la captura de datos sobre el terreno y para la modelización de monumentos $u$ otros objetos, utilizando imágenes fotográficas, siendo por lo tanto un método totalmente objetivo y con información continua y muy completa.

En cuanto a los resultados obtenidos, destacar la coincidencia posicional entre varias de las atalayas de las redes obtenidas a partir de la metodología propuesta en este trabajo con atalayas de la red existente, teniendo en cuenta la antigüedad de dichas construcciones (algunas de ellas, datan del siglo IX), por lo que es muy probable la desaparición de muchas de ellas, dejando reducida la red de atalayas real. Además de esta circunstancia, hay que tener en cuenta que los límites administrativos actuales sobre los que se ha basado el análisis no corresponden con los de la época en la que se materializaron y utilizaron dichas atalayas.
Finalmente, en cuanto a líneas futuras de trabajo, destacar que el análisis realizado ha tenido en cuenta unos parámetros iniciales muy generales, por lo que el análisis realizado se podría ejecutar de manera más específica. Concretamente, en relación al presente estudio, podrían tenerse en cuenta más parámetros para la simulación como la ubicación de las vías de comunicación, poblaciones colindantes, y diversos elementos que pudiesen afectar en mayor o menor medida a la distribución de las atalayas.

\section{Agradecimientos}

Agradecimientos al departamento Ingeniería Cartográfica, Geodésica y Fotogrametría y al Grupo de Investigación Sistemas Fotogramétricos y Topométricos, por facilitar el material para la realización del presente trabajo.

Agradecer también al Excmo. Ayuntamiento de Alcalá la Real por la aportación de la documentación que disponían acerca del fenómeno de estudio.

\section{Referencias}

MERCHÁN, M.Z., y PREYSLER, J.B., 2012. Los SIG en la Arqueología española: una valoración 'CAA' del contexto actual. Cuadernos de Prehistoria y Arqueología de la Universidad de Granada, 20, 49-64.

OJEDA, E.V., y LORCA, A.M.G., 2012. Comunicación visual mediante técnicas GIS en el litoral del Campo de Dalías: la defensa costera de los pueblos del interior. Virtual Archaeology Review, 3(6), 93-97.

TORRES, J.C., SOLER, F., CANO, P., LEÓN, A., LUZÓN, V., y MARTíN, D., 2012. Sistema de Información para Patrimonio Histórico. Virtual Archaeology Review, 3(5), 53-57. 


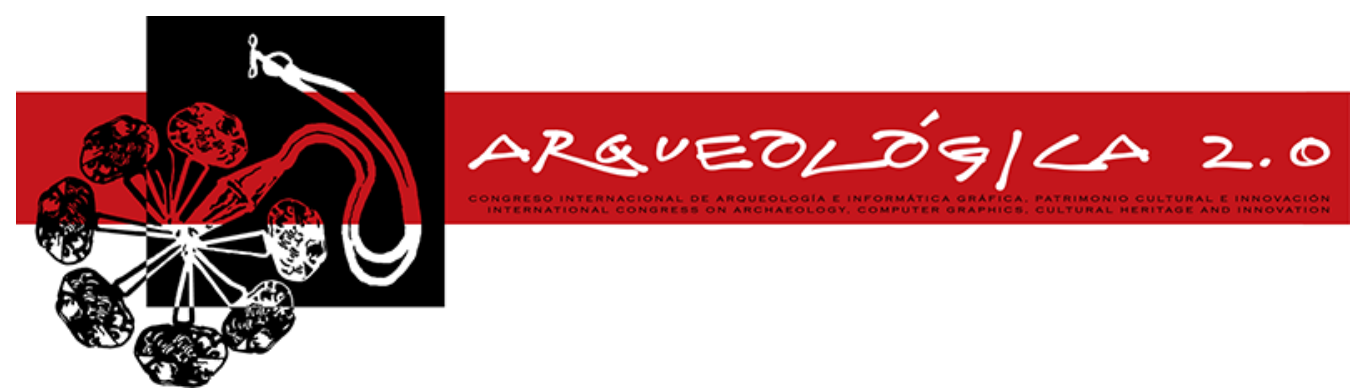

Proceedings of the $8^{\text {th }}$ International Congress

on Archaeology,

Computer Graphics,

Cultural Heritage and Innovation

'ARQUEOLÓGICA 2.0'

in Valencia (Spain),

Sept. 5-7, 2016

DOI: http://dx.doi.org/10.4995/arqueologica8.2016.3564

Received: 07/03/2016

Accepted: 04/05/2016

\title{
SIMULACIÓN 3D CON INTERFACES HÁPTICAS PARA LA RECUPERACION DEL PATRIMONIO CULTURAL DEL TREN EN RIOBAMBA
}

\author{
3D HAPTIC INTERFACES SIMULATION FOR RECOVERY OF CULTURAL HERITAGE TRAIN IN RIOBAMBA \\ Miguel Duque *, Fernando Proaño, Ramiro Santos \\ Grupo de Investigación 3D-FIE-ESPOCH, Escuela Superior Politécnica de Chimborazo, Panamericana Sur Km 1 1⁄2, EC060155, \\ Riobamba, Ecuador. m duque@espoch.edu.ec; fproanio@espoch.edu.ec; ramiro.santos2005@gmail.com
}

\begin{abstract}
:
The present work had studied and determined various levels of usability and interactivity in haptic interfaces for manipulating 3D applications. It was applied to a Heritage Cultural system composed by Train Station and Steam Locomotive. A physical model and a railroad model were built. The system was operated by high school students. The information gathering was performed by the deductive method, collecting data about preferences, needs, and requirements for developing a 3D virtual environment using 3DSMAX 2011 Trial (3D Modeled Software) and Unity 4.3 Trial (Simulation Software), capable to engage and transmit information relevant to geographical, social and cultural aspects of the central highlands. Subsequently connected to a real model controlled by electronic systems. The inquiry made from high school students shows that $56 \%$ possess ability and willingness for interfaces manipulation. Also, it was found an $80 \%$ of criteria for usability acceptance, and interactivity of $84 \%$ towards the current applications on mobile devices. As the final evaluation of the application, it was shown that the intervention of haptic interfaces on threedimensional applications connected to tangible environments, increased $95 \%$ of the usability and $100 \%$ of interactivity. We conclude that combining virtual systems with real ones accelerates learning processes at the secondary education level. It improves retention of information and allows the user to actively participate in virtual environments, converting recreational applications into academic and research tools.
\end{abstract}

Key words: haptic interface, interactivity, cultural heritage

\section{Resumen:}

El presente trabajo estudió y determino diferentes El presente trabajo estudió y determino diferentes niveles de usabilidad e interactividad en interfaces hápticas para manipulación de aplicaciones 3D. Se aplicó a un Patrimonio Cultural que comprende la Estación del tren y una locomotora a vapor, los mismos que fueron representados en una maqueta física y un sistema de trenes eléctricos respectivamente. Este sistema fue operado por estudiantes secundarios. La obtención de información se realizó mediante el método deductivo, recolectando datos sobre necesidades y requerimientos para elaborar un entorno virtual 3D utilizando 3DSMAX 2011 Trial (Software Modelado 3D) y Unity 4.3 Trial (Software Simulación), capaz de vincularse y transmitir información relevante sobre aspectos geográficos, sociales y culturales de la serranía central. Posteriormente conectada a una maqueta real controlada por sistemas electrónicos. La indagación realizada a estudiantes, muestra que el $56 \%$ poseen capacidad y disposición de manipulación de interfaces, también se encontró aceptación del $80 \%$ en criterios de usabilidad y $84 \%$ en interactividad hacia aplicaciones actuales en dispositivos móviles, como evaluación final a la aplicación se demostró que la intervención de interfaces hápticas en aplicaciones tridimensionales conectadas a entornos tangibles, incrementaron la usabilidad al $95 \%$ y la interactividad al $100 \%$. Se concluye que combinar sistemas virtuales con reales acelera procesos de aprendizaje a nivel de educación secundaria, mejora la retención de información y permite al usuario participar activamente con entornos virtuales, convirtiendo aplicaciones lúdicas en herramientas académicas e investigativas.

Palabras clave: interfaces hápticas, interactividad, patrimonio cultural

"Corresponding Author: Miguel Duque, $\underline{m \text { duque@espoch.edu.ec }}$ 


\section{Introducción}

En la actualidad todo sistema que va a ser controlado por el hombre debe cumplir con aspectos técnicos de diseño centrado en el usuario y usabilidad que permitan obtener la mejor experiencia cuando el usuario maneja la aplicación, la importancia de una interfaz sencilla, amigable y usable determinan muchas veces que el usuario final se quede o abandone una aplicación.

En la actualidad el auge que los dispositivos móviles tienen entre los adolescentes ha provocado una serie de estudios sobre los aspectos positivos y negativos de los mismos, según un estudio independiente publicado en el portal Kubernética, a lo largo de las últimas décadas las nuevas tecnologías de la comunicación han tenido una enorme penetración en la sociedad y principalmente en los jóvenes, si bien este es un aspecto destacable de esta tecnología, pueden ser consideradas un riesgo si se vuelen adictivas y distractoras de actividades académicas como manifiesta un grupo de investigadores de la Universidad Autónoma del Estado de México (Méndez et al. 2015), sin embargo su facilidad de uso y el poco conocimiento necesario para instalar y configurar aplicaciones móviles han sido consideradas para que en el presente estudio sea considerado el dispositivo ideal sobre el cual funcionará la aplicación 3D que permita concientizar y revivir un patrimonio cultural de la ciudad de Riobamba entre los estudiantes de nivel secundario de esta ciudad.

Considerando las ventajas que los dispositivos móviles pueden brindar al desarrollo del proyecto se investigó la posibilidad de realizar interfaces hápticas (táctiles) utilizando software 3D de base y aplicaciones complementarias en las cuales se consideraron los principios y procesos de diseño gráfico, al final, se pudo combinar el uso de sistemas interactivos 3D en el modo digital y virtual con una integración innovadora a sistemas físicos analógicos de una maqueta con elementos de transporte como es el ferrocarril ecuatoriano. La aplicación final 3D entró en una etapa de análisis, para medir los niveles de interactividad y usabilidad de los usuarios en una aplicación interactiva eligiendo a la estación del tren de Riobamba, considerado un Patrimonio Cultura de la ciudad. De igual manera se analizó e identificó el nivel de usabilidad e interactividad que puede alcanzar una interfaz háptica al momento de manipular una aplicación y a su vez identificar parámetros técnicos que debe poseer una interfaz háptica para programarla en un sistema interactivo $3 \mathrm{D}$ y posteriormente integrarla a una maqueta física real (Aparici y Silva 2012).

El procedimiento de investigación utilizado fue el método deductivo, debido a que se hizo una revisión sistemática de los casos generales existentes y documentados hasta la actualidad y aplicarlos en un caso particular formulado para el presente estudio.

\section{Marco teórico}

Considerando que el diccionario de la lengua española define la palabra háptico/a como táctil, la presente investigación pretende utilizar esta característica para crear una interfaz que sea probada a través de dispositivos móviles (smartphone, tablets) para controlar el ambiente simulado del recorrido del tren de la ciudad de Riobamba, aquí nace una importante pregunta, ¿qué son las interfaces hápticas? los autores del trabajo Interfaz háptica para tareas de manipulación las describen como aquellas interfaces que permiten al usuario interactuar con sistemas tele operados en entornos remotos o con objetos simulados en entornos virtuales (López et al. 2010), por su parte el portal EcuRed (2016) amplía el termino y habla de tecnologías hápticas como el conjunto de interfaces tecnológicas que interaccionan con el ser humano mediante el sentido del tacto y que conjuntamente con nuevos métodos para generar contenido en realidad virtual científicos europeos ya han logrado teletransportar de forma virtual objetos reales a través del ciberespacio, algunas de las aplicaciones de esta tecnología puede ser observada en los simuladores hápticos empleados en entrenamiento de operaciones médicas y en simuladores de vuelo para el entrenamiento de pilotos, otro ejemplo de su actual uso, son los juegos, con las denominadas "tabletas vibradoras" ("rumble packs") con las que el usuario siente como hay irregularidades tales como un terreno desigual cuando conduce un automóvil, en medicina existen diversas interfaces hápticas en el caso de simulación médica y que pueden resultar útiles a la hora de intentar minimizar los daños ocasionados por el uso de procedimientos invasivos, a futuro esta tecnología podría utilizarse también para aplicaciones más profesionales que, por ejemplo, permitieran a médicos tratar pacientes a distancia o a diseñadores industriales colaborar de forma remota mediante la teletransportación a través de Internet de maquetas digitales palpables de sus diseños, otro ejemplo es el poder controlar un vehículo creado utilizando el kit Lego Mindstorms a través de una interfaz háptica generando un modelo de comunicación bidireccional mediante tecnología Bluetooth (Carrasquilla 2012). Sin duda el futuro permitirá acoplar esta tecnología a las actividades diarias y como manifiesta Andreas Schweinberger, coordinador de Immersence. "Los aspectos audiovisuales de la realidad virtual han avanzado mucho en los últimos años, por lo que añadir el sentido del tacto es un paso lógico".

La usabilidad es aplicada en cualquier caso donde exista una interacción entre un humano y un dispositivo, permitiendo al humano manipular, controlar y aprovechar de manera eficiente tanto el software como el hardware. El grado de usabilidad que se puede encontrar en la interacción humano-ordenador se basa en parámetros cuantificables permitiendo el establecimiento de niveles de usabilidad. La utilización de los gestos propios del usuario para interactuar con un sistema de comunicación puede resultar natural, directa e intuitiva (Cabral et al. 2005). Sin embargo, algunos autores también critican la naturalidad y la facilidad de intuición de estas interfaces y su usabilidad (Nielsen et al. 2003). Estos denominados niveles de usabilidad se los puede organizar con criterios de errores y opiniones técnicas (Tabla 1).

Coincidiendo en que la usabilidad es reconocida como un factor de calidad importante para sistemas interactivos incluidas las interfaces de usuario de una gran variedad de dispositivos y que el objeto de la evaluación de usabilidad de interfaces es utilizar los resultados para realizar una retroalimentación, con el fin de mejorar los diseños y por ende la interactividad con el usuario (Hurtado y Forero 2014), se realizó un test a estudiantes secundarios que en su mayoría utilizan 
dispositivos de pantalla táctil, siendo el celular el más utilizado seguido por las tabletas, cada criterio de usabilidad fue definido bajo tres funciones de pertenencia que son baja, media y alta como indica el sistema difuso basado en las reglas de Takagi-Sugeno, una vez tabulados los resultados, se obtuvo que alrededor del $80 \%$ de estudiantes consideran que las aplicaciones creadas en la actualidad son fáciles de usar, en un $56 \%$, los estudiantes muestran disposición y capacidad de manipular una interfaz con éxito, existiendo errores leves al momento de realizar tareas, y un $41,25 \%$ de los estudiantes encuestados consideraron que la aplicación sometida a la prueba, tienen un nivel de usabilidad medio, ubicándolo en la tercera posición de una escala del 1 al 5.

Tabla 1: Niveles de usabilidad

\begin{tabular}{|c|c|c|}
\hline Nivel & Grado de error & Descripción \\
\hline Nivel 5 & Fatal & $\begin{array}{l}\text { Error de concepto, errores que } \\
\text { impiden la realización de la tarea }\end{array}$ \\
\hline Nivel 4 & Grave & $\begin{array}{c}\text { Errores que confunden al usuario } \\
\text { disminuyendo la facilidad en el } \\
\text { ejercicio establecido }\end{array}$ \\
\hline Nivel 3 & Leve & $\begin{array}{l}\text { Problemas que pueden confundir } \\
\text { al usuario pero no afectan a la } \\
\text { conclusión de la tarea }\end{array}$ \\
\hline Nivel 2 & Cosmético & $\begin{array}{l}\text { Opiniones que no afectan el } \\
\text { desempeño de la aplicación, pero } \\
\text { afectan a su estética }\end{array}$ \\
\hline Nivel 1 & Nulo & $\begin{array}{c}\text { Interfaz usable y visualmente } \\
\text { Atractiva }\end{array}$ \\
\hline
\end{tabular}

La interactividad entre personas y máquinas nace bajo el concepto del comportamiento interactivo entre el aparato y la experimentación del humano, totalmente apartado del aspecto o apariencia visual de la máquina sus componentes y procesos internos o significados que transmitan (Fernández 2011). Las interfaces de usuario dependiendo de su nivel de interactividad pueden ser ubicadas en distintos grados, los cuales se tabularon en la Tabla 2.

Tabla 2: Grados de Interactividad

\begin{tabular}{c|c} 
Grado & Descripción \\
\hline Interactivo & $\begin{array}{c}\text { Comunicación entre sistema interfaz-humano } \\
\text { constante, respuesta mutua }\end{array}$ \\
Reactivo & $\begin{array}{c}\text { Comunicación entre interfaz-humano mínima, } \\
\text { respuesta unilateral }\end{array}$ \\
Estático & Comunicación nula entre interfaz-humano
\end{tabular}

El test de usuario basado en el tema de la interactividad se ejecutó en algunos colegios de la ciudad de Riobamba, según lo determinó la muestra calculada para tal propósito, para la aplicación del presente test fue indispensable la utilización de una aplicación controlada mediante una interfaz háptica, misma que fue estudiada con el fin de establecer grados de interactividad y similitud con la interfaz propuesta para el proyecto, dicha aplicación debía ser usada por el segmento de estudio sin ningún tipo de guía o ayuda de parte de los evaluadores, únicamente se debía intuir su manejo y configuración necesaria para alcanzar los mejores resultados.

Con estos antecedentes fue seleccionada una aplicación creada por Gameloft, cuya trayectoria se remonta al año 2011, existiendo ya varias actualizaciones y variaciones del video juego permitiendo a los usuarios jugarlo desde cualquier plataforma de dispositivo móvil. La totalidad de estudiantes de nivel secundario encuestados, considera que una pantalla táctil incrementa la interactividad dentro de una aplicación, de estos un $84 \%$ de usuarios considera que las aplicaciones actuales tienen un alto nivel de interactividad directa con el usuario. El nivel de Intervención del usuario dentro de la realización de tareas en una interfaz háptica se encuentra en un rango equilibrado siendo alrededor del $30 \%$ para nivel bajo, medio y alto; pero existe aún predominancia por el nivel más adecuado. Al momento de realizar las tareas, el usuario está en capacidad de formar parte de las actividades virtuales, mostrándose una igualdad del $36 \%$ entre el nivel más alto y el nivel más bajo de participación.

Sin duda las interfaces hápticas presentan muchas ventajas sobre otro tipo de interfaces gráficas existentes, sin embargo para usuarios con poco conocimiento de las mismas puede resultar complicado como lo señala Cabral cuando presenta los resultados de su estudio y manifiesta que sus experimentos muestran que el tiempo para la realización de tareas de apuntamiento simples es considerablemente más lento en comparación con un ratón y que su uso durante incluso breves períodos de tiempo causa fatiga (Cabral et al. 2005), sin embargo en la actualidad el dominio de las aplicaciones móviles y sus interfaces, demostró que fue una excelente opción el haber escogido una interfaz háptica táctil para el desarrollo del presente proyecto.

Los motores gráficos que permiten crear videojuegos para diferentes plataformas y que en este caso fueron considerados para crear los entornos gráficos $3 D$ son los siguientes:

- UDK de Epic Games (https://epicgames.com/)

- CryEngine de Crytek (http://www.crytek.com/)

- Unity 3D de Unity Technologies (https://unity3d.com/es/company)

Si bien cada uno de ellos presenta una serie de ventajas solo uno fue seleccionado para implementar las interfaces de la aplicación.

\section{Métodos y herramientas}

El motor gráfico seleccionado para el desarrollo del presente proyecto fue Unity 3D debido principalmente a los siguientes factores:

1. Posibilidad de disponer de una versión tanto para Windows como para Mac, aspecto importante considerando que los estudiantes que trabajaron en el diseño durante su carrera manejaron el entorno de desarrollo en Mac.

2. Además la versión de pago que es completa, brinda una versión gratuita con todas las facilidades técnicas y de diseño para cumplir con los objetivos planteados. 
3. Posibilidad de crear entornos 3D para PC, Mac y Web y lo más importante durante el desarrollo del proyecto estuvo habilitada la versión para realizar desarrollo para dispositivos iOS y Android, plataformas a las que está enfocado el proyecto.

4. Permite trabajar con iluminación global, efectos de post-procesado, light flare, vignetting, rayos de luz, profundidad de campo y corrección de color, entre otras.

5. Integración con la herramienta LabView.

6. Finalmente y quizá el más importante es que el equipo desarrollador durante su formación académica estudio Unity 3D para el desarrollo de videojuegos.

La selección de un entorno de desarrollo que permita conectar el hardware que controla la maqueta física de tren y las estaciones con la interfaz háptica 3D estuvo considerado entre las tres opciones que brinda la empresa National Instrument y que son:

- LabVIEW.

- LabWindows/CVI.

- Measurement Studio.

LabVIEW, software que proporciona un potente entorno de desarrollo gráfico fue seleccionado entre otros aspectos por:

- Integración de primera clase con hardware.

- Interfaces de usuario personalizadas.

- Extenso IP de análisis y procesamiento de señales.

- Sintaxis de programación gráfica

El proyecto Computational Thinking enabled by Robotmediated Interactions in a 3D Virtual Simulation of the Fukushima nuclear power plant (Vallance et al. 2015) fue tomado como ejemplo debido a que mostró un ambiente similar al que se buscaba alcanzar en el proyecto. Con las herramientas seleccionadas, el siguiente paso fue definir las actividades requeridas para realizar el simulador siguiendo las acciones generales de funcionamiento, el estudio realizado indica la manera correcta de elaborar un escenario para interacción usuario-máquina.

Bajo poligonaje. El modelado adecuado para una simulación fluida corresponde a un control en el número de polígonos creados por el modelador, entre más polígonos posee el objeto, mayor será la cantidad de información que el motor de video juegos procese, ralentizando la simulación y perdiendo la continuidad de la interacción del usuario.

Texturizado. Las texturas de los diferentes objetos modelados deberán ser colocadas de manera correcta, abarcando el total de la superficie visible, logrando una simulación realista. El tamaño de pixeles en las imágenes utilizadas para texturizar objetos, beben ser inferiores, con el fin de economizar espacio virtual en la simulación.

Tamaño de terreno. Se recomienda terrenos pequeños, dependiendo del uso requerido por el diseñador, para una mejor vinculación con el espacio virtual asimilada por el usuario.
Basado en los puntos anteriores se realizó el modelado 3D y en base a los resultados parciales empezar a construir la maqueta física, en este caso la estación del tren de Riobamba. En general los pasos del Modelado 3D fueron los siguientes.

1. Se diseñó el objeto $3 \mathrm{D}$ con unidades reales (Fig. 1).

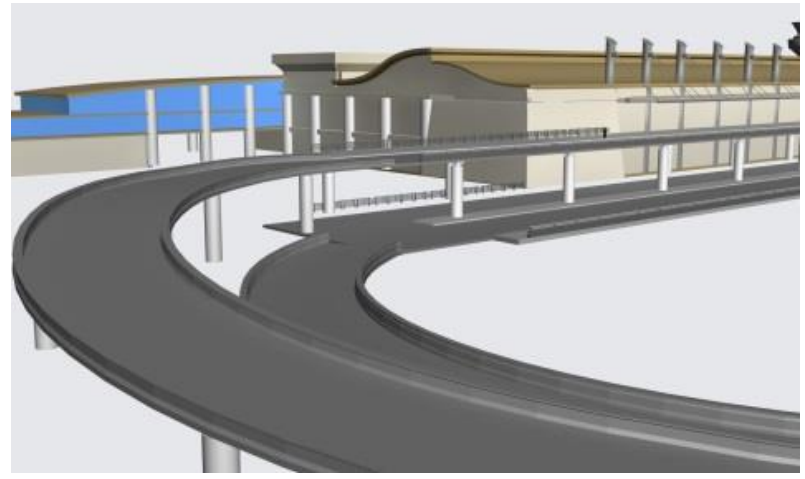

Figura 1: Modelado 3D.

2. Se construyó la maqueta de la estación de trenes (Fig.2).

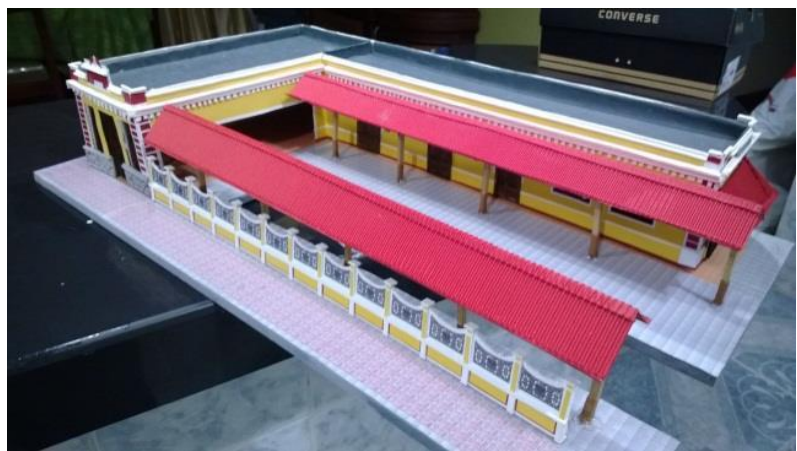

Figura 2: Maqueta de la Estación del tren.

3. Se diseñó en 3D el sistema de rieles y trenes y luego se construyó el modelo físico usando técnicas de ferro modelismo (Fig. 3).

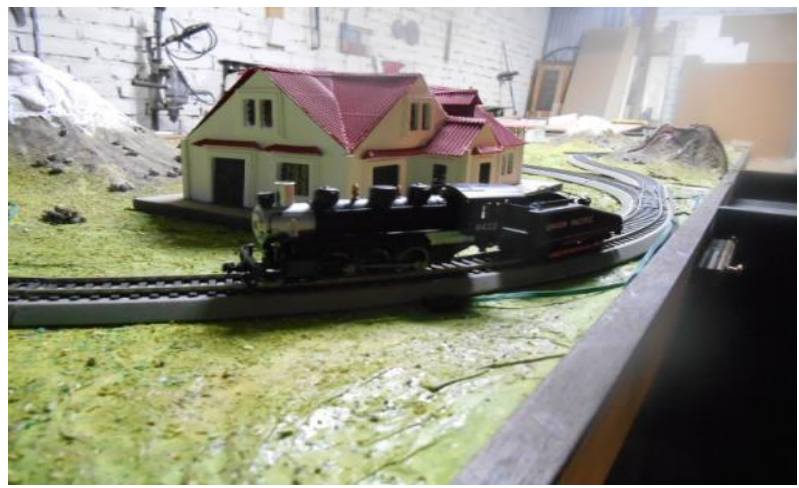

Figura 3: Sistema de trenes eléctricos.

4. Se integró en ambiente 3D, estación y trenes y se construyó la maqueta completa con las estaciones de trenes y el sistema de trenes eléctricos (Fig. 4).

5. Se construyeron componentes electrónicos para activar el sistema de modelos de trenes. 
6. Se diseñó una interfaz de comunicación entre la maqueta física y un programa instalado en un dispositivo móvil.

7. Al final se hicieron varias pruebas y se invitó a estudiantes para que realizaran la operación completa que consistía en "manejar" el tren de Riobamba, considerado Patrimonio Cultural, a través del dispositivo móvil en el que se instaló la aplicación.

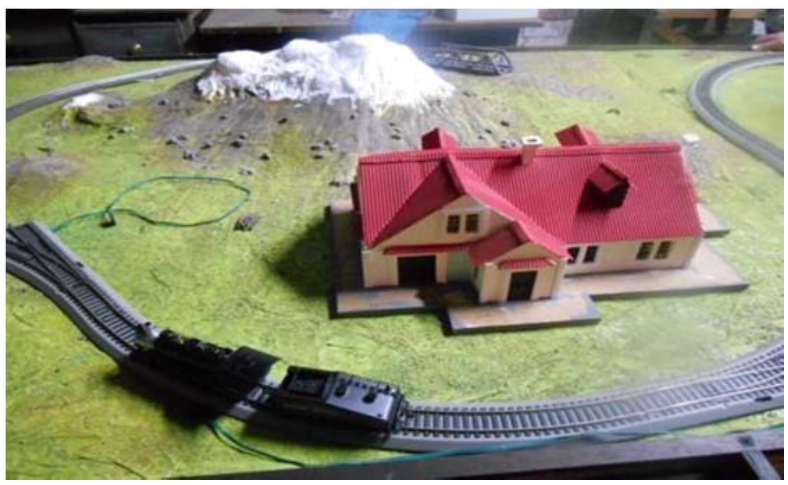

Figura 4: Sistema completo de maqueta y trenes.

La maqueta física fue activada mediante comandos realizados desde el celular. Se crearon varios controles, el control de movimiento determina el desplazamiento del personaje dentro del entorno debe ser fluido y controlado para lograr un desarrollo normal y realista de las actividades en el ambiente 3D. El control de eventos permite controlar luces, semáforos, sonidos del tren y el control de interacción permite al usuario interactuar con la maqueta física realizando las siguientes funciones:

- Movimiento del tren eléctrico mediante una interfaz similar a la del tren a vapor (Fig. 5).

- Activación de pitos.

- Activación de sonidos.

- Activación de letreros con información de la ciudad o sitio turístico (ej. Monte Chimborazo) donde el tren está pasando (Fig. 6).

- Información sobre rutas del tren

- Ingreso a la estación

- Efectos especiales en la maqueta como sonidos de la ciudad / campo.

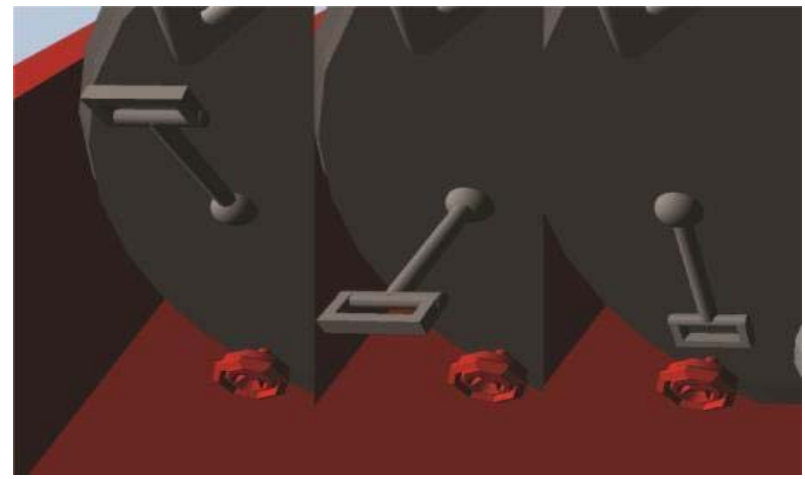

Figura 5: Interfaz que simula las palancas de una locomotora real.

Para la programación de los componentes hápticos y lógicos se utilizó el programa Unity 3D Personal Edition con sus opciones de motor de videojuegos. Para las conexiones físicas se diseñó a partir del software LabView.

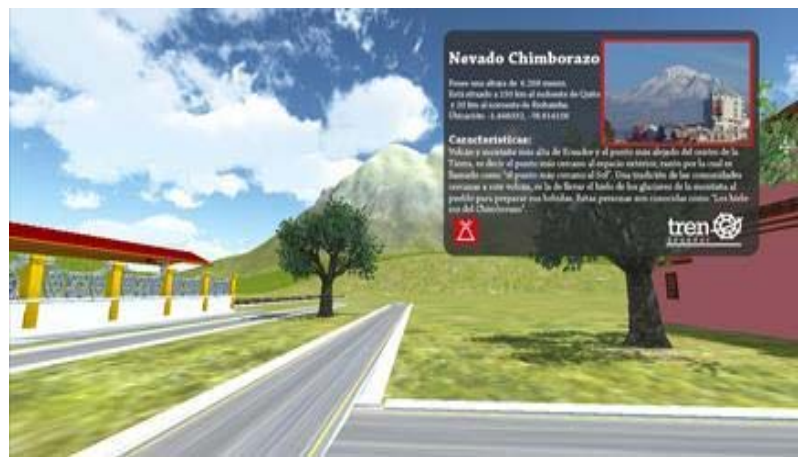

Figura 6: Información sobre el Chimborazo.

Con la información tanto de LabView y de Unity 3D se integró en una consola de control para manipular todos los eventos antes descritos (Fig. 7).

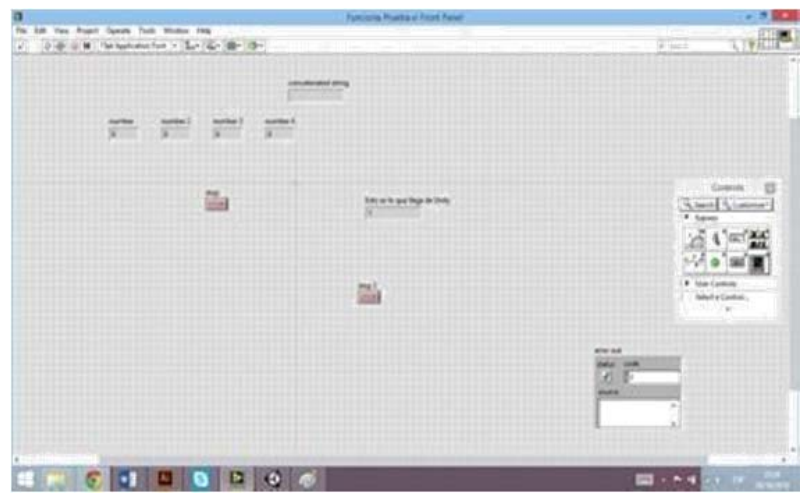

Figura 7: Consola datos UNITY-LabView-UNITY.

Todos los requerimientos y necesidades que se obtuvieron luego de la investigación realizada en este proyecto han sido implementados al momento de la creación de esta aplicación y su interfaz. Todos los componentes, requerimientos y la aplicación en general se los diseño siguiendo pautas de procesos de modelado digital (Vaughan 2012).

Se debe recalcar que, para lograr una vinculación virtual - real como la que se presenta en el presente sistema fue necesaria la utilización de dos aplicaciones que permitieron obtener los mejores resultados en cada uno de sus procesos, LabView producto más famoso de National Instruments encargado de controlar el sistema electrónico presente en la maqueta a través del uso de la tarjeta DAQ OEM 6009 de la misma empresa, esta recibe y emite las señales necesarias para el encendido, apagado y otros controles de los componentes electrónicos, como sensores QRD, luces leds, potenciómetros, etc.

Por otro lado Unity 3D, aplicación utilizada para programar y estructurar la interfaz de la aplicación que posteriormente permitirá tener un control táctil de los elementos inmersos dentro del mundo virtual. La conexión que se realiza entre estas dos aplicaciones es bidireccional, lo que quiere decir que cuando la aplicación configurada con Unity 3D reciba una indicación mediante el dispositivo háptico, enviará una señal a LabView y este ejecutará una secuencia. De 
igual modo, cuando LabView reciba una señal de los sensores ubicados en la maqueta real, enviará un dato a Unity 3D para que este lo interprete y ejecute una secuencia dentro del sistema virtual. Este tipo de conexión se la conoce como "Conexión por Sockets" y consiste en la apertura de clientes y servidores, que escuchen o envíen señales. Estos sockets funcionan en base a la dirección IP del ordenador, quien puede enviar o recibir señales desde cualquier dispositivo conectado a la red, pudiendo ser este un ordenador, un dispositivo móvil, o incluso el mismo ordenador principal, la conexión permite descartar la necesidad de un servicio de internet, necesitando únicamente una red WiFi o WLAN para funcionar correctamente.

\section{Resultados}

La operación del sistema fue realizado en varias etapas por estudiantes que previamente fueron seleccionados. Un número total de 20 fueron seleccionados por su conocimiento en el uso del celular de manera ampliada.

Luego de la tabulación de los resultados obtenidos se pudo determinar que el $95 \%$ de los estudiantes que colaboraron con este test, pudieron realizar las tareas de una manera fácil, el $100 \%$ opinaron que los mensajes mostrados por la aplicación fueron apropiados, el 95\% mostraron facilidad para desplazarse por el entorno, mientras el $90 \%$ de estudiantes evaluados consideran que la aplicación posee un nivel de usabilidad óptimo y un $10 \%$ lo considera Usable. En la segunda parte de la investigación, se obtuvieron resultados que muestran un $100 \%$ de interactividad de los estudiantes. Con los resultados obtenidos de la tabulación de las dos evaluaciones, se muestra un aumento notable del nivel de percepción de la usabilidad e interactividad, quedando así comprobada la hipótesis planteada.

\section{Conclusiones}

El uso de una interfaz háptica en una aplicación 3D, mejora la usabilidad e interactividad del usuario en el aprendizaje y manipulación de un sistema tanto virtual como físico. Un sistema virtual - real ayuda a mejorar la retención de información y permite al usuario participar activamente en entornos virtuales. La tecnología móvil con su versatilidad y prestaciones se constituyó en el dispositivo ideal para dar a conocer el funcionamiento e historia del tren de Riobamba y contribuir con la recuperación de uno de los patrimonios culturales de la ciudad. El uso de interfaces hápticas en la actualidad constituyen una necesidad frente a la constante evolución de los sistemas informáticos, la importancia de incrementar el grado de usabilidad e interactividad obliga a la actualización en la forma de controlar las aplicaciones y sus interfaces. La cantidad de usos y aplicaciones que poseen las interfaces hápticas, permiten la vinculación de estas en diferentes campos de acción, como la mecánica, la medicina, la astronomía, la educación, la industria, la cultura y demás campos que requieran la interacción hombremáquina.

\section{Agradecimientos}

Se agradece a la ESPOCH - FIE por la facilidad física brindada a Leonardo Arévalo, Miguel Ángel Urgilez, Martha Dávalos y Patricia Avalos por su valiosa participación en la programación de los sistemas y por la recolección de datos in situ.

\section{Referencias}

APARICI, R. y SILVA, M., 2012. Pedagogy of Interactivity/Pedagogía de la interactividad. Comunicar,19(38), 51. DOI: http://dx.doi.org/10.3916/C38-2012-02-05

CABRAL, M., MORIMOTO, C. y ZUFFO, M., 2005. On the usability of gesture interfaces in virtual reality environments. In Proceedings of the 2005 Latin American conference on Human-computer interaction (CLIHC '05). ACM, New York, NY, USA, pp. 100-108. DOI: http://dx.doi.org/10.1145/1111360.1111370

CARRASQUILLA, A., 2012. Teleoperación de un vehículo remoto en un medio de acceso inalámbrico mediante el uso de una interfaz háptica. Vol. 25, №. Extra 5, 2012 pp. 5-13.

ECURED, 2016. Tecnología háptica. Disponible: http://www.ecured.cu/Tecnología_háptica [5/30,2016].

FERNÁNDEZ, M., 2011. Modelado, texturizado y ajuste de malla. Postproducción digital. Madrid: Bubok, pp. 105-132.

HURTADO, L. y FORERO, J., 2014. Metodología de evaluación de usabilidad de interfaces humano-máquina. Revista Tecnura, 18, pp. 103-114. DOI: http://dx.doi.org/10.14483/udistrital.jour.tecnura.2014.SE1.a08

LÓPEZ, J., TORRES, J., GIMÉNEZ, A., GALIANA, I. y FERRE, M., 2010. Interfaz háptica para tareas de manipulación, XVIII Congreso Nacional de Ingeniería Mecánica.

NIELSEN, M., STÖRRING, M., MOESLUND, T., y GRANUM, E., 2003. A procedure for developing intuitive and ergonomic gesture interfaces for $\mathrm{HCl}$. In Gesture-Based Communication in Human-Computer Interaction, pp. 409420. Springer Berlin Heidelberg. DOI: 10.1007/978-3-540-24598-8_38

MÉNDEZ, R., CASTRO, G. y CASTRO, M., 2015. Un análisis de la adicción a los dispositivos móviles y su impacto en el rendimiento académico de los estudiantes de la licenciatura en informática administrativa del centro universitario UAEM TEMASCALTEPEC. Atlante. Cuadernos de Educación y Desarrollo.

VALLANCE, M., MARTIN, S. y NAAMANI, C., 2015. A situation that we had never imagined: post-Fukushima virtual collaborations for determining robot task metrics. International Journal of Learning Technology, Vol. 10, No. 1, pp. 30-49. DOI: http://dx.doi.org/10.1504/IJLT.2015.069453

VAUGHAN, W., 2012. Modelado Digital (Espacio de Diseño). Washington - USA., Anaya Multimedia. 


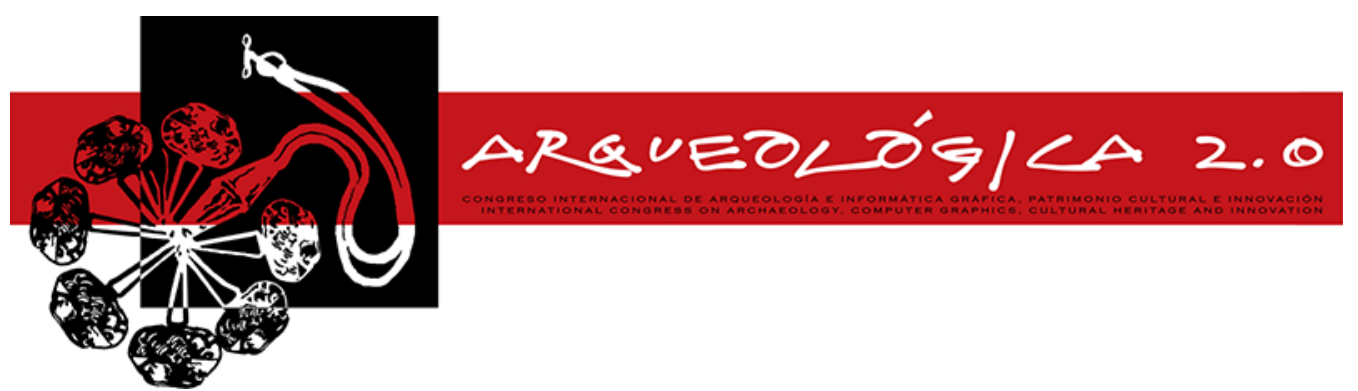

Proceedings of the

$8^{\text {th }}$ International

Congress on

Archaeology,

Computer Graphics,

Cultural Heritage and Innovation

'ARQUEOLÓGICA 2.0'

in Valencia (Spain)

Sept. 5-7, 2016

\title{
EXPLOTACIONES MINERAS EN PATRIMONIO INDUSTRIAL: UN CASO DE USO DE DOCUMENTACIÓN Y SIMULACIÓN
}

\author{
MINING IN INDUSTRIAL HERITAGE: A CASE STUDY OF DOCUMENTATION AND SIMULATION \\ David Marcos $^{\mathrm{a},{ }^{*},}$, José Martínez ${ }^{\mathrm{a}}$, Fco. Javier Delgado ${ }^{\mathrm{b}}$, Javier Finat ${ }^{\mathrm{b}}$ \\ ${ }^{\text {a }}$ Laboratorio de Fotogrametría Arquitectónica, Universidad de Valladolid, Avda. Salamanca s/n, Valladolid, 47140, Spain. \\ Ifa@ega.uva.es; imr@ega.uva.es \\ ${ }^{\text {b } G r u p o ~ M o B i V A P, ~ U n i v e r s i d a d ~ d e ~ V a l l a d o l i d, ~ P a s e o ~ d e ~ B e l e ́ n ~ 11, ~ 47011, ~ S p a i n . ~ j i n a t @ a g t . u v a . e s ~}$
}

\begin{abstract}
:
Mining operations are an essential part of Industrial Heritage. They provide an important reference in order to understand changing past realities, relationships between groups and reconfiguration in the communication between regions whose consequences still remain reference. These realities and relationships have led to the current socio-economic and political framework, which is projected into the future. The documentation of physical vestiges and machinery, now obsolete, is a metaphor that serves to illustrate and understand the past from our present perspective. Threedimensional models from the fusion of different techniques and physical structures contextualization allow to simulatethe mechanisms to promote sustainable tourism as paradigms of a modernity that only serves the immediate appearances. Our approach for documentation and simulation of mechanisms for the extraction and the treatment of mineral is provided as graphical support to understand a reality that goes beyond the "ThematicPark" approach. Moreover, the visualization provides a metaphor for the destruction of natural, physical and human resources of entire areas doomed to depopulation and disappearance. This also opens the door to broader developments that can use multimedia resources to support an all-embracing narrative experience.
\end{abstract}

Keywords: industrial heritage, simulation, 4D reconstruction

\section{Resumen:}

Las explotaciones mineras forman una parte esencial del Patrimonio Industrial. Proporcionan una referencia crucial para entender realidades pretéritas muy cambiantes, relaciones entre dominación entre grupos y reconfiguración en redes de comunicación entre regiones cuyas consecuencias aún perduran. Estas realidades y relaciones han dado lugar a un entramado socioeconómico y político que llega hasta hoy y se proyecta al futuro. La documentación de vestigios físicos y de maquinarias, actualmente obsoletas, son una metáfora que sirve para ilustrar y comprender mejor el pasado y su proyección hacia el futuro desde nuestra perspectiva actual. El modelado 3D de estructuras físicas y su contextualización a partir de la fusión de diferentes técnicas y la simulación de los mecanismos pretenden inicialmente una recuperación museística o impulsar un turismo sostenible como paradigmas de una modernidad que sólo atiende a las apariencias. El enfoque desarrollado para la documentación de instalaciones y simulación de mecanismos para la extracción y el tratamiento del mineral se presenta como soporte gráfico para entender una realidad que va más allá del Parque Temático. La visualización proporciona asimismo una metáfora de la destrucción de los recursos naturales, físicos y humanos de zonas enteras condenadas al despoblamiento y la desaparición, abriendo la puerta a desarrollos más amplios que puedan utilizar recursos multimedia como soporte a una narración más omnicomprensiva.

Palabras clave: patrimonio industrial, simulación, reconstrucción 4D

\section{Introducción}

El Patrimonio Industrial es una de las áreas seleccionadas por la Unesco como emblemática para entender el pasado más reciente vinculado a la Revolución Industrial. La clasificación llevada a cabo en
1999 de forma conjunta por la UNESCO con ICOMOS menciona el Patrimonio Industrial como un área a documentar y proteger, como parte reciente de una memoria colectiva. A finales de los noventa, el Patrimonio Industrial constituía el $5.3 \%$ de sitios culturales y el $4 \%$ de Patrimonio Cultural de la

*Corresponding Author: David Marcos, Ifa@ega.uva.es 
Humanidad $^{1}$; desde entonces, este porcentaje no ha dejado de crecer.

En múltiples ocasiones se ha subrayado que el Patrimonio Industrial no se restringe sólo a los siglos XIX y XX, sino que se remonta a la misma prehistoria. La naturaleza depredadora de la especia humana y la utilización de tecnologías muy destructivas son una constante desde la Antigüedad ${ }^{2}$. En las épocas antigua y medieval y, sobre todo, a partir del Renacimiento, hay una utilización creciente de dispositivos mecánicos para la manufactura que culmina en la primera Revolución Industrial, sin la cual es imposible entender el mundo moderno. Sin embargo, el Patrimonio Industrial suele referirse al período que comienza a finales del s. XVIII y llega aproximadamente hasta 1930.

La rápida obsolescencia de las máquinas iniciales y su sustitución por otras más eficientes, como resultado de la competencia y la disminución de los rendimientos de capital, han dado lugar al abandono o la destrucción de instalaciones, maquinaria y entornos próximos. Esta estrategia responde a una lógica interna depredadores en la que se pretende borrar el pasado (incluso el más reciente), entronizando la inmediatez como si hubiera existido desde siempre.

Asimismo, la desaparición del factor humano en las representaciones documentadas tiene claras consecuencias. De forma implícita, se transmite una representación presuntamente objetiva de un espacio inmutable (como algo dado), el mensaje del carácter inexorable de la destrucción y de la independencia de los procesos con respecto a los agentes que operan sobre ellos. La virtualización de procesos y relaciones, la visualización en la modificación del espacio, la acumulación de capital necesaria para producir los recursos, la representación de los medios técnicos (maquinaria, instalaciones) disponibles en las explotaciones y los papeles desempeñados por los diferentes agentes permiten articular y entender una realidad compleja a partir de vestigios aparentemente inconexos ${ }^{3}$.

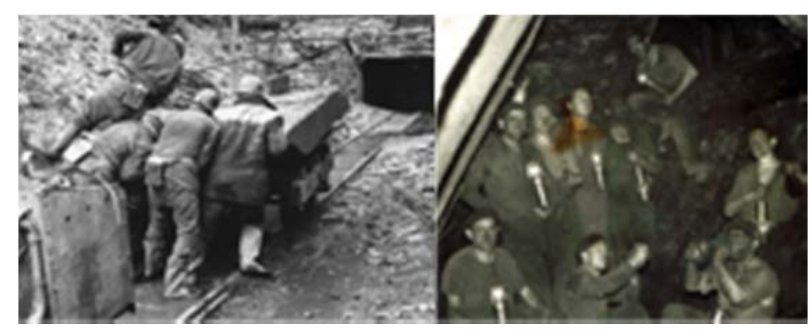

Figura 1: Los mineros como protagonistas del patrimonio industrial.

Nuestra propuesta consiste en que la recuperación del Patrimonio Industrial pasa no sólo por la documentación

Según los datos de World Heritage Site (http://www.worldheritagesite.org).

Un ejemplo extremo bien conocido está dado por la explotación romana de las minas de oro en Las Médulas (Ruina Montium) es el primer paradigma clásico de explotación física, tecnológica y humana a gran escala.

${ }^{3}$ La Ruta de la Plata representa un ejemplo bien conocido de articulación del territorio con unas relaciones sociales cambiantes a lo largo de dos milenios.
3D de instalaciones y la simulación 4D de mecanismos, sino por subrayar el papel y las formas en las que los diferentes agentes de producción (capital, tecnologías, trabajo) se articulan entre sí en un paisaje modificado por la acción del hombre para la producción de mercancías, así como la participación humana en los procesos relacionados en un contexto geográfico y social cambiante. El papel del paisaje hace referencia a una cartografía que va más allá de los aspectos físicos (Maurin 2011)

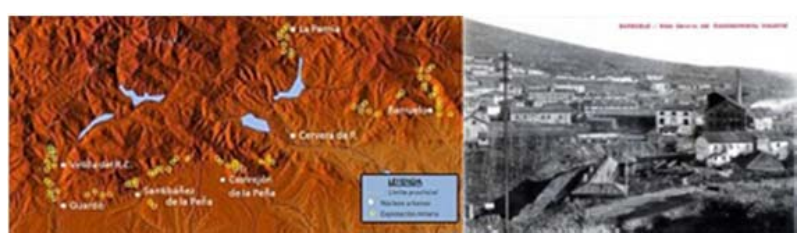

Figura 2: La contextualización geofísica para una comprensión del Patrimonio Industrial.

Por ello, aunque este trabajo esté centrado en la documentación de instalaciones y simulación de maquinaria, debe entenderse como un primer paso para la posterior introducción de un flujo narrativo en el que interactúan diferentes agentes que pueblan y dan sentido a las componentes virtuales y aumentadas en un entorno contextualizado.

En nuestra propuesta, la percepción del paisaje cultural minero requiere una vivencia virtual o real pero adecuadamente contextualizada que reúna elementos gráficos, literales, sonoros, y hasta olfativos que coloquen al visitante en un papel activo en el que pueda percibir que su acción es el motor del cambio, al igual que lo fuera la mano de obra humana incluso en los momentos más inhumanos de la actividad industrial, como se presenta en la Figura 1.

Las tecnologías usadas en la virtualización deben tratar de hacerse imperceptible para ser el instrumento y no el fin (Carrozzino y Bergamasco 2010). Si en el pasado la tecnología minera y sus máquinas camparon en estos paisajes devorando sus recursos y la cultura ancestral transformándolos en otros paisajes con tintes bastante oscuros, hoy debe ayudar a revertir el proceso y contribuir a sacar de la atonía y el subdesarrollo a comarcas enteras que han sido sobreexplotadas hasta perder buena parte de su identidad y su riqueza (Fig. 2).

En una fase posterior, al flujo actual se añadirán avatares (representando a visitantes) que interactúan con personajes (mineros dentro de la aplicación) mediante interfaces de Realidad Aumentada. En el marco virtual actual o en el aumentado por desarrollar, los modelos de realidad virtual o aumentada propuestos para el Patrimonio Industrial permiten recuperar e interpretar el pasado más reciente, al tiempo que proporcionan un soporte ideal para la comprensión de una actividad humana como agentes del cambio, sobre el cual desarrollar recursos narrativos multimedia.

\section{Justificación del enfoque adoptado}

Las explotaciones mineras han sido desde la prehistoria a la actualidad una de las influencias más importantes para el desarrollo de zonas, para el control de recursos y flujos económicos; han determinado variaciones en la distribución de la población concentrándola en los 
núcleos urbanos, han dado pie al desarrollo de industrias locales, y dan explicación a fenómenos migratorios, o a la articulación de redes comerciales entre grupos, regiones o países. Por ello, la documentación de los lugares mineros y técnicas de explotación es uno de los factores más importantes para contextualizar el pasado y entender el presente; en otras palabras, constituye una parte esencial para conocer la Historia, entender la sociedad actual, su evolución desde el pasado hacia el futuro más cercano y las manifestaciones tecnológicas y culturales relacionadas. Para llevar a cabo esta tarea, es necesario contextualizar desde el punto de vista geográfico, histórico, económico y social el espacio físico asociado a las explotaciones mineras y sus transformaciones.

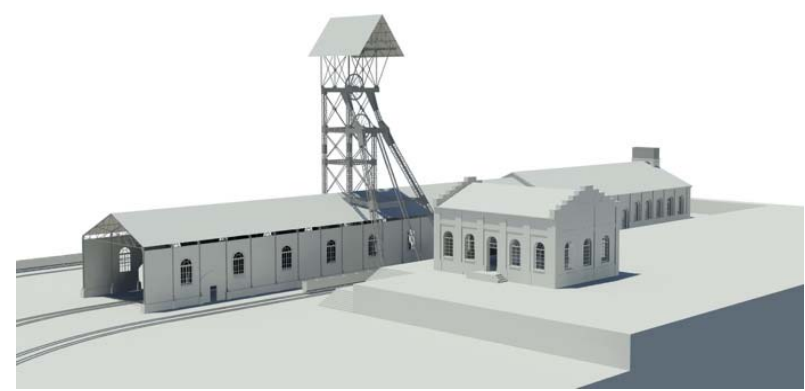

Figura 3: Edificios centrales del Pozo de Herrera.

A la vista del proceso de degradación observado actualmente $y$ de la irreversibilidad de las transformaciones, para recuperar la articulación entre los diferentes aspectos, es necesario llevar a cabo una virtualización de escenarios. Los modelos asociados a esta virtualización proporcionan el soporte para visualizar el entorno y representar una interacción que permita avanzar en el conocimiento de una realidad tan compleja. Para ilustrar esta estrategia hemos desarrollado una documentación y una virtualización del Pozo Herrera dentro de la mina 4 de Sabero situado en la montaña oriental de León (España), cuyos edificios aparecen representados en la Figura 3 y el castillete en la Figura 4.

La labor de documentación del Patrimonio Industrial afecta no sólo a la explotación minera propiamente dicha, sino al entorno y a los agentes que operan sobre él, modificando el paisaje y las relaciones que la especie humana establece con el medio que le rodea y del que forma parte. En la mayor parte de los casos, la relación ha sido y es depredadora, guiada por el principio de maximizar el beneficio en el plazo más breve posible, a costa de la explotación hasta el agotamiento de recursos naturales, físicos y humanos. Esto ha sido así desde épocas históricas antiguas como atestiguan el paisaje de las Médulas explotadas con la técnica de ruina de los montes o las condiciones infrahumanas que se dieron en las iniciales minas de carbón (incluyendo explotación infantil). Tecnologías que sacrificaban todo al objetivo de la producción; medio ambiente, medio físico, cultura y hasta la propia vida.

La extracción del carbón en el Norte de la provincia de Palencia, la parte oriental de la provincia de León y su posterior desplazamiento hacia el Bierzo han dado lugar a profundos cambios en la orografía y las comunicaciones (Sen 1993). Esta extracción presenta diferentes fases de auge y declive asociadas a ciclos económicos tanto financieros (quiebras de mediados del siux y de 1873), como industriales (desmantelamiento de recursos en el Norte de Castilla y León para su concentración en la siderurgia vizcaína). En épocas más recientes también se ha asistido a la deslocalización de recursos entre regiones asociadas a fenómenos estructurales (mala planificación de redes de ferrocarril, yacimientos agotados) o coyunturales (crisis económicas, cambios en las correlaciones de fuerzas de los grupos políticos, ayudas mal utilizadas); la actual fiebre del oro del occidente asturiano o el fracking, son los nuevos paradigmas tecnológicos de una barbarie incesante ligada a la sobreexplotación de toda clase de recursos.

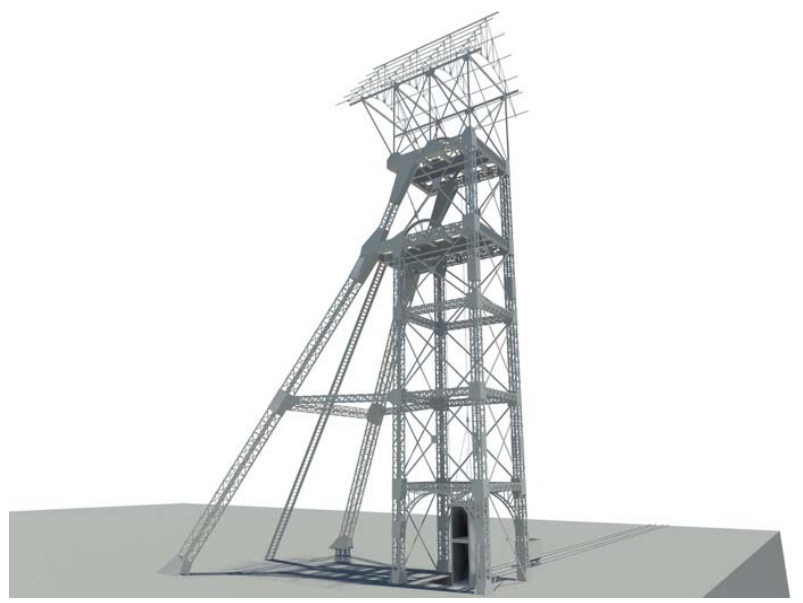

Figura 4: Castillete sobre el brocal del pozo de Herrera.

Lejos de ser una foto fija, la documentación de las explotaciones mineras y su evolución con las estrategias de acumulación originarias reflejan la realidad local, regional y nacional cambiante y, por ello, forman parte de una concepción más amplia del Patrimonio. En (Rabanal 2012) y (Sen 1993) se expone más detalladamente la evolución del sector minero energético que llega hasta finales de los noventa. Estas referencias a la Historia Económica reciente ayudan a comprender la evolución de un sector en crisis casipermanente desde hace un siglo, así como la incapacidad de las políticas institucionales para llevar a cabo una reconversión de la zona actualmente abocada al declive y la despoblación.

A partir de los vestigios físicos representados relacionados con la extracción, es necesario documentar la acumulación de recursos (de capital y tecnológicos), así como la configuración de un tejido socioeconómico que se articula en torno a dichas formas de explotación física, natural y humana. Más allá de una concepción gráfica, la propuesta que desarrollamos consiste en la recreación de una explotación minera como un reflejo de las relaciones sociales y económicas.

Las configuraciones socioeconómicas han cambiado, pero siguen reproduciéndose en la sociedad actual, si bien con una visibilidad y un impacto mucho menor debido a la irrelevancia del subsector minero en el sector primario. Las tecnologías disponibles (vinculadas antes a la Ingeniería de Minas) están al servicio de dichas relaciones $y$, por ello, su documentación y 
visualización gráfica no es un ejercicio aséptico, sino que está vinculado a ilustrar la circulación de mercancías y la reproducción de los recursos utilizados.

El estudio de casos de uso específicos para ilustrar desarrollos de alcance nacional o internacional no es novedoso. En (Vega 2004) se analiza el problema desde un punto de vista más empresarial o sectorial que histórico, complementando el enfoque llevado a cabo por (Rabanal 2012) o (Sen 1993). La visualización gráfica permite acceder a un mayor público y comunicar contenidos académicos o sociales de una forma más. Bajo ningún concepto se pretende ocupar un espacio o reemplazar el trabajo de los profesionales de la Historia Económica reciente, sino proporcionar un soporte que pueda ser reutilizado por expertos procedentes de otras áreas para facilitar una mejor comprensión de entornos olvidados o en declive.

\section{Un caso de uso: el pozo Herrera en Sabero}

La documentación gráfica propuesta utiliza diferentes recursos que permiten enlazar con diferentes aspectos técnicos, históricos o socioeconómicos. Así, por ejemplo, la navegación en las fases iniciales incorpora elementos que pueden ser activados a partir de los cuales se despliegan menús que permiten acceder a dispositivos, modelos y herramientas utilizados para la captura, procesamiento y análisis de la información, incluyendo las diferentes capas superpuestas al objeto virtual o aumentado. De este modo, el soporte gráfico funciona como un referente común a partir del cual se desarrollan diferentes contenidos narrativos que se pueden enlazar al objeto, incluyendo materiales sobre diferentes soportes multimedia.

Este enlazado de contenidos afecta no sólo a recursos tecnológicos, sino también a una intrahistoria de los lugares documentados a partir de los cuales se despliega una historia que ayuda a comprender el pasado durante una visita real o virtual. Las narrativas están vinculadas a objetos digitales que se encuentran embebidos dentro de la aplicación. En particular, el levantamiento arquitectónico permite identificar componentes estructurales y comprender la evolución de la arquitectura civil utilizada en el Patrimonio Industrial.

Por otro lado, los contenidos a insertar a partir de la edición de video están estructurados según diferentes perfiles que pueden ser seleccionados por los usuarios, incluyendo aspectos básicos relativos a las herramientas TIC o a contenidos históricos que facilitan una contextualización de los contenidos mostrados. Un ejemplo típico de estos últimos relevante para la actualidad consiste en mostrar el crecimiento, inicialmente exponencial, de las industrias ligadas a la explotación del carbón. Este crecimiento no es uniforme, sino que está sometido a fuertes vaivenes relacionados con la especulación financiera hacia mediados de los sesenta en el siglo XIX y el consiguiente hundimiento del sector bancario, textil y manufacturero en casi toda la economía castellana.

De forma simultánea y como contrapartida en una economía dual como la española de la época, la prolongación de la industria harinera (como mecanismo de capitalización en mercados interiores) y el crecimiento de las explotaciones mineras (inicialmente en el Norte de Palencia, posteriormente en el Bierzo) proporcionan los principales referentes para repuntes económicos que contribuyen a dinamizar la economía regional. La construcción de líneas locales de ferrocarril para facilitar el traslado del carbón a centros industriales genera una realimentación entre actividades industriales vinculadas al carbón y al hierro que dinamizan regiones emergentes antes de estallar la crisis de 1873. A lo largo del s. XX, la sobre-explotación de recursos hasta el agotamiento de estos últimos, con un valor añadido cada vez más pequeño, unos costes de extracción cada vez más elevados y unos rendimientos decrecientes abocan al cierre de un sector que a finales del s. XIX aportaba más del $40 \%$ de los recursos mineros del territorio nacional (DE VEGA 1995). Los desarrollos vinculados a la transformación se ilustran a partir de la navegación sobre el modelo $3 \mathrm{D}$ de un pequeño horno de siderurgia, modelo sobre el cual se han mapeado las texturas originales.

La sofisticación de los mecanismos de extracción, la percepción actual del carácter esquelético para las construcciones auxiliares, 0 el funcionamiento inexorable (ahora mudo) de una maquinaria (Fig. 5) que trabaja sin descanso hasta agotar todos los recursos son metáforas ilustrativas para entender la sobreexplotación de toda clase de recursos naturales, físicos y humanos. Las construcciones de galerías o el diseño de mecanismos y maquinarias cada vez más complejos son asimismo metáforas, tanto del dominio de la Naturaleza por el hombre -como los ilustrados pretendían hacernos creer- como de una forma de entender la explotación de recursos naturales que, para su efectiva consecución, requiere la explotación de todos los recursos disponibles, incluidos los humanos, a cualquier precio.

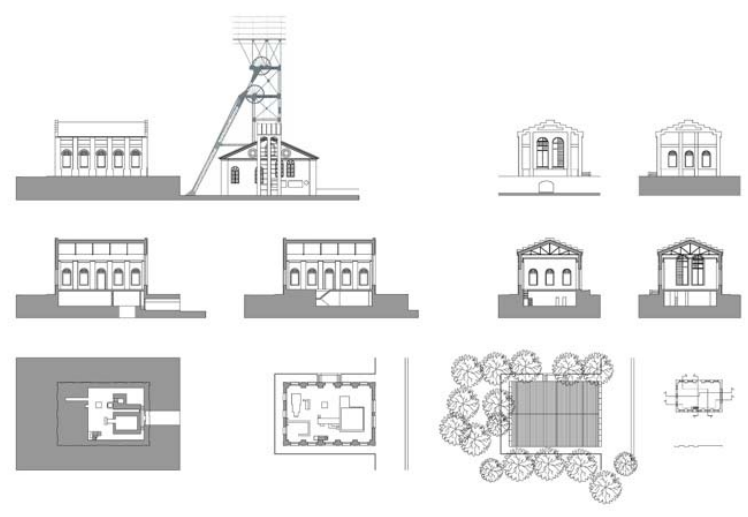

Figura 5: Diferentes planos de la casa de máquinas.

Una representación de los recursos y las tecnologías utilizadas pone de manifiesto que su representación no puede ser neutral. La acumulación de capital para las explotaciones mineras en la segunda mitad del s. XIX procede de los restos de la especulación que conduce a una primera quiebra del sistema financiero en torno a 1864, como prólogo de la general de 1873. Las tecnologías basadas en máquinas de vapor se realimentan del carbón extraído inicialmente en las mismas minas. Sin embargo, el mal diseño de la incipiente red ferroviaria (localización equivocada, tres anchos de vía) lastra el desarrollo inicial de la minería en el Bierzo que no despegará hasta las últimas 
décadas del s. XIX, en detrimento de la hulla palentina (Revilla 1906).

Estos factores muestran un desarrollo desigual de una sociedad dual, pero mantenido durante más de cien años, con importante valor añadido generador de una dinámica completamente diferente a la de la economía basada en rentas agrarias predominante en otras zonas de la Meseta castellana. La concentración de capitales con una dinámica que combina el apalancamiento con la especulación genera empleo en las zonas mineras. Sin embargo, los beneficios son reinvertidos en otras zonas generando un desarrollo desigual y desequilibrado.

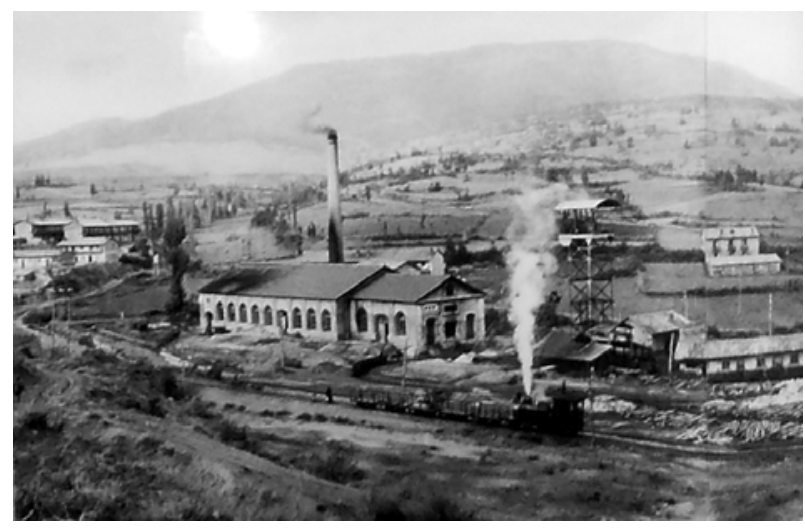

Figura 6: El Pozo de Herrera en los años 30. Años después el castillete fue reemplazado por el actual y la nueva sala de máquinas. La fotografía pertenece al fondo del Museo de la Siderurgia de Sabero.

A medio plazo y a pesar de las infraestructuras generadas, esta dinámica provoca una destrucción del medio. El Museo de la Siderurgia y la Minería de Castilla y León en Sabero (http://www.museosm.com) es una importante iniciativa que trata de recuperar la memoria, a través de diferentes tipos de actividades vinculadas a las antiguas explotaciones mineras, pero aún carece de herramientas para dar soporte multimedia y promover diferentes narraciones superpuestas a diferentes representaciones de un espacio físico. La Figura 6 sirve como ejemplo de los contenidos de este museo.

Esta iniciativa debe motivarse con una comprensión de un medio articulado en torno a explotaciones dispersas. La presencia de maquinarias -muchas herrumbrosas- y equipamientos complejos -algunos peligrosos- quedan como mudos testigos de una dinámica extinta $\mathrm{y}$, como símbolos de la destrucción de un medio, con la imposibilidad de recuperación del tejido social que les daba sentido inicial. La visualización de su funcionamiento es una herramienta útil para comprender la tecnología, pero también para dar una nueva vida a las explotaciones. Para completar este recorrido es necesario desarrollar recursos narrativos en diferentes formatos (texto, imagen, video, representaciones 3D, animaciones) que permitan comprender y proyectar realidades vinculadas al entorno documentado.

En particular, la recuperación del Patrimonio Industrial presenta aspectos relacionados con una dinámica socioeconómica compleja en tejidos urbanos y otros dispersos en explotaciones aisladas. Los primeros se pueden abordar en términos de cambios de uso o reconversiones a espacios culturales y existen diferentes iniciativas en el marco de Proyectos Europeos (como Europa Nostra, p.e.), la reconversión para otros usos (mirador de las estrellas en San Cebrián de Mudá, p.e.) o de iniciativas como la del Museo antes citado en Sabero. Sin embargo y al margen de la recuperación de algunos núcleos para uso vacacional, el despoblamiento de zonas alejadas de los núcleos urbanos, hace realmente difícil una recuperación que vaya más allá del abandono y la constatación del carácter depredador.

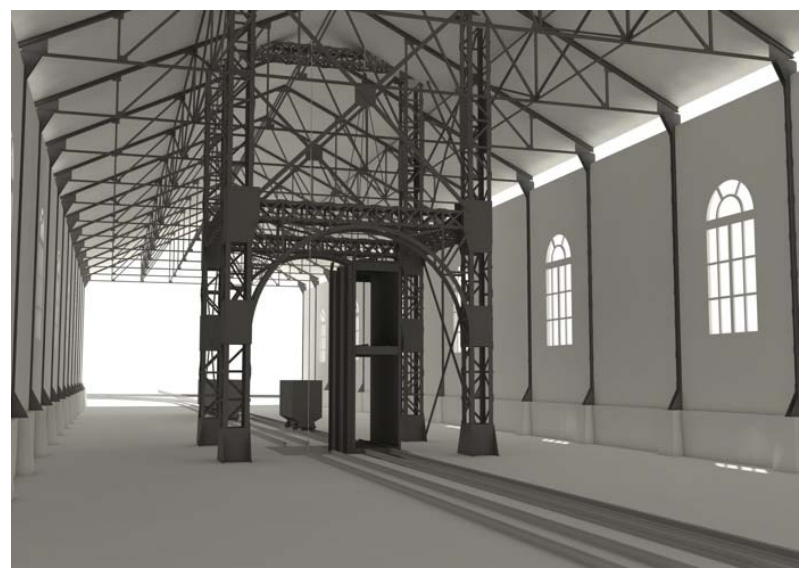

Figura 7: Interior de la nave de vaciado y llenado con base del castillete.

Con estos mimbres, la documentación del Patrimonio Industrial adquiere un carácter completamente diferente del que nos ofrecen declaraciones oficiales o documentos asépticos; tanto los emanados de la Comisión Europea (siempre bienintencionados), como los procedentes de la misma Unesco en relación con el Patrimonio Industrial. Al tiempo que se proclama la necesaria reconversión de zonas que no son rentables, no se ofrece ninguna alternativa real más allá del parque temático. La UE ofrece varios ejemplos de reconversión industrial de zonas mineras deprimidas en polos de producción multimedia en los que colaboran todo tipo de expertos en diferentes tecnologías multimedia y artistas gráficos. La opción del "parque temático" para recuperar zonas arruinadas por el saqueo y la destrucción natural, física y humana tiene un horizonte incierto y por ello es difícil que pueda contribuir a una recuperación del tejido económico y social. Sin embargo, la potenciación del turismo y el desarrollo de recursos narrativos tiene un alcance potencial mucho mayor. Este último involucra a una gran cantidad de agentes que van desde la documentación 3D (como la presentada en este trabajo) hasta la producción de recursos multimedia vinculadas a diferentes soportes.

\section{Localización y contextualización del entorno}

Centrar la atención en los aspectos físicos del entorno, en el triunfo de la tecnología o la generación de una riqueza pasada son otras formas de mixtificación de una realidad muy compleja que las representaciones virtuales o aumentadas pueden contribuir a explicar. EI entorno se ha modificado por la acción del hombre, las tecnologías tienen una vida efímera y la riqueza ha ido a parar siempre muy lejos de las zonas en las que se ha generado. Todos estos aspectos se pueden leer e interpretar a partir de modelos virtuales. Así, por ejemplo: 
a) Las modificaciones sobre el terreno se deben mostrar no sólo sobre Mapas de Elevación Digital para contextualizar la parte visible, sino los sistemas de galerías sobre los cuales se desarrollan las actividades de extracción.

b) La recreación de obras maestras de la ingeniería minera como el canal subterráneo de Orbó $^{4}$ para el transporte de material (1885), o la simulación de las tecnologías utilizadas representadas sobre torres vinculadas a extracción y transporte del mineral.

c) La red ferroviaria articula un espacio económico que facilita la distribución y al cabo del tiempo consolida la desaparición de los recursos por la ausencia de reinversión; un ejemplo paradigmático es el ferrocarril de La Robla construido entre 1889 y 1894 para dar salida al carbón del norte de las provincias de Palencia y León hacia la siderurgia vasca. La utilización posterior en centrales térmicas ha cambiado los recorridos, aunque no los flujos económicos y las actividades vinculadas.

Lamentablemente, las últimas explotaciones que a duras penas sobrevivían han sido cerradas en 2014 , sin apenas otras iniciativas que la creación del Museo de la Siderurgia y la Minería de Castilla y León (Sabero, León) dentro del Plan Sectorial del Patrimonio Industrial incluido en el plan PAHIS (2004-2012). Este cierre condena al ostracismo cuando no a la diáspora a la mayor parte de la población de esas zonas que solo muestran algún signo de vitalidad en los períodos vacacionales. El abandono de las torres y el silencio de los mecanismos que las hicieron funcionar son tan elocuentes de una riqueza evaporada y del carácter depredador como en su día lo fueron de una actividad incesante vinculada a la explotación. La recreación virtual permite mantener viva la memoria relativa a estas actividades, así como una representación de las relaciones que las hicieron posibles. En particular, la recreación virtual de los mecanismos que hacen funcionar los dispositivos adquiere múltiples sentidos que va más allá de la apariencia física o de las tecnologías (máquinas de vapor, electricidad) que las mueven.

En este trabajo hemos analizado y modelado la mina del Pozo Herrera. El levantamiento $3 \mathrm{D}$ ha sido llevado a cabo de forma híbrida, es decir, combinando escáner láser y fotogrametría convencional.

La captura de datos del complejo minero y de su entorno se ha realizado mediante escaneos 3D con un escáner de la marca Optech IIris 3D. Se trata de un escáner de rango de medición de tiempo de vuelo de largo alcance que permite escaneos a una distancia de un kilómetro con una precisión centimétrica. Su elección está justificada debido a la complejidad del entorno, ya que los edificios se encuentran ubicados en un valle y con este escáner podemos obtener mediciones precisas desde posiciones elevadas a cierta distancia capturando zonas amplias del complejo. Para este trabajo se han escaneado tanto el exterior como el interior del complejo (nave de llenado, oficinas, vestuarios, salas de

4www.arqueologiaypatrimonioindustrial.com/2008/12/minas-deorb-el-canal-subterraneo.html máquinas, etc.). Desde la posición de cada tomase han realizado mediciones radiométricas (color) mediante fotografías panorámicas que serán utilizadas para colorear las nubes de puntos en el post-procesamiento.

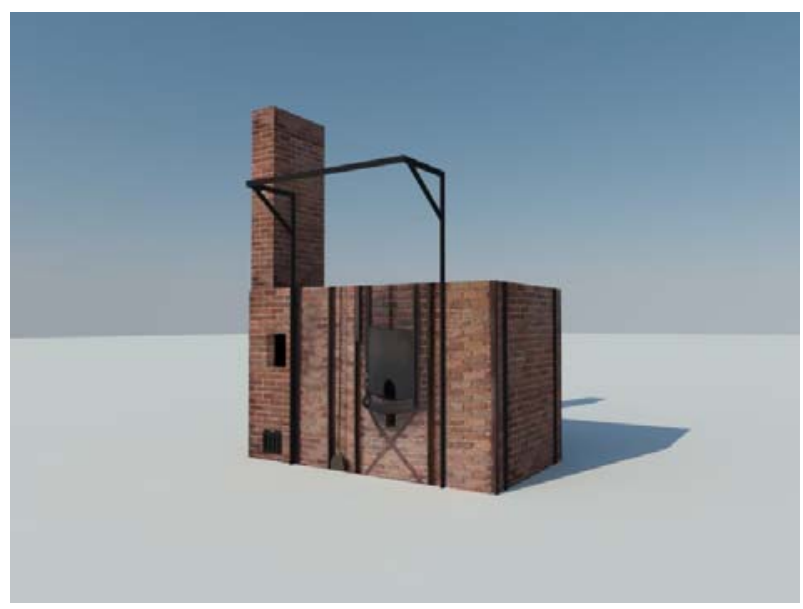

Figura 8: Pequeño horno de siderurgia en las instalaciones anexas

Además de los escaneos, el complejo ha sido digitalizado con fotografía de alta resolución, utilizando una cámara DSLR. Estas capturas han incluido vistas detalladas de todos los elementos y espacios significativos que más tarde han servido como texturas durante el modelado 3D. La Figura 8 ilustra la generación de un modelo $3 \mathrm{D}$ con texturas para representar un horno de siderurgia. Estas fotografías han sido combinadas con panorámicas equirectangulares esféricas de espacios significativos por su relevancia histórica, con la intención de mostrar el estado actual del edificio en los nuevos dispositivos de realidad virtual y en otras aplicaciones.

El procesado de los datos obtenidos con el escáner permite construir una única nube de puntos del complejo de edificios y de su entorno. A su vez, este modelo proporciona un soporte 3D para la obtención de ortoalzados y secciones 2D (perfiles) conformadas mediante proyección de puntos seleccionados sobre planos. Para este proceso se ha utilizado UVaCAD®, un software propio creado por el LFA-DAVAP de la Universidad de Valladolid. A partir de estas representaciones planas se vuelve a una tridimensionalidad generalizada 0 simplificada, construida a base de primitivas y operaciones de diseño asistido por computador, tales como extrusión, simetría, etc. Esta etapa de simplificación fue llevada a cabo con el software Autodesk AutoCAD®.

La reconstrucción de la maquinaria ha sido llevada a cabo siguiendo las mediciones realizadas con el escáner láser y las fotografías, fusionando la información con el tratado de maquinarias de (Flachat 1842). Una vez conseguido un modelo con una complejidad geométrica aceptable, se han diseñado y reconstruido las complejas estructuras mecánicas de las torres vinculadas a la extracción del mineral y las edificaciones que alojaban la actividad minera o industrias auxiliares. En esta etapa se han diseñado nuevos materiales para el modelo 3D, así como animaciones mediante la técnica de fotogramas clave o keyframes. El trabajo consiste en determinar las 
acciones que se desencadenarán en esos fotogramas clave, para que el software de animación sea capaz de determinar el valor de las variables por interpolación entre frames.

El último paso ha consistido en generar un vídeo con una parte estática en la que se describen los elementos más significativos del entorno del pozo que pueden ser visitados de forma segura y que se describen a continuación.

1. La sala de máquinas, en cuyo interior estaba el motor diésel que movía el cable para subir y bajar los ascensores.

2. El castillete o torre utilizada para la extracción del material mediante un sistema de poleas sobre el brocal del pozo. La extracción del material (sobre trenes de vagones), o el desplazamiento de personas, se llevaban a cabo mediante izado vertical utilizando cabrestantes, que pueden incluir castilletes para izado/bajada y mejorar la seguridad de los trabajadores (Fig. 4).

3. La nave de llenado y vaciado, con dos vías para la entrada y salida de vagonetas (vacías o llenas de carbón, respectivamente), como aparece en la Figura 7.

4. Las vías, que aparecen resaltadas para indicar el flujo de trabajo hacia el interior de la mina con vagonetas inicialmente vacías que se bajaban utilizando la maquinaria del castillete para ser cargadas por los mineros.

5. Las vías de vaciado, que salen de la nave de llenado o vaciado, cierran el ciclo básico asociado a la extracción del material en relación con las vagonetas procedentes del interior de la mina, una vez cargadas.

6. Una nave anexa que contenía las salas de vestuarios, duchas y una enfermería.

7. Una serrería (parte izquierda del vídeo) en la que se realizaban las tareas necesarias para fabricar elementos que permitan consolidar la estructura interna de las minas (entibaciones).

La segunda parte del video es dinámica, y muestra una navegación visual alrededor de las instalaciones y en el interior del pozo mediante una cámara virtual. Del interior se muestran detalles de la arquitectura civil, de las instalaciones industriales y de la maquinaria, incluyendo una recreación de su funcionamiento.

\section{Retos y trabajo futuro}

Uno de los principales retos abordados en este proyecto es la eliminación de los obstáculos físicos para la visita y el reconocimiento de estos paisajes. La virtualización del patrimonio ha de convertirse en el medio por excelencia para la superación de todas las limitaciones. La adopción de estas tecnologías por el sector turístico debe saber sacar partido a los recursos que hoy permiten ampliar el espectro de potenciales visitantes a todas las edades y condiciones físicas. La revitalización del sector será clave para la creación de polos de atracción y la generación de empleo en toda la cadena: productores de contenidos, servicios de gestión, desarrollo de herramientas de realidad virtual $y$ aumentada, agentes y gestores de turismo, hostelería, comercio etc.

Esto conlleva además otro reto añadido asociado a la necesidad de incrementar las habilidades, capacitación y profesionalización de los agentes culturales y turísticos involucrados alrededor de este tipo de contenidos, que a su vez debería traer consigo el acercamiento y la participación de las empresas de tecnología en áreas geográficas que hoy se encuentran en un proceso de desvitalización que es necesario atajar. Así se pueden promover líneas negocio en sectores culturales ligados a la arqueología y el patrimonio industrial necesitados de inversores privados. Es necesario facilitar la difusión internacional de los paisajes culturales en general, y mineros en particular, con su inclusión en redes europeas para que formen parte de una memoria que tiene elementos dignos de ser conservados y que forman parte de nuestra identidad cultural.

En un trabajo que todavía está en ciernes se distinguen algunas de las posibles líneas de trabajo futuro. Una de ellas consiste en la posibilidad de seleccionar de forma interactiva los modelos digitales con zonas o regiones que pueden ser seleccionadas de forma interactiva para componer relatos. Los diferentes usuarios podrán insertar sus experiencias y conocimientos en forma de diferentes recursos narrativos (geológicos, históricos, literarios, fílmicos) con los que ayuden a preservar el patrimonio al mismo tiempo que se fomenta la participación en la memoria colectiva.

Otra posible línea de trabajo consiste en incorporar agentes humanos vinculados a las explotaciones mineras y que hagan funcionar los dispositivos. El esquema para incorporar estos agentes se plantea en términos de herramientas avanzadas para la interacción (usando herramientas de Second Life, p.e.) o adaptando estrategias de videojuegos. La ausencia actual de figuras humanas en estas simulaciones es otra mistificación de la técnica, como si pudiera funcionar más allá de los agentes que las utilizan, como si la explotación de los recursos físicos a través de los tecnológicos no se pudiera hacer sin la explotación de los recursos humanos, invisibles en las representaciones asociadas a la documentación. Por ello, es necesario incorporar a diferentes agentes humanos en la visualización del Patrimonio Industrial, como actividad de transformación. Por el momento, los desarrollos se han centrado en la virtualización del entorno y en la simulación de las técnicas que hacen funcionar los diferentes dispositivos mecánicos asociados a la extracción.

\section{Conclusiones}

Este trabajo presenta una primera aproximación al levantamiento fotogramétrico, modelado 3D y simulación del caso de estudio del Pozo de Herrera de las minas de Sabero como ejemplo del Patrimonio Industrial en explotaciones mineras. El esquema desarrollado en esta propuesta parte de la representación gráfica como un pretexto a partir del cual se desarrollan diferentes narrativas vinculadas a actividades humanas. El resultado final ha sido un video en el que una cámara virtual recorre las instalaciones mientras se reproduce la simulación. Al igual que en otras aplicaciones del Patrimonio Histórico, los modelos 3D diseñados nos 
proporcionan un soporte digital para la producción de contenidos multimedia adicionales, pudiendo incorporar investigaciones recientes sobre el desarrollo regional, productivo vinculado a la minería y socioeconómico.

\section{Agradecimientos}

Este trabajo ha formado parte del proyecto "Inventario y Documentación del Patrimonio Histórico Industrial de la provincia de León" (número de expediente 01360/200966), financiado por la Dirección General de Patrimonio de la Junta de Castilla y León. Igualmente, los autores agradecen las facilidades prestadas por la Asociación Llámpara y el Museo de La Siderurgia y La Minería de Castilla y León (Sabero, León) para el acceso y la recopilación de la documentación histórica necesaria.

\section{Referencias}

CARROZZINO, M. y BERGAMASCO, M. 2010. Beyond virtual museums: Experiencing immersive virtual reality in real museums. Journal of Cultural Heritage, 11(4), pp 452-458.

DE VEGA, M.E., 1995. El sueño imposible de una burguesía agraria. Historia de una Cultura (las castillas que no fueron). Sever-Cuesta. 1(3), pp. 323-359. ISBN 84-7846-462-X

FLACHAT, E., BARRAULT, A. ET PÉTIET, J., 1842. Traité de la fabrication du fer et de la fonte envisagée sous les rapports chimique, mécanique et commercial. $D$ Avanzo et cie.

MAURIN ALVAREZ, M., 2011: Huella, memoria y patrimonio territorial de la minería española. Una síntesis cartográfica. Ería 86, pp. 187-214. Available: https://dialnet.unirioja.es/descarga/articulo/3819919.pdf [1/06, 2016]

RABANAL, N.G., 2012: El sector minero energético. In: XXV años de Economistas y Economía Leonesa. Colegio de Economistas de León, pp. 63-90.

REVILLA HAYA, J., 1906: Riqueza minera de la provincia de León. Su descripción, industria y estudio de soluciones para explotarla. Madrid, Imprenta Alemana. Suplemento $1^{\circ}, 48$ pages.

SEN RODRÍGUEZ, L.C. 1993: La minería leonesa del carbón, 1764-1959: una historia económica. Universidad de León. Secretariado de Publicaciones y Medios Audiovisuales. 371 pages. ISBN 84-7719-364-9.

VEGA CRESPO, J., 2004: Minería y desarrollo empresarial en León: el caso de la minero-siderúrgica de Ponferrada. Departamento de Economía Aplicada, Universidad de Valladolid. Available: http://www.usc.es/estaticos/congresos/histec05/b16 vega crespo.pdf [1/06, 2016] 


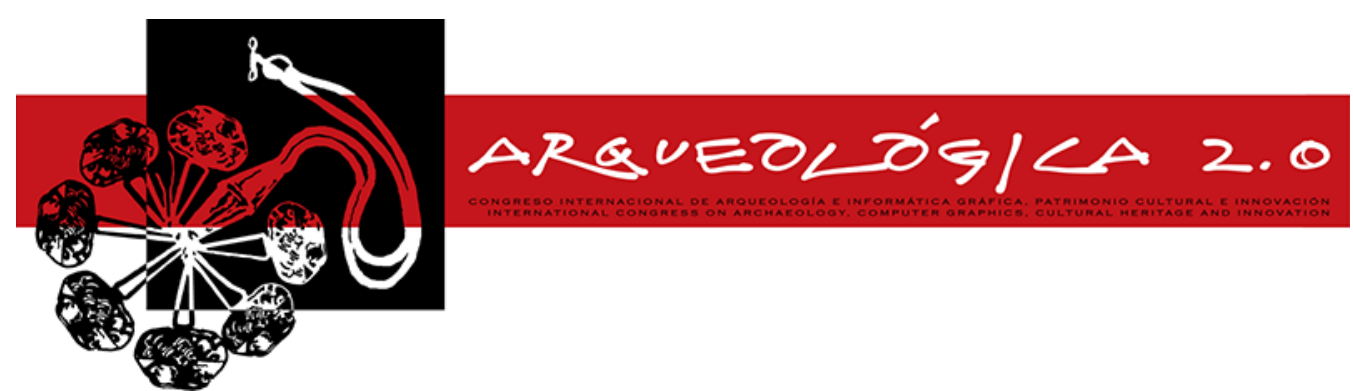

Proceedings of the $8^{\text {th }}$ International Congress

on Archaeology,

Computer Graphics,

Cultural Heritage and Innovation

'ARQUEOLÓGICA 2.0'

in Valencia (Spain),

Sept. $5-7,2016$

DOI: http://dx.doi.org/10.4995/arqueologica8.2016.3567

Received: $07 / 03 / 2016$

Accepted: 07/05/2016

\title{
KUÉLAP VIRTUAL: VIRTUALIZACIÓN DE UNA CIUDADELA PREINCA EN LOS ANDES AMAZÓNICOS DEL PERÚ MEDIANTE FOTOGRAFÍA ESFÉRICA, MODELADO 3D E IMPRESIÓN 3D
}

\author{
KUÉLAP VIRTUAL: VIRTUALIZING AN PREINCA CITADEL IN AMAZONIAN ANDES OF PERU WITH 360 \\ PHOTOGRAPHY, 3D PRINTING AND 3D MODELING
}

Esteve Ribera

CEO of Panograma Labs. Chachapoyas, Reasearcher in Centro Mallqui, Institute of Bioarchaeology, Leymebamba, Perú. eribera@panograma.net

\begin{abstract}
:
Between 2010 and 2012, under the International Cooperation for Development, a virtual archeology project was realized in Amazonian Andes of Peru. The project was carried out with collaboration from Universitat Politécnica de València (UPV) and the Agencia Española de Cooperación Internacional al Desarrollo (AECID), with archeologists taking part in Proyecto Especial Kuélap (PEK). The goal was to create a virtualization of Kuélap, an important monumental citadel constructed by the ancient Chachapoya society. The fruits of the project was the website "kuelapvirtual.com", that offers an interactive virtual visit (like street view) as well as geographical and archaeological information of interest. Furthermore, a virtual 3D reconstruction was created from blueprints, topographic data available and assistance from archaeologists. The $3 \mathrm{~d}$ digital model made the fabrication of a two prototipes: an archaeological model in scale 1:750 and a topographical model in scale 1:17500, obtained through 3D printing at the Department of Engineering Projects at Universitat Politècnica de València.
\end{abstract}

Key words: Kuélap virtual, virtual tour, spheric photography, 3D reconstruction, 3D print, Chachapoya, Peru.

\section{Resumen:}

Entre 2010 y 2012, en el marco de la Cooperación Internacional al Desarrollo, se llevó a cabo un proyecto de arqueología virtual en los Andes Amazónicos del Perú. Este proyecto fue producto de la colaboración de la Universidad Politécnica de València (UPV) y la Agencia Española de Cooperación Internacional al Desarrollo (AECID) con los arqueólogos del Proyecto Especial Kuélap (PEK). El proyecto tuvo por objeto la virtualización de Kuélap, una importante ciudadela monumental construida por la antigua sociedad Chachapoya. Fruto de este proyecto, se lanzó en la red el portal "kuelapvirtual.com": una visita virtual basada en la técnica de la fotografía esférica inmersiva (street view) con información geográfica y arqueológica de interés. Por otro lado, se realizó una reconstrucción virtual en 3D a partir de los planos y datos topográficos disponibles, gracias a la asistencia de los arqueólogos. Este modelo digital sirvió para la fabricación de dos prototipos: una maqueta arqueológica a escala 1:17500 y una maqueta topográfica a escala 1:750, obtenidas mediante impresión 3D en el Departamento de Proyectos de Ingeniería de la UPV.

Palabras clave: Kuélap virtual, visita virtual, fotografía esférica, reconstrucción 3D, impresión 3D, Chachapoya, Perú

\section{Introducción}

El presente artículo presenta los procesos y resultados del proyecto de arqueología virtual que se desarrolló entre el 2010 y el 2012 en la Región Amazonas del Perú. Este proyecto fue posible gracias a la colaboración de la UPV y la AECID con los arqueólogos del Proyecto Especial Kuélap del Gobierno Regional Amazonas (GRA), contribuyendo, a los fines de dicha entidad, en la investigación, conservación y difusión científica del sitio arquelógico de Kuélap.
Este trabajo conjunto se desarrolló en el marco de un proyecto de Cooperación Internacional (AECID - UPVGRA) que llevaba por título "Simulación virtual, difusión telemática y prototipado de Conjunto arqueológico de Kuélap". De forma paralela a esto, se desarrolló el Proyecto Final de Carrera (PFC) de Ingeniería Técnica en Diseño Industrial de la UPV por parte de E. Ribera, ejecutor responsable del Proyecto, bajo la dirección técnica de José Antonio Diego Mas. Se destaca que el proyecto ganó el premio a la mejor defensa de PFC de la Escuela Técnica Superior de Ingeniería del Diseño (ETSED) durante el curso 2012-2013. 
Finalmente, cabe señalar que uno de los alcances del proyecto fue el Convenio de Cooperación Interinstitucional suscrito por el GRA y la UPV, con el propósito de facilitar futuros proyectos e intercambios entre ambas entidades.

\section{Kuélap, complejo arqueológico monumental de la cultura Chachapoya}

Kuélap es el nombre con el que se conoce el asentamiento de élite de mayor importancia de la civilización Chachapoya en los Andes nororientales del Perú. Su construcción debió iniciarse en los primeros siglos de la era cristiana y su ocupación culminó hacia mediados del siglo XVI. Sus colosales murallas y su compleja arquitectura interior son evidencias de su función como conjunto poblacional bien organizado, que incluye recintos de índole administrativa, religiosa, espacios ceremoniales y de residencia permanente.(L.A. Narvaez 2011) (Fig.1).

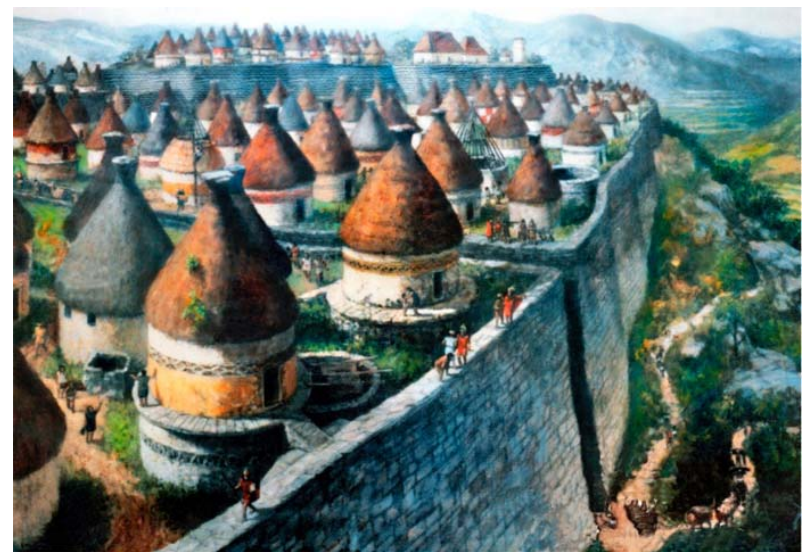

Figura 1: Recreación de Kuélap en plena ocupación. Fuente: Museo Leymebamba.

Esta importante fortaleza de aproximadamente 5 hectáreas se ubica en las coordenadas $6^{\circ} 25^{\prime} 05^{\prime \prime} \mathrm{S} 77^{\circ} 55^{\prime} 24^{\prime \prime} \mathrm{O}$, a más de $3.000 \mathrm{msnm}$, en el distrito de Luya de la Región Amazonas del Perú. En la actualidad, el sitio representa uno de los atractivos turísticos principales de la Región Amazonas, la cual recibe hasta la fecha un turismo de baja intensidad (Fig.2).

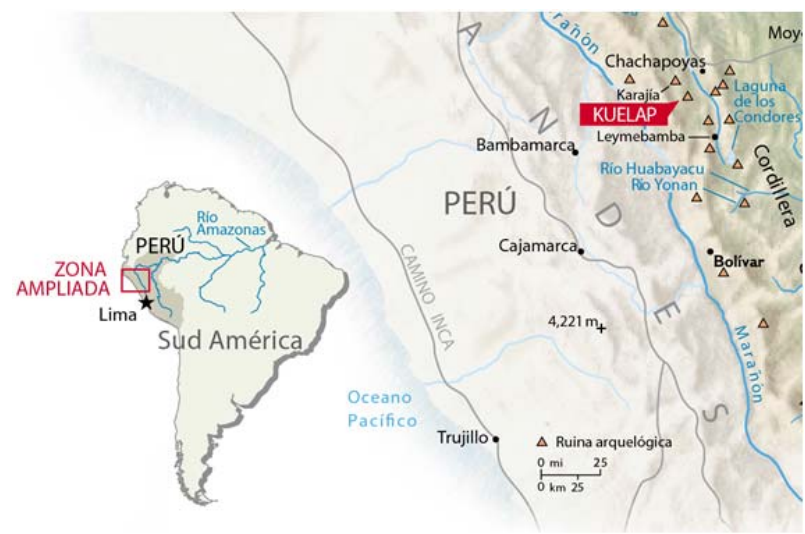

Figura 2: Infografía de ubicación geográfica de Kuélap. Fuente: Elaboración propia a partir de Infografía National Geographic 198/3: 63-81.
Cabe señalar que desde el Ministerio de Cultura del Perú y el Gobierno Regional Amazonas se han impulsado algunas campañas de excavación y conservación arqueológica del sitio, aunque de manera discontinua e insuficiente.

\section{Objetivos}

Tal y como plantea la "Carta para la Gestión y Protección del Patrimonio Arqueológico", el proyecto contempló como objetivo fundamental conseguir un equilibrio sostenido entre investigación, conservación y difusión. Cabe decir que si bien estos tres fines siempre se manifiestan de manera conjunta, en cada parte del proyecto, uno de ellos adquirió un diferente peso específico. En lo referente a la investigación, el PFC se desarrolló en colaboración con los arqueólogos y especialistas responsables de las intervenciones arqueológicas de Kuélap, quienes garantizaron resultados de gran rigor científico e integridad intelectual.

El fin de documentar el patrimonio arqueológico se materializó en la visita virtual en base a fotografía esférica de Kuélap. Esta técnica de representación virtual permitió documentar, de manera fidedigna, el estado de la Ciudadela en el preciso momento en que se obtuvieron las fotografías, con la precisión que representa una visión $360^{\circ}$ del campo visual.

Si bien la investigación y conservación (virtual) son esenciales y están siempre presentes, en la difusión es donde el proyecto puso más énfasis, debido al enorme alcance geográfico y demográfico que permite la divulgación de los resultados a través de internet.

En esta línea, uno de los objetivos logrados fue acercar el conocimiento histórico preincaico y del patrimonio arqueológico de Kuélap tanto a los especialistas en arqueología y conservación, como al gran público. De esta manera, viene fomentando el conocimiento y reconocimiento de la cultura Chachapoya como pasado histórico propio de las comunidades locales.

Por otro lado, desde el punto de vista socio-económico, el proyecto contribuyó a fomentar la promoción de una actividad turística sostenible en Kuélap, basada en el turismo cultural, que genera ingresos para la población local, y que favorece la consolidación paulatina del turismo sostenible como actividad económica alternativa a la minería y la actividad agro-pecuaria.

\section{Técnicas empleadas}

El proyecto consideró, desde sus inicios, dos productos diferenciados: simulación virtual y prototipado.

Para el primero, se tomaron en consideración las necesidades planteadas por los arqueólogos, eligiendo la técnica de la fotografía esférica inmersiva, con el propósito de ofrecer una visita virtual, a través de la red, con realismo fotográfico y como testimonio documental del estado del sitio en el año 2010.

Esta técnica se consideró la más indicada por los siguientes motivos:

- Buenos resultados gráficos

- Buena implementación en web

- Realismo fotográfico 
- Facilidad de inserción de textos y gráficos

- $\quad$ Capacidad para editar la interfaz

- Softwares asequibles

- Equipos asequibles

- Archivos livianos / carga rápida

Por otra parte, el prototipado estaba necesariamente vinculado al uso de CAD/CAM. Un equipo de topógrafos del PEK realizó un levantamiento topográfico con estación total de Kuélap. Este trabajo sirvió de base para la generación de un modelo 3D de Kuélap, sobre el que se realizó una "reconstrucción arqueológica" del sitio para mostrar su estado en plena ocupación.

\section{Etapas de ejecución}

La ejecución del proyecto se definió en 4 fases:

\begin{tabular}{c|c|} 
Fase & Título \\
\hline 1. & Fotografía esférica inmersiva \\
2. & Diseño, desarrollo y difusión web \\
3. & Modelado 3D \\
4. & Prototipado
\end{tabular}

\subsection{Fotografía esférica Inmersiva}

La fotografía esférica es una técnica que consiste en la obtención de una imagen $360^{\circ}$ del entorno (imagen equirectangular), que luego es procesada informáticamente para generar una aplicación interactiva donde el usuario puede rotar el punto de vista $360^{\circ}$ a su alrededor. Hoy en día, podemos encontrar cámaras que permiten capturar fotografías esféricas con un solo disparo, como es el caso de la Ricoh Theta o algunos dispositivos android, inexistentes en el año 2010. Sin embargo, la calidad que se obtiene con esas cámaras aún dista mucho de las cámaras DSLR (Reflex), como la utilizada en el proyecto, con un lente "ojo de pez" (Fig. 3).

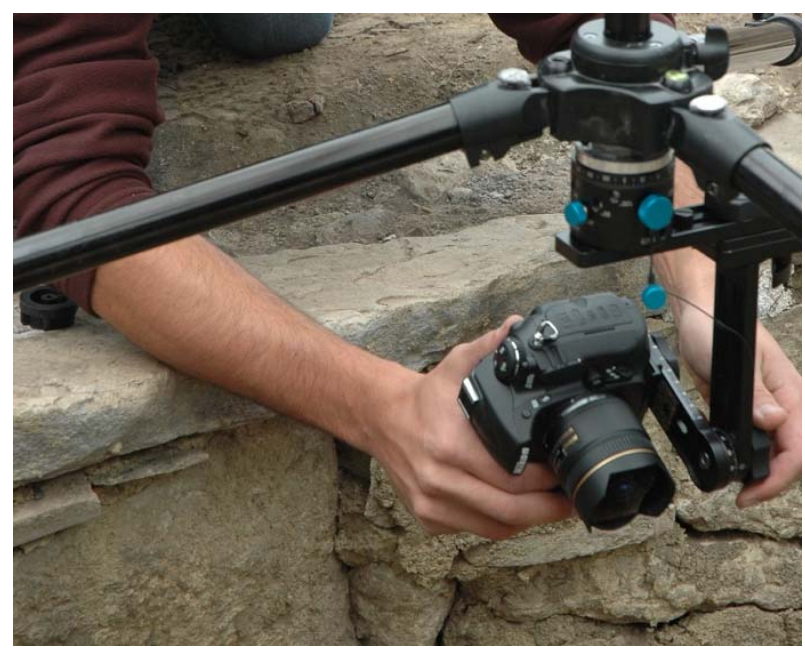

Figura 3: Fotografiando el interior de la Tumba encontrada en el Pueblo Alto de Kuélap. Foto: Marla Toyne.

\subsubsection{Cabezal panorámico}

La clave para obtener buenos resultados consistió, principalmente, en la precisión de las fotografías originales. Los panoramas equirectangulares se consigueron con la unión de varias fotografías, para lo cual fue esencial que estas estuvieran tomadas adecuadamente. Una vez realizado esto, el software encargado de la costura fotográfica (stitching) pudo realizar correctamente las uniones, evitando así, uno de los principales problemas conocido como efecto "parallax". Es decir, girando la cámara con un cabezal convencional, la posición aparente entre objetos situados en diferentes planos de profundidad varía con el ángulo (Fig. 4) con lo que se producen deformaciones o interpolaciones extrañas al unir las imágenes con la consecuente falta de definición y calidad. Para evitar esto, se utilizó un "cabezal panorámico", que permitió girar la cámara alrededor del punto nodal, también llamado "punto de pupila" o "punto de no paralaje", evitando así esta distorsión. (Fig. 5).
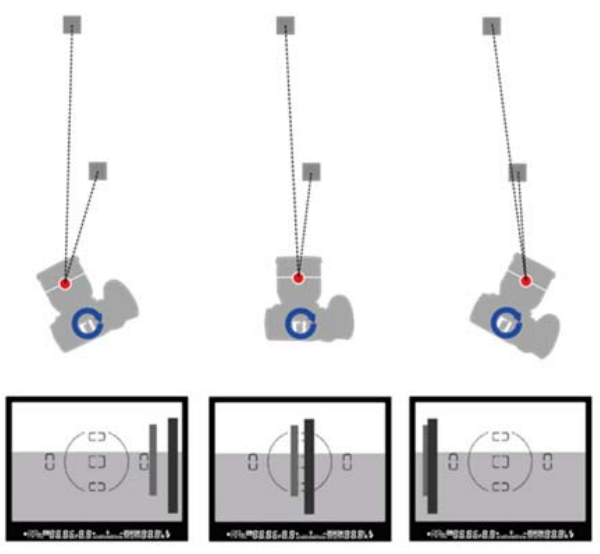

Figura 4: Rotación con cabezal convencional. Elaboración propia inspirada en Big Ben's Panorama Tutorials.

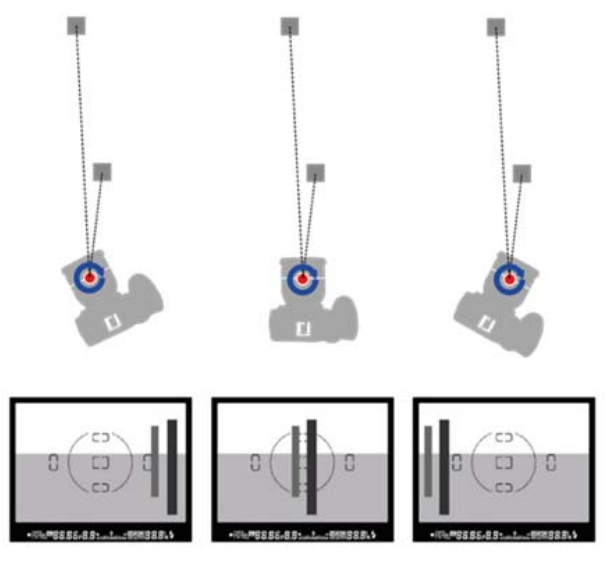

Figura 5: Rotación calibrada con cabezal panorámico alrededor del NPP o punto de no paralaje.

\subsubsection{Trabajo de campo: fotografiando Kuélap}

Conjuntamente con el equipo arqueológico, se seleccionaron los espacios de mayor interés para realizar los panoramas. Finalmente, fueron 19 los puntos elegidos, siendo estos suficientes para mostrar el conjunto arqueológico en profundidad $\mathrm{y}$, especialmente, para exhibir sitios no accesibles al visitante, como el interior del Templo Mayor o el interior de una tumba de la élite; un importante hallazgo que se produjo justo al iniciar el proyecto (Fig. 6). 


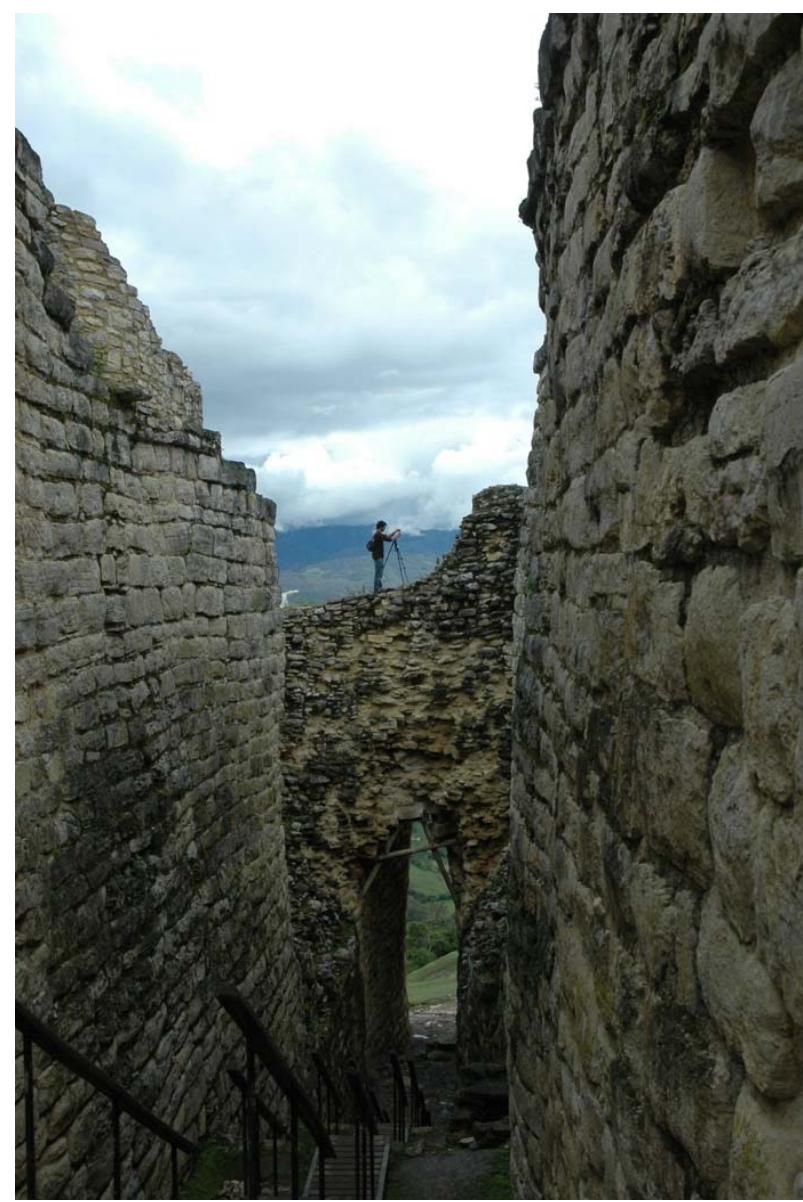

Figura 6: Fotografiando la parte superior del Acceso 1 de Kuélap. Foto: Marla Toyne.

La técnica empleada para cada panorama consistió en capturar 6 tomas horizontales (una cada $60^{\circ}$ ), más la captura del zénit. Para controlar el ángulo de giro de la cámara, fue muy útil un accesorio fotográfico llamado "rotador", que permitió definir el giro en $60^{\circ}$ y rotar así la cámara con total exactitud y comodidad.

En algunos casos, se tomaron 3 fotografías por cada posición de la cámara, haciendo uso del braketing. Esta función permitió la captura automatizada de una misma escena, variando el valor de exposición (EV), con lo que se obtuvo una secuencia escalonada de 3 exposiciones por cada imagen.

Con este método, se aseguró captar la máxima información fotográfica "en bruto" y de manera sistemática, llegando a los resultados deseados con la técnica del Hight Dinamic Range (HDR).

\subsubsection{Pocesado digital}

El hecho de combinar la fotografía panorámica con el HDR/Exposure fusion amplió enormemente el número de variables en el flujo de trabajo, ya que eran necesarias un gran número de operaciones, y la casuística, derivada del orden de ejecución y los programas a utilizar, era muy grande. Por este motivo, se consultó a especialistas en fotografía digital y se realizaron numerosas pruebas con distintos softwares y procesos hasta llegar a definir un flujo de trabajo sistemático óptimo para ser aplicado a la edición de todos los panoramas.
En este sentido, fue inestimable la ayuda aportada por el especialista en fotografía digital Guillermo Luijk a través de los artículos de su web y, especialmente, por compartir libremente el software "Zeronoise" del cual es autor y que se empleó en el proyecto.

La primera decisión a la hora de definir la metodología fue elegir si realizar inicialmentela fusión (HDR / Exposurefusion) y luego la costura fotográfica (Stitching) o hacerlo en el orden inverso. Se comprobó que las dos opciones eran válidas y se podían conseguir resultados similares, así que se prefirió hacer la fusión primero y la costura después pues resultaba más práctico.

El flujo de trabajo utilizado fue el siguiente:

- Balance de Blancos con Zeronoise

- Revelado RAW neutro con Zeronoise

- Exposure Fusion con Tufuse

- Costura fotográfica con PTgui

- Retoque fotográfico con Photoshop

- Interactividad e interfaz con Pano2vr

\subsubsection{Balance de Blancos y Revelado RAW}

El formato fotográfico RAW, que en el caso de cámaras Nikon corresponde a la extensión de archivo .NEF, es un tipo de archivo "en crudo", es decir que conserva la máxima información fotográfica de la escena tal y como ha sido captada por el sensor. Se trata de un "negativo", que requiere de un "revelado" para poder visualizarse como imagen final. Existen numerosos reveladores RAW como el Adobe Lightroom o el propio revelador de Nikon (ViewNX), pero finalmente, se prefirió emplear el programa Zeronoise porque permitía definir el balance de blancos con gran precisión y brindabacomo resultado un archivo TIFF de 16 bits en bruto, sobre el que se podía realizar ajustes de exposición, contraste y saturación posteriormente, sin perder calidad. Cabe señalar que Zeronoise utiliza internamente el revelador DCraw (programado por David Coffin), de libre distribución y gran control manual.

\subsubsection{HDR y Exposure-fusion}

EI HDR es una técnica que muchas veces se asocia a un uso artístico de la fotografía caracterizado por efectos muy llamativos, con altas saturaciones y un alto nivel de artificialidad; pero no siempre es así. Las posibilidades que ofrece esta técnica son muy variadas y también es ampliamente utilizada con el propósito de obtener fotografías naturales y realísticas, como en en el caso del proyecto que se realizó

Su uso es muy apropiado cuando existe una gran diferencia entre luces y sombras en la escena (algo común en fotografía esférica), como sucede por ejemplo, en el Templo Mayor, donde el interior está muy oscuro y el exterior altamente iluminado.

\section{Fusión de tomas con HDR (32 bits)}

Existe cierta controversia a la hora de definir el HDR. Internacionalmente, las siglas HDR suelen utilizarse para hacer referencia a la fusión de la exposición en que se genera un archivo de 32 bits en bruto que contiene un rango dinámico mucho mayor que el de las fotografías capturadas por la cámara. Este archivo tiene 
extensión .HDR y no es visualizable en el monitor del ordenador debido a su número de bits. Para ello, es necesario su compresión mediante un "mapeado de tonos", que generará un LDR (Low Dinamic Range) como resultado final. Para realizar este proceso se utilizan softwares como Photomatix o Dynamic Photo HDR, pero los algoritmos que se utilizan no suelen dar resultados muy naturales.

\section{Fusión de tomas sin HDR: Exposure-fusion}

Por otra parte, existen otros métodos como los que utiliza el programa Zeronoise o Tufuse que, estrictamente hablando, también son HDR, ya que emplean archivos TIFF de 16 bits con un rango dinámico muy superior al que la cámara es capaz de capturar. Sin embargo, en estos casos suele hablarse de "exposure fusion", para diferenciarlo del clásico HDR de 32 bits. Los algoritmos que emplean estos softwares producen resultados mucho más naturales y realísticos, por lo que parecieron más apropiados para el proyecto, eligiendo Tufuse para realizar este proceso.

\subsubsection{Costura Fotográfica (Stitching)}

Como ya se ha comentado, la proyección que utilizan las fotografías esféricas es la proyección equirectangular (también conocida como proyección cilíndrica equidistante o proyección latitud-longitud). Se trata de un tipo de proyección de una superficie esférica en una imagen plana, muy utilizada en los mapamundis para representar la tierra. Ésta se basa en la traducción directa de longitud y latitud como coordenadas cartesianas, que se ha convertido en un estándar en aplicaciones informáticas para procesar mapas globales, por su correspondencia entre píxeles y su posición geográfica.

Cabe decir que los resultados de esta proyección son imágenes distorsionadas no conformes (con distorsión en las formas y los ángulos) y no equivalentes (con distorsión en las superficies). Esta distorsión es nula en el ecuador y máxima en los polos (zenit y nadir), como se observa en la Figura 7.

El programa que se eligió para realizar la costura fotográfica fue PTGui. Este programa también permite trabajar con HDR y Exposure-Fusion, y acepta los archivos RAW de Nikon (con extensión .NEF) como imágenes de entrada, pero se prefirió realizar estas operaciones con otros softwares que permitieran tener más control sobre el proceso.
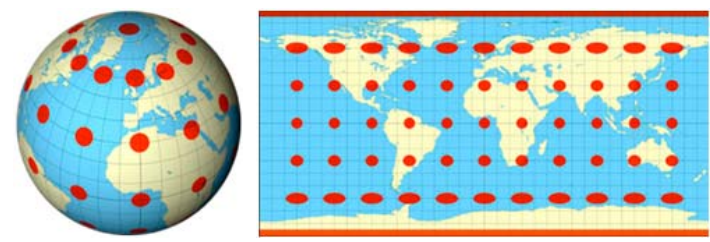

Figura 7: Proyección equirectangular plana de la superfície "esférica" terrestre, con indicadores de la deformación relativa.

\subsubsection{Retoque fotográfico}

Como último paso, para la obtención del panorama equirectangular definitivo, se realizaron algunos retoques y ajustes en Photoshop. El principal de ellos fue la corrección del nadir. Después de la costura equirectangular, siempre aparece el trípode y su sombra en la parte inferior, y una pequeña zona en blanco que no ha sido fotografiada por la cámara. Esta parte se muestra completamente distorsionada porque la distorsión es máxima en los extremos inferior y superior, con lo que la edición se hace muy difícil. Por este motivo fueron de gran utilidad los plugins de Photoshop "Super cubic filters" (Fig. 9), que permitieron la transformación del zenit y el nadir en imágenes planas sin distorsión muy fácilmente editables, que después de ser modificadas, se incorporaron de nuevo al panorama equirrectangular.

La edición consistió en reconstruir el suelo, eliminando el trípode y sus sombras, para lo cual se hizo uso de las herramientas de corrección puntual como "tampón de clonar", "pincel corrector" y "parche" (Fig. 10). Una vez corregido el suelo, se aplicó el filtro "super cubic reverse" para recuperar la proyección equirectangular (Fig. 11).

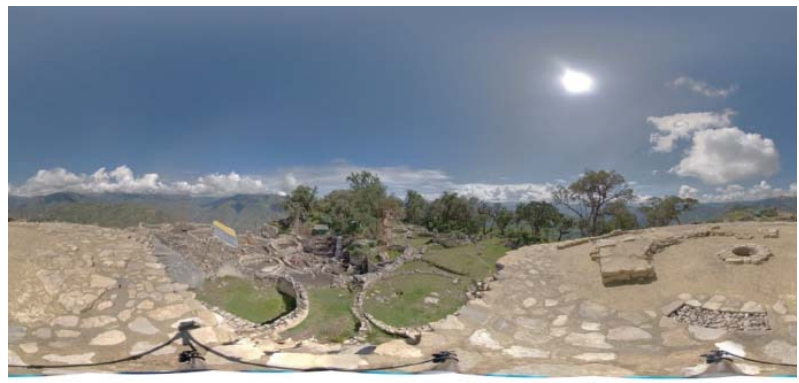

Figura 8: Panorama equirectangular original.

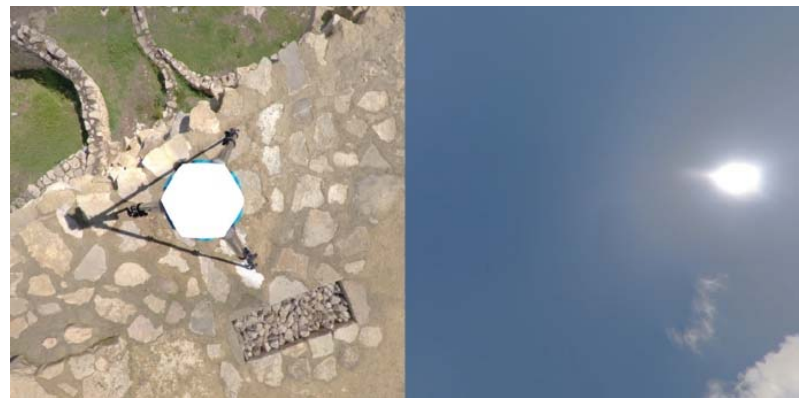

Figura 9: Proyección del nadir y el zenit tras aplicar el plugin "super cubic filter" en Photoshop.

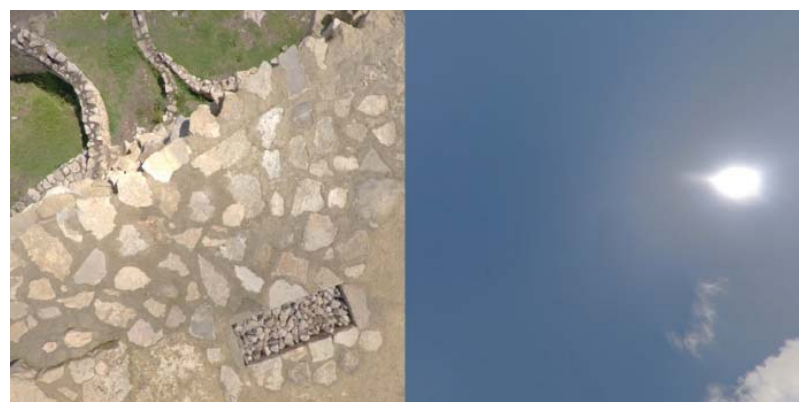

Figura 10: Resultado de la edición fotográfica local en Photoshop mediante "tampón de clonar" y "parche".

En algunos casos, en que la calibración de la cámara no fue perfecta, aparecieron pequeños fallos de costura debido al efecto parallax, que requirieron ser corregidos puntualmente. Por último, se realizaron algunos ajustes de carácter general, como definir el contraste global y la 
saturación, para obtener el panorama equirectangular definitivo.

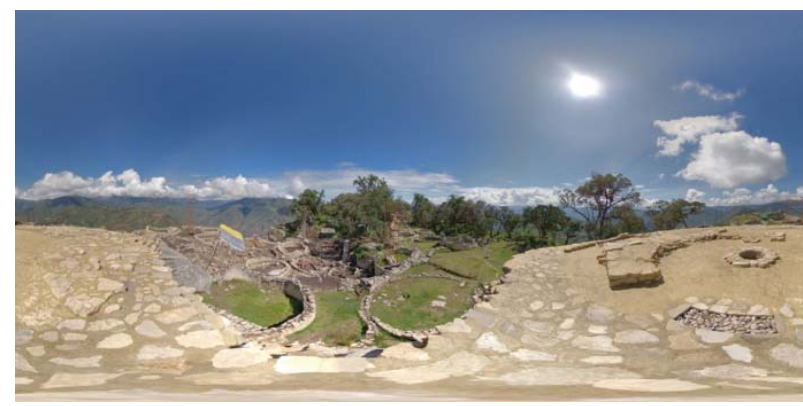

Figura 11: Panorama equirrectangular resultante con el nadir corregido, tras aplicar el plugin "super cubic reverse"

\subsubsection{Interactvidad}

Los panoramas equirectangulares son imágenes estáticas que contienen todo el entorno esférico alrededor de un punto concreto del espacio. Desde el punto de vista fotográfico, pueden resultar interesantes por si mismas, pero en lo referente a este proyecto, lo que realmente interesó fue su interactividad e implementación web para lograr una visita virtual donde los diferentes panoramas estén conectados. Esto se consiguió mediante el programa Pano2VR; los panoramas equirectangulares (con formato TIFF o JPG) fueron utilizados como "datos de entrada", para conseguir archivos Flash, Quicktime o HTML5 interactivos como "datos de salida". Originariamente, la visita virtual se publicó en formato Flash.

Se plantea, de cara al futuro, publicar la visita virtual en formato HTML5 para permitir la indexación de contenidos por parte de Google y hacer la aplicación compatible con la mayoría de dispositivos actuales.

Para la navegación de un panorama a otro, se optó por dos métodos complementarios: la navegación por "hotspots" o puntos interactivos del panorama; y la navegación mediante "mapa de ubicación" (Fig. 12). De esta manera, el usuario tiene siempre a su alcance un mapa general que le permite saber exactamente dónde se encuentra en cada momento, y le permite desplazarse a cualquiera de los puntos interactivos de la aplicación.

\subsubsection{Graphical User Interface (GUI)}

Quizá una de las partes más complejas en la creación de la visita virtual fue la edición de su interfaz gráfica. El programa Pano2VR cuenta con un "skin editor", o editor de GUI, que se utiliza para crear un entorno gráfico con el cual controlar la aplicación. Los principales componentes en la visita virtual fueron el "panel de botones interactivos" y el "mapa de ubicación" (Fig. 13). Las funciones desarrolladas para el panel de botones fueron las siguientes:

- Girar izquierda

- Girar derecha

- Girar arriba

- Girar abajo

- Zoom in

- Zoom out

- Start/stop auto-rotación
- Pantalla complete

- Instrucciones

- Copyleft

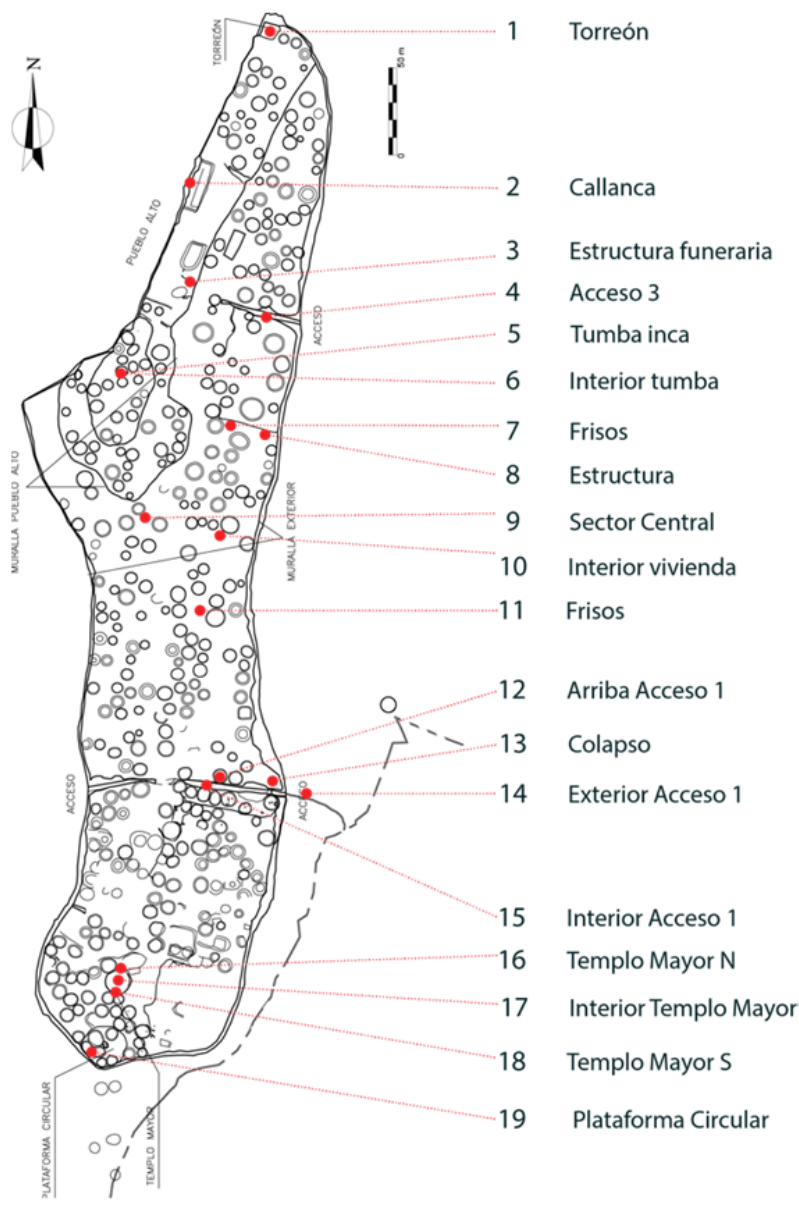

Figura 12: Puntos interactivos elegidos para la visita virtual de Kuélap. Elaboración própia. Plano: PEK - GRA.

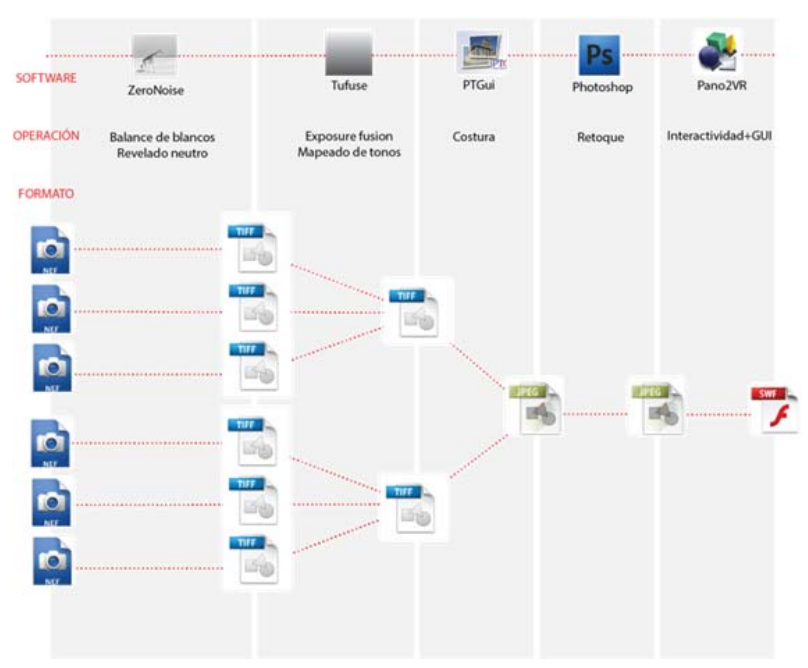

Figura 13: Diagrama simplificado del flujo de trabajo utilizado en el proyecto. Fuente: Elaboración propia.

\subsubsection{Datos y metadatos}

Con el fin de divulgar los resultados de las investigaciones realizadas en Kuélap con todo el rigor científico, se incorporaron a la visita virtual una serie de 
textos descriptivos de las principales estructuras arqueológicas de la Ciudadela, facilitados por el director arqueológico de Kuélap, Alfredo Narvaez. Estos textos se dispusieron en el lateral izquierdo de la aplicación.

Por otro lado, se consideró oportuno añadir una ventana dedicada a mostrar enlaces para ampliar la información relativa al proyecto, de forma que cualquier usuario pueda consultar el PFC, así como la presentación en Prezi del proyecto desarrollado, donde se expone toda la información contenida en este artículo de forma más ampliada.

\subsection{Diseño, desarrollo y difusión web}

\subsubsection{Diseño web}

El diseño del portal web se realizó con los requerimientos de que fuese intuitivo, atractivo, altamente visual y compatible con diferentes navegadores y dispositivos. En su desarrollo, se utilizaron los lenguajes HTML y CSS fundamentalmente, utilizando Flash para la visita virtual y JavaScript para la parte correspondiente a la aplicación de Google Earth que posteriormente se comentará (Fig. 14).

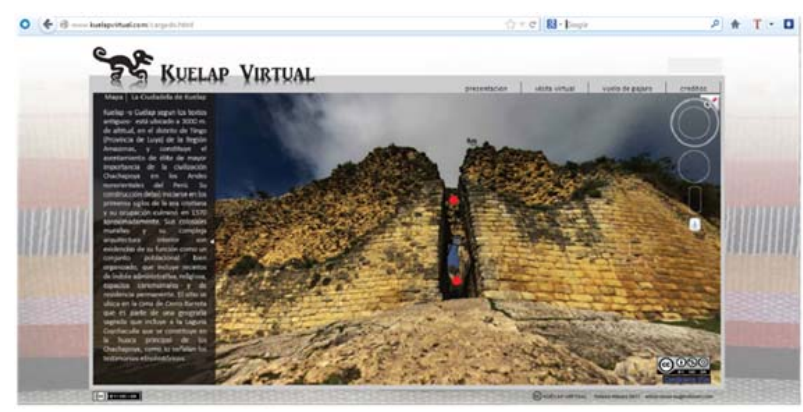

Figura 14: Versión definitiva del portal web www.kuelapvirtual.com, en la "visita virtual".

En el año 2010, empezaba a replantearse de forma global la forma en que las webs eran diseñadas, pasando de una concepción estática del diseño ,heredada de los medios impresos, a una dinámica con contenidos flexibles que se adaptan a cada tipo de pantalla y resolución. Esta nueva concepción es conocida como "diseño web responsivo". El portal web asumió este planteamiento como algo fundamental, por lo que todos los elementos de la web fueron diseñados para adaptarse a diferentes relaciones de aspecto y resoluciones de pantalla. Por otro lado, el formato de la visita virtual se basó en Flash, que es un formato que ha ido quedando desfasado con el paso de los años, ya que no es compatible con algunas plataformas actuales.

La web está estructurada en las siguientes secciones, accesibles a través del menú principal, situado en la parte superior:

- Presentación

- Visita Virtual

o Kuélap s. XI

o Kuélap s. XX

- Vuelo de pájaro
o Vista especial
o Perú-amazonas
o Kuélap de lejos

o Kuélap de cerca
- Créditos
- Info

Aplicación basada en Google Earth

Google Earth es un programa que permite navegar por un espacio virtual basado en información geográfica, presentando un globo terráqueo con diferentes niveles y contenidos de mapas geográficos (Fig. 15). Además de la versión online y el programa de escritorio, Google Earth cuenta con una API para desarrollar aplicaciones propias de gran complejidad para web. En lo relativo al proyecto, se tomó la decisión de utilizar esta herramienta para ubicar geográficamente al usuario en el espacio, mostrando diferentes niveles de zoom:

- Vista espacial (20.000 km s.n.d.m)

- Perú-amazonas (3000 km s.n.d.m)

- Kuélap de lejos (20 km s.n.d.m)

- Kuélap de Cerca (4 km s.n.d.m)

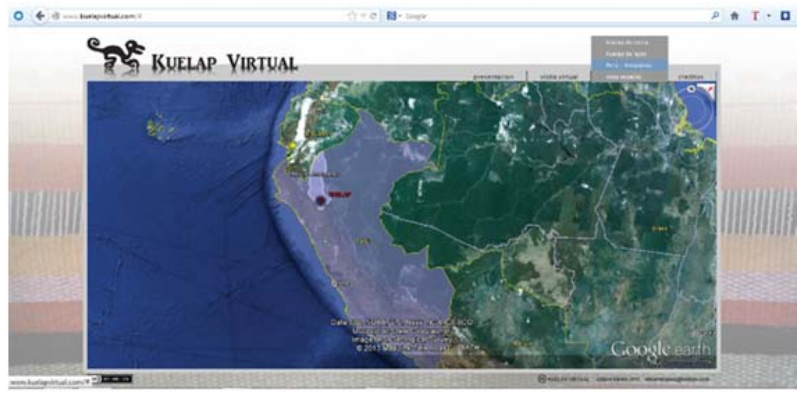

Figura 15: Versión definitiva del portal web www.kuelapvirtual.com, en la aplicación de Google Earth.

\subsection{Modelado 3D}

Modelar para el prototipado requirió de modelos con geometrías limpias, precisas y cerradas, aptas para la impresión 3D, a diferencia de lo que sucede cuando se modela con el propósito de obtener renders o animaciones. Por otra parte, el rigor científico del proyecto requería de un modelo fidedigno al original, aunque la escala del producto final determinó el nivel de detalle. En el caso del proyecto, se optó por modelar dos prototipos: una maqueta arqueológica que muestra una reconstrucción de la Ciudadela de Kuélap, a escala $1: 750$ y una maqueta topográfica que muestra el entorno circundante, a escala 1:17500. En la maqueta arqueológica se aplicó la hipótesis reconstructiva para mostrar cómo sería el sitio en su estado original hacia el sigo XI d.C.. Para ello, se contó con el asesoramiento de los arqueólogos, quienes ayudaron a definir la apariencia e inclinación de los tejados, así como la altura de los muros de las estructuras. Se decidió hacer este prototipo monocromático, por el hecho de tratarse de un modelo hipotético, mientras que la parte topográfica se realizó a todo color, con la textura de una ortofoto satelital proyectada sobre el relieve, a lo que se añadió la información toponímica extraída de un mapa físico de la zona. En el diseño de ambos prototipos, se utilizó el software de modelado 3D "Rhinoceros". 


\subsubsection{Modelado topográfico}

\subsubsection{Importación de superficie de G.E.}

En el modelado del volúmen topográfico, la geometría fue importada directamente desde el Google Earth v 4.2 con el plugin "Rhino Terrain", y la textura se trabajó independientemente. La versión 4.2 del G.E. es una versión antigua que no permite extraer ortofotos a gran resolución. En cambio, con esta version es posible importar superficies con mucha más definición y calidad que con las versiones posteriores donde esto está limitado. Por este motivo, el relieve fue importado con la versión 4.2, óptima para trabajar con el plugin Rhino Terrain.

\subsubsection{Importación de ortofoto satelital}

Con el fin de obtener una buena ortofoto, que sirviera como textura de la superficie importada, se utilizó el Google Earth Pro 6.1 que permite guardar ortofotos satelitales a gran resolución $(4800 \times 2800)$ a diferencia de la versión 4.2. En este punto, se consideró oportuno modificar la ortofoto para complementarla con la mayor cantidad de información toponímica posible, ya que además de informar sobre los nombres de montañas, quebradas, barrancos y pueblos, en la toponimia autóctona es donde más sustrato ha quedado de las lenguas prehispánicas y pre-incaicas. Como sería el caso, según algunos autores, de una hipotética lengua Chachapoya anterior al Quechua local, caracterizada entre otras cosas por el uso de las terminaciones -mal,huala, -gat y -lap, como en el caso de "Kuélap".

\subsubsection{Importación de topónimos}

Para importar la información toponímica se tomó como referencia un mapa físico de la zona, elaborado por el Instituto Geográfico Nacional (IGN) del Perú, a escala 1:100.000.

Con el programa Adobe Illustrator, y tomando el mapa como base, se reescribieron todos los topónimos en una capa nueva, conservando su ubicación original. Como último paso, se incorporó esta capa la ortofoto satelital obtenida en el paso anterior.

\subsubsection{Modelado de la reconstrucción arqueológica}

El siguiente paso a realizar fue el modelado de las edificaciones de Kuélap. En este punto, fue imprescindible la coordinación técnica con la Dirección Arqueológica de Kuélap para lograr que la hipótesis arqueológica de la Ciudadela, en su periodo ocupacional utilizada en la maqueta, contara con el rigor científico necesario.

Por el hecho de utilizar una escala de 1:750 en la fabricación de esta parte de la maqueta, las construcciones no precisaron de gran detalle ya que su tamaño real era, en su mayoría, inferior a un centímetro. De esta manera, se omitió la representación de puertas y ventanas, y la forma de las estructuras circulares típicas de Kuélap fue sintetizada y simplificada en formas geométricas básicas.

La mayor parte de las construcciones de Kuélap, exceptuando algunas estructuras singulares, presentan una planta en forma circular u ovoide; patrón arquitectónico prototípico de la cultura arqueológica Chachapoya.

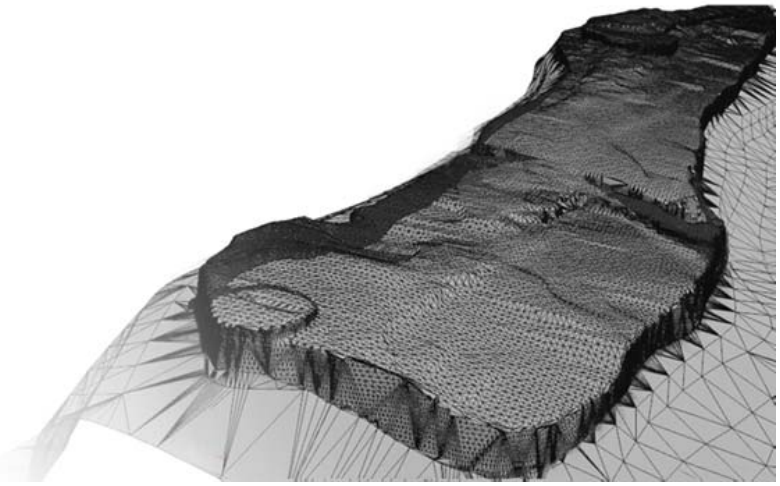

Figura 16: Malla triangular de la superficie de Kuélap sin estructuras obtenida con Rhinoceros

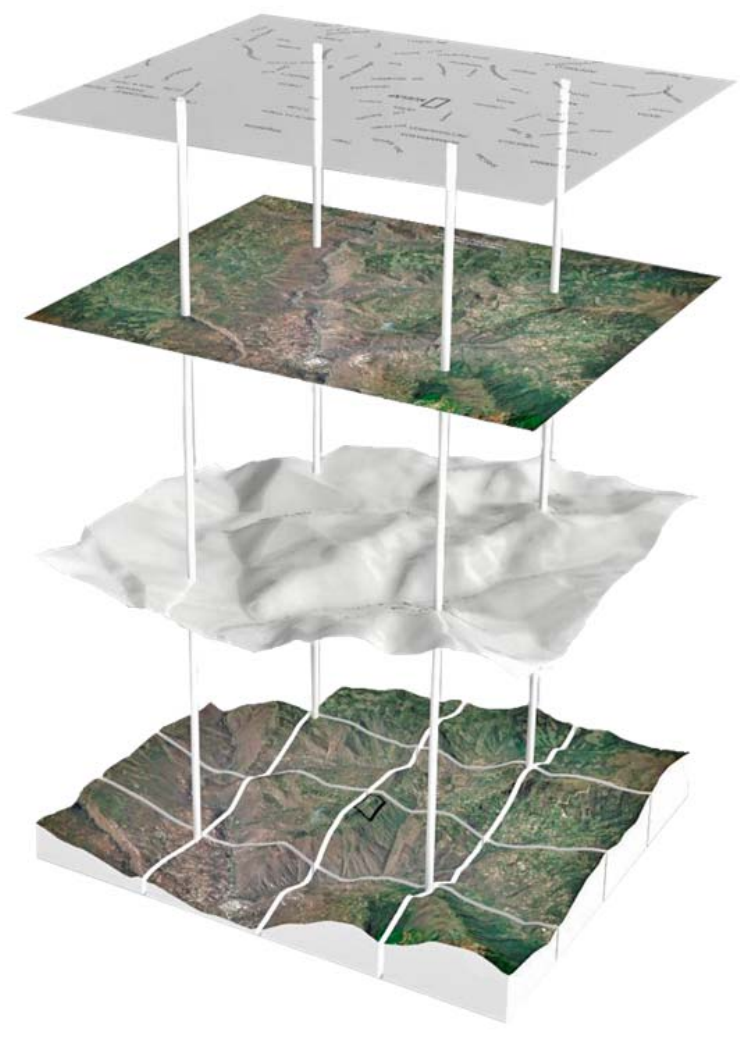

Figura 17: Capas del modelo topográfico: toponímia (a), ortofoto (b). Malla importada del GE (c). Modelo final dividido en 16 módulos (d)

En primer lugar, se modeló una casa prototípica, con un cuerpo cilíndrico y un tejado cónico, coronado por un pequeño tronco-de-cono invertido. Fue de gran utilidad la representación pictórica de Kuélap en plena ocupación que exhibe el "Museo de las Momias" de Leymebamba, que sirvió como referencia en el diseño del modelo. Con las curvas de nivel visibles, se fue clonando la casa prototípica y situándola en cada una de las plantas constructivas de viviendas que mostraba el plano y adaptándolas a su forma y dimensiones.

La reconstrucción presentaba, además, algunas estructuras singulares que fueron modeladas individualmente, como es el caso del Templo Mayor, el 
Castillo, la Callanca y algunas estructuras de planta rectangular pertenecientes a la época inca, última etapa de la ocupación poblacional de Kuélap.

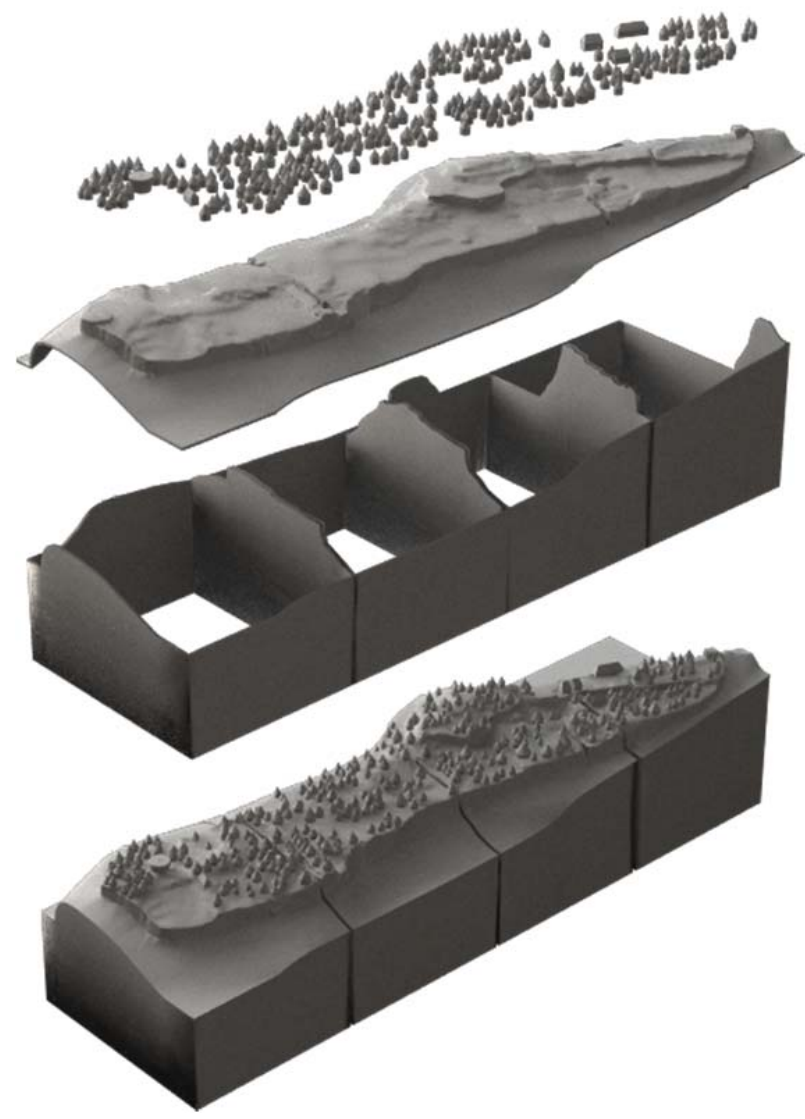

Figura 18: Capas del modelo: estructuras reconstuidas (a). Superfície modelada a partir del levantamiento topográfico(b). Soportes (c). Modelo final dividido en 4 módulos(d).

Debido a las limitaciones del área imprimible de la máquina de prototipado rápido Z-Printer $450(203 \times 254$ x $203 \mathrm{~mm}$ ), se diseñó la maqueta general en 20 módulos de 200 × $240 \mathrm{~mm}$, contando con unas dimensiones totales de $1,20 \times 0,8$ metros. La superficie del prototipo arqueológico se planteó de tal manera que en planta ocupara una área de $800 \times 240 \mathrm{~cm}$, para poder dividirla perfectamente en cuatro módulos. Tras seccionar la superficie en cuatro partes, sobre cada una de estas, se aplicó el comando del Rhinoterrain "create base", con lo que se obtuvo una base o soporte para cada módulo, tal y como se muestra en la Figura 19. Para terminar, se aplicó el comando "offset mesh" para dar grosor a la superficie correspondiente a cada módulo, generando cuatro mallas perfectamente cerradas y aptas para el prototipado rápido.

\subsubsection{Modelo Final}

Tras proyectar la ortofoto con los topónimos correspondientes al relieve importado del Google Earth, se obtuvo la superficie mapeada definitiva. Esta superficie se dividió en 16 módulos (4x4), de 200 x 240 $\mathrm{mm}$ cada uno, creando sus respectivas bases con un espesor de pared definido en $4 \mathrm{~mm}$. Todo esto se realizó mediante la opción "exportar a Z-Corp" integrada en el plugin Rhino Terrain, que permitió crear módulos directamente a partir de la malla y del rectángulo que define cada módulo en planta. Gracias a este comando, se obtuvo ,fácilmente, 16 módulos perfectamente aptos para su impresión 3D con la Z-Printer 450, economizando el material necesario para su impresión (Fig. 20).

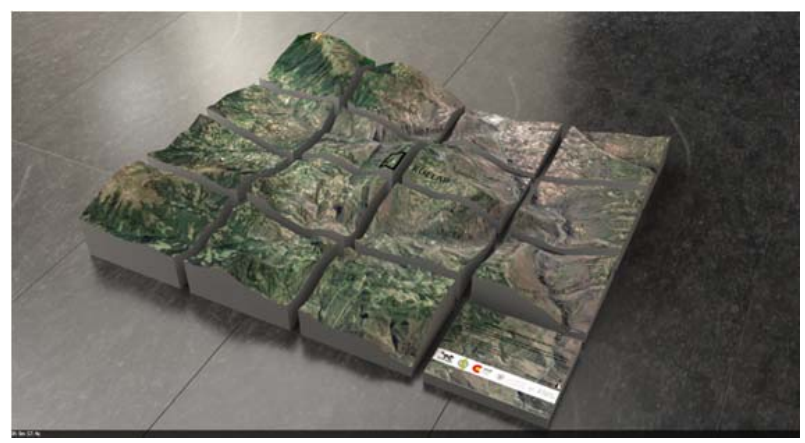

Figura 19: Render de la parte $B$ (maqueta del entorno de Kuélap) separada en sus 16 módulos.

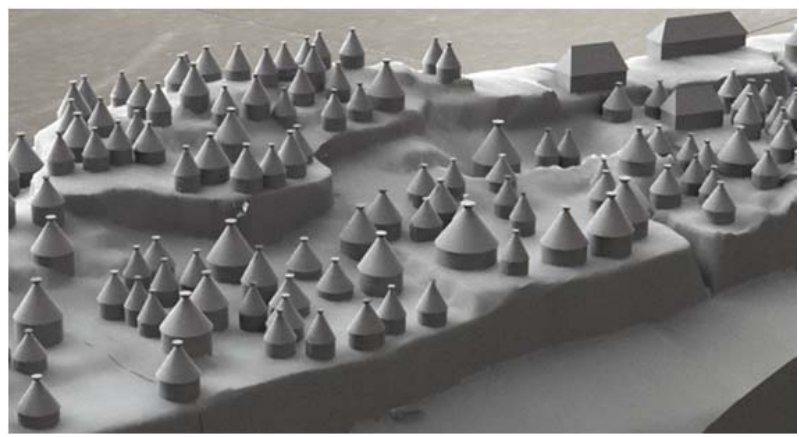

Figura 20: Modelo 3D de Kuélap con estructuras arquitectónicas incorporadas. Vista general.

\subsection{Prototipado}

\subsubsection{Hardware de impresión 3D: Z-Printer 450}

EI Departamento de Proyectos de Ingeniería de la UPV puso a disposición la máquina de prototipado rápido ZPrinter450, por lo que esta última fase se desarrolló íntegramente en dicho departamento bajo la tutela del director de PFC, José Antonio Diego Mas. Mediante este equipamiento, los módulos diseñados con Rhinoceros se materializaron en objetos físicos, que finalmente fueron sometidos a un infiltrado para aumentar su resistencia y mejorar su acabado.

\subsubsection{Software impresión 3D: Z-Print}

Mediante el software Z-Print, se validaron los modelos $3 \mathrm{D}$ antes de enviados a la máquina de prototipado (Figs. 21,22 y 23).

Después de exportar todos los módulos en formato .zpr, (formato compatible con la impresora 3D) e importarlos al programa Z-Print, todos estos fueron testeados para estimar el material necesario y planificar los tiempos de impresión. A pesar de ser una máquina de prototipado rápido, la impresión de cada módulo osciló entre las 3 y las $20 \mathrm{~h}$ de fabricación; encontrándose la media en $9 \mathrm{~h}$ $32 \mathrm{~min}$ por módulo. Por otro lado, este estudio también permitió determinar qué consumibles y en qué cantidades era necesario solicitar al distribuidor. 
El proceso de impresión por cada módulo requirió de los siguientes pasos:
a) Impresión por capas de la pieza
b) Curado
c) Retirada del polvo composite sobrante
d) Infiltrado con cianoacrilato

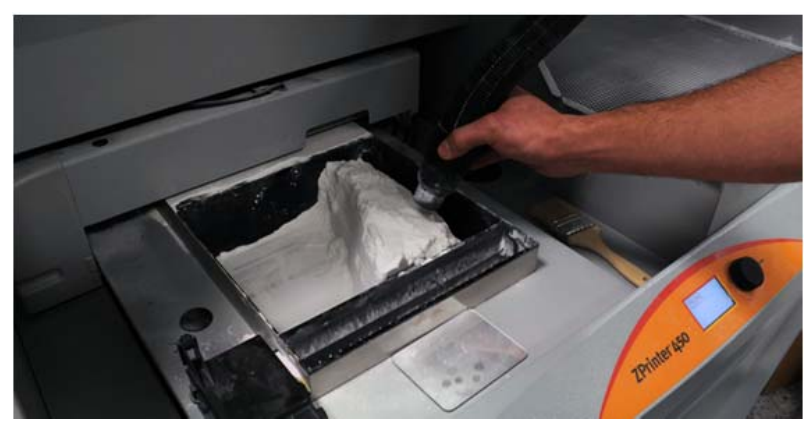

Figura 21: Retirada del polvo composite sobrante.

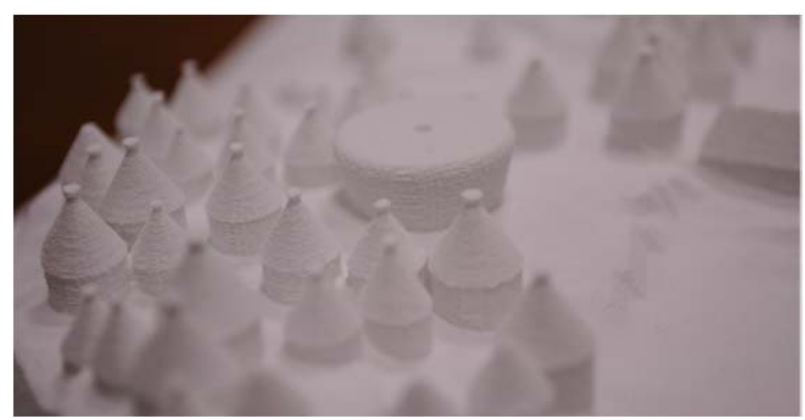

Figura 22: Detalle de la maqueta arqueológica donde se distingue el Templo Mayor.

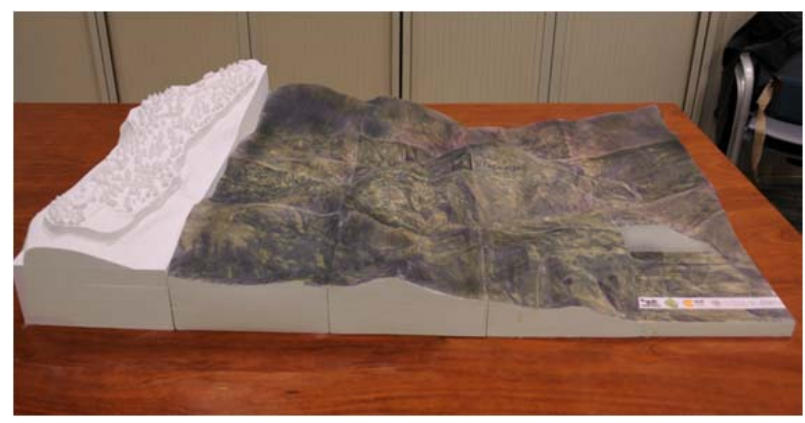

Figura 23: Prototipos arqueológico y topográfico finalizados.

\section{Conclusiones}

Se puede concluir que el proyecto logró los objetivos planteados inicialmente, ya que se consiguieron los resultados esperados y se realizó la trasferencia de los mismos a la entidad contraparte. Sin embargo, es justo reconocer que hemos encontrado muchas dificultades en el camino, que no han sido impedimento para llegar hasta el final. En esta línea, es remarcable que seis años después de iniciar el proyecto, el portal web sigue estando en activo recibiendo visitas de todas partes del mundo.

Como valoración general, se puede decir que se han conseguido resultados tangibles y útiles en cuanto a la conservación y difusión de un patrimonio de valor incalculable como la Ciudadela de Kuélap. Una de las mayores virtudes del proyecto ha sido y es su vocación comunicativa, plasmada en el enorme alcance geográfico y demográfico que permite internet.

Por otro lado, no fue posible la exhibición pública de las maquetas arqueológica y topográfica, como se esperaba, debido a los sucesivos cambios de Gobierno Regional y sus funcionarios, quienes lamentablemente no asumieron esta responsabilidad.

Finalmente, se resalta la importancia de haber alcanzado productos con una gran integridad y rigor científico, en un proyecto pluridisciplinar que ha aplicado los conocimientos técnicos del diseño en un contexto arqueológico, y con un beneficio social y divulgativo.

\section{Referencias}

BEN KREUNEN, 2000. Big Ben's Panorama Tutorials. Determining the Nodal Point of a Lens. Available: http://archive.bigben.id.au/tutorials/360/photo/nodal.html [12/02,2013].

ICOMOS, 1990. Carta Internacional para la Gestión del Patrimonio Arqueológico.

LERCHE, P. y WILTSIE, G., 2000. Lost tombs of Peru. National Geographic 198/3, pp 63-81.

LUIJK, G., 2008. Tutorial Zero Noise. Available: http://www.guillermoluijk.com/tutorial/zeronoise/index.html [13/04, 2013].

NARVAEZ, L.A., 2011. Kuélap Virtual. Available: http://www.kuelapvirtual.com/ [02/29, 2011].

VALQUI, J., 2003. Reconstrucción de la lengua chacha mediante un estudio toponímico en el distrito de La Jalca Grande (Chachapoyas-Amazonas). 


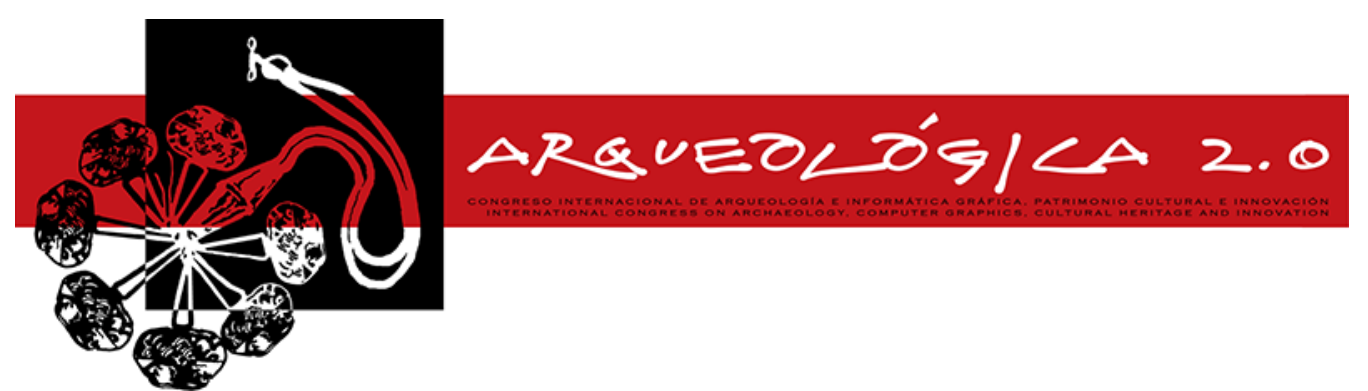

Proceedings of the $8^{\text {th }}$ International Congress

on Archaeology,

Computer Graphics,

Cultural Heritage and Innovation

'ARQUEOLÓGICA 2.0'

in Valencia (Spain),

Sept. $5-7,2016$

DOI: http://dx.doi.org/10.4995/arqueologica8.2016.3659

Received: $15 / 03 / 2016$

Accepted: 09/05/2016

\title{
CONSERVATION MODEL FOR BASILICA OF SMYRNA AS AN THEORETICAL INTENTION
}

\author{
Tugba Saricaoglu \\ Department of Architectural Restoration, University of Dokuz Eylul, Izmir, 35290, Turkey. tugbasaricaogluts@gmail.com
}

\begin{abstract}
:
History is the space of the time and also an accumulation of knowledge. This accumulation transforms into layers, layers provides knowledge. Also, historical envaronen has undeniable importance due to knowledge it has especially when it comes to architecture. Historical enviroment is like an architectural laboratuary which provides knowledge from past to present. That gives the reason why historical environment should be analyzed, preserved, rehabilited and restored in the first place. Sustainabilty of the knowledge can be supported by studying historical enviroment in every field. The main focus of this reasearch is integrating Baslica of Agora in Smyrna into today by analysing its cultural, historical and physical situation. Before the integration of the Basilica, information should be gathered and documentions related to the building and its close vicinty should be concluded. Documentation generated (measured and drawn) of the whole basilica in order to develope intervention decisions on scientific platform in any scale. Therefore, intervention orders took place on both whole basilica and the main intervention part of basilica as a modulatible scale. Basilica of the agora in Smyrna ancient city which has never been architecturally studied, documanted by using advanced technics surveying methods. Using all the data from documentation and academic studies 35. and 36. axles of the basilica determined to be the definite place where intervention orders -determined by analitical studies on whole scale of the basilica and detailed studies on the axles- took place.
\end{abstract}

Key words: basilica of Symrna, digital archaeology, cultural heritage, 3D documentation, 3D survey

\section{Introduction}

Historical enviroment is like an architectural laboratuary which provides knowledge from past to present. That gives the reason why historical enviroment should be analyzed, preserved, rehabilited and restored in the first place. Studying historical enviroment in every field can support sustainabilty of the knowledge.

Basilica of the Smyrna is the one of the most interesting Roman basilicas (Akurgal 2002), 2nd century BC, which has significiant scale (161,4 meters to 29,3 meters) and also original graffito (Taslialan and Drew-Bear 2004) (Fig. 1) on its cryptoporticus walls (Fig. 2). The ultimate purpose of this reasearch is integrating Baslica of Agora in Smyrna into today by analysing its cultural, historical and physical situation using digital methods to survey it. Even this integration will be theoretical it will be a method and survey model for the future studies which will be not just theoric but also practicable hopefully.

In this article analitical process of defining conservative problems of the basilica will be discussed to explain which part of the basilica studied.

\section{Identifying the Area of Intervention}

Documentation of the building made by using terrestrial laser scanner (Saricaoglu 2015) (TLC)-Faro Focus 3D S
120) (Fig. 3). The pointcloud of the building scanned up to 200 scans and two different scan durations- 9 minutes and 16 minutes, and took ten days. These time differences were decided accordingly detail of the elements of the ruins. In other words, cryptoporticus walls which has graffito remnant was scanned for 16 minutes, the other part of the basilica scanned in 9 minutes per scan for 200 scans. Pointcloud data (Figs. 4 and 5) developed and used to generate orthopoint data (Fig. 6). Subsequently, CAD based drawings of the building made from generated data.

Conservation problems evaluated after documentation of the building exclusievely. The model intervention area (Fig. 7) is decided according to those conservative issues which are conservative problems, structural problems, and awareness problems of the building.

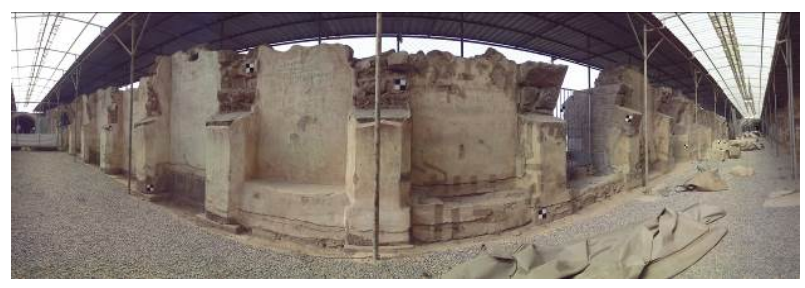

Figure 1: Grafito on cryptoporticus wall. 


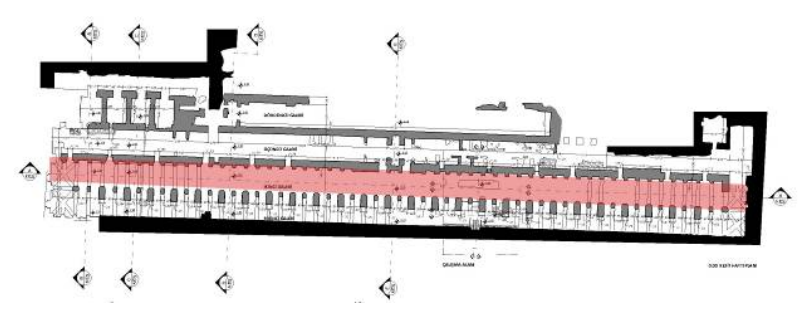

Figure 2: Cryptoporticus wall (second gallery).

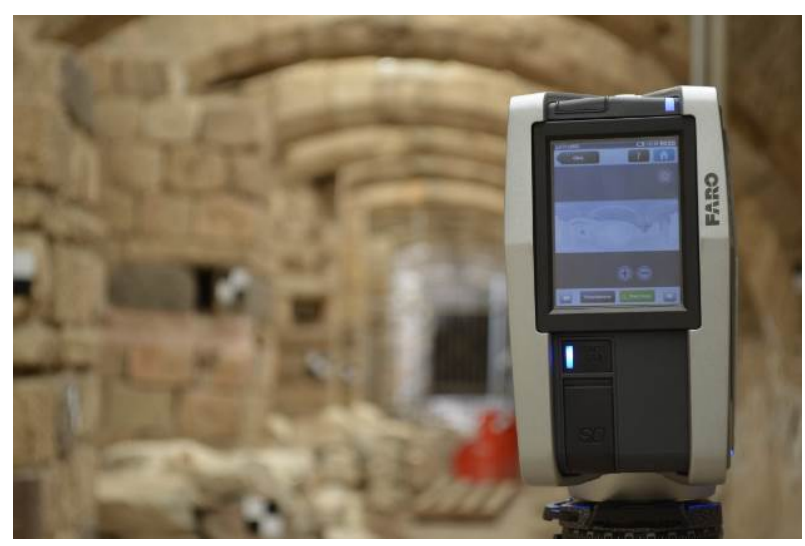

Figure 3: Faro Focus 3D S 120.

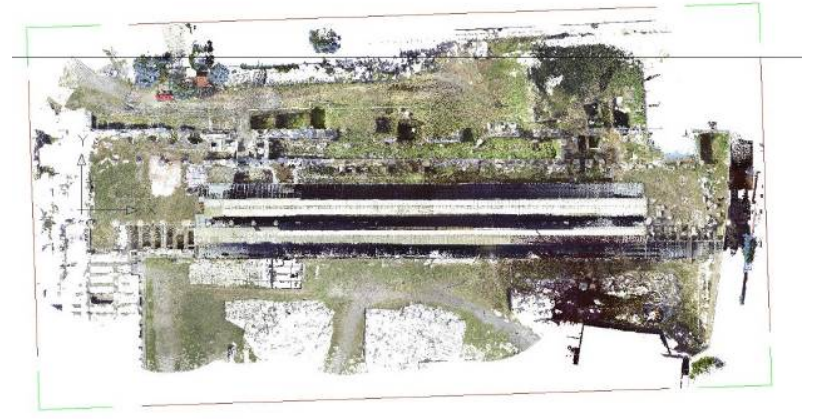

Figure 4: Pointcloud data of the basilica and its near surroundings.

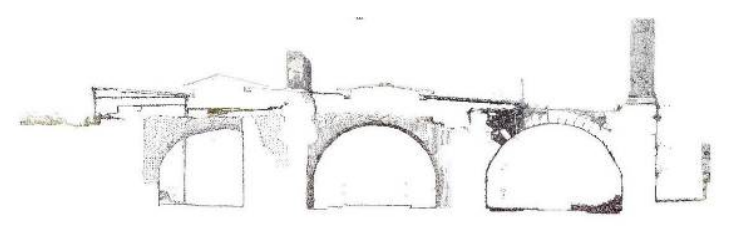

Figure 5: Pointcloud data of the basilica as a section sample.

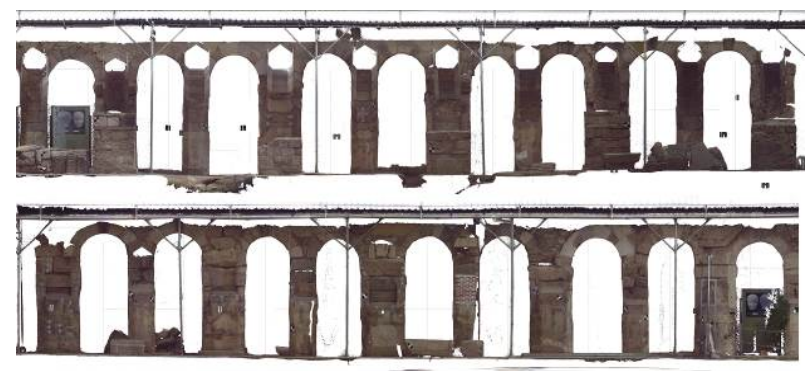

Figure 6: Orthopoint samples of the basilica.

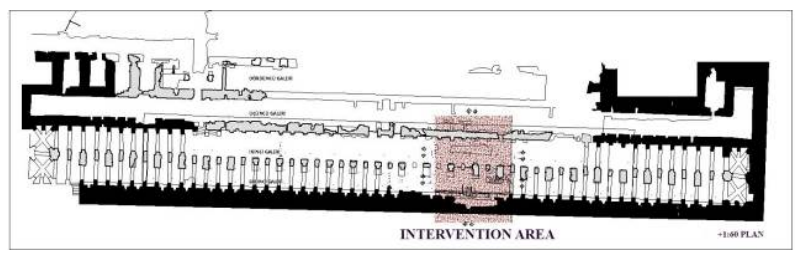

Figure 7: Intervention area.

\subsection{Evaluation of the Conservation Problems}

Revealing the conservation problems of the agora, which is the area it takes place in, is required before determining the conservation issues of basilica in order to generate intervention model.

Site usage and visitor guidance not being consistent with urban archeological site planning and does not provide legal conformity (Yaka 2006) is determined as the one of the primary problem. Today entrance of the agora is placed agora for employees and visitors (Ipekoglu and Uygun 2011) is in the south of the area. The only planning (not be projected) including field management and guidance construction on agora is the foresight of taking the visitor entrance from north street, basement of agora and basilica, and after visiting the west stoa, providing the entrance from the Faustina gate of bouleuteron building and the mosaic structure at the west.

In conclusion, general conservation problems are evaluated by integrated approach of the whole site.

\subsection{Conservation Problems of Basilica}

Due to management problems of the site, agora of the Symrna and basilica are becoming very undistinguished both academically and socially. Additionally, due to management problems, considered primary, of the site conservation of the basilica is evaluated under two subtopics namely structural and awareness basically.

\subsection{Structural Problems of Basilica}

Basilica was built in stone masonry technique (also techniques of belt, vault, cross vault etc. masonry, gap passing) matching with its periods (Hellenistic, Roman). The main problem when basilica's material and spatial qualifications evaluated within this scope is that there are material deprivation especially in the bearing elements in consequence of building's being under earth and its being urgently repaired because of the earthquake (Bean 2001), A.D. 178, it earlier on faced with. Although these deprivations are not in a very systematical construct, they are in high level that can affect the holistic stability of the building in long term, as presented in Figure 8.

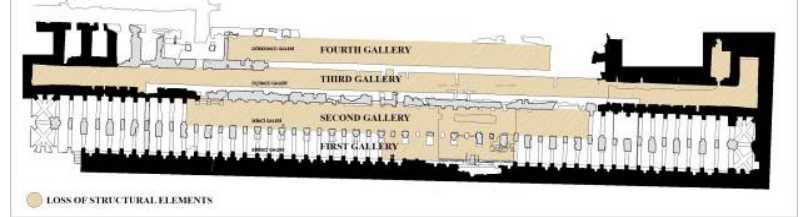

Figure 8: Deprivation of structural elements. 
Another one of the material deprivation of the basilica is the demolished area other than belts. These areas are comprised of walls dividing the galleries and terrace walls, ruins in the area with ladder where a modern metal-made systematic gate was constructed, as presented in Figure 9.

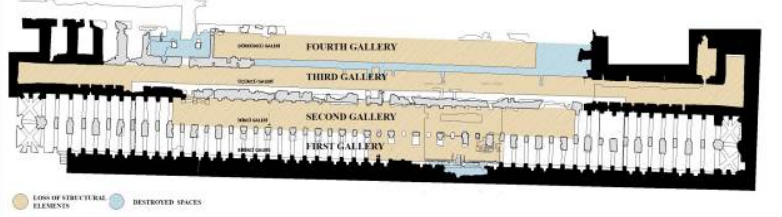

Figure 9: Loss of structural elements and destroyed spaces.

When the structural material deprivation examined systematically, the deprivation of the same bearer axes detected in the first and second gallery, as presented in Figure 10. In addition to this finding, the area where all the material deprivations overlap, most damaged area (Fig. 11), is decided to considerable as one of the intervention model data parameters.

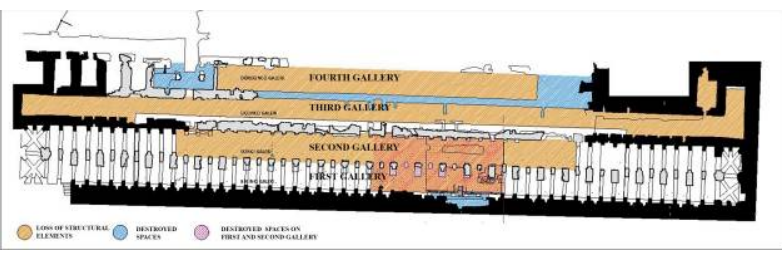

Figure 10: Loss of structural elements on first and second gallery.

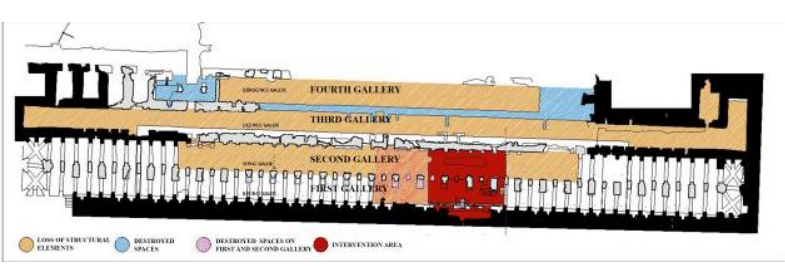

Figure 11: Most structurally damaged area.

\subsection{Awareness Problems of Basilica}

Another problem of the basilica that occurs due to site's management problem is the limited spatial perception of basilica. Hence, the phscical and cultural existence of the building could not be provided and results awareness problems.

Since, basilica's tree-dimentional aspect is not spatially and socially perceptable former interventions that are three-dimentionally made are decrypted. Nothwithstanding, those interventions are made in an urgent manner such as, "save the day" kind of context, they are physically sensible and radical. The one of the interventions are protection roofs (Figs. 12 and 13). The first roof, which covers abutments of the basilica's first and second galleries, made before 2007 after excavation (Ersoy 2010). The second roof is the one built for the covering of the bare places of the ruins in 2007 (Ersoy 2010).

ther intervention is metal doors (Fig 14), in between east and west gaps of the secand gallery. Although metal doors provide entrance to basilica from east and west, the metal ladder that was added to the destroyed wall in the southeast of basilica provides direct entrance to inside (galleries) (Fig. 15). However, as this entrance is demolished during excavation (Ersoy 2010), it was fixed with temporary expedients and only exists for the usage of academic and profecional employees.

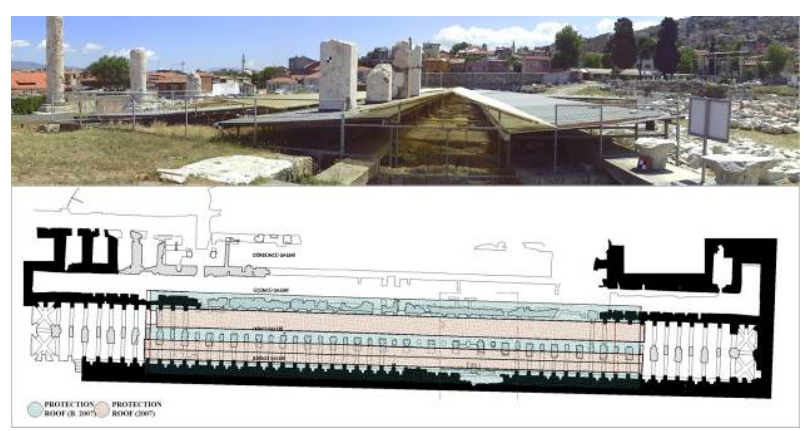

Figure 12: Protection roofs of the basilica.

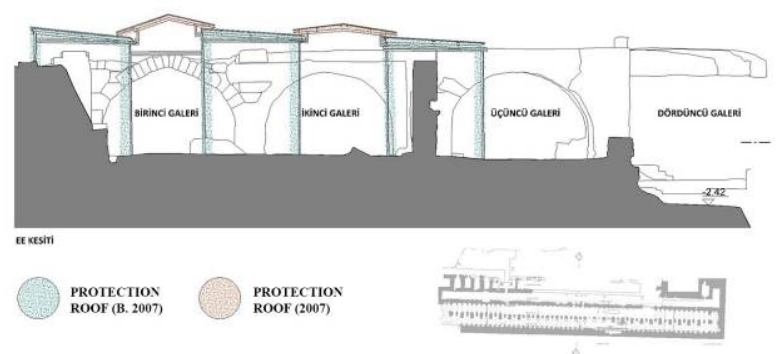

Figure 13: Protection roof sof the basilica, section.

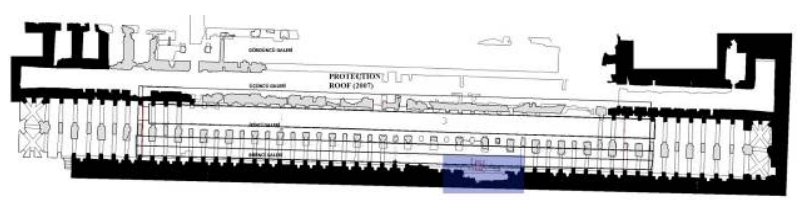

Figure 14: Modern enterance of the basilica.

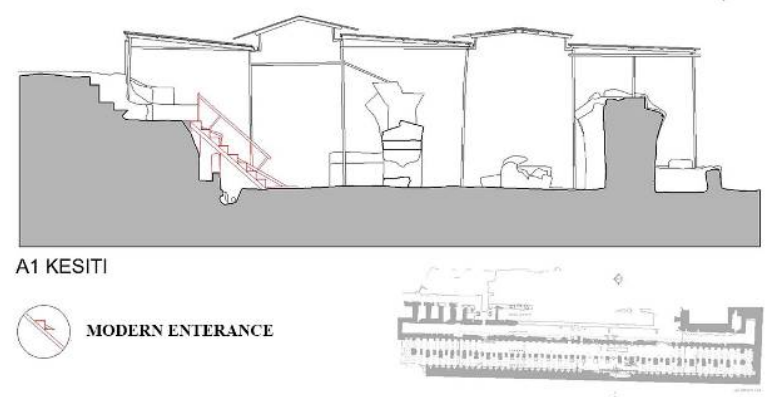

Figure 15: Modern enterance of the basilica, section.

The other intervention is the metal stands which supports belts and abutments (Fig. 16). These strengthenings were made urgently and actually prove basilica's being under a systematic physical threat. One of the other reinforcement is recontraction of eight belts, with little belts in between, are placed in the first gallery (Fig. 17).

Since all these interventions have been made for avoiding structural thaw, they underline the one of the main conservative issues, awareness, as a result of structural problems of the building. All in all, all of the interventions mentioned before creates specific area 
when overlap (Fig. 18), that spatial intersection will be considered second of the intervention model data parameters.

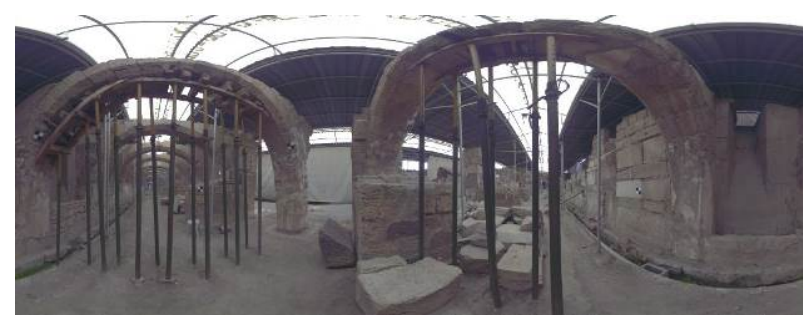

Figure 16: Metal stands to strenght abutments.

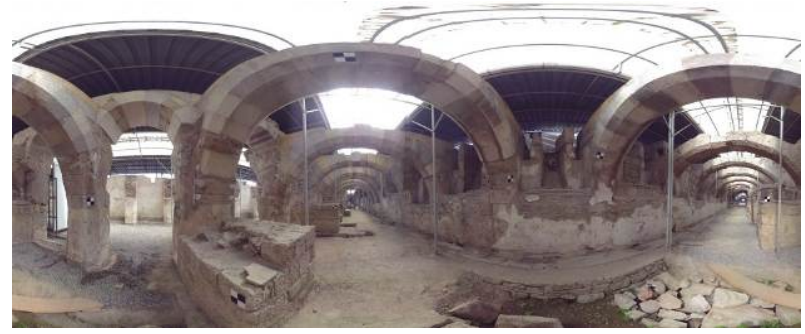

Figure 17: Restorated belts.

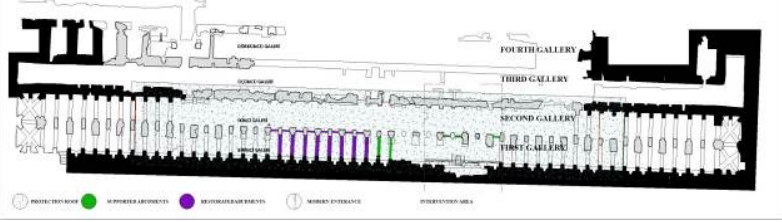

Figure 18: Conservative interventions on site.

\section{Conclusion}

In conclusion, after identifying basilica's conservative issues under the names of, structural, and awareness, modeling sample intervention intersection (Figs. 7 and 19 ) is generated by using those outcomes. Accordingly, sample intervention area is decided to be at the southeast of the basilica and limited with 33th and 38th axes involving the first and the second galleries (Fig. $20)$. The 35th and 36th of these axes have been chosen as an application area, in order to make two different sampling and proving modulation for the future, as presented in Figure 21 and Figure 22.

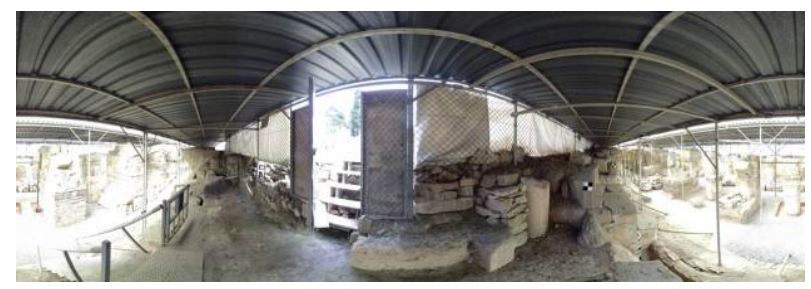

Figure 19: Intervention area, image.

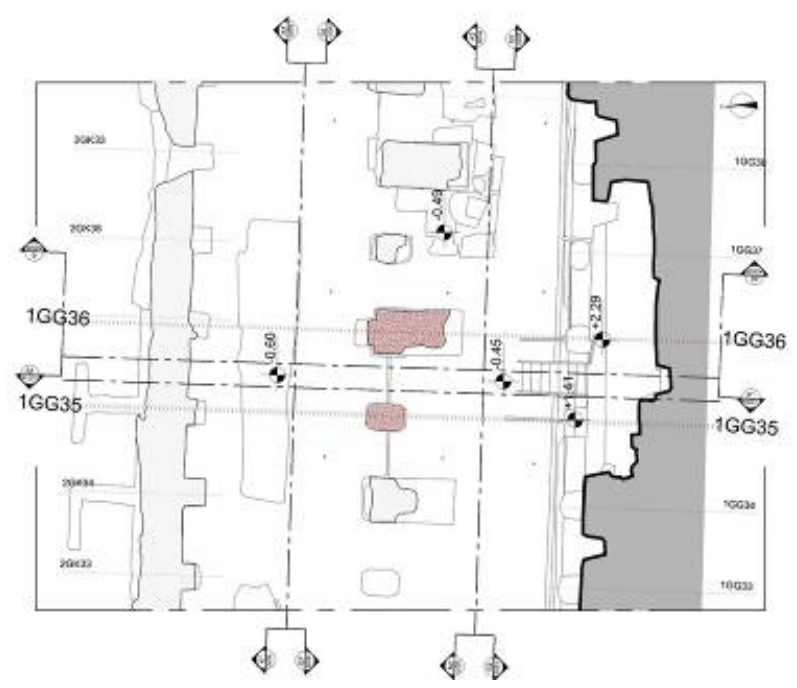

Figure 20: Intervention area, plan.
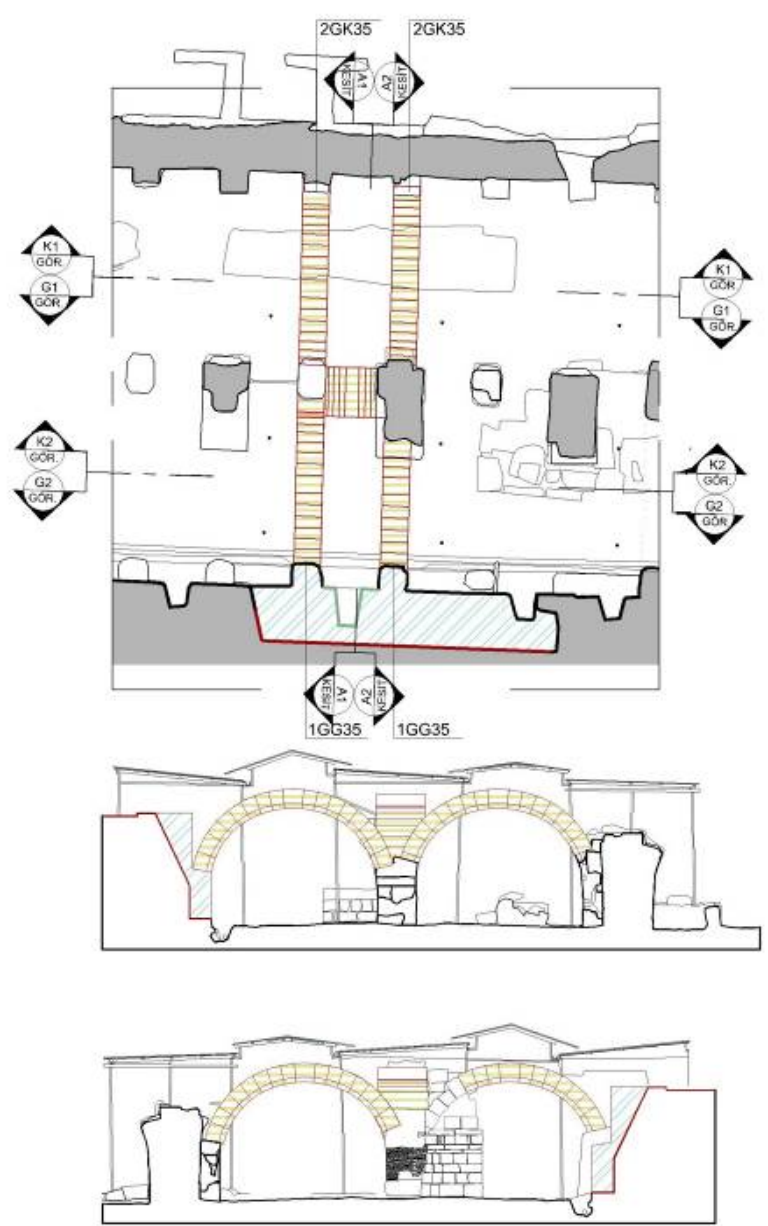

Figure 21: Intervention area, drawing, intervention maping. 


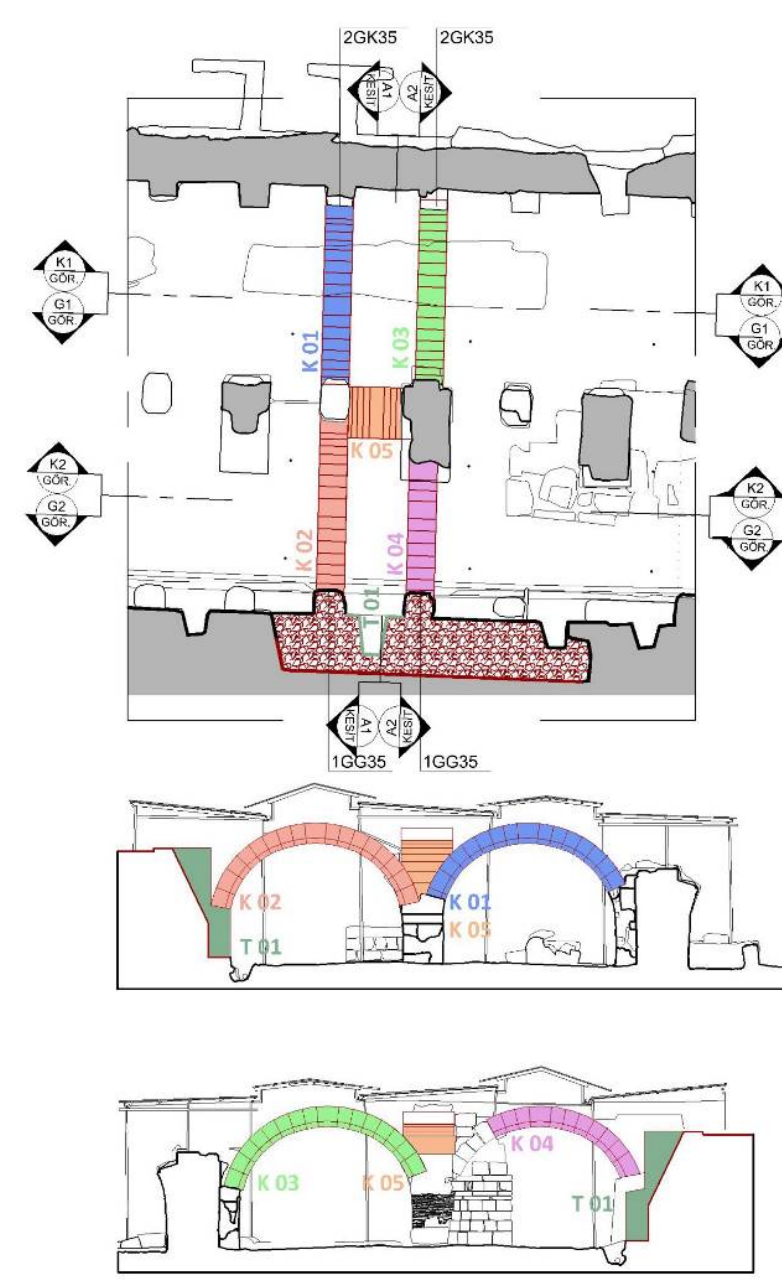

\section{Results and Discussion}

The study mainly focuses on revealing of basilica's conservational problems (along with 3D laser scanner survey and CAD studies of the whole building) after narrating the historical and structural evaluations. Moreover, the main aim of the study is making a model base for the future restoration studies to contribute both therocically and digitally sustaibale knowledge. Within this framework, under the light of digital and theorocial datas partial analytical restoration studies have been developed of the cultural heritage.

\section{Acknowledgements}

This survey studies of the work was funded by the University of Dokuz Eylül under Scientific Research Project named: 'Restoration Studies on Third Nave of Basilica of Smyrna'.

Figure 22: Intervention area, drawing, detailed maping.

\section{References}

AKURGAL, E., 2002. Ancient Civilisations and Ruins of Turkey. İstanbul: Net Turistik, pp. 12-58.

BEAN, G., 2001. Eski Çağda Ege Bölgesi. İstanbul: Arion.

ERSOY, A., 2010. Ancient Smyrna: Archeology in İzmir and Stratigraphy in Ancient City Centre.IN: A.E. GÖKSU, Ş. G. DÜNDAR, eds, Urban hiztorical stratum: From Smyrna to İzmir. İzmir: Dokuz Eylül Üniversitesi Press, pp.131-139.

IPEKOGLU, B. and UYGUN F., 2011. Evaluation of interventions in western stoa of Agora in Izmir. Journal of Cultural Heritage, 42(2), pp.18-25.

SARICAOGLU, T., 2015. Development of Intervention Orders Upon Basilica of Smyrna Agora: 35.-36. Axles. Master Thesis, University of Dokuz Eylül.

TASLIALAN, M. and DREW-BEAR, T. 2004. Rapport sur les Travaux Effectués sur l'agora de Smyrne. Anatolia Antiqua, 12(12), pp 293-308.

YAKA, N.F., 2006. Evaluation of Interventions in Western Stoa of Agora in İmir. Master Thesis, Izmir Institue of Technology. 


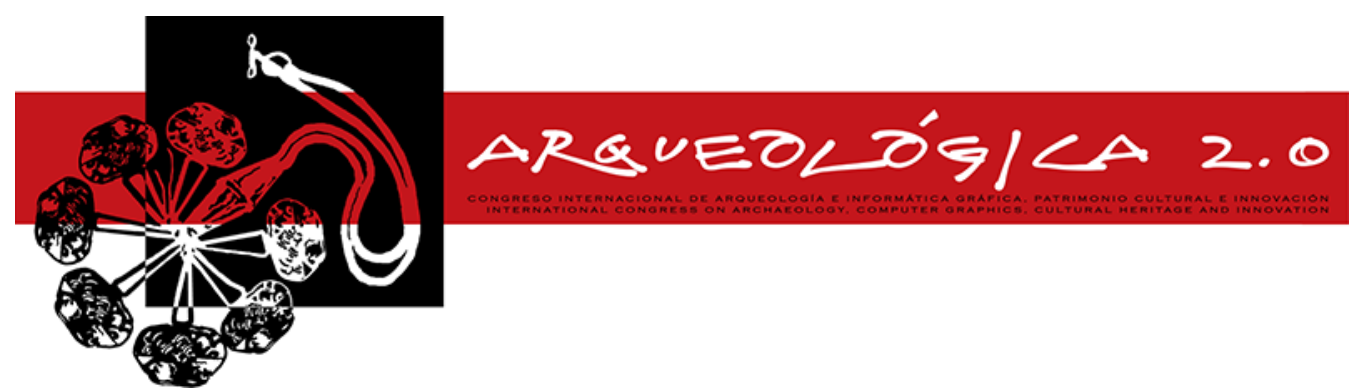

Proceedings of the $8^{\text {th }}$ International Congress

on Archaeology,

Computer Graphics,

Cultural Heritage and Innovation

'ARQUEOLÓGICA 2.0'

in Valencia (Spain),

Sept. $5-7,2016$

DOI: http://dx.doi.org/10.4995/arqueologica8.2016.3998

\title{
LA APLICACIÓN DE NUEVAS TECNOLOGÍAS EN LA DOCUMENTACIÓN ARQUEOLÓGICA DE LA VILLA ROMANA DE NOHEDA Y SU PROYECCIÓN TURÍSTICA DIGITAL
}

\section{THE APPLICATION OF NEW TECHNOLOGIES IN ARCHAEOLOGICAL DOCUMENTATION ABOUT THE ROMAN VILLA OF NOHEDA ITS TOURIST DIGITAL PROJECTION}

\author{
Miguel Ángel Valero ${ }^{\mathrm{a},{ }^{*}}$, Nuria Huete ${ }^{\mathrm{b}}$ \\ ${ }^{a}$ Centro Asociado de la Universidad Nacional de Educación a Distancia en Cuenca, Colón 6, 16002 Cuenca, España. \\ mvalero@cuenca.uned.es \\ ${ }^{\mathrm{b}}$ Departamento Economía Española e Internacional, Econometría, Historia e Instituciones Económicas. Facultad de Ciencias \\ Económicas y Empresariales de Albacete, Universidad de Castilla-La Mancha, Plaza de la Universidad 1, 02071 Albacete, España. \\ Nuria.Huete@uclm.es
}

\begin{abstract}
:
The Roman villa of Noheda has become one of the crucial site to understand the messages that the high Roman aristocracy intended to convey by the building infrastructure in these large rural complex of Late Antiquity. Therefore, for the application of a correct archaeological methodology we should add the use of the most modern techniques of research and analysis that were within our grasp, in order to document in the best possible detail, the archaeological remains. Understanding that only through a close reading we can get to properly decrypt the data housed in the cluster of structures and artifacts hosted in the stratigraphic sequence. Therefore, the aim of this article is to present concisely, how technological advances have been used such as ground penetrating radar, 3D scanning, laser scanner, photogrammetry, etc. and the best results which have been obtained. In the same way, we will explain that these results are just a first step, because today the project of musealisation of the site has begun in order to be ready for its opening to the public and, within the innovations that bring the new technologies will be taken into account and they will be used in situ with mobile telephony, such as 3D modeling of parts and its Georeferencing, the increased virtual reality, etc. Nonetheless we must not forget other advances which help understand, spread and bring archeology closer to society.
\end{abstract}

Key words: roman villa, triclinium, photogrammetry, three-dimensional scanning, georradar, virtual reality.

\section{Resumen:}

La villa romana de Noheda se ha convertido en uno de los yacimientos cruciales para entender los mensajes que la alta aristocracia romana pretendía transmitir mediante la edilicia en estos grandes complejos rurales de la Antigüedad Tardía. Por ello, a la aplicación de una correcta metodología arqueológica debía sumarse el uso de las más modernas técnicas de investigación y análisis que estaban a nuestro alcance, con el fin de poder documentar con el mayor detalle posible los restos arqueológicos. Entendiendo que solo mediante una lectura minuciosa se puede llegar a descifrar adecuadamente los datos albergados en el cúmulo de estructuras y artefactos insertos en la secuencia estratigráfica. Por ello, el objetivo de este artículo es exponer de manera concisa, cómo se han utilizado avances tecnológicos como el georradar, escaneado 3D, láser escáner, fotogrametría, etc. y los óptimos resultados que se han obtenido. Del mismo modo, se explicará que estos resultados no son sino un primer paso, pues a día de hoy se ha comenzado con el proyecto de musealización del yacimiento de cara a su apertura al público y en él se tendrán muy presentes las novedades que aportan las nuevas tecnologías que puedan ser usadas in situ con la telefonía móvil, como el modelado 3D de piezas y su georreferenciación, la realidad virtual aumentada, etc. Pero sin olvidar otros avances que ayuden a comprender, difundir y socializar la arqueología.

Palabras clave: villa romana, triclinium, fotogrametría, escaneado tridimensional, georradar, realidad virtual.

*Corresponding Author: Miguel Ángel Valero, mvalero@cuenca.uned.es 


\section{Introducción}

La presente contribución supone la presentación de cómo se han aplicado algunas de las más novedosas técnicas de documentación en el proyecto de investigación que estamos efectuando en la villa romana de Noheda. Con el empleo de las mismas se busca un objetivo primordial, el registro exhaustivo de todos los datos obtenidos en el proceso de excavación del yacimiento, entendiendo a ésta como la única manera de plasmar de forma rigurosa la información exhumada, que posteriormente ayudará a la recostrucción no solo del inmueble, sino también del entorno del mismo y del mensaje que el dominus quería transmitir a los visitantes del complejo.

Este trabajo surge de la necesidad de contribuir al estudio integral del yacimiento, ya que, si bien es justo reconocer que hasta el momento ha sido mosaico figurado localizado en el triclinium de la villa la evidencia más notoria del mismo por la cual es conocido (Valero 2009; 2010; 2011; 2013a; 2014b; 2014c; 2015a; 2015b; Valero y Gómez 2013). Consideramos que la investigación sobre el enclave debe plantearse de manera integral, es decir, sin olvidar el tapiz musivario, pero otorgando la misma relevancia al resto de los aspectos conformadores del complejo. En esta línea, y aplicando algunas de las técnicas que más adelante detallaremos, ya se han efectuado algunos estudios analizando arquitectónicamente diversas estancias, la cronológica del complejo, la evolución de las fases constructivas, la edilicia empleada y el proceso de destrucción (Valero 2014a). Del mismo modo, también se han abordado análisis sobre los elementos que ornamentaban la pars urbana del conjunto (Valero et al. 2015), el estudio de captación de recursos hídricos con los que se abastecía el complejo rural (Mejías et al. 2013; Martínez et al. 2014), o los primeros resultados sobre los programas de prevención y conservación efectuados en el tapiz musivario (Valero et al., 2014). Además también se ha realizado el analisis del territorio susceptible de conformar el fundus de la quinta, y sus adaptaciones y/o transformaciones con motivo de la inserción de este espacio, en el ámbito de explotación de la villa (Valero e.p.).

\section{El yacimiento}

La existencia del yacimiento de la villa romana de Noheda y de mosaicos en el mismo, es conocido desde antiguo (Larrañaga 1966; Abascal 1982; Palomero 1987), si bien la constancia del tapiz figurado fue documentada en los años 80 del siglo pasado como consecuenca de la realización de unos trabajos de mejora agrícola que se estaban efectuando en la parcela (Lledó 2007, 2010).

Pero es tan solo en fechas recientes cuando ha comenzado a ser difundido de manera rigurosa, (Valero 2009; 2010; 2011; 2013a; 2014a; 2014b; 2014c; 2015b; Valero y Gómez 2013; Valero et al. 2014; Valero et al. 2015).

El enclave se ubica en la parte central de la Península Ibérica, próxima de las ciudades de Segóbriga (a 58 $\mathrm{km}$ ), Ercávica (a 44,5 km) y Valeria (a 43,5 km), situándose a $17 \mathrm{~km}$. al norte de la ciudad de Cuenca. La villa se localiza a escasos $500 \mathrm{~m}$ al noroeste de la localidad de la cual toma su nombre, siendo ésta pedanía del municipio de Villar de Domingo García (Fig. 1).

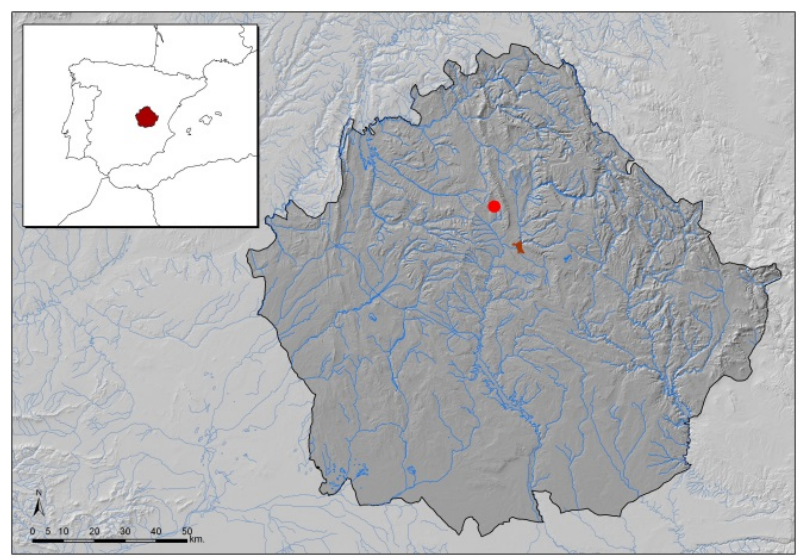

Figura 1: Plano de localización de Noheda en el contexto peninsular.

El complejo arqueológico fue declarado Bien de Interés Cultural en 2012, principalmente por los mosaicos descubiertos en él, si bien no es solo la etapa tardoantigua la que cuenta con evidencias antrópicas, aunque es justo reconocer que es hasta el momento, la mejor documentada. Las investigaciones realizadas en los últimos años han puesto de manifiesto que bajo la villa tardorromana, resulta probada la existencia de estructuras arqueológicas pertenecientes al Alto Imperio, en un estado de conservación aceptable pese a haber sido cantera de las construcciones suprapuestas. Éstas últimas coinciden cronológicamente con el proceso de eclosión y auge de las grandes villae documentadas en la parte occidental de Imperio (Vera 1992-1993; Volpe 1996; Sfameni 2006; Chavarría 2006; 2007; Pensabene 2010-2011; Hidalgo, 2014).

Además los análisis territoriales efectuados en su entorno inmediato (Valero 2013b), denotan una intensa actividad humana en estas tierras, evidenciando poblamiento desde época protohistórica hasta la alta Edad Media de manera ininterrumpida.

Su ubicación geográfica en el contexto peninsular, determina un marcado carácter de cruce de caminos, convirtiéndose en un paso natural de sur a norte entre las cordilleras montañosas que la rodean, haciendo de esta zona una vía natural de comunicación (Valero 1999a; 1999b; 2008) que precisamente recorren algunas calzadas romanas (Abascal 1982; Palomero 1987; Valero 2013b).

Hasta el momento son tres las áreas exhumadas del complejo rural. Por un lado, algunas estructuras pertenecientes a la pars rustica que con su sola presencia, implica que el complejo contaría con los edificios necesarios que le otorgarían esa vocación agrícola que resulta inherente al concepto de villa rústica (Richmond 1970; McKay 1975; Percival 1976; Johnston 1983; Balmelle 2001; Gros 2001; Mulvin 2002; Chavarría 2005; 2007; Arce 2006; 2009; 2012; Sfameni 2006).

Por otro lado, y habiendo centrado los esfuerzos en estas zonas, se ha excavado una parte de la pars urbana, compuestas por el balneum y determinadas estancias del sector residencial. Por lo que respecta al 
primer edificio, disfruta de unas dimensiones de casi 900 $\mathrm{m}^{2}$ y cuenta con esquema axial-simétrico (García-Entero 2005; 2006). Está compuesto por diversas salas de uso, -a los que hay que sumar varios praefurnia- dispuestos en torno al eje central que marcan la entrada en narthex, el apodyterium y el gran frigidarium. Tal y como se manifiesta en otros recintos termales fechados a partir de finales del siglo III o a lo largo del siglo IV , en Noheda se aprecia el gusto por la complejización de los esquemas de funcionamiento y la profusión de espacios absidados $\mathrm{u}$ octogonales.

A la monumentalización arquitectónica del balneum, se le suma la preeminencia de las salas de ambiente frío, que no solo ocupan la mayor parte del edificio, sino que disfrutan de un recargado aparato ornamental compuesto por un vistoso pavimento de mosaico -del cual solo quedan algunas evidencias- y un colorido zócalo en los paramentos murados que se resuelve mediante opus sectile en alternancia de tonos y tipos gran parte de los mismos importados de casi todo el ámbito mediterráneo- que pone de manifiesto el empleo de materiales constructivos nobles en la decoración de las estancias principales de la villa, pudiendo ser asociados al gusto de la élite social que tal y como han apuntado otros (Rodà 2004), promociona el surgimiento de talleres locales e itinerantes dedicados a ejecutar complejos y caros programas decorativos

Por lo que respecta a las estructuras de uso residencial, hasta el momento han sido siete las estancias completamente excavadas, pero entre ellas destaca la denominada Sala Octogonal y la Sala Triabsidada (Fig. 2) que disfruta de unas imponentes dimensiones -de 290,64 $\mathrm{m}^{2}-$, y de unos extraordinarios pavimentos, a lo que ha hay que sumar una compleja articulación arquitectónica y una cuidada decoración parietal compuesta por un zócalo de placas de mármol y un alzado de pintura mural. Su morfología cuadrangular con exedras en tres de sus lados, permiten adscribirla al tipo de salas tríforas que se hacen frecuentes en los más lujosos conjuntos residenciales datados a partir de finales del siglo III (Romizzi 2006). Se trata de dependencias de articulación trichora que se interpretan como triclinia (Hidalgo 1998; 2014; Dunbabin 2003; Mar y Verde 2008; Arce 2010), adaptando así las formas arquitectónicas a las nuevas tendencias en la organización espacial de los comensales de banquetes, con lechos dispuestos en semicírculo, los stibadia (Rossiter 1991; Volpe 2006).

Es en esta estancia donde se halla un excepcional mosaico con unas dimensiones conservadas de 231,62 $\mathrm{m}^{2}$, realizado en su mayor parte con opus vermiculatum de una variadísima gama cromática, utilizándose para determinados colores piezas de pasta vítrea en multitud de tonos e incluso doradas.

La composición ornamental de este pavimento está formada por un lado, de una amplia zona central dividida en seis paneles con escenas de temática mitológica y alegórica, que presentan un carácter unitario y donde se abigarran profusamente las figuras, aglutinándose en grupos escénicos. Este conjunto figurativo, cuya forma rectangular se reparte el espacio principal de la sala, se extiende entre el centrado estanque monumental y el enmarque realizado con una amplia orla vegetal de roleos de hojas de acanto, más elaborados en la parte central de las tiras, en los espacios coincidentes con el acceso a las tres exedras de la estancia, que contarían con decoración geométrica, a tenor de lo observado en las dos conservadas.

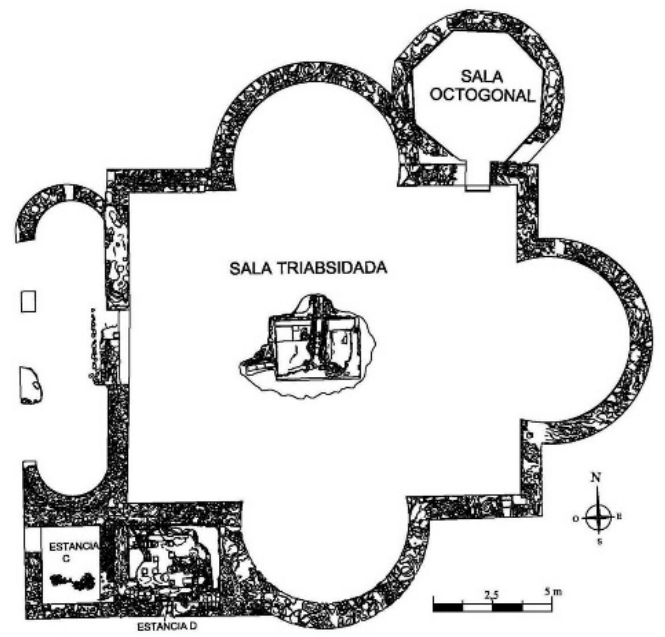

Figura 2: Planimetría de las principales estancias del sector residencial hasta ahora excavadas.

Los cuadros figurativos fueron estructurados en seis franjas rectangulares, denominadas, a efectos de descripción y estudio, por orden de visionado del visitante a la sala: $A, B, C, D, E$ y $F$ (Fig. 3).

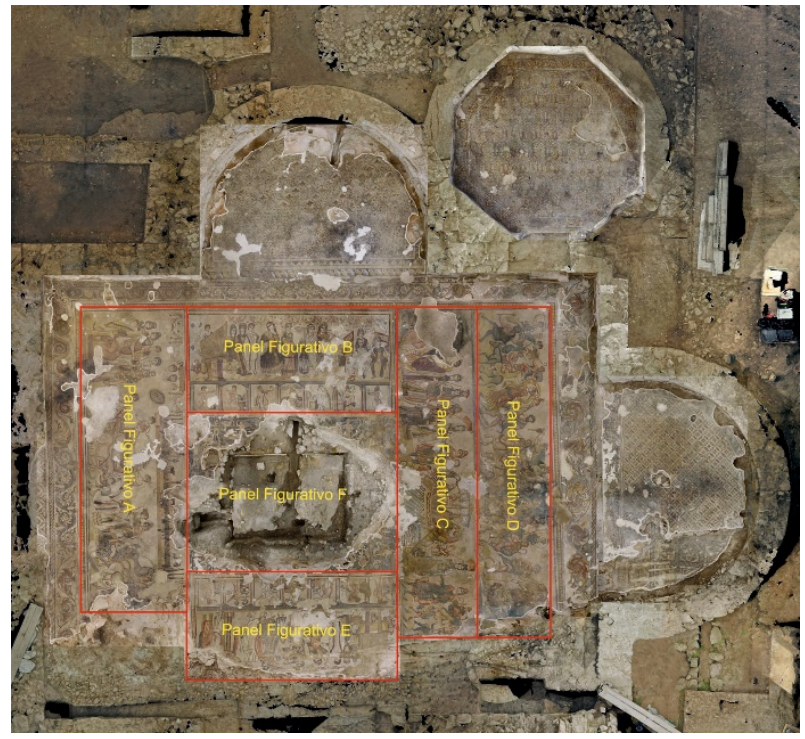

Figura 3: Indicación de las bandas figurativas del mosaico. Foto J. Latova.

Así el Panel Figurativo A representa la contienda mantenida entre el rey de Olimpia, Enómao y el príncipe anatolio, Pélope por Hipodamia, la hija de aquel. Se divide en tres grupos escénicos, el primero de ellos compacto, de cinco personajes en torno al monarca entronizado, el siguiente refleja en primer lugar, el violento naufragium sufrido por la cuadriga del soberano, continuando con la plasmación de Pélope vencedor descendiendo de la barquilla del carro mientras es abrazado por Hipodamia y recibe de ésta la palma de la victoria. Completaría la escena un tercer conjunto del que solo quedan dos personajes que asisten a los corceles, habiendo sido destruido por la 
acción del arado. Sobre el cuadro escénico principal, otro ubicado en la parte superior de menores dimensiones en la que se aprecia un circo -alusivo a la carrera de cuadrigas- donde se plasma la cavea, la arena, la spina, las metae, los ovaria, el phala, así como varias esculturas de dioses $y$ animales que ornamentarían el edificio.

El Panel Figurativo B, ubicado en la zona norte de la sala se divide igualmente en dos subescenas, en la principal, representa una compañía teatral en la que se suceden todos los componentes de la pantomima, bajo ésta se sitúa otra de menores dimensiones cuyos personajes, alusivos a los ludi, se encuentran enmarcados entre dobles columnas techadas por una sucesión de dinteles rectos y arcos escarzanos

El Panel Figurativo C se localiza en la parte oriental de la estancia, dividiéndose igualmente en grupos escénicos. El primero de ellos compuesto por un conjunto de cinco personajes, tres femeninos frente a uno masculino vestido con túnica y sentado sobre una roca a la sombra de un árbol, entre ellos Eros. Representa el juicio de Paris. El siguiente conjunto escénico, se desarrolla en torno a un barco con cuatro marineros a bordo, dos de ellos que se afanan en izar las velas y desatracar la nave, mientras los otros dos tripulantes centran sus esfuerzos en atar amarras, simbolizando unos la partida y otros la llegada a puerto. Al navío, mediante una rampa situada en la popa, accede Paris mientras agarra la mano de la raptada Helena que va acompañada de tres asistentas, que portan respectivamente, una sombrilla, un espejo y un cofre. Al otro lado de la nave, por la proa, los mismos cinco personajes descienden por la pasarela, para ser recibidos por dos parejas de danzantes con indumentaria frigia, ante una construcción amurallada identificable con Troya.

El Panel Figurativo D, está ubicada igualmente en ese lado oriental de la sala. En él se plasma un cortejo dionisiaco en el que el dios representado como un joven de largos cabellos, aparece subido en una cuadriga tirada cubierta por un pardalis, y tirada por cuatro centauros músicos que tocan el aulos y la siringa. El carro es antecedido por el resto de personajes asociados a este thiasos: ménades, sátiros, el dios Pan, Sileno y animales de filiación oriental.

El Panel Figurativo E, localizado y orientado hacia la parte meridional de la sala es muy similar al panel B arriba mencionado, apreciándose solamente ligeras variaciones en la posición y dinamismo de las figuras, así como en el cambio de orientación de determinados personajes. Como en el caso antes analizado, las escenas menores son alusivas a ludi.

Por último, el Panel Figurativo $\mathrm{F}$ parcialmente destruido por la caída de la cúpula de la estancia, representa diversos motivos marinos, -escenas de pesca, erotes, tritones y nereidas-, acordes con la naturaleza acuática del estanque que enmarcaban.

Sumado a la ornamentación estructural, se han documentado una gran cantidad de fragmentos escultóricos, que al igual que en otros casos (Rodà 2004), apuntan a la posibilidad de que los propietarios de la villa pertenezcan a la más alta clase social, con capacidad para importar excepcionales piezas de la Península Itálica y de la parte oriental del Mediterráneo.

\section{Aplicación de nuevas tecnologías al método arqueológico usado en Noheda}

La metodología y las técnicas de excavación arqueológica se han ido depurando y normalizando en las últimas décadas. De hecho, en Noheda se han aplicado las últimas novedades, empezando por obviar el obsoleto método arqueológico basado en la apertura de pequeñas cuadrículas en retícula, para pasar a la excavación en área abierta que permite documentar sin interrupciones artificiales, toda la secuencia estratigráfica.

En concordancia con la adopción de las últimas tendencias en metodología y las técnicas de excavación arqueológica en el yacimiento, se ha optado por la aplicación de algunos de los más novedosos avances tecnológicos de cara a la obtención de una documentación rigurosa que permita, por un lado el adecuado registro de la ingente información extraída en el proceso excavado, y por otro, obtener un excepcional banco de datos que admita continuar usando y "explotando" las nuevas tecnologías de cara a la museización y difusión del enclave.

Como se podrá comprobar en las páginas sucesivas, el equipo científico responsable de las investigaciones en Noheda, ha estado muy atento a los avances tecnológicos, siendo siempre unos de los primeros yacimientos en aplicar las más novedosas técnicas conforme se posibilitaba su uso en el mundo de la arqueología.

\subsection{Fotogrametría aplicada a la planimetría}

En la actualidad, algunas de las técnicas empleadas en la arqueología han evolucionado de manera exponencial con la llegada de la era digital. Dos de las más destacadas han sido la fotografía y la topografía.

Los últimos años ha supuesto un salto cualitativo en las técnicas de registro topográfico con la llegada de estaciones totales robotizadas, GPS diferenciales, láser escáner, etc. Además la evolución de registro fotográfico ha tenido un crecimiento fulgurante, permitiendo tanto el aumento de la calidad de las imágenes, como las posibilidades de edición y presentación.

La fusión de ambas vertientes es la fotogrametría, que adquiere unas destacadas posibilidades para la documentación del registro arqueológico, pero también para la ulterior puesta en valor del yacimiento.

De este modo, la fotogrametría es una disciplina que une las matemáticas, la fotografía y la óptica para determinar las propiedades geométricas de los objetos fotografiados a través de solapamiento de fotografías, basadas en principios trigonométricos.

Atrás quedaron los costosos programas y los potentes computadores necesarios para generar los cálculos matemáticos aplicados para obtener la orientación del modelo. En la actualidad diversos programas - muy asequibles, incluso gratuitos- se encargan de manera casi automática de todo el procesado y sin necesidad de contar con maquinarias específicas, solo con una cámara de fotos de buena calidad y un ordenador (Westoby et al. 2012). 
En nuestro caso, se han empleado aplicaciones de software libre, concretamete Visual SfM que cuenta con reconocida eficiencia de cara a la obtención de modelos fotogramétricos aplicables a 3D (Wu 2013; Shan et al. 2014). Además las ortoimágenes se han tratado con un programa específico de reconocida eficiencia en otros proyectos (Jancosek y Pajdla 2011).

De este modo, los resultados obtenidos en Noheda han tenido gran éxito, sumándose a un grupo de yacimientos que los emplean de manera satisfactoria (Doneus et al. 2011; De Reu et al. 2013; McCrarthy 2014).

Desde que el equipo científico tuvo acceso a este tipo de tecnología, en 2012, las secuencias estratigráficas de interés, así como diversos ítems destacados que resultan cruciales para el entendimiento del contexto arqueológico, han sido documentados mediante esta técnica (Fig. 4). Con ello, se deja constancia con coordenadas absolutas y un error métrico de como mucho $3 \mathrm{~mm}$, de toda la información extraída de la tierra. Ésto permite - si fuese necesario-, "reexcavar" ya en el laboratorio cualquier sedimento, quedando así abierta la posibilidad a ulteriores revisiones que pueden venir motivadas por diversos hallazgos conforme se vaya avanzando en la excavación.

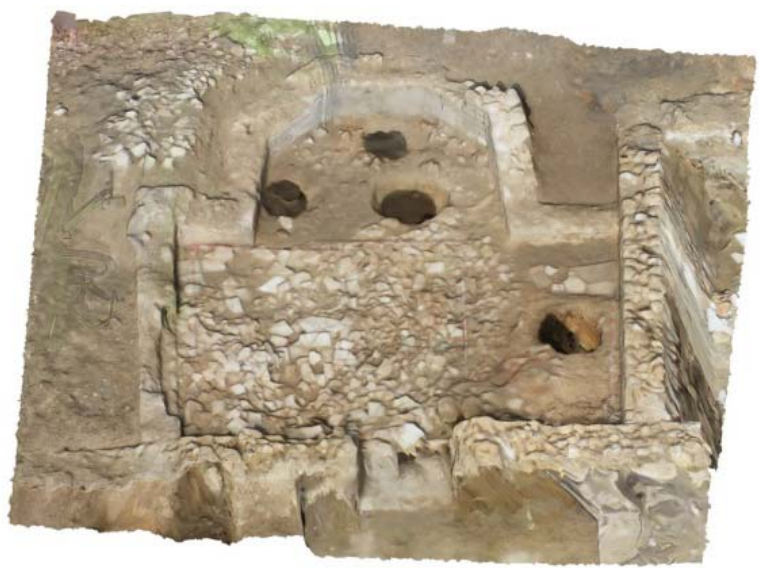

Figura 4: Proyección fotogramétrica del uctorium de la balneum en en proceso de excaación de la UE 34

Con ello, se ha documentado con gran precisión todos los restos arqueológicos, permitiendo que la ingente cantidad de datos obtenidos, sea convenientemente tratada, con un bajo coste y grandes posibilidades de gestión digital de los resultados. Esto permite desde la integración a un GIS, hasta la generación de archivos básicos para la reconstrucción completa del yacimiento (Bezzi 2013).

\subsection{Aerofotogrametría con drone}

De manera paralela al desarrollo fotogramétrico aplicado en el yacimiento, desde 2015 se optó por la combinación de esta técnica con otra de reconocida eficiencia en yacimientos de grandes dimensiones, como es fotografía por drone (Poirier et al. 2014).

Esta tecnología aérea también ha experimentado una evolución importante en los últimos años, dejando atrás los caros y pesados drones dotados con motores de gasolina. En la actualidad se ha pasado modelos eléctricos dotados de estabilizadores, brújula digital,
GPS, control remoto por ordenador y planificación de rutas (Ruiz et al. 2015) y lo más importante, precios muy competitivos que ha permitido su empleo en proyectos como el nuestro.

En primer lugar se fijaron los puntos de referencia para la triangulación de la parcela objeto de estudio, en nuestro caso los vértices geodésicos más cercanos al yacimiento.

Posteriormente, a la hora de programar el vuelo aerofotogramétrico, el itinerario a realizar por el drone de cara a la obtención de las tomas generales georreferenciadas de la excavación no se ejecutó de manera manual ya que podría dar lugar a cierta subjetividad a la hora de incidir en la documentación de determinadas zonas en detrimento de otras. Por ello, de acuerdo a la meticulosa metodología aplicada, se planificó previamente la ruta del aparato en el ordenador con un programa específico (Fig 5).

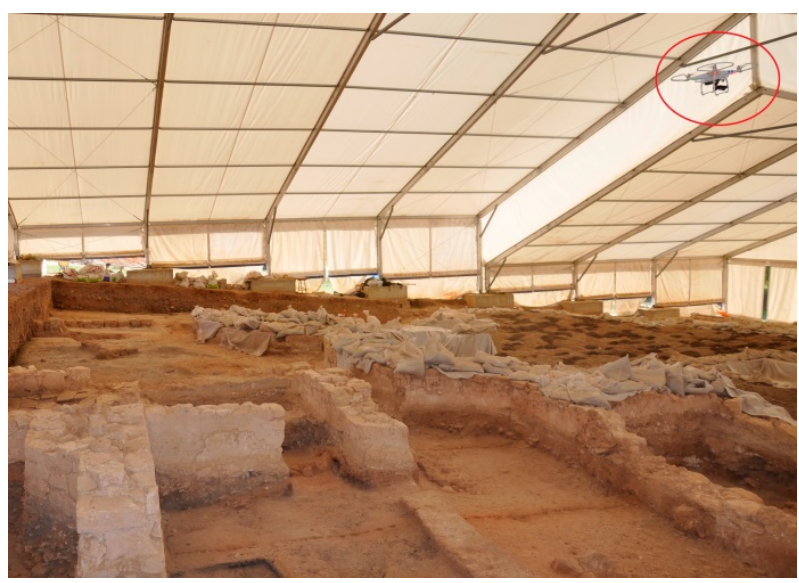

Figura 5: Vuelo del drone sobre los restos del sector residencial de la villa de Noheda.

Las imágenes tomadas en el vuelo se efectuaron con una cámara Nikon D 7100 con sensor de imagen CMOS de formato DX y 24.1 megapíxeles, con un rango focal f2-5.9, una velocidad máxima de obturación de 1/2000 y una distancia focal de $24 \mathrm{~mm}$. Se instaló un programa adicional (CHDK) para actualizar el firmware de cara a la generación de fotografías a intervalos. Del mismo modo, también se han realizado fotos con una cámara GoPro Hero3+, con una apertura del diafragma de f2.8 fija y equipada con una óptica potente con un gran angular. Las imágenes fueron realizadas tanto en JPG como en RAW para exprimir más los datos fotográficos.

Ambas cámaras se programaron para realizar fotografías cada segundo. De este modo se consigue que las imágenes obtenidas se solapen al menos en un $60 \%$, por lo que si alguna fotografía está defectuosa podría ser eliminada con total tranquilidad, sin afectar al conjunto del proyecto.

Una vez comprobadas las imágenes, se pasa al trabajo de laboratorio que se desarrolla con los mismos programas ya indicados en el apartado anterior.

\subsection{Escaneado 3D de triclinium y sus mosaicos}

Como se apuntó anteriormente, uno de los elementos más destacados del yacimiento es su impresionante 
mosaico figurativo. Del mismo, resalta la gran calidad técnica conseguida a la hora de ejecutarlo, por lo que parece una obra pictórica más que musivaria.

Se trata por tanto de pavimento realizado en su mayor parte de opus vermiculatum, con teselas milimétricas algunas de ellas de $1,5 \mathrm{~mm}$ - de una variadísima gama cromática, utilizándose para determinados tonos piezas de pasta vítrea e incluso doradas. Se consiguen así infinidad de matices, destacando el cuidado estudio anatómico del cuerpo humano, el dinamismo de las figuras en movimiento y la expresividad de los personajes. A todo esto se suma, el excelente estado de conservación, habiendo perdido, sólo una pequeña parte de su superficie, que en modo alguno afecta a la interpretación global de las escenas.

Esta excepcionalidad, hacía necesario una documentación acorde a su relevancia, aplicando un método de medición no intrusivo que permitiera una captura de información rápida, detallada y precisa de una superficie por medio de una herramienta basada en la tecnología de escáner con láser.

Por ello, en 2009 se optó por efectuar un escaneado 3D, mediante un láser escáner tipo FARO LS 880 3D (Fig. 6 ), que permite generar gran cantidad de mediciones tomadas de manera rápida y muy precisa. Dimensiona hasta 140.000 puntos por segundo, siendo necesarios solamente 4 minutos para realizar los $360^{\circ}$.

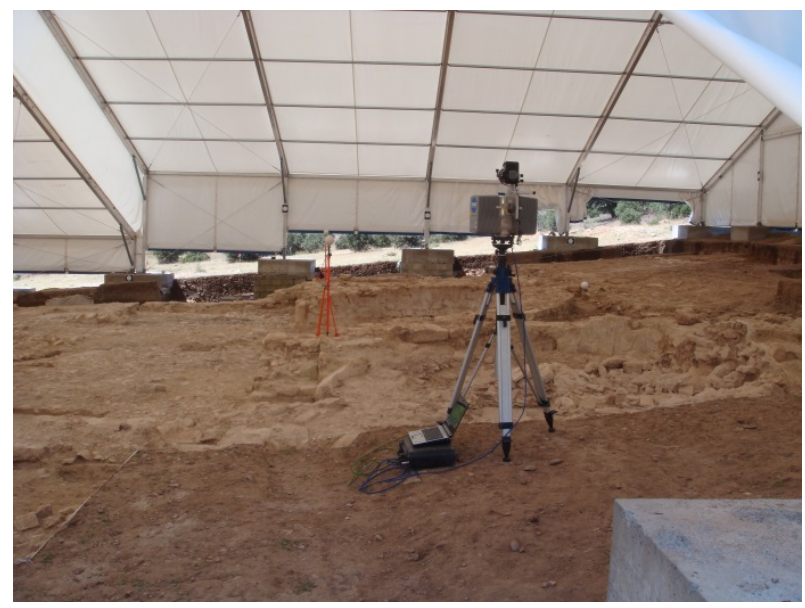

Figura 6: Toma de datos del mosaico mediante láser escáner.

Como en otros casos de características parecidas (Mañana-Borrazás et al. 2008), al ser un sistema que documenta una superficie por medio de láser, se tuvo que combinar distintas posiciones del escáner ya que la existencia de muros de hasta $1,20 \mathrm{~m}$ de altura conservada, impedia el registro de algunas partes de otros elementos que permanecían ocultas desde la posición de la máquina, generando zonas de sombra en la nube de puntos.

Posteriormente, el conjunto de escaneos fueron combinados en un registro único gracias a las dianas de control que sirven como referencia.

El resultado final fue la obtención de una nube de puntos 3D compuesta por cientos de miles de mediciones individuales en un sistema de coordenadas $(\mathrm{x}, \mathrm{y}, \mathrm{z})$, que en sí mismas componían un modelo tridimensional del triclinium de Noheda y sus mosaicos.
Paralelamente se realizaron las pertinentes fotografías con cámaras dotadas de objetivo de alta gama, a lo que se suma un respaldo digital que permitió obtener ficheros con al menos 60 megas. De esta manera, las imágenes georreferenciadas reflejaban todas las teselas y las juntas existentes entre ellas. Esta documentación sirvió para ulteriores investigaciones efectuadas sobre el tapiz musivo.

En la actualidad, se cuenta con la posibilidad de realización de otra campaña de escaneado 3D del triclinium de Noheda y sus mosaicos con una maquinaria más avanzada, acorde a las fechas actuales, concretamente un modelo Faro Focus ${ }^{3 \mathrm{D}}$ X130. La nube de puntos obtenidos en la primera lectura, es de gran valor y será cotejada con la resultante a efectuar. Con ello, se dispondrá de un completísimo mapeado milimétrico de la superficie de la alfombra musiva que además indicará si ha habído movimientos o no, así como cualquier otro tipo de variación del estado del tapiz tras su exhumación en 2009 y su inmediata protección.

Esto resulta tremendamente relevante para este yacimiento y para otros que cuenten con suelos de estas características. Con la doble lectura del mismo pavimento se podrá testar el comportamiento de los mosaicos tras la retirada de la capa de tierra que los cubrían, pudiendo así programar de manera adecuada actuaciones preventivas tanto en éste como en otros tapicez musivos.

\subsection{Teledección}

En la actualidad, se estima que se ha excavado entre un 7 y un $10 \%$ de la totalidad de la superficie que ocupaba el complejo rural.

Para intentar avanzar en el conociento integral del complejo rural, en 2008 se realizó una prospección geofísica de una parte de la parcela donde se inserta el yacimiento. El objetivo era doble, por un lado avanzar en el conocimiento de la superficie ocupada por la villa, por otro lado, intentar discernir posibles trazas constructivas o de ocupación sectorial, de tal modo que estos datos ayudasen a planificar de manera coherente las ulteriores campañas de excavación, para intentar así optimizar los escasos recursos.

El principio de esta metología es bien conocido, basándose de manera sintética, en el análisis de los contrastes y variaciones de ciertos parámetros físicos característicos del suelo (como la conductividad eléctrica o la permeabilidad magnética) a partir de los cuales mediante un proceso de interpretación, se puede inferir la existencia o no de estructuras en el subsuelo.

Para este trabajo se empleó un equipo GEM-2 de Geophex, Ltd (Fig. 7).

De acuerdo con el método de trabajo establecido, en primer lugar se limpió de vegetación la zona a estudiar. Posteriormente se proyectaron sobre la superficie del terreno un total de 38 mallas rectangulares de $25 \times 30 \mathrm{~m}$ aproximadamente. Una vez marcados la totalidad de los ítems a analizar, el equipo técnico pasó el georradar en cada una de las cuadrículas, recorriéndolas en sucesivas batidas paralelas $y$ en dos direcciones perpendiculares entre sí, hasta rastrear la totalidad del 
espacio comprendido en cada una de los ajedrezados (Fig. 8). En total se analizó una superfie de $2 \mathrm{Ha}$.

La configuración del equipo hace que se tome una muestra cada $15 \mathrm{~cm}$, con frecuencias de $47875 \mathrm{~Hz}$, lo que proporcionó una información que alcanzaba los $2 \mathrm{~m}$ de potencia en algunos puntos.

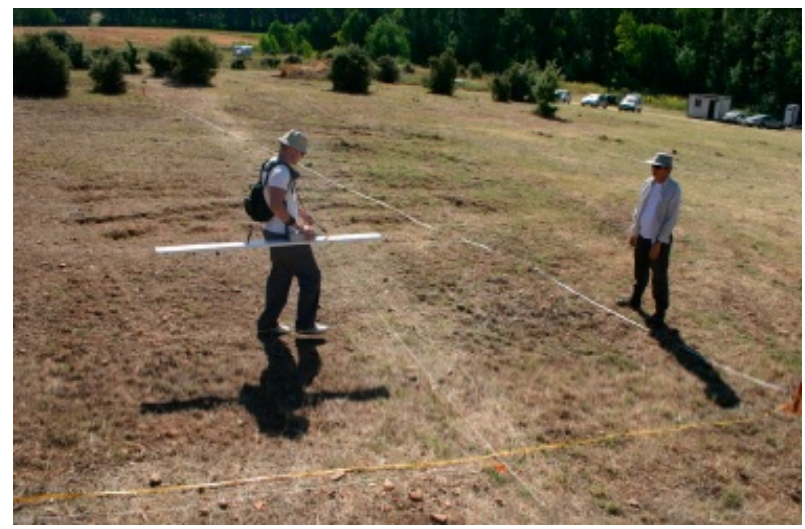

Figura 7: Equipo de trabajo.

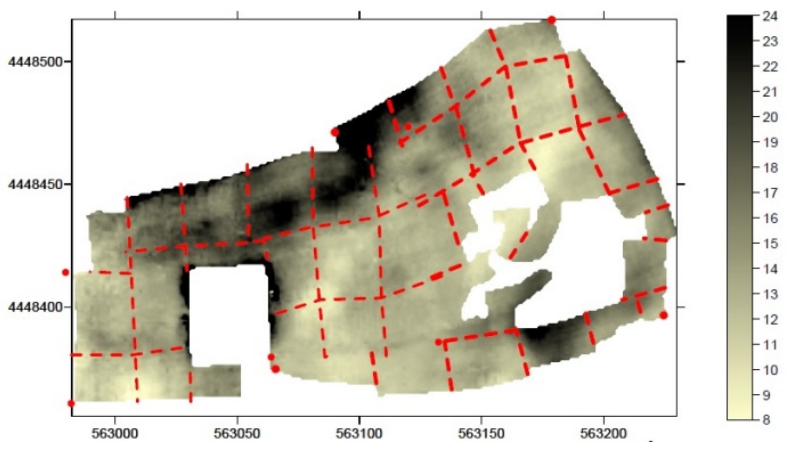

Figura 8: Aplicación del sistema de captación de datos en mallas equidistantes.

El resultado fue la documentación de una importante acumulación de alteraciones correspondientes a registros no geológicos, distinguiéndose patrones lineales de baja conductividad, junto a otros de alta correspondencia eléctrica.

Los datos tecnológicos indicaron algo que las posteriores campañas de excavación tuvieron la oportunidad de comprobar. La presencia de estructuras en posición yuxtapuesta y a diversas cotas, lo que permitía intuir varias fases de ocupación del yacimiento, con construcciones relevantes en cada una de las etapas cronoculturales.

Pese a que la capacidad técnica permitía abarcar un amplio espectro en profundidad (recordemos más de 2 m.), la lectura de los datos resultaba trementamente compleja, ya que sí en ocasiones ya es difícil descifrar testimonios sincrónicos ubicados a una cota similar, mucho más complicado resultaba discernir las referencias que se acumulaban en determinados puntos, presentando una extraordinaria acumulación de estructuras, muchas de ellas, como se ha indicado, yuxtapuestas.

Por este motivo, se optó obtener toda la información posible del yacimiento, pero solamente analizar las lecturas más superficiales de hasta $1 \mathrm{~m}$. de profundidad, dejando para una segunda etapa el estudio de los cortes que alcanzaron mayor calado.

Se obtuvo así un primer plano donde se indicaban las zonas de posibles acumulaciones de vertidos, las probables trazas de los muros, e incluso factibles pavimentaciones.

De este modo resultaba fácilmente identificable un posible trazado edilicio que podía corresponder a estructuras de grandes dimensiones ubicadas en el sector central. En los años posteriores se efectuaron algunos sondeos comprobatorios con resultados desiguales. Así, en determinados puntos sí se hallaron restos estructurales que tenía su correspondencia con la lectura efectuada por el georradar, mientras que en otros lugares, el análisis efectuado con los medios técnicos no tuvo su reflejo en los resultados obtenidos en la excavación arqueológica (Fig. 9).

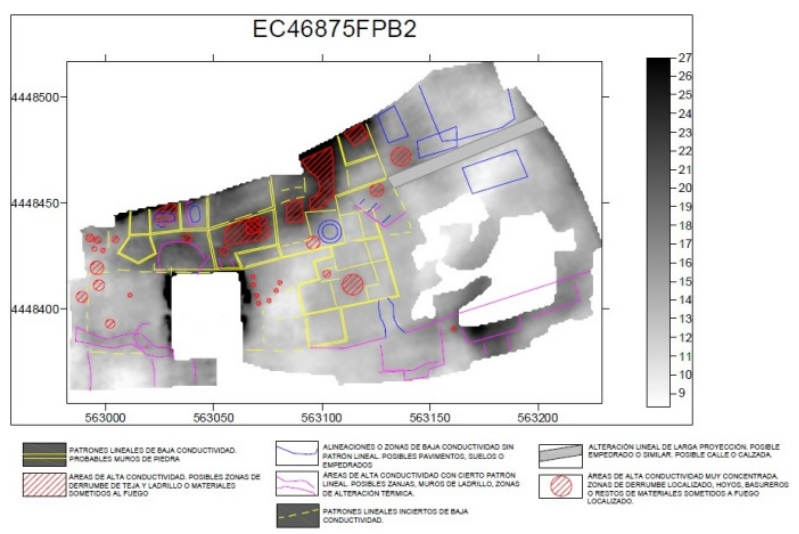

Figura 9: Interpretación arqueo-física de la zona.

El avance de las investigaciones arqueológicas en el yacimiento, aportará más información acerca de la eficiencia de los datos obtenidos mediante este sistema de prospección electromagnética.

\section{La atracción turística de la arqueología virtual: Noheda, el futuro del pasado}

El sector turístico en general y el arqueológico en particular, está constantemente sometido a un proceso de innovación, debido a que tiene que estar proporcionando emociones nuevas a los turistas ya que si no innovan los destinos se pueden convertir en rutinarios y dejan de ser visitados. Una manera de innovar ha sido ir adaptándose a las nuevas tecnologías.

En los últimos tiempos la utilización de estas nuevas tecnologías se ha convertido en un elemento necesario para cualquier destino turístico (Alles y Marqués 2014).

La innovación tecnológica que más ha avanzado ha sido la tecnología móvil, la cual ha teniendo una repercusión muy fuerte en la industria del turismo ya que permite obtener información en tiempo real de cualquier destino que se quiera visitar de manera muy sencilla. Realmente, los aparatos móviles, a través de distintos medios (posicionamiento, realidad aumentada, redes sociales, internet, etc.) han permitido facilitar esa conexión entre el turista y el el enclave histórico visitado (Imbert-Bouchard et al. 2013). 
Con el tiempo las nuevas tecnologías se han ido utilizando en todos los aspectos de nuestra vida, y en el caso de la arqueología no ha sido una excepción, ya que con ellas se ha tratado de representar yacimientos arqueológicos, edificios, objetos y de todo aquello que la mente de una persona pueda concebir.

Es interesante poder aprovechar todas las herramientas útiles que tenemos a nuestro alcance en internet (geoinformación, realidad aumentada, 3D, etc) para dar a conocer el rico patrimonio de un lugar. Éstas pueden llegar a ofrecen oportunidades para el desarrollo de estos destinos turísticos, como es el caso del yacimiento arqueológico de Noheda. Sin duda, pueden ser utilizas como una fuente de atracción turística.

Insertar este tipo de herramientas en el campo de la arqueología es lo que se denomina arqueología virtual. Su objetivo no solo es ayudar a los científicos a la demostración de sus hipótesis arqueológicas, sino también difundir los yacimientos mediante su reconstrucción para una fácil comprensión y siempre teniendo en cuenta la adaptación de los mismos a cualquier tipo de visitante. El empleo de estas tecnologías podrá llegar a fomentar el turismo arqueológico de la villa romana de Noheda ya que con estas herramientas se puede apoyar a su difusión turística, como una forma de poder conocer y recorrer este enclave mediante un recorrido virtual.

Unas de las herramientas tecnológicas más importantes que se podrían ofrecer en este excepcional yacimiento es la realidad aumentada. A pesar de que es un concepto que se ha venido manejando en los últimos años, en investigación teórica ya se hacía desde los años 60 del siglo XX (Wei et al. 2014).

La realidad aumentada es una tecnología que trata de unir el entorno real con un entorno virtual, basándose en la sobreimpresión de elementos virtuales en la realidad a tiempo real (Callejas et al. 2011). Esto, aplicado para este yacimiento, se puede conseguir a través de una aplicación móvil (App) que le va a permitir una diferenciación a nivel de otros destinos arqueológicos.

Para cualquier persona no especialista en arqueología, a veces resulta excesivamente complicado poder entender un yacimiento observando solamente los restos encontrados o expuestos. Para evitarlo, una buena opción será esa recreación virtual tanto del yacimiento, a través de la realidad aumentada como la herramienta del modelado 3D de piezas (sobre todo esculturas) que se van encontrando en determinados puntos del enclave y que el visitante podrá observar simplemente leyendo los códigos bidimensionales o QR con sus dispositivos móviles o tablets. Estos códigos serán colocados en el punto donde se encontraban las piezas en el momento de uso de la villa.

La utilización de esta otra herramienta del 3D en el yacimiento se puede realizar con un doble objetivo, por un lado, para generar la visión conexa de los fragmentos reales y por otro lado, la integración de éstos dentro de la reconstrucción, siempre diferenciándose los restos originales, de los que no lo son. Será una manera para visualizar las dos propuestas de un solo vistazo (GarcíaMorales et al. 2015).

Este uso virtual, que en los últimos tiempos se desarrolla en el campo de la arqueología está teniendo un gran éxito. La posibilidad y capacidad de la representación virtual de de Noheda facilitará el entendimiento de éste, para cualquier público, añadiéndole siempre un especial atractivo. Esto puede ayudar a conseguir que la sociedad muestre interés por su propio patrimonio, especialmente por su puesta valor, pues difícilmente se puede proteger algo si se desconoce. También esta tecnología nos ayudaría a que en caso de pérdida o mala conservación sepamos cómo era inicialmente.

Pero sin duda, la incorporación de estas nuevas tecnologías en arqueología la villa romana de Noheda, no solo contribuirá al trabajo de los arqueólogos sino que también será una medida de atracción turística que ayudará a la difusión y protección del patrimonio cultural.

\section{Conclusiones}

Un yacimiento arqueológico de la relevancia de Noheda, en el cual se hallan uno de los mosaicos figurativos más destacados del imperio romano, está llamado a ser un acicate en la revitalización turística de la zona. Pero para que un enclave pueda ser adecuadamente difundido, valorado y enseñado, es necesario la aplicación de una correcta metodología arqueológica que ayude a interpretar correctamente el sitio. En esta línea, no solo se han de tener en cuenta las tradicionales técnicas de excavación arqueológica, sino también el empleo de las nuevas tecnologías como elemento que ayudan a planificar y enterner los procesos arqueológicos, así como para utilizarlos en la musealización de la villa.

De este modo, en Noheda, tal y como se ha expuesto, desde hace años ya se están usando toda una serie de métodos no intrusivos de investigación arqueológica. Pero esto no es sino un primer paso en el empleo de estas nuevas tecnologías que serán aplicadas con profusión de cara a conocer y difundir de manera adecuada el enclave.

\section{Agradecimientos}

Este artículo se ha elaborado en el marco del proyecto Conservación preventiva de los mosaicos romanos de la villa romana de Noheda (Cuenca), del lugar arqueológico de I'Almoina (Valencia) y otros HAR 201347895-C2-1-P, dirigido por F. García-Diego. Por otro lado, algunos de los estudios enumerados en este trabajo fueron sufragados gracias a los proyectos de investigación: Estudio integral del triclinium $y$ dependencias anejas de la villa romana de Noheda 14.546 y Estudio estratigráfico del sector residencial de la villa romana de Noheda 15.0923, dirigidos por Miguel Ángel Valero Tévar.

Además el desarrollo de las excavaciones se ha efectuado gracias a la financiación de la Junta de Comunidades de Castilla-la Mancha, la Excma. Diputación de Cuenca y la colaboración del Excmo Ayuntamiento de Villar de Domingo García. 


\section{Referencias}

ABASCAL, J.M., 1982. Vías de Comunicación romanas de la provincia de Guadalajara, Ed. Diputación Provincial de Guadalajara. Instituto Provincial de Cultura "Marqués de Santillana”, Guadalajara.

ALLES, M.T.F., y MARQUÉS, R.C., 2014. El impacto de las nuevas tecnologías en el sector turístico: aplicación de la realidad aumentada al turismo cultural, en Cultura, desarrollo y nuevas tecnologías: VII Jornadas de Investigación en Turismo, Sevilla, 11 y 12 de Junio de 2014, pp. 317-333.

ARCE, J., 2006. Villae en el paisaje rural de Hispania romana durante la Antigüedad tardía, en CHAVARRÍA, A., ARCE, J. y BROGIOLO, G.P. eds., Villas Tardoantiguas en el Mediterráneo Occidental, Anejos de AEspA XXXIX, Madrid, pp. 9-15.

ARCE, J., 2009. El último siglo de la España romana, 284-412, Madrid.

ARCE, J., 2010. El complejo residencial tardorromano de Cercadilla, (Corduba), En VAQUERIZO, D., ed., Las áreas suburbanas en la ciudad histórica. Topografía, usos, función, Monografías de Arqueología Cordobesa, 18, pp. 397412.

ARCE, J., 2012. Campos, tierras y villae en Hispania, En CABALLERO, L., MATEOS, P. y CORDERO, T. eds., Visigodos y Omeyas. El territorio, Mérida, pp. 21-30.

BALMELLE, C., 2001. Les demeures aristocrutiques d'Aquitaine, Ausonius-Aquitania, Supplément, 10, Bordeaux-Paris.

BEZZI, A., 2013. Caldonazzo castle - from ruins to archaeological 3D reconstruction, ATOR (Arc-Team Open Research), 9 de diciembre de 2013 DOI: http://arc-team-open-research.blogspot.com.es/2013/12/caldonazzo-castle-from-ruinsto.html [Consulta: 23-02-2016].

CALLEJAS, M., QUIROGA, J.G. y ALARCÓN, A.C., 2011. Ambiente interactivo para visualizar sitios turísticos, mediante realidad aumentada implementando Layar, Ciencia y Tecnología Neogranadina, 21-2, pp. 91-105.

CHAVARRÍA, A., 2005. Villas in Hispania during the fourth and fifth Centuries, En BOWES, K. y KULIKOWSKI, M. eds., Hispania Late Antiquity. Current Perspectives, Leiden-Boston, pp. 518-555.

CHAVARRÍA, A., 2006: Villas en Hispania durante la Antigüedad tardía, En CHAVARRÍA, A., ARCE, J. y BROGIOLO, G.P. (eds.), Villas Tardoantiguas en el Mediterráneo Occidental, Anejos de AEspa XXXIX, Madrid, pp. 17-35.

CHAVARRÍA, A., 2007. El final de las uillae en Hispania (siglos IV-VIII), BAT 7, Brepols, Turnhout.

DE REU, J., Plets, G., VerhoeVEN, G., DE SMEDT, P., BATS, M., CheRRetTe, B., DE MAEYER, W., DECONYNCK, J., HERREMANS, D., LALOO, P. y VAN MEIRVENNE, M., 2013. Towards a three-dimensional costeffective registration of the archaeological heritage, Journal of Archaeological Science, 40, pp. 1108-1121. DOI: http://www.journals.elsevier.com/journal-of-archaeological-science/ [Consulta: 27-2-2016]

DONEUS, M., VERHOEVEN, G., FERA, M., BRIESE, C., KUCERA, M. y NEUBAUER, W., 2011. From deposit to point cloud e a study of low-cost computer vision approaches for the straightforward documentation of archaeological excavations, En CEPEK, A. ed., XXIII International CIPA Symposium, Prague, 12-16 September 2011, Geoinformatics, Vol. 6, Prague: Faculty of Civil Enginnering, Czech Technical University, pp. 81-88. DOI: http://pubgeo.tuwien.ac.at/showentry.php?ID=206899/=6\&nohtml=1. [Consulta:15-2-2016].

DUNBABIN, K.M.D., 2003. The Roman Banquet. Images of conviviality, Cambridge University Press, Cambrige.

GARCÍA-ENTERO, V., 2005. Los balnea domésticos -ámbito rural y urbano- en la Hispania romana, Anejos de Archivo Español de Arqueología, XXXVII, Madrid.

GARCÍA-ENTERO, V., 2006. Los balnea de las villae tardoantiguas en Hispania, Anejos de Archivo Español de Arqueología, XXXIX, pp. 97-111.

GARCÍA-MORALES, R.M., CORTINA, M.L., PINTADO, J.A., y NOVELLA, L.R., 2015. Princeps Resurgens: investigación arqueológica y documentación fotogramétrica en el estudio de una estatua romana thoracata de Los Bañales (Uncastillo, Zaragoza), Virtual Archaeology Review, 6(13), pp. 65-71. DOI: http://dx.doi.org/10.4995/var.2015.4379 [Consulta: 29-02-2016].

GROS, P., 2001. L'Architecture romaine, 2. Maisons, palais, villas et tombeaux, París.

HIDALGO, R., 1998. El triclinium triconque del palatium de Córdoba, Anales de Arqueología Cordobesa, 9, pp. 273-300.

HIDALGO, R., 2014. ¿Fue Cercadilla una villa? El problema de la función del complejo de Cercadilla en Corduba, Archivo Español de Arqueología, 87, pp. 217-241.

IMBERT-BOUCHARD, D., LLONCH, N., MARTIN, C. y OSÁCAR, E., 2013. Turismo cultural y apps. Un buen panorma de la situación actual, HER\&MUS, 2, sept-oct, pp. 44-54.

JANCOSEK, M. y PAJDLA, T., 2011. Multi-View Reconstruction PreservingWeakly-Supported Surfaces, CVPR, pp. 3121-3128. DOI: http://dx.doi.org/10.1109/cvpr.2011.5995693 [Consulta: 29-02-2016]. 
JOHNSTON, D.E., 1983. Roman Villas, Aylesbury Shire.

LARRAÑAGA, J., 1966. Guía de Cuenca, Cuenca: Excma. Diputación Provincial de Cuenca.

LLEDÓ, J.L., 2007. El Mosaico de Noheda (Cuenca): Su descubrimiento, Cuenca: Ed. Excma. Diputación Provincial de Cuenca.

LLEDÓ, J.L., 2010. El Mosaico Romano de Noheda: Historia personal de un alumbramiento, Madrid: Ed. Visión Libros.

MAÑANA-BORRAZÁS, P, RODRÍGUEZ, A. y BLANCO-ROTEA, R., 2008. Una experiencia en la aplicación del Láser Escáner a los procesos de documentación y análisis del Patrimonio Construido: su aplicación a Santa Eulalia de Bóveda (Lugo) y San Fiz de Solovio (Santiago de Compostela, Arqueología de la Arquitectura, 5, pp. 15-32.

MAR, R. y VERDE, G., 2008. Las villas tardoantiguas: cuestiones de tipología arquitectónica, En FERNÁNDEZ, C.; GARCÍA, V. y GIL, F. eds., Las villae tardorromanas en el occidente del imperio: Arquitectura y Función. Gijón: Ed. Trea, pp. 50-83.

MARTÍNEZ, C., MEJÍAS, M., GOICOECHEA, P.P. y VALERO, M.A., 2014. Posibilidades de abastecimiento subterráneas de la villa romana de Noheda y características geológicas de su entorno, Cuenca: IGME-Excma. Diputación Provincial de Cuenca.

McCARTHY, J., 2014. Multi-image photogrammetry as a practical tool for cultural heritage survey and community engagement Journal of Archaeological Science, 43, pp. 175-185. DOI:10.1016/j.jas.2014.01.010

McKAY, A.G., 1975. Houses, Villas and Palaces in the Roman World, London.

MEJÍAS, M., MARTíNEZ, C., GOICOECHEA, P.P. y VALERO, M.A., 2013. Estudio Geológico e Hidrológico del yacimiento arqueológico de Noheda (Villar de Domingo García, Cuenca), Instituto Geológico y Minero de España, IGME.

MULVIN, L., 2002. Late Roman Villas in the Danube-Balkan Region, Oxford: BAR Int. Ser. 1064.

PALOMERO, S., 1987. Las vías romanas de la provincia de Cuenca, Cuenca: Excma. Diputación Provincial de Cuenca.

PENSABENE, P., 2010-2011. La villa del Casale tra Tardo Antico e Medioevo alla luce dei nuovi date archaeologici: funcioni, decorazioni e transformazioni, Rendiconti della Pontificia Accademia Romana di Archeologia, LXXXIII, pp. 141-226.

PERCIVAL, J., 1976. The Roman Villa, A Historical Introduction, London.

POIRIER, N., HAUTEFEUILLE, F. y CALASTRENC, C., 2014. Utilisation des micro-drônes pour la prospection archéologique à basse altitude, Colloque scientifique francophone. Drones et moyens légers aéroportés d'observation. Montpellier, 24-26 Juin 2014. DOI: http://drone.teledetection.fr/restitue.php [Consulta: 29-02-2016].

RICHMOND, I., 1970. The plans of roman villas in Britain, En RIVET, A.L.F. ed., The Roman Villas in Britain, London, pp. 49-70.

RODÀ, I., 2004. El mármol como soporte privilegiado en los programas ornamentales de época imperial, En RAMALLO, S. ed., La decoración arquitectónica en las ciudades romanas de Occidente. Actas del Congreso Internacional celebrado en Cartagena entre los días 8 y 10 de octubre de 2003. Murcia: Universidad de Murcia, pp. 405-420.

ROMIZZI, L., 2006. Le ville tardo-antiche in Italia, En CHAVARRÍA, A., ARCE, J. y BROGIOLO, G.P. eds., Villas Tardoantiguas en el Mediterráneo Occidental, Anejos del Archivo Español de Arqueología, 39, pp. 37-59.

ROSSITER, J., 1991: "Convivium and Villa in Late Antiquity", En SLATER, W. J. (ed.), Dinning in a classical Context, Michigan, pp. 199-214.

RUIZ, J.A., GALLEGO, D., PEÑA, C., MOLERO, J.M. y GÓMEZ, A., 2015. Fotogrametría aérea por drone en yacimientos con grandes estructuras. Propuesta metodológica y aplicación práctica en los castillos medievales del Campo de Montiel, Virtual Archaeology Review, 6(13), pp. 5-19. DOI: http://dx.doi.org/10.4995/var.2015.4366 [Consulta: 29-02-2016].

SHAN, Q., WU, Ch., CURLESS, B., FURUKAWA, Y., HERNÁNDEZ, C. y SEITZ, S.M., 2014. Accurate Geo-registration by Ground-to-Aerial Image Matching, International Conference on 3D Vision 2014. Tokyo.

SFAMENI, C., 2006. Ville residenziali nell'Italia Tardoantica, Edipuglia, Bari.

VALERO, M.A., 1999a. La Necrópolis tumular de la Punta del Barrionuevo. Iniesta-Cuenca, En VALERO, M.A., ed., Actas de las $1^{a}$ s Jornadas de Arqueología Ibérica en Castilla-La Mancha. Toledo: Serie Patrimonio Histórico, pp. $181-200$

VALERO, M.A., 1999b: El Origen del Mundo Celtibérico en la Meseta Sur, Actas de I Encuentros sobre el Mundo Celtibérico. Guadalajara, pp. 213- 219.

VALERO, M.A., 2008. El territorio Ibérico en La Manchuela: avance de los primeros resultados, Studia académica, Número extraordinario 1, pp. 155-195.

VALERO, M.A., 2009. La villa de Noheda: esplendor tardoimperial, Revista Memorias, 15, pp. 53-58. 
VALERO, M.A., 2010. La villa romana de Noheda: Avance de los primeros resultados, Informes sobre Patrimonio 1, http://informes.patrimoniohistoricoclm.es/2010-03/patrimonio.html. [2/15/ 2016].

VALERO, M.A., 2011. Les images de ludi de la mosaïque romaine de Noheda (Villar de Domingo García, Cuenca), Nikephoros, 24, pp.91-114.

VALERO, M.A., 2013a. The late-antique villa at Noheda (Villar de Domingo García) near Cuenca and its mosaics, Journal of Roman Achaeology, 26, pp. 307-330.

VALERO, M.A., 2013b. El cambio de patrón poblacional en el territorium de Ercávica: Avance sobre un proyecto de evolución del paisaje en La Alcarria, en CERDEÑO, Ma.L., SAGARDOY, T. y GAMO, E. eds., La Romanización en la provincia de Guadalajara. Guadalajara: La Ergástula, pp. 221-236.

VALERO, M.A., 2014a. El triclinium de la villa de Noheda (Villar de Domingo García. Cuenca), En PENSABENE, P. y SFAMENI, C., eds., La Villa Restaurata e i Nuovi Studi sull'Edilizia Residenziale Tardoantica. Bari: Edipuglia, pp. $521-531$.

VALERO, M.A., 2014b. Estudio arqueométrico de las muestras procedentes del mosaico de la villa romana de Noheda (Cuenca): primeros resultados, Actas del X Congreso Ibérico de Arqueometría, Castellón: Instituto de Conservación y Restauración Valenciano, pp. 54-68.

VALERO, M.A., 2014c. La representación de instrumentos musicales en el mosaico de la villa romana de Noheda, Libro de la 53 SMR de Cuenca, Cuenca: Excma. Diputación de Cuenca, pp. 81-104.

VALERO, M.A., 2015a. La villa romana de Noheda: la sala triclinar y sus mosaicos. Tesis Doctoral, Universidad de Castilla-La Mancha.

VALERO, M.A., 2015b. Los mosaicos del triclinium de la villa romana de Noheda (Villar de Domingo García, Cuenca), En ÁlVAREZ, J.M., NOGALES, T. y RODÀ, I. eds., Proceedings XVIIITH International Congress of Classical Archaeology. Mérida: Museo Nacional de Arte Romano, pp. 1347-1351.

VALERO, M.A., e.p.: El territorium de la villa romana de Noheda, Cuenca, En SANZ, R. y CARNEIRO, A., Actas del I Congresso Internacional sobre Arqueologia de Transição: "Entre o Mundo Romano e a Idade Média", Évora: Universidad de Évora.

VALERO, M.A. y GÓMEZ, J., 2013. El mimo celoso adinerado: literatura y espectáculo en la uilla romana de Noheda, Quaderni Urbinati de Cultura Classica, 102, pp. 87-106.

VALERO, M.A., MERELLO, P., FERNÁNDEZ, A., y GARCíA-DIEGO, F.J., 2014. Characterisation and evaluation of a thermo-hygrometric corrective action carried out at the Noheda archaeological site (Noheda, Spain), Sensors, 14, pp. 1665-1679.

VALERO, M.A., GUTIÉRREZ, A. y RODÀ, I, 2015. First preliminary results on the marmora of the late roman villa of Noheda (Cuenca, Spain), En PENSABENE, P. y GASPARINI, M. eds., Interdisciplinary Studies on Ancient Stone. ASMOSIA X. Roma: L'Erma di Bretscheider, pp. 359-380.

VERA, D., 1992-1993. Schiavitù rurale e colonato nell'Italia imperiale, Scienze dell'Anchiquità Storia Archaeologica Antropógica, 6-7, pp. 291-339.

VOLPE, G., 1996. Contadini, pastori e mercanti nell'Apulia tardoantica, Munera 6, Bari.

VOLPE, G., 2006. "Stibadium e convivium in una villa tardoantica (Faragola-Ascoli-Satriano)", en SILVESTRINI, M., SPAGNUOLO VIGORITA, T. y VOLPE, G. (eds.), Studi in onore di Francesco Grelle, Bari, p. 319-349.

WEI, S., RENI G. y O'NEILL, E., 2014. Haptic and Audio Displays for Augmented Reality Tourism Applications, IEEE Haptics Symposium 2014, pp. 485-488. DOI: 10.1109/HAPTICS.2014.6775503 [Consulta: 29-02-2016].

WESTOBY, M.J., BRASINGTON, J., CLASSER, N.F., HAMBREY, M.J. y REYNOLDS, J.M., 2012. "Structure-fromMotion photogrammetry: A low-cost, effective tool for geoscience applications, Geomorphology, 179, pp. 300-314. DOI:10.1016/j.geomorph.2012.08.021 [Consulta: 29-02-2016].

WU, Ch., 2013. Towards Linear-time Incremental Structure from Motion, International Conference on 3D Vision 2013. Seattle. DOI: 10.1109/3DV.2013.25 [Consulta: 29-02-2016]. 


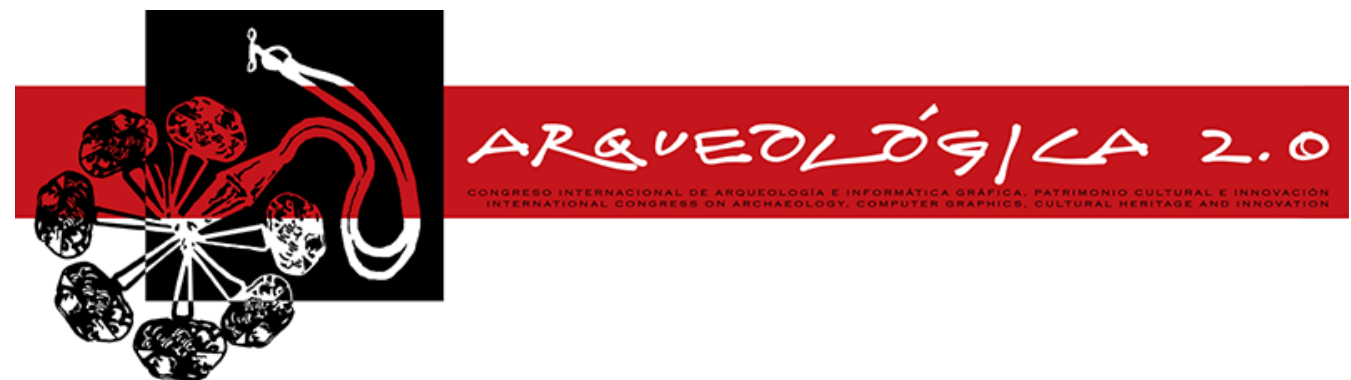

Proceedings of the $8^{\text {th }}$ International Congress

on Archaeology,

Computer Graphics,

Cultural Heritage and Innovation

'ARQUEOLÓGICA 2.0'

in Valencia (Spain),

Sept. $5-7,2016$

DOI: http://dx.doi.org/10.4995/arqueologica8.2016.4175

Received: $15 / 04 / 2016$

Accepted: 16/05/2016

\title{
VIRTUAL RECONSTRUCTION APPLIED TO THE RECOVERY AND HERITAGE DISCLOSURE OF THE OLD VILLAGE OF BELCHITE
}

\section{RECONSTRUCCIÓN VIRTUAL APLICADA A LA RECUPERACIÓN Y DIVULGACIÓN DEL PATRIMONIO DEL VIEJO BELCHITE}

\author{
Ana Alfaro ${ }^{\mathrm{a},{ }^{,}, \text {María Pilar Biel }^{\mathrm{b}} \text {, Diego Gutiérrez }}{ }^{\mathrm{c}}$ \\ ${ }^{a}$ Escuela de Ingeniería y Arquitectura, Universidad de Zaragoza, España. ana.alfaro.ro@gmail.com \\ ${ }^{\mathrm{b}}$ Departamento de Historia del Arte, Universidad de Zaragoza, España. pbiel@unizar.es \\ ${ }^{c}$ Instituto de Investigación en Ingeniería de Aragón, Universidad de Zaragoza, España. diegog@unizar.es
}

\begin{abstract}
:
Virtual reconstruction allows recovering missing heritage whilst becoming a useful tool for documenting and disseminating, when physical reconstruction is non-viable. This article explains the application of new technologies of virtual reconstruction (modelling and photogrammetry) to the recovery of the historic-artistic heritage of the Old Village of Belchite, specifically applied to the case of the San Augustin's Convent. This village was a battle scene in the Spanish Civil War in 1937 which has been abandoned since 1964. These days, it presents a state of ruin that increases exponentially over the time.
\end{abstract}

Key words: Old village of Belchite, arquitectonic 3D reconstruction, historic artistic heritage, photogrammetry, 3D model

\section{Resumen:}

La reconstrucción virtual permite recuperar entidades patrimoniales desaparecidas convirtiéndose en una útil herramienta de documentación y divulgación de las mismas cuando la reconstrucción física es inviable. El presente artículo trata sobre la aplicación de tecnologías de reconstrucción virtual (modelado y fotogrametría) a la recuperación del patrimonio histórico artístico del Pueblo Viejo de Belchite, en concreto aplicadas al caso del Convento de San Agustín. Esta localidad fue escenario de una batalla de la Guerra Civil Española en 1937 y lleva abandonada desde el año 1964. En la actualidad presenta un estado de ruina que aumenta exponencialmente con el tiempo.

Palabras clave: Pueblo Viejo de Belchite, reconstrucción arquitectónica 3D, patrimonio histórico artístico, fotogrametría, modelado 3D

\section{Introduction}

The old Belchite is a desolated village located in the district Campo de Belchite, in the province of Zaragoza (North East of Spain). Its narrow streets with dilapidated houses and empty yards make a great impact on people who visit it. Feeling that increases when its current state is compared with old photographs (from the first half of the twentieth century) in which people can appreciate the architectural wealth it had, and their streets full of life. These days most of its buildings have collapsed, and only some houses and religious buildings are preserved, but all in a very poor state. For this reason, virtual reconstruction has been considered as a useful tool to bring the viewer or visitor to a previous era (Gutierrez et al. 2004; Gutierrez et al. 2008; Fiamminghi et al. 2008; Scaglioni 2014; Balawat 2015; Peripimeno and Strufaldi 2015) when the village was inhabited and its houses were in perfect condition, and in this way, contribute to recovering the artistic heritage that has been lost.

This project has been focused on the making of a video showing the reconstruction of the Convent of San Agustin by modelling and photogrammetry techniques. This point has been chosen for its high architectural value being a representative example of monastic architecture of the 15th -17 th centuries. In relation with the techniques that has been used, modelling allows you to digitally reproduce the reconstructing of the missing parts of the building while photogrammetry allows you to reproduce the exact state of the ruins with a high level of accuracy. All of this to generate a video featuring its

`Corresponding Author: Ana Alfaro, ana.alfaro.ro@gmail.com 
virtual reconstruction, and its evolution over the time, in order to raise awareness of the importance of heritage legacy left to us (Fiamminghi et al. 2008; Laboratoire MAP du CNR 2014; Peripimeno and Strufaldi 2015).

\section{The Old Belchite}

Belchite is a village located $50 \mathrm{~km}$ South East of Zaragoza. In the past it was an important town with great architectural richness, characteristic of the area "el Bajo Aragón". Among its most representative buildings you can appreciate styles such as Mudejar, Renaissance, Baroque and neoclassical, both in civil and religious architecture (Vidal 2014; Baquero 1988; Cinca et al. 2008).

The Battle of Belchite (in 1937) was a Republican Army offensive during the Spanish Civil War in an effort to recover the northern side of the country. Once the war was finished, the village had significant damages, but even though it had a chance to recover (Fig. 1), the government of the francoist dictatorship decided Belchite should be abandoned to become a monument of exaltation of this regime. The result was the construction of a new village (Fig. 2) which was inaugurated in 1954, although the population did not abandon the former village until 1964 (Vidal 2014; Baquero 1988; Cinca et al. 2008).

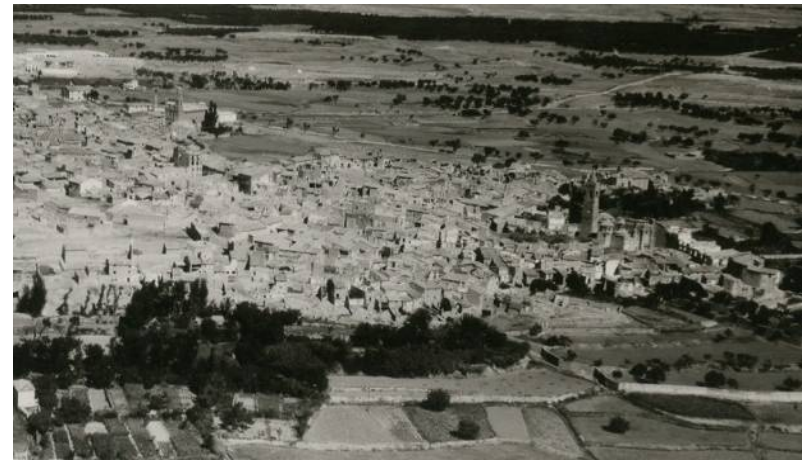

Figure 1: Aerial view of the old Village after the war (40s) in which most houses are still standing. (General Administration Archive).

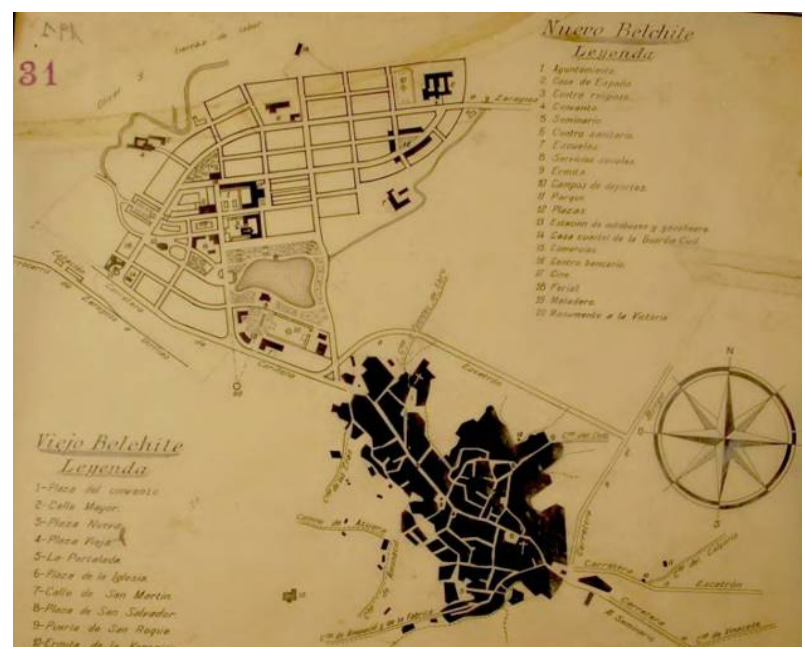

Figure 2: Map of the two villages of Belchite (Provincial Historic Archive of Zaragoza).
The venue was declared "Bien de Interés Cultural" (Heritage of Cultural Interest) in 2002 and as a result of that, a Project Action Plan in the old Belchite was drafted (Vidal 2014). It projects among other things, the consolidation and restoration of some of its buildings. In recent years, the restoration of three of these buildings has been carried out: the tower of the missing church of San Juan, known as "Torre del reloj" (2003) followed by the two main gates of the village which are known as "Arco de la Villa (2008) and "Arco de San Roque" (2010). Nowadays, the enclosure of the old Belchite is fenced allowing access to the public only with the guided tours organized by the tourist office in the village. There is a need to supplement these tours with other materials that can explain visually and didactically where the streets and major monuments can be found. Thanks to this appreciation, the virtual reconstruction project emerges as a great support to the promotion and dissemination of its architectural heritage.

\section{Methods}

This essay aims to be the beginning of a more ambitious project to be extended to cover the entire village. But this requires extensive research work of a team of professionals from different disciplines (Gutierrez et al. 2004; Gutierrez et al. 2008) like architects, historians, designers, etc., as well as the involvement of different administrations.

\subsection{Delineating the framework}

The choice of the convent of San Agustin for developing the virtual reconstruction is motivated by it being one of the most emblematic buildings of the enclosure with some historic and artistic values. In addition to this, there is the availability of abundant technical information, given the fact that monographs have been published, plans have been raised and lots of photographic material is kept (Vidal 2014; Baquero 1988).

This is a convent built in various stages between 1597 and 1716, and consists of a cloister from the renaissance period and a Baroque church, which facade and tower had certain influences of the Múdejar style characteristic of "el Bajo Aragón". The plan of the church is that of a Latin cross, with a hemispherical dome with lantern. It has a central aisle with a barrel vault with stained glasses and two heights lateral chapels with cross-vaulted. One of these chapels culminates with another hemispherical dome with a lantern, lower than the central chapel. Attached to the right wall is a chapel of late Baroque style that was added in the last phase of the construction of the building. The cloister had a square ground plant and it was attached to the left wall of the church. It was made of two floors of vaulted galleries that opened to the outside by semi-circular arches. The cells of the monks were distributed in two of its sides (Vidal 2014; Baquero 1988).

These days, all it remains in this building is the structure of the church as well as the facade and tower, with significant damage (Fig.3). There are only a few remains from the cover and rear and right side walls of the church. The same applies to the cloister, where the only thing left is its plot full of debris and two arcs that make up one corner of the gallery vaults on the first floor. 


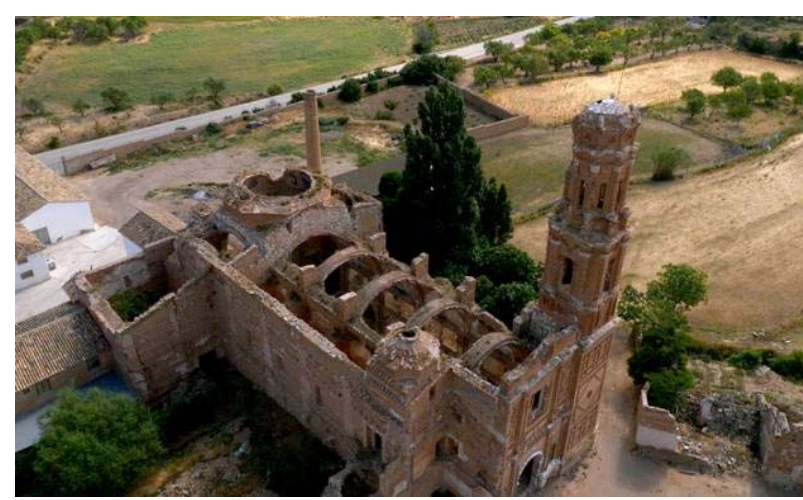

Figure 3: Aerial view of the convent of San Agustin (2015), in which you can see its current aspect.

\subsection{Election of the final product}

A virtual reconstruction serves as an element of exposure and dissemination of the reconstructed object. In the case of a building in ruins or already destroyed, virtual reconstruction provide support to research it and to raise different hypotheses in a graphical way. Among its many applications you can have the virtual reality (Scaglioni 2014), the possibility of hosting a virtual museum on a website (e.g. www.balawat.com and www.segobriga.org), all kinds of computer graphics and interactive tools that serve as content support. It can also be used as settings for video games or movies (e.g. www.entropystudio.net) as well as to create $3 \mathrm{D}$ printing models.

After analyzing all these applications, it was determined that the final product would be an informational video which serves as a comparison between the past (when the building was not in ruins yet) and the current time. This application allows showing the reconstruction on a very didactic and attractive way for the viewer, and allows easy webcasting, and/or display in exhibition halls. In order to show past, modeling techniques were chosen, while it was decided to alternate photogrammetry technique with real images of the building to represent the present moment. Starting from this decision, the video contents and modeling were planned adjusting this latter to the elements that were to appear in the audiovisual (Fig. 4).

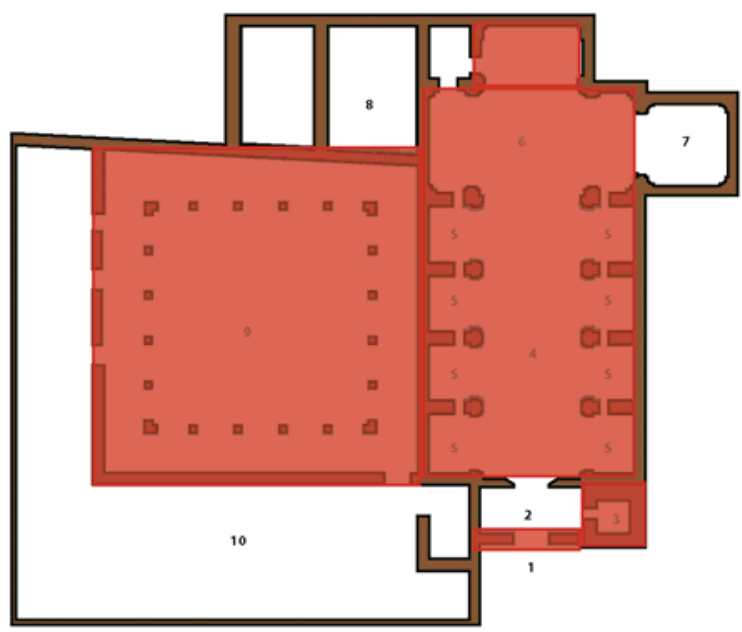

Figure 4: San Agustin's convent's floor, highlighting in red the elements that have been deeper analised in the modeling.
The proposed scenes for the video are as follows:

- Scene 1: Location of the building on the map of the village.

- Scene 2: General view of the building

- $\quad$ Scene 3: Tower view

- Scene 4: View of the facade

- Scene 5: View of the cloister

- Scene 6: View from inside the church

They stand out the most characteristic elements of the building and what the most architectural and artistic value is. In order to optimize resources, modeling assignments have focused especially on items that are displayed in the scenes.

\subsection{Modeling}

The previous information which was available for modeling was as follows

- $\quad$ Buildings plans (Vidal 2014; Baquero 1988)

- Pictures past and present (Cinca et al. 2008; Administration General Archive).

- Visits to the building

Taking as a reference the existing plans of the set, it has been built the building with SolidWorks, a 3D modeling software. For the making of the most damaged areas, visualization and analysis of old photographs have been necessary. Most of the consulted old photographs are dated after the war; from the 40s of the twentieth century approximately, in these you can see that the building still has its cover, and part of the cloister. The back of the presbytery and the domes had already been lost.

Modeling process consists on a sequence of operations trought the volume of the building is generated, as well as extrusions, lofts, sweeps, symmetries, pattern operations, etc. Some operations are shown in Figure 5.

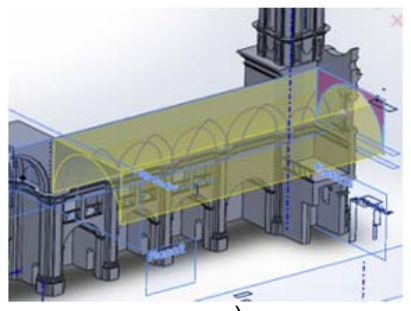

a)

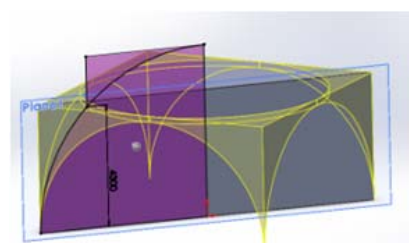

c)

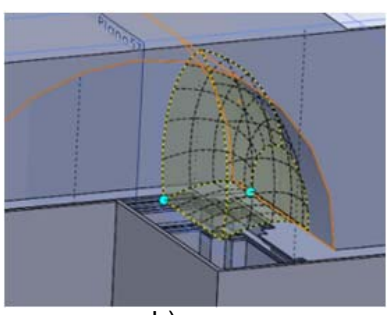

b)

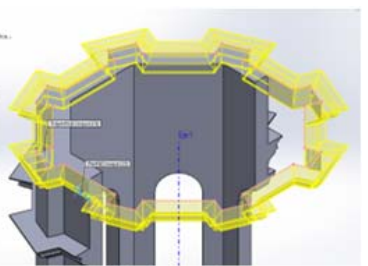

d)
Figure 5: Diferent modelling operations: a) Extrusion; b) Lofting; c) Revolved cut; d) Sweep.

As an example of the methodology used, the process of generating the 3D model of the cloister will be detailed. To this end remains visits were conducted in order to obtain information about them. It was noted that the lateral wall left of the church traces of the vaulted gallery 
on the first floor are preserved (Fig. 6), thanks to which the number of arches that had and its dimensions are known, reflected in existing plans (Vidal 2014). You can also appreciate the holes where the beams of the ceilings and floors were placed, thanks to which you can determine the height of the floors. It is then compared with the existing old photographs, which are after the war (from 1939 and 1940). In these pictures you can see the exterior details (Fig. 7), which are repeated modularly along the four facades, which assumes that they were equal because the cloister was square floor (Vidal 2014; Baquero 1988). In Figure 8 you can see the cloister's 3D reconstruction.

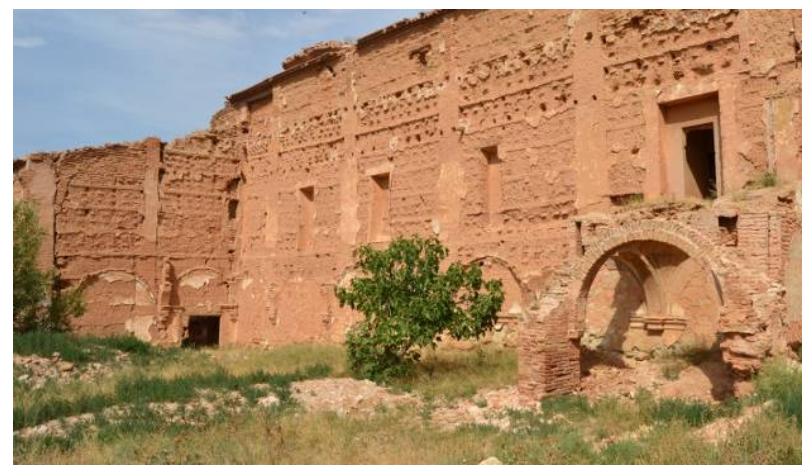

Figure 6: Cloister current aspect (2015). The remains of the arches of the vaulted gallery can be seen on the wall.

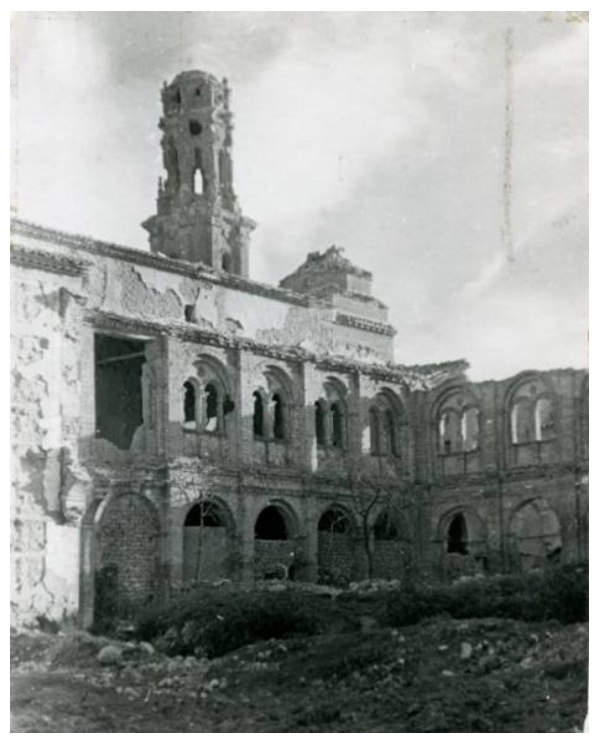

Figure 7: Cloister view in the 40s (Administration General Archive)

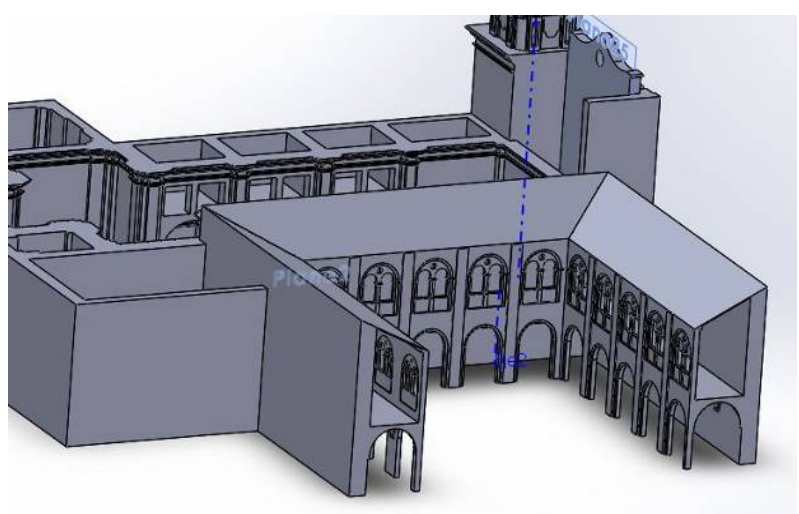

Figure 8: Cloister modelling process.

The final result of the total reconstruction shown in Figure 9 emphasizes the elements already lost.

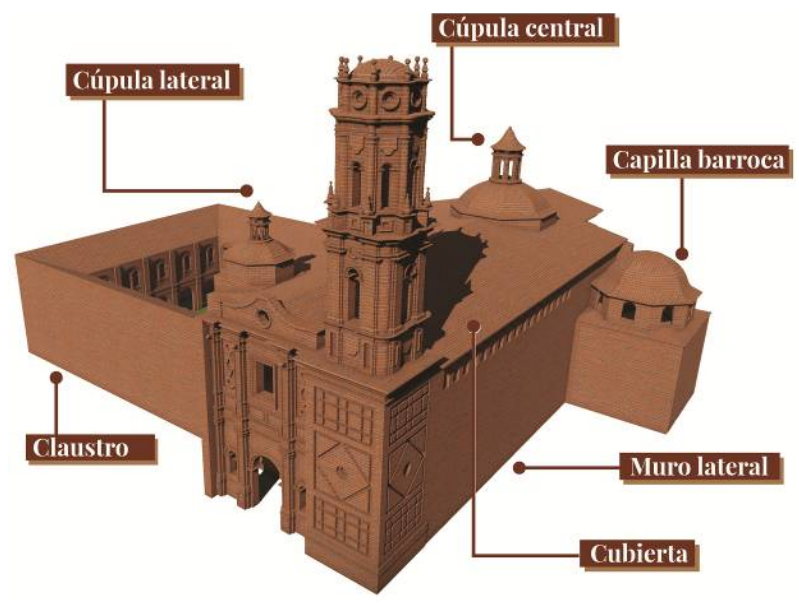

Figure 9: The end result of the reconstruction. They have highlighted the elements of the building that no longer exist today and therefore it has been necessary to go to old photographs in order to figure the hypothesis of reconstruction.

\subsection{Photogrammetry}

In addition to real images either coming from video or photograph, a way to show the current state of the building it is through the technique of photogrammetry. This means taking pictures all around the object being scanned (Figs. 10 and 11), and then process them with an appropriate software in order to generate the 3D model. In this project Autodesk 123D Catch has been the choosen software.

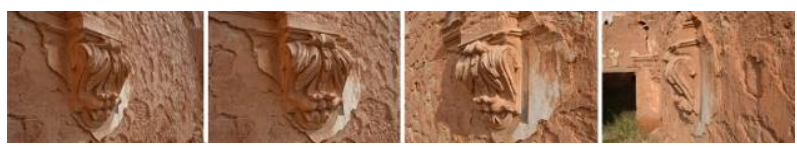

Figure 10: Detail of some of the photographs used to generate the photogrammetric model. 


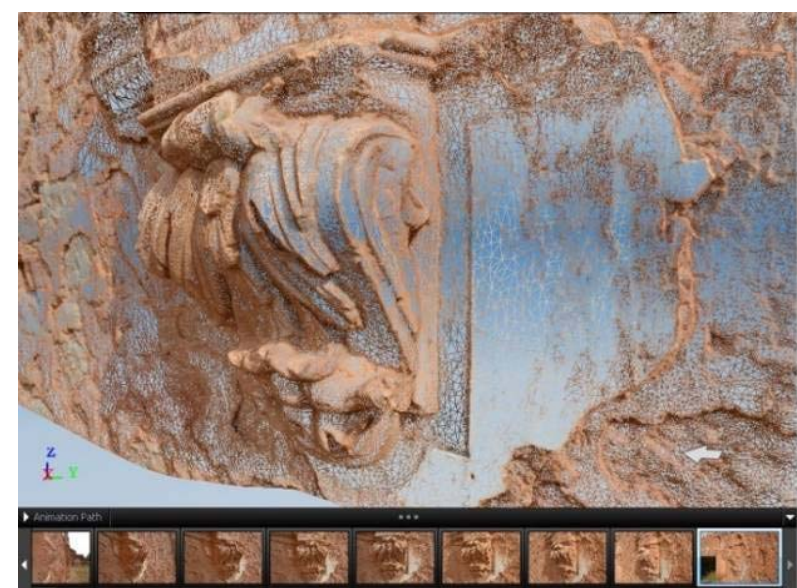

Figure 11: Photogrammetric model of the capitel in mesh view. In the bottom sequence are some of the nine pictures used for its realization.

In the present case, three tests were made with this technique, with elements of different sizes. They are the following, listed from smallest to largest: one of the capitals with which they began the vaults of the cloister (Fig. 11), corner arches that remains from the cloister (Fig. 12), the main facade next to the tower (Fig. 13).

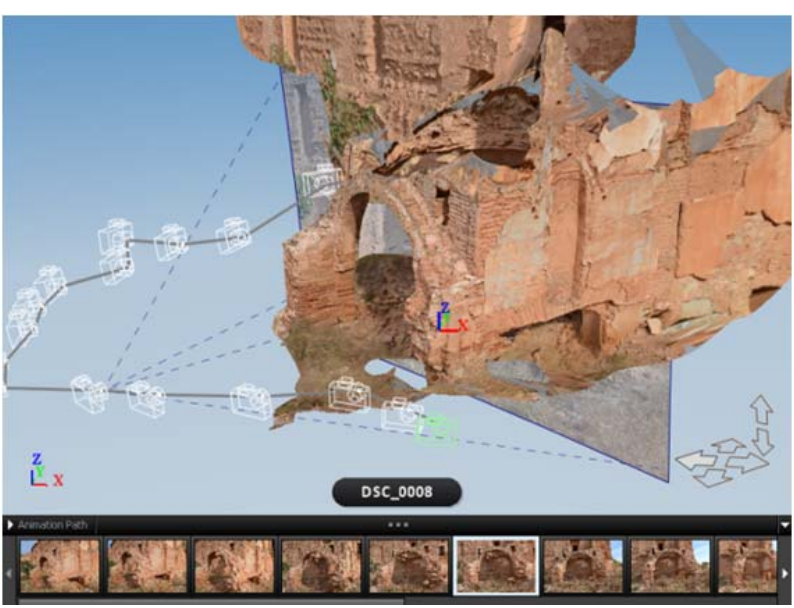

Figure 12: Photogrammetric model of the remains of arcs from the cloister made with 15 photographs. In the image it has been marked the different points were pictures have been taked from, which are shown on the bottom sequence.
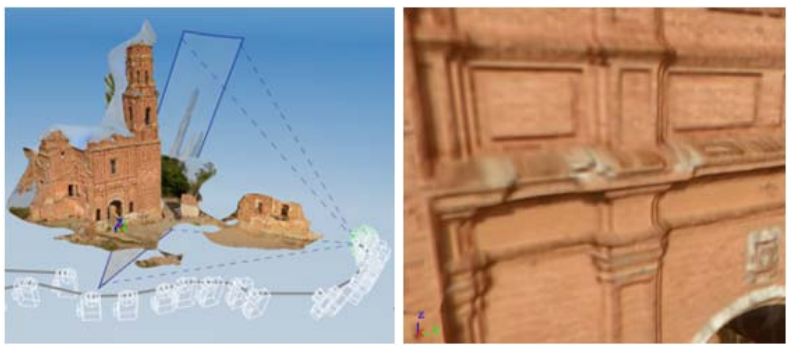

Figure 13: Left: Photogrammetric model of the church facade made with 21 photographs. Right: detail of the facade. Because the greater distance shooting photos this model is less accurate than the others.

It is noted that the smaller the scanned object was the greater was its precision; this is because the photographs are taken at a shorter distance so they have more definition. One of the advantages that photogrammetric models have is that not only they scan the object geometry but they also digitize the texture, giving the model greater realism.

\section{Results}

\subsection{Audiovisual production}

Finally we proceeded to the production of the audiovisual. It has some input materials which have served as the starting point to approach some of the scenes. It is as follows:

- A map of the town of 1920 (Spanish National Geographic Institute).

- Different drone recorded videos showing the ruins (Air Media 360, Belchite Tourism)

\subsubsection{Animation process}

Starting from a basic modeling, without details (Fig. 14), the ornamentation of the building emerges through an animation made by the SolidWorks Motion tool (Fig. 15). Ornamental elements have been divided and subsequently animated.

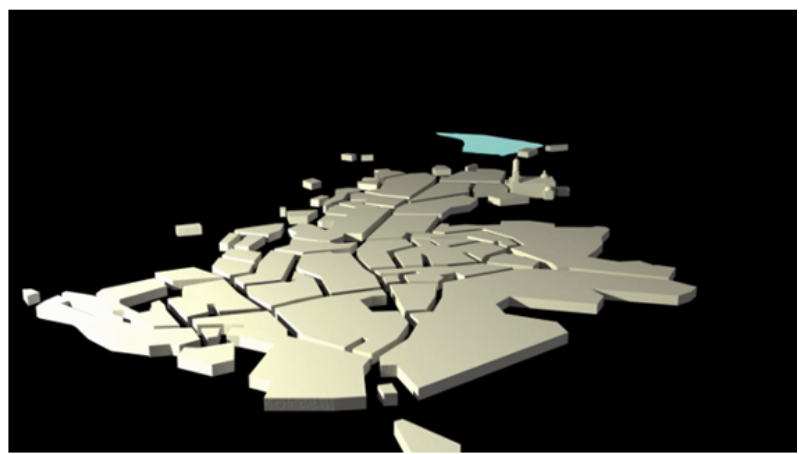

Figure 14: Extruded Map of the old Belchite. Emphasizes the church with a more detailed modeling.

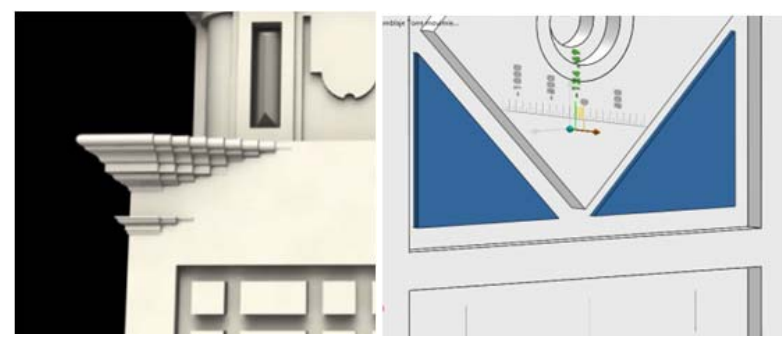

Figure 15: Ornamental elements animation process.

For other scenes it has been used 3D model with wireframe hidden lines removed view to be overlaid over the real image of the building (Fig. 16). Thereby the missing parts are displayed.

\subsubsection{Final result}

The final result is a video about 3 minutes long which alternates current images with images of the 3D model.

It begins with the map of the town (Fig. 14) that places the action in 1920, and then it moves to the place where the convent is located. By a transition between the 3D model and one of the videos, it then goes on to display the current status of the building. At the end of the video 
the image stops at a picture and it draws on the image the elements of the building that don't exist any longer in reality (Fig. 16).

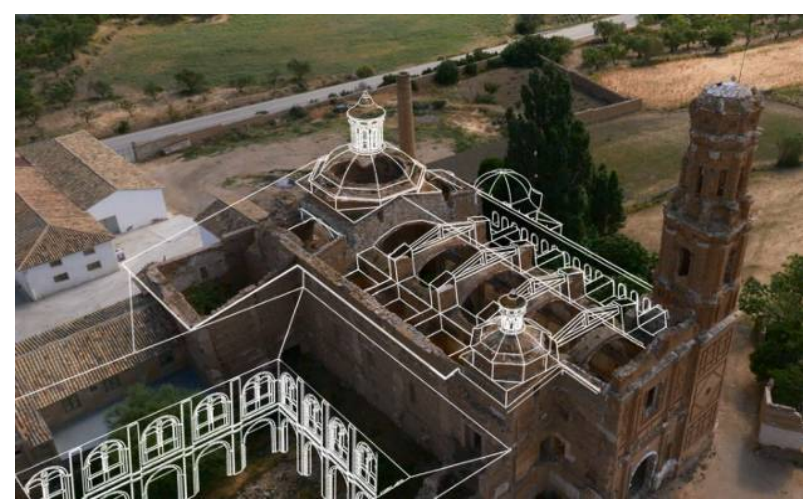

Figure 16: 3D model with wireframe view overlaid over the real image of the building.
The following scene show details of the tower, the facade and the cloister. The latter shows the photogrammetric model of the unique remains that are left from it. This 3D model merges with a picture of the current state on which the missing elements are drawn.

Finally another video of the rear of the building is shown, in which the camera enters the interior behind the remains of the dome. Image that overlaps with a rendering of the interior. In Figure 17 a series of frames of video are displayed, for your understanding.

Among the advantages of an audiovisual production is the fact that the distribution channel can be very wide, thanks to the Internet, to reach a larger audience and serve as advertising of the historic complex. It can also serve as a complement to a documentary, or even belong to the contents of a future center of interpretation.

The final video can be played on the following link: https://www.youtube.com/watch?v=NQYJI1IQwAE
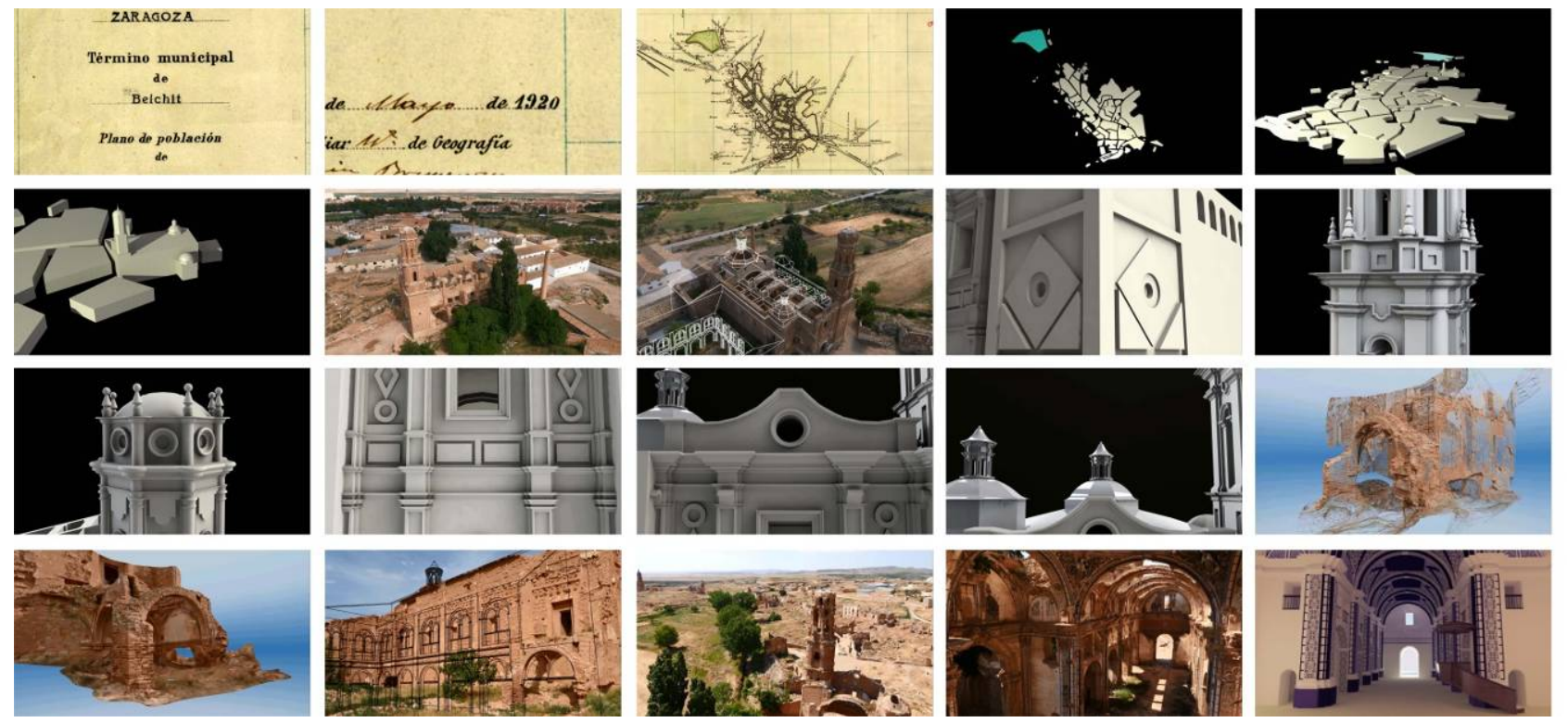

Figure 17: Selection of keyframes Video.

\subsection{Digital model applications}

The divulgative video is one of many applications that the 3D model resulting from this work can have. Listed below are some of the various applications that migh have:

- $\quad$ Generation of a model using a 3D printer (Fig. 18).

- Being part of a virtual and interactive museum that was housed in the network.

- Infographics and exhibition panels.

\subsection{Impact}

This work was presented in the exhibition "Old Belchite. Ruins of inspiration and creation..." held in December 2015 in the Belia exhibition hall in the new Belchite (Fig. 19). The audiovisual was projected and was well received by the audience.

\section{Conclusion}

As has been observed, a virtual reconstruction is a useful tool for the dissemination of the lost heritage. It would be interesting make the reconstruction of the whole village. The book "El viejo Belchite, la agonía de un pueblo" (Cinca et al. 2008) collects the largest collection of old photographs of the town coming from different files. Based on that book it could be said that there are photographs of most of the village (40s) but not from all. The biggest problem is that nowadays most of these buildings no longer exist, so no reference measurements. The reconstruction could be made based only on the photographs, and the dimensions of the streets. For this reason the result would be less accurate, although approximate and fulfill its function that would show to the viewer the lost heritage value. 


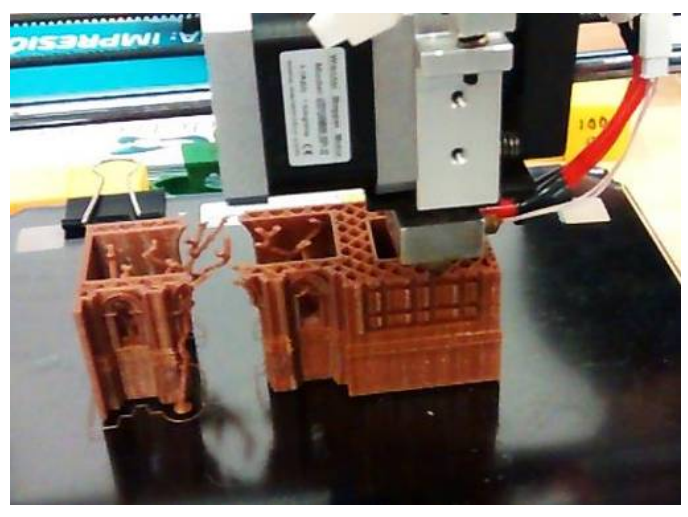

a)

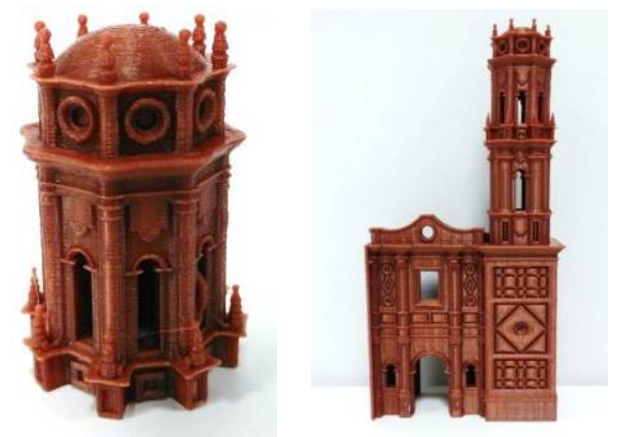

b)

Figure 18: Above: 3D printing process: a) first printed part of the tower finished; b) complete assembly of the facade.
In the case that the whole town was rebuilt, it would be interesting that the viewer could walk through it, either through a website or through an application of virtual reality. For this kind of reconstruction it would be appropriate that have a realistic look, therefore would be necessary to generate the textures of the materials of the buildings from photographs and with the help of image editing software. It should also be considered ways to interact with the propagation of light based on the laws of physics, such as the types of material, fog, dust, aerial perspective, etc. (Gutierrez et al. 2008). Thus the realism of the reconstruction is emphasized.
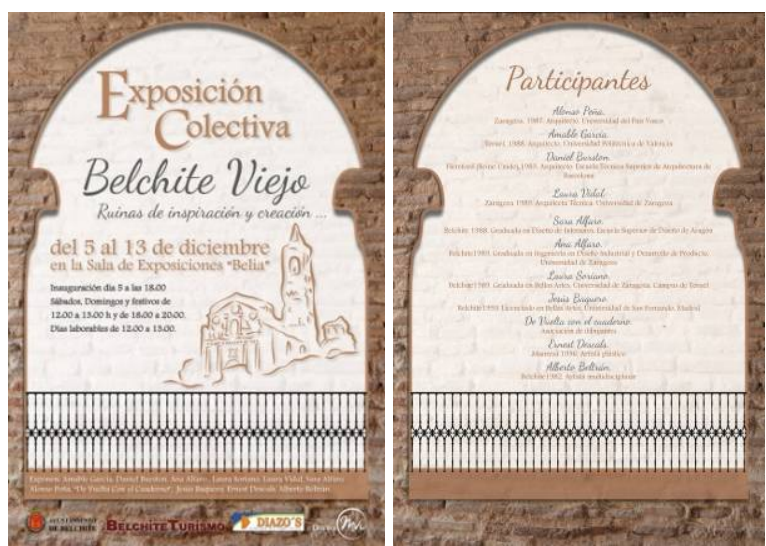

Figure 19: Group exhibition poster "Old Belchite. Ruins of inspiration and creation...".

\section{References}

BALAWAT, 2015. Balawat.com. Comunicación multimedia para la Arqueología [online] www.balawat.com/ [Consult: 12/07/2015].

BAQUERO, J., 1988. Inventario del patrimonio arquitectónico del Pueblo Viejo de Belchite (Zaragoza). Institución Fernando el Católico. ISBN:84-7820-019-3

CINCA, J., ALLANEGUI, G. and ARCHILLA, A.P, 2008. El Viejo Belchite, la agonía de un pueblo. Programa "Amarga Memoria". ISBN: 978-84-8380-085-0

FIAMMINGHI, S., BARTOLINI, G., DESKSPACE and SCAMPOLI, E., 2008. Firenze dall'età romana al Trecento [online] www.youtube.com/watch?v=nvJZHOS3VBO [Consult: 15/04/2016].

GUTIÉRREZ, D., SERÓN, F.J., MAGALLÓN, J.A., SOBREVIELA, E.J. and LATORRE, P., 2004. Archaeological and cultural heritage: bringing life to an unearthed Muslim suburb in an immersive environment. Journal of Cultural Heritage, 5 (2004), pp. 63-74. DOI: 10.1016/j.culher.2003.10.001

GUTIÉRREZ, D., SUNDSTEDT, V., GÓMEZ, F. and CHALMERS, A., 2008. Modeling light scattering for virtual heritage. ACM J. Comput. Cult. Herit. 1, 2, Article 8 (October 2008), 15 pages. DOI: 10.1145/1434763.1434765 http://doi.acm.org/10.1145/1434763.1434765

LABORATOIRE MAP du CNR (Marseille), 2014. L'Abbaye en animation 3D. http://abbayecuxa.com/index.php/presentation/ [Consult: 22/12/2014].

PERIPIMENO, M. and STRUFALDI, F., 2015. Piero di Cosimo e la Firenze del '500 [online] https://vimeo.com/132442094 [Consult: 20/10/2015].

SCAGLIONI, A., 2014. Zaragoza a lápiz (APP de realidad aumentada) [online] http://zgzalapiz.blogspot.com.es/p/appde-realidad-aumentada.html [Consult: 13/12/2014].

VIDAL, L., 2014. Estudio/análisis histórico-constructivo del convento de San Agustín del Pueblo Viejo de Belchite, Zaragoza. Universidad Politécnica de Cataluña 


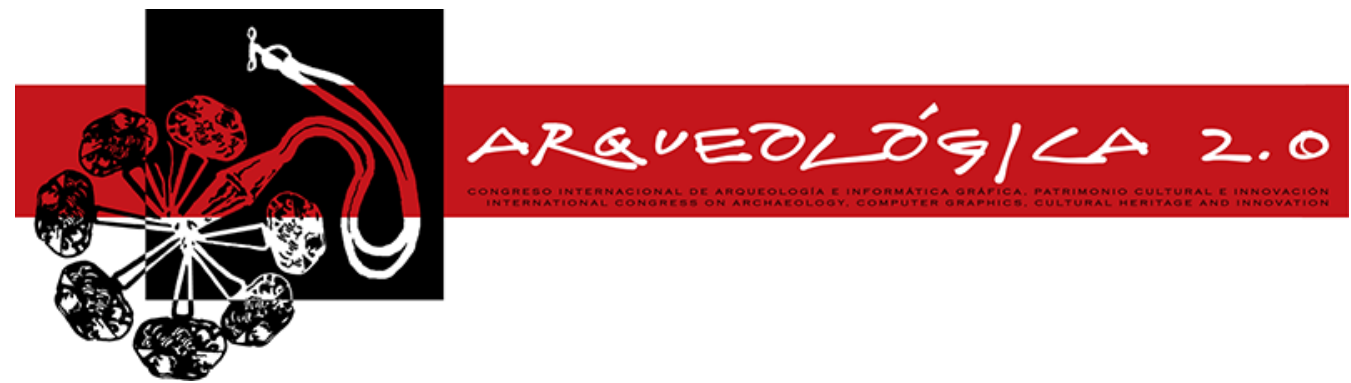

Proceedings of the $8^{\text {th }}$ International Congress

on Archaeology,

Computer Graphics,

Cultural Heritage and Innovation

'ARQUEOLÓGICA 2.0'

in Valencia (Spain),

Sept. 5-7, 2016

DOI: http://dx.doi.org/10.4995/arqueologica8.2016.4200

Received: $17 / 04 / 2016$

Accepted: 01/06/2016

\title{
BIG DATA IN LANDSCAPE ARCHAEOLOGICAL PROSPECTION
}

\author{
"BIG DATA" EN PROSPECCIÓN ARQUEOLÓGICA DEL PAISAJE \\ Juan Torrejón", Mario Wallner, Immo Trinks, Matthias Kucera, Nika Luznik, Klaus Löcker, \\ Wolfgang Neubauer \\ Ludwig Boltzmann Institute for Archaeological Prospection and Virtual Archaeology, Hohe Warte 38, 1190 Vienna, Austria. \\ Juan.Torrejon-Valdelomar@archpro.lbg.ac.at
}

\begin{abstract}
:
While traditionally archaeological research has mainly been focused on individual cultural heritage monuments or distinct archaeological sites, the Austrian based Ludwig Boltzmann Institute for Archaeological Prospection and Virtual Archaeology goes beyond the limitations of discrete sites in order to understand their archaeological context. This is achieved by investigating the space in-between the sites, studying entire archaeological landscapes from the level of individual postholes to the mapping of numerous square kilometres. This large-scale, high-resolution, multi-method prospection approach leads to enormous digital datasets counting many terabytes of data that until recently were technically not manageable. Novel programs and methods of data management had to be developed for data acquisition, processing and archaeological interpretation, in order to permit the extraction of the desired information from the very big amount of data. The analysis of the generated datasets is conducted with the help of semi-automatic algorithms within complex three-, or even four-dimensional geographical information systems. The outcome of landscape archaeological prospection surveys is visually communicated to the scientific community as well as to the general public and stakeholders. In many cases, a visualization of the scientific result and archaeological interpretations can be a powerful and suitable tool to illustrate and communicate even complex contexts to a wide audience. This paper briefly presents the great potential offered by a combination of large-scale non-invasive archaeological prospection methods and standardized workflows for the integration of big data, its interpretation and visualization. The proposed approach provides a context for buried archaeology across entire archaeological landscapes, changing our understanding of known monuments. We address the overcome and remaining challenges with the help of examples taken from outstanding landscape archaeological prospection case studies.
\end{abstract}

Key words: big data, large-scale, high-resolution, non-invasive, archaeological prospection, near-surface geophysics, virtual archaeology, data interpretation, landscape archaeology, preservation, dissemination

\section{Resumen:}

Aunque tradicionalmente la investigación arqueológica ha estado fundamentalmente centrada en monumentos y yacimientos arqueológicos de forma individual, el Ludwig Boltzmann Institute for Archaeological Prospection and Virtual Archaeology (Austria) va más allá de los límites de yacimientos particulares con el objetivo de entender su contexto arqueológico. Esto es conseguido mediante la investigación del espacio entre yacimientos y estudiando paisajes arqueológicos completos yendo desde un hoyo de poste hasta el mapeado de varios kilómetros cuadrados. El enfoque de prospección multi-metodológico a gran escala y de alta resolución conduce hacia un enorme conjunto de datos digital que incluye varios Terabytes de información los cuales no habían podido ser manipulados hasta hace poco debido a limitaciones tecnológicas. Por consiguiente, nuevos programas y métodos de gestión de datos han sido diseñados para la adquisición y procesado de datos así como interpretación arqueológica para así permitir la extracción de la información deseada desde estos enormes bancos de datos. El análisis de estos conjuntos de datos generados es llevado a cabo a través de análisis de sistemas de información geográfica tridimensionales e incluso cuatridimensionales. El resultado de la prospección de paisajes arqueológicos es transferido de forma visual a la comunididad científica así como al gran público e interesados en la materia. En muchos casos una visualización de los resultados científicos e interpretaciones arqueológicas puede ser una herramienta más poderosa y adecuada para ilustrar y comunicar contextos arqueológicos complejos a un público mayor. Este artículo presenta de forma breve el gran potencial ofrecido por la combinación de métodos de prospección arqueológica de gran resolución a gran escala y unos flujos de trabajo estandarizados para integración, interpretación y visualización de datos. La estrategía propuesta proporciona un contexto para restos arqueológicos enmarcados en paisajes arqueológicos que viene a cambiar nuestra

*Corresponding Author: Juan Torrejón, Juan.Torrejon-Valdelomar@archpro.lbg.ac.at 
forma de entender monumentos ya conocidos. Pretendemos también superar los desafios que quedan con la ayuda de ejemplos sacados de excepcionales paisajes arqueológicos que son nuestros estudios de caso a prospectar.

Palabras clave: big data, gran escala, alta resolución, métodos no-invasivos, prospección arqueológica, métodos geofísicos en superficie, arqueología virtual, interpretación de datos, arqueología del paisaje, preservación, difusión.

\section{Introduction}

Archaeology, as a discipline of humanities, is defined by its subject of study, which always has been the scholarly investigation of remains, activities and culture of past people and societies. Scientifically, archaeology has also been defined by the methods and techniques that are used. Over the past decades, archaeological science increasingly gained importance due to the introduction of various analytical tools and techniques rooting in, or derived from the field of natural sciences. Today, a large number of advanced scientific methods can be applied to study and solve archaeological problems, reflecting the complexity of the investigated multi-layered systems and the past interactions of people and societies with their natural environment, which they were part of and dependent on. Given the argument that every archaeological context, site or landscape, is unique, the question arises how to choose among the different available methods and how to apply them in a welldefined way and efficient manner in order to protect this steadily decreasing cultural resource.

Archaeologists are usually prone to rather describe than to interpret the collected data. This might be due to the very specific character of archaeology as a discipline located in-between humanities and natural sciences, and the resulting tension. Therefore, some archaeologists may tend more to describe situations with respect to objectivity (e.g. by documenting stratigraphic units during an archaeological excavation and by collecting and describing material samples) instead of providing an archaeological interpretation of the data. Archaeological interpretations, especially when derived from data gained with different methods, may be more likely to be exposed to criticism, and therefore often seem to be avoided. However, new knowledge on the development and history of archaeological landscapes and the embedded sites can only be gained when an archaeological interpretation of all the available data is conducted and provided.

In order to counteract criticism of subjective constructions and to achieve greatest possible degree of objectivity concerning the resulting archaeological interpretations, the reproducibility of the interpretation has to be ensured by application of well-defined methods. In this way we could get closer to answering the question of how observed archaeological remains might have looked at specific moments in time, reflecting the entire circle of their production, use and decay. For this purpose the archaeological interpretation process has to follow strict rules. A possible interpretation could be presented among other plausible versions, and their probabilities should be discussed.

In order to investigate a specific archaeological site, the knowledge about the archaeological landscape in which it is embedded is crucial. As an example, the functionality of a settlement depends on the surrounding fields, communication pathways, minor rural buildings, military constructions, etc. A traditional archaeological investigation by invasive excavation of a site and its surrounding landscape would imply its destruction in an unrealistically expensive and time-consuming process, which neither is possible nor desirable.

If the surrounding area is not investigated, most of the context of an archaeological site would be missing. Without this information past societies could hardly be described in a thoroughly manner. Being aware, that a complete invasive study of archaeological remains at the scale of landscapes is not possible, the aim should be to apply methods that have the potential to close this gap, even if only partly. Modern archaeology should be understood as a multi-methodological discipline, which results in a large amount of data and information that has to be interlinked and interpreted within a given archaeological setting.

Non-invasive, large-scale, high-resolution archaeological prospection using a combination of remote sensing and near-surface geophysical survey methods offers the potential to permit the detailed investigation of archaeological sites and their surrounding landscapes with blanket coverage in a cost- and time-efficient manner without damaging the cultural heritage.

Aside of the aspect of archaeological research, another important reason for the use of innovative large-scale non-invasive prospection methods is related to the preservation of endangered cultural heritage, which primarily requires knowledge on the distribution and extent of the archaeological remains hidden in the subsurface.

While landscape archaeological prospection is well suited to discover and document new archaeological evidence and sites, it can also be applied to the investigation of already known monuments.

An important issue that is encountered when dealing with landscape archaeological investigations using a multi-methodological large-scale prospection approach are the enormous amount of data that are generated, corresponding data management issues, data integration, data interpretation and the dissemination of the results. The huge datasets have to be handled and interpreted following well-defined workflows and procedures. In this paper we address these issues relating to Big Data in landscape archaeological prospection, drawing on case study examples of the Austrian Ludwig Boltzmann Institute for Archaeological Prospection and Virtual Archaeology (LBI ArchPro).

The data dealt with in this context and presented here truly constitutes Big Data since the size of the data sets have been beyond the ability of commonly used software tools and special algorithm had to be developed to permit the processing, analysis and interpretation of the data. The followed approach to dealing with the Big Data involved the development and application of automatic and semi-automatic data segmentation and classification 
algorithms as well as the development of new data fusion tools.

\section{Methodology}

While large-scale archaeological excavation and trenching still is commonly used within rescue and exploration archaeology, since few years increasingly non-invasive means for the exploration, documentation and investigation of buried heritage are entering the commercial sector as well as archaeological research. The common knowledge about the potential of archaeological prospection methods is continuously increasing.

Regarding remote sensing methods, apart from aerial photography (both oblique- and ortho-photos), airborne laser scanning and hyperspectral scanning are promising methods for the digital detection, mapping and documentation of buried archaeological sites and remaining traces in the topography (Doneus 2013, Neubauer 2012b, Neubauer 2014). The most appropriate geophysical measurement methods for large-scale high-resolution archaeological prospection are magnetometer measurements and groundpenetrating radar surveys. While some of these methods, such as magnetometry and aerial photography, look back at several decades of development and use, others have only recently been introduced into the archaeological toolbox.

\subsection{Remote sensing}

Remote sensing methods used by the LBI ArchPro for large-scale archaeological prospection are aerial photography, airborne laser scanning and airborne hyperspectral scanning.

\subsubsection{Aerial photography}

Aerial archaeology is a very cost-effective method for site discovery with the potential to provide detailed maps of archaeological structures, showing up on the surface as so called "visibility marks", i.e. slight topographic variations visible as shadow-marks, soil-marks due to varying chemical and physical properties affecting soil colour on the surface, and crop-marks due to variable growth of the vegetation or frost-marks due to varying thermal properties. Georeferenced and rectified vertical and oblique aerial photos from reconnaissance flights are used to derive the archaeological interpretation of detected structures or features. In that way, repetitive observations can be combined into an extensive overall view of an archaeological region, which will be used as basic information for further prospecting, excavations, protection measures, and spatial archaeology.

\subsubsection{Airborne imaging spectroscopy (AIS)}

Aerial archaeologists conventionally focus their interest on the visible and near-infrared (NIR) radiation. Using analogue film or digital sensors, these visible as well as the NIR bands of the spectrum can be recorded within up to three bands with bandwidths of roughly $100 \mathrm{~nm}$. However, each plant is showing a characteristic signature within the entire spectrum depending on its type, environmental conditions and stress due to the archaeological structure underneath. This characteristic spectral "fingerprint" can only be visualized crudely by the three bands of conventional imaging. Therefore, current standard photographic techniques do often not allow for the detection of crop-marks if the contrast exhibited to the surrounding matrix is too low within the range of the visible or NIR spectrum. Using airborne imaging spectroscopy (AIS - also referred to as airborne hyperspectral scanning) devices, there is a high potential to overcome the limitations of conventional aerial photography and significantly enhance the detection of archaeological structures even under less favourable conditions.

Commercial AIS systems have become available only during the past decade. They measure upwelling electromagnetic radiation (reflected and/or emitted) in a multitude of small spectral bands of only a few nanometres width. Since all of these bands can be analysed individually, a detailed investigation of those parts of the plant's spectral signature that are most significant for signs of stress, is possible.

In this way, imaging spectroscopy data does have the potential to overcome the limitations of conventional aerial photography, strengthening the understanding of the particular phenomena aerial archaeologists try to visualize, and significantly enhancing the possibilities for the detection of archaeological structures even under less favourable conditions. However, AIS and its archaeological application is still a new technology requiring further systematic investigation.

\subsubsection{Laser scanning (airborne \& terrestrial)}

Over the past few years, airborne (ALS) and terrestrial laser scanning (TLS) has turned out to be a potential tool for recognition and measurement of archaeological features that survived in the topography in open and wooded areas. ALS results in a precise model of the surface, however, there is no way to detect buried features or sites that have not left traces in the relief using this method. While archaeological applications of ALS are increasing, they are still often restricted to nonforested areas. Due to its ability to measure the ground under a vegetation canopy, ALS has a major impact on the archaeological reconnaissance of forested areas. To extend aerial archaeology with state-of-the-art ALS and to develop and advance the application of ALS for archaeological prospection is a promising field of research.

Full-waveform (FWF) LS systems have considerable advantages for the generation of digital terrain models (DTM) in vegetated areas, as the FWF-parameters might improve the classification of LS data into terrain and offterrain points, resulting in improved DTM quality and a greater potential for the subsequent archaeological interpretation.

LS data provides the basis for accurate post-processing and spatial analysis of prospection data in landscape archaeology, as well as for the monitoring of cultural heritage sites.

\subsection{Near-surface geophysical prospection}

Traditionally, near-surface geophysical prospection methods have been used manually, permitting only slow measurement progress. Using multichannel motorized 
magnetometer and ground-penetrating radar (GPR) arrays and exact satellite positioning systems is has become possible to map large areas quickly and with very high resolution, resulting in data of unprecedented quality and quantity.

\subsubsection{Magnetic prospection}

Magnetometry is most suitable to map all kinds of archaeological structures causing anomalies in the Earth's magnetic field, such as pits, trenches, postholes, walls, fire places and kilns, across large, open, unobstructed areas. Magnetometer surveys result in one single data value per surface point without direct information about the depth of detected buried structures.

The most important issues regarding professional archaeological prospection are speed, sensitivity and spatial resolution. The coverage of considerably larger areas and increased sample densities at constant expenditure of time in the field are today possible by high inherent sample rates of the used instruments, by higher survey speed through the use of motorized multichannel survey systems and advanced data positioning and navigation solutions. The use of motorized measurement devices for archaeological prospection implicates several technological and methodological challenges.

State-of-the-art fluxgate gradiometer (FG) and very sensitive Caesium (CS) magnetometer systems are operated on purpose-built non-magnetic carts towed by motorized All-Terrain-Vehicles (ATV) or Quad bikes. The ATVs carry the power supply, the data logging unit and advanced positioning and navigation systems. Multiple sensor arrangements with up to $10 \mathrm{FG}$ probes mounted with $25 \mathrm{~cm}$ cross-line spacing on the trailers, as well as access to two dozen CS sensors permits the setup of several magnetometer arrays for efficient large-scale magnetic surveys.

\subsubsection{Ground-penetrating radar surveys}

GPR surveys provide under suitable ground conditions detailed three dimensional information about approximate depth, shape and location of archaeological structures at a high spatial resolution. They can be used to detect for example stone structures (walls or postholes containing stones), interfaces caused by pits and trenches, cavities and differences in soil humidity.

Until recently, GPR surveys have been limited to relatively small-scale applications due to the lack of availability of multichannel antenna arrays. The common use of single antenna systems with often inappropriately large profile spacing results mostly in low-resolution data images. New multichannel GPR arrays, which have been developed over the past years, appear on the market and are being tested for archaeological prospection. They permit considerably increased spatial coverage with simultaneously greatly improved sample spacing, resulting in images of the subsurface with unprecedented resolution and structural clarity. Largescale GPR prospection is conducted using various multichannel GPR arrays of fixed frequency, such as the 16 channel $400 \mathrm{MHz}$ MALÅ Imaging Radar Array (MIRA) with $8 \mathrm{~cm}$ channel spacing.

\subsection{Data processing}

Appropriate data recording software as well as efficient navigation solutions are required for high-speed largescale archaeological prospection gathering really Big Data. The huge amount of data generated by the remote sensing and geophysical prospection measurements demands appropriate data processing and visualization tools. Data acquired with motorized survey systems requires correct interpolation algorithms. New filtering tools for the removal of disturbing noise and for the generation of optimised final data images needed to be developed. The effect of the surface conditions and topography has to be taken into account.

While commercially available software for the processing of near-surface geophysical prospection data are severely limited in amount and size of data that can be handled, our specifically developed tools for the handling of the Big Data sets acquired are now only limited by the physical specs of the computers used.

Different data sets collected at various scales need to be merged and integrated into a GIS geo-database prior to archaeological interpretation. The novel GIS extension ArchaeoAnalyst is a toolbox for Big Data visualisation and exploration, permitting improved spatio-temporal data analysis in 3D. It was specially designed to interact as the central steering-wheel for the control of the huge archaeological information projects. The researcher gains the opportunity to adapt the processed and visualized data to a specific research question, and therefore is able to efficiently extract detailed 4D information from the massive digital data volumes.

Within the huge datasets also the data management is an important task, since many Terabytes of raw- and processed data have to be dealt with and countless of resulting data visualization images are generated.

\subsection{Integrated archaeological interpretation}

The proposed approach produces new complex datasets of archaeological landscapes. These demand adequate data management and an integrated archaeological interpretation. Therefore, novel concepts of dynamic analysis including temporal relations and attributes have been developed. The main challenge has been the transformation of the acquired and processed complex physical prospection data into interpretative archaeological information that is accurate, readable and ready to use for our researchers and the scientific community.

Based on these requirements, an integrative platform is developed, permitting close collaboration on data management and integrated archaeological interpretation. The main platform is a GIS-based archaeological information system (AIS), extended by appropriate tools for dynamic visualization, spatial analysis for integrated archaeological interpretation, data archiving, data retrieval, and long term maintenance.

While data analysis and interpretation in GIS environments have become commonplace in professional practise, the development and use of intelligent feature extraction and semi-automatic interpretation algorithms and advanced visualization tools still are in their infancy. 
It is reasonable that an archaeological interpretation shouldn't be based on the analysis of data obtained with a single method alone. Only by integrating all available data into one archaeological interpretation it is possible to gain the most complete information on the buried archaeology, compensating the weaknesses of the different methods.

Once all the different georeferenced prospection data are interpreted within the AIS, a general overview on the archaeological structures is compiled from the different datasets. Through this integration of different sources of archaeological information it is possible to investigate huge areas in great detail, and to understand the temporal development of an archaeological landscape in its regional and historical context. The bigger and seamless the surveyed area is, the higher is the chance to find overlapping or intersecting structures that hold the key to address these temporal questions.

\section{3D visualization of the interpretation(s)}

The idea behind the $3 \mathrm{D}$ visualization process, as the final step of the proposed approach on how to deal with big data in landscape archaeological prospection projects, is in its essence rather straightforward. The generated virtual models follow the guidelines established in the London Charter (2009) and Principles of Seville (2011). Special attention is given to scientific transparency and traceability.

Handling big data sets is still a challenge for the generation of detailed 3D visualizations due to the inherent computational demands of detailed highpolygonal models. Questions concerning model reductions and simplifications need to be addressed and it may be necessary to explore novel ways to present the large amount of data in 3D (atoms instead of polygons).

Special care has to be given to the correct alignment of the data derived from multiple sources. To the extent possible, the data is georeferenced and aligned automatically.

As a base for any placement of anthropogenic features a scientifically evaluated model of historical landscape is created first. It is very important that all the traces of recent human activities are erased from the DTM of the area and appropriate different, natural features, such as rivers or seashore, are recreated. In order to do so, historical maps may be of use.

Following best scientific knowledge, anthropogenic structures are placed in the model, starting with infrastructural features, such as roads, up to reconstructed architecture and entire settlements. The reconstruction of architectural features starts slowly with the definition of their volumes, and it is continuously refined, where appropriate to high levels of detail. Most of the areas are not shown in detail and the mayor parts of the models remain rather coarse; there details are merely represented through the applied texture.

At each site there exist better preserved parts, suited for a closer representation and detailed modelling. The sources for such detailed visualizations can either be directly found as analogies in archaeological excavations, historical sources, and still standing architectural remains.

Additionally important are architectural and structural models based on experimental archaeology. These test archaeological hypotheses by employing methods, techniques, analyses and approaches relying on archaeological source material (Ascher, 1961).

When comparing datasets from archaeological excavations and geophysical prospection surveys, mismatches may be observed. In any case, it is important to make clear that an archaeological excavation is neither able to verify nor to falsify the results of a geophysical prospection survey; it is only able to question the quality of the archaeological interpretation derived from the geophysical prospection data (Löcker et al., 2015).

An innovative approach in this field is to create $3 D$ models from features existing in reality by laser scanning and/or image based modelling techniques. These models can then directly be imported into the visualization scene. Through this process we are able to capture reality and to transfer it into our digital environment, consequently enhancing the virtual scene.

Our approach to the scene enrichment varies from bare architectural models in a land- or townscape to fully naturalistic environments with vegetation, animals, people and small everyday objects. In order to better understand the development of the landscape through time, multiple phases are thoroughly modelled. These models provide the possibility to explore and gain further insights into the interaction between the past landscape and its inhabitants.

\section{Application examples}

The 'Stonehenge Hidden Landscape Project', the 'ArchPro Carnuntum' project and the 'Kreuttal' case study represent application examples of the proposed approach. With over 12 square kilometres of prospected area surrounding the main Stonehenge monument, an entirely new picture of the past landscape and its use throughout times emerged. Numerous buried monuments and countless features of archaeological interest have been discovered, mapped, interpreted and added to the archaeological record (Figs. 1 and 2).

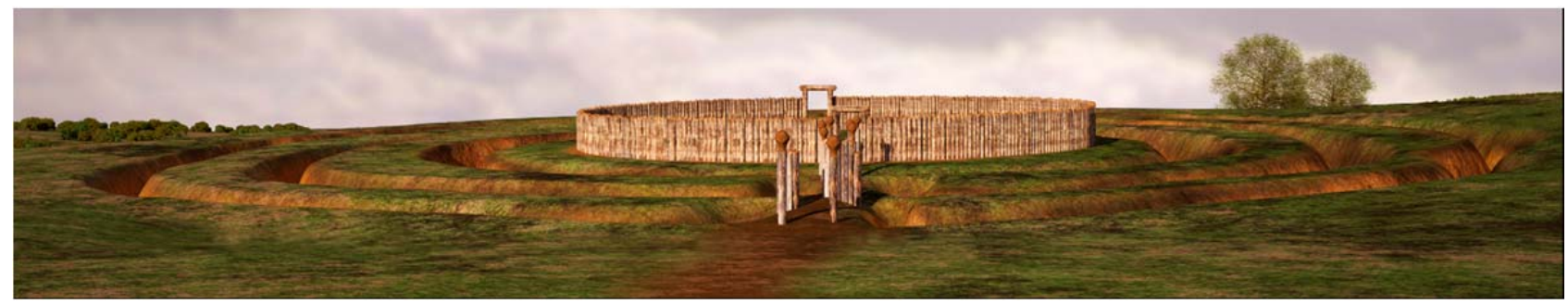

Figure 1: 3D visualisation of the landscape in Kreuttal, Austria. 


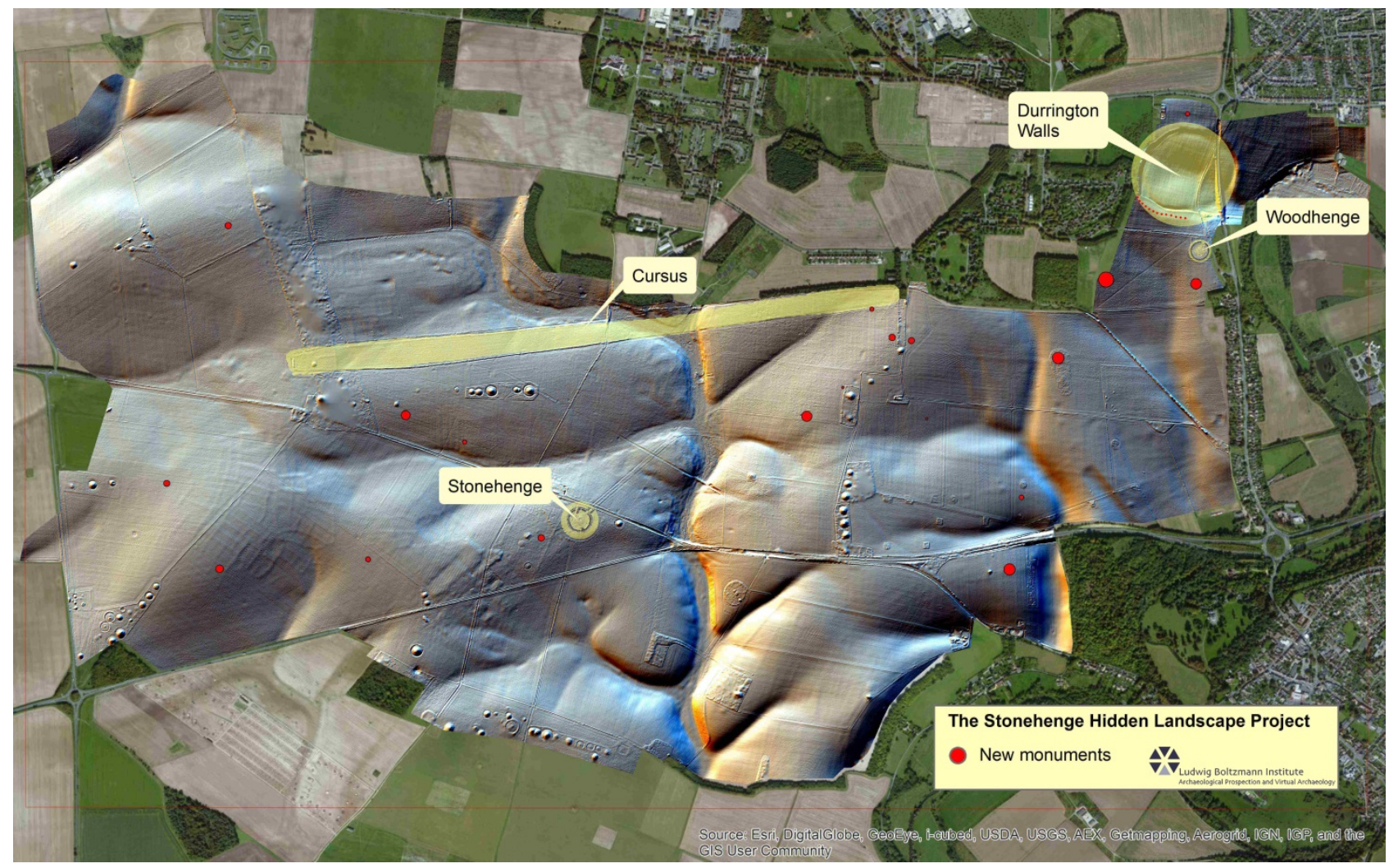

Figure 2: The Stonehenge Hidden Landscape Project Area.

The Roman town of Carnuntum in Austria and the associated Legionary camp and military installation have been explored using the described landscape archaeological methodology, covering eight square kilometres of magnetometry and almost three square kilometres of ultra-high-definition GPR measurements, embedded into an ALS-derived DTM (Fig. 3). The acquisition, processing and interpretation of this truly Big Data set has been accomplished within 36 months, which only has been possible due to the here presented best practice (Neubauer et al. 2012a, Trinks et al. 2012, Neubauer 2011, Doneus and Briese 2011).

The case study 'Kreuttal' covers an area of 54 square kilometres, providing a variety of different data sets, such as large-scale magnetometry, hyperspectral scanning data, ALS data, historical aerial photographs, historical maps, archaeological field walking data, and data from archaeological excavations. Its depth in time ranges from the early Neolithic to modern times. It provides an ideal example to study the perceived emptiness in-between and to fill the gaps in our understanding of this archaeological landscape.

\section{Dissemination}

Dissemination of the generated findings is the last and equally important step, where the gathered knowledge is shared with the community, being it scientific and/or the general public. There are many ways to do so and the dissemination techniques and visualisation format varies according to the target audience.

One of the last successful dissemination projects presenting the Big Data acquired at Stonehenge was the
Stonehenge exhibition realized at MAMUZ museum in Mistelbach, Austria.

Here, the entire exhibition is dedicated to reveal the significance of the vast prehistoric landscape of the wider Stonehenge area. It is linked to results from the Kreuttal case study concerning Middle Neolithic monumental architecture that today only is visible in the prospection data.

In doing so, many different techniques have been utilized, ranging from still images, descriptive texts, animations showing the change of the landscape throughout time, highlighting several special areas, an interactive 3D game placing the visitor in the role of the archaeologist exploring the landscape, as well as a 3D printed scale-model and life-sized reconstruction of parts of the monument. In doing so many aspects and facets of the landscape can be displayed for an enhanced offsite visitor experience.

While exhibitions like this are of value for the dissemination of novel research to the wider public, even the research community benefits from the possibilities to immersively experience Big Data and to discuss monuments in their wider landscape setting and archaeological context.

\section{Conclusions}

For the interpretation of a specific archaeological context, a well-defined workflow of applied techniques and methods concerning the acquisition, managing, processing and analysis of Big Data is necessary. All presented procedures and workflows have to be standardized in order to guarantee reproducibility. Specific training in the interdisciplinary analysis of 
landscape archaeological prospection data is necessary. As the environment for the subsequent spatio-temporal analysis of archaeological datasets, a GIS-based AIS consisting of recently developed tools has proven to be the most efficient modus operandi. Together with predefined geodatabases the huge data volumes become manageable. The implementation of time into AIS following the fundamental rules of superposition, resulting in a stratigraphic sequence, enables us to examine the spatio-temporal correlations and introduces time into the GIS.

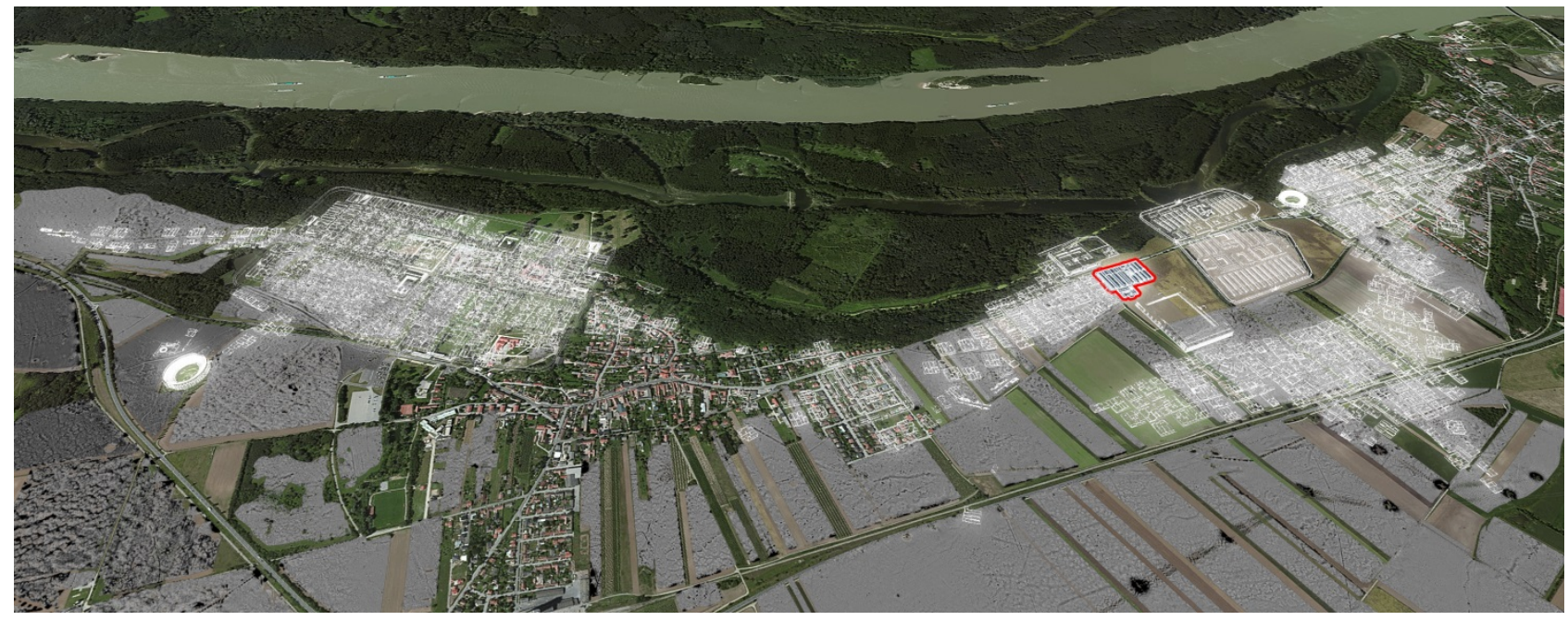

Figure 3: The Roman town of Carnuntum and its landscape.

The geospatial-temporal conclusions derived from the proposed approach are sufficient to understand the complexity of an archaeological landscape, to such an extent that destructive methods must not be applied beyond key-hole inspections.

Non-invasive archaeological investigations of entire landscapes have become possible by finding ways to deal with the large amount of acquired data, for the first time permitting the generation of a detailed bigger picture without the need to destroy cultural heritage.

\section{Acknowledgements}

The Ludwig Boltzmann Institute for Archaeological Prospection and Virtual Archaeology (archpro.lbg.ac.at) is based on an international cooperation of the Ludwig Boltzmann Gesellschaft $(A)$, the University of Vienna (A), the Vienna University of Technology (A), ZAMG - the Austrian Central Institute for Meteorology and Geodynamics (A), the Province of Lower Austria (A), Airborne Technologies (A), 7reasons (A), the Austrian Academy of Sciences (A), the Austrian Archaeological Institute (A), RGZM - the Roman-Germanic Central Museum in Mainz (D), the Swedish National History Museum (S), the University of Birmingham (GB), Vestfold County Council (N), and NIKU - the Norwegian Institute for Cultural Heritage Research (N).

\section{References}

ARROYO-BISHOP, D. and LANTADA ZARZOSA, M.T., 1995. To be or not to be: will and object-space-time GIS/AIS become a scientific reality or end up an archaeological entity? In Archaeology and geographical information systems: a European perspective, edited by G. Lock and Z. Stančič, London, pp. 43-53.

ASCHER, R., 1961. Experimental archaeology in: American Anthropologist, Menasha 63, 4, pp. 793-816.

ASPINALL, A. et al., 2008. Magnetometry for Archaeologists, AltaMira Press.

BECKER, H., 2009. Caesium-magnetometry for landscape archaeology. In: Campana S. and Piro S. (Eds.), Seeing the unseen - Geophysics and landscape archaeology, London, pp.129-165.

CARVER, G., 2004. Archaeological Information Systems (AIS): Adapting GIS to archaeological contexts, in Archäologie und Computer, Vienna.

CONYERS, L., 2004. Ground-Penetrating Radar for Archaeology, AltaMira Press.

DONEUS, M. and BRIESE, C., 2011. Airborne Laser Scanning in Forested Areas - Potential and Limitations of an Archaeological Prospection Technique. In: Cowley D. C. (ed.) 2011, Remote Sensing for Archaeological Heritage Management, proceedings of an EAC Symposium, Reykjavik, Iceland, 25 -27 March 2010, EAC Occasional Paper No. 5, Archaeolingua.

DONEUS, M. and NEUBAUER, W., 2005. Multiple survey techniques at Roman Carnuntum. Integrated prospection of the largest archaeological landscape in Austria. In: Chris Musson, Rog Palmer, Stefano Campana, In volo nel 
passato. Aerofotografia e cartografia archaeological. Biblioteca del dipartimento di archaeologia e storia delle arti sezione archaeologica, Siena, pp. 272-279.

DONEUS, M., 2013. Die hinterlassene Landschaft - Prospektion und Interpretation in der Landschaftsarchäologie, Mitteilungen der prähistorischen Kommission der ÖAW, Bd. 78, Wien.

DONEUS, M., DONEUS, N. and Neubauer, W., 2002. Integrated archaeological interpretation of combined prospection data, Zwingendorf (Austria) - a case study. In: R.H.Bewley, W. Raczkowski (Eds.) Aerial Archaeology, pp. 149-165.

DONEUS, M., GUGL, C. and DONEUS, N., 2013, Eine Modellstudie der Erforschung römischer Lagervorstädte, Von der Luftbildprospektion zur siedlungsarchäologischen Synthese. ÖAW (Der römische Limes in Österreich, Heft 47), Wien.

EDER-HINTERLEITNER et al, 2003. The city map of ancient Carnuntum - combining archaeological prospection, photogrammetry and GIS. Archaeologia Polona, 41, pp. 156-157.

GAFFENY C.F. and J. Gater, 2003. Revealing the buried past: geophysics for archaeologists. Tempus.

JOSEPH, N. et al., 2004. Replication in Archaeological Information Systems. In [Enter the Past] The E-way into the Four Dimensions of Cultural Heritage. CAA 2003. Computer Applications and Quantitative Methods in Archaeology; Proceedings of the 31st Conference, Vienna, Austria, April 2003, edited by Magistrat der Stadt Wien, Referat Kulturelles Erbe, and Stadtarchäologie Wien, Oxford, pp. 216-220.

KAREL, W. et al., 2013. Oriental - Automatic Geo-Referencing and Ortho-Rectification of Archaeological Aerial Photographs. In: P. Grussenmeyer (Hg.): TC V. XXIV International CIPA Symposium. Strasbourg, France, 02.06.09.2013 (ISPRS Annals, II-5/W1). Online verfügbar unter DOI: 10.5194/isprsannals-II-5-W1-175-2013.

KEAY, S. et al., 2009. The Role of Integrated Geophysical Survey Methods in the Assessment of Archaeological Landscapes: the Case of Portus. Archaeological Prospection 16, pp. 154-166.

KVAMME KI., 2007. Integrating Multiple Geophysical Datasets, 345-374 In: Remote Sensing in Archaeology, (Eds) Wiseman, J. And El-Baz, F., Springer.

KVAMME, KI., 2006. Integrating multidimensional geophysical data. Archaeological Prospection 13, pp. 57-72.

LANGRAN, G., 1992. Time in Geographic Information System, London.

LECKEBUSCH, J., 2003. Ground-penetrating Radar: A Modern Three-dimensional Prospection Method. Archaeological Prospection, 10, pp. 213-240.

LÖCKER et al., 2015. Successfully falsified ... On epimestological problems of archaeological excavations and geophysical surveys. In: Archaeological prospection: The Institute of Archaeology and Ethnology, Polish Academy of Sciences (Archaeologia Polona, 53), pp. 222-224.

LYATSKY H, 2004. The Meaning of Anomaly. CSEG Recorder, 29(6).

NEUBAUER, W. et al., 1999. Kombination archäologisch-geophysikalischer Prospektionsmethoden am Beispiel der römischen Zivilstadt Carnuntum. Archaeologia Austriaca Bd. 82/83, 1998/99, pp. 493-551 (17 ref.), 1-26.

NEUBAUER, W. et al., 2000. Kombinierte archäologische Prospektion am Beispiel der römischen Zivilstadt Carnuntum. Carnuntum Jahrbuch 2000, pp. 27-52.

NEUBAUER, W. et al., 2005. Large Scale GPR Surveys of Roman Buildings. Proceedings of the 33rd int. Symposium on Archeometry. Geoarchaeological and Bioarchaeological studies, vol. 3, pp. 23-30.

NEUBAUER, W. et al., 2012. Long-term Integrated Archaeological Prospection at the Roman Town of Carnuntum/Austria. In: P. Johnson und M. Millett (Hg.): Archaeological Survey and the City. Oxford: Oxbow (Monograph Series, No. 2), pp. 202-221.

NEUBAUER, W. et al., 2012. The Roman town of Carnuntum - an outstanding example of long-term integrated archaeological prospection. In: The Roman Archaeology Conference 22. Frankfurt am Main, Germany, 29.03 01.04.2012. Abstracts. Institutum Archeologicum Germanicum. Frankfurt am Main.

NEUBAUER, W. et al., 2014. The discovery of the school of gladiators at Carnuntum, Austria. In: Antiquity (88), pp. 173190.

NEUBAUER, W., 2001. Magnetische Prospektion in der Archäologie. Mitteilungen der prähistorischen Kommission der ÖAW, Bd. 44, Wien.

NEUBAUER, W., 2004. GIS in Archaeology - The Interface between Prospection and Excavation. Archaeological Prospection 11, pp. 159-166.

NEUBAUER, W., 2011. Archäologische Prospektion der Landschaft Carnuntum. In: Carnuntum und Limes. Denkmalpflege in Niederösterreich, Bd. 45, pp. 23-26.

SCHMIDT, A., 1996. Visualisation of multi-source archaeological geophysics data. Annales Geophysicae, 14, Suppl. I: C165. 
SCHMIDT, A., 2001. Visualisation of multi-source archaeological geophysics data. In M. Cucarzi and P. Conti (eds) Filtering, Optimisation and Modelling of Geophysical Data in Archaeological Prospecting, Rome: Fondazione Ing. Carlo M. Lerici, pp. 149-160.

SCOLLAR, I., TABBAGH, A., HESSE, A. and HERZOG, I., 1990. Archaeological Prospecting and Remote Sensing, Cambridge University Press.

TORREJÓN VALDELOMAR, J. et al., 2015. 4D investigation of Digital Heritage an interactive application for the auxiliary fortress of Carnuntum In: IEEE Conference Publications, 2015 Digital Heritage International Congress, Granada, Spain, 28.09-02.10.2015, Vol. 2, pp. 81-84. Online: DOI: 10.1109/DigitalHeritage.2015.7419457

TRINKS, I., JOHANSSON, B., GUSTAFSSON, J., EMILSSON, J., FRIBORG, J., GUSTAFSSON, C., and NISSEN, J., 2010. Efficient, large-scale archaeological prospection using a true 3D GPR array system. Archaeological Prospection, 17(3), 2010a. doi:10.1002/arp.381, pp. 175-186.

TRINKS, I., NEUBAUER, W. and DONEUS, M. 2012. Prospecting Archaeological Landscapes. In: loannides M. et al. (Eds.) EuroMed 2012, Progress in Cultural Heritage Preservation. Lecture Notes in Computer Science 7616, pp. 21-29.

WALLNER et al., 2015. Application of georeferenced Archaeological Information Systems for archaeological digital heritage - the auxiliary fortress of Carnuntum (Lower Austria). In: IEEE Conference Publications, 2015 Digital Heritage International Congress, Granada, Spain, 28.09-02.10.2015, Vol. 1, pp. 159-162. online: DOI: 10.1109/DigitalHeritage.2015.7413859

WALLNER et al., 2015. ArchPro Carnuntum Project Large-scale non-invasive archaeological prospection of the Roman town of Carnuntum. In: Archaeological prospection: The Institute of Archaeology and Ethnology, Polish Academy of Sciences (Archaeologia Polona, 53), pp. 400-403.

WHEATLEY, D. and GILLINGS, M. (ed.), 2002. Spatial Technology and Archaeology. The archaeological applications of GIS. London. 


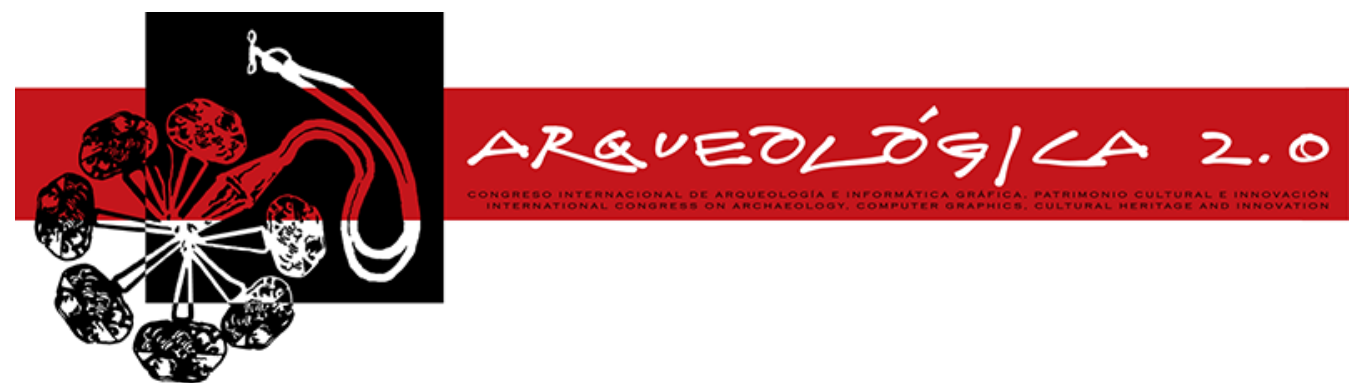

Proceedings of the $8^{\text {th }}$ International Congress

on Archaeology,

Computer Graphics,

Cultural Heritage and Innovation

'ARQUEOLÓGICA 2.0'

in Valencia (Spain),

Sept. 5-7, 2016

DOI: http://dx.doi.org/10.4995/arqueologica8.2016.4210

Received: 21/04/2016

Accepted: 27/06/2016

\title{
CASTLE4D: AN ARCHAEOLOGICAL INFORMATION SYSTEM BASED ON 3D POINT CLOUDS
}

\author{
Andrea Luczfalvy Jancsó ${ }^{a, b,{ }^{,},}$Benoît Jonlet ${ }^{a}$, Pierre Hallot ${ }^{a}$, Florent Poux ${ }^{a}$, Patrick Hoffsummer ${ }^{b}$, \\ Roland Billen ${ }^{\mathrm{a}}$ \\ a Geomatics Unit, Department of Geography, University of Liège, Quartier Agora, Allée du 6 Août 19, 4000 Liège, Belgium. \\ andrea.luczfalvyjancso@doct.ulg.ac.be; bjonlet@ulg.ac.be; p.hallot@ulg.ac.be; fpoux@ulg.ac.be; rbillen@ulg.ac.be \\ ${ }^{b}$ European Archaeometry Centre (CEA), University of Liège, Quartier Agora, Allée du 6 Août 19, 4000 Liège, Belgium. \\ phoffsummer@ulg.ac.be
}

\begin{abstract}
:
During the past decade, the implementation of 3D visualization and Geographic Information System (GIS) in archaeological research has increased and is now well established. However, the combination of these two factors remains rather complicated when faced with archaeological data. Some of the characteristics of this discipline impose the development of applications that will be able to cope with all of the specificities of archaeological data. Our research aims to create an Archaeological Information System (AIS) that will gather all of the characteristics of an archaeological work. In order to develop such an AIS, our first step was to identify its purposes and consequently, the features that should be available to the users. As it is destined to help with archaeological research, it is therefore of the outmost importance that the particularities of such a study are also taken into account. Moreover, the AIS is intended to incorporate point clouds that serve as a base for the three-dimensional model. These 3D point clouds result from the use of photogrammetry and/or lasergrammetry and, at a later stage, will be inserted into a GIS similar structure. The archaeological data will then be linked to the relevant section of the 3D model. However, these various stages and during the development of the AIS itself, we will encounter a series of issues that require to be addressed in order to produce a working system. This paper aims to identify and define the AIS characteristics as well as the issues and obstacles that we are going to face so that this system becomes a functional tool for archaeological research.
\end{abstract}

Key words: digital archaeology, 3D point clouds, AIS, GIS, 4D.

\section{Introduction}

Archaeological research is characterized by the various types of documents and data that are taken into account while examining a site, a monument or an artefact. Results are based on their analysis (Laurenza and Putzolu 2001). Yet, along with the speedy evolution of the digital world, archaeologists can now rapidly produce big amounts of data (Entwistle et al. 2009). All of this information needs to be examined in order to draw pertinent conclusions.

In order not to lose sight of any of the dataset, we are currently developing an Archaeological Information System (AIS) based on 3D point clouds and considering the temporal aspect as a fourth dimension. With this, every shred of data is linked to the area on which they provide information.

The development of the 4D AIS is taking place in our research project CASTLE4D in which several Belgian castles located in the province of Liège are being studied under the light of archaeological sciences and geomatics. This procedure enables the elaboration of new research topics as well as new data that will lead to a better understanding of the history of each castle site.

This paper aims at presenting the features of the 4D AIS that we are developing as part of our doctoral research. To achieve this, a state-of-the-art will summarize today's use of 3D representation in archaeological research. Following this, the system's main characteristics will be named and described. Finally, we are going to address the issues that we are going to face and the reasons why it is necessary for this project to deal with them.

\section{Current 3D models}

Now, as far as archaeological research is concerned, 3D models are generally used for visualization, reconstruction, measuring and documentation (Entwistle et al. 2009).

`Corresponding Author: Andrea Luczfalvy Jancsó, andrea.luczfalvyjancso@doct.ulg.ac.be 
its angles, depths and structures. Volumes are easier understandable and smaller pieces as well as objects can be handled without damaging them (Laurenza and Putzolu 2001; Paliou 2013).

Virtual reconstruction offers different possibilities: theories can be checked, a better understanding can be reached where only a small part is preserved and it is a frequently used tool for vulgarisation purposes. In addition to the elements that remain and, if it applies, are still situated at their original location, the missing parts are reconstructed based on previously gathered data (Hallot et al. 2015).

Photogrammetry and lasergrammetry produce 3D models that include a possibility to perform distance or angular measurements. Yet, in the first case, local or georeferenced coordinates must be considered in order to assure the geometric coherence as well as the scale of the reproduced element. Once the coordinates are inserted, measurements can be taken and crosssections or plans can be extracted (Ballarin et al. 2013).

Three-dimensional recording of cultural heritage acquires a great importance since it assists in preserving monuments and objects that are likely to face natural disasters, wars or degradation over time (Doulamis et al. 2015; Entwistle et al. 2009).

All of the examples listed above consider a static 3D model. Once the data has been recorded and the threedimensional representation has been assembled or, in some cases, reconstructed, the final product is rarely altered. It is analysed as a whole or through segments. In accordance with the research and the communication purposes, it is often inserted into a map, an information system or a visualization tool. However, its appearance is conserved and as for the data, it is stored next to it, but seldom in the 3D model itself (Dell'Unto et al. 2016).

$3 \mathrm{D}$ models are slowly starting to serve other purposes besides those already discussed above. Indeed, some researchers are developing them into analytical tools: data is accessible and managed through them (Ardissone et al. 2013; De Roo et al. 2013a; Dell'Unto et al. 2016; Houshiar et al. 2015; Koehl et al. 2008). Moreover, spatial relations between findings or between zones can be easier understood than with a twodimensional approach (Belussi et al. 2015; Dell'Unto et al. 2016; Paliou 2013; Robles Ortega et al. 2015).

\section{Ideal components}

Within our research, we aim at developing a 4D AIS (mixing 3D and the temporal aspect) especially created in order to deal with archaeological information that is characterized among others by uncertainty, imprecision, ambiguity and incompleteness (De Roo et al. 2013a; De Runz 2008). Currently, these aspects are not efficaciously managed in recent GIS-based tools. Time, which is of a great importance in archaeological studies, represents a fourth dimension in addition to the betterknown 3D model (De Roo et al. 2014).

Our planned system should ideally provide us with a range of possibilities. With these, a better understanding of the current research object should be obtained. The system should help to analyse the actual study object as well as all of the collected data related to it, to visualize the available sources and to record different work stages.

\subsection{D model}

A 3D point cloud of the studied object will be considered as the virtual working space that is destined to organize and group every bit of information gathered during fieldwork and sources examination (Cripps 2013). This interface will also serve as a place to gain an overview of current studies that evolve daily and to exchange ideas and theories between all of the researchers (Landeschi et al. 2015; Laurenza and Putzolu 2001).

The point cloud will be acquired using photogrammetry and/or lasergrammetry with a geodetic reference system (local or national grid). However, a georeferenced 3D model can also be considered for an on site research since it will ease the integration of various other elements surrounding the research site that can provide new insights (Ardissone et al. 2013).

There are several reasons that lead to the choice of a three-dimensional representation. Recent technological advances allow a quick and accurate data acquisition. In addition, users can sort of "walk around" in the virtual environment. So, even if it does not substitute for an on site study, it can nevertheless support the outdoor work by providing a way to access out of reach sections. Consequently, they will be easier to observe since such a $3 \mathrm{D}$ model can be turned and observed from every point of view (Koehl et al. 2008).

\subsection{Data storage and consultation}

In addition to the 3D model, a database is planned to store every known source, document and other data. The file types used by archaeologists are various, which generally implies that numerous softwares are needed to consult them (De Roo et al. 2014). Therefore, each of them will be accessible through the semantic context information added to the virtual reproduction. This way, the data will be directly linked to the element or part of the research object it holds information about (Dell'Unto et al. 2016; Doulamis et al. 2015; Koehl et al. 2008; Landeschi et al. 2015; Manferdini et al. 2008; Wulff and Koch 2013). Therefore, if the coordinates are known, the data will be inserted in the same location than in real life. Unlike a plan or a drawing, this kind of information will no longer be projected in a two dimensional presentation. This procedure will provide a better understanding of the spatial relation between every element. Furthermore, some questions inherent to a $2 \mathrm{D}$ projection may also be answered through a more accurate representation of the spatial distribution and by using the spatial reasoning capabilities of the supporting GIS system (Dell'Unto et al. 2016; Paliou 2013; Robles Ortega et al. 2015).

This data storage will also allow the researcher to consult all of the available sources and documentation (Coughenour et al. 2015; Laurenza and Putzolu 2001). Since they are linked to the part of the $3 D$ model that they contain information about, it will be possible to visualize all of the data related to specific segments the researcher is interested in at a given time. 


\subsection{Data production}

The 3D point cloud itself can also be exploited. Orthophotos, profiles, plans and cross-sections can be created, distances as well as angles measured (Ballarin et al. 2013). The model itself can be segmented in order to focus on a smaller sector (Koehl et al. 2008). Every action can be recorded and the results will then be added to the previous data.

\subsection{Topographic setting and environmental analysis}

Since the model is based on a georeferenced framework, topographic information such as maps, LiDAR datasets or geological context is included transparently. All the information is interoperable (Entwistle et al. 2009).

All of this added data about the surrounding territory can then be integrated into the research. Therefore, analyses combining the cultural heritage and its physical environment can be carried out. Some of the possible applications could be territorial visibility, positioning in relation to the natural environment or even the provenance of the materials (Entwistle et al. 2009). Other analyses may also be available based on the nature of the data used for the research.

Moreover, the ancient perception of space and its appropriation by its past inhabitants can also be studied through this interactive system (Dell'Unto et al. 2016; Paliou 2013).

\subsection{Time management}

Time is the key element in an archaeological research. However, a 3D model provides a static view of a recorded monument, site or object (De Roo et al. 2013a; De Roo et al. 2013b). Within the 4D AIS, the researcher should therefore be able to assign a time frame to each element (Belussi et al. 2015; Doulamis et al. 2015; Manferdini et al. 2008). Once this step is done, he could then choose which sections should be visible by applying a terminus post quem and a terminus ante quem. A timeline feature is also being considered. This tool will be able to display chronologically the appearance and, in some cases, the disappearance of the timed parts (Doulamis et al. 2015; Hallot et al. 2015; Van Ruymbeke et al. 2015).

\subsection{Work flow and developed theories}

Since the 4D AIS will provide a virtual workspace, it will be interesting to save different versions in order to be able to get back to them if new ideas or new data are inserted.

Another option will be the opportunity to register elaborated theories (Van Ruymbeke et al. 2015). Along with these, the data that they are based on will also be included. This will provide an overview of the used information and it will support the discussion about the pertinence of each of the generated hypotheses.

\subsection{Adaptability}

Archaeological study objects come in various types, forms, sizes and complexity levels. In addition to that, as an archaeological research is also characterized by uncertainty, imprecision, ambiguity and incompleteness (De Runz 2008), it is of the outmost importance that a 4D AIS that deals with these features has to be malleable (Haskiya 2002).

Fieldwork is another argument supporting this feature. In those cases, data is collected on multiple days, months or even years. New spaces can be uncovered, the research site can be increased in size and unexpected events are numerous (Laurenza and Putzolu 2001). A $3 \mathrm{D}$ point cloud is a practical solution to which new scans can be added. This way, the old appearance as well as the new one can overlap and therefore, they are easier to compare and study together.

\section{Issues}

The above sections cite and describe the ideal components of our application. However, as already stated, it deals with an ideal. Therefore, we will now address the issues with which we will have to cope in order to reach our goal.

\subsection{Development of the Archaeological Information System}

Although Geographic Information Systems are widely used for archaeological research, some of the properties of archaeological data are complicated to integrate in such a structure (De Roo et al. 2013a). In addition, as research on archaeological subjects continuously grows and evolves (Haskiya 2002), the AIS should include a virtual workspace in order to allow at the same time consultation of already recorded information, navigation in the 3D model, working on the theories as well as adding and modifying data. As the newly inserted entries can affect previously registered work steps and the current development of theories, a notification needs to be issued in order to highlight all the sections that are affected by an extension. With this, the researcher can review them and update his theories.

It will be necessary to develop an application able to handle all these aspects at once. At the same time, all of these options need to be organized and clearly presented. A structured display will also have a big impact for an easier apprehension of the different elements in an AIS based on a 3D model.

One of the main features of this system will be to be able to handle modification to its basic presentation (Dell'Unto et al. 2016). Since every archaeological study or site has its own characteristics, new categories need to be inserted without disrupting the stored data beforehand. This should also apply when adding an extension to the 3D model: the links, which were previously established between the data and an older state of the 3D point cloud, have to be conserved without any disruption.

\subsection{The multivocality of archaeological data}

As Cripps (2013) mentions it, archaeological data consists mostly of various and fragmentary information and archaeologists often construct multiple narratives based on the collected data. This multivocality forces the development of an application that is able to adjust to the versatility of archaeological studies (Dell'Unto et al. 2016). 
Amongst those characteristics, different elements need to be addressed. The temporal aspect is one of the most important ones. However, the integration of such a parameter in an Information System is still limited as an attribute. Moreover, time is not a constant feature as far as archaeological data is concerned and its delimitations are often fuzzy (Belussi et al. 2015; De Roo et al. 2013b).

Therefore, this 4D AIS, as we conceive it, should propose the opportunity to hide unwanted parts of the $3 \mathrm{D}$ model and the information that is linked to it. Of course, this procedure will not be able to automatically reconstruct the parts that disappeared over time, but it can assist the archaeologist by hiding unneeded data and visual information. This option could be a useful tool for the researcher to understand use of space as well as the reasons that lead to later modifications. For this concept to be effective, the semantic classification of the point cloud will be crucial. Indeed, it will be very important to sort the data correctly and to link it to the appropriate sections of the 3D model (Doulamis et al. 2015; Wulff and Koch 2013). The attributes that will be added to them will also need to be carefully selected so that the information, if it is linked to two or more parts, is still available even if some of those sections are not on display.

Since archaeological data is multivocal, as Van Ruymbeke (2015) states, different theories can be elaborated. In order to keep track of their evolution, saving a new development should replace the old entry. This will allow to review the thought process that led to the current interpretation and to assess the links that have been created between some of the hypotheses.

\subsection{Data volume}

As the AIS is destined to store almost all of the data about the study object the archaeologist is working on, the number of files can vary from small to quite large depending on the stage of the research and of its extend (Coughenour et al. 2015).

The 3D model on its own contains billions of points that are defined by $X, Y$ and $Z$ coordinates and semantic information. Laser scanners also produce photographic panoramas in order to colorize the point cloud. Each of these panoramas can range from 70 megapixels (for the Trimble TX5) (Trimble 2012) to 700 megapixels (for the Leica ScanStation P30) (Leica 2015). Therefore, depending on the size of the studied area, the resolution and the quality of the recorded data, the size of the 3D model can begin with a few gigabytes with no maximal size.

As for the collected documentation, it can present itself in different file types and formats going from a simple text document to a high-resolution image scan. As for the size of all of these entries, it can fluctuate from almost nothing to a perpetual addition of data (Coughenour et al. 2015).

In order to consider this huge amount of data, solutions will need to be set up so that the application is not slowed down.

\subsection{Standardization of the file formats}

All of the used file formats will need to be standardized and compatible with one another. This will allow to switch from the system to another one as well as to share the results of the research with other parties (Houshiar et al. 2015; Laurenza and Putzolu 2001; De Roo et al. 2013a). Therefore, already existing and widespread formats are going to be selected in order to ensure an easy data transmission and sharing.

\section{Conclusion}

In this paper, we presented the main features of the system we are currently developing within research project CASTLE4D. This application is destined to support archaeological research and fieldwork by providing a virtual workspace which allows the researcher to incorporate all of the available data to a 3D model of its research object as well as to analyse the information and to export the results of his study.

The ideal components we identified for this system include a 3D model based on a point cloud, data storing and consultation as well as data production based on the analyses carried out by the researcher. Additionally, the user will be presented with the possibility to insert the study object into its surrounding topographical and environmental context and a temporal feature that will assist the researcher sort and visualize the interesting data for a specific topic. Furthermore, work status and theories can be saved in order to get back to them on a later stage. This will enable the user to document the thought process that led to the conclusions. Finally, an emphasis is set on adaptability since every archaeological research has its own particularities.

However, along with this hypothetical application, a number of issues have to be addressed in order to create a system that will work the way it is supposed to and that will not collapse when some modifications are necessary in order to adapt to some singularities of the research object.

First, the AIS has to be developed according to the needs of archaeological research. In addition to this, the AIS interface will have to be clear in order to be easily used by the researcher. Indeed, several aspects such as visualization, the workspace and the storage will be accessed through the graphical interface.

Then, we have to make sure that the multivocality of an archaeological research is taken into account by the system as well as the temporal aspect. At the same time, the system must be able to handle frequent modifications, addition of data and new links between different entities. All of this has to happen without deleting or changing any of the previous constructed relations.

Going on, data volume will have to be addressed since the totality of the inserted data (point cloud and other information) will be of a very large size which could greatly slow down. Therefore, different approaches will be tested so that the most appropriate one is selected.

Finally, the file formats will be standardized. This step will reduce a few variables that could impeach the good functioning of the application. The choice of widespread formats enables compatibility with other systems. 
The next step of this research will be the development of the above defined AIS. A prototype will be worked out and tested on the castle of Franchimont (Theux, province of Liège, Belgium) before applying it on other study objects.

\section{References}

ARDISSONE, P., BORNAZ, L., DEGATTIS, G. and DOMAINE, R., 2013. A 3D Information System for the Documentation of Archaeological Excavations. International Archives of the Photogrammetry, Remote Sensing and Spatial Information Science. XXIV International CIPA Symposium 2013, Strasbourg, France, XL-5/W2, pp. 55-60.

BALLARIN, M., GUERRA, F. and SPERTI, L., 2013. Instruments and Methods for the Survey and Analysis of Amphitheatres, CAA2012. Archaeology in the Digital Era. Papers from the 40th Annual Conference of Computer Applications and Quantitative Methods in Archaeology (CAA), Southampton, United States, pp. 147-153.

BELUSSI, A., MIGLIORINI, S. and GROSSI, P., 2015. Managing Time Dimension in the Archaeological Urban Information System of the Historical Heritage of Rome and Verona, CAA2014. $21^{\text {st }}$ Century Archaeology. Concepts, methods and tools. Proceedings of the $42^{\text {nd }}$ Annual Conference on Computer Applications and Quantitative Methods in Archaeology, Paris, France, pp. 235-244.

COUGHENOUR, C. M., VINCENT, M. L., DE KRAMER, M., SENECAL, S., FRITSCH, D., FLORES GUTTIÉRREZ, M., LOPEZ-MENCHERO BENDICHO, V. M. and IOANNIDES, M., 2015. Embedding Knowledge in 3D Data Frameworks in Cultural Heritage. ISPRS Annals of the Photogrammetry, Remote Sensing and Spatial Information Science. $25^{\text {th }}$ International CIPA Symposium 2015, Taipei, Taiwan, II-5/W3, pp. 47-52. DOI: 10.5194/isprsannals-II-5-W3-47-2015

CRIPPS, P., 2013. Places, People, Events and Stuff; Building Blocks for Archaeological Information Systems, CAA2012. Archaeology in the Digital Era, Volume II. e-Papers from the 40th Annual Conference of Computer Applications and Quantitative Methods in Archaeology (CAA), Southampton, United States, pp. 487-497.

DE ROO, B., DE MAEYER, P. and BOURGEOIS, J., 2013a. On the Way to a 4D Archaeological GIS: State of the Art, Future Directions and Need for standardization, Proceedings of the 2013 digital heritage international congress, 2, Marseille, France, pp. 617-620.

DE ROO, B., VAN DE WEGHE, N., BOURGEOIS, J. and DE MAEYER, P. 2013b. The Temporal Dimension in a 4D Archaeological Data Model: Applicability of the Geoinformation Standard, ISPRS Annales of the Photogrammetry, Remote Sensing and Spatial Information Sciences, Volume II-2/W1, Istanbul, Turkey, pp. 111-121.

DE ROO, B., OOMS, K., BOURGEOIS, J. and DE MAEYER, P., 2014. Bridging Archaeology and GIS: Influencing Factors for a 4D Archaeological GIS, Digital heritage: progress in cultural heritage: documentation, preservation, and protection. 5th International conference on Cultural Heritage (EuroMed 2014), Limassol, Cyprus pp. 186-195.

DE RUNZ, C., 2008. Imperfection, temps et espace : modélisation, analyse et visualisation dans un SIG archéologique, Doctoral Dissertation, University of Reims Champagne-Ardenne.

DELL'UNTO, N., LANDESCHI, G., LEANDER TOUATI, A.-M., DELLEPIANE, M., CALLIERI, M. and FERDANI, D., 2016. Experiencing Ancient Buildings from a 3D GIS Perspective: a Case Drawn from the Swedish Pompeii Project, Journal of Archaeological Method and Theory, 23(1), pp. 73-94. DOI: 10.1007/s10816-014-9226-7

DOULAMIS, A., DOULAMIS, N., IOANNIDES, C., CHRYSOULI, C., GRAMMALIDIS, N., DIMITROPOULOS, K., POTSIOU, C., STATHOPOULOU, E. K. and IOANNIDES, M., 2015. 5D Modelling: an Efficient Approach for Creating Spatiotemporal Predictive 3D Maps of Large-Scale Cultural Resources. ISPRS Annals of the Photogrammetry, Remote Sensing and Spatial Information Science. $25^{\text {th }}$ International CIPA Symposium 2015, Taipei, Taiwan, II-5/W3, pp. 61-68. DOI: 10.5194/isprsannals-II-5-W3-61-2015

ENTWISTLE, J., MCCAFFREY, K. and ABRAHAMS, P., 2009. Three-Dimensional (3D) Visualization: the Application of Terrestrial Laser Scanning in the Investigation of Historical Scottish Farming Townships, Journal of Archaeological Science, 36(3), pp. 860-866. DOI: 10.1016/j.jas.2008.11.018

HASKIYA, D., 2002. Developing an Information System for Archaeological Sites and Monuments - Data Model and Construction, Archaeological Informatics: Pushing the Envelope. CAA2001. Computer Applications and Quantitave Methods in Archaeology. Proceedings of the $29^{\text {th }}$ Conference, Gotland, Sweden, pp. 49-52.

HALLOT, P., STEWARD, K. and BILLEN, R., 2015. Les états spatio-temporels d'existence et de présence. Vers une définition des relations entre objets absents ou inexistants, Revue internationale de Géomatique, 25(2), pp. 173-196. DOI: $10.3166 /$ RIG.25.

HOUSHIAR, H., BORRMANN, D., ELSEBERG, J., NÜCHTER, A., NÄTH, F. and WINKLER, S., 2015. CASTLE3D - A Computer Aided System for Labelling Archaeological Excavations in 3D. ISPRS Annals of the Photogrammetry, Remote Sensing and Spatial Information Science. $25^{\text {th }}$ International CIPA Symposium 2015, Taipei, Taiwan, II-5/W3, pp. 111-118. DOI: 10.5194/isprsannals-II-5-W3-111-2015

KOEHL, M., MEYER, E., KOUSSA, C. and LOTT C., 2008. SIG 3D et 3D dans les SIG: Application aux modèles patrimoniaux, GéoEvènement 2008, Versailles, France, pp. 1-15. 
LANDESCHI, G., DELL'UNTO, N., FERDANI, D., LINDGREN, S. and LEANDER TOUATI, L., 2015. Enhanced 3D-GIS: Documenting Insula V 1 in Pompeii, CAA2014. $21^{\text {st }}$ Century Archaeology. Concepts, methods and tools. Proceedings of the $42^{\text {nd }}$ Annual Conference on Computer Applications and Quantitative Methods in Archaeology, Paris, France, pp. 349-360.

LAURENZA, S. and PUTZOLU, C., 2001. From Stratigraphic Unit to the Mouse: a GIS Based System for the Excavation of Historical Complex. The Case Study of Pompeii, Archaeological Informatics: Pushing the Envelope. CAA2001. Computer Applications and Quantitative Methods in Archaeology. Proceedings of the 29th Conference, Gotland, Sweden, pp. 93-104.

LEICA GEOSYSTEMS AG, 2015. Leica ScanStation P30/P40. Available: http://www.leicageosystems.be/downloads123/hds/hds/general/brochures-datasheet/Leica ScanStation P30P40 DS HERITAGE en.pdf $[4 / 10,2016]$.

MANFERDINI, A. M., REMONDINO, F., BALDISSINI, S., GAIANI, M. and BENEDETTI, B., 2008. 3D Modeling and Semantic Classification of Archaeological Finds for Management and Visualization in 3D Archaeological Databases. Proceedings of the $14^{\text {th }}$ International Conference on Virtual Systems and MultiMedia (VSMM), Limassol, Cyprus, pp. 221-228.

PALIOU, E., 2013. Reconsidering the Concept of Visualscapes: Recent Advances in the Three-Dimensional Visibility Analysis. In: A. BEVAN and M. LAKE, eds, Computational Approaches to Archaeological Spaces. Walnut Creek: Left Coast Press, pp. 243-265.

ROBLES ORTEGA, M. D., ORTEGA ALVARADO, L. and FEITO HIGUERUELA, F. R., 2015. Avances en systemas de Información Espacial 3D. Applicaciones en patrimonio y arqueología virtual. Virtual Archaeology Review, 6(12), pp. 77-91.

TRIMBLE NAVIGATION LIMITED, 2012. Trimble TX5 Scanner. Datasheet. Available: http://trl.trimble.com/docushare/dsweb/Get/Document-628869/022504-122 Trimble TX5 DS 1012 LR.pdf [4/10, 2016].

VAN RUYMBEKE, M., CARRÉ, C., DELFOSSE, V., PFEIFFER, M. and BILLEN, R., 2015. Towards an Archaeological Information System: Improving the Core Data Model, CAA2014. 21st Century Archaeology. Concepts, methods and tools. Proceedings of the 42nd Annual Conference on Computer Applications and Quantitative Methods in Archaeology, Paris, France, pp. 245-253.

WULFF, R. and KOCH, R., 2013. Image-Based 3D Documentation of Archaeological Trenches Considering Spatial, Temporal and Semantic Aspects, CAA2012. Archaeology in the Digital Era, Volume II. e-Papers from the 40th Annual Conference of Computer Applications and Quantitative Methods in Archaeology (CAA), Southampton, United States, pp. 324-336. 


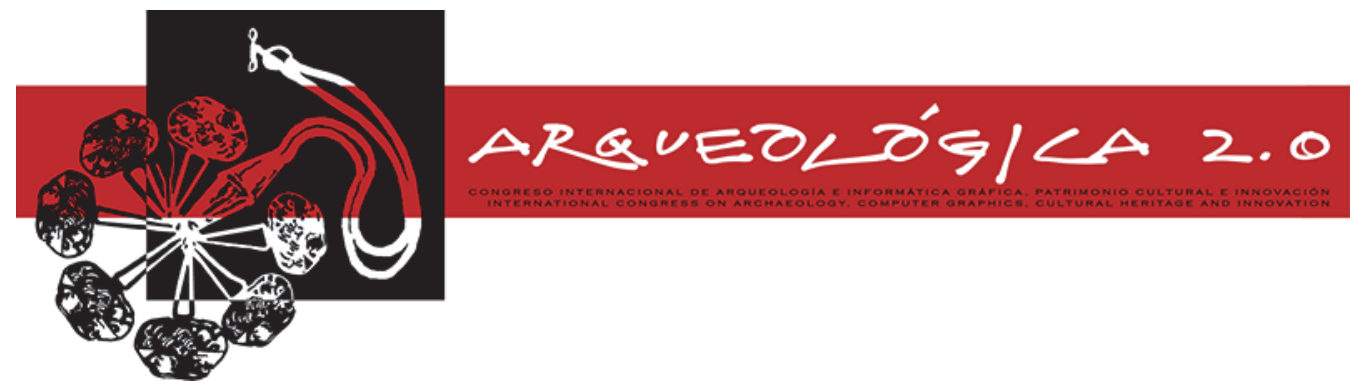

Proceedings of the 8th International Congress on Archaeology, Computer Graphics, Cultural Heritage and Innovation 'ARQUEOLÓGICA 2.0' in Valencia (Spain), Sept. 5-7, 2016

\section{Works in progress}




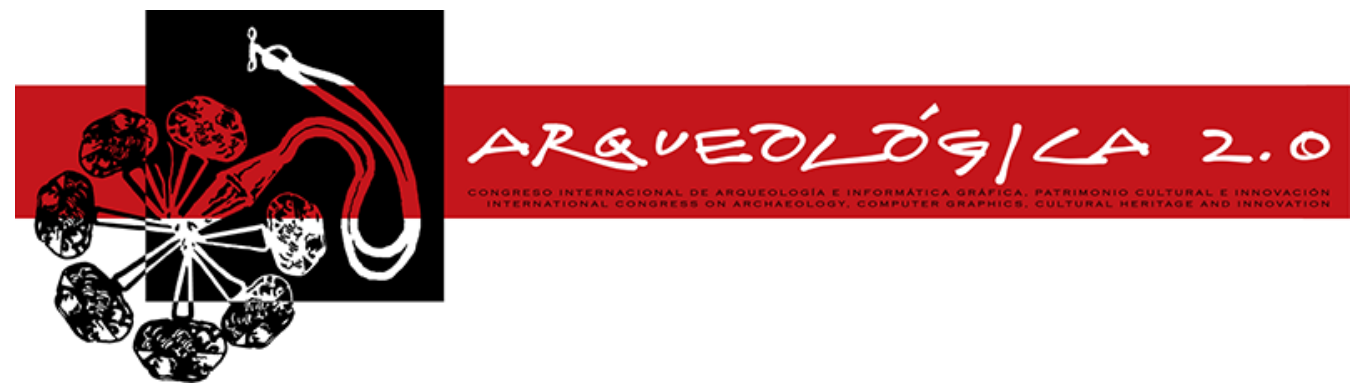

Proceedings of the $8^{\text {th }}$ International Congress

on Archaeology,

Computer Graphics,

Cultural Heritage and Innovation

'ARQUEOLÓGICA 2.0'

in Valencia (Spain)

Sept. $5-7,2016$

\title{
BETWEEN LANDSCAPE AND ARCHITECTURE: ENVISIONING CAPPADOCIAN RUPESTRIAN MONASTERY THROUGH COLORFUL CONTOUR LINES
}

\author{
Fabio Colonnese*, Marco Carpiceci, Carlo Inglese \\ Department of History, Drawing and Restoration of Architecture, University Sapienza of Rome, Piazza Borghese 8, 00186 Rome, Italy. \\ fabio.colonnese@uniroma1.it; marco.carpiceci@uniroma1.it; carlo.inglese@uniroma1.it
}

\begin{abstract}
:
Architectural heritage preservation bases on a deep, layered and interdisciplinary knowledge of the sites, especially when they are on the edge between natural and artificial, like rupestrian architecture often is. Survey and representation of rock-cut architecture are between the most problematic issues for a number of problems concerning the geometrical complexity of the interior and exterior enveloping surfaces. Laser-scanner is an appropriate tool concerning the registration of geometric and spatial properties of those artificial caves in continuity with the external topography, but automatic representations are often unable to convey their hidden geometric and spatial relationships. In the context of a work methodology customized on the rupestrian habitat of Cappadocia, the authors developed an original envisioning model in which an associate use of contour lines and chromatic codes transforms traditional orthogonal projections after the numeric model into drawings able to offer a synthesis and transmit the complex forms and relationships of rupestrian settlements.
\end{abstract}

Key words: Cappadocia, Karanlik Monastery, Rock-cut architecture, Cultural Heritage, Infographic representation

\section{Introduction}

In the traditional practice of architecture survey, after a first phase of acquisition of the basic measures, a geometrical model is built, first mentally and then either graphically or digitally. This model represents the architectural subject through elementary geometric elements, such as parallelepipeds, cylinders, and spheres, which approximate the actual parts of the building. This geometrical model can be sectioned and projected in order to obtain plans, elevations and sections in an appropriate reduction scale and according to a metric tolerance that is proportional to the scale adopted. The introduction of laser scanning and digital photogrammetry (Briese and Pfeifer 2007) has changed this process, which was cognitive and representational at the same time. The cloud of points generated by laser scanner procedure is the visual outcome of the process of measures acquisition. It reproduces the architectural body silhouette but despite the appearance of a defined numerical model (points model), it still requires a long processing stage to represent the morphological and chromatic features of the artefact in a consistent and univocal way to result in a scientific document of reality.

\section{Rock-cut architecture in Cappadocia}

The knowledge and preservation of architectural heritage are based on a deep, layered and interdisciplinary knowledge of the sites, especially when the architectural monuments are on the edge between natural and artificial as well as between archaeology and landscape, like rupestrian architecture often is. As a survey team of a national research, in the last years the authors have focused on the survey and representation of Cappadocia rock-cut architecture (Carpiceci 2013), also experimenting a work procedure to meet the needs of both metric precision and correctness of the final graphic outcomes. Rupestrian architecture has its constructive specificity in being cut out of natural rock formations: this means that interior space is realized by subtracting matter rather than adding and assembling parts. As a consequence of this way of producing space, there is no direct relationship between interior and exterior surfaces. The external look of a rupestrian church is made of the natural surface of a cliff while ancient builders shaped interiors by generally replicating rooms and forms after traditional architectures of the same ages, which can be easily reduced to their geometric models.

*Corresponding Author: Fabio Colonnese, fabio.colonnese@uniroma1.it 


\section{Survey criteria}

The three levels of rooms of the so-called Monastery of Karanlik (the Dark Church) in Goreme Open Air Museum (Fig. 1) have been surveyed thorugh a small and light laser scanner FARO Focus3D X130. Spherical target shapes have been extensively used during the recording of individual clouds. The external surfaces of Karanlik Monastery have been scanned at sunset while the internal surfaces of its rooms have been scanned in the dark of the night, for three consecutive days. This procedure responds to the problem of the crowd of tourists walking in this monument all day long. Surveying the painted surfaces within many of the rooms has required a special consideration (Carpiceci and Colonnese 2014; Carpiceci 2013, Carpiceci et al. 2015). With the existing artificial lighting, RGB scanner recording procedure produces bad pictures that do not record the chromatic data of the surfaces. A proper registration through high definition cameras and with a controlled uniform light on all of painted surfaces would have required too much time. An acceptable compromise has been found in recording a black and white cloud by the reflectance in a complete darkness.

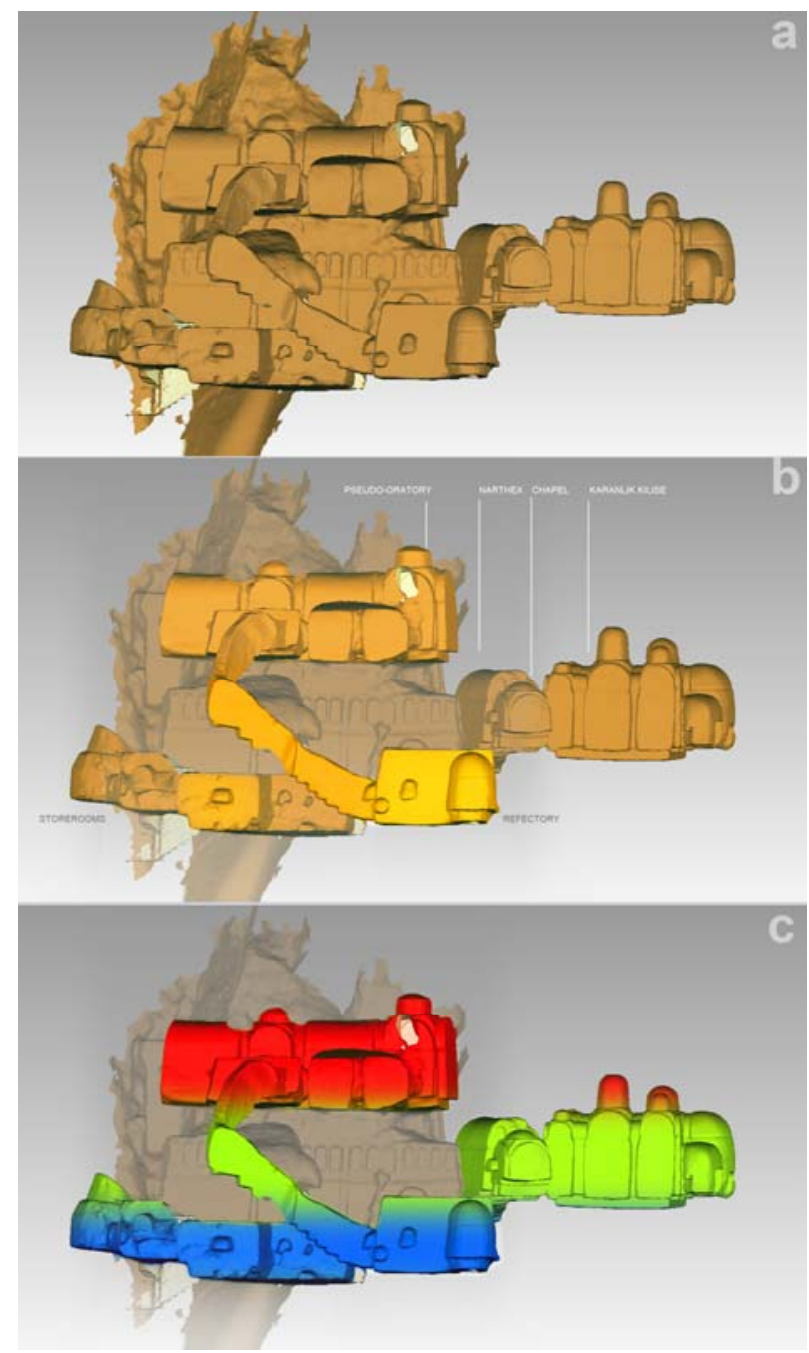

Figure 1: Meshed model after laser scanning, view from the east: a) Basic view of internal volums; b) Atmosphere treated view to enhance apparent deepness; c) Color treated view of main rooms related to the grouped contour-line representations. Karanlik Monastery
After the registration, the numerical model (per points) has been processed and translated into a meshed model (per surfaces). This model has been used to understand the organization of the interiors and decide the strategy of the following representations. The model of the interior volumes has been treated to optically enhance the deepness effect (Fig.1c), according to the principle of the atmospherical density or "prospettiva aerea" as defined by Leonardo da Vinci. However, this kind of images offers only a partial comprehension of the complex organization of the carved settlement.

\section{Representation criteria}

The sculptural nature of rock-cut architecture makes it impossible to envision rooms unambiguously through apparent contours or edges. Even advanced representations of rupestrian monuments after laser scanning are elaborated almost exclusively through photomapping and generally focus on internal spatial systems (Andaloro et al. 2013). Therefore, the authors opted for a contour line representation, like in topographic charts. This was also suggested by the morphological continuity between interiors and exteriors. A number of significant section plans have been identified according to their ability to describe the complex morphology of the settlement: horizontal for the plans and vertical plans for elevations and sections. In the cartographic practice, the equidistance (i.e. the constant gap between successive contour lines) is conventionally set at $1 / 1000$ of the denominator of the scale of representation in meters. An equidistance of 5 $\mathrm{cm}$ is usually set for a canonical 1:50 architectural representation, but tests undertaken by the authors with this step have not given a readable result. The authors have consequently decided to adopt an equidistance of $10 \mathrm{~cm}$ that allows contour lines to describe the architectural shapes without becoming a sort of confusing background noise produced by excessive visual data. This envisioning model points out the relationships among the several rock-cut rooms and between them and the natural external surface of the rocky cliff. To make sense of the horizontal and vertical complexity of the whole settlement as well as the 3D relationships between the rooms, an experimental representation has been developed by multi-colored contour lines (Fig. 2).

The next step is the choice of the reference plans to produce the vertical sections. While a plan cannot but refer to a horizontal section plan, the vertical sections require a careful choice to describe most of the architectural characteristics of the rock-cut rooms whose configuration is so changing. In the case of Karanlik Monastery, authors have oriented the vertical sections in a perpendicular way to the longitudinal axes of the larger decorated rooms. By producing a number of sections driven by the position of the significant section plans adopted with regular intervals, this graphical strategy allows an efficient visualization of the tufa wall surfaces (Fig. 3). 


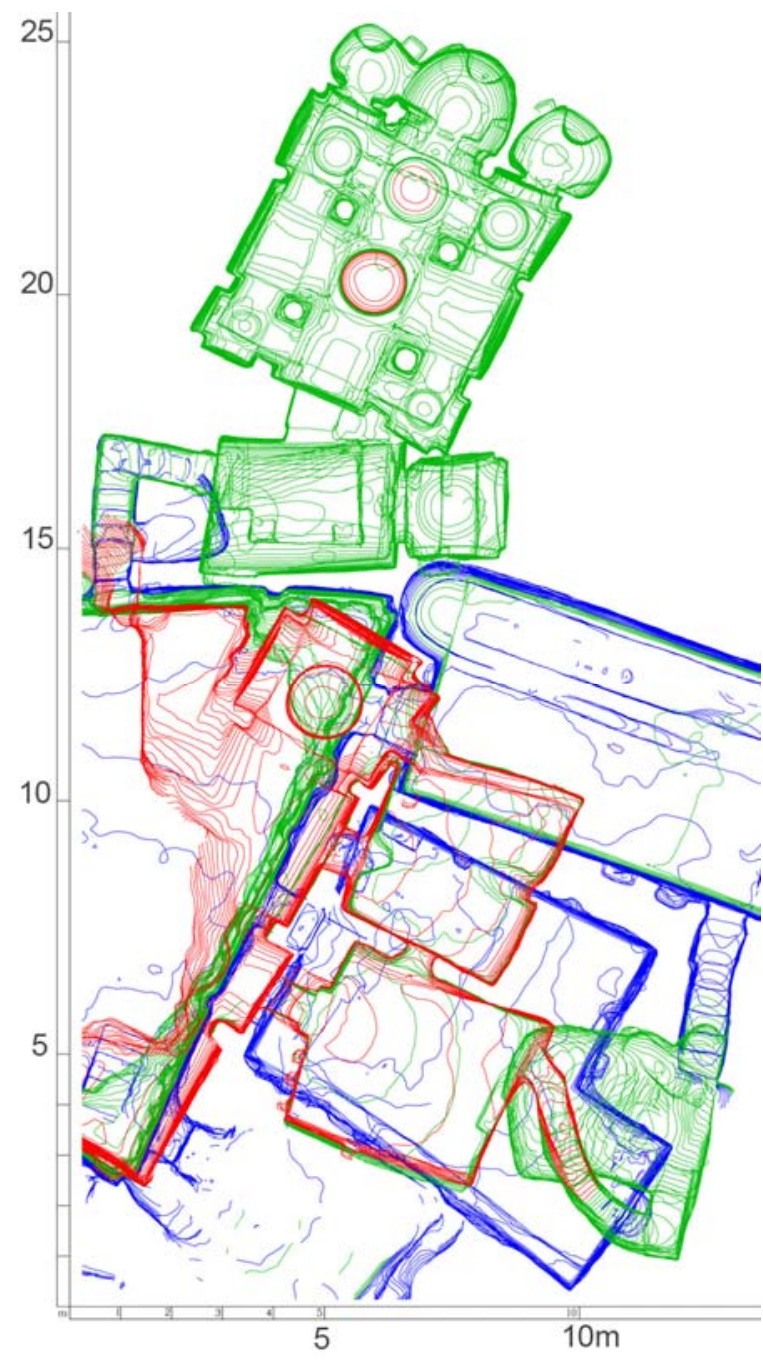

Figure 2: General plan, detail: lower level in blue; middle level in green; upper level in red. Karanlik Monastery

\section{Conclusions}

Until a few years ago, the drawings of Cappadocia rupestrian architecture were obtained with traditional procedures and showed plans and sections with rectangular rooms, definitely regularized if not invented. They were a direct representation of that geometrical model that every surveyor builds in his or her mind to study and gradually master an architecture configuration.
However, this sort of aggregation of parallelepipeds and cylinders should be only a stage of the process and not the final graphical result. The authors believe that a neutral and faithful representation of actual forms by contour lines can:

- describe the strong continuity between external natural surfaces and internal carved rooms;

- $\quad$ suggest meanings and intent beyond the cliché of the "rough imitation of traditional Byzantine architecture";

- $\quad$ cast a new light on constructive intents;

- emphasize the visual perceptive role of paths, openings and curved surfaces.

Moreover the use of polychromatic drawings to envision the relationships between distant rooms may contribute to form new hypothesis on both their uses and their transformation stages. For example, they are able to reveal unpredictable geometrical relationships between distant rooms, as in the case of the church and the rooms of monastery, despite the triangular shape of court and the rotated entry hall.

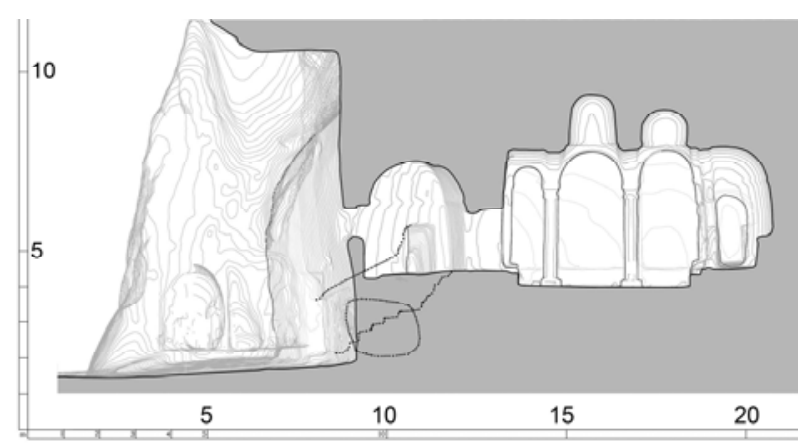

Figure 3: Longitudinal section per contour lines through the church. Karanlik Kilise.

\section{Acknowledgements}

This paper is a collective work of the three authors and part of a larger study on rupestrian habitat from the Italian national research called "Arte e habitat rupestre in Cappadocia (Turchia) e nell'Italia centromeridionale. Roccia, architettura scavata, pittura: fra conoscenza, conservazione, valorizzazione", whose National Coordinator is Maria Crocifissa Andaloro, and Scientific Director of Sapienza University unity is Marco Carpiceci.

\section{References}

ANDALORO, M., BIXIO, R., and CRESCENZI, C., 2013. The complex of S. Eustachius in Göreme, Cappadocia reading the relationship between the landscape and a very articulated underground settlement. In W. Börner, and S. Uhlirz (Eds.), 18th International Conference on Cultural Heritage. Wien: Museen der Stadt Wien. ISBN 9783200036765

BRIESE, C., and PFEIFER N., 2007. Laser Scanning. Principles and Applications. In III International Scientific Conference, pp. 93 - 112. Geo-Sibir, Nowosibirsk.

CARPICECI, M., 2013. Cappadocia Laboratorio-Rilievo (2007-2015). In M. FILIPPA and A. CONTE (Eds.), Patrimoni e Siti Unesco, memoria, misura e armonia, pp. 221-229. Roma: Gangemi. ISBN 978-88-492-2728-4

CARPICECI, M., and COLONNESE, F., 2014. Rilievo e documentazione del colore in architettura: un problema attuale e irrisolto. In S. Bertocci, S. Van Riel (Eds.), La cultura del restauro e della valorizzazione, Vol.I, pp. 189-196. Firenze: Alinea. ISBN 978-88-6055-829-9

CARPICECI, M., INGLESE, C., and COLONNESE, F., 2015. Potential and limitations of new technologies for the survey of morphology and colour of rupestrian habitat. In Proceedings of Hypogea2015 International Congress of Speleology in Artificial Cavities, pp. 399-407. Urbino: AGE. ISBN 978-88-89731-79-6. 


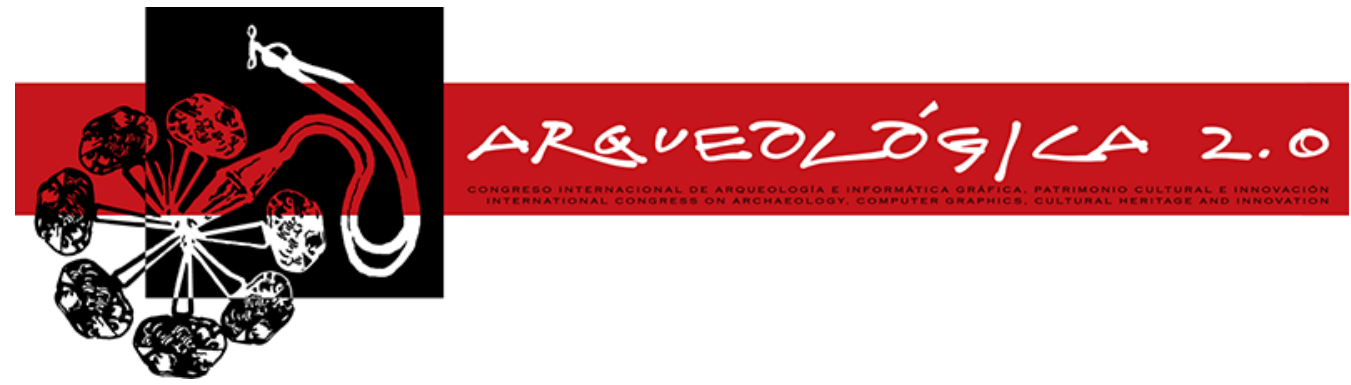

Proceedings of the $8^{\text {th }}$ International Congress

on Archaeology,

Computer Graphics,

Cultural Heritage and Innovation

'AROUEOLÓGICA 2.0'

in Valencia (Spain),

Sept. $5-7,2016$

\title{
MODELADO TRIDIMENSIONAL DE LA PALEOTOGRAFÍA DE CARTAGENA
}

\author{
TRIDIMENSIONAL MODELLING OF THE PALEOTOPOGRAPHY OF CARTAGENA \\ Josefina García-León ${ }^{a,}$, , María Milagrosa Ros ${ }^{c}$, Antonio Garcíab $^{b}$, Manuel Torres ${ }^{b}$, Felipe Cerezoc, \\ Sebastián F. Ramalloc. \\ ${ }^{a}$ Departamento de Arquitectura y Tecnología de la Edificación, Universidad Politécnica de Cartagena. Paseo Alfonso XIII 50, 30203 \\ Cartagena, España. Josefina.leon@upct.es \\ ${ }^{\text {b }}$ Departamento de Ingeniería Minera, Geológica y Cartográfica, Universidad Politécnica de Cartagena, Paseo Alfonso XIII 50, 30203 \\ Cartagena, España. antonio.gmartín@upct.es; manuel.torres@upct.es
}

${ }^{\mathrm{c}}$ Departamento de Prehistoria, Arqueología, $\mathrm{H}^{\mathrm{a}}$ Antigua, $\mathrm{H}^{\mathrm{a}}$ Medieval y CC y TT Historiográficas, Universidad de Murcia, Campus de la Merced, 30001 Murcia, España.milagros@um.es; felipe.cerezo@um.es; sfra@um.es

\begin{abstract}
:
Topographic changes have been significant in the city of Cartagena and its surroundings along history. The city that Polybius described in II century B.C. has spread northward, occupying the old Almarjal, now desiccated by the diversion of the wadis that flooded it. The palaeotopography of the city has been documented and analyzed from the lithology of 377 geotechnical drillings and other 20 new continuous drilling within the framework of the Project "Surveying and planning of a privileged Mediterranean city, Arqueotopos I and II". Digital terrain models (DTM) of the layers of interest, consisting of anthropic fills and sediments, have been generated. Thickness of each layer has been studied by drawing longitudinal profiles. Finally, a three-dimensional virtual reconstruction has been made to show graphically the documented changes in each layer, to serve both research and divulgation of knowledge.
\end{abstract}

Key words: virtual reconstruction, geoarchaeology, Cartagena, 3D reconstruction, DTM

\section{Resumen:}

Los cambios topográficos experimentados por la ciudad de Cartagena y su entorno a lo largo de la historia han sido considerables. La ciudad que describió Polibio en el s. II a.C. se ha extendido hacia el norte, ocupando el antiguo Almarjal, ahora desecado por el desvio de las ramblas que recurrentemente lo inundaban. La paleotopografía de la ciudad se ha documentado y analizado a partir de la litología de 377 sondeos geotécnicos y de otros 20 sondeos nuevos realizados en el marco de los Proyectos "Topografía y urbanismo de una urbe mediterránea privilegiada, Arqueotopos I y II". Se han elaborado los modelos digitales del terreno (MDT) de las capas de interés, constituidos por rellenos y sedimentos. Se ha estudiado la potencia de cada capa trazando los correspondientes perfiles longitudinales. Finalmente, se ha realizado una reconstrucción virtual tridimensional que permite apreciar gráficamente los cambios documentados producidos en cada capa, con fines tanto investigadores como de divulgación.

Palabras clave: reconstrucción virtual, geoarqueología, Cartagena, reconstrucción 3D, MDT

\section{Introducción}

La urbe romana de Cartagho Nova, tal como la describe Polibio a mediados del s. II a.C., se levantaba al fondo de una bahía, sobre un promontorio configurado por cinco cerros; añade que estaba limitada al sur y oeste por el mar y, al norte, por una zona lacustre interior o estero que comunicaba con el mar (Polibio 1983). De los cinco cerros que conforman el sustrato geológico sobre el que se erigió la ciudad romana, Molinete, Monte Sacro, Monte de San José, Despeñaperros y Monte de la Concepción, destaca este último, ya que sobre sus laderas se edificaron el Teatro y el Anfiteatro romanos (Fig. 1).

La topografía de la zona ha sufrido cambios considerables a lo largo de la historia, hasta transformarse en la actual ciudad de Cartagena. La Figura 2 muestra un plano de Villamarzo (1907) que representa la urbe idealizada en época púnico-romana, superpuesto a una ortofoto actual que se empleó para georreferenciarlo. El área del estero, de carácter subsidente y situada al norte de la ciudad romana,

`Corresponding Author: Josefina García-León", Josefina.leon@upct.es 
registró una somera influencia marina y la fracturación de su sector más meridional, debido a la dinámica de las fallas de Cartagena-La Unión y Benipila (Ramallo y RosSala 2016; Ramallo et al. in press).

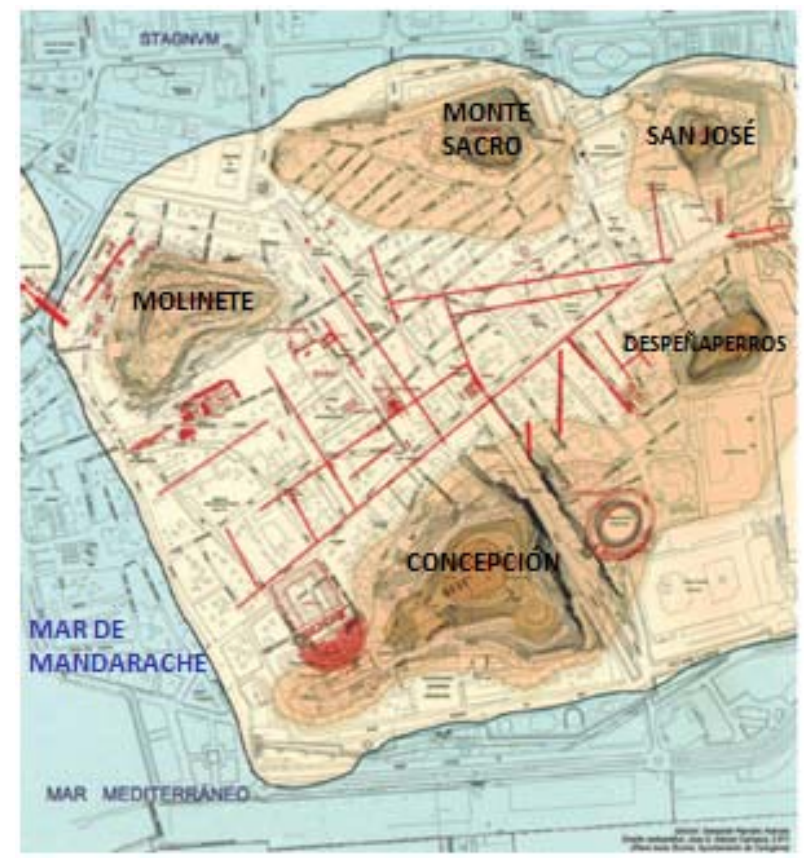

Figura 1: Plano de Carthago Nova con las cinco colinas y la localización de los principales hallazgos arqueológicos de época romana (Ramallo 2011).

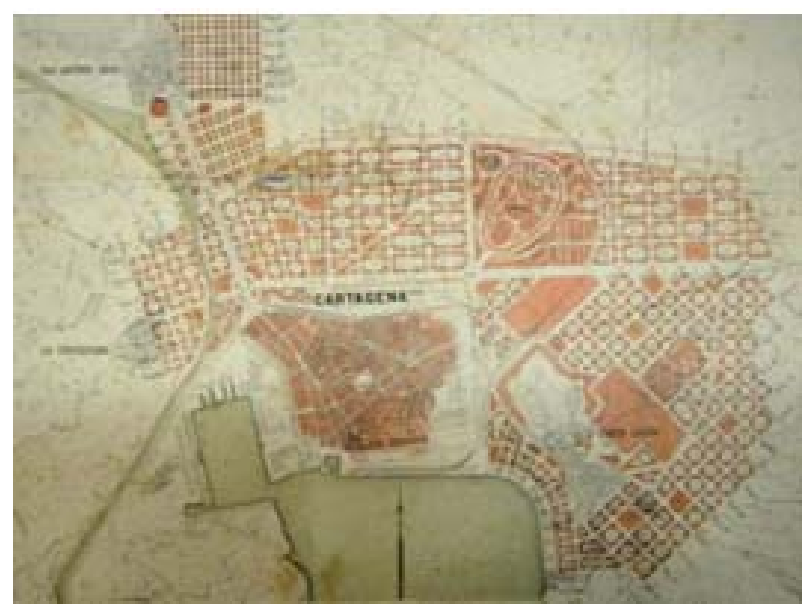

Figura 2: Plano que representa la ciudad idealizada en la época púnico-romana sobre ortofoto actual (García-León et al. 2015).

Los aportes continentales de distintas ramblas fueron colmatando el estero y convirtiéndolo en un área pantanosa y salobre. La construcción del Arsenal Militar, finalizado en 1872, supuso el desvió de la rambla de Benipila y la transformación de la antigua área lacustre en una zona insalubre conocida como el Almarjal.

En 1900 se aprueba el Proyecto de Ensanche, Reforma y Saneamiento de la ciudad. El ensanche propuesto incluía la zona ocupada anteriormente por el estero, una vez desecada. La Figura 3 muestra uno de los planos del Proyecto.

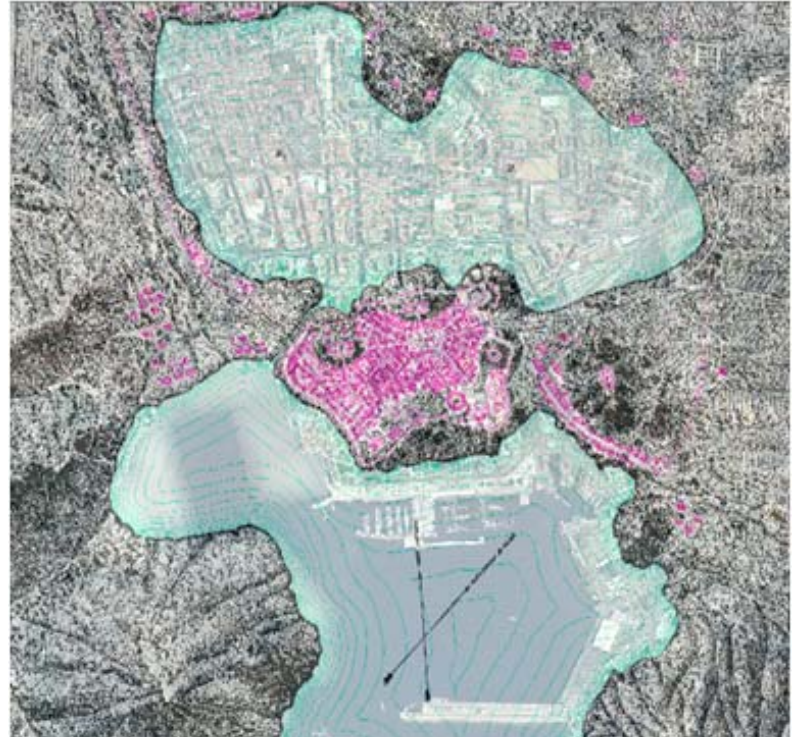

Figura 3: Proyecto de Ensanche, Reforma y Saneamiento de Cartagena, 1896.

Para realizar la reconstrucción virtual de la paleotopografía de la ciudad se ha dispuesto de la información procedente de 377 sondeos geotécnicos, la mayoría destinados a la edificación y la obra civil. De especial importancia han sido los 20 nuevos sondeos a testigo continuo, realizados en el marco del Proyecto Arqueotopos, que han permitido definir los cambios sufridos a través del estudio sedimentario, apoyado en dataciones de $14 \mathrm{C}$ y en el análisis de bioindicadores. Estos sondeos se dispusieron en zonas de especial interés o con escasa información, y han estado condicionados por la existencia de solares o espacios públicos en los que ubicarlos. En los modelos realizados se han tenido en cuenta la naturaleza y el espesor de los depósitos originados durante los procesos de sedimentación, tanto los aportados por las ramblas como los de origen marino. Los sondeos son necesarios, precisamente, para poder obtener esa información.

También se realizó una alineación de 6 sondeos propios para estudiar en detalle el valle interior entre los cerros de La Concepción y del Molinete, que en tiempos fue un área anegada que pudo haber desempeñado funciones portuarias.

\section{Metodología}

La primera fase de este trabajo ha consistido en la recogida de información de todo tipo, hasta generar nuestra propia base de datos, en un proceso en que la transparencia es fundamental (Vico 2011). Se ha analizado la cartografía histórica de la zona y se ha realizado un estudio previo a partir de datos de excavaciones arqueológicas realizadas en la ciudad. Con esa información se elaboraron modelos del área delimitada por las cinco colinas y comprendida en el promontorio primigenio (García-León et al. 2015).

La segunda fase consistió en la elaboración de modelos digitales del terreno, basados en las descripciones litológicas de los sondeos y representando los cambios producidos en la zona a través de las distintas capas de interés que configuran su columna estratigráfica. La 
capa más superficial es la de relleno antrópico, con potencias de más cuatro metros en algunos puntos, formado, principalmente, por materiales procedentes de derribos y desescombros de la propia ciudad. Le sigue la capa de fangos, cuya composición y espesor permiten conocer si en algún momento la zona estuvo sumergida. También se ha estudiado la capa de techo del sustrato rocoso.

Para cada capa se han recogido los datos procedentes de los sondeos, con su cota correspondiente. Además, se han incluido puntos situados en la superficie de las colinas, que se han considerado invariantes. Las fallas se introdujeron en los modelos como líneas de rotura. A partir de esta información se generraron los TIN (triangulated irregular network) de las capas, se realizaron los curvados de estas y, finalmente, se elaboraron los correspondientes modelos digitales del terreno.

La tercera y última fase es la reconstrucción tridimensional del entorno. Se ha hecho para las distintas capas de interés, empleando como base la del muro de fango (Fig. 4). Se han utilizado tramas de colores y texturas que permiten distinguir qué zonas estaban sumergidas. Finalmente, la iluminación ha aportado realismo al modelo, lo que permite apreciar mejor algunos aspectos del mismo (Flores et al. 2013).

Se ha supuesto que el nivel del mar estaba a la misma cota que en la actualidad (Fairbanks 1989).

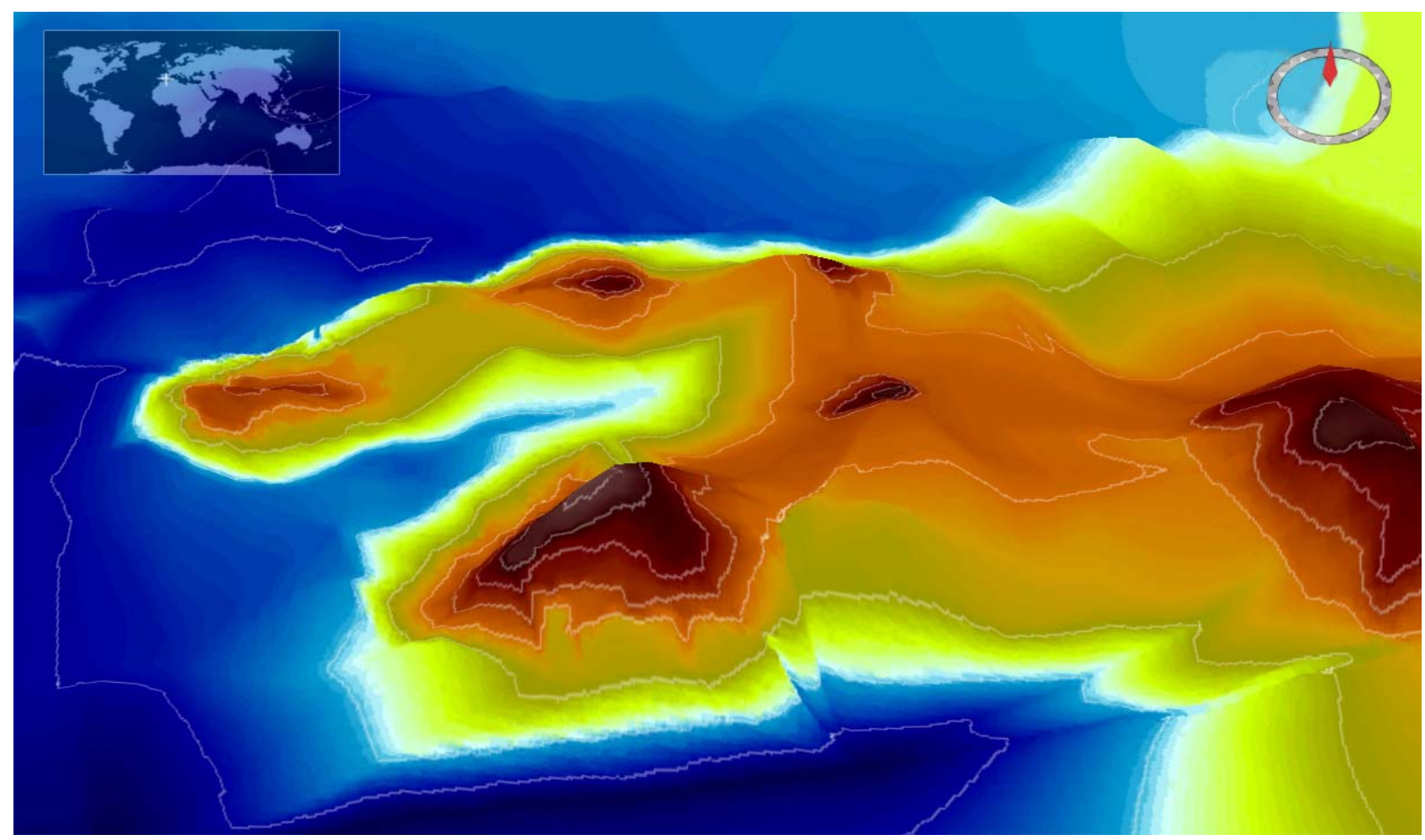

Figura 4: Reconstrucción virtual tridimensional de la capa de muro de fango.

\section{Resultados y conclusiones}

Una vez depurada la información, se ha obtenido un modelo digital del terreno de cada capa de interés: muro del relleno antrópico, techo y muro de la capa de fangos y techo de la capa de roca. A partir de los modelos digitales del terreno se pueden obtener perfiles, estudiar la potencia de cada capa en cualquier punto de la zona y calcular el volumen de los sedimentos. Al delimitar la capa de fangos se puede cartografiar con precisión la zona que ocupaba el Almarjal. Esa zona está actualmente edificada.

La reconstrucción virtual realizada permite apreciar gráficamente los profundos cambios que, a lo largo del tiempo, ha sufrido la topografía del área ocupada por la ciudad. La Figura 4 muestra la correspondiente a la capa de muro de fango, inicando con colores y texturas cuáles serían las zonas sumergidas. Estos modelos digitales tridimensionales son útiles para realizar simulaciones que permitan la validación de hipótesis de trabajo en el campo de la paleotopografía. Asimismo pueden contribuir a reforzar el concepto de Patrimonio y a su difusión.

En este trabajo se han utilizado esas herramientas, sobre la información aportada por la Geoarqueología, en el contexto del Proyecto Arqueotopos, en cuya metodología de trabajo se inserta. Las conclusiones obtenidas del estudio de los datos litológicos, sedimentológicos e hidrográficos, de cronologías absolutas y de la caracterización de biomarcadores se han reflejado en los modelos digitales del terreno. De este modo, la situación y características del área lacustre septentrional y del medio marino, la evolución de la paleotopografía de la urbe en sus primeras fases, etc., se pueden mostrar a través de la reconstrucción virtual.

\section{Agradecimientos}

Este proyecto se ha realizado en el marco de los proyectos: Carthago Nova: Topografía y urbanística de una urbe mediterránea privilegiada I y II (Mineco- 
HAR2011-29330 y Mineco HAR2014-57672-P), parcialmente financiados con fondos FEDER. Asimismo hacemos extensivo nuestro agradecimiento a la empresa Horysu, S.A. y a todos los organismos, instituciones y particulares que nos han permitido la consulta de los datos de sus sondeos. Finalmente, agradecemos a Jaime Fernández Vázquez su contribución a la visualización tridimensional de los modelos.

\section{Referencias}

FAIRBANKS, R.G., 1989. A 17.000 year glacio-eustatic sea level record: Influence of glacial melting rates on the Younger Dryas event and deep-ocean circulation. Nature, 342, pp. 637-642.

FLORES, M., ROMERO, A. y MARTÍNEZ, J.M., 2013. Virtual visualization of La Quintilla. Virtual Archaeology Review, 4(9), 143-147. DOI: http://dx.doi.org/10.4995/var.2013.4265.

GARCIA-LEÓN, J., GARCÍA, A. y CÁNOVAS AMBIT, J.A, 2015. La ciudad de Cartagena en la época romana altoimperial: Generación y análisis de un modelo digital de elevaciones. EGA, 26, 224-231. DOI: 10.4995/ega.2015.4055

POLIBIO, 1983. Historias libros V-XV. Traducción y comentarios, M. Balasch Ricort. Madrid: Editorial Grecos, vol. 43.

RAMALLO, S.F. y ROS-SALA, M.M., 2016. De Qart hadast a Carthago Nova: la conquista de Scipión como trasfondo. En: M. Bendala Galán (ed.), Catálogo a la exposición "Los Escipiones. Roma conquista Hispania". Museo Arqueológico Regional (Alcalá de Henares, Madrid), pp. 162-179.

RAMALLO, S.F., ROS-SALA, M., CEREZO, F. MANTECA, I., RODRÍGUEZ-ESTRELLA, T., NAVARRO, F., MARTÍNEZ, M., DE TORRES, T., GARCÍA, J. y FERNÁNDEZ, A. (en prensa). Topografía y urbanística de Carthago Nova, una urbe mediterránea privilegiada: el Proyecto Arqueotopos, Fifth International Congress on Underwater Archaeology, IKUWA V, Octubre-2014, Cartagena.

RAMALLO, S.F. 2011. Carthago Nova. Puerto Mediterráneo de Hispania. Murcia: Darana Editorial.

VICO, L., 2011. Metodología y criterios para la reconstrucción virtual del Patrimonio Arquitectónico romano. Virtual Archaeology Review, 2(3), pp. 151-155. DOI: http://dx.doi.org/10.4995/var.2011.4671. 


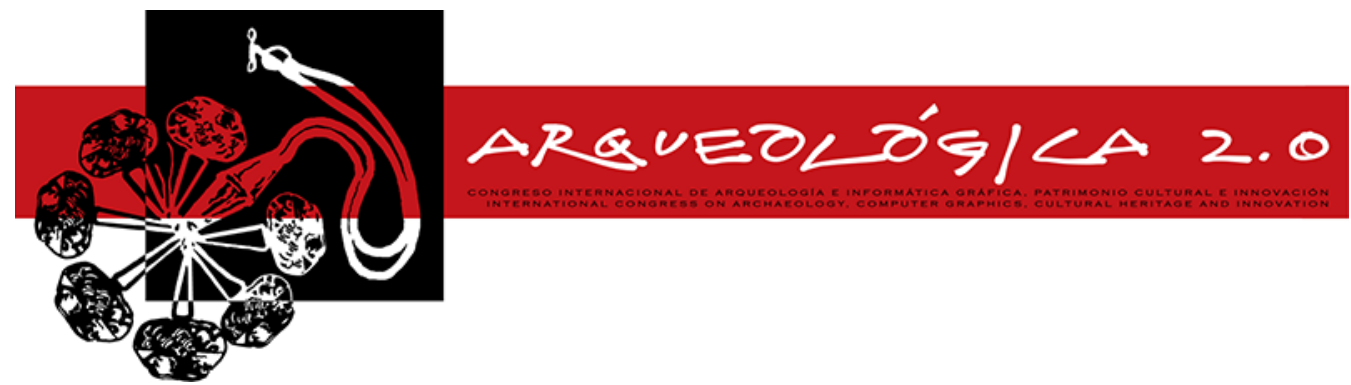

Proceedings of the $8^{\text {th }}$ International Congress

on Archaeology,

Computer Graphics,

Cultural Heritage and Innovation

'ARQUEOLÓGICA 2.0'

in Valencia (Spain),

Sept. $5-7,2016$

\title{
RECUPERACIÓN GRÁFICA DE LA MÁQUINA PARA CORTAR LA HIERBA DE LOS CANALES NAVEGABLES DE AGUSTÍN DE BETANCOURT Y MOLINA: MODELADO TRIDIMENSIONAL Y DOCUMENTACIÓN GEOMÉTRICA CON SOLID EDGE
}

\author{
GRAPHICAL RECOVERY OF THE AGUSTIN DE BETANCOURT'S MACHINE FOR CUTTING GRASS IN \\ WATERWAYS: 3D MODELING AND GEOMETRIC DOCUMENTATION WITH SOLID EDGE \\ José Ignacio Rojas-Sola ${ }^{a,}{ }^{,}$, José Porras-Galán ${ }^{b}$, Laura García-Ruesgas ${ }^{c}$ \\ ${ }^{a}$ Departamento de Ingeniería Gráfica, Diseño y Proyectos, Universidad de Jaén, Campus de las Lagunillas s/n, 23071 Jaén, España. \\ jirojas@ujaen.es \\ ${ }^{\text {b }}$ Departamento de Ingeniería Mecánica, Universidad Pontificia Comillas, Alberto Aguilera 23, 28015 Madrid, España. \\ iporras@icai.comillas.edu \\ ${ }^{c}$ Departamento de Ingeniería Gráfica, Universidad de Sevilla, Isla de la Cartuja, Camino de los Descubrimientos s/n, 41092 Sevilla, \\ España. lauragr@us.es
}

\begin{abstract}
:
Agustín de Betancourt and Molina was one of the most distinguished engineers of the eighteenth and nineteenth century with numerous contributions to various fields of engineering, including civil engineering. This research shows the process followed in the documentation of the cultural heritage of that canary engineer, especially in the geometric documentation of the machine for cutting grass in waterways presented in England in 1795 after three years researching on theory of machines. The baseline information has been recovered from the Canary Orotava Foundation of History of Science who has spent years collecting information about the Project Betancourt, in particular, planimetric information as well as a small report on its operation and description of parts of machine. From this information, we have obtained its 3D reconstruction using CAD techniques with the cooperation of Solid Edge ST7 parametric software, which has enabled to obtain the 3D model as well as different detail plans and exploded views.
\end{abstract}

Key words: cultural heritage, geometric documentation, 3D reconstruction, Agustín de Betancourt y Molina, machine for cutting grass in waterways

\section{Resumen:}

Agustín de Betancourt y Molina fue uno de los más ilustres ingenieros del siglo XVIII y XIX, siendo muy numerosas sus aportaciones a diferentes ámbitos de la ingeniería, en particular a la ingeniería civil. La presente investigación muestra el proceso seguido en la documentación del patrimonio cultural del citado ingeniero canario, en particular, en la documentación geométrica de la máquina para cortar hierba de los canales navegables que presentó en Inglaterra en 1795 tras tres años investigando sobre la teoría de las máquinas. La información de partida se ha podido rescatar de la Fundación Canaria Orotava de Historia de la Ciencia que lleva años recopilando información sobre el Proyecto Betancourt, en concreto, se ha dispuesto de información planimétrica así como de una pequeña memoria sobre su funcionamiento y descripción de las partes del ingenio. A partir de dicha información, se ha obtenido su reconstrucción 3D, mediante técnicas CAD gracias al concurso del software paramétrico Solid Edge ST7, lo que ha posibilitado la obtención del modelo 3D así como diferentes planos de detalle y perspectivas estalladas.

Palabras clave: patrimonio cultural, documentación geométrica, reconstrucción 3D, Agustín de Betancourt y Molina, máquina para cortar hierba de los canales navegables

`Corresponding Author: José Ignacio Rojas-Sola, jirojas@ujaen.es 


\section{Introducción}

Agustín de Betancourt y Molina fue un célebre ingeniero canario nacido en la población tinerfeña del Puerto de la Cruz en 1758 y fallecido en la ciudad rusa de San Petersburgo en 1824.

Sus aportaciones a diferentes ámbitos de la ingeniería han sido muy numerosas, destacando aquellas que tienen que ver con la ingeniería civil.

En 1784 marcha a la Escuela de Puentes y Caminos de París para realizar estudios de hidráulica y mecánica y a diseñar máquinas para el Real Gabinete de Máquinas cuya creación se produjo en Madrid en 1792.

En 1792 se inaugura el Real Gabinete de Máquinas del que es nombrado Director, publicando el primer catálogo de modelos, planos y manuscritos que contiene 270 máquinas, 358 planos y más de 100 memorias con 92 gráficos, diseñados todos ellos en su estancia en París.

Posteriormente, en 1795 presenta en Inglaterra el diseño de la máquina para cortar la hierba de los canales navegables. Ya de regreso a España, es nombrado Director General de Puertos y Caminos, y en 1802 se crea la primera Escuela de Ingenieros de la que fue su primer Director.

\section{Objetivos}

El objetivo principal de esta comunicación es la restitución digital de un modelo $3 \mathrm{D}$ preciso así como la documentación geométrica del ingenio desarrollado, obteniendo diversas perspectivas de cada uno de los sistemas y elementos principales.

La investigación en marcha es el principio de una más completa en el que se abordarán otros aspectos relacionados como la realización de una recreación virtual y el análisis estático realizado sobre el modelo 3D con herramientas de ingeniería asistida por ordenador, mostrando en estudios previos la estructura a seguir (Villar-Ribera et al. 2011), o la impresión 3D (fabricación aditiva) del modelo obtenido por técnicas CAD.

\section{Material y Métodos}

El material de partida ha sido únicamente la información disponible en el proyecto digital Agustín de Betancourt de la Fundación Canaria Orotava de Historia de la Ciencia promovido por el Centro de Estudios Históricos de Obras Públicas y Urbanismo (CEHOPU), el Centro de Estudios y Experimentación de Obras Públicas (CEDEX), el Ministerio de Fomento y la Fundación Juanelo Turriano (Proyecto Digital Betancourt 2016)

En particular, la presente investigación se ha realizado apoyándose en el material que aparece en dicho sitio web (Expediente de la máquina para cortar hierba de los canales navegables 2016)

En dicha web, se muestra la información relacionada con dicho expediente titulado: Description d'une machine à couper les roseaux et les autres plantes aquatiques qui obstruent beaucoup de Canaux et de rivières navigables, datado de 1800 y con el número de manuscrito 2420 .

La lámina realizada a escala en piés, se presenta en formato vertical dispuesta en tres franjas: arriba, se observa el mecanismo en la barca en vista de alzado, en el centro se observa la planta superior, y abajo, el mecanismo funcionando en una ribera y la cuchilla cortadora (Fig. 1)

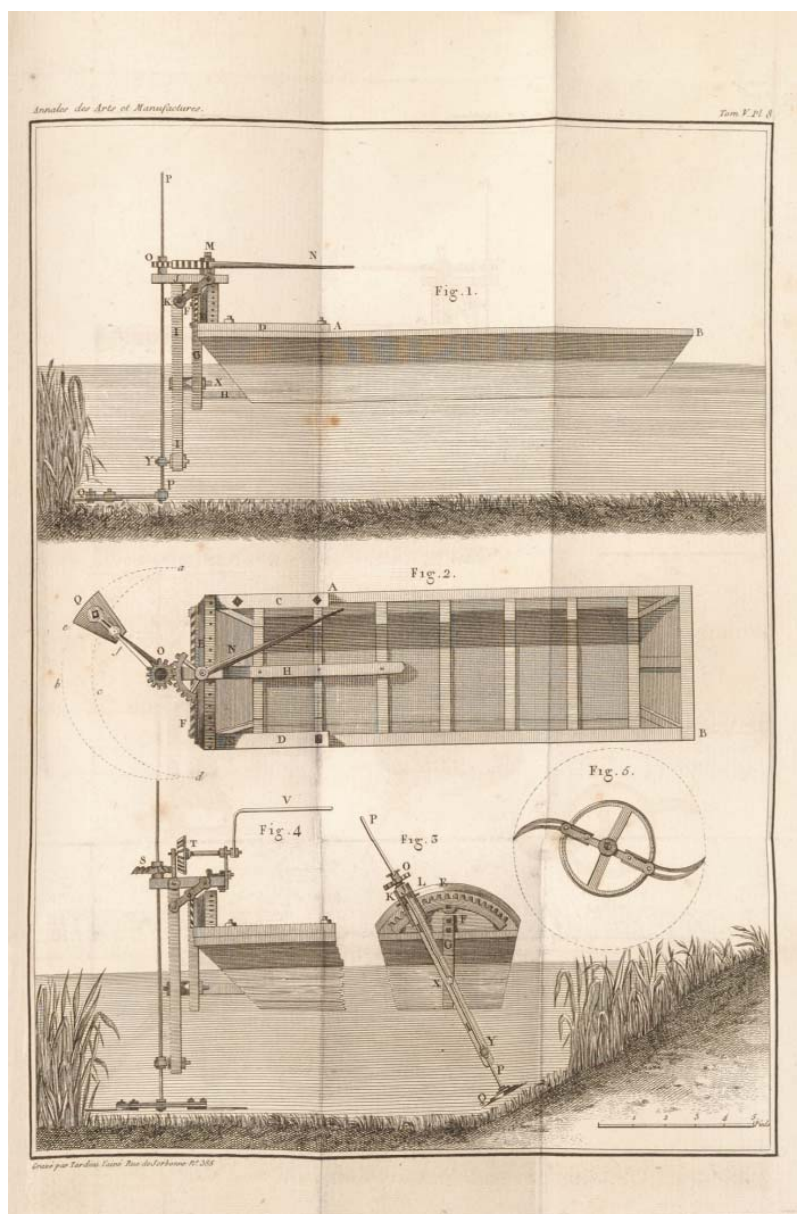

Figura 1: Vistas principales de la máquina. Imagen de la "Fundación Canaria Orotava de Historia de la Ciencia".

La metodología empleada ha sido la restitución digital del modelo 3D utilizando como herramienta Solid Edge ST7, software paramétrico de diseño asistido por ordenador desarrollado por Siemens AG, y cuya última versión estable data de julio de 2014 (Tickoo 2015).

Su kernel de modelado geométrico era inicialmente ACIS, pero fue cambiado a Parasolid desarrollado por Siemens PLM Software, y es utilizado como motor geométrico de otras muchas herramientas de CAD (del inglés, Computer-Aided Design).

\section{Resultados y discusión}

A la hora de realizar el modelo tridimensional de la máquina en estudio se han tenido en cuenta diversas consideraciones que se detallan a continuación.

La información de partida, como se ha podido observar anteriormente, no sigue los estándares modernos, es decir, no se pueden considerar las láminas como planos de fabricación tal y como se entienden en la actualidad. Además, no están sujetos a ninguna normativa, ya que en su momento éstas no existían. Cada ingeniero representaba sus invenciones como consideraba más conveniente. Se trata, por tanto de representaciones 
conceptuales del diseño que no resuelven completamente las dificultades de fabricación y funcionamiento. Así pues, se dispone de varias representaciones con pequeñas incongruencias tanto entre dimensiones de algunos elementos como en la disposición geométrica de los mismos. Por tanto, al realizar las representaciones geométricas ha sido necesario realizar algunas hipótesis tanto de dimensiones como de geometría.

Para realizar el modelado se han considerado tres partes diferenciadas: en primer lugar, los elementos solidarios a la embarcación y de unión (tornillos, pasadores, roblones), así como la propia embarcación; en segundo lugar, el sistema destinado a orientar y posicionar el aparato de corte respecto del fondo del canal, y por último, los elementos que constituyen el propio sistema de corte.

A la hora de estudiar las uniones entre las piezas se han considerado fundamentalmente uniones atornilladas, y en algunos casos, el uso de roblones entre piezas metálicas. Para la elección de las dimensiones de los tornillos, y teniendo en cuenta que en la época de la que estamos tratando no existía como se ha expuesto normalización, se han considerado valores aproximados a partir de las dimensiones observadas en las láminas, tratando de minimizar la variedad de tornillos distintos empleados en toda la máquina. Asimismo, no se ha modelado la rosca en dichas uniones atornilladas al no ser necesario ni interesante su estudio de cara al funcionamiento de la máquina.

Tampoco se han tenido en consideración las tolerancias de montaje entre las diferentes piezas, ya que debido al tipo de fabricación artesanal, los ajustes entre las piezas se harían por el propio artesano durante la fabricación propiamente dicha.

Por otro lado, la geometría de todas las piezas se ha modelado de forma paramétrica, esto es, todas las dimensiones están regidas por una variable modificable asociada y todas las relaciones geométricas están establecidas de forma independiente y se verifican ante cualquier modificación de la geometría. Esto permite que cualquier modificación en el diseño sea mucho más sencilla, pudiéndose probar diferentes variantes muy fácilmente. La elección de las dimensiones paramétricas y de las relaciones se ha realizado previendo posibles modificaciones y teniendo en cuenta la magnitudes más interesantes de cara a la fabricación de las piezas.
Asimismo, de cara a dicho proceso de modelado, se han divido la invención en diferentes sistemas: modelado de elementos solidarios a la embarcación, sistema de posición y orientación, y sistema de corte de las hierbas.

Para obtener el ensamblaje final del conjunto, se ha buscado mantener los grados de libertad entre los diferentes elementos que permitieran el movimiento real de los mismos, realizándose gracias al concurso del software Keyshot 5 (Fig. 2).

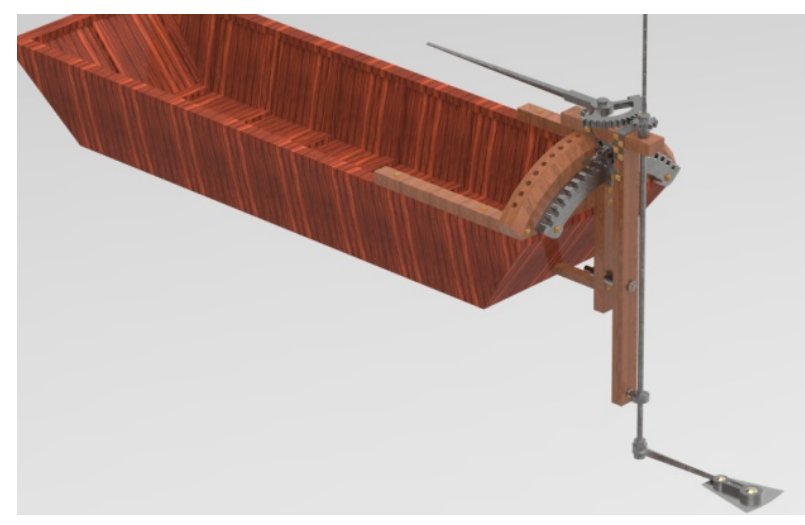

Figura 2: Imagen fotorrealista del conjunto ensamblado.

\section{Agradecimientos}

Este trabajo se ha desarrollado en el seno del proyecto de investigación titulado: "El patrimonio histórico de Agustín de Betancourt: estudio integral de las aportaciones a la ingeniería civil desde la ingeniería gráfica para su puesta en valor y difusión" (HAR201563503-P), financiado por el Ministerio de Economía y Competitividad, dentro del Programa Estatal de Fomento de la Investigación Científica y Técnica de Excelencia, Subprograma Estatal de Generación del Conocimiento, en el marco del Plan Estatal de Investigación Científica y Técnica y de Innovación 20132016, y por el Fondo Europeo de Desarrollo Regional (FEDER).

Asimismo queremos agradecer muy sinceramente a la Fundación Canaria Orotava su disponibilidad y autorización a utilizar el material de su web, en la persona del que fue su Director, Sergio Toledo Prats, así como en la persona de María Rodríguez Hernández que ha sido la persona que ha gestionado toda la información necesaria.

\section{Referencias}

EXPEDIENTE DE LA MÁQUINA PARA CORTAR LA HIERBA DE LOS CANALES NAVEGABLES, 2016. Disponible en: http://fundacionorotava.es/pynakes/lise/betan coupe fr 01 1800/ [12/15, 2015].

PROYECTO DIGITAL BETANCOURT, 2015. Disponible en: http://fundacionorotava.es/betancourt [04/16, 2016].

TICKOO, S. 2015. Solid Edge ST7 for designers. Lafayette (Indiana, EE.UU): Purdue University Calumet. 752 páginas.

VILLAR-RIBERA, R., HERNÁNDEZ-ABAD, F., ROJAS-SOLA, J.I., y HERNÁNDEZ-DÍAZ, D., 2011. Agustin de Betancourt's telegraph: Study and virtual reconstruction. Mechanism and Machine Theory, 46(6), pp. 820-830. DOI: 10.1016/j.mechmachtheory.2011.01.008. 


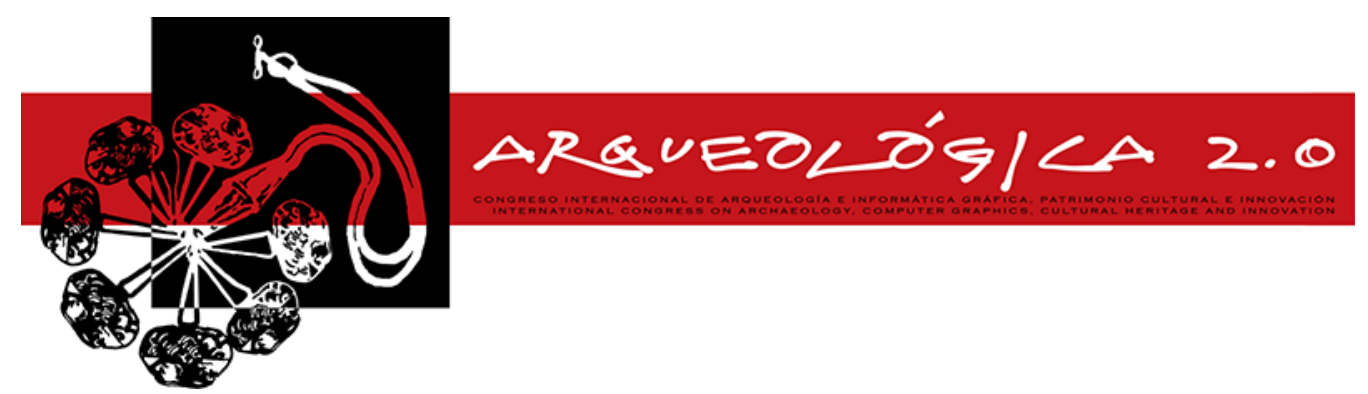

Proceedings of the $8^{\text {th }}$ International Congress

on Archaeology,

Computer Graphics,

Cultural Heritage and Innovation

'ARQUEOLÓGICA 2.0'

in Valencia (Spain),

Sept. $5-7,2016$

\title{
A PERSPECTIVE ON PROCEDURAL MODELING BASED ON STRUCTURAL ANALYSIS
}

\author{
UNA PERSPECTIVA SOBRE MODELADO PROCEDURAL BASADO EN ANALISIS ESTRUCTURALES \\ Josep Lluis Fita*, Gonzalo Besuievsky, Gustavo A. Patow \\ ViRVIG, Universitat de Girona, Girona, Spain. joseplluis.fita@gmail.com; gonzalo@ima.udg.edu; gustavo.patow@udg.edu
}

\begin{abstract}
:
We introduce a study focused on procedural modeling papers that use methods of structural analysis, especially in its application to historic buildings such as churches and cathedrals. Moreover, we have taken a geometric structure of one of these papers and studied their behavior in a generic simulation tool, thus showing the feasibility of its analysis with non-specialized tools.
\end{abstract}

Key words: procedural modeling, virtual historical buildings, masonry structures, stable structures.

\section{Resumen:}

Introducimos un estudio centrado en aquellos trabajos de modelado procedural que utilizan métodos de análisis estructural, especialmente en su aplicación para edificios históricos como iglesias y catedrales. Por otra parte, hemos tomado una estructura geométrica de uno de estos artículos y estudiado su comportamiento en una herramienta de simulación genérica, mostrando su factibilidad para realizar análisis con herramientas no especializadas.

Palabras clave: modelado procedural, edificios históricos virtuales, estructuras de ladrillos, estructuras estables.

\section{Introduction}

Modeling urban environments is becoming popular in computer graphics research for application software. Recently, some researchers have found some ways to explore methodologies that combine visual results with structural analysis, especially on masonry structures. For this reason, we have focused our perspective analysis on this kind of methodologies with the aim of knowing their influence in the virtual environment creation. Thus, this paper describes an open perspective with the most suitable techniques for research about procedural modeling based on the structural stability studies, masonry structures and especially in those religious buildings built on the middle ages. Moreover, we made a structural analysis of feasibility, through a freely physical simulator tool, of a geometrical structure provided by one of these works (Panozzo et al. 2013), which was obtained after a sound procedural methodology.

\section{Perspective on Procedural Modelling}

This section discusses about procedural modeling techniques that are suitable for modeling buildings.

\subsection{Procedural Modelling}

Müller et al. (2006) presented a methodology based on the concept of a shape grammar, which is based on a base rule called seed; with an iterative application of transforming rules. Each rule starts with the specification of a label, called predecessor, where an input shape (part of a building) is selected, and then the rules themselves, called successors, change the geometry and, consequently, the shape of the building. Indeed, when we add a new rule successor to a given predecessor, we are actually creating a graph of rules (Patow 2012). Recently, Kelly and Wonka (2011) introduced a methodology where the concept of a generalized extrusion is applied on a building through a set of profiles. Talton et al. (2011) describe a methodology where a Markov Chain Monte Carlo system is used to create variations on a given rule set, and apply their technique to complex structures like vegetation or buildings. Later, Musialski, Wimmer and Wonka (2012), based their work on an interactive framework that use images for the building facade modeling. Following a similar approach, Krecklau and Kobbelt (2012) created a tool designed for ordinary users without any programming knowledge that manipulates the procedural grammars in a transparent way when a building is created or modified. Although,

`Corresponding Author: Josep Lluis Fita, joseplluis.fita@gmail.com 
the methodologies presented represent a great advance, they still pose some problems for the non-expert users. In that line, some researchers presented visual editing systems, like the one described by Patow (2012), or the one simultaneously developed by Procedural, now part of Esri, for their CityEnigne system (City Engine 2016). Moreover, these works described above, have ignored any sort of structural problems, crucial for ancient buildings like churches. This is the main reason because we will focus in those works based on structural analysis tools too.

\subsection{Structural Masonry Buildings}

Whiting et al. (2009) introduced one of the first works to describe a method based on masonry structures such as cathedrals or stone bridges, for procedural modeling. Following the previous work, Whiting (2011) presented an extension with a new set of methods for allowing the study of the building soundness through the integration of architecture design and structural analysis. Recently, Whiting et al. (2012) introduced a method to analyze a given masonry building geometry through their vertex coordinates. Once the geometry is loaded, the aim of the method is to create a new stable structure through the analysis of the stability gradient, according to constraints previously introduced by the user. Following another way, Panozzo et al. (2013), introduced an algorithm that does not require any structural knowledge from users because it automatically generates a 3D masonry structure from an input shape (an input patch, like a NURBS surface) and a given height. Later on, Deuss et al. (2014), introduced a new algorithm that processes all kind of masonry models, from historical buildings to freeform ones. Initially, it takes a masonry structure built in rigid blocks and transforms this into an ordered sequence, where each block can be added to the construction process by the use and placement of chains and hooks.

\section{Static Study of a Masonry Structure}

In the medieval period, a critical key stage for the construction of cathedrals was the vault. In that time, a trial and error brick fitting procedure was used, allowing them to build vaults without mortar because the vault self-supported its weight through friction. Following a similar reasoning, we have taken a model for our structural tests, the vault from the work of Panozzo et al. (2013). To perform the structural tests of this vault, we have chosen freely available commercial software like Houdini from SideFX (2016) and the open source Bullet solver (incorporated by default in Houdini). Moreover, we have built the geometry that supports the masonry vault. So, with the aim of building a structure that resembling a Romanesque church, we built three supporting walls of voussoirs (blocks) with a width of 2 meters. Given this basic structure, we placed the imported vault geometry (Panozzo et al. 2013) on top of it. In this case, the voussoirs were added without mortar among them, following Panozzo et al.'s specifications (Fig. 1).

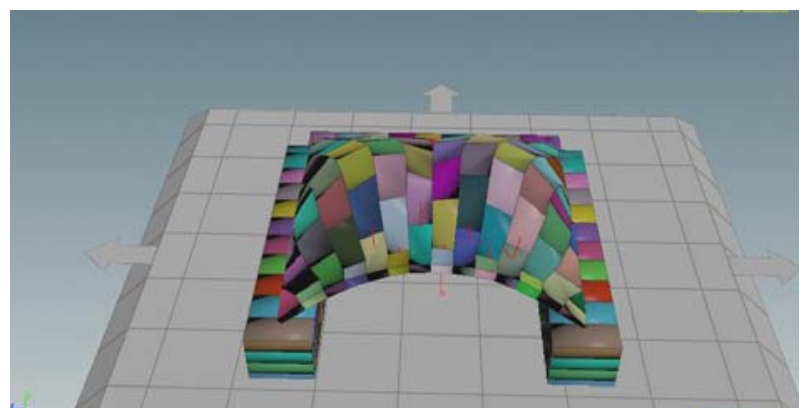

Figure 1: Our vault over the walls that simulate a Romanesque church.

At this point, we have run our structural simulation. As a result of it, we can observe that the vault collapses. In order to improve stability, we adjusted (increased) the value of the so called "rotational stiffness" for the vault until it worked in the simulation. At this point, we begin reducing the width of the walls until $1.5 \mathrm{~m}$ in an iterative way. We found out that the vault supports their weight with the new wall parameters, but we observed a few cracks (in our case, represented by some loose stones) on the walls. We continued decreasing the walls width until a value of $1.2 \mathrm{~m}$, where the number of the cracks on the walls increased, as expected. Beyond this point, the whole structure would fall into pieces then, we added buttresses to the entire structure obtaining better results: the vault now supported its own weight and the walls did not show any damage in their structure. At this point, we decided to reduce the width of our walls again, until $0.5 \mathrm{~m}$. With these wall parameters, we still obtained good results for the structure (i.e., the vault and the walls).

\section{Perspective Work}

With the previous analysis, we have obtained a basis for following the research about procedural modelling in the context of sound masonry structures. Also, we plan to focus on the construction, structure, form and general evolution of masonry buildings, like medieval churches.

\section{Conclusions}

We have reviewed the state-of-the-art literature on techniques involving procedural modeling tools that incorporate soundness analysis. From this analysis we found that only a handful of papers deal with this complex, but crucial aspect of modeling. As part of an ongoing experimental study, we have tested the statics of a structure that combines the geometry of the walls and an imported vault where the methodology proposed by Panozzo et al. (2013), have been validated under different simulation conditions.

\section{Acknowledgements}

This work was partially funded by the TIN2014-52211C2-2-R project from Ministerio de Economía y Competitividad, Spain.

\section{References}

CITY ENGINE, E., 2016. [online] Esril.com. Available at: http://www.esril.com/software/cityengine/index.html [Accessed 6 Feb. 2016]. 
DEUSS, M., PANOZZO, D., WHITING, E., LIU, Y., BLOCK, P., SORKINE-HORNUNG, O. and PAULY, M., 2014. Assembling Self-Supporting Structures. p.1. DOI: 10.1145/2661229.2661266

KELLY, T. and WONKA, P., 2011. Interactive architectural modeling with procedural extrusions. TOG, 30(2), pp.1-15. DOI: $10.1145 / 1944846.1944854$

KRECKLAU, L. and KOBBELT, L., 2012. Interactive modeling by procedural high-level primitives. Computers \& Graphics, 36(5), pp.376-386. DOI: 10.1016/j.cag.2012.03.028

MÜLLER, P., WONKA, P., HAEGLER, S., ULMER, A. and VAN GOOL, L., 2006. Procedural modeling of buildings. TOG, 25(3), p.614. DOI: 10.1145/1141911.1141931

MUSIALSKI, P., WIMMER, M. and WONKA, P., 2012. Interactive Coherence-Based Façade Modeling. Computer Graphics Forum, 31(2pt3), pp.661-670. DOI: 10.1111/j.1467-8659.2012.03045.x

PANOZZO, D., BLOCK, P. and SORKINE-HORNUNG, O., 2013. Designing unreinforced masonry models.TOG, 32(4), p.1. DOI: $10.1145 / 2461912.2461958$

PATOW, G., 2012. User-Friendly Graph Editing for Procedural Modeling of Buildings. IEEE Comput. Grap. Appl., 32(2), pp.66-75. DOI: 10.1109/MCG.2010.104

SIDEFX, HOUDINI, 2016. [online]. Available at: http://www.sidefX.com/, [Accessed 6 Feb. 2016].

TALTON, J., LOU, Y., LESSER, S., DUKE, J., MĚCH, R. and KOLTUN, V., 2011. Metropolis procedural modeling. TOG, 30(2), pp.1-14. DOI: 10.1145/1944846.1944851

WHITING, E., OCHSENDORF, J. and DURAND, F., 2009. Procedural modeling of structurally-sound masonry buildings. TOG, 28(5), p.1. DOI: 10.1145/1661412.1618458

WHITING, E., 2011. Design Of Structurally-Sound Masonry Buildings Using 3D Static Analysis. PhD. MIT.

WHITING, E., SHIN, H., WANG, R., OCHSENDORF, J. and DURAND, F., 2012. Structural optimization of 3D masonry buildings. TOG, 31(6), p.1. DOI: 10.1145/2366145.2366178 


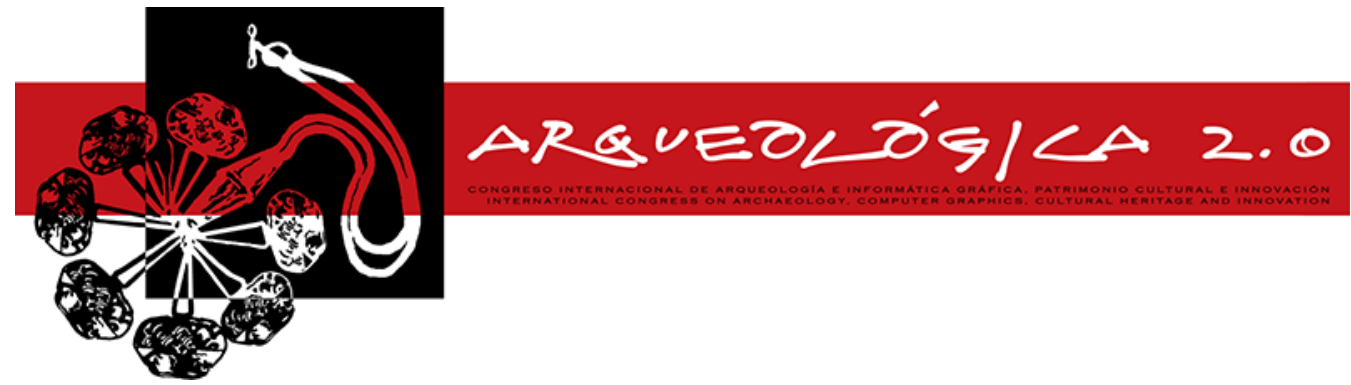

Proceedings of the

$8^{\text {th }}$ International

Congress on

Archaeology, Computer

Graphics, Cultural

Heritage and Innovation

'ARQUEOLÓGICA 2.0'

in Valencia (Spain),

Sept. $5-7,2016$

\title{
3D VISIBILITY ANALYSIS AS A MEAN TO VALIDATE ANCIENT THEATRE'S RECONSTRUCTIONS
}

\author{
ANÁLISIS DE VISIBILIDAD EN 3D PARA VALIDAR LAS RECONSTRUCCIONES DE LOS TEATROS ANTIGUOS \\ Maria Cristina Manzetti \\ School of Architecture, Technical University of Crete, K4 Building Campus, 73100 Chania, Greece. mmanzetti@isc.tuc.gr
}

\begin{abstract}
:
Correct interpretation of lost monuments is something really craved from an archaeological point of view but most of the time it is also very hard to obtain. In recent years, Virtual Archaeology and 3D modelling are providing valid instruments to facilitate the comprehension of ancient scenarios, and new input to investigate different aspects of the past. A new methodology is presented in this paper in order to achieve a high reliability of reconstruction of architectural elements of the large Roman theatre of Gortyn in Crete, through 3D visibility analysis.
\end{abstract}

Key words: 3D visibility analysis, 3D modelling, virtual archaeology, Roman theatre, Gortyn, Crete.

\section{Resumen:}

La correcta interpretación de los monumentos perdidos es algo realmente anhelado desde un punto de vista arqueológico, pero difícil de obtener en la mayoría de los casos. Desde hace unos años la Arqueología Virtual y el modelado 3D se consideran instrumentos válidos para facilitar la comprensión de los escenarios antiguos, permitiendo investigar aspectos diferentes del pasado. En este artículo se presenta una nueva metodología para conseguir una elevada fiabilidad en la reconstrucción de los elementos arquitectónicos del gran teatro Romano de Gortina, en Creta, por medio del análisis de la visibilidad en 3D.

Palabras clave: análisis de visibilidad en 3D, modelado 3D, Arqueología virtual, teatro Romano, Gortina, Creta.

\section{Introduction}

During the centuries, the discipline of archaeology has developed theories, methods and instruments whose first aim is to understand and reconstruct the past. In more recent time, Virtual Archaeology gives the possibility to visualize and interact with the past, but above all it can be useful to verify hipothesis and reconstructions if used together with well established methodology such as archaeological reports, written sources, plans and pictures, plus geophysical prospection and 3D modelling.

GIS is widely used in archaeology since many years, above all to study ancient landscapes. Now, with the introduction of 3D spatial analysis tools (e.g. 3D analyst toolkit in ArcGis), is also possible to analyze 3D archaeological environments. In this study, visibility analysis has been done for five 3D models, representing different hypothesis about the architectural reconstruction of the large Roman theatre of Gortyn, in order to know which is the most realistic one, verifying the visibility of the stage from observer points placed in the cavea. The 3D model with the best visibility according to the analysis will be further verified by virtual acoustics.

\section{Methodology and preliminary results}

The large theatre placed on the south-east slopes of the acropolis of Gortyn was modelled through the software 3D Studio Max 2013 and several reconstructions have been made taking into account different characteristics:

1. The first $3 \mathrm{D}$ model, taken as reference reconstruction for the rest, is the result of the integration and interpretation of three different plans (one by Belli, end of XVI century, one by Falkener (1854), midst of XIX century, and one by Taramelli, beginning of $X X$ century), the section of Taramelli (1902), geophysical prospection (Sarris and Papadopoulos 2009), orthophoto, Vitruvian rules (Pollione 29-23 a.C.), descriptions of travellers and scholars (Manzetti et. al. 2015).

2. In the second model the stage has been placed closer to the cavea because in the first model it is in an unusual position, indicated by Belli (Beschi 1999), namely too far from the seating area.

3. For the third model, the first one has been used modifying the wall of the diazoma and making it $1,40 \mathrm{~m}$ 
higher. This wall is often higher than the one indicated by Taramelli, because in many ancient theatres arcade are opened in that wall to allow the entrance of the spectators and actually these possible arcades are testified by Barresi (2004). The difference height of this wall is also evident in a picture within the paper about the current excavations of the theatre, but it does not record any measure and it does not show any arcade (Kanta et.al. in press).

4. Another model was constructed as a combination between the second and the third, therefore with the stage and the diazoma's wall modified.

All these 3D models have been exported as .3DS files in order to easily import them in ArcScene as a multipatch shapefile (this application has been preferred to use 3D analyst tools of ArcGIS because it allows 3D visualization).

A grid indicating the observer's locations, at some of the spectators' seats, has been realized in AutoCad 2013 and then add to ArcScene catalog and export to shapefile. The grid consists of six rows of points, for a total of 133 observers, each one of them placed $0,75 \mathrm{~m}$ up the corresponding seat, that it is the height of the eyelevel of a seated man. It has been decided to experiment with only six rows of points, located in the most interesting areas of the theatre, because the process for the visibility analysis in ArcGIS is long time consuming and six rows are enough to verify the quality of visibility, considering that from the large part of the central area of the theatre, the stage is obviously visible. In particular, it is important to examine the visibility conditions of the spectators seating at the sides of the building, whereas other rows are placed also in the central area to compare the results among different seats. The following step was to edit a line, approximately at the centre of the stage that covers almost the full length of the stage, placed at $1,60 \mathrm{~m}$ from the floor of the stage; this line represents the possible positions of different actors playing a performance, so it is the object observed by the grid's points. Subsequently, sight lines among the observers' locations and the line on the stage have been constructed through the "visibility" kit of 3D Analyst tool in ArcScene. This step is necessary in order to build the lines of sight (Fig. 1 ), that show through two different colours which spectators have a full visibility of the actors (green lines) and which have a partial visibility of it (red lines). In addition, the obstruction points have been also constructed: they mark which are the exact points which impede the complete visibility. In case of virtual architectural reconstructions based on uncertain data, this option is very useful because it gives the possibility to easily find the potential errors and modify the structure accordingly. In this specific case of study, obstruction points are, as expected, on the converging walls of the analemmata which cannot be made lower because they have to respect some safety measurements for spectators. Instead, the distance of the stage from the cavea has been easily modified to verify how it is possible to obtain a proper visibility.

This first procedure has been realized in order to have a 3D visualization of the line of sight: it allows to comprehend from which area of the theatre there is a total visibility and from which part there is a partial visibility, in order to decide which modifications could be necessary in the architectural structure of the building.

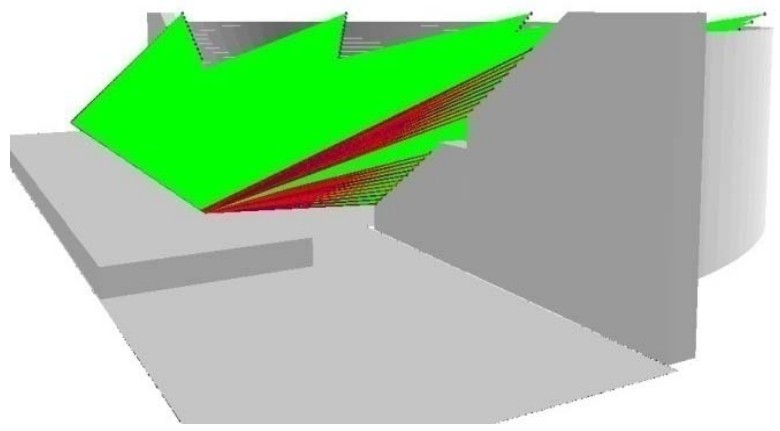

Figure 1: example of lines of sight of the model number 1 produced by $3 \mathrm{D}$ visibility analysis.

The second procedure that was employed in this research indicates the frequency of visibility of the theatre from the observers' locations and the result of the process is a raster with different colours representing the more and the less visible area. After having imported the .3DS file as a multipatch in ArcScene, a raster can be produced from it and used it, together with the grid, to process the visibility analysis. In this case, it is necessary to set the $Z$ offset of the grid with respect to the raster, that is $0,75 \mathrm{~m}$. This procedure produces a better output showing if the stage is actually visible from the large part of the spectators (in this case we are talking about the surface of the stage, we are not referring to the line representing the actors on the stage). In all the cases there is a high visibility of the stage from the selected seats, but it is clear that when the stage is farer (as indicated in Belli's plan) and the wall of the diazoma higher (as sustained by Barresi and by recent excavations), the full visibility (blue colour) expands at an even larger part of the stage. Figure 2 shows that the purple-fuchsia colour, indicating a partial level of visibility for a range of 103-118 spectators, occupies a very small area (the upper corners of the stage), while the blue colour (referring to the full number of spectators) is spread almost all over the stage.

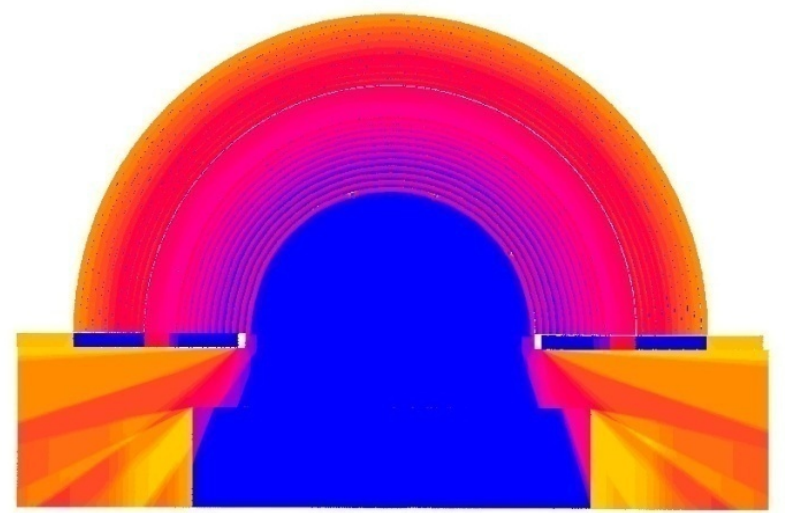

Figure 2: 3D visibility analysis' result of model n.3. The scale of colours indicates different frequency of visibility of the area of the theatre by selected seats in the cavea: light yellow means not visible by anyone, blue means visible from everyone.

Having established that the reconstruction with the stage far from the cavea and with the wall of the diazoma $2 \mathrm{~m}$ high (n. 3) can be the most correct one according to 3D visibility analysis, another test has been done using this 
reconstruction but with a higher stage. The first stage has been modelled with a height of $1,30 \mathrm{~m}$ because of the indications of Vitruvio about the architecture of the Roman theatres, and because that height looks coherent with the rest of the structure. But if we consider the other Roman theatres with converging analemmata (as in Gortyn's theatre) in Greece and Asia Minor, they have a much higher stage, from 2,13 to $3,55 \mathrm{~m}$ (Aphrodisia, Tralles, Ephesus, Miletus, Sagalassus). Then a stage of $2,75 \mathrm{~m}$ (average of the heights of the above-mentioned theatres) was add to this reconstruction (in place of the first one), and a new 3D visibility analysis has been processed, and its result indicates that the whole area of the stage is visible only from a range of $112-118$ spectators and consequently not visible at all by 21-26 spectators.

Finally, the 3D model realized in the previous work has been modified accordingly to the new results, making the wall of the diazoma $2 \mathrm{~m}$ high instead of $0,60 \mathrm{~m}$ as indicated in Taramelli's section.

\section{Conclusion and future works}

This paper has highlighted the importance of the accuracy in projects of Virtual Archaeology and has suggested the use of 3D visibility analysis as an additional approach to accomplish such a goal especially when we are dealing with historical architectural reconstructions. The 3D visualization gives the possibility to observe our hypothesis and have a shape which is approaching a more realistic representation. The observation of a 3D graphical depiction of our idea helps to visualize problems and inconsistencies of the reconstructions. Therefore it is necessary and fundamental studing and analyzing architectural reconstructions in a fully $3 \mathrm{D}$ environments. The introduction of 3D visibility analysis enhances such kind of studies making possible the identification of potential obstacles in the visualscape and then understanding what is incoherent and misfitting in the reconstruction.

The results of this research show how 3D visibility analysis can easily and quickly sustain an interpretation and how significantly can support substantial modifications to a model.

The large Roman theatre of Gortyn has been taken as the pilot object of this study, but this is a method that can be applicable to all the ancient theatres and more generally to the ancient buildings reserved to public performances, such as odeons, amphitheatres, stadiums and circuses.

The next goal will be obtaining an additional validation or further information about the architectural structure of this theatre through the acoustics analysis of its $3 D$ model.

Furthermore, if the acoustic analysis will confirm the position of the stage so far from the cavea, new archaeological questions will be formulated. Only two Roman theatres can be assimilated to the large one of Gortyn concerning the peculiar location of the stage: the one of Pola (Croatia) and the other of Bovillae (Italy), (Sear 2006). Both of them are localized on natural slopes and both are half digged in the rock and half built on substructures, exactly like the theatre object of this study.

\section{Acknowledgements}

This research was supported by the Greek State Scholarship Foundation (I.K.Y.) under the grant for post graduated study of foreigners students in Greece.

I would like to thank Dr. Apostolos Sarris for his helpful suggestions both during my research and about this paper.

\section{References}

BARRESI, P., 2005. Gortyna: la sistemazione del teatro all'Acropoli in età Severiana. In: M. LIVIADOTTI and I. SIMIAKAKI eds., Creta Romana e proto-bizantina, Atti del Congresso internazionale (Herakleion, 23-30 September 2000). Padova: Bottega d'Erasmo, pp. 557-572.

BESCHI, L., 1999. Onorio Belli a Creta: un manoscritto inedito della scuola archeologica italiana di Atene (1587). Atene: Scuola Archeologica Italiana di Atene 95 pages.

FALKENER, E., 1854. A description of some important theatres and other remains in Crete, from a ms. History of Candia by Onorio Belli in 1856. Supplement to the Museum of Classical Antiquities. London: Trübner \& Co. 63 pages.

KANTA, A., LIRINTZIS, A. and NIKOLOPOULOU, K., 2013. To megalo theatro tis Gortina: ta prota apotelesmata. In: Proceedings of the I International Gortyna Conference 2012, Gortyn, Greece, pp. 91-99.

MANZETTI, M.C., PARTHENIOS, P. and SARRIS, A., 2015. Integrating traditional methods with new technologies. Architectural study of the large theatre at Gortyn. In: Proceedings of the Conference on Digital Heritage, International Congress 2015, Granada, Spain, 2, pp. 173-176. DOI: 10.1109/DigitalHeritage.2015.7419480.

POLLIONE, M.V., 29-23 a.C. De Architectura, book 5. Translated by MORRIS H.M., 1914: Vitruvius the ten books on architecture. London: Humphrey Milford 321 pages. Available: http://www.simeac.net/publications/vitruvarchitecture/\#Page 137

SARRIS, A. and PAPADOPOULOS, N., 2009. Techniki ekthesi tis geofisikis ereunas \& chartografisis tou chorou tou archaiou theatrou tis Gortinas. Herakleion.

SEAR, F., 2006. Roman theatres. An architectural study. New York: Oxford University Press 465 pages.

TARAMELLI, A., 1902. Cretan expedition: XXI Gortyna. American Journal of Archaeology, 6, 2, pp. 101-165. Boston: Archaeological Institute of America. 


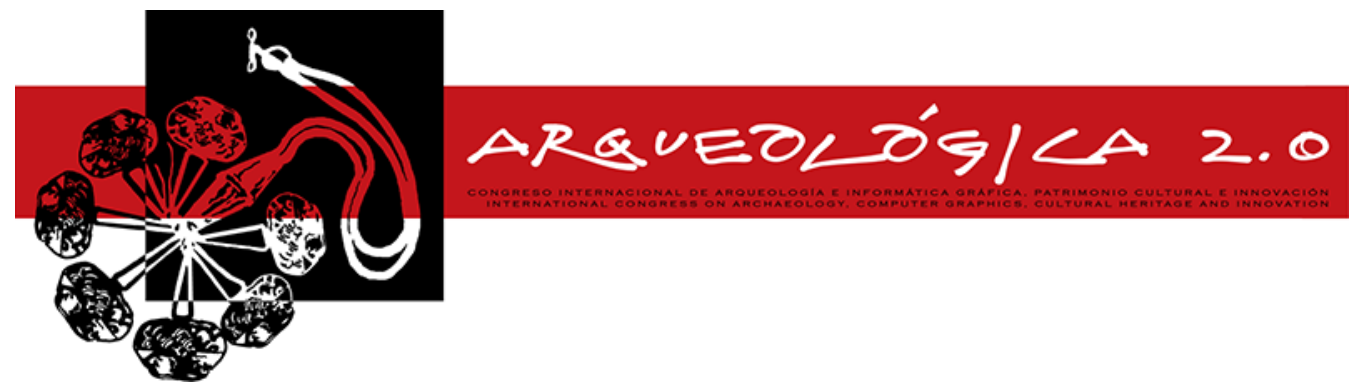

Proceedings of the $8^{\text {th }}$ International Congress

on Archaeology,

Computer Graphics,

Cultural Heritage and Innovation

'AROUEOLÓGICA 2.0'

in Valencia (Spain),

Sept. $5-7,2016$

\title{
ALGUNOS APUNTES SOBRE LA DIGITALIZACIÓN Y LA RECONSTRUCCIÓN VIRTUAL DEL CASTRO DE SAN CHUIS (ALLANDE, ASTURIAS, ESPAÑA)
}

\author{
SOME NOTES ON THE DIGITALIZATION AND THE VIRTUAL RECONSTRUCTION OF SAN CHUIS HILLFORT \\ (ALLANDE, ASTURIAS, SPAIN)
}

Juana Molina*, Jesús F. Jordá

Departamento de Prehistoria y Arqueología, Facultad de Geografía e Historia. Universidad Nacional de Educación a Distancia (UNED). Senda del Rey 7, 28040 Madrid, España. juanamsalido@gmail.com; jijorda@geo.uned.es

\begin{abstract}
:
With the firm conviction that current Archaeology needs to use all the tools that computer science provides, we have developed a project of mechanization and structuring of all the information gathered from the different campaigns of excavation carried out in San Chuis hillfort (Allande, Asturias, Spain). In order to do it, we have developed the Spatial Data Infrastructure (SDI) of the hillfort, for subsequently proceed to the virtualization of it.
\end{abstract}

Key words: Cyber-archaeology, SDI, 3D reconstruction, Hillforts, Iron Age

\section{Resumen:}

Con el firme convencimiento de que la Arqueología actual necesita servirse de todas las herramientas que le proporciona la informática hemos desarrollado un proyecto de mecanización y estructuración de todos los datos recogidos en las diferentes campañas de excavación llevadas a cabo en el castro de San Chuis (Allande, Asturias, España). Para ello hemos desarrollado la Infraestructura de Datos Espaciales (IDE) del castro, para posteriormente, proceder a la virtualización del mismo.

Palabras clave: ciber-arqueología, IDE, reconstrucción 3D, castros, Edad del Hierro

\section{La IDE del castro de San Chuis}

El castro de San Chuis se encuentra situado al sur de la aldea de San Martín de Beduledo (Allande, Asturias, España) ocupando el vértice de un pico troncocónico cuya altitud máxima es de $781 \mathrm{~m}$ sobre el nivel del mar. La superficie excavada alcanza los $1600 \mathrm{~m}^{2}$ siendo su extensión total de $37000 \mathrm{~m}^{2}$. Su larga ocupación se articuló en tres fases principales: la primera fase, Primera Edad del Hierro, se desarrolla entre los años 890 y 530 cal. BC.; la segunda fase, Segunda Edad del Hierro, tuvo una duración máxima estimada de 670 años; la tercera fase, de ocupación romana, se desarrolla desde los comienzos del siglo I d.C. hasta el abandono del castro en un momento impreciso.

Sobre los resultados de las diferentes excavaciones han cristalizado varios proyectos. El último se enmarca en la tesis doctoral ya finalizada y defendida de uno de los firmantes (JMS). En dicha tesis, nos propusimos recoger toda la información obtenida en las excavaciones arqueológicas de los años 60 y 80, y mecanizarla y estructurarla a fin de elaborar la IDE (Infraestructura de
Datos Espaciales). Una vez elaborada la IDE realizamos el análisis espacial del registro arqueológico. Finalmente, reconstruimos virtualmente el castro de acuerdo con los conocimientos sobre la evolución de su arquitectura y de su urbanismo que teníamos. Buscábamos de forma primordial dotar de interoperabilidad a toda la información que habíamos reelaborado para que se encontrase en disposición de ser aprovechada con los medios actuales.

Para desarrollar la IDE hemos partido de dos tipos de material: el generado en excavaciones e investigación en formato papel, y el álbum fotográfico. La primera tarea que emprendimos fue la actualización del plano en formato CAD ya existente, reintegrándolo en un Sistema de Información Georreferenciado (SIG), de acuerdo con el Datum Geodésico ETRS 89, vigente en España actualmente y dotándolo de coordenadas UTM. Después, procedimos a la elaboración de nuevos planos y de toda una planimetría descriptiva de la estratigrafía del castro (formato CAD). Además, iniciamos el desarrollo de una base de datos general en la que incluimos tablas para catalogar tanto el registro

"Corresponding Author: Juana Molina, juanamsalido@gmail.com. 
arqueológico como las Unidades Estratigráficas y las Unidades Estratigráficas Murarias.

Con la integración de nuestro plano en un sistema SIG no solo dotábamos de coordenadas todas las estructuras que aparecían en él, sino que además, este plano estaría en condiciones de proporcionar las coordenadas de cualquier punto que incluyéramos en el mismo. Con este pensamiento nos dispusimos a situar los puntos representativos de los elementos del registro en el plano y restituirlos en su antigua posición con el fin de levantar planos de distribución de materiales tanto por campañas, como por tipos, y proceder a la ejecución de un análisis tanto macro como micro espacial del registro. Para realizar este trabajo partimos de dos tipos de información: por una parte planos milimetrados de las cuadrículas excavadas con los elementos del registro representados en ellos mediante puntos, y por otra parte las medidas de referencia $X$ e $Y$ de cada elemento encontrado durante la excavación, que se comenzaron a tomar en las campañas del 83 y del 85. De acuerdo con esto proyectamos dos formas de insertar los puntos en el plano. Si partíamos de los planos antiguos, el escaneo y posterior inserción de dichos planos en el general de cada campaña. Si partíamos de las medidas $\mathrm{X}$ e $\mathrm{Y}$ simplemente midiendo sobre el plano siguiendo la cuadrícula de referencia que se había realizado ya en 1980. Escaneamos por lo tanto todos los planos, completando una base documental de 112, de la que seleccionamos los indicados para nuestro propósito, es decir, los que representaban las cuadrículas de $4 \times 4$ con las estructuras dibujadas y/o los puntos de hallazgo de los diferentes materiales señalizados. Insertamos estos planos en el general (AutoCAD) de la campaña correspondiente mediante la aplicación Raster Design, que procesa las imágenes permitiendo trabajar con ellas, e implantarlas exactamente en el lugar y con la escala correcta. Trazamos los puntos y les asignamos el mismo número que tenían en el registro general de la base de datos, donde cada pieza está descrita exhaustivamente.

Por lo que a la base de datos se refiere, esta está compuesta de tres tablas: la tabla del registro arqueológico, la de las unidades estratigráficas (UE) y la de las unidades estratigráficas murarias (UEM). La tabla del registro está formada por 20 campos descriptivos y en total hemos incluido 3326 registros. A la hora de introducir los datos hemos seguido diferentes métodos según la situación con la que nos hemos encontrado. Para las campañas de 1962 y 63, en las que aún no existía cuadrícula de referencia, hemos realizado prácticamente una investigación bibliográfica, analizando todos los diarios donde los hallazgos venían descritos. A estos elementos solamente le hemos dado las siglas con el nombre del castro y el año de su descubrimiento, sin poder discriminar ni su cuadrícula ni sus niveles exactos. Evidentemente que esta parte del registro no se pudo reintegrar. En cuanto a las campañas de 1979 a 1986, utilizamos el inventario que ya existía en formato papel y donde ya sí se señalaba la cuadrícula y el nivel de aparición. Además, examinamos las cajas de materiales de las que disponíamos para revisar tanto los registros ya introducidos como los nuevos que hiciese falta introducir. Fotografiamos todo este material e hicimos un recuento de todos los fragmentos y piezas.
En cuanto a la tabla de las UE, la hemos diseñado con 14 campos descriptivos. Antes de introducir los datos, hemos reorganizado la estratigrafía centrándonos en la unidad física mínima identificada en los registros arqueológicos, la unidad estratigráfica (UE), de las que hemos establecido 105. Para determinarlas, hemos considerado todas las cuadrículas de las que poseíamos plano milimetrado analizando y redibujando en CAD todos los croquis descriptivos que teníamos, dotando de unidad estratigráfica cada nivel, de manera que hemos intentado dar unidades a todos los niveles, manchas, e irregularidades descritas o dibujadas. Además, hemos seguido las anotaciones del inventario de piezas, en el que se indicaba el nivel donde se habían encontrado, con lo que hemos podido determinar las capas existentes en algunas zonas excavadas pero de las que no había descripción ni croquis. En cualquier caso señalar que ha sido del todo imposible establecer todas las UE de un castro ya excavado. Junto a esta tabla, hemos desarrollado una tercera, la de las UEM, donde hemos descrito por medio de 14 campos las estructuras excavadas del castro. En lo tocante a la planimetría (formato CAD), hemos delineado tres grupos de planos: los descriptivos de la estratigrafía del castro; los descriptivos del propio medio físico del castro, entorno topográfico, geográfico y geológico, incluyéndose también sus características urbanísticas; los dedicados al análisis de la distribución de los materiales. Para divulgar esta información, hemos construido una página web.

\section{San Chuis virtual}

Señalar, en primer lugar, que hemos empleado como software de modelado 3D Blender y un PC doméstico, lo que conlleva limitaciones técnicas. Previamente al comienzo de la reconstrucción planteamos una hipótesis de trabajo guía a fin de conseguir la mayor exactitud posible, siempre considerando que es una deducción a partir de los estudios urbanísticos que se han hecho sobre el castro y de los datos que poseemos hasta ahora. En este sentido es importante tener presente la evolución urbanística que sufre el castro durante sus tres fases: en la primera Edad del Hierro, construcción a base de materiales vegetales y perecederos; en la Segunda Edad del Hierro, petrificación, amortización de varias estructuras y cerramiento de lugares semipúblicos, y construcción de la muralla de módulos; por fin, remodelación y construcción de nuevas estructuras rectangulares, sobre todo en el conocido como barrio alto o parte sur del castro, en la época romana. Al ser los datos que poseíamos para la Primera Edad del Hierro tan escasos, nos pareció imposible acometer la reconstrucción del castro en estas fechas, por lo que hemos desarrollado dos modelos, uno para la Segunda Edad del Hierro y otro para la época romana (Fig. 1).

Para diseñar las estructuras, hemos partido del plano de planta en AutoCAD con las medidas exactas y hemos ido elevando los muros, dándoles a las estructuras indígenas una media de altura de $1,40 \mathrm{~m}$. (al no encontrarse demasiados restos de derrumbe de muros junto a las estructuras cuando se excavaron, se pensó que en ningún momento debieron sobrepasar esa altura). Sin embargo, las techumbres sí que se presentan más elevadas dándole la altura necesaria a la vivienda. Solo hemos situado un poste central en las 
estructuras circulares en las que hemos encontrado restos de su existencia (E-3). En el caso de no existir, simplemente hemos puesto una cubierta cónica elaborada con estructuras en madera como es tradicional en estos casos. En el caso de la E-9 que es muy particular, hemos trazado una de las hipótesis posibles de reconstrucción: no existen trazas de que se usaran postes centrales por lo que el sistema de vigas debió de ser más sofisticado y fuerte, con un sistema de nervios de más envergadura. Hay que tener en cuenta que es una cubierta muy amplia ya que esta estructura es fruto de la amortización de dos antiguas viviendas circulares que se unieron en una durante la Segunda Edad del Hierro.

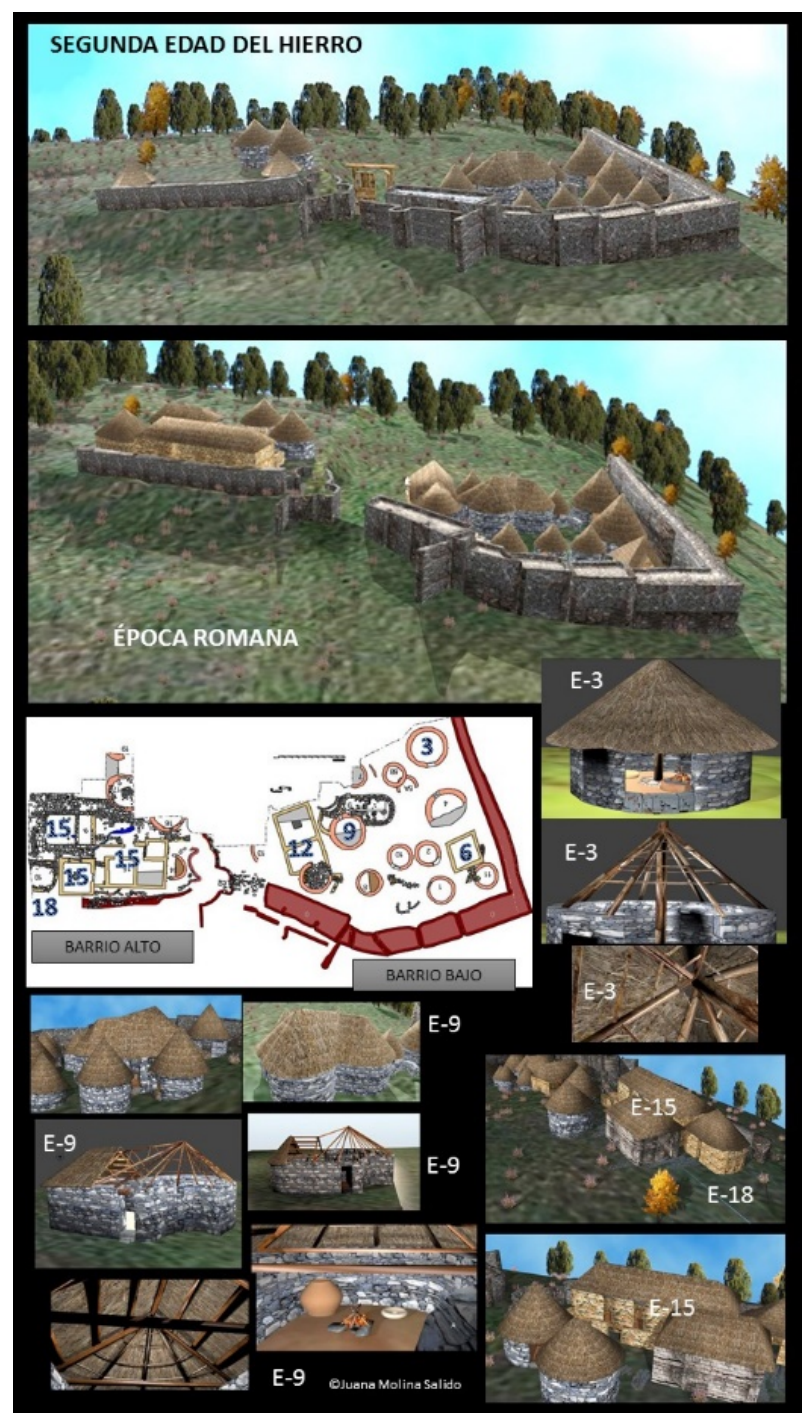

Figura1. Selección de imágenes del castro de San Chuis virtualizado.

Por lo que se refiere a la zona romana los muros son más altos y la techumbre aunque será vegetal, tendrá otra estructura distinta (E-15, 18, 12 y 6, Fig. 1). Hemos decidido que la cubierta sea vegetal porque al estudiar la distribución espacial de los materiales, no hemos encontrado una cantidad de restos de tégula o de tejas de pizarra que nos permitiera pensar en una cubierta de tejas de una clase o de otra. En ciertas zonas aparecen algunas tejas de pizarra, pero la verdad es que no darían para cubrir una superficie medianamente extensa. Sí que hemos encontrado restos de clavos de hierro a lo largo de los muros lo que nos lleva a pensar en cubiertas de madera con los clavos reforzando o ayudando a la construcción del armazón de vigas. Probablemente los clavos se utilizarían también para fijar tejas de pizarra en los bordes de la cubierta como refuerzo ya que es uno de los puntos más débiles del armazón.

Para las texturas de los muros, hemos seleccionado imágenes originales del castro. Además, hemos particularizado las dos diferentes épocas de las estructuras aplicando una textura diferente en cada caso. En el interior de las viviendas se colocaron los hogares y los enlosados originales, como es el caso de la E-12 (antigua estructura indígena circular a la que en época romana se añade una cuadrangular) y 3 , por ejemplo. Para dar forma a la superficie donde se asienta el castro hemos utilizado los planos de AutoCAD con las curvas de nivel desarrollando así no solo la planta sino también los perfiles de las pendientes. En primer lugar exportamos los planos de AutoCAD a Blender donde fuimos levantando la malla $3 \mathrm{D}$ del terreno siguiendo las líneas de las curvas de nivel y elevándolas en altura cada $2.5 \mathrm{~m}$. Después suavizamos la malla para finalmente darle textura.

\section{Conclusiones}

Nuestro trabajo nos ha confirmado la necesidad $y$ utilidad de reunir y de estructurar toda la información dispersa recogida durante las antiguas campañas de excavación realizadas en numerosos yacimientos. El volumen de información que se podría manejar, y a los niveles de análisis a los que se podría llegar sería formidable, siendo un gran avance para los estudiosos del pasado. Por otra parte, el uso de todas las nuevas tecnologías en las excavaciones actuales se nos antoja imprescindible: digitalizar la información desde su recogida integrándola en un SIG, facilitaría muchísimo el trabajo de campo y el posterior de análisis. Nunca se perderá la localización original de ninguna pieza y se podrá reconstruir la excavación a nivel estratigráfico y de registro en cualquier momento. Cuando excavamos destruimos. Tener la posibilidad de mantener esta información de forma exacta e imperecedera es cuando menos muy interesante, si no imprescindible hoy en día.

En cuanto a la reconstrucción virtual del patrimonio histórico arqueológico, las posibilidades que presenta son inmensas. No solo esclarece la visión del propio yacimiento, sino de la época en la que se inscribe. Por lo tanto, como instrumento divulgador de una época y de un yacimiento no tiene precio. Es por esto que todo este tipo de restituciones son fundamentales en los proyectos de musealización. En cuanto a la restitución de San Chuis se refiere, señalar que hemos querido ser lo más fieles posibles a la realidad. Nuestra mayor limitación han sido los medios técnicos y nuestro interés en no fantasear: restituir si, inventar no. Es por esto que hemos tenido muy presentes en todo momento los restos de los que hemos partido y el entorno arqueológico del castro. 


\section{Referencias}

JORDÁ, J.F., MARÍN, C. y MOLINA, J., 2014. El castro de San Chuis (San Martín de Beduledo, Allande, Asturias): cincuenta y dos años de investigación arqueológica. Anejos de Nailos. Estudios Interdisciplinares de Arqueología. Francisco Jordá Cerdá (1914-2004) Maestro de Prehistoriadores, 2, pp. 135-175.

JORDÁ, J.F. y MOLINA, J., 2015. El castro de San Chuis (Allande, Asturias, España): ensayo metodológico para la integración y digitalización de la información procedente de antiguas excavaciones arqueológicas. En A. Maximiano Castillejo and E. Cerrillo-Cuenca, eds., Arqueología y Tecnologías de Información Espacial: una perspectiva iberoamericana. Oxford: Archaeopress Publishing Ltd, pp. 75-87. 


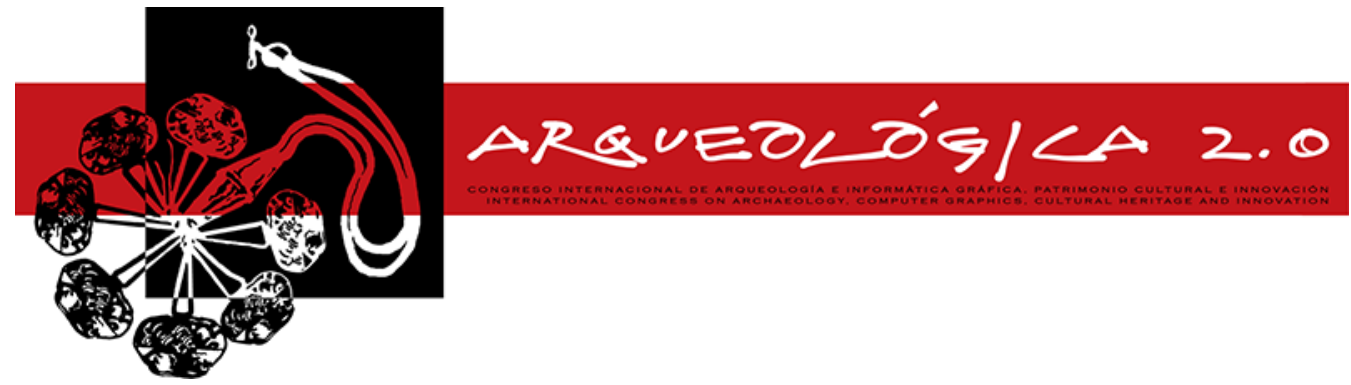

Proceedings of the $8^{\text {th }}$ International Congress

on Archaeology,

Computer Graphics,

Cultural Heritage and Innovation

'ARQUEOLÓGICA 2.0'

in Valencia (Spain),

Sept. $5-7,2016$

\title{
ESQUINA MULTIMEDIA - MUSEUM EXHIBITION FOR THE VISUALIZATION OF CHAN CHAN ARCHAEOLOGICAL SITE
}

\author{
Roberto Pierdicca ${ }^{a,},{ }^{*}$ Eva Savina Malinverni ${ }^{b}$, Emanuele Frontoni $^{\mathrm{a}}$, Francesca Colosi ${ }^{\mathrm{c}}$, Roberto \\ Orazic $^{\mathrm{C}}$ \\ a Dipartimento di Ingegneria dell' Informazione, Università Politecnica delle Marche, Via Brecce Bianche, 60131 Ancona, Italy. \\ r.pierdicca@univpm.it; e.frontoni@univpm.it \\ ${ }^{b}$ Dipartimento di Ingegneria Civile, Edile e dell' Architettura, Università Politecnica delle Marche, Via Brecce Bianche, 60131 Ancona, \\ Italy. e.s.malinverni@univpm.it \\ ${ }^{c}$ Istituto per le Tecnologie Applicate ai Beni Culturali, CNR, Via Salaria km. 29,300, 00016 Monterotondo Street, Roma, Italy. \\ francesca.colosi@itabc.cnr.it; roberto.orazi@itabc.cnr.it
}

\begin{abstract}
:
Chan Chan, an archaeological site located at Trujillo, Peru, is a huge historical settlement very large and difficult to visit and some well-conserved architecture, like Huaca Arco Iris, is very far from the core centre of the site. Furthermore many other heavy factors, as illegal excavations, marine salt transported by the wind and the sometime devastating phenomenon of the Niño, are the reasons of the lost of many decorative elements, which are covered due to conservation issues. To overcome the aforesaid problems, we designed, developed and realized the museum exhibition called "Esquina Multimedia", providing the tourists with interactive and enjoyable applications. An Augmented Reality application has been developed in order to discover ancient artefacts that are invisible because covered by the earth (or by protection structures). A web-browser has been specifically designed to show bas-relieves, with HD visualization and with anaglyph stereoscopic view. Herewith, a wall-mounted panel representing a metric 3D reconstruction by an accurate survey of the building helps the user to find the artefact position.
\end{abstract}

Key words: virtual exhibition, cultural heritage, documentation, 3D model reconstruction, digital photogrammetry, orthophoto, stereoscopic view, augmented reality

\section{Introduction}

One of the major challenges in the archaeological domain is nowadays represented by the communication of ancient artefacts to the visitors. The work reported in this paper is aimed at describing the realization of a real exhibition, installed in an archaeological museum. The framework in which we operated is the Italian Mission in Peru (MIPE), which is working on the Chan Chan site since 2002 (Colosi et. al. 2009), enhancing Chan Chan and its territory through the realization of an Archaeological Park; providing an international dissemination of the information regarding the site; collecting and organising data into a Geographical Information System (Colosi et. al. 2013); and finally producing some virtual 3D exhibitions of ancient ruins, in order to show them into the Museum.

In archaeology, the complexity and some limitations make the use of new media (and technologies) unavoidable. Visitors, who can exploit the potentials of new ways of communication to improve their knowledge and an immersive and multimedia solutions enhances their experience. Users "interacts" and "reacts",
(Malinverni et. al. 2015; Pescarin 2014). The installation described took place in Trujillo, Perù, within the permanent installation of "Museo de Sitio Chan Chan" and it was named "Esquina Multimedia". The exhibition is composed of three sections where different technologies are used depending on the problem it is attempting to solve:

- A virtual tour of Chan Chan site to overcome the archaeological area wideness;

- The use of Augmented Reality (AR) to display on mobile device of some archaeological rests of the main entrance of the largest square of Palacio Rivero. In (Pierdicca et. al. 2015), AR was tested in outdoor scenario.

- A web-browser to discover and explore the basrelieves of Huaca Arco Iris to enhance the perception of the architecture and its decorations. Furthermore, it permits to discover ancient findings with different levels of details (LODs).

`Corresponding Author: Roberto Pierdicca, r.pierdicca@univpm.it 
The contents used to create the exhibition were obtained from different acquisition techniques:

- Spherical panoramas for the creation of $360^{\circ}$ virtual tour;

- Digital photogrammetry for dense points cloud $3 \mathrm{D}$ reconstruction of the remains of Palacio Rivero;

- A complete 3D model of Huaca Arco Iris with a new operation of data fusion from the two abovementioned techniques.

\section{Museum Exhibition}

The exhibition was opened to the public the 27 November 2015, and the users when interacting with the three areas of the "Esquina Multimedia" (Fig. 1).

A portion of the exhibition regarding the virtual tour, acquired and produced with the consents described in (Colosi et. al. 2013) (Fig. 1a).

The Augmented Realty application has been designed using a wall-mounted poster, which reports some information of Palacio Rivero, the HD image of the main entrance door ruins and a $Q R$ code to retrieve the $3 D$ model channel, stored in a remote repository. We adopted image-based tracking system (i.e. markerless), using as tracking images ("trackables") a small portions of the picture. Once the video stream of the built in camera is on, the device implements a matching with the pre-loaded "trackables", searching for the key points associated to the images. Then, the digital contents are projected on the screen from the perspective of the camera's view, based on the orientation of the device (Fig. 1b).

The third section of the installation was reached with a wall-mounted poster containing the $3 \mathrm{D}$ reconstruction of Huaca Arco Iris, with the correct position of the decoration. The latter were labelled with the same code of the web browser, so that the user can interact between the artwork and the digital tool. A dataset of hundreds pictures has been processed after the acquisition campaign on field, using Structure from Motion approaches, with specific tools like Photoscan ${ }^{\circledR}$. Once the 3D meshes of the artefacts were ready, it was possible to manage them into specific tools for orthoimages with high resolution and $3 \mathrm{D}$ models stereoscopic visualization by anaglyph, (Fig. 1c).

In the Figure 2 is shown the web browser in detail. To allow the use of huge imagery for users visualization purposes, we used a virtual texturing technique, a combination of classical MIP-mapping and virtual memory usage. The approach consists in storing tiled images composing a multi-resolution pyramid, loading only the tiles needed to perform the texture at user request. For each level of zoom, the set of tiles corresponding to the observed texture lookup (2D+levelof-detail/scale coordinates), (Petrovic et.al. 2014).

Finally, to augment the three dimensional perception of the images, we realized the anaglyph view, composed of two monochrome stereoscopic images, each composed with a dominant of a different colour superimposed and printed on the same support. To obtain the 3D perception of course, the users need special optical filters, provided during the exhibition.

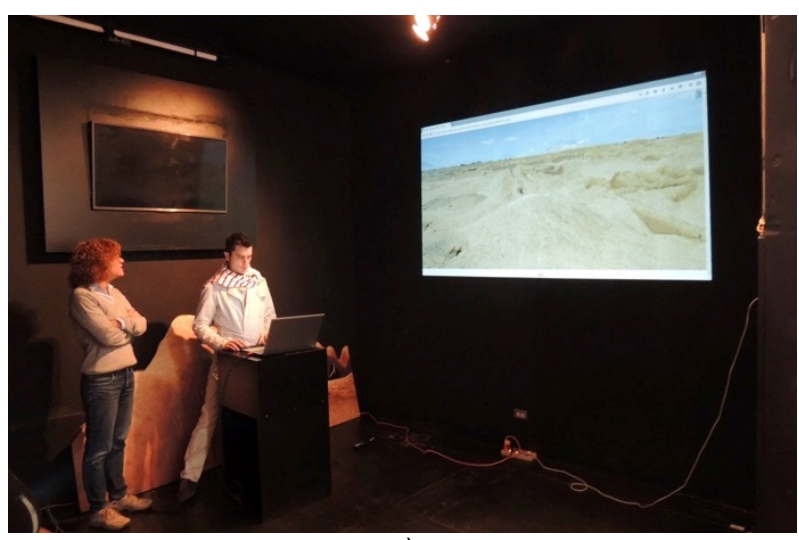

a)

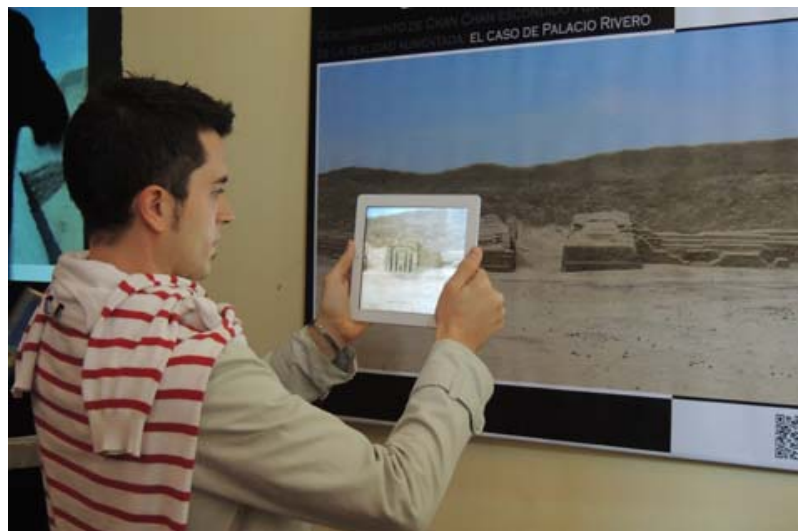

b)

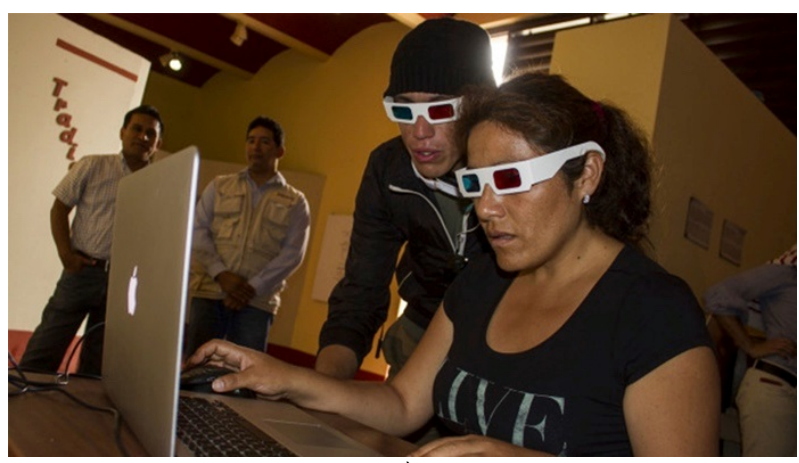

c)

Figure 1: Some pictures of the "Esquina Multimedia" during the exhibition: a) the Virtual Tour running and user discovering Chan Chan whole archaeological site; b) user discovering 3D models with AR function; c) users using the web-browser with 3D glasses for anaglyph view.

\section{Conclusions}

In this work, we presented a novel and interactive way to show the priceless heritage of Chan Chan site. The adoption of state of the art technologies, designed to overcame commons problems of archaeological settlement, is the demonstration of how cultural objects are protagonist, only with the help of a bi-directional interaction by the visitors. By arranging the Virtual Tour into the museum, tourist who cannot visit the entire site (due to time constrains, the wideness of the site and security issues) can reach far areas, having the overview of the whole settlement. The Augmented Reality 
application allows visitors to discover hidden artefacts. The web-browser, containing the HD images of the decorations, gives a completely novel way of experiencing objects with a resolution that cannot be reached with the naked eye. Further, the design of a 3D visualization augments the reality of the experience. The mediation between classical exposition techniques (like posters) to enhance the interaction with digital contents has proved to be a winning choice.

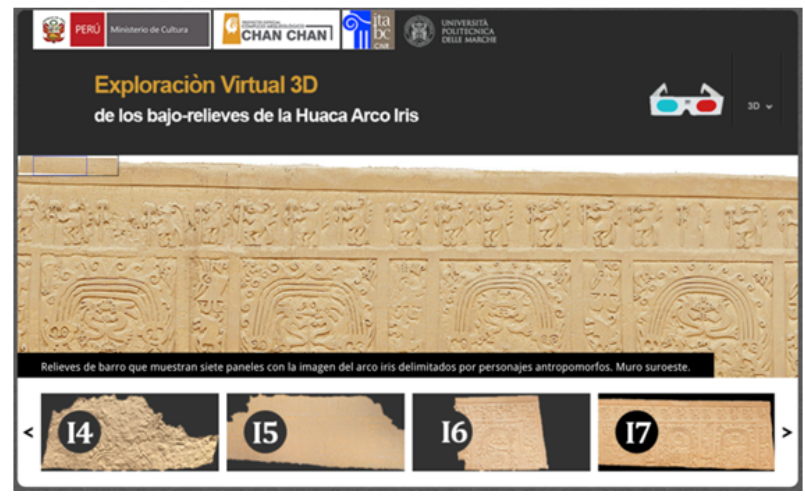

Figure 2: In the last picture the browser to explore the HD switching between 2D and 3D model.

\section{Acknowledgements}

The authors would like to thank Daniela Amadei for the concept of the installation, Gianni Plescia for the browser implementation and some students which have made their stage: E. Battistoni, V. Cernetti, A. Rahali, K. Sifakis and $V$. Tombolini for the creation of contents. Thanks also to all the staff of Museo de Sitio for the support.

\section{References}

COLOSI, F., GABRIELLI, R., ORAZI, R. and MALINVERNI, E.S., 2013. Discovering chan chan: modern technologies for urban and architectural analysis. Archeologia e Calcolatori 24, pp. 187-207

COLOSI, F., GABRIELLI, R., MALINVERNI, E.S. and ORAZI, R., 2013. "Strategies and technologies for the knowledge, conservation and enhancement of a great historical settlement: Chan Chan, Perù", Proceedings of Conference Built Heritage 2013 "Monitoring Conservation and Management", Milano, 18-20 November 2013, Editor in chief M. Boriani, edited by R. Gabaglio, D. Gulotta, ISBN 978-88- 908961-0-1, pp. 56-64.

COLOSI, F., FANGI, G., GABRIELLI, R., ORAZI, R., ANGELINI, A. and BOZZI, C.A., 2009. Planning the archaeological park of chan chan (Peru) by means of satellite images, GIS and photogrammetry. Journal of Cultural Heritage 10, e27-e34.

MALINVERNI, E.S., D'ANNIBALE, E., FRONTONI, E., MANCINI, A. and BOZZI, C.A., 2015. Multimedia Discovery of the Leonardo's Vitruvian Man. SCIRES-IT-SClentific RESearch and Information Technology, 5(1), pp. 69-76.

PESCARIN, S., 2014. Museum And Virtual Museums In Europe: Reaching Expectations. SCIRES-IT, 4(4), pp. 131-140.

PETROVIC, V., VANONI, D.J., RICHTER, A., LEVY, T.E. and KUESTER, F., 2014. Visualizing high resolution threedimensional and two-dimensional data of cultural heritage sites. Mediterranean Archaeology and Archaeometry 14(4), pp. 93-100.

PIERDICCA, R., FRONTONI, E., ZINGARETTI, P., MALINVERNI, E.S., COLOSI, F. and ORAZI, R., 2015. Making Visible the Invisible. Augmented Reality Visualization for 3D Reconstructions of Archaeological Sites. In Augmented and Virtual Reality, pp. 25-37. Springer International Publishing. 


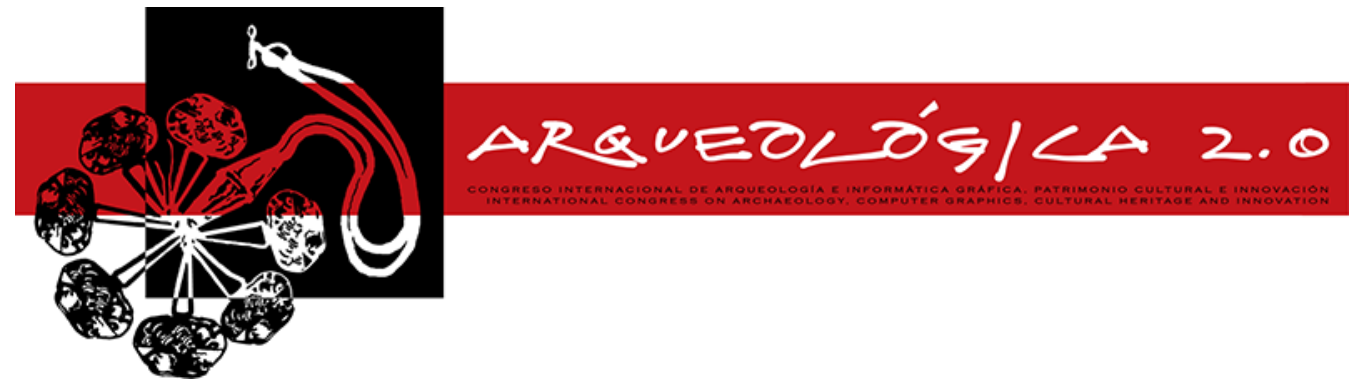

Proceedings of the $8^{\text {th }}$ International Congress

on Archaeology,

Computer Graphics,

Cultural Heritage and Innovation

'ARQUEOLÓGICA 20'

in Valencia (Spain),

Sept. 5 - 7, 2016

\title{
3D GIS TOOLS FOR SUBSOIL MANAGEMENT
}

\author{
HERRAMIENTAS SIG 3D PARA MANEJO DEL SUBSUELO \\ Manuel Herrador ${ }^{*}$, Alejandro Graciano, Francisco R. Feito, Lidia Ortega \\ Department of Computer Science, University of Jaen, Paraje las Lagunillas s/n, 23071 Jaen, Spain. mherrador@ujaen.es; \\ graciano@ujaen.es; ffeito@ujaen.es; lidia@ujaen.es
}

\begin{abstract}
:
Applications of Geographical Information Systems (GIS) on several archaeology fields have been increasing during the last years. Recent approaches in these technologies make possible to work with even more realistic 3D models with the so-called GIS 3D. However, these systems are currently far from being the perfect tool to integrate the subsoil management in Arqueology. In this paper we focus on the state of the art in 3D GIS for subsoil management as well as the hybrid subsoil model for 3D data management.
\end{abstract}

Key words: virtual archaeology, 3D GIS tools, 3D subsoil management

\section{Resumen:}

Las aplicaciones de los Sistemas de Información Geográficos (SIG) en muchos campos de la Arqueología se han ido incrementando en los últimos años. Las nuevas propuestas en estos sistemas permiten trabajar con modelos cada vez más parecidos a la realidad con los denominados SIG 3D. Sin embargo, estos sistemas actualmente distan de ser la herramienta ideal para el manejo del subsuelo en Arqueología. En este artículo nos centramos en el estado del arte en los SIG 3D para manejo del subsuelo y también en un nuevo modelo de datos en 3D, el modelo híbrido de integración de información espacial.

Palabras clave: arqueología virtual, herramientas SIG 3D, manejo de modelos 3D del subsuelo

\section{Introduction}

The three-dimensional modeling of archaeological environments is one of the pillars of the virtual archaeology, because it allows to display an environment that no longer exists based on the remains found. The 3D recreation using consolidated techniques of computer graphics are focused on various elements, such as the objects extracted from the excavations on the ground and also the architecture and landscape that locate these vestiges to recreate them as they were in ancient times (Feito et al. 2010).

Emerging technologies applied to archaeological heritage have led to the resulting digital or virtual archaeology, basically aims at research, documentation, preservation and dissemination of the sets of asset value, scientific, educational and outreach purposes. One of the biggest challenges facing professionals who are dedicated to the study of assets is to explain - to the general public or the rest of the scientific community items from the archaeological settlement with which you are working. This is sometimes difficult even for a specialist, if we consider a complex set of walls, holes, decorations and furniture. Therefore, generating three- dimensional computer aided models are valuable tools aimed primarily at professionals working in the field of cultural heritage and secondly, for the general public, the scientific community and for teaching.

However, the strong spatial character of the vestiges makes some scientist raise to work with Geographic Information Systems (GIS). Nowadays, GIS are under development (Robles et al. 2015) and evolving in order to increases their features and possibilities. Threedimensional visualization is one of the most notable improvements being included in many GIS, both commercial and Open Source. In geometric terms, existing methods for modeling these systems can be classified into three categories: vector, volumetric or hybrid (Shen et al. 2006). In overall, most often 3D GIS focus exclusively on the vector model (Whang 2006). However, for many applications it is also needed to handle those models obtained directly from the data source in order to represent volumetric models more efficiently (Fisher-Gewirtzman et al. 2013), such as layers of an archaeological excavation. Therefore, at present some authors are beginning to consider the concept of hybrid integration models for the joint management of the raster information vector (Becker et

*Corresponding Author: Manuel Herrador, mherrador@ujaen.es 
al. 2012). In (López-Fraile et al. 2014), it is described the use of GIS in studies for micro-spatial in Paleolithic settlements, obtaining a topographical database associated with archaeological one.

Since our environment is 3D, the obtained geoknowledge must be in 3D. This involves a set of challenges which are still pending to be even properly defined. The integration of Computer Graphics and GIS which will allow us a better approach for true 3D GIS. The application fields are relevant in Archeology where the study of subsoil is essential.

\section{Overview of the existing 3D GIS for subsoil management}

In this section we describe several features of 3D GIS software products for managing subsoil solutions. These have been chosen to have a particular aspect which make it special in the context 3D GIS. However, the expansion of GIS in specific 3D environments is not quite complete. Usually real $3 D$ representation is not obtained but rather 2.5D models. They are those extruded from 2D information, for instance prismatic buildings obtained from their footprints.

We now go over current GIS tools with 3D capabilities and discuss their potential for being used in $3 \mathrm{D}$ subsoil management.

ArGis: It highlights 3D Analyst performed by means of two extensions and two specific modules that are supported by a set of tools (3D Analyst Tool). The latter facilitates working with various $3 \mathrm{D}$ vectors, raster and TIN elements.

ArcMap is the basic module of Arcgis. It provides the following features: methods of analysis and creation of 3D surfaces, visualization of surfaces, scanning and incorporation of 3D symbols. ArcCatalog is the main module for data management. The key functionality previews 3D data and also generates new layers and properties for $3 \mathrm{D}$ visualization.

Together with the two previous extensions, 3D Analyst incorporates two specific modules. ArcScene with which enables the visualization of multilayer 3D data, the creation of surfaces (TIN or raster), and surface analysis. Also, it allows comprehensive geo-processing of digital terrain models, including those from LIDAR data. It is also possible to change views and combine different sources of information and as well as modify them.

However, ArcGIS does not support volumetric data (Raster 3D), the developer community is the final responsible for creating additional modules for specific scenarios such as Geology. Further, all representation is based on $2.5 \mathrm{D}$, therefore there are not real 3D integrated models.

Grass: Their use has been done in various projects in Archaeology (for example Bezzi et al. 2006).

Grass is able to perform various processes on models for digital terrain surfaces which are always considered $2,5 \mathrm{D}$. The model can be obtained from importing formats such as DEM or TIN. Models can be generated using digital interpolation from contour or from a set of given points. It is also possible to work with data from laser sensors. 3D modeling in Grass covers both 3D vector elements and 3D raster elements (volumes).

It is possible to import from files of points $(x, y, z)$ or from a set of specific ones. It is also possible to obtain volumetric models by joining $2 \mathrm{D}$ raster layers. Grass offers total extension to 3D from classical algebra of raster maps. It is also possible to get $2 \mathrm{D}$ sections, calculate statistics and export data to ASCII or VTK formats.

In general terms, Grass is a very versatile and free distribution tool that can be used joined to many different independent modules and spatial data bases, such as PostGis or Oracle Spatial. The major drawback is 3D visualization. In many cases the results are better displayed using different tools.

Engage 3D: This is the 3D tool of Maplnfo whose accuracy in 3D data visualization has been proved with both raster and vectorial data. Voxel visualization is a desired feature for Archeology since objects and terrain layer disposition have volumetric nature.

The software allows different format conversion but the analysis functionality is very limited for this type of data in 3D. Figure 1 shows the resulting model after integrating DEM information, and layers of buildings and underground infrastructures.

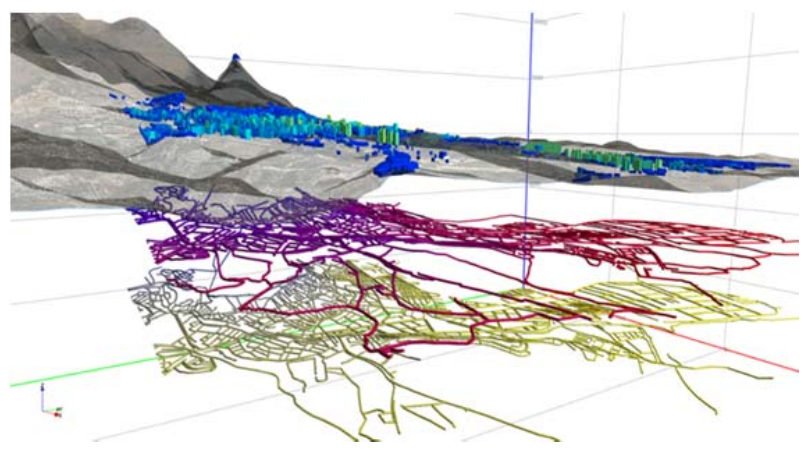

Figure 1: Engage 3D for underground infrastructure.

\section{The Subsoil Management Use Case}

This section details a possible application for the field of Archaeology. In 2015, the GGGJ group obtained National funding with the Call: Proyectos de I+D "EXCELENCIA" and Proyectos de I+D+I "RETOS INVESTIGACIÓN", for developing a R\&D project titled "Contributions to Smart Cities. Towards a subsurface 3D GIS" with code: TIN2014-58218-R. This project will help as brief example in order to better understanding and interconnect the applications of 3D GIS solutions to the subsoil management and the virtual architecture of cultural heritage.

Numerous services that make a city to work properly are in the underground. Along the history, humans have used the subsurface as a form of shelter or a place from where to obtain resources. At present, much of the infrastructure relating to urban development are under the surface to preserve the space available on the cities, reduce the flow of traffic, provide security and isolation facilities (Herrador et al. 2016) this technology can be also applied to Archaeology. Many archeological remains are or have been underground and their spatial arrangement is under study. 
Underground infrastructures also require this functionality for an efficient management but the third dimension is normally provided with a high level of abstraction. The inclusion of 3D models of various layers of soil and infrastructure elements - such as tunnels - is the next step to achieve substantial progress in the suburban area of management (Fig. 2).

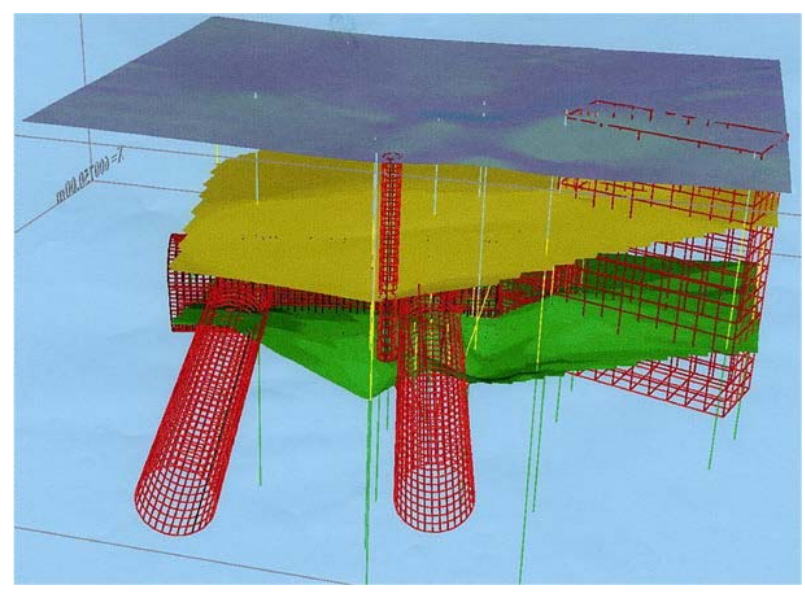

Figure 2: Subsoil representation with tunnels.

Obviously, 3D models allow direct display of objects within the soil layers as well as the spatial interaction or relationship between them. The model may reflect this disposition even after being excavated. The camera or virtual observer can navigate through the entire model and it also could be connected with spatial data bases by means of a simple picking operation. Figure 3 shows an example of underground pipeline infrastructure supporting all these desired features.

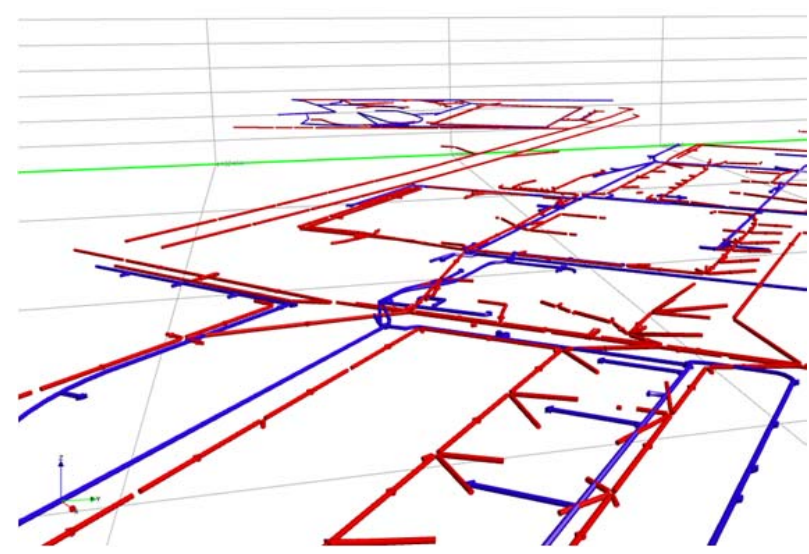

Figure 3: 3D layer disposition.

Recently, some authors are beginning to consider the concept of hybrid models of integration for the joint management of volumetric and geometric information (Becker et al. 2012). A hybrid system should not modify or change the nature of the data, but rather should integrate both representations under a model capable of managing both at the same time, and providing results regardless of their nature. This kind of models have not been worked generically, but focus exclusively on very specific types of scenarios (Lee et al. 2008).

In subsurface analysis by integration of different data sources and formats, the work of (Lei X. et al. 2015) focused exclusively on integration of different types of input data for analysis of the soil layers without direct expansion for general use (Fig. 4). CAD/CAM has hybrid models for the management of regular geometric objects, but they are non-existent for the representation of information with irregular nature.

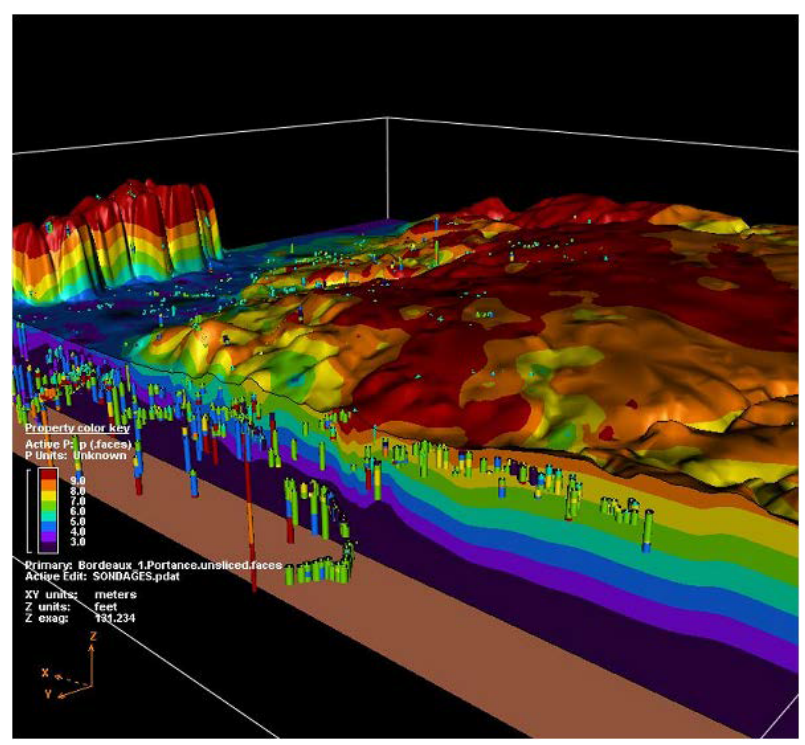

Figure 4: 3D rendering of exploration on the ground in layers.

The vector representation would focus more on visualization and analysis of the surface of objects, or in our particular case, the analysis of the length of pipelines, connectivity, slopes, etc. On the other hand, the volumetric representation or voxelized would be responsible for the global representation model of the interaction of the different soil layers with vector data. Advances in this field have been insufficient in last years.

Our research group has begun working with volumetric libraries, specifically OpenVDB software. This library enables you to store large volumes of spatial information using efficient mechanisms for handling and storage. The possibility of using the tree structure of this library to link to other vector data structures representing geometric information, is a starting point to address the problem of integrating posed models.

Similarly, another objective would be to cover the inclusion of the temporary variable in the system, which allows reliably reflect the changes undertaken over time. Driving time trends in such systems would help to change work environments to allow the location of obsolete nature infrastructure, analyzing the possible expansion of the design of future facilities, etc. The process that efficiently manages temporary variables is more complicated than simply adding a date data type to manage the systems (Eshel 2011).

\section{Conclusions}

In the coming years it is expected true 3D utilities integrated in GIS in order to transcend the simple use as $3 D$ viewers, allowing better modeling of reality. At the same time, their use shall be provided in a greater number of devices, especially mobile, which will open new applications for distributing archaeological elements. This will provide a future approach for viewing and interacting with information, allowing us to achieve 
new graphics capabilities for the development of new languages for $3 \mathrm{D}$ visualization using web applications (Held et al. 2004).

In general, there are few research groups consolidated in the urban 3D GIS work, although this trend is modified in recent years to Smart Cities considered as an objective of Horizon 2020. In Europe stands out by Dr. Sisi Zlatanova, Technological University of Delft (Netherlands), with long experience in this subject and with some members of the applicant research group have recently worked, and whose contribution will also be of special interest in this project. Another research group with experience in GIS and urban modeling is the Dr. António Augusto de Sousa, Faculty of Engineering,
University of Porto (FEUP), who have collaborated (Robles et al. 2013) as a possible planned joint work. Contributions of the Graphics Group at the University of Jaén are also recent regarding urban 3D GIS (Robles et al. 2012).

Arqueology may be benefited with all these achievements regarding 3D GIS and hybrid data models.

\section{Acknowledgements}

This work has been partially supported by the Ministerio de Ciencia e Innovación and the European Union (via ERDF funds) through the mentioned research project TIN2014-58218-R.

\section{References}

BECKER, S., WALTER, V., FRITSCH, D., 2012. Integrated management of heterogeneous geodata with a hybrid 3D geoinformation system. ISPRS Annals of Photogrammetry, Remote Sensing and Spatial Information Sciences. DOI: 10.5194/isprsannals-I-2-87-2012.

BEZZI, A. BEZZI, L., FRANCISCI, D. and GIETL, R., 2006. L'utilizzo di Voxel in campo archeologico. Geomatic workbooks 6, 2006 Available: http://geomatica.como.polimi.it/workbooks/ [2/17, 2016].

ESHEL, G., 2011. Spatiotemporal Data Analysis, Princeton University Press. DOI: 10.1515/9781400840632

FEITO, F.R. and SEGURA, R., 2010. Herramientas SIG 3D. Virtual Archaeology Review, vol 1, no 1, pp. 87-91. DOI: 0.4995/var.2010.4795

FISHER-GEWIRTZMAN, D., SHASHKOV, A. and DOYTSHER, Y.,2013. Voxel based volumetric visibility analysis of urban environments. Survey Review. Volumen 45, n 333, pp. 451-461. DOI: 10.1179/1752270613y.0000000059

HELD, G., RAHMAN, A.A., ZLATANOVA, S., 2004. Web 3D GIS for urban environments, In: Proceedings of the International Symposium and Exhibition on Geoinformation 2004 (ISG2004).

HERRADOR, M., GRACIANO, A., FEITO, F.R., ORTEGA, L., 2016. Towards a subsurface 3D GIS. Contributions to Smart Cities. (Submitted to the International Conference on Smart Cities, SMART CT 2016, Málaga).

LEE, J. and ZLATANOVA, S., 2008. A 3D data model and topological analyses for emergency response in urban areas. Geospatial information technology for emergency response (ISPRS book series). Taylor \& Francis Group, London, 2008.

LEI, X., LIXIN, W., XUEXI, C., DEFU, C., YUN, J., 2005. A conceptual model for 3D subsurface spatial data integration: the integrated information voxel. Geoscience and Remote Sensing. Symposium IGARSS '05. Proceedings. DOI: 10.1109/IGARSS.2005.1525233

LÓPEZ-FRAILE, F.J., ALCARAZ-CASTAÑO, M., LÓPEZ-RECIO, M., BAENA, J., MORÍN, J., ROCA, M., RODRÍGUEZAVELLO, L., TAPIAS, F., PÉREZ-GONZÁLEZ, A., and SANTONJA, M., 2014. Aplicaciones SIG en la caracterización geoarqueológica del yacimiento paleolítico de Las Delicias (Madrid, España) y visualización en 3D de los resultados. Virtual Archaeology Review. Volumen 5, n 10, pp. 32-44.

ROBLES, M.D., ORTEGA, L., FEITO, F.R., 2015. Avances en Sistemas de Información Espacial 3D. Aplicaciones en patrimonio y arqueología virtutal. Virtual Archaeology Review, vol 6, nº 12. DOI: 10.4995/var.2015.4161

ROBLES, M.D., ORTEGA, L., COELCHO, A., FEITO, F.R., DE SOUSA, A., 2013. Automatic Street Surface Modeling for Web-Based Urban Information Systems. Journal of urban planning and development. 139 - 1, pp. 40 - 48 . DOI: 10.1061/(asce)up.1943-5444.0000131

ROBLES, M.D., ORTEGA, L., FEITO, F.R., 2012. Design of Topologically Structured Geo-database for Interactive Navigation and Exploration in 3D Web-Based Urban Information Systems. Journal of Environmental Informatics. 19 2, pp. 79 - 92. DOI: 10.3808/jei.201200211

SHEN, DY., TAKARA, K., TACHIKAWA, Y. and LIU, Y.L., .2006. 3D simulation of soft geo-objects. International Journal of Geographical Information Science. Volumen 20, nº 3, pp. 261-271. DOI: 10.1080/13658810500287149

WANG, Y., 2006. 3D GIS Spatial Modeling for City Surface and Subsurface Integration. IGARSS'06. DOI: 10.1109/igarss.2006.391 


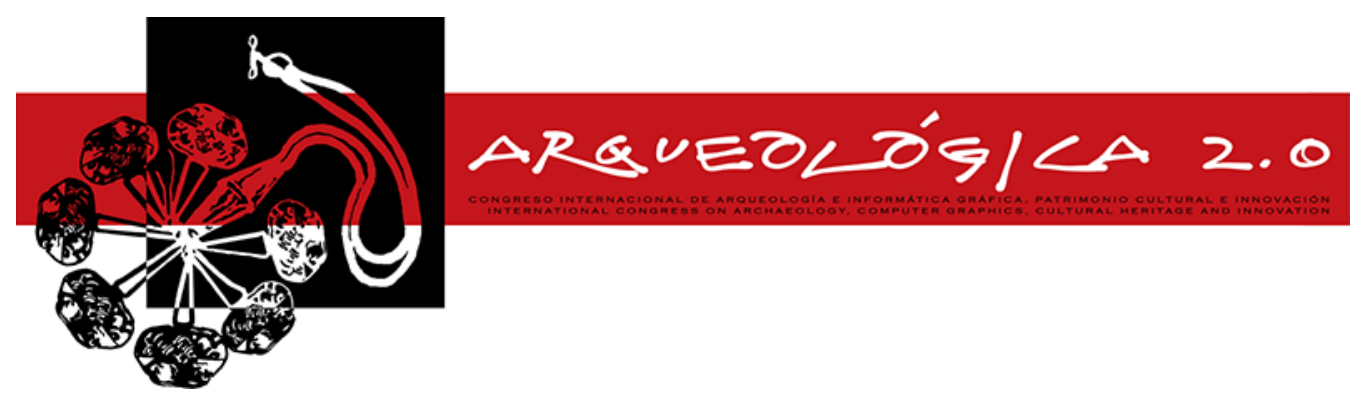

Proceedings of the $8^{\text {th }}$ International Congress

on Archaeology,

Computer Graphics,

Cultural Heritage and Innovation

'ARQUEOLÓGICA 2.0'

in Valencia (Spain),

Sept. $5-7,2016$

\title{
VIRTUAL TOURS OF HISTORICAL AND ARTISTIC HERITAGE IN THE PROVINCE OF CACERES
}

\author{
RECORRIDOS VIRTUALES DEL PATRIMONIO HISTÓRICO ARTÍSTICO EN LA PROVINCIA DE CACERES \\ José Manuel Naranjo ${ }^{\mathrm{a}}$, María Ángeles Parrilla ${ }^{\mathrm{b},}$, Manuel Sanchez ${ }^{\mathrm{a}}$ \\ ${ }^{a}$ Department of Graphic Expression, University of Extremadura, University Avenue, 10003 Caceres, Spain. jnaranjo@unex.es; \\ manuel.1633@gmail.com

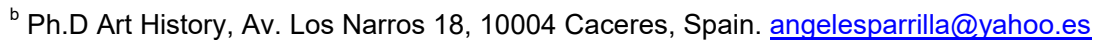

\begin{abstract}
:
The 3D visualization of historical-artistic heritage in the province of Caceres is an essential tool for touristic promotion. To this end, a methodology is offered based on the application of panoramic spherical photography and terrestrial laser scanner (TLS). The general aim is the creation of geometric representations of sites of cultural interest by the visualization of spherical scenarios and the application of 3D modelling techniques. Particular aims include the geometric cataloguing and acquisition of this artistic heritage and the development of an interactive tool for tourists. A hypermedia atlas is created in which 3D spherical scenarios is visualized displaying videos obtained from the point of clouds and ASCII format downloadable 3D models are made freely available. Other benefits of this project are gains in the knowledge and assessment of the cultural heritage in Caceres.
\end{abstract}

Key words: geometric characterisation, 3D modelling, historical-artistic heritage, tourism promotion, atlas hypermedia

\section{Resumen:}

La visualización 3D del patrimonio histórico-artístico en la provincia de Cáceres, es una herramienta esencial para su promoción turística. Con este fin, se ofrece una metodología basada en la fotografía panorámica esférica y el uso del láser escáner. Como objetivo general se realiza la caracterización geométrica de los Bienes de Interés Cultural, mediante técnicas de visualización de escenarios esféricos y generación de modelado 3D. Los objetivos particulares son catalogar y adquirir de forma geométrica este patrimonio y desarrollar una herramienta interactiva de consulta. Por ello, se crea un atlas hypermedia donde visualizar escenarios fotográficos tridimensionales, videos a partir de las nubes de puntos e incluso su descarga en formato ASCII, todo de forma gratuita. Otros beneficios del proyecto son el conocimiento y la puesta en valor del patrimonio de Cáceres.

Palabras clave: caracterización geométrica, modelado 3D, patrimonio histórico-artístico, promoción turística, atlas hypermedia

\section{Introduction}

Any attempt at promotion of tourism of architectural and archaeological heritage needs "the withdrawal of information" (Ismagilova et al. 2014) and the geometry of the constructed reality must be obtained, meaning a topographical survey that rigorously documents its current state (Rua and Gil 2014). Depending on the agents promoting tourism, the degree of detail required may vary (Ramos and Remondino 2015).

The purpose of this work is to establish a methodology for the geometric characterization of historical heritage by means of the combination of different methods of study, measurement, test and analysis, to be used as a basis for touristic promotion.
Compared with common modelling methods, the virtual panoramic view has the advantages of economy and simplicity. Moreover, the requirements for data acquisition are not strict and the resulting panoramic roam is vivid and smooth (Feng et al. 2014; He 2015).

Precisely, one such use is the promotion of tourism (Beeton 2015), the aim of which is to promote tourism through the generation of virtual tours from panoramic photographs, which it does with great effect (Alja'am 2010; Wu et al. 2014).

On the other hand, terrestrial laser scanning (TLS) has become a powerful technology for 3D object information acquisition, since it permits the use of dense high accuracy $3 D$ terrain information. Nowadays, TLS is often

`Corresponding Author: María Ángeles Parrilla, angelesparrilla@yahoo.es 
used for object modelling in geographic information systems in various fields such as civil engineering and archaeology (Xu et al. 2015). The latter of these fields highlights the work intended for the conservation of cultural heritage (Fanti et al. 2013; Calin et al. 2015).

\section{Materials and methods}

\subsection{Study area}

There were made virtual tours in 31 municipalities of the 62 monuments of cultural interest: Abadía, Alcántara, Alcuéscar, Aldea del Cano, Almoharín, Arroyo de la Luz, Baños de Montemayor, Bohonal de lbor, Brozas, Cabezuela del Valle, Cáceres, Coria, Cuacos de Yuste, Galisteo, Garganta la Olla, Garrovillas de Alconétar, Gata, Guadalupe, Jaraíz de la Vera, Malpartida de Cáceres, Oliva de Plasencia, Pasarón de la Vera, Piornal, Plasencia, Robledillo de Gata, Santa Cruz de la Sierra, Trujillo, Valencia de Alcántara, Valverde de la Vera and Villanueva de la Vera and Zarza de Granadilla.

\subsection{Materials}

A Canon EOS 5D Mark III camera was used to capture photographs, capable of capturing 22 megapixels with a lens with a focal curvature of $15 \mathrm{~mm}$. In addition, the tripod Manfrotto $303 \mathrm{PH}$ with an espherical ball VR was used too. Panoweaver Professional 7 software was used to join photographs and Tourweaver 6.50 to generate spherical photographic scenes.

Furthermore, in order to obtain the 3D models, two types of laser scanner were used: 1) Leica LC10 with an accuracy of $4 \mathrm{~mm}$ on the measurement of the distance from point clouds located between 1-50 meters and 2) Faro Focus 3DS120 with an error of $2 \mathrm{~mm}$ to a range of $0.6-130 \mathrm{~m}$.

The Leica Cyclone Model 7.4 software was used to unload the $3 \mathrm{D}$ point cloud. In addition, the Trimble RealWorks software was used for the management and exploitation of these clouds.

\subsection{Method}

The method carried out follows the next lines of work:

Acquisition of aerial and terrestrial images: The acquisition of aerial images was crucial to the location of each of the monuments of cultural interest examined. Regarding the capture of terrestrial images, it was used the Manfrotto 303PH tripod and the "VR" spherical ball, designed for the computerized creation of virtual scenes from digital panoramic images.

The camera was mounted on the tripod and positioned over the nodal point before taking the spherical panoramic setting so as to obtain a panoramic scene. Several sequences must be taken from different horizontal angles, in our case, 18 shots with a separation of $24^{\circ}$. In addition, we took a photograph of the zenith and another of the tripod to complete the stage.

Generation of panoramic photographs and virtual tours: Once the photographs had been obtained, EasyPano Panoweaver 7 Professional software was used to join the photographs in one single panoramic photo. After, this was then transformed into a cubic panoramic photo. Finally, a Flash file was generated.

To generate the final configuration of a virtual tours presentation, we used Tourweaver 6.50 Professional software. Once different spherical panoramic photographs have been created, it processes an assembly of all of them to facilitate the virtual interactive immersion of the user. Each spherical view contains a text indicating the municipality in which it is located and its name and its historical information.

Acquisition of geometric information: For the study, the structures of the monuments of cultural interest had to be represented in 3D. Terrestrial laser scanning was capable of carrying out the topographic surveys swiftly and efficiently with an accuracy of within a few millimetres, always using a vertical field of view with a breadth of 270 degrees and a horizontal plane of 360 degrees. 50,000 points were thus captured per second.

The following tasks were then performed: the location and number of data to be collected were planned, and the optimal scanning resolution to represent the monument in detail was determined.

Processing of $3 D$ point clouds: The alignment of the clouds of points was performed first. Using the methodology of resection of targets, which consists of scanning the same targets form different positions, a minimum of three targets were scanned. As each cloud is expressed in its local system, there must be at least three homologous points between neighbouring point clouds. Each consecutive pair of point clouds is oriented with three common targets in order to provide a set of orientation-related parameters.

The alignment of each of the clouds of points is based on the calculated transformation solution. This solution produces the 3D transformation that leads to the following equation Eq. (1):

$$
\left[\begin{array}{l}
X^{\prime} \\
Y^{\prime} \\
Z^{\prime}
\end{array}\right]=\left[\begin{array}{l}
\Delta X \\
\Delta Y \\
\Delta Z
\end{array}\right]+\left[\begin{array}{ccc}
1 & -\Delta k & \Delta \varphi \\
\Delta k & 1 & -\Delta \omega \\
-\Delta \varphi & \Delta \omega & 1
\end{array}\right]\left[\begin{array}{l}
X \\
Y \\
Z
\end{array}\right]
$$

where:

- $\left(X^{\prime}, Y^{\prime}, Z^{\prime}\right)$ are the coordinates in the new frame.

- $(X, Y, Z)$ are the coordinates of the entry framework.

- $(\Delta \mathrm{X}, \Delta \mathrm{Y}, \Delta \mathrm{Z})$ and $(\varphi \mathrm{k}, \omega)$ are the parameters of relative orientation.

The alignment will be refined through an iterative process of adjustment by minimum squares in order to reduce the error. After that, the Leica Cyclone 7.4 software showed us the results of the adjustment.

Subsequently, it automatically cleaned and segmented the point clouds. Therefore, everything that was not needed for the job (the noise) was removed, like all points whose depth was outside the separation distance between the laser scanner and the measured object or points that did not define the model itself, such as people crossing during measurement, or trees.

Registration and integration of models: The next phase of the work was to set up the union of the scans. Trimble RealWorks program was used to perform the union of 
scans. Then, using this same software, videos were generated from the clouds of points obtained.

\section{Results}

Once all spherical photographic scenarios and 3D points clouds had been obtained, there were uploaded to the Internet. For this purpose the following web page was created for use as a hypermedia atlas: http://158.49.247.14/caceresvirtual/.

The information can be accessed in different ways using the menu, on wich not only can we select the municipality, but also the point of cultural interest we want to display. In that way, the videos and spherical scenes will be viewed. The most intuitive way for the user to access the information, however, is to interact with the map of the province of Caceres appearing on screen.

\section{Conclusions}

We think it is necessary to facilitate the knowledge and appreciation of cultural heritage of Caceres using free software and creating a highly accurate 3D geometric model. The transfer of project results to institutions and educational, scientific, and social entities is motivated by the commitment to share between research teams and public agencies for its development.The website created as a result of the investigation should be incorporated other smaller towns of Caceres to make viable the possibility of the growth of our project. Moreover, the results not only contribute to improving decisions regarding future restorations, but also respond to the challenges of preserving the quality of these artistic testimonies.

\section{Acknowledgements}

The present developed work was developed under the 2013 Plan of Initiation to Research of the University of Extremadura within the Program Orientated at Projects of Initiation to the Research called Action VIlth. The program was financed by the provincial government in Cáceres. We also thank the Junta de Extremadura for providing the aerial images.

\section{References}

ALJA'AM, J.M., ALSAADY, M., ALMARRI, M. and AL-KUWARI, H., 2010. An experience to develop a web portal about the historical and archeological sites in Qatar. Computer Engineering Conference (ICENCO), 2010 International, IEEE, Cairo, Egypt, pp. 86-88. DOI 10.1109/ICENCO.2010.5720432

BEETON, S., 2015. Travel, Tourism and the Moving Image. London: Channel View Publications. 264 pages. ISBN 13:978-1-84541-527-3

CALIN, M., DAMIAN, G., POPESCU, T., MANEA, R., ERGHELEGIU, B. and SALAGEAN, T., 2015. 3D Modeling for Digital Preservation of Romanian Heritage Monuments. Agriculture and Agricultural Science Procedia, 6, pp. 421428. DOI: 10.1016/j.aaspro.2015.08.111

FANTI, R., GIGLI, G., LOMBARDI, L., TAPETE, D. and CANUTI, P., 2013. Terrestrial laser scanning for rockfall stability analysis in the cultural heritage site of Pitigliano (Italy). Landslides, 10 (4), pp. 409-420. DOI: 10.1007/s10346-0120329-S

FENG, J.P., WU, L.H. and MA, S.Q., 2014. Research of 3D Virtual Scene Generation and Visualization Based on Images. In: C. BING-YUANG, M. SHENG-QUAN, C. HU-HUA, eds. Ecosystem Assessment and Fuzzy Systems Management. London: Springer. pp. 375-386. DOI: 10.1007/978-3-319-03449-2_34

HE, Y., 2015. Application of Panoramic Image Technology in Distance Teaching System. International Journal of Emerging Technologies in Learning, 10(6). DOI: 10.3991/ijet.v10i6.4848

ISMAGILOVA, G., SAFIULLIN, L. and BAGAUTDINOVA, N., 2014. Tourism development in region based on historical heritage. Life Science Journal, 11(6), pp. 363-367. DOI: 10.1016/j.sbspro.2015.03.355

RAMOS, M.M. and REMONDINO, F., 2015. Data fusion in Cultural Heritage-A Review. 25th International CIPA Symposium 2015, Taipei, Taiwan. pp. 359-363. DOI:10.5194/isprsarchives-XL-5-W7-359-2015

RUA, H. and GIL, A., 2014. Automation in heritage - Parametric and associative design strategies to model inaccessible monuments: The case-study of eighteenth-century Lisbon Águas Livres Aqueduct. Digital Applications in Archaeology and Cultural Heritage, 1 (3-4), pp. 82-91. DOI: 10.1016/j.daach.2014.06.002.

WU, L.H., FENG, J.P. and HE, S.Q., 2014. Construction and Implementation of the Three-Dimensional Virtual Panoramic Roaming System of Hainan Ecotourism. In: C. BING-YUANG, M. SHENG-QUAN, C. HU-HUA, eds. Ecosystem Assessment and Fuzzy Systems Management. London: Springer.pp. 339-351. DOI: 10.1007/978-3-319-03449-2_31

XU, X., YANG, H. and NEUMANN, I., 2015. Concrete Crack Measurement and Analysis Based on Terrestrial Laser Scanning Technology.Sensors \& Transducers, 186 (3). pp. 168-172 


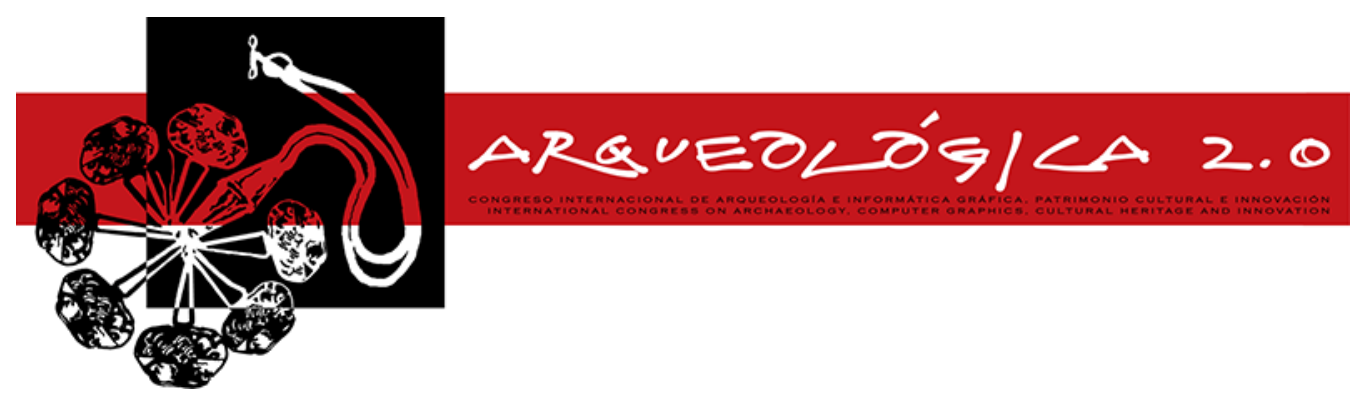

Proceedings of the $8^{\text {th }}$ International Congress

on Archaeology,

Computer Graphics,

Cultural Heritage and Innovation

'ARQUEOLÓGICA 20 '

in Valencia (Spain),

Sept. 5-7, 2016

\title{
NATURAL GESTURE INTERACTION IN ARCHAEOLOGICAL VIRTUAL ENVIRONMENTS: WORK IN PROGRESS
}

\author{
INTERACCIÓN GESTUAL PARA ENTORNOS DE INMERSIÓN ARQUEOLÓGICOS: TRABAJO EN CURSO \\ Niccolò Albertini ${ }^{a,{ }^{*}}$, Andrea Brogni ${ }^{a}$, Baptiste Caramiaux ${ }^{b}$, Marco Gillies ${ }^{b}$, Riccardo Olivito ${ }^{a}$, \\ Emanuele Taccola ${ }^{\mathrm{C}}$ \\ a Scuola Normale Superiore, Pisa, Italy. niccolo.albertini@sns.it; andrea.brogni@sns.it; riccardo.olivito@sns.it \\ b Goldsmiths University. London, UK. b.caramiaux@gold.ac.uk; m.gillies@gold.ac.uk \\ c Università di Pisa, Pisa, Italy. emanuele.taccola@unipi.it
}

\begin{abstract}
:
Archaeological data are heterogeneous (i.e., data-sheets and pictures, stratigraphic data, 3D models), and innovative virtual reconstractuions helps to visualize and study those data. In this short paper, we describe our work in progress in the design of an innovative way to interact with the complexity of a virtual reconstruction, using natural gestures and advanced machine learning, in close collaboration with archeaeologists.
\end{abstract}

Key words: cyber-archaeology, gesture recognition, virtual reality

\section{Resumen:}

Los datos arqueológicos son heterogéneos (por ejemplo, ficha técnica e imágenes, datos estratigráficos y modelos 3D), y las nuevas tecnologías pueden ser capaces de ayudar en la visualizacion y el estudio de dichos datos. En este documento se presenta nuestro trabajo en curso que describe el diseño de una forma innovadora de interactuar con la complejidad de una reconstrucción virtual, mediante gestos naturales y avanzadas técnicas de aprendizaje, en directa colaboración con los arqueólogos.

Palabras clave: cyber-arqueología, reconocimiento de gestos, realidad virtual

\section{Introduction}

Nowadays, we can see, thanks to the new technologies, an increase in types and amount of data in any research field. Having pictures or 3D models, writing long report or plot statistical tables became normal not only for engineers or architects, but also for humanists and archaeologists. Manipulating and visualizing those kind of data has always been a limiting factor in the research and the scientific history is full of new graphical conventions, coming out just for better representing new data in a new perspective.

Archaeology is a field that more than others may take advantages from this innovation, because a virtual reconstruction, for example, puts the scientists in front at his/her hypothesis, making it real the availability for verifying it, studying archeological materials and their use. The theory of embodied cognition stresses the importance of our interactions with the world in our cognitive understanding of it. The ability to rotate an artefact in our hand helps us to see it better from different perspectives, the ability to hold a tool helps us to understand how it can be used. We propose that one of the great benefits of virtual reality is the ability to enable more natural forms of interaction that will better support archaeologists in understanding their digital artefacts. Our work goes in this direction, with a virtual reality representation of archeological data that includes a gestural interface enabling researchers to interact with data immersively, using their hand movements without the intermediary of desktop interface devices. This work comes straight from the archaeological researchers and their curiosity toward virtual technologies. The idea is to transfer actions from the excavation to the virtual environment, placing the archaeologist in a working replica of the excavation area, where he/she can access and manipulate the data, edit and consult information, moving around the reconstruction and the actual area. A very important issue will be to design such interactions with these virtual reality representations in a way that he/she feels natural and familiar in his/her imaginative concept of acting on the excavation area.

`Corresponding Author: Niccolò Albertini, niccolo.albertini@sns.it 


\section{The Application}

The aim of the application was to contribute to the development of a new approach to the consultation and analysis of stratigraphic archaeological data. The first experiment was in fact based on a leap-sensor integrated on the 3D glasses to be used within a CAVElike system, which enabled the interaction with the models through an interface consisting of a small set of gestures (Olivito et al. 2015). Although activated by hand movements, the gestures looked quite artificial because the user had to continuously interact with a selection menu mimicking a desktop or touch screen interface. In addition to this, since the 3D glasses and the leapsensor were not wireless, they strongly limited the freedom of movement within the CAVE.

New tracking technology and new interaction strategy: these two key points are driving our work to improve the quality and effectiveness of the original system. The validation of the functionality of the gestures represents the result of a continuous debate between archaeologists and system developers, whose main goal has been to satisfy two specific requests by the archaeologists: on one hand, the possibility to use a limited gestures set, which easily memorizable because it is natural and, on the other hand, to reproduce through these gestures the movements an archaeologist usually carries out, not only during the field activity, but also in the cognitive process activated during the excavation and the interpretation phases.

The case study is the agora of Segesta, in Sicily, Italy. In 2014, archaeologists started a project of photogrammetric documentation of the digging activity, creating six 3D image-based models of the stratigraphic sequence. The objective is to support the traditional tools used in the archaeological field, so as to enrich the interpretative process due to the use of $3 \mathrm{D}$ data and to a simulation of the excavation activity while operating within an immersive virtual environment, that allows for a full embodiment and an interaction with the digital models as natural as possible. A further benefit is represented by the possibility of re-creating, also from an emotional and perceptive side, the mental dynamics an archaeologist processes during the field activity or even after.

Virtual reality and 3D visualization improved the observing process, letting the researcher perceive the data in a more natural way. An immersive visualization adds new feedback in the perception of the data, adding to vision the proprioception of our own body and inducing natural reactions during the exploration of the virtual objects. This will help to recognize shapes and dimensions, distances and spatial relationships between elements of the scene, increasing our space perception at a level more similar to reality. In the case of archaeology, for example, seeing an artefact in a 3D reconstruction and comparing it with others, it is more intuitive and efficient than watching pictures or columns of numbers.

Gestures and hand manipulations are actions that we perform every day without thinking, and in many cases, they can also be the best solutions in specific interactions. Physical gestures and actions are a natural way to interact with our external environment. However, designing gesture interaction still involves important challenges such as defining a gesture vocabulary that is relevant to the application area, as well as designing an accurate gesture recognizer that allows for taking into account expressive components of the performed gestures. Gesture design has been investigated following two distinct approaches. The first was designer-centered, considering ergonomics and technical constraints, while the was user-centered. Long et al. (2000) asked users to rate similarity between shape-based gestures to define a vocabulary avoiding ambiguity. Also, there may not be a single gesture that is applicable to all people. Gestures can be highly culturally specific: for this reason, it is often better to allow easy personalisation of gestures by individuals, an approach we take in our work.

A recent promising approach, in gesture recognition field, has been proposed (Caramiaux et al. 2014), where input gesture variations are explicitly taken into account in the model and estimated continuously while the gesture is performed. This method is called gesture variation follower (GVF) and it is the one we have applied.

The whole design strategy used in this work is also inspired by User Centred Design and in particular Participatory Design (Muller and Kuhn 1993). User Centred Design (Norman 2002) is an approach to designing technology where the needs of users are the key driving force behind any design decisions. Participatory design is key to multidisciplinary endeavors like digital heritage because it ensures that stakeholders like archaeologists are able to determine the design of their tools, even if they are eventually implemented by computer scientists. They key enabling technology has been Interactive Machine Learning (Fiebrink et al. 2011), the use of statistical machine learning algorithms to allow users to design interactive systems by giving examples of interaction rather than by programming. This has the advantage that the creation of the system can be much quicker and that it can be done by end users who do not have programming skills.

\section{Work in Progress}

The aim was to make gesture design and personalization as easy as possible, with users only having to record a single example of each gesture. On th one side, this enables each user to design and perform gestures in a way that is the most natural and comfortable for them and avoids the problem of trying to build gesture vocabularies that generalize across different individuals, professional specialisations, cultures and physical abilities. On the other side, visual feedback allows users to support them in training and using gestures.

The main idea behind the design of the application was to give archaeologists the opportunity to think about the data and not the interface. In particular, the application should allow the researchers to access to the data in a natural way by manipulating them with simple recorded gestures.

The first step was defining tasks and gestures which areintegrated into the working pipeline. The archaeologists identified the tasks (e.g., comparison between layers of excavation, analysis of the finds). They also identified suitable gestures. The first task is 
selecting the layer of excavation via two gestures to move up and down; a layer of interest is chosen; particular finds are selected by touching them (this was not implemented via the gesture system). Once selected, objects need to be measured and then deselected. There is also a context menu that displays different data types depending on where you are. This needs to be opened and closed.

For the creation of the scene, we imported 3D models of layers stacked on each other and for each layer we imported 3D models of the most interesting findings, lined up with the excavation. The scene was integrated with a reconstruction of the entire agora, which can be useful for comparison with the current state of excavations.

The set of gestures under test consists of two sets of two coupled gestures, in which one gesture is the inverse of the other: opening and closing the menu and moving up and down levels. There are also two single gestures: initiating measurement of the selected object and deselecting an object.

These gestures exemplify a number of gesture design strategies. The open and close menu gestures are relatively arbitrary, they do not use a particular metaphor, but were designed based on convenience of movement and the constraints of the system. The measurement gesture used a fairly straightforward real world metaphor: stretching out the hands in a clear echo of the movement made when using a measuring tape. The deselection gesture was similar: a sharp downward movement of the hands similar to the movement that would be made to throw down an object that was being held or to shake off an object stuck to the hands. Both of these have clear metaphors from daily life and are generic in the sense that it easy to see them being applicable in many domains, not just archeology. The gestures to move between levels, however, are much more specific to archeologist because they use a metaphor directl from their practice. The gesture to unearth a layer is an upward movement of the hand as if lifting soil off from the layer would reveal the layer below (the archaeologists explicitly described the movement in this way). Conversely, movement to the layer above is a downward movement replacing the earth and covering the current layer (Fig. 1). This is particularly interesting as it contrasts directly with the gestures used by the engineers in the team when doing initial testing on the system. Unlike the archaeologists, they immediately and without thinking about it used an upward gesture to move up a layer. This example clearly shows that, while many gestures are sufficiently generic to be similar and usable across a wide range of domains, certain gestures are specific of archaeologists. They are gestures that have clear metaphors to the archaeologists' physical practice of digging and handling artifacts (in fact, in later discussion the archaeologists raised the possibility of gestures mimicking the use of toolst is therefore important, when designing interfaces for heritage experts (or experts in other domains for that matter) that the experts themselves are participants in the design and as far as possible could design the interface themselves. Otherwise, the result will be generic interfaces that miss the particular physical metaphors that arise from expert practice.

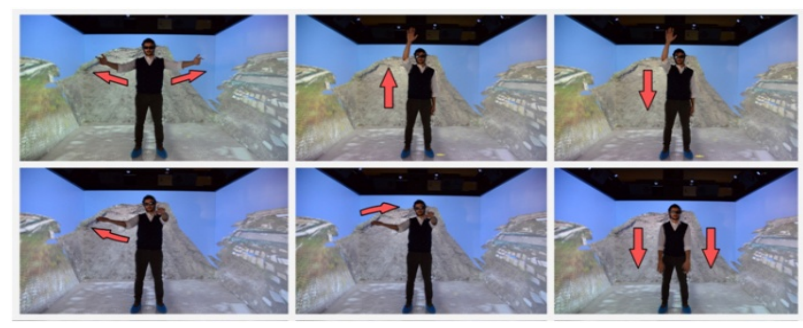

Figure 1: The gesture vocabulary. From left to right and top to bottom: 1) initiating measurement by stretching hands out 2) moving to a lower layer by raising the hand 3 ) moving to a higher layer by lowering the hand 4) Rotation of the right forearm from inside to outside for opening the contextual menu 5 ) closing the menu with an inverse movement 6 ) deselecting the current object with a sharp downwards movement of both hands.

\section{Conclusions}

The application design process forced a reflection on the interaction modalities that archaeologists could use in virtual environments. This has made possible not only to visualize 3D models, but also to re-design and use natural gestures, in order to interrogate and consult data associated with models.

The gesture recogniser gave promising results, both for the efficiency of the application and its future developments. Archaeologists have emphasized the importance of having the possibility to mentally and virtually reproduce the field activity, so to be able to rethink and/or re-formulate interpretations elaborated during the excavation. Besides the possibility to operate in a completely hand-free interaction, thanks to handtracking sensors, the system will allow the use of external devices (i.e. tablets) for a wider consultation of metadata linked to 3D models, which are at present hardly visualizable within the CAVE.

\section{References}

CARAMIAUX, B., MONTECCHIO, N., TANAKA, A. and BEVILACQUA, F., 2014. Adaptive gesture recognition with variation estimation for interactive systems. ACM Transactions on interactive intelligent systems (TiiS), 4(4), 18. DOI: $\underline{10.1145 / 2643204}$

FIEBRINK, R., COOK, P.R. and TRUEMAN, D., 2011. Human model evaluation in interactive supervised learning, Proceedings of the 2011 annual conference on human factors in computing systems, CHI, 147, 2011. DOI: $\underline{10.1145 / 1978942.1978965}$

LONG JR, A.C., LANDAY, J.A., ROWE, L.A. and MICHIELS, J., 2000. Visual similarity of pen gestures, Proceedings of the SIGCHI conference on human factors in computing systems, pp. 360-367. DOI: 10.1145/332040.332458

MULLER, M.J. and KUHN, S., 1993. Participatory design, Communications of the ACM, 36(6), pp. 24-28. DOI: $\underline{10.1145 / 153571.255960}$ 
NORMAN, D.A. 2002. The design of everyday things, New York: Basic books, 2002.

OLIVITO, R., TACCOLA, E. and ALBERTINI, N., 2015. A hand-free solution for the interaction in an immersive virtual environment: the case of the agora of Segesta. The International Archives of the Photogrammetry, Remote Sensing and Spatial Information Sciences, 40-5/W4, pp. 31-36. DOI:10.5194/isprsarchives-XL-5-W4-31-2015, 2015 


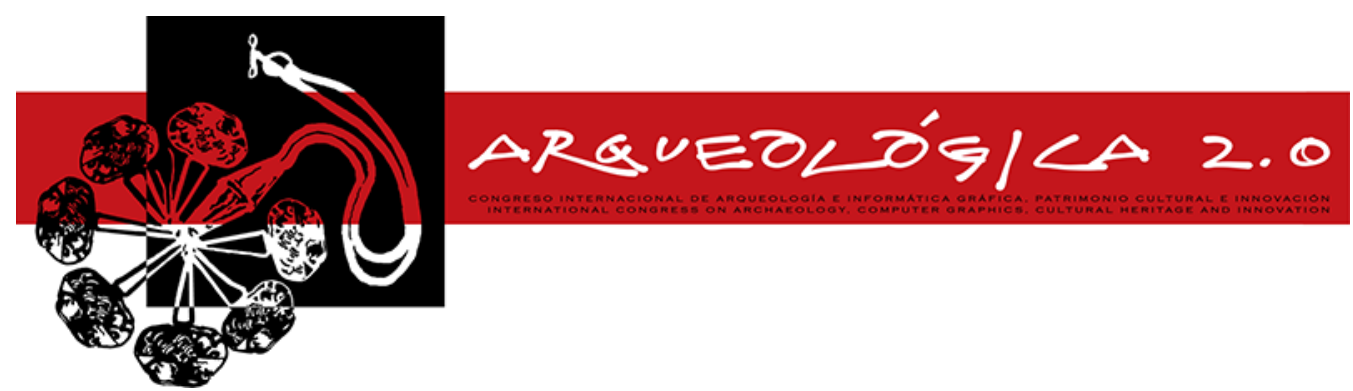

Proceedings of the $8^{\text {th }}$ International Congress

on Archaeology,

Computer Graphics,

Cultural Heritage and Innovation

'ARQUEOLÓGICA 2.0'

in Valencia (Spain),

Sept. $5-7,2016$

\title{
HISTORICAL TRACES' INTERPRETATION AND VIRTUAL RECONSTRUCTION - THE CASE OF ACROCORINTH CASTLE
}

\author{
Demetrios Athanasoulis ${ }^{a}$, Xeni Simou ${ }^{\mathrm{b},{ }^{*}}$, Theodora Zirogianni ${ }^{\mathrm{b}}$ \\ ${ }^{a}$ Hellenic Ministry of Culture, Cyclades Ephorate of Antiquities, Epameinonda 10, 10555 Athens, Greece. dathanasoulis@culture.gr \\ ${ }^{\mathrm{b}}$ Hellenic Ministry of Culture, Argolid Eph.of Antiquities, Greece. xeni.simou@gmail.com; t.zirogianni@gmail.com
}

\begin{abstract}
:
When archival information misses or is insufficient, the structure itself becomes the most valuable archive unfolding stories of monument's life. The current essay examines how the building traces can be used as tools of historical interpretation and how important is digital survey in this respect through the presentation $3 \mathrm{~d}$ virtual documentation of the castle of Acrocorinth. The overall venture was initiated by the 25th Ephorate of Byzantine Antiquities under the supervision of the Ephorate dr archaeologist Demetrios Athanasoulis on the occasion of developing the web-platform ecastles.culture.gr for the Digital Enhancement of the Castles of Peloponnese (Athanasoulis et al. 2015).
\end{abstract}

Key words: virtual archaeology, virtual reconstruction, data acquisition, documentation of cultural heritage, 3d-modelling

\section{Introduction}

Despite the development of automated techniques of $3 d$ documentation, every survey demands the tailoring of a unique suitable methodology, bonded with the specific aim of documentation. When working in situ the surveyor deals with complicated problems of function, historic phases and construction in order to produce not only accurate but also comprehensive measuring results. The survey of Acrocorinth castle was executed in summer 2015 by the writers architects-conservators. The questioning that arised through the documentation process was the cause for the conducting of this essay, that aims to display the interdependency of survey method and monument's interpretation.

Acrocorinth castle crowns the abrupt cliff that rises by Ancient Corinth in Peloponnese, a city of major importance in Ancient Greek and Medieval times. It consists of three successive fortification lines and runs a perimeter of $3000 \mathrm{~m}$. The current formation is a longtime process, a byzantine core that was extensively tranformed in the mid-byzantine period following in a large scale the ancient wall understructure (Athanasoulis 2014) with later alterations of capturers (Ottoman, Venetians). The $3 d$-visualization period concerns the mid-byzantine castle (843-1210) due to the relatively big existing structural elements that permit the re-thinking of its peak-point period. The survey was restricted in the area of the castle that is located on the western and more accessible side of the rock between the first and second byzantine defence line (Figs. 1, 2).

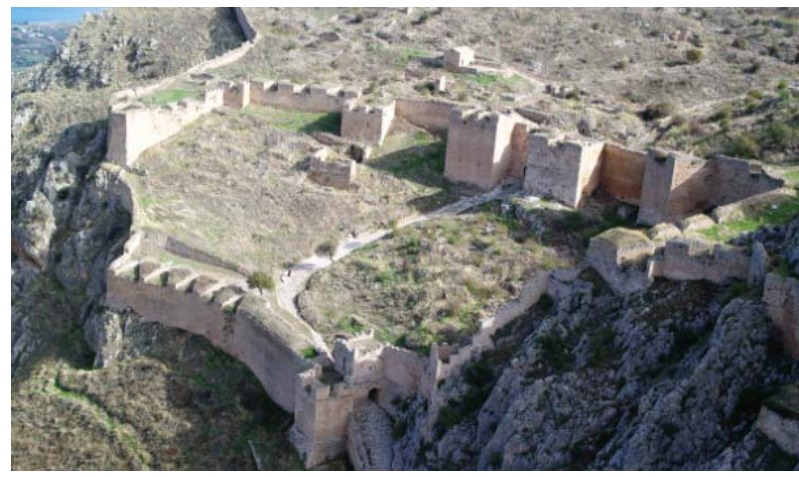

Figure 1: Aerial view of the survey area between the two defense lines, photographer: K. Xenikakis.

\section{Survey and $3 d$ representation method}

The digital survey was based on multiple techniques and required developing a methodology of seamless combination, filling gaps and avoiding overlapping (Remondino et al. 2009). The natural rock peculiarities and the necessity of creating analytic plans of the existing situation for further restoration projects of Acrocorinth's complex forced to develop a synthetic approach of documentation methodology with combination of different tools. Total station Leica TS06 was extensively used for the measuring of general plans after sketching of the preliminary recording plans. The blind areas were completed by hand measured details. Image rectification processing for both inner and outer walls followed. Laser scanning data for geometrically interesting selected areas and interior spaces (El-Hakim, et al., 2007) from previous and new surveys was

“Corresponding Author: Xeni Simou, xeni.simou@gmail.com 
exploited and linked to general plans by using common check points.

Because castles pose complications in their presentation in digital virtual reality formats (Finan 2012) there was a necessity of tailoring a personalized $3 \mathrm{~d}$ methodology for Acrocorinth. The $3 \mathrm{~d}$ model construction followed a synthetic process and not an automated scanner-based reproduction due to the fragmented overal icon of the castle and the natural obstacles. The careful analysis of the possessed material was fruitful for the building phases' identification and the creation of $2 d$ graphic reconstruction plans. The representation was equally based on the existing indicators on the masonry of the castle and the assumptions created by comparisons with similar elements and archival information.

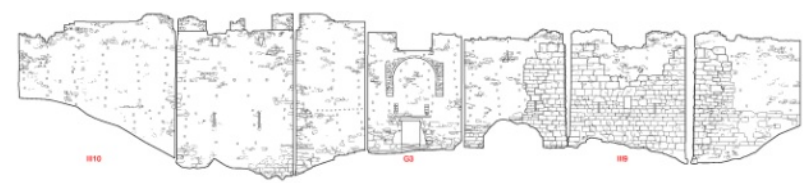

a)

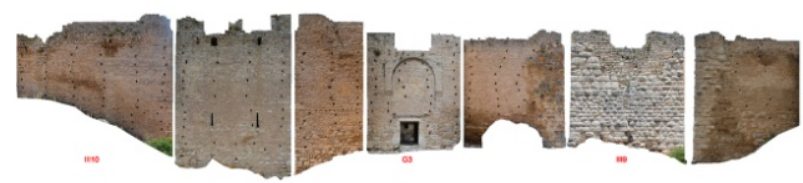

b)

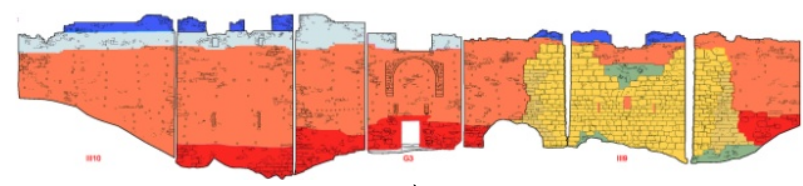

c)

Figure 2: a) Elevations-existing condition; b) Image Rectification; c) analysis of building phases.

The $3 d$ representation was made in $3 d$-studio max environment with small number of polygons, in order to be lighter for touring options, after inserting the $2 d$ reconstruction plans. The final $3 d$-touring outcome was made in Unity WebGL in collaboration with a web developing company where hot-spots of archaeological information were introduced (Fig. 3).

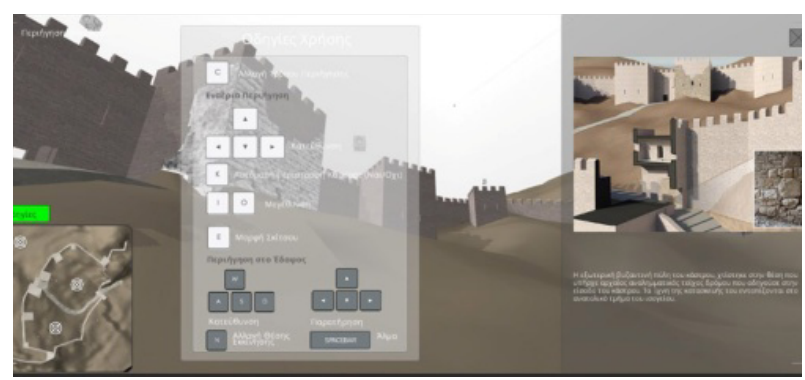

Figure 3: Final 3d tour in Unity with pop-up info windows.

\section{Interpretation of special survey traces}

\subsection{Continuity and extension assumptions - Completion with analogies}

Although relics standing scattered are incomprehensive, if we investigate them as a part of a whole they become valuable. The continuity of a construction can be confirmed and missing elements can be supplemented based on analogies. This was the case in the gate of the southeast corner where lateral wall relics' if prolonged reveal a previous elbow tower whose form could be completed in comparison with the standing towers.

\subsection{Peculiar structural elements recognition}

Another method is the recognition of peculiar indications on the construction that could possibly confirm a construction hypothesis. Survey revealed that a suspicious corner extruding from the parapets of the southern tower could solve the accessibility problem to the superstructure of the tower (Fig. 4). The metrical reconstruction was matching with the hypothesis of a straight line staircase attached to the towers platform.

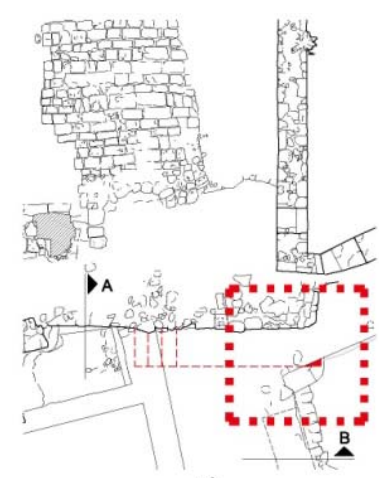

a)

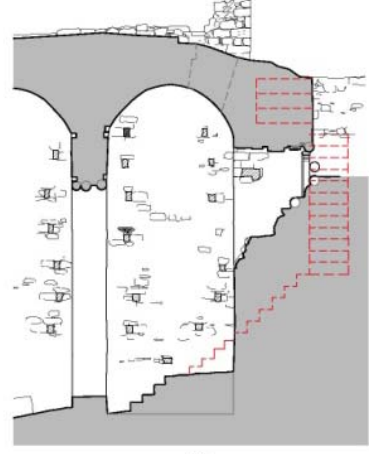

Figure 4: South Tower's survey Plans with special indication of staircase trace: a) ground plan; b) cross-section.

\subsection{Corresponding joints or Parallels}

The accuracy often defines if joints and parallels are corresponding and correlated with a building phase. The precise measuring of these features in comparison with other prototypes in the multilayered second Byzantine Gate led to a reasonable deduction. The gate was initially a rectangular-shape tower protected by a portcullis mechanism, whose core was later on alterated in order to facilitate the access to artillery platforms (Fig. 5).
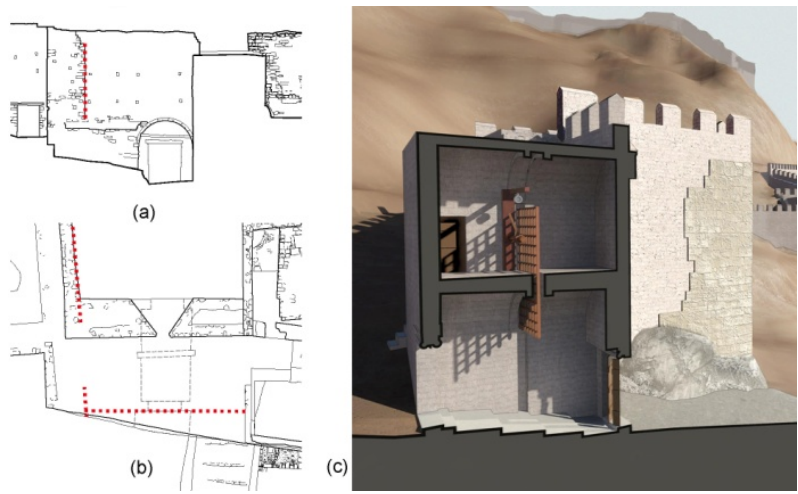

Figure 5: a) 2d graphic reconstruction plans-indication of joints and parallels; b) 3d representation of Byzantine Gate 2.

\subsection{Rejecting and confirming scenarios}

When other methods are inadequate, the conclusions could come by a "reductio ad absurdum" techniquesuch as in the re-thinking of the complicated first Byzantine Gate where multiple possible scenarios were made and 
rejected for different reasons each. The most reasonable scenario prevailed and resulted to the representation of a two story passageway tower with a two-unit first floor (Fig. 6).
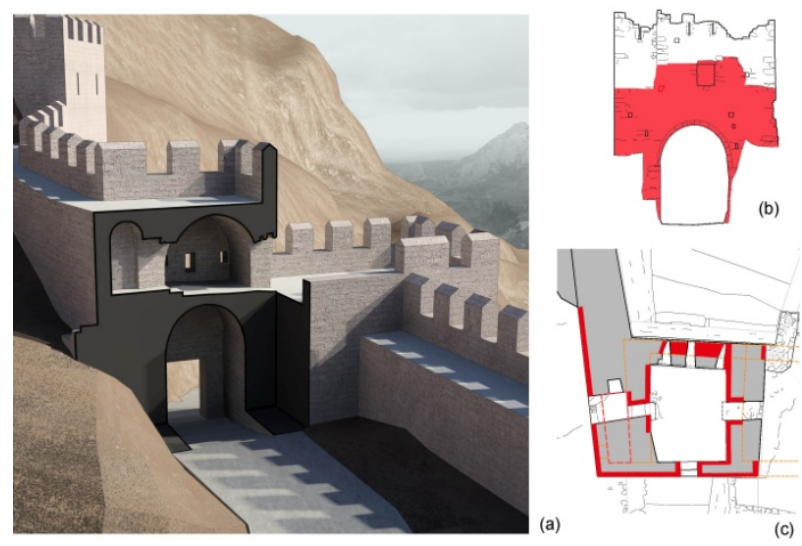

Figure 6: a) First Byzantine Gate 3d representation; b-c) Survey plans with indications of fragmented byzantine masonry.

\section{Assessment of survey's contribution to interpretation and $3 d$-reconstruction}

Appropriate selection of documentation methodology provides an indisputable accuracy in surveys, crucial in deducing conclusions about building's history. While elaborating data, the surveyor gathers multiple-sourced information that serve complementary to interpretation. Fragmented site elements like disrupted masonry can be reconnected due to the digital precision and can confirm the reconstruction hypothesis and cases like misleading eye-illusions can be rejected. In addition to this, the survey in unexcavated areas helps to surface investigation for any further archaeological excavation.

As Pletinckx (2009) noted "virtual archaeology complements perfectly documentation and conservation efforts and even can act as an integration activity to bring all information together in a structured way". In general all the acquired data from this survey can be stored and connected with older and new surveys for future use when necessary.

Unlike material reconstruction which has specific limitations, 3d-archaeological reconstruction must be as complete as possible in order to cover virtual-touring demands. In such a synthetic and subtractive approach, scholars have to give answers to the totality of the monument and fulfil huge gaps, although assumptions are inevitable. When there is no evidence, $3 \mathrm{~d}$ modeling is based on hypothesis on different degrees of likelihood, (Georgopoulos 2014). 3d reconstruction is a nondestructive way with great potentials of reusing data for future different alternatives where the historic scenarios are weak.

\section{Acknowledgements}

The project was a part of a wider collective attempt for the digital enhancement of Peloponnese castles under NSRF funding. We owe special thanks to the Ephorate of Argolid Antiquities dr A.Papademetriou, to archaeologists A.Georgiou, A. Sfika, V.Klotsa, architecteng G.Kousoulos, civil engineers N.Sidiropoulos, and At.Xourafis as well as the surveyors and workers that participated in previous enhancement projects of Acrocorinth.

\section{References}

ATHANASOULIS, D., 2014. The castle of Acrocorinth and its Enhancement Project (2006-2009), Ancient Corinth: Hellenic Ministry of Culture publication

ATHANASOULIS, D., GEORGIOU, A., SIMOU, X., SFIKA, A., KLOTSA, V., ZIROGIANNI, T.,THEODOROPOULOS, C. and DELIGIANNI, E.O., 2015. Bridging Monuments through Digital Repository and Graphic Reconstruction Methodologies - The Digital Enhancement Project of Argolid, Arcadia and Corinthia Castles, Greece. In International Conference Digital Heritage, (pp. 107-110). Granada: Spain

EL-HAKIM, S., GONZO, L., VOLTOLINI, F., GIRARDI, S., RIZZI, A., REMONDINO, F. and WHITING E., 2007. Detailed 3D Modelling of Castles. International Journal of Architectural Computing , 5(2), pp 199-220.

FINAN,T., 2012.3d Castle reconstruction as interpretive modelling: The medieval Lough Cé Project, Château Gaillard 2 : L'origine du château médiéval, actes du colloque de Rindern, Allemagne 2010, p. 45-49

GEORGOPOULOS, A., 2014. 3d Virtual Reconstruction of Archaeological Monuments in Mediterranean Archaeology and Archaeometry, Vol. 14, No 4, pp. 155-164

PLETINCKX, D., 2009. Virtual Archaeology as an Integrated Preservation Method, in Virtual Archaeology Review, Vol.2, No. 4 , pp. $33-37$

REMONDINO, F., EL-HAKIM, S., GIRARDI, S., RIZZI, A., BENEDETTI, S. and GONZO, L., 2009. 3d Virtual reconstruction and visualization of complex architectures - The "3d-Arch" Project, 3D-ARCH 2009, Trento, Italy 


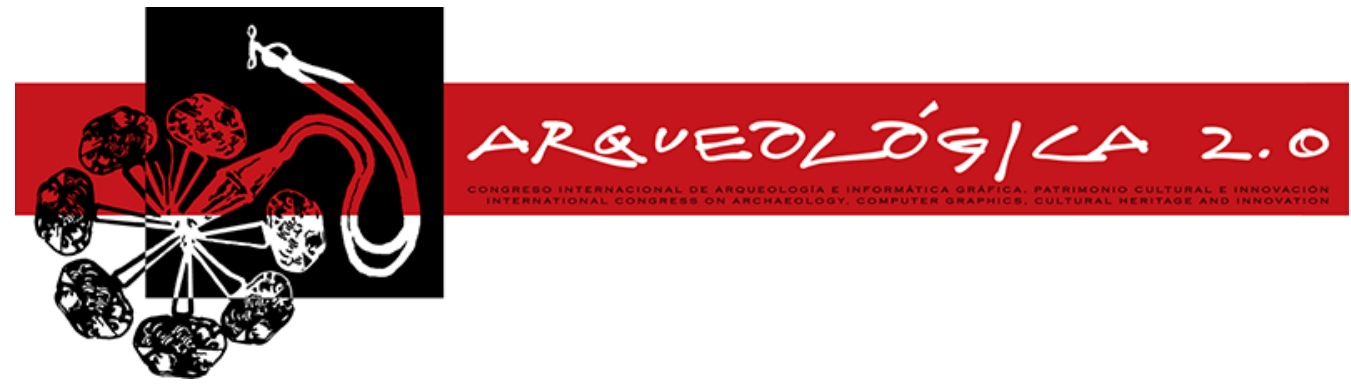

Proceedings of the $8^{\text {th }}$ International Congress

on Archaeology,

Computer Graphics,

Cultural Heritage and Innovation

'ARQUEOLÓGICA 2.0'

in Valencia (Spain),

Sept. $5-7,2016$

\title{
THE DOCUMENTATION OF CULTURAL HERITAGE WITH BIM OPEN SOURCE SOFTWARE
}

\author{
S. Logothetis*, E. Stylianidis \\ Faculty of Engineering, School of Spatial Planning \& Development, Aristotle University, Thessaloniki, 54124, Greece. \\ slogothet@auth.gr; sstyl@auth.gr
}

\begin{abstract}
:
The Building Information Modelling (BIM) software enables the users to communicate and design, understand appearance, performance and cost in the spatial and urban design process. Another important use of the BIM technology is the documentation and 3D reconstruction of cultural heritage monuments. The appropriate BIM software equips the users with tools to easily capture and analyse concepts and maintain the coordination of design data through documentation and 3D modelling. Many developments come up in the BIM field and software industry for design, construction-reconstruction, restoration and management of the cultural heritage 3D models, using BIM tools; mainly commercial as well as free or open source. Nevertheless, recently the growing popularity of open source has altered the landscape in software industry, as they attract many users.

This paper presents a review of some recent research on the topic. We review the recent developments focusing on the OSS that can be used at various stages of BIM process in the digital documentation of cultural heritage. The results show that there is more preference in the commercial software due to the fact that the OSS is not yet complete and covers all stages of the BIM process. However, lately we have the Edificius in architectural BIM design and "BIM Vision" as Industry Foundation Classes (IFC) model viewer that try to attract as many users as possible. These tools are free and they could well be used for the digital reconstruction of cultural heritage.
\end{abstract}

Key words: BIM, cultural heritage, digital documentation, open source software, free software, 3D modelling

\section{Introduction}

Over the last few years, in architecture, engineering and construction (AEC) industries, an increased use of specific software that processes building information models for visualisation of construction projects is observed. These are BIM tools and, nowadays, make it possible to preserve cultural heritage. Using modern modelling tools, such as ArchiCAD, Revit Architecture, Allplan Architecture etc., the models produced by the users have evolved from traditional $2 \mathrm{D}$ drawings and written specifications to parametric object oriented 3D models, embedded with information to describe any historical structure in detail (Singh et al. 2011).

As a digital visualisation of the functional and physical characteristics of the structure, BIM serves as source of information supporting many applications along the processes of visualisation or reconstruction, including structural analysis, cost estimation and specification management. In addition, BIM concept fosters the use of real time visualisations as a tool to communicate concepts and sharing information between stakeholders in a cultural heritage project (Eastman et al. 2008).
Nowadays, software developers have created many BIM tools dealing with various categories of historical structures information, such as the representation of cultural heritage. Mainly, these tools are quite expensive and inaccessible. This reason led the users to face major challenges; to choose what tools they can use, in which construction/restoration activity and how to use them effectively.

This paper explains the BIM software that used for collecting, processing data, parametric modelling, and evaluating the historic model across the process to finalise a cultural heritage project. We emphasise on free and OSS that are more affordable and customisable to the end-users needs.

\section{BIM software groups}

The BIM models include both geometric and nongeometric data such as object specifications and attributes. The creation of these models enables the various project participants (architects, conservators, engineers, etc.) to visualise the activities progress. This project management technique with BIM tools has the potential to improve management and delivery of the

*Corresponding Author: Sotiris Logothetis, slogothet@auth.gr 
digital documentation, concerning any size or complexity of a cultural heritage object (Singh et al. 2011).

In the case of cultural heritage documentation, the objects consist of components and materials whose geometry and characteristics are not represented by libraries of typical software and thus there is a need to introduce the Historic BIM (HBIM) approach (Logothetis et al. 2015). HBIM is the process by which the architectural elements collected using a terrestrial laser scanner and photogrammetric survey data are converted into parametric objects (Dore and Murphy 2012).

The BIM tools are distinguished into 3 basic categories depending the licence that is a legal instrument governing the software use. The tools categorised into commercial, free and open source software (FOSS). Moreover, depending on the software use and purpose, these can be categorised into 3 types: visualisation software (authoring tools and viewers), tools for file sharing-collaboration (BIM Servers) and analysis tools.

\subsection{BIM visualisation software}

This category concerns all the tools which enable the users to provide a $3 D$ virtual representation of the cultural heritage objects. These tools can provide renderings, walkthroughs, and sequencing of the model for better understanding of what the final structure may look like. The software divided into BIM authoring tools and BIM viewers.

"BIM authoring tools" are specific programs that allow users to produce structural models that consist of parametric objects for creating the actual model. They also include all the tools that are used during the design phase until the documentation (Eastman et al. 2008).

On the other hand, "BIM viewers" are programs that can access data connected to the BIM structural model without the need to extract the entire model. The most common file used is IFC developed by buildingSMART (http://www.buildingsmart.org/) in order to provide an interoperability solution between different software applications. (Eastman et al. 2008).

\subsection{File sharing and collaboration tools}

As a collaboration platform, a BIM Server manages, archives building data, and allows applications to export and import files from the database for checking, viewing, modifying and updating the data model. BIM Servers allow exchange $3 \mathrm{D}$ model data between the various applications involved in a BIM project life cycle including analysis tools, design tools, Facility Management (FM) tools, Document Management Systems (DMS), etc. (Singh et al. 2011).

\subsection{BIM analysis tools}

"BIM analysis tools" are programs used for the model behaviour analysis and also for the model validation to be compliant with specific standards. Normally, these tools are used in the preliminary design phase until the construction phase or the final 3D reconstruction (Quattrini and Baleani 2015). These tools are useful when a partial repair or reconstruction of a historic monument is needed.

\section{OSS and free software solutions}

OSS means that the source code, i.e. any group of computer instructions written using a human-readable computer language, is freely accessible by everyone interested in. The software can be freely used, improved, changed, copied and distributed by anyone and for any purpose (Statskontoret 2003).

In the field of cultural heritage documentation used mainly "3D BIM viewers" FOSS in most research papers. San Jose et al. (2013) used CityGML, an open standard data model which based on geometry, for representing 3D urban objects. Saygi et al. (2013) used Trimble SketchUP for the creation of 3D models, BIMserver as a platform to handle IFC data and OpenBIM for attribute data enrichment, related to building elements, zones or complete buildings. Zheliazkova et al. (2015) used Grasshopper 3D a graphical algorithm editor integrated with Rhino's 3-D modelling tool. Moreover, they used MeshLab an open source system for the processing and editing of unstructured triangular meshes, which also deals with automatic $3 \mathrm{D}$ reconstruction.

\subsection{Benefits of using FOSS}

According to Peeling and Satchell (2001), open source and free software holds several fascinating advantages: (a) Cost. The first perceived advantage is the fact that FOSS is made available cost-free or at a low cost. Unlike most commercial packages that are expensive enough and inaccessible for many businesses; (b) Quality. OSS is closer to the professional users' needs. A developer, who is also a BIM program user, can create what he/she wants; (c) Customisability. The availability of the source code and the right to modify it is of high importance. In fact, it enables the unlimited software improvement or the addition of new abilities. (d) Freedom. With FOSS, the users make their own decisions and do what they want with the software, to suit their individual needs.

\subsection{Limitations in working with FOSS}

In the last few years, the development of FOSS for BIM has expanded and the use of FOSS tends to be consolidated due to their advantages and the freedom that provide. However, it is possible to present some limitations when someone chooses to use this software category in some cases such as: (a) They are often intractable; because less attention is paid to the development of user interface and as a result they become less "user-friendly"; (b) Sometimes, there is data incompatibility; (c) It requires programming skills and expertise for the customisation of the application; (d) There may also less support available and there is no also a user manual; (e) Although the OSS is mostly free, there may still be some indirect costs involved, such as paying for an extra feature; (f) Small companies may not have software skills or resources to work with a few of the more complex OS BIM programs or toolkits.

\section{Edificius and free software}

Free BIM software is computer software that gives the users the freedom to run the program for any purpose. Edificius is free BIM software and can be used in cultural heritage documentation projects (ACCA 2015). It is a 
professional architectural, engineering and bill of quantities/estimating software. The user can use for free the full featured program version for architectural BIM design and must pay only when there is a need for printing. Projects and professional collaborations are possible to be shared with every user; all data is stored in a single file that anyone can open.

\section{OSS selection and future development}

The OSS that we selected for future development is an IFC model viewer, the "BIM Vision" from Datacomp (BIM Vision 2011). It can be used for providing documentation of cultural heritage projects. Is a freeware IFC model viewer that allows viewing the virtual models coming from BIM systems like Archicad, Revit, Bentley, etc. (Kogut 2015). The main reason "BIM Vision" was chosen for further development, is the ability to create plug-ins that allows extension to the existing functionalities and integration with other applications. Some of the future investments in the software "BIM Vision" could be: (a) adding support for extra file types e.g.Trimble SketchUp (.skp) models; (b) exporting individual cultural heritage data files such as walls, floors, areas etc. (c) running conflict checks of the different project's parts.

\section{Conclusions and discussion}

This paper presents a review of the BIM FOSS used for the documentation of cultural heritage. The goal of this study is to identify and encourage the users to use FOSS for HBIM processes. The complexity and diversity of HBIM technology is obvious in many fields and for this reason there are many specific software, mainly commercial that offers several possibilities to their users.
However, in the field of open source there are no integrated platforms to cover all stages of HBIM process. The survey showed that the users prefer commercial software BIM instead of FOSS because there is not a program that can be used for the overall cultural heritage documentation. They use only a few "BIM Viewers" to visualise the final produced historical 3D model.

We reported Edificius and BIM Vision, and we focus on the second that provides all the necessary tools to create plug-ins to expand its capabilities. This is our plan for the next research phase; to build upon this existing platform using Python programming language to create specialised plug-ins.

Moreover, we discussed the benefits and limitations of using FOSS in comparison with commercial software. Nevertheless, there is a question; can we believe the information provided on the websites about the features and functionalities of the software from their manufacturers? For open source BIM software systems is easy for users to verify, by simply downloading and testing the application. For commercial software, despite the availability of trial versions, is a huge challenge as most trial versions usually have limited scope.

In the recent years, many technological advances have taken place in the field of HBIM software. However, in the field of OSS, there could be more growth in order to reduce the prices of expensive commercial solutions. Further, given the important function of plug-ins in different areas of the BIM software, it is important to create more, which could be freely available to a community of professional designers, architects, engineers and conservators for their utilisation.

\section{References}

ACCA, 2015. Edificius for BIM Architectural Design. Available: http://download.acca.it/Files/Scheda/Edificius.pdf [1/29, 2016].

BIM VISION, 2011. BIM Vision a freeware IFC viewer. Available: http://www.bimvision.eu/home/ [2/5, 2016].

DORE, C. and MURPHY, M., 2012. Integration of Historic Building Information Modeling and 3D GIS for Recording and Managing Cultural Heritage Sites, 18th International Conference on Virtual Systems and Multimedia: "Virtual Systems in the Information Society", 2-5 September, 2012, Milan, Italy, pp. 369-376.

EASTMAN, C., TEICHOLZ P., SACKS, R. and LISTON K., 2008. BIM Handbook: A Guide to Building Information Modelling for Owners, Managers, Designers, Engineers and Contractors, John Wiley \& Sons, New Jersey.

KOGUT, P., 2015. BIM Vision in Poland.International Construction Information Society.ICIS 2015.

LOGOTHETIS, S., DELINASIOU, A. and STYLIANIDIS E., 2015. Building Information Modelling for Cultural Heritage: A review. ISPRS Annals of the Photogrammetry, Remote Sensing and Spatial Information Sciences, Volume II-5/W3, 25th International CIPA Symposium 2015. Taiwan, pp. 177-183.

PEELING, N. and SATCHELL, J., 2001. Analysis of the Impact of Open Source Software.QINETIQ/KI/SEB/CR010223. Available: http://www.featuredrivendevelopment.com/files/QinetiQ_OSS_rep.pdf [2/7, 2016].

QUATTRINI, R. and BALEANI, E., 2015. Theoretical background and historical analysis for 3D reconstruction model. Villa Thiene at Cicogna, Journal of Cultural Heritage 16, pp. 119-125.

SAN JOSE, I., MARTINEZ, J., ALVAREZ, N., FERNANDEZ, J., DELGADO, F., MARTINEZ, R, PUCHE J. and FINAT, J., 2013. An open source software platform for visualizing and teaching conservation tasks in architectural heritage environments. ISPRS Annals of the Photogrammetry, Remote Sensing and Spatial Information Sciences, Volume XL-5/W2, XXIV International CIPA Symposium 2013.Strasbourg, France, pp. 367-372.

SAYGI, G., AGUGIARO, G., HAMAMCIOĞLU-TURAN, M. and REMONDINO, F., 2013. Evaluation of GIS and Bim Roles for the Information Management of Historical Buildings, ISPRS Annals of Photogrammetry, Remote Sensing and Spatial Information Sciences, Volume II-5/W1, 2013, pp.283-288. 
SINGH, V., GU N. and WANG, X., 2011. A theoretical framework of a BIM-based multi-disciplinary collaboration platform, Automation in Construction Vol. 20, Issue 2, pp. 134-144.

STATSKONTORET, 2003. Free and Open Source Software - a feasibility study. Available: http://www.statskontoret.se/globalassets/publikationer/2000-2005-english/200308a.pdf [2/4, 2016].

ZHELIAZKOVA, M., NABONI, R. and PAOLETTI, I., 2015. A parametric-assisted method for 3D generation of as-built BIM models for the built heritage. WIT Transactions on The Built Environment, Vol 153. doi:10.2495/STR150581. 


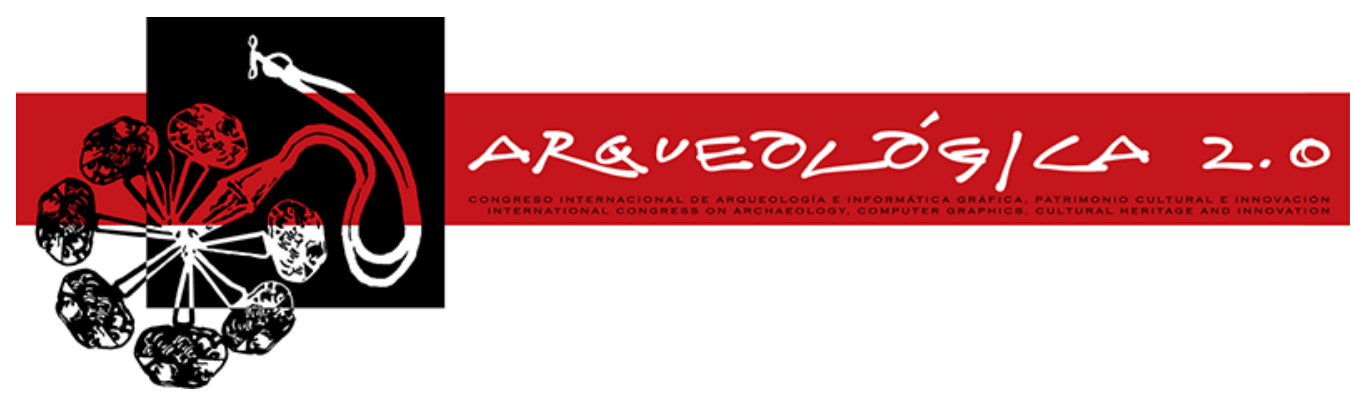

Proceedings of the $8^{\text {th }}$ International Congress

on Archaeology,

Computer Graphics,

Cultural Heritage and Innovation

'ARQUEOLÓGICA 2.0'

in Valencia (Spain),

Sept. $5-7,2016$

\title{
UNVEILING DAMNATIO MEMORIAE. THE USE OF 3D DIGITAL TECHNOLOGIES FOR THE VIRTUAL RECONSTRUCTION OF ARCHAEOLOGICAL FINDS AND ARTEFACTS
}

\author{
Anna Maria Manferdini ${ }^{a,}{ }^{,}$, Sofia Gasperoni ${ }^{a}$, Federica Guidi ${ }^{b}$, Marinella Marchesi ${ }^{b}$ \\ a Department of Architecture, University of Bologna, Viale Risorgimento 2, 40136 Bologna, Italy. am.manferdini@unibo.it; \\ sofia.gasperoni@gmail.com \\ ${ }^{\mathrm{b}}$ Archaeological Museum of Bologna, Via dell'Archiginnasio 2, 40124 Bologna, Italy. federica.guidi@comune.bologna.it; \\ marinella.marchesi@comune.bologna.it
}

\begin{abstract}
:
The aim of this paper is to show how the possibility to acquire 3D reality-based data from archaeological finds allows to build 3D digital models that can be analysed and managed in a virtual environment and can be relocated, assembled or restored in order to suggest or graphically support archaeologists' interpretations and reconstructions. In particular, the paper shows how the use of 3D digital technologies is extremely helpful in contexts where iconographic sources are damaged or completely lost. In ancient Rome, for example, damnatio memoriae was a practice of erasing the memory of condemned persons from historical records after their death. This condemnation usually included practices such as the erasure of names sculpted on inscriptions and the destruction or reworking of statues and of any other image of the person. The paper shows the methodology developed for the virtual restoration of the statue of Nero that was found 500 years ago by the Roman theatre of Bologna, Italy, starting from the 3D digitization of the torso, to the reconstruction of its damaged and missing parts.
\end{abstract}

Key words: 3D reality-based survey, virtual archaeology, virtual reconstruction, 3D sculpturing, 3D modelling, Nero

\section{Introduction and aims}

In Archaeology, sculptures are considered an extremely interesting and rich field of investigations. Indeed, they are the tangible evidence of the specific cultural and historical context in which they were conceived.

Since the pionieristic project of the 3D digital survey of Michelangelo's David statue held 15 years ago (Levoy et al. 2000), the digitization of statues still represents an important body of knowledge that can support various kinds of investigations in different research fields (www.digitalsculpture.org, Grün et al. 2004, Frisher and Fillwalk 2012, Patay-Horvàth 2013).

In this context, the purpose of this paper is to show how the use of $3 \mathrm{D}$ digital technologies can help the reconstruction of the past through its iconographic repertoires. In particular, the paper shows the results of investigations held on a statue of Emperor Nero that was found in Bologna, Italy, five centuries ago and that was intentionally damaged after Nero was condammned to damnatio memoriae by the Roman Senate. This practice destroyed a wide iconographic repertoire that can actually be recovered thanks to the integrated use of 3D survey and modelling tools that facilitate the combination of fragments from different finds and that allow scholars to verify their interpretations, as well as to effectively communicate the results of their analisys.

This loricated torso attributed to Emperor Nero is one of the masterpieces conserved in the Archaeological Museum of Bologna.

Although its attribution now seems indisputable (Mansuelli 1956), the exact dating of the sculpture is more arduous. It could have been made between 53 B.C., when Nero advocated Bononia's case with the Senate, and 60 B.C., when an honorary inscription that was discovered near the theatre where the statue was found was dedicated to Nero.

The statue (Fig. 1a) represents a male figure wearing military garments and is preserved to the height of 117 centimetres. It was defaced, lacking the head and the neck, which were taken away in a violent manner. The arms and the legs are lost too; only the stumps of the forearms and the upper part of the legs remain.

The virtual reconstruction of the statue of Nero required a series of preliminary analysis aimed at detecting geometric details within other finds that share similar features with the supposed original look of Nero's statue.

The remainders of the arms do not allow an unequivocal interpretation of their original position: the left arm was

“Corresponding Author: Anna Maria Manferdini, am.manferdini@unibo.it 
reasonably raised to hold a spear, whereas the right one did not lean along the flank, as most scholars suggested. In view of the slight inclination of the right forearm stump, the arm must have been stretched out forward, possibly to hold a patera or phiale for libations.
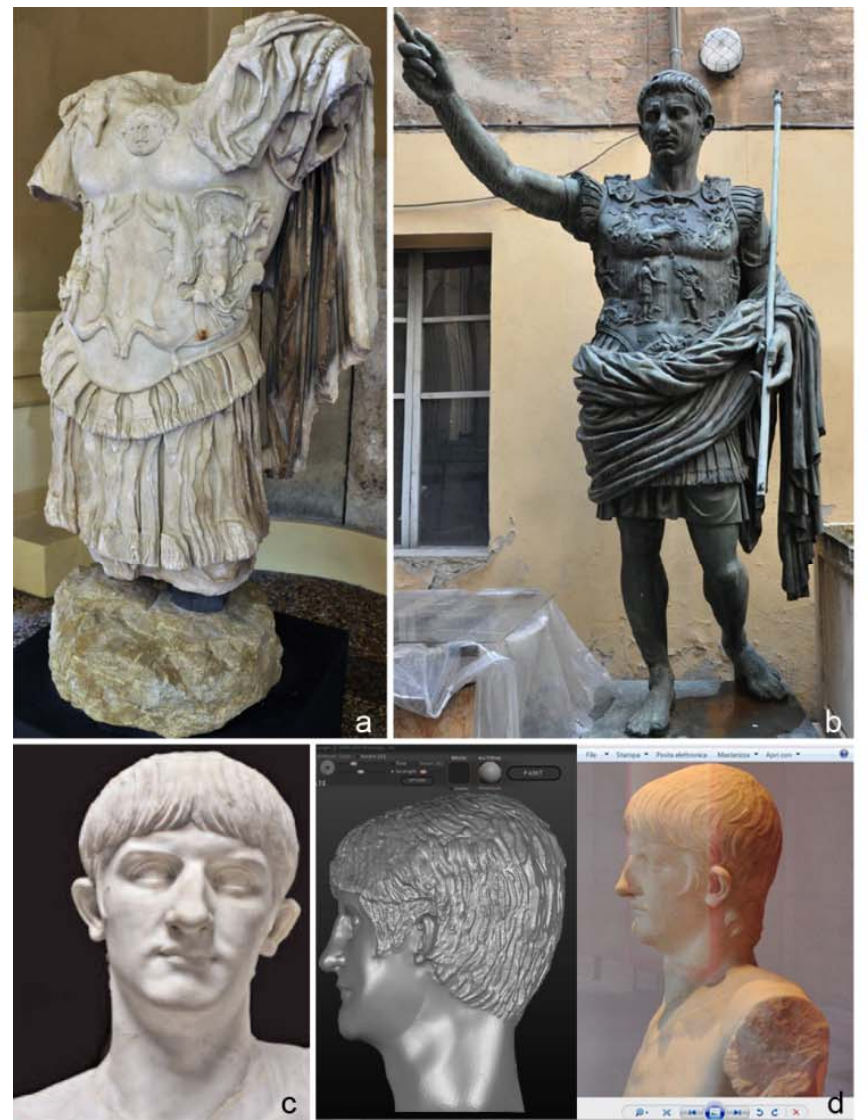

right arm, left hand and legs derived from Augusto of Prima Porta

In order to rebuild the statue's limbs, we selected the Augustus of Prima Porta statue, which represents the earliest example of Roman Imperial loricated sculptures. A twentieth-century copy of it is preserved at the Archaeological Museum of Bologna (Fig. 1b).

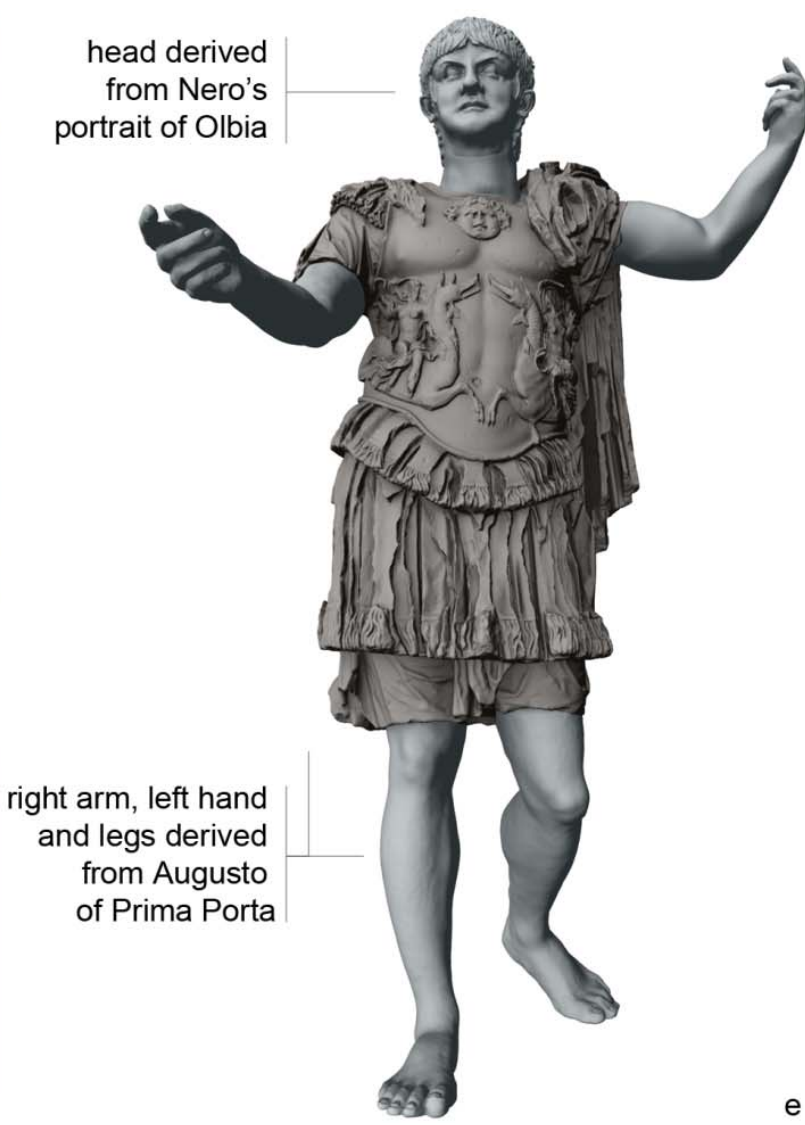

Figure 1: a) Picture of the torso of Nero (Archaeological Museum of Bologna); b) bronze copy of the Augustus of Prima Porta statue (Archaeological Museum of Bologna); c) Nero's portrait from Olbia (Cadario 2011); d) 3D sculpting of the head of Nero based on visual correspondences with the Olbia portrait; e) integrated digital 3D model of the statue of Nero.

Instead we encountered severer difficulties to find an appropriate head for the statue. If the statue's alleged date of creation is reliable, a head pertaining to the portrait of Nero Type 2 must be considered (Cadario 2011) juvenile and still related to the canons of JulioClaudian portraiture in common use in A.D. 55. This portrait is from Olbia and is now preserved at the National Archaeological Museum in Cagliari (Fig. 1c). The Emperor still has a juvenile and yet non-idealised face, compared to his childlike portraits, with hollow features and the distinctive coiffure with longer hair and fringe combed clockwise over the right side of his forehead and counter clockwise over the left.

\section{The adopted methodology}

The 3D modeling process was basically organized within three main phases: $i$. the accurate and detailed 3D survey of the torso; ii. the 3D sculpting of missing parts starting from geometries derived by other finds; iii. the integration of data collected within the previous two steps.

As far as the first step is concerned, the selection of the most suitable methodology was driven by the purpose of collecting the most accurate and detailed geometric information of the torso, in order to document its conservation conditions and also to provide a digital replica of the find

The second step consisted in the detection of the most suitable methodology to adopt in order to easily and quickly derive the main geometric information from other finds related, for example, to the position of the limbs, to gestures, to the shape of the face, to facial features and to the hairstyle. In this case, image-based technologies were privileged over range-based ones.

The third step consisted in the manipulation of data acquired from other finds in order to adapt geometry, scale, spatial orientation and level of detail of face and limbs both to archaeologists' reconstruction hypothesis and to the replica of the torso. 3D sculpting techniques were adopted to modify surface geometries and to add details. 


\subsection{The high resolution 3D survey of the torso}

The torso was surveyed using a Konica Minolta Range 7 triangulation laser scanner. During survey campaign, the main difficulties arose due to to the geometric complexity of cloak and tunic, since they present deep convexities that required redundant scans and long post processing of data (i.e. in the manual closing of small lacks).

The survey of the whole torso required the capturing of 300 scans that were aligned, merged and topologically corrected in order to provide a high resolution 100 million polygonal mesh that was afterwards decimated in order to be easily manipulated.

\subsection{The 3D survey of fragments from other finds}

For the reconstruction of the shape and arrangement of legs and arms derived from the bronze statue of Augustus of Prima Porta, a Nikon D90 camera equipped with an AF-S DX Nikkor 18-105 mm lens was adopted. Images were processed using a well-known pipeline and the tools integrated in the Agisoft PhotoScan package.

The rebuilt mesh was afterwards manipulated in order to add missing details, such as, for example, wrinkles near articulations and nails. Furthermore, other 3D sculpting tools were adopted to scale and modify the arrangement and the overall shape of limbs and integrate them with the torso.

\subsection{The sculpting of missing elements and the whole integrated 3D model}

The 3D model of the head was entirely sculpted inside a 3D digital environment using the Pixologic Sculptris package. Nero's characteristic features were sculpted through the detection of visual references on pictures of its marble reference portrait from Olbia (Fig. 1d).
This visual matching allowed the intuitive detection of symmetries and evaluation of sizes.

Some details were afterwards modified in order to adapt features, build and hairstyle to the age of the torso, which is supposed to represent Nero at a more mature age with respect to the reference portrait (Fig. 1e).

\section{Conclusions and future works}

The present project shows how 3D digital technologies can provide effective graphic representations that can easily and intuitively communicate the results of deep and complex analysis and therefore support the work of archaeologists and historians involved in the interpretation and reconstruction of history.

From a scientific point of view, we are aware that no reconstruction will ever return the original statue, because no source is available to describe them precisely. This reconstruction of the monument can therefore be only one of many possible.

Nevertheless, from an archaeological point of view, being able to communicate a plausible reconstruction of the original look of the statue to a non-specialist audience represents a very important challenge and task.

In addition to this aspect, the model has an unquestionable documentary value and it also allows the combination of geometric 3D reality-based data with radiometric information captured through multispectral investigations that are actually being held in order to identify traces of pigments on the torso and restore the original colors of the statue (Baraldi et al. 2014).

\section{Acknowledgements}

This project was carried out thanks to the precious support of Daniele Molina of Konica Minolta who provided the technology that was used for the digitization of the torso of Nero.

\section{References}

BARALDI, P., DEL GALLO, C., MARCHESI, M. and ROSSI, A., 2014. II torso loricato di Nerone da Bologna: restauro e indagini sulla policromia, VIII Congresso Nazionale di Archeometria Scienze e Beni Culturali: stato dell'arte e prospettive, 2014, Bologna, Italy, poster.

CADARIO, M., 2011. Nerone e il "potere delle immagini". In M.A. TOMEl and R. REA, eds, Nerone, Catalogue of the Exhibition. Milano: Electa, pp. 176-189.

FRISCHER, B. and FILLWALK, J., 2012. The Digital Hadrian's Villa Project. Using Virtual Worlds to Control Suspected Solar Alignments, VSMM 2012, 2012, Milan, Italy, pp. 49-55. DOI: 10.1109/vsmm.2012.6365906

GRÜN, A., REMONDINO, F. and ZHANG, L., 2004. Photogrammetric Reconstruction of the Great Buddha of Bamiyan, Afghanistan. The Photogrammetric Record, 19(107), pp. 177-199. DOI: 10.1111/j.0031-868x.2004.00278.x

LEVOY, M., PULLI, K., CURLESS, B., RUSINKIEWICZ, S., KOLLER, D., PEREIRA, L., GINZTON, M., ANDERSON, S., DAVIS, J., GINSBERG, J., SHADE, J. and FULK, D., 2000. The Digital Michelangelo Project: 3D Scanning of Large Statues, SIGGRAPH 2000, 2000, New Orleans, Louisiana, USA, pp. 131-144. DOI: 10.1145/344779.344849

MANSUELLI, G.A., 1959. II torso neroniano di Bologna. Strenna Storica Bolognese, 6, 1959, pp. 81-87.

PATAY-HORVÁTH A., 2013. The virtual 3D reconstruction of the east pediment of the temple of Zeus at Olympia an old puzzle of classical archaeology in the light of recent technologies. Digital Applications in Archaeology and Cultural Heritage, 1, pp. 12-22. DOI: 10.1016/j.daach.2013.06.001 


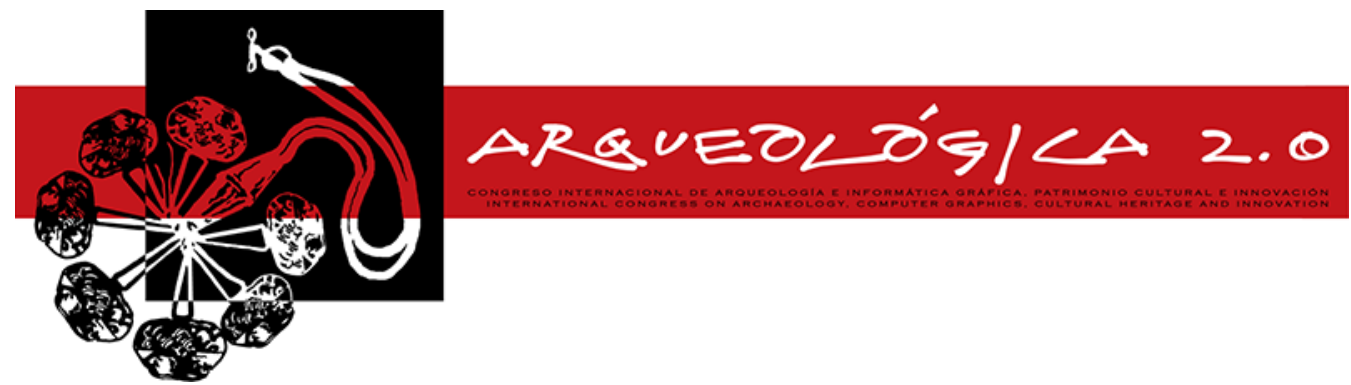

Proceedings of the $8^{\text {th }}$ International Congress

on Archaeology,

Computer Graphics,

Cultural Heritage and Innovation

'ARQUEOLÓGICA 2.0'

in Valencia (Spain),

Sept. $5-7,2016$

\title{
THE ROLE OF VIRTUAL ARCHITECTURE: PHENOMENOLOGICAL PERSPECTIVE
}

\author{
Hyuk-Jin Lee \\ School of Library and Information Studies, Texas Woman's University, Stoddard Hall, Room 404, P.O. Box 425438 Denton, TX 76204, \\ U.S.A. hlee@twu.edu
}

\begin{abstract}
:
Virtual reality (VR) will soon allow users to access experiences that have never before been possible. Many cultural institutions such as museums, tourism sites, or libraries will undoubtedly utilize VR more for historical, scientific, artistic, and educational learning and enjoyment. Human cognition includes both physical and virtual experiences and thoughts, and we need to understand how and why different cognitive media such as real, visual including VR, or text object are differently recognized by people. Based on phenomenological consideration and analysis with the case of Korean built heritage, this theoretical study suggests the philosophical and theoretical frame for the usage and role of VR in cultural discourse of the community. Further research may seek to identify differences between the experiences of participants exploring those forms through experiencing both physical and virtual cultural heritage objects.
\end{abstract}

Key words: virtual archaeology, digital archaeology, cyber-archaeology, cultural heritage, documentation, 3D reconstruction

\section{Introduction}

The loss of cultural heritage leads to the loss of cultural identity for the community, and the symbolic built heritage gives the foundation of social and concrete development (Stephens and Tiwaria 2015). Built heritage is believed to be one of the most influential and fundamental objects among several tangible cultural heritage such as clothing or food. It is because a built heritage is the stage or space where the social activities could be realized with both tangible and intangible heritage (Lee 2013).

Compared to its regional neighbours in East Asia, Korea has suffered enormous loss of historical materials including cultural heritage, which led to the current situation lacking the diachronic Epistemological frame due to mainly two reasons; 1) the major wars with its neighbouring countries such as the invasion from Genghis Khan in 13th century, and Japanese invasion in 16 th century, and 2) its rapid modernization and industrialization in 20th century. There also existed a rather scornful attitude about the artists from mid to late Joseon dynasty (17th to 19th century) based on strict Neo-Confucianism. This attitude was even harsher on the professional artist group compared to the ones belong to the royal court.

As a result, current discourse on the tradition of Korea mainly focuses on its relatively recent era, late Joseon dynasty $(17 \sim 19 \mathrm{C})$ and the discourse on the traditional architecture is no exception. Thus, this lack of diachronic and substantial cultural heritage leads the shortage of visible tangibility in built heritages, clothing, and art paintings. In this regard, there lies the gist of the identity issue in Korean society, that is, absence of entities and sense of reality. The current discourse for Korean national cultural identity seems to be confined in idealism. That is, as Lee said (2013), there have been many studies in Korean study dealing with the idea, concept, or notion without the entity or reality by asking the metaphysical questions such as "What is the definition of something Korean?" or "What is the identity of beauty of Korean?" (Lee 2013, p.3). And this tendency also leads to the neglect of more active usage of the existing visible resources. I believe that via the inductive process, the individual entities with the concrete shapes develop the identity of the cultural community and also create the discourse on how to utilize them. Afterwards, those visible entities become the perceptible objects of Korean culture.

\section{Phenomenological point of view}

Hence, it is argued that we need to apply a strict view for the cultural discourse as it seems a necessary work to have the cultural discourse with minimizing any possible biases from the knowledge gained from the society or existing education on the cultural entities. It is suggested to apply the philosophical methodology from Phenomenology in order to analyze the human cognition on the cultural heritage. Before introducing the detailed methodology, the basic theoretical background of Phenomenology is briefly reviewed. Edmund Husserl, the father of Phenomenology, explained that the actual meaning of the sentence, "I think", is in fact "I think (something)". That is because human consciousness is always the consciousness of (toward) something. This is 
called 'Intentionalität (Intentionality)'. Park (2007) explained that the object in your mind might not exist without Intentionalität. He added that "this does not mean that it is not existing in the real physical world but means that it just can not be the perceptible object for us" ${ }^{\prime \prime}$. Husserl named such a process that activates the hylomorphism (cognitive materials) and constitutes the meaning of the object 'Noesis', and its outcome 'Noema'. Thus, Noema is the content itself that appears in the operation of awareness.

In order to understand Noema, which is beyond the scope of expressions from the language, Husserl suggested the methodology called 'Epoche', in other words, suspension of judgment. Park (2010) argued that this is the right process for Epoche as the language contains the biases or ideology of the specific speech community. If we apply this process to the perception on cultural heritage, we may find that there are different perceptions or impressions on the same heritage between the community who are familiar with this heritage based on plentiful information, and the foreign community without such information ${ }^{2}$.

Thus, we would like to define this study's scope of Epoch as the perspectives of the member of the society (community) on cultural objects with minimized bias from any metaphysical impression or the education effect, but instead, only from their sheer experiences on the objects. After this process, the object in human cognition is finally ready to be analyzed. Yoon (2010) argued that the important work in understanding the senses is the correct understanding of how the cognition is composed by (different types of) experiences rather than the discussions focusing on the object itself (p. 390). For this purpose, tthrough phenomenological classification, four types of cultural heritage (excluding imaginary heritage) within the human cognition are illustrated.

In this classification, 'self-identity' means that something that a person recognizes as an existing thing. Vice versa for Negative self-identity. So this axe is based on 'human cognition'. 'Real existence' means something that physically exists in the real world. Vice versa for 'Real non-existence'. However, 'Real non-existence' is something that had existed until some point in history but disappeared for several reasons.

According to Park (2010), when human recognize an object, there are two types of experiences; 'Intuition' (Intuitive process) and 'Signifikation' (Signification process). The former involves the 'materie' (material) when he or she experiences it, while the latter does not. Park (2010) pointed out there is an important distinction between the two processes; that is, whether the materie is involved or not. The experience occurs in both cases but the former is 'the establishing process (of the perceptual object)' and the later is 'the non-establishing process'. The intuitive process with the material gives the person the senses that are 'full' (fülle, rich and

1 In other words, unless my consciousness reaches that building, there is no way that the building becomes the perceptible object to me (Park 2007, p. 76).

${ }^{2}$ In this study, we redefine the scope of Epoch, which allows the basic cultural backgrounds of the community members because it is practically almost impossible for them to exclude those basic backgrounds completely. authentic), however, the significance process only gives the coreless relationship with the perceptual object and this object is only 'supposed' (vermeint) without the sensuous contact. Thus, when there becomes the 'full' unification between the cognition on the object and the intuition, then only the verification on the object becomes possible. In short, when there is the existing cultural heritage in reality that you can experience something with your own senses, your experience is more intuitive and fulfilled. In this respect, we would examine the possible impacts from the landmark built heritage on other types of heritage considering the phenomenological dynamics in the classified Table 1.

Table 1: Phenomenological classification of cultural heritage

\begin{tabular}{c|c|c} 
& Real existence & Real non-existence \\
\hline $\begin{array}{c}\text { Positive } \\
\text { self- } \\
\text { identity }\end{array}$ & $\begin{array}{c}\text { Real object: } \\
\text { something existing in } \\
\text { the physical world \& } \\
\text { people are recognizing } \\
\text { it }\end{array}$ & $\begin{array}{c}\text { Object with } \\
\text { Intentionality: } \\
\text { something existing in } \\
\text { the physical world \& } \\
\text { people are NOT } \\
\text { recognizing it }\end{array}$ \\
$\begin{array}{c}\text { Negative } \\
\text { self- } \\
\text { identity }\end{array}$ & $\begin{array}{c}\text { Unrecognized object: } \\
\text { something existing in } \\
\text { the physical world \& } \\
\text { people are NOT } \\
\text { recognizing it }\end{array}$ & $\begin{array}{c}\text { Object without } \\
\text { Intentionality: } \\
\text { something NOT existing } \\
\text { in the physical world \& } \\
\text { people are NOT } \\
\text { recognizing it }\end{array}$ \\
& &
\end{tabular}

\section{Role of Virtual Reality}

Among the candidates that belong to "Object with Intentionality" in table 1, let us take the gigantic temple of Hwangnyongsa for example, which was built in A.D. 569 (or 645) and destroyed by Genghis Khan's Mongolian invasion in 1238. Hwangnyongsa temple is one of the most well known lost built heritages in Korea, which could be the symbol of ancient Korean culture not just in architecture but also in early Buddhism representing ancient Korean religion (Fig.1).

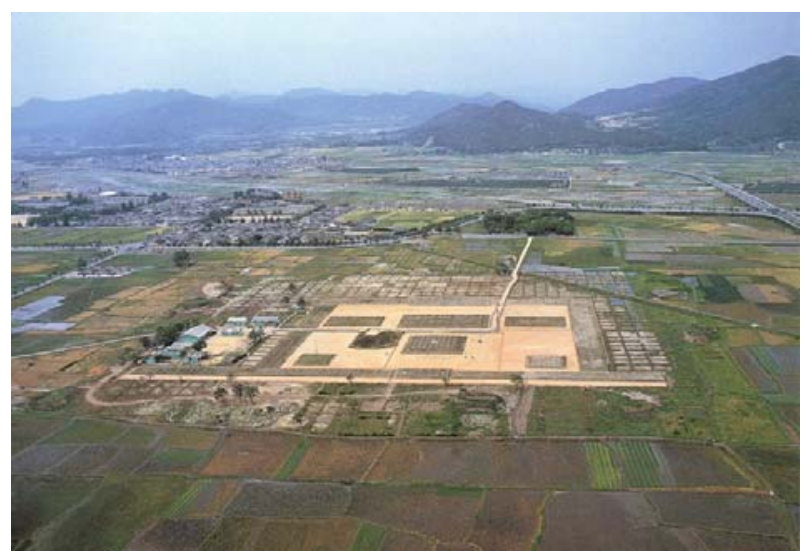

Figure 1: Hwangnyongsa Temple Site.

If the temple were rebuilt, the influence of its existence would be significant in various other types of cultural heritage. If Hwangnyongsa temple were rebuilt, its status would be transformed from 'Objective with Intentionality' to 'Real Object' in table 1. It is, however, not an easy task to rebuild a landmark built heritage due to several complicated issues such as the technology levels, theoretical rationales, or financial problems. As an 
alternative or a preconstruction phase, there is an emerging technology, Virtual Reality (VR). VR, a rapidly advancing field in computer science, will soon allow users to access experiences that have never before been possible. The fields impacted are varied, but the institutions including museums, libraries, and sightseeing sites will undoubtedly utilize VR for historical, scientific, artistic, and educational learning and enjoyment (Grant and Woodland 2013; Moorefield-Lang 2015; Lewis 2015). As there have been very few studies analyzing the effectiveness of VR replacing the real object, understanding how the experiences of VR differ requires specific inquiry through phenomenological exploration and analysis. Among the four types of cultural heritage in table 1 in human brain (cognition), the VR is located as below (Table 2 ).

Table 2: Possible role of virtual Hangnyongsa in phenomenological classification table

\begin{tabular}{|c|c|c|c|}
\hline & Real existence & & $\begin{array}{l}\text { Real non- } \\
\text { existence }\end{array}$ \\
\hline \multirow[t]{2}{*}{$\begin{array}{l}\text { Positive } \\
\text { self- } \\
\text { identity }\end{array}$} & $\begin{array}{l}\text { Real object } \\
\text { (Rebuit } \\
\text { Hwangnyongsa } \\
\text { temple) }\end{array}$ & $\begin{array}{c}\text { Virtual } \\
\text { Reality } \\
\text { (Virtual } \\
\text { Hwangnyongs } \\
\text { a temple) }\end{array}$ & $\begin{array}{l}\text { Object with } \\
\text { Intentionality } \\
\text { (Empty site } \\
\text { with textual } \\
\text { information to } \\
\text { Koreans) }\end{array}$ \\
\hline & $\begin{array}{l}\text { Virtual Reality } \\
\text { (Virtual } \\
\text { Hwangnyongsa } \\
\text { temple) }\end{array}$ & & \\
\hline $\begin{array}{l}\text { Negative } \\
\text { self- } \\
\text { identity }\end{array}$ & $\begin{array}{c}\downarrow \\
\text { Unrecognized } \\
\text { object }\end{array}$ & & $\begin{array}{l}\text { Object without } \\
\text { Intentionality } \\
\text { (Empty site } \\
\text { with textual } \\
\text { information to } \\
\text { foreigners) }\end{array}$ \\
\hline
\end{tabular}

Human cognition includes both physical and virtual experiences and thoughts. Through experiencing both physical and virtual cultural heritage objects, a further research may seek to identify differences between the experiences of participants exploring those forms. We may find how and why a person feels or recognizes the different levels of medium (Real, Visual, and Text) of cultural heritage. Then, the next study may analyze the rationales of how the different levels of medium influence on the transformation from two Negative self-identity types (Unrecognized object \& Object without Intentionality) to each type of Positive self-identity types
(Real objects \& Object with Intentionality) in the Phenomenological heritage classified table. For example, we may investigate whether the virtual Hwangnyongsa temple has effects on other cultural heritage in various categories such as Object with Intentionality or Unrecognized object compared with other types of media. Besides, the research on the motivation to transform the two types of Positive selfidentity may be studied. For example, we may investigate whether people want to see the real object, the physically rebuilt Hwangnyongsa temple, or are just satisfied with the virtual model of the temple (Fig.2). These are all interesting research topics that could be investigated based on the Phenomenological classified table.

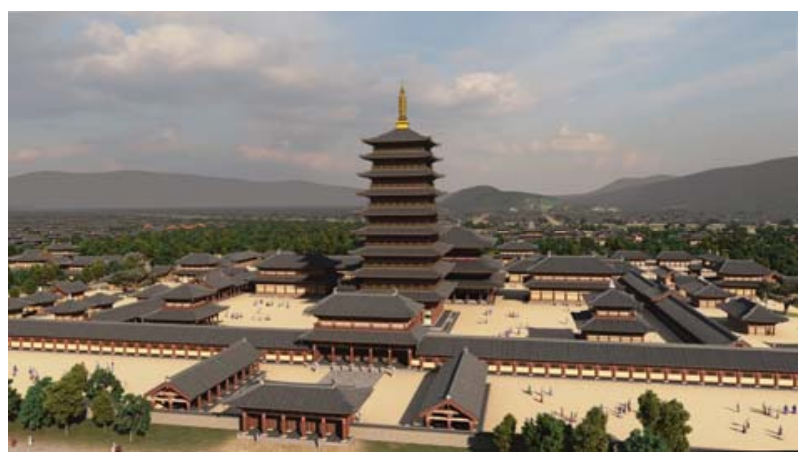

Figure 2: Virtual Hwangnyongsa Temple.

By studying this, we may understand what kinds of media including the VR architecture would be most influential in recognizing the cultural heritage that does not physically exist, and how it could influence on the social recognition on the heritage.

\section{Conclusion}

When artifacts of cultural significance are lost due to wars or natural disasters, a generation of youth have no access to the history of their people. This study suggests the theoretical background for exploring the role of virtual reality including the architecture in cultural heritage study through phenomenological classification. This may contribute to a more clear understanding of best practices for education and appreciation of virtual cultural heritage. And the results from further researches may be applicable for many interdisciplinary fields such as architecture, tourism, library and archive study, and cognitive science

\section{References}

GRANT, J.T. and WOODLAND, J.R., 2013. Libraries in Second Life: Linking Collections, Clients, and Communities in a Virtual World. Journal of Web Librarianship, 7(2), pp. 123-141.

LEE, H.J., 2013. Lost memory and identity: Philosophical consideration of Korean built heritages. Full proceeding paperDigital Heritage International Congress 2013, Marseille, France, Oct. 28- Nov. 1, 2013, pp. 21-29.

LEWIS, R., 2015. Virtual Reality: Soon to Become Mainstream in Libraries? Information Today, 32(4), pp.1-29.

MOOREFIELD-LANG, H., 2015. Libraries and the Rift. Knowledge Quest, 43(5), pp.76-77.

PARK, J., 2010. Static and Genetic Analysis in Husserl's Theory of Evidence. Philosophical ideology, 35, pp. $175-212$.

PARK, S., 2007. Edmund Husserl \& Martin Heidegger: Phenomenology. Gyeonggi-do: Gimmyong publishers.

STEPHENS, J. and TIWARI, R., 2015. Symbolic estates: community identity and empowerment through heritage. International Journal of Heritage studies, 21(1), pp. 99-114. 
YOON, B., 2010. A Study of the Relation between Experience and World: Toward the Internalistic Externalism. Philosophical ideology, 36, pp. 369-394. 


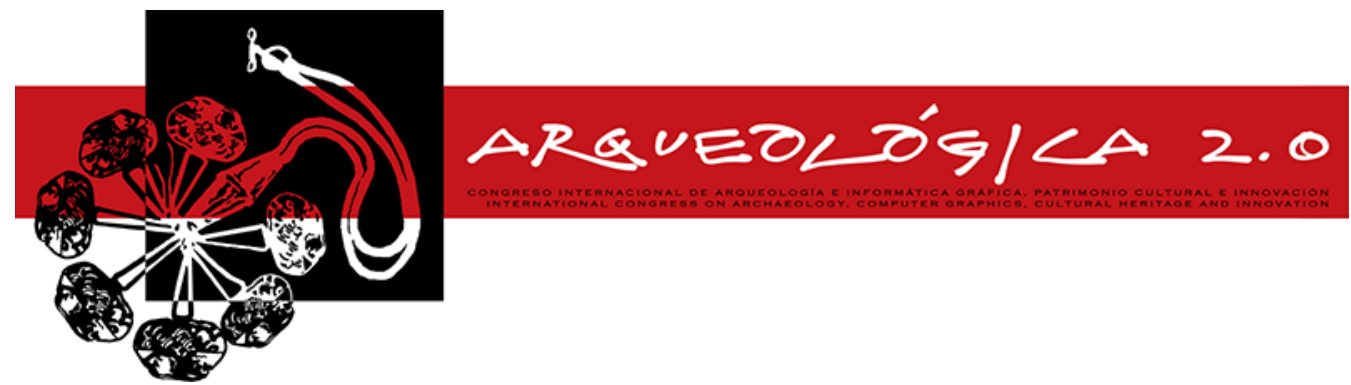

Proceedings of the $8^{\text {th }}$ International Congress

on Archaeology,

Computer Graphics,

Cultural Heritage and Innovation

'ARQUEOLÓGICA 2.0'

in Valencia (Spain),

Sept. $5-7,2016$

\title{
REGISTRO TRIDIMENSIONAL DEL EDIFICIO “E” DEL SITIO ARQUEOLÓGICO EL HUARCO-CERRO AZUL, CAÑETE, PERÚ
}

\author{
TRIDIMENSIONAL RECORDING OF THE "E" BUILDING AT THE ARCHAEOLOGICAL SITE OF EL HUARCO- \\ CERRO AZUL, CAÑNTE, PERU
}

\author{
Gerardo Miguel Quiroga*, Giancarlo Marcone
}

Proyecto Qhapaq Ñan - Sede Nacional, Ministerio de Cultura, Av. Javier Prado Este 2465 - San Borja, 01, Perú. gquiroga@cultura.gob.pe; gmarcone@cultura.gob.pe

\begin{abstract}
:
As part of a general policy to develop new technological tools to visually record structures, architectural elements, excavation units, archaeological contexts and morphology of ancient landscapes, we are using 3D Laser Scan in the registration of excavations and archeological future recovered by the "El Huarco- Cerro Azul project of the Qhapaq Nan Project- Ministry of Culture Peru". The application of this registration system in The Huarco site is especially important as the preservation of the site profile represents a challenge for intervention that seeks to put the site for public use. The laser recording has become an essential tool in the diagnosis of the preservation state of the pre-Hispanic structures, but also, and no less important, a tool that enhances the appreciation of the site and its visualization, minimizing the preservation risk that implied any interventions in the unstable areas of a site that is literally adjacent to the sea.
\end{abstract}

Key words: Qhapaq Ñan, archaeological regsiter, architectural reconstruction, tridimentional, conservation, laser scanner

\section{Resumen:}

Como parte de la aplicación de nuevas tecnologías en el registro gráfico de estructuras y elementos arquitectónicos, unidades de excavación, contextos arqueológicos y morfología del terreno, se viene implementando el uso del Scanner Laser 3D en el Proyecto de investigación, conservación y puesta en valor "El Huarco - Cerro Azul", desarrollado por el Proyecto Qhapaq Nan del Ministerio de Cultura del Perú. La aplicación de este sistema de registro en el sitio El HuarcoCerro Azul es de especial importancia considerando que, debido a las características de su conservacion, representa un reto para la puesta en valor del monumento y su posterior presentación al público. El registro láser no solo se ha convertido en una herramienta fundamental para los diagnósticos de conservación de las estructuras, sino también en una herramienta que favorece su exposición y visualización reduciendo el riesgo de las intervenciones de conservación en las áreas inestables de un monumento próximo al mar.

Palabras clave: Qhapaq Ñan, registro arqueológico, reconstrucción arquitectónica, tridimensional, conservación, escaner láser

\section{Registro de información}

La aplicación del registro tridimensional en el Edificio "E" del sector público central de El Huarco-Cerro Azul, iniciada el año 2005, tiene como objetivo desempeñar labores de análisis estructural y de lesiones a nivel de conservación, elaborar material audiovisual y difusión para la puesta en valor del sitio arqueológico.

"El Huarco-Cerro Azul" (Cañete, Perú) es un prominente sitio inca de incalculable valor histórico y turístico, no solo famoso por su presencia en relatos históricos o por su arquitectura monumental, sino también por ser potencialmente un eje de desarrollo social. Las facilidades que presenta el sitio, combinando turismo cultural y recreativo, engranado a circuitos preexistentes

y sumando las expectativas de los diversos actores locales, hace que su puesta en valor constituya una necesidad estratégica no solo a nivel regional, sino también nacional. Sin embargo, el sitio se encuentra amenazado por diversos factores negativos que han afectado severamente el estado de conservación de sus estructuras, entre los más graves se incluyen el clima, la humedad, salinidad y el arrastre eólico, además de la acción del hombre. Si bien estos factores son un limitante para la puesta en valor del sitio, con su documentación en 3D, el Proyecto Qhapaq Ñan busca

`Corresponding Author: Gerardo Quiroga Díaz, gquiroga@cultura.gob.pe 
innovar los procesos de registro arqueológico, empleando un método más rápido y preciso que permita realizar evaluaciones reales de las condiciones de conservación y un registro gráfico multifuncional que facilite la produccion de información y la apropiación del sitio de manera libre.

\section{Trabajo de campo}

Se trabajó con un escáner láser faro X130 y 10 esferas de georreferenciación de 139 milímetros de diámetro como puntos de referencia móviles. El área de trabajo del Edificio "E" fue de aproximadamente 5142.291 metros cuadrados con un perímetro de $285.390 \mathrm{mts}$ con una vista en planta de forma trapezoidal. Este edificio presenta orientación $\mathrm{N}-\mathrm{S}$. La disposición arquitectónica de sus muros de tapia, con alturas promedio de 3.5 y 8 metros hacia los lados norte y oeste, respectivamente, obligó a utilizar un número mayor de posiciones de escaneo con el fin de obtener la mayor información correspondiente a lesiones y grados de inclinación de elementos arquitectónicos. El escáner láser 3D trabajó con una capacidad de captura de $1 / 4$ de disparo, es decir, un resolución de 44.4 millones de puntos (escaneo completo) y una calidad de imagen a color de $4 \mathrm{X}$ por cada estación de trabajo, configuración suficiente para la captura de la forma original de los elementos arquitectónicos (ver Tabla 1).

Tabla 1: Descripción general de parámetros de escaneo, resolución y calidad (Faro technologies INC. 2013).

\begin{tabular}{c|c|c}
$\begin{array}{c}\text { Millones de puntos - } \\
\text { Capacidad de toma }\end{array}$ & $\begin{array}{c}\text { Calidad de } \\
\text { captura }\end{array}$ & $\begin{array}{c}\text { Duración sin captura } \\
\text { de imágenes }\end{array}$ \\
\hline $710.7-1 / 1$ & $4 \mathrm{X}$ & $1: 54: 32$ \\
$177.7-1 / 2$ & $4 \mathrm{X}$ & $0: 28: 38$ \\
$44.4-1 / 4$ & $4 \mathrm{X}$ & $0: 07: 09$ \\
$28.4-1 / 5$ & $4 \mathrm{X}$ & $0: 04: 35$
\end{tabular}

Se registró un total de 67 posiciones del escáner láser (Fig. 1) cuidando que en cada posición se tuviera una distancia de separación moderada al objeto de levantamiento no excediendo los 10 metros, tanto para el escáner como para las esferas de referencia que fueron ubicadas a distintas alturas. Estas consideraciones permitieron obtener una captura más rápida y precisa de la información sobre la geometría en campo.

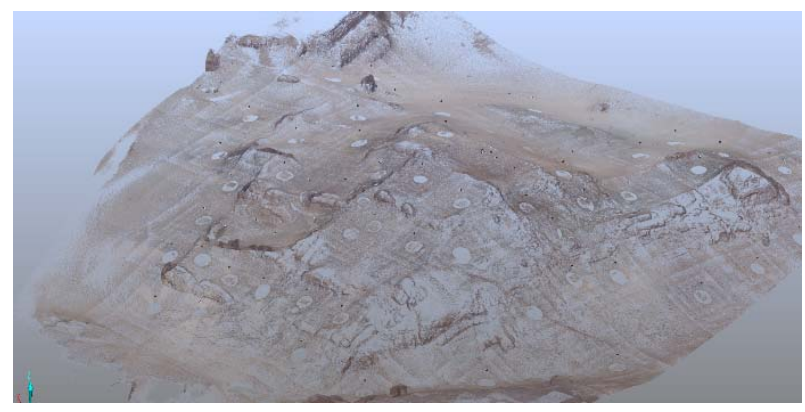

Figura 1: Vista oblicua de la nube de puntos del Edificio $\mathrm{E}$ generada en Faro Scene.

\section{Proceso y obtención de modelo 3D}

El proceso de información se realizó en distintas plataformas de procesamiento de puntos tales como
FARO SCENE, GEOMAGIC WRAP y demás software libres para la difusión audiovisual. Con el software FARO SCENE se trabajó el armado del modelo tridimensional, es decir, la colocación de escaneos se basó en objetivos (esferas) buscando las correspondencias por cada uno de los 67 escaneos de campo, teniendo valores promedio de desajuste angular de $0.013^{\circ}$ y desplazamiento del punto de 0 milímetros (Faro technologies INC. 2014).Para la limpieza de puntos en el modelo tridimensional, se utilizaron filtros por defecto y el filtro para puntos oscuros con un valor de 800 para el umbral de reflactancia de tal forma que se eliminan los puntos fallidos que contienen demasiado ruido producido por el entorno de trabajo de campo (polvo y excesiva luz solar). Culminada la depuración de puntos fallidos, las imágenes capturadas en cada posición de escaneo fueron colocadas dentro de sus respectivas vistas finalizando así el proceso de armado y coloreado de datos, que permitirá realizar un análisis de las propiedades del entorno arqueológico del Edificio "E". Para la reconstrucción arquitectónica, es decir, la conversión de la información de nube de puntos en un objeto sólido, como un edificio, elemento arquitectónico o contexto arqueológico, se utilizó el software GEOMAGIC WRAP, importándose el $100 \%$ de los puntos contenidos en el archivo. Para la generación de mallas tridimensionales, se trabajó una segunda limpieza de puntos del modelo 3D seleccionando y eliminando puntos aislados (Fig. 2), compensando errores del escáner al mover puntos a ubicaciones correctas (disposición más uniforme) y dando al mismo tiempo los parámetros para la generación de la malla $3 \mathrm{D}$, utilizando el parámetro de Formas Prismáticas (conservadoras) con nivel de uniformidad medio, con valor de Iteraciones 2 y límite de desviación por defecto de 0.11838 milímetros.

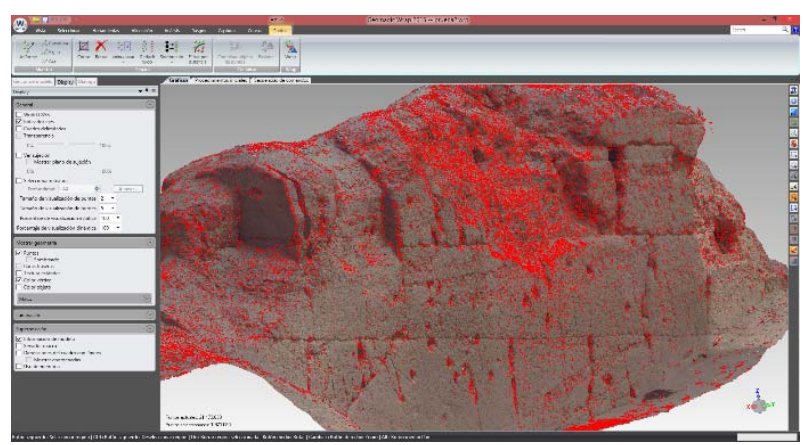

Figura 2: En color rojo se aprecia la reducción de ruido o limpieza de puntos de la pointcloud.

La extrapolación de información permitió la consulta métrica a nivel lineal y de volumen de los elementos arquitectónicos del edificio; así mismo, se identificaron y midieron lesiones y patologías sobre los elementos solidos reconstruidos con precisión milimétrica. Otra herramienta que proporciona información óptima para elaborar un diagnóstico estructural es la generación de contornos bidimensionales sobre el sólido creado de tal forma que se intersectan uno o más planos sobre dicho elemento (3D Systems 2014). La plataforma GEOMAGIC WRAP nos permitió disgregar información específica de puntos del modelo 3D original, es decir, se crearon copias por capas de los elementos arquitectónicos puntuales de tal forma que se obtuvieron 
sólidos individuales otorgando un manejo de información versátil (Fig. 3).

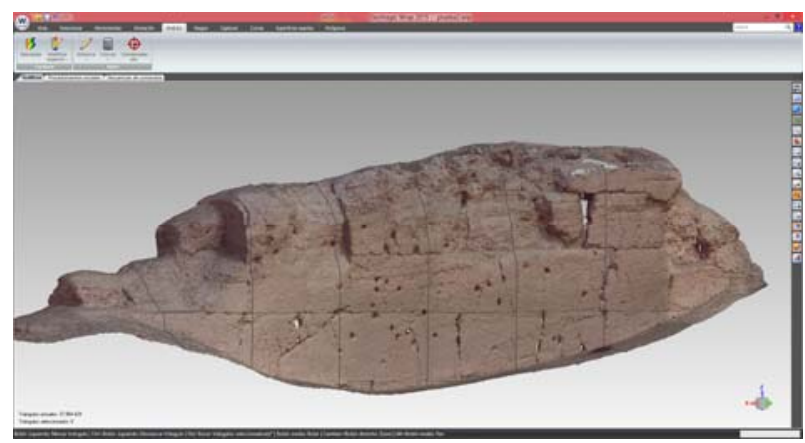

Figura 3: Geometría en color del vértice correspondiente al paramento de tapia y trazado de planos verticales o cortes.

Este registro ha sido instrumental para elaborar diagnósticos de conservación e integralidad de las estructuras de El Huarco-Cerro Azul. El uso de esta herramienta facilita el registro en detalle de patologías y puntos estructurales débiles en los paramentos, como agrietamientos, deformaciones, pérdida de masa estructural y procesos de disgregación tales como la erosión, perforaciones, fisuras, esgrafiados y descamación (Fig. 4).

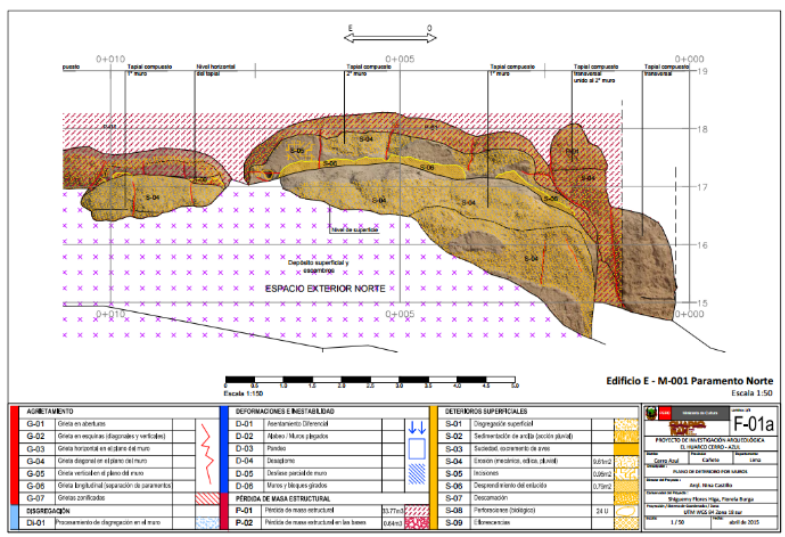

Figura 4: Diagnóstico y clasificación de deterioros en paramento (tomado de Flores y Burga 2015).

No es factible exponer elementos arquitectónicos en tanto no se consideren y realicen acciones de conservación de manera permanente, en tal sentido, se hace necesaria la preservación digital del monumento que se caracteriza por la documentación con una nube densa de puntos suficiente para recuperar la información arquitectónica a detalle (Mañana y Blanco 2011), el intemperismo es uno de los principales factores de deterioro de las edificaciones del sitio arqueológico y principalmente la acción de los vientos con dirección suroeste - noroeste arrastrando partículas de arena y provocando la erosión de la superficie de los muros en especial los que se encuentran en proceso de disgregación. (Flores y Burga 2015). La obtención de ortofotos ya sea por restitución fotogramétrica por medio de una cámara digital o mediante el trabajo con nube de puntos obtenidos de un scanner laser son una herramienta fundamental para los trabajos de metrado como se muestra en la Figura 5.; esta forma de trabajo acorta los tiempos en las labores de campo y gabinete y mejora la precisión de los metrados.

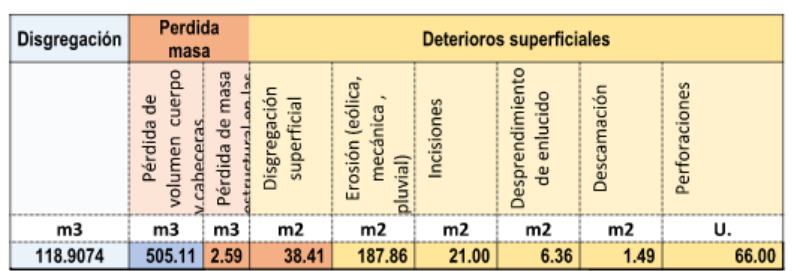

Figura 5: Cuadro de resumen de lesiones halladas (tomado de Flores y Burga 2015)

\section{Conclusiones}

Más allá de los aspectos meramente técnicos, la captura de la información en forma densa y precisa, permite desarrollar muchos otros productos, de interpretación y comunicación, que constituyen el insumo principal para una puesta en uso social del sitio, basada no en las estructuras, sino en su apropiación por parte de los pobladores de Cañete, asi como de sus visitantes.

El registro con escáner láser no solo provee de los insumos básicos para diagnósticos de conservación y de estructuralidad de los edificios, también permite recorridos virtuales, reconstrucciones hipotéticas, planificación de circuitos y demás actividades que, con otra tecnología, implicarían varias actividades de registro diferentes. Con esta metodología, un registro básico permite obtener productos tan diferentes como mapas y reconstrucciones.

\section{Agradecimientos}

Al equipo de arqueólogos y tecnicos del Proyecto de Investigacion El Huarco - Cerro Azul, Proyecto Qhapaq Ñan del Ministerio de Cultura del Perú, y a la arquitecta Shiguemy Flores Higa.

\section{Referencias}

FARO TECHNOLOGIES INC., 2013. Manual del Faro laser Scanner Focus 3D. Lake Mary, Florida USA: FARO Technologies INC., pp. 55 - 56, 79 - 80.

FARO TECHNOLOGIES INC., 2014. Manual del usuario Faro Scene. Lake Mary, Florida USA: FARO Technologies INC., pp. $132-135$.

MAÑANA, P y BLANCO, R., 2011. El uso del laser escaner 3D en arqueología de la arquitectura. Disponible: http://hdl.handle.net/10261/31888 [25, 2011].

3D SYTEMS, 2014. Helpr for Geomagic Wrap. Rock Hill, SC USA.

FLORES, S. y BURGA, F., 2015. Informe de diagnóstico del edificio "e" del sitio arqueológico El Huarco, Proyecto Qhapaq Ñan, Ministerio de Cultura - Perú. 


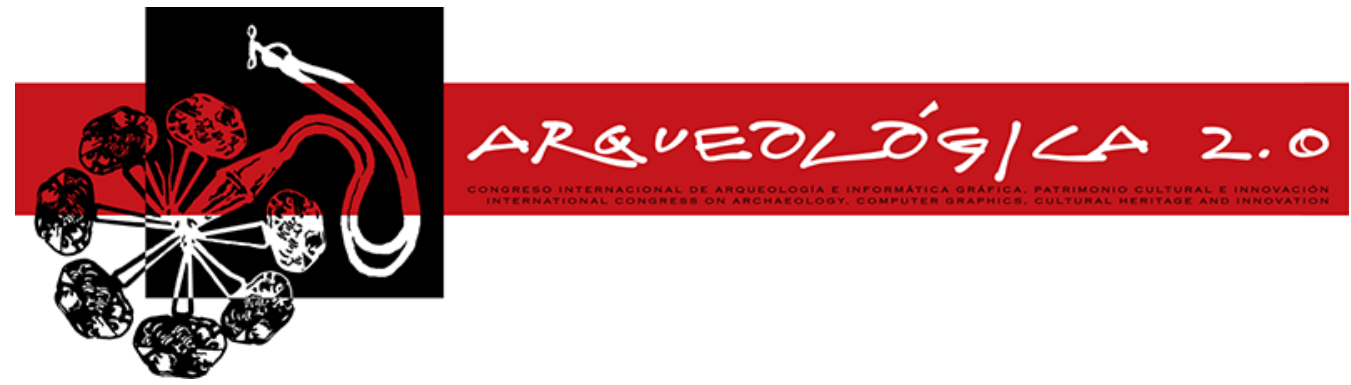

Proceedings of the $8^{\text {th }}$ International Congress

on Archaeology,

Computer Graphics,

Cultural Heritage and Innovation

'ARQUEOLÓGICA 2.0'

in Valencia (Spain),

Sept. $5-7,2016$

\title{
UN REGRESO VIRTUAL: RECREACIÓN DE LA APARIENCIA ORIGINAL DEL CORO DEL CONVENTO DE SANTA CLARA DE TORO (ZAMORA) CON SUS PINTURAS MURALES MEDIEVALES, EN LA ACTUALIDAD ARRANCADAS Y DESPLAZADAS
}

\section{A VIRTUAL RETURN: RECREATION OF THE ORIGINAL APPEARANCE OF THE CHOIR OF THE CONVENT OF SANTA CLARA OF TORO (ZAMORA) WITH ITS NOW DISPLACED MEDIEVAL WALL PAINTINGS}

\author{
Fernando Gutiérrez ${ }^{\mathrm{a},{ }^{*}}$, Francisco M. Morillo ${ }^{\mathrm{b}}$, Jesús I. San José ${ }^{\mathrm{b}}$, Juan José Fernández ${ }^{\mathrm{b}}$ \\ ${ }^{a}$ Departamento de Historia del Arte, Facultad de Filosofía y Letras, Universidad de Valladolid, Plaza Campus Universitario s/n, 47011 \\ Valladolid, España. fbanos@fyl.uva.es \\ ${ }^{\mathrm{b}}$ Laboratorio de Fotogrametría Arquitectónica, E.T.S.Arquitectura, Universidad de Valladolid, Av. De Salamanca 18, 47014 Valladolid, \\ España. pako.vll@gmail.com; Ifa@ega.uva.es; juanjo@ega.uva.es
}

\begin{abstract}
:
The convent of Santa Clara of Toro (Zamora), founded in the mid- $13^{\text {th }}$ century and restored in the early $14^{\text {th }}$ century, housed in its choir one of the richest ensembles of Medieval wall paintings ever recorded in Castile and León or even in Spain. However, these wall paintings were detached in 1962 and, after different disgusting circumstances, are now exhibited in another building of the very same city of Toro. The aim of this contribution is demonstrating how virtual rendering techniques can restore the wall paintings to its original location providing a vivid impression of its appearance by the time they were created. Essential for this is not only an accurate art historical analysis of both the building and the wall paintings, but also the use of photogrammetry to generate reliable 3D models.
\end{abstract}

Key words: gothic painting, Toro (Zamora), museography, cultural heritage, documentation, 3D reconstruction

\section{Resumen:}

El convento de Santa Clara de Toro (Zamora), fundado a mediados del siglo XIII y restaurado a principios del siglo XIV, albergaba en su coro uno de los conjuntos de pinturas murales medievales más importantes de Castilla y León e, incluso, de España. Sin embargo, estas pinturas murales fueron arrancadas en 1962 y, después de una serie de vicisitudes incómodas, se exponen actualmente en otro edificio de la ciudad de Toro. El propósito de esta contribución es demostrar cómo las técnicas de recreación virtual pueden devolver las pinturas murales a su lugar de origen proporcionando una vívida impresión de su aspecto en el momento de su creación. Esencial para este propósito es no solo un análisis histórico-artístico preciso del edificio y de sus pinturas murales, sino también el uso de de la fotogrametría para generar modelos 3D precisos.

Palabras clave: pintura gótica, Toro (Zamora), museografía, patrimonio cultural, documentación, reconstrucción 3D

\section{Antecedentes}

Del coro del convento de Santa Clara de Toro, fundado a mediados del siglo XIII, procede uno de los conjuntos más importantes de pinturas murales del periodo gótico que se han podido recuperar en Castilla y León y, en general, en España. Desde finales de la década de 1970 , estos murales se exhiben, fuera de contexto, en la iglesia de San Sebastián de los Caballeros de la propia ciudad de Toro después de ser trasladados a lienzo desde su soporte original. Localizados, en origen, a lo largo de los muros septentrional y meridional del coro conventual, estos murales fueron realizados, en su mayor parte, a mediados del siglo XIV, siguiendo el estilo gótico lineal, si bien con posterioridad, dentro, aún, del periodo medieval, se añadió un mural dedicado a San Bernardino de Siena. Los murales de mediados del siglo XIV desarrollan varios ciclos iconográficos: relatos de las vidas de Santa Catalina, de San Juan Bautista y de Cristo (con una peculiar selección de escenas), representaciones de santas y de santos (entre ellos, el popular San Cristóbal) y un rico y complejo Juicio final, apenas conservado. 
El objetivo del presente trabajo de investigación es restituir virtualmente las pinturas murales a su contexto originario mediante el empleo de tecnologías digitales, planteándolo, además, no como un mero ejercicio de erudición, sino como una aportación a su más adecuada musealización y difusión.

\section{2. ¿Cómo pudo ocurrir? De Toro a Toro pasando por Madrid}

Las pinturas murales se descubrieron de manera casual en la década de 1950, ocultas, en parte, por enlucidos y, en parte, por mobiliario (retablos y sillería del coro). En la década de 1960, la necesidad, por parte de las religiosas, de encontrar financiación para los trabajos de mantenimiento del vasto complejo conventual condujo a un acuerdo con la Dirección General de Arquitectura que consistió en que esta adquiriría las pinturas murales por un importe 500.000 pesetas con el que las religiosas tendrían que pagar al restaurador Antonio Llopart Castells el coste del arranque de las mismas. Este se efectuó en 1962 y las pinturas murales, extraídas en veinte fragmentos, partieron para Madrid, abandonando, para siempre, su lugar y su contexto de origen.

Tras una serie de vicisitudes, el 29 de julio de 1977 regresaron, finalmente, a Toro para ser instaladas en la iglesia de San Sebastián de los Caballeros y, tras ser exhibidas en la catedral de Valladolid en 1988-89, en el marco de la recordada exposición Las Edades del Hombre. El arte en la iglesia de Castilla y León, se efectuó un montaje permanente que es el que se puede disfrutar en la actualidad.

El proyecto museográfico no atiende a la disposición original las pinturas murales en el coro del convento de Santa Clara, ni en lo que se refiere a su ubicación en uno o en otro muro, ni en lo que se refiere a su sucesión, pues, con un criterio plausible, se ha atendido a la mejor adecuación de los distintos murales al espacio museístico, pero esto no hace sino agudizar la descontextualización de las pinturas murales.

Por ello es por lo que creemos necesario aprovechar las posibilidades que ofrecen las tecnologías de recreación digital de entornos virtuales para completar el proyecto museográfico desde la perspectiva del siglo XXI, restituyendo las pinturas murales a su contexto original: en el muro septentrional del coro del convento de las clarisas toresanas se disponían, de este a oeste, los murales de Santa Catalina, de San Juan Bautista y de San Bernardino de Siena y en el muro meridional del coro del convento de las clarisas toresanas se disponían, de este a oeste, los murales del Juicio final, de San Cristóbal, de Santa Águeda, Santa Lucía y otros santos y de la vida de Cristo.

\section{Premisas para la restitución virtual de la disposición original de las pinturas murales del coro}

Esta hipótesis se fundamenta en varios elementos de juicio que a continuación se detallan:

1. Croquis elaborados en 1959 por Antonio Llopart Castells para la elaboración del presupuesto de arranque de las pinturas murales (IPCE, Archivo de la Guerra, caja 258).
2. Fotografías tomadas en 1968 por José Gudiol Ricart a raíz de la Exposición de murales góticos castellanos (Institut Amatller d'Art Hispànic, Arxiu Mas, G-51655-51683).

3. Documentación escrita y fotográfica elaborada en 1975-77 por el ICROA con ocasión de la restauración de las pinturas murales (IPCE, Obras Restauradas, reg. gral. nos. 1324-1343).

4. Testimonio de José Navarro Talegón, quien, en su análisis de estas pinturas murales en el catálogo monumental de Toro, sigue, en realidad, el orden de su primitiva disposición, aunque no lo declare explícitamente.

5. Recuerdos de algunas religiosas que vivieron el descubrimiento y el arranque de las pinturas murales en las décadas de 1950 y de 1960, registrados en 1999.

6. Examen minucioso del espacio del coro conventual de Santa Clara de Toro, efectuado en 2015 en el transcurso del desarrollo del presente trabajo de investigación merced a la aquiescencia de las religiosas y del sacerdote responsable.

\section{Trabajos de documentación efectuados en 2015/16}

Para realizar la toma de datos se desplazó hasta la localidad de Toro un equipo del Laboratorio de Fotogrametría Arquitectónica de la UVa junto al investigador del que había partido la idea inicial del proyecto, el Doctor en Historia del Arte y Profesor Titular de Universidad de la UVa D. Fernando Gutiérrez Baños. El instrumental utilizado para esta labor fue una cámara réflex digital Nikon D700 y un escáner laser FARO Focus3D.

Para la documentación de las pinturas se procedió a la realización de un barrido fotográfico completo de detalle que obtuvo 101 tomas fotográficas realizadas con un objetivo Nikon 85-150 que permitiría recomponer los paños completos. En el convento de Santa Clara se realizaron 5 barridos de escaner (dos desde la tribuna del órgano y tres en el espacio inferior) para poder obtener un modelo completo del espacio en el que originalmente estuvieron ubicadas las pinturas.

\section{Metodología empleada para la restitución virtual de la disposición original de las pinturas murales su espacio arquitectónico de origen}

Tras la toma de datos se procedió al procesado digital de toda la información. Se obtuvo una nube de puntos para cada uno de los dos espacios, así como ocho imágenes panorámicas de alta resolución. Estas panorámicas se realizaron con el software PTGui, mientras que las nubes de puntos y los modelos fotogramétricos se procesaron con SCENE y PhotoScan.

Los datos del espacio actual sirvieron para poder determinar con precisión el lugar exacto en el que se localizaban algunos de los restos más conflictivos de situar. Las hornacinas del retablo, la altura de la sillería 
o las trazas de la puerta indicaron la posición de los diferentes paneles.

\section{Conclusiones: una propuesta y varias perspectivas}

El proceso documental descrito conlleva la obtención de unos resultados razonados, cuya presentación, a través de las nuevas tecnologías informáticas, hace posible la recreación virtual de lo que fue el escenario histórico original en el que fueron contemplados los murales con la articulación que tuvieron en origen (Fig. 1). En definitiva lo que se pretende es que, más allá de una representación convencional, "técnica", expresada a través de planimetrías y "dibujos" en perspectiva cónica, el espectador pueda percibir el espacio y el ambiente del contenedor que albergaba las pinturas, ambientado con los elementos que estableció su uso.

\section{Agradecimientos}

Este trabajo es parte de la actividad de investigación del G.I.R. de la Universidad de Valladolid IDINTAR:
Identidad e Intercambios Artísticos. De la Edad Media al Mundo contemporáneo. Los autores están en deuda con D. Roberto Castaño Joaquín, sacerdote a cargo de las iglesias parroquiales de Toro, por permitirnos documentar las pinturas murales que ahora se encuentran en la iglesia de San Sebastián de los Caballeros, y con las comunidades de clarisas del convento de Santa Clara y de las dominicas del convento de Sancti Spiritus por darnos acceso a sus hogares con el fin de documentar las estructuras arquitectónicas necesarias para este trabajo. Así mismo hacemos extensivo nuestro agradecimiento al Laboratorio de Fotogrametría Arquitectónica de Valladolid, y en especial a David Marcos y Natalia Redero por su trabajo y entusiamo a la hora de llevar a cabo la reconstrucción virtual de este conjunto de pinturas y a la empresa GEOBIT por la cesión de licencias del software empleado.

Por último debemos agradecer a la Fundación "Las Edades del Hombre" su interés y apoyo económico para hacer realidad la difusión de este trabajo.

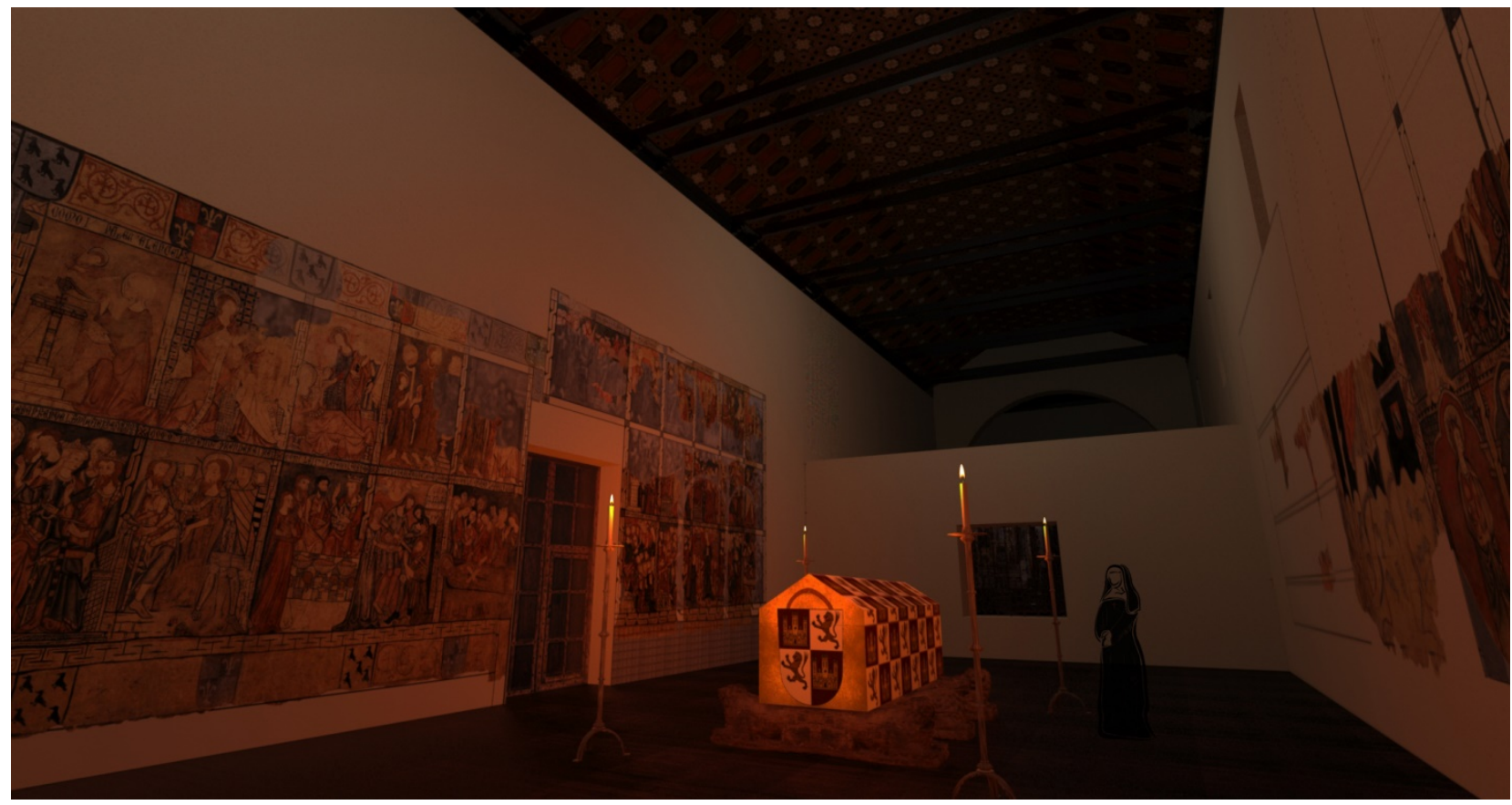

Figura 1: Vista de la recreación de la disposición original de las pinturas en los paramentos del coro del convento de Santa Clara. Toro (Zamora)

\section{Referencias}

FERNÁNDEZ, G., 2001. Las pinturas murales del coro del convento de Santa Clara de Toro (Zamora). Un marco para la nueva devoción franciscana. Zamora: Instituto de Estudios Zamoranos "Florián de Ocampo", 92 pages.

GUTIÉRREZ, F., 2005. Aportación al estudio de la pintura de estilo gótico lineal en Castilla y León: precisiones cronológicas y corpus de pintura mural y sobre tabla. Madrid: Fundación Universitaria Española, 2 ts., $500+492$ pages.

LERMA, J., 2008. Implementation of an architectonic gis on a brickwork farmhouse. ISPRS Congress, The International Archives of the Photogrammetry, Remote Sensing and Spatial Information Sciences XXXVII, no. Part B5. Beijing. 1013 - 1015 pages.

NAVARRO, J., 1980. Catálogo monumental de Toro y su alfoz. Zamora: Caja de Ahorros Provincial de Zamora, 696 pages.

REMONDINO, F., 2011. Heritage Recording and 3D Modeling with Photogrammetry and 3D Scanning. Remote Sensing, pp. 1104-1138. 


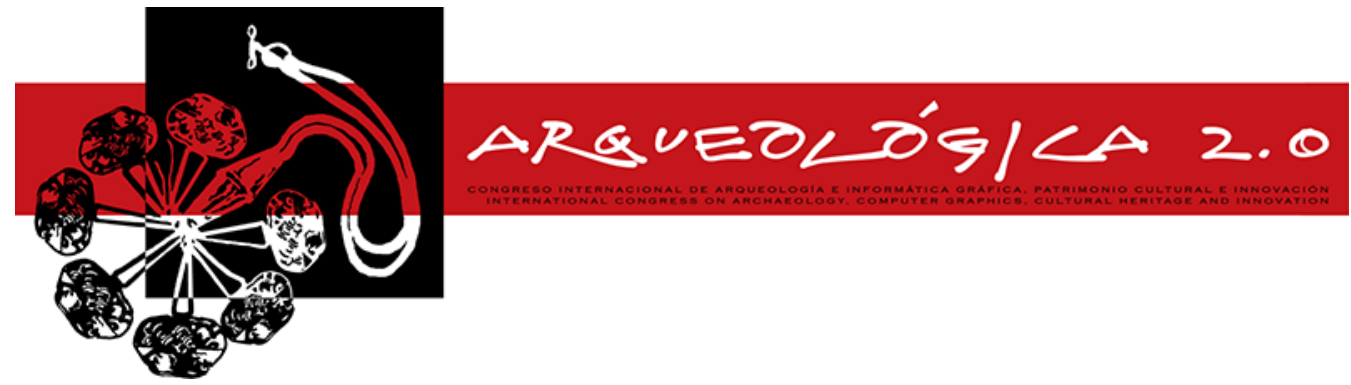

Proceedings of the $8^{\text {th }}$ International Congress

on Archaeology,

Computer Graphics,

Cultural Heritage and Innovation

'AROUEOLÓGICA 2.0'

in Valencia (Spain),

Sept. $5-7,2016$

\title{
PROSPECCIÓN GEOFÍSICA EN EL SECTOR PÚBLICO CENTRAL DEL SITIO ARQUEOLÓGICO EL HUARCO - CERRO AZUL 2016
}

\author{
GPR SURVEY OF HUARCO - CERRO AZUL ARCHAEOLOGICAL SITE'S, PUBLIC SECTOR, SEASON 2016 \\ Gerardo Miguel Quiroga*, Giancarlo Marcone, Nina Mireya Castillo \\ Proyecto Qhapaq Ñan - Sede Nacional, Ministerio de Cultura, Av. Javier Prado Este 2465, San Borja 01, Perú. \\ gquiroga@cultura.gob.pe; gmarcone@cultura.gob.pe; ncastillo@cultura.gob.pe
}

\begin{abstract}
:
Geophysical surveys with GPR were performed as part of the archaeological research at the El Huarco- Cerro Azul site project, which is part of the Qhapaq Nan National Project. The goal is to promote the use of new technologies into the record and preservation of the cultural heritage. The GPR was used, as none invasive survey methodology. The comparison between cultural layers reconstructed from excavations, with the imagines generated by the GPR, showed a consistency between each other, which in turn allow us to make generalizations about the sequence of the Inca occupation of the site. These generalizations are possible for the use of this technology, instead of more traditional methodologies, that need for extensive archaeological interventions. We suggest that the use of both methodologies (GPR and traditional excavations) should be used in a complementary way in order to define cultural sequences and functional arrangements of archaeological sites.
\end{abstract}

Key words: Incas, Perú, georadar, radargrama, El Huarco, Cerro Azul, underground

\section{Resumen:}

La aplicación de métodos de prospección geofísica con georadar fue implementada a partir del año 2015 por el Proyecto Qhapaq Ñan en el marco del Proyecto de Investigación Arqueológica El Huarco -Cerro Azul, en el valle de Cañete; esta tecnología como método de prospección no invasivo, se enmarca dentro de la búsqueda de promover el uso de herramientas vinculadas a la arqueología virtual en favor de la protección y documentación del patrimonio cultural. Estas imágenes comparadas con los resultados de la excavación arqueológica, muestran una consistencia entre las capas culturales identificas durante la misma y las obtenidas de la lectura del Georadar, permitiéndonos realizar inferencias y generalizaciones de la ocupación inca en El Huarco - Cerro Azul, inferencias que serían imposibles de alcanzar con métodos tradicionales. Proponemos que el uso complementario de métodos geofísicos con métodos manuales tiene una potencial particular para determinar secuencia de uso y función de los sitios arqueológicos.

Palabras clave: Incas, Perú, georadar, radargrama, El Huarco, Cerro Azul, soterrados

\section{Introducción}

El "Proyecto de Investigación Arqueológica El Huarco Cerro Azul", forma parte de las actividades que viene realizando el Proyecto Qhapaq Ñan - Sede Nacional del Ministerio de Cultura, en cumplimiento del Decreto Supremo 031-2001-ED del 9 de mayo del 2001, que declara de preferente interés nacional la investigación, identificación, registro, conservación y puesta en valor del Camino Inca en el territorio nacional; y a los planes operativos del 2016 de la Secretaría Técnica del Proyecto Qhapaq Ñan, referidos a la Red Vial Inca y sus sitios asociados.

El sitio arqueológico El Huarco - Cerro Azul, se ubica en la Costa Centro Sur del Perú, entre los paralelos $11^{\circ} 58^{\prime}$ y $13^{\circ} 09^{\prime}$ de Latitud Sur. El sitio se localiza entre los cerros El Fraile, Centinela y Camacho, zona que se encuentra cerca de la línea de playa, en la margen derecha del valle bajo del río Cañete, en el distrito de Cerro Azul, provincia de Cañete, departamento de Lima.

El proyecto de investigación planteado para el sitio arqueológico El Huarco - Cerro Azul, tiene como objetivo general abordar la problemática concerniente a la interacción entre los grupos locales y el Imperio Inca en el valle bajo de Cañete. Para enfrentar esta problemática se han planteado las siguientes interrogantes: ¿Cómo se muestran los cambios en las manifestaciones locales cronológicamente? y ¿Cómo se manifiesta la Ocupación Inca en el Sitio?, ¿existe un aumento o disminución de la evidencia Inca?, ¿existe un aumento o disminución de la evidencia foránea

`Corresponding Author: Gerardo Quiroga Díaz, gquiroga@cultura.gob.pe 
contemporánea a los incas? Para contestar estas interrogantes se ha planificado un muestreo sistemático por todo el sitio, que incluye excavaciones tradicionales y métodos de prospección geofísica como parte importante de la investigación científica; el muestreo nos proporcionará una imagen general del sitio, su cronología, los cambios que se dieron durante toda su ocupación y la caracterización estratigráfica del sitio arqueológico. Los trabajos iniciales de excavación y prospección con georadar se centraron en el sector público central, donde se esperaba encontrar evidencia de la superposición de materiales incas y locales, entendiendo como la forma de las edificaciones y el arreglo espacial del sitio se van modificando en relación a los cambios en la cultura material.

\section{Prospección de campo}

Se trabajó con un georadar modelo Noggin100 de la marca Sensors\&Sonftware con $100 \mathrm{MHZ}$ de amplitud de señal con dos antenas: una emisora y otra receptora; el método de prospección utilizado fue el de Survey\&Map el cual llevo a realizar una cuadrícula de prospección geofísica de $30 * 30$ metros con una separación de líneas de 1 metro en cada eje; la necesidad del uso de una antena de baja frecuencia va en relación a las características del suelo, se conoce que para toda la costa central del Perú el suelo es de propiedades muy conductivas y la zona de estudio se ubica a pocos metros de la línea de playas sobre un terreno arenoso, con presencia de sales, capas de arcilla y humedad, en sondeos de Georadar no es conveniente una absorción alta ya que reduce la profundidad de penetración (Bonomo y De La Vega 2006).

La cuadricula fue georreferenciada con un GPS Topcon GR5 en modo RTK ubicándose entre las coordenadas $E=338737.5230, \quad N=8558994.6500$ en la esquina noroeste $(\mathrm{XO}-\mathrm{Y0})$ y $\mathrm{E}=338771.0547, \mathrm{~N}=8558969.0665$ para la esquina sureste $(X 30-Y 30)$ dentro del sector público central. La ubicación de la malla corresponde a la necesidad de definir la secuencia arquitectónica de la plaza central de este sector, partiendo de la hipótesis que estas plazas suelen ser remodelaciones de la ocupación del sitio local para la construcción de un nuevo arreglo, ejemplos similares se conocen para los sitios de Pachacamac al Norte y La Centinela al sur. Las primeras excavaciones parecían rechazar esta posibilidad, sin embargo, el tamaño de la plaza impedía tener una excavación de las dimensiones adecuadas; la prospección con georadar nos permitiría evaluar esta plaza y descartar o confirmar su superposición sobre estructuras anteriores. Como resultado de las excavaciones realizadas en este sector en el año 2014 se descubrió dos momentos de ocupación de esta plaza, representados en ocho capas, en una secuencia de relleno- piso de fácil identificación. Como referencia estratigráfica se tienen los datos de la Unidad de Excavación 4, la cual se encuentra distanciada de nuestra cuadricula por 17 metros; los hallazgos en dicha unidad corresponden a muros de barro compactados con gravilla (tapia) y contextos funerarios sobre pisos de arcilla compacta; estos elementos se encuentran soterrados por tierra arcillosa y cubiertos a mayor profundidad por una capa de relleno que presento material como coprolitos, malacológico, fragmentos de cerámica y restos óseos. Como parámetro de configuración, se muestran en la Tabla 1 (Sensors \&
Software INC 2013a) algunas de las velocidades típicas del georadar sobre diversos materiales.

Tabla 1: Velocidades típicas de propagación de onda.

\begin{tabular}{c|c|c} 
Material & Velocity $(\mathrm{m} / \mathrm{ns})$ & Velocity $(\mathrm{ft} / \mathrm{ns})$ \\
\hline Dry Soil & 0.140 & 0.460 \\
Dry Rock & 0.120 & 0.394 \\
Soil & 0.100 & 0.328 \\
Wet Rock & 0.100 & 0.328
\end{tabular}

Se supone la emisión de los pulsos electromagnéticos con una velocidad promedio de $0.10 \mathrm{~m} / \mathrm{ns}$; como resultado in situ se puede apreciar en las imágenes sin procesar los cambios de las propiedades eléctricas de los estratos o elementos soterrados, es decir, se tienen reflexiones correspondientes a anomalías que probablemente correspondan a evidencia de material cultural con características resistivas evitando así la completa atenuación de la señal.

\section{Proceso de Información}

El proceso de información consistió en realizar 2 tipos de análisis a nivel de Radargrama o Slice, ya sea de forma individual en el módulo LINEVIEW o de forma grupal con SLICEVIEW; estos módulos forman parte del conjunto de herramientas del software EKKOPROJECT. El módulo SLICEVIEW otorga la vista de los datos de cuadricula tanto en planta como en corte observando así reflexiones, su extensión y nivel de profundidad. De la prospección geofísica se tienen respuestas electromagnéticas las cuales corresponderían a anomalías ubicadas en los pares X22-Y7, X22-Y8, X23$Y 9, X 20-Y 23, X 19-Y 28, X 19-Y 29$ en un intervalo de profundidad de 0.75 a 1.00 metro, de 1.00 a 1.25 metros (Fig: 1) se tiene continuación de las respuestas ya mencionadas y se añaden reflexiones en los pares $X 10$ $Y 19, \quad X 10-Y 21, \quad X 8-Y 19, \quad X 8-Y 21$ lo cual vendría probablemente a corresponder a un recinto de forma rectangular de $2 \times 2$ metros que se profundiza hasta 1.50 metros. De manera complementaria a los resultados de vista en planta se corrobora dicha información realizando un análisis por radargrama obtenido en el módulo LINEVIEW; en las líneas de prospección se aplicaron filtros como Dewow con el fin de remover componentes de frecuencias muy bajas y/o altas (Sensors \& Software INC 2013b), se realiza un ajuste en Offset ya que el equipo no identifica la profundidad sino que la calcula en base al tiempo de retorno de las señales según la naturaleza del suelo; se realizaron ajustes de ganancia por cada Radargrama ya que la señal sufre de atenuación según va ganando profundidad, para nuestro proyecto de prospección geofísica se trabajó en su mayoría con el tipo SEC2 GAIN con un nivel 5, el cual intenta impulsar las señales más débiles correspondientes a objetivos más profundos.

Del análisis de las 62 líneas prospectadas y procesadas en gabinete, se destacan la presencia de anomalías en forma de hipérbola y vertical las que probablemente hagan referencia a elementos arquitectónicos soterrados. Las franjas grises sobre las imágenes corresponde al resultado de la aplicación del filtro BS o 
filtro de sustracción de fondo (Background Substraction); las formas mejor definidas en color blanco y negro corresponden a alteraciones electromagnéticas; en las Figuras 2, 3 y 4 se pueden observar los dos tipos de variaciones de onda mencionados corroborando así la presencia de elementos de mayor reflexión apreciados en la vista en planta.

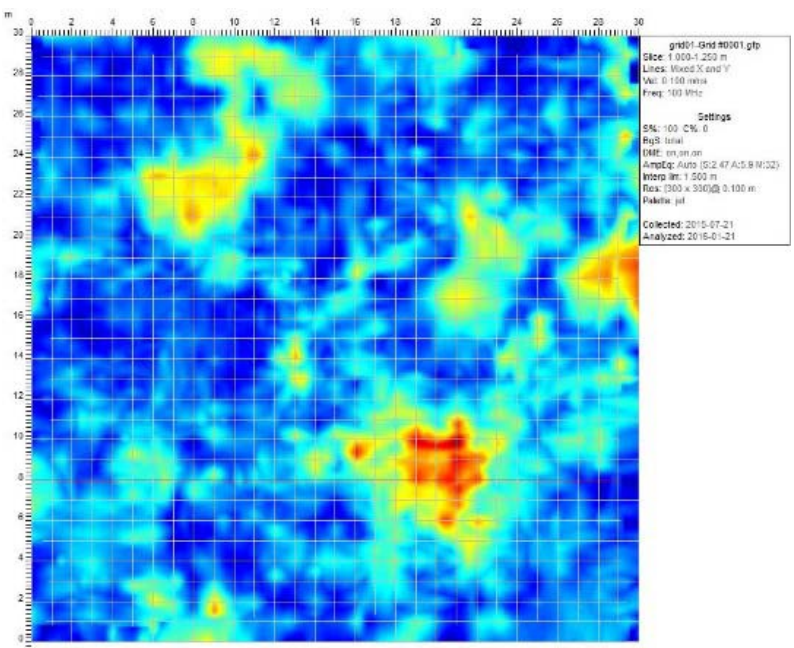

Figura 1: Vista en planta de respuestas electromagnéticas de 1.00 a 1.25 metros de profundidad; se observan múltiples reflexiones y se destaca la ubicación de un posible recinto.

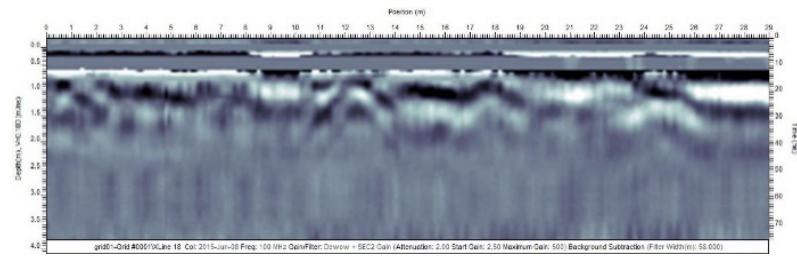

Figura 2: Radargrama X18 con orientación $\mathrm{N}-\mathrm{S}$, se destaca la presencia de una hipérbola de los 12 a 13 metros de longitud.

\section{Conclusiones}

El Proyecto de prospección geofísica con Georadar nos ayudó a relacionar nuestras capas culturales identificadas a través de la excavación, con las capas detectadas durante la prospección con georadar. Esta correlación entre capas de ambos métodos, nos permitió examinar un porcentaje mayor de la plaza del sector público central. Permitiendo confirmarla existencia de dos momentos de uso de esta plaza. Del mismo modo la prospección parece confirmar la idea de que existe una ocupación a la construcción de esta plaza. La prospección electromagnética muestra evidencias de posibles estructuras que habrían sido removidas por esta plaza, sugiriendo un reordenamiento intensivo del sitio en épocas Incas. Es importante señalar, que por lo restringido de la excavación arqueológica, inicialmente se dudó la presencia de estas estructuras y es solo cuando la escala de análisis se incrementó, donde aparecen estas evidencias de reordenamiento arquitectónico Inca.

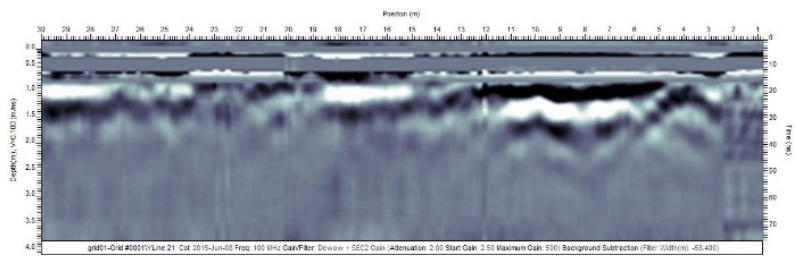

Figura 3: Radargrama Y21 con orientación $E$ - O, se destaca la presencia de una respuesta en forma de hipérbola adyacente a una respuesta vertical ubicadas desde los 3 hasta los 11 metros de longitud, así mismo, se tienen 2 respuestas puntuales de forma vertical en 18 y 25 metros de recorrido.

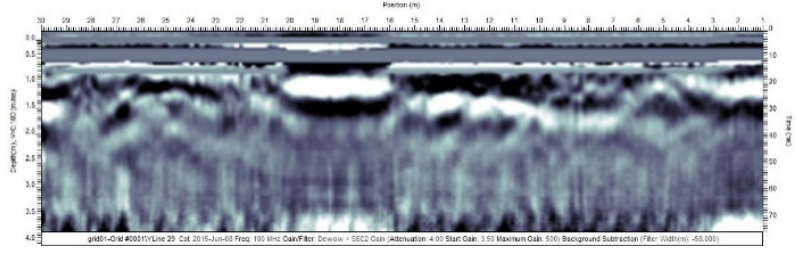

Figura 4: Radargrama Y29 con orientación E - O, se destaca la presencia de una respuesta vertical y demás reflexiones.

\section{Agradecimientos}

Al equipo técnico del Proyecto de Investigación Arqueológica El Huarco - Cerro Azul por su colaboración en los trabajos de campo y al ingeniero Fernando Nakamoto Toyama, por impartir la capacitación sobre el uso de georadar y proceso de radargramas.

\section{Referencias}

SENSORS\&SOFTWARE INC., 2013a. Noggin User's Guide. Mississauga, Canada: Sensors \& Software INC.187 pages.

SENSORS\&SOFTWARE INC., 2013b. SliceView User's Guide. Mississauga, Canada: Sensors \& Software INC. 84 pages.

BONOMO, N., y DE LA VEGA, M., 2006. "EL MÉTODO DE GEORADAR". Capítulo 4, en: Arqueogeofísica. Una metodología interdisciplinaria para explorar el pasado. Compiladores: Ana Osella y José Luis Lanata. Editores: fundación de historia natural Félix de Azara, departamento de ciencias naturales y antropológicas, CEBBAD CONICET; e instituto superior de investigaciones, universidad Maimónides, 196 pág., pp. 79-81. DOI: 987-05-18478. 


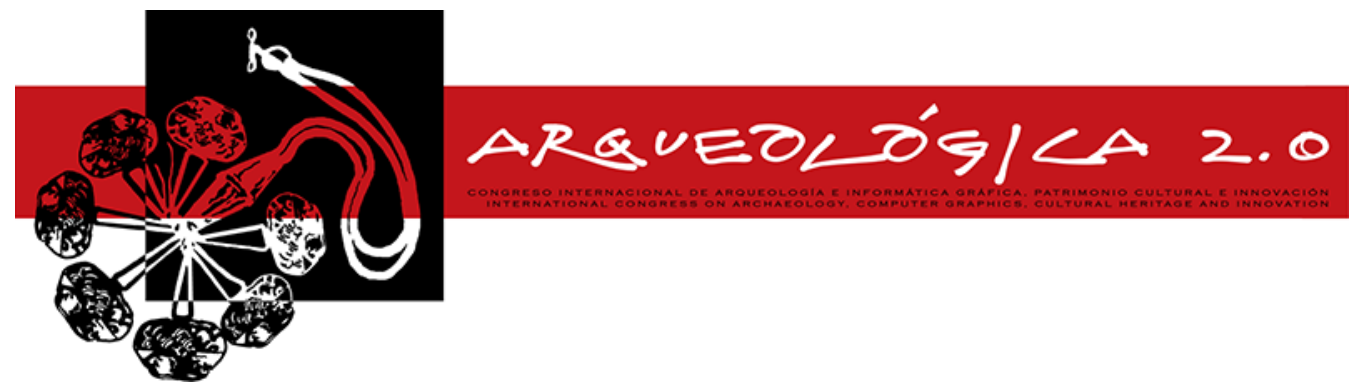

Proceedings of the $8^{\text {th }}$ International Congress

on Archaeology,

Computer Graphics,

Cultural Heritage and Innovation

'AROUEOLÓGICA 2.0'

in Valencia (Spain),

Sept. $5-7,2016$

\title{
UN PROCEDIMIENTO DE SEGMENTACIÓN DE MALLAS 3D DE EDIFICIOS HISTÓRICOS
}

\author{
A SEGMENTATION METHOD FOR 3D MESHES OF HISTORIC BUILDINGS \\ Borja Javier Herráez ${ }^{*}$ Eduardo Vendrell \\ Instituto de Automática e Informática Industrial, Universitat Politècnica de València, Camino de Vera s/n, 46022 Valencia, España. \\ borherco@fiv.upv.es; even@upv.es
}

\begin{abstract}
:
In this article, a method for 3D mesh segmentation focused on the representation of historic buildings is proposed. This type of buildings are characterized by having singularities and characteristic elements in the facades. The main objective is to recognize these features in the buildings, understanding features as those parts of the model that differ from the main structure of the building, such as doors or windows. The idea is to use a recognition algorithm of flat faces allowing to create a graph that reflects the shape of the three-dimensional model. At a later step, this graph will be matched against some pre-defined graphs that will represent the patterns to look for.
\end{abstract}

Key words: segmentation, 3D meshes, graphs, pattern recognition, features

\section{Resumen:}

En este artículo se propone un método de segmentación de mallas 3D enfocado a representaciones de edificios históricos.Este tipo de edificios se caracterizan por tener singularidades y elementos caracteristicos en las fachadas. El objetivo principal consiste en reconocer estas características en los edificios, entendiéndose como características aquellas partes del modelo que difieren de la estructura principal del edificio, tales como puertas o ventanas. La idea es utilizar un algoritmo de reconocimiento de caras planas que permita crear un grafo que refleje la forma del modelo tridimensional. En una etapa posterior, este grafo se comparará con grafos predefinidos que conformaran los patrones a buscar.

Palabras clave: segmentación, mallas 3D, grafos, reconocimiento de patrones, características

\section{Introducción}

En la actualidad, los objetos $3 \mathrm{D}$ se representan principalmente a partir de mallas poligonales, esto es, un conjunto de caras planas conectadas que conforman y aproximan la propia superficie del objeto. El elemento principal de una malla poligonal es una cara triangular, representada por sus tres vértices y el vector normal a la superficie.

Cuando por cualquier motivo hay que analizar partes diferenciadas de estos modelos poligonales, se necesita segmentar la malla 3D. Segmentar una malla tridimensional consiste en fraccionar la misma en diferentes partes, aplicando procedimientos para indicar qué partes del objeto pertenecen a un grupo determinado, en función de diversas características del objeto.

En este artículo se presenta un método de segmentación que tiene como objetivo distinguir las partes de un edificio, con el fin de asistir a los procedimientos de levantamiento arquitectónico de edificios históricos. Este trabajo surge a partir de la colaboración entre el Grupo de Robótica del Instituto Universitario de Automática e Informática Industrial (AI2) de la Universitat Politècnica de València y el Dipartamento di Architettura de la Università degli Studi di Firenze. En concreto, esta colaboración se plasma en el apoyo tecnológico por parte del Al2 a los procesos de levantamiento que se llevan a cabo en el Dipartamento di Architettura de la Università degli Studi di Firenze.

\section{La segmentación de mallas poligonales}

La segmentación de mallas puede interpretarse desde dos puntos de vista diferentes (Attene et al. 2006). Por un lado, de forma puramente geométrica y por otro lado de manera semántica.

Entre los diferentes métodos existentes se encuentran primeramente los que incluyen el uso de grafos para representar las relaciones existentes entre las caras del objeto 3D (Marefat y Kashyap, 1990). Otros

*Corresponding Author: Borja Javier Herráez, borherco@fiv.upv.es 
procedimientos consisten en aplicar el algoritmo "watersheds" (Mangan y Whitaker, 1999), (Page et al., 2003). Otro método comúnmente empleado se basa en crear el esqueleto de los objetos para guiar la segmentación (Li et al., 2001). Por otro lado, existen técnicas que hacen uso de la curvatura gaussiana para delimitar los puntos frontera de las regiones (Zhang et al., 2002). También existen las técnicas de "spectral clustering (Liu y Zhang, 2004) y los algoritmos basados en expansión de regiones (Vieira y Shimada, 2005).

\section{Método propuesto}

El método propuesto aborda como objetivo primordial la localización de partes diferenciadas. El principio de ortogonalidad es el argumento seguido para su búsqueda dado que en la mayoría de edificios, este principio se encuentra en las caras que componen sus elementos (puertas, ventanas).

\subsection{Distinción de caras planas}

Para proceder a la distinción de caras planas, se emplea un algoritmo de crecimiento de regiones. Se establece un procedimiento de coloreado para identifcar regiones, de manera que cada región plana estará formada por un conjunto de triángulos a los que se les asigna un mismo color. Así, a lo largo del proceso, cada triángulo que no tenga asignado un color es considerado como una "cara semilla".

El siguiente paso consiste en expandir la región de las "caras semilla". Para ello se comprueban sus triángulos vecinos y a continuación se calcula ángulo que existe entre sus normales. Se establece un umbral o "factor de coplanaridad" de manera que si el ángulo está por debajo de este umbral, se asigna la misma región a ambos triángulos. En caso contrario, se asignan regiones diferentes.

Una vez procesadas todas las "casas semilla" se tiene como resultado un conjunto de regiones coloreadas que se corresponderán con las regiones planas del modelo tridimensional.

\subsection{Distinción de características}

Se diferencian dos tipos de características, por un lado las características cóncavas o hendiduras en la fachada principal, tales como ventanas o puertas, y por otro lado las características convexas o salientes, como canalones o escudos ornamentales.

Tras haber diferenciado las regiones planas del objeto, el siguiente paso es construir un "grafo topológico". El grafo topológico describe las relaciones de vecindad entre las regiones planas detectadas en el paso anterior. Con el fin de detectar los vértices de corte se ha empleado el algoritmo de Tarjan (Tarjan y Hopcroft, 1973). Si se elimina este vértice de corte, se divide el grafo topológico en varios subgrafos, cada uno representando una de las características que se buscan.

El siguiente paso consiste en definir un "grafo de consulta". Los grafos de consulta son "grafos topológicos" que se corresponden con una característica concreta, de manera que cada característica representa un patrón concreto. Se toma ventaja del conocimiento que posee el propio usuario en la definición de la topología de las características.

En el último paso, se comparan los subgrafos obtenidos al eliminar los vértices de corte con los "grafos de consulta" definidos. La comparación de grafos se ha realizado utilizando un algoritmo recursivo clásico (Ullman, 1976). Cada coincidencia detectada implica la existencia de la característica en la malla poligonal.

No obstante el grafo que describe la topología del objeto no siempre es un distintivo único de la característica y será necesario en ocasiones añadir posteriores restricciones, para discernir entre características con topología similar.

\section{Resultados}

Las pruebas mostradas en el presente artículo se realizaron sobre las mallas tridimensionales asociadas a los edificios escaneados de la ciudad medieval de Pietrabuona, en Italia. Estas mallas tridimensionales han sido proporcionadas por el Dipartamento di Architettura de la Università degli Studi di Firenze a partir de un estudio de levantamiento completo (Troiano et al., 2014).

En la Figura 1 se refleja el coste temporal como resultado de comparar grafos de diferentes tamaños respecto a un grafo patrón de 10 nodos. Éste depende directamente del número de nodos que conforma el patrón que define la característica. Dado que la búsqueda se hace sobre una malla que ya está simplificada y que los patrones que definen características típicas en un edificio (ventanas, puertas, vigas, etc.) no incluyen un elevado número de nodos, se puede decir que el orden del coste temporal se sitúa en torno a los milisegundos.

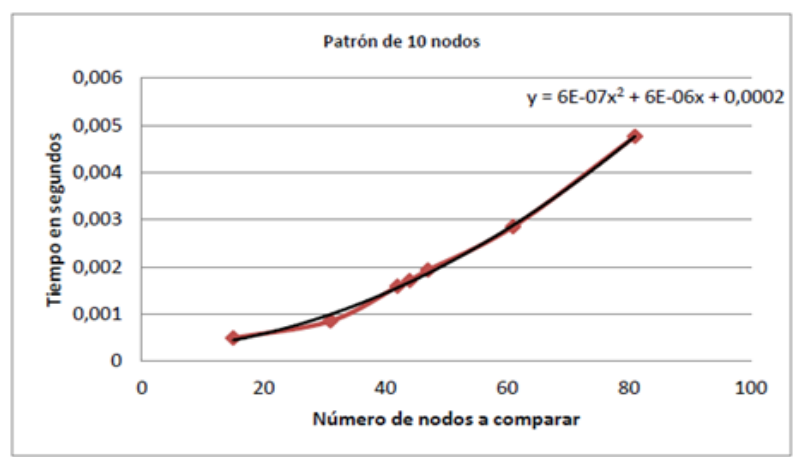

Figura 1: Coste temporal para la búsqueda de un patrón de 10 nodos.

En la Figura 2 se muestra el resultado de aplicar el algoritmo completo, donde se puede observar que todas las características ortogonales se visualizan del mismo color, identificando las posiciones de las ventanas y características cóncavas en la fachada. También se aprecia cómo el método desarrollado es capaz de identificar características que no presentan ortogonalidad como son ventanas 0 escalones circulares. 


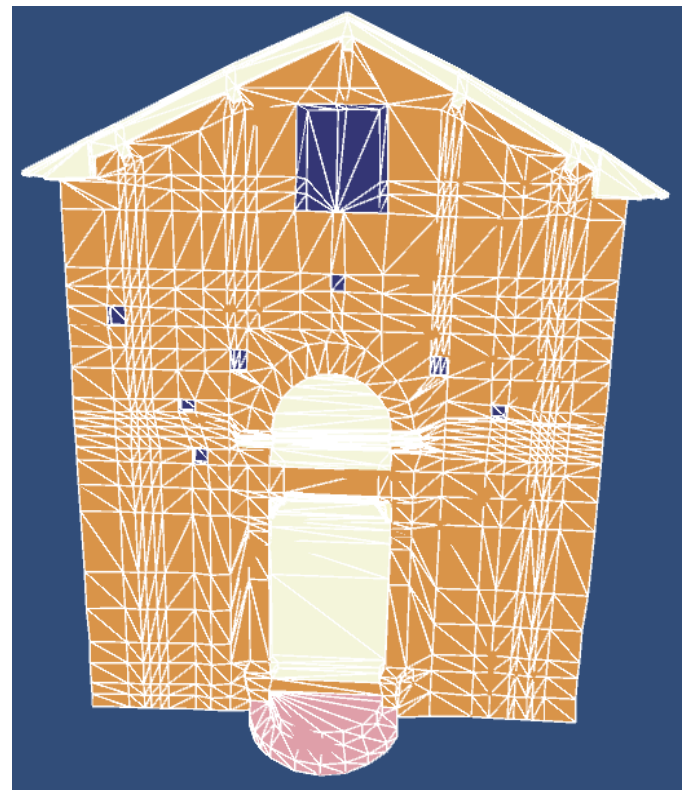

\section{Conclusiones}

En este artículo se ha presentado un método que permite la detección de características o elementos diferenciales sobre mallas $3 \mathrm{D}$ que representan fachadas de edificios. El procedimiento se presenta como una técnica de apoyo para el levantamiento arquitectónico de edificios históricos.

En primer lugar, se ha desarrollado un algoritmo de detección de caras planas. Con este algoritmo se crea un grafo que representa las relaciones de vecindad entre las caras planas del modelo. Posteriormente se aíslan los subgrafos que representan las características, eliminando los vértices de corte del grafo anterior.

En una segunda instancia se crean "grafos de consulta", que se comparan con los subgrafos anteriores. Encontrar una coincidencia significa que se ha encontrado una característica o elemento diferencial como la especificada en el "grafo de consulta".'

Figura 2: Reconocimiento de características sobre un edificio escaneado.

\section{Referencias}

ATTENE, M., KATZ, S., MORTARA, M., PATANE,, G., SPAGNUOLO, M., y TAL,A., 2006. Mesh segmentation-a comparative study. In International conference on shape modeling and applications SMI 06, pp. 14-25. Matsushima, Japan. DOI: 10.1109/SMI.2006.24

HOPCROFT, J. y TARJAN, R., 1973. Algorithm 447: efficient algorithms for graph manipulation. Communications of the ACM 16(6), pp. 372-378. DOI: 10.1145/362248.362272

LI, X., TOON, T.W. y HUANG, Z., 2001. Decomposing polygon meshes for interactive applications, SI3D, pp. 35-42. DOI: $10.1145 / 364338.364343$

LIU, R. y ZHANG, H. 2004. Segmentation of 3D meshes through spectral clustering, Pacific Conference on Computer Graphics and Applications, pp. 298-305. DOI: 10.1109/PCCGA.2004.1348360

MANGAN, A.P. y WHITAKER R.T., 1999. Partitioning 3D surface meshes using watershed segmentation, IEEE Transactions on Visualization and Computer Graphics, 5(4), 308-321. DOI: 10.1109/2945.817348

MAREFAT, M. y KASHYAP, R., 1990. Geometric reasoning for recognition of three-dimensional object features. DOI: $10.1109 / 34.58868$

PAGE, D.L., KOSCHAN, A. y ABIDI, M., 2003. Perception-based 3D triangle mesh segmentation using fast marching watersheds, In Proc. of Computer Vision and Pattern Recognition, pp. 27-32. DOI: 10.1109/CVPR.2003.1211448

TROIANO, D., GARCÍA, A., MERLO, A. y VENDRELL, E., 2014. From a Model of a City to an Urban Information System: The SIUR 3D of the Castle of Pietrabuona. DOI: 10.1007/978-3-319-13695-0_12

ULLMAN, J.R., 1976. An algorithm for Subgraph Isomorphism. DOI: 10.1145/321921.321925

VIEIRA, M. y SHIMADA, K., 2005. Surface mesh segmentation and smooth surface extraction through region growing, Computer-Aided Geometric Design, 22(8), pp. 771-792. DOI: 10.1016/j.cagd.2005.03.006

ZHANG, Y., PAIK, J., KOSCHAN, A. y ABIDI, M.A., 2002: A simple and efficient algorithm for part decomposition of 3D triangulated models based on curvature analysis, Proc. Intl. Conf. on Image Processing, pp. 273-276. DOI: 10.1109/ICIP.2002.1038958 


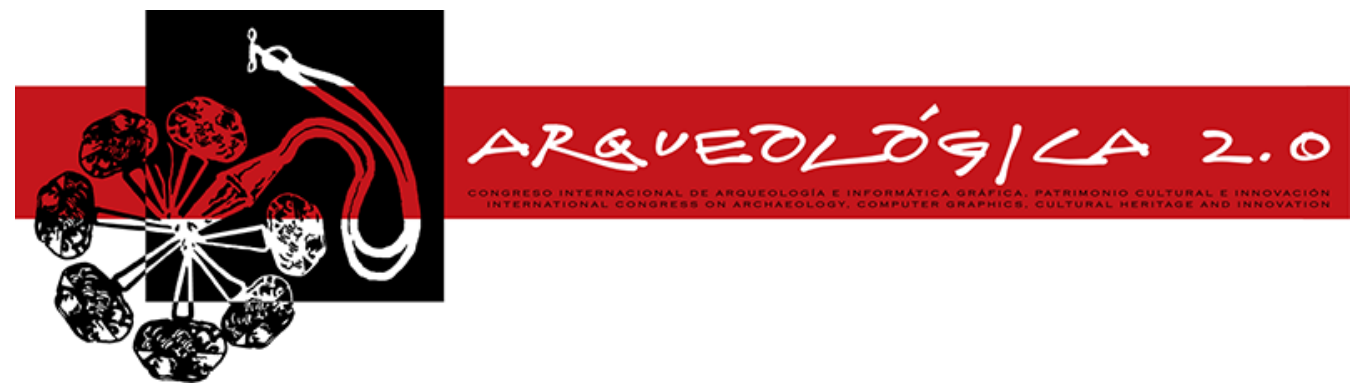

Proceedings of the $8^{\text {th }}$ International Congress

on Archaeology,

Computer Graphics,

Cultural Heritage and Innovation

'ARQUEOLÓGICA 2.0

in Valencia (Spain),

Sept. $5-7,2016$

\title{
ARCHAEOBIM: AN INNOVATIVE METHOD FOR ARCHAEOLOGICAL ANALYSIS OF AN ETRUSCAN TEMPLE IN MARZABOTTO
}

\author{
Simone Garagnani ${ }^{a}{ }^{,}$, Andrea Gaucci ${ }^{b}$, Bojana Gruška ${ }^{b}$ \\ ${ }^{a}$ Department of Architecture, School of Engineering and Architecture, Alma Mater Studiorum, University of Bologna, viale Risorgimento \\ 2, 40136 Bologna, Italy. simone.garagnani@unibo.it \\ ${ }^{\mathrm{b}}$ Department of History, Culture and Civilization, Alma Mater Studiorum, University of Bologna, Piazza San Giovanni in Monte 2, 40124
} Bologna, Italy. andrea.gaucci3@unibo.it; bojana.gruska@studio.unibo.it

\begin{abstract}
:
The digital reconstruction of the recently discovered Tuscanic temple of Uni in Marzabotto gave the chance to test the application of the Building Information Modeling (BIM) process to the combined fields of Archaeology and Engineering. In addition to the traditional historic and archaeological analysis, a new methodology in Experimental Archaeology is proposed; it proved to be original and innovative in the examination of the buried building, taking advantage of technologies focused on the architectural reliability validated by inferred digital models.
\end{abstract}

Key words: Building Information Modeling, Etruscan temple, Digital model, Marzabotto, ArchaeoBIM, Digital archaeology

\section{Preface}

The preliminary results of the Project FIR 2013 titled "KAINUA. Reconstructing, perceiving, disseminating the lost reality. Transmedial technologies for the Etruscan city of Marzabotto" were presented at the Digital Heritage 2015 Conference in Granada (Gaucci et al. 2015) as they represent some achievement in the application of new methods and technologies to the analysis of ancient structures. The aim of the project is the development of a virtual model of the entire Etruscan town of Marzabotto near Bologna, that visitors can enjoy directly on site, through Augmented Reality devices. In this perspective, the virtual reconstruction of some Etruscan buildings allowed to experiment new applications of informative computer modelling. The extensive use of digital models followed an emerging approach that properly mimic the building process in contemporary engineering, referred to as BIM (Building Information Modeling). Digital models produced in a BIM environment are also $3 \mathrm{D}$ archives with a considerable potential in terms of conservation, research and dissemination. Therefore, the models generated in this work lead to the virtual reconstruction proposal for those buildings that have no more existing elevations, with hypothetical elements justified by the numerical simulation analysis. In addition to the traditional and historical studies, the highly innovative aspect of this research is the application of technologies that enable reflections on the architectural credibility of the model; a new method for virtual Experimental Archeology was started beginning from the building's remains, following an approach that was defined ArchaeoBIM. This method fosters a virtuous cycle, controlling all the development stages starting from the data used to author the model until the simulation and final postfiguration, which is the virtual conjectural restitution of how the building actually existed in the past.

During the 2013-2015 excavations in Regio I, 4, the team of Bologna University, directed by Elisabetta Govi, discovered a new urban Tuscanic temple sacred to Uni (Roman luno). This is a significant discovery, both for the scientific relevance of the building itself and for new reflections on the issues about the urban plan and the history of the town (Govi in press). Therefore the temple has been elected as Case Study. The ArchaeoBIM method granted a deep analysis based on the archaeological record and information about elevations, inferred from ancient sources. Then, the architectural remains, mainly the roof elements, were digitally acquired in order to get a more definite quantification of shapes and loads to model. The last phase was the production of the whole model of the temple, following a specific ArchaeoBIM approach later described in this contribution. The primary aim was to establish credibility of architectural and engineering criteria expressed by a virtual building process.

\section{Archaeological Analysis}

The archaeological record of the temple is limited broadly to massive foundations made of pebbles, mostly taken away by peasants during the past centuries (Fig. 1). Nothing was found to describe the original building as

“Corresponding Author: Simone Garagnani, simone.garagnani@unibo.it 
it was standing on the ancient ground level. It can be assumed that the temple followed the Tuscanic order, as described by Vitruvius in De Architectura (IV 7, 1-5). However, the plan proportions do not follow exactly the famous Vitruvius' tuscanicae dispositiones, although they do not differ so much. These are some of the initial reflections that guided the preliminary archaeological analysis, taking into account some critical issues to be solved in order to build up a believable model, which had to properly consider building materials, the reconstructive hypothesis for elevations and the roof, based on ancient sources and scientific literature.
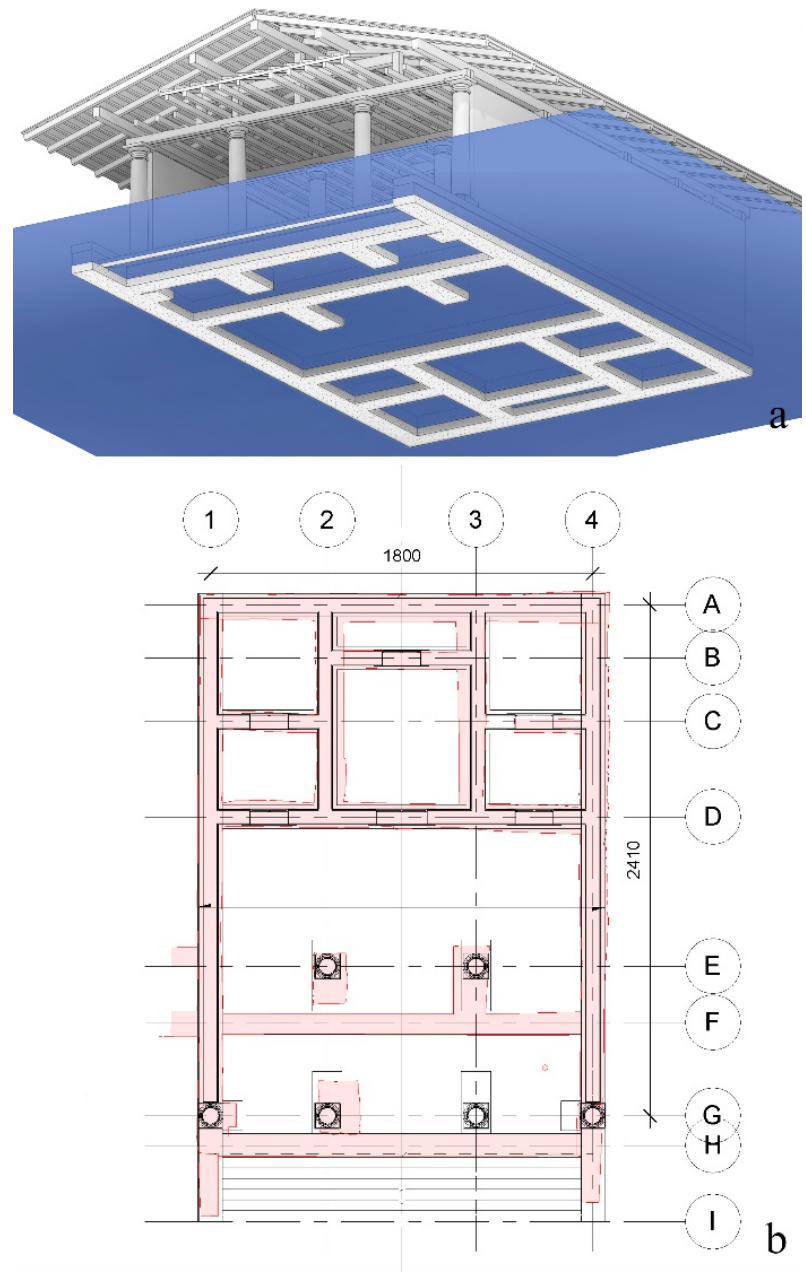

Figure 1: The ArchaeoBIM digital model (a) produced beginning from the real foundation plan (represented in red color, b).

Materials used for the elevation walls were not discovered during the excavations, as well as in the entire town. They would have been mudbricks walls, eventually supported by wooden beams, as hypothesized for the dwellings. Columns could be made of straight trunks or, less likely, by stone; the bases and the capitals could be made of local travertine. Coming to the wood (this consideration is also valid later, for the roof), a prevalent use of the deciduous oak can be presumed, due to the medium-hill environment, as confirmed by the paleoenvironmental studies conducted by M.L. Carra.

The Vitruvian criteria were parametrically translated into digital models, even if conscious of the historical limits of his work compared to the archaeological records. Therefore, the height of the elevation was modelled following the dispositiones tuscanicae given by Vitruvius.

The wooden structure of the roof has been generated following Vitruvius descriptions (IV 7, 4-5). The oak allows the use of great supporting beams but ancient sources testified a maximum lenght of 7-8 m. Beams of such length are essential to support loads, especially considering that in the Etruscan (but also Roman) architectural technology the roof system ignores the use of the truss. It has yet to be investigated the connection system among the wooden elements: various solutions can be found in the Greek world, as witnessed by the ancient sources (Orlandos 1966, pp. 45-49; hypothesis of grappa, nails and ties for the Temple II dell'Ara della Regina, Bonghi 2012, p. 38). The roof was covered with tegulae and imbrices. These elements, mainly similar to modules destined to house roofs (Pizzirani and Pozzi 2010), were found during excavations of the areas around the temple, in contexts intended as a late walkway around the sacred building. A few fragments of palmette antefixes, according to a decorative scheme well known in the acropolis sacred buildings, were found as well. The excavation of the temple temenos is not ended, thus it is not possible to establish if greater tegulae were used for the slopes. At the present state of the excavation, it is plausible to speculate a roof composed by elements in special modules, considering the use of the house modules for the small front roof only. It seems not methodologically correct to place on the temple other decorative elements not yet found beyond palmette antefixes.

\section{The digital acquisition of artifacts' datasets}

By starting the FIRB 2013 project, it was possible to apply and test directly on the site under investigation some of the latest 3D digital acquisition techniques. In recent years systems based on passive sensors, such as digital photogrammetry and computer vision algorythms, were progressively optimized (Buscemi et al. 2014). From the combination of digital photogrammetry and computer vision techniques, algorithms like Structure from Motion were implemented into software, like Agisoft PhotoScan, which allows reconstructing $3 \mathrm{D}$ models from photographs following a typical automated process, as experimented in this research work.

During the excavations at Marzabotto in 2014, it was decided to take advantage of these methodologies using PhotoScan, combined to total station's data acquisitions in the field: the aim was the production of referenced three-dimensional models related to the various digging stages.

The metric accuracy of measurements and models made during the excavation led to the use of the same technology aimed at the digital acquisition of materials related to the temple of Uni's roof system, including roof tiles and, in particular, brim gutters with palm-shaped antefixes.

Several tile fragments hypothetically attributable to the roof structure were found in stratigraphic units 1119 and 1142. Because of the fragmentary state of conservation of these materials, we proceeded to a measurement 
aimed at the estimation of modules and most of them can be identified as simple elements, just like the ones found for common settlements around the town. The only exception was represented by a couple of well preserved palm-shaped antefixes similar to the ones belonging to the Kainua's acropolis and some tile fragments that, according to their thickness, appear to be more similar to the covering elements discovered nearby the close Temple of Tinia (Sassatelli 2009, p. 332, fig. 13).

The presence of both shapes leads to believe preliminarily that the simple module was used for the small front roof slab, the greater for the wide temple coverage instead. The temple of Uni takes up an area of 492 square meters, slightly larger than the Temple $C$ in the Acropolis. These sacred buildings, both Tuscanic, had probably similar coverage.

Once verified the right module to use, artifacts in good state of conservation were digitally acquired. Then, roof tiles, shingles and antefixes were processed in order to evaluate their shape, volume and weight for the accurate reconstruction performed using computer models (Fig. 2).

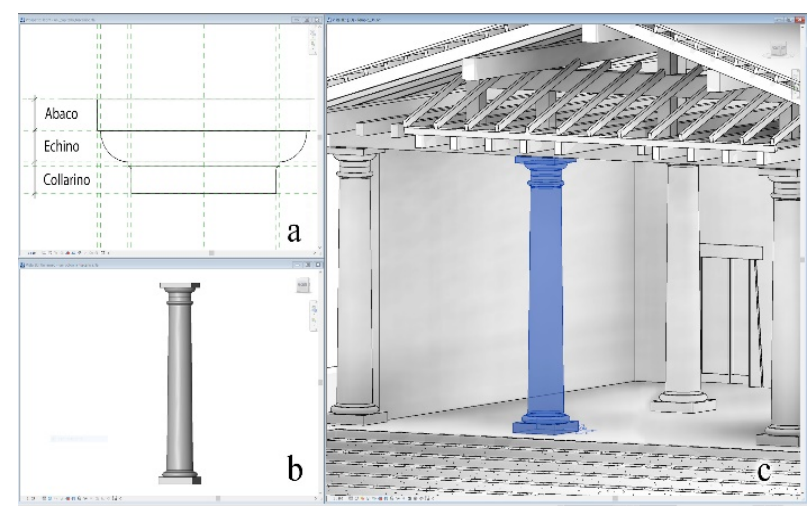

Figure 2: Detail of the parametric column generated as a custom family in Autodesk Revit (a, b). All the Tuscanic elements were modelled using a parametric approach then assembled into the final ArchaeoBIM model (c).

\section{ArchaeoBIM: digital semantics for archaeological investigations}

Over the past years the field of contemporary architecture and building engineering have been affected by a major change in design methodology, following an approach called Building Information Modeling (BIM), aimed at a better fulfillment of the requirements that apply to the construction industry (Eastman et al. 2008). One of the main features of the BIM approach is the interoperability among disciplines, which share information during all the different stages of the building process. BIM models are three-dimensional representations of facilities based on assembled objects including information about their physical properties and their mutual relationships (Fai et al. 2011). Even if BIM was developed for new constructions at the industrial level, some works dealing with the process application to existing buildings and monumental sites were published over the years, with the acronym of HBIM (Historic Building Information Modeling). HBIM was originally proposed as a modeling system for historic structures surveyed using laser scanning combined with digital photogrammetry, in order to generate parametric 3D models by comparing real elements to already prepared digital libraries (Dore and Murphy 2012). Since the HBIM's goals and methodologies are based on different premises, the term ArchaeoBIM was chosen to distinguish this research scenario and to identify the workflow developed to inflect the common BIM matrix to the archaeological virtual reconstruction. The temple of Uni's ArchaeoBIM model was produced investigating semantics and morphology largely following Vitruvian rules, even if the only element that could be acquired with surveys was the foundation plan (Fig. 1). A hypothetical reconstruction, consisting of precise metrics for the elevations and sections, was generated beginning from groundwork's extents. The original ArchaeoBIM process consists of digital elements that have to be combined just like in the real building assembly: the reliable parametric engine of Autodesk Revit software was chosen to create these smart components. Like in BIM semantics, the individual elements retain memory of data associated to them, so the overall geometric reconstruction is supposed a visual index for various contents (Garagnani 2015). Walls were traced following the foundations path, built on top of the podium with plastered, sun-dried clay bricks about 1 meter on the ground line. Also the Tuscan order columns, digitized with a parametric schema based on the shaft diameter (Fig. 2), were created as custom Revit families considering weights and materials, since some structural analysis are still in progress in order to validate elements' dimensions and their stress behavior. The preliminary results of this methodology suggested some further explanations for the actual position of some plinths close to the linear foundations. On the top of pars antica and pars postica, an impressive frame made of oak timber would have been erected as a roof, covered in tiles that were mostly found during previous excavations in Marzabotto. The different oak beams, probably 8 meters long, were placed in the ArchaeoBIM model following a well-known diagram in the scientific literature: a horizontal sequence of beams (mutuli) were placed on the top of the walls to allow coupled transversal girders (trabes compactiles) to be sustained. Other layers of sloped frames, made of crossed beams (cantherii and templa), were modeled according to $16^{\circ}$ declivity to arrange roof tiles and decorations (antefisse) (Fig. 3).

\section{Conclusion}

Archaeology often needs to reconstruct ancient buildings or monumental sites in order to study and preserve the cultural heritage they represent. That is why ArchaeoBIM was chosen as the name of a proposed methodology that applies the BIM-based modeling to no more existing architectural domains that cannot be directly investigated. The authors of this research work believe that the ArchaeoBIM process can really represent a versatile and profitable approach to the documentation of the archaeological heritage, by standing as a complete knowledge management system, as useful for the consultation of the materials contained as for the deepen study of ancient building technologies, which lead to possible conscious reconstructions. 

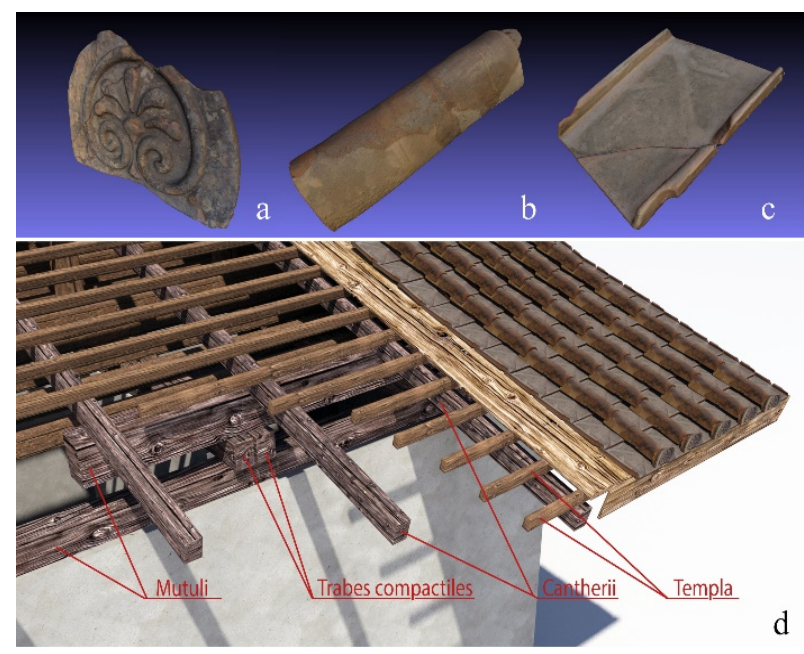

d

Figure 3: Detail of the ArchaeoBIM model for the temple of Uni's roof. The original elements were acquired using digital photogrammetry $(a, b, c)$ then they were assembled in the final 3D model, following a real building sequence (d).

\section{Acknowledgements}

This work was supported by the Italian Ministry of University and Research (MIUR) concerning the "Future in Research" program FIRB 2013, under Grant RBFR13X8CN.

The authors would like to thank Giuseppe Sassatelli and Elisabetta Govi, respectively former and current director of the University of Bologna excavations in Marzabotto, and the Superintendence for Archaeological Heritage of Emilia-Romagna.

\section{References}

BONGHI, M., 2012. Tempio II. In: M. Bonghi Jovino and G. Bagnasco Gianni, eds, Tarquinia. II santuario dell'Ara della Regina. I templi arcaici. Roma: "L'Erma" di Bretschneider, pp. 33-40.

Buscemi, F., MILITELlo, P., D’AgostinO, G. and SAMMITO, A.M. 2014. Tecniche di fotomodellazione per la documentazione e la comunicazione in archeologia: il sito di Calicantone (RG). Archeologia e Calcolatori, 25, pp. $131-156$.

DORE, C., and MURPHY, M., 2012. Integration of HBIM and 3D GIS for Digital Heritage Modelling. In: Prooceedings of Digital Documentation 2012 (Edinburgh, 22-23 October 2012).

EASTMAN, C., TEICHOLZ, P., SACKS, R., and LISTON, K., 2008. BIM Handbook. A guide to Building Information Modeling for Owners, Managers, Designers, Engineers, and Contractors, Hoboken, Jonn Wiley \& Sons.

FAI, S., DUCKWORTH, T., GRAHAM, K., and WOOD, N., 2011. Building Information Modelling and the Conservation of Modern Heritage. In: The 24rd World Congress of Architecture, Union Internationale des Architectes (UIA), Tokyo.

GARAGNANI, S., 2015. Semantic Representation of Accurate Surveys for the Cultural Heritage: BIM Applied to the Existing Domain. In: S. BRUSAPORCI, ed, Emerging Digital Tools for Architectural Surveying, Modeling, and Representation. Hershey: IGI Global. 829 pages.

GAUCCI, A., GARAGNANI, S. and MANFERDINI, A.M., 2015. Reconstructing the Lost Reality. Archaeological Analysis and Transmedial Technologies for a Perspective of Virtual Reality in the Etruscan City of Kainua. In: Proceedings of the 2nd International Congress on Digital Heritage 2015, vol. 2, 21, pp. 1-8.

GOVI, E., in press. La dimensione del sacro nella città di Kainua - Marzabotto. In: La città etrusca e il sacro. Santuari e istituzioni politiche.

ORLANDOS, A., 1966. Les matériaux de construction. la technique architecturale des anciens Grecs, I. Paris: de Boccard. 162 pages.

PIZZIRANI, C., and POZZI, A., 2010. Laterizi e materiali da costruzione. In: GOVI and SASSATELLI 2010, pp. $285-313$.

POGGESI, G., DONATI, L., BOCCI, E., MILLEMACI, G., PAGNINI, L., and PALLECCHI, P., 2005. Prato - Gonfienti: un nuovo centro etrusco sulla via per Marzabotto. In: Sassatelli and Govi 2005a, pp. 267-300.

POTTS, C.R., 2011. The Development and Architectural Significance of Early Etrusco-Italic Podia. Babesch, 86, pp. 4152. 


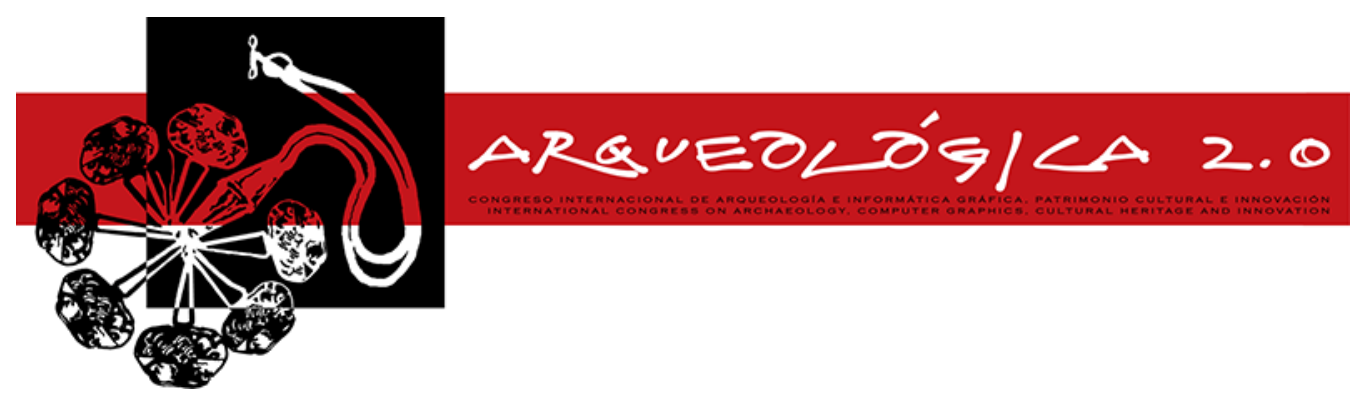

Proceedings of the $8^{\text {th }}$ International Congress

on Archaeology,

Computer Graphics,

Cultural Heritage and Innovation

'ARQUEOLÓGICA 2.0'

in Valencia (Spain),

Sept. $5-7,2016$

\title{
VIRTUAL PALMYRA: 3D RECONSTRUCTION OF THE LOST REALITY OF "THE BRIDE OF THE DESERT"
}

\author{
PALMIRA VIRTUAL: 3D RECONSTRUCCIÓN DE PERDIDO DE LA REALIDAD DE LA“ NOVIA DEL DESIERTO” \\ Ahmet Denker \\ Faculty of Engineering and Natural Sciences, Istanbul Bilgi University, Eyup, 34060 Istanbul, Turkey. ahmet.denker@bilgi.edu.tr
}

\begin{abstract}
:
Palmyra in Syria had been, with its Corinthian colonnades, amphitheater and splendidly built temples to ancient gods, source of inspiration and imagination for Western architecture. Virtual Palmyra project offers a glimpse of the grandeur and beauty of the ruins of Palmyra, none of which any longer remains. 3D models of the most significant structures of Palmyra, including Temple of Bel and Temple of Baalshamin which have been leveled as a result of conflict based vandalism, as well as the colonnaded street and the amphitheater are presented as "ghost images" through reconstructed 3D models. Focus has been in maintaining the accuracy and validity of the visualized data of the relics and environment of Palmyra, as they were once extant.
\end{abstract}

Key words: Palmyra, virtual archaeology, world cultural heritage, 3D reconstruction, digital cultural heritage

\section{Resumen:}

Palmira en Siria, ha sido con sus columnatas, anfiteatro y los templos de antiguos dioses Corintios, construidos espléndidamente, una fuente de inspiración e imaginación para la arquitectura Occidental. El proyecto de Palmira virtual ofrece una vista rápida de la grandeza y la belleza de las ruinas de Palmira, de las cuales ninguna permanece hoy en día. Los modelos de 3D de las estructuras más significativas de Palmira, incluyen el Templo de Bel y el Templo de Baalshamin, los cuales están severamente destruidos a causa de los conflictos basado en el vandalismo, así como el gran columnata monumental y el anfiteatro son presentados como "imágenes fantasma" a través de los modelos reconstruidos de 3D. El enfoque ha sido mantener la precisión y la validez de la información visualizada de las reliquias y del ambiente de Palmira, como eran antiguamente.

Palabras clave: Palmira, arqueología virtual, Patrimonio mundial, reconstrucción 3D, Patrimonio cultural digital

\section{Introduction}

Pliny the Elder said: "Situated in a vast expanse of sand and renowned for its fertile soil and pleasant streams, the ancient city of Palmyra was a stopping point for caravans traversing the Syrian Desert" (Pliny the Elder, Natural History 5.88.1) An oasis in the Syrian desert, Palmyra was known as "the Venice of the sands" and "the bride of the desert". Palmyra used to contain well preserved temples which were dedicated to ancient Arab gods, a colonnaded street with Corinthian columns, an amphitheater, and the valley of tombs. It had long been counted among the most eloquent and stupendous ruined cities from the ancient world. As one of the outstanding cultural centres of the world, it was also listed as a UNESCO world heritage site.

Being a pearl of our cultural heritage which holds a significant part of the historical wealth of our modern society, Palmyra had constantly been under threat of demolition. As the latest act in the dark history of vandalism, Isis (Islamic State of Iraq and al-Sham) imperiled Temple of Baal Shamin. It was followed by the Temple of Bel and the Arch of Triumph. They were unique monuments of a hybrid architectural style which blended Graeco-Roman canons with ancient MiddleEastern architecture. All landmarks of Palmyra are now gone. With their destruction and disappearance, irreplaceable treasures of the World Cultural Heritage are lost to posterity.

3D computer graphics and virtual reality are the only means of remedy for our collective and irreversible loss. By the project of "Virtual Palmyra" we have aimed at reviving the lost reality of Palmyra by digitally constructing its "ghost images." Virtual Palmyra project offers a glimpse of the grandeur and beauty of the treasures of Palmyra, none of which any longer remains. 3D models of the most significant structures of Palmyra, including Temple of Bel and Temple of Baalshamin which have been leveled as a result of conflict based 
vandalism, as well as the colonnaded street and the amphitheater are presented.

\section{Digital reconstruction of Palmyra}

Records of Palmyra by travellers in the 17th and 18th centuries contributed greatly to this reconstruction work. The British explorer Robert Wood's book (Wood 1753) which had appeared subsequent to Wood's visit to Palmyra provided important sources of graphical data thanks to the drawings by Giovanni Battista Borra. These were the first accurate records of the monumental ruins of Palmyra. Another important source of graphical data has been the drawings of Louis Francois Cassas (Cassas 1900). Cassas had travelled to Palmyra in 1785. He made several drawings of the ruins of Palmyra. His drawings are of indispensible value in providing the much needed graphical data about these ruins. Photos taken between 1867 and 1876 by Felix Bonfils provided the most complete visual record of Palmyra from the 19th century. Wiegand's book (Wiegand 1932) has been the main repository of 20th century information in this reconstruction work as regards to graphical data. Transporting this information into digital models may be compared with Evans' procedure of "translation from drawings to buildings" (Evans 1995).

\subsection{Digital reconstruction of the temples}

Palmyra's temples were the remarkable examples of monumental architecture which blended the GrecoRoman architecture with Oriental architecture. The hybrid elements of these temples demonstrated the numerous cultures that frequently overlapped and intermixed in Palmyra. Temples of Palmyra were among the greatest architectural achievements of mankind until they fell victim to vandalism. They drew on wealthy, canonical forms stemming from both Graeco-Roman and Ancient Near Eastern roots.

\subsubsection{Temple of Bel}

Temple of Bel was the most impressive and the primary sanctuary in Palmyra. It was dedicated to God Bel, the most important of the Palmyrene Gods, the equivalent of Greek Zeus and Roman Jupiter (Schlumberger 1971). Its relic was preserved remarkably well and constituted the most impessive part of the ruins. It used to exhibit the splendid synthesis of Graeco-Roman and Ancient Near Eastern Architectures. The temple building was in the middle of an almost square temenos (205 by 210 meters). The cella was a rectangular building which was surrounded by one row of columns. The order was Corinthean. In its outward appearance, the temple looked to derive from the canon of Hellenistic architecture. The isomorphic reconstruction of this temple was presented in (Seyrig et al. 1975). The drawings of Propylaeum were given in Wood's book. A scene from the reconstruction of Temple of Bel is given in Figure 1.

\subsubsection{Temple of Baalshamin}

As with Temple of Bel, Temple of Baalshamin also exhibited hybridity in design. The Greco-Roman traits were demonstrated by its colonnaded precinct, prostyle façade and tetrastyle structure (Collart 1970). The four free standing columns in the façade were finished in
Corinthean order. Alongside overall Classical GraecoRoman appearance, it also embodied prominent Near Eastern motives. The most visible of them were the windows of cella. These windows which did not exist in the Greco-Roman cannon signified that the Deity was inside (Fig. 2).

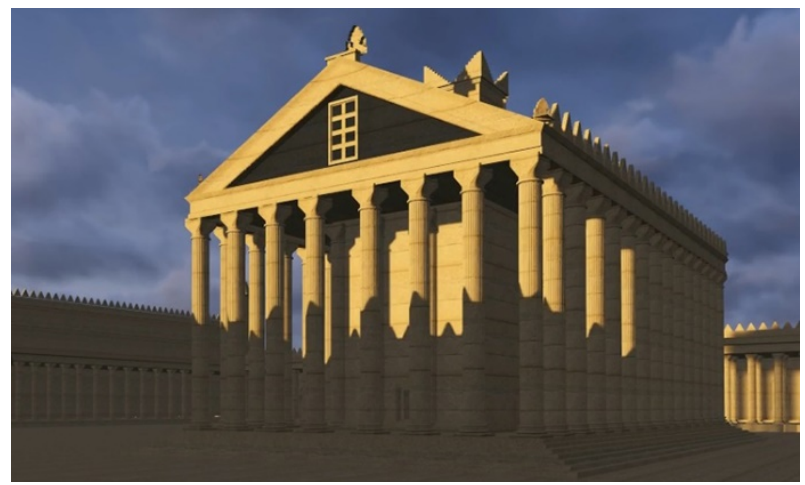

Figure 1: Reconstructed view of the Temple of Bel while sun is setting.

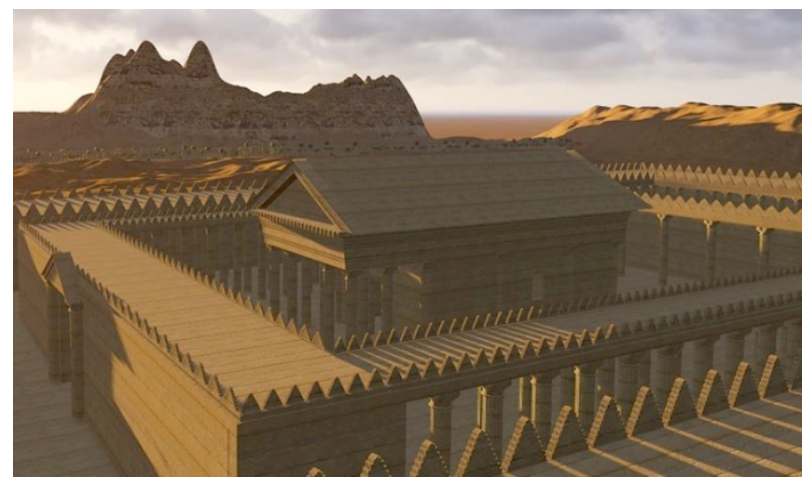

Figure 2: Reconstructed outer-view of the Temple of Baalshamin and its environment.

\subsection{Digital reconstruction of other landmarks}

\subsubsection{Colonnaded Street}

Colonnaded street is another of Palmyra's great archaeological sites. Despite the Graeco-Roman character of the columns, the colonnaded street itself was the most significant of the traits of Eastern traditon in Palmyra. This is because, in contrast to the ubiquitness of the colonnaded streets in the Eastern provinces of the Roman Empire, they were almost completely absent in the Western provinces (Ball 2014). It had bestowed upon Palmyra an architectural unity, a common thread that brought Eastern, Western and Central sections of the city together.The Eastern section which ended at the Temple of Bel connected the temple to the Monumental Arch which led the way to Temple of Bel (Fig. 3).

\subsubsection{Amphitheater}

The Amphitheater has a totally western form. It is a horseshoe-shaped building with a cavea of 92 meters in diameter and an adjoining portico. It was surrounded by a ring -shaped area of $104 \times 82 \mathrm{~m}$. 
This expansive area had been very likely to be used both by the visitors of the theater and of the caravan dealers who were coming to market their merchandise at the Agora (Fig. 4).

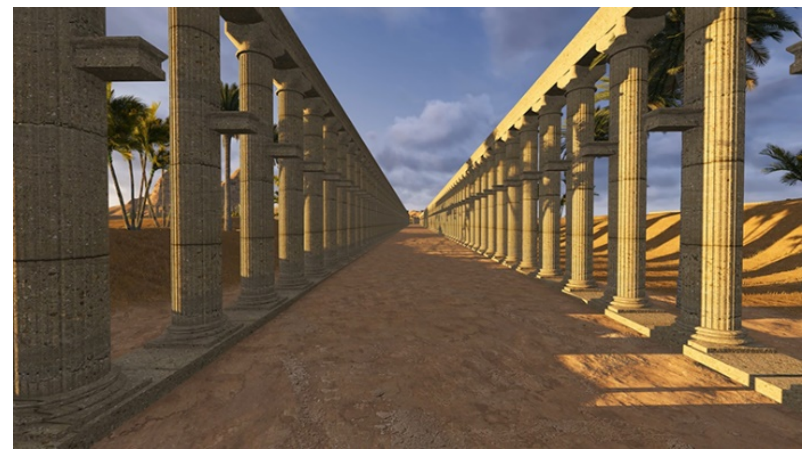

Figure 3: Reconstructed view of the colonnaded street.

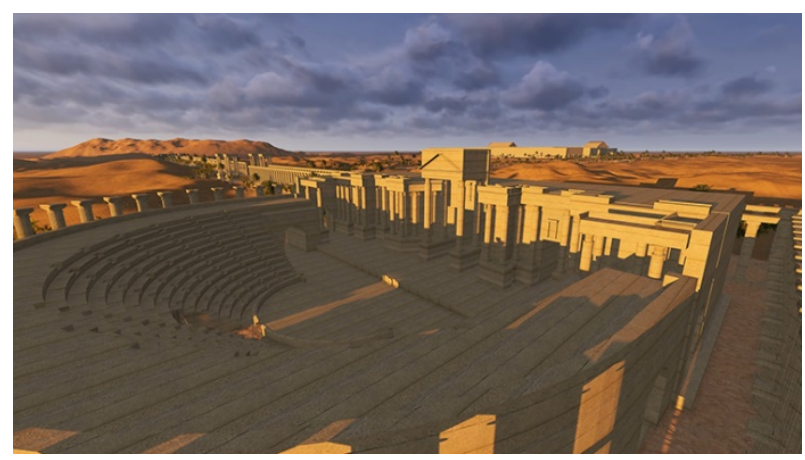

Figure 4: Reconstructed view of the Amphitheater.

\section{Conclusions}

3D Computer Graphics, through technological innovations, offers an ability in 'reconstructing the past' beyond those originally imagined. Starting from 90's (Forte and Siliotti 1997) the use of 3D computer graphics in relation with archaeology and cultural heritage has been a focus of attention for scholars in multi-disciplinary fields. An abundance of publications have emerged in the last two decades which have presented photorealistic reconstructions of the past. This stream continues to make contributions to the creation of a new legacy in cultural heritage. Reconstructions of the past with the advent of 3D computer graphics and high resolution rendering are increasingly produced and maintained in digital form, thus creating a legacy: Digital cultural heritage. With this work lost reality of Palmyra has been recreated as a new edition to our digital cultural heritage.

\section{Acknowledgements}

The author acknowledges with pride the contributions of his students Berk Gencan, Eren Can Yildirir, Mehmet Cicekler and Meltem Sezer in creation of the 3D reconstructions of this project.

\section{References}

BALL, W., 2014, Rome in the East: The Transformation of an Empire, Routledge.

CASSAS, L. F., 1900, Voyage pittoresque de la Syrie, de la Phoenicie, de la Palaestine et de la Basse Aegypte Available: http://digi.ub.uni-heidelberg.de/diglit/cassas1800bd3/0001

COLLART, P., 1970, Reconstruction Du Thalamos Du Temple De Baalshamîn a Palmyre, Revue Archéologique, Nouvelle Série, Fasc. 2 (1970), pp. 323-327

EVANS, R., 1995. Projective Cast: Architecture and Its Three Geometries, MIT Press, ISBN 978-0262550383.

FORTE, M. and SILIOTTI, A., 1997. Virtual archaeology: re-creating ancient worlds. London: Harry N Abrams B.V. 288 pages.

O' BRIEN, J., 2015, Palmyra: Ruins that inspired the architecture of power, BBC News, Washington. Available: http://www.bbc.com/news/magazine-33659376

PLINY THE ELDER, Natural History 5.88.1.

SCHLUMBERGER, D., 1971 Les quatre tribus de Palmyre, Syria, 48:121-133.

SEYRIG, H., AMY, R. and WILL, E., 1975. Le Temple de Bel à Palmyre, 2 vols. Paris: Geuthner.

WIEGAND, T, 1932. Palmyra Ergebnisse der Expeditionen von 1902 und 1917. Text-und Tafelbd.

WOOD, R., 1753. The ruins of Palmyra, otherwise Tedmor, in the desart. Available: http://digi.ub.uni-heidelberg.de/diglit 


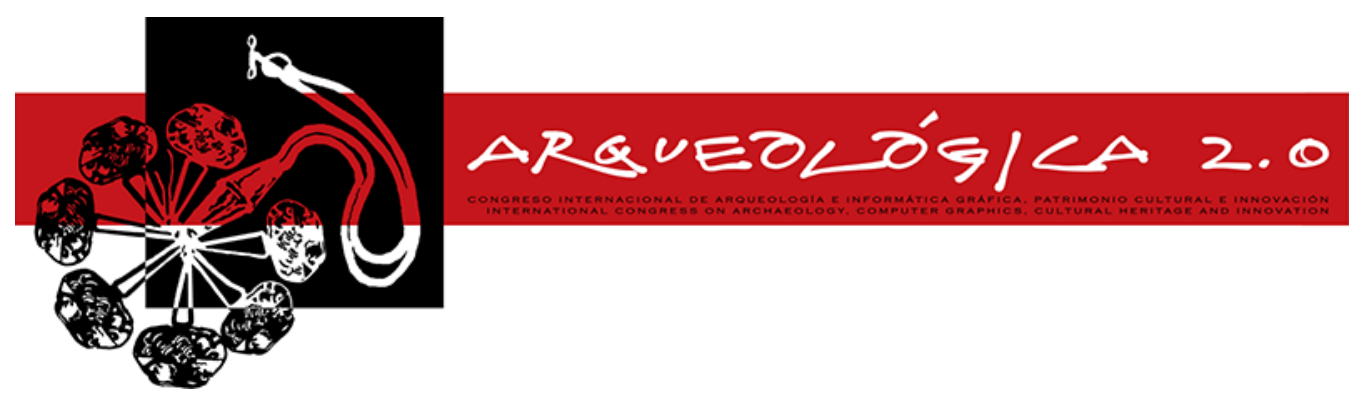

Proceedings of the $8^{\text {th }}$ International Congress

on Archaeology,

Computer Graphics,

Cultural Heritage and Innovation

'ARQUEOLÓGICA 2.0'

in Valencia (Spain),

Sept. $5-7,2016$

\title{
LA HISTORIA EN EL PAISAJE: DIFERENTES LUGARES Y ANÁLOGAS REPRESENTACIONES. ANÁLISIS E INTERPRETACIÓN CON LAS NUEVAS TECNOLOGÍAS DE MODELIZACIÓN VIRTUAL
}

\section{THE HISTORY IN THE LANDSCAPE: DIFFERENT PLACES AND SIMILAR REPRESENTATIONS. ANALYSIS AND INTERPRETATION WITH THE NEW TECHNOLOGIES OF VIRTUAL MODELING}

\author{
Xosefina Otero ${ }^{a}$, Mercedes Farjas ${ }^{a}$, Manuel Santos ${ }^{b}$ \\ ${ }^{a}$ ETS de Ingenieros en Topografía, Cartografía y Geodesia, Universidad Politécnica de Madrid, Campus Sur- UPM Crta. de Valencia \\ km 7, 28031 Madrid, España. artabria@gmail.com; m.farjas@upm.es \\ ${ }^{\mathrm{b}}$ Lab2Pt Universidade do Minho, Braga, Portugal. manuel.santos@mundo-r.com
}

\begin{abstract}
:
In this paper we present new methods of the documentation and registration of the petroglyphs of the exceptional archaeological site located on Khor Fakkan, emirate of Sharjah, on the east coast of the United Arab Emirates along the Gulf of Oman, and coordinates $24^{\circ} 59^{\prime} 06.06^{\prime \prime} N-56^{\circ} 20^{\prime} 36.70^{\prime \prime} \mathrm{E}$. The engravings on the surface of the serpentine rock fragments, of the Semail ophiolite complex that was generated when the Saudí plate was introduced under the IranZagros, in the Cretaceous, are made with the technique and striped characteristic of the Bronze Age and Iron Age. We conducted the study respecting its conservation without any intervention on them, using the latest technologies available and applying at the same time the methodology of landscape archeology. One of the tools we use to analyze is the tablet EyesMap, a new professional device that allows real-time measurement and 3D modeling of supports. It has two Sony 13 megapixel cameras each, depth sensor, an inertial system and a GNSS system, among other devices. The research focuses on advanced measurement techniques that allow the virtual reconstruction of the archaeological site and details of the petroglyphs and fit them in their original landscape to reproduce the environmental conditions in which the authors of the petroglyphs and their communities lived.
\end{abstract}

Key words: petroglyphs, Bronze Age, Iron Age, 3D scanning, modeling, photogrammetry

\section{Resumen:}

En este artículo presentamos los nuevos métodos de documentación y registro de los petroglifos de un sitio arqueológico excepcional localizado en Khor Fakkan, en el Emirato de Shrajah, en la costa este de los Emiratos Árabes Unidos, a lo largo del Golfo de Omán y cuyas coordenadas geográficas son 2459'06.06" N - 56²0'36.70" E. Los grabados, en la superficie de fragmentos de roca serpentina del complejo ofiolítico Semail, que fue generado cuando la placa Saudí se introdujo bajo la Irán-Zagros, durante el Cretácico, se realizaron con técnicas y estilos propios de la Edad del Bronce y del Hierro. Llevamos a cabo su estudio respetando su perfecta conservación y sin ningún tipo de intervención sobre ellos, utilizando las ultimas tecnologías disponibles y aplicando, a la vez, la metodología de la arqueología del paisaje. Una de las herramientas que utilizamos para analizarlos es la tablet EyesMap, un nuevo dispositivo profesional que permite la medición en tiempo real y el modelado 3D de los soportes. Posee dos cámaras Sony de 13 megapíxeles cada una, un sensor de profundidad, un sistema inercial y un sistema GNSS, entre otros dispositivos. La investigación se centra en las técnicas de medición avanzadas que permiten hacer la reconstrucción virtual del emplazamiento arqueológico y de los detalles de los petroglifos y encajarlos en su paisaje original para reproducir las condiciones ambientales en las que vivían los autores de los petroglifos y sus comunidades.

Palabras clave: petroglifos, Edad del Bronce, Edad del Hierro, 3D escáner, modelado 3D, fotogrametría

\section{Introducción}

Khatm al Melaha es un emplazamiento arqueológico único, ubicado en Kalba (Khor Fakkan), perteneciente al
Emirato de Sharjah, en la costa este de los Emiratos Árabes Unidos (Fig.1)

Durante miles de años Khatm al Melaha poseyó, sin duda, una innegable finalidad simbólico-mágica, que se

‘Corresponding Author: Xosefina Otero, artabria@gmail.com 
evidencia en un impresionante número de petroglifos hallados en la zona.

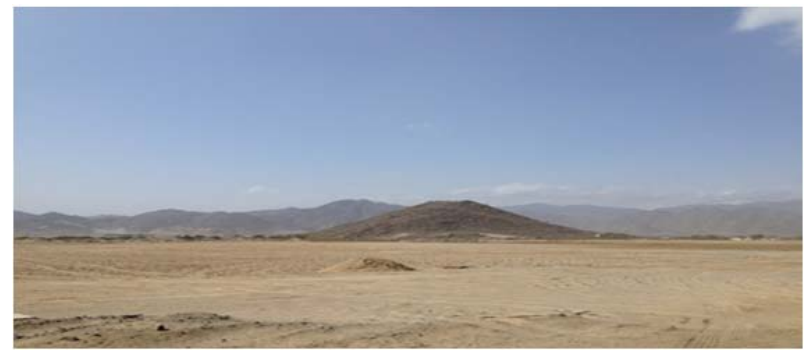

Figura 1: Emplazamiento de Khatm al Melaha.

Los planteamientos metodológicos que proponemos para abordar el estudio de los petroglifos son métodos de trabajo de la Arqueología del Paisaje y a nivel técnico, la utilización de las nuevas tecnologías de fotogrametría digital y escaneado láser como recurso óptimo para el registro, documentación, procesamiento y posterior divulgación de los resultados.

\section{La fotogrametría}

La fotogrametría digital nos permite una mayor agilidad en el registro del arte rupestre, especialmente en los grabados (Rodríguez 2014). Más allá del modelado de imagen 3D por fotogrametría convergente, en esta investigación, además de realizar las tomas con una cámara digital Nikon D3200, se ha contado con una nueva herramienta que permite la medición y modelado 3D mediante fotogrametría estereoscópica y escaneado por triangulación óptica en tiempo real. Se trata de un dispositivo profesional denominado EyesMap, fabricada por la empresa española e-Capture.

El equipo EyesMap cuenta con un procesador Intel Core i7, de 16 gigas de RAM, y funciona sobre el sistema operativo Windows 8 , fácil de usar una vez nos familiarizamos con su manejo (Fig. 2).

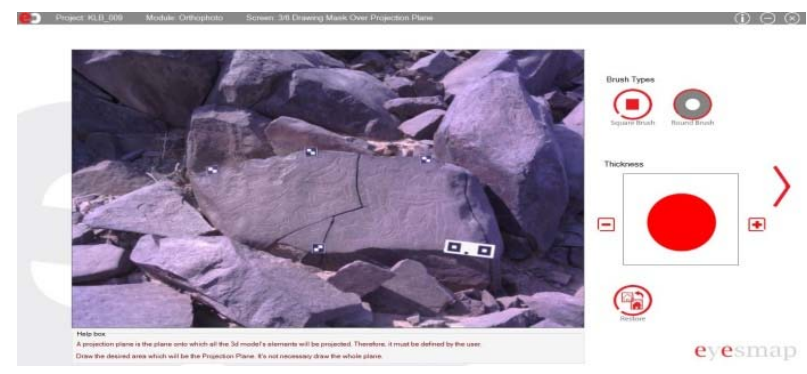

Figura 2: Interfaz de la Tablet EyesMap.

\section{Una aproximación al arte rupestre de Khatm al Melaha}

Los grabados de Khatm al Melaha fueron trazados en la superficie de fragmentos de roca serpentina, del complejo ofiolítico Semail, que se generó cuando la placa Saudí se introdujo bajo el sistema Irán-Zagros durante el Cretácico. Hay localizados en la colina más de un centenar de paneles. La presente investigación se centra en la utilización de técnicas de medición avanzadas que permiten obtener una reconstrucción virtual del emplazamiento y encajarlo en su paisaje original (Santos 1998), reproduciendo las condiciones ambientales en las que vivían los autores de los petroglifos y sus comunidades.

La tecnología fotogramétrica, antes descrita, posibilitó obtener "in situ" y en pocos minutos la geometría 3D de cada uno de estos paneles (Fig. 3), lo que permitió, entre otras cosas, registrar con precisión los surcos de las superficies grabadas. Dicha precisión en el registro posibilitó, también, la identificación de dos diferentes técnicas de grabado.

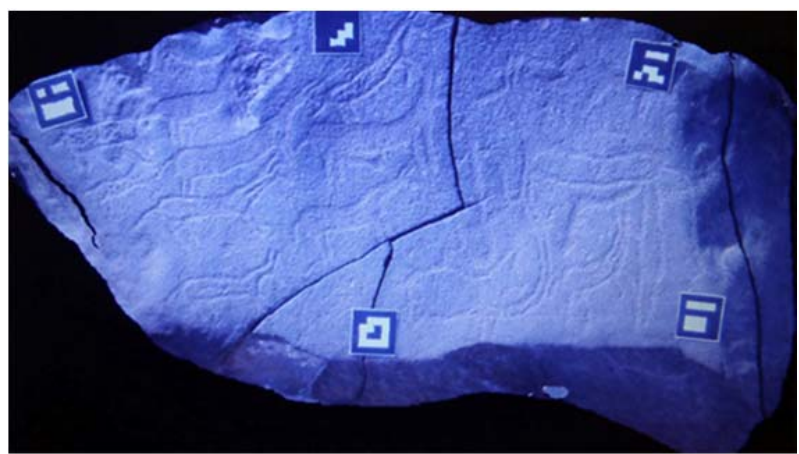

Figura 3: Geometría de uno de los paneles generada por la Tablet EyesMap en tiempo real.

En los motivos de los grabados del Bronce, con datación aproximada del 2000 BC, predominan cuadrúpedos característicos de la zona, órix, ibex, y otros ungulados, así como otros motivos diferenciados, como la que se supone podría ser una embarcación, y la representación humana con los círculos concéntricos centrales que ya hemos mencionado.

Encontramos paneles de manadas, hembras con crías en actitud relajada, sin gestos de tensión de caza, y con evidentes esfuerzos por intentar representar diferentes perspectivas, y otros de menor tamaño con individuos sueltos, tanto machos como hembras.

Otro capítulo muy interesante estaría compuesto por las representaciones esquemáticas de formas sinuosas, círculos concéntricos y diseños de "rectángulos con esquinas redondeadas y segmentados en el interior por diámetros horizontales y verticales" (Santos 2007).

En cuanto a las representaciones de la Edad del Hierro, tal como señala Santos (2007) para el Arte Rupestre Atlántico de la misma época, observamos que los paneles parecen representar la preponderancia de la sociedad sobre la naturaleza, expresada a través del dominio sobre los seres humanos sobre los animales.

Vemos paneles con escenas en las que dicho dominio queda patente en determinados rituales que conocemos de prácticas recogidas en estudios sobre el mundo mágico-religioso de culturas europeas (Santos 2004). La técnica empleada para la realización de estas figuras es por abrasión, muy probablemente con un objeto pétreo punzante.

A lo largo de la Prehistoria Reciente y Protohistoria, en diversas áreas geográficas distantes, tales como la Península Arábiga y Europa Occidental, parecen expresarse, a través del arte rupestre, con iconografías semejantes. Dichas semejanzas podrían ser explicadas por contactos a larga distancia entre ambas zonas, especialmente intensos a partir de la innovación de la metalurgia que demanda redes de intercambio para 
conseguir materias primas que no se encuentran distribuidas de forma regular (Kristiansen y Larsson 2005).

\section{Conclusiones}

Los objetivos iniciales de nuestro proyecto son dar a conocer esta zona arqueológica inédita y llevar a cabo una documentación minuciosa de los petroglifos del sitio arqueológico, implementando una tecnología concreta con base fotogramétrica y de escaneado $3 \mathrm{D}$, y, como paso ulterior, llevar a cabo un estudio más detallado desde la óptica de la Arqueología del Paisaje (Criado 2012), abordando, desde dicho marco teórico, su emplazamiento, iconografía y contexto histórico. Se ha realizado una primera captura de documentación métrica y se está realizando el tratamiento de los datos y un primer análisis de los mismos.

\section{Agradecimientos}

Este trabajo es posible gracias a la colaboración con el Department of Culture and Antiquities del Emirato de Sharjah, Emiratos Árabes Unidos.

Se realiza dentro de los proyectos HAR2015-65649-C22-P (MINECO/FEDER) y S2015/HUM-3377 (CAM/FEDER).

\section{Referencias}

CABEZOS, P.M. y CISNEROS, J.J., 2012. Fotogrametría con cámaras digitales convencionales y software libre. Disponible: http://dx.doi.org/10.4995/ega.2012.1407 [5/28, 2016].

CRIADO, F., 2012. Arqueológicas. La Razón Perdida. Barcelona: Bellaterra. Disponible: Disponible: Disponible:http://www.arqueologicas.com/ [5/28, 2016].

KRISTIANSEN, K. y LARSSON, T.B., 2005. La Emergencia de la sociedad del Bronce. Viajes, transmisiones y transformaciones. Bellaterra: Barcelona. http://www.ed-bellaterra.com/php/llibresInfo.php?idLlibre=292 [5/28, 2016].

RODRÍGUEZ, F.I., 2014. Representación 3D de petroglifos: propuesta de metodología de modelización de los grabados del Valle de Tamanart, Marruecos. Trabajo Fin de Máster, 2014. Universidad Politécnica de Madrid. Disponible: http://oa.upm.es/30703/ [5/28, 2016].

SANTOS, M., 1998. Los espacios del arte: El diseño del panel y la articulación del paisaje en el arte rupestre gallego. Trabajos de Prehistoria. 55 (2): 73-88. Disponible: http://hdl.handle.net/10261/6752 [5/28, 2016].

SANTOS, M., 2004. Arte rupestre, estilo y construcción social del espacio en el Noroeste de la Península Ibérica. Tesis doctoral.

SANTOS, M., 2007. Petroglifos y paisaje social en la prehistoria reciente del noroeste de la península ibérica. Traballos de Arqueoloxía e Paisaxe. Traballos de Arqueoloxía e Patrimonio, 38.220 p. Disponible:http://hdl.handle.net/10261/37908 [5/28, 2016]. 


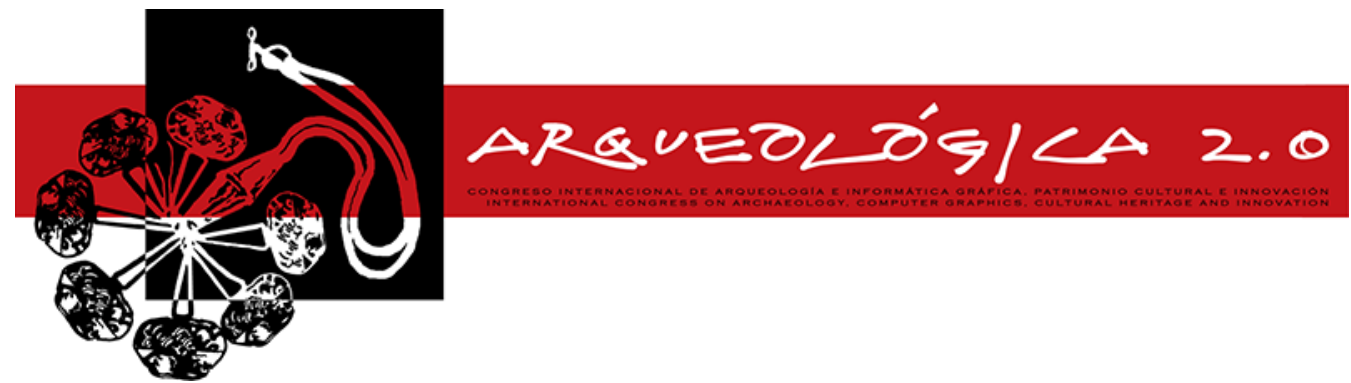

Proceedings of the $8^{\text {th }}$ International Congress

on Archaeology,

Computer Graphics,

Cultural Heritage and Innovation

'ARQUEOLÓGICA 2.0'

in Valencia (Spain),

Sept. 5-7, 2016

\title{
DOCUMENTACIÓN GEOMÉTRICA DE LA TORRE VALLFEROSA DE TORÀ
}

\author{
GEOMETRIC DOCUMENTATION OF THE TORRE VALLFEROSA OF TORÀ \\ Rafael Tortosa Garcia ${ }^{a}$, Josep Blasco i Senabre ${ }^{a}$, Oscar Aparicio González ${ }^{a}$, Luis Gimeno \\ Martínez ${ }^{a}$, Andrea Vilaplana Sellés ${ }^{a}$, Joan Menchón i Bes ${ }^{b}$ \\ ${ }^{a}$ Global Geomática s. I., C/. Santiago Rusiñol, 32, 46019 Valencia, España. rtortosa@globalgeomatica.es; \\ iblasco@globalgeomatica.es; fotogrametria@globalgeomatica.es; arqueologia@globalgeomatica.es; avilaplana@globalgeomatica.es \\ ${ }^{\mathrm{b}}$ Ajuntament de Tarragona, P/. de la Font 1, 43003 Tarragona, España. jimb@tinet.cat
}

\begin{abstract}
:
The Architecture and Archaeology depends on Geomatics to document Cultural Heritage in the best way, especially in the most complex situations or with those that present particular specifications. In this particular case, the Project of Torre de Vallferosa (Torà, Catalonia) has solved the way of representing indoor and outdoor tower's Surface (cylindrical and conical shape). The solution provided to this is to develop and expand the surface through ad hoc software.
\end{abstract}

Key words: digital archaeology, documentation, laser scan, cylindrical and conic structures, digital photogrammetry, surface development

\section{Resumen:}

Los campos de la Arquitectura y de la Arqueología necesitan de la Geomática para poder resolver la mejor forma de documentar el Patrimonio, sobre todo en los casos más complejos o que presenten unas características específicas o extraordinarias. En el presente trabajo presentamos el caso particular de la Torre Vallferosa (Torà, Catalunya), un proyecto donde se ha tenido que resolver la forma de representar la superficie de la torre, tanto la interior como la exterior, de aspecto cilíndrico y cónico, respectivamente. La solución adoptada ha sido la de desarrollar y desplegar la superficie mediante una aplicación realizada ad hoc para la ocasión.

Palabras clave: arqueología digital, documentación, láser escáner, estructuras cilíndricas y cónicas, fotogrametría digital, desarrollo de superficies

\section{Introducción}

En abril de 2014, se encargó a Global Geomática el proyecto de Documentación gráfica y geométrica de alta definición de la Torre Vallferosa por parte del Servei de Patrimoni Arquitectònic de la Direcció General d'Arxius, Biblioteques, Museus i Patrimoni del Departament de Cultura de la Generalitat de Catalunya.

La Torre Vallferosa (Fig. 1), está situada en Catalunya, en el término municipal de Torà, perteneciente a la comarca de la Segarra y a la provincia de Lleida. Su posición responde a la latitud $41,8616^{\circ}$ y longitud $1.4454^{\circ}$.

Esta torre de vigilancia construida hacia el año $970 \mathrm{~d}$. C., se encuentra situada en el camino que va de Solsona a Torà, cerca de la riera tributaria de Llanera que lleva las aguas hacia el río Llobregós. Declarada
Bien Cultural de Interés Nacional (BCIN), por sus características, la hacen única siendo considerada la obra maestra de la arquitectura militar del siglo $X$ (Menchon 2011 y 2014).

Su estructura exterior es similar a la de un tronco de cono, con un radio inferior de $6.30 \mathrm{~m}$ y una altura de unos $31 \mathrm{~m}$ aproximadamente. La puerta de acceso está ubicada a unos $10 \mathrm{~m}$ de altura y por debajo de esta altura se encuentra un depósito de aspecto cilíndrico. Por el interior se accede hasta la parte superior mediante una escalera de madera. Destacar que en la cuarta planta se conserva parte del techo original de la época románica.

La documentación de la Torre Vallferosa, como apreciamos en su descripción, tiene el hándicap de su geometría, que responde a una forma cónica en su parte exterior y cilíndrica en el imnterior, aparte de la

"Corresponding Author: Rafael Tortosa Garcia, rtortosa@globalgeomatica.es 
dificultad que conlleva el uso de aparatos de medición y de cámaras fotográficas en el entorno de la misma edificación así como en su interior.

Para su representación se propuso el desplegado o desarrollo de la superficie que puede ser aproximada analíticamente, en parte o totalmente. Para ello se necesitaba una aplicación que fuera capaz de realizar este desplegado o desarrollo, teniendo como datos de partida un modelo 3D texturizado y los parámetros de la figura teórica que mejor se aproximara a la real.

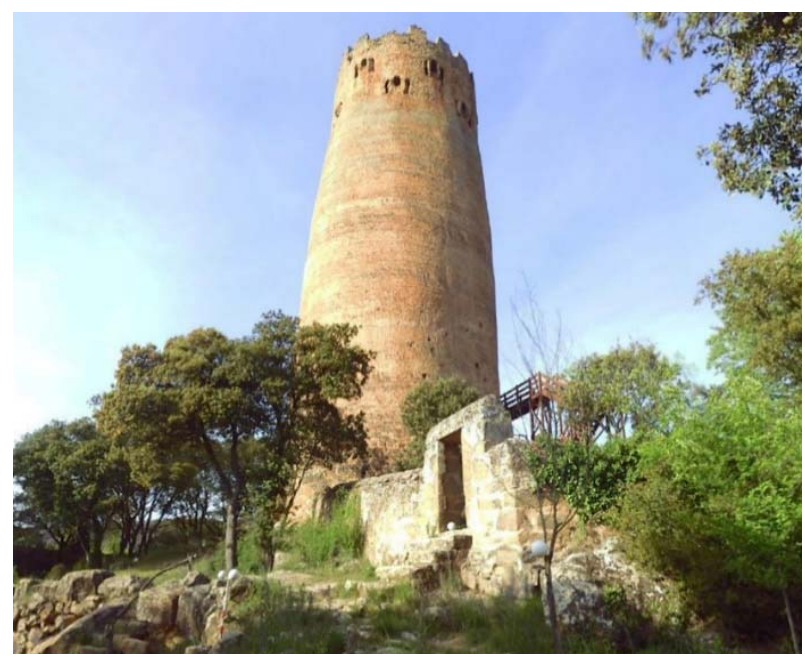

Figura 1: Vista de la Torre Vallferosa. GLOBAL GEOMÁTICA

La solución adoptada fue la realización de una nueva aplicación, denominada DESENREC 3D 1.0, que es capaz de desarrollar modelos cilíndricos o desplegar modelos cónicos. Esta aplicación és una evolución de DESENREC 2.0 (Tortosa 2003), de la cuál se mantiene la base matemática y el proceso de utilización.

La principal característica de la nueva aplicación, respecto a la anterior versión, es que el proceso metodológico propuesto para la aplicación fotogramétrica no parte de una imagen sino de un modelo tridimensional texturizado al cual se le aplica una transformación de acuerdo con los parámetros de definen la figura teórica, que responde a la primitiva que mejor se aproxima a la real. Los parámetros de la figura —cónico o cilíndrico-son obtenidos mediante el análisis y cálculo por mínimos cuadrados de la nube de puntos que define la superficie de la torre. La transformación, partiendo de un modelo tridimensional, puede generar otro modelo tridimensional, donde la tercera dimensión se corresponde con el error de ajuste en cada punto (discrepancia entre la figura teórica del objeto real), o bien generar un modelo bidimensional (plano) -la tercera dimensión es nula en todos sus puntos-, que se corresponde con el desarrollo ortofotográfico de la superficie de la torre de forma desplegada.

\section{Procesos de documentación}

\subsection{Toma de datos}

Para la toma masiva de puntos de la geometría de la torre se ha utilizado un Láser Escáner Terrestre (TLS), en concreto el FARO FOCUS 3D, un instrumento que nos ofrece gran versatilidad y rapidez en la adquisición de datos. En el exterior se han realizado dos anillos alrededor de la torre, uno más próximo al paramento y otro más alejado. Para el interior, se han realizado diversos escaneados en los distintos forjados y espacios, En total se han realizado 96 posicionamientos para definir la torre: 53 en la parte exterior y 43 en la interior.

Para las tomas fotográficas se ha utilizado una cámara convencional digital de calidad óptima, en concreto, la CANON EOS 600D, con una focal fija de $18 \mathrm{~mm}$. Se han tomado fotografías de todas las partes de la torre con un recubrimiento entorno al $60 \%$ entre imágenes contiguas.

Las imágenes de la parte inferior de la torres se realizaron a pie de campo y para la realización de las imágenes del paramento exterior, en las partes media y elevada, se ha utilizado un sistema que consiste en suspender la cámara con la consideración de que la disposición del plano focal sea el más paralelo a la superficie de la torre. Al extremo de un perfil metálico, dispuesto en horizontal, se ha desplegado un cable metálico que engancha la cámara y con la ayuda de dos cables la cámara es redireccionada desde la base de la torre. Para el cálculo se han seleccionado para el cálculo 640 imágenes.

Para el interior, la toma de las fotografías se realiza de forma convencional. La suma total de las fotografías del interior es de 1492, a las que hay que sumar las 252 realizadas al depósito.

\subsection{Procesos de edición y cálculo}

En primer lugar se realiza la correspondencia de los escaneados mediante la identificación de referencias y el cálculo del mejor ajuste posible de las referencias homólogas, obteniendo la posición relativa de todos los posicionamientos en un mismo sistema de coordenadas. Las nubes son exportadas para la generación del modelo digital de la superficie.

En otra línea de trabajo, las imágenes son introducidas en el software AGISOFT PHOTOSCAN, donde el primer paso es calcular la orientación relativa de todas las imágenes. Para darle métrica a esta orientación, además de trabajar en el mismo sistema de coordenadas que el modelo 3D obtenido a partir del TLS, introducimos los puntos de apoyo. Realizada la orientación absoluta, introducimos el modelo obtenido anteriormente. Este modelo es texturizado con una calidad óptima, mediante 25 texturas de una dimensión de 4096 x 4096 píxeles, a partir de las imágenes geoorientadas.

Como se ha explicado anteriormente, a consecuencia de la forma geométrica de la torre, la mejor forma de representarla es mediante el desplegado de la superficie. Así, de esta forma, se puede medir directamente sobre esta proyección ya que se mantiene la escala en ambos ejes y se corresponde con un producto que no presenta discontinuidades y facilita el estudio de patologías y deformaciones además de posibilitar zonas de actuación, gestión y mantenimiento.

Para la realización del desplegado se ha utilizado la aplicación DESENREC 3D 1.0, descrita en el apartado anterior. En primer lugar se necesitan calcular los parámetros que definen la figura que mejor se asimila la 
superficie de la torre para poder realizar la transformación entre el sistema de coordenadas tridimensional y su desplegado o desarrollo en un plano en su debido sistema bidimensional.

A partir del modelo 3D, seleccionando sólo las partes que pertenecen a la superficie lisa de la torre, hemos testeado la superficie con la conclusión de que la figura responde a un tronco de cono (Fig. 2), con un radio inferior de $6.27 \mathrm{~m}$, un radio superior de $4.81 \mathrm{~m}$ y una altura de $30.70 \mathrm{~m}$. Esta aproximación tiene una desviación estándar de $0.19 \mathrm{~m}$ y un valor máximo de $0.72 \mathrm{~m}$

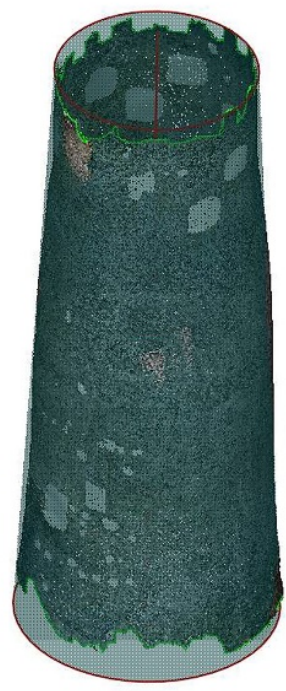

Figura 2: Mejor ajuste de la superficie exterior con un cono. GLOBAL GEOMÁtICA

Respecto al interior de la torre, la superficie responde a un cilindro tanto en el cuerpo principal como en el depósito ubicado en la zona inferior. El interior tiene un radio de $2.05 \mathrm{~m}$ con altura de $18.99 \mathrm{~m}$ y los datos estadísticos responden a una desviación estándar de $0.17 \mathrm{~m}$ y un valor máxmimo de $0.43 \mathrm{~m}$, mientras que el depósito tiene un radio de $1.08 \mathrm{~m}$ y altura $5.25 \mathrm{~m}$ con una desviación estándar de 0.072 , con error máximo de discrepancia de $0.26 \mathrm{n}$

La aplicación DESENREC 3D 1.0, cuando genera el modelo resultante da opción a que el valor de la coordenada $Z$ sea nulo para cada punto o se corresponda con la diferencia del ajuste entre el valor real y la superficie teórica. En caso de elegir la primera opción, automáticamente habremos generado la proyección ortofotográfica que hemos pretendido obtener mediante la generación de una imagen ráster con la relación métrica (píxel/m) conocida (Fig. 3). Si se elige la segunda opción, nos genera un modelo que es la base del mapa de discrepancias donde apreciamos las desviaciones respecto al modelo teórico, una cartografía básica e imprescindible, que se debe adjuntar siempre con el desplegado ortofotográfico.

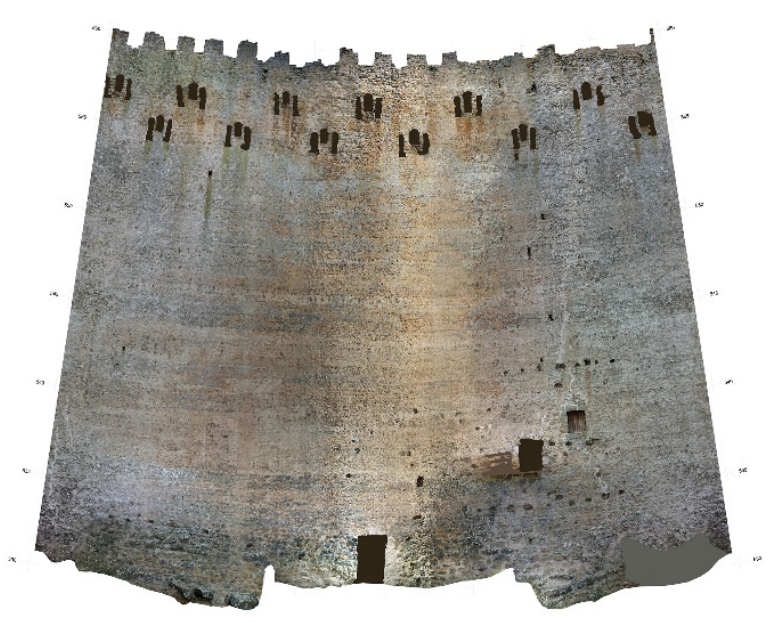

Figura 3: Desplegado ortofotográfico de la superficie exterior de la torre. GLOBAL GEOMÁTICA

\section{Conclusiones}

Los trabajos de documentación geométrica mediante técnicas fotogramétricas necesitan continuamente apoyarse en las nuevas tecnologías digitales y en la programación informática, que nos pueden aportar soluciones a proyectos con características específicas, como ha sido el caso de la Torre Vallferosa. El producto final ha cumplido con las especificaciones iniciales de calidad y precisión, con la obtención de planos de precisión centimétrica y unas ortofotos con resolución de 2 píxeles por milímetro. Respecto al desplegado ortofotográfico, somos conscientes de que el ajuste principalmente en el exterior-, presenta diferencias de aproximación de hasta $72 \mathrm{~cm}$, pero con la ayuda del mapa de discrepancias somos capaces de localizar estas máximas diferencias, destacando en todo momento la discontinuidad de la ortofoto, considerando en todo momento, que esta ha sido la mejor solución de documentación gráfica y geométrica posible.

\section{Agradecimientos}

Agradecer al Ayuntamiento de Torà y al Departament de Cultura de la Generalitat de Catalunya todas las facilidades dadas en la gestión y en los procesos de elaboración del proyecto.

\section{Referencias}

MENCHON BES, J., 2011. La torre de Vallferosa (Torà, Segarra). Aproximació a la seva arquitectura i datació radiocarbónica, Actes del IV Congrés d'Arqueologia Medieval i Moderna a Catalunya. Tarragona 10 al 13 de juny de 2011, Ajuntament de Tarragona, TAU 3, vol. 2, pp. 769-782.

MENCHON BES, J., 2014. La torre de Vallferosa (Torà, Segarra): cronología i construcció, Tribuna d'Arqueologia 2011 2012, Departament de Cultura de la Generalitat de Catalunya, pp. 264-294.

TORTOSA, R., 2003. Programari de Fotogrametria Digital: Rectificació i Desenvolupament. PFC, ETS Geodèsica, Cartogràfica i Topogràfica. Universitat Politècnica de València. 


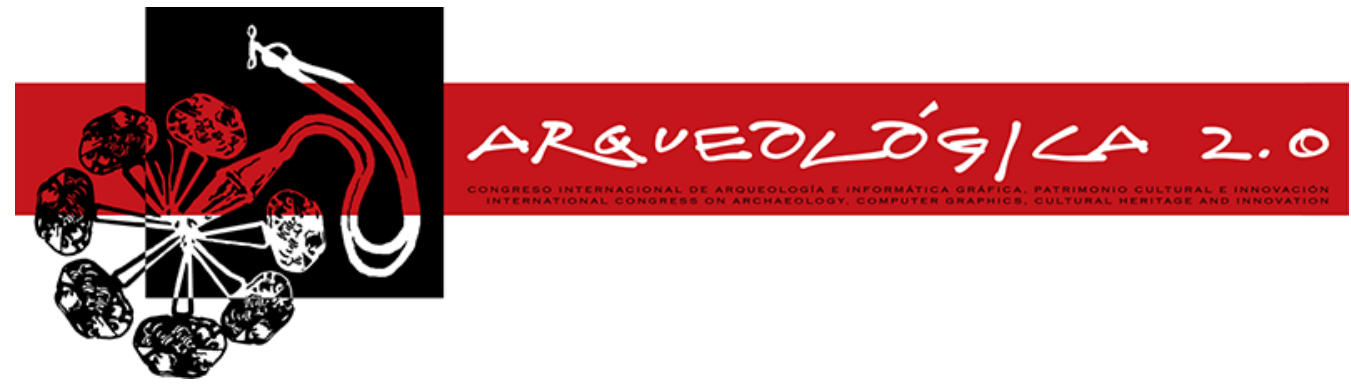

Proceedings of the $8^{\text {th }}$ International Congress

on Archaeology,

Computer Graphics,

Cultural Heritage and Innovation

'AROUEOLÓGICA 2.0'

in Valencia (Spain),

Sept. $5-7,2016$

\title{
CATALOGACIÓN DIGITAL 3D DE MACROÚTILES LÍTICOS PROCEDENTES DE COVES DE SANTA MAIRA Y CUEVA DE NERJA
}

\author{
3D DIGITAL CATALOGING OF LITHIC MATERIALS FROM "COVES DE SANTA MAIRA" AND "CUEVA DE NERJA"
}

\author{
Rafael Tortosa Garcia a, ${ }^{\star}$, Josep Blasco i Senabre ${ }^{a}$, Oscar Aparicio Gonzáleza ${ }^{a}$, Luis Gimeno \\ Martínez $^{\mathrm{a}}$, Andrea Vilaplana Sellés ${ }^{\mathrm{a}}$, J. Emili Aura Tortosa ${ }^{\mathrm{b}}$
}

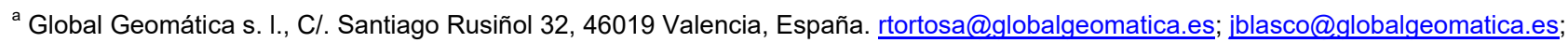
fotogrametria@globalgeomatica.es; arqueologia@globalgeomatica.es; avilaplana@globalgeomatica.es

${ }^{\text {b }}$ Dept. de Prehistoria i Arqueologia, Avda. Blasco Ibañez 28, 46010 Valencia, España. emilio.aura@uv.es

\begin{abstract}
:
The aim of this Project consists on obtaining textured and geometric high accuracy 3D models from archaeological pieces of the following archaeological sites: Coves de Santa Maira (Castell de Castells, Alacant) and Cueva de Nerja (Nerja, Málaga). They are part of a project wich has been developed by Prehistoric and Archaeology Dept. at University of Valencia. This Project is based on the state-of-the-art technology applied to preservation, dissemination, study and architectural and archaeological management.
\end{abstract}

Key words: digital archaeology, documentation, cataloguing, 3D scan, digital photogrammetry

\section{Resumen:}

El objetivo del proyecto consiste en la obtención de los modelos tridimensionales de gran precisión geométrica y texturizados de piezas arqueológicas recuperadas en dos yacimientos: les Coves de Santa Maira (Castell de Castells, Alacant) y la cueva de Nerja (Nerja, Málaga) y que forman parte de un proyecto desarrollado desde el Departamento de Prehistoria y Arqueología de la Universitat de València. Para la realización de dicho modelo se ha estimado utilizar las últimas tecnologías aplicadas a la conservación, difusión, estudio y gestión de espacios y elementos arqueológicos y arquitectónicos.

Palabras clave: arqueología digital, documentación, catalogación, escáner 3D, fotogrametría digital

\section{Introducción}

Se han elegido dos series de materiales arqueológicos procedentes de yacimientos con unas características muy contrastadas (Aura 2005; Aura y Jordá, 2004). Se trata de objetos líticos de mediano y gran tamaño (6-23 $\mathrm{cm}$ ), en comparación con el utillaje lítico tallado, que no excede en su mayoría los $3 \mathrm{~cm}$. Su estudio morfológico, técnico y funcional indica que fueron objetos utilizados en diferentes acciones, sobre todo de mantenimiento y en ámbitos domésticos. No se trata de equipos de caza, más bien de mantenimiento, lo que junto a su tamaño permite agruparlos bajo la denominación de macroútiles líticos, pues la cronología de los contextos de procedencia de los objetos cubre el final del Pleistoceno superior y el inicio del Holoceno (ca. 15 - 9 ka calBP).

El primero de los yacimientos es Coves de Santa Maira (Castell de Castells, Alacant), localizado en la solana de serra d'Alfaro (1166 m), en la cabecera del riu Gorgos (Aura 2004). La cavidad se abre en el macizo de las calizas pararrecifales del Eoceno del Prebético externo a una altitud de $600 \mathrm{~m} \mathrm{snm}$, a $14 \mathrm{~m}$ sobre el actual lecho del río y a unos $25 \mathrm{~km}$ de la costa. Los materiales utilizados proceden de la Unidad SM·3, considerada Mesolítica y con una edad radiocarbónica que la sitúa en el Boreal (ca. 10,5 - 9,5 Ka calBP). Se trata de cantos de caliza de diferente tamaño, obtenidos del lecho del rio y seleccionados posiblemente por su forma natural.

El segundo de los yacimientos es la Cueva de Nerja (Maro-Nerja, Málaga) es una importante cavidad kárstica que se encuentra situada a $935 \mathrm{~m}$ de distancia de la línea de costa actual y a $158 \mathrm{~m}$ de altitud sobre el nivel del mar (Aura y Jordá 2004). Geológicamente, la cueva se abre en los mármoles dolomíticos de edad triásica, a los pies de la Ladera del Águila en la vertiente SO de la Sierra Almijara. La cronología de los contextos de procedencia de los objetos cubre el final del Pleistoceno superior final (ca. $15-11$ ka calBP) y corresponde a ocupaciones del Magdaleniense superior

*Corresponding Author: Rafael Tortosa Garcia, rtortosa@globalgeomatica.es 
y Epimagdaleniense. Se trata de cantos de diferentes rocas metamórficas, de grano medio y grueso, y obtenidos a pie de playa.

Por la importancia de las piezas, en los límites cronológicos que han sido datados se produjeron importantes cambios ecológicos y transformaciones tecnoeconómicas, es decisivo incorporar nuevas herramientas de estudio para la comprensión sobre las formas y usos de un macroutillaje lítico cada vez más diversificado.

El desarrollo de las técnicas fotogramétricas y escáner 3D ofrece un amplio abanico de posibilidades parala realización de un registro documental preciso, útil y de fácil manejo por parte de los gestores, difusores e investigadores del patrimonio.

Los escáneres 3D de alta resolución, con precisión submilimétrica, utilizan las técnicas fotogramétricas para hacer reproducciones reales en 3D del objeto abordado, aspecto que contrasta con las técnicas empleadas hasta la fecha (moldes, calcos, fotografía tradicional).

\section{Metodología y plan de trabajo}

El proyecto de digitalización tridimensional de 25 piezas de los yacimientos mencionados ha consistido en la realización de dos procesos paralelos para la obtención de unos modelos tridimensionales que sean lo más fidedignos al original. El primer proceso se realiza utilizando las técnicas fotogramétricas, obteniendo el modelo digital a partir del cálculo de la posición exacta de cada una de las imágenes que componen la colección de fotografías. Bastará con aplicarle un factor de escala al modelo calculado, a partir de una medida precisa, y obtener una copia digital al que se le aplica un texturizado utilizando las imágenes que rodean el objeto de estudio.

El otro proceso consiste en la obtención geométrica de alta precisión a través de la utilización de un escáner 3D de luz estructurada, que proyecta un patrón de luz en el objeto y analiza, através de dos cámaras de video, la deformación del patrón producida por su geometría.

\subsection{Procesos de digitalización}

La pieza se dispone sobre una base para ser escaneada y fotografiada, intentando en todo momento evitar la mínima ocultación de la superficie de la pieza. Se realizan al menos dos tomas para que la pieza sea escaneada por completo, que se corresponden con las dos caras que se puede disponer la pieza.

Para la obtención de imágenes de las piezas se utiliza la cámara fotográfica CANON Powershot G15, una cámara compacta pero con opciones similares a una Réflex. En la realización de las tomas se usa una caja blanca con dos focos de luz fluorescente.

En la toma de fotografías, la pieza se sitúa sobre una placa calibrada con marcas en forma de damero que sirven para obtener el factor escala del modelo de forma precisa. La placa está dispuesta sobre un torno que nos ayuda a girar la pieza de forma eficiente, y de este modo, no se mueve el trípode con la cámara. Para cada disposición de la pieza se realizan dos pasadas alrededor de la pieza, una pasada paralela y otra oblicua (Fig. 1).

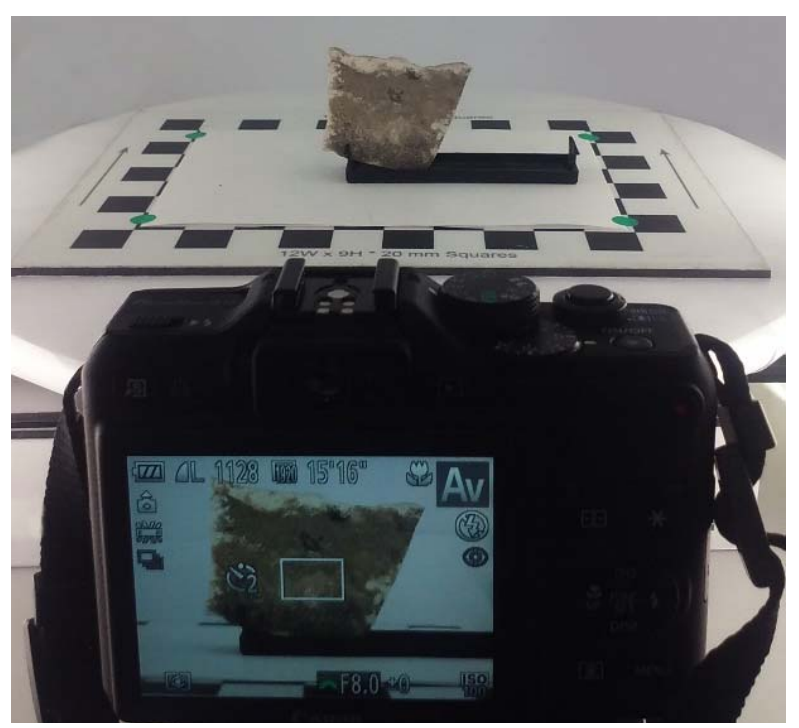

Figura 1: Instantánea de la toma de fotografías del objeto. GLOBAL GEOMÁTICA

Por otra parte, para la obtención del modelo digital de precisión se ha utilizado el escáner HDI ADVANCE 3D SCANNER que trabaja con luz estructurada a una velocidad de 0.88 segundos por escaneado, consiguiendo una resolución de 5.2 millones de triángulos por escaneado llegando a obtener una distancia entre puntos de $0.075 \mathrm{~mm}$. La precisión varía entre $50 \mu \mathrm{m}$ y $80 \mu \mathrm{m}$. La elección de este tipo de escáner radica en la complejidad de la mayoría de las piezas, que contienen pequeños relieves, marcas y rasgos.

Antes de realizar el trabajo de escaneado, deben ser compensadas las distorsiones geométricas de la óptica y de la perspectiva mediante la calibración del equipo, donde se calculan los parámetros intrínsecos y extrínsecos de las cámaras. Estos parámetros son necesarios para realizar la reconstrucción 3D del entorno y situar las cámaras correctamente. También se tienen que considerar la lente, las distorsiones geométricas y la aberración óptica del proyector.

Para adquirir un gran número de muestras simultáneamente, la técnica más rápida y versátil consiste en proyectar un patrón de rayas correlativas entre sí. Para obtener la información tridimensional completa se necesitan múltiples escaneos alrededor de la banda de dibujos y con recubrimiento entre sí.

\subsection{Tratamiento de los datos}

Digitalizadas las piezas, los datos son tratados para obtener dos modelos tridimensionales diferentes utilizando las dos técnicas referidas anteriormente. En el proceso por técnicas fotogramétricas se ha utilizando el software AGISOFT PHOTOSCAN, donde las imágenes son insertadas, y por correlación automática de puntos homólogos, se calcula la posición y orientación exacta de la imagen en el momento de ser tomada. Generada esta posición, obtenemos una nube de puntos del objeto de estudio y, seguidamente, el modelo 3D texturizado.

Por otra parte tratamos los datos obtenidos del escáner de luz estructurada. Estos se corresponden con mallas tridimensionales de cada toma. Se utiliza el programa 
FLEXSCAN 3D, que gestiona el escaneado y realiza el proceso de generación de mallas tridimensionales. El proceso de gabinete consiste básicamente en la referenciación de las distintas tomas mediante métodos de ajuste por homología de geometrías. Una vez todas las tomas se encuentran en el mismo sistema de coordenadas, son fusionadas en un único modelo.

Llegamos al final del proceso de obtención de un modelo tridimensional con dos modelos generados, uno texturizado y el otro con mayor definición geométrica. La fase final consiste en la unión de ambos modelos 3D generando el definitivo que contiene la mejor definición geométrica y de color. Para la generación del modelo final, los dos modelos de partida se han dispuesto en un mismo sistema de coordenadas y luego se ha transferido la textura del modelo fotogramétrico a la obtenida por el escáner. Finalmente se ha realizado una corrección radiométrica de la textura para igual el color al de la pieza original.

\section{Producto final y conclusiones}

El conjunto de modelos 3D obtenidos necesita de una plataforma de visualización que sea accesible para el usuario. Después de barajar la posibilidad de los distintos formatos existentes en el mercado, se ha decidido generar una serie de archivos Adobe PDF. Este tipo de archivos contiene, entre sus herramientas multimedia, la creación de ventanas para la visualización de modelos 3D. Para la mejor catalogación de los modelos, en aras de la realización de consultas, hemos considerado la realización de una ficha documental para cada una de las piezas, completando el modelo 3D con una serie de datos que lo describen (Fig. 2). Compuestas las fichas de las primeras 25 piezas que componen el proyecto, se realiza una ficha índice con enlaces a las fichas individuales (Fig. 3).

La introducción de entornos 3D así como la aplicación de técnicas de documentación geométrica procedentes de la Geomática, aportan excelentes precisiones y resoluciones, facilitando una catalogación digital de cualquier inventario procedente de una excavación o perteneciente a los fondos de un museo. Estas herramientas digitales aplicadas al análisis de piezas arqueológicas facilitan el acceso a la visualización, estudio, comparación por parte de técnicos, investigadores y público en general.

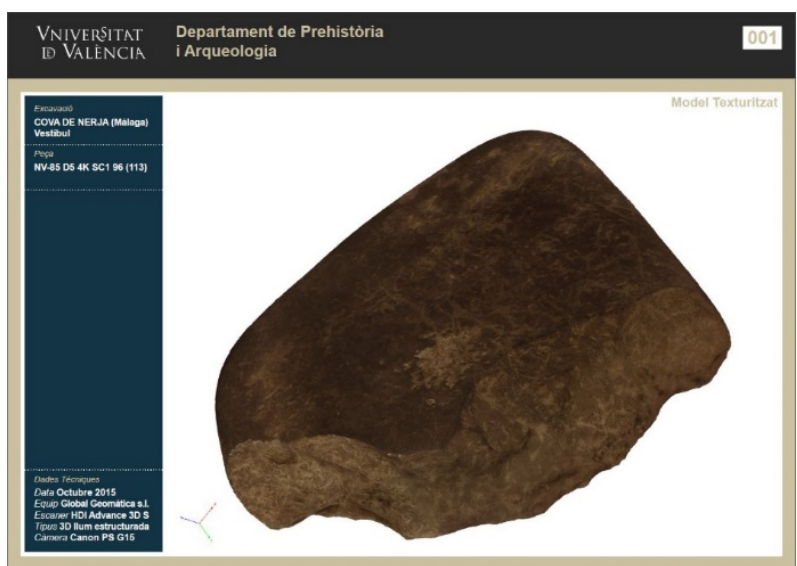

Figura 2: Ficha documental de una pieza en formato PDF.

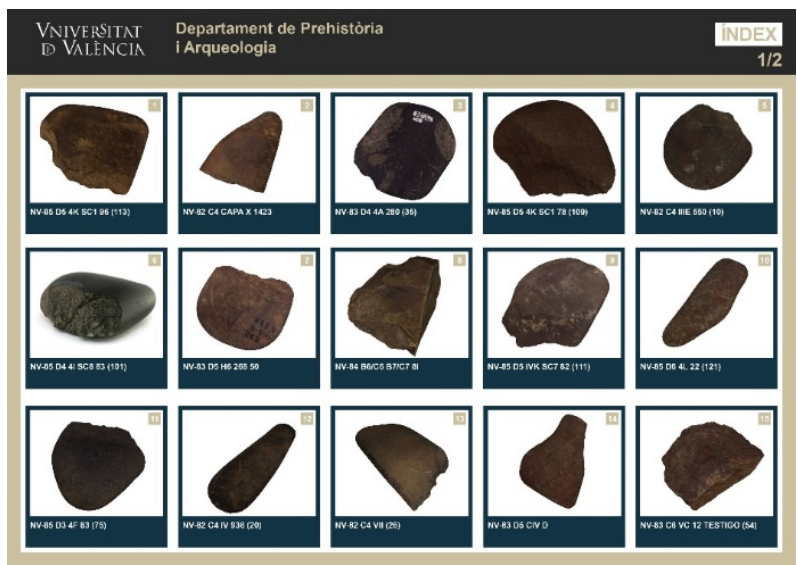

Figura 3: Ficha índice de las piezas en formato PDF.

\section{Agradedicimientos}

Este trabajo está financiado por el NPI del Ministerio de Economía y Competitividad español (Proyecto: LongTransMed, HAR2013-46861-R). Las excavaciones arqueológicas en las Coves de Santa Maira y la Cueva de Nerja fueron autorizadas por las autoridades culturales de Valencia y Andalucía.

\section{Referencias}

AURA, J.E., 2014. Coves de Santa Maira. En: Sala, R. (ed.), Carbonell, E., Bermúdez de Castro, J.M. y Arsuaga, J.L. (coords.), Los cazadores recolectores del Pleistoceno y delHoloceno en Iberia y el Estrecho de Gibraltar. Estado actual del conocimiento del registro arqueológico. Universidad de Burgos-Fundación Atapuerca, pp 353-356.

AURA, J.E.; JORDÁ, J.F., 2014. Cueva de Nerja. En: Sala, R. (ed.), Carbonell, E., Bermúdez de Castro, J.M. y Arsuaga, J.L. (coords.), Los cazadores recolectores del Pleistoceno y delHoloceno en Iberia y el Estrecho de Gibraltar. Estado actual del conocimiento del registro arqueológico. Universidad de Burgos-Fundación Atapuerca, pp 442-450. 


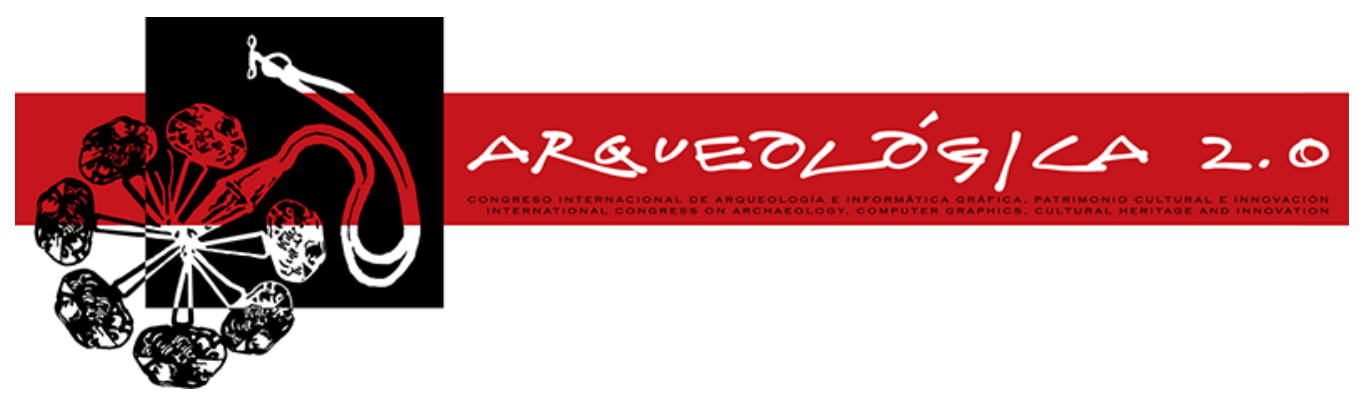

Proceedings of the $8^{\text {th }}$ International Congress

on Archaeology,

Computer Graphics,

Cultural Heritage and Innovation

'ARQUEOLÓGICA 2.0'

in Valencia (Spain),

Sept. $5-7,2016$

\title{
RESTAURACIÓN DE VIDRIO ARQUEOLÓGICO: RECONSTRUCCIÓN DE FRAGMENTOS FALTANTES MEDIANTE MODELADO E IMPRESIÓN 3D
}

\author{
RESTORATION OF ARCHAEOLOGICAL GLASS: RECONSTRUCTION OF GAP AREAS USING 3D MODELLING \\ AND PRINTING TECHNIQUES
}

Carmen Díaz-Marín *, Elvira Aura-Castro

Instituto Universitario de Restauración del Patrimonio, Universitat Politècnica de València, Camino de Vera s/n, 46022, Valencia, España. madiama@posgrado.upv.es; eaura@crbc.upv.es

\begin{abstract}
:
This paper aims the development of the restoration of archaeological glass vessels through 3D modelling and printing techniques of gap areas to aesthetic or reinforcement reasons. Usual reconstruction of gap areas in archaeological glass involves a handmade process that is notoriously complicated and requires a lot of time and patience, also it is common that glass is exposed to a high risk of deterioration due to its fragile and delicate condition. To deal with this problem, in which the risk of damage intensifies when the restoration is undertaken, a non-invasive method to recuperate its losses by $3 \mathrm{D}$ virtual modelling and printing techniques is presented. Application of this method avoids manipulation of archaeological objects during reconstruction of its gap areas and also it is an alternative treatment that it is advantageous in this sense.
\end{abstract}

Key words: archaeological glass, 3D reconstruction, 3D modelling, 3D printing, restoration

\section{Resumen:}

En este artículo se presenta el desarrollo de la restauración de recipientes de vidrio arqueológico mediante la técnica de modelado e impresión en 3D de sus zonas faltantes con el objetivo de recuperar su estética o reforzarlo. La reconstrucción de faltantes de vidrio arqueológico habitualmente implica un proceso manual caracterizado por ser una tarea laboriosa y difícil donde frecuentemente el vidrio queda expuesto a un gran riesgo de deterioro por su fragilidad intrínseca y su delicado estado de conservación. Ante esta problemática, en la que el riesgo de deterioro se intensifica cuando se acomete la restauración directa, se propone un método de restauración no invasivo para recuperar las áreas faltantes en vidrio arqueológico mediante modelado virtual e impresión 3D de las mismas. Con la aplicación de este método se ha conseguido evitar la manipulación de los objetos arqueológicos durante la fase de reconstrucción volumétrica permitiendo un tratamiento alternativo que resulta ventajoso en este sentido.

Palabras clave: vidrio arqueológico, reconstrucción 3D, modelado 3D, impresora 3D, restauración

\section{Introducción}

Una gran parte del vidrio arqueológico exhumado presenta un deterioro característico con indicadores claros de las condiciones de elevada humedad con la que ha interactuado durante años. Su extracción conlleva una rápida deshidratación del material provocando pérdida de transparencia, iridiscencia y desprendimientos de la superficie material (Navarro 1999). También es frecuente la observación de fragmentaciones en el objeto que pueden dar lugar a áreas correspondientes a fragmentos no encontrados, denominadas áreas de fragmentos faltantes. Esas zonas pueden recuperarse a través de las reconstrucciones volumétricas que consisten en volcar resinas translúcidas o transparentes dentro de unos moldes que reproducen el hueco de las áreas que faltan.

Este tipo de reconstrucción implica procesos manuales caracterizados por constituir tareas laboriosas, a menudo difíciles en la que, de manera frecuente, el vidrio queda expuesto a un gran riesgo de deterioro por su fragilidad intrínseca y su delicado estado. Ante esta problemática se propone un método de restauración no invasivo al llevar a cabo el modelado digital en 3D de las áreas faltantes y la impresión de estos implantes. De este modo se intenta someter a la pieza original a la mínima manipulación reduciendo los procesos a los que es sometida puesto que se sustituye el objeto original por un modelo $3 \mathrm{D}$ con el que trabajar, evitando la manipulación excesiva que conllevan las reconstrucciones volumétricas. 
El estudio de técnicas que potencialmente pueden sustituir a las tradicionales va en aumento constituyendo una opción que debe ser investigada.

\section{Proceso}

El proceso propuesto se inicia una vez que la pieza seleccionada ha sido estabilizada durante la fase de intervención y todos los fragmentos han sido adheridos. Se ha optado por un cuenco de vidrio del siglo XVI-XVII del Museo de Cerámica de Manises. En la Figura 1 se muestran el proceso completo.
Para su adquisición se ha utilizado un escáner 3D Konica Minolta vivid 900. Para solucionar la incompatibilidad del sistema de registro que usa este tipo de escáner, con las superficies transparentes, refractivas/reflexivas o brillantes, se buscó una solución que ha permitido volver opaca la superficie del objeto temporalmente. Para ello se utilizó Ciclododecano en aerosol, una sustancia muy conocida y utilizada en el campo de la restauración, que crea una capa blanca opaca que se evapora a temperatura ambiente y no deja residuos. La bondad de este método ha quedado demostrado en Díaz et al. (2015).

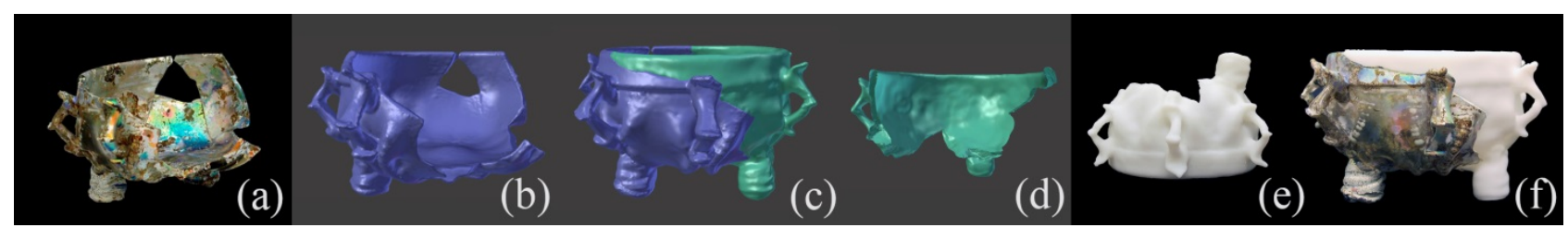

Figura 1: Imágenes que muestran el proceso propuesto. (a) objeto original, (b) modelo 3D del objeto, (c) modelo e implante 3D, (d) implante 3D, (e) Implante impreso y (f) objeto original con el implante.

El escaneado ha generado dos modelos (interior y exterior de la pieza), que hay que alinear y fusionar para obtener el modelo completo y posteriormente corregir las imperfecciones. El tiempo de trabajo de esta fase se ve reducido considerablemente por el resultado tan satisfactorio en la calidad de la malla obtenida con la ayuda del Ciclododecano.

A partir del modelo 3D del objeto se realiza el modelado del implante (zona faltante). En vez de modelar desde cero la zona faltante, hemos adaptado la parte que ya existía al área vacía. El proceso se realiza a partir del modelo 3D que importamos a MeshLab para extraer el implante y éste es importado a Blender para retocar el modelado y con la opción Boolean (Diferencia) que encontramos en la barra de Propiedades obtener el perfil de la fractura.

Una vez obtenido el implante se exporta en .stl para su impresión en 3D.

Por último, la impresión 3D se ha llevado a cabo utilizando una impresora 3D Mini Up! y filamento ABS (acrilonitrilo butadieno estireno) de $1.75 \mathrm{~mm}$ que se funde y deposita sobre una plataforma precalentada (Modelado por Deposición Fundida). Este tipo de filamento es el termoplástico más utilizado en la impresión 3D. Es duro y rígido, presenta cierta resistencia química y a la abrasión aunque le afectan los rayos UV y es soluble en acetona (Shashoua 2009). En este caso se han utilizado dos tipos de ABS en blanco (White) y translúcido (Clear). La buena calidad de la impresión del implante se refleja en el resultado de la decoración exterior que posee la pieza.

Durante el proceso de escaneado y optimización el modelo ha perdido un poco de precisión con respecto al original, esto provoca algunos errores en el acople entre el objeto y el implante que son corregidos tras la primera impresión y su prueba en el objeto original.

\section{Resultados y Discusión}

Tras el proceso explicado obtenemos el modelo 3D del objeto original, el modelo 3D del implante (Fig. 2) y las impresiones 3D. Las piezas impresas resultantes (Fig.
3) son de dos colores, blanco y translúcido, donde tras un tratamiento superficial, a base de lijas y microtorno, se obtiene una superficie óptima para reintegrar cromáticamente. En cuanto al perfil de fractura de unión con la pieza original, se ha conseguido el acople óptimo a pesar de que en ciertas zonas del implante llegan a detectarse puntualmente ligeros desajustes en el material termoplástico. Estos implantes que sustituyen a las zonas perdidas han devuelto la estabilidad a la pieza y recrean la morfología original. Sin cubrir cromáticamente la superficie del implante, cada una de las opciones ofrece diferentes cualidades a valorar para seleccionar la más adecuada: en White las formas de la decoración se aprecian bien definidas, mientras que en Clear las formas se difuminan por el color del material. Tras el tratamiento superficial las dos opciones adquieren brillo y en el caso de Clear mayor grado de transparecia. Dependiendo del resultado que se quiera (con recubrimiento cromático o no) se aconseja un tipo u otro. De este modo, la opción Clear puede resultar idónea si se opta por no cubrir la superficie de color y aprovechar así el brillo de este material translúcido.

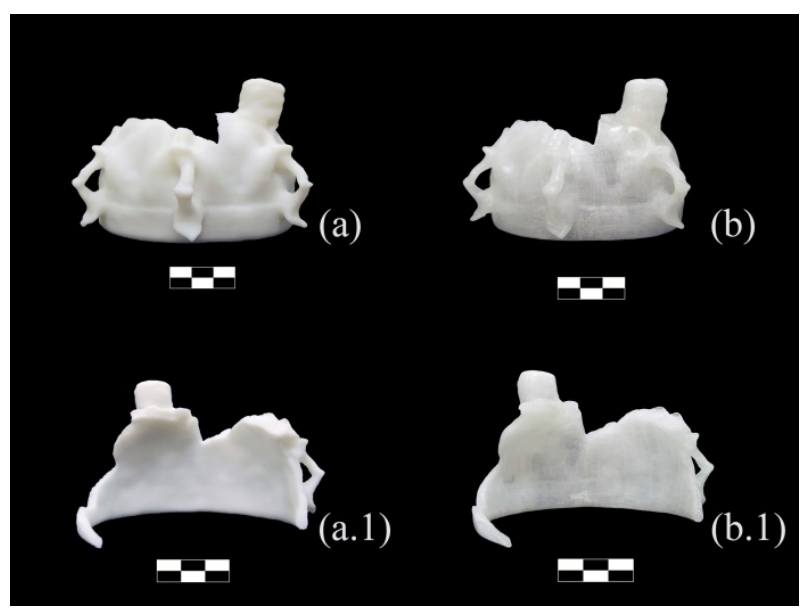

Figura 2: Implantes impresos. ABS Clear (a, a.1) y ABS White (b, b.1). 


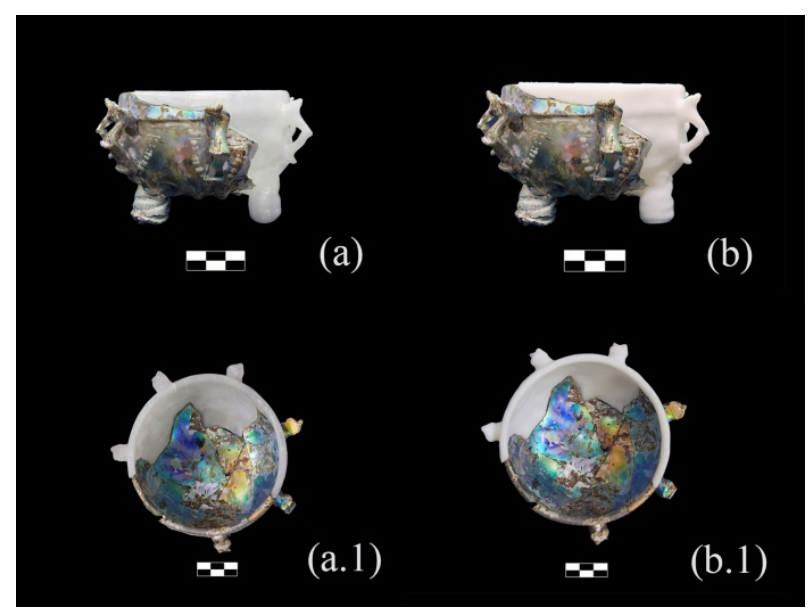

Figura 3: Resultado final con los dos filamentos: ABS Clear ( $a$, a.1) y ABS White (b, b.1)

\section{Conclusiones}

Se ha propuesto un método de restauración no invasivo al llevar a cabo el modelado digital en 3D de las áreas faltantes y la impresión de estos implantes en ABS para incorporarlos al vidrio arqueológico intervenido. Con este método se ha evitado la manipulación de los objetos arqueológicos durante la fase de reconstrucción volumétrica permitiendo un tratamiento ventajoso que resulta viable. El resultado puede ser comparado al obtenido por métodos tradicionales pero difiere en la excesiva manipulación del objeto contribuyendo así a la preservación y salvaguarda del material recuperado. No se han encontrado diferencias significativas en cuanto a los resultados obtenidos con los dos tipos de filamentos utilizados.

\section{Agradecimientos}

El trabajo se ha desarrollado gracias al Programa del Plan Nacional de I+D+i 2008-2011 del Ministerio de Economía y Competitividad de España, Proyectos ID: HAR2012-38391-C02-01 and HAR2012-38391-C02-02. El trabajo también se ha desarrollado a través del Programa Estatal de Investigación, Desarrollo e Innovación Orientada a los Retos de la Sociedad en el marco del Plan Estatal de Investigación Científica y Técnica y de Innovación 2013-2016 del Ministerio de Economía y Competitividad de España con cofinanciación del Fondo Europeo de Desarrollo Regional (FEDER), Proyecto HAR2015-69408-R (MINECO/FEDER). Los autores quieren agradecer la colaboración del Museo de Cerámica de Manises y especialmente a su directora Dña. Sara Blanes Ibáñez, por proporcionar la pieza usada para ilustrar la técnica propuesta.

\section{Referencias}

DÍAZ, C., AURA, E., SÁNCHEZ, C. y VENDRELL, E., 2016. Cyclododecane as opacifier for digitalization of archaeological glass. Journal of Cultural Heritage, 17, pp. 131-140. DOI: 10.1016/j.culher.2015.06.003

NAVARRO, J.M.F., 1999. Causas del deterioro físico y químico de los vidrios históricos. En: Jornadas Nacionales sobre Restauración y Conservación de Vidrios. $3^{\mathrm{a}}$ ed. Segovia: Fundación Centro Nacional del Vidrio, pp. 17-37.

SHASHOUA, Y., 2009. Conservation of plastics : materials science, degradation and preservation. Oxford: Elsevier/Butterworth-Heinemann. 


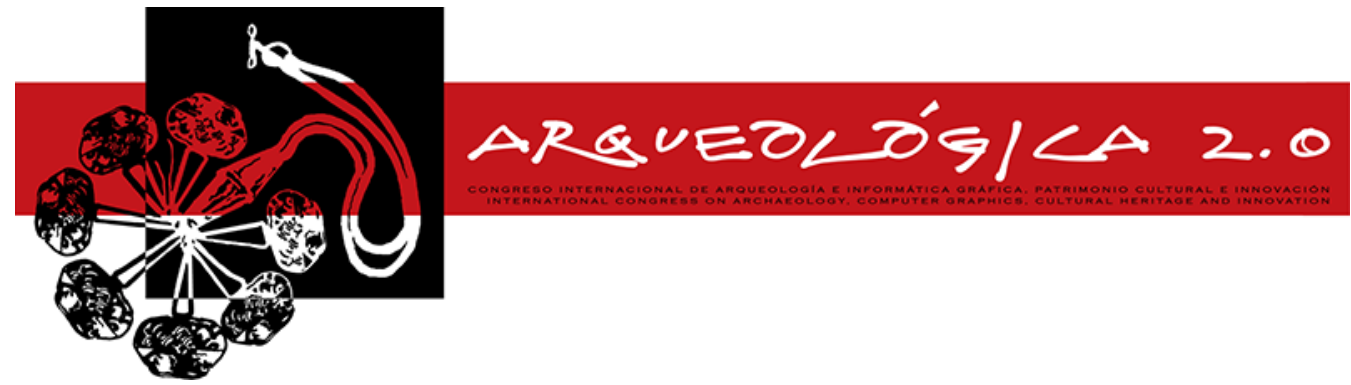

Proceedings of the $8^{\text {th }}$ International Congress

on Archaeology,

Computer Graphics,

Cultural Heritage and Innovation

'ARQUEOLÓGICA 2.0'

in Valencia (Spain),

Sept. $5-7,2016$

\title{
DEVELOPMENT OF A GEOREFERENCED ARCHAEOLOGICAL INFORMATION DATA BASE FOR ELEUTHERNA IN CRETE
}

\author{
Sevi Tapinaki $i^{\mathrm{a},{ }^{*}}$, Andreas Georgopoulos ${ }^{\mathrm{a}}$, Charalabos loannidis ${ }^{\mathrm{a}}$, Elias Frentzos ${ }^{\mathrm{b}}$, Nikos \\ Stampolidis ${ }^{c}$, Nikos Maragoudakis ${ }^{d}$ \\ ${ }^{a}$ Laboratory of Photogrammetry, School of Rural \& Surveying Engineering, National Technical University of Athens, Iroon Polytehniou \\ 9, Zografou, 15780, Greece. sevi@survey.ntua.gr; drag@central.ntua.gr; cioannid@survey.ntua.gr \\ ${ }^{\mathrm{b}}$ Geonoesis Ltd, 48 Dedousi str, GR-15562, Cholargos, Greece. efrentzo@geonoesis.gr \\ ${ }^{\mathrm{c}}$ Department of History \& Archaeology, School of Philosophy, University of Crete, Museum of Cycladic Art, Greece. \\ nstampolidis@cycladic.gr \\ ${ }^{\mathrm{d}}$ Department of History \& Archaeology, School of Philosophy, University of Crete, Greece, External collaborator \\ nikosmaragudakis@gmail.com
}

\begin{abstract}
:
Cultural Heritage Information Management Systems (CHIMS) have been developed in order to achieve the georeference of the items in the Cultural Heritage database. Eleutherna in Crete is one of the most significant archaeological sites in Greece, with. many buildings constructed and destroyed during its long life. Hence, it is easily understandable that this vast archaeological site is complicated and difficult to understand, even by experts. In this paper the development of a Cultural Heritage Management System, called ARCHAEOsystem, is described and analyzed. The system has as geographic base a recent orthophoto of the area and for its design several parameters were taken into account. The conceptual design of the data base with the Entity-Relational (E-R) model preceded the development of this object oriented system. This E-R model is described and evaluated for its operability. After the initial experimental operation of the system, eventual practical problems will be identified and confronted. Finally, presentation of future prospects is being attempted and eventual uses of such a system are proposed.
\end{abstract}

Key words: GIS, digital archaeology, cultural heritage, documentation, monument information system

\section{The Eleutherna Archaeological Site}

Eleutherna was an ancient city-state in Crete, Greece, situated $25 \mathrm{~km}$ southeast of Rethymno. It is located on a narrow NW spur of Mount Ida, the highest mountain in Crete. The site spans between the two modern villages of Eleutherna (W) and Ancient Eleutherna (E) on two hills and the valley in between; it flourished from the dark Ages (11th-8th c. B.C.), a time also narrated in the Homeric epics (Fig. 1). A team of archaeologists from the University of Crete has been in charge of the systematic Eleutherna excavation project, since 1984. Surveys and systematic excavations revealed the city's settlement patterns, sanctuaries and necropoleis, even stone quarries in the surroundings of the Prines hill. Significant, in terms of architecture, are the bridges, one of them with pointed arc still visible.

\section{Development of ARCHAEOsystem}

The archaeologists of the excavation needed a tool to manage and store all data and findings with the possibility to link them together over time, but also for the exploitation of all conventional documentation actions realized so far. Various systems exist, such as ARCHES, developed jointly by the Getty Conservation Institute and World Monuments Fund (http://archesproject.org/) and ARK (Archaeological Recording Kit) developed by L-P: Archaeology (http://ark.lparchaeology.com/), but the development of a new system, designed especially for the particular excavation, was preferred mainly for three reasons: the flexibility and capability of expansion, the adaptation to the knowledge of the archaeologists-users and the integration of existing digital data.

\subsection{Methodology}

The ARCHAEOsystem DataBase Management System (DBMS) was designed and developed with the following aims: (a) to organize and georeference the existing documentation data acquired during the past 30 years of excavation activity, (b) to enable the integration and interrelation of different data formats, (c) to give the ability of recording and storing new data via user friendly data entry procedures, (d) to visualize the various

`Corresponding Author: Sevi Tapinaki, sevi@survey.ntua.gr 
archaeological locations and findings in 2D and 3D space, (e) to enable the creation and export of new information and data and the production of reports and (f) to assist the decision making.

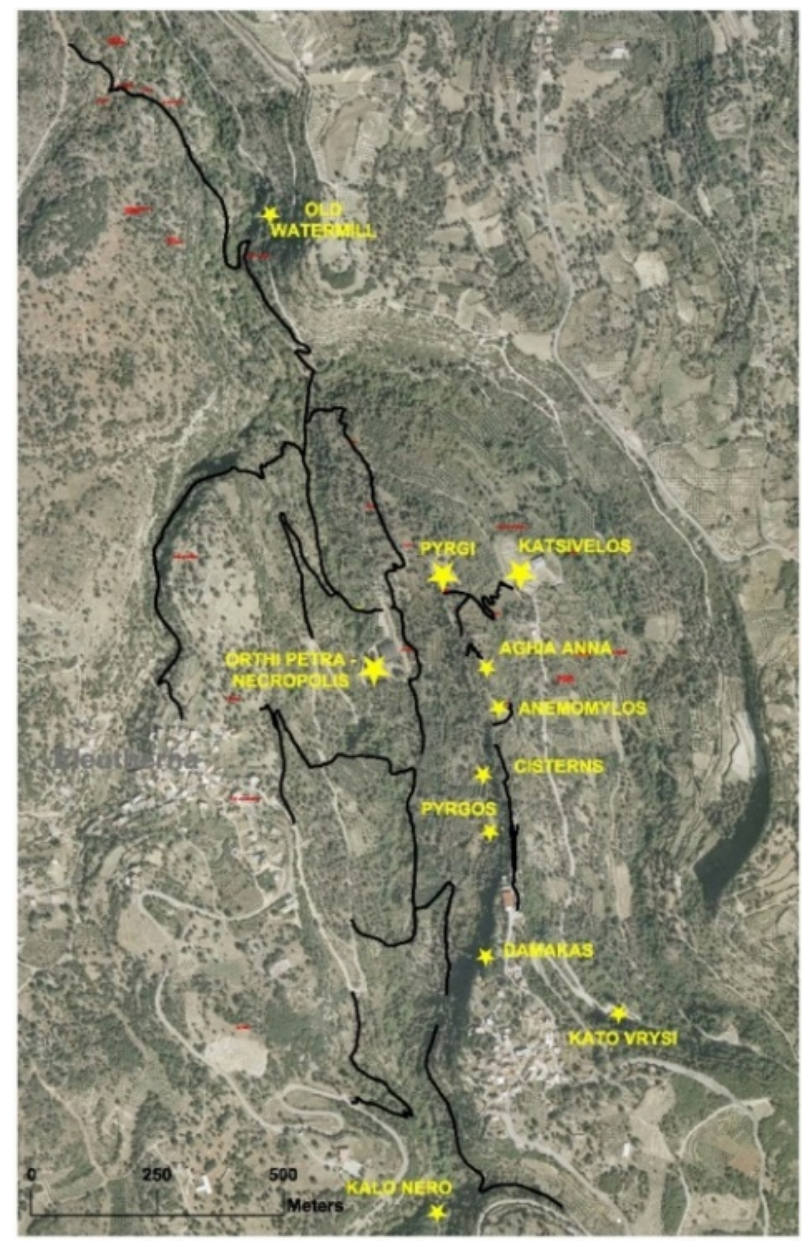

Figure 1: The archaeological site of Eleutherna

Diverse data of archaeological locations and findings, like documentation images, descriptions, scanned and digitized hand sketches, topographic measurements and drawings, orthoimages, $3 \mathrm{~d}$ models etc. will be integrated into a single database, providing a powerful tool for data management and analysis. Furthermore, when data entry is completed the production of Archaeological maps at several scales will also be possible. Moreover, the ARCHAEOsystem will be used for data exchange from the physical data storage to a CAD environment.

For the development of ARCHAEOsystem the following actions were considered necessary: a) Establishment of a specific coordinate reference system b) Georeferencing of the existing analogue maps and orthophotos to be used as base geographic material c) Field data acquisition d) Georeferencing of hand-made drawings e) Recording of locations' names f) Production of 3D models of the monuments g) Design and Development of the Data Base Management System, and h) Indicative data entry and test of the system.

Field survey methods and RTK GPS were applied to collect the necessary data using the existing triangulation network, established during previous fieldworks, that was referenced to the Hellenic Geodetic
Reference System 1987 (HGRS87 SRID=2100). The handmade drawings, that were of high detail and accuracy and the 3D models, that were produced, were georeferenced in this reference system using the minimum constraints, in order to avoid deformations due to the projection of the reference system and to keep their internal accuracy unaffected.

The base-map of the DBMS is the orthophoto of the area of $0.50 \mathrm{~m}$ spatial analysis, produced by the National Cadastre \& Mapping Agency S.A. in 2007 and three analogue topographic drawings, at a scale of 1:5000, produced by the Hellenic Military Geographical Service (HMGS). The main spatial data that the archaeologists need is the position of all individual monuments and places of interest, which, in the database, are called locations, and the entire network of the main paths and access roads, connecting and allowing access to these locations. Each location has certain essential information, which are considered as data having metadata and must also be stored in the database.

The system offers access to all interested persons, but with different permissions. Experts involved with the excavation have the right to manage or edit the data. The system should easily organize all necessary data and metadata which the Archaeologists need to manage, provide a security system and supply suitable tools for data management and continuous updating and retrieval of data and metadata, pointing to their exact storage location.

\subsection{Data Modelling and DBMS Architecture}

The Entity-Relationship Model (E-R Model) was used for the representation of the conceptual model. The Relational Model was used for logical modelling and the implementation of the DBMS was performed taking under consideration two main constraints: to ensure the future extensibility of the system and to fully exploit the existing experience and familiarity of the users with the AutoCAD environment. The extensibility of the system is ensured since data is stored in a central database and can be visualized, analyzed and edited in several software - clients (e.g., other GIS like QGis or ArcGIS), while, at the same time, data could be used in different environments (e.g. mobile devices).

The Data Base Management System is based on the Microsoft SQL Server 2008 R2 express version, which allows storage and processing of spatial objects, with the advantage that the whole information, either spatial or thematic, is in the same physical storage location. A special application, named ARCHAEOsystem, was developed in Visual Basic .NET using the Integrated Development Environment (IDE) Visual Studio 2010. This application uses .NET Managed Application Program Interface (API) of AutoCAD Map 3D 2012, and allows thematic and spatial data management and visualisation in an integrated environment. The spatial objects stored in the SQL Server are visualised within AutoCAD Map using the open source Feature Data Object (FDO) Data Access Technology. Through FDO Technology, AutoCAD Map is not used in the traditional way of processing CAD objects, but it operates more like an editing and visualizing tool of data stored in another warehouse, in this case the SQL Server. Access to thematic data, stored also in SQL Server, is achieved using the Entity Framework (EF), through the special 
application that was developed. EF is an open source Object-Relational Mapping (ORM) framework which converts the database tables to objects in the application programming environment of Microsoft Visual Studio. The architecture of the system is shown in Figure 2.

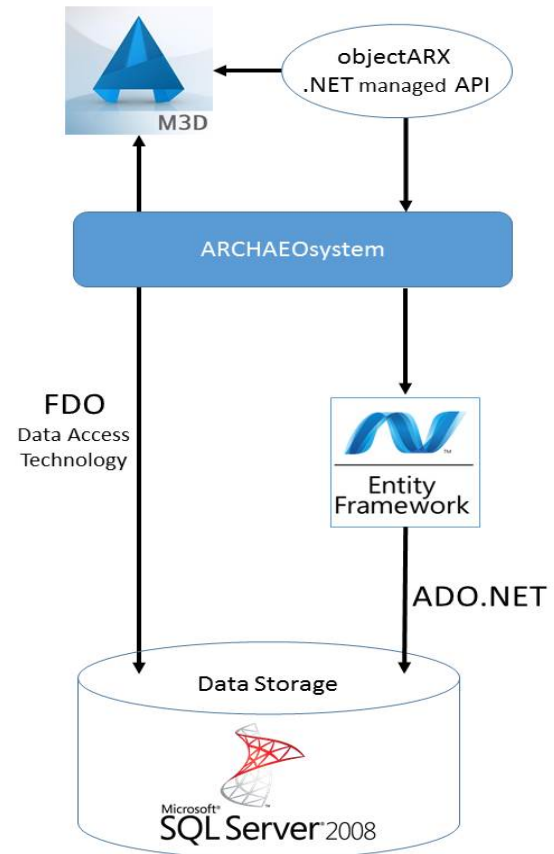

Figure 2: The DBMS Architecture

\section{Operation}

The user interface of ARCHAEOsystem is friendly and easy to use especially by users who are familiar with AutoCAD. Once the appropriate installation is completed, the main window of the system and a toolbar with basic buttons appear within the AutoCAD environment. Then the connection with the database requires login information. The system provides the tools for updating and retrieving operations through the database. The main window of the system is divided into two parts (Fig. 3). During updating of the database, the upper part, provides the tools for creating, updating or deleting a parent location, while the lower one, provides the tools for data entry and retrieval related to the parent location which is selected in the upper part.

The related data could be locations contained in this particular one, other information, images, video, documents, 3d models, etc. Each contained location could be selected as parent location and its related data can be imported in the same way. Data entry is possible with direct selection of CAD objects or by giving the physical storage location of the files. The system is able to identify and record the georeferencing parameters of raster objects, as long as the raster file is associated with the corresponding world file, e.g., a *.tif file with the *.tfw file. During retrieval operations the user has the necessary tools to search data through certain attributes, for example the locations by name or the sketches by author, etc. Once data entry is completed, tools for visualization of selected data could be used. In this way the different mapping alternatives could be produced at this stage. ARCHAEOsystem is being updated by the archaeologists of the excavation almost everyday in order to record new data and information. Another main goal is to fill the database with all existing data acquired during the past 30 years of excavation activity.

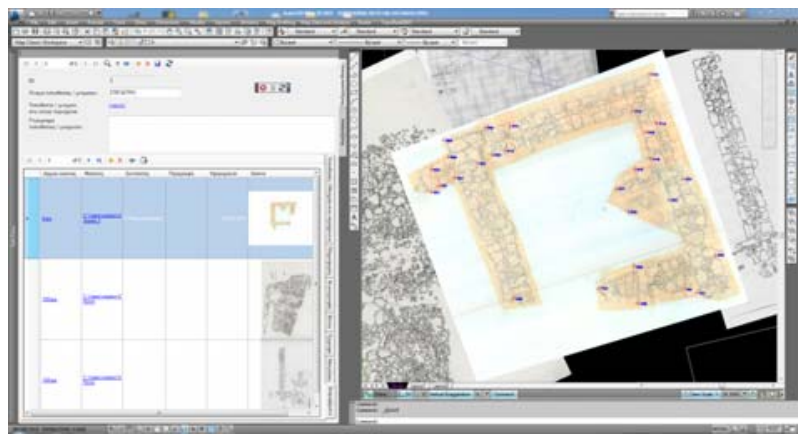

Figure 3: An example of the DBMS interface

\section{Evaluation and Concluding Remarks}

The ARCHAEOSystem developed especially for the excavation of Eleutherna in Crete is actually being used by the responsible archaeologists during the past months with great success. Archaeologists now have a tool of collecting, analysing, managing, and communicating their data. They are able to combine data and through these interrelations to draw more reliable conclusions. Furthermore, the complete overview of the excavation gives the ability to easily grasp the relative position of all findings which makes the analysis and related research easier and more effective. The architecture of the system, where both spatial and thematic data is stored in a database, gives the ability of creating various data views and maps at several scales. It is envisaged that in the future, when the data base has been completely filled, the ARCHEOsystem will become a cross-platform system. This means that it may be loaded to a smartphone and assist experts and visitors to freely navigate and learn about this vast site. Furthermore, a web application will be developed in order for virtual visitors to be able to get familiar with Eleutherna at the ease of their mouse click. It is believed that such a possibility will definitely attract more visitors in the area.

\section{Acknowledgements}

The indispensable help of our colleagues Mr. P. Agrafiotis and Mr. F. Bourexis for the fieldwork, as well as the contribution of Mrs S. Soile to the post processing of data is gratefully acknowledged.

\section{References}

ARCHES. http://archesproject.org/

ARDISSONE, P., BORNAZ, L., DEGATTIS, G. and DOMAINE, R., 2013. A 3D Information System for the Documentation of Archaeological Excavations. International Archives of the Photogrammetry, Remote Sensing and Spatial Information Sciences, Volume XL-5/W2, 2013 XXIV International CIPA Symposium, 2 - 6 September 2013, Strasbourg, France 
ARK (The Archaeological Recording Kit). http://ark.lparchaeology.com/

FOOTE, K. and LYNCH, M., 1995. Geographic information systems as an integrating technology: context, concepts, and definitions. http://www.colorado.edu/geography/gcraft/notes/intro/intro_f.html

HATZITHOMA-PANAGIOTOU, S., GEORGOPOULOS, A. and TAPINAKI S., 2014. Development of a Cultural Heritage Management System, Implementation to The Ancient Athenian Agora. Computer Applications and Quantitative Methods in Archaeology CAA-GR 2014, Friday 7th - Saturday 8th March 2014 Rethymno, Crete, Greece. 


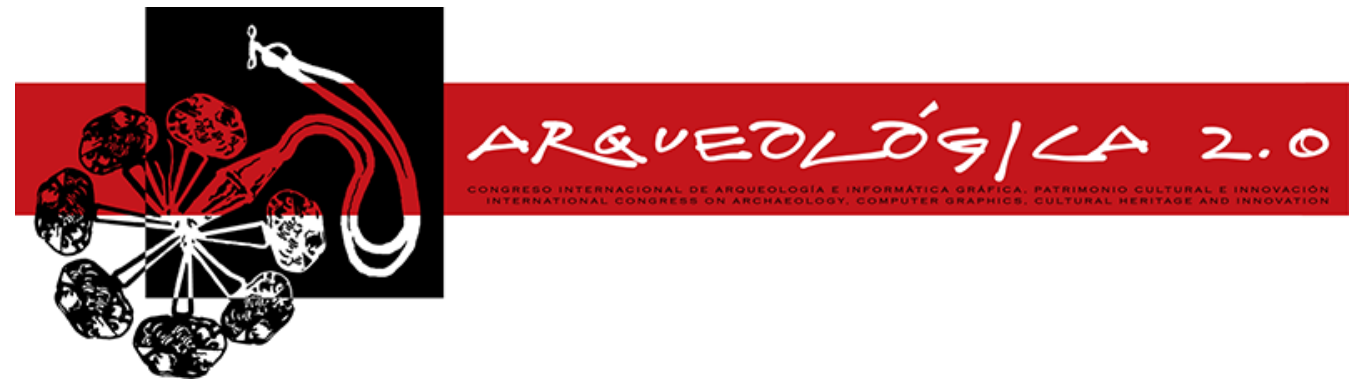

Proceedings of the $8^{\text {th }}$ International Congress

on Archaeology,

Computer Graphics,

Cultural Heritage and Innovation

'ARQUEOLÓGICA 2.0'

in Valencia (Spain),

Sept. $5-7,2016$

\title{
A NEW METHODOLOGY FOR THE 3D PHOTOREALISTIC VIRTUAL RECONSTRUCTION OF THE ARCHAEOLOGICAL SITE "CASTELLET DE BERNABÉ" (LLÍRIA, SPAIN)
}

\author{
UNA NUEVA METODOLOGÍA PARA LA RECONSTRUCCIÓN VIRTUAL 3D FOTORREALISTA DEL YACIMIENTO \\ ARQUEOLÓGICO “CASTELLET DE BERNABÉ" (LLIRIA, ESPAÑA) \\ Cristina Portalés ${ }^{a,{ }^{,},}$Pau Alonso-Monasteriob ${ }^{b}$, María José Viñals ${ }^{c}$ \\ ${ }^{a}$ Institute of Robotics and Information and Communication Technologies (IRTIC), Universitat de València, Catedrático José Beltrán 2 , \\ 46980 Paterna (Valencia), Spain. cristina.portales@uv.es \\ ${ }^{\mathrm{b}}$ Dep. Economy and Social Sciences, Universitat Politècnica de València, Camí de Vera S/N, 46022 València, Spain. paualfer@upv.es \\ ${ }^{\mathrm{c}}$ Dep.Cartographic Engineering, Geodesy and Photogrammetry, Universitat Politècnica de València, Camí de Vera S/N, 46022 \\ València, Spain. mvinals@upv.es
}

\begin{abstract}
:
In recent decades, the 3D virtual reconstructions and visualizations of archaeological sites have been commonly used by scientists to better understand the missing structures. They have also been considered as an interesting communication tool for addressing the presentation of these assets to the audiences because virtual immersive environments presentations are an easy and meaningful way to understand the archaeological remains. However, the 3D reconstruction of archaeological sites is challenging, because some of most of the parts of the assets do not exist nowadays. This paper presents a methodology for the the 3D photorealistic virtual reconstruction of the lberian settlement Castellet de Bernabé (Llíria, Spain).
\end{abstract}

Key words: virtual archaeology, digital archaeology, cultural heritage, documentation, 3D reconstruction

Resumen:

En las últimas décadas, la comunidad científica utiliza las reconstrucciones visuales en 3D y las visualizaciones de los yacimientos arqueológicos para comprender mejor las estructuras que han desaparecido. Estas técnicas también se han considerado una herramienta de comunicación interesante para abordar la presentación de estos bienes a las audiencias, pues las presentaciones en ambientes virtuales inmersivos son una forma fácil y significativa de entender los yacimientos arqueológicos. Sin embargo, la reconstrucción 3D de los yacimientos arqueológicos puede suponer un reto, ya que alguna o la mayor parte del yacimiento puede no existir en la actualidad. Este trabajo presenta una metodología para la reconstrucción virtual 3D fotorrealística del yacimiento íbero Castellet de Bernabé (Llíria, España).

Palabras clave: arqueología virtual, arqueología digital, patrimonio cultural, documentación, reconstrucción 3D

\section{Introduction}

Cultural Heritage $(\mathrm{CH})$ is a fundamental expression of the richness and diversity of our culture and therefore, its conservation, documentation and dissemination is thus considered of the utmost importance. The 3D virtual reconstruction of cultural heritage buildings and archaeological sites is of high interest for different reasons, namely the accurate documentation of our tangible cultural legacy, the determination of mechanical alteration on the assets, or the mere shape acquisition prior to restoration and/or reconstruction works, etc.
Reconstructing and understanding the past allows local people to reinforce their identity and permits the general public to access to history (Viñals et al. 2013).

Different technologies exists nowadays to deal with the 3D reconstruction of assets, mainly stereophotogrammetry, laser scanning or structured lightbased techniques (Groves et al. 2014; Zhang et al. 2012; Zlot et al. 2013).

The visual appearance or photometric properties is also of utmost importance. These aspects can be acquired from the use of conventional cameras, mobile phones, or cameras (Pires and Cruz 2007; Navarro et al. 2009; Lerma et al. 2011; Remondino et al. 2011). However,

‘Corresponding Author: Cristina Portalés, cristina.portales@uv.es 
when dealing with archaeological sites, the 3D reconstruction and visualization is usually not fully possible with the use of acquisition devices, because most or part of the assets do not exist nowadays. In this sense, alternative approaches have to be used such as e.g. the vitual reconstruction and visualization with augmented reality approaches (Portalés et al. 2009).

In this work, we will deal with the reconstruction and visualization of the archaeological site "Castellet de Bernabé" by means of the virtual reality technology, following a customized mixed methodology that includes on site observation, comparative research and archaeological interpretation, among others. We aim at enhancing heritage values by allowing the intellectual and emotional engagement to $\mathrm{CH}$ of the visitors.

\section{The Archaeological Site}

The archaeological site of Castellet de Bernabé was first excavated in 1984, and it was restored in 1988. It is located in LLíria, in the inland of Valencian Region (Spain). It is an Iberian settlement that flourished from the 5th to the 3rd century BC (Pla 1945; Guérin 2003), and was a village in territory of Edeta (actually Llíria), that spread from the Mediterranean mountain range of Calderona to the Túria river. The Iberians were a diverse western Mediterranean civilization group that shared common cultural characteristics, including urban and trade networks.

\section{3D Photorealistic Virtual Reconstruction and Visaulization}

The virtual reconstruction of the Castellet de Bernabé is challenging, as most of the site is nowadays not present. In this regards, the site was reconstructed by using a customized methodology in order to determine its original size, materials or colours. The methodology involves the following approaches:

- Bibliographic research including: an aerial image of the site, a map of contour lines, drawings of the original shape of the houses, detailed written description of artifacts made by historians, etc.

- Case study: review of other archaeological Iberian sites, including Bastida de les Alcusses (Moixent, València), Puntal dels Llops (Olocau) or Tossal de Sant Miquel (Llíria), among others.

- In-depth interview: the archaeologist expert in Castellet de Bernabé excavation and study, Pièrre Guérin, was the referee along all the process.

- On site observation: there were gathered, analysed and incorporated to the reconstruction many detailed images regarding colours and textures.

- Comparative research: it was also developed a field study in the area of Middle Atlas, as many areas of Moroccan Middle Atlas had still very similar housing to those constructed by lberians in Lliria.

From the map with contour lines, a digital terrain model (DTM) was generated by using Geographic Information Systems (GIS) tools, and then exported to 3D Studio Max to serve as a basis for the virtual reconstruction of the site. The aerial image of the site served to draw the plant of the site. From the written texts and drawings, other issues such as the height of the houses was derived.

Once the site was virtually reconstructed in its shape, different materials and textures were added in order to give it a photorealistic appearance. To that end, several information and images of other similar archaeological sites presenting nowadays a better conservation stage were gathered. The result of the $3 D$ and photorealistic reconstruction is presented in Figure 1, where in Figure $1 \mathrm{a}$, an overall view of the generated digital terrain model together with the reconstructed site is depicted. In Figure $1 \mathrm{~b}$, a view of the interior of the site is given, where the textures and materials (of the walls, doors, etc.) can be better appreciated.

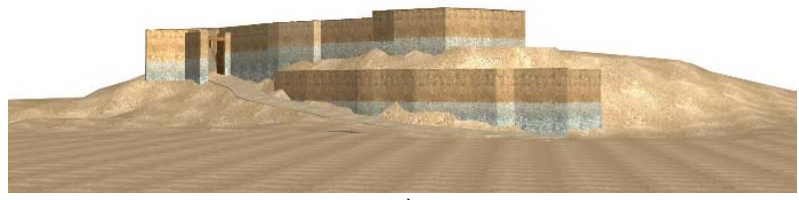

a)

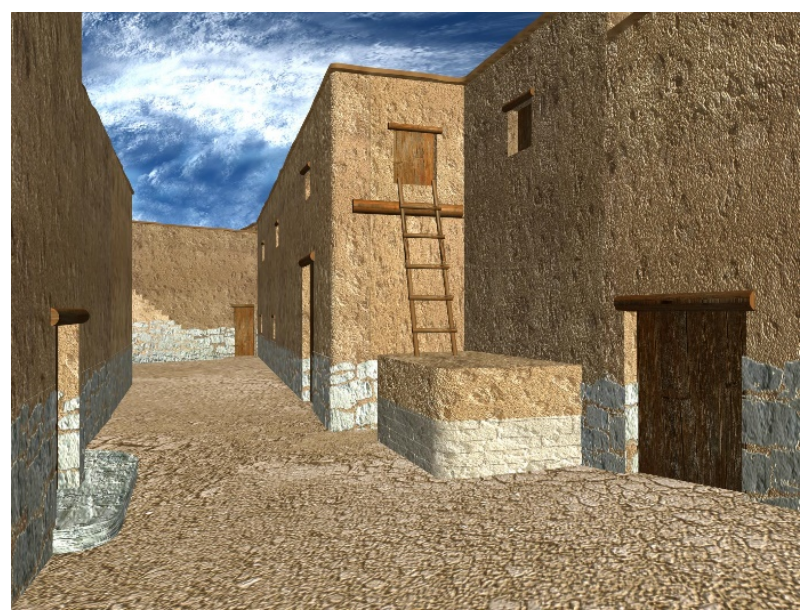

b)

Figure 1: Virtual reconstruction of the Castellet de Bernabé, where: a) Overall view of the digital terrain model and the 3D reconstructed site; b) Detailed view of the interior of the site.

After the 3D reconstruction of the Castellet de Bernabe archaeological site, there were developed different kinds of visual materials, which were part of the different interpretation materials designed for the settlement communication. A total of the four different visual materials were prepared from the $3 D$ reconstruction: a past and present book (Viñals et al. 2008a; Wikipedia 2014); a virtual flight (YouTube 2016); a multi-use trail (Alonso-Monasterio 2014); and an explorer diary (Viñals et al. 2008b).

\section{Conclusion}

Heritage interpretation is a powerful tool that enhances heritage values and allows the intellectual and emotional access to heritage of the visitors. This process is developed from original objects, using both personal and non-personal resources. 3D reconstruction of archaeological sites allows an easy and rapid intellectual access to heritage, so visitors have time and energy to emotionally engage with the site, what leads to deeper connections that allow mindfulness and understanding. 
Thanks to the $3 \mathrm{D}$ and photorealistic reconstruction of the Castellet de Bernabé, its visitors can develop proconservation behaviours and sense of place.

These virtual reality based techniques arise as highly efficient tools to support interpretation, especially in cultural heritage interpretation of archaeological sites, where it is necessary to describe and create mental images of the sites to boost the deep understanding of the heritage and of the civilizations that created them. They provide a synoptic image upon which the interpretation discourse can be constructed.

\section{References}

ALONSO-MONASTERIO, P., 2014. Análisis de la eficiencia comunicativa y las funciones interpretativas de los mapas turísticos para la visita de espacios con patrimonio. Tesis doctoral. Departamento de Ingeniería Cartográfica, Geodesia y Fotogrametría, Universitat Politècnica de València.

GROVES, R. M., PORTALÉS, C. and RIBES-GÓMEZ, E., 2014. Assessment of Mechanical and Chemical Deterioration of Artworks. Paper presented at the International Conference on Ageing of Materials \& Structures (AMS), Delft, The Netherlands.

GUÉRIN, P., 2003. El poblado del Castellet de Bernabé (Llíria) y el horizonte ibérico pleno edetano. Universitat de València, Valencia, ISBN: $9788477953494,384 \mathrm{pp}$.

LERMA, J. L., CABRELLES, M. and PORTALÉS, C., 2011. Multitemporal thermal analysis to detect moisture on a building façade. Construction and Building Materials, 25(5), pp. 2190-2197. DOI: http://dx.doi.org/10.1016/j.conbuildmat.2010.10.007

NAVARRO, S., SEGUÍ, A.E., PORTALÉS, C., LERMA, J.L., AKASHEH, T. and HADDAD, N., 2009. Integration of TLS data and non-metric imagery to improve photo-models and recording. Paper presented at the International Conference on Virtual Systems and Multimedia, Vienna (Austria).

PIRES, J. and CRUZ, A.J., 2007. Techniques of thermal analysis applied to the study of cultural heritage. Journal of Thermal Analysis and Calorimetry, 87(2), pp. 411-415. DOI: 10.1007/s10973-004-6775-0

PLA, E., 1945. Las Actividades del S.I.P. Archivo de Prehistoria Levantina II. Valencia, pp. 361-383.

PORTALÉS, C., LERMA, J.L. and PÉREZ, C., 2009. Photogrammetry and augmented reality for cultural heritage applications, The Photogrammetric Record, 24(128), pp. 316-331. DOI: 10.1111/j.1477-9730.2009.00549.x

REMONDINO, F., 2011. Heritage Recording and 3D Modeling with Photogrammetry and 3D Scanning. Remote Sensing, 3(6), pp. 1104-1138.

VIÑALS, M.J., ALONSO-MONASTERIO, P. and ALONSO-MONASTERIO, M., 2013. Analysis of the spatial standards and perceptual components of the recreational carrying capacity applied to archaeological sites: Case study of Castellet de Bernabé (Llíria, Spain). Methods and Analysis on Tourism and Environment. Eds. J.M Jiménez, M.V Vargas, F.J.O. Rosell et al. New York: Nova Science Publishers, Inc. ISBN: 978-1-62417-824-5

VIÑALS, M.J., PLANELLES, M. and GUÉRIN, P., (Eds) 2008a. El yacimiento arqueológico de El Castellet de Bernabé. Valencia: Editorial de la Universitat Politècnica de València. 40pp. ISBN: 978-84-8363-304-5

VIÑALS, M.J., PLANELLES, M. and GUÉRIN, P., (Eds) 2008b. Rutas "Andando, rodando y trotando al Castellet de Bernabé". Cuaderno del Explorador. Valencia: Editorial de la Universitat Politècnica de València. 46pp. ISBN 978-848363-306-9

WIKIPEDIA, 2014. Castellet de Bernabé. Available: https://es.wikipedia.org/wiki/Castellet_de_Bernab\%C3\%A9 [28/02, 2016].

YOUTUBE, 2016. Vuelo virtual del yacimiento arqueológico Castellet de Bernabé. Available: https://youtu.be/K41MFT2hWRc [29/02, 2016].

ZHANG, X., BLAAS, J., BOTHA, C., REISCHIG, P., BRAVIN, A. and DIK, J., 2012. Process for the 3D virtual reconstruction of a microcultural heritage artifact obtained by synchrotron radiation CT technology using open source and free software. Journal of Cultural Heritage, 13(2), pp. 221-225. DOI: http://dx.doi.org/10.1016/j.culher.2011.08.004

ZLOT, R., BOSSE, M., GREENOP, K., JARZAB, Z., JUCKES, E. and ROBERTS, J., 2013. Efficiently capturing large, complex cultural heritage sites with a handheld mobile 3D laser mapping system. Journal of Cultural Heritage 15(6), pp. 670-678. DOI: http://dx.doi.org/10.1016/j.culher.2013.11.009 


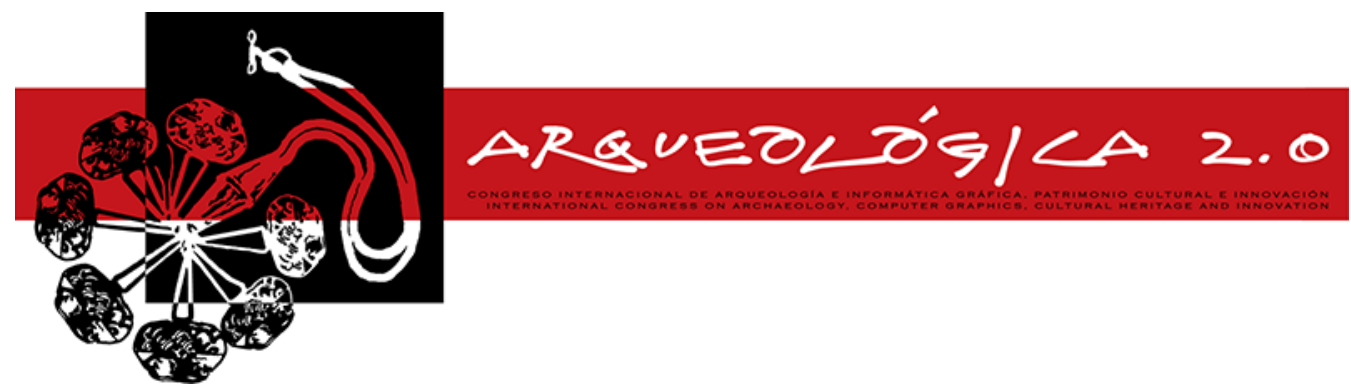

Proceedings of the $8^{\text {th }}$ International Congress

on Archaeology,

Computer Graphics,

Cultural Heritage and Innovation

'ARQUEOLÓGICA 2.0'

in Valencia (Spain),

Sept. $5-7,2016$

\title{
DIFUSIÓN DE PROYECTOS DE PATRIMONIO CULTURAL EN ENTORNOS WEB. PRIMERAS EXPERIENCIAS CON LA LIBRERÍA THREE-JS
}

\author{
DISSEMINATION OF CULTURAL HERITAGE PROJECTS FOR WEB ENVIRONMENTS. FIRST EXPERIENCES \\ USING THREE-JS LIBRARY \\ Jesús Palomar-Vázquez , María José Viñals-Blasco \\ Departamento de Ingeniería Cartográfica, Geodesia y Fotogrametría, Universitat Politècnica de València, Camino de Vera s/n, 46022 \\ Valencia, España. jpalomav@upvnet.upv.es; mvinals@cgf.upv.es
}

\begin{abstract}
:
Dissemination of 3D information is a key process in cultural heritage projects. Most web-based platforms use WebGL technology for 3D data visualization. They normally provide generic wiewers with a low level of customization, however. By contrast, we usually find that Open Source based technologies allow for a complete adaptation to the specific project features by means of a large number of available dedicated javascript libraries. In the present paper we describe the minimum requirements any dissemination project should contain and the corresponding needs for implementation using Three-js, one of the most versatile Open Source 3D visualization libraries.
\end{abstract}

Key words: 3D models, heritage dissemination, WebGL, Three-js

\section{Resumen:}

Para cualquier proyecto relacionado con el estudio y conservación del patrimonio cultural, la fase de difusión de la información tridimensional debe ser una parte fundamental de todo el proceso. La mayoría de las plataformas existentes utilizan la tecnología WebGL para difundir contenido 3D a través de navegadores Web, aunque suelen ser de propósito genérico, con visores con bajo nivel de personalización. En el extremo opuesto están las tecnologías Open Source, representadas aquí por una serie de librerías programadas en lenguaje JavaScript que permiten un alto grado de adaptación a las necesidades de un proyecto específico. En el presente artículo se estudiarán las características mínimas que debería tener un proyecto de difusión en el campo del patrimonio cultural y su implementación en una de las librerías más utilizadas hoy día en los entornos de software libre, como es Three-js.

Palabras clave: modelos 3D, difusión del patrimonio, WebGL, Three-js

\section{Introducción}

En los últimos años, la posibilidad de crear reconstrucciones virtuales se ha convertido en un pilar fundamental en los proyectos de conservación de los bienes del patrimonio cultural, permitiendo su estudio sin la necesidad de trasladarse hasta su emplazamiento físico (Domingo et al. 2013, Koutsoudis 2014). Es en este punto cuando comienza la fase de difusión. La representación virtual de gráficos por computador en Internet, se está convirtiendo en un estándar de difusión, debido sobre todo a la capacidad de alcance de Internet y a la naturalidad con la que los seres humanos entendemos los modelos tridimensionales (Stefani et al. 2014).

Este trabajo aborda el proceso de difusión mediante el uso de la librería Open Source Three-js (TJS) basada en la tecnología WebGL, que permite incluir modelos $3 D$ en entornos Web sin necesidad de instalar ningún tipo de plugin (Parisi 2012). De esta forma, se describen las características mínimas que un proyecto de difusión de patrimonio cultural debería tener y cómo se implementa dentro de TJS.

\section{Escenario de proyecto base con TJS}

\subsection{Caso de estudio}

Este proyecto se desarrolla sobre una estructura de tipo búnker perteneciente a la línea defensiva de trincheras Puig-Carassols (Durbán 2014), en el término municipal de Paterna, España (Fig. 1). Los objetivos principales son el modelado 3D de la estructura y el estudio de la situación y tipología de los grafitos. Se ha desarrollado

`Corresponding Author: Jesús Palomar-Vázquez, jpalomav@upvnet.upv.es 
un prototipo de visor basado en TJS donde se muestran los resultados obtenidos en un entorno Web (http://goo.gl/2X4rhN).

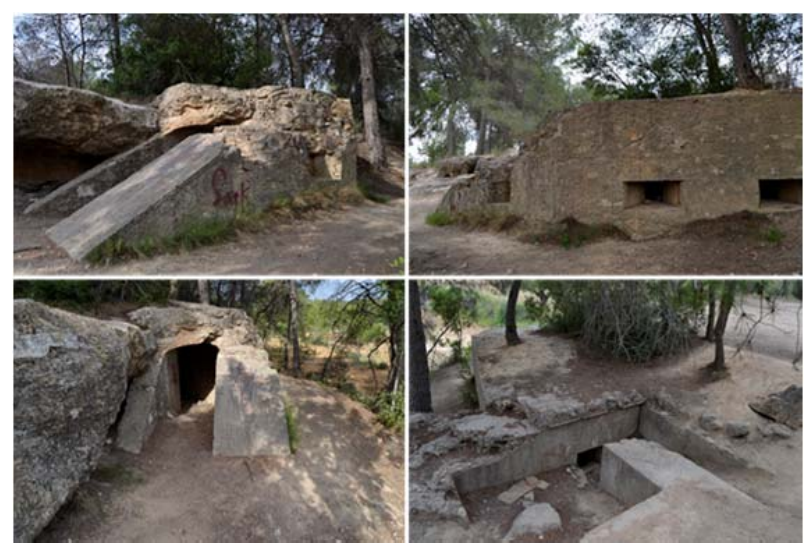

Figura 1: Vistas del búnker objeto de studio.

\subsection{Medios de difusión de contenido 3D}

La difusión online de contenidos 3D tiene dos vías bien diferenciadas: por un lado las plataformas comerciales que ofrecen repositorios de modelos $y$ visores especializados con características básicas; por otro lado encontramos alternativas Open Source que usando librerías especializadas, permiten la creación de visores adaptados a las necesidades de cada usuario.

Al primer grupo pertenecen los casos de p3d.in, Verold o Sketchfab, la más conocida. En el segundo grupo estarían librerías como TJS, Babylon-js, PlayCanvas o Potree.

A pesar de que con cualquiera de estas librerías podríamos desarrollar un proyecto dentro del ámbito de la difusión del patrimonio cultural, descartamos las librerías Babylon-js y PlayCanvas por estar más orientadas a la creación de juegos y Potree, por estar enfocada únicamente a la gestión de nubes de puntos. En este sentido, escogeremos TJS por ser una librería más madura, de propósito general y disponer de una batería enorme de ejemplos, una comunidad activa y un API bien documentado.

\subsection{Diseño del prototipo}

Atendiendo a las necesidades del proyecto en cuestión, se han implementado las siguientes características: carga del modelo, aplicación dinámica de texturas, visualización de distintos modos de geometría, puntos de vista, paseos virtuales, puntos de información, visibilidad y opacidad de los modelos, medidas, secciones y editor de imágenes. También se ha diseñado una sencilla interfaz para la interacción entre el visor y el usuario.

- Carga del modelo. El visor permite la carga del modelo 3D en formato collada e informa del porcentaje de carga de forma dinámica.

- Aplicación dinámica de texturas. Las texturas del modelo han sido procesadas mediante la técnica Decorrelation Stretching (Harman 2005) para realzar los grafitos poco visibles. El visor permite alternar entre la textura original y las realzadas (Fig. 2).

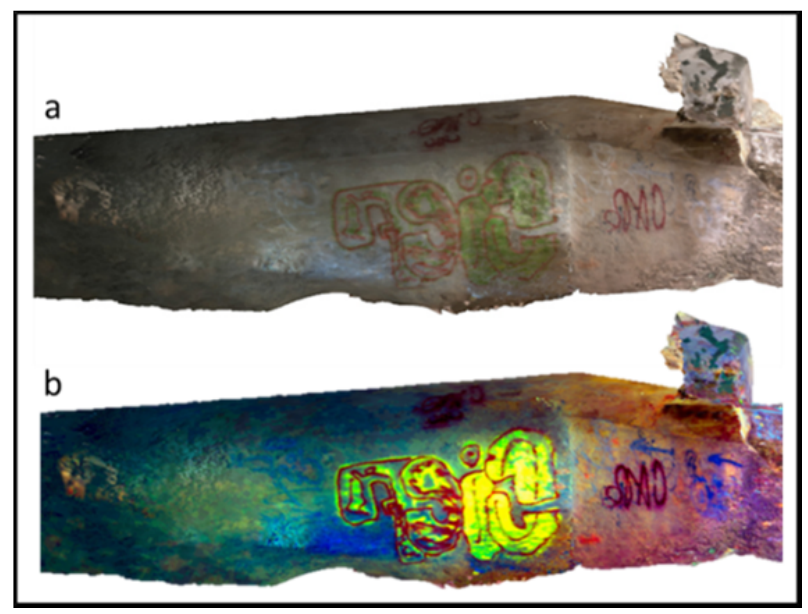

Figura 2: a) Textura original; b) Decorrelation Stretching (algoritmo LDS).

- Modos de geometría. El modelo puede ser visualizado de tres modos: textura, malla de alambre o nube de puntos. Para este último tipo de representación TJS emplea una malla especial denominada sistema de partículas donde cada partícula lleva asociada una posición y un material.

- Puntos de vista. Se han definido múltiples puntos de vista para la exploración guiada del modelo. La posición $3 \mathrm{D}$ del origen de la cámara y su rotación en los tres ejes se determina previamente para definir todos aquellas vistas a las que se quiera navegar. Para ello se ha implementado una herramienta que captura esta información sobre la vista actual del usuario.

- Paseos virtuales. De igual manera, se han definido unos itinerarios que recorren el modelo siguiendo una trayectoria predefinida. Para ello se utilizan interpolaciones de tipo spline a partir de una serie de puntos de paso en los que se define una posición y una rotación de la cámara.

- Puntos de información. Se han implementado varios puntos de información representados por esferas que al ser seleccionadas abren una nueva ventana con información adicional. La selección se basa en la técnica del Ray Casting, por medio de la cual se obtiene la intersección del vector cámara-ratón con los objetos del mundo 3D (Fig. 3).

- Visibilidad y opacidad. La aplicación de un nivel de transparencia sobre las texturas de un modelo permite estudiar las estructuras internas del modelo, lo que facilita su comprensión.

- Medidas. De nuevo, la utilización de la técnica de Ray Casting permite seleccionar sobre el modelo dos puntos con el cursor del ratón, y obtener la distancia entre ellos (Fig. 4).

- Secciones. La complejidad de realizar secciones con modelos grandes se ha solventado generando las secciones a partir de la nube de puntos. El visor permite establecer el plano de la sección y su ancho. 


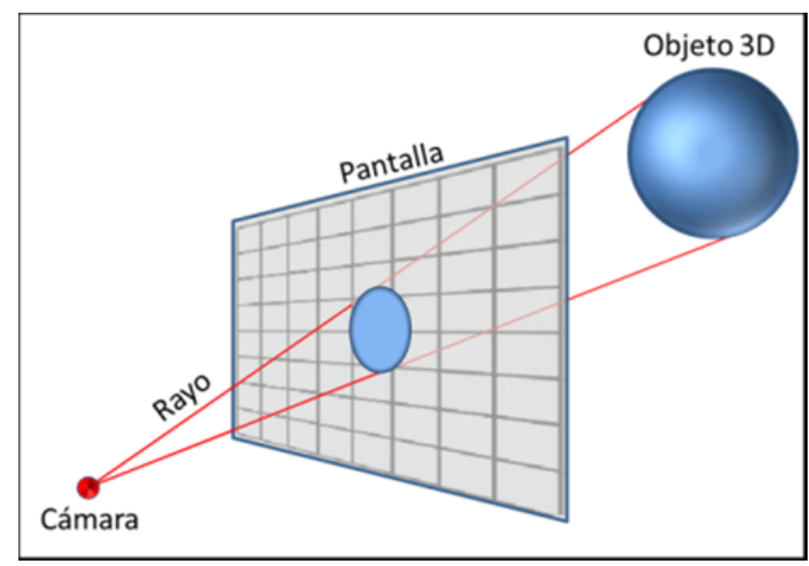

Figura 3: La trayectoria entre la cámara y el objeto 3D determina la proyección sobre la pantalla.

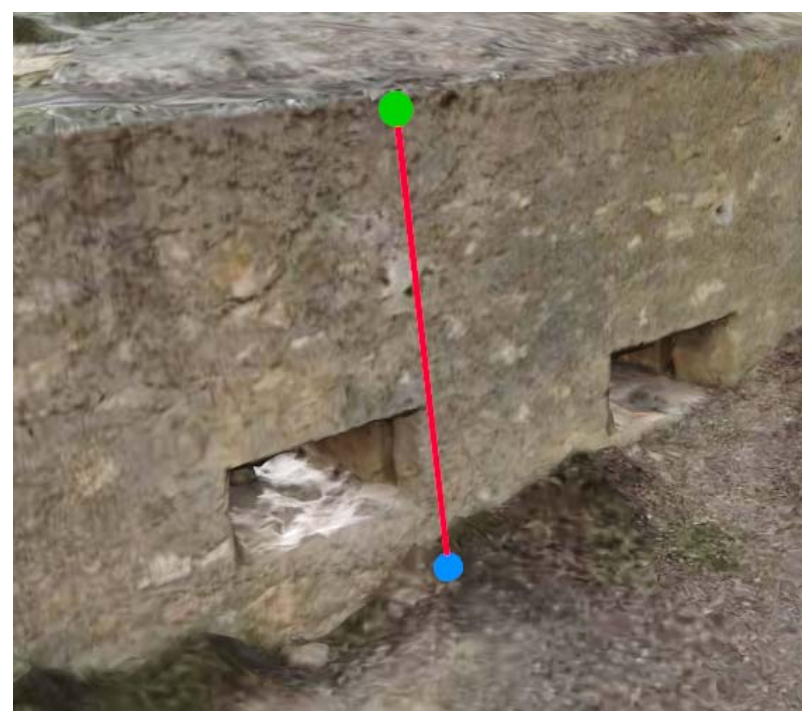

Figura 4: Las esferas verde y azul representan los puntos seleccionados por el usuario de forma interactiva.
- Editor de imágenes. Se han mejorado las capacidades de TJS mediante la posibilidad de realizar procesamiento digital de las texturas mediante JavaScript. El prototipo permite aplicar filtros de brillo, contraste y detección de bordes.

- Interfaz gráfica. Se ha utilizado la librería dat.GUI, una librería simple pero eficiente para modificar variables en JavaScript. Esta librería permite incluir controles básicos como botones, selectores booleanos, barras deslizadoras, cajas de texto, selectores de color, listas desplegables, etc.

\section{3. conclusiones}

A lo largo de este trabajo hemos ido viendo cómo a través de la librería TJS podemos establecer las bases mínimas que todo proyecto de difusión de contenido 3D asociado al patrimonio cultural debería tener. Queda demostrada la potencia de esta librería y cómo en unión con HTML5 y otro tipo de librerías, enriquecen las capacidades del visor.

\section{Trabajo futuro}

Será necesario la exploración profunda de las capacidades de la librería TJS y su unión con otro tipo de librerías para continuar mejorando las capacidades del prototipo: entre las mejoras posibles estarían la personalización de la interfaz de usuario, el procesamiento digital optimizado de las texturas (añadiendo también un mayor número de filtros), o la inclusión de múltiples vistas simultáneas del modelo.

\section{Referencias}

DOMINGO, I., CARRIÓN, B., BLANCO, S. and LERMA, J.L., 2013. Evaluating conventional and advanced visible image enhancement solutions to produce digital tracings at el Carche rock art shelter. Digital Applications in Archaeology and Cultural Heritage. 2, pp. 79-88. DOI:10.1016/j.daach.2015.01.001

DURBÁN J., 2014. Tipologías y estrategias en la defensa de Valencia. Estudio del punto de apoyo de san Antonio de Benagéber en el centro de resistencia de la Vallesa de Mandor. La Linde, revista digital de arqueología, 3.

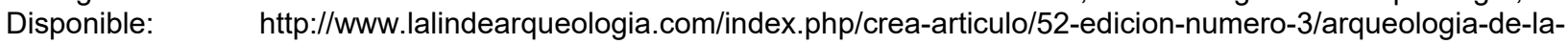
guerra-civil-3/125-san-antonio-de-benageber [1/15, 2016].

HARMAN, J., 2005. Using Decorrelation Stretch to Enhance Rock Art Images. American Rock Art Research Association Annual Meeting, May 28-30, Sparks, Nevada.

KOUTSOUDIS A., VIDMAR B., IOANNAKIS G., ARNAOUTOGLOU F., PAVLIDIS G. and CHAMZAS C., 2014. Multiimage 3D reconstruction data evaluation. Journal of Cultural Heritage, 1, pp. $73-79$. DOI:10.1016/j.culher.2012.12.003

PARISI, T., 2012. WebGL: Up and Running. Building 3D Graphics for the Web. O'Reilly Media. ISBN $144932357 X .230$ pages.

STEFANI, C., BRUNETAUD, X., JANVIER-BADOSA, S., BECK, K., DE LUCA, L. and AL-MUKHTAR, M., 2014. Developing a toolkit for mapping and displaying stone alteration on a web-based documentation platform. Journal of Cultural Heritage, 15(1), pp. 1-9. DOI:10.1016/j.culher.2013.01.011

THREE-JS. Javascript 3D library. Disponible:http://threejs.org [10/1, 2016] 


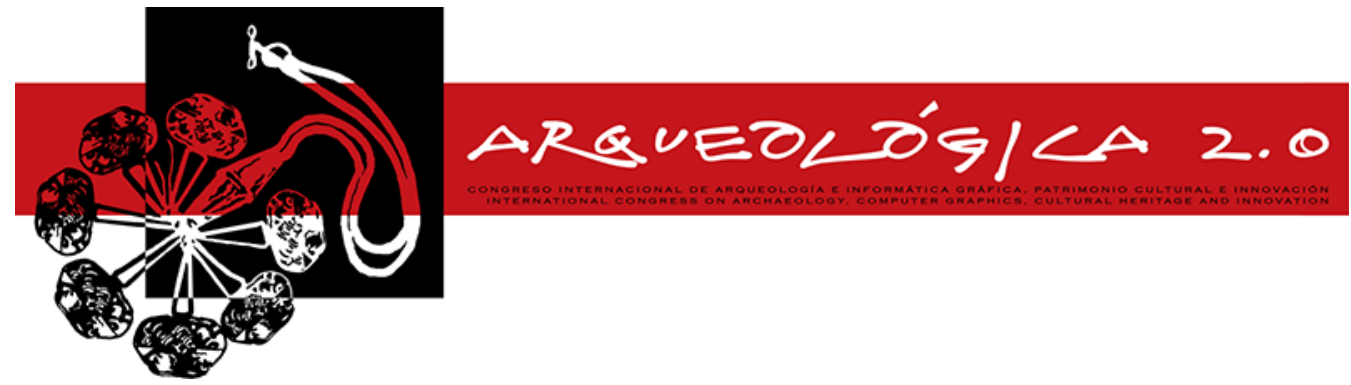

Proceedings of the $8^{\text {th }}$ International Congress

on Archaeology,

Computer Graphics,

Cultural Heritage and Innovation

'ARQUEOLÓGICA 2.0'

in Valencia (Spain),

Sept. $5-7,2016$

\title{
PRELIMINARY EVALUATION OF HDR TONE MAPPING OPERATORS FOR CULTURAL HERITAGE
}

\author{
Rossella Suma ${ }^{a,}{ }^{*}$, Georgia Stavropoulou ${ }^{b}$, Elisavet K. Stathopoulouc, Luc van Gool ${ }^{\mathrm{b}}$, Andreas \\ Georgopoulos ${ }^{\mathrm{c}}$, Alan Chalmers ${ }^{\mathrm{a}}$ \\ a WMG, University of Warwick, CV4 7AL, Coventry, UK. r.suma@warwick.ac.uk; alan.chalmers@warwick.ac.uk \\ ${ }^{\text {b }}$ ESAT - PSI, VISICS, KU Leuven, Kasteelpark Arenberg 10, 3001 Heverlee, Belgium. georgina.stavropoulou@esat.kuleuven.be; \\ luc.vangool@kuleuven.be \\ ${ }^{c}$ Laboratory of Photogrammetry, National Technical University of Athens, Heroon Polytechneiou 9, 15780, Athens, Greece. \\ elliestath@central.ntua.gr; drag@central.ntua.gr
}

\begin{abstract}
:
The ability of High Dynamic Range (HDR) imaging to capture the full range of lighting in a scene has led to an increasing interest in its use for Cultural Heritage $(\mathrm{CH})$ applications. Photogrammetric techniques allow the semi-automatic production of 3D models from a sequence of images. Current photogrammetric methods are not always effective in reconstructing objects under harsh lighting conditions, as significant geometric details may not have been captured accurately in under- and over-exposed regions of the images. HDR imaging offers the possibility to overcome this limitation. In this paper we evaluate four different HDR tone-mapping operators (TMOs) that have been used to convert raw HDR images into a format suitable for state-of-the-art photogrammetric algorithms, and in particular keypoint detection techniques. The evaluation criteria used are the number of keypoints and the number of valid matches achieved. The comparison considers two local and two global TMOs.
\end{abstract}

Key words: high dynamic range imaging, HDR tone mapping, features detection, 3D reconstruction

\section{Introduction}

High Dynamic Range (HDR) is an imaging technique that enables the acquisition, storage and display of a wider range of luminance values than normal cameras allow (Banterle et al. 2011). The ability of HDR to capture all the detail in a scene, even in cases of harsh lighting conditions, makes it a very useful method for providing robust data for photogrammetric reconstruction and photorealistic texturing. This is especially true with Cultural Heritage $(\mathrm{CH})$ environments, which are often characterised by highly reflective or shiny materials and intense presence of shadows and bright areas. Using HDR imaging for generating the input of photogrammetric processes such as Structure from Motion (SfM) could significantly improve the final results. Focusing on the keypoint detection, in cases of Low Dynamic Range (LDR) images with strongly shadowed or very bright areas, the detected keypoints tend to cluster only in the well-exposed areas of the image. This non-uniform spatial distribution of points, can increase, as a result, the image registration error and potentially compromise the stability of the reconstructed geometry. HDR imaging is capable of overcoming these limitations and therefore represents a more reliable input for the SfM pipeline.
One problem with providing HDR input for photogrammetric purposes is that most 3D reconstruction algorithms have been designed to work with traditional 8-bit LDR images. Therefore HDR images need first to be converted to LDR equivalents, a process commonly achieved by applying Tone mapping operators (TMOs). Various TMOs have been developed in the latest years, generally divided into global and local, depending on their working principle.

Although researchers have suggested the use of HDR images as a possible enhancement in the photogrammetric pipeline, especially for archaeological applications (Wheatley 2011); (Ntregka et al. 2014); (Guidi et al. 2014), HDR has not been frequently used in $\mathrm{CH}$ and photogrammetry up until now. Kontogianni et al. (2015) conducted a comparative study of feature detectors on tone mapped images with respect to the number of detected points but only one tone mapper was applied. Pribyl et al. (2016) evaluated the suitability of original Low Dynamic Range (LDR), native HDR and tone mapped HDR images with feature point detectors. An important aspect of tone mapping research field is that not all tone-mapping techniques have been developed for the same purpose. With the aim of documentation, reuse and processing using photogrammetry and computer vision techniques, it is

*Corresponding Author: Rossella Suma, r.suma@warwick.ac.uk 
important that the TMO preserves reality-such as radiometry, while also being efficient for the applications.

In this paper we address the problems related to the initial steps of SfM with an in depth analysis on how feature detection is affected when applied on images that have been tone-mapped with four different TMOs: the Gradient Domain HDR Compression (Fattal et al. 2002), the local and global version of Reinhard et al. (2002); and a video Tone Mapping Operator called Display Adaptive Tone Mapping (Mantiuk et al. 2008). Regarding the detection, three of the most popular feature detectors were used; Difference of Gaussians (DoG), a keypoint detection method used by SIFT (Lowe 1999), Fast Hessian approximation, a process integrated in the SURF package (Bay et al. 2006) and, finally, FAST, that is based on accelerated segment test (AST) (Rosten and Drummond 2006).

\section{Methodology}

The images were captured with the exposure bracketing technique in various cultural heritage sites with the use of DSLR cameras and tripods. Depending on the dynamic range of the scene, either five or seven different exposures were taken with the full frame camera. The RAW data was processed with the Matlab HDR Toolbox (Banterle et al. 2011), which merges the different exposures into an HDR image using Debevec and Malik's method (1997). These HDR images were subsequently tone mapped with each of the four TMOs under study using pfstools library (Mantiuk et al. 2007). The tone mappers operators applied are: Fattal et al. (2002), Reinhard et al. (2002) in its two variants and Mantiuk et al. (2008) from now on referred to as Fattal, ReinhardGlobal ReinhardLocal and Mantiuk. In particular Mantiuk video TMO was selected for our tests because photogrammetry requires a sequence of images, and as we are tone mapping this entire sequence, we wanted to investigate its performance in terms of brightness, colour appearance, and coherence preservation for the entire sequence.

The criteria under which the tested TMOs and the respective LDR images were evaluated in this paper are the number of detected keypoints and the number of matches achieved between stereo pairs. The number of detected keypoints in each tone-mapped image alone may be a misleading criterion when it comes to photogrammetry applications, as a large number of keypoints does not necessarily offer a noise-free and homogenous coverage of the image or good and sufficient matches between images. Therefore, visual inspection was also performed in order to evaluate the distribution of the keypoints as well as their density. In the next step, keypoint description and matching were performed in order to evaluate the TMOs based on the number of matches. For this test, only the SURF descriptor was applied so that the results would be comparable only in terms of detection. For the matching process, the Flann-based (Muja et al. 2009) matcher was used and the resulting matches were filtered in order to keep the best ones, based on Lowe's ratio test criterion (Lowe 2004).

\section{Results}

Figure 1 illustrates the average number of keypoints and how three different TMOs and the original LDR image perform under the three selected feature detection methods. As can be seen, all detectors perform better with Mantiuk TMO than with ReihardLocal and ReinhardGlobal and the middle exposed original LDR image. ReinhardLocal is marginally better than ReinhardGlobal. Fattal was not included in Figure 1 as it detects significantly more keypoints compared to any of the other 3 TMOs ( 700000 for FAST, 176451 for SIFT and 108183 for SURF). The excessive number of keypoints possibly stems from Fattal's ability to intensify the contrast in dark regions, enhancing previously not visible details and texture. However, a larger number of keypoints does not guarantee a better 3D reconstruction, and, specifically in the case of Fattal TMO, image noise may also have been enhanced, leading to erroneous detection of keypoints. The combination of FAST and Fattal supports this argument and can produce a number of keypoints that is higher than $5 \%$ of the image pixels (around 1 out of 20 pixels is detected as an interest point). The results were also inspected visually by plotting all the detected points on the images.

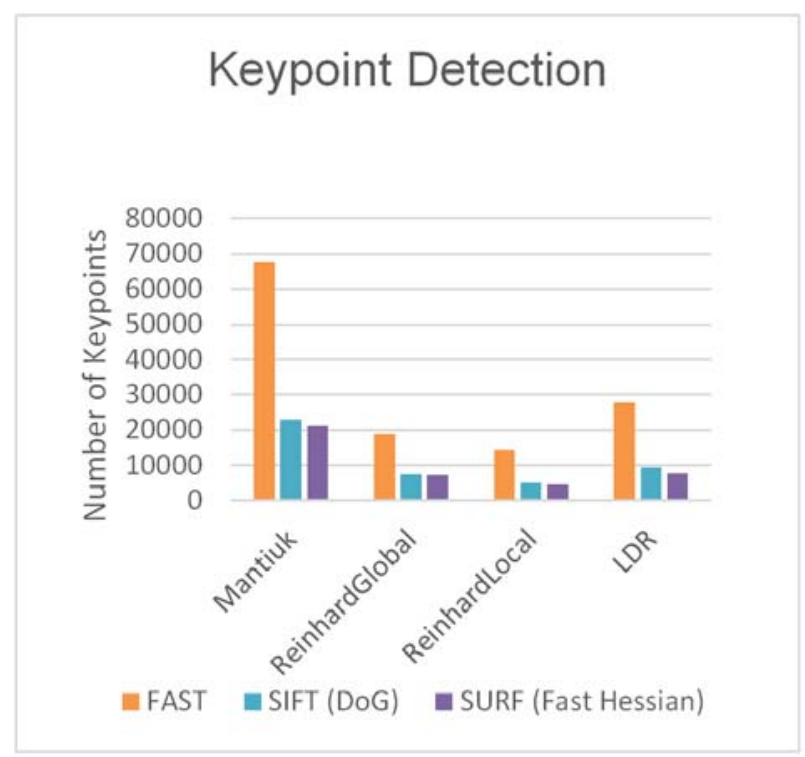

Figure 1: Comparison of the average number of keypoints detected with FAST, SIFT and SURF for Mantiuk, ReinhardGlobal, ReinhardLocal and LDR.

In Figure 2 only a detail of a fresco belonging to the Asinou Church in Cyprus is used to illustrate the density of the points and their distribution in the image space across different combinations of TMOs and detectors. In terms of density, the combination of FAST and Fattal produces an excessive amount of points that almost completely covers the image. Although less intense results are produced with the coupling of Fattal and the Fast Hessian (SURF) and DoG (SIFT) detectors, the density of points is still high even in regions where the fresco lacks in relevant details. Both Reinhard's methods produce images with low contrast and this is also reflected in the density of keypoints. Regarding the points' spatial distribution, apart from Fattal, the rest of the TMOs produce more points in highly textured areas. 

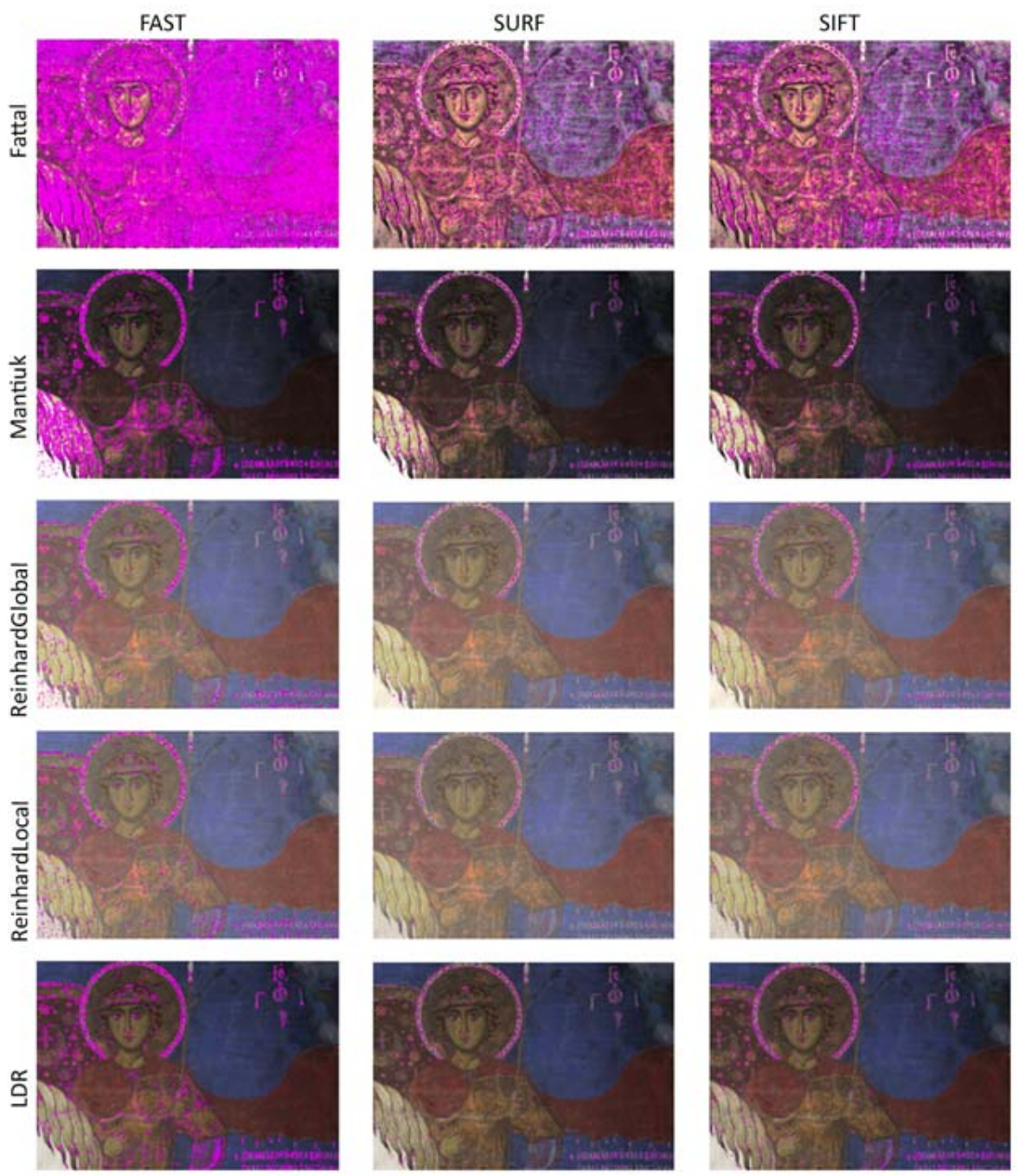

Figure 2: Particular of Asinou Church fresco with keypoints for all the TMOs and LDR tested with all three detectors.

Figure 3 shows the number of matches that have succesfully passed Lowe's ratio test (good matches). Again, Mantiuk TMO outperforms the other three, while the number of succefull matches is much bigger when the SURF (Fast Hessian) detector is being used. ReinhardGlobal and standard LDR images follow, with ReinhardGlobal performing slightly better, whereas ReinhardLocal has the lowest scores. The number of good matches can be considered as a more reliable criterion than the number of detected keypoints, as it reensures keypoint repeatability between sequential frames and subsequently produces more stable results for $3 \mathrm{D}$ reconstruction.

\section{Conclusions}

In this paper four different tone-mapping methods were compared in terms of their suitability for keypoint detection and matching. The results suggest that Mantiuk's method is a more suitable TMO for photogrammetric procedures since both the number of keypoints and the number of matches are high enough but not excessive. In the case of Fattal, in fact, the quantity of detected keypoints is higher but this does not imply better quality in the reconstruction, but rather computationally-intensive, time-consuming and prone-to- error during image matching and registration. Regarding the Reinhard's methods, surprisingly, more points are detected in the original LDR images than in the tonemapped images.

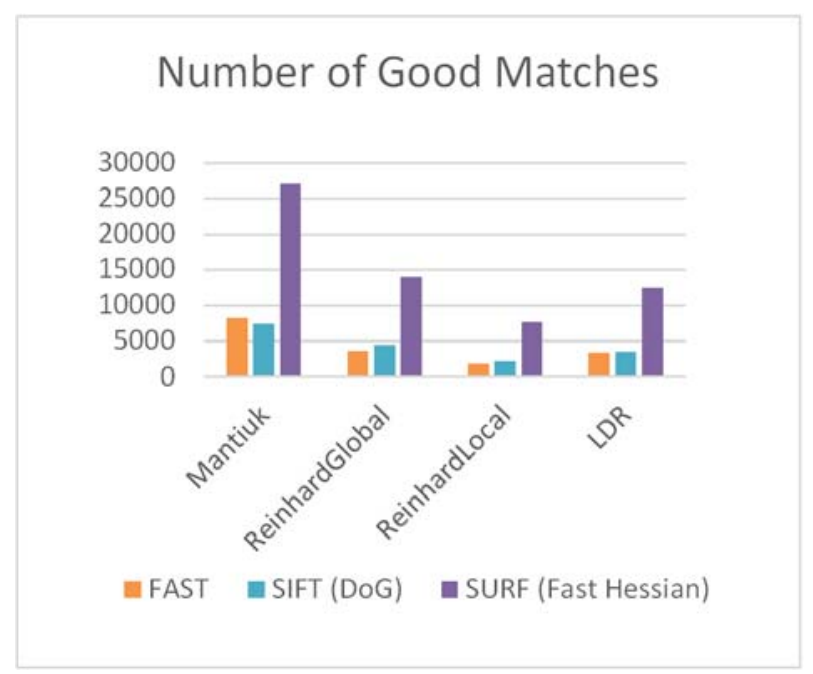

Figure 3: Comparison of number of good matches achieved on strereopairs tone-mapped with different TMOs. 
This paper has shown that, despite the availability of a plethora of HDR TMOs in literature, not all of them are suitable for the specific task of cultural heritage site documentation and reconstruction. Moreover, most of the tone mapping algorithms have previously been evaluated based only on the visual appeal of their results. Therefore, our future work will keep exploring the potential of HDR TMOs specifically tailored for photogrammetric applications, and a more in depth and quantitative evaluation of the TMOs will be intended by including further criteria and more case studies, which demonstrate the lighting difficulties in cultural heritage environments. The future work will involve the use of a common criterion, such as the Repeatability Rate by
Schmid et al. (2000) to evaluate the robustness of the different detectors over TMOs.

\section{Acknowledgements}

We would like to thank Kurt Debattista, Timothy Bradley, Ratnajit Mukherjee, Diego Bellido Castañeda and TomBashford Rogers for their suggestions, help and encouragement. This project has received funding from the European Union's Seventh Framework Programme for research, technological development and demonstration under grant agreement no 608013, titled "ITN-DCH: Initial Training Network for Digital Cultural Heritage: Projecting our Past to the Future."

\section{References}

BANTERLE, F., ARTUSI, A., DEBATTISTA, K. and CHALMERS, A., 2011. Advanced high dynamic range imaging: theory and practice. CRC Press.

BAY, H., TUYTELAARS, T. and VAN GOOL, L., 2008. Surf: Speeded up robust features. Computer Vision and Image Understanding, 110(3), pp. 346-359.

DEBEVEC, P.E. and MALIK, J., 1997. Recovering high dynamic range radiance maps from photographs. In proceeding of the SPIE: Image Sensors (Vol. 3965, pp. 392-401).

FATTAL, R., LISCHINSKI, D. and WERMAN, M., 2002. Gradient domain high dynamic range compression. In ACM Transactions on Graphics (TOG), 21(3), ACM, pp. 249-256.

KONTOGIANNI, G., STATHOPOULOU, E.K., GEORGOPOULOS, A. and DOULAMIS, A., 2015. HDR imaging for feature detection on detailed architectural scenes. The International Archives of Photogrammetry, Remote Sensing and Spatial Information Sciences, 40(5), p. 325.

GUIDI, G., GONIZZI, S. and MICOLI, L.L., 2014. Image pre-processing for optimizing automated photogrammetry performances. ISPRS Annals of The Photogrammetry, Remote Sensing and Spatial Information Sciences, 2(5), p. 145.

LEDDA, P., CHALMERS, A., TROSCIANKO, T. and SEETZEN, H., 2005. Evaluation of tone mapping operators using a high dynamic range display. ACM Transactions on Graphics (TOG), 24(3), pp. 640-648.

LOWE, D.G., 2004. Distinctive image features from scale-invariant keypoints. International journal of computer vision, 60(2), pp. 91-110.

MANTIUK, R., DALY, S. and KEROFSKY, L., 2008. Display adaptive tone mapping. ACM Transactions on Graphics (TOG), 27(3), p. 68.

MANTIUK, R., KRAWCZYK, G., MANTIUK, R., and SEIDEL, H., 2007. High dynamic range imaging pipeline: Perceptionmotivated representation of visual content. Human Vision and Electronic Imaging XII. doi:10.1117/12.713526

MUJA, M. and LOWE, D.G., 2009. Fast approximate nearest neighbors with automatic algorithm configuration. VISAPP (1), 2, pp. 331-340.

NTREGKA, A., GEORGOPOULOS, A. and QUINTERO, M. S., 2014. Investigation on the use of HDR images for cultural heritage documentation. International Journal of Heritage in the Digital Era, 3(1), pp. 1-18.

PŘIBYL, B., CHALMERS, A., ZEMČíK, P., HOOBERMAN, L. and ČADÍK, M., 2016. Evaluation of feature point detection in high dynamic range imagery. Journal of Visual Communication and Image Representation.

REINHARD, E., STARK, M., SHIRLEY, P. and FERWERDA, J., 2002. Photographic tone reproduction for digital images. In ACM Transactions on Graphics (TOG), 21(3), ACM, pp. 267-276.

ROSTEN, E. and DRUMMOND, T., 2006. Machine learning for high-speed corner detection. In Computer Vision-ECCV 2006, Springer Berlin Heidelberg, pp. 430-443.

SCHMID, C., MOHR, R. and BAUCKHAGE, C., 2000. Evaluation of interest point detectors. International Journal of computer vision, 37(2), pp. 151-172.

WHEATLEY, D., 2011. High dynamic range imaging for archaeological recording. Journal of Archaeological Method and Theory, 18(3), pp. 256-271. 


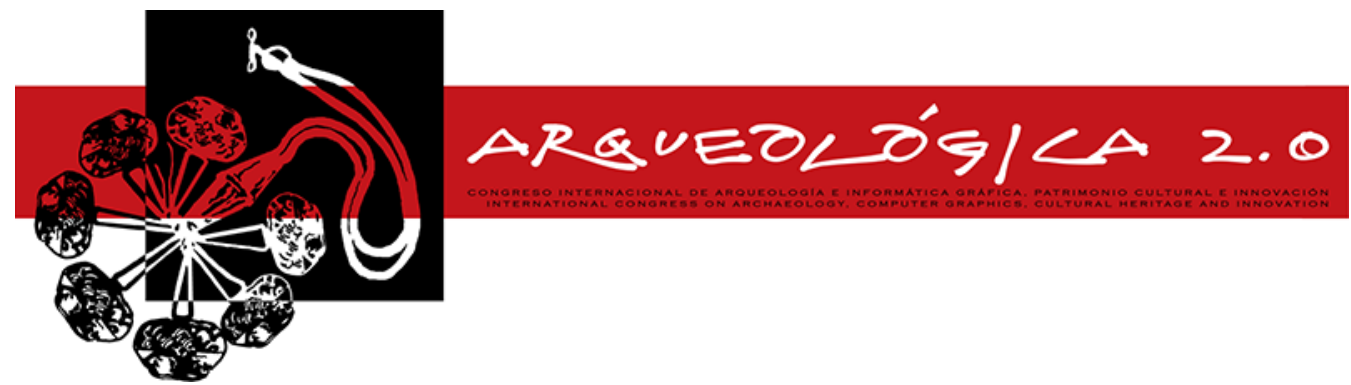

Proceedings of the $8^{\text {th }}$ International Congress

on Archaeology,

Computer Graphics,

Cultural Heritage and Innovation

'ARQUEOLÓGICA 2.0'

in Valencia (Spain),

Sept. $5-7,2016$

\title{
3D MODELLING FROM UAV DATA IN HIERAPOLIS OF PHRIGIA (TK)
}

\author{
Filiberto Chiabrando ${ }^{a}$, Francesco D'Andria ${ }^{b}$, Giulia Sammartano ${ }^{a, *}$, Antonia Spanò ${ }^{a}$ \\ ${ }^{a}$ Department of Architecture and Design, Politecnico di Torino, Viale Mattioli 39,10129 Torino, Italy. filiberto.chiabrando@polito.it; \\ giulia.sammartano@polito.it; antonia.spano@polito.it \\ ${ }^{\mathrm{b}}$ Department of Cultural Heritage, Università del Salento, Via Dalmazio Birago 64, 73100, Lecce, Italy. francesco.dandria@unisalento.it
}

\begin{abstract}
:
In areas of archaeological excavation with architectural complexes, the generation of 3D data and their spatial information updating can now benefit from UAV photogrammetry. This technique shows a very rapid development in many fields, as it provides effective results for high-resolution and detailed surfaces, adding to both quickness and suistainable costs, quite irrespective of the form and extension. That is very important in Documentation phases of Cultural Heritage. In the field of archaeological researches, the nadir view from low altitude has always been a preferential point of view, then the generation of very large-scale models and orthophotos is of great interest today, and it seems to promise high future developments. So the paper focuses on a workflow to obtain photogrammetrical products generation using eBee system, by Sensefly, of growing popularity in the scenario of survey techniques. The potential of outcomes is also given by the selected monumental case studies in the city of Hierapolis in Phrygian, on which the MAIER (Italian archaeological Mission of Hierapolis) operates from the 60s of the twentieth century. The variety and complexity of the buildings, as well as the height of their ruins offers numerous trouble spots that is interesting to deal. A particular attention on the accuracy of DSM (Digital Surface Model) will be evaluated and reported thanks to the GCPs (ground control points) that have been easily measured since these aerial photogrammetry experiences by UAV are the last of extensive previous metric surveys conducted in the recent past.
\end{abstract}

Key words: UAV, DSM, aerial photogrammetry, Archaeological Heritage, 3D modelling, maps updating, data integration

\section{3D Documentation by UAV in archaeological sites}

In Archaeological context, daily prone to environmental and human risks, the whole Heritage monitoring process, must be steadily fed by dedicated investiments and kept under control by careful documentation, designed as a perpetual practice during years. From this point of view the the digital 3D perception and handling, and in particular the use of geomatics integrated techniques, allows to conceive a $3 D$ survey as a complete and detailed database of information, that may be instantly queried to obtain multiple representations and multidisciplinary analysis can be conducted on it. Moreover, 3D information derived from aerial and terrestrial sensors, belonging to the same spatial system, can be integrated to generate multi-scale and multi-resolution detailed models, according to time and space (Aicardi et al. 2015; Moussa et al. 2012). This is a part of continuous documentation processes and nowadays it become more and more crucial to reach the characteristics of completeness needed by multidisciplinary context, as archaeological ones. In particular, the production of surface models from aerial sensors is useful for terrain analysis and reconstructions, structural analysis, studies of materials and decay.
For the data acquisition phase, in these last years many platforms have been developed to produce, update and integrate various geospatial information, according to different mechanics features, devices equipement and organization of flights (Colomina and Molina 2014; Themistocleous et al. 2015). Several technological refinement in RPAS (remotely piloted aerial system) are taking on by research, both from the point of view of the hardware component (image acquisition) both in the software (data processing). From an operational point of view, platforms mostly employed in manifold types of applications are generally the fixed wings and the multicopter drones. One of the lately updated and costeffective one is the eBee SenseFly autonomous drone (Fig. 1), used in Hierapolis site. It is a fully automatic UAV with a central body equipped by sensors. The main characteristics are a maximum flight time 50mins, flight speed $11-25 \mathrm{~m} / \mathrm{sec}$, radio link range $3 \mathrm{~km}$. SenseFly manages the eBee platform with all the information about the flight plan through eMotion software based on a photogrammetric approach.

\section{New aerial documentation in Hierapolis: $\mathbf{3}$ flights for $\mathbf{3}$ goals}

Here it will be presented the acquisition of UAV data and the production of surface models (DSM) from aerial

"Corresponding Author: Giulia Sammartano, giulia.sammartano@polito.it 
sensors for terrain analysis and high-scale representations of the current state of three excavation areas in Hierapolis (Pammukkale, TK) with the aim to update spatial information. Hierapolis is an ancient city of Phrygia, founded on a calcareous shelf, rich in springs emerging from subterranean galleries. (D'Andria 2015) The geological context of the site conditioned the ancient and current arrangement of the city, the Pamukkale village, characterized by frequent destructive earthquakes, because of the location in the northeastern and seismically active side of the Denizli Basin, which is a $70 \mathrm{~km}$ long graben. (Alcicek 2007) During the last years, the MAIER (Italian archaeological Mission of Hierapolis) activities have identified two very important monumental buildings. Starting from 2008, many huge restoration activities have been achieved by Turkish or foreign funding. Restoration works concerned the Severian Theatre façade, the S. Philip church, the the Martyrion and the excavation of the main road of north Necropolis. In 2011 the church built upon the tomb attributed to the apostle Philip has been brought to light. The year later the famous Ploutonion cave, considered the "entrance to hell", has been discovered. Three very important areas of the ancient city have been selectet for this documentation project in Hierapolis: the central area pertaining the Plutonium next to the Apollo sanctuary area; the massive masonry building of the so-called Terme-Chiesa and the Northern Necropolis area. It is interesting how the surveys have been conducted very similarly from a technical point of view and they obtained objectives declined to individual needs of the study areas (Fig. 2).

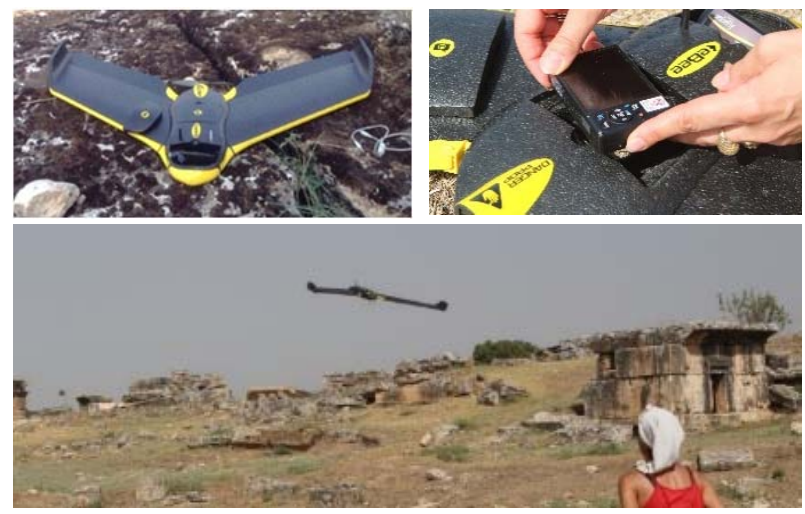

Figure 1: The setting up of the fixed wing eBee platform with the customized camera and take-off phase.

For the data acquisition, the eBee drone was equipped with the Canon S110 RGB (12 MP, CCD size $7.44 \mathrm{x}$ $5.58 \mathrm{~mm}$ ). According to the Turkey UAV regulations, platforms under $4 \mathrm{~kg}$ of weight and under $100 \mathrm{~m}$ of altitude could flight without any authorization. Furthermore, pursuance of the aims of the project the GSD (Ground Sampling Distance) was set up at $2 \mathrm{~cm}$ in order to achieving suitable information for very accurate large maps. The photogrammetric process, by Pix4D software is composed into different steps: initial processing of interior and exterior camera orientation and point cloud densification. The final step of the workflow is the production of DSM and a complete True Orthomosaic. True orthophotos are common endproducts obtained from digital surface models where the aerial images are rectified from a perspective to an orthographic projection using an underlying DSM, the single orthos are automatically clustered in the software. The Plutonium area $(0.11 \mathrm{~km} 2)$, for example, was covered in about 10 minutes (80\% overlapping in both directions) at an altitude of $57.2 \mathrm{~m}$, with measurement of 20 GCPs. The Necropolis area is wider, the flight altitude is almost $100 \mathrm{~m}, 0.23 \mathrm{~km} 2$ with $18 \mathrm{GCPs}$, and $22 \mathrm{GCPs}$ in the Thermal Bath Church $(0.12 \mathrm{~km} 2)$. It is very interesting the result of accuracy of the models, which is around 1 centimeter for GCPs and around $2 \mathrm{~cm}$ for the CPs. This data concerning the promising precision, along with the resolution that is around $2 \mathrm{~cm}$ per pixel for flights of lower altitude and $3 \mathrm{~cm}$ per pixel for the flight to the higher altitude of the Necropolis, it means that the scale of the outcomes is between 1:100 and 1:200. The main purposes of the photogrammetric flights on the areas were the revising of available documentation. In particular, for the Plouonium area, the integration with the updating data after the last excavation near Apollo's sanctuary; for the Terme-Chiesa the integration of the previous terrestrial LiDAR survey with aerial models; for the Necropolis the aerial documentation and production of an updated terrain model for pathways elevation analysis.

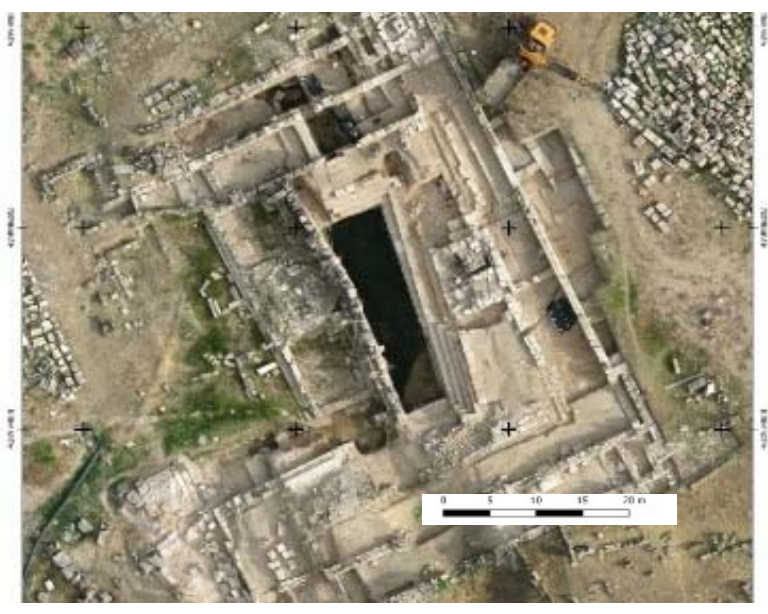

Figure 2: Othophoto of the Plutonium area and Apollo Templum.

Surely, drone surveys and the resulting products such as orthophotos and DSM cannot be compared to the extreme detailed models offered by terrestrial LiDAR (Fig. 3), particularly for the vertical portions of the structure. It's important, however, to consider that all the elevated parts of the structure, including the top surface of the large bumpy cylindrical vaults, are difficult to measure from the ground, and this experience of integrating the terrestrial and aerial survey by drone, not reached before on Hierapolis data, in other occasion was effectively accomplished. For the North Necropolis area interested by the 2015 drone flights, the main aim was the documentation of terrain comformation, in relation to the pathways accross the funerary area that extend at the edge of the west travertine terrace. The mounds which are particularly common represent the oldest burial (II - I cent. BC). At a later stage, from the end of the first century A.D., some burial structure had been placed, arranged along the main street and along internal lines. The detailed campaign of necropolis map updating, that has positioned the large number of sarcophagi (Scardozzi and Ahrens 2015) is essential to understand the organization and the temporal succession of graves; the drone survey provides a very 
substantial completion to that with a highly detailed terrain model on the tissue of the necropolis and its domestic routes. Up until now, these data were not available and we believe that the ability to measure on a digital model every possible level or height differences within the necropolis points is an important opportunity in the perspective to continue the studies on this area. (Fig. 4)
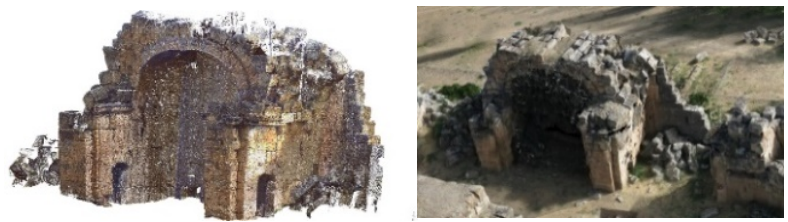

Figure 3: The entire complex and corresponding views of LiDAR model and the drone one, quite deficient in upstanding walls, especially high.

\section{Perspectives}

These type of aerial acquisition and processing, starting from the same device equipment, have been analysed and compared firstly according to the context area on which they have been planned, then on the type of terrain and buildings features, finally related by the outcomes and their numerical evaluation. The results of the presented three photogrammetric projects open the way to assess the drone survey as extremely effective in archaeological contexts, thanks to the versatility respect to the archaeological features of the sites and structures and the excavation process needs. In perspective, it can be expected that the acquisition phase, the elaboration process, and the results will be more and more strictly linked to information required for the documentation purposes. $2 \mathrm{~cm}$ resolution and less than $2 \mathrm{~cm}$ of metric accuracy show that these products are key elements in the documentation updating in aechaeological contexts. Another important perspective is the ability to equip flight systems with other sensors that may give significant support to the archaeological investigations, especially with predictive tools, together with the need to put in safety conditions the excavations area.
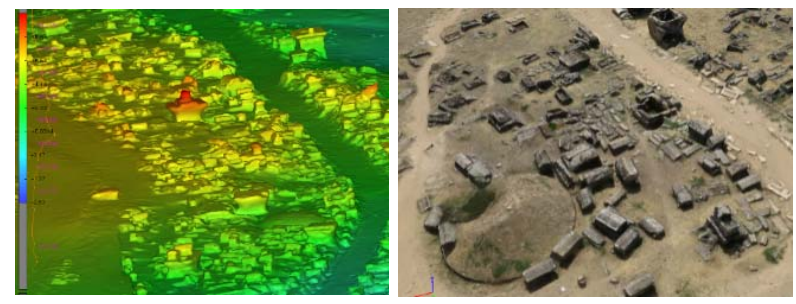

Figure 4: A view of of Necropolis: DSM in range color and texture.

\section{References}

AICARDI, I., BOCCARDO, P., CHIABRANDO, F., DONADIO, E., LINGUA, A., MASCHIO, P., NOARDO, F. and SPANÒ, A., 2015. Modelli 3D multisensore per l'acropoli segusina. In: L'arco di Susa e i monumenti della propaganda imperiale in età augustea. Segusium - Soc. di Ricerche e Studi

COLOMINA, I. and MOLINA, P., 2014. Unmanned aerial systems for photogrammetry and remote sensing: A review. ISPRS Journal of Photogrammetry and Remote Sensing, 92, pp. 79-97.

D'ANDRIA, F., 2015a. Ploutonion, in SCARDOZZI (ed), Nuovo atlante di Hierapolis di Frigia, Hierapolis di frigia VII, Yayinlari.

D'ANDRIA, F., 2015b. Cd Terme Chiesa, in SCARDOZZI (ed), Nuovo atlante di Hierapolis di Frigia, Hierapolis di frigia VII, Yayinlari.

MOUSSA, W., ABDEL-WAHAB, M. and FRITSCH, D., 2012: An Automatic Procedure for Combining Digital Images and Laser Scanner Data. - Int. Archives of the Photogrammetry, Remote Sensing and Spatial Information Sciences; Melbourne, Australia, Vol. XXXIX, Part B5: 229-234.

SCARDOZZI, G. and AHRENS S., 2015. Le necropoli: inquadramento topografico generale e sviluppo storico, in SCARDOZZI (ed), Nuovo atlante di Hierapolis di Frigia, Hierapolis di frigia VII, Yayinlari.

THEMISTOCLEOUS, K., IOANNIDES, M., AGAPIOU, A. and HADJIMITSIS, D. G., 2015. The methodology of documenting cultural heritage sites using photogrammetry, UAV, and 3D printing techniques: the case study of Asinou Church in Cyprus. In: 3rd Int. Conf. on Remote Sensing and Geoinformation of the Environment. Int. Society for Optics and Photoni 


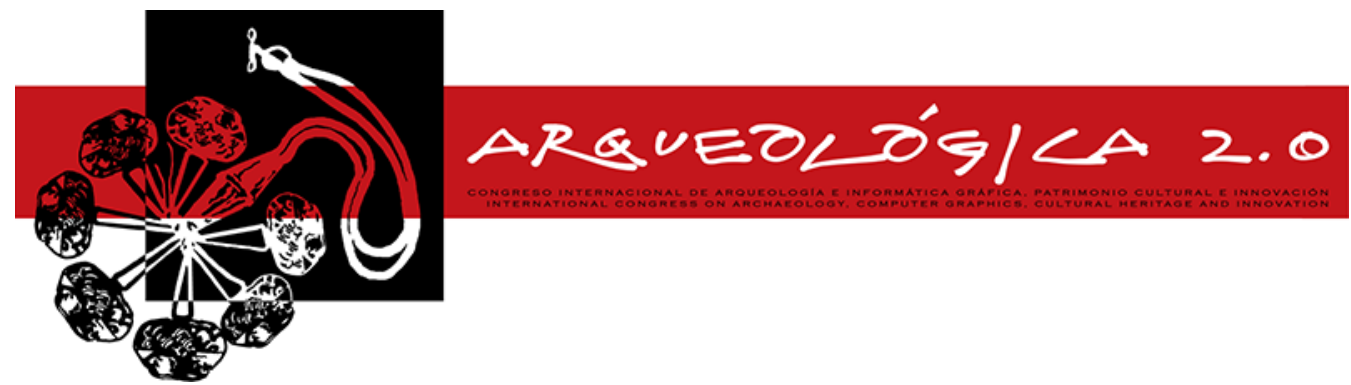

Proceedings of the $8^{\text {th }}$ International Congress

on Archaeology,

Computer Graphics,

Cultural Heritage and Innovation

'ARQUEOLÓGICA 2.0

in Valencia (Spain),

Sept. $5-7,2016$

\title{
UAV OBLIQUE DATA AND LASER SCANNING IN AN EXCAVATED AREA
}

\author{
Filiberto Chiabrando, Antonia Spanò, Giulia Sammartano, Lorenzo Teppati ${ }^{\star}$ \\ Dep. Architecture and Design, Politecnico di Torino, Viale Pier Andrea Mattioli, 39 - 10125 Torino, Italy. filiberto.chiabrando@polito.it, \\ giulia.sammartano@polito.it, antonia.spano@polito.it, lorenzo.teppati@polito.it
}

\begin{abstract}
:
This paper discusses some enhancements concerning 3D modelling and integration of 3D data from aerial and terrestrial sensors, developed by geomatics in the field of Cultural Heritage metric documentation. For archaeological purposes, it is interesting to deal with the considerable advantages in term of sustainability (automated acquisition, quickness, precision, time and cost cutting) of new multi-sensors approaches for the data acquisition and the management phases. In particular, the UAV (Unmanned Aerial Vehicles) Photogrammetry with the joint use of nadiral and oblique cameras, can be valuably combined with the large-scale details reach by terrestrial LiDAR in vast areas or complex objects, especially in mostly vertical sized objects. Here it will be reported an experience of integrated 3D survey in an archaeological context in Piedmont region (Italy), the Hercules Fountain in the gardens of the Venaria Reale. It has witnessed several historical phases during centuries, from its construction in 16th to the disuse and dismantling in 17th, up to the 21th century in which it was lastly brought back to light. The goal of the test is the generation of a 3D continuous model of the site for documentation purposes, future consolidation and enhancement projects finalized to a public promotion. To meet these aims a terrestrial laser scanning (TLS) survey has been designed combining terrestrial and UAV photogrammetric data acquisition, to produce a high detailed 3D textured model from which infer standard 2D drawings, digital orthoimages and further $3 \mathrm{D}$ releases. The entire workflow and outputs were compared together to evaluate the effectiveness of each elaboration according to the survey goals.
\end{abstract}

Key words: 3D documentation, Building Archaeology, Lidar, UAVs Photogrammetry, Oblique Cameras, Savoy Architecture

\section{3D data documentation role in archaeology: integration of ground- based data and UAV nadiral and oblique cameras}

New strategies with 3D multi-sensor metric survey prove that the documentation process can reach good levels of sustainability, in the direction of quality of information and in terms of time and cost. The georeferencing of spatial data is essential for interoperability during times, as a continuous part of the whole process of monitoring and Heritage preservation envolving sector-specific experts. Furthermore, the attempts of effective applications in archaeological contexts, must keep into account the importance of their spatial and temporal complexity and the choice of targeted surveys and sensors in terms of scale detail requested and of resources involved. A good numbers of research in Geomatics scenario towards these themes are approaching to improve and adapt themselves to the different sites needs (Remondino et al. 2011; Lerma et al. 2011; Balletti et al. 2015). In specific, for documentation purposes in the field of Building Archaeology, the high scale dense data generally reached by the combined use of TLS (active sensor) and close range photogrammetry (passive sensor) lead to a complete model rich in metric and non-metric information together with the completeness provided aerial documentation by UAV. In fact, these models allow studying not only the geometry of the surveyed object, via standars $2 \mathrm{D}$ and $3 \mathrm{D}$ representation (Boehler and Marbs 2004), but also for material analysis, pathologies and degradations, structural assessments, conservation monitoring (Patias 2013), virtual restoration and digital communication e.g. AugmentedIVirtual Reality, 3D GIS and HBIM tools to manage 3D reality-based information (Landeschi et al. 2016). Concurrently, UAV platforms are becoming in the last years one of the most employed system for aerial mapping and 3D modeling issues. For archaeological sites, either multi-rotor or fixed wing UAVs, offer low-cost alternatives to the classical manned aerial photogrammetry, performing data acquisition with high-resolution digital camera in semi-automatic and autonomous ways. Point clouds, DSM/DTM, orthophoto, textured 3D models, 2D drawing data, etc. can be quickly produced with controlled accuracy. Usually the acquisition for architectural and archaelogical documentation are performed using the camera oriented in the nadir direction, but a big attention is now focused also on the use of oblique images (Rupnik et al. 2014; Xiao et al. 2012) and the research activities in the geomatic field are even more oriented in optimization of these algorithms.

“Corresponding Author: Lorenzo Teppati, lorenzo.teppati@polito.it 


\section{The Hercules Fountain experience}

The integration of $3 D$ metric survey techniques is presented here in a complex test site: the Hercules Fountain in Venaria Reale (Fig. 1), a UNESCO Heritage site, belonging to the residences of Savoy Royal House, located $15 \mathrm{~km}$ northwest of Turin (Piedmont, Italy). Nowadays the ruins of the ancient masonries uncovered 11 years ago, are involved in a second step of restoration project that needed a detailed and complete 3D metric documentation, as base for restoration, promotion and valorization projects by the Venaria Reale Royal Palace Management Consortium (client of the documentation).

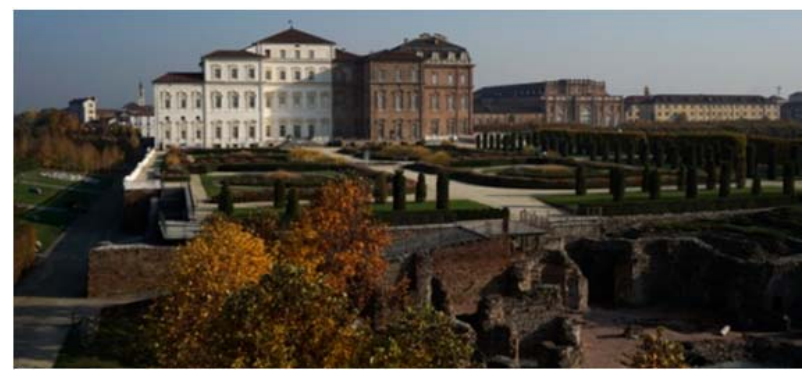

Figure 1: A view of the Reggia di Venaria Reale

Amedeo di Castellamonte (the royal architect of the Savoy family) projected the Reggia di Venaria in the second half of the XVII century, to be a hunting residence for the Royal Family, and the Fontana d'Ercole, richly decorated and covered with mosaics of shells and stones, located in the lower gardens between 1669 and 1672 (Cornaglia 1994). The Hercules fountain was subjected to a series of restorations and was finally dismantled in the 1751. The works for the restoration started only in the 1999 and, after years of efforts, the original magnificence of Reggia di Venaria was returned to the public; today, with 573.337 visitors in the last year, is one of the most visited historical sites in Italy. In the summer of 2005, the Fontana d'Ercole was brought to light during some work of excavation in the gardens, was restored and is now part of the tours of the Reggia (Cornaglia 1994). The structure of the masonries in the Hercules Fountain is quite complex and irregular; the Northern part of the structure, recently excavated, is exposed at the ground level and constrained by many trees, while the Southern area is still underground. Furthermore, the Eastern and the Western parts of the fountain differ in the terrain elevation and in the upstanding structures height. Finally, all masonries present a deep status of alteration and generally a bad conservation, since the architectural coating is almost totally lost.

In the site, an integrated multisensor 3D survey was conducted: the UAV photogrammetric acquisitions integrate the terrestrial one, via close-range photogrammetry and LiDAR survey. A complete oblique acquisition by UAV was performed with the aim to understand the real potentiality of the oblique cameras for large-scale documentation purpose. The collection of data have been carried out in several steps. The measurement of the topographic network by using static GPS/GNSS of 7 vertices. A group of Ground Control Points (GCPs) were placed on the masonries using paper targets, and then measured with a Total Station, for the photogrammetric process and scans registration.
The LiDAR scans performed by Focus3D Cam2 by Faro were planned to cover all the area $n^{\circ} 82$ acquisitions at $360^{\circ} ; n^{\circ} 79$ registered scans; $20^{*} 105$ points/scans; Resolution MPti $1 \mathrm{pt} / 6 \mathrm{~mm}$ at $10 \mathrm{~m})$. The terrestrial photogrammetric recording, using a Nikon D800E reflex digital camera (457images, $24 \mathrm{~mm}$ lens, $36 \mathrm{Mpx}$ CMOS sensor, image size $7360 \times 4912$ pixel, pixel $4.89 \mu \mathrm{m}$ ) using an overlapping $>80 \%$, complete the terrestrial documentation. The fieldwork was finally completed by three photogrammetric flights on the area, based on nadiral and oblique acquisitions to produce a detailed DSM of the fountain with a high-scale detail especially in the vertical dimension. They were perfrmed using a Hexakopter by Mikrokopter (Fig. 2) with a ground sample distance of $0.51 \mathrm{~cm}$. In the employed configuration the multi-rotor platform is equipped with a commercial offthe-shelf (COTS) Sony Alpha 5100 digital camera (24.3 MPx CMOS sensor, $6000 * 4000$ max resolution, pixel $3.92 \mu \mathrm{m}$, equipped with a $20 \mathrm{~mm}$ lens).

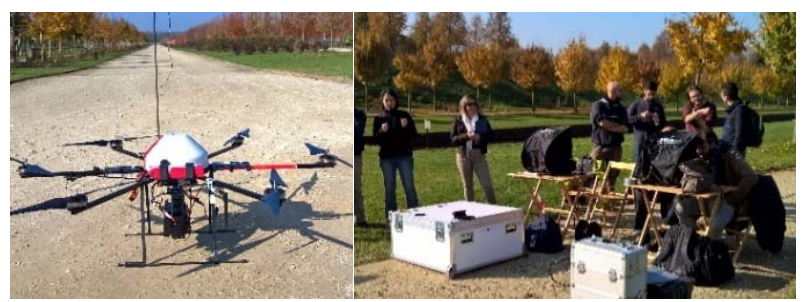

Figure 2: The multi-rotor system and the ground control station

Thanks to the Lidar precision in the very high scale, after the point clouds registrations, many orthoimages have been extracted (Using Pointcab software). Starting from this data, an accurate interpretation and drawing using CAD software (Figs. 3 y 4 ) have been performed. Furthermore, the terrestrial images collected on the field were processed as well, by photogrammetric approach based on Structure from motion (SfM) using Agisoft PhotoScan software. The results from the photogrammetric process on an area of $154 \mathrm{sqm}$ are: (GSD) $1.23 \mathrm{~mm} / \mathrm{px}$. (RMS) on 14 GCPs: $14 \mathrm{~mm}$. Final point cloud, 100millions of points, contains around $9608.06 \mathrm{pt} / \mathrm{m} 2$. Final digital surface: 1.6 million of triangles. Finally, the workflow has included the processing of the aerial acquisitions: camera orientation, images georefereincing using GCPs, point cloud densification, mesh calculation and texturization, with the software Pix4D for the generation of the final DSM and orthoimage (Fig. 3 y 5). The results from the photogrammetric process on an area of 10.700 sqm are: (GSD) $0.51 \mathrm{~cm}$. (RMS) on $29 \mathrm{GCPs}: 0.4 \mathrm{~cm}$. (RMS) on $12 \mathrm{CPs}$ : $0.5 \mathrm{~cm}$. Final point cloud, $71 \mathrm{ml}$ of points. Final mesh, $10 \mathrm{ml}$ of triangles.
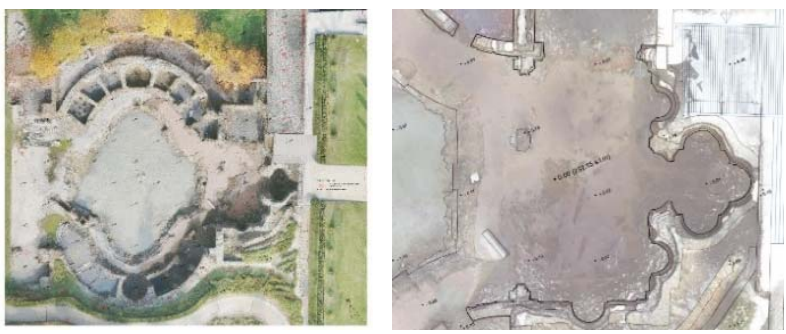

Figure 3: (left) The orthoimage from the UAV acquisition and (right) detail of top view of the vectorialized laser point cloud 

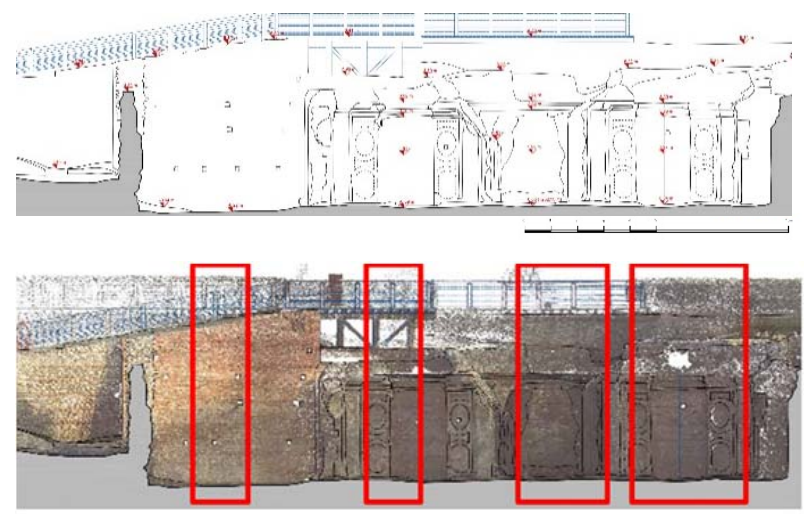

Figure 4: The digitalization of section G-G' from LiDAR data and the 4 samples for analysis: (a) masonry wall; (b) pilaster with niches, mixed stones-bricks walls; (c) central apse part, mixed stones-bricks walls; (d) lateral apse and walls ridges.
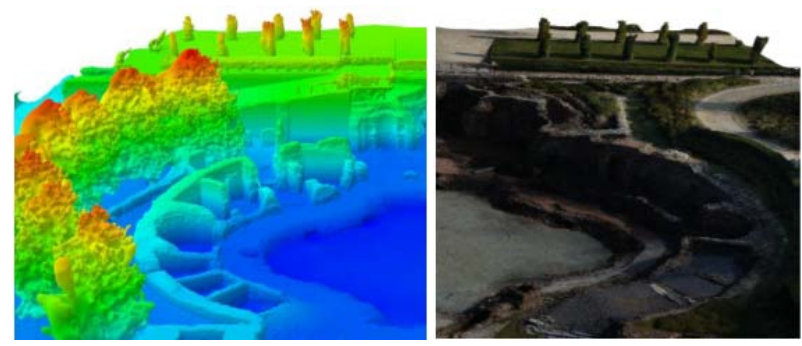

Figure 5: Images of the DSM in colors range by elevation (left) and the RGB textured one (right).

Since the aims of the 3D survey were the definition of the whole volume and the determination of the main geometries of the fountain, a comparison between different results and employed techniques is needed. Firstly, for the production of the plan it was necessary to integrate the terrestrial LiDAR data and the orthoimages from the aerial ones. The laser point cloud defined in a hight detailed way all the masonries features in order to cover different levels of the entire fountain area, both in the caves and in the bassin. The coverage of the TLS was generally very good and wide but lacked in details in the higher portions of the masonries. Otherwise, the data from UAV, despite the intrinsic different scale, allowed filling deficiencies of the terrestrial point cloud and generating a complete $3 \mathrm{D}$ model of the site. In Table1 some comparison data on one (Fig. 6) of the samples tested for a global evaluation on the 3 different sensors.

\section{Conclusions}

In case these complex objects or sites, the integration of multisensors data can be pinpointed, according to acheived results, as the best solution for a multiscale 3D documentation. Infact, the level of detail offered by the three approaches applied on the case study, if distinctly evaluated, are indeed different, and then their scale is diverse in terms of quality of image, richness of information, time and resources consumption (human, software, hardware). Thus, their selection depends mostly by the characteristics of the sites and the available time for the fieldwork. Neverthless the use of TLS has to be combined anyway with cameras acquisition for high quality texturing of the model. Then time processing and human involvement in close-range acquisitions can be defined as very competitive factors thanks to the more and more automated algorithms of digital photogrammetry now available. It is importan to underline that all these technology improvements in digital photogrammetry softwares are largely affected by computer hardware configuration. The geometrical definition provided from the UAV photogrammetry process is radically different in terms of scale, but this technique complete necessarily the terrestrial survey and reach a good definition of DSM, thanks to the combinated nadiral and oblique cameras, now increasingly use in research applications.
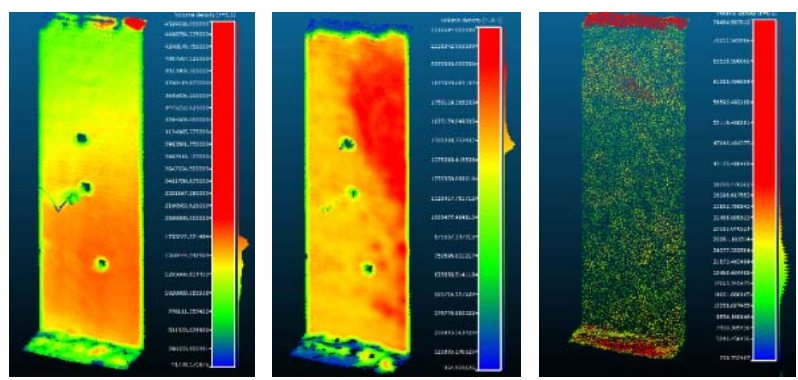

Figure 6: Example of Density analysis on Sample (a): point clouds (left) from LiDAR, $n^{\circ}$ pt 2.617.678, Density 186.995 $\mathrm{pt} / \mathrm{m} 2$; (centre) close-range phot., $\mathrm{n}^{\circ} \mathrm{pt} 2.734 .377$, Density $205.860 \mathrm{pt} / \mathrm{m} 2$; (right) UAV nºt 44.823, Density $3.489 \mathrm{pt} / \mathrm{m} 2$.

Table 1: Results from comparison between points clouds. Close-range and UAV photogrammetry were matched to LiDAR by "cloud/cloud distance" tool in Cloud Compare software.

\begin{tabular}{l|c|c|c}
\multicolumn{2}{c|}{ Absolute distances $(m)$} & Lidar-close-r & Lidar - UAV \\
\hline Sample (a) & mean & 0.012 & 0.016 \\
& st. dev. & 0.007 & 0.013 \\
Sample (b) & mean & 0.009 & 0.017 \\
& st. dev. & 0.011 & 0.021 \\
Sample (c) & mean & 0.004 & 0.021 \\
& st. dev. & 0.003 & 0.030 \\
Sample (b) & mean & -- & 0.014 \\
& st. dev. & - & 0.015
\end{tabular}

\section{References}

BALLETTI, C., GUERRA, F., SCOCCA, V. and GOTTARDI, C., 2015. 3D integrated methodologies for the documentation and the virtual reconstruction of an archaeological site. The International Archives of Photogrammetry, Remote Sensing and Spatial Information Sciences, 40(5), 215.

BOEHLER, W. and MARBS, A., 2004. 3D scanning and photogrammetry for heritage recording: a comparison. Proceedings of the 12th International Conference on Geoinformatics, University of Gavle, Sweden, pp. 291-298

CORNAGLIA, P., 1994. Giardini di marmo ritrovati. La geografia del gusto in un secolo di cantiere a Venaria Reale (1699-1798). Torino: Lindau. 226 pages. 
LANDESCHI, G., DELL'UNTO, N., LUNDQVIST, K., FERDANI, D., CAMPANARO, D.M. and LEANDER, A.M., 2016. 3DGIS as a platform for visual analysis: Investigating a Pompeian house, Journal of Archaeological Science, Vol. 65, pp. 103-113

LERMA, J.L., SEGUÍ, A.E., CABRELLES, M., HADDAD, N., NAVARRO, S. and AKASHEH, T., 2011. Integration of laser scanning and imagery for photorealistic 3D architectural documentation. INTECH Open Access Publisher.

PATIAS, P., 2013. Overview of applications of close-range photogrammetry and vision techniques in Architecture and Archaeology, in MCGLONE, C. (edited by), Manual of Photogrammetry, 6th edition, Asprs (American Society of Photogrammetry and Remote Sensing), pp. 1093-1107.

RUPNIK, E., NEX, F., REMONDINO, F., 2014. Oblique multi-camera systems - orientation and dense matching issues. Int. Archives of the Photogrammetry, Remote Sensing and Spatial Information Sciences, Vol. 40 (3/W1), pp. 107-114

STRECHA, C., 2014. The rayCloud-a vision beyond the point cloud. FIG Congress 2014, Engaging the Challenges Enhancing the Relevance, Kuala Lumpur, Malaysia 16 - 21 June 2014

WIEDEMANN, A. and MORE, J., 2012. Orientation strategies for aerial oblique images. ISPRS Archives of Photogrammetry, Remote Sens ing and Spatial Sciences, Vol. 39 (B1).

XIAO, J., GERKE, M., VOSSELMAN, G., 2012. Building extraction from oblique airborne imagery based on robust façade detection, Int. Journal of Photogrammetry and Remote Sensing, 68, pp. 56 - 6 


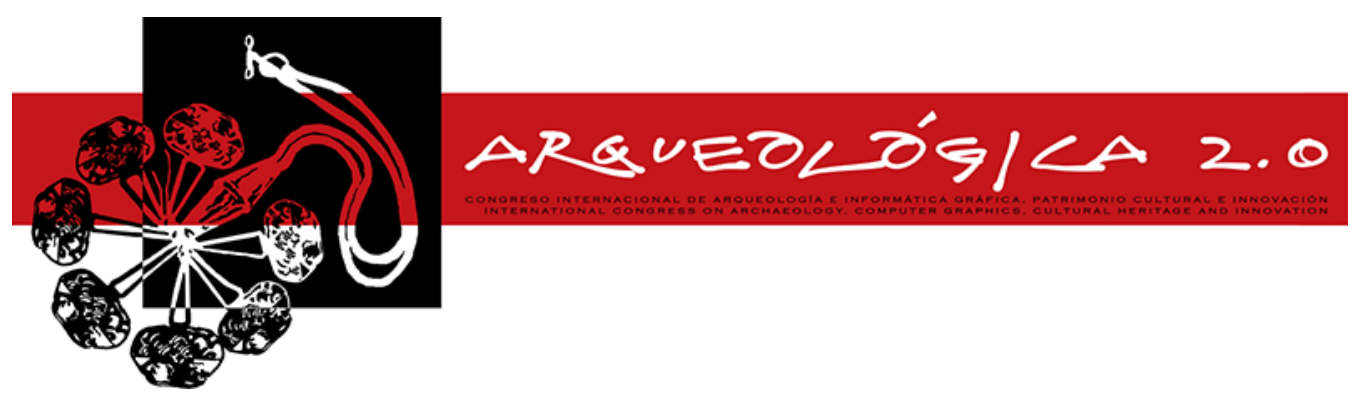

Proceedings of the $8^{\text {th }}$ International Congress

on Archaeology,

Computer Graphics,

Cultural Heritage and Innovation

'ARQUEOLÓGICA 2.0'

in Valencia (Spain),

Sept. $5-7,2016$

\title{
REPORT ON THE DIGITAL RECONSTRUCTION OF THE 4TH CENTURY SUSA (WORK IN PROGRESS)
}

\author{
Filiberto Chiabrando $^{a}$, Livio Dezzani ${ }^{\mathrm{b}}$, Antonio Prencipe ${ }^{\mathrm{c}}$, Antonia Spanò ${ }^{\mathrm{a}^{*}}$ \\ ${ }^{a}$ Department Architecture and Design, Politecnico di Torino, Mattioli 39, 10125 Torino, Italy. filiberto.chiabrando@polito.it; \\ antonia.spano@polito.it \\ b “Immagine e Territorio”, Corso Stati Uniti 27, 10129 Torino, Italy. livio.dezzani@gmail.com \\ ${ }^{c}$ Pworx LAB, Via Monginevro 7, 10050 Sant'Antonino di Susa (TO), Italy. antonio prencipe@libero.it
}

\begin{abstract}
:
The reconstructive study of the urban arrangement of Susa in the fourth century arise from the intention to exploit some resources derived by local studies and survey activities fulfilled by innovative methods from which the modeling of architectural heritage $(\mathrm{AH})$ and virtual reconstructions are derived. The digital Segusio presented in this paper is the result of intensive discussion and exchange of data and information shared among the urban landscape documentation activities, and systems of virtual models generation, able to provide the charm of an ancient landscape. The land survey has been accomplished using aerial and terrestrial acquisition systems, mainly using digital photogrammetry from UAV (Unmanned Aerial Vehicle) and terrestrial laser scanning. Results of both methods have been integrated to medium scale geographical data available from regional map repository and some processing and visualization supported by GIS (Geographical Information System) have been fulfilled.

Then, starting from accurate and detailed DEM (digital elevation model) and from other architectural scale models concerning the ancient heritage, the modelling of the ancient scenery arose. The reconstruction of an ancient scene begins with an accurate account of all the evidences from the studies of materials and documentary sources. The analysis and representation of the territory, supervised with the tools of geographic data management, are therefore primarily a media of analysis, then of comparison and validation with other data. Only after these steps, the land and the built heritage models become tools of communication and education, which are the typical functions of the virtual reconstruction of ancient environments. The integration of the history of city with digital and multimedia resources will be offered to the public in the city museum housed in the restored castle of Maria Adelaide, which stands in the place where the acropolis of the city lay in ancient times
\end{abstract}

Key words: digital archaeology, 3D models, 3D survey, GIS, cultural landscape, 3D reconstruction

\section{Aims}

The history of the valley and the city of Susa in the Celtic and Roman periods are widely present in the literature, especially related to archaeological investigations, which is a scientific proof of the interest of the land's history and its heritage.

The ancient remains are partly well-preserved but a unified and organic transposition of this important story told through modern multimedia has not yet made. Such tools are currently recognized to be a feasible means to bring the stories of the past to a wider audience, even, and perhaps in specifically, that in school age.

The innovative tools and the significant advances that have radically changed and expanded the descriptive potential of traditional metric survey techniques are now more adaptable to the evolving framework of needs, featured by a rapid specialization in many fields of application.

Especially when the relationships with the natural environment and the landscape are significant (but now the belief that it is a relevant factor in any context is shared), it has to be possible to relate the objects of historical and archaeological interest with the natural component of the landscape.

This paper reports the development of a study that started from the set of known information about the city of Susa and continued with the adoption of innovative survey systems, terrestrial laser scanning and aerial and terrestrial photogrammetry, for the documentation of archaeological preserved emergencies in relation to urban and natural territory. The spatial multiscale information managed with GIS tools in a single system has enabled to achieve in different phases of approach

`Corresponding Author: Antonia Spanò, antonia.spano@polito.it 
to the ancient hypothetical configuration, until the 3D virtual reconstruction.

\section{Brief news item on the history of the city}

Segusio (today: Susa, near Turin, Italy) is located at the far west edge of the Po Valley, where the climb towards the passes of Mont Cenis and the Montgenevre start. The present paper concerns this city of Celtic origin.

We know nothing concrete on Celtic Segusio, however we know perfectly the time when Segusio entered in the influence of Rome.

The Arch of Augustus is the imposing and very well preserved monument describing this particular moment. The arch arose in the year 8 B.C., as a testimony of the agreement arranged between the Celtic king named Cozio and Emperor Augustus. (Fig. 1)

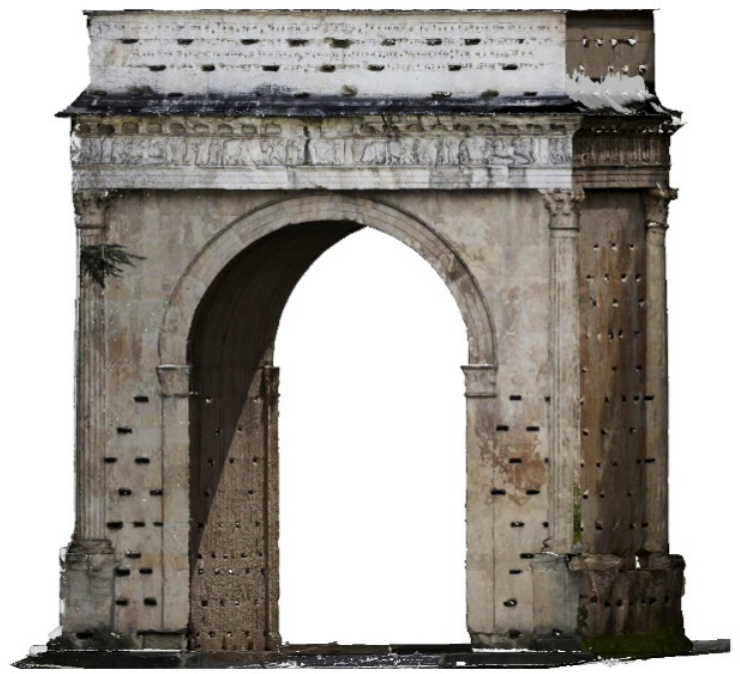

Figure 1: Integrated photogrammetical and laser scanning model of the Arch of Augustus.

Unfortunately, the related ruins are very limited, but a typical Roman urban arrangement, with temples and monuments and without town walls may be assumed. (Mercando 1993; Barello 2007, 2008).

In an imprecise moment but dated somewhere around 275 AD, the "first Susa" was violently swept away by one of the first barbarian invasions. Therefore, a "second Segusio" developed presumably in about ten years, not as an open city but as a heavily fortified urban settlement (Dezzani and Patria 2009, 2010).

That Segusio has been submit to a digital reconstruction. More precisely, the attempt is the reviving of Segusio in 355 AD. Marcellinus was traveling with the emperor, and he left a description of Segusio defining it as a fortified city.

\section{Landscape and Heritage reality based modelling}

The new survey technologies offered by Geomatics allow in a rather accessible way to acquire terrestrial and aerial data compatible with each other, so the integration is possible. The low altitude of UAV flights is particularly significant in the field of ancient and architectural heritage located in urban contexts. This ability added to the chance of describing an object from different points of view, aerial and terrestrial ones, are a topical issue in the architectural and landscape survey and modelling since this operation makes possible to analyze the objects in a more detailed and complete way, helping the phase of knowledge, comparing and monitoring.

The ancient Architectural Heritage $(\mathrm{AH})$ of Susa has undergone in the recent past to a wide campaign of surveys, via terrestrial techniques (photogrammetry and laser scanning) and aerial methods by the use of UAV photogrammetry, with the aim of documenting and thus enhancing a little-known heritage (Aicardi et al. 2015).

From UAV photogrammetry images it is possible to extract point clouds, 3D textured models, Digital Surface Model (DSM) and Orthophoto. The data processing techniques are mainly automated by an image matching approach (Kersten and Lindstaedt 2012; Remondino et al. 2014) The automation derive from the use of the Structure-from-Motion (SFM) method, that allow estimating the 3D position of points represented in multiple images, reconstructing the geometry of the represented object (structure) and the acquisitions position (motion), even when are not available the defined camera calibration parameters.

Moreover the LiDAR technology (Light Detection And Ranging) is well-established for applications in the field of Cultural Heritage, in the knowledge and documentation phases, allowing to gain a lot of information on surfaces also articulated with a high precision and quality.

The obtained 3D models are featured by the different resolution and a multiscale information content. (Fig. 2).

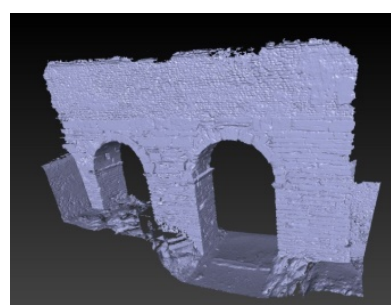

a)

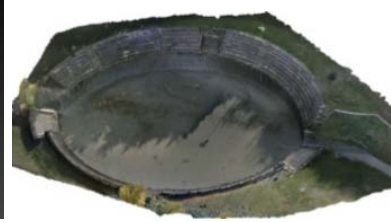

b)

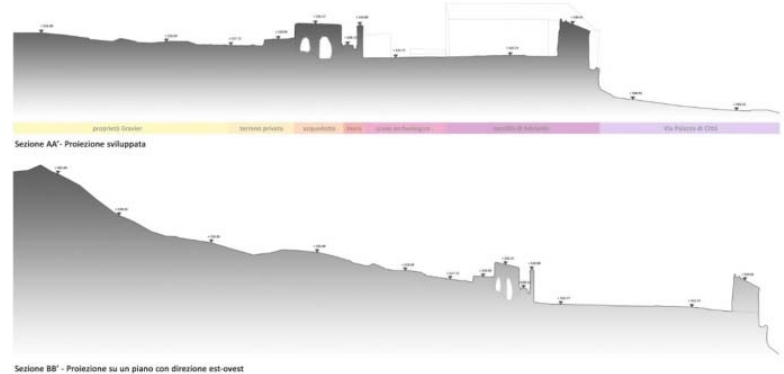

c)

Figure 2: 3D models: a) Very high detailed model of arches of the aqueduct; b) UAV model (30m height flight) of the amphitheater; c) Section profiles, accomplished by GIS tools, aimed to study the path of water flow connected with the aqueduct arches. 
This is the reason why the data at different scales have been finally implemented within a GIS structure in order to connect multiple needs.

\section{The ancient city model}

One of the most critical aspects in the study of reconstruction of monuments and ancient cities is the need to assume shape and consistency of public and private buildings especially in their configuration in elevation, and compositional aspects of fronts.

Despite the objective lack of direct material sources, inevitable in the contexts in which the urban continuity has succeeded over the centuries up to the present configuration, the graphic reconstruction was inspired by the representations and descriptions handed down by historical figures who saw directly the chosen scene (as Ammianus) and of course the available literature of studies, research, insights.

Given the scarceness of data assured, the accomplished virtual reconstruction, does not claim to be a true representation of a bygone era, but rather wants to be credible in the general overview and in some of its structural parts.

We therefore believe that the reconstruction model created (Fig. 3) show a credible idea of how the city could appear in 355 A.D.
It was a small town of about 1,500/2,000 inhabitants, including the Cardo and Decumanus as main streets, but with an additional artery that connected the two major ports: Port Savoy and Porta Piemonte.

The city then had a regular frame, but not squared with the Castrum area and the Arch of Augustus that dominates from the imposing fortress. A back door also allowed the exit to the arena, located outside the walls in a natural depression. The city wall was surrounded on the north by the river Dora, to the east by the river Cenischia and to the south by the ditch.

We believe that this project will lead to demonstrate the valuable possibility of using heterogeneous tools of investigation, analysis and representation of the territory and of the built heritage developed within different scientific communities, enabling to group the study outcomes into products that communicate ancient scenarios in some detail.

The use of the results of historical research, as well as those of the non-standard photogrammetric surveys (UAV) and terrestrial laser scanning (TLS), the management of geographic information in GIS and even virtual reconstruction tools (Maya - Autodesk) have made possible to coordinate the pieces of certain knowledge and and those hypothesized in a single "picture" of the whole city.

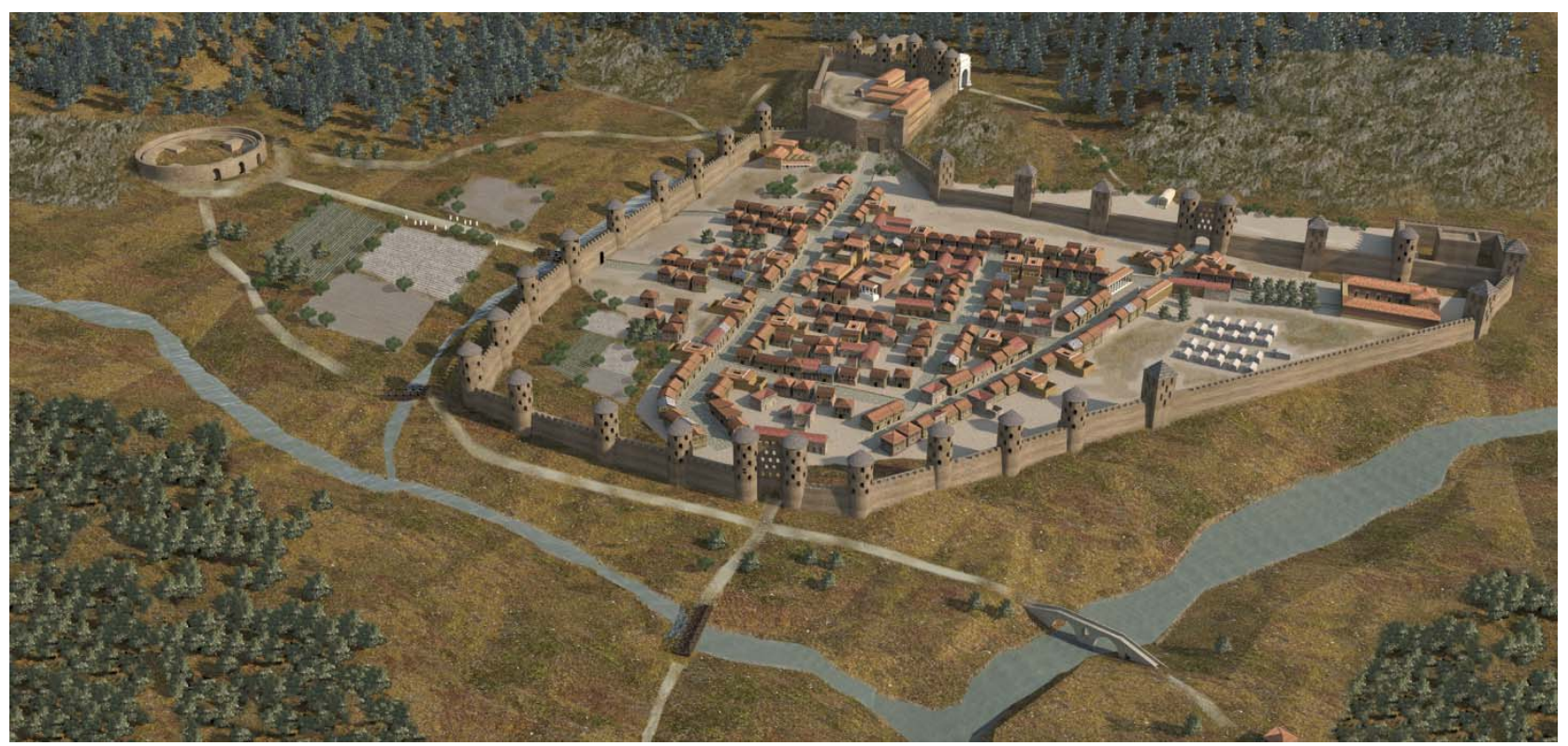

Figure 3: The reconstructive model of Segusio.

\section{References}

AICARDI, I., BOCCARDO, P., CHIABRANDO, F., DONADIO, E., LINGUA, A., MASCHIO, P., NOARDO, F. and SPANÒ, A., 2015. Modelli 3D multisensore per l'acropoli segusina, in L'arco di Susa e i monumenti della propaganda imperiale in età augustea, Segusium, pp195-216.

BARELLO, F., 2007. Archeologia urbana a Segusio, in Brecciaroli Taborelli L. (eds), Forme e tempi dell'urbanizzazione nella Cisalpina, Firenze, 2007.

BARELLO, F., 2008. Segusio, nuovi dati archeologici sulla nascita di una capitale, in Alpis Poenina Une voie à travers l'Europe, Aosta, 2008.

DEZZANI, L. and PATRIA, L., 2009. Dalla Segusio romana alla villa Secusie medioevale: forme urbane, strade e risorse ambientali, in Segusium, 48. 
DEZZANI, L. and PATRIA L., 2010. Territorio, strade e città fortificate: tarda antichità e medioevo a cavallo delle Alpi, in Segusium, 49.

KERSTEN, T.P. and LINDSTAEDT, M. 2012. Potential of Automatic 3D object reconstruction from multiple Images for applications in Architecture, Cultural Heritage and Archaeology. International Journal of Heritage in the Digital Era, Multi Science Publishing, pp. 399-420.

MERCANDO, L., 1993 (eds). La Porta del paradiso. Un restauro a Susa, Stamperia Artistica nazionale, Torino.

REMONDINO, F., SPERA, M.G., NOCERINO, E., MENNA, F. and NEX, F. 2014. State of the art in high density image matching, The Photogrammetric Record, XXIX-146, DOI:10.1111/phor.12063, pp. 144-166. 


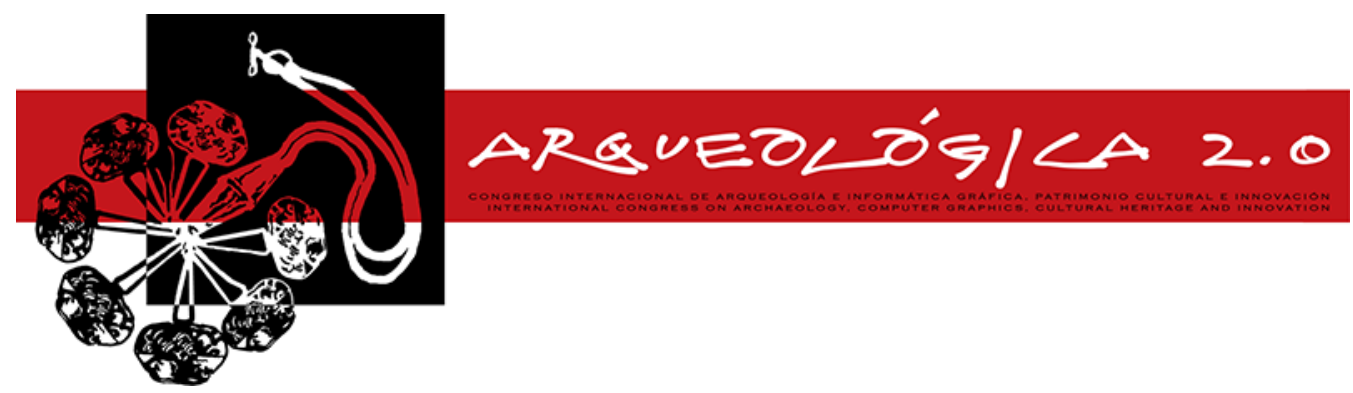

Proceedings of the

$8^{\text {th }}$ International

Congress on

Archaeology, Computer

Graphics, Cultural

Heritage and Innovation

'ARQUEOLÓGICA 2.0'

in Valencia (Spain),

Sept. $5-7,2016$

\title{
UN NUEVO ESPACIO TERMAL DE ÉPOCA ROMANA ANEXO A LA VILLA DEL CASALE (PIAZZA ARMERINA, SICILIA): PROPUESTA DE RECONSTRUCCIÓN VIRTUAL DE SUS AMBIENTES FRÍOS A LA LUZ DE LOS HALLAZGOS ARQUEOLÓGICOS
}

\author{
A NEW ROMAN THERMAL SPACE ATTACHED TO THE VILLA DEL CASALE (PIAZZA ARMERINA, SICILY): \\ PROPOSAL FOR VIRTUAL RECONSTRUCTION OF ITS COLD ROOMS TO THE LIGHT OF THE NEW \\ ARCHAEOLOGICAL FINDS.
}

\author{
Javier Atienza \\ Universidad Nacional de Educación a Distancia (UNED). arkeografia@gmail.com
}

\begin{abstract}
:
The archaeological excavations conducted in the surroundings of the villa of Casale, near the town of Piazza Armerina, Sicily, have unearthed the remains of an unknown new thermal complex to date. Together with the remains of architectural structures, it have been exhumed other evidences of decorative or ornamental nature whose study has allowed the elaboration a working hypothesis about what might have been the look of some of the main rooms that shaped this, unpublished until now, thermal installation. The excavation campaigns carried out to date in this area have not been enough to know the total extension of this new thermal complex, so the final results are necessarily subject to the results that may be obtained once it has proceeded to the total excavation of the affected area and the study of materials collected during these future interventions.

However, the work that is posed here is primarily focused on the space identified as frigidarium or cold environment, which has provided very meaningful data about its decoration. Sometimes, the remains preserved in situ regarding the decoration of walls and floors were sufficiently significant to discard any doubts about their appearance and composition; on other occasions, the fragmentary remains of pictorial decorations have been sufficiently numerous and revelators to deduce in a convincing way its original compositional scheme.
\end{abstract}

Key words: virtual archaeology, frigidarium, thermal complex, villa of Casale, 3D reconstruction

\section{Resumen:}

Las excavaciones arqueológicas realizadas en los alrededores de la villa del Casale, cerca de la localidad de Piazza Armerina, en Sicilia, han sacado a la luz los vestigios de un nuevo complejo termal desconocido hasta la fecha. Junto con los restos de las estructuras arquitectónicas, han sido exhumadas otras evidencias de carácter decorativo u ornamental cuyo estudio ha permitido elaborar una hipótesis de trabajo acerca de cuál pudo haber sido el aspecto de algunos de los ambientes que conformaron este, hasta ahora inédito, espacio termal. Las campañas de excavación efectuadas hasta la fecha en esta área no han sido suficientes como para conocer la extensión total de este nuevo complejo termal, por lo que los resultados definitivos quedan, necesariamente, supeditados a los resultados que se puedan obtener una vez que se haya procedido a la excavación total del área afectada y al estudio de los materiales recogidos durante esas futuras intervenciones.

No obstante, el trabajo que aquí se plantea se centra fundamentalmente en el espacio identificado como frigidarium o ambiente frío, el cual ha aportado unos datos muy significativos sobre su decoración. Unas veces, los restos conservados in situ de la decoración pavimental y parietal eran lo suficientemente significativos como para desechar cualquier duda sobre su apariencia y composición; en otras ocasiones, los restos fragmentarios de la decoración pictórica han sido lo suficientemente numerosos y reveladores como para deducir de una manera convincente su esquema compositivo original.

Palabras clave: arqueología virtual, frigidarium, complejo termal, villa del Casale, reconstrucción 3D 


\section{Introducción y contexto histórico}

Desde hace más de diez años, un equipo de arqueólogos de la Universidad "La Sapienza" de Roma viene realizando excavaciones arqueológicas en el entorno de la villa del Casale (Piazza Armerina, Sicilia). El presente trabajo, que se enmarca dentro de un estudio integral sobre la decoración marmórea del conjunto residencial principal, no hubiera sido posible sin el apoyo y el impulso del Prof. Patrizio Pensabene.

En la campaña de excración de 2008 se localizaron las primeras estructuras de lo que más tarde se indentificó como un nuevo complejo termal. Este edificio, aún en fase de excavación, fue construido en época tardoantigua, posiblemente al tiempo que se levantaban el resto de las estancias del complejo principal de la villa del Casale. A lo largo de los siglos posteriores, este edificio sufre diversas refacciones, y sus instalaciones e infraestructura son utilizadas en época islámica como recinto o área eminentemente industrial.

El edificio se articula en torno a dos sectores claramente diferenciados: un grupo de ambientes cálidos (por la presencia de parte del hipocaustum), conformado por al menos tres estancias individualizadas, situadas en la mitad sur; en contraste con los ambientes de la mitad norte, donde hasta el momento se han individualizado cinco estancias, las cuales no presentan signos de haber tenido ningún sistema de calefactado (Fig. 1).

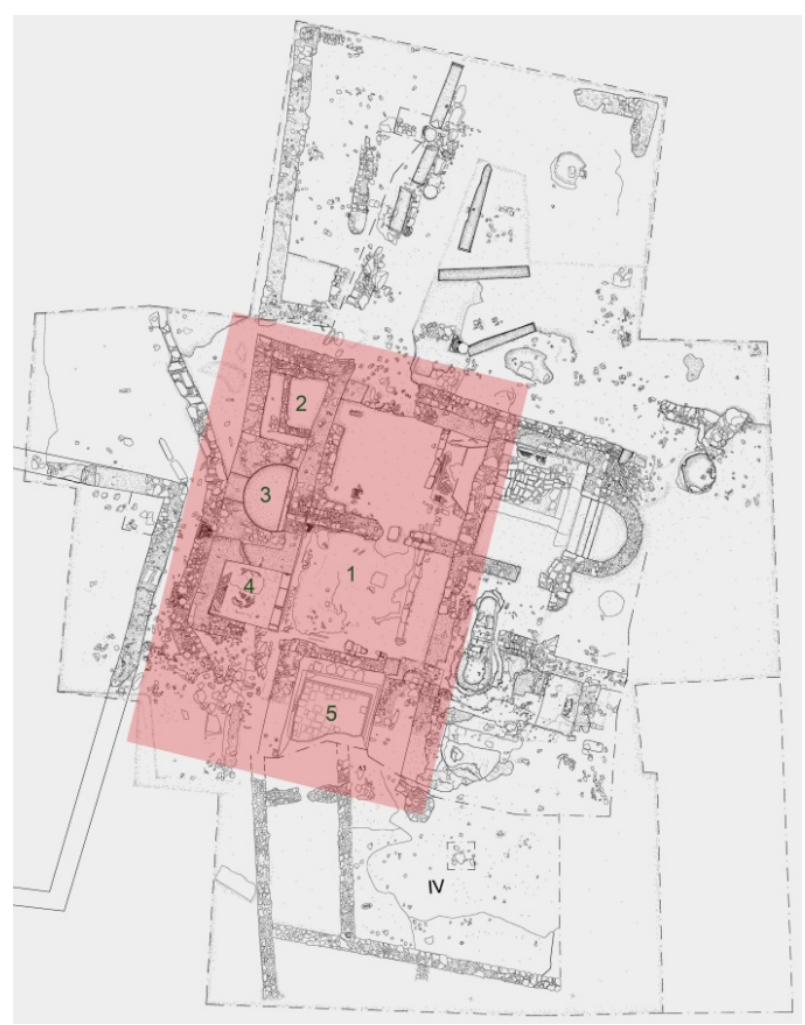

Figura 1: Plano general del establecimiento termal al sur de la Villa del Casale. Se ha destacado el ambiente del frigidarium y los números indican las estancias referenciadas en este trabajo: 1 frigidarium; 2 ¿latrina?; 3 bañera absidiada; 4 ¿apodytherium?; 5 natatio mayor.

\section{Los ambientes fríos: el frigidarium y las estancias perimetrales}

El ambiente identificado como frigidarium es el más amplio de todos los que se han localizado hasta el momento. Presenta unas medidas que alcanzarían los $5,8 \mathrm{~m}$. de anchura y los $10 \mathrm{~m}$. de longitud. El acceso principal a este espacio se realizaria a través de un vano centralizado localizado en el muro oriental. Originalmente, este espacio presentaría un pavimento musivo continuo compuesto por teselas que varían entre los 0,5 y los 1,5 centímetros de lado (Barresi y Pensabene 2014). El diseño general del mosaico está conformado por un damero central realizado a base de pequeños cuadrados de 2,5 a 3 centímetros de lado, de diversos colores (negro, blanco, gris, verde y rojo) que se van combinando hasta formar una composición a base de líneas quebradas o en zigzag de manera alterna y siempre en el mismo orden. Este diseño central está circundado en todo su perímetro por una ancha franja decorada a base de ondas y dentículos, también polícromos.

La regularidad de este diseño del pavimento musivo del frigidarium se ve alterada en varias ocasiones con la aparición de otros elementos, también musivos. Así, en el lado sur, junto al vano que da acceso a las estancias caldeadas, se puede observar un área de forma rectangular, enmarcada mediante cintas lisas (dos de color negro en los extremos y una central, más ancha, de color blanco) que repite en su parte central los mismos motivos zigzagueantes que el mosaico principal. En uno de los ángulos de esta zona enmarcada aparece otro pequeño mosaico con la representación de un tipo de calzado ligero ${ }^{1}$. Finalmente, otro recuadro musivo de pequeñas dimensiones (unos $40 \mathrm{~cm}$. de anchura y 50 $\mathrm{cm}$. de altura) se localiza en la parte central, y lo forma una inscripción a base de teselas blancas sobre un fondo de teselas rojas; todo ello enmarcado mediante cintas de color negro (Fig. 2).

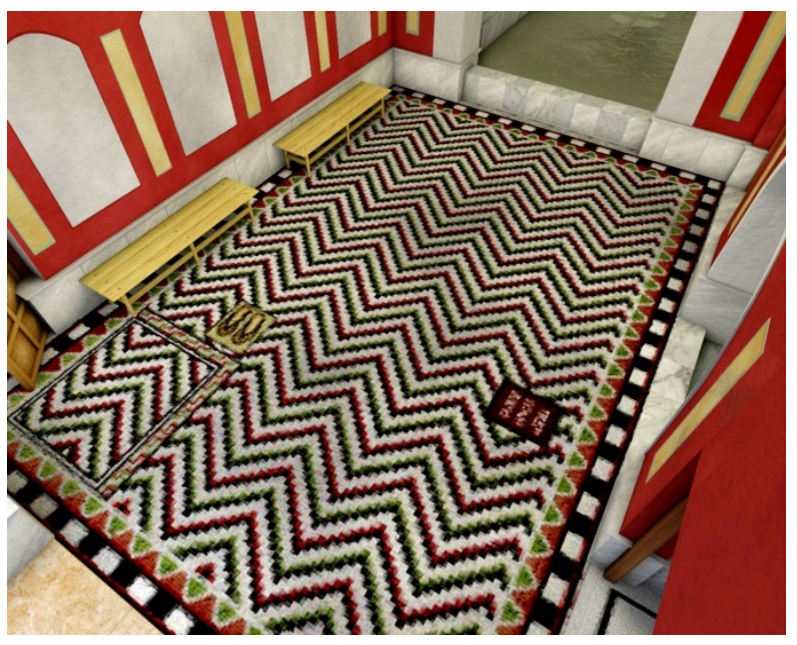

Figura 2: Vista sobreelevada de la recreación virtual del frigidarium en base a los elementos originales conservados in situ.
${ }^{1}$ Este motivo decorativo estaba ampliamente difundido en los ámbitos termales desde la época imperial, y serviría, además, como advertencia a los usuarios de estas instalaciones del uso de un calzado específico en las estancias calefactadas. 
La ausencia de ninguna huella ni resto de elemento arquitectónico de apoyo aislado, como columnas o pilares, e incluso adosados, como pilastras, hace pensar que este espacio central debió de cubrirse con una bóveda de cañón corrido (Fig. 3).

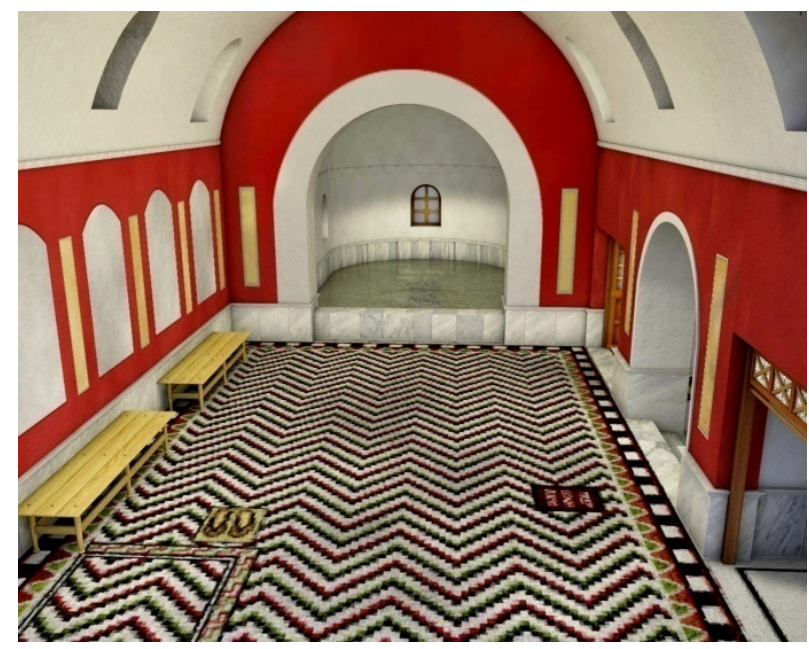

Figura 3: Vista general de la recreación del frigidarium con la disposición de las distintas estancias en torno al espacio central.

En el muro del lado norte del frigidarium se abren tres estancias secundarias: una bañera central, con el muro del fondo en forma de ábside, flanqueada en sus lados oriental y occidental por dos habitaciones de planta ligeramente rectangular.

La bañera central presenta el fondo a un nivel inferior respecto al pavimento de la parte central del frigidarium y el acceso a ella se realiza a través de tres peldaños revestidos originalmente de placas marmóreas de tonalidades claras. La pared, absidiada, conserva la decoración original consistente en un mosaico parietal de teselas blancas, con una banda decorada con ondas polícromas sobre fondo oscuro, a modo de imposta, y que coincide con el nivel del pavimento del espacio central. Por encima de esta cenefa decorativa, los restos conservados son muy fragmentarios, pero es posible que, sobre el fondo blanco se representasen motivos marinos $^{2}$. Justo por encima de la cenefa, aproximadamente en la parte central del ábside, se conservan los restos de un vano de sección cuadrada, identificado como una ventana, que otorgaría una iluminación adicional a este ambiente. Aunque no se ha conservado resto alguno de la cubrición de este espacio, ésta, al igual que ocurre y se ha documentado en otros establecimientos termales similares $y$ contemporáneos cronológicamente, debió realizarse con una bóveda hemisférica (Fig. 4).

La estancia rectangular del flanco oriental no ha conservado ningún resto de su decoración original ni en sus paramentos ni en su pavimento. Por el contrario, la estancia occidental, a la que se accedía a través de un umbral conformado por tres losas de mármol blanco, conserva los restos de un mosaico pavimental,

\footnotetext{
${ }^{2}$ Esta circunstancia parece repetirse en la decoración musiva del interior de la gran fuente central del Peristilo principal de la villa del Casale.
}

geométrico y polícromo, donde el motivo central (un octógono) está conformado por la intersección de dos cuadrados. En el centro, a modo de emblema, aparece un motivo cruciforme ${ }^{3}$.

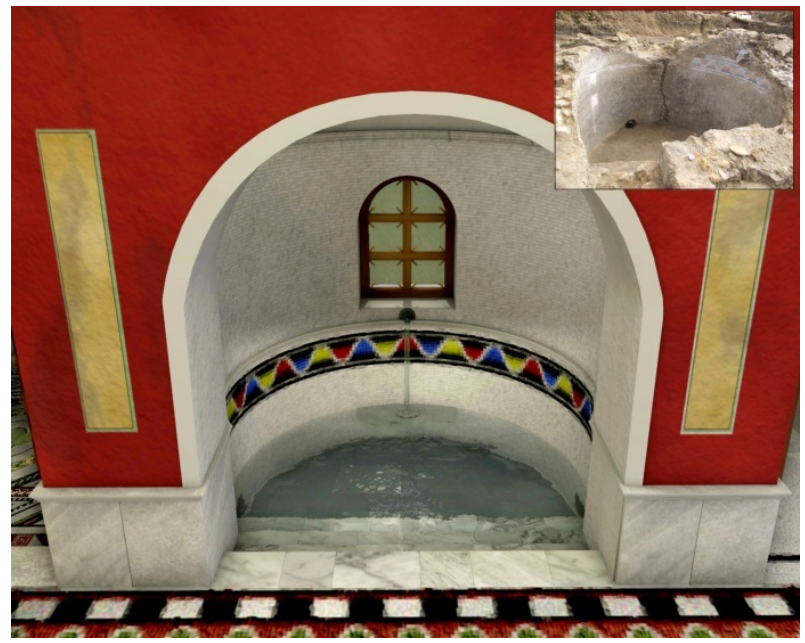

Figura 4: Recreación virtual de la bañera absidiada abierta en la parte central del muro norte del frigidarium. En el recuadro superior, una imagen de los restos conservados.

Tanto la funcionalidad de la estancia occidental como la de la estancia oriental son desconocidas. No obstante, su ubicación próxima al acceso principal al edificio, así como la necesidad manifiesta de este tipo de establecimientos de disponer de estancias destinadas a dar servicio a los ususarios, parecen indicar una función de vestuario o apodytherium ${ }^{4}$. Esta es al menos la funcionalidad más aceptada para la estancia occidental, mientras que para el ambiente oriental se ha propuesto también que funcionase como latrina (Carloni y Piay 2014). Por lo que respecta a su cubrición, los restos exhumados no ofrecen una respuesta definitiva.

En 2013 se descubrió, abierta en el muro occidental del frigidarium, una estructura que parece corresponder con otra bañera o natatio, de mayores dimensiones que la anterior. Aunque la excavación de este ambiente no ha finalizado, los restos exhumados permiten extraer algunas conclusiones sobre su apariencia y configuración. Así, el acceso a la misma se realizaba a través de un vano de $2,5 \mathrm{~m}$. de anchura, parcialmente cerrado por un pequeño pretil de unos $40 \mathrm{~cm}$. de altura. Tras el pretil se encuentran dos escalones que descienden hasta el fondo de la natatio y que pudieron servir, además, como asientos o lugares de reposo para los usuarios. Tanto los escalones de acceso como los muros laterales han conservado restos de las lastras marmóreas de recubrimiento, todas ellas de tonalidades claras. El fondo de la natatio está pavimentado con baldosas de barro cocido de tonalidad ocre/amarillenta. En el encuentro entre las superficies verticales de las paredes laterales y del escalón inferior y el pavimento

\footnotetext{
${ }^{3}$ Muy similar en cuanto a ejecución y temática con el mosaico pavimental existente en el "larario" del Gran Peristilo del interior de la villa del Casale.

${ }^{4}$ La disposición de los apodytheria o vestuarios en el complejo termal principal de la villa del Casale se situan también en el frigidarium y, además, flanqueando por ambos lados las dos bañeras existentes.
} 
del fondo se dispuso un cordón sanitario en forma de medio bocel para facilitar la limpieza y el mantenimiento de estos espacios.

Al no estar completamente terminada la excavación arqueológica de este espacio, es imposible determinar la forma que adoptaba el cerramiento de fondo: podría tratarse de un muro recto o de uno en forma de ábside. La recreación virtual que aquí se presenta propone un cerramiento absidiado basándose principalmente en el hecho de que todos los espacios internos de la villa del Casale destinados a contener agua presentan este tipo de solución arquitectónica. La solución más lógica para la cubrición de este ambiente debió ser, como ocurrió en la natatio grande del complejo termal del interior de la villa del Casale, mediante una bóveda de cañón en el tramo recto y una bóveda de cascarón en la parte absidiada. La iluminación de este ambiente debió realizarse mediante la apertura de uno o varios vanos en los muros laterales y probablemente también en el muro de cierre, no obstante, no se ha conservado ninguna huella al respecto (González y Atienza, forthcoming).

Las paredes perimetrales del frigidarium también debieron de estar decoradas. La excavación arqueológica del frigidarium ha aportado información suficiente como para tratar de restituir el aspecto original que pudo tener esta estancia. Así, los fragmentos de lastras marmóreas de revestimiento recogidas hasta la fecha, en su mayoría de tonalidades blancas, sugieren la presencia de un zócalo inferior (del que se desconoce la altura que pudo haber alcanzado) que evitaría el contacto directo de la decoración pictórica parietal con el pavimento musivo del suelo, propenso a encharcarse o, cuando menos, a ser una fuente constante de humedad. Por encima de este zócalo marmóreo se extendería la decoración pictórica, de la que se conservan restos todavía in situ en gran parte del muro sur y de la que se han recuperado suficientes fragmentos como para proponer una restitución fiable de su programa decorativo: grandes paneles rectangulares, al menos en su base inferior, de tonalidades muy claras o blancas, separados mediante otros paneles más estrechos y alargados verticalmente, también rectangulares, de tonalidad más amarillenta. El fondo general sobre el que se destacaban y contrastaban cromáticamente los motivos descritos parece ser de una tonalidad rojiza intensa (Pensabene et al. 2015).

\section{Conclusión}

Este nuevo espacio termal viene a enriquecer y a complementar el ya de por sí valiosísimo legado arqueológico de la villa del Casale. Las similitudes de todo tipo identificadas entre los edificios del interior de la villa y este espacio termal extramuros de la misma (Pensabene et al. 2014) parecen indicar que ambos edificios forman parte de un mismo momento constructivo, es decir, que se construyeron prácticamente al mismo tiempo y que, por lo tanto, estuvieron en uso simultáneamente (Pensabene 2014).

Por su parte, la existencia de ambos complejos termales y su diferente situación respecto al conjunto de edificios que conforman la pars urbana de la villa, (este nuevo edificio termal se encuentra en el exterior del acceso principal al interior de la villa) lleva a pensar en la posibilidad de que se diera una diferenciación en cuanto al estatus social de los usuarios de cada uno de estos establecimientos (Atienza 2015). Así, mientras que las termas principales, en el interior de la villa, darían servicio al propio Dominus, a su familia e invitados, en las termas externas meridionales los usuarios principales pudieron haber sido sobre todo miembros del personal de servicio y subalterno.

\section{Referencias}

ATIENZA, J., 2015. El programa decorativo marmóreo de la villa romana del Casale (Piazza Armerina, Sicilia). In J.M. ÁLVAREZ, T. NOGALES and I. RODÀ, eds. Proceeding XVIIt International Congress of Classical Archaeology. Centre and Periphery in the Ancient World. Vol. II. Mérida, pp. 1915-1917.

BARRESI, P. y PENSABENE, P., 2014. Nuovi mosaici dal complesso della Villa del Casale a Piazza Armerina. In Atti del XIX Colloquio dell'Associazione Italiana per lo studio e la Conservazione del Mosaico (AISCOM). Tívoli, pp. 199-208.

CARLONI, CH. y PIAY, D., 2014. Le terme meridionali: nuovi scavi 2010-2012. L'evoluzione del frigidarium. In P. PENSABENE and C. SFAMENI, eds. La Villa restaurata e i nuovi studi sull'edilizia residenziale tardoantica. Atti del convegno internazionale del CISEM, Piazza Armerina, 7-10 novembre 2012. Bari, pp. 595-608.

GONZÁLEZ, L. y ATIENZA, J., (forthcoming). La decoración arquitectónica del complejo termal meridional de la Villa del Casale de Piazza Armerina: elementos marmóreos de las campañas de excavación de los años 2011 al 2013. Proceedings of the Congress DECOR. Linguaggio architettonico romano. 21-24 maggio, 2014. Roma.

PENSABENE, P., 2014. Nuove scoperte alla Villa del Casale di Piazza Armerina: magazini, terme, e fornaci. In P. PENSABENE and C. SFAMENI, eds. La Villa restaurata e i nuovi studi sull'edilizia residenziale tardoantica. Atti del convegno internazionale del CISEM, Piazza Armerina, 7-10 novembre 2012. Bari, pp. 9-18.

PENSABENE, P., DI DIO BALSAMO, G., GALLOCCHIO, E. y GALLOTTA, E., 2015. II nuovo complesso termale della villa del Casale di Piazza Armerina. Lo scavo, il rilievo e la ricostruzione. In J.M. ÁLVAREZ, T. NOGALES and I. RODÀ, eds. Proceeding XVIII International Congress of Classical Archaeology. Centre and Periphery in the Ancient World. Vol. II. Mérida, pp. 1907-1910.

PENSABENE, P., GONZÁleZ DE ANDRÉS, L. y ATIENZA, J., 2014. La villa del Casale en Piazza Armerina: cálculo volumétrico y análisis tipológico de los mármoles de revestimiento y de los elementos arquitectónicos. In $P$. PENSABENE and C. SFAMENI, eds. La Villa restaurata e i nuovi studi sull'edilizia residenziale tardoantica. Atti del convegno internazionale del CISEM, Piazza Armerina, 7-10 novembre 2012. Bari, pp. 595-608. 


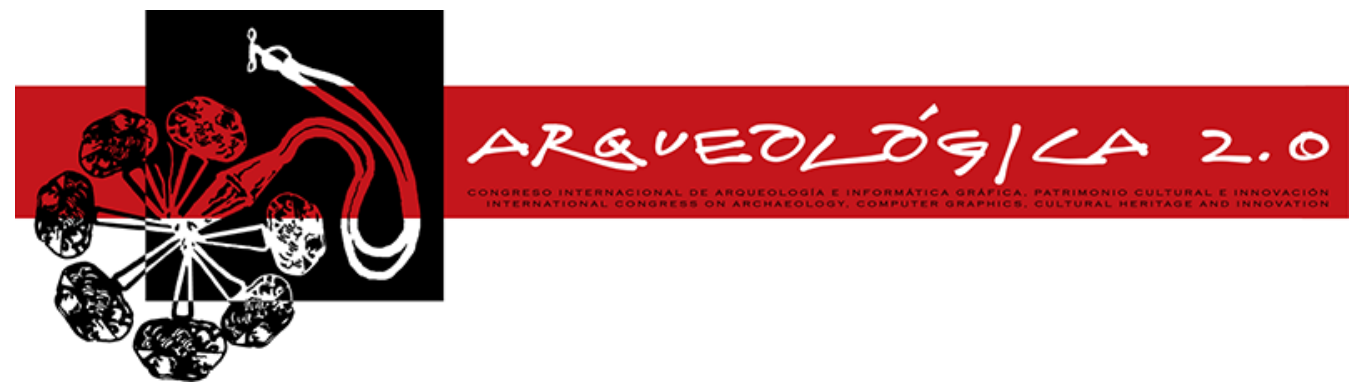

Proceedings of the $8^{\text {th }}$ International Congress

on Archaeology,

Computer Graphics,

Cultural Heritage and Innovation

'ARQUEOLÓGICA 2.0'

in Valencia (Spain),

Sept. $5-7,2016$

\title{
GEORRADAR Y TOMOGRAFÍA ELÉCTRICA PARA LA CARACTERIZACIÓN DE UN YACIMIENTO ARQUEOLÓGICO MEDIEVAL (CONJUNTO ARQUEOLÓGICO CASTILLO DE LA ESTRELLA, MONTIEL)
}

GPR AND ERT FOR THE CARACTERIZATION OF A MEDIEVAL ARCHAEOLOGICAL SITE (CASTLE OF LA ESTRELLA, MONTIEL)

\author{
José Luis Sánchez ${ }^{\mathrm{a}, \mathrm{d}}$, David Gallego ${ }^{\mathrm{b}}$, Jesús Molero ${ }^{\mathrm{a}, \mathrm{d}}$, Jesús Sánchez ${ }^{\mathrm{c}, \mathrm{d}}$, Óscar Merlo ${ }^{\mathrm{c}, \mathrm{d}}$ \\ ${ }^{a}$ Facultad de Letras de Ciudad Real, Universidad de Castilla-La Mancha, Avenida Camilo José Cela s/n, 13071, Ciudad Real, España. \\ ibericaarqueologia@gmail.com; jesus.molero@uclm.es \\ ${ }^{b}$ Fundación Castillo de la Estrella, Calle de la Diputación 8, 13326, Montiel, España. davidgallegovalle@gmail.com \\ ${ }^{c}$ Escuela Técnica Superior de Ingenieros de Caminos, Canales y Puertos de Ciudad Real, Universidad de Castilla-La Mancha, Avenida \\ Camilo José Cela s/n, 13071, Ciudad Real, España. jesus.svizcaino@uclm.es; oscar.merlo@uclm.es \\ d Laboratorio de Arqueología, Patrimonio y Tecnologías emergentes (LAPTE), Universidad de Castilla-La Mancha, Avenida Camilo \\ José Cela s/n, 13071, Ciudad Real, España.
}

\begin{abstract}
:
This paper presents the results of recent geophisycal prospection in Castle of La Estrella (Montiel, Spain). This is one of the most important archaeological medieval sites located in Castilla-La Mancha. The fortress was built between $10^{\text {th }}$ and $11^{\text {th }}$ centuries like an Islamic hisn. Later it becomes into an encomienda of Order of Santiago in $13^{\text {th }}$ century. The western area of the fortress was explored in order to investigate the identification of buried structures associated to the Homage Tower, and the existence of the historical access called "Puerta del Patio". The methods used were electric resistivity tomography (ERT) 2D-3D and electromagnetic prospection (ground penetrating radar-GPR). An archaeological excavation was subsequently carried out in this area to verify the validity of the geophisycal exploration results.
\end{abstract}

Key words: applied geophysics, ground penetrating radar, electric tomography, 3D resistivity imaging, Montiel.

\section{Resumen:}

Este trabajo presenta los resultados de la reciente prospección geofísica realizada en el Castillo de la Estrella (Montiel, España). En la actualidad, este es uno de los yacimientos arqueológicos medievales más importantes localizados en Castilla-La Mancha. La fortaleza se construyó entre los siglos X y XI como hisn islámico organizador de los territorios aledaños. Posteriormente se convirtió en encomienda de la Orden de Santiago en el siglo XIII. La investigación en la zona oeste de la fortaleza se realizó con el objetivo de identificar posibles estructuras enterradas asociadas a la Torre del Homenaje, así como a la localización del acceso histórico denominado "Puerta del Patio". Los métodos empleados fueron la tomografía eléctrica en 2D y 3D, y la exploración electromagnética mediante georradar. Sobre la base de esta investigación inicial, se llevó a cabo en esta zona una excavación arqueológica destinada a verificar la validez de los resultados obtenidos a partir de los trabajos geofísicos desarrollados.

Palabras clave: geofísica aplicada, georradar, tomografía eléctrica, imágenes de resistividad 3D, Montiel.

\section{Introducción}

El Conjunto Arqueológico Castillo de La Estrella de Montiel (Ciudad Real) (Fig. 1), es un yacimiento con una andadura muy joven aún. Las actuaciones arqueológicas comenzaron en el año 2012, dentro del marco de colaboración de la UCLM, el Ayuntamiento de Montiel, y la incorporación posterior de la Fundación Castillo de La Estrella, que actualmente gestiona el conjunto. El proyecto forma parte del programa de ayudas a la investigación arqueológica de la Junta de Comunidades de Castilla-La Mancha, con el se han desarrollado numerosas intervenciones.

Desde el punto de vista arqueológico, se trata de un asentamiento con una ocupación prehistórica, especialmente durante la Edad del Bronce, y un contexto medieval muy ámplio con una fortificación con fases construcitvas entre los siglos IX al XV. En la

`Corresponding Author: José Luis Sánchez Sánchez, ibericaarqueologia@gmail.com 
ladera sur, dentro del Sector I del yacimiento, se ha localizado una intensa ocupación entre la que destaca el hallazgo de la iglesia de Nuestra Señora de la Estrella (ss. XIII-XV), así como parte de una zona de edificios islámicos (ss. IX-XIII) y el primitivo camino de acceso al castillo (ss. XIII-XVI) (Molero y Gallego 2013).

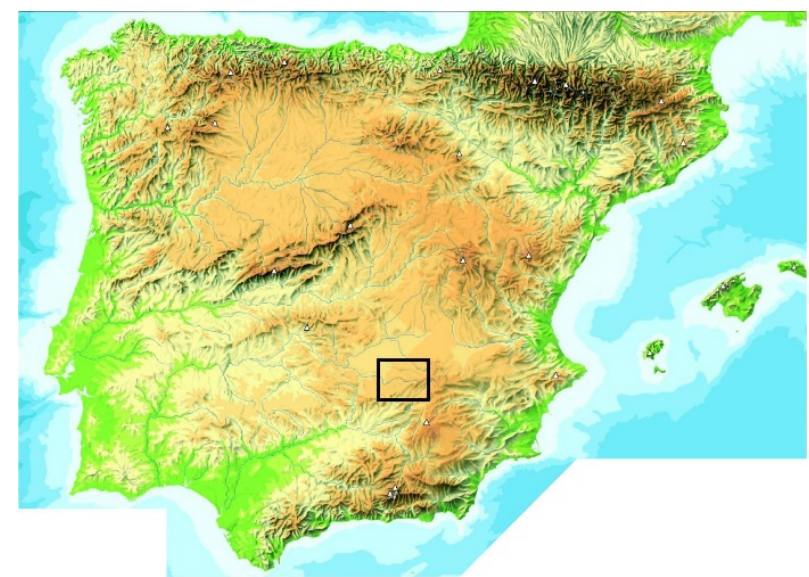

Figura 1: Localización del Conjunto Arqueológico Castillo de La Estrella de Montiel.

El plan de intervenciones en el yacimiento ha tenido, desde el primer momento, una apuesta decidida como marco de experimentación de las nuevas tecnologías aplicadas al patrimonio. Por ello, desde el 2012 aplica la fotogrametría terreste y por medio de drone, como apoyo a la excavación y los trabajos de conservación de las estructuras (Ruiz et al. 2015). Por otro lado, con el fin de programar eficientemente las actuaciones, se ha realizado un amplio plan de estudios geofísicos en los diversos sectores del yacimiento.

Con el fin de colaborar en la mejora del conocimiento subsuperficial del conjunto arqueológico, se seleccionó para la realización de los trabajos de prospección geofísica y arqueológica el lado oeste del castillo propiamente dicho, que se corresponde con el recinto interior construido por la Orden de Santiago. Se ubica en la cota más elevada del cerro y se adapta a la geomorfología del terreno. En este sitio donde se sitúa la torre del Homenaje, se pretende en primer lugar, conocer las dimensiones exactas de la misma, así como el grosor y potencia de su muro de cierre este, colapsado y soterrado. En segundo lugar, documentar la existencia de la puerta del patio, que funcionaría según las fuentes archivísticas como un acceso principal a este recinto fortificado. $Y$, en tercer lugar, la documentación de otras posibles estructuras constructivas anexas, pertenecientes al entramado urbano militar de esta zona del yacimiento.

\section{Métodos y equipos}

En la presente investigación se han aplicado los métodos eléctrico y electromagnético, mediante el uso de la tomografía eléctrica y del georradar-GPR (Ground Penetrating Radar). Para la elección de estos métodos se ha tenido en cuenta las dimensiones y topografía de la zona, y los posibles contrastes de valor que puede presentar el parámetro físico a medir a un tiempo entre los materiales del yacimiento y en el sustrato geológico que los alberga (Sánchez et al. 2015).
El equipo de tomografía empleado fue el SuperSting R8 $\mathrm{PI}$, resistivímetro multi-canal del subsuelo con almacenamiento en memoria de lecturas de los ciclos de medida definidos. En cuanto al software de inversión utilizado, AGI Earthlmager 2D y 3D es el software estándar para imágenes de resistividad de Advanced Geosciences.

En nuestra campaña de trabajo con georradar, se utilizó el equipo NOGGIN 250 y SpiView, que es software estándar suministrado con el equipo.

\section{Metodología}

En la zona de exploración de la torre del homenaje, el estudio con georradar consistió en la ejecución de catorce perfiles, todos separados entre sí $1 \mathrm{~m}$. Se situaron en función de la topografía del terreno. Seis perfiles de $7 \mathrm{~m}$ en la parte superior, en un área amesetada delimitada por la proyección de los muros pertenecientes a la torre del homenaje, con más de $2 \mathrm{~m}$ de grosor, observables en superficie. Medidos según la orientación NO-SE (dirección A). Otros ocho perfiles de $12 \mathrm{~m}$ (P6 a P9) y $15 \mathrm{~m}$ (P10 a P12), medidos según la orientación NE-SO (dirección B), ejecutados en paralelo a la zona con pendiente, originada por el colapso de la torre. La longitud total de estos perfiles es de $157 \mathrm{~m}$ y abarcan una superficie de $93 \mathrm{~m} 2$.

La investigación mediante tomografía eléctrica en esta zona ha consistido en la ejecución de un total de cuatro perfiles paralelos entre sí, de dirección SO-NE, de 28 electrodos cada uno, con espaciado inter-electródico de $1 \mathrm{~m}$ y separados entre sí $1,5 \mathrm{~m}$ (Fig. 2). Conforman un rectángulo regular de toma de medidas de $27 \times 4,5 \mathrm{~m}$. Y un bloque 3D con 56 electrodos (con punto inicial en el electrodo 15 del perfil de tomografía M010). Estos perfiles se midieron con las configuraciones dipolodipolo 3D, radial gradient 3D, dipolo-dipolo, WennerSchlumberger y strong gradient. A partir de estas medidas se han realizado las correspondientes secciones de resistividad 2D.

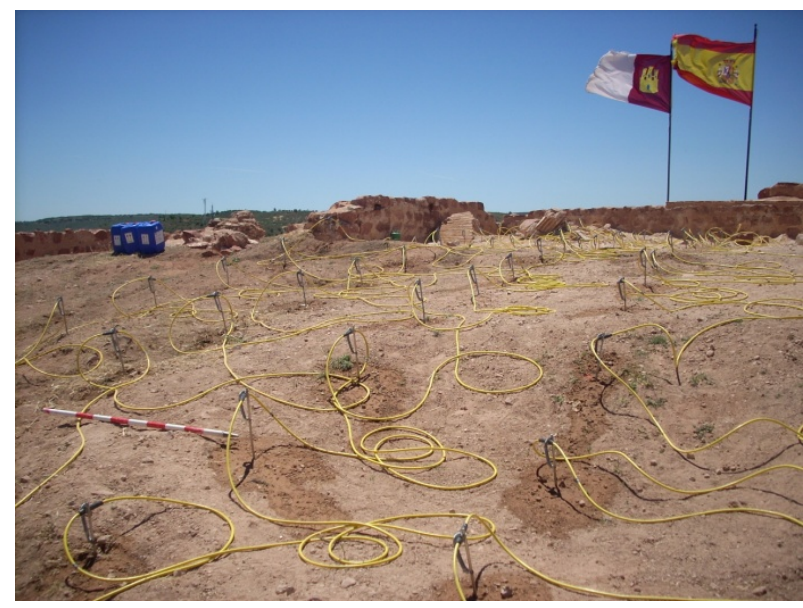

Figura 2: Vista general de la zona oeste del castillo. Electrodos dispuestos sobre el terreno para medición 3D.

Adicionalmente, los perfiles realizados en las zonas de exploración torre del homenaje, han sido indexados para obtener un modelo virtual 3D de cada uno de ellos (Fig. 3). 


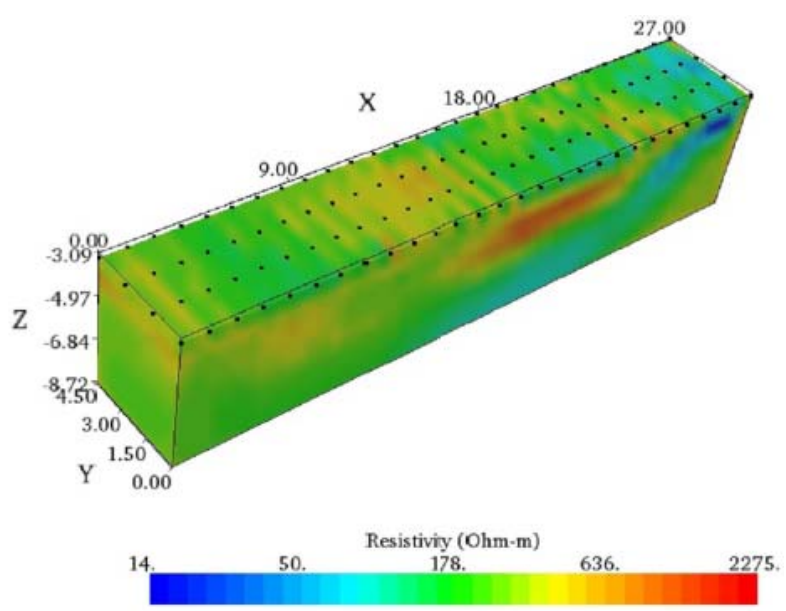

Figura 3: Bloque 3D generado a partir de los cuatro perfiles ejecutados en la zona Torre del Homenaje. Las anomalías constructivas se destacan en color amarillento y rojizo.

\section{Resultados preliminaries y conclusiones}

La exploración geofísica ha permitido determinar los sectores en los que se registran una cantidad importante de elementos anómalos. Con estos datos se pretende caracterizar la disposición espacial y naturaleza física de las anomalías documentadas en la prospección geofísica, y su contraste a partir de excavaciones arqueológicas sistemáticas.

\subsection{GPR}

Los registros obtenidos en esta zona con georradar son muy complejos, los potentes restos constructivos colapsados de la torre, conformados por grandes mampuestos y sillares de arenisca, provocan que la onda transmitida por la antena de $250 \mathrm{MHz}$ sufra multitud de refracciones, obteniéndose unos radargramas donde las anomalías que generan las principales estructuras quedan atenuadas. Se caracterizan por una continuidad horizontal o con una leve inclinación en la secuencia de reflexión de los radargramas (Fig. 4). Se corresponden con materiales procedentes del desplome de los muros de la torre del homenaje, de la muralla de la fortaleza y del muro del patio, por lo tanto, con una composición física idéntica a la de estas estructuras. Tienen unas dimensiones longitudinales de entre 7 y $15 \mathrm{~m}$, según el perfil de exploración, y ocupan la totalidad del espacio analizado. En este sentido señalar que las principales anomalías hiperbólicas, se relacionan con gruesos muros enterrados o cubiertos prácticamente en su totalidad por los derrumbes antes descritos.

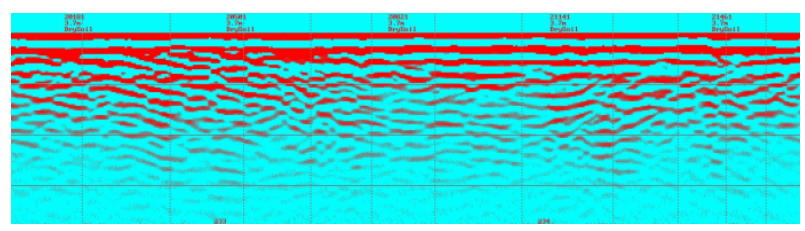

Figura 4: Perfil de georradar adquirido con antena de 250 $\mathrm{MHz}$. Las numerosas reflexiones de onda confirman los derrumbes masivos de material constructivo.

\subsection{Tomografía eléctrica}

Los perfiles 2D y los bloques 3D de tomografía han permitido obtener una visión del subsuelo del yacimiento en esta zona con bastante precisión horizontal (Fig. 5). Se han caracterizado correctamente las distintas tipologías basadas en el binomio estructuras arquitectónicas-colapsos murarios. Se ha observado que cuando existe un derrumbe muy potente tanto en altura como en espesor, compuesto por grandes sillares de arenisca y morteros de cal disgregado, como el documentado mediante excavación en la zona del patio, los muros cubiertos por esta unidad pierden nitidez lateral en el perfil, aumentando considerablemente su tamaño como anomalía resistiva en comparación con el muro arqueológico real. Por el contrario, la posición subvertical de las estructuras arquitectónicas y de los paquetes de relleno constructivo se corresponde exactamente con el metro indicado en cada sección eléctrica.

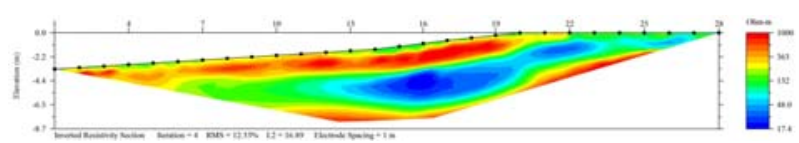

Figura 5: Perfil de tomografía eléctrica en el área de estudio. La escala de colores representa los valores de resistividad de los materiales $(\Omega . m)$.

\section{Referencias}

MOLERO, J. y GALLEGO, D, 2013, El primer encastillamiento cristiano del Campo de Montiel, In: A. PRETEL MARÍN, coord., Alcaraz del Islam al concejo castellano. Alcaraz, pp. 113-142.

RUIZ, J.A, GALLEGO, D., PEÑA, C., MOLERO, J. y GÓMEZ, A., 2015. Fotogrametría aérea por drone en yacimientos con grandes estructuras. Propuesta metodológica y aplicación práctica en los castillos medievales del Campo de Montiel, Virtual Archaeology Review, 6 (13), pp. 5-19. DOI: 10.4995/var.2015.4366

SÁNCHEZ, J.L., SÁNCHEZ, J. y MERLO, O., 2015. Exploración geofísica del Conjunto Patrimonial de Las Virtudes, In: V. M. LÓPEZ-MENCHERO, coord., El enigma de Las Virtudes. Estudio histórico-arqueológico del Santuario de Las Virtudes (Santa Cruz de Mudela). Ciudad Real, pp. 115-155. 


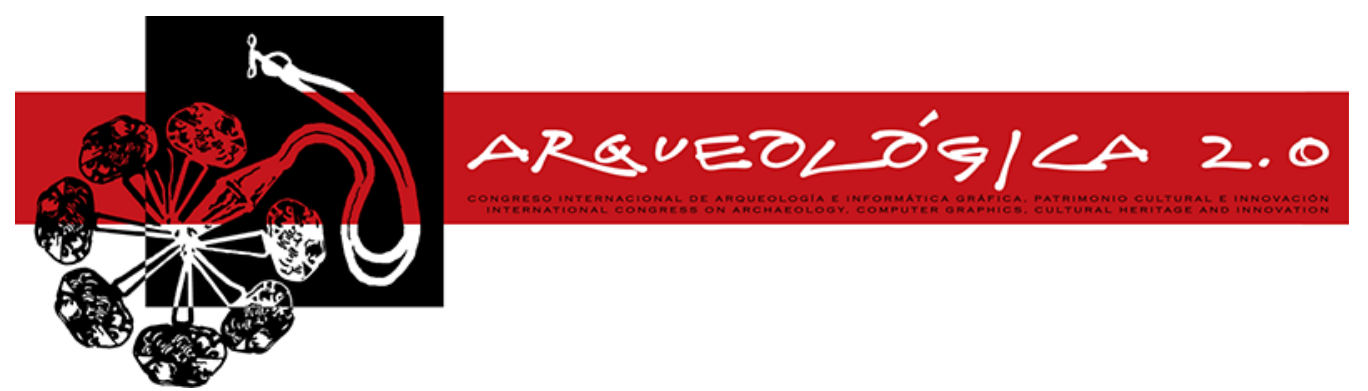

Proceedings of the $8^{\text {th }}$ International Congress

on Archaeology,

Computer Graphics,

Cultural Heritage and Innovation

'AROUEOLÓGICA 2.0'

in Valencia (Spain),

Sept. 5-7, 2016

\title{
PRIMEROS RESULTADOS DE LA RECONSTRUCCIÓN VIRTUAL DEL CASTILLO DE TURÍS (TURÍS, VALENCIA, ESPAÑA)
}

\author{
THE FIRST RESULTS OF THE VIRTUAL RECONSTRUCTION OF TURIS CASTLE (TURÍS, VALENCIA, SPAIN) \\ José Luis Jiménez*, Enrique Díes, José Tierno \\ Departamento de Prehistoria y Arqueología, Facultad de Geografía e Historia, Universidad de Valencia, Avda. Blasco Ibáñez, 28, \\ 46010 Valencia, España. jose.I.jimenez@uv.es; endiescu@gmail.com; itiernor@hotmail.com
}

\begin{abstract}
:
The Turís's castle (Turís, Valencia, Spain), named commonly, The Castellet, is a construction that between the eleventh and fifteenth century, played an outstanding role in the defense of the territory of Valencia. In the last years the University of Valencia comes developing historical - archaeological investigations and there have been carried out several actions of consolidation and enhancement. We present the first results of the virtual reconstruction of the castle.
\end{abstract}

Key words: virtual archaeology, cultural heritage, documentation, 3D reconstruction, Middle Ages, castle

\section{Resumen:}

El castillo de Turís (Turís, Valencia, Spain), denominado comúnmente, El Castellet, es una construcción que entre los siglos XI y XV, jugó un papel destacado en la defensa del territorio de Valencia. En los últimos años la Universitat de València viene realizando investigaciones histórico-arqueológicas y se han llevado a cabo varias actuaciones de consolidación y puesta en valor. Presentamos los primeros resultados de la reconstrucción virtual del castillo.

Palabras clave: arqueología virtual, patrimonio cultural, documentación, reconstrucción 3D, Edad Media, castillo

\section{El Castillo de Turís}

El castillo de Turís, comúnmente conocido como El Castellet, se encuentra situado sobre una loma alargada localizada al sur de Turís, población integrada en la comarca de la Ribera Alta, perteneciente a la provincia de Valencia (Fig. 1).

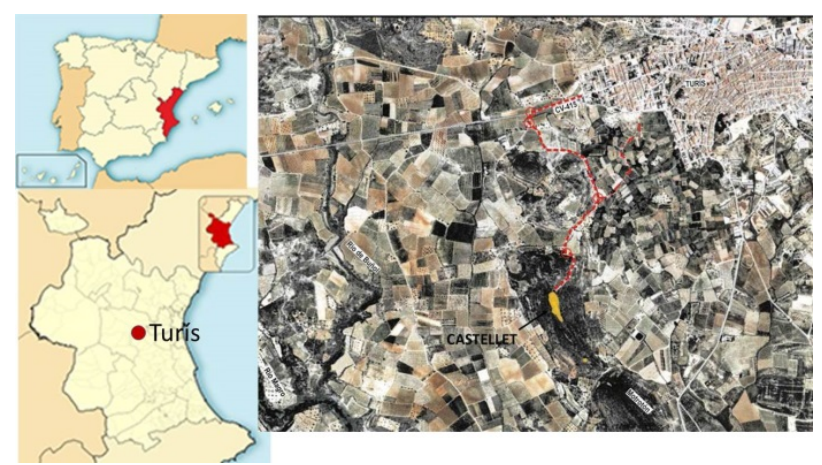

Figura 1: Turís. Situación geográfica y localización del castillo.

En los últimos años la Universitat de València viene realizando investigaciones histórico-arqueológicas y se han llevado a cabo varias actuaciones de consolidación y puesta en valor (Cruselles 2007; Díes 2007; Jiménez et al. 2011, 2014; Díes y Jiménez 2015, 2016). Estos trabajos han sido financiados con el programa del $1 \%$ Cultural, Ayuntamiento de Turís, Diputación de Valencia y Generalitat Valenciana (Fig. 2).

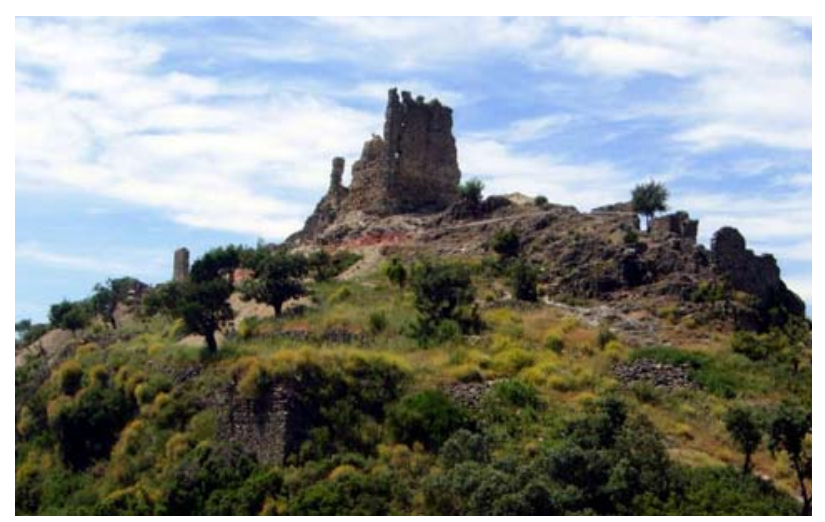

Figura 2: Vista general del castillo de Turís.

Como resultados más relevantes de estas actuaciones, cabe destacar la identificación definitiva del castillo sobre la que existían dudas motivadas por la presencia de otra construcción homónima dentro del actual núcleo

`Corresponding Author: José Luis Jiménez, jose.I.jimenez@uv.es 
urbano. Pero sin duda, la principal aportación ha sido la constatación de su secuencia cronológica, comprendida entre los comienzos del siglo XI y las postrimerías del siglo $\mathrm{XV}$, cuando sus últimos propietarios pertenecientes a la influyente familia Borja, procedieron al traslado de su residencia a la nueva edificación construida en la localidad junto a la iglesia. A lo largo de prácticamente quinientos años, esta fortificación desempeñó un papel destacado en el control y defensa del territorio situado al oeste de Valencia, primero en época islámica y posteriormente bajo dominio cristiano tras la conquista de Jaime I.

Los restos hoy en día visibles junto con los exhumados durante la campaña de excavación arqueológica acometida en 2010, han permitido documentar diversas fases constructivas que se resumen a continuación (Fig. 3). Paralelamente, se ha desarrollado una labor de estudios documentales que ha resultado de gran valor para conocer mejor la evolución histórica y constructiva del castillo.

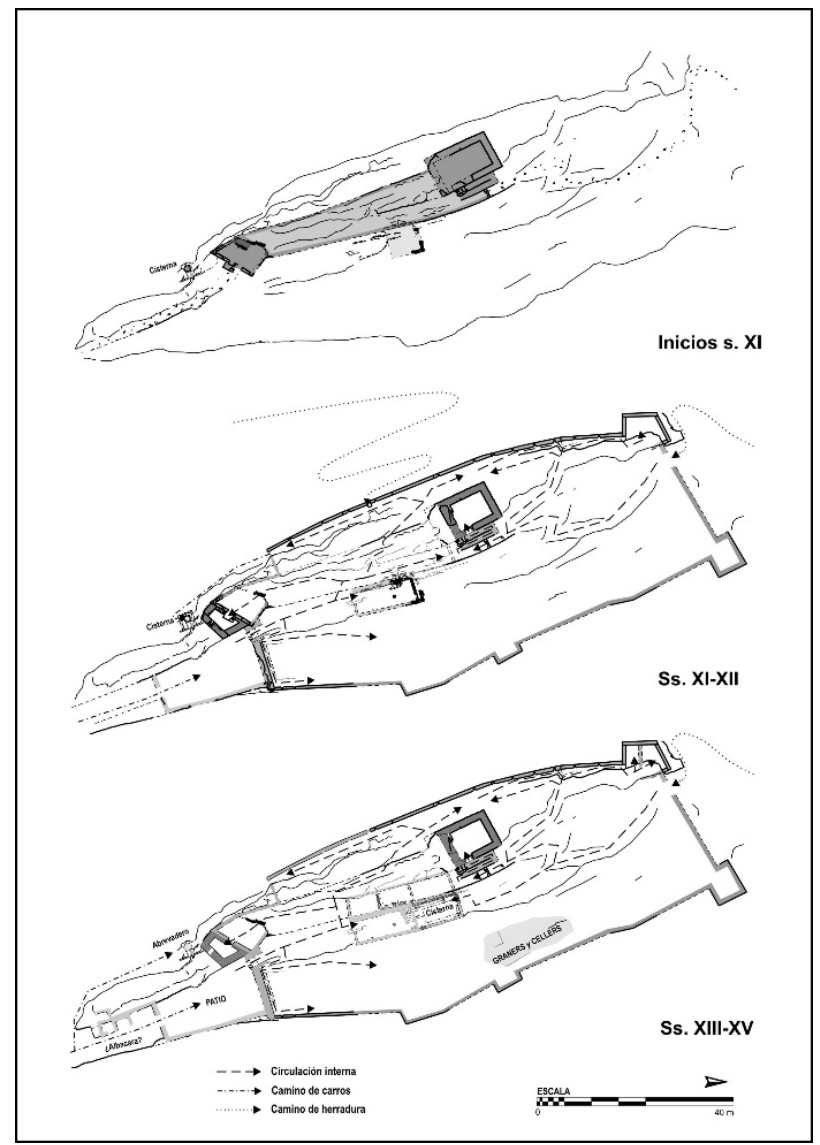

Figura 3: Fases constructivas del castillo de Turís.

(Elaboración de E. Díes sobre base planimétrica de Global Alicante).

La primera construcción ha podido fecharse a comienzos del siglo XI. Su superficie era tan solo de 500 $\mathrm{m}^{2}$ y contaba con dos elementos singulares unidos por una doble muralla. Por una parte, un torreón de planta rectangular $(12 \times 8 \mathrm{~m})$ de unos $12 \mathrm{~m}$ de altura, que probablemente diera origen al topónimo Turish (arabización del latín, Turris) y por otra, un oratorio (zawiya), dedicado a una persona santa con su sepultura (maqbara). Tenía otro acceso desde el exterior por el muro llamado de la Qibla (orientado hacia la Meca), donde también se abría la hornacina (Mihrab) hacia la que se dirigían los fieles para orar. Esta primera fase parece coincidir con el primer momento de la taifa de Balansiya, creada tras la fitna del califato.

La inestabilidad generada por la caída del califato y el establecimiento de las taifas, que se agudizó a mediados del siglo XI, afectó de manera directa al castillo de Turís, que fue objeto de una gran ampliación en todas direcciones alcanzando ahora una superficie de $3.000 \mathrm{~m}^{2}$ y una nueva muralla rematada por almenas. Asimismo, se eliminó la zawiya, protegiendo el lado sur con una torre, mientras que el torreón sirvió de residencia y atalaya. Hasta el establecimiento del reino cristiano de Valencia, debió sufrir las consecuencias de su carácter fronterizo durante la dominación almorávide $y$ almohade $y$, en los momentos finales de esta segunda época, su torreón fue remodelado para convertirlo en una atalaya para permitir la conexión visual con los castillos de Buñol y Macastre. Así se aseguraba el control de los caminos naturales que, a través del río Magro y sus afluentes, llevaba al llano de UtielRequena. Además, se mejoró el camino de ronda y se construyeron nuevas dependencias en el interior.

La conquista cristiana hizo del castillo sede de un Señorío y para ello se levantó la Casa del Señor que incluyó una nueva cisterna con mayor capacidad. Las paredes de esta última han dejado constancia de varios graffiti, entre los que destacan los de grafía árabe, escritos muy probablemente por quienes edificaron el aljibe y que debían ser de cualquiera de las alquerías del término del castillo, como demuestra una mención del gentilicio de Turís. Asimismo, se sabe que el castillo poseía bodegas en las que se almacenaba parte de la cosecha pagada como impuesto y en ellas, se elaboraba aceite y vino.

Entre la documentación de archivo hallada cabe destacar dos inventarios realizados del castillo. El de 1322 se efectuó con motivo del fallecimiento del propietario, Ramón Colom, y permite identificar unas siete habitaciones. En 1449 se hizo otro inventario para proceder al secuestro del señorío y al nombramiento de un administrador a petición de los acreedores de Pere Boïl de Lladró. En este caso, tras describir una serie de estancias localizadas en el exterior y en las cinco estancias de la celoquia del castillo, se detalla lo hallado en la habitación de la Torre, dividida en varias plantas. Gracias a este inventario ha podido identificarse una veintena de títulos que formaban parte de la biblioteca del Señor. Por otra parte, en 1451 se hizo una reforma de las cubiertas del pastador y de la recambra y queda claro que el castillo se hallaba en muy mal estado por lo que el administrador destinó parte de los recursos del señorío a hacer reparaciones imprescindibles. A comienzos del siglo XV, probablemente con los Boïl de Lladrò, se replanteó toda la defensa del castillo, adaptada al empleo de armas de fuego, mencionadas en el inventario de 1449. Así, la torre sur fue rebajada y convertida en una batería para una bombarda, mientras que las almenas originales fueron sustituidas por un parapeto con aspilleras para el empleo de espingardas y ballestas

Los últimos propietarios medievales del señorío, pertenecientes a la familia Borja, concentraron la población en una sola aldea, Turís. La unión dinástica del reino de Castilla y de la Corona de Aragón (1480) 
acabó con el papel defensivo del castillo y los nuevos señores decidieron trasladar su Casa a un nuevo edificio construido en el pueblo junto a la iglesia.

\section{La restitución virtual del castillo}

A la hora de presentar los resultados de la investigación histórico-arqueológica llevada a cabo en el castillo de Turís, en todo momento se ha tenido muy en cuenta la necesaria diferenciación gráfica de las distintas fases constructivas documentadas, tanto en planta, como secciones y alzados. En este sentido, se ha pretendido atender tanto la parcela científica como la faceta de la divulgación y en ambos casos, no podía faltar la restitución en 3D. A modo de ejemplo, presentamos la propuesta elaborada del torreón con el aspecto que tendría en distintas fases comprendidas entre los siglos XI y XV (Fig. 4).

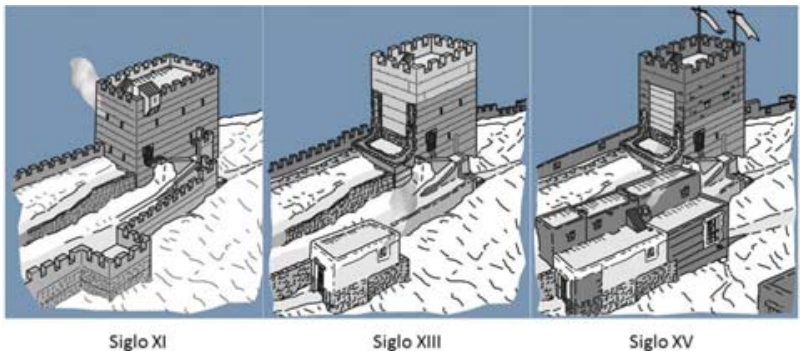

Figura 4: Restitución del torreón entre los siglos XI y XV. (Dibujos E. Díes).

En este otro ejemplo, se muestra el aspecto que ofrecería la muralla oeste, en sus fases, inicial y final, donde se ha incluido información sobre el tipo de armamento utilizado en cada una de ellas (Fig. 5).

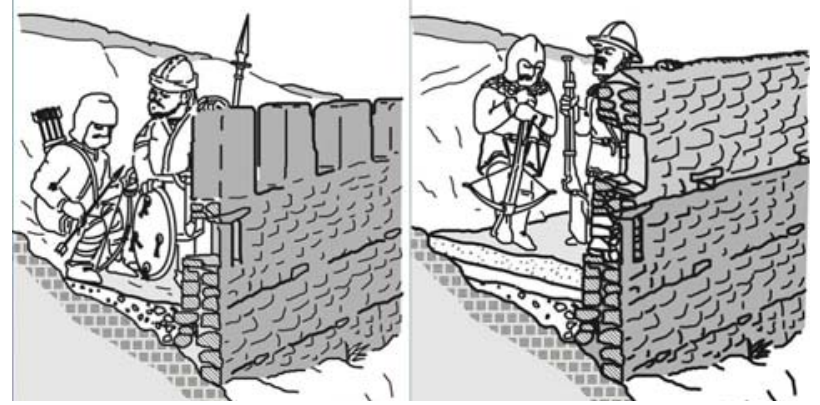

Figura 5: Detalle del aspecto que tendría la muralla oeste, en el siglo XI (izquierda) y siglo XV (derecha). (Dibujos E. Díes).

El empleo de imágenes virtuales se ha dirigido también como elemento de apoyo en las labores de consolidación y restitución que vienen realizándose de acuerdo con un plan de actuación cuya prioridad viene marcada por el estado de conservación, tanto de estructuras emergentes como de las recuperadas en el transcurso de la intervención arqueológica. Ello supuso una primera intervención en el muro norte del torreón que ofrecía un mayor riesgo de ruina. En otros sectores del castillo, como es el caso de la muralla oeste, un largo tramo ofrece un estado de conservación muy precario, prácticamente arrasado, lo que ha permitido realizar una infografía con la que se ha recreado el aspecto que debía mostrar en toda su integridad (Fig. $6)$.

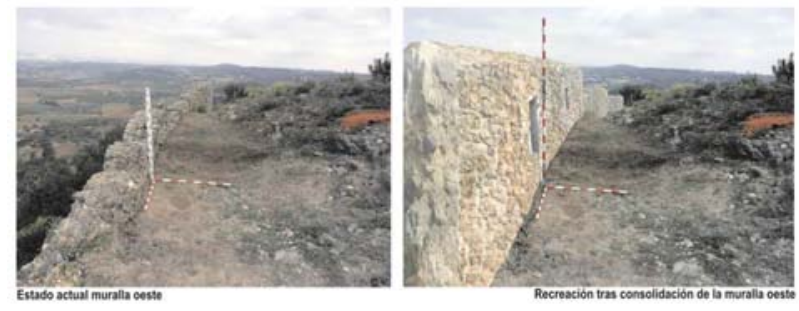

Figura 6: Tramo conservado de la muralla oeste (izquierda) y restitución virtual de la fase del siglo XV (derecha). (Infografía J. Tierno)

Con esta misma técnica se ha procedido a restituir la imagen que debía ofrecer desde el oeste, el castillo en su fase final del siglo XV, en la que por su destacada altura, se aprecia la sensación de dominio que el torreón ejercía sobre todo el conjunto (Fig. 7).

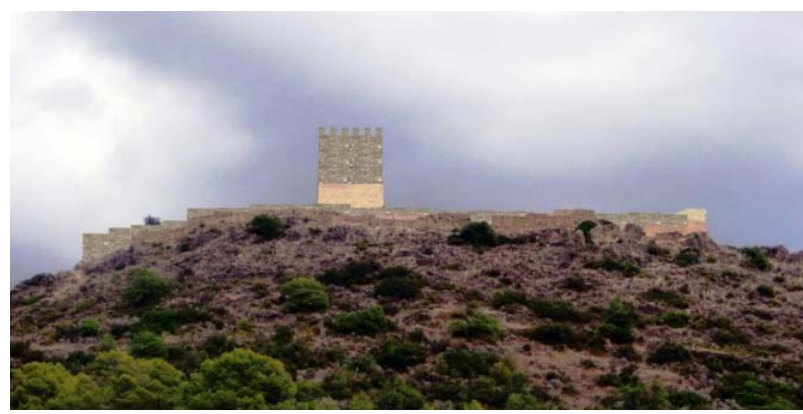

Figura 7: Hipótesis de restitución virtual de la última fase del castillo de Turís (siglo XV) desde el oeste. (Infografía J. Tierno).

Tomando como base toda la documentación gráfica elaborada durante las labores arqueológicas y las sucesivas intervenciones de consolidación y rehabilitación parcial, J. Tierno ha procedido a realizar el levantamiento volumétrico del castillo, mediante el escalado de los distintos elementos que lo integraban (Fig. 8). Para esta labor se ha servido de los dibujos elaborados por E. Díes, de los que se ha mostrado algún ejemplo en las Figuras 4 y 5 .

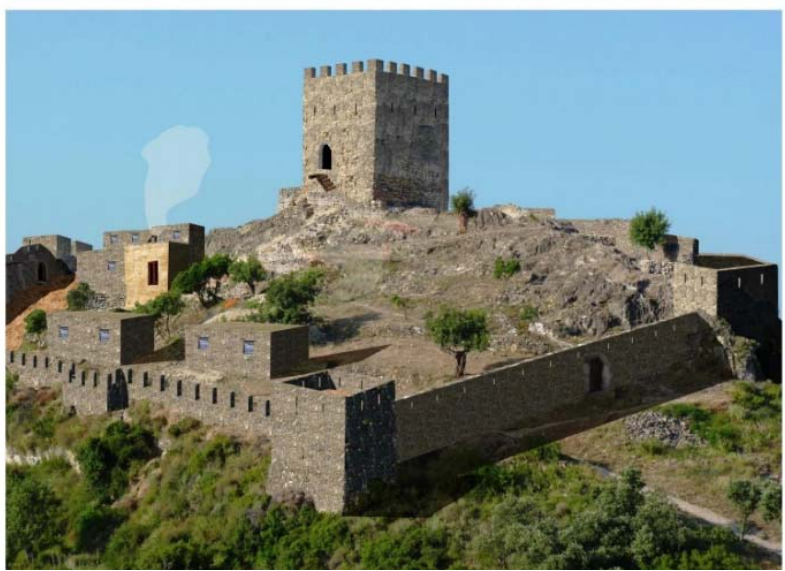

Figura 8: Hipótesis de restitución virtual del castillo de Turís en el siglo XV (J. Tierno).

El programa utilizado para esta restitución volumétrica ha sido el SketchUp que puede utilizarse también con el AutoCad y si se desea se puede volcar, una vez finalizado el dibujo en el google maps, sirviendo como ejemplo el castillo de Montsegur, en Francia. 
Se decidió que la imagen que debía ofrecerse sería la de la fase final del castillo, la del siglo XV, por cuanto a ella corresponden los muros mejor conservados, que poseen una mayor altura.

En el caso de las murallas, esto supuso que se coronarían por un parapeto aspillerado del que se conserva un tramo en su totalidad hasta su acabado en albarda (Fig. 9).

Este $3 \mathrm{D}$ es una primera aproximación a la reconstrucción volumétrica del conjunto de la fortificación. Para su realización se ha seguido los siguientes pasos, de acuerdo con los Principios de Sevilla (Principles of Seville 2013), que irán perfeccionándose a medida que avancen los trabajos en curso:

- Reproducir la orografía del terreno, previamente escalada.

- Escalar la planimetría dentro de la orografía.

- Estudio de los dibujos y fotografías.

- Alzamiento de las diferentes estructuras del castillo.
- Estudio de las texturas para introducirlas en el modelo.

- Realización de infografías.

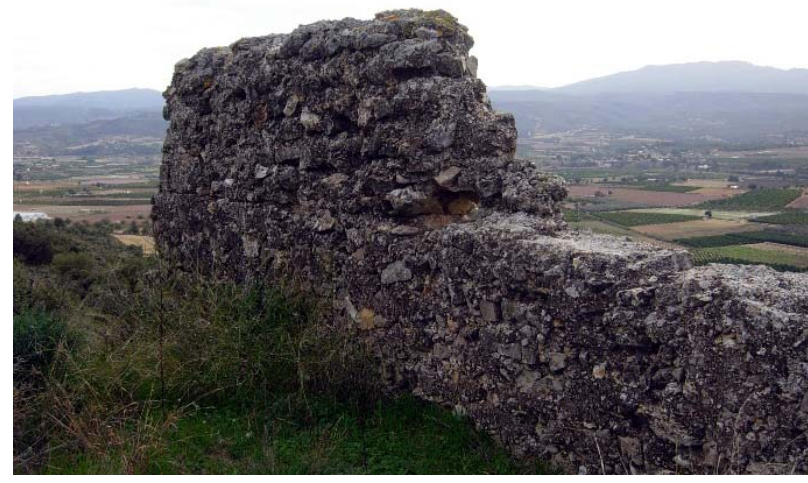

Figura 9: Parapeto aspillerado del siglo XV conservado en su totalidad hasta su acabado en albarda. Forma parte del lado oeste de la muralla.

\section{Referencias}

CRUSELLES, E., 2007. Els senyors de la terra. Història de Turís. Universitat de València, Valencia, pp. 142-158.

DÍES, E., 2007. Fins al hisn Turi-š. Història de Turís. Universitat de València, Valencia, pp. 137-141.

DIES, E. y JIMÉNEZ, J. L., 2015. El castellet de Turis. Intervenció arqueológica i posada en valor, ARMENGOL, P. (Ed.), Estudis històrics sobre la Ribera del Xúquer, XV Assemblea Història de la Ribera (Benimodo, novembre de 2012), Benimodo, pp. 33-50.

DÍES, E. y JIMÉNEZ, J. L. 2016. El castell de Turis, LEDO, A.; MORALES, A. (Eds.), La Universitat de València i el seus entorns comarcals: La Ribera del Xúquer, Universitat de València, Valencia, pp. 24-27.

JIMÉNEZ, J. L.; DÍES, E. y CRUSELLES, E., 2011. El Castellet (Turis, Valencia). Intervencion arqueológica dentro del proyecto de consolidacion y puesta en valor del Castillo. Saguntum (P.L.A.V.), 43, pp. 223-227. DOI: 10.7203/SAGVNTVM.43.1661

JIMÉNEZ, J. L.; DÍES, E. y TIERNO, J., 2014. Hisn turiš - Castell de Turís - El Castellet 500 años de historia. Saguntum (P.L.A.V.) Extra 16, Universidad de Valencia.

PRINCIPLES OF SEVILLE, INTERNATIONAL PRINCIPLES OF VIRTUAL ARCHAEOLOGY, 2013. Available: http:// www.arqueologiavirtual.com/carta/wp-content/uploads/2012/03/BORRADOR-FINAL-FINAL-DRAFT.pdf [27/11/2015]. 


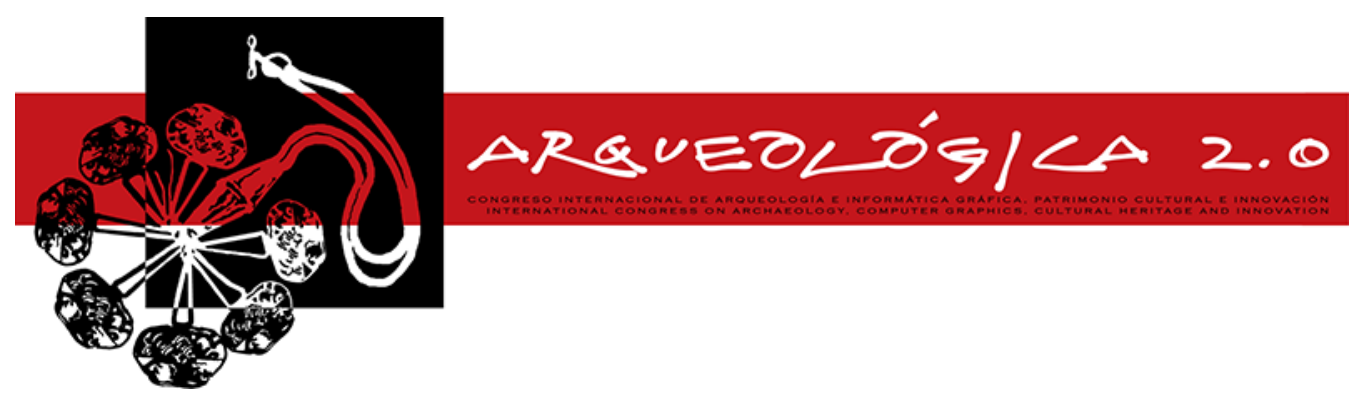

Proceedings of the $8^{\text {th }}$ International Congress

on Archaeology,

Computer Graphics,

Cultural Heritage and Innovation

'ARQUEOLÓGICA 2.0'

in Valencia (Spain),

Sept. $5-7,2016$

\title{
COMUNICACIÓN ESTRATÉGICA APLICADA AL DESTINO TURÍSTICO- CULTURAL DE CARTAGENA (MURCIA- ESPAÑA)
}

\author{
STRATEGIC COMMUNICATION APPLIED TO THE CULTURAL-TOURISTIC DESTINATION OF CARTAGENA \\ (MURCIA - SPAIN) \\ María Dolores Teruel-Serrano ${ }^{\mathrm{a},{ }^{*},}$, María José Viñals-Blasco ${ }^{\mathrm{b}}$ \\ ${ }^{a}$ Departamento de Economía y Ciencias Sociales, Universitat Politècnica de València, Camino de Vera s/n, 46022 Valencia, España. \\ dteruel@upvnet.upv.es \\ ${ }^{\mathrm{b}}$ Departamento de Ingeniería Cartográfica, Geodesia y Fotogrametría. Camino de Vera s/n, 46022 Valencia, España. \\ mvinals@cgf.upv.es
}

\begin{abstract}
:
Arqueological heritage is presented as a development resource of tourism in Mediterranean destinations. The work of public managers to reach obtain balance in conservation-tourism is a challenge to achieve in the majority of heritage destinations. So that, among other tourist management tools, strategic communication through ICT offers a great value considering the behaviour of virtual approaches to heritage by users, in a planned manner, can well perform if objectives are assigned beyond the promotional or informational ones. Thus, in an attempt to futher focus on this topic, this research work was suggested as an objective to identify the communicative capacities of three tourist and cultural websites of Cartagena (Murcia-Spain). This was carried out by a methodological tool of analyses and evaluation (called Comunicative Eficiencia Survey). The results hightlight the potential of strategic communication and the opportunity to attribute it higher uses in heritage and tourism management.
\end{abstract}

Key words: strategic communication; heritage resources; tourist management; websites

\section{Resumen:}

El patrimonio arqueológico se presenta como un recurso dinamizador del turismo en los destinos mediterráneos. La labor de los gestores públicos para alcanzar un balance equilibrado entre la conservación-turismo es un reto a alcanzar en la mayoría de los destinos patrimoniales. Para ello, entre otras herramientas de gestión turística, se plantea conceder a la comunicación estratégica a través de las TIC mayor valoración, dado el comportamiento de acercamiento virtual al patrimonio por parte de los usuarios, y la contribución que, de forma planificada, puede realizar si se le asignan objetivos más allá de los promocionales o informativos. Así, en un intento de profundizar en este tema, este trabajo de investigación se plantea como objetivo identificar las capacidades para la comunicación estratégica de tres sitios web turístico-culturales de Cartagena (Murcia-España) a través de un instrumento metodológico de análisis y evaluación (que se ha denominado "Cuestionario de Eficiencia Comunicativa") referido a indicadores para conocer la aplicación del mismo. Los resultados ponen de manifiesto el potencial de la comunicación estratégica y la oportunidad de atribuirle usos superiores en aspectos de gestión turística y patrimonial.

Palabras clave: comunicación estratégica; recursos patrimoniales; gestión turística; sitios web

\section{Introducción}

Los destinos turísticos que cuentan con patrimonio arqueológico recurren a estos activos para su puesta en valor. Así, muchos municipios turísticos incorporan esta oferta cultural como estrategia de diferenciación y diversificación de sus atractivos turísticos. El estado de conservación de estos recursos, la fragilidad o vulnerabilidad de los mismos condicionarán la puesta en valor de este patrimonio y su gestión turística que será diferente si el destino ya tiene consolidadas las relaciones turismo-patrimonio o si, por el contrario, se estrena en este binomio. En cualquier caso, es necesario planificar la experiencia turística y esto no siempre está planificado lo cual, a menudo, trae consigo consecuencias no deseadas para los destinos provocando el efecto antagónico en la población y en el patrimonio como ya apuntó Doxey (1975).

Los gestores públicos se preocupan por la conservación, difusión y promoción del patrimonio

`Corresponding Author: María Dolores Teruel-Serrano, dteruel@upvnet.upv.es 
turístico conscientes de las oportunidades pero también de las consecuencias negativas que puede conllevar el desarrollo turístico para la población receptora y para el patrimonio en sí mismo. Se hace necesario, por tanto, el establecimiento de herramientas de gestión básicas y tradicionales como es la puesta en valor del patrimonio, la planificación y gestión turística (inventario y valoración de recursos turísticos, determinación de la capacidad de carga recreativa, gestión de la congestión, control de impactos, gestión de visitantes, etc.) ampliamente descritas en la bibliografía especializada, pero también aparecen otras nuevas de base tecnológica relacionadas con la comunicación estratégica. Entre estas nuevas herramientas de gestión basadas en las Tecnologías de la Información y las Comunicaciones (TIC) se sitúan los sitios web los cuales, si se aprovechan bien sus capacidades comunicativas, permiten otras prestaciones más allá de las puramente comunicativas y permiten establecer un diálogo eficiente entre todos los sectores implicados en la gestión del patrimonio, el desarrollo turístico y los usuarios o visitantes. Los sitios web y las redes sociales de los sitios patrimoniales son un medio excelente para llevar a cabo este tipo de comunicación ya que facilita la interpretación del patrimonio a los visitantes, entendida ésta en los términos descritos ya por Ham en 1992. Se observa pues, que la utilización de herramientas tecnológicas presenta muchas ventajas como es la de ofrecer una amplia información pública actualizada, disponible para cualquier persona y en cualquier momento, además de servir como fuente de información y de inspiración previa a la realización de un viaje como ya apuntaba Lyons (2002). Además, es importante tener presente que el sitio web es la carta de presentación y reflejo de la identidad de los sitios Patrimonio de la Humanidad, ya que de esta forma, se transmite el prestigio y marca de calidad de la UNESCO, lo cual contribuye también en el proceso de motivación y generación de expectativas del visitante (Viñals et al. 2014).

\section{Metodología}

A pesar de que se constata una creciente utilización de las TIC en general y de los sitios web en particular de sitios con patrimonio cultural, se puede decir que no todas las capacidades previstas son aplicadas. En una investigación previa (Teruel y Viñals 2012) se planteaba un Plan de Comunicación Estratégica para los sitios patrimoniales en el que se reparaba en el estudio de las capacidades comunicativas y de gestión para el desarrollo turístico de estos enclaves. A partir de la situación de partida y en un intento de profundizar en este tema, este trabajo de investigación se plantea como objetivo el identificar las capacidades de los sitios web patrimoniales como herramientas comunicativas estratégica a través de un instrumento metodológico de análisis y evaluación (que se ha denominado "Cuestionario de Eficiencia Comunicativa") referido a indicadores para conocer la aplicación del mismo.

Para verificar los resultados de esta propuesta metodológica se han analizado en profundidad los sitios web de contenido turístico e informativo en torno al patrimonio arqueológico de Cartagena (Murcia-España). Concretamente, se ha centrado el análisis en: el sitio web del "Museo del Teatro Romano de Cartagena" del Ayuntamiento de Cartagena, del proyecto "Cartagena
Puerto de Culturas", y el sitio web turístico "Cartagena Turismo". La actividad que se refleja del análisis de estos tres sitios web contempla las acciones de desarrollo turístico y de promoción de la conservación y difusión de los hallazgos arqueológicos en torno al patrimonio cultural de la ciudad de Cartagena lo cual ha servido para convertir al turismo cultural como una actividad estratégica para el desarrollo económico de la ciudad, mediante la implementación de procesos de recuperación y musealización de los recursos arqueológicos como el Museo del Teatro Romano o las Temas del Barrio del Foro entre otros (Ruiz et al. 2005). Son diversas las instituciones que promueven la conservación y difusión de los hallazgos arqueológicos en torno a este importante recurso patrimonial.

\section{Aplicación del Cuestionario de Eficiencia Comunicativa}

Los resultados de la aplicación del CEC a los sitios web objeto de estudio ofrece datos significativos. En términos generales, los sitios web analizados cuentan como responsable de los mismos la concejalía de nuevas tecnologías por lo que el diseño es bastante similar. Además, existen enlaces entre todas ellas y cumplen con los estándares de accesibilidad de la Web Accesibility Initiative, normativa en cuanto a accesibilidad y buenas prácticas encaminadas a salvaguardar y asegurar la accesibilidad de los contenidos de la web. A pesar de estas similitudes, cada una de ellas tiene una proposición comunicativa clara siendo informativa y comercializadora de la oferta en el caso de la web turística donde queda patente las relaciones establecidas entre el sector público y el sector privado; informativa-institucional en el caso de la web de "Puerto de Culturas" y descriptiva-interpretativa del patrimonio arqueológico en el caso del sitio web del "Museo Teatro Romano".

En todos los sitios web analizados queda patente la voluntad de los gestores por presentar el patrimonio arqueológico como un recurso turístico más que apoye la desestacionalización y que convierta a la ciudad de Cartagena en un referente de turismo cultural. Así, en general, los temas incluidos en sus comunicaciones web presentan el interés mostrado por sus responsables en la ampliación y mejora de la difusión del patrimonio.

Una vez analizadas las fortalezas y debilidades comunicativas de las mismas, se revelan aquellos aspectos en donde las nuevas tecnologías pueden ofrecer más prestaciones que las que actualmente se están utilizando para la comunicación estratégica en cuanto a la gestión de la conservación del patrimonio y el desarrollo turístico sostenible de los sitios, sobre todo, en relación a la existencia o no de programas de interpretación ya que se considera un instrumento fundamental para la concienciación, educación y formación de las personas que tratan con el turismo y para los visitantes $y$, además, es muy relevante para poder involucrar mejor a las comunidades locales en el proceso de conservación y puesta en valor del patrimonio. 


\section{Conclusiones}

Entre las conclusiones más destacables a las que se llega de los casos analizados se encuentran las siguientes:

- Se constata que los sitios web analizados en la fase previa a la visita contribuyen a alimentar las motivaciones y expectativas, y en la fase posterior consolida actitudes y conocimientos y se postulan como herramientas de gestión turística por las diferentes capacidades que pueden alcanzar. No obstante, existen riesgos como es la falta de plan de comunicación o la inexperiencia o pericia del gestor de contenidos en la emisión de mensajes interpretativos. También el exceso de información o la falta de contenidos interpretativos puede constituir un riesgo.

- El cuestionario de Eficiencia Comunicativa es una herramienta que permite la evaluación de la calidad de los contenidos comunicativo-interpretativos así como la forma y habilidad con la que son presentados en los sitios web.

- Cabe destacar que señalar que el destino turísticocultural Cartagena encuentra un equilibrio en la emisión de contenidos a través de los tres sitios web los cuales se complementan entre sí. el sitio web Cartagena Turismo contiene mensajes informativos-descriptivos centrados en la información útil y comercial; Cartagena Puerto de Culturas se encarga de concentrar la oferta de destino y aporta datos a nivel institucional, mientras que el Museo Teatro Romano se centra en mensajes interpretativos con mayor profundización en los mensajes transmitidos y estructurados lo cual refleja el interés divulgativo del patrimonio $y$ amplifica la información histórica y científica de importante recurso arqueológico.

- Las redes sociales permiten una comunicación más popular menos institucionalizada con mensajes puntuales y efímeros similar a la proposición comunicativa que pretende la publicidad frente a una información dinámica pero permanente que presentan los sitios web.

- $\quad$ Se consiguen un buen equilibro entre los tres sitios web y esto se refleja en los resultados obtenidos en la aplicación del CEC. En su conjunto el CA1 alcanza resultados superiores a la media si se compara con una investigación anterior sobre sitios patrimoniales en España (Teruel 2016).

\section{Agradecimientos}

Este trabajo se enmarca en el proyecto I+D de la D.G. Investigación Científica y Técnica (Ministerio de Economía y Competitividad): "Teatros Romanos de Hispania" (BIA2012-37063), 2013-1015.

\section{Referencias}

DOXEY, G.V., 1975. A causation theory of visitor-resident irritants: methodology and research inferences. In travel and tourism research associations.Sixth annual conference proceedings. San Diego. pp. 195-98.

HAM, S.H., 1992. Interpretación ambiental. Una guía práctica para gente con grandes ideas y presupuestos pequeños. Fullcrum/ North Americam Press. Golden, Colorado, USA.

LYONS, G., 2002. Internet: investigating new technology's evolving role, nature and effects on transport. Transport policy, 9 (4), pp. 335-346. http://dx.doi.org/10.1016/S0967-070X(02)00023-9

RUIZ, E., LECHUGA, M. y MARTINEZ, A., 2005. Cartagena Puerto de Culturas: una apuesta por el patrimonio de la ciudad. En c. De Francia Gómez y Erice Lacabe (coords.), De la excavación al público: procesos de decisión y creación de nuevos recursos. Congreso Internacional Sobre Musealización De Yacimientos Arqueológicos. Ayuntamiento de Zaragoza, Zaragoza, pp. 197-202.

TERUEL, L. y VIÑALS, M.J., 2012.Internet applications for strategic communication, tourism and local communities in relation to heritage. Community development through World Heritage, 54.

TERUEL, I., 2016. Eficiencia comunicativa de las páginas web en el caso de la Gestión turística de los Sitos Patrimonio de la Humanidad en España. Boletín de la Asociación de Geógrafos Españoles, 71, pp 325-345.

UNESCO, 2001. World Heritage Tourism Programme. Disponible en http://whc.unesco.org/en/sustainabletourism/ $(21 / 01 / 16)$

UNESCO, 2002. Managing Tourism at World Heritages Sites. UNESCO ED. 2002.

UNESCO, 2008. Directrices prácticas para la aplicación de la Convención del Patrimonio Mundial. Comité intergubernamental de protección del patrimonio mundial cultural y natural. World Heritage Centre 2008. PARIS.

VIÑALS, M.J.; MORANT, M. y TERUEL, L., 2014. Confort psicológico y experiencia turística. Casos de estudio de espacios naturales protegidos de la comunidad valenciana (ESPAÑA). Boletín de la Asociación Geógrafos Española, 65, pp. 293-316. 


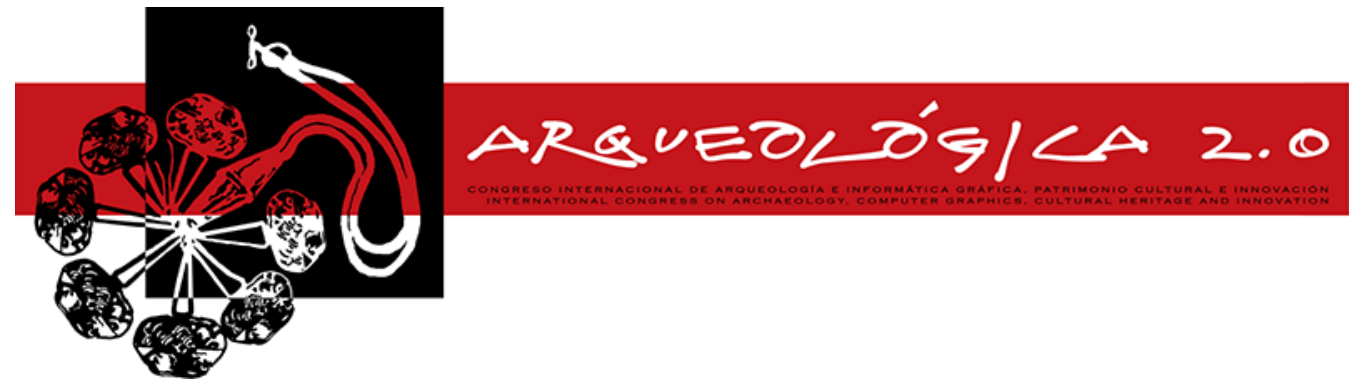

Proceedings of the $8^{\text {th }}$ International Congress

on Archaeology,

Computer Graphics,

Cultural Heritage and Innovation

'AROUEOLÓGICA 2.0'

in Valencia (Spain),

Sept. $5-7,2016$

\title{
RAPID MAPPING AND VISUAL NOISE: RECORDING FOR THE VISITOR, RESIDENT, PILGRIM AND TOURIST; AJMER, INDIA (WORK IN PROGRESS)
}

\author{
LA CARTOGRAFÍA RÁPIDA Y RUIDO VISUAL: GRABACIÓN PARA EL VISITANTE, RESIDENTE, PEREGRINO Y \\ TURÍSTICO; AJMER, INDIA (TRABAJO EN CURSO) \\ Oriel Prizeman*, Adam Hardy \\ Welsh School of Architecture, Cardiff University, Bute Building, King Edward VII Avenue, CF72 9NR Cardiff, UK. prizemano@cf.ac.uk; \\ HardyA@cardiff.ac.uk
}

\begin{abstract}
:
This paper examines issues arising from an inter-disciplinary work in progress involving ethnographers, architects, historians and conservators. The aim is to develop a digital model through which information relating to the history, ritual use, religious significance and cultural habits of a mixed community can be accessed for the purpose of more responsive conservation planning. The case study site is the walled city of Ajmer in Rajasthan, India, a populous pilgrimage centre that holds tangible and intangible cultural value for many diverse groups of residents and visitors but which remains largely unmapped in conventional terms.
\end{abstract}

Key words: mapping public space, digital pilgrimage, conservation planning, cultural heritage, documentation, rapid urbanisation

\section{Resumen:}

Este artículo examina los problemas que surgen a partir de un proyecto de investigación interdisciplinario en curso, que involucra etnógrafos, historiadores, arquitectos y conservadores del patrimonio. El objetivo del trabajo es desarrollar una modelo digital que hace disponible la información que corresponde a la historia, el uso ritual, el significado religioso y los hábitos culturales de una comunidad mixta, para permitir una planificación de la conservación más sensible. El sitio del caso de estudio es la ciudad amurallada de Ajmer en Rajasthan, India, un centro de peregrinaje muy poblado que tiene un valor cultural tangible e intangible para muchos diversos grupos de residentes y visitantes, pero lo que sigue siendo en gran parte sin cartografía en términos convencionales.

Palabras clave: mapeo de espacio público, peregrinación digital, planificación de la conservación, el patrimonio cultural, la documentación, la urbanización rápida

\section{Introduction}

The potential for interactive interfaces to contribute to better planning decisions has been a long held ambition. Today, the greater availability and access to handheld digital media offers the opportunity to play out such ambitions. The models envisaged here might potentially suggest a prototypical "Serious Game" interface for the contemplation of planning decisions in certain environments. The emphasis of the research here, is however, not on developing the technology, but on developing the methodology and upon testing the actual value of pursuing such lines of inquiry for the implementation of design decisions. The technology deployed is already in common usage, however, the dialogue between citizens and planning authorities remains fractured.
It is well documented that the roots of the conservation movement lay in the mobilisation of vociferous and historically, privileged non-governmental organisations and amenity societies (Jokilehto 2002, Glendinning 2013). As these groups have multiplied and movements against 'top down' practices have been prioritised, the significance of intangible cultural heritage has been driven to the fore of ICOMOS and UNESCO declarations. The imperative to democratise cultural identity, to make tourism and heritage protection more intelligent and better at recognising diversity is challenging and demands focus in terms of both construction and communication. The project anticipates increasing digital accessibility but cannot presume it.

The potential for the better communication and deliberation of both historic and current practices to

*Corresponding Author: Oriel Prizeman, prozemano@cf.ac.uk 
contribute to the formulation of better strategic decisions should be obvious. Nevertheless, it can be inestimably difficult to balance or take account of such factors given the restricted periods for consideration and restricted channels for consultation (Waterton and Smith 2010). This project is a pilot and as such its aim is to develop a prototypical approach, the successes and failures of which have potential to be transformative in the context of these complex contexts but also as exemplars for deployment in parallel conditions of multifaceted urban conditions.

The case study city of Ajmer (Fig. 1) is described as never having been "static" - a place in which the "political and spiritual co-exist" and a "constant space of interaction" (Hooja 2016). Government of India National Programmes HRIDAY (Heritage Rejuvenation Development and Augmentation Yojana) and PRASAD (Pilgrimage Rejuvenation and Spiritual Augmentation Drive) both relate to the city of Ajmer. Surrounded by the Aravalli mountains, it has a population of around 550,000 . Founded in the $7^{\text {th }}$ century, its mutual religious significance for both Hindus and Muslims is rare in India. The shrine of the Sufi Saint Khwaja Moinuddin Chishti in Ajmer attracts millions of Muslim pilgrims each year whereas the Bramah temple at Pushkah is the only one of its kind in India and is an ancient Hindu pilgrimage site. Heritage zones of the Dargah, Brahma Temple and lakefronts were identified in consultation with local residents (DRONAH 2016).

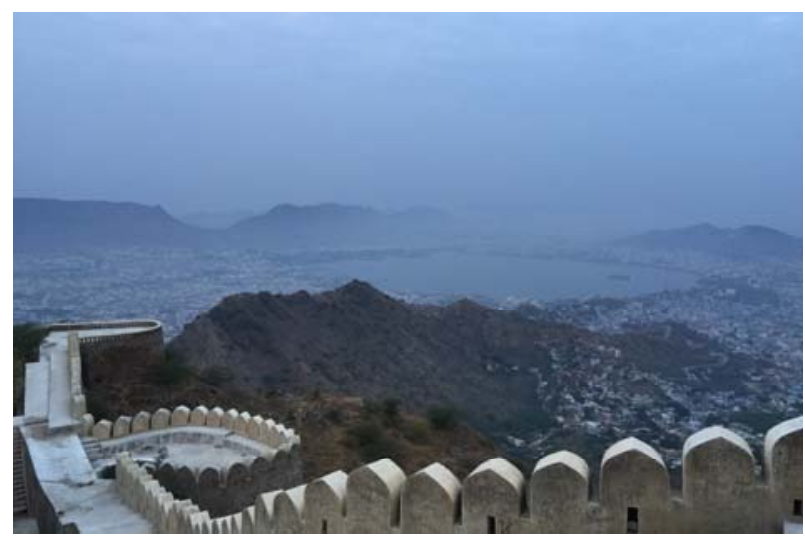

Figure 1: Overview of Ajmer from Taragarh Fort (OP).

\section{Method}

The concept of a historical model, tipified by Italo Gismondi's 1933 'plastico di Roma Imperiali' in EUR in Rome to transmit a history in a didactic form is well established. The facility for modern museums and cultural heritage sites to use digital interfaces is rapidly increasing but the provision of a virtual model of an urban room that can be written upon by multiple contributors is new. The need to include a physical as well as a digital interface is evident. In 2014 only $18 \%$ of people in India were estimated to have had access to the internet in the past twelve months (World Bank 2016). An interactive tool cannot claim to be accessible at such a rate.

The aim here is twofold - on the one hand it presents a means to present soft data to statutory authorities, on the other, it has potential to enable greater interaction with intangible cultural heritage for both inhabitants and visitors. It is not part of this project's anticipated outcome that both will be delivered, rather that the potential will be developed, tested and designed. The primary objective remains to create a tool to inform planning authorities, however, the additional capacity to contribute to intergenerational and intercultural dialogue will be an ambition for the future development of the scheme.

The initial intention was to carry out a terrestrial laser scan (Böhler 2002) using a terrestrial phase comparison laser scanner- Faro Focus 3D X130 using targets and spheres for registration. Point Density As recommended by Historic England for cultural heritage features $>100 \mathrm{~mm}$, was set at a minimum point density of $5 \mathrm{~mm}$ (English Heritage 2011). Scan data was to be registered and combined with the use of Scene software to provide geo-referenced point clouds for each 'block'. Point clouds were to be cleaned of unnecessary peripheral data (Barber 2003). Scan data deliverables were to be shared with colleagues at DRONAH using Autodesk ReCap 360 and 3D surfaces point clouds are to be meshed to provide OBJ, STL, PLY formats for incorporating into the final model. Presentation 'orbit' V.R. / GIF / AVI files were to be supplied to illustrate the form of each block. In order to construct $3 d$ physical models, point clouds were to be manipulated to share multiple orthoimages which could later be combined with hand measured site surveys.

In addition to TLS, photographs were taken by students along the street to enable creation of a Structure-FromMotion photogrammetric model using Agisoft Photoscan and dimensional data using conventional measuring tools to corroborate measurements from the scan.

All initial scan data will be securely stored through both cloud based and terrestrial methods. Datasets relating to information garnered from surveys and field research including workshops will be organised to reflect a temporal cycle which can be used to peg out the potential animation sequence of the model's interface.

\section{Unanticipated results, emerging challenges and questions}

The initial aim was to scan and model the intersection of streets immediately in front of the Dargah Sharif. Students for SPA Bhopal had already mapped the buildings and their uses along the whole street from the Dargah to the Delhi Gate. Notwithstanding the practical challenges of setting up a tripod for any length of time at this spot, it was agreed that the straightened street and twentieth century buildings were in fact uncharacteristic of the surrounding bazaar based network. A more geometrically complex 'chowk' or public intersection, was chosen. The students of SPA Bhopal set out to record the final approach to the Dargah (Fig. 2) using less intrusive structure-from-motion techniques. The aim is to tie these later to their existing GIS surveys.

Laxmi Chowk (Fig. 3) lies further along the pilgrimage route and provided the opportunity to model a complete transition from public to private. Two nineteenth century havelis (courtyard houses) adjoin the space. One opens on to it and through a sequence of thresholds leads to a small shrine at the rear. The other, built in 1840 in Jaisalmeri style, backs onto the street with many 'jarohkas' or perforated projecting windows at first floor level and above. Orthophotos of the site are being used 
to start the interactive dialogue of the ethnographic team. They intend to create a physical model from them with which to consult residents, pilgrims, visitors and tourists. At the same time, local historians will be providing new narratives to underpin the wider context. The aim is to then add these oral and written testimonies to a digital model based on a $3 d$ scan.

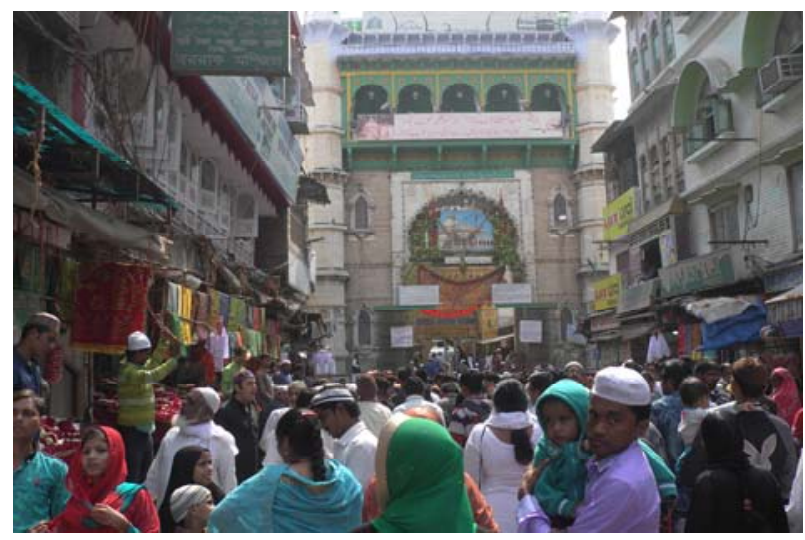

Figure 2: Main Entrance to the Dargah Sharif, Ajmer (OP).

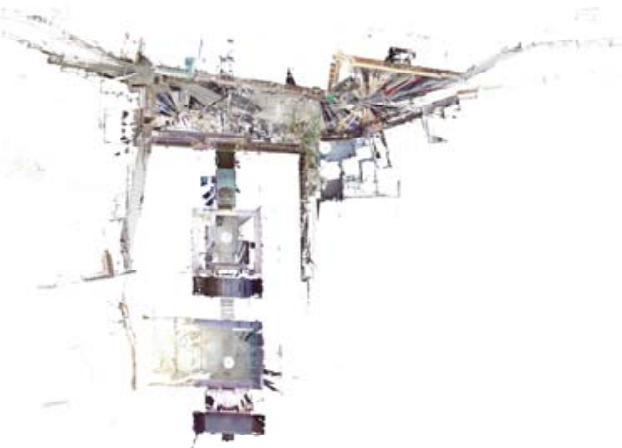

Figure 3: Laxmi Chowk orthophoto plan receding into haveli.

Our intention to carry out a terrestrial laser scan at Laxmi Chowk was still a challenging task. The 15 scans were taken early in the morning with the central part of the road blocked by a bench and a motorbike. This did not of course stop the remaining bustle of human, vehicular and animal traffic past the scene. The scans therefore are full of visual noise. The unintended consequence of which is to step up the potential interpretative value of the model.

The maps accrued form the students of SPA Bhopal, the HIRIDAY project and other historical sources will be overlaid. The intention here is to animate the maps with temporal data across the year. These data are very varied: a ritual calendar, an itinerary of festivals, a legacy of seasonal weather conditions, historic extreme weather events, the opening and closing times of shops, offices and schools, meal times, prayer times. These two prototypical models will me made available online for discussio.n and comment.

\section{Conclusion}

The indifference of orthophotos effortlessly reveals the visual transition from calm interior courtyard to ebullient street (Fig. 4). The aim of maintining a flexibility to learn and adjust in this project inspires a willingness to allow the chaotic nature of activity to infect and inform the clarity of the geometrical space depicted. The result is open to more detailed inspection and suggests an overlayering even within the moments of its data capture. We aim to seize this scattering of occlusions as an opportunity for more diverse forms of representation. During the course of its development, it will be possible to test the feasibility and efficacy of the model both locally and remotely. The use of digital and physical means of communication will be explored. Governmental and statutory stakeholders will have potential to critique the output, as will users from remote web locations and on site. The interface and model produced in this project has potential to generate significant interest if further iterations were to be created for other urban contexts. However, the need to consider the representation of visual noise presents new opportunities and paths for consideration.

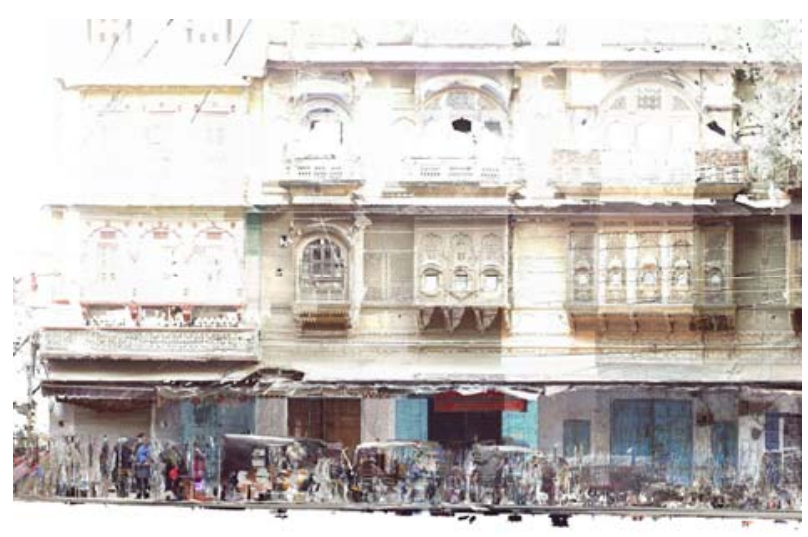

Figure 4: Laxmi Chowk animated orthophoto street elevation.

\section{Acknowledgements}

This work was supported by the Newton-Bhabha fund through a collaboration of the Arts and Humanities Research Council (UK) and the Indian Council for Historical Research (India) Networking Grant for Culture Heritage and Rapid Urbanisation in India. The project is titled "The historic city of Ajmer-Pushkar: $\square$ mapping layers of history, use and meaning for sustainable planning and conservation". The core collaborators are the Welsh School of Architecture (WSA), Cardiff University (Prof. Adam Hardy, Principal Investigator; Dr. Oriel Prizeman, Co-investigator), the School of Planning and Architecture (SPA), Bhopal (Prof. Ajay Khare, CoInvestigator), and DRONAH Foundation, the not-forprofit wing of the heritage NGO (Dr. Shikha Jain, CoInvestigator).

The work builds on a workshop held in Ajmer in February 2016 involving all parties. It includes the GPS survey and occupancy investigation work of students from the MArch Conservation of the School of Planning and Architecture, Bhopal led by Dr. Vishakha Kawathekar and laser scans made on site with their assistance. It also rests upon the reports of DORNAH's contribution to the National Heritage City Development and Augmentation Yojana (HRIDAY) scheme for Ajmer. 


\section{References}

BARBER, D., MILLS, J. and BRYAN, P., 2003. Towards a standard specification for terrestrial laser scanning of cultural heritage. CIPA International Archives for Documentation of Cultural Heritage, 19, 619-624.

BÖHLER, W.M., 2002. '3D Scanning Instruments'. Proceedings of CIPA WG6 Scanning for Cultural Heritage Recording, 2002 September 1-2, Corfu, Greece.

DEVELOPMENT AND RESEARCH ORGANISATION FOR NATURE, ARTS AND HERITAGE IN INDIA (DRONAH), 2016. Draft Report for City HIRIDAY plan for Ajmer

ENGLISH HERITAGE, 2011. 3D Laser Scanning for Heritage (2nd ed.) Advice and guidance to users on laser scanning in archaeology and architecture. . In: HERITAGE, E. (ed.).

GLENDINNING, M., 2013. The Conservation Movement: A History of Architectural Preservation: Antiquity to Modernity. Routledge, 530 pages

HOOJA, R., 2016. Historic Layers of Ajmer/Pushkar. The Historic City of Ajmer Pushkar AHRC ICHR Workshop, Ajmer, India Feb18-19

JOKILEHTO, J., 2002. A History of Architectural Conservation. Butterworth-Heinemann, 354 pages

WATERTON, E and SMITH, L, 2010. The recognition and misrecognition of community heritage in International Journal of Heritage Studies, 16(1-2), pp.4-15 DOI:10.1080/13527250903441671

WORLD BANK, 2016. Internet users (per 100 people) International Telecommunication Union, World Telecommunication/ICT Development Report and database, and World Bank estimates. Available: http://data.worldbank.org/indicator/IT.NET.USER.P2?cid=GPD_44 [3/11,2016] 


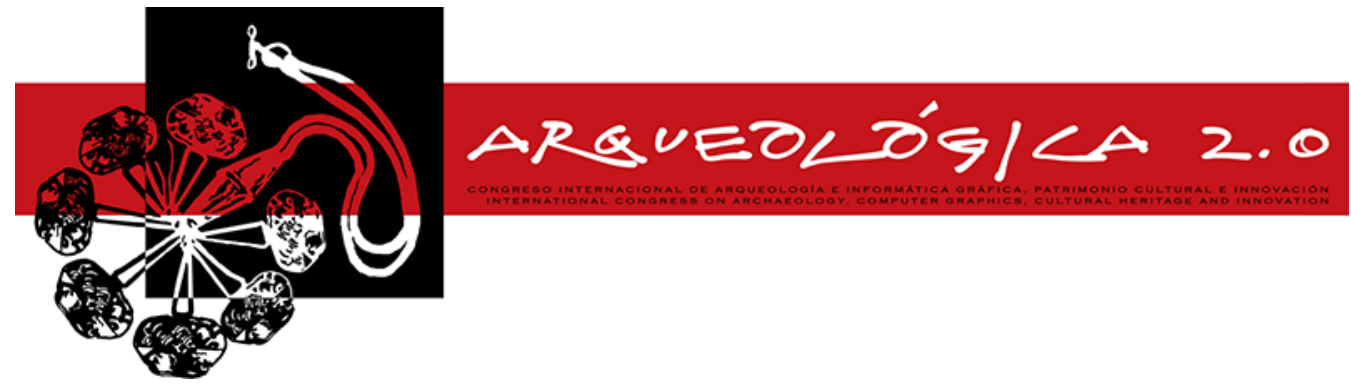

Proceedings of the $8^{\text {th }}$ International Congress

on Archaeology,

Computer Graphics,

Cultural Heritage and Innovation

'ARQUEOLÓGICA 20'

in Valencia (Spain),

Sept. $5-7,2016$

\title{
EDETA 360: VIRTUAL TOUR FOR VISITING THE HERITAGE OF LLÍRIA (SPAIN)
}

\author{
EDETA 360": TOUR VIRTUAL PARA VISITAR EL PATRIMONIO DE LLÍRIA (ESPAÑA)
}

\author{
José Miguel Maícas, María José Viñals
}

Dept. of Cartographic Engineering, Geodesy and Photogrammetry, Universitat Politècnica de València. Camino de Vera s/n, 46022 Valencia, Spain. jomaipra@hotmail.com; mvinals@cgf.upv.es

\begin{abstract}
:
Virtual enhancement of cultural heritage by using $360^{\circ}$ panorama photography technologies have become well established as a mean of digitally recording heritage sites for conservation, education and tourism purposes. This paper describes the work undertaken to create an interactive virtual tour based on panorama photos of the town of Llíria and its surroundings, called "Edeta $360^{\circ}$ ". This application aims to allow the general public to learn about the heritage of Llíria and to appreciate, disseminate and share it, while at the same time engaging users in a real experience of the town. Methodologically, this work has been addressed following an easy procedure with off-the-shelf equipment and using both freely available software (Hugin 2014.0.0) and Easypano Tourweaver 7.90®, while ensuring the quality of the final product.
\end{abstract}

Key words: ICT and cultural heritage, virtual tour, panoramic images

\section{Resumen:}

Potenciar el patrimonio cultural mediante el uso de la tecnología fotográfica panorámica en $360^{\circ}$ es un medio ampliamente utilizado por los sitios patrimoniales para propuestas de conservación, educación y turismo. Este documento describe el trabajo de creación de un tour virtual interactivo basado en fotos panorámicas de $360^{\circ}$ del municipio de Llíria, llamado Edeta $360^{\circ}$. La aplicación permite dar acceso general a los ciudadanos y fomentar de este modo el aprendizaje y el aprecio del patrimonio de Llíria. A la vez, sirve para difundir y compartir el amplio y rico patrimonio del municipio, ofreciendo a los usuarios una experiencia única de la ciudad de Llíria. Metodológicamente, este trabajo ha seguido un procedimiento sencillo, utilizando equipamiento propio y software libre (Hugin 2014.0.0), como Easypano Tourweaver 7.90®, consiguiendo con pocos medios un producto final de calidad.

Palabras clave: TICs y patrimonio cultural, tour virtual, imágenes panorámicas

\section{Introduccion and objective}

In the last few decades, numerous studies have researched into how to apply Information and Communication Technologies (ICT) to cultural heritage (Monod and Klein 2005; Styliaras et al. 2010; Hermon and Kalisperis 2011; Ott and Pozzi 2011; RogerioCandelera 2014), with special attention given to architectural heritage and urban spaces.

More recently, with the development of spatial simulation and visualisation tools for spaces that cannot be accessed easily, several applications have focused on studying immersive and realistic forms of communication which provide public access to the contents of cultural heritage. According to Niccolucci (2002), virtual heritage productions may be ideal in responding to a need for a fashionable synergy between scientific enquiry, technology, art, and everyday life, and, consequently, influence more serious cultural demand.

Among these applications, virtual environments have been widely used in the field of cultural heritage. They allow the general public to appreciate remote (in space and time) cultural assets with an immersive experience. Virtual tours (VT) are one of the most popular virtual productions (Bastanlar et al. 2008; Wessels et al. 2014). A virtual tour consists of a panoramic photography application that provides views of a wide variety of spatial data (realistic vision of building and surroundings) in a single environment, and to do so in a very attractive, interactive and meaningful way, thereby facilitating site cognition and learning.

The objective of this paper is to describe the work undertaken to create an interactive virtual tour, called

*Corresponding Author: María José Viñals, mvinals@cgf.upv.es 
"Edeta $360^{\circ}$ ", based on panoramic photos for the town of Llíria and its surroundings.

This work, at all times, followed the London Charter for the Computer-Based Visualisation of Cultural Heritage (2009), which establishes internationally-recognised principles for the use of computer-based visualisation by researchers, educators and cultural heritage organisations.

\section{The town of Llíria and its surroundings}

Llíria, the county town of the Camp de Túria, is located $25 \mathrm{~km}$ away from Valencia between the Mediterranean coastal strip and the Iberian mountains. The municipal district covers an area of $228 \mathrm{~km}^{2}$, being one of largest in the province. This strategic location has favoured the settlement of several historical civilisations going back to pre-Roman times (at least the second millennium B.C.). Archaeological remains of all of these civilisations (Iberians, Romans, Visigoths, Byzantines, Muslims and Christians) are scattered throughout the entire municipal district and many of them are also concentrated in the historical town itself.

Edeta $360^{\circ}$ (www.edeta360.com) focuses, in this first approach, on the virtualization process of the historical buildings located in the historical centre of Llíria.

The decision for ICTs was justified because the existent unbalance between the high amount of heritage assets to be managed and the limited staffing resources. Additionally, accessibility reasons are raised in relation to urban orographic difficulties, and also because the private ownership of some historical buildings does not allow visitors on their properties. On the other side, many old buildings present also accessing difficulties to certain rooms as the bell towers, upper floors, etc.

\section{Methodology}

This work employs the easiest procedure in order to use off-the-shelf equipment and mostly freely available software, while still ensuring the quality of the final product. The simulation environment is based on the same concept as that used by Google Street View; namely, it consists of a set of spherical images that capture the whole environment around the data collection point where they are performed.

The selection of the different heritage assets and/or environments was the first step in the elaboration of the virtual tour. The criteria applied to select these heritage elements were primarily: significance, singularity, representativeness and uniqueness, but also physical accessibility. Thus, eighteen visitable Llirian cultural assets were included in the virtual tour.

Secondly, all information related to these assets was recorded from documentary and bibliographic sources (digital, graphical and written materials), so that they could be enhanced virtually. This material includes aerial images of the town, old pictures, historical texts, artistic drawings, etc.

The steps to develop the virtual tour were:

1) Taking photos. The purpose of this task is to create the panoramic view by applying $360^{\circ}$ photography techniques in order to capture the entire surroundings of a location. To this end, at each cultural asset a central shooting position was established to guarantee the same focal length and taking into account the radius on which it will swing so as to ensure there was enough image overlap (at least $25-30 \%$ ) to allow the photos to be stitched together, as suggested by Fangi (2006). A total of 6,000 photos of Llíria were captured during 12 field campaigns between January and June 2015.

2) Rendering the spherical images onto flat $2 d$ surfaces. First of all, some photo edits or corrections were performed; then, luminosity and colour-level adjustments were made in order to obtain homogeneous images, and optical lens distortions were also corrected. The most commonly available rendering options for virtual tours, according to Ippoliti et al. (2014), are spherical geometric projections (also called equirectangular projection).

3) Stitching photos to create $360^{\circ}$ panorama images. This was performed by using the open source panorama stitcher Hugin 2014.0.0 which imports the photos and generates a single panoramic image of the deployed sphere that can be mapped onto planar surfaces.

4) Converting a $360^{\circ}$ panorama into a virtual tour with Easypano Tourweaver $7.90 \AA$ software application to produce the visitable and interactive urban virtual tour. To further explore the site, the visitor can move on to investigate other structures and the landscape (from one scene to another) by way of clickable invisible polygonal hot spots, which will be triggered when a pointing device (usually a mouse) is moved over another heritage element if visual contact exists between them. The images to be connected can be both exteriors and interiors. In order to contemplate the building from different angles, the spheres needed to be able to walk around were constructed. Afterwards, the interior of the building can be visited. The spheres are connected consistently, and the inside of the building can only be accessed through a sphere that includes a door.

5) Adding extras to the virtual visit. Navigation instruction texts, heritage information documents (different plans showing the evolution of the building over time, documentary texts, etc.), audio files, images (old pictures, etc.) are included in the application as pop-up windows.

Edeta $360^{\circ}$ opens when you right-click the virtual tour; it then shows a contextual menu. The second screen displayed consists of an introductory text with instructions on how to navigate and which also invites the user to enter.

Navigation starts with an urban aerial photo of the historical town of Llíria and related zooming images of the different virtually enhanced heritage sites and surroundings. The visitor can select one of them by clicking on the area and, afterwards, a historical building can be chosen by clicking on it; then, a first image of the main access door of the building appears.

\section{Concluding remarks}

Concluding remarks from this work point out that, beyond the well-established methods that have traditionally been employed in the field of cultural heritage to date, ICTs, and particularly virtual tours, have become increasingly more popular tools to achieve heritage enhancement, tourism experience development 
and dissemination. This is because virtual tours have the ability to arouse fascination far beyond a tourist brochure or any printed material. For this reason, it is a widely used application in cultural events and tourism fairs.

On the other hand, an online virtual tour can effectively contribute to the recreational experience in the sense that Viñals et al. (2014) noted. Hence, besides the onsite phase of visitation, the virtual tour has a high potential to generate motivation and expectations in the phase prior to the visit. A virtual online tour can also consolidate feelings of appreciation after the visit.

Other specific advantages have been identified such as its contribution to address accessibility issues (private ownership of the heritage, physical difficulties to visit some places, etc.) and the overall vision from an urbanistic perspective rather than a vision of single elements.

On the other hand, it is noteworthy that the current approach with simple off-the-shelf equipment is an important strength of the project. It thus gives an idea of the broad potential of its extrapolation to other similar heritage assets.

However, it must be recognised that it is necessary to look deeper into how to strengthen the emotional dimension of these presentations. Some authors, like Roussou (2008), have already opened up this debate.

\section{References}

BASTANLAR, Y., GRAMMALIDIS, N., ZABULIS, X., YILMAZ, E., YARDIMCI, Y. and TRIANTAFYLLIDIS, G., 2008. 3D Reconstruction for a Cultural Heritage virtual tour system. The International Archives of the Photogrammetry, Remote Sensing and Spatial Information Sciences, XXXVII (part b5). Beijing, 2008.

FANGI, G., 2006. Investigation on the suitability of the spherical panoramas by Realviz Stitcher for metric purposes. ISPRS Archives, XXXVI (part 5).

HERMON, S. and KALISPERIS, L., 2011. Between the real and the virtual: 3D Visualization in the cultural heritage domain - expectations and prospects. Virtual Archaeology Review, 2(4), pp. 59-63.

IPPOLITI, E., CALVANO, M. and MORES, L., 2014. 2.5/3D Models for the enhancement of architectural-urban heritage. A virtual tour ofr design of the Facist Headquarters in Littoria. ISPRS Annals of the Photogrammetry, Remote Sensing and Spatial Information Sciences, vol.II-5, pp. 189-196.

MONOD, E. and KLEIN, H.K., 2005. A phenomenological evaluation framework for cultural heritage interpretation: from e-HS to Heideggers' historicity. Proceedings of the eleventh Americas Conference on Information Systems, Omaha, USA, pp. 2870-2877.

NICCOLUCCI, F. (ed.), 2002. Virtual Archaeology: An Introduction. Virtual Archaeology. In Noccolucci (ed.): Virtual Archaeology. Proceedings of the VAST 2000 Euroconference, Arezza, Italy, 24-25 November 2000, 93-100. BAR International series 1075, Oxford, Archaeopress, 2002.

OTT, M. and POZZI, F., 2011. Towards a new era for Cultural Heritage Education: Discussing the role of ICT. Computers in Human Behavior, 27(4), pp. 1365-1371.

ROGERIO-CANDELERA, M.A. (ed.), 2014. Science, Technology and Cultural Heritage. CRC Press, 514 pages.

ROUSSOU, M., 2008. The components of engagement in virtual heritage environments. Proceedings of New heritage: beyond Verisimilitude. Conference on Cultural heritage and New Media, Hong Kong, pp. 265-283.

STYLIARAS, G., KOUKOPOULOS, D. and LAZARINIS, F. (eds.), 2010. Handbook of Research on Technologies and cultural heritage: Applications and Environments. Ed. Information Science Reference (USA), 592 pages.

VIÑALS, M.J., MORANT, M. and TERUEL, L., 2014. Confort psicológico y experiencia turística. Casos de estudio de espacios naturales protegidos de la Comunidad Valenciana (España). Boletín de la AGE, 65, pp. 293-316.

WESSELS, S., RUTHER, H., BHURTHA, R. and SCHRÖEDER, R., 2014. Design and creation of a 3D Virtual Tour of the world heritage site of Petra, Jordan. Proceedings of AfricaGeo, 1-3 July 2014. 


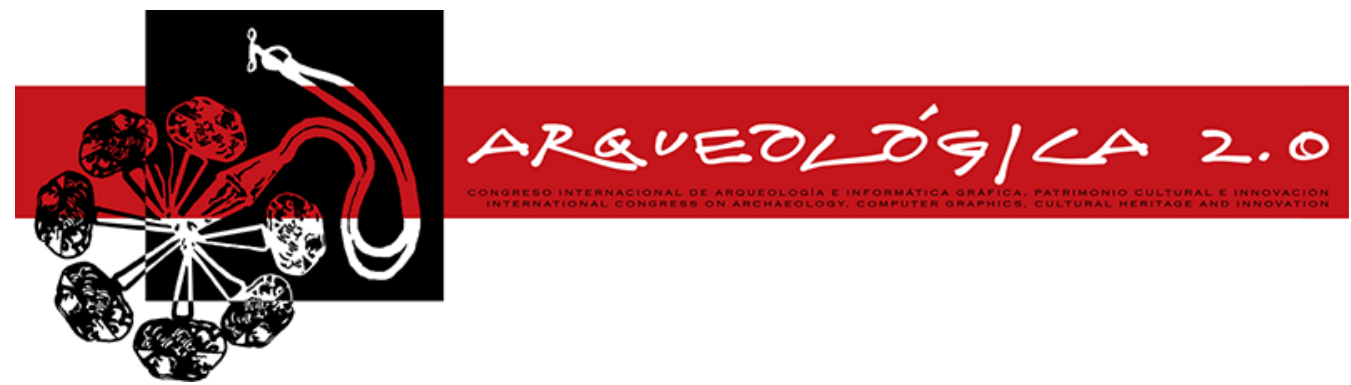

Proceedings of the $8^{\text {th }}$ International Congress

on Archaeology,

Computer Graphics,

Cultural Heritage and Innovation

'ARQUEOLÓGICA 2.0'

in Valencia (Spain),

Sept. $5-7,2016$

\title{
PROPUESTA DE PROTOCOLO GIS Y DE UTILIZACIÓN DE UN ENTORNO 3D PARA LA INTERVENCIÓN ARQUEOLÓGICA 2015 EN CUEVA DE LA COCINA (DOS AGUAS, VALENCIA)
}

\author{
PROPOSAL OF GIS PROTOCOL AND 3D TECHNIQUES IN THE ARCHAEOLOGICAL FIELDWORK AT COCINA \\ CAVE (DOS AGUAS, VALENCIA, SPAIN) \\ Agustín Díez , Alfredo Cortell, Oreto García, Pilar Escribá \\ Departament de Prehistòria i Arqueologia, Universitat de València, 46010, España. agustin.diez@uv.es; alfredo.cortell@ext.uv.es; \\ oreto.garcia@uv.es; esruizma@alumni.uv.es
}

\begin{abstract}
:
With this paper we mean to present our procedure for the digitalization of the field information, as well as the virtual stratigraphical reconstruction, of the site of Cueva de la Cocina (Dos Aguas, Valencia). The main tool for GIS implementation has been the OpenJUMP, whilst for the 3D recreation of the cave virtual environment Meshlab, Paraview, Cloud Compare and $\mathrm{R}$ open software have been used. According to the data recovered during the last intervention, accomplished between June and July 2015, we present a preview of the digitalization of the stratigraphy of the excavated sectors.
\end{abstract}

Key words: 3D reconstruction, GIS tools, archaeological fieldwork, Mesolithic, Neolithic, Cocina Cave

\section{Resumen:}

Presentamos en este trabajo el protocolo seguido para la digitalización de la información de los trabajos de campo y la reconstrucción virtual de la estratigrafía en el yacimiento prehistórico de Cueva de la Cocina (Dos Aguas, Valencia). La implementación GIS se ha efectuado mediante el uso del programa OpenJUMP mientras que para la recreación del entorno 3D se han utilizado los programas de software libre Meshlab, Paraview, CloudCompare y R. Los resultados presentados corresponden a un avance de la digitalización de la estratigrafía de los sondeos efectuados en la intervención llevada a cabo entre los meses de Junio y Julio del año 2015.

Palabras clave: entorno 3D, herramientas SIG, excavación arqueológica, Mesolítico, Neolítico, Cueva de la Cocina

\section{Introducción}

Presentamos en este trabajo una propuesta metodológica que integra la información espacial de una excavación arqueológica en un entorno de trabajo digital, con el objetivo de proceder a la reconstrucción estratigráfica de la intervención de campo y su recreación 3D. Para ello se utiliza de forma prominente el SIG libre OpenJUMP pero también Qgis (Qgis Development Team 2015) y gvSIG (gvSIG 2015). Para el mallado 3D se ha utilizado el software libre Meshlab y los paquetes rgl (Adler et al. 2016) y VecStatGraphs3D (Felicísimo et al. 2016) para R (R Core Team 2015a) y para su visualización Paraview. Cueva de la Cocina (Dos Aguas, Valencia) ha servido de base de pruebas para la implementación de estas tecnologías. Se trata de un yacimiento arqueológico reconocido (García et al. 2015), cuya secuencia comprende niveles que abarcan desde el Mesolítico Geométrico hasta la Edad del Bronce.

Uno de los objetivos de la intervención arqueológica de 2015 era el de poner en común los trabajos de Luis Pericot (entre 1941 y 1945) y los de Javier Fortea (19741981) e integrarlos en el modelo geomático actual. Para ello se realizó, en el año 2014, un escaneado de 3D de la planta de la cavidad. Posteriormente, ya durante la intervención de 2015, se siguió un protocolo de digitalización tridimensional de la información recabada en el yacimiento, derivando en notorias ventajas para su tratamiento en la labor de investigación.

\section{Metodología}

La meticulosa labor de Javier Fortea en sus excavaciones en Cueva de la Cocina nos ha permitido disponer de un listado de referencia que incorpora coordenadas $\mathrm{XYZ}$; todo ello acompañado, además de

`Corresponding Author: Agustín Díez, agustin.diez@uv.es 
material fotográfico y croquis de plantas y elementos destacados.

Apoyándonos en las nuevas tecnologías, hemos seguido parte de esta metodología, implementando dispositivos como la estación total o el escáner 3D. Toda la información recogida en campo ha sido tratada en laboratorio. Los planos de cada una de las unidades estratigráficas (UUEE) se han realizado con OpenJump (http://www.openjump.org); uno de los pocos programas capaces de dibujar tridimensionalmente las geometrías a partir de las coordenadas de los puntos tomadas en campo, así como de incluir nodos 3D complementarios (Fig. 1). El dibujo se realiza manualmente uniendo los puntos importados, o gracias a la librería Sextante (Olaya 2009), mediante varios algoritmos, como la triangulación delaunay o el algoritmo envolvente mínima.

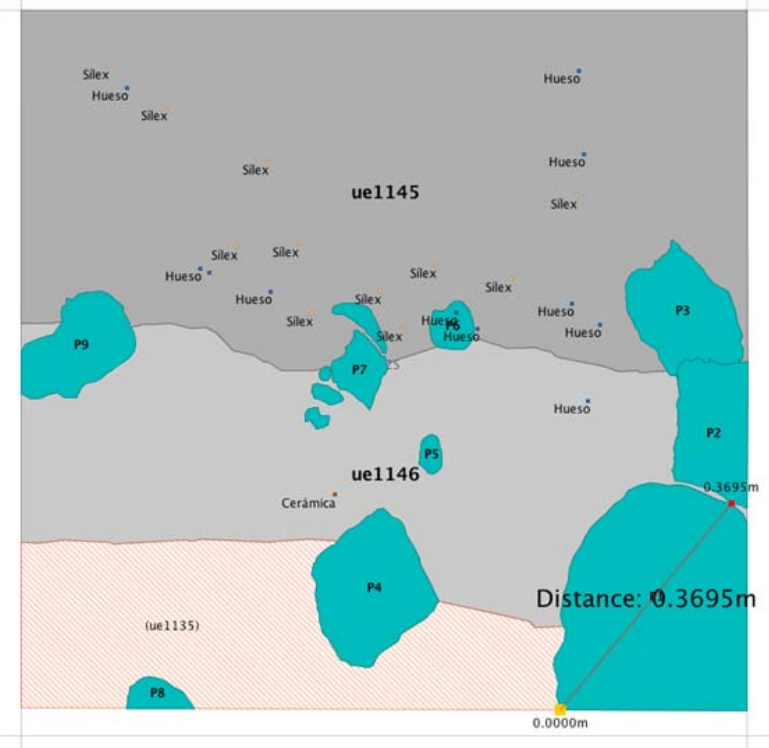

Figura 1: Reconstrucción de las UUEE 1145 y 1146 con OpenJUMP, incluyendo los puntos de hallazgos tomados en campo.

Para el mallado de las UUEE, desarrollado mediante el software Meshlab, el primer paso ha sido la realización de una base de datos relacional compuesta de tres tablas, que describen la unidad, el material gráfico y las coordenadas de los puntos de campo. Esta base de datos se ha desarrollado sobre Filemaker.

A partir de la consulta de la tabla de puntos se dibujan las plantas y se realiza su reconstrucción volumétrica. Los hallazgos que no han podido ser registrados tridimensionalmente en la excavación se generan dentro del volumen de la Unidad Estratigráfica correspondiente con una rutina en la que intervienen las librerías foreign (R Core Team 2015b), spatstat (Baddeley y Turner 2005) y alphashape3d (Lafarge y Pateiro López 2016) del programa $\mathrm{R}$ ( $\mathrm{R}$ Core Team 2015a). A partir de la envolvente mínima tridimensional de los datos tomados en la cueva se genera el volumen de cada una de las UUEE y, posteriormente, se generan de forma aleatoria, tantos puntos como hallazgos. Por último, se introducen de manera definitiva en la base de datos. El aspecto metodológico se completa con la consolidación de los hallazgos en la base de datos y un protocolo que permite dibujar de forma semiautomática las plantas de cada una de las UUEE.

\section{Resultados}

La implementación en el campo arqueológico de las tecnologías descritas proporciona interesantes resultados. Por un lado permite una ubicación correcta del yacimiento; no solo en cuanto a su situación en el espacio, sino también en referencia a las relaciones que las propias UUEE guardan entre sí.

Por el otro lado, el tratamiento informático de los datos de campo ofrece una mejor comprensión de las relaciones entre los mismos mediante su situación espacial; facilitando así el análisis, interpretación y la realización de cortes virtuales. En la intervención 2015 se digitalizaron los datos $X Y Z$ de los puntos tomados en campo, definiendo tanto las UUEE, como varios tipos de material recuperado in situ (Fig. 2).

Dada la gran cantidad de información recuperada durante la excavación, cualquier elemento que agilice la gestión de datos supone un gran avance para una interpretación precisa de la información disponible.

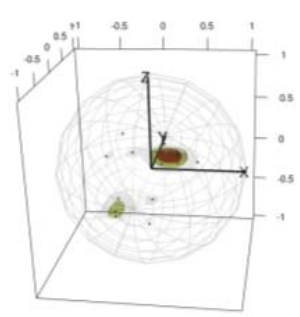

A) Cerámica

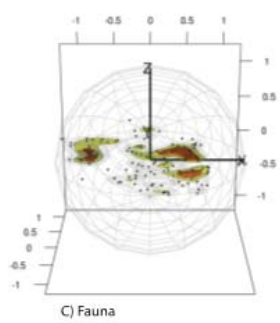

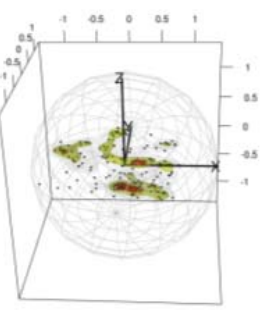

B) Malacofauna

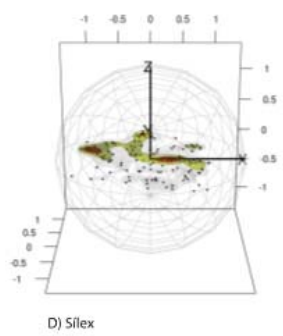

Figura 2: Densidad tridimensional de materiales en el sondeo 4 a partir del paquete VectStatGraph3D para $\mathrm{R}$ (Felicisimo et al. 2014).

\section{Agradecimientos}

El trabajo presentado se ha llevado a cabo en el marco del proyecto HAR2012-33111 "MESO COCINA: Ios últimos caza-recolectores y el paradigma de la neolitización en el mediterráneo occidental", y el proyecto HAR2015-68962 "EVOLPAST: Dinámicas evolutivas y patrones de variabilidad cultural de los últimos caza-recolectores y el primer neolítico en el este peninsular (circa 7000-4500 cal BC)", Ministerio de Economía y Competividad, Gobierno de España. El escaneado láser de la cavidad ha sido efectuado por la empresa Global Mediterránea\&Geomática (Valencia). Los trabajos de campo (Campaña 2015) han sido subvencionadas por el SIP-Museu de Prehistòria, Diputación de Valencia. 


\section{Referencias}

ADLER, D., MURDOCH, D., NENADIC, O., URBANEK, S., CHEN, M., GEBHARDT, A., BOLKER, B., CSARDI, G., STRZELECKI, A. y SENGER, A., 2016. Rgl: 3D Visualization Using OpenGL. R package version 0.95.1441. Disponible: https://CRAN.R-project.org/package=rgl [2/14/2016].

BADDELEY, A. y TURNER, R., 2005. Spatstat: An R Package for Analyzing Spatial Point Patterns. Journal of Statistical Software. Disponible: http://www.jstatsoft.org/v12/i06/ [2/14/1016].

CLOUDCOMPARE PROJECT, 2016. CloudCompare (version 2.6) [GPL software]. Disponible: http://www.cloudcompare.org/ [2/14/2016].

FELICÍSIMO, A., RUIZ, J.C., POLO, M.E., CUARTERO, A. y GARCÍA, P., 2014. VecStatGraphs3D: Vector analysis using graphical and analytical methods in 3D. $R$ package version 1.6. Disponible: https://CRAN.Rproject.org/package=VecStatGraphs3D [2/14/2016]

GARCÍA, O., JUAN, J., McCLURE, S.B., DIEZ, A. y PARDO, S., 2015. Avance de resultados de los nuevos trabajos arqueológicos en Cueva de la Cocina (Dos Aguas, Valencia): campaña de 2015. Saguntum (PLAV), 47, pp. $251-255$. DOI: $10.7203 /$ SAGVNTVM

GVSIG, 2015. Disponible en http://www.gvsig.com/es/productos/gvsig-desktop

LAFARGE, T. y PATEIRO-LÓPEZ, B., 2016. Alphashape3d: Implementation of the 3D Alpha-Shape for the Reconstruction of 3D Sets from a Point Cloud. $R$ package version 1.2. Disponible: https://CRAN.Rproject.org/package=alphashape3d [2/14/2016].

OLAYA, V., 2009. Sextante, la libreria de análisis geoespacial libre: presente y futuro. En 'III Jornadas de SIG Libre'. Girona: La Universitat. [Consulta: 14 febrero 2016]. Disponible en: http://hdl.handle.net/10256.1/1035

QGIS DEVELOPMENT TEAM, 2015. QGIS Geographic Information System. Open Source Geospatial Foundation Project. http://qgis.osgeo.org

R CORE TEAM, 2015a. R: A language and environment for statistical computing. Disponible: https://www.R-project.org/ [2/10/2015].

R CORE TEAM, 2015b. foreign: Read Data Stored by Minitab, S, SAS, SPSS, Stata, Systat, Weka, dBase, .... R package version 0.8-66. Disponible: https://CRAN.R-project.org/package=foreign [2/14/2015].

THE JUMP PILOT PROJECT, 2015. OpenJUMP SIG - The free and open source Java-based desktop SIG. Disponible: http://www.openjump.org/ [2/14/2015]. 


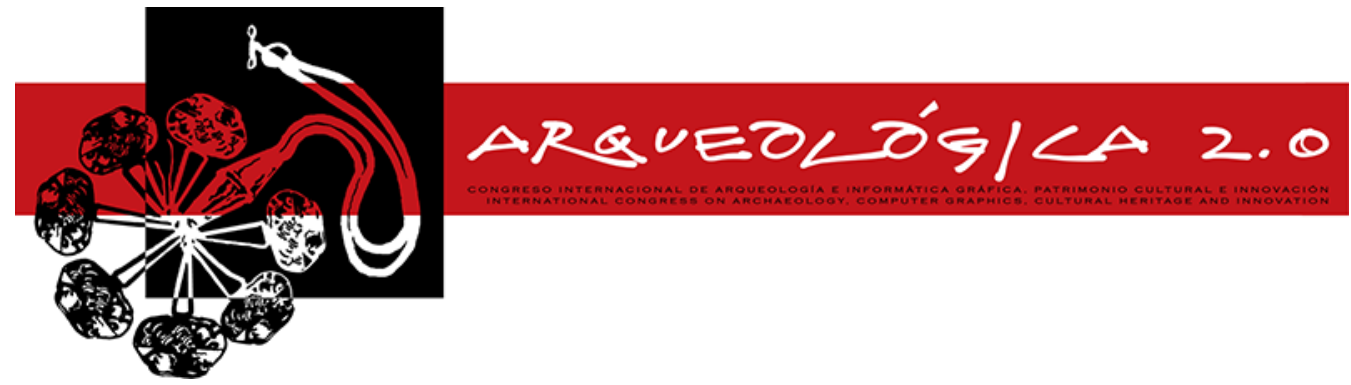

Proceedings of the $8^{\text {th }}$ International Congress

on Archaeology,

Computer Graphics,

Cultural Heritage and Innovation

'AROUEOLÓGICA 2.0'

in Valencia (Spain),

Sept. $5-7,2016$

\title{
IMAGING AND VISUALIZING MAYA CAVE SHRINES IN NORTHERN QUINTANA ROO, MEXICO
}

\author{
CREACIÓN DE IMÁGENES Y VISUALIZACIÓN DE SANTUARIOS MAYAS EN CUEVAS DEL NORTE DE QUINTANA \\ ROO, MÉXICO \\ Dominique Rissolo a, ${ }^{*}$, Michael R. Hess ${ }^{a}$, Aliya R. Hoff ${ }^{b}$, Dominique Meyer ${ }^{a}$, Fabio Esteban \\ Amador $^{\mathrm{c}}$, Adriana Velázquez ${ }^{\mathrm{d}}$, Vid Petrovic ${ }^{\mathrm{a}}$, Falko Kuester $^{\mathrm{a}}$ \\ ${ }^{a}$ Center of Interdisciplinary Science for Art, Architecture, and Archaeology (CISA3), University of California, San Diego, 9500 Gilman \\ Drive, La Jolla, California, 92093-0436, USA. drissolo@ucsd.edu; mrhess@ucsd.edu; demeyer@ucsd.edu; fkuester@ucsd.edu \\ b Department of Anthropology, Arizona State University, PO Box 872402, Tempe, Arizona, 85287-2402, USA. arhoff1@asu.edu \\ ${ }^{c}$ National Geographic Society, $114517^{\text {th }}$ Street NW, Washington, DC, 20036. USA. famador@ngs.org \\ ${ }^{d}$ Centro INAH Quintana Roo, Avenida Insurgentes 974, CP77025, Chetumal, Quintana Roo, Mexico. avelazquez.qroo@inah.gob.mx
}

\begin{abstract}
:
Innovative imaging and visualization techniques allow for the capture and display of features or objects within their broader spatial contexts. With respect to Maya cave architecture, high-resolution panoramic visualization and the production of $3 \mathrm{D}$ models can be powerful analytical tools, enabling the evaluation of potentially meaningful relationships between natural features and constructed features within a cave. A collaboration between the Instituto Nacional de Antropología e Historia (INAH) in Quintana Roo and the University of California, San Diego involves a study of at-risk cave shrines. Initial comparative and multiscalar analyses across terrestrial and subterranean environments provide insight into the form, function, and meaning of Postclassic cave architecture in the northeastern Maya lowlands.
\end{abstract}

Key words: 3D documentation, Maya, caves, shrines, Mexico

\section{Resumen:}

Innovadoras técnicas de captación, creación de imágenes y visualización permiten la captura y exposición de entidades u objetos dentro de sus contextos espaciales. En cuanto a la arquitectura maya en cuevas, las panorámicas de gran resolución y la creación de modelos 3D se convierten en potentes herramientas de visualización y análisis que permiten la evaluación de potencialmente significantes relaciones entre las características naturales y construcciones humanas dentro de las mismas. Una nueva colaboración entre el Instituto Nacional de Antropología e Historia (INAH) en Quintana Roo y la Universidad de California en San Diego contempla estudiar santuarios rupestres en riesgo. El análisis inicial a través de los entornos terrestres y subterráneos proporciona información sobre la forma, función y significado de la arquitectura postclásica maya en cuevas de las tierras bajas del noreste Maya.

Palabras clave: Documentación 3D, Maya, cuevas, santuarios, México

\section{Introduction}

The Caribbean coast of Quintana Roo provides a unique glimpse into Maya ritual practice and notions of sacred space on the eve of the Spanish conquest. Architecture, like iconography, offers a palpable link between the constructed ceremonial spaces of surface sites and the intensively used and often physically transformed subterranean realms.

Many archaeological sites along the coast are well known for their enigmatic temples and shrines, and it is within this architectural canon that regional cave shrines appear to reside. Late Postclassic buildings in Quintana Roo are typically crude affairs, coated with multiple layers of stucco plaster and typically painted blue-green and red. The high, corbelled vaults of the Classic Period are absent; instead, buildings are capped by low, simple vaults or beam-and-mortar roofs. Interiors are sometimes graced with spectacular murals executed in the so-called Mixteca-Puebla style. Temple facades are typically encircled by characteristic moldings and often support high-relief stucco sculptures.

Shrines can be, in essence, miniature temples - as they contain many of the interior and exterior architectural

*Corresponding Author: Dominique Rissolo, drissolo@ucsd.edu 
details of temples, but executed on a smaller, cruder scale. Only a few examples of such structures have been formally reported in caves along the Quintana Roo coast (Andrews and Andrews 1975; Leira and Terrones 1986; Martos 2002). Another category of constructions in caves include more open structures or masonry features and may closely resemble the altars or "thrones" found within temples at surface sites (Rissolo 2004).

The relationship between caves and surface architecture in the Maya area has received considerable attention over the past two decades (Brady 1997). Both the physical co-association between cave and structure and its symbolic significance have gone largely unrecognized at a number of recorded and reported sites. A reassessment of this broadly shared pattern in northern Quintana Roo, including the consideration of more recently identified examples, emphasizes a complementary or parallel tradition involving the incorporation of East Coast Style architectural elements characteristic of Postclassic temples into the construction of cave shrines (Rissolo 2004). Such spatial and stylistic interrelationships reaffirm the integral role of caves in site configuration and ritual practice.

\section{Recent and On-Going Research}

Innovative imaging and visualization techniques allow for the capture and display of features or objects within their broader spatial contexts. With respect to Maya cave architecture, high-resolution panoramic visualization and the production of 3D models can be powerful analytical tools, enabling the evaluation of potentially meaningful relationships between natural features - be they entrances, pools of water, or speleothems - and constructed features within a cave. Given their remarkable stylistic correspondence to Postclassic temple architecture, cave shrines and altars provide compelling and unambiguous evidence for religious practice in the cave environment. Initial comparative and multiscalar analyses across terrestrial and subterranean environments - facilitated, in part, by specific visualization techniques - provide insight into the form, function, and meaning of Postclassic cave architecture in the northeastern Maya lowlands.

In collaboration with the state office of the Instituto Nacional de Antropología e Historia (INAH), we had the opportunity to thoroughly document an at-risk cave shrine near the town of Puerto Aventuras in March 2014. The name of the cave is not officially reported here, but will be referred to as "Oratorio." Our integrative and multimodal approach to imaging and visualization was developed by the Center of Interdisciplinary Science for Art, Architecture, and Archaeology (CISA3) at the University of California, San Diego. Our efforts associated with the Cueva de Oratorio served as a trial application of our image acquisition, processing, and visualization workflow in the cave context (Hoff et al. 2015) and are being expanded to include other Maya shrines and altars that are currently at risk of vandalism or destruction.

The cave itself can be described as a large rockshelter, which opens onto a broad shallow sinkhole or area of collapse. This twilight cave is well decorated and slopes downward to pools of water along its deeper periphery. Just inside the dripline, and facing the expansive entrance, is a remarkably well constructed and well preserved Late Postclassic shrine. The miniature masonry building is $2.8 \mathrm{~m}$ on side and $1.6 \mathrm{~m}$ high and rests atop a low plinth, which is supported by a basal platform (loose rubble core) that conforms to the slope of the cave floor. The single doorway is spanned by a stone lintel (with inset panel) and the flat beam-andmortar roof is encircled by a three-part molding. A seated plastered figure (perhaps a deity) was once affixed to the roof above the doorway; all that remains are its legs, which hang over the molding. Also, the roof appears to have been adorned at one time by stone almenas; however, only one remains intact (in the NW corner).

Exterior and interior surfaces are finely plastered. A layer of organic growth on the shrine's exterior surface makes it difficult to determine whether or not it was once painted. Interior surfaces are unpainted and remain bright white. Inside the shrine, the intact roof beams are striking in their degree of preservation and integrity. Paired center beams (laid back to front, and resting on tie beams set into the walls) carry tightly-spaced transverse beams. A plastered bench along the rear interior wall of the shrine once held a venerated object, which has since been torn from its purchase.

Three primary imaging modalities have so far been used in our investigation of cave shrines within their physiographic and speleological contexts. The CAVEcam produces high-resolution stereoscopic spherical panoramas, which can be viewed in $3 D$ via immersive environments or personal VR headsets. CAVEcam field photography enables the archaeologist to view cave architecture within its broader context and within a single panorama. Such navigable point-of-view panoramas can capture and allow for seamless and uninterrupted visual movement within and between light and dark areas, entrances, cave floors and walls, speleothems and other natural as well as cultural (or culturally modified) features.

Terrestrial laser scanning (TLS) and image acquisition for structure-from-motion (SfM) photogrammetry have been conducted in tandem - producing complementary 3D data that combine trusted geometry and photorealism. In cave environments where adequate lighting for photogrammetric techniques can be challenging, TLS is particularly valuable (especially with respect to documenting the morphology of the cave itself). We produced 35 scans in Cueva de Oratorio, totaling approximately 1.5 billion points. These coordinates have become the digital "scaffold" into which photogrammetric point data can be integrated and onto which CAVEcam panoramas can be draped. The resulting models (Figs. 1,2) enable the archaeologist to view and evaluate cave architecture in its entirety as well as make critical measurements and conservation-related recommendations. 


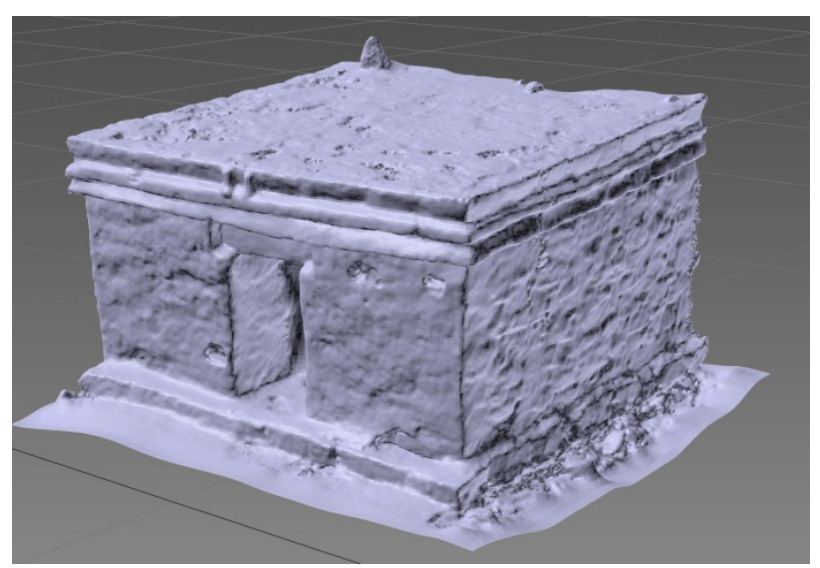

Figure 1: Mesh of the shrine in Cueva de Oratorio.

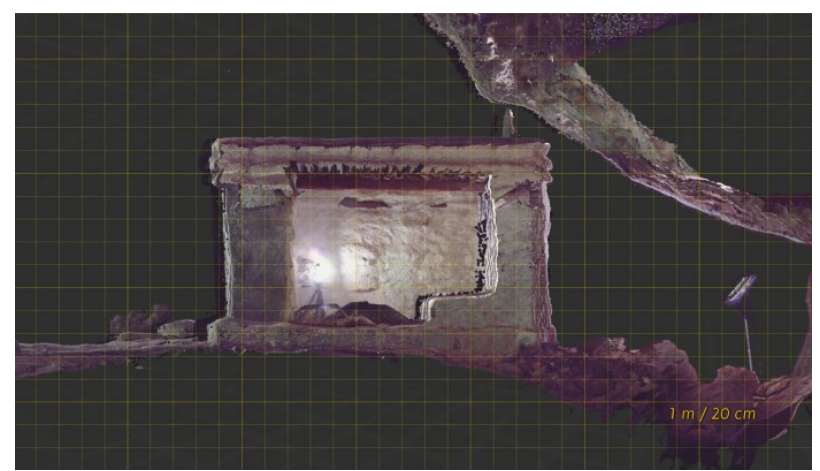

Figure 2: Side-view section of shrine in Cueva de Oratorio.

\section{Concluding Remarks}

The ancient Maya appropriated and transformed subterranean spaces in ways that were both patterned and imbued with meaning. The interplay between natural features or spaces and cave architecture reveals a tendency to conceptualize caves in a manner that is consistent with emic notions of the built environment (Rissolo 2003, 2005). Evaluating these relationships involves documenting (and being able to view) architecture within its environmental context. Continuation of our research in Quintana Roo will not only serve to digitally preserve these unique cave shrines, but will provide for current and future comparative analyses of constructed features related to ancient Maya ritual practice in caves.

\section{Acknowledgements}

Research was conducted under the auspices of the Instituto Nacional de Antropología e Historia (INAH), and we wish to recognize the staff of Centro INAH Quintana Roo. This work was supported by the National Science Foundation (NSF) under grant number DGE-0966375 and by the Kinsella Endowed Fund. We would like to thank Fred Devos, David Carillo, and Marcia Kirby for their invaluable contribution to the project. Finally, we would like to recognize the efforts of Germán Yañez and others who have surveyed the cave featured in this study.

\section{References}

ANDREWS, E.W. and ANDREWS, A. P., 1975. A Preliminary Study of the Ruins of Xcaret, Quintana Roo, Mexico: With Notes on Other Archaeological Remains on the Central East Coast of the Yucatán Peninsula. New Orleans: Tulane University, Middle American Research Institute, Publication 40.

BRADY, J.E., 1997. Settlement Configuration and Cosmology: The Role of Caves at Dos Pilas. American Anthropologist 99(3):602-618. DOI: 10.1525/aa.1997.99.3.602.

HOFF, A.R., MEYER, D., HESS, M.R., AMADOR, F.E., and RISSOLO, D., 2015. Integrative 3D Visualization for Spatial Analysis and Interpretation of Rock Shelters in Quintana Roo, Mexico. Paper presented at the $80^{\text {th }}$ Annual Meeting of the Society for American Archaeology, San Francisco.

LEIRA, L.J. and TERRONES, E., 1986. Aktun Na Kan. Boletín de la Escuela de Ciencias Antropológicas de las Universidad de Yucatán 14(79), pp. 3-10.

MARTOS, L.A., 2002. Por las Tierras Mayas: Arqueología en la Área de CALICA, Quintana Roo, México. Mexico City: INAH.

RISSOLO, D., 2003. Ancient Maya Cave Use in the Yalahau Region, Northern Quintana Roo, Mexico. Austin: Association for Mexican Cave Studies.

RISSOLO, D., 2004. Maya Cave Shrines along the Central Coast of Quintana Roo. AMCS Activities Newsletter 27, pp. 57-59.

RISSOLO, D., 2005. Beneath the Yalahau: Emerging Patterns of Ancient Maya Ritual Cave Use from Quintana Roo, Mexico. In J.E. BRADY and K.M. PRUFER, eds, In the Maw of the Earth Monster: Mesoamerican Ritual Cave Use. Austin: University of Texas Press, pp. 342-372. 


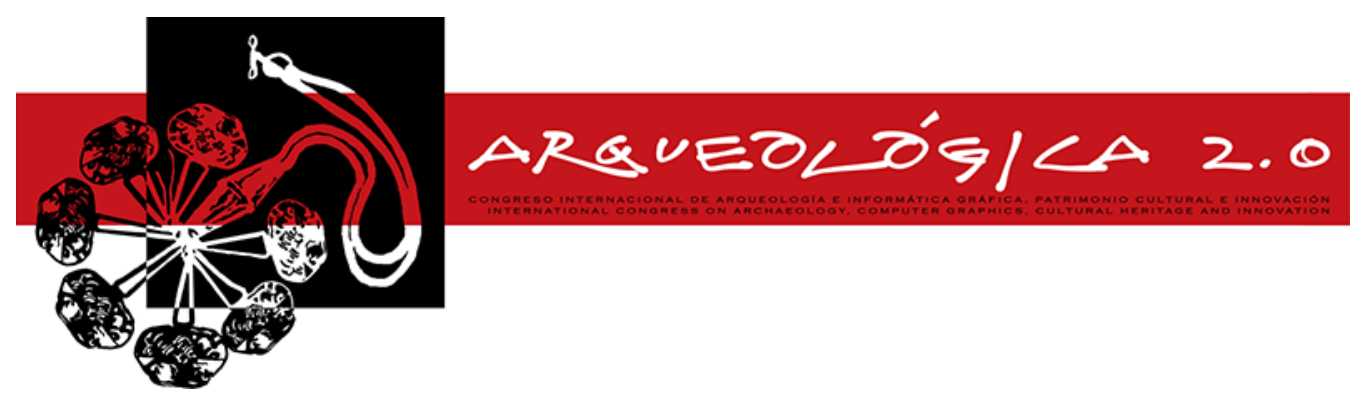

Proceedings of the $8^{\text {th }}$ International Congress on Archaeology, Computer Graphics, Cultural Heritage and Innovation 'ARQUEOLÓGICA 2.0' in Valencia (Spain), Sept. 5-7, 2016

\title{
DEL REGISTRO MANUAL AL DIGITAL: APLICACIÓN DE GRÁFICOS VECTORIALES EN ESTUDIOS ARQUEOLÓGICOS
}

\author{
FROM MANUAL TO DIGITAL RECORD: APPLICATION OF VECTOR GRAPHICS IN ARCHAEOLOGICAL STUDIES \\ Agustina Papúa, ${ }^{a}$, Laura Marina Berisso ${ }^{a}$, Damián Bozzuto ${ }^{b}$ \\ ${ }^{a}$ Universidad de Buenos Aires, Facultad de Filosofía y Letras - Instituto Nacional de Antropologia y Pensamiento Latinoamericano, 3 de \\ febrero 1378, C.A.B.A. (1426), Argentina. agus.papu@gmail.com; lauramberisso@gmail.com \\ ${ }^{\mathrm{b}}$ CONICET - Universidad de Buenos Aires, Facultad de Filosofía y Letras - Instituto Nacional de Antropoologia y Pensamiento \\ Latinoamericano, 3 de febrero 1378, C.A.B.A. (1426), Argentina. damianbozzuto@gmail.com
}

\begin{abstract}
:
This paper proposes the application of vector graphics editing software in archaeological studies to digitally trace handwritten records of excavation plans. This methodological approach is implemented in the analysis of the spatial distribution of the material remains of the site Cerro Casa de Piedra 7 in Santa Cruz Province, Argentina. Its application allows, on the one hand, the assemblage of those digitally traced copies corresponding to the excavated micro-sectors into a single general plan of the site. On the other hand, it enables the discernment of the various types of material identified in order to further study the existing relationships between them. In a first investigation two layers, associated with different moments of occupation of the site, were analyzed. The amplified display of the total distribution, allowed the identification of "activity centers", areas with high concentrations of bone and lithic materials, associated with evidences of combustion. These in turn were found located in the same sectors in the different layers analyzed, suggesting a similar use of space over time.
\end{abstract}

Key words: digital archaeology, vector graphics, spatial distribution, hunter-gatherers, intrasite, Patagonia,

\section{Resumen:}

El presente trabajo propone la aplicación de programas informáticos de diseño y edición de gráficos vectoriales en estudios arqueológicos para generar calcos digitales de plantas de excavación registradas en papel. Esta propuesta metodológica se implementa en el análisis de la distribución espacial de los vestigios materiales del sitio Cerro Casa de Piedra 7, en la Provincia de Santa Cruz, Argentina. Su aplicación permite, por un lado, el ensamble de aquellos calcos correspondientes a los microsectores excavados en una única planta general del sitio. Por el otro, posibilita el discernimiento de los diversos tipos de material identificados para profundizar en el estudio de las relaciones existentes entre sí. En un primer trabajo se analizaron dos capas asociadas a distintos momentos de ocupación del sitio. La visualización ampliada de la distribución total permitió la identificación de "focos de actividad", áreas de mayor concentración de material óseo y lítico asociadas con evidencias de combustión. Estas a su vez se encontraron ubicadas en los mismos sectores en las diferentes capas analizadas sugiriendo un similar uso del espacio a lo largo del tiempo.

Palabras clave: arqueología digital, gráficos vectoriales, distribución espacial, cazadores- recolectores, intrasitio, Patagonia

\section{Introducción}

Los importantes avances tecnológicos desarrollados hasta el momento han facilitado y optimizado el proceso de toma de datos y su análisis, brindando a los arqueólogos una útil herramienta para la investigación. Pero ¿qué sucede con la abundante información sistemáticamente recolectada de forma manual en sitios más inaccesibles o en excavaciones más tempranas?
Décadas de investigación arqueológica pueden ser encontradas únicamente registradas en papel, en plantas de excavación y libretas de campo cuidadosamente detalladas, y corren el riesgo de no explotar su total potencial informativo.

Esto se debe principalmente a la forma segmentada en la que se registra la información en campo, por lo que en muchos casos no es viable una apreciación de la

`Corresponding Author: Agustina Papú, agus.papu@gmail.com 
distribución total de los materiales del sitio en un mismo momento de ocupación y a lo largo del tiempo.

Aunque no sea posible volver a excavar un sitio y registrar la evidencia con tecnologías nuevas y más rigurosas, sí es posible utilizar los valiosos recursos del desarrollo informático para revisar y reanalizar dicha información ya documentada.

Con este objetivo, en el marco del proyecto "Al oeste del Río Pinturas: poblamiento e interacciones con el área cordillerana (Noroeste de Santa Cruz)" y enfocados en las excavaciones del sitio Cerro Casa de Piedra 7 (CCP7) en la Provincia de Santa Cruz; se optó por comenzar a utilizar programas de edición y diseño de gráficos vectoriales para transpolar las plantas de excavación a un soporte digital, complementando su información con aquella registrada en las libretas de campo (Fig 1).

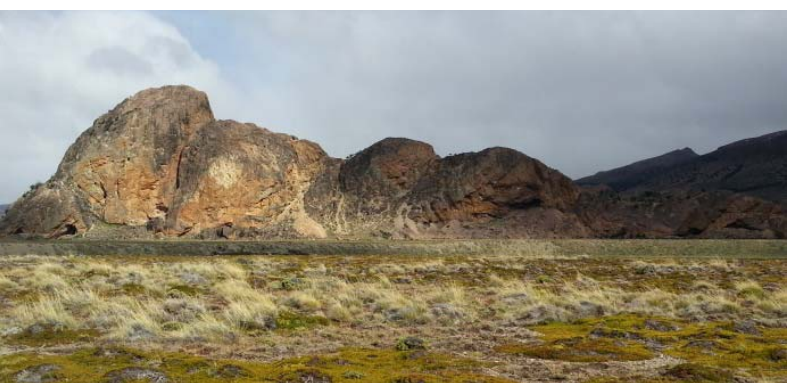

Figura 1: Cerro Casa de Piedra, en el Parque Nacional Perito Moreno (Provincia de Santa Cruz). En el extremo derecho puede verse el ingreso a la cueva 7 .

\section{Metodología aplicada en CCP7}

CCP7 se encuentra ubicado en la cuenca del Lago Burmeister, al Noroeste de la provincia de Santa Cruz en el Parque Nacional Perito Moreno. La evidencia sugiere una serie de ocupaciones por grupos cazadores recolectores que se extiende aproximadamente entre los 10690 y 3400 AP (Aschero et al. 1992-93). El sitio ha sido excavado por más de 20 años y gran parte de su registro está comprendido por detalladas plantas de excavación dibujadas en campo. Es a partir de esta documentación que se desarrolla el trabajo.

La digitalización de dicha información implica, en primera instancia, el escaneo de plantas de los distintos microsectores excavados, y luego su calcado en un programa de diseño y edición de gráficos vectoriales. Para este proyecto se optó por CorelDRAW, aunque Illustrator, su equivalente Adobe ha mostrado generar los mismos resultados. En esta instancia preliminar de investigación tales programas permiten graficar la distribución total de los materiales registados en el sitio de manera más ágil que otros. A su vez, este tipo de representación digital tiene la ventaja de poder ser ampliada cuanto sea necesario y trabajar en gran detalle sin correr el riesgo de disminuir la resolución, como ocurre con una imagen de mapa de bits.

Al momento de calcar cada planta se respeta una referencia única y se separan en distintas capas CorelDRAW los diferentes tipos de material representados en el registro. Esto permite visualizar la distribución de cada tipo de vestigio por separado, y a su vez comparar los distintos tipos de material para evaluar la posibilidad de relaciones significativas entre sí (Berisso y Papú 2016).

Por otra parte, al tener la evidencia representada por iconos de referencia y estos discernidos en distintas capas CorelDRAW, es posible una cuantificación de los elementos presentes registrados en campo.

Pero la gran ventaja a la hora de utilizar estos programas, es la posibilidad de ensamblar la versión digitalizada de los diferentes microsectores en una única planta general del sitio correspondientes a un mismo momento de ocupación o capa arqueológica. La visión más amplia y general de las distribuciones materiales a través de la cueva, brindan nuevas posibilidades en la identificación de las diferentes actividades llevadas a cabo en los distintos sectores del sitio (Fig. 2).

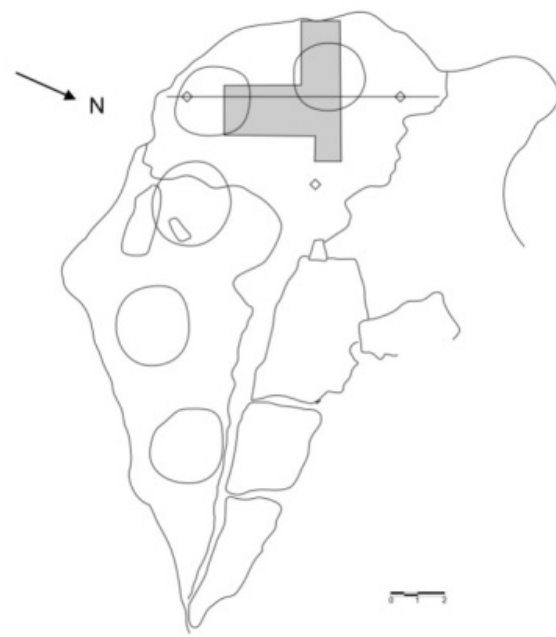

Figura 2: Representación digital de la planta de CCP7, utilizando un programa de gráficos vectoriales. El área sombreada corresponde al sector principal de excavación del sitio.

A medida que este procesamiento de información es implementado para diferentes momentos de ocupación, se abre la posibilidad de comparaciones no solamente de carácter sincrónico sino también diacrónico. Las concentraciones y dispersiones de cada material pueden brindar información sobre los criterios de selección e intensidad de ocupación de un sitio; al poder contrastar esta data manifestada en las distintas capas arqueológicas, se hace posible a su vez adentrarse en el análisis de los cambios en los patrones ocupación y de distribución de actividades en el espacio a lo largo del tiempo.

En un primer trabajo en que fue implementada esta metodología de análisis, se retomó la información recolectada de las capas 17 y 11 del sector principal de excavación en CCP7, con fechados ca 9600 y 7800 AP respectivamente (Berisso y Papú 2016).

Una vez realizadas las plantas generales se llevaron a cabo una serie de comparaciones, a partir de la cuales fueron identificadas áreas de mayor concentración de material óseo y lítico asociadas con evidencias de combustión. Estos denominados "focos de actividad" se encontraron ubicados en los mismos sectores en ambas instancias de ocupación, sugiriendo similar uso del espacio a través del tiempo. 
A su vez, con la posibilidad de cuantificar la evidencia registrada, se pudo identificar, por un lado, una mayor manifestación de todos los tipos de materiales en la ocupación más tardía; por el otro, se registró una significativa predominancia en ambos casos de la obsidiana sobre cualquier otro tipo de materia prima lítica presente.

\section{Conclusión y consideraciones a futuro}

La aplicación de programas de diseño y edición de graficos vectoriales permitió así la elaboración de una versión digital de aquel registro en papel, posibilitando la extracción de nueva información y la conservación de la misma en un soporte de datos más estable y duradero. De este modo, los datos fueron reintroducidos al contexto de investigación vigente, caracterizado por constantes avances tecnológicos.

Es por ello que el presente trabajo busca dar cuenta de las ventajas en la aplicación de esta propuesta metodológica, que puede ser adoptada con facilidad en cualquier abordaje arqueológico con similares problemáticas.

Nuevos estudios en curso en CCP7 buscan afinar el grado de análisis al aplicar esta metodología en otras capas excavadas para continuar evaluando los cambios y continuidades en los patrones de ocupación y uso del espacio intrasitio a lo largo del tiempo.

Futuros avances en esta dirección podrían introducir otros programas, como los Sistemas de Información Geográficos (SIG). Si bien estos pudieron haber sido utilizados desde un principio para llevar a cabo una similar propuesta metodológica, debido a la alta inversión de tiempo que demanda la introducción inicial de datos en los SIG, no se optó por utilizarlos en esta instancia preliminar de la investigación (Araneda 2002).

Lo que permite el calcado de plantas con programas como el CorelDRAW o el Illustrator, es un procesamiento más veloz del registro, dando lugar a la posibilidad de obtener en tiempo relativamente breve, una visión general de los patrones de distribución manifestados en el sitio. Este reconocimiento de la totalidad del material registrado permite al investigador elegir de forma más dirigida en que sectores o para que momentos de ocupación le interesa profundizar su análisis. Es para esta segunda etapa que la utilización de los SIG se torna más ventajosa (Figs. 3 y 4 ).

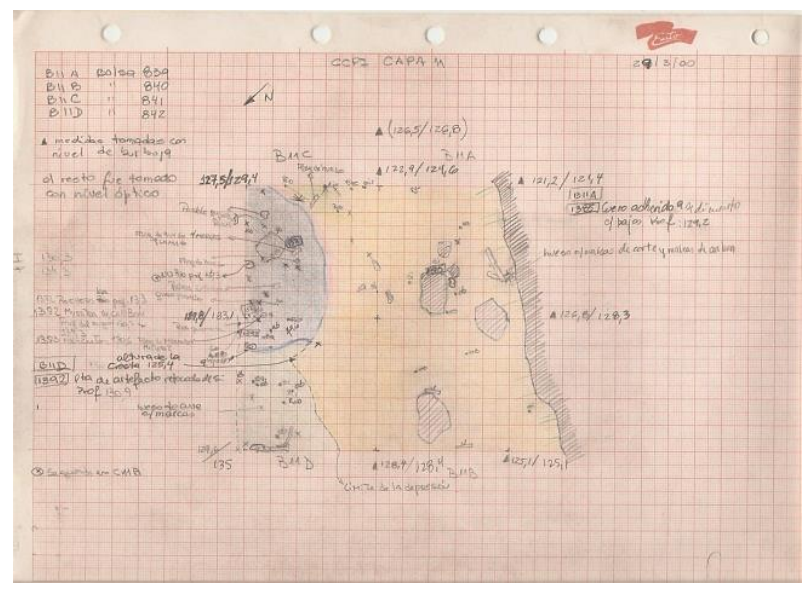

Figura 3: Planta de excavación registrada en campo correspondientes a los microsectores B11A, B11B, B11C y B11D de la capa 11 en CCP7.

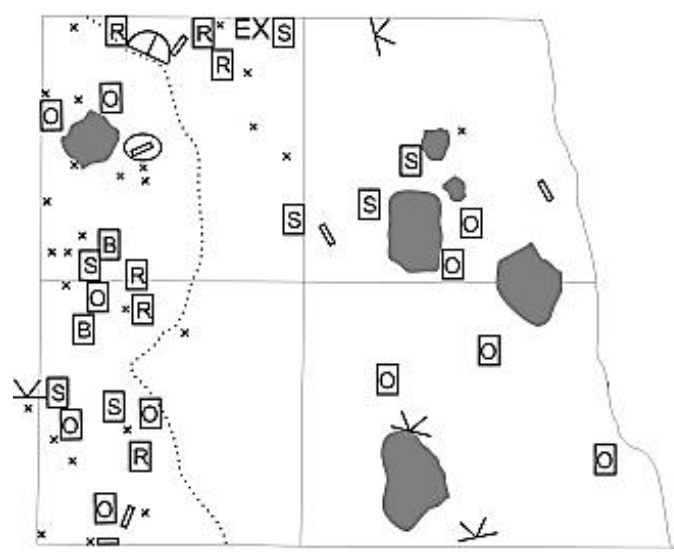

Figura 4: Calco digital de los microsectores registrados en la Figura 3.

\section{Agradecimientos}

A Carlos Aschero, Teresa Civalero y al resto de los integrantes del equipo que participaron en las tareas de campo y laboratorio a lo largo del tiempo.

\section{Referencias}

ARANEDA, C.E. 2002. Uso de Sistemas de Información Geográficos y análisis espacial en arqueología: Proyecciones y limitaciones. Estud.atacam., San Pedro de Atacama, n.22, pp. 59-75. Disponible en <http://www.scielo.cl/scielo.php?script=sci_arttext\&pid=S0718-10432002002200004\&lng=es\&nrm=iso>.

DOI:10.4067/S0718-10432002002200004.

ASCHERO, C.A., BELLELLI, C. y GOÑI, R.A., 1992-1993. Avances en las investigaciones arqueológicas en el Parque Nacional Perito Moreno (provincia Santa cruz, Patagonia Argentina). Cuadernos del Instituto Nacional de Antropología y Pensamiento Latinoamericano 14: 143-170.

BERISSO, L.M y PAPÚ, A. 2016. Patrones en el uso del espacio en Cerro Casa de Piedra 7, Provincia de Santa Cruz. Presentado a Cuadernos del Instituto Nacional de Antropología y Pensamiento Latinoamericano, Series Especiales. $X$ Jornadas de Jóvenes Investigadores en Ciencias Antropológicas, INAPL, Argentina 


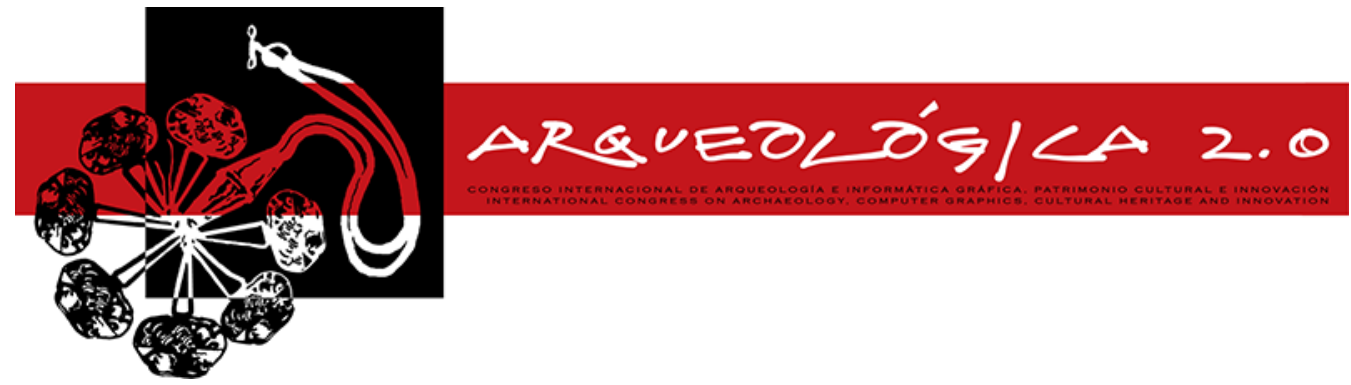

Proceedings of the $8^{\text {th }}$ International Congress

on Archaeology,

Computer Graphics,

Cultural Heritage and Innovation

'ARQUEOLÓGICA 2.0'

in Valencia (Spain),

Sept. $5-7,2016$

\title{
FOTOGRAMETRÍA AÉREA Y TERRESTRE PARA LA DOCUMENTACIÓN 3D DEL CASTILLO DE BARXELL (ALCOI, ALICANTE, ESPAÑA)
}

\author{
AERIAL AND GROUND PHOTOGRAMMETRY FOR 3D RECORDING OF THE BARXELL CASTLE (ALCOI, \\ ALICANTE, SPAIN) \\ Natxo Segura ${ }^{\mathrm{a},{ }^{\star}}$, Enric A. Paredes ${ }^{\mathrm{b}}$, José David Busquier ${ }^{\mathrm{c}}$ \\ ${ }^{a}$ El Tossal Cartografies, Alcoi, España. info@eltossaltopografia.com \\ ${ }^{\mathrm{b}}$ Arquitecto freelance, Alcoi, España. enricparedes1@gmail.com \\ ${ }^{c}$ Abydos arqueologica S.L., Elda, España. info@abydosarqueologica.es
}

\begin{abstract}
:
Photogrammetry is presented as an essential tool for the study of the Barxell Castle. This technic adapts to the conditions of high quality, speed and low cost, achieved by combining air and ground data collections with the use of a single camera, and avoiding optics with large angular. We have generated a three-dimensional homogeneous model from which are designed respective elevations of high quality and resolution that are of key importance for architectural and archaeological analysis.
\end{abstract}

Key words: aerial photogrammetry, data acquisition, cultural heritagerecording, medieval castle

\section{Resumen:}

La fotogrametría se presenta como una herramienta imprescindible para la aproximación al estudio del Castillo de Barxell. Se adapta a las condiciones de alta calidad, rapidez y coste reducido, conseguidas mediante la combinación de tomas aéreas y terrestres de datos con la utilización de una misma cámara fotográfica, y evitando ópticas con grandes angulares. El resultado, ha permitido generar un modelo tridimensional homogéneo a partir del cual se han concebido los respectivos alzados de gran calidad y resolución que han sido cruciales para los estudios arquitectónicos y arqueológicos.

Palabras clave: fotogrametría aérea, adquisición de datos, documentación del patrimonio cultural, castillo medieval

\section{Introducción}

En el mes de julio de 2014 se planteó la necesidad de actuación de emergencia para los trabajos de consolidación del Castillo de Barxell. La fortificación medieval destaca compositivamente por su torre prismática, ubicada en el punto más alto del reducto principal, de planta rectángular con $8,50 \times 5,60 \mathrm{~m}$. de base y de $15,75 \mathrm{~m}$. de altura, al que se adosa un patio en dos de sus frentes, cerrando al sur con una nave rectangular de dimensiones $23,10 \times 6,60 \mathrm{~m}$. El recinto superior conforma una extensión de $331 \mathrm{~m}^{2} \mathrm{y}$ un perímetro de $80 \mathrm{~m}$ (Paredes 2011). Además de la propia configuración espacial del bien, con existencia de puntos inaccesibles; las interferencias propias que los restos conservados producen entre sí por la elevada altura; los giros y la diferencia de cotas entre piezas, se puso de manifiesto, un repertorio de impedimentos difícilmente salvables de cara a una efectiva toma de datos.
De otra parte, la actuación sobre la fortificación de propiedad privada entrañaba unos retos, por añadidura, que venían exigiendo de origen, un equipo técnico capaz de desenvolverse ante una dinámica presupuestaria cambiante, discontinua y de bajo coste.

Desde la disciplina arquitectónica y para la fase de análisis y diagnosis, se hacía necesario contar con una toma de datos objetiva, que pudiera dar respuesta a las dificultades especiales que planteaban las fábricas murarias a interpretar, permitiendo obtener unos resultados de suficiente calidad y precisión dentro de unos plazos razonables.

De igual manera, desde la disciplina arqueológica la fotogrametría, como técnica incorporada, implementaba una evolución tecnológica a las posibilidades de trabajo de campo y posterior laboratorio, debiendo ser la base interpretativa de algunas de las partes del elemento patrimonial dentro de ese análisis multidisciplinar planteado. El dibujo técnico y toma de datos con este

*Corresponding Author: Natxo Segura, info@eltossaltopografia.com 
procedimiento nos permitiría la perfecta lectura sedimentológica y el establecimiento de una secuencia estratigráfica que diera una composición cronológica digital del proceso de trabajo con una precisión mayor que la de los dibujos manuales al uso, utilizados en otros ámbitos de estudio similares.

Por todo ello, se optó por un tipo de levantamiento basado en métodos indirectos: levantamiento fotogramétrico.

\section{Planificación y captura de las tomas fotográficas}

Es importante destacar que los trabajos de captura se desarrollaron en tres fases: la primera fue en septiembre de 2014, y su objetivo fue documentar las fachadas principal y lateral del castillo. Las otras dos fases se realizaron en marzo de 2015 y septiembre de 2015.

Con la finalidad de obtener un resultado uniforme en la documentación, consideramos importante la utilización de una misma cámara fotográfica tanto para las tomas aéreas como para las terrestres: en esta primera fase, la captura de datos se realizó con una cámara "GoPro Hero 3+ Black edition" de $12 \mathrm{Mp}$ de resolución. Para las tomas aéreas se utilizó el cuadricóptero "Phantom 2" de DJI. Para las tomas terrestres empleamos una pértiga de 4 metros de altura. En ambos casos las fotografías se efectuaron a una distancia de 4 metros de las fachadas a documentar (Fig. 1).

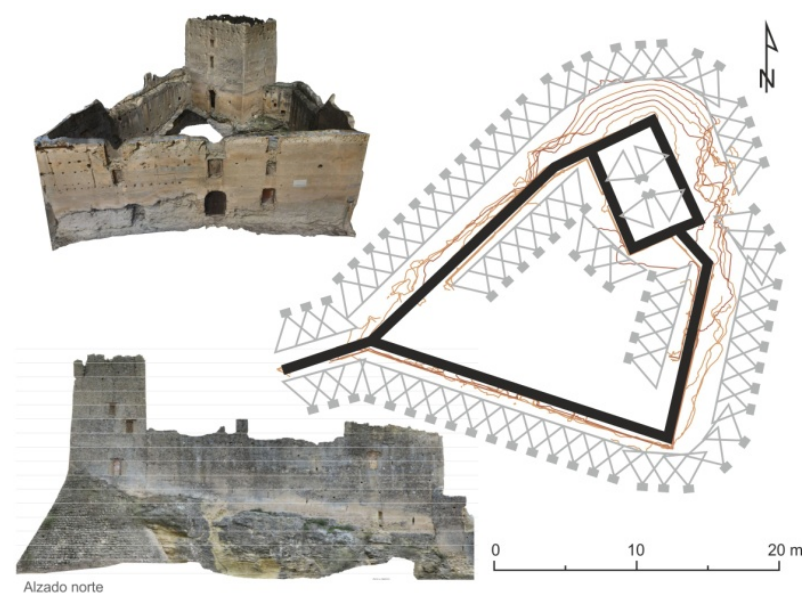

Figura 1: Planificación de las tomas fotograficas.

El primer problema que apareció, una vez procesadas las fotografías, fue la falta de resolución de los alzados ortográficos obtenidos. Cabe destacar que el principal propósito de la documentación se basaba en el registro exhaustivo de las paredes del castillo. Las cámaras "GoPro" tienen la ventaja de contar con un reducido tamaño, ligereza y portabilidad para su uso en drones, pero por el contrario, su óptica proporciona un amplio ángulo de visión $\left(123^{\circ} \mathrm{FOV}\right.$ horizontal), los objetos se alejan y la resolución, de los modelos fotogramétricos realizando las tomas a igual distancia de las fachadas a restituir, es la mitad comparada con el uso de focales cuyo campo de visión es más pequeño $\left(60^{\circ} \mathrm{FOV}\right.$ horizontal).

A raíz de los resultados obtenidos se procedió a cambiar la cámara fotográfica en la segunda fase de los trabajos, utilizando esta vez una "Canon Powershot SX 700". Esta cámara compacta y ligera de 16,1 Mp y conectividad Wi-Fi nos permitiría, aumentar notablemente la resolución de las tomas. Para la sujeción de la cámara en el drone se construyó un pequeño soporte compuesto de unas almohadillas de amortiguación y un sistema articulado para controlar la inclinación de las tomas fotográficas (Fig. 2). La conectividad Wi-Fi fue crucial para el control y captura de las tomas tanto sobre el drone como sobre la pértiga, gracias a la utilización de una tablet y de la aplicación Canon Connect. Señalar como inconveniente, que esta aplicación solo permite fotografíar en modo automático; este inconveniente no hubiera sido tal de haber contado con el firmware CHDK, sin embargo, hasta la fecha y para este modelo el CHDK no ha sido todavía desarrollado.

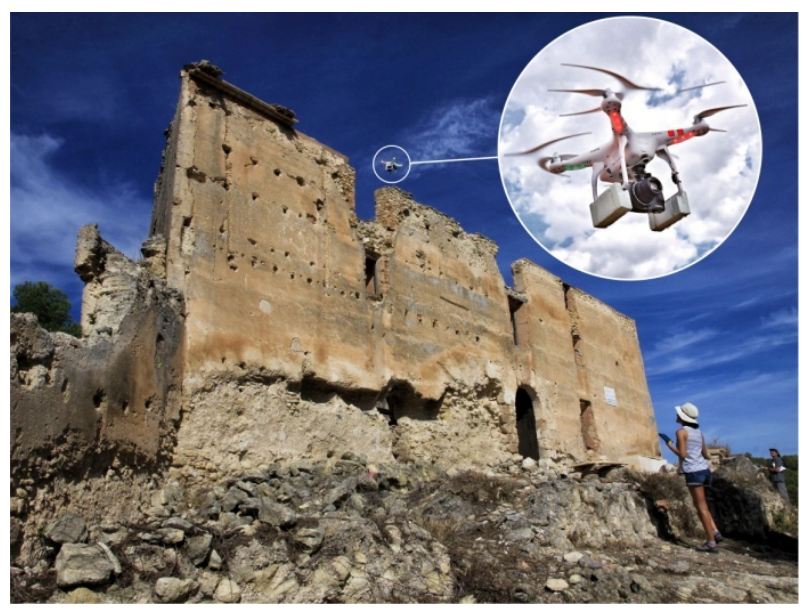

Figura 2: Fachada principal del castillo y detalle del "Phantom 2" con la cámara "Canon".

En esta segunda fase, las tomas aéreas y terrestres se realizaron en un día nublado de modo que la iluminación fuera uniforme, sin sombras y vientos flojos. En las zonas accesibles mediante la pértiga, las tomas fueron terestres, el resto aéreas, volando en modo manual y realizando los disparos a través de la aplicación Canon Connect. En cuanto a la planificación, el criterio seguido fue similar al de la primera fase: fotografías a 4 metros de las fachadas y un solape del del $60 \%$ tanto vertical como horizontal. Previo al vuelo y tomas terrestres se establecieron una serie de puntos control métrico sobre las fachadas e interiores del castillo y torre. Estos puntos fueron registrados mediante estación total obteniéndose las coordenadas necesarias para escalar y georreferenciar nuestro modelo fotogramétrico. Para el registro topográfico fue necesario dotar la zona de trabajo de una red de bases sobre la que se efectuaron las mediciones.

La tercera fase de trabajos se centró en la intervención arqueológica, en la que se realizaron sondeos en un sector junto a la fachada principal. En este caso, las tomas fotográficas se realizaron con pértiga.

\section{Procesamiento de los datos y resultados}

Después del trabajo de campo seleccionamos las imágenes obtenidas para conseguir una superposición entre tomas del $60 \%$, descartamos las fotos movidas, 
saturadas u oscuras (Ruiz et al. 2015). Con la finalidad de agilizar el procesamiento de datos y optimizar el rendimiento del ordenador, las fotografías seleccionadas fueron clasificadas en 4 bloques, cada uno de ellos correspondiente con un modelo fotogramétrico independiente: 1. Bloque exterior (sur y este); 2. Bloque exterior (norte); 3. Bloque interior (patio) y 4 . Bloque interior (torre). Cada bloque fue procesado por separado obteniendo 4 nubes de puntos, posteriormente fueron georreferenciadas a partir de los puntos de control, alineando con ello los 4 bloques en un mismo sistema de coordenadas, finalmente se procedió a unir los 4 bloques formando una única nube de puntos que fue depurada, reduciendo el ruido existente antes de generar la malla tridimensional que representaría geométricamente el castillo (Tabla 1).

Tabla 1. Bloques fotogramétricos y puntos de control

\begin{tabular}{c|c|c}
$\begin{array}{c}\text { Bloque / Número } \\
\text { de fotos }\end{array}$ & $\begin{array}{c}\text { Número de puntos } \\
\text { de control }\end{array}$ & $\begin{array}{c}\text { Error de precisión del } \\
\text { modelo }(m)\end{array}$ \\
\hline $1 / 167$ & 8 & 0.03 \\
2 / 185 & 8 & 0.04 \\
3 / 108 & 9 & 0.02 \\
4 / 145 & 7 & 0.01
\end{tabular}

El programa utilizado para el cálculo fotogramétrico fue "Photoscan" de Agisoft. Su entorno de trabajo es sencillo (Peinado et al. 2014) y nos permitió este cálculo en cuatro bloques. Los puntos de control nos permitieron, por un lado georreferenciar los modelos, y por otro, establecer la bondad del ajuste métrico. El esquema para la obtención de los modelos tridimensionales consistió en 6 fases: orientación automática de las tomas fotográficas; control métrico de los bloques; alineación de los bloques a un mismo sistema de coordenadas; depuración de la nube de puntos final; generación de la malla y aplicación de la textura.

Se utilizaron un total de 605 fotografías. La densidad de las nubes de puntos para cada bloque osciló el 1.000 .000 de vértices. Una vez alineados los 4 bloques la nube de puntos final se utilizó para procesar una única malla con 1.115 .000 triángulos, este único modelo tridimensional fue clave para la generación los diferentes alzados ortográficos. El tamaño del pixel resultante en los alzados fue de 0,001 metros.

\section{Conclusiones}

La fotogrametría se presenta como una herramienta imprescindible para la aproximación al estudio del
Castillo de Barxell, y precisamente adaptada a las condiciones de partida de alta calidad, rapidez y coste reducido, conseguida mediante la combinación de tomas aéreas y terrestres utilizando una misma cámara fotográfica, y evitando ópticas con grandes angulares que han permitido la generación de un modelo tridimensional homogéneo: la densidad de puntos de los diferentes bloques en relación a la superficie cubierta por ellos ha sido similar y la resolución (píxeles) de las texturas obtenidas ha sido la misma. A partir de este modelo se han concebido los respectivos alzados ortográficos de gran calidad y resolución.

Desde la disciplina arquitectónica, en la fase analítica, ha sido crucial la fotogrametría para el estudio de las fábricas de tapia y su particular sistema constructivo. Los estudios murarios alcanzan cotas de definición a escala de detalle, mejorando el reconocimiento de las juntas horizontales entre hiladas y las verticales dejadas por las distintas tapialeras ejecutadas, también se precisa para ubicar huellas constructivas de vital importancia como agujas, barzones, etc. y conocer sus ritmos, orden, secuencia, etc. (Fig 3). Esta copiosa información que al natural es arduo y complejo leer e interpretar, y en este caso en particular, imposible para determinados puntos inaccesibles, se hace viable a través del modelo digital.

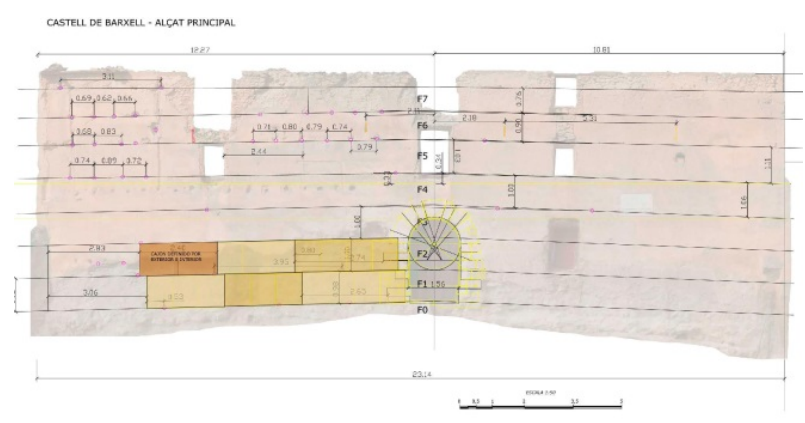

Figura 3: Fachada principal. Estudio de la tapia sobre alzado.

Para la disciplina arqueológica se han abierto nuevas vías de trabajo, dando valor añadido, permitiendo que los datos obtenidos puedan ser tratados con diversos programas como el caso de los SIG. El resultado ha permitido, tanto precisar plantas de excavación secuenciales, estableciendo fases cronológicas, como calcular secciones acumulativas de todas las zonas en las que el proceso de trabajo e interpretación posterior lo requiere, identificando con ello la secuencia estratigráfica que completa el registro arqueológico e histórico del monumento que, junto a los parámetros arquitectónicos, posibilitarán el planteamiento de medidas correctoras precisas a adoptar en cada uno de los casos futuros.

\section{Referencias}

PAREDES, E.A., 2011. Aproximación a la arquitectura de las fortificaciones en las montañas del valle central del Serpis. Las Torres. Actas del Séptimo Congreso Nacional de Historia de la Construcción. Madrid: Instituto Juan de Herrera, vol. 2, pp. 1043-1053.

PEINADO, Z., FERNÁNDEZ, A. y AGUSTíN, L., 2014. Combinación de fotogrametría terrestre y áerea de bajo coste: el levantamiento tridimensional de la iglesia de San Miguel de Ágreda (Soria). Virtual Archaeology Review, vol. 5, núm. 10, pp. 51-58. DOI: 10.4995/var.2014.4210 
RUIZ, J.A., GALLEGO, D., PEÑA, C., MOLERO, J.M. y GÓMEZ, A., 2015. Fotogrametría aérea por drone en yacimientos con grandes estructuras. Propuesta metodológica y aplicación práctica en los castillos medievales del Campo de Montiel. Virtual Archaeology Review, vol. 6, núm. 13, pp. 5-19. DOI: 10.4995/var.2015.4366 


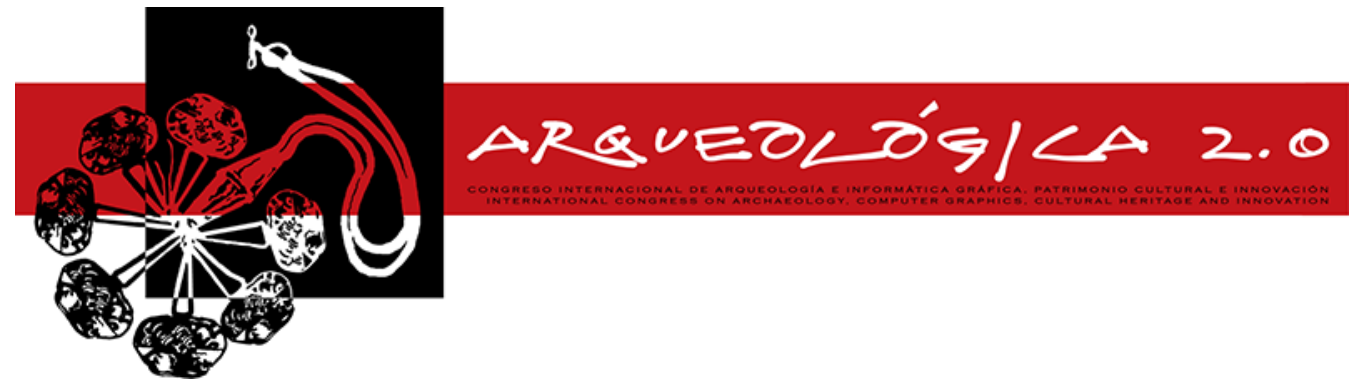

Proceedings of the $8^{\text {th }}$ International Congress

on Archaeology,

Computer Graphics,

Cultural Heritage and Innovation

'ARQUEOLÓGICA 2.0'

in Valencia (Spain),

Sept. $5-7,2016$

\title{
3D IMAGING ANALYSIS AND DIGITAL STORYTELLING FOR PROMOTION OF CULTURAL HERITAGE: THE SCHOOL OUTREACH PROJECT OF REALMONTE
}

\section{ANÁLISIS DEL ESCANEO EN 3D Y NARRACIÓN DIGITAL PARA LA PROMOCIÓN DE LA HERENCIA CULTURAL: UN PROYECTO DE GRAN ALCANCE PARA LAS ESCUELAS DE REALMONTE.}

\author{
Elisa Bonacini ${ }^{\mathrm{a}}$, Domenica Gulli ${ }^{\mathrm{b}}$, Davide Tanasi ${ }^{\mathrm{c},{ }^{*}}$ \\ a Università di Catania, Dipartimento di Scienze Umanistiche, Piazza Dante 32, 95124 Catania, Italia. ebonacini@unict.it \\ ${ }^{\mathrm{b}}$ Superintendence of Cultural Heritage of Agrigento, Via Imera 50, 92100 Agrigento, Italy. domenica.gulli@regione.sicilia.it \\ ${ }^{c}$ University of South Florida, Center for Virtualization and Applied Spatial Technologies (CVAST) \& Department of History, 4202 E \\ Fowler Ave, Tampa, FL 33620, USA. dtanasi@usf.edu
}

\begin{abstract}
:
This paper presents a work in progress carried out by the authors with the students of three high schools of Agrigento (Sicily, Italy) for the promotion of the cultural heritage of the city of Realmonte, near Agrigento. Through the combination of 3D imaging, storytelling and video production, the project aims to spread knowledge about the archaeological site of the $1^{\text {st }}$ century AD Roman villa of Durrueli, the Italkali salt mines and the natural site of the Scala dei Turchi.
\end{abstract}

Key words: virtual archaeology, 3d imaging, cultural heritage, experiential learning, Roman archaeology

\section{Resumen:}

Esta obra presenta un trabajo en progreso llevado a cabo por los autors conjunto con los estudiantes de tres secundarias de Agrigento (Sicilia, Italia) para la promoción de la herencia cultural de la ciudad de Realmonte, cercana a Agrigento. Con la combinación del escaneo en $3 \mathrm{D}$, narración de la historia, y la producción de video, el projecto trata de divulgar el conocimiento de Durrueli, sobre el sitio arqueológico de una villa Romana del primer siglo D.C, las minas de sal de Italkali y los sitios naturales de la Scala Dei Turchi.

Palabras clave: arqueología virtual, escaneo en 3D, herencia cultural, aprendizaje experiencial, arqueología romana

\section{1. \#ComunicaCultura: a school outreach project about the territory of Realmonte}

This paper deals with the preliminary results of the educational project \#ComunicaCultura fostered by the Superintendence of Cultural Heritage of Agrigento, in collaboration with external experts in 3D modeling and digital storytelling, within the framework of a 2015 school outreach program, named School-Museum and sponsored by the Sicilian regional Department of Culture and Sicilian Identity. Students of three high schools of the Agrigento area have been involved, in order to educate them to respect cultural heritage and to understand the importance of its communication and promotion.

Realmonte is a small municipality of some 4.500 people located about 15 kilometres west of Agrigento, in Sicily. The most popular tourist attraction of this area is the Scala dei Turchi, a rocky marlstone cliff by the coast, famous for its white color and its staircase-shape, lying between two sandy beaches.

The other two main sites are the so-called Roman Villa of Durrueli and the gigantic salt mines of Scavuzzo, still active and run by the company Italkali, extending for kilometres in the subsurface, well known for the cathedral carved by miners into the salt walls.

This project aims to make students aware of the wonders of their natural and cultural landscape and to contribute to the spread of that knowledge. The goal is to engage the students with experiential activities such as field studies, analysis of media related with cultural heritage and to guide them in the process of creation of short videoclips, including screenplay conception, live footage, high quality pictures and 3D models.

“Corresponding Author: Davide Tanasi, dtanasi@usf.edu 


\section{The Roman Villa of Durrueli}

The Roman villa of Durrueli is one of the most significant examples of the material cultural output of the Early Roman Imperial period in Sicily. The villa is located on the western coast of Sicily, a few kilometers west of Porto Empedocles, the ancient commercial terminal of Agrigento. The villa is the only example of villae maritimae in all of Sicily, situated on the sea-shore. The discovery of the villa occurred in December 1907, during the construction of the railway line between Porto Empedocle and Siculiana. In 1908 an excavation directed by Antonio Salinas brought to light some rooms paved in opus sectile and opus tessellatum. Archaeological research was only resumed with two campaigns in 1979 and 1981, under the direction of the Superintendence of Agrigento, in collaboration with the University of Tsukuba, in Japan (Aoyagi 1980-1981; Fiorentini 1993-1994: 728-730; Fiorentini 2006).

Currently, the complex is made up of a residential block on the eastern side of the archaeological area, with several reception rooms opening onto a courtyard with a peristyle overlooking the sea, probably with an architectural monument, surrounded by a wall with cement running to the beach (Fig. 1). Analyzing the plan of the house (Fig. 2), five columns on each side of the square peristyle surround a wide open unpaved court interpreted as a viridarium, a sort of garden. On the north side of the peristyle is the entrance of the reception hall of the dominus, the so-called tablinum.

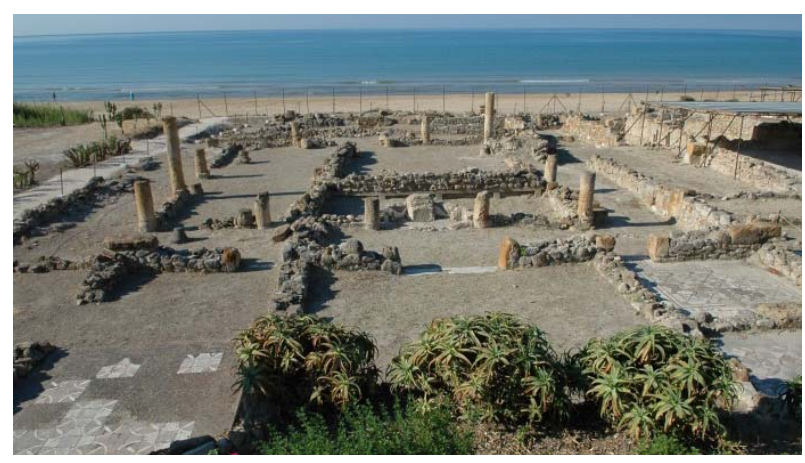

Figure 1: The peristyle of the villa from north.

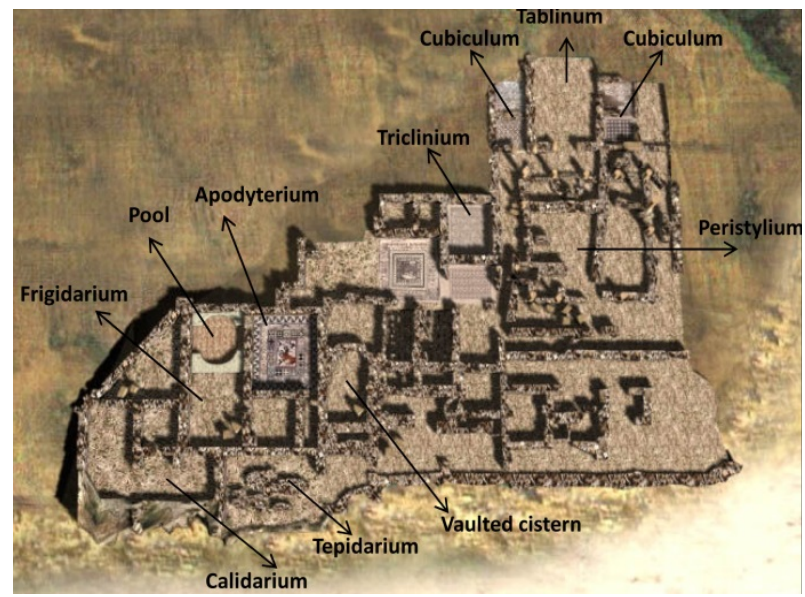

Figure 2: Axonometric plan of the villa with indication of the function of the rooms.
To the west of the residential area are the termae divided into two juxtaposed parts which also include a large oval pool whose walls were covered with marble slabs (Fig. 3). Each part consisted of a large room used as a a dressing room, apodyterium, with a complex floor decoration, leading to the heated rooms, in which all the elements of the hypocaust system are still visible, such as the suspensurae, the ducts and the kilns (Fig. 4). A tank inserted between the two nuclei guaranteed the necessary water supply in both baths.

A large quadrangular room paved with two-tone black and white mosaic that includes touches of color limited to the figure of Neptune on the hippocampus can be found in the first part of the termae. The apodyterium of the second group is a large room paved with even more precisely constructed mosaic, depicting Scylla in the act of brandishing a rudder at the center (Fig. 5). Again the mosaic is two-toned, with touches of color reserved to the figure of Scylla. Remains of the marble facing of the walls, both in this environment and in the adjoining one with the floor in opus sectile and hot frigidarium, document the wealth of the termae. Based on the finds and especially the stylistic analysis of the floors in opus sectile and opus tessellatum, the architectural complex has been dated between the late $1^{\text {st }}$ and the first half of the $2^{\text {nd }}$ century A.D.

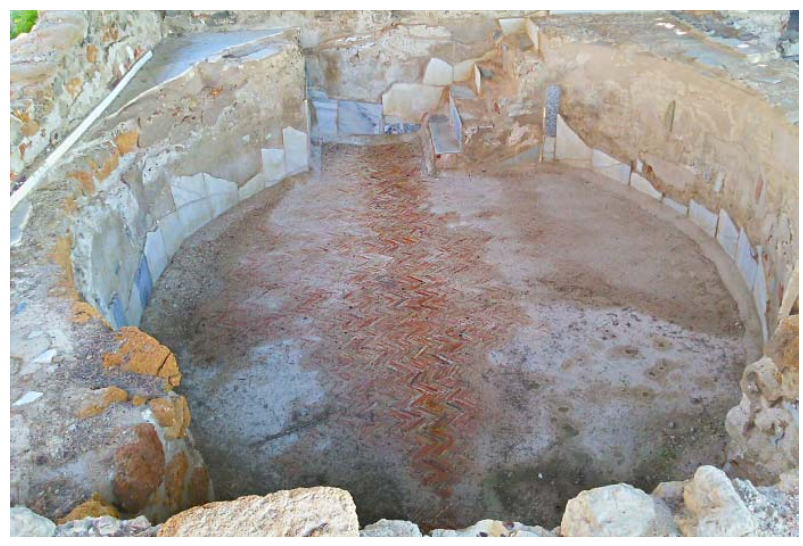

Figure 3: The pool of the termae complex.

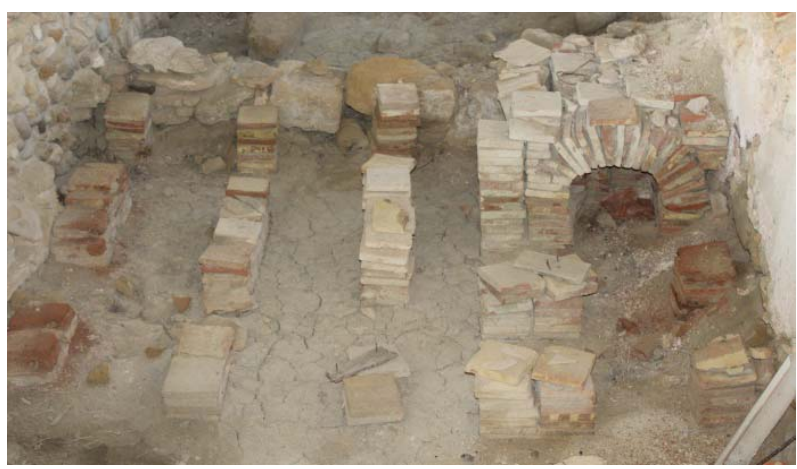

Figure 4: Kiln and suspensurae of one of the heated rooms in the termae district.

\section{The virtualization of the Roman Villa}

After a few lectures on digital communication and documentation of cultural heritage, the students, supervised by external experts and by their own professors, produced 3D models of the most important rooms of the villa using both $3 D$ scanning and Image 
Based 3D modelling techniques, as seen elsewhere (Levy et al. 2012), in order to enrich the videoclips with enganging content. Sets of digital pictures of the peristyle, the western cubicle, the apodyterium with the mosaic of Scylla and the pool (Figs. 6 and 7) were processed with the software Agisoft Photoscan in order to produce 3D models. Furthermore, some details of the rooms, such as the kiln of one the heated rooms (Fig. 8) was acquired using the Occipital Structure sensor for Ipad. Subsequently, 3D models were processed and decimated with Meshlab and short clips of the models were created using Cinema 4D.

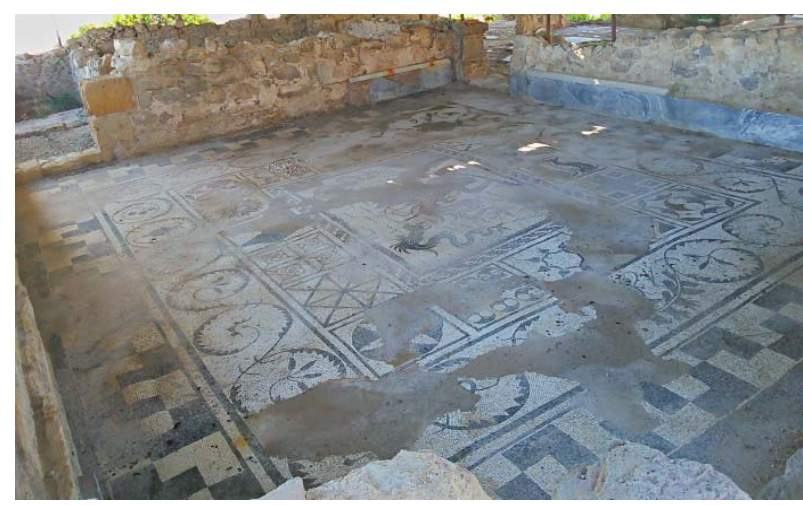

Figure 5: The apodyterium with the mosaic of Scylla.

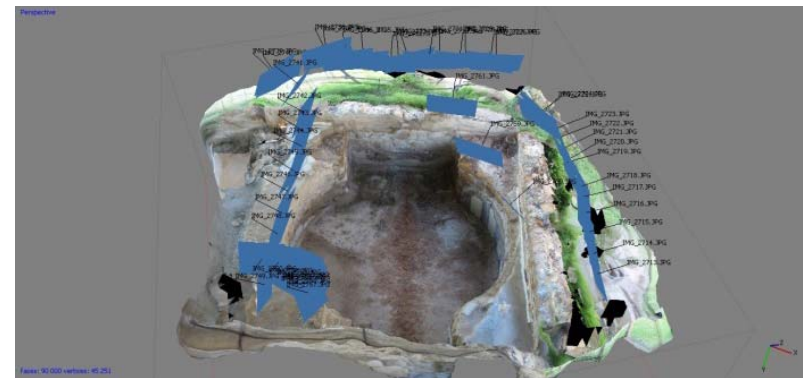

Figure 6: 3D model of the pool with indications of the camera positions from which pictures where taken.

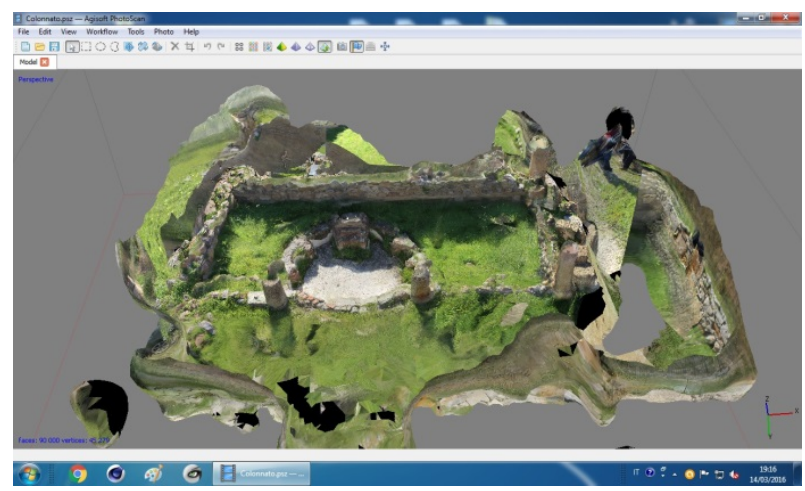

Figure 7: Unprocessed 3D model of the peristyle.

\section{Digital narrative and original script}

The project being still ongoing, no content related with the Scala dei Turchi or the salt mines has yet been produced. However, 3D models of the altar and the pulpit of the cathedral carved in the salt walls of the mines have been generated (Fig. 9). Simultaneously to the gathering of the source material, students produced original scripts for their videoclips and, under the tutors' supervision, designed the related storyboard in order to arrange a proper production pipeline. The main theme of their scripts has been their generation compared with that of the elders of Realmonte in an evocative and emotional process of heritage knowledge in which the $3 \mathrm{D}$ reconstructions have become a real instrument of heritage promotion. The very first result has been a wide involvement of the students in the creation process of digital cultural contents in order to promote their territory. Students also revealed from the very beginning a good affinity with the devices and the 3D modeling techniques, understanding the meaning of the cultural creative process of user generated contents as a tool that is able to create forms of multimedia cultural dissemination. Finally, videoclips will be voted on in a video contest on YouTube at the end of the school year for the best advertising video about the cultural heritage of Realmonte.

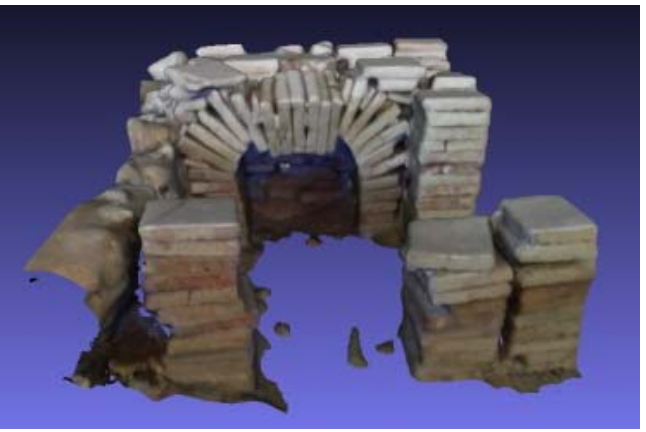

Figure 8: 3D model produced with Occipital Structure sensor of the kiln in one of the heated rooms.

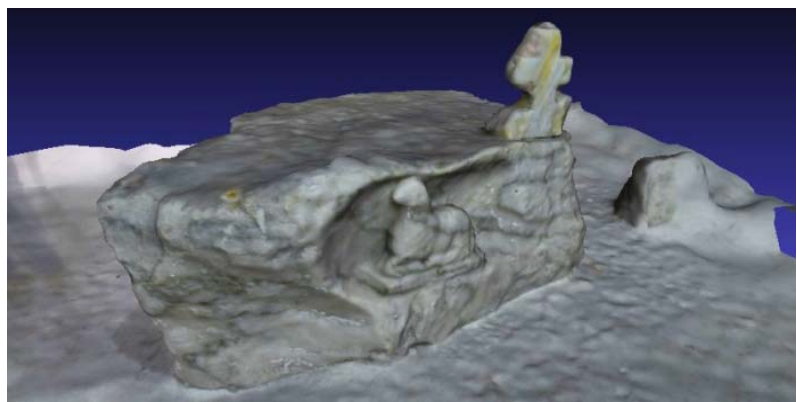

Figure 9: 3D model of the altar carved in the salt rock of the cathedral in the Scavuzzo mines.

\section{References}

AOYAGI, M. 1980-1981. Ripresa degli scavi nella villa romana di Realmonte. Kokalos XXVI-XXVII, pp. 668-673.

FIORENTINI, G. 1993-1994. L'attività della Soprintendenza BB .CC.AA. di Agrigento. Kokalos XXXIX-XL, pp. 717-734.

FIORENTINI, G, 2006. La villa romana di Durrueli presso. Realmonte (Agrigento), Agrigento 2006. 
LEVY, T. E., C.A. TUTTLE, M. VINCENT, M. HOWLAND, A. RICHTER, V. PETROVIC and D. VANONI 2013. The 2012

Petra Cyber-Archaeology Cultural Conservation Expedition: Temple of the Winged Lions and Environs, Jordan. Antiquity (Project Gallery). Available: http://antiquity.ac.uk/projgall/levy335/ [22/5, 2016]. 


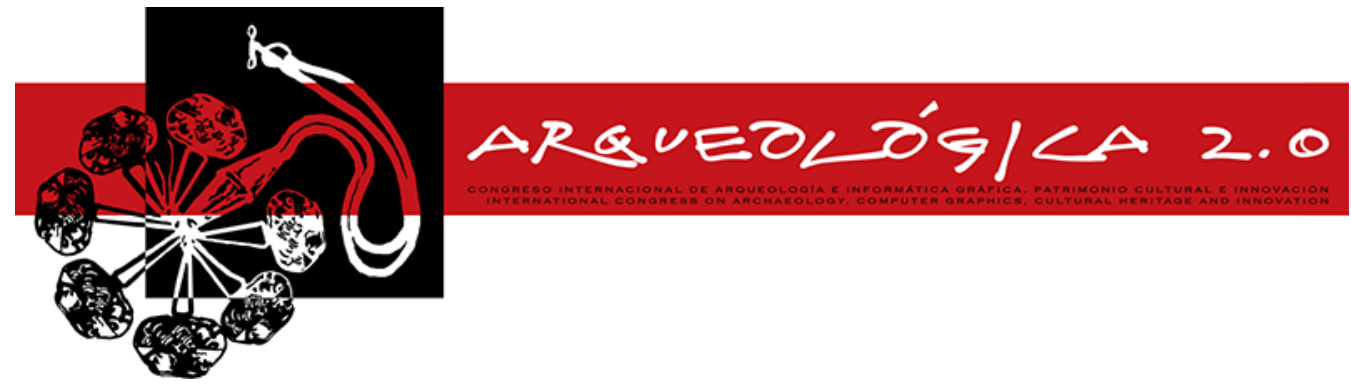

Proceedings of the $8^{\text {th }}$ International Congress

on Archaeology,

Computer Graphics,

Cultural Heritage and Innovation

'ARQUEOLÓGICA 2.0'

in Valencia (Spain),

Sept. $5-7,2016$

\title{
RECONSTRUCCIÓN FOTOGRAMÉTRICA DE LA TORRE GÓTICA DE LA IGLESIA DE SANTA MARIA DE ALCAÑIZ
}

\author{
PHOTOGRAMMETRIC RECONSTRUCTION OF THE GOTHIC TOWER OF THE CHURCH OF SANTA MARIA IN \\ ALCAÑIZ
}

\author{
Luis Agustín, Angélica Fernández-Morales*
}

Department of Architecture, Institute of Architectural Graphics, University of Zaragoza, María de Luna 3, 50018 Zaragoza, Spain. lagustin@unizar.es; af@unizar.es

\begin{abstract}
:
This paper presents the photogrammetric reconstruction of a Gothic building, a tower with an approximate height of 45 meters and an approximately octagonal (chamfered square) plan, from 280 photographs taken with a drone and distances measured manually. Due to the number of photographs, the reconstruction work was done in several parts or chunks, corresponding to the photographs of the different drone flights, which were combined to create a single mesh. For sizing the model, by not having topographical heights distances but manually measured distances, CAD drawing and triangulation were used for the creation of a coordinate system and obtainment of a set of coordinates. Subsequently, copies of the model were used to obtain meshes of different resolutions, as well as to generate orthophotos of the chamfers, rotating the model 45 degrees. Based on the three-dimensional model four types of 2D documents were obtained: orthophotos, automatic elevations in raster format, automatic elevations in CAD format and manually redrawn elevations; in all four cases for both facades as chamfers.
\end{abstract}

Key words: cultural heritage, Gothic, Aragon, photogrammetry, 3D reconstruction

\section{Resumen:}

En esta comunicación se presenta un trabajo de reconstrucción fotogramétrica de una construcción gótica, una torre de 45 metros de altura y planta aproximadamente octogonal (cuadrada con chaflanes), a partir de 280 fotografías tomadas con un dron y de distancias medidas manualmente. Debido al número de fotografías, se trabajó en varias partes o grupos de trabajo, correspondientes a los distintos paquetes de fotografías de distintos vuelos, que fueron combinados para la creación de una malla única. Para el dimensionado del modelo, al no contar con cotas topográficas sino distancias, fue necesario recurrir al dibujado en CAD y a la triangulación que hicieran posible la creación de un sistema y la obtención de un conjunto de coordenadas. Posteriormente se utilizaron copias del modelo para la obtención de mallas de diferentes resoluciones, así como para la generación de ortofotos de los chaflanes, girando el modelo $45^{\circ}$. A partir del modelo tridimensional se obtuvieron cuatro tipos de documentos 2D: ortofotos, alzados automáticos en formato de imagen, alzados automáticos en formato CAD y alzados redibujados manualmente; en los cuatro casos tanto para las fachadas como para los chaflanes.

Palabras clave: patrimonio cultural, gótico, Aragón, fotogrametría, reconstrucción 3D

\section{Contexto del estudio}

El trabajo aquí presentado se realizó en el contexto de un proyecto de investigación sobre arquitectura gótica aragonesa, que engloba la documentación fotográfica, la reconstrucción gráfica y el estudio históricoarquitectónico comparado de diferentes edificios de la antigua Corona de Aragón, que comparten rasgos arquitectónicos y constructivos.

Alcañiz (Teruel) fue uno de los enclaves más activos del bajo Aragón en la época medievalpor su ubicación en la ruta del valle del Ebro hacia el mar, eje de actividad económica y cultural de la Corona de Aragoón. Muestra de ese pasado han llegado hasta nuestros días cuatro edificios del siglo XIV de Alcañiz: el Castillo Calatravo, la Lonja, el Palacio Ardid y la Iglesia-Colegiata de Santa María, cuya torre es el objeto del trabajo aquí presentado.

\section{Objeto del estudio}

La iglesia gótica, de tres naves, fue demolida en el periodo barroco para su sustitución por otra de mayor tamaño y en el estilo imperante en la época. De la

"Corresponding Author: Angélica Fernández-Morales, af@unizar.es 
construcción gótica solo se conserva la torre campanario, imponente volumen de planta cuadrada y gran altura, construida en base a una planta baja con contrafuertes, tres plantas alzadas y una azotea transitable. Cabe destacar la peculiaridad de la construcción de su escalera, no continua en toda la torre, y la doble entrada desde el templo y el exterior.

\section{Proceso de trabajo}

\subsection{Parámetros generales de trabajo}

\subsubsection{Material disponible}

La documentación de partida para la reconstrucción 3D fueron:

- 280 fotografías de vuelos verticales en altura realizados con dron y tomados con cámara Canon PowerShot G16

- dos series de fotografías terrestres para resolver conexión con el suelo, tomadas con cámara Nikon 810.

Para la reconstrucción se utilizó Agisoft Photoscan (versión 1.1.0) por la experiencia previa de buenos resultados en la reconstrucción de modelos de este tipo, y ser el software del que disponemos de licencia.

Para el dimensionado del modelo se contó con las distancias medidas manualmente de la azotea transitable. Se disponía además de un dibujo en CAD 2D con una planta y una sección realizadas a partir de un croquis manual, incompleto y no muy exacto, pero que nos permitió medir superficies aproximadas.

\subsubsection{Nivel de detalle elegido}

Se buscó una precisión adaptada al volumen total del objeto a reconstruir y a los medios y el tiempo disponibles. A partir del dibujo CAD se calculó una superficie total a reconstruir de $15 \times 10^{6} \mathrm{~cm}^{2}$, en base a lo cual se acordó una precisión de 4 centímetros, con una malla de 2 millones de caras, tamaño más que suficiente para los fines previstos con el apoyo de la información visual que aporta la textura fotográfica.

\subsection{Creación del modelo tridimensional}

El trabajo se dividió en partes o grupos de trabajo, correspondientes a los cinco vuelos verticales que había realizado el dron - fachadas norte, sur, este, oeste y vuelo cenital- $\mathrm{y}$ en una segunda fase se incorporaron las fotografías terrestres del arranque de la torre. Se realizaron cuidadosamente máscaras para todas las fotografías. Para la orientación de los diferentes grupos se optó por la inclusión en cada uno de varias fotografías coincidentes con otros, de modo que la alineación de los grupos mediante cámaras fue sencilla.

Se combinaron los cinco grupos dando como resultado una nube de un total de 15 millones de puntos. A partir de ella se generó una malla de dos millones de caras. La textura fotográfica se realizó con dos imágenes de 4096 x 4096 píxeles (2 píxeles por cada $\mathrm{cm}^{2}$ de la superficie total) con la que se completaba la información geométrica de la malla triangular.
Para el escalado de la malla a las dimensiones de la edificación se insertaron una serie de puntos de referencia en el modelo y se les asignaron unas coordenadas. Con ese fin hubo que transformar medidas lineales, tomadas a cinta, en una serie de puntos con valores $X Y Z$ (Fig. 1), suponiendo la horizontalidad del plano de la azotea transitable. A partir de ello se pudieron definir coordenadas.

Una vez dimensionado el modelo se hizo una copia de él reduciendo el número de caras a 50.000 , para tener una versión "ligera", en un fichero más pequeño de más fácil manejo y navegación.
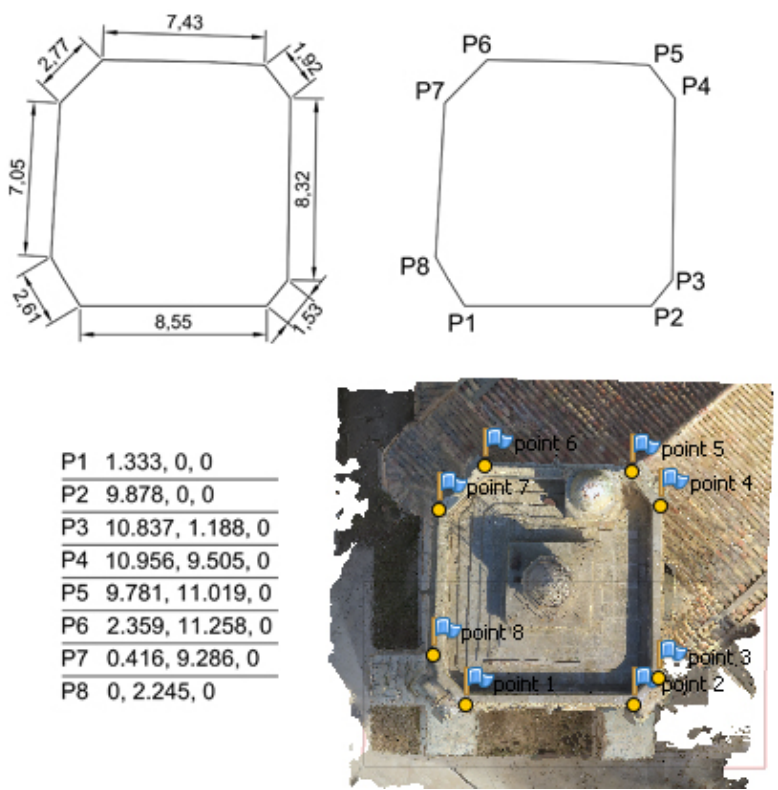

Figura 1: Creación de coordenadas a partir de medidas lineales tomadas en cubierta.

\subsection{Generación de ortofotos}

Habiendo alineado la fachada sur con el eje $X$, las fachadas restantes quedaron prácticamente alineadas con las vistas predefinidas del espacio de trabajo del programa de reconstrucción fotogramétrica. Fue así posible obtener las ortofotos de las cuatro fachadas principales. Para la obtención de vistas frontales de los chaflanes, se duplicó el modelo y se modificaron los valores $X Y$ de los ocho marcadores, de forma que el modelo quedara rotado 45 grados. Para obtener esas coordenadas bastó con girar el dibujo creado en Autocad y tomar los nuevos valores $X Y$ de los vértices (Fig. 2).
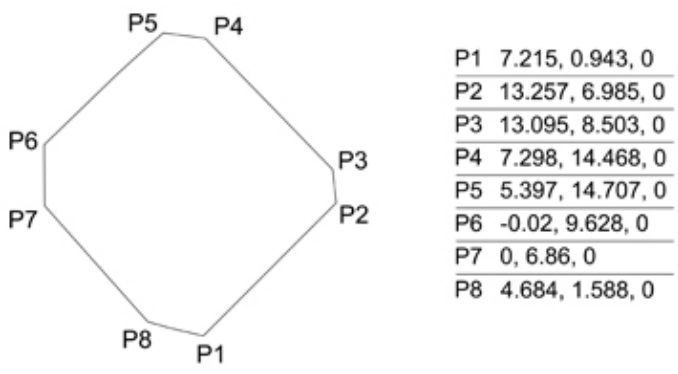

Figura 2: Rotación de coordenadas $45^{\circ}$.

Las imágenes obtenidas fueron completadas mediante software de edición de imagen para la adición de 
elementos de cubierta finos, que no habían sido modelados correctamente (Fig. 3).
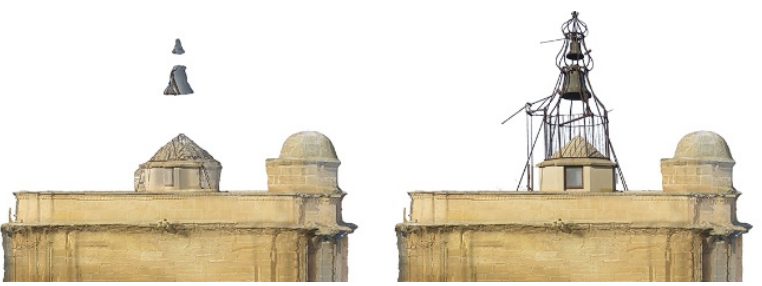

Figura 3: Adición de elementos mediante fotomontaje.

\subsection{Creación de alzados automáticos (jpg)}

Una primera aproximación a alzados automáticos se realizó mediante un software de edición de imagen y un filtro de detección automática de aristas. El resultado fue el mostrado en la Figura 4.
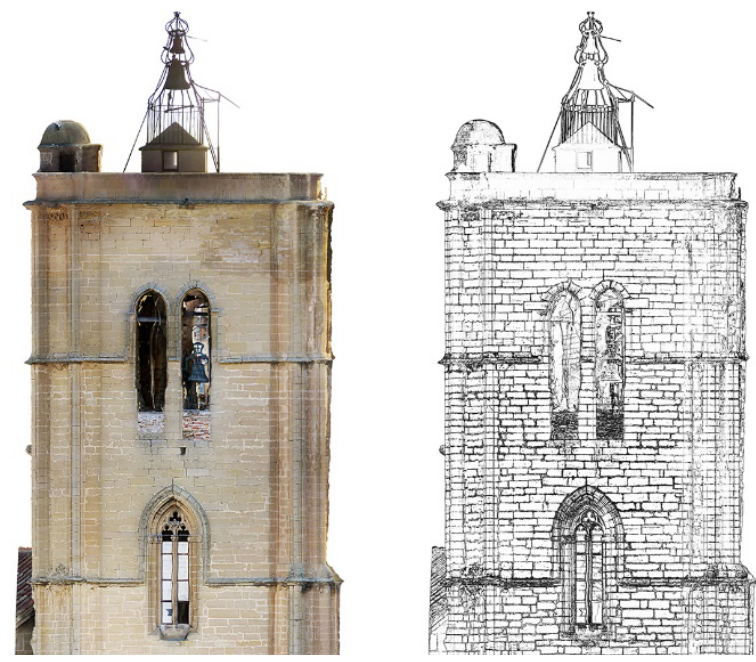

Figura 4: Creación de alzados mediante filtros de imagen.

\subsection{Creación de alzados automáticos (dwg)}

Tras este intento se probó a obtener alzados en formato vectorial a escala a partir de la malla tridimensional en lugar de las ortofotos, en los cuales poder tomar medidas en Autocad.

Para ello, la malla se exportó a formato .dae (Collada) y se importó en un programa de modelado (Sketchup). La malla por defecto se muestra con todas sus aristas, lo cual dificulta distinguir las aristas relevantes del volumen entre los miles de triángulos. Para resolver eso es necesario hacer uso de la opción de suavizar las aristas de un componente, mostrando sólo las más importantes (fig. 5). Es posible decidir el ángulo a partir del cual se marca la arista; cuanto más pequeño es el valor, más aristas se muestran.

Los alzados en formato dwg fueron obtenidos con la opción de exportación a gráficos $2 \mathrm{D}$ desde las vistas principales de los alzados. De nuevo fue necesario utilizar una malla girada $45^{\circ}$ para obtener las vistas de los chaflanes. El resultado fue el mostrado en la Figura 6.

\subsection{Redibujado manual de alzados}

Finalmente se realizó un redibujado manual de los ocho alzados en Autocad, para una mejor selección de la información y el modo de mostrarla.

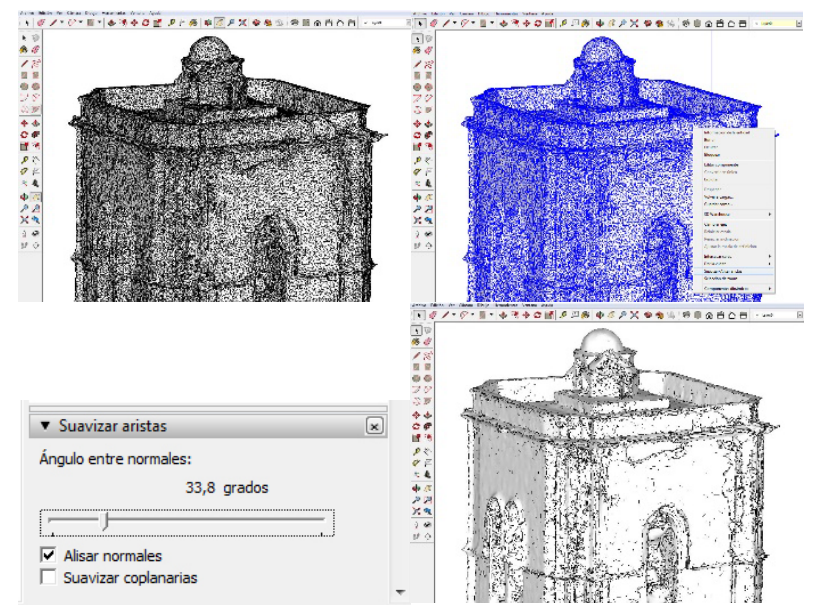

Figura 5: Importación a Sketchup y suavizado de aristas.

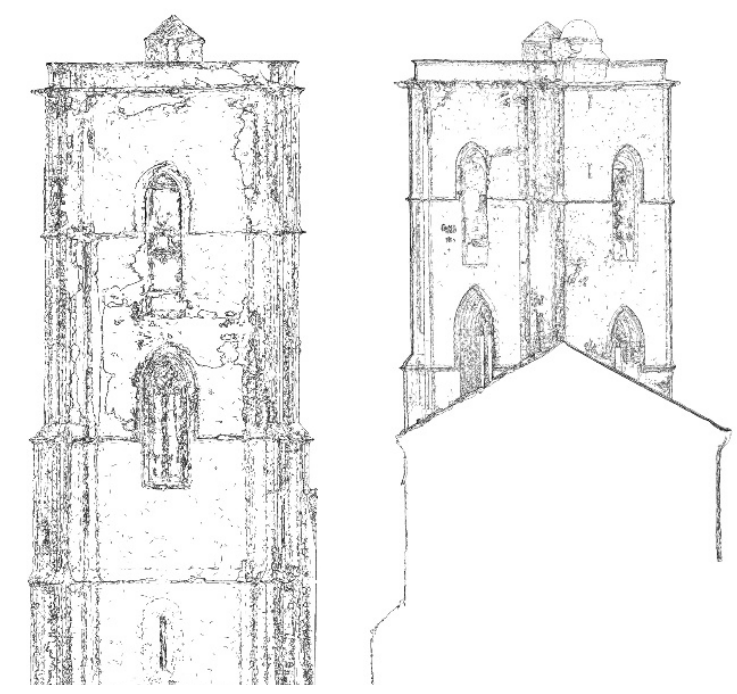

Figura 6: Alzados vectoriales en dwg a partir de la exportación de gráficos 2D de mallas suavizadas en Sketchup.

\section{Conclusiones}

En este trabajo se ha experimentado con el uso de grupos de trabajo no sólo para la división del modelo en partes, orientada a una mejor gestión de los recursos informáticos, sino también para la asignación de diferentes orientaciones a un modelo y, de ese modo, la obtención de ortofotos de fachadas con orientaciones no ortogonales, como chaflanes.

También se ha experimentado con la creación automática de alzados, en la búsqueda de una economía de tiempo. Aunque los métodos probados no han resultado del todo satisfactorios en este caso, merece la pena seguir probando métodos de obtención de alzados que excluya el redibujado manual 2D a partir de fotografías, como por ejemplo la reconstrucción 3D simplificada a partir de puntos marcados manualmente para la extracción de vistas. 
El trabajo realizado ha permitido constatar la utilidad de programas no destinados a fotogrametría - software de edición de imagen, CAD 2D, modelado 3D- como complementos para la elaboración o compleción de la documentación $2 \mathrm{D}$ de un proyecto de reconstrucción fotogramétrica.

\section{Referencias}

JIMÉNEZ, F.J. et. al. 1998. El Castillo de Alcañiz. Teruel: Instituto de estudios turolenses.

GÓMEZ, C., 1991. «Arquitectura civil pública: las lonjas de Aragón», en: Borrás, Gonzalo (coord.), Los Palacios Aragoneses. Zaragoza: Diputación General de Aragón. 


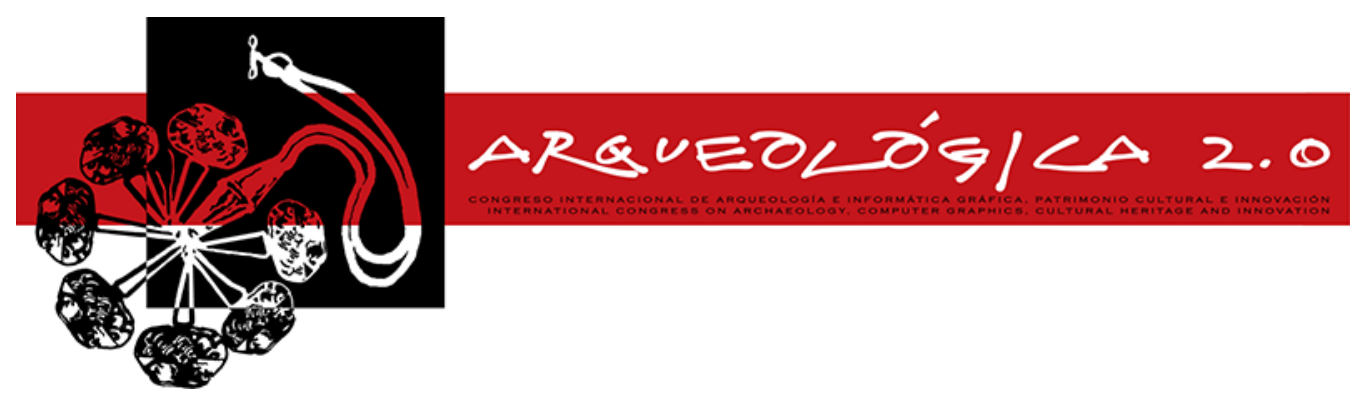

Proceedings of the $8^{\text {th }}$ International Congress

on Archaeology,

Computer Graphics,

Cultural Heritage and Innovation

'ARQUEOLÓGICA 2.0'

in Valencia (Spain),

Sept. $5-7,2016$

\title{
BUILDING A VIRTUAL TIME MACHINE FOR THE ANCIENT RUINS OF JIAOHE
}

\author{
Britt Lonneville", Nina Vanhaeren, Annelies Vandenbulcke, Alain De Wulf, Philippe De Maeyer \\ Department of Geography, Ghent University, Krijgslaan 281, 9000 Ghent, Belgium. Britt.Lonneville@UGent.be; \\ Nina.Vanhaeren@UGent.be; Annelies.Vandenbulcke@UGent.be; Alain.DeWulf@UGent.be; Philippe.DeMaeyer@UGent.be
}

\begin{abstract}
:
The goal of this work in progress is the virtual 3D reconstruction of one of the temples of the Ancient Ruins of Jiaohe (China). This site, considered as one of the key locations on the Silk Road, is slowly deteriorating due to erosion and human activity. One of its buildings, the Northwest Small Temple, was partially reconstructed as part of the Master plan for preservation and restoration as proposed by the UNESCO/Japan Trust Fund. Furthermore, a replica of the temple was built at the site entrance.

The UNESCO master plan serves as the starting point for the 3D reconstruction, which is performed in three phases. The first phase comprises an initial 3D reconstruction of the temple based on floor plans and sections, and the placement of this reconstruction in a low-resolution 3D model of Jiaohe. The second phase consists of a field campaign at the site, in order to acquire the necessary data to complement the initial reconstruction: a high-resolution 3D model of the current state of the Northwest Small Temple, 3D models of the statues inside the replica of the temple and imagery of the murals inside the replica. After combining the data from phase one and two, a 3D model of the Northwest Small Temple, completed with textures and statues inside, will be placed on a 3D model of its surroundings. This final 3D model will then be made available to a broad audience as a virtual time machine, allowing the visitors to both experience the site as it is today, as the way it used to be at the peak of the site's civilisation.
\end{abstract}

Key words: Jiaohe, Yar City, digital heritage, 3D reconstruction, 3D modelling, erosion studies

\section{Introduction}

Many of the earthen heritage sites that remain along the route of the Silk Road are decaying due to environmental factors such as erosion (Li et al. 2011). In order to preserve these sites for future generations and monitor the decline of the earthen structures, creating virtual models of some of the key buildings of such a site can be a starting point (Barton 2009). This can be done by adopting various techniques, such as topographic measurements or photogrammetry (Yastikli 2007; Remondino 2011).

On the other hand, by projecting virtual 3D models on the site, visitors are able to explore what the site and its buildings used to look like before (Addison 2000). Such an augmented reality system allows visitors to get access to valuable information and improves the visitor's experience (Kounavis et al. 2012).

Both aspects of the creation and application of virtual 3D models will be explored throughout this work in progress, as a 3D model of an ancient temple will be created using existing contruction plans, and newly acquired data will allow the creation of a 3D model which will then be used to monitor the erosion of the temple.

\section{Research area}

The Ancient Ruins of Jiaohe in northwestern China (Fig. 1) used to be a key location on the Silk Road. The city was founded in the second century BC and flourished for over 1500 years. It was of great military, cultural, political and economic importance and today it still has a high historical and scientific value (Fig. 2). However, due to erosion and human interference, the site is slowly deteriorating (Shao et al. 2013). Consequently, data should be available to monitor the destructive processes and preserve the site for future generations.

Between 1992 and 1995, the UNESCO/Japan Trust Fund launched a surveying and restoration campaign to perform research on the site and make it more accessible to visitors. As part of this campaign, the Northwest Small Temple was partly restored on the site and a replica was built near the site entrance (Fig. 3). The presented research expands on this campaign. It attempts to virtually reconstruct the Northwest Small Temple in $3 \mathrm{D}$, based on the master plan published by

*Corresponding Author: Britt Lonneville, Britt.Lonneville@UGent.be 
the UNESCO Beijing Office (UNESCO Office Beijing 1999) and additional field measurements.

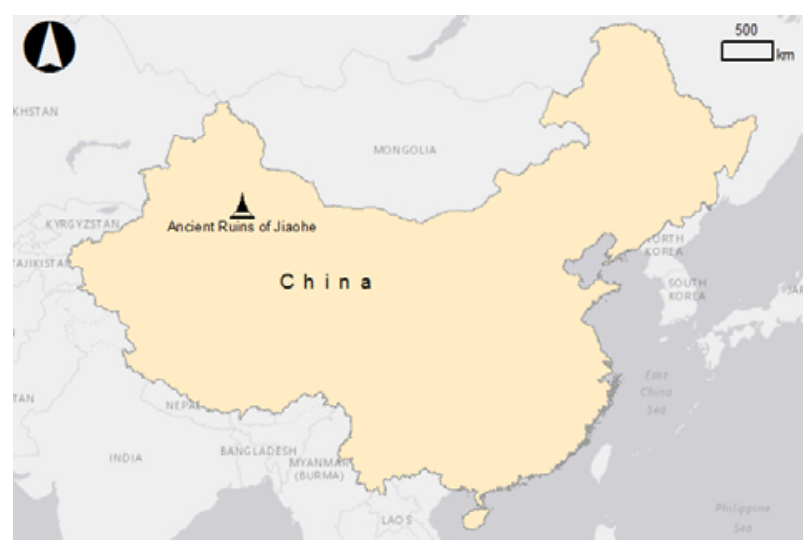

Figure 1: Location Ancient Ruins of Jiaohe.

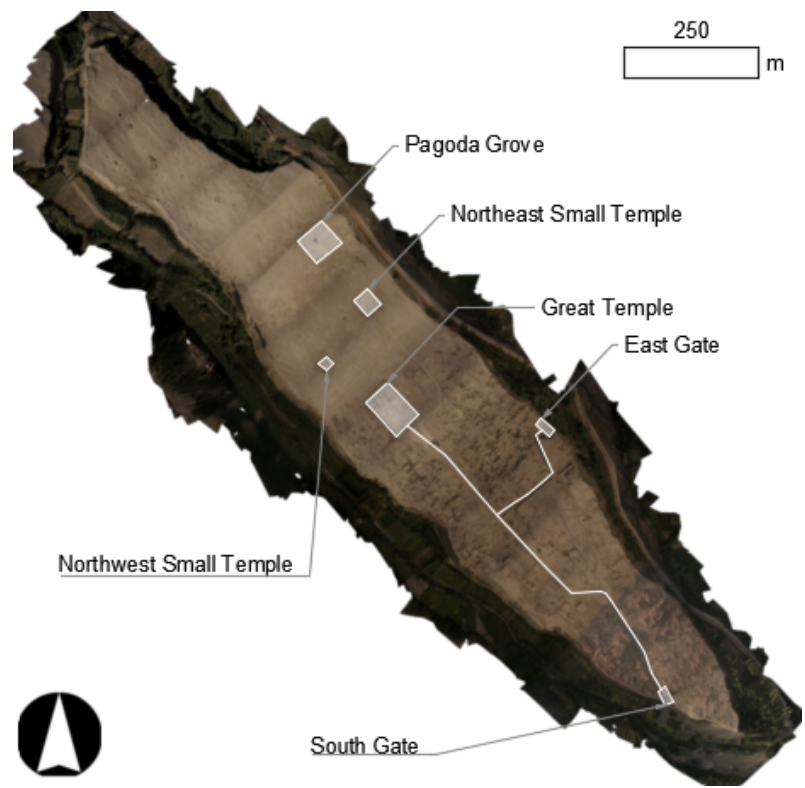

Figure 2: Layout site and most important buildings.

This work in progress consists of three phases:

(i) 3D reconstruction of the Northwest Small Temple based on the UNESCO master plan, and connection to previously created (low-resolution) 3D models of the Ancient Ruins of Jiaohe (captured during field campaigns in October 2014 and October 2015) (Vanhaeren et al. 2016).

(ii) Survey campaign at the Ancient Ruins of Jiaohe to create high-resolution 3D models of the remains of the Northwest Small Temple and the sculptures inside the replica, and to gather imagery of the murals.

(iii) Update of the initial 3D reconstruction of the Northwest Small Temple with 3D models of murals and sculptures, connection to the new (high-resolution) 3D model of the temple and publication of 'virtual time machine' of the site.
Furthermore, the collected data will also be used in a comparative study that attempts to determine the decay of the site since the measurements performed in the light of UNESCO's master plan. To this end, the photogrammetric data that was gathered in 1993 will be compared to a 3D model generated in 2016. This 3D model will, in turn, form a basis for future erosion monitoring.

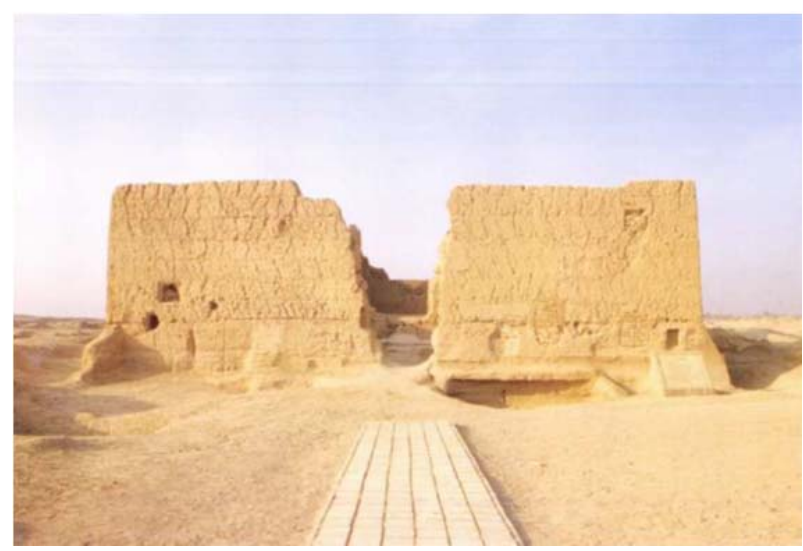

Figure 3: Northwest Small Temple after restoration on site (UNESCO Beijing office 1999).

\section{Methods}

\subsection{Phase one}

The first phase has already been started with the digitisation of several plans of the Northwestern Small Temple and the 3D reconstruction of the central stupa.

The UNESCO master plan comprises five plans of the Northwest Small Temple: one floor plan, one front view, two cross sections and one longitudinal section. These plans were digitized and scaled in AutoCAD, based on the dimensions provided by the documents. Afterwards, they were put together in one comprehensive plan (Fig. 4).

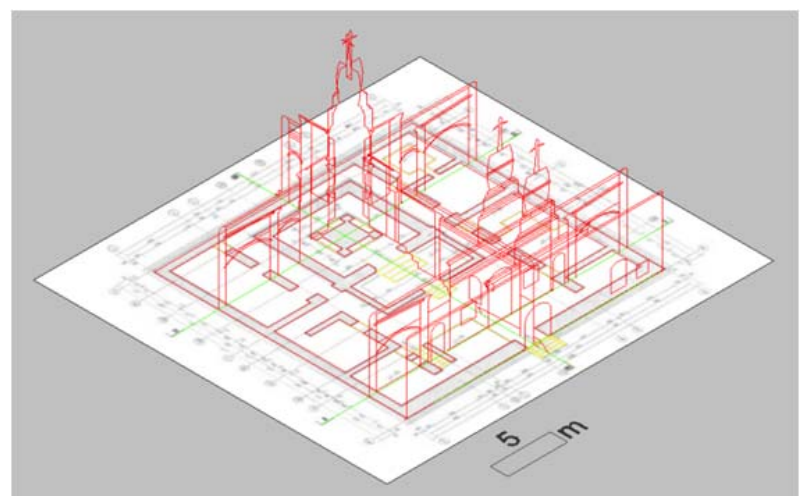

Figure 4: Combination of digitized sections and plans.

Based on these plans, the central stupa was reconstructed in 3D. This process was performed in AutoCAD. Initially, the textures were also assigned in AutoCAD. Later, the 3D model was exported to Blender to add a more realistic texture and to place 3D models of buddhas in the niches of the stupa. Moreover, the reconstructed stupa was combined with the 3D model of the Northwest Small Temple that was created using UAV imagery. This imagery was captured during a field 
campaign in 2014 (Vanhaeren et al. 2016). However, a more detailed $3 D$ model of the building is needed, as well as more realistic buddha representations and textures.

\subsection{Phase two}

The second phase will consist of a two-week field campaign to the Ancient Ruins of Jiaohe, which will be undertaken in July 2016. During this campaign, the aim is to generate three end products: a high-resolution 3D model of the current remains of the Northwest Small Temple, 3D models of the sculptures inside the replica of the Northwest Small Temple and imagery of the murals inside this replica, which will then be used as texture for the final $3 D$ reconstruction.

The technique of photo modelling will be adopted for the creation of the 3D models. In order to create a 3D model of the Northwest Small Temple, a UAV will be deployed.

\subsection{Phase three}

In the final phase, the output of the first two phases will be combined. The initial 3D model from phase one will be supplemented with the $3 \mathrm{D}$ models of the statues that were created during the field campaign. Furthermore, textures for this 3D model will be extracted from the gathered imagery of the replica. The finalised 3D model will then be placed on top of the high-resolution $3 D$ model of its environment.

Moreover, the newly created photorealistic 3D model of the ruins of the Northwest Small Temple can be compared to previous measurements on the site, and will be used as a basis for future erosion monitoring.

The data will also be made available to researchers of the Xinjiang Institute of Ecology and Geography for further research and dissemination, by exporting the models in different formats (e.g. Collada or X3D) and providing the necessary metadata.

\section{Results}

Some preliminary results of the first phase can be seen in Figures 5 and 6 . Both images were rendered in Blender. Figure 5 represents the initial 3D reconstruction of the central stupa of the Northwest Small Temple, Figure 6 shows this reconstruction within the (lowresolution) 3D overview model of the site.

The final result will combine the reconstructed 3D model of the Northwest Small Temple, the textures gathered from the replica and the 3D model created through photo modelling of the temple's environment. This will allow the user to not only visit the site in its current state, but also get an impression of what the site and its buildings used to look like over 1000 years ago.

\section{Conclusion and future research}

This work in progress attempts to create a 3D reconstruction of the Northwest Small Temple, one of the key landmarks of the Ancient Ruins of Jiaohe (China). In order to arrive at this 3D model, several data are combined: floor plans and sections produced by UNESCO, 3D models created during previous field campaigns, imagery of the replica of this temple and a new, high-resolution 3D model of the temple in its current state. Through this approach, a virtual time machine is created for the site, allowing the public to relive the Chinese empire at its peak and discover various aspects of the way of life at that time through a virtual visit. Moreover, the possibilities of augmented reality to communicate this $3 \mathrm{D}$ model to visitors of the site, as discussed by Stricker et al. (2010), can be tested. Finally, the 3D model created during the field campaign will be used in erosion monitoring studies of the site.

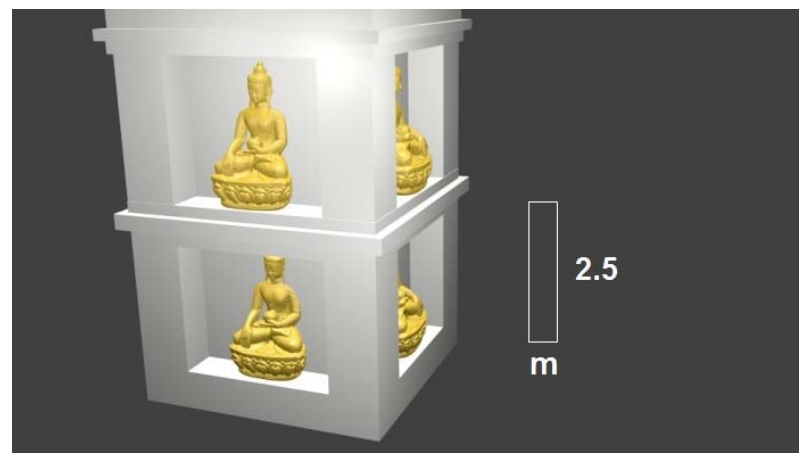

Figure 5: Render of stupa (Blender).

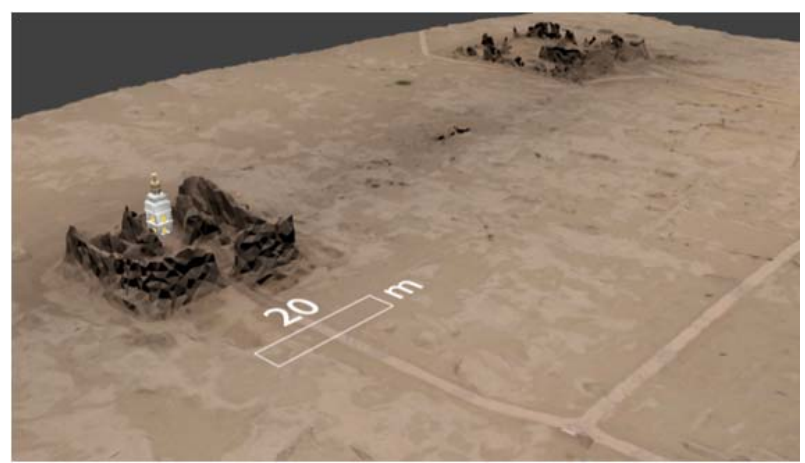

Figure 6: Render of stupa and low-poly 3D model of environment (Blender).

\section{Acknowledgements}

The authors would like to thank the Xinjiang Institute of Ecology and Geography and the Xinjiang Turpan Bureau of Cultural Heritage, and especially Alishir Kurban, for introducing us to the site and for their willingness to support us during the second phase of the research. Furthermore, financial support from the Special Research Fund (BOF) of Ghent University is gratefully acknowledged.

\section{References}

ADDISON, A., 2000. Emerging trends in virtual heritage. IEEE MultiMedia, 7(2), pp. 22-25. DOI: 10.1109/93.848421

BARTON, J., 2009. 3D laser scanning and the conservation of earthen architecture: a case study at the UNESCO World Heritage Site Merv, Turkmenistan. World Archaeology, 41(3), pp. 489-504. DOI: 10.1080/00438240903112518 
KOUNAVIS, C., KASIMATI, A. and ZAMANI, E., 2012. Enhancing the tourism experience through mobile augmented reality: challenges and prospects. International Journal of Engineering Business Management, 4, pp. 1-6. DOI: $10.5772 / 51644$

LI, L., SHAO, M., WANG, S. and LI, Z., 2011. Preservation of earthen heritage sites on the Silk Road, northwest China from the impact of the environment. Environmental Earth Sciences, 64(6), pp. 1625-1639. DOI: 10.1007/s12665-0100829-3

REMONDINO, F., 2011. Heritage recording and 3D modeling with photogrammetry and 3D scanning. Remote Sensing, 3(6), pp. 1104-1138. DOI: 10.3390/rs3061104

SHAO, M., LI, L., WANG, S., WANG, E. and LI, Z., 2013. Deterioration mechanisms of building materials of Jiaohe ruins in China. Journal of Cultural Heritage, 14(1), pp. 38-44. DOI: 10.1016/j.culher.2012.03.006

STRICKER, D., PAGANI, A. and ZOELLNER, M., 2010. In-situ visualization for cultural heritage sites using novel augmented reality technologies. Virtual Archaeology Review, 1(2), pp. 37-41. DOI: 10.4995/var.2010.4682

UNESCO OFFICE BEIJING, 1999. Master plan for preservation and restoration of the Ancient Ruins of Jiaohe. Available: http://unesdoc.unesco.org/Ulis/cgi-bin/ulis.pl?catno=145411\&set=4B31DD3D_3_9\&gp=1\&lin=1\&II=1 [3/9, 2016].

VANHAEREN, N., KURBAN, A., ABLEKIM, A., SHIJIA, A., XIAOLIAN, D., DE SLOOVER, L., LONNEVILLE, B., DE WIT, B., STAL, C., BOURGEOIS, J. and DE MAEYER, P., 2016. Modelling Yar City on the fly: applying UAVs for the creation of archaeological 3D models, 2nd International Conference of Aerial Archaeology 2016, Rome, Italy.

YASTIKLI, N., 2007. Documentation of cultural heritage using digital photogrammetry and laser scanning. Journal of Cultural Heritage, 8(4), pp. 423-427. DOI: 10.1016/j.culher.2007.06.003 


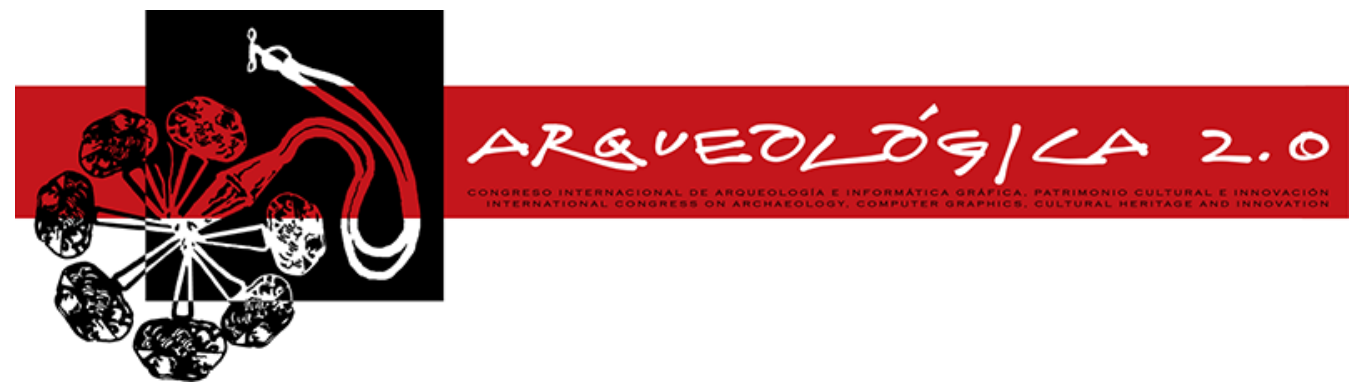

Proceedings of the $8^{\text {th }}$ International Congress

on Archaeology,

Computer Graphics,

Cultural Heritage and Innovation

'AROUEOLÓGICA 2.0'

in Valencia (Spain),

Sept. 5- 7, 2016

\title{
PIXEL-LEVEL IMAGE FUSION FOR ARCHAEOLOGICAL INTERPRETATIVE MAPPING
}

\author{
Geert Verhoeven", Milena Nowak, Rebecca Nowak
}

LBI for Archaeological Prospection \& Virtual Archaeology (LBI ArchPro), Franz-Klein-Gasse 1, A-1190 Vienna, Austria. Geert.Verhoeven@archpro.Ibg.ac.at; Milena.Nowak@archpro.Ibg.ac.at; e0626227@student.tuwien.ac.at

\begin{abstract}
:
This article reports on the current capabilities and future developments of TAIFU, a MATLAB Toolbox for Archaeological Image FUsion. After introducing the need for archaeological image fusion and the benefits it can bring for the interpretation of archaeological image data, the paper briefly explains some of the major fusion methods that are embedded in TAIFU. Afterwards, additional functionality such as metadata tracking and various pre- and post-processing steps are detailed. The paper concludes with a short roadmap of future TAIFU developments.
\end{abstract}

Key Words: distribution fitting, image blending, image fusion, MATLAB, pansharpening, remote sensing

\section{Introduction}

Due to the constant development of new and better imaging sensors working according to different physical principles, the need arises for a meaningful combination of all this imagery. For many years, various research fields have been trying to integrate imaging data of different modalities, not at least in the geoscience and medical communities, to facilitate a better understanding and interpretation of particular phenomena. Also in the field of archaeology and more specifically archaeological prospection, the constant growth in the number and variety of image acquisition techniques creates an increasing demand for image fusion techniques to be incorporated in the analysis of these data.

Image fusion is a process in which the data from two or more images are combined in a specific way, so that a single composite output image is generated. This output image holds specific and/or substantial information from the input images. Ideally, the processing techniques used in image fusion should be efficient and reliable and the newly generated image more comprehensive and thus easier to use for a human interpreter or subsequent processing tasks. In the medical field, image fusion is often used to improve the quality of the original images and to decrease data and information redundancy so that the assessment of medical problems becomes much easier (James and Dasarathy 2014).

In remote sensing, image fusion has been used since the eighties (Chavez, Jr. 1986). The variety of air- and spaceborne sensors that capture the same scene in dissimilar spectral bands and with different groundsampling distances obviously provides a strong motivation to come up with formal solutions to combine these data. To enhance the information that can be extracted about that scene, the spectral information from an image with a lower spatial resolution is often fused with the luminance data from a panchromatic image with a higher spatial resolution. This so-called pansharpening procedure yields an image with different spectral bands (i.e. the colour data) as well as a high spatial resolution. Such a pansharpened image is thus an answer to the physical trade-off between spatial versus spectral resolution, since it effectively holds more useful information than could be extracted from a single sensor.

Aside from medical and remote sensing fields, image fusion has also received increasing attention by a wide spectrum of applications such as vehicle guidance or robot vision. Ideally, the fused image holds all redundant information from multiple images and additionally displays the features which are unique for one (or more) of these input images. This newly created image should thus be more suitable for human reading and analysis tasks such as image interpretation. Often, the fused image even reveals information that is not apparent in any of the separate input images. Finally, fusing different image modalities helps in reducing the storage cost.

The fusion of images can take place at different stages. Very often, these different stages are categorized as the signal-, pixel-, feature- and symbolic-level. Here, only methods that work on the pixel-level are considered.

\section{TAIFU}

Since image fusion has hardly been used in any type of archaeological research, a dedicated MATLAB toolbox TAIFU (the Toolbox for Archaeological Image FUsion) has been created. TAIFU serves as a platform for testing

*Corresponding Author: Geert Verhoeven, Geert.Verhoeven@archpro.lbg.ac.at 
of well-established and state-of-the-art image fusion methods (see 2.1) and facilitates the development of new data integration routines. This toolbox is thus designed to benefit archaeological interpretive mapping of diverse prospection datasets. For example, the data from a magnetogram can be fused with an aerial image to aid the archaeologist in correlating feature locations for a more trustworthy information extraction and better interpretation of the hidden geo-cultural landscape.

\subsection{Incorporated fusion methods}

The following section presents a short overview of the various image fusion approaches that are presently embedded in TAIFU (version 0.2). Three big families of methods will be explained in slightly more detail.

\subsubsection{Blending modes}

In many popular image editing programs such as Photoshop (Adobe), GIMP (Open Source) or Pixelmator (Pixelmator Team), the user can choose between several blending modes. These modes, which are often denoted as layer modes, change the appearance of the upper layer or image (called blend layer) based on the base image(s)/layer(s) beneath it. As such, blending modes can also be seen as image fusion algorithms.

TAIFU incorporates all (except the useless "Dissolve") blending modes which can be found in common image processing applications and even offers several others which are not found amongst the biggest players in the image editing world (Fig. 1). Because TAIFU converts all input images to double-precision floating-point numbers in the range $[0,1]$, no extra normalisation step is needed when working with conventional 8-bit or 16-bit images.

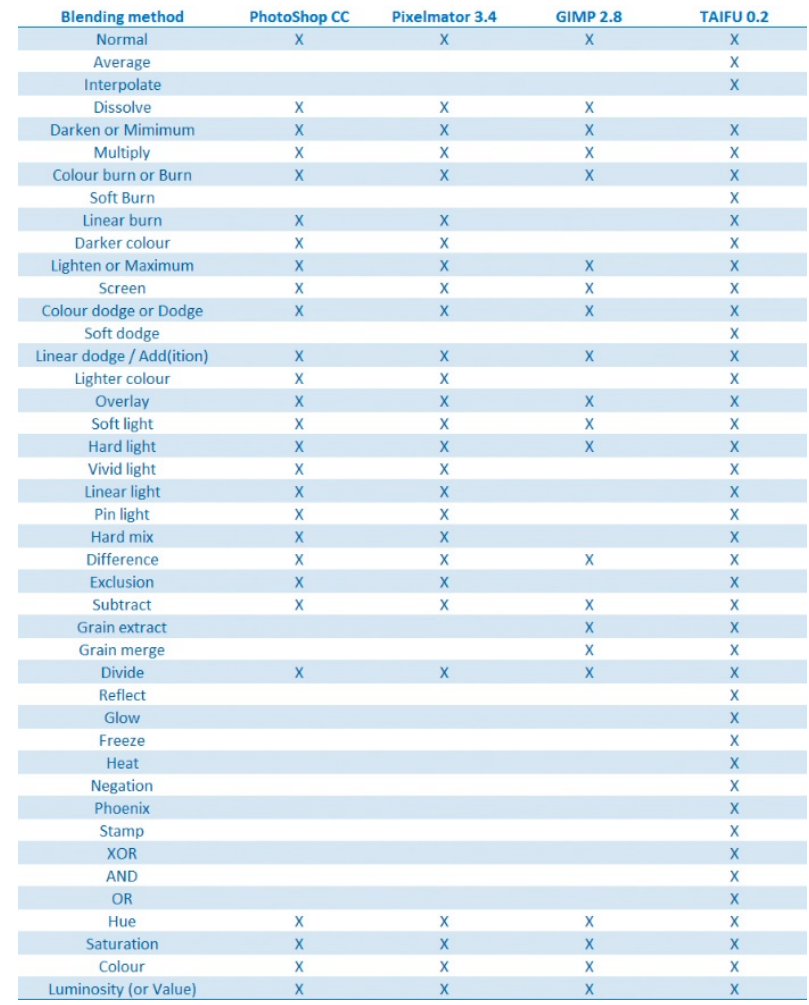

Figure 1: Overview of the different image blending methods that can be found in popular raster editing programs.

\subsubsection{Pansharpening}

It was already mentioned above that pansharpening is an approach in which the spatial information of a high resolution panchromatic image is integrated with the spectral information from an image with a lower spatial resolution. Panchromatic fusion can be accomplished by several techniques. So far, TAIFU embeds IHS (Intensity Hue Saturation) pansharpening (the original IHS method as well as the adaptive IHS approach - Rahmani et al. 2010), wavelet-based pansharpening, Principal Component Analysis (PCA) and Brovery pansharpening. In addition, the user can choose to (de)active image histogram matching and channel normalisation.

\subsubsection{Distribution fitting}

Distribution fitting creates an $\mathrm{N}$-band image from the input images (e.g. two three-band images deliver a sixband image). Afterwards, a histogram is computed for every image pixel (i.e. for the six-band image, a pixelspecific histogram is computed from the six samples). The user then defines a theoretical Probability Density Function (PDF) which is fitted to every pixel-specific histogram. Since every PDF is defined by one or more parameters, the parameters that define the fitted PDF for that pixel can be saved and form the new pixel values. More information about this method can be found in Doneus et al. (2014). TAIFU offers several discrete and continuous PDFs for uni- or bimodal fitting. Multithreading (interactively customisable) is also exploited.

\subsubsection{Additional fusion approaches}

Aside from these three big families of fusion approaches, many other methods have been implemented: (weighted) PCA fusion; ICA or Independent Component Analysis-based fusion (see Fig. 2), (discrete stationary) wavelet-based fusion, logistic weighting, guided-filtering (Li et al. 2013) and gradient domain fusion.

\subsection{Other functionality}

TAIFU is currently coded in such a way that the user has to load two images (Fig. 2). Upon import, the toolbox verifies and stores the metadata of the images (such as georeferencing, Exif and IPTC tags). In addition, the user has a variety of pre-processing steps at his/her disposal: individual image channels and their histograms can be viewed and extracted, various (perception-based) colourmaps can be used to colour-code single band imagery and a handful of contrast enhancement algorithms can make certain image features better perceivable. Moreover, colour-to-greyscale (and vice versa) conversions allow to fuse imagery for which the fusion method expects an (un)equal amount of bands.

In a next step, the above-mentioned fusion methods (often with additional options such as alpha values) can be chosen to create a fused output. When a useful result is obtained, the fused image can be saved with all the metadata embedded, although the latter can also be stored as a sidecar ASCII file. These new metadata originate from both input images, but they also contain data about the contrast enhancement(s), colour-map(s), channel-conversion(s) and fusion algorithm(s) that were used to obtain the final result. All abovementioned steps can be fully batched as well. Finally, all buttons feature (deactivatable) tooltips, all fusion methods come with 
explanations and a separate notification window informs the user about on-going and possible processes (Fig. 2).

\section{Future additions and improvements}

For the next release (0.3), many additional capabilities have been planned. TAIFU 0.2 only accepts single band or three band images. From version 0.3 onwards, multiband imagery will be supported. This, however, means that many image fusion and contrast enhancement algorithms will have to be reprogrammed so that they are flexible enough to deal with a varying amount of input bands. Second, version 0.3 will provide various image metrics that can hopefully reliably assess the quality of the fused output. Third, a few processor intensive methods will be ported to $\mathrm{C}++$.

TAIFU 0.4 will be capable of interpreting several coordinate reference systems (CRSs) and offer some simple tools for dealing with images that are not perfectly co-registered or those that are expressed in dissimilar CRSs. Moreover, the possibility to interpret CRSs will make it possible to automatically or manually extract the overlapping part of the images. In this way, TAIFU will be able to deal with datasets that have a varying spatial extent and feature dissimilar spatial resolutions, something that is currently not supported.

Finally, it is hoped that TAIFU 0.4 can be released freeof-charge or at a very moderate cost, but negotiations concerning this issue are still on-going.

\section{Acknowledgements}

The Ludwig Boltzmann Institute for Archaeological Prospection and Virtual Archaeology (archpro.lbg.ac.at) is based on the cooperation of the Ludwig Boltzmann Gesellschaft (A), the University of Vienna (A), the Vienna University of Technology (A), ZAMG, the Austrian Central Institute for Meteorology and Geodynamics (A), the Province of Lower Austria (A), Airborne Technologies (A), 7reasons (A), the Austrian Academy of Sciences (A), the Austrian Archaeological Institute (A), RGZM, the Roman-Germanic Central Museum Mainz (D), the National Historical Museums - Contract Archaeology Service (S), the University of Birmingham (GB), the Vestfold County Council (N) and NIKU, the Norwegian Institute for Cultural Heritage Research (N).

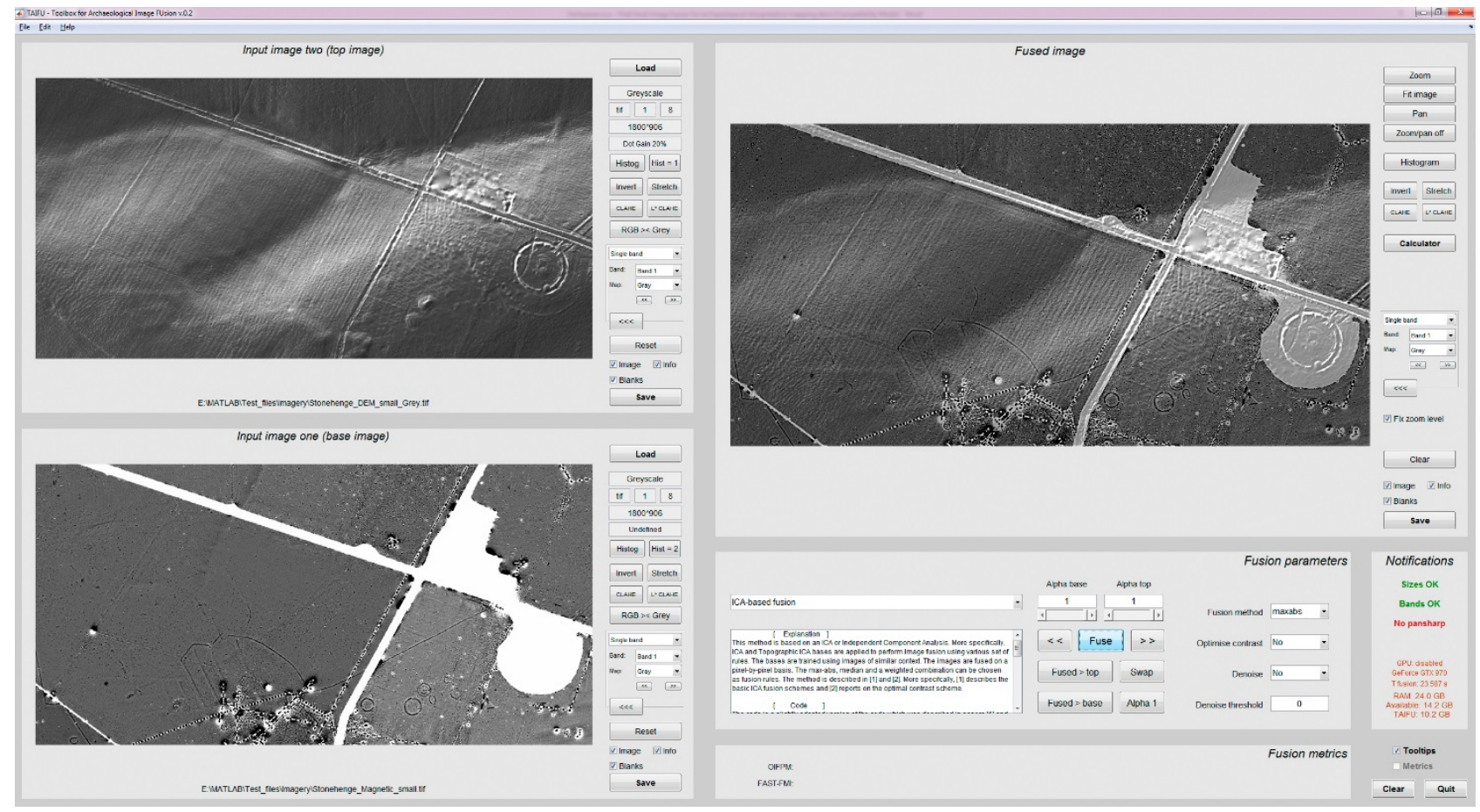

Figure 2: The main TAIFU window. A digital terrain model (upper left) is fused with a magnetogram (lower left) using ICA-based fusion.

\section{References}

CHAVEZ, P.S., Jr., 1986. Digital merging of Landsat TM and digitized NHAP data for 1:24 000-scale image mapping. Photogrammetric Engineering \& Remote Sensing, 52 (10), pp. 1637-1646.

DONEUS, M., VERHOEVEN, G., ATZBERGER, C., WESS, M. and RUŠ, M., 2014. New ways to extract archaeological information from hyperspectral pixels. Journal of Archaeological Science, 52, 84-96. DOI: 10.1016/j.jas.2014.08.023

JAMES, A.P. and DASARATHY, B.V., 2014. Medical image fusion: A survey of the state of the art. Information Fusion, 19, pp. 4-19. DOI: 10.1016/j.inffus.2013.12.002

LI, S., KANG, X. and HU, J., 2013. Image fusion with guided filtering. IEEE transactions on image processing, 22 (7), pp. 2864-2875. DOI: 10.1109/TIP.2013.2244222 
RAHMANI, S., STRAIT, M., MERKURJEV, D., MOELLER, M. and WITTMAN, T., 2010. An Adaptive IHS PanSharpening Method. IEEE Geoscience and Remote Sensing Letters, 7 (4), pp. 746-750. DOI:

10.1109/LGRS.2010.2046715 


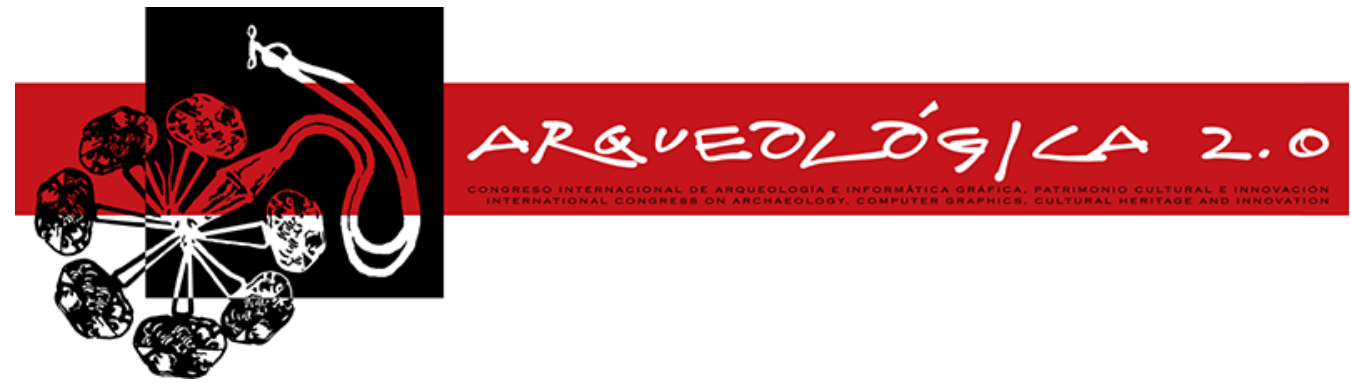

Proceedings of the $8^{\text {th }}$ International Congress

on Archaeology,

Computer Graphics,

Cultural Heritage and Innovation

'ARQUEOLÓGICA 2.0'

in Valencia (Spain),

Sept. $5-7,2016$

\title{
USING 3D MODELLING IN THE VALLEY OF TURU ALTY (SIBERIA, RUSSIA) FOR RESEARCH AND CONSERVATIONAL PURPOSES
}

\author{
Annelies Vandenbulcke ${ }^{a,{ }^{,}}$, Cornelis Stal ${ }^{a, b}$, Britt Lonneville $^{a}$, Jean Bourgeois ${ }^{a}$, Alain De Wulf ${ }^{a}$ \\ ${ }^{\text {a }}$ Department of Geography, Ghent University, Krijgslaan 281 (building S8), Ghent, Belgium. Annelies.Vandenbulcke@Ugent.be; \\ Cornelis.Stal@Ugent.be; Britt.Lonneville@Ugent.be; Jean.Bourgeois@Ugent.be; Alain.Dewulf@Ugent.be \\ ${ }^{\mathrm{b}}$ Department of Real Estate and Land Surveying, University College Ghent, Valentin Vaerwyckweg 1 (building P), Ghent, Belgium. \\ Cornelis.Stal@HoGent.be
}

\begin{abstract}
:
Since 1999 the Department of Archeology and the Department of Geography of Ghent University undertake field surveys to the Altai Region in Siberia, Russia. This region is a very important archaeological heritage area in the world. Scattered throughout the region are hundreds of frozen tombs, ritual monuments and petroglyphs. Research of these relics helps to understand the life of Eurasian nomads in the $4^{\text {th }}$ century BC. Even more important, due to upcoming touristic activities and climate change, the documentation of the frozen tombs is imperative. A traditional archaeological survey consists out of a basic description, a drawing, one or two pictures and the GNSS location of each monument. With support of the department of Geography several topographical maps are created based on satellite images (IKONOS, Pleiades) and measurement of Ground Control Points (GCP) on site. Furthermore, since 2012 the use of 3D realistic photo modelling is being applied to survey the monuments in higher detail. The method of photo modelling proves to be successful and cost-effective. Besides their high detail, the almost real-life virtual representation of the monuments makes these techniques less abstract than a traditional archaeological survey. During the field campaigns in the summer of 2014 and 2015 this method was implied to record hundreds of monuments in the valley of Turu Alty (Siberia, Russia). Using 3D modelling software the models are created to document the monuments and petroglyphs of the study area for research and conservational purposes.
\end{abstract}

Key words: Russia, Siberia, Altai, digital archaeology, cultural heritage, 3D reconstruction

\section{Introduction}

The Altai Mountain region in Siberia, Russia (Fig. 1) is known to contain a very high amount of archaeological heritage, e.g. burial mounds, ritual surface monuments and rock art sites. These monuments date back to the late Neolithic (3200 BC) (Plets et al. 2012a). The archaeological finds date back to the 1920s, it was then discovered that because of the frozen grounds in the permafrost, the tombs of the Scythian civilization are very well preserved. The tombs contain mummified bodies and textiles, wooden objects, weaponry and even food (Bourgeois et al. 2007). Since 1999, extensive areas of the Russian Altai have been surveyed by Ghent University, using satellite imagery and Global Navigation Satellite Systems. Since 2012 the use of 3D realistic photo modelling is being applied to survey the monuments with more detail. Exceptional monuments with striking variations, decorations, or a complex typology can be documented with a very high level of detail.

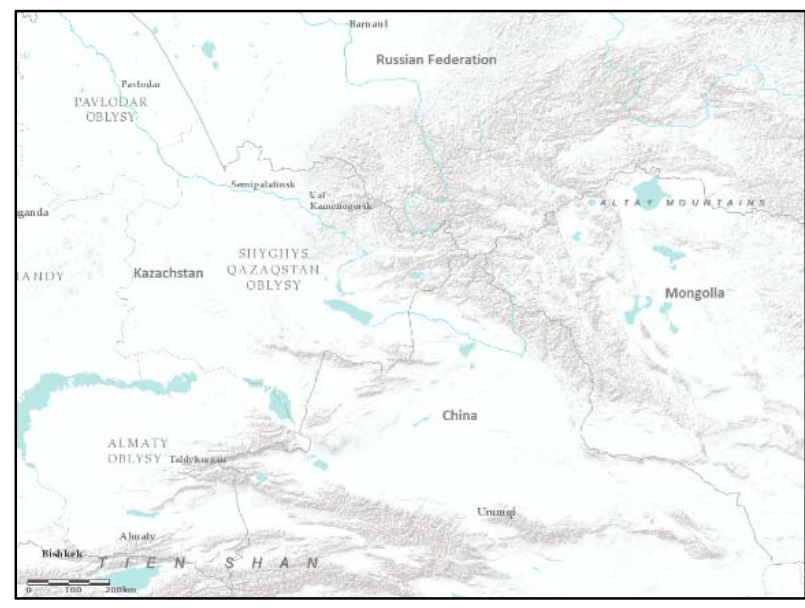

Figure 1: The Altai Mountain Region, Siberia, Russia.

\section{Macro scale: using satellite images to create a geographic base map}

High resolution satellite images have been used since the beginning of the project for the detections of 
archaeological remains and for mapping purposes. In the beginning the geographic mapping was based on the photogrammetric processing of CORONA stereoscopic high-resolution satellite images (Goossens, et al. 2006). With the help of ground control points (points on the images whose exact coordinates are known), digital terrain models (DTM) and reliable topographic maps are produced based on the CORONA stereo pairs. However the CORONA images are more than 40 years old. In 2015 the decision was made to also implement Pleiades-1 satellite imagery. The imagery is from the European company Airbus Defence and Space and provides sub-meter geometric resolution for panchromatic imagery.

To make restitution possible the groundcontrol points need to be selected. These points have to be searched on site and have to be accurately measured, with the aid of a GNSS receiver. In a remote area as the Altai Mountains this is a challenging task. The C-Nav 2050 (Fig. 2) was chosen as the GNSS device. This system receives correcton signals on the L-band. The corrections are received from the Inmarsat geostationary communication satellites (http://www.cnavgnss.com/). The accuracy of the device is of decimeter-level.

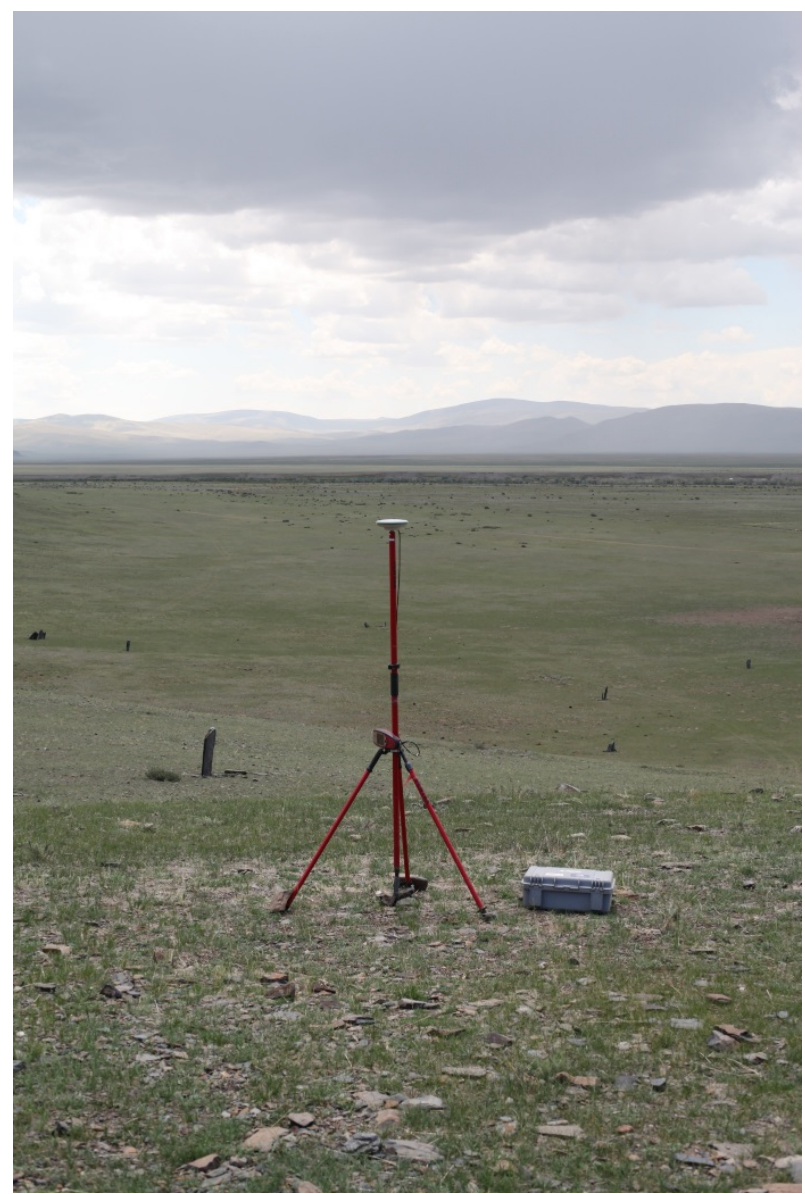

Figure 2: Using the C-Nav 2050 system to measure ground control points to make restition of satellite images possible.

To restitute the Pleiade images a total of 27 ground control points were selected on site in July 2015. These ground control points and the Pleiade images are imported in the software Erdas Imagine $2015 \AA$ (Fig. 3).

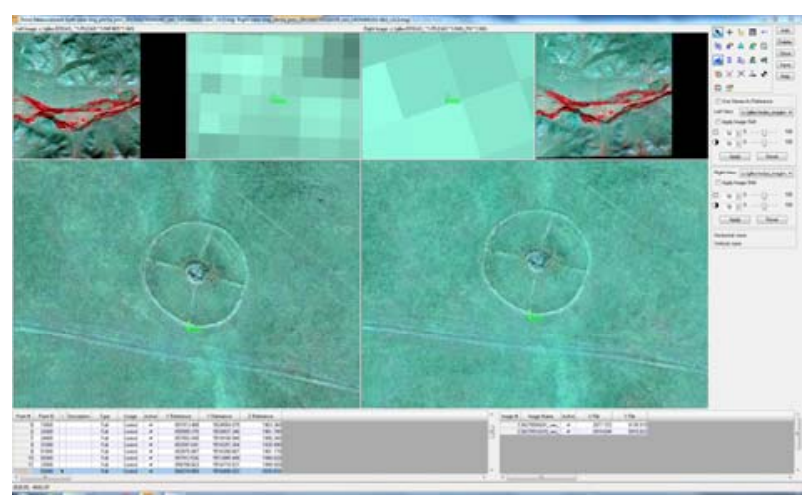

Figure 3: Importing ground control points to the Pleiade images.

After refinement and triangulation an RMS of 0.7 pixels was obtained. After this process the eATE (extended Automatic Terrain Extraction) module can be used to produce first the Digital Elevation Models and afterwards orthofoto's, if needed.

In Figure 4 the first results of the point clouds are shown.
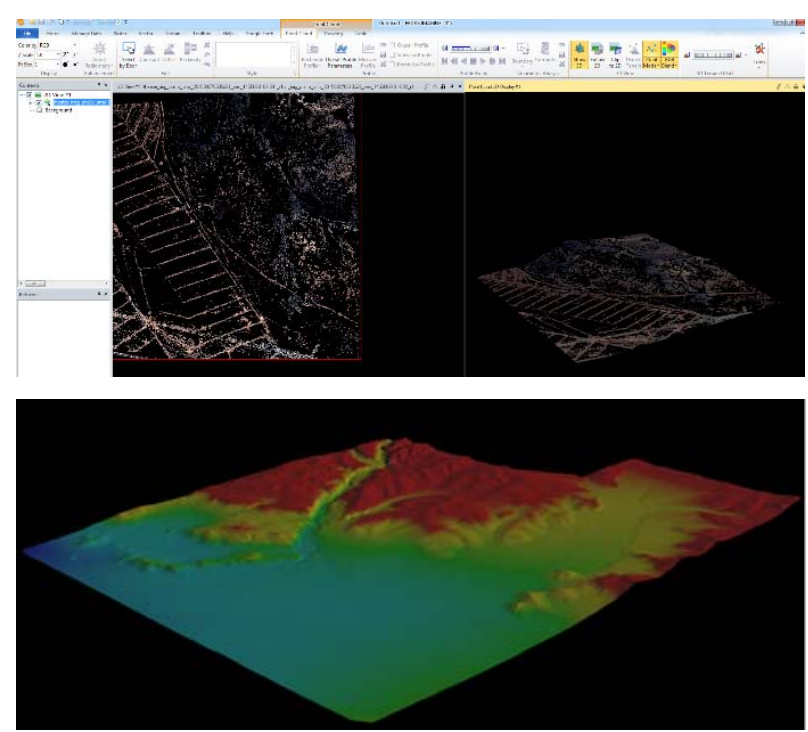

Figure 4: Resulting pointcloud in 2D (top left), 3D (top right) and 3D model colored with the elevation data (bottom).

\section{Meso scale: using helium balloons to map the valley of Tury Alty in high detail}

Next to the geographic mapping of the Altai mountains, the valley of Turu Alty is of particular interest to archaeologists, the valley has a high account in petroglyphs and burial mounds. During the campaign of July 2015 an experimental use of helium balloons (Fig. 5 ) was exploited to map the entire valley in higher detail. Since the use of a drone was not possible, was chosen to work with helium balloons. The use of helium balloons as a low cost and straightforward alternative for UAVs has been described by Lonneville et al. 2014. The helium balloons carry a non-metric camera of 16.1 megapixels, Sony Nex 5-R.

The procedure involves two operators walking around on the site, on which artificial ground control points (GCPs) have been placed (black-and-white targets). Of the more 
than 3000 photographs a selection needs to be made and then processed using Agisoft Photoscan Professional. Agisoft Photoscan will be used to combine the photographs into a mosaic. The aerial triangulation with camera calibration and subsequent model generation is mostly an automated process, the process is described in section 4.

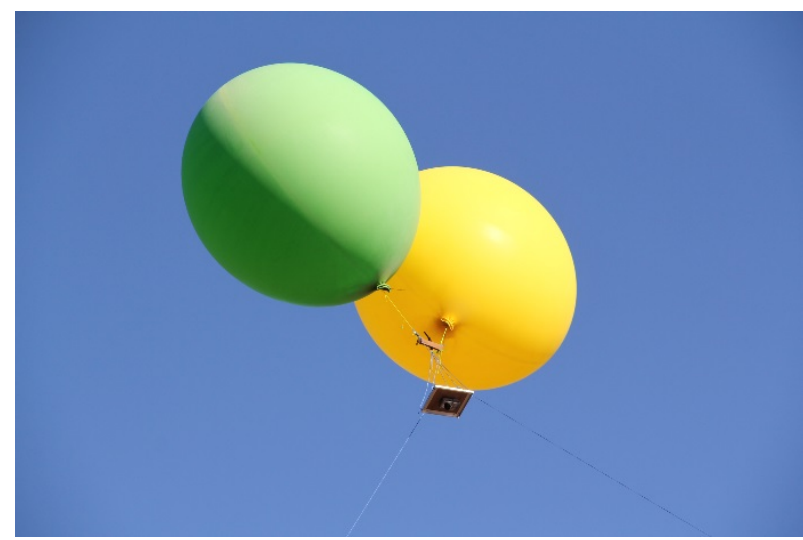

Figure 5: he use of helium balloons to map the valley of Turu Alty.

To georeference and orthorectify the photomosaic the artificial ground control points are used. To achieve the best positional accuracy, the GCPs are surveyed with a total station (Fig. 6).

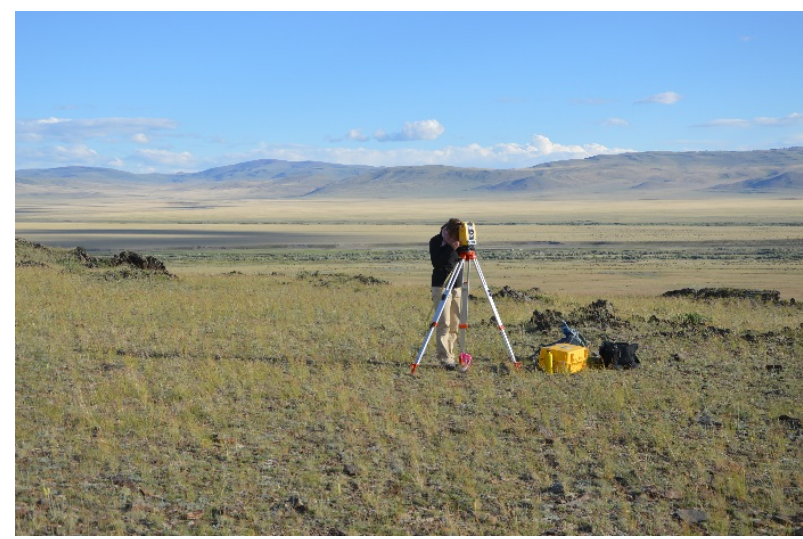

Figure 6: Using a total station to measure the ground control points.

\section{Micro scale: using 3D modelling to reconstruct archaeological monuments}

As mentioned above the area is known for the abundance of archaeological monuments. The GNSS Leica SR20 devices are used in the field to create a location for each monument. One unit serves as a reference station and a second unit is carried around as a rover in the field to collect location data. Location is determined with an accuracy of ca. $30 \mathrm{~cm}$. Next to a location the monuments are photographed using a Canon 5D Mark II camera. The 2D images are taken in such a way that they allow the reconstruction of 3D models using the photogrammetric software Agisoft PhotoScan Professional. Since the final result largely depends upon the texture present in the imagery, it is best to mask those image areas which lack texture, e.g. sky and shiny objects. The masked areas will be excluded from the calculations (AgiSoft LLC 2016).
After the masking, the photographes are aligned.Using the Structure from Motion algorithm the relative orientation of each photograph is determined and a 3D sparse point cloud is created of the object. In this step the internal camera orientations (principal distance, principal point location, skew, radial and tangential distortion coefficients) are computed.Consequently it is not obligatory to calibrate the lenses used (Verhoeven 2011). In the next step, the geometry of the model is built. The result of this step is a meshed 3D model with low-detail texturisation (Figs. 7 and 8). Following this, the 3D model can be texturised based on a selected photograph or a blend of various (selected) photographs.

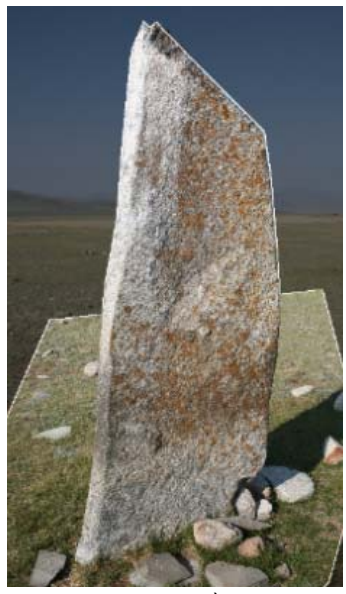

a)

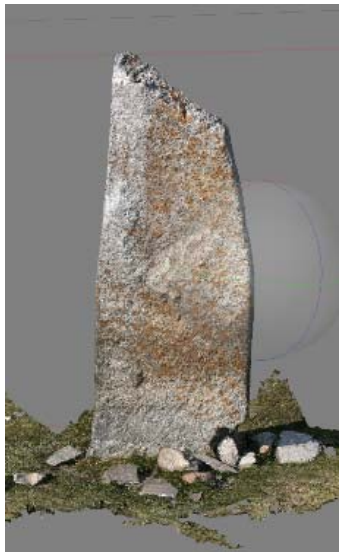

c)

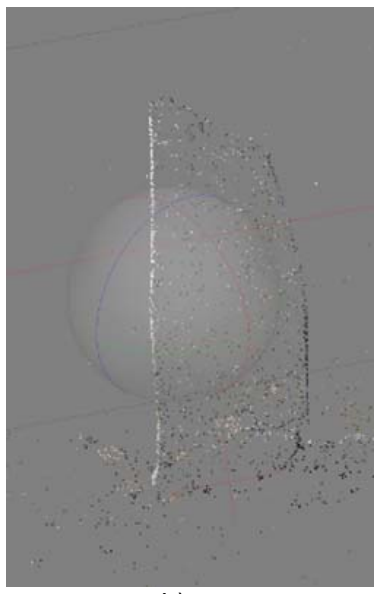

b)

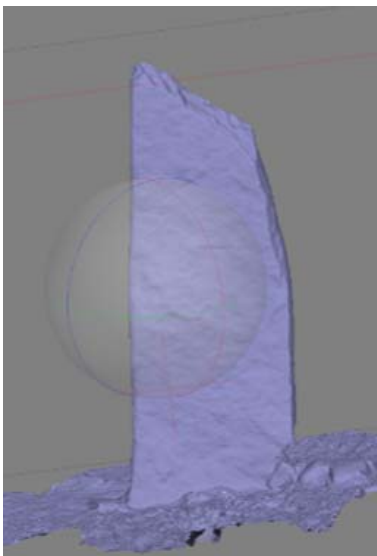

d)
Figure 7: a) masking of the photographs; b) sparse point cloud of the model; c) dense point cloud of the model; d) mesh created from the dense point cloud.

expressed in a local coordinate framework. To make this relative model metric, different approaches can be followed (Plets et al. 2012b). One option is to georeference the model in an absolute coordinate framework using at least three ground control points of which the $X, Y$ and $Z$ coordinates are known. Alternatively, one can define a distance between two reference points. Although this approach does not georeference the $3 \mathrm{D}$ model, it initialises a scaling of the model so that real-world metric information can be extracted. A comparison of the remaining reference distances with those deduced from the 3D model enables the assessment of its accuracy. This absolute 3D model can subsequently be exported to different exchangeable formats (OBJ, 3DS, VRML, PLY, DAE, 
DXF and U3D), which can be easily accessed outside Photoscan Professional using both commercial and freeware 3D packages.

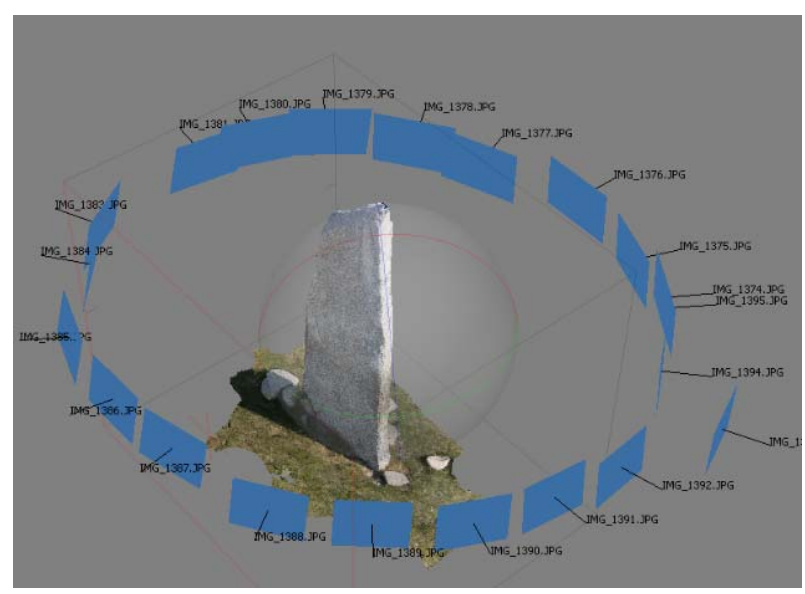

Figure 8: Agisoft PhotoScan Professional.
At this stage, the reconstructed $3 D$ scene is still Discussion

When all models are available, the site can be virtually visited. Archaeologist can use the data for further research without having to go to the remote area. The research can also be used for conservational purposes, since some monuments may in danger due to climate change and the upcoming tourists in the region. If the consequences of global change are detectable on individual tombs, methods have to be considered to preserve the graves in their frozen condition. Obviously, still more research is to be realised here.

\section{Acknowledgements}

Many thanks go to Professor Jean Bourgeois of the Department of Archaeology at the University of Ghent for the organisation of all field trips to the Altai region.

\section{References}

AGISOFT, LLC, 2016. Agisoft PhotoScan User Manual Professional Edition, Version 1.2. Available at: http://www.agisoft.com/pdf/photoscan-pro 12 en.pdf (accessed 11 March 2016).

BOURGEOIS, J., DE WULF, A., GOOSSENS, R., and GHEYLE, W., 2007. Saving the frozen Scythian tombs of the Altai Mountains (Central Asia). World Archaeology, 39(3), pp. 458-474.

GoOSSENS, R., DE WULF, A., BOURGEOIS, J., GHEYLE, W. and WILLEMS, T., 2006. Satellite imagery and archaeology: the example of CORONA in the Altai Mountains. Journal of Archaeological Science, 33, pp. 745-755.

LONNEVILLE, B., STAL, C., DE ROO, B., DE WIT, B., DE WULF, A. and DE MAEYER, P., 2014. Helium balloons for 3D modelling: off to a flying start? Low Cost 3D, Papers of the workshop, 2014, Berlin, Germany, pp. 7

PLETS, G., GHEYLE, W., VERHOEVEN, G., DE REU, J., BOURGEOIS, J., VERHEGGE, J., and STICHELBAUT, B., 2012a. Three-dimensional recording of archaeological remains in the Altai Mountains. Antiquity, 86(333), pp. 884897.

Plets, G., VerhoeVen, G., Cheremisin, D., Plets, R., BOURGeOIS, J., STICHELBAUt, B., GHEYLE, W., and DE REU, J., 2012b. The deteriorating preservation of the Altai Rock art: assessing three-dimensional image-based modelling in rock art research and management. Rock art research, 29(2), pp. 139-156

VERHOEVEN, G., 2011. Taking computer vision aloft: archaeological three-dimensional reconstructions from aerial photographs with PhotoScan. Archaeological prospection, pp. 67-73 


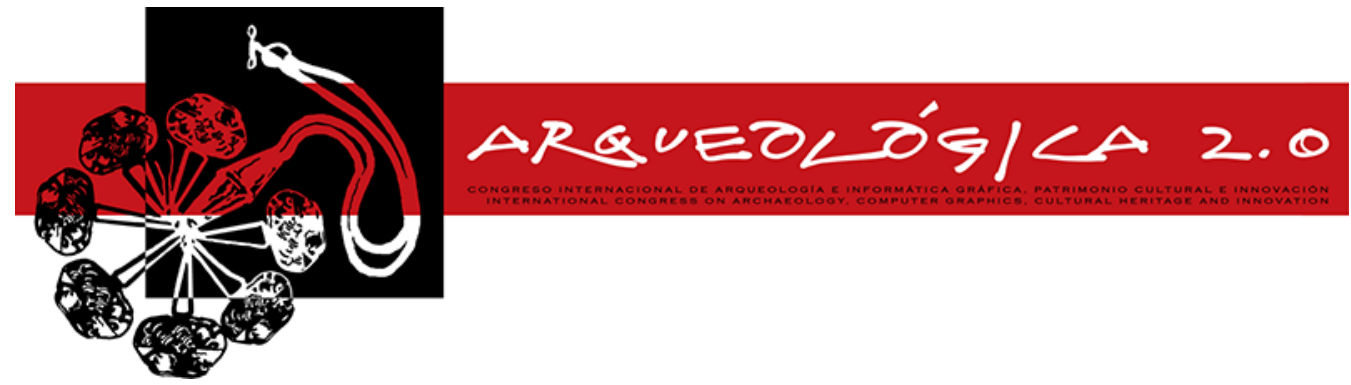

Proceedings of the $8^{\text {th }}$ International Congress

on Archaeology,

Computer Graphics,

Cultural Heritage and Innovation

'AROUEOLÓGICA 2.0'

in Valencia (Spain),

Sept. $5-7,2016$

\title{
LA PUNTA DEL ICEBERG: ARQUEOLOGIA ANTÁRTICA EN LA ERA DIGITAL
}

\author{
THE TIP OF THE ICEBERG: ARCHAEOLOGY ANTARCTIC IN THE DIGITAL AGE \\ Fernanda Codevilla ${ }^{\mathrm{a}}$, Jimena Cruz ${ }^{\mathrm{a}}$, Gerusa de Alkmim Radicchi ${ }^{\mathrm{b},{ }^{,},}$, Andrés Zarankin ${ }^{\mathrm{a}}$ \\ ${ }^{a}$ Departamento de Antropologia y Arqueologia, Universidade Federal de Minas Gerais, Av. Pres. Antônio Carlos, 6627 - Pampulha, \\ Belo Horizonte - MG, 31270-901, Brazil. fernandacodevillasoares@gmail.com; ïmenacrz@gmail.com, zarankin@yahoo.com \\ ${ }^{\mathrm{b}}$ Escuela de Doctorado, Universitat Politècnica de València. Campus de Vera, Camino de Vera, s/n, 46022 València, Valencia, España. \\ gerusaradicchi@hotmail.com
}

\begin{abstract}
:
This presentation seeks to discuss the use of digital technologies in the research conducted in the fieldwork and in the laboratory of the Antarctic Archaeological Project. This effort that is being done by the members of the LEACH tries to contribute to a better record of the information produced through the work carried out and also to elaborate new research and divulgation tools.
\end{abstract}

Key words: Antarctic Archaeology, digital archaeology, documentation, 3D reconstruction, public archaeology

\section{Resumen:}

El presente trabajo busca discutir la utilización de tecnologías digitales en las investigaciones de campo y de laboratorio del proyecto de arqueología antártica. Este esfuerzo, que viene siendo realizado por parte del equipo del Laboratório de Estudos Antárticos em Ciências Humanas - LEACH -, pretende contribuir para un mejor registro de las informaciones producidas a partir del trabajo desarrollado y también elaborar nuevos instrumentos de investigación y de divulgación de los resultados de la misma.

Palabras clave: Antártica, arqueología digital, documentación, reconstrucción en 3D, arqueología pública

\section{Introducción}

La Antártida fue el último continente en ser ocupado por los seres humanos, a fines del siglo XVIII e inicios del siglo XIX. Situado en la región más austral del planeta, rodeado por los Océanos Pacífico, Atlántico e Indico, es considerado la region más frio, más seco, más desértico, más elevado y más ventoso de todos (MEC 2006). Su incorporación en la economía mundial ocurrió de forma tardía impulsionada la expansión del capitalismo y su búsqueda de nuevos territorios para extraer materiais primas.

El proyecto internacional "Paisajes en blanco: arqueología y antropología Antártica"- que viene siendo desarrollado por el equipo del Laboratorio de Estudios Antárticos en Ciencias Humanas (LEACH) de la Universdidade Federal de Minas Gerais - tiene como objetivos comprender las estrategias humanas de ocupación de la Antártida (Zarankin y Senatore 2007). En esta tarea, se suman arqueólogos, historiadores, antropólogos y conservadores de diferentes instituciones y nacionalidad (brasileiros, argentinos, chilenos, norte-americanos y australianos).

La historia oficial ha construido una narrativa centrada en los "primeros hombres" que llegaron al continente austral, es decir, de los grandes descubridores, exploradores y/o científicos, que poseían un espíritu de lideranza y aventura (Maddison 2014). Según esa perspectiva, el "descubrimiento" de la Antártida fue un evento puntual, datado el 19 de enero de 1819, fruto de una acción casual, según la cual el capitán William Smith, de nacionalidad inglesa, al desviarse de vientos fuertes durante un viaje comercial que estaba realizando entre Buenos Aires (Argentina) y Valparaíso (Chile), habría avistado por primera vez, las islas Shetland del Sur (Busch 1985; Stackpole 1953). De modo general, se trata de una narrativa histórica positivista, factual y que exalta grandes hombres y eventos (Le Goff 1986). Oponiéndose a esa perspectiva, nuestra investigación ha centrado su atención en las personas comunes que fueron operarios en este proceso de incorporación de la Antártida al mundo moderno. Tales personajes son trabajadores de diversas nacionalidad que eran

`Corresponding Author: Gerusa de Alkmim Radicchi, gerusaradicchi@hotmail.com 
enviados a la Antártida con el fin de cazar mamíferos marinos para aprovechar la piel y grasa como materia prima para la industria del vestuario en expansión, como combustible para la iluminación pública y como lubrificante para las maquinas. A partir de una historia centrada en lo cotidiano de estos foqueros, la narrativa arqueológica viene contando historias alternativas sobre la ocupación de la Antártida, trayendo a tono el día a día de esas personas, así como también los vínculos de la ocupación antártica con el proceso económico mundial de expansión del capital, del cual estos trabajadores fueron explotados e invisibilidades (Zarankin et al. 2011).

Considerando la cultura material como principal fuente de información para el estudio arqueológico del proceso inicial de ocupación humana de la Antártida y para la construcción de la historia de las personas sin historia, entendemos que el uso de tecnologías digitales en la investigación presenta una contribución importante por posibilitar la preservación y divulgación de los materiales arqueológicos de modos alternativos e innovadores.

\section{La tecnología digital aplicada a la divulgación del acervo}

De acuerdo con Almeida y Rangel (2012), el principal impulso del mundo cibernético en el área de humanidades (incluida la arqueología) se relaciona con el "mayor vinculo entre las ciencias y la población a través de la posibilidad de la divulgación global de los resultados", bien como con una mayor colaboración entre investigadores e instituciones de pesquisa, focando a la divulgación de contenidos maleables, "abiertos a la creación y co-creacion", incentivando la construcción conjunta de conocimientos. Hugget (2012) llama a la coyuntura actual de "giro computacional", "vuelta digital" o "giro espacial". A pesar de Huggett (2012) referirse al momento actual como de gran transformación, el autor resalta que el uso de datos electrónicos en arqueología remonta a finales de la década de 1950, con los trabajos de Peter Ihm y Jean Claude Gardin en 1959-1960 y James Deetz en 1960. Sin embargo, diferentemente de estos, en las investigaciones actuales, el impacto que la tecnología ha ocasionado exige, por parte de los arqueólogos, una reformulación de las prácticas, metodologías y objetivos, exigiendo trabajos más dinámicos, flexibles, fluidos y colaborativos.

Frente a este contexto, el equipo del proyecto de arqueología antártica se está focando en la elaboración de ese sistema digital que auxiliara a la integración de conocimientos entre los diferentes profesionales que actúan en el proyecto y beneficiara a la extroversión de los conocimientos para el publico general, de forma alternativa e interactiva, creando flujos de trabajo más dinámicos y sistematizando las informaciones producidas a lo largo del trabajo.

La aplicación del sistema tuvo como punto de partida el uso en campo de dispositivos móviles para la colecta de informaciones in situ a través del sistema operacional Android. Optamos por las aplicaciones open source, en la cual fueron creados los formularios a través de un lenguaje disponibilizado por el Grupo de Investigación Modi, de la Universidad de Columbia (USA), ya utilizada por The Earth Institute Columbia University. La universidad disponibiliza un servidor de banco de datos online, donde es posible mantener un repositorio de datos seguro y confiable para el almacenamiento de las informaciones colectadas. A través de la interface de gerenciamiento del servidor de banco de datos se realiza una integración con las herramientas de Google Maps e Google Earth para el mapeo geoespacial. Los recursos son posteriormente migrados para la base de datos general del laboratorio.

A la aplicación de la propuesta de tecnología digital se le agrega el escaneo de los sitios a partir de un Laser Scan 3D (Fig. 1). Con el, reproducimos las estructuras constructivas de los abrigos, el entorno y también la posición in situ de los vestigios de manera eficiente. La representación panorámica recibe apoyo de las fotografías realizadas por el drone (Fig. 2) instrumento auxiliar también en el registro de los proceso de excavación. En laboratorio, algunos artefactos serán sometidos a la acción del scanner 3D de objetos, para ser inseridos tridimensionalmente en los proyectos gráficos de los sitios. El scanner 3D de objetos también nos posibilita optar por el restauro virtual o por la impresión 3D de los objetos con fines didácticos.

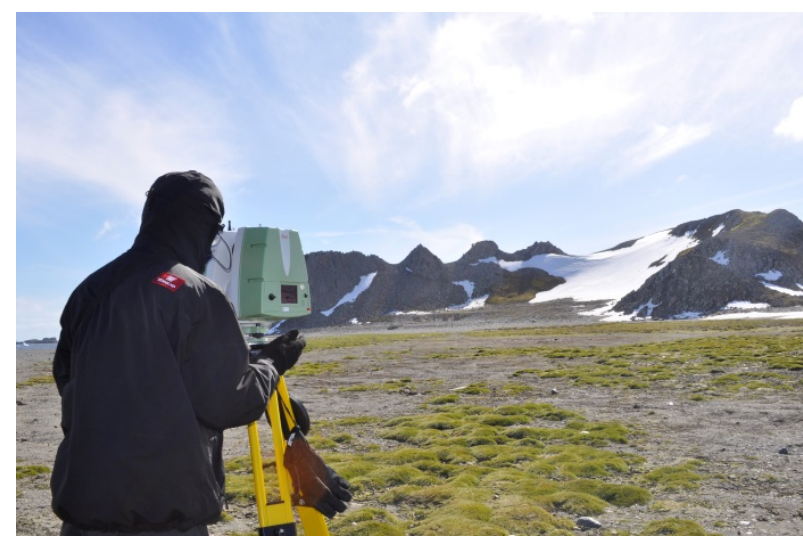

Figura 1: Uso del Laser Scan 3D. Fuente: LEACH, 2016.

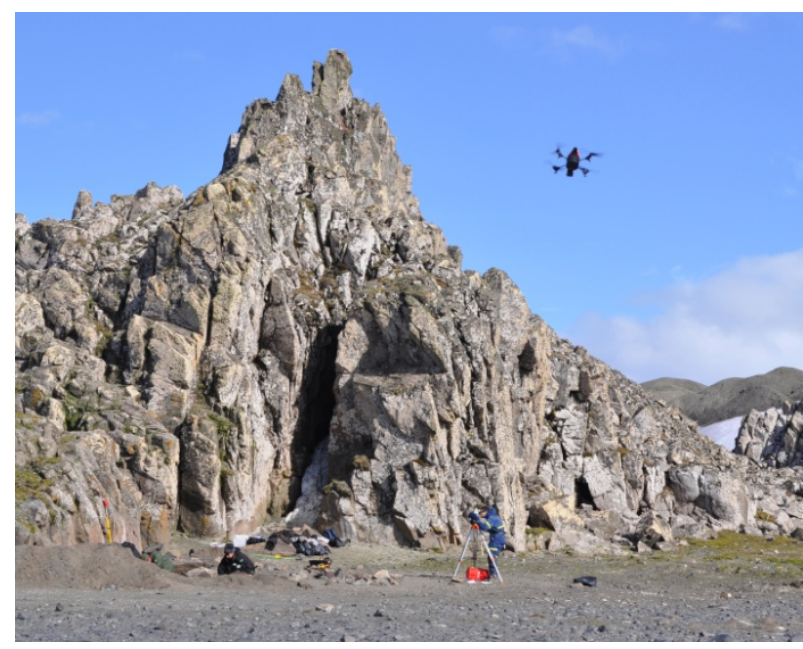

Figura 2: Uso del drone. Fuente: LEACH, 2014.

Los productos de la aplicación de tecnología digital serán posteriormente integrados a la base de datos general del LEACH, que contara con una interface de acceso para el publico a través del website del laboratorio, permitiendo que este tenga contacto con 
historias alternativas sobre la ocupación de la Antártida de forma alternativa.

\section{Evaluación de los resultados}

La aplicación de tecnología digital en los métodos de colecta de datos fue desarrollada en las campañas arqueológicas antártica en los veranos de 2013-2014 y 2015-2016, en 14 sitios arqueológicos de la Península Byers y Punta Elefante (Isla Livingston). Además de esto, en el laboratorio, el análisis del material viene siendo realizado para alimentar el Banco de Datos digital que está siendo programado por el equipo del $\mathrm{LEACH}$, el cual estará disponible en un website georreferenciado.

La captura de la información en los escaneos tridimensionales se realizaron desde el Laser Scan 3D Leica P20. El drone utilizado es del modelo Parrot Ar Drone 2.0. Los escaneos de los vestigios han sido realizados a partir del Scanner Makerbot Digitize y la impresión tridimensional de los artefactos ha sido realizada con la Impresora 3D Makerbot Replicator 2x.

Las imágenes de los drones y las nubes de puntos generados por los escaneaos de los sitios han sido tratadas a partir de los programas Cyclone y Re-shaper de Leica (Figs. 3 y 4). El modelado de los vestigios y la impresión son procesadas a partir de los programas Fusión 360 de Autodesk.

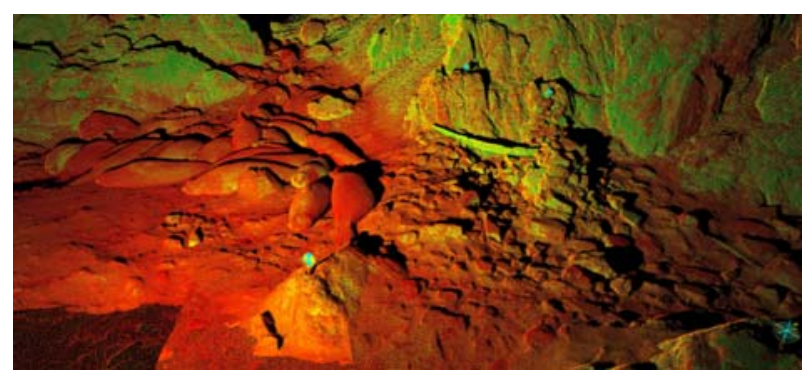

Figura 3: Resultado preliminar de los escanemientos tridimensionales (nubes de puntos del laser scan 3D) del sitio PX-2, Península Byers, Isla Livingston, Islas Shetland del Sur, Antártida. Fuente LEACH, 2016.

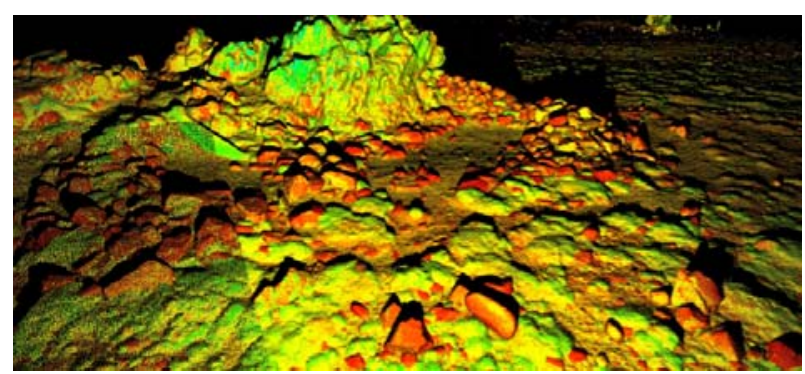

Figura 4: Resultado preliminar de los escanemientos tridimensionales (nubes de puntos del laser scan 3D) del sitio Sealer 4, Península Byers, Isla Livingston, Islas Shetland del Sur, Antártida. Fuente LEACH, 2016.
Con base en los resultados obtenidos hasta el momento, creemos que el uso de herramientas tecnológicas en el trabajo de investigación puede ir más allá de "el registro, visualización, representación y reconstrucción de objetos, monumentos y sitios" (Tsiafaki y Michailidou 2015), es decir, excede la presentación de los restos y sitios con una finalidad actual y moderna. Los principales beneficios de las herramientas digitales para la arqueología son: ayudar a las excavaciones y facilitar la toma de decisiones en el campo de manera fundamentada y atractivamente (Taylor et al. 2015; Tsiafaki y Michailidou 2015); contribuir al contexto interdisciplinario de los datos producidos por las excavaciones y las pruebas de laboratorio (Tsiafaki y Michailidou, 2015); facilitar el análisis de los objetos en laboratorio y acciones de conservación preventiva de la colección de la base de datos en línea, actualizada y abierto a la co-creación (Figueirôa 2012; Peris et al. 2013); y sobre todo, fomentar la interacción entre la forma accesible y de relevancia para los arqueólogos (profesionales) y público en general (Bowles et al. 2013)

Flujos de trabajo que sugieren tecnologías y estimulan el desarrollo de nuevas formas de investigación, proporcionando diferentes percepciones del pasado y del presente, teniendo en cuenta la agencia (Hodder 2000; dobles y Roob, 2000) el estudio de los sujetos, y los arqueólogos, además del general público.

Procediendo a una autoevaluación del trabajo en desarrollo, entendemos que el uso de las tecnologías digitales en la investigación arqueológica representa algunos avances y desafíos para la investigación.

Por un lado, los instrumentos utilizados, por contar con flujos de trabajo específicos, acaban siendo proponentes de preguntas sobre los vestigios y los sitios. Sin embargo, esto no significa que las tecnologías substituyan los conocimientos y la capacidad de decisión de los arqueólogos. De hecho, las tecnologías auxilian en la toma de decisiones, no obstante, no suprimen o aprisionan las decisiones del investigador.

Y, por otro lado, el uso de tecnologías digitales presenta algunos desafíos en relación a la práctica arqueológica, ya que exige que todos los investigadores utilicen tales herramientas y se sientan aptos para transitar entre las diferentes áreas de actuación del proyecto, incentivando, en la práctica, una formación interdisciplinar.

Además de esto, la tecnología también facilita una interacción con el público académico y no académico de forma pionera y original.

El uso de tecnologías digitales presenta un gran potencial y en este trabajo hemos intentado mostrar el punto de partida de un camino que creemos va a aportar resultados interesantes. Como la "punta de un iceberg", que representa lo hecho hasta ahora, aun falta develar lo que está "debajo del agua", es decir las infinitas posiblidades y desafíos antes impensados

\section{Referencias}

BUSCH, B., 1985. The War Against the Seals: A History of the North American Seal Fishery. McGill-University Press. Kingston e Montreal. 
DOBRES, M., y ROBB, J., 2000. Agency in archaeology: paradigm or platitude? In: DOBRES, M. e ROBB (orgs). Agency in Archaeology. Routledge. London \& New York. p.1-18.

FIGUEIRÔA, R., 2012. Por uma arqueologia das mídias: digitalizando em 3D o acervo cerâmico do museu de arqueologia de Xingó. In: $2^{\circ}$ Colóquio de História e Arte História, arte e religiosidade nos caminhos da educação, 2012, Recife. Disponível em: http://www.encontro2012.rj.anpuh.org/resources/anais/15/1338211118_ARQUIVO_ArtigoAnpuhRio2.pdf. Acessado em 19 de Abril de 2016.

HODDER, I., 2000. Agency and individuals in long-term processes. In: DOBRES, M. e ROBB, J (orgs). Agency in Archaeology. Routledge. London \& New York. p.21-33.

HUGGETT, J., 2012. Core or Periphery? Digital Humanities from an Archaeological Perspective. Historical Social Research. Historische Sozialforschung. 37 (3): 86-105.

MADDISON, B., 2014. Class and colonialism in Antarctic exploration, 1750-1920 (empires in perspective). Pickering \& Chatto Publishers, London.

MEC, 2006. Antártica: ensino fundamental e ensino médio. Ministério da Educação, Brasília.

PERIS, J., FELICÍSIMO, A. y POLO, M., 2013. Three-dimensional models of archaeological objects: from laser scanners to interactive PDF documents. In: Technical briefs in historical archaeology, 7: 13-18.

RANGEL, D. y ALMEIDA, N., 2012. A Arqueologia na Era Digital: Contexto e tendências. Revista Internacional de Humanidades. Common Ground Publishing España S.L., Madri.

STACKPOLE, E., 1953. The Sea-Hunters: The New England Whalemen During Two Centuries, 1635-1835. J. B. Lippincott Company, New York.

TAYLOR, J., BERGGREN, A., DELL'UNTO, N., FORTE, M., HADDOW, S., HODDER, I., ISSAVI, J., LERCARI, N., MAZZUCATO, C. y MICKEL, A., 2015. Revisiting reflexive archaeology at Çatalhöyük: integrating digital and 3D technologies at the trowel's edge. In: Antiquity, 89: 433-448. DOI: http://dx.doi.org/10.15184/aqy.2014.43.

TSIAFAKI, D. y MICHAILIDOU, N., 2015. Benefits and problems through the application of 3D technologies in archaeology: recording, visualisation, representation and reconstruction. Scientific culture, 1 (3): 37-45. DOI: $10.5281 /$ zenodo. 18448 .

ZARANKIN, A. y SENATORE, X., 2007. Histórias de um passado em Branco: Arqueología Historica Antártica. Belo Horizonte: Argumentum.

ZARANKIN, A., HISSA, S., SALERMO, M., FRONER, Y., RADICCHI, G., ASSIS, L.G.R. y BATISTA, A., 2011. Paisagens em branco: arqueologia e antropologia antárticas - avanços e desafios. Vestígios. Revista LatinoAmericana de Arqueologia Histórica, 5 (2): 9-52. 


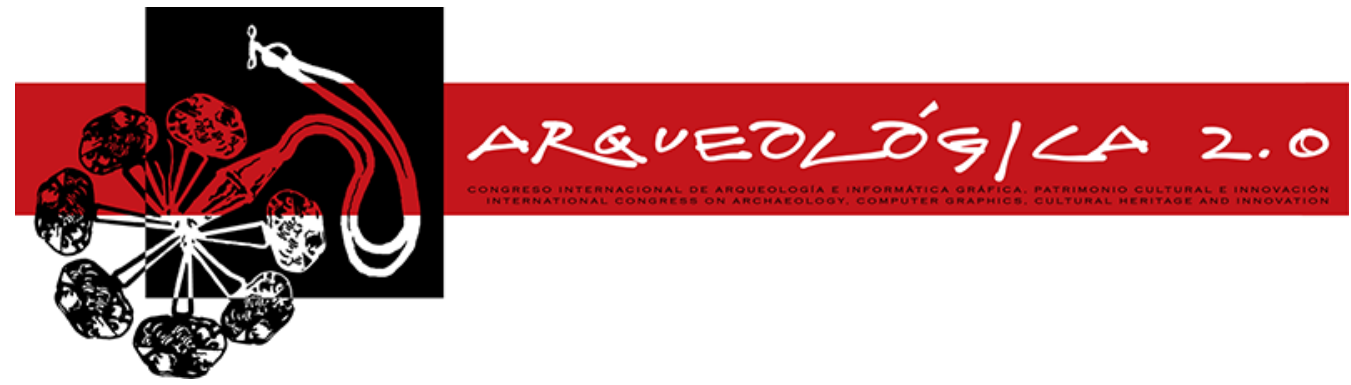

Proceedings of the $8^{\text {th }}$ International Congress

on Archaeology,

Computer Graphics,

Cultural Heritage and Innovation

'ARQUEOLÓGICA 2.0'

in Valencia (Spain),

Sept. $5-7,2016$

\title{
RECUPERANDO EL PALACIO VISIGODO DE PLA DE NADAL (RIBA- ROJA DE TÚRIA, VALENCIA)
}

RECOVERING THE VISIGOTH PALACE IN PLA DE NADAL (RIBA-ROJA DE TÚRIA, VALENCIA)

\begin{abstract}
Albert Ribera ${ }^{a,}{ }^{,}$, Isabel Escrivàa ${ }^{a}$ Josep $M^{a}$. Macias ${ }^{b}$, José Julio Marín ${ }^{c}$, Jorge Morín ${ }^{d}$, Josep $M^{a}$. Puche $^{b}$, Miquel Rosselló ${ }^{e}$, Isabel Sánchez ${ }^{\mathrm{e}}$, Alfredo Santonja ${ }^{\mathrm{c}, \mathrm{f}}$, Cristina Silvestre ${ }^{\mathrm{g}}$

a Secció d'Investigació Arqueològica Municipal, Ajuntament de València, Traginers s/n, 46014 Valencia, España. ariberalacomba@gmail.com; maescho@uv.es
\end{abstract}

\footnotetext{
b Institut Català d'Arqueologia Clàssica, Plaça d'en Rovellat s/n, 43003 Tarragona, España. jmmacias@icac.cat; jpuche@icac.cat

${ }^{c}$ Arquitectura Virtual S.L., Los Sauces 2, Urb. Lloma llarga, 46185 Pobla de Vallbona, España. josejuliomt@gmail.com

${ }^{\text {d }}$ AUDEMA, Auditores de Energía y Medio Ambiente S.A., Santorcaz 4, 28002 Madrid, España. jmorin@audema.com
}

e Ausonius, Université de Bordeaux Montaigne, Maison de l'Archéologie Domaine universitaire 8, Esplanade des Antilles, 33607 Pessac Cedex, Francia.miquelrome@gmail.com; isabelsanchez255@hotmail.com

f Departamento de Expresión Gráfica, Universidad Politécnica de Valencia, Camino de Vera s/n, 46022 Valencia, España. santonja.alfredo@gmail.com

${ }^{9}$ Concejalía de Patrimonio y Turismo, Ajuntament de Riba-roja de Túria, Cisterna 30, 46190 Riba-roja de Túria, España. patrimonio@ribarroja.es

\begin{abstract}
:
The palace was a monumental building with two towers on the front, a central courtyard, a ground floor with utilitarian function and a luxury upper floor with an aristocratic and representative character and an extraordinary architectural decoration. The building was used a short time, less than a century, because a great fire caused its collapse and destruction of the building. After a lot of historical, archaeological and architectural dimension studies, there is a new interpretation of the palatine building. For the 3-D modelling of the palace, we use a data collection with a laser-scanner, and the plans from the excavation and the architectural modulation previously elaborated. The conclusions of the multidisciplinary work from the reconstruction have been used extensively in archaeological publications and, especially in the didactic information for the new Visigoth Museum and other touristic activities. There's also a 3-D printed model of the reconstruction.
\end{abstract}

Key words: virtual archaeology, cultural heritage, Visigoth architecture, diffusion applications, History

\section{Resumen:}

Fue un edificio monumental con dos torres en fachada, patio central, planta baja con función utilitaria, planta superior lujosa con carácter señorial y extraordinaria decoración arquitectónica. Duró poco tiempo, menos de un siglo. Se derrumbó y destruyó por un gran incendio. Tras una serie de estudios históricos, arqueológicos y de modulación arquitectónica, se ha propuesto una nueva interpretación del conjunto. Para el alzamiento infográfico se empezó por un nuevo levantamiento en escáner -laser, sobre el que se levantó la reconstrucción previamente preparada tras el estudio de la planimetría de la excavación y de la modulación arquitectónica. El resultado del trabajo multidisciplinar de la reconstrucción se ha usado profusamente en publicaciones científicas arqueológicas y, especialmente, en la información didáctica del nuevo museo visigodo y en otras actividades de difusión turística. También ha servido para realizar una maqueta con una impresora 3D.

Palabras clave: arqueología virtual, patrimonio cultural, arquitectura visigoda, aplicaciones para la difusión, historia

\section{Introducción}

El palacio visigodo de Pla de Nadal está en Riba-roja de Túria, a unos 20 kilómetros al noroeste de Valencia. Fue descubierto hace 45 años, ha sido excavado (19811989), restaurado y acondicionado para visitas. Se ha iniciado su estudio con la colaboración de investigadores de especialidades diversas y de varios

“Corresponding Author: Albert Ribera, ariberalacomba@gmail.com 
lugares e instituciones (Institut d'Arqueologia Clàssica de Catalunya de Tarragona, Auditores de Medio Ambiente de Madrid, Institut Ausonius de la Universidad de Burdeos, Sección de Investigación Arqueológica Municipal de Valencia, Universidad Politécnica de Valencia, empresa Arquitectura Virtual) con la colaboración y complicidad de la Concejalía de Patrimonio y Turismo del Ajuntament de Riba-roja (Ribera et al. 2015).

Fue construido a finales del siglo VII o ya en el siglo VIII y destruido a finales de este mismo siglo.

El edificio lo formaba una planta baja, austera y funcional, y un piso superior, derrumbado, del que procedían gran cantidad de piezas arquitectónicas, por lo que esta planta superior sería la planta noble. A pesar de haber sido incendiado, se había conservado en muy buen estado y con los restos del primer piso desplomado y roto pero en su sitio. Los muros tienen un espesor de casi un metro y en algunas partes mantienen una altura de 2,35 metros, con varias ventanas. Estas paredes no tenían cimiento, ya que apoyan sobre el sólido suelo natural, lo que daría bastante solidez a la estructura (Juan y Pastor 1989).

\section{Características del edificio}

Es un conjunto palatino excepcional del modelo de villae con galería y torres angulares en los flancos, abiertas a un espacio central abierto y con un piso superior. El aula central de la fachada meridional, la que se ha conservado (Fig. 1), tiene $17 \mathrm{~m}$. de longitud por 5,30 m. de anchura.

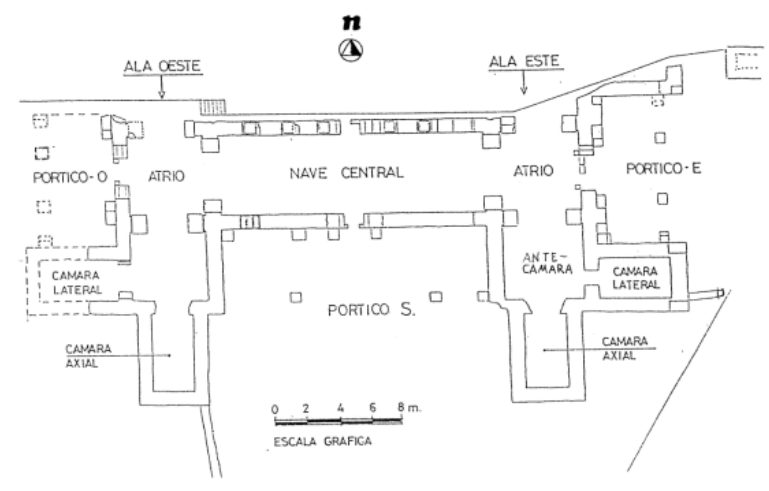

Figura 1: Plano del edificio.

El piso superior se decoró con escultura y estucos que conservaban policromía.

Las cubiertas eran de tejas planas y curvas a distintas aguas, con un elaborado sistema de evacuación pluvial con gárgolas (Juan y Lerma 2000).

Abunda la sillería, con grandes piedras romanas reutilizadas, aunque la mayor parte de los muros son de mampostería. Los paramentos estarían enlucidos, como se conserva en algunas partes. Destaca la gran cantidad de elementos sueltos de la decoración arquitectónica, más de 800 y de gran variedad, con capiteles grandes, gran cantidad de frisos decorados, fustes de columnillas, dovelas, gárgolas, cruces patadas y diversas piezas decorativas del exterior (Ribera y Rosselló 2007).

\section{Interpretación del edificio}

Se ha vinculado al dux Teodomiro, un conocido magnate del final del reino visigodo, que gobernó en el sudeste peninsular y luchó y pactó con los árabes (Llobregat 1973). Se daría la extraordinaria circunstancia de conocer al promotor del edificio, un importante dirigente en los albores del reino visigodo y los inicios de los árabes (Ribera y Rosselló 2009, 2011).

Presenta una estructura compacta que le da un aire de palacio-fortaleza. Fue una estructura oficial de tipo áulico y residencial con paralelos en palacios del Oriente bizantino.

\section{Propuesta de reconstrucción}

La reconstrucción ha sido el fruto de un trabajo coordinado multidisciplinar de varios profesionales y especialistas: arqueología, arquitectura, topografía escáner-láser, infografía, museografía.

Hasta el momento, se ha trabajado en la parte exterior del edificio y en la planta baja del interior. Quedaría por completar la reconstrucción del interior de la planta principal (Fig. 2).

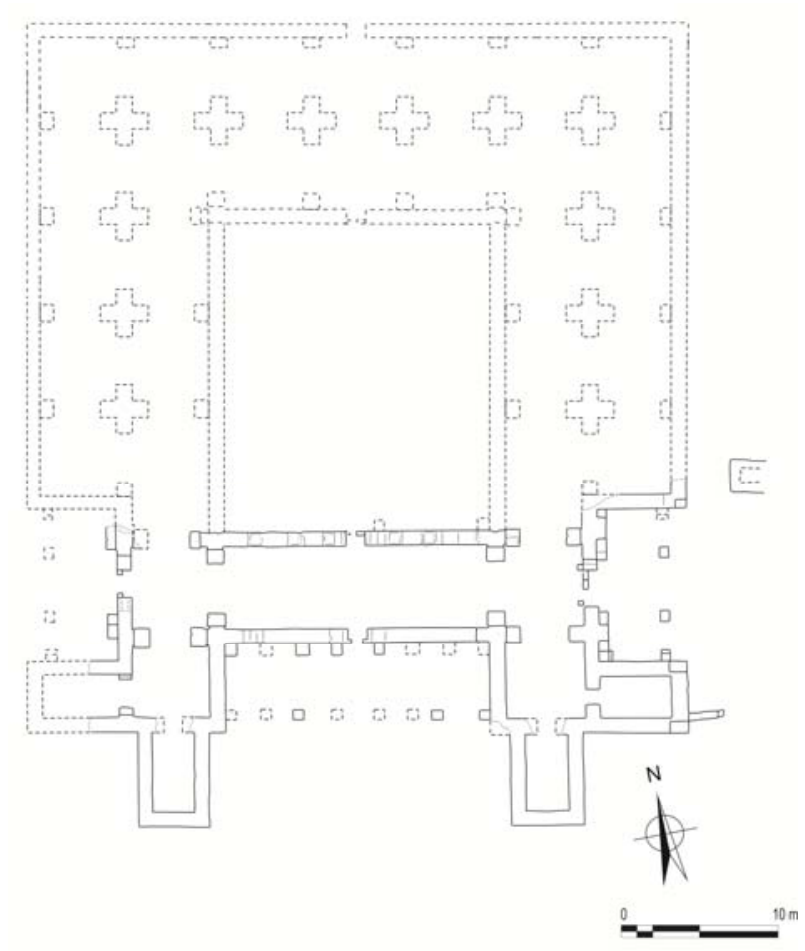

Figura 2: Reconstrucción modulada de la planta del edificio.

Dentro del proyecto del Ministerio de Economía y Competitividad HAR2012-36963-C05-03, se hizo la documentación tridimensional mediante un escáner láser Este levantamiento, junto con la planimetría y documentación de la excavación, ha sido la base de la reconstrucción infográfica (Fig. 3). Los detalles, como balaustradas, ventanas, pórticos externos y elementos arquitectónicos en la fachada y en los pináculos de las torres, proceden de las piezas originales de la excavación. 


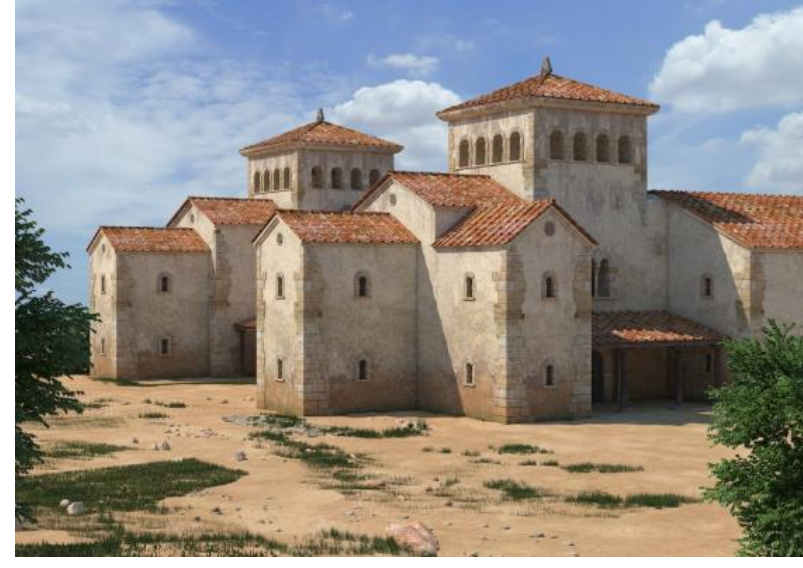

Figura 3: Vista desde el sudeste, de la reconstrucción infográfica del palacio.

Esta reconstrucción se ha usado profusamente en el nuevo Museo Visigodo de Pla de Nadal (MUPLA), y en una serie de publicaciones divulgativas. También se usa en las visitas guiadas que desde hace años se realizan en el yacimiento. Asímismo se ha presentado en congresos internacionales sobre palacios y centros de poder en la época visigoda.

Como culminación del trabajo, se ha elaborado una maqueta en relieve 3D de esta reconstrucción (Fig. 4) en el Departamento de Expresión Gráfica de la Escuela de Arquitectura de la Universidad Politécnica de Valencia.

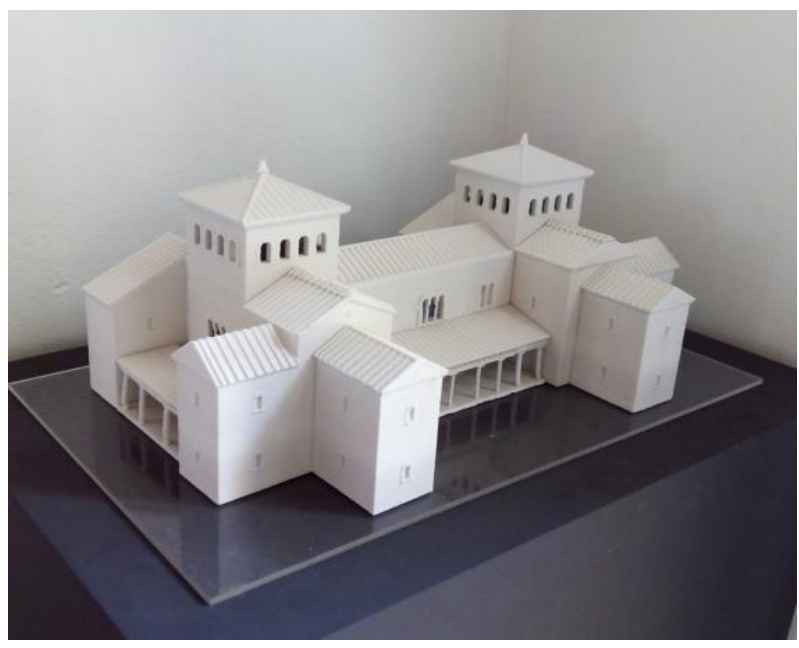

Figura 4: Maqueta en el Museo Visigodo de Pla de Nadal.

\section{Conclusiones}

La experiencia de los últimos años en el proyecto de Pla de Nadal ha servido como un ejemplo de la aplicación práctica e inmediata de la investigación arqueológica y arquitectónica, estrechamente combinada con el uso de las nuevas tecnologías, a la didáctica y la difusión a todos los públicos y niveles de los bienes culturales.

Sería de resaltar no sólo la colaboración multidisciplinar entre diversas categorías de conocimiento (arqueología, arquitectura, informática, topografía,..) sino también, y especialmente, la cooperación entre varias entidades, desde el Ayuntamiento, promotor del proyecto, a universidades y centros de investigación.

\section{Referencias}

JUAN, E. y LERMA, J.V., 2000. La villa áulica del Pla de Nadal (Riba-roja de Túria). Los orígenes del cristianismo en Valencia y su entorno. Grandes Temas Arqueológicos 2, València, pp. 135-142.

JUAN, E. y PASTOR, I., 1989. El yacimiento de época visigótica de Pla de NadaL. Archivo de Prehistoria Levantina, vol. XIX, tomo III, València, pp. 357-373.

LLOBREGAT, E., 1973. Teodomiro de Oriola. Su vida y su obra. Alicante: Instituto de Estudios Alicantinos, 111 páginas.

RIBERA, A., BARROSO, R., ESCRIVÀ, I., JUAN, E., MACIAS, J.M., MORIN, J., PUCHE, J.M., ROSSELLÓ, M. y SANCHEZ, I., 2015: Pla de Nadal (Riba-roja del Túria). El palacio de Teudinir. Ajuntament de Riba-roja de Túria, 46 páginas.

RIBERA, A. y ROSSELLÓ, M., 2007. Escultura decorativa de época tardoantigua en Valencia y su entorno. L. Caballero, P. Mateos (eds.): Anejos de AEspA XLI, Escultura decorativa tardorromana y altomedieval en la península ibérica, Madrid/Mérida, pp. 345-366.

RIBERA, A. y ROSSELLÓ, M., 2009. Valentia en el siglo VII, de Suinthila a Teodomiro. L. Caballero, P. Mateos, M.A. Utrero (eds.), Anejos de AEspA LI. El siglo VII frente al siglo VII. Visigodos y Omeyas 4: Arquitectura. Madrid, pp. 185-204.

RIBERA, A. y ROSSELLÓ, M., 2011. Valencia y su entorno territorial tras el 713: epilogo visigodo. 711, Arqueología e historia entre dos mundos (v. 2). Zona Arqueológica 15, Alcalá de Henares, pp. 85-102. 


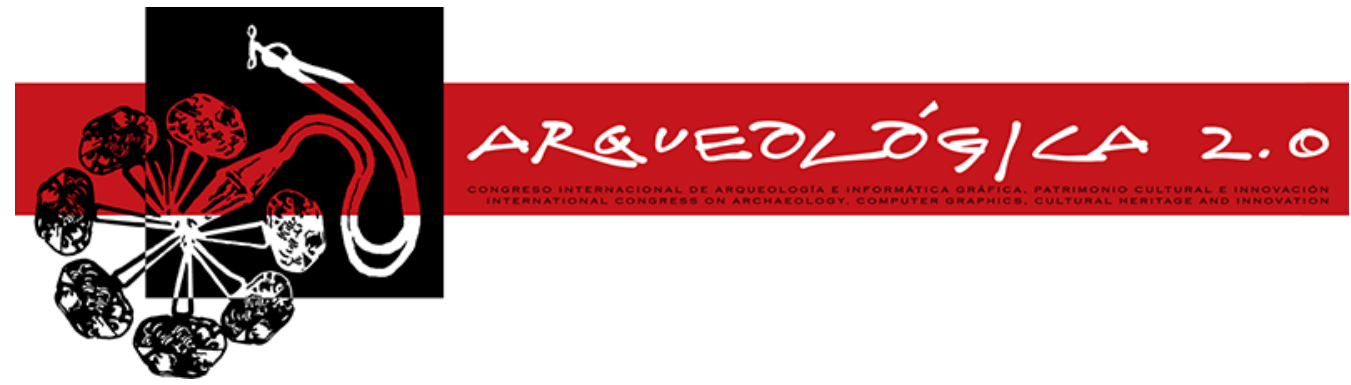

Proceedings of the $8^{\text {th }}$ International Congress

on Archaeology,

Computer Graphics,

Cultural Heritage and Innovation

'ARQUEOLÓGICA 2.0'

in Valencia (Spain),

Sept. 5-7, 2016

\title{
PHOTOGRAMMETRIC SURVEY IN THE LATRINES OF CHAMBORD
}

\section{LEVANTAMIENTO FOTOGRAMÉTRICO DE LAS LETRINAS DE CHAMBORD}

\author{
Pinte Antoine ${ }^{\mathrm{a},{ }^{,},}$, Simon Bryant ${ }^{\mathrm{b}}$ \\ aÉcole Nationale des Sciences Géographiques, 6-8 av. Blaise Pascal - Cité Descartes, Champs-sur-Marne 77455 Marne-la-Vallée \\ cedex 2, France. antoine.pinte@ensg.eu \\ bINRAP, UMR 7041 ArScan, Centre archéologique d'Orléans, 525 av. de la Pomme de Pin, 45590 Saint-Cyr-en-Val, France. \\ simon.bryant@inrap.fr
}

\begin{abstract}
:
The two rooms of a latrine of the château de Chambord were surveyed by photogrammetry. The paper reports on the specific constraints of the acquisition (small and dark rooms, isolated from the outside world and separated by a narrow corridor) as well as on the processing operations elaborated (compensated scaling and relative registration from manual points). The resulting 3D clouds and orthoimages provide metrical models for archaeological analysis.
\end{abstract}

Key words: digital archaeology, cultural heritage, documentation, 3D reconstruction, photogrammetry

\section{Resumen:}

Este artículo trata de un estudio fotogramétrico de las letrinas de Chambord. Las restricciones de la adquisición (pequeños y oscuros cuartos, aislados y separados por un estrecho corredor) y las operaciones de tratamiento elaboradas para la ubicación métrica se exponen. Los productos fotogramétricos ayudan al análisis arqueológico.

Palabras clave: arqueología digital, patrimonio cultural, documentación, reconstrucción 3D, fotogrametría

\section{Introduction}

\subsection{Context of the survey}

The château de Chambord, an emblem of French Renaissance architecture, is one of the most famous castles in the world. Built at the beginning of the $16^{\text {th }}$ century, it was inscribed on the UNESCO World Heritage list in 1981. The monitoring of the monument requires scientific descriptions, notably in the forms of orthoimages and 3D models. A photogrammetric survey was recently performed by students from the specialized master in Positionning, Photogrammetry and Deformation Measurement (PPMD) of the French national school for geographic sciences (ENSG).

The many acquisitions carried out by the students have provided, among other results, orthoimages of all the outer walls and towers of the castle (Pinte et al. 2015). The present paper reports on the surveying of the latrines in highly-constrained conditions, and on the data processing strategies applied to ensure precise results.

The latrines at Chambord are integrated into the foundations of the towers, cylindrical masonry structures some $5 \mathrm{~m}$ deep, dug into the marshy ground of the valley of the Cosson. The vaulted cess-pits materialise the earliest stages of the building project which underwent several modifications between the initial laying out and foundation work in the early 1520's and the final state of the mid 1540's. As such, they form an important element in the ongoing debates as to the original plan of the castle "keep" and the influence of Leonardo $\mathrm{Da}$ Vinci in its design (Guillaume 1974; Lesueur 1954; Ranjard 1973; Ponsot 2007). Recent research tends to favour the hypothesis of a "gyrating" plan (Caillou and Hofbauer 2003 and 2007).

Until then, the latrines were documented only through manual drawings and sketches. Simon Bryant, archaeologist at Inrap Orléans, needed more reliable data, especially of the North-West tower latrine. He needed orthoimages, in order to analyse how the stones are disposed in the wall and to create an accurate series of plans and elevations for further archaeological analysis. We decided to perform a photogrammetric acquisition in this latrine, which is composed of two rooms connected by a very narrow corridor.

\subsection{Constraints of the survey}

The acquisition conditions were severely constrained:

`Corresponding Author: Pinte Antoine, antoine.pinte@ensg.eu 
- $\quad$ Given the extent of the castle, only one day could be dedicated to the surveying of the latrine rooms. In addition, the whole acquisition had to be made during the opening hours of the castle.

- The latrine rooms are neither artificially nor naturally lit. We had to operate the lighting.

- The two rooms are connected by a sole corridor, which is about $2 \mathrm{~m}$ long and less than $50 \mathrm{~cm}$ wide at its narrowest (Fig. 1).

- The smallest room is exiguous for photographing $\left(5 \times 3 m^{2}\right)$. Moreover, it was encumbered with a heap of rubble bags in a corner.

- The larger room was flooded by water (10 to $30 \mathrm{~cm}$ deep) (Fig. 2).

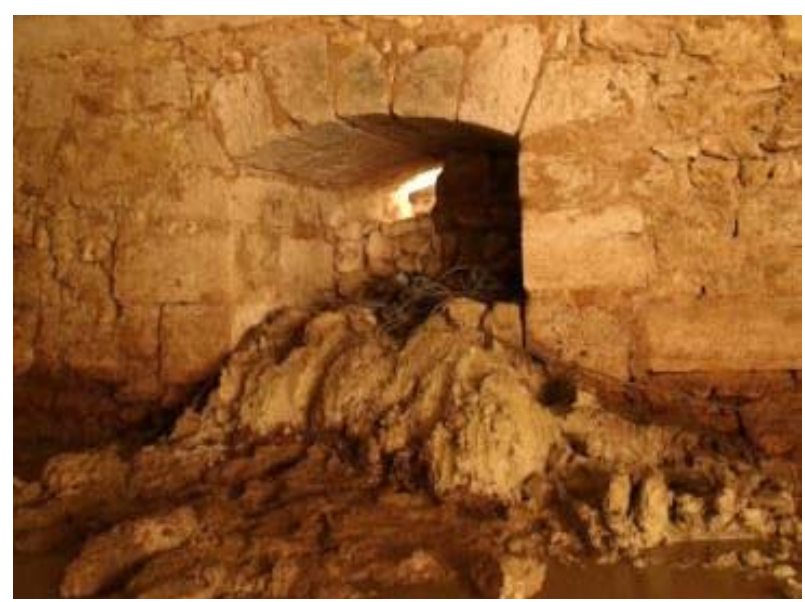

Figure 1: Corridor between the two rooms.

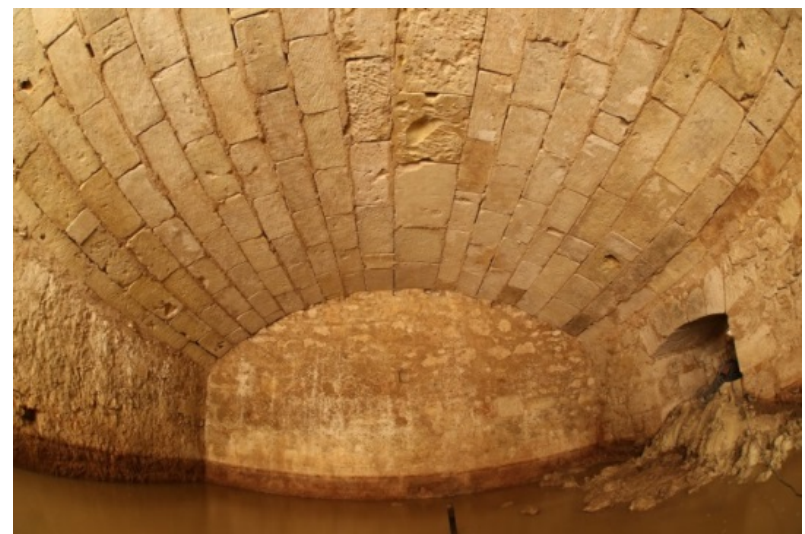

Figure 2: Image of the second room of the latrine, captured with a fisheye lens and with opposite lightning.

The next sections report on the methods used for photographing the rooms and on the solution chosen to scale the two models and to reconcile them in a same referential.

\section{Acquisition protocol}

\subsection{Lighting}

Neither room being lit, we resorted to a powerful spot set on a tripod. After many tests, it appears that the most adequate configuration is radical indirect lighting where spot and camera aim at opposite directions. This solution provides a uniform light on the walls and prevents hot spots as well as under-exposed parts in the images, even when taken with a fisheye lens (Fig. 2).

\subsection{Image acquisition}

Acquisition was made with Canon EOS 5D Mark II and III cameras. Given the exiguity of the rooms, we resorted to short focal lenses $(24 \mathrm{~mm})$. Some images were taken with fisheye lenses (focal length: $15 \mathrm{~mm}$ ), in order to improve recovery and to help to orientate all the images. A total of 285 images were taken in the two rooms.

\section{Image processing}

Data, at all stages, were processed with MicMac, a set of free open source photogrammetric software solutions to build $3 \mathrm{D}$ models from images (Pierrot-Deseilligny et al. 2006).

\subsection{Image orientation}

First were computed the position and orientation of the cameras for either room separately. Tie points between all images of one room were extracted with MicMac, using a specific module based on the SIFT algorithm (Lowe 2004), followed by a multiple matching phase. In total, almost 7 million tie points were calculated, and bundle adjustment (including self-calibration for the two cameras) led to an average image residual of 0.6 pixel. The two rooms were processed separately, because we had no time for a specific acquisition in the corridor, and also because, at the beginning, common registration was not planned.

\subsection{Scaling}

Two methods were used to compute the scaling of the rooms. The first solution, quite simple, consisted in measuring the size of the stones first in the room, and then in stereoscopy on the images. However, no adjustment algorithm on measures meant for scaling is available in MicMac: a locally imprecise measure on a given stone will lead to imprecise parameters which will greatly distort the scaling on other parts of the room.

To prevent such problems, we tested another solution. It was based on the choice of 4 points, well distributed in the room, all at the same level. The 6 possible distances between any two of these four points were measured. Least square adjustment provided the 3D coordinates of the 4 points in a fictive system. The four points were also measured in the images, and an adjustment was computed, scaling the orientation. Moreover, with this method, since the four points are chosen on a same high level, the new orientation is verticalized.

\subsection{Common orientation of the two rooms}

No specific images were taken for the narrow corridor (Fig. 1) which connects the two rooms. As a consequence, all automatic solutions to assemble the rooms are doomed to fail.

Nevertheless, we manually identified a few tie points between the two rooms. Due to the very different perspectives, it was difficult to find common details. Four points however could be found on the sides of the corridor, and two extra points, one in each room, could 
be found on the opposite walls of the corridor. These 6 points were measured on 2 images at least in each room. The images for each room being oriented, the 3D coordinates of all 6 points could be computed in both room systems. Between these two datasets of 3D points, a Helmert transformation was then computed, in order to tilt the orientation of the second room into the first room system, which is at scale and verticalized. Eventually, all orientations are defined in the same coordinates system (Fig. 3).

\section{Photogrammetric products}

\subsection{D reconstruction}

3D reconstruction for each room was computed independently, with a new module for MicMac, based on image geometry reconstruction (Fig. 3). From points cloud, sections can be computed (Fig. 4).

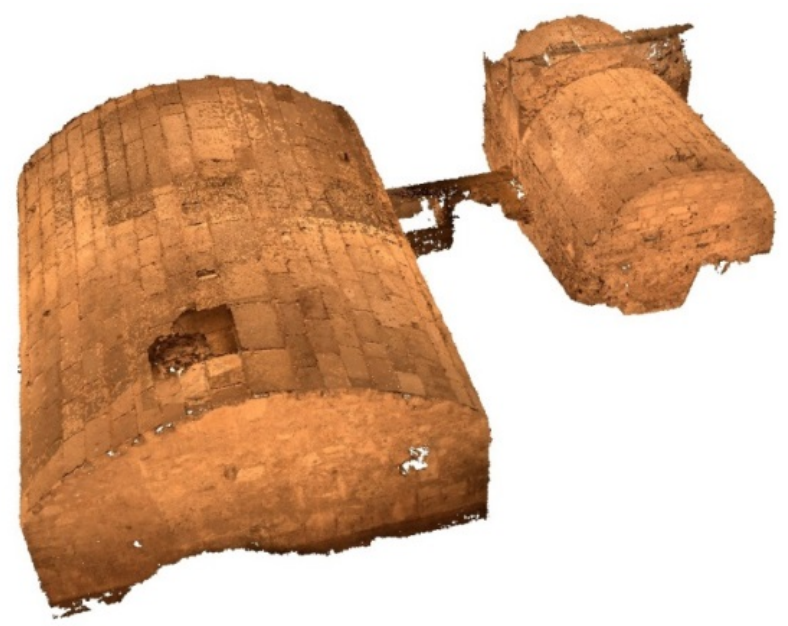

Figure 3: 3D reconstruction of the two rooms in the same system coordinates.

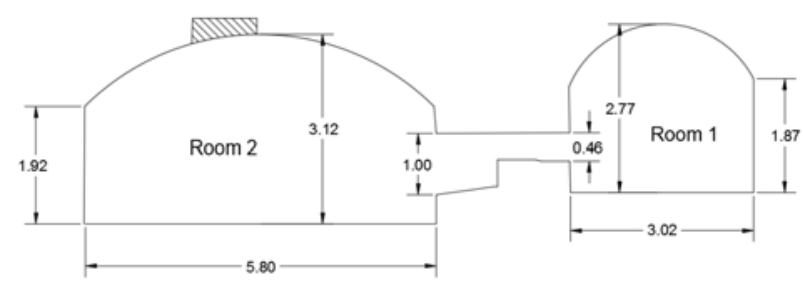

Figure 4: Vertical section computed from 3D reconstruction.

\subsection{Orthoimage}

Orthoimages of the walls of the latrine could be computed easily, on any adequate plan chosen for the orthorectification. Orthoimages of the vaults could also be computed, using a cylinder, estimated from the 3D point cloud, as projection surface. The point cloud is first converted into a depth map on this cylindrical surface: an unwrapped orthoimage can be computed using this depth map (Fig. 5).

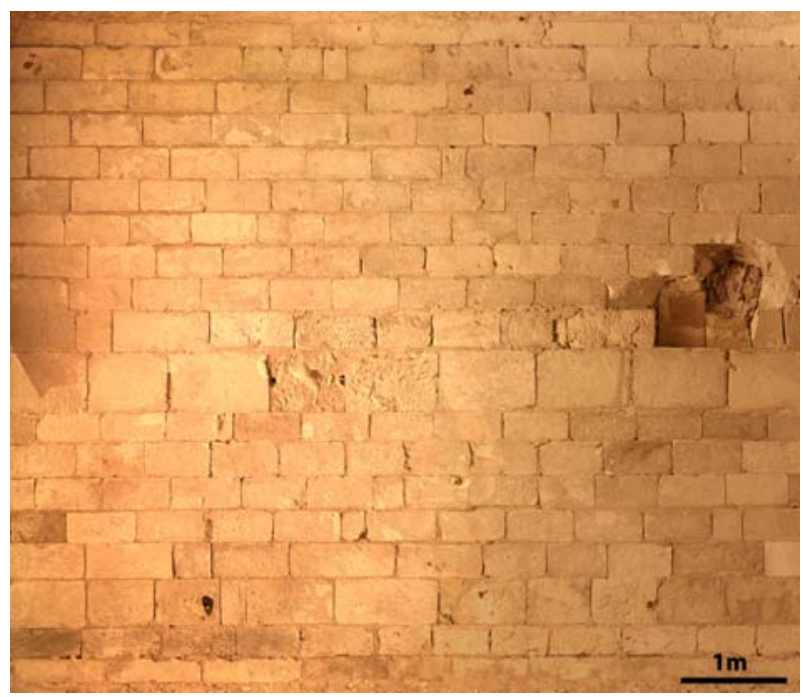

Figure 5: Unwrapped orthoimage of the second room vault.

\section{Perspectives}

Chambord castle remains a fertile ground for scientific research along many lines. The needs of monitoring and architectural conservation have impelled the development of accurate and detailed scientific descriptions in the form of orthoimages, 3D scans and photogrammetric models. These provide an evolving archive of the state of the edifice at any given moment and constitute valuable tools for the recording of different types of archaeological data at different scales and on a variety of supports. They also offer new opportunities for ongoing archaeological research and allow manual survey and drawing methods to fulfil a more interpretative and reflexive role in the recording of archaeological remains whilst improving the accuracy and interchangeability of acquired data. This is of particular interest for a site where many different researchers may intervene at different times and for different reasons since the documentation may be reused, updated and enriched through time. Older archaeological data may be integrated into these documents and offer the possibility to re-evaluate findings and guide future research programs.

\section{References}

CAILLOU, J.S. and HOFBAUER, D., 2003. Les latrines du château de Chambord: nouveaux développements, Concepteurs et conception d'espaces souterrains, Actes du colloque international de subterranologie, Auxi-leChâteau, mai 1999. Bulletin spécial du Cercle historique d'Auxi-le-Château, n 2, p. 47-61.

CAILLOU, J.S. and HOFBAUER, D., 2007. Chambord. Le projet perdu de 1519. ARCHEA, Tours.

GUILLAUME, J., 1974. Léonard de Vinci et l'architecture française : Le problème de Chambord, Revue de l'art, n²5, p. 71-84.

LESUEUR, F., 1954. Léonard de Vinci et Chambord, L'art et la pensée de Léonard de Vinci (Actes du congrès international du Val de Loire, 1952), dans Études d'art, Paris-Alger, n 8,9,10, 1953-1954, p. 225-238. 
LOWE, D.G., 2004 Distinctive Image Features from Scale-Invariant Keypoints, International journal of computer vision, 60,2 , p. $91-110$.

PIERROT-DESEILLIGNY, M. and PAPARODITIS, N., 2006. A multiresolution and optimization-based image matching approach: An application to surface reconstruction from SPOT5-HRS stereoimagery, ISPRS Workshop on Topographic Mapping from Space (With Special Emphasis on Small Satellites), Ankara, Turkey.

PINTE, A., HÉNO, R., PIERROT-DESEILligNY, M., BRUNETEAUD, X., JANVIER-BADOSA, S. and JANVIER, R., 2015. Orthoimages of the outer walls and towers of the château de Chambord, ISPRS Annals of Photogrammetry, Remote Sensing and Spatial Information Sciences, Volume II-5/W3, pp.243-250

PONSOT, P., 2007. Les terrasses du donjon de Chambord : un projet de Léonard de Vinci ?, Bulletin Monumental, Vol.165, n 3.

RANJARD, M., 1973. Contribution à l'étude du plan de Chambord, Monuments historiques de la France, p. 30-39. 


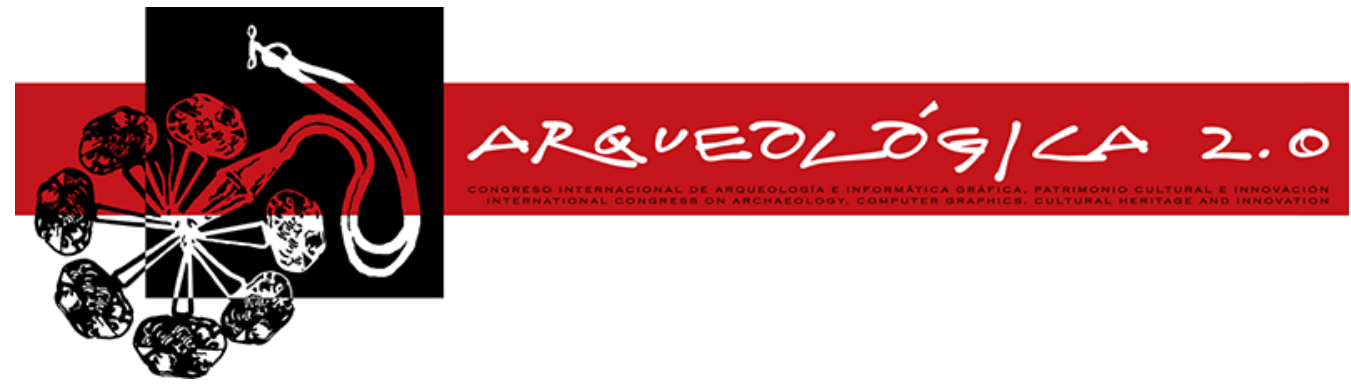

Proceedings of the $8^{\text {th }}$ International Congress

on Archaeology,

Computer Graphics,

Cultural Heritage and Innovation

'ARQUEOLÓGICA 2.0'

in Valencia (Spain)

Sept. $5-7,2016$

\title{
SITUACIÓN EN EL ESPACIO E INVERSIÓN DE TRABAJO DE LAS CONSTRUCCIONES MEGALÍTICAS A PARTIR DE LOS SISTEMAS 3D, IMÁGENES PANORÁMICAS Y $360^{\circ}$
}

\author{
SITUATION IN SPACE AND WORK INVESTMENT OF THE MEGALITHIC CONSTRUCTIONS THROUGH 3D \\ SYSTEMS, PANORAMIC IMAGES AND $360^{\circ}$
}

\author{
Elisabet López
}

Departamento de Prehistoria, Laboratorio ARCHAEOM, Universidad Autónoma de Barcelona, Bellaterra, 08193, España. elisabet.loga@gmail.com

\begin{abstract}
:
There are several methodologies and computer techniques for the study of archaeological objects. These systems, traditionally used for diffusion and graphical representation, are powerful tools for data collection. This study is an example of the application of 3D systems, panoramic images and images in 360 degrees to the problem of megaliths in Catalonia; dealing aspects such the situation in space and work investment.
\end{abstract}

Key words: 3D reconstruction, panoramic images, $360^{\circ}$ images, megalithic constructions, space, work investment

\section{Resumen:}

Existen diversas metodologías y técnicas informáticas para el estudio de los objetos arqueológicos. Estos sistemas tradicionalmente usados para la difusión y representación gráfica constituyen además potentes herramientas de obtención de datos. El presente trabajo es una muestra de la aplicación de sistemas 3D, imágenes panorámicas e imágenes en $360^{\circ}$ a la investigación en torno al megalitismo en Cataluña; abordando aspectos como su situación en el espacio o la determinación de la inversión de trabajo realizada en su construcción.

Palabras clave: reconstrucción 3D, imágenes panorámicas, imágenes $360^{\circ}$, construcciones megalíticas, espacio, inversión de trabajo

\section{Introducción}

La investigación entorno al megalitismo en Cataluña ha sido y es una de las principales problemáticas de la investigación prehistórica en esta zona. Tradicionalmente, las investigaciones se han centrado en la definición de tipos arquitectónicos y en su posible adscripción crono-cultural, así como en la de los elementos materiales documentados en su interior. Pero las construcciones megalíticas pueden ser objeto de investigación desde otras perspectivas y metodologías, como la representación en 3D, las fotografías panorámicas y fotografías en $360^{\circ}$, con el objetivo de obtener datos sustantivos que amplíen nuestro conocimiento sobre estas construcciones y sobre los grupos humanos que los erigieron y utilizaron.

\section{Metodología}

La combinación de los sistemas de modelización 3D, las fotografías panorámicas, las fotografías en $360^{\circ}$ y los Sistemas de Información Geográfica es una línea de estudio muy interesante para obtener información hasta el momento desconocida o poco utilizada entorno al megalitismo en Cataluña. En este estudio se utilizan estas téncicas para la captación de información geográfica tratada en el posterior estudio de la inversión de trabajo y la situación espacial de las construcciones megalíticas.

Para inferir en la inversión de trabajo el método utilizado es el cálculo volumétrico de los espacios construidos de una construcción megalítica, es decir, la cámara y/o el corredor y la estructura tumular. Para conseguir estos valores se puede utilizar dos métodos: el cálculo tradicional mediante las fórmulas matemáticas geométricas o la modelización digital en 3D. En el presente trabajo se utiliza la fotogrametría para el levantamiento en $3 \mathrm{D}$ de los megalitos como método de obtención del valor volumétrico.

A partir del valor volumétrico, y con el programario SIG, se realizan análisis espaciales para observar las relaciones entre las dimensiones de los espacios construidos, es decir, el tamaño de los megalitos, y realizar agrupaciones o delimitar zonas con similitudes, elaborar análisis de visibilidad, proximidad a la red hidrográfica y puntos elevados en el territorio. A la vez, 
inferir en el grado de inversión de trabajo necesario para el levantamiento de cada uno de los megalitos.

Referente a la situación en el espacio, complementando el trabajo de campo, se utiliza las fotografías panorámicas y en $360^{\circ}$ para la obtención de diversa información posteriormente tratada y analizada con los Sistemas de Información Geográfica. En este sentido, se estudia la distribución espacial de las construcciones en relación a la inversión de trabajo, la proximidad entre megalitos y la red hidrográfica y la realización de análisis de visibilidad.

\section{Caso de estudio}

El caso de estudio propuesto en este trabajo es el sepulcro megalítico de Puigseslloses. Se trata de una gran galería del Iller milenio cal BC situada en un punto con una alta dominancia visual sobre el territorio (Fig.1) (Gamarra y Clop 2000).

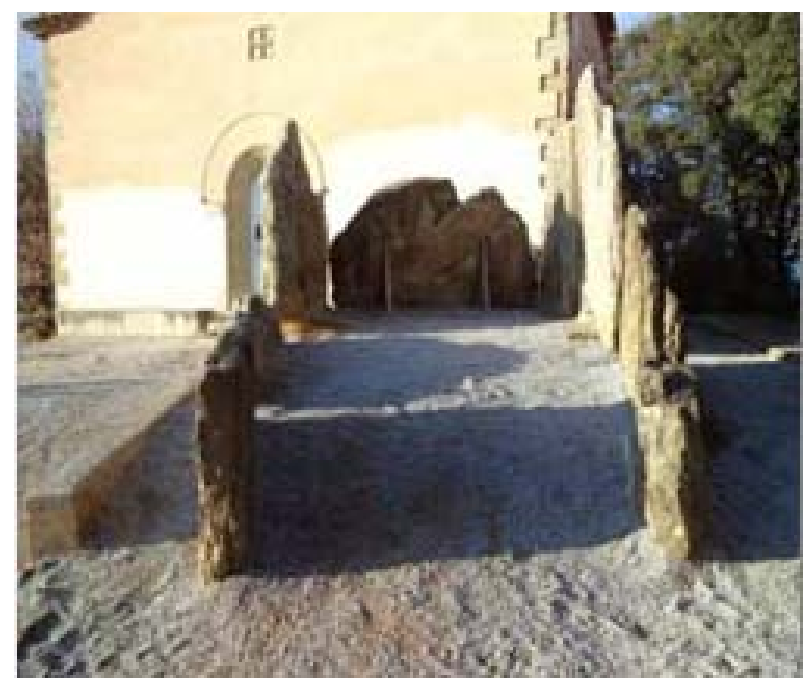

Figura 1: Fotografía del megalito de Puigseslloses.

Se encuentra en la parte superior de un pequeño, aislado y característico cerro-testimonio de la llanura de Vic (Fig.2), en el interior de Cataluña. Sus coordenadas UTM son X: 441696, Y: 4644211 y Z: 528, huso 31N.

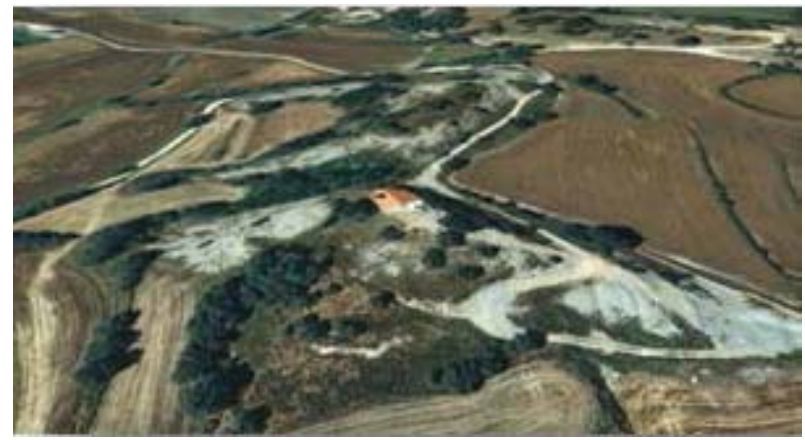

Figura 2: Vista google earth de la situación del megalito en el promontorio.

Está formado por ocho losas de grandes dimensiones (de hasta 4'5 toneladas de peso) que configuran una construcción de forma trapezoidal (Vicens et al. 2010). Tiene 9.75 metros de largo, 4.5 metros de anchura en la cabecera y 2.7 metros de ancho en la zona de acceso al corredor. La altura máxima se registra en la zona de la cámara, donde llega a 1.9 metros, siendo similar en toda ella. El corredor de acceso está compuesto por cuatro losas de entre 0.5 y 0.9 metros de altura. De hecho, la diferencia entre la cámara y el corredor se marca por la diferencia de altura de las losas de la cámara y del corredor. Las dimensiones del corredor son casi 5 metros de largo máximo por 4.5 metros de anchura máxima. El sistema de cubierta de la estructura es desconocido. Se desconoce por completo cualquier posible dato del túmulo que eventualmente rodearía y soportaría toda la estructura de la cámara y el corredor, ya que ha desaparecido a causa de la reiterada utilización de este sitio desde la construcción del megalito hasta nuestros días.

\section{Inversión de trabajo}

En el presente estudio se utiliza las características arquitectónicas de las construcciones megalíticas para inferir en la inversión de trabajo realizada mediante los sistemas de tridimensionalidad; concretamente el uso de fotogrametría tratada con Photoscan (Fig.3). El uso de modelos digitales 3D para el estudio de estas construcciones permite la obtención de información geométrica y volumétrica, y por tanto poder obtener el cálculo volumétrico de los espacios construidos con un alto grado de fiabilidad (López 2014; López Inédito).

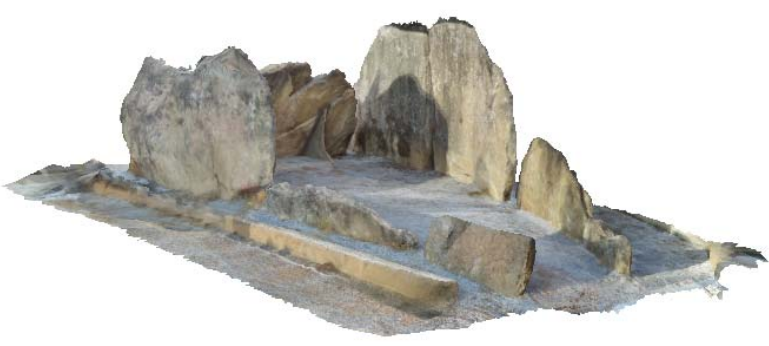

Figura 3: Reproducción del megalito de Puigseslloses.

Las partes del megalito consideradas para el cálculo volumétrico son: a) la cámara y el corredor, en tanto que son los espacios construidos vacíos donde se practica la inhumación de los muertos, b) la estructura tumular, que implica el movimiento de un gran volumen de sedimento. Las similitudes o diferencias entre las volumetrías de distintos sepulcros megalíticos constituyen evidencias que permiten establecer similitudes o diferencias cuantitativas en el trabajo social invertido en su construcción.

\section{Emplazamiento en el espacio}

El punto en el espacio donde se ubican las construcciones megalíticas no es, en ningún caso, fruto del azar. Partiendo de la premisa de que las construcciones megalíticas son productos en tanto que se trata de elementos materiales construidos para satisfacer determinadas necesidades sociales, se puede considerar que existe una relación directa entre el emplazamiento y la visibilidad (Fig.4) desde el megalito y hacia el megalito, su distancia respecto a cursos fluviales, caminos y pasos naturales, la orientación de la entrada,... 


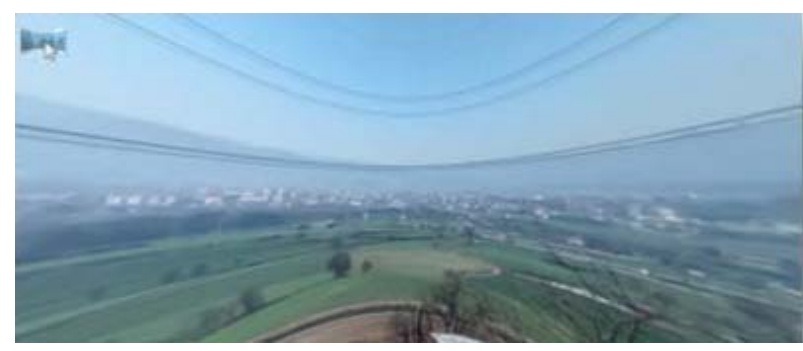

Figura 4: Panorámica y aplicación $360^{\circ}$ de la visibilidad del megalito dirección sur.

En la actualidad, las fotografías panorámicas, los recorridos virtuales y las fotografías en $360^{\circ}$ constituyen innovadores sistemas de registro y visualización de información que permiten extraer gran cantidad de información sobre aspectos poco abordados hasta el momento en la investigación en torno a los sepulcros megalíticos.

\section{Discusión}

Esta propuesta metodológica y las técnicas de estudio presentadas forman parte de una tesis doctoral que analiza la situación en el espacio de los megalitos de la cuenca del río Llobregat en Cataluña. El objetivo es determinar la estructura social de las comunidades que los erigieron y utilizaron, con el fin de avanzar en el uso de posibilidades que ofrecen las nuevas tecnologías no solo en aspectos descriptivos y de difusión sino también en espacios de investigación centrados en cuestiones como las características sociales de las comunidades del pasado.

Al tratarse de una investigación en curso, existen unos resultados preliminares que se están contrastando con los resultados de los análisis geográficos y volumétricos para determinar el patrón de situación en el espacio e inversión de trabajo.

\section{Referencias}

GAMARRA, A y CLOP, X., 2000. Sepulcre Megalític de Puigseslloses, Folgueroles (Osona). Informe preparat per la Generalitat de Catalunya, Departament de Cultura, Direcció General del Patrimoni Cultural, Servei de Suport Tècnic i Inventari , Biblioteca del Patrimoni Cultural. №3120. pp.1-16

LÓPEZ, E., 2014. Volumetric Study of Megalithic Constructions of the Eastern Pyrenees. Proceedings of the International Workshop on Landscape and Spatial Analysis in Archaeology. pp.243-250.

LÓPEZ, E. Inédito. Aplicació de models digitals 3D a l'estudi volumètric de les construccions megalítiques.

VICENS, E.; ARRIBAS, M.E.; CLOP, X.; ESTRADA, M.R.; MAESTRO, E.; OMS, O.; SERRAT, D.; MOLIST, M., 2010. Characterization and provenance of the slabs of the Puigseslloses megalith, Barcelona, Spain. Geoarcheaeological: An International Journal 25 (2): 195-219. 


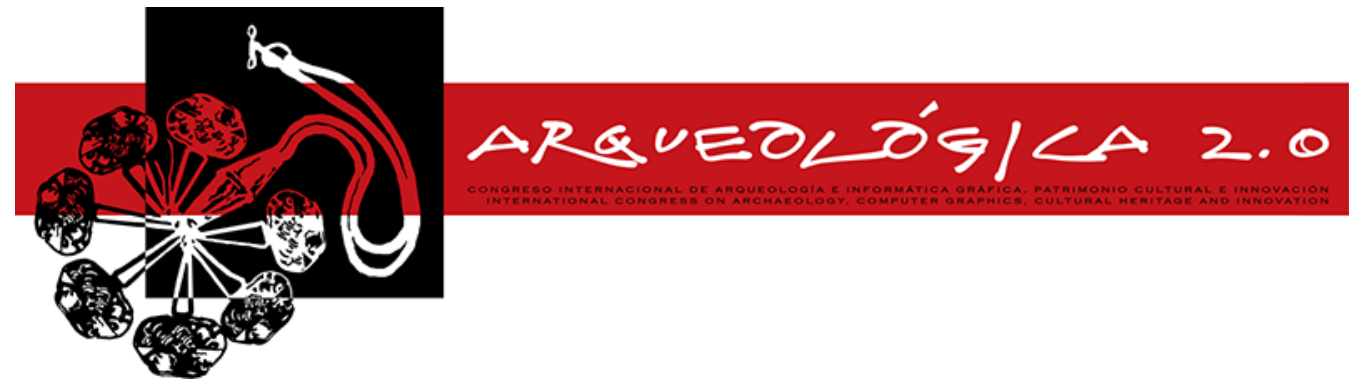

Proceedings of the $8^{\text {th }}$ International Congress

on Archaeology,

Computer Graphics,

Cultural Heritage and Innovation

'ARQUEOLÓGICA 2.0'

in Valencia (Spain),

Sept. $5-7,2016$

\title{
COMPLEX 3D HERITAGE ARCHITECTURES ACCESSIBLE ON THE WEB
}

\author{
M. Magda Ramos ${ }^{a,{ }^{*}}$, Diego Bellido ${ }^{b}$, Nicola Carboni ${ }^{c}$, Matevz Domajnko ${ }^{d}$, Elisavet K. \\ Stathopoulou ${ }^{e}$, Georgina Stavropoulou ${ }^{f}$, Daniele Morabito ${ }^{a}$, Fabio Remondino ${ }^{a}$ \\ a 3D Optical Metrology (3DOM) unit, Bruno Kessler Foundation (FBK), Trento, Italy. ramos@fbk.eu; morabito@fbk.eu; \\ remondino@fbk.eu \\ ${ }^{\mathrm{b}}$ ArcTron3D GmbH, Altenthann, Germany. dbellido@arctron.de \\ ${ }^{c}$ UMR 3495 MAP CNRS/MCC, Marseille, France. nicola.carboni@map.cnrs.fr \\ ${ }^{d}$ Fraunhofer Institute for Computer Graphics Research IGD, Darmstadt, Germany. matevz.domajnko@igd.fraunhofer.de \\ ${ }^{\mathrm{e}}$ Laboratory of Photogrammetry, National Technical University of Athens. elliestath@central.ntua.gr \\ ${ }^{f}$ KU Leuven - University of Leuven, Belgium. gina.stavropoulou@esat.kuleuven.be
}

\begin{abstract}
:
3D digitization, based on active or passive sensors, is a need for all man-made or natural heritage structures. It is indeed important to digitally preserve our past using the latest ICT solutions to protect and valorize it. This paper presents a collaborative work for the 3D surveying of a complex heritage monument, its annotation and segmentation for semantic reasons and the final access on the web for dissemination and valorization purposes. We report a scalable methodology for 3D surveying and exploration of large 3D results. The case study is a large castle decorated with frescoes and ornamental elements which was surveyed using photogrammetry. The 3D results (dense coloured point clouds) are enriched with metadata and historical information and shared on the Internet using a customized point-based viewer.
\end{abstract}

Key words: cultural heritage, documentation, 3D reconstruction, valorization, web-based access

\section{Introduction}

The continuous improvement and availability of 3D digitization solutions as well as the proliferation of interactive methods for 3D data access and sharing are reshaping how we digitally preserve, study, learn and even access information about our environment. People nowadays are constantly connected to information using Internet browsers even on mobile devices and many software packages allow the generation of 3D data without any particular technical knowledge. These two aspects play an important role in the Cultural Heritage sector where detailed $3 \mathrm{D}$ information is necessary to fully represent, inspect and valorize a heritage site, monument or artefact. At the same time, VR/AR applications, virtual tours, web-based 3D access, mobile applications and e-collections are fast growing technologies that have significantly altered the field of Digital Cultural Heritage (Callieri et al., 2013; Di Benedetto et al. 2014; Evans et al. 2014; Marton et al. 2014). For these reasons the actual challenge for ICT technologies in the heritage sector is to provide innovative solutions for sharing knowledge about the heritage building, increasing its prominence, augmenting the possibilities of interactions with its digital models and improving its commercial viability.
This paper presents a scalable methodology developed to survey large architectures and explore the realized segmented and enriched 3D data online. The monument under study is the Buonconsiglio castle in Trento (Italy), the largest and most important monumental complex of the Trentino - Alto Adige region (Fig. 1). It was the residence of the prince-bishops of Trento from the 13th century to the end of the 18th century when it started to be used as a barrack and then as Austrian military headquarter until the end of the First World War. Following its restoration in 1924, it became a National Museum and since 1973 it belongs to the Autonomous Province of Trento. The castle is composed of a series of buildings of different eras, enclosed by walls and positioned slightly higher than the city.

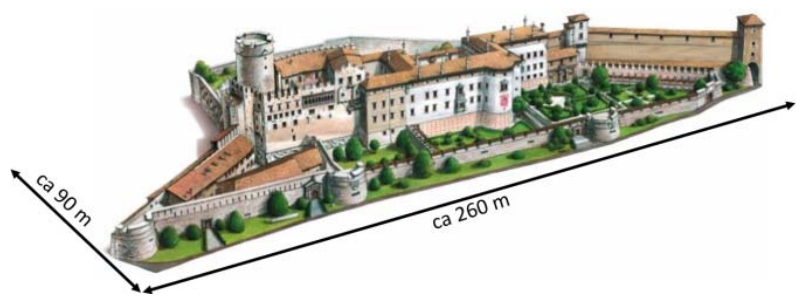

Figure 1: A sketch of the Buonconsiglio castle in Trento, Italy.

*Corresponding Author: M. Magda Ramos, ramos@fbk.eu 
The work hereafter presented is focused on the multiresolution 3D survey of the entire outdoor structure of the castle and of some important internal rooms and structures. The results were enriched with annotations and historical information for dissemination purposes. All the results are stored in an online point-based viewer available online at http://3dom.fbk.eu/repository/buonconsiglio castle/index. html.

\section{Image-based 3D surveying}

Surveying complex architectural objects requires a detailed prior planning in order to ensure the data completeness and, overall, the proper data assembling (Remondino et al. 2013). Due to the complexity of the scenarios, time and personnel restrictions, image-based techniques were considered as the best methodology for the $3 \mathrm{D}$ reconstruction of the castle.

A 3D aerial point cloud with ca. $10 \mathrm{~cm}$ resolution was available from previous projects, as well as idealized plans of each floor of the castle in raster format. Therefore, 3D information about the upper parts (roofs) of the castle was already recorded, while the facades and other vertical surfaces were incomplete or totally missing. The plans provided for each floor could be used to roughly locate the interior rooms of interest that were to be digitised. A multi-resolution approach was selected: for the interior part of the castle (rooms) an average GSD smaller than $5 \mathrm{~mm}$ was selected due to the presence of highly detailed decorative elements and frescos on ceilings and walls; whereas for the facades and the exterior walls, given the aerial point cloud, a GSD of $1 \mathrm{~cm}$ was considered sufficient.

The image-based survey was performed considering the following aspects:

(i) cameras: two full-frame SRL cameras were mainly used, but additional lower resolution DSRL cameras were employed for the interior rooms where the distance to the object was short enough to obtain the desired GSD.

(ii) objectives/lenses: long focal lengths with full frame cameras were used for the external walls acquisition when available, whereas short focal lengths were employed for small internal rooms and narrow corridors. The optimal combination of cameras and lenses ensured the required/planned GSDs were achieved.

(iii) lighting conditions: a diffuse illumination system was chosen for indoor image acquisitions in poorlyilluminated areas, while a careful combination of aperture and exposure time was the option where additional illumination was not allowed. Increasing the aperture, the changes of the depth of field for short focus distances were also taken into consideration in order to avoid blurry areas on the images.

As the acquisition was performed during different days and under varying lighting conditions, white balance correction (white/grey card) was applied before each acquisition.

(iv) image format: RAW format enables further postprocessing of the images, radiometric correction and no compression artefacts. Furthermore, in areas where colorimetry was critical (e.g. rooms covered by frescos like Torre Aquila), colour chart calibration was also employed. (v) scaling and referencing: for a metric result a reference or scale is needed. For the internal rooms, either a scale bar or several distance measurements were taken. For the external facades and walls, common points on the overlapping areas between the aerial point cloud and the point cloud of the facades were used for referencing

In total, more than 2000 images were collected for the complete acquisition of the external part of the castle, whereas about 300 images were acquired for each of the castle rooms. All datasets were processed combining various state-of-the-art software applications (Agisoft PhotoScan, aSPECT3D and SURE). It was decided to (i) deliver the surveying results in the form of a dense, coloured 3D point clouds, direct output of the image-based workflow, (ii) combine the geometric 3D data with metadata, paradata and annotations (Section 3 ) and (iii) let free online access to the results (Section 4).

\section{Annotations and semantics}

The London Charter and the Sevilla Principles (Denard 2009; Lopez-Menchero and Grande 2011) clearly express the need for highlighting the intellectual integrity of the methods in relation to the outcome provided. They also underline how a set of principles is needed to ensure that digital heritage visualisation is, at least, as intellectually and technically rigorous (Denard 2009). Following such suggestions and in order to tackle the complexity of the process employed to deliver a final scientific product (therefore reviewable in its basic composition), it was decided to document the various phases of the castle's survey using the conceptual structure presented in (Carboni et al. 2016). Such choice was made in order to document the process provenance and therefore "the sources of information, such as entities and processes, involved in producing or delivering an artefact" (Missier et al. 2013). The aim was to normalise and preserve the information about the used methodology (normally called "paradata"), as well as to present to the experts the technical and scientific approach employed. This methodology, focusing on documenting the event and not only on the subject of the digitization, allow the documentation of the different acquisition activities that compose an acquisition project (Fig. 2), keeping records of the different parameters used.

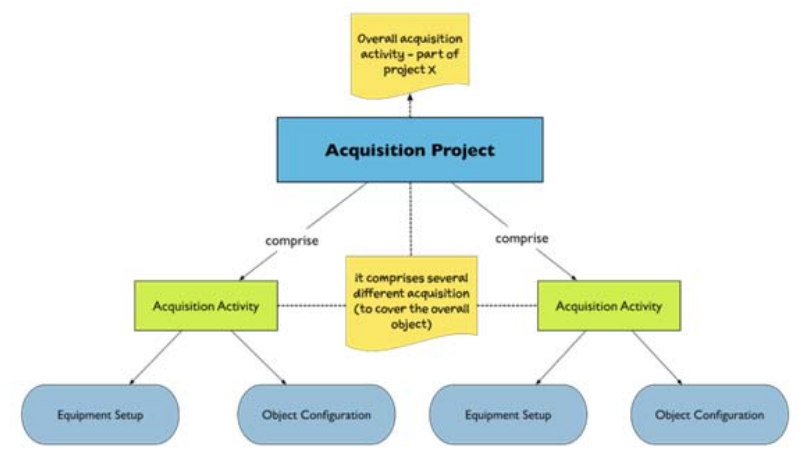

Figure 2: Schema followed for the documentation of the different agencies and subjects during the acquisitions events.

The information regarding the geometric construction of the $3 \mathrm{D}$ point cloud of the castle was documented using 
the methodology cited above. The information, together with the metadata of the surveyed scenes, was registered and put in relation with each of the performed acquisitions, in order to have, in a web interface, not only the result in 3D, but a set of elements describing the shooting, the object, the environment, and the postprocessing information, which are essential for assessing the results by the professional public.

This methodology allows the public to see/read/access/enjoy the composition of the various parts of the castle as a single unit, or as an overall product, allowing the exploration of the different details of a multi-actor and multi-resolution type of acquisition.

\section{Web point-based visualization}

For the visualization of dense point cloud datasets, the Potree WebGL open source viewer (version: 1.4RC) was used. This solution (i.e. point-based rendering) has the main advantage of being specifically developed for rendering large point clouds using standard web-based technologies that work within a web browser.

The castle raw point clouds were first cleaned, resampled and exported in .las/.laz format. The .laz files were then promptly re-encoded in an octree data structure using a converter (Schütz 2014).

The visualisation was enriched with interactive points of interest (POI) linked to additional visualizations of internal rooms or to textual description of the content of a specific part of the castle e.g. about frescoes (Fig. 3b).

The results were presented in a web interface, which, targeting both professional and cultural heritage enthusiast, allow the visualisation and the exploration of 3D data (combination of aerial with terrestrial data) (Fig. 3a), 2D information (raster plans and images), textual description (iconography) together with the semantic information of the process, providing furthermore the possibility to perform various user interaction (e.g. distance or surface measurements) within the 3D model.

\section{Conclusions}

The article has presented the 3D surveying of a complex heritage site. The collected and enriched 3D data are then used for valorization, dissemination and communication purposes by means of a web-based visualisation of the point cloud linked to annotations and other semantic information. The current paper highlights the importance of the collaborative work of a multidisciplinary team when it comes to a holistic documentation approach of large scale monuments realized not only for geometric documentation but also for valorization purposes. The combined expertise from different scientific domains can significantly speed up and, more importantly, improve the documentation processing steps, from acquisition to visualisation and dissemination.
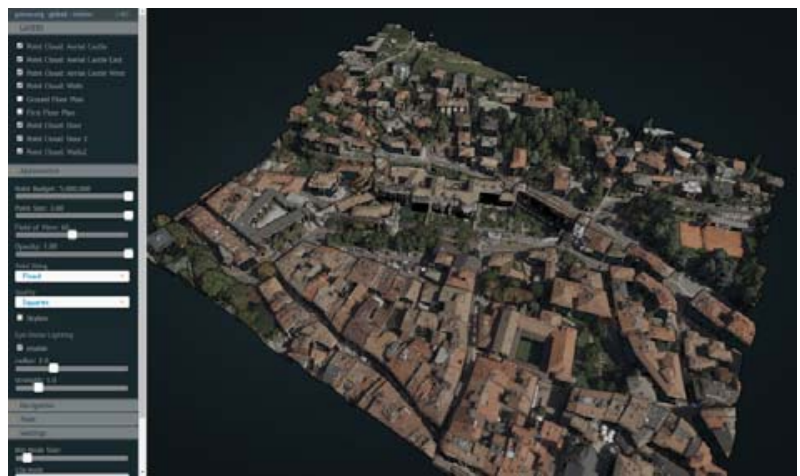

a)

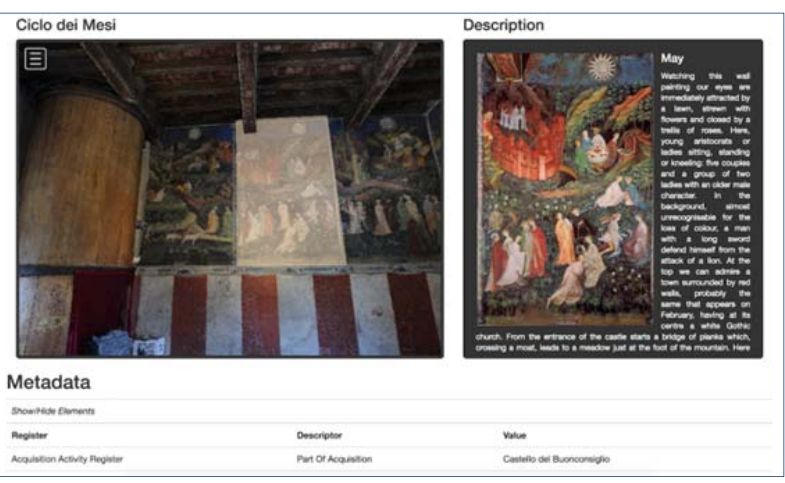

b)

Figure 3: a) The initial visualization with the castle and the surrounding urban area; b) POI (Torre Aquila) with its frescoes.

\section{Acknowledgements}

The authors are really thankful to all the personnel of Buonconsiglio castle in Trento (Italy). In particular we wish to acknowledge Silvano Zamboni and Adriano Conci for their kindness and support during the data collection. The authors are also thankful to the ITN-DCH project (http://itn-dch.org/), funded from the EU's $7^{\text {th }}$ FP for research, technological development and demonstration (Grant Agreement no 608013).

\section{References}

CALLIERI, M., LEONI, C., DELLEPIANE, M. and SCOPIGNO, R., 2013. Artworks narrating a story: a modular framework for the integrated presentation of three-dimensional and textual contents. Proc. ACM Web3D, pp. 167-175. DOI: $10.1145 / 2466533.2466548$.

CARBONI, N., BRUSEKER, G., GUILLEM, A., BELLIDO, D.C., COUGHENOUR, C., DOMAJNKO, M., DE KRAMER, M., RAMOS, M.C., STATHOPOULOU, E.K. and SUMA, R., 2016. Data provenance in photogrammetry through documentation protocols. To be presented at: ISPRS Annals of Photogrammetry, Remote Sensing and Spatial Information Sciences, in press.

DENARD, H., 2009. The London Charter for the Computer-based Visualisation of Cultural Heritage. King's College London. 
DI BENEDETTO, M., PONCHIO, F., MALOMO, L., CALLIERI, M., DELLEPIANE, M., CIGNONI, P. and SCOPIGNO, R., 2014. Web and mobile visualization for Cultural Heritage. 3D Research Challenges in Cultural Heritage. Springer, pp. 18-35. DOI: 10.1007/978-3-662-44630-0_2

EVANS, A., ROMEO, M., BAHREHMAND, A., AGENJO, J. and BLAT, J., 2014. 3D graphics on the web: A survey. Computers \& Graphics, Vol. 41, pp. 43-61. DOI: 10.1016/j.cag.2014.02.002

LOPEZ-MENCHERO, V.M. and GRANDE, A., 2011. The Principles of the Seville Charter. 23rd CIPA symposium, pp. 15.

MARTON, F., BALSA, M., BETTIO, F., AGUS, M., JASPE, A. and GOBBETTI, E., 2014. IsoCam: Interactive Visual Exploration of Massive Cultural Heritage Models on Large Projection Setups. ACM JOCCH Journal, Vol. 7(2): article 12

MISSIER, P., BELHAJJAME, K. and CHENEY, J., 2013. The W3C PROV family of specifications for modelling provenance metadata. Extending Database Technology, ACM Press, Genoa, pp. 773-776.

POTREE VIEWER, 2016 - http://potree.org/ [Last Accessed: 27/03/2016]

REMONDINO, F., MENNA, F., KOUTSOUDIS, A., CHAMZAS, C. and EL-HAKIM, S., 2013. Design and implement a reality-based 3D digitisation and modelling project. Proc. IEEE Conference "Digital Heritage 2013", Vol. 1, pp. 137144. DOI: 10.1109/DigitalHeritage.2013.6743723SCHÜTZ, M., 2014. PotreeConverter - Uniform Partitioning of Point Cloud Data into an Octree. Available at: http://potree.org/downloads/converter_documentation.pdf [Last Accessed: 27/03/2016].

SCHÜTZ, M., 2014. PotreeConverter - Uniform Partitioning of Point Cloud Data into an Octree. Available at: http://potree.org/downloads/converter_documentation.pdf [Last Accessed: 27/03/2016] 


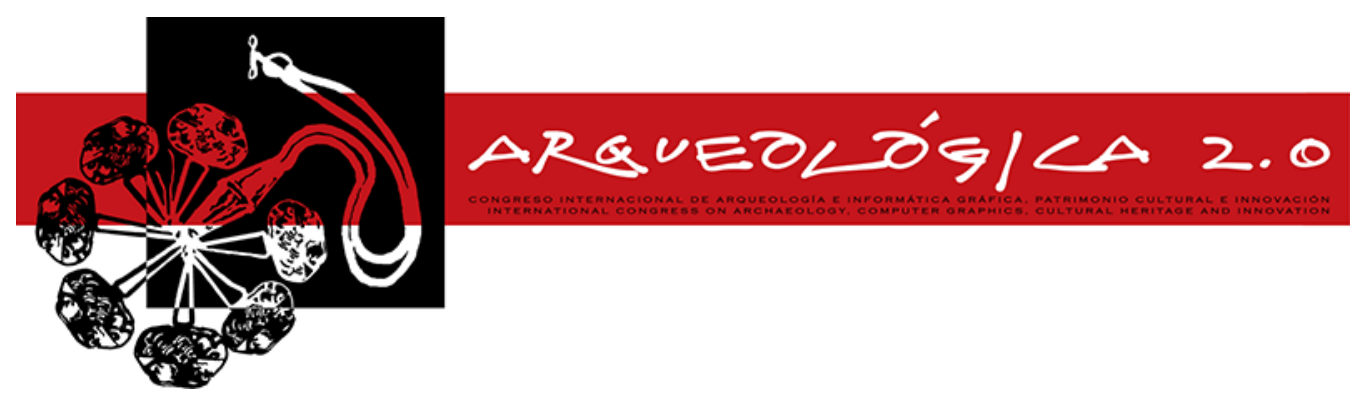

Proceedings of the $8^{\text {th }}$ International Congress

on Archaeology,

Computer Graphics,

Cultural Heritage and Innovation

'AROUEOLÓGICA 2.0'

in Valencia (Spain),

Sept. $5-7,2016$

\title{
A PILOT PROJECT AERIAL STREET VIEW TOUR AT THE VALLEY OF THE TEMPLES (AGRIGENTO)
}

\author{
UN PROYECTO PILOTO DE STREET VIEW AERIAL TOUR EN EL VALLE DEL LOS TEMPLOS (AGRIGENTO) \\ Elisa Bonacini ${ }^{a, b}$ \\ a Università di Catania, Dipartimento di Scienze Umanistiche, Piazza Dante 32, 95124 Catania, Italia. ebonacini@unict.it \\ ${ }^{\mathrm{b}}$ IEMEST, Istituto Euro Mediterraneo di Scienze e Tecnologie, Via Michele Miraglia 20 - 90139 Palermo, Italia
}

\begin{abstract}
:
The aim of this paper is to offer a preview of the pilot project in progress at the Unesco site Agrigento Valley of the Temples (Italy). Thanks to a partnership with Google Business Photos/Street View Indoor, we managed to map the Temple of Juno Lacinia, the only temple that can be visited online on a $360^{\circ}$ tour on a Google platform, browsable inside. Also some POls will be selected which can be clicked and explored, taking captions in Italian and in English languages with descriptive sheets of architectural and decorative elements, videos and aerial virtual tours realized with drones.
\end{abstract}

Key words: virtual archaeology, virtual heritage, cultural heritage, Google, Greek archaeology

\section{Resumen:}

El objetivo del presente artículo es ofrecer una vista previa del proyecto piloto en curso en el Unesco sitio de la Agrigento Valle de los Templos (Italia). Gracias a la asociación con Google Business Photos/ Street View Indoor logramos un mapa de el Templo de Juno Lacinia, el único templo que se pueden visitar en una plataforma de Google en una gira $360^{\circ}$, navegable interior. También se seleccionará algunos puntos de interés que puede engancharse y explorado, teniendo subtítulos en idiomas italiano y Inglés con fichas descriptivas de los elementos arquitectónicos y decorativos, videos y visitas virtuales realizados con aviones teledirigidos.

Palabras clave: arqueología virtual, herencia virtual, herencia cultural, Google, arqueología greca

\section{Born of the pilot project}

This project was born in collaboration with Mr. Gianfranco Guccione, a certified Google Business Photo photographer, to "increase" fruition and enhancement of Sicilian cultural heritage.

It was decided to choose as a sample of this pilot project two cultural regional institutions.

The very first example of this project has been carried out at the "Paolo Orsi" Regional Archaeological Museum in Syracuse, now browsable at the museum link http://www.regione.sicilia.it/beniculturali/museopaoloorsi/ google-maps/museo-paolo-orsi-siracusa-primopiano/index.php (Bonacini 2015).

The second one is the Valley of the Temples in Agrigento, that is the very first UNESCO Sicilian site since 1997 and, with its 1300 hettars (Fig. 1), the bigger archaeological park in the world.

The project at the Valley of the Temples was then structured as a research fellow project at the University of Catania and carried out in close collaboration with the staff of the Archaeological Park. The ultimate goal of our projects is to begin to solve the Sicilian cultural heritage gap on the web (Bonacini 2015: 155-156).

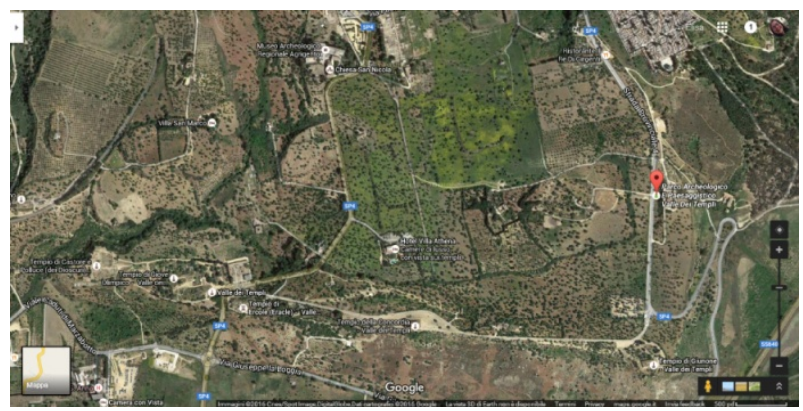

Figure 1: The Agrigento Valley on Google Maps, Italy.

Here we are going to present a Street View level virtual tour in progress, regarding a portion of the Valley with the Temple of Juno Lacinia, "augmented" by virtual aerial tours, videos and the addition of description, photos and virtual tour of the ancient temple. 


\section{The Temple of Juno Lacinia}

The Temple of Juno Lacinia stands on top on a raised spur, in large part artificial, in the South-East corner of the Valley of the Temples (Fig. 2). It was built in local yellow limestone in the middle of the fifth century $B C$ about the year $450 \mathrm{BC}$, and it belongs to the Doric style (Mertens 2006: 386-390). The building, facing East (Fig. 3 ), is around 38.15 metres long by 16.90 metres wide; it has 6 columns on the short sides and 13 on the long ones (it is an hexastyle peripteros, for a total of 34 columns), resting on a crepidoma of 4 steps, according to a Greek homeland canon used both for this temple and for the most famous Temple of Concord.

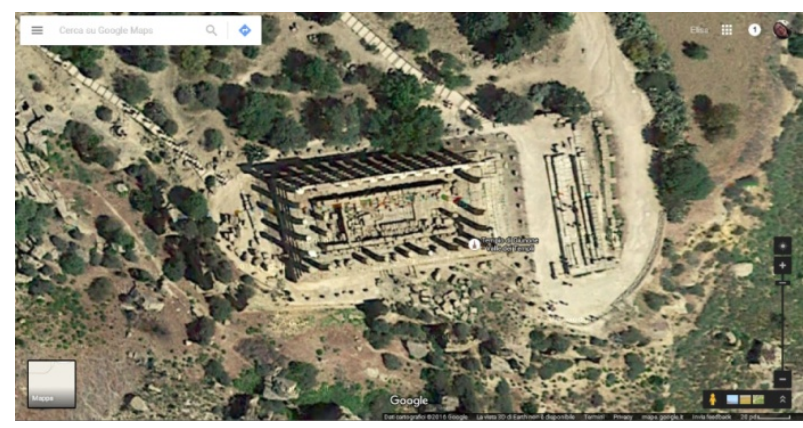

Figure 2: The Juno Lacinia Temple on Google Maps, Agrigento, Italy.

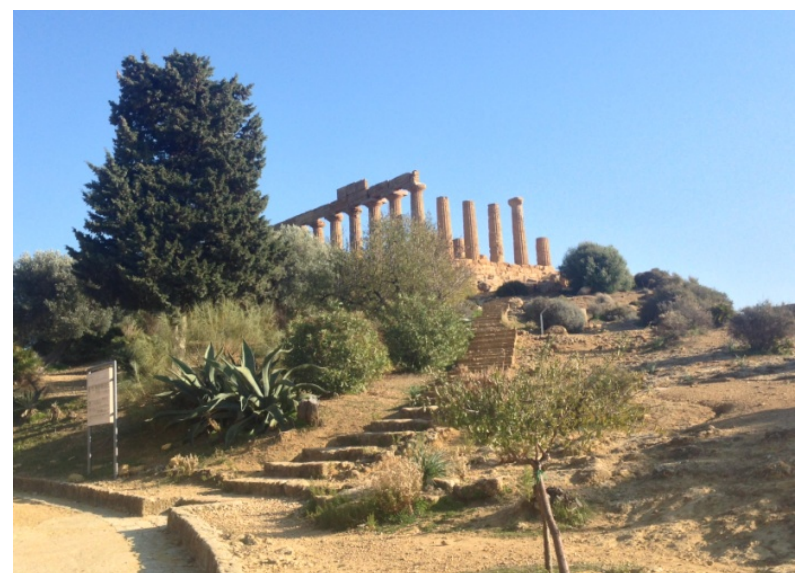

Figure 3: The hill with the Juno Lacina Temple, Agrigento, Italy.

The interior of the temple is the cella (naos), the inner area that was used to house the hidden cult image of the God. The entrance was manumentalized by a pronaos (this is the so called antis type), that is mirrored by the opisthodomos at the back - both framed by 2 ranks of columns (distyle). Stairs were built into the wall, separating the naos from the pronaos, perhaps used for the inspection of the roof or for religious purposes.

The temple was restored at the end of III century BC, when Sicily become a Roman province: the original marble roof was being replaced by one made of terracotta tiles.

The building has been being restored using anastylosis since the eighteenth century: today, after 30 columns are standing but only the northern colonnade with the architrave and part of the frieze is completely preserved; only 16 columns stands with their capitals. In front of the eastern face are the remains of the ancient altar.

\section{The pilot project at the Temple of Juno}

A photographic survey began with the aim of mapping all the area of the Temple of Juno Lacinia. We worked with the full cooperation of the staff of the Archaeological Park, in particular director Arch. Giuseppe Parello and Dr. Maria Serena Rizzo.

Mr. Guccione used a mobile station made up by a reflex camera with fisheye type camera lens, tripods with panoramic head. We chose clear days, to avoid sudden cloudiness during the shots and take in its best the yellow-pink color of the stone.

We present here some pictures from the backstage shooting (Figs. 4 y 5) and some screenshots of the virtual online tour (Fig. 6 y 7). We photographated all the areas around the temple in all its perimeter and, finally, also its inside to make it possible, for the first time ever, the virtual tour of a Greek temple inside. We hope the remote user could perceive the same emotion that we felt upon entering the cell of the temple, seeing the blocks closely, while running across the walkway along the side of the cell, between it and the columns, until getting a look over the opisthodomus' side and admire the Valley with the Temple of Concord in distance at the bottom, following a not allowed path in a traditional visit.

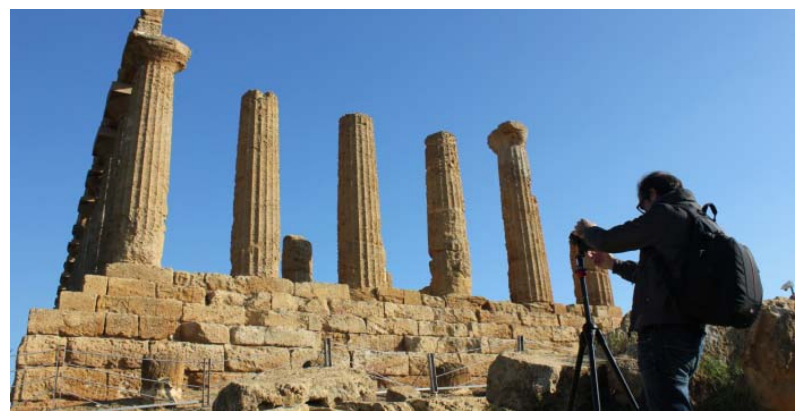

Figure 4: The Juno Lacinia Temple pilot project backstage.

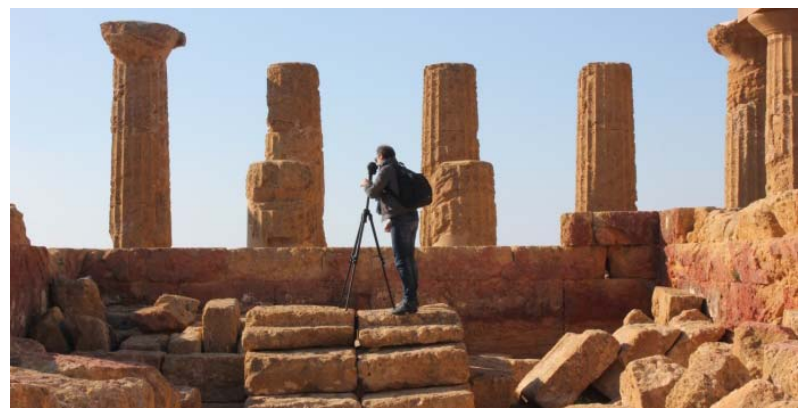

Figure 5: The Juno Lacinia Temple pilot project backstage.

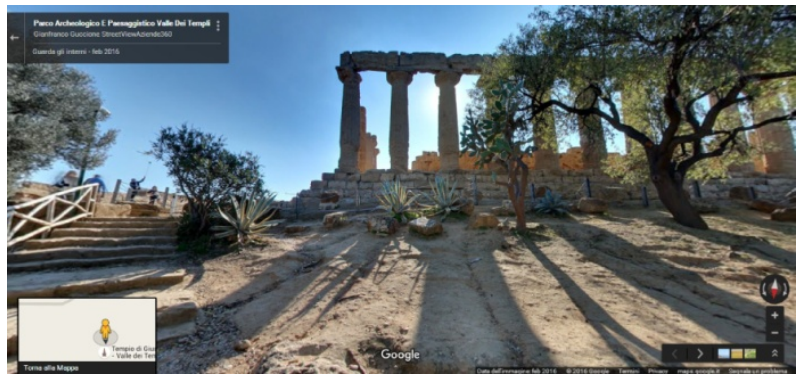

Figure 6: The Juno Lacinia Temple virtual tour on Google Street View. 


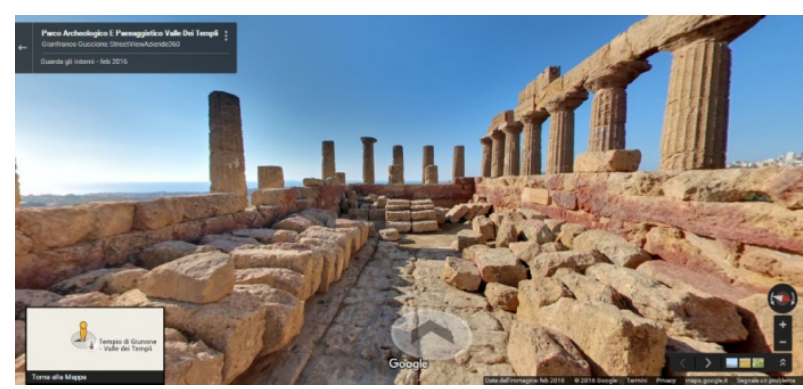

Figure 7: The virtual tour of the cella of the Juno Lacinia Temple on Google Street View.

Once loaded on Google's software, the pack of images were geolocated in Street View, mounted avoiding defects of sight between the images: the traditional Street view $360^{\circ}$ virtual tour is here https://goo.gl/maps/KJxK7NGgSfy, where the remote user can browse and enter in the temple.

We are going to "augment" this traditional street view tour through a POI with general information on the Valley, POls about the Temple, its architectonic details and the educational panels along the route. Captions will be both in English and in Italian languages, as in the "Paolo Orsi" Museum project.

The project will provide the opportunity to carry out a $360^{\circ}$ "augmented" virtual tour, innovative compared to what has been previously seen on Google's platforms: the aerial virtual tour will allow the virtual visitor to browse the temple with a never seen perspective.

\section{Conclusion}

The use of satellite imagery for scientific research has dramatically improved. Maps tools like Earth and Street View increase, for e.g., the functionalities in virtual globes for geographic studies at the global scale on environmental changes (Yu and Gong 2011).

After aerial photography and satellite imagery used in the last century (Parcak 2009), Google Earth and its maps tools, as scholars state (Meyers 2010; Thakuria et al. 2013), become the faster and publicly available tool for archaeological research to acquire vertical perspectives on archaeological landscapes and locate and identify ancient sites, or, to reconstruct 3D models on Earth (Lonneville et al. 2015) and disseminate archaeological data (Welham et al. 2015).

This project is an example how to increase access to the world of art and culture and to improve visit experiences through Google multimedia solutions.

We can rightfully say that it is the first archaeological temple in the world and the first archaeological monument in Sicily entirely browsable on Google Maps platforms with a traditional virtual tour, also inside, and with an aerial $360^{\circ}$ virtual tour with integration of captions and description of architectural elements. In that a way, we can give the user two levels of understanding, both for who lacks specific skills and for who wants to examine artworks in a more intimate perception and a closer knowledge.

The integration of Google web platforms with mobile devices through Street View and Google + services, can enable users to visualize multimedia facilities (POls with $360^{\circ}$ virtual tour and captions) even when they are walking around and looking at the temple: combined with Qr codes or sensor technologies, traditional captions allow those who are physically visiting the Temple of increase their visit by accessing depth digital contents.

Finally, the possibility to display a $360^{\circ}$ virtual tour through cheapest devices for immersive visualization, such as Google Cardboards, may allow to further "augmented" the in situ visit of the Temple, by providing its internal digital accessibility.

In the near future we hope to allow $360^{\circ}$ "augmented" visualization of all the Temples and archaeological evidences of the Valley, with their accompanying captions in audio version.

\section{References}

BONACINI, E., 2015. A Pilot Project with Google Indoor Street View: a 360 tour of "Paolo Orsi" Museum. SCIRES, 5(2), pp.151-168. DOI: http://dx.doi.org/10.2423/i22394303v5n2p151.

LONNEVILLE, B., DE ROO, B., STAL, C., DE WIT, B., DE WULF, A. and DE MAEYER, P., 2015. Google Earth and KML as GIS tools for 3D archaeological models. Computer Applications \& Quantitative Methods in Archaeology (CAA 2015). Available: https://biblio.ugent.be/record/6842704 [8/3, 2016]

MERTENS, D., 2006. Città e monumenti dei Greci d'Occidente, Roma 2006.

MYERS, A., 2010. Camp Delta, Google Earth and the ethics of remote sensing in archaeology. World Archaeology, Archaeology and Contemporary Society, 42(3), pp. 455-467. DOI:10.1080/00438243.2010.498640.

PARCAK, S.H., 2009. Satellite Remote Sensing for Archaeology. London: Routledge.

THAKURIA, T., PADHAN, T., MOHANTY, R.K. and SMITH, M.L., 2013. Google Earth as an Archaeological Tool in the Developing World: An Example from India. The SAA Archaeological Record, 13(1), pp. 20-24.

YU, L. and GONG, P., 2011. Google Earth as a virtual globe tool for Earth science applications at the global scale: progress and perspectives. International Journal of Remote Sensing, 33(12), 3966-3986.

WELHAM, K., SHAW, L., DOVER, M., MANLEY, H., PARKER PEARSON, M., POLLARD, J., RICHARDS, C., THOMAS, J. and TILLEY, C., 2015. Google Under-the-Earth: Seeing Beneath Stonehenge using Google Earth - a Tool for Public Engagement and the Dissemination of Archaeological Data. Internet Archaeology 40(5). DOI:10.11141/ia.40.5. 


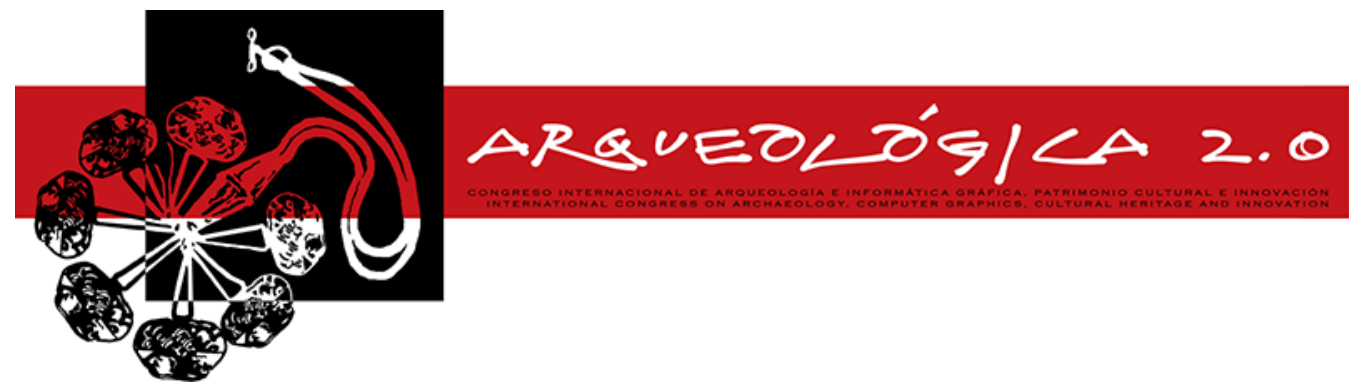

Proceedings of the $8^{\text {th }}$ International Congress

on Archaeology,

Computer Graphics,

Cultural Heritage and Innovation

'ARQUEOLÓGICA 2.0'

in Valencia (Spain),

Sept. $5-7,2016$

\title{
COMMUNICATING THE CUTURAL HERITAGE THROUGH THE USE OF DRONES, 3D MODELS AND APP. CASE OF STUDY: "FERRAN3DINA"
}

\author{
DIFUNDIR EL PATRIMONIO CULTURAL A TRAVÉS DEL USO DE DRONES, MODELOS 3D Y APPS. CASO DE \\ ESTUDIO: "FERRAN3DINA"
}

\author{
Antonio Pecci \\ National Research Council, CNR-IBAM, Tito Scalo (Pz), Italy, a.pecci@bam.cnr.it
}

\begin{abstract}
:
In recent years we have witnessed to a great change in the archaeological and architectural relief due to the introduction of the laser scanner (Böhler 2006; Vosselman and Maas 2010) and to the improvement of the Structure from Motion techniques (Remondino and El-Hakim 2006; Caprioli and Scognamiglio 2009). These new methods allow the restitution of accurate 3D models of small objects, monuments, and territories, for the purpose of study, documentation, divulging, monitoring and restauration (Kourtzellis 2009; De Reu 2013; Hörr and Brunnett 2013; Forte et al. 2015). The data acquisition is made through the use of UAVs (Unmanned Aerial Vehicles) (Colomina and Molina 2014), tools that are becoming ever more economic and efficient. Through the utilization of a drone and by the application of SFM techniques we can realize 3D models in a short time and with reduced costs. This models can be published on the internet or implemented on an APP for tablet or smartphone. Through new technologies we can take advantage of digital content in 3D (Bruno et al. 2010) to observe artifacts, historic buildings and archaeological sites through a different, intriguing and interactive approach, improving communication as well as encouraging real visits of the objects. In the following contribution we first create the 3D models of particular prestigious buildings of the city of Ferrandina (Basilicata, Italy) and after an APP for smartphones and tablets that allows viewing in three dimensions of some monuments, accompanied by a descriptive card and useful information such as opening times, etc. This is a work-in-progress project so the early interesting results presented here are partial.
\end{abstract}

Key words: UAV, 3d model, APP, SfM, cultural heritage, tourism.

\section{Resumen:}

En los últimos años hemos asistido a un gran cambio en el levantamiento arqueológico y arquitectónico, debido a la introducción del escáner láser (Böhler 2006; Vosselman and Maas 2010) y la mejora de las técnicas de SFM (Remondino and El-Hakim 2006; Caprioli and Scognamiglio 2009). Estos nuevos métodos permiten la restitución de los modelos 3D precisos de pequeños objetos, monumentos y sitios, con el propósito de estudio, documentación, divulgación, vigilancia y restauración (Kourtzellis 2009; De Reu 2013; Hörr and Brunnett 2013; Forte et al. 2015). La adquisición de datos se hizo en su mayoría desde arriba, mediante el uso de UAVs (Unmanned Aerial Vehicles) (Colomina and Molina 2014), es más económica y eficiente. A través de la utilización de un dron y mediante la aplicación de técnicas de SFM podemos tener modelos 3D en un poco tiempo y a coste reducido, los modelos pueden ser publicados en Internet o implementados en una aplicación para tablet o smartphone. A través de las nuevas tecnologías podemos ayudarnos de los contenidos digitales en 3D (Bruno et al. 2010) para observar objetos, edificios históricos, sitios arqueológicos a través de un enfoque diferente, interesante e interactivo, mejorar la comunicación, así como fomentar las visitas reales de objeto. En la siguiente contribución se procedió en primer lugar a la creación del modelo 3D de determinados edificios prestigiosos de la ciudad de Ferrandina (Basilicata, Italia) y después a la creación de una aplicación para teléfonos inteligentes y tabletas que permiten ver en tres dimensiones algunos monumentos, acompañados de un tarjeta descriptiva e información útil, como los horarios de apertura, las direcciones de las rutas, etc. En este artículo presento el trabajo parcial, dejando al descubierto los primeros resultados interesantes.

Palabras clave: UAV, modelo 3d, APP, SfM, patrimonio cultural, turismo.

\section{Introduction}

Ferrandina (Basilicata, Italy) is located on a hill on the right side of the river Basento, $480 \mathrm{~m}$. above sea level, thirty kilometers from Matera (European Capital of
Culture in 2019) and about forty kilometers from the Ionian coast of Basilicata (Fig.1). The old town of Ferrandina has a continuity of life from the VIII century B.C. until to the present day, but the most important and impressive monuments are dated to the modern age 
(Lisanti and Barbone 1987; Palestina 1994; Palestina 1996). From the XV century, during the Aragonese period, prestigious buildings and noble palaces were built and they are attractors of tourists coming mainly from Matera and Metaponto. To increase the awareness of the cultural heritage of Ferrandina was born "Ferran3dina", an APP for Android smartphones which displays some cultural goods in 3D, made through the use of drones and SFM (Neitzel and Klonowski 2011; Nex and Remondino 2013; Pecci et al. 2015; Lasaponara et al. 2016). The sites identified to detect using the drone are about ten (although the list is absolutely provisional): the castle of Uggiano, the monastery of San Domenico, the convent of Santa Chiara, the church of Santa Maria della Croce, some houses of historical center characterized by their unique architecture, the monastery of San Francesco. At present have been detected and included in the APP the first two of the list.

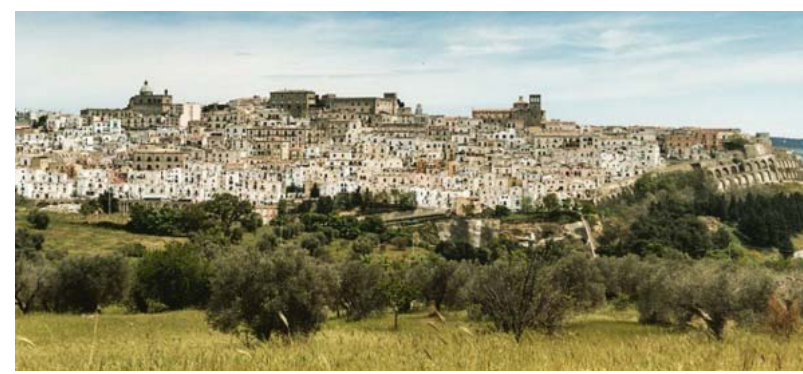

Figure 1: Ferrandina (Basilicata, Italy).

\section{The castle of Uggiano}

The castle of Uggiano (Fig.2), a very important fortified medieval site, is situated a few kilometers from Ferrandina (Matera, Basilicata). It stands on a hill at 420 meters above sea level to control the valleys of Vella and Salandrella streams. The ruins of its towers still dominate a very extensive area from the Ionian coast of Basilicata until the Calabrian mountains. The written sources, although they are very rare, allow us to dated the castle before 1029 (Protospata 1731, p. 102). Some episodes, like the retreat in the walls of the castle of Robert the Guiscard (he was not able to conquer the city of Montepeluso in $1068^{1}$ ) lets us know the names of many owners from Norman period ${ }^{2}$ until the end of the fourteenth century, period in which the castle was probably abandoned (Alberti 1595). Although the Uggiano castle has an architectural structure of considerable interest among the castles of the south of Italy, archaeological excavations, research and study projects have never been carried out. The defensive structure, articulated on an irregular polygonal plan, was made up of high walls of three meters thick and imponent towers. In the defensive circuit there are the ruins of several buildings, a noble residence and a chapel.

\footnotetext{
${ }^{1}$ Ibidem, pag. 109; SALERNITANUS R., 1804, p. 187.

2 In the Catalogus Baronum it is mentioned Rogerius de Ogiano.
}

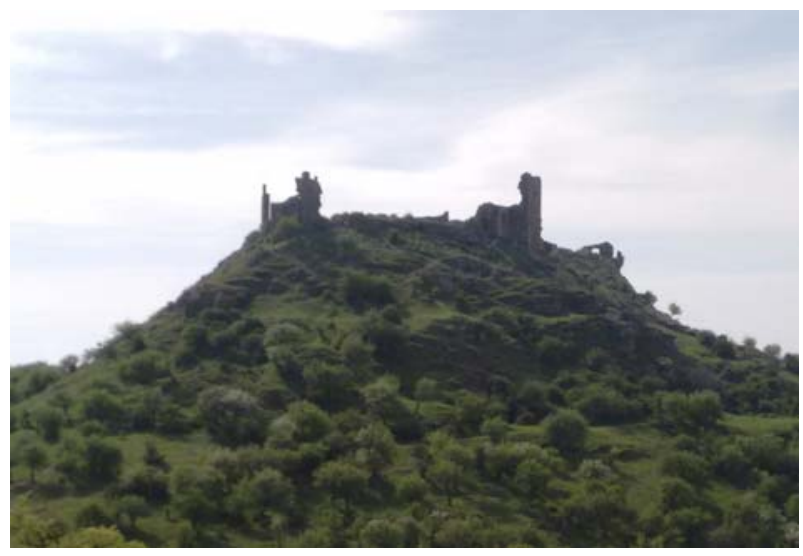

Figure 2: General outer view of the castel of Uggiano (Ferrandina, Basilicata, Italy).

\section{The monastery of San Domenico}

The construction of the monastery of San Domenico (Fig.3) began in 1721 and the opera project was entrusted to the engineer Andrea Molto of Rome, who used skilled workers from Puglia and Campania. It is a very large building with cloister, directly connected to the sixteenth century's San Domenico church. The dominant element is the dome covered with majolica that overhangs the entire building. Inside the monastery there is a cloister with a square layout; the central space is composed of twenty pillars as a continuous porch of twenty cross vaults. At the center of the cloister there is a well and the courtyard is paved. Above the vaults are located different rooms that currently home the high school. After the recent restauration work, the monumental complex houses the municipal library, the municipal historical archive, the high school and the cloister is used for cultural activities.

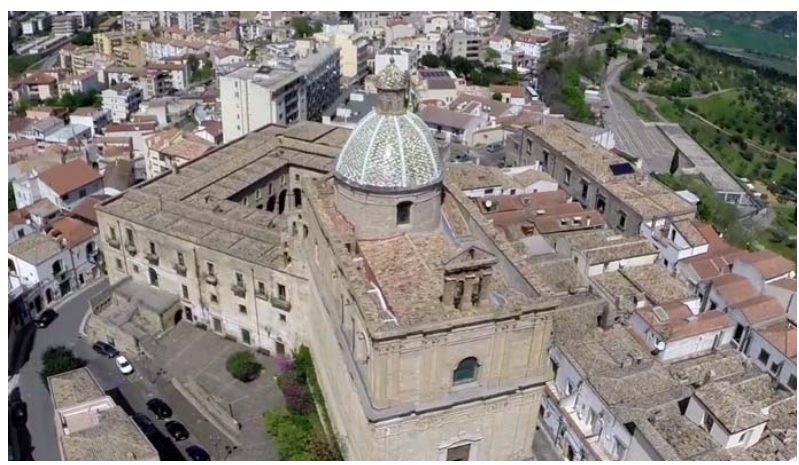

Figure 3: View from the drone of the monastery of San Domenico (Ferrandina, Basilicata, Italy)

\section{Acquisition and processing data}

Before making a photogrammetric capture, the drones require flight planning and the control of the area, these are fundamental operation for the acquisition of the images to the desired resolution. The photogrammetric acquisition is conditioned by the topography of the site, the presence of potential dangers such as electrical cables, buildings, the weather conditions and the stability of the flying platform. In our case, and according to our configuration, displacements of the drone are monitored on our smartphone and controlled in real time, the shots are automatic by setting the time-lapse feature to 3 
seconds. After we have been planned the flight and prepared the $\mathrm{UAV}^{3}$ (Fig.4), we proceed with the flight and in the acquisition of the images.

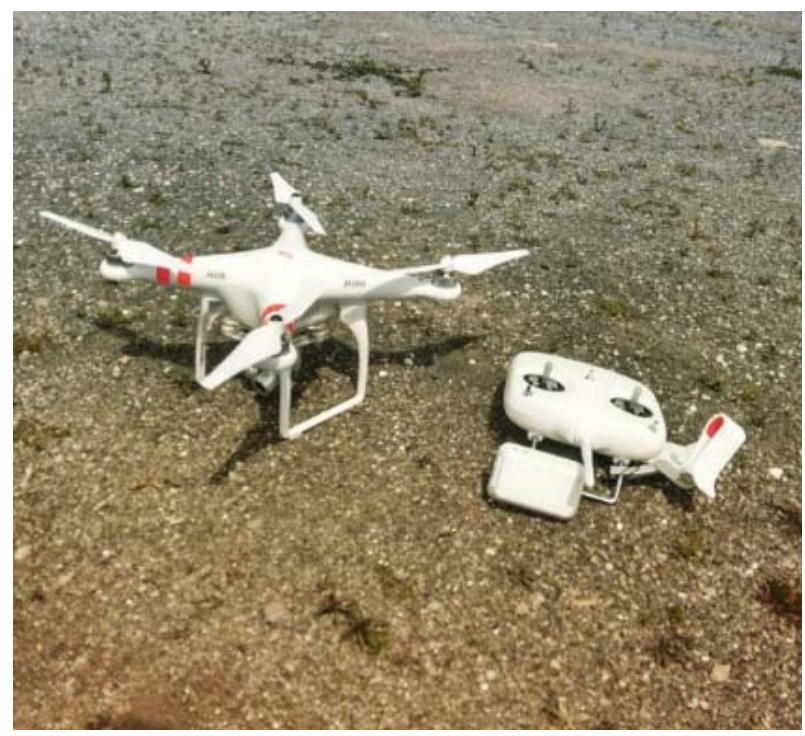

Figure 4: Phantom Vision 2 plus

To achieve a complete and detailed photogrammetric coverage in the two cases in exam we made acquisitions of zenith photographs (at a constant height of 30 meters above the ground) and of oblique photos to resume the elevations of buildings. After that, the photos were processed to obtain the point cloud, mesh and textured 3D model AgisoftPhotoScan. This software is characterized by user-friendly interface and is based on a semi-automated workflow (the program manages the entire phase of work, from the orientation of the picture until the creation of the outputs).

\section{Ferran3dina}

The APP for Android devices "Ferran3dina" comes from a similar project dedicated to the fortified heritage of Basilicata, "BasiliCastle"" (Masini et al. 2014) made by IBAM CNR of Tito Scalo (Potenza, Italy) and in collaboration with the Italian Castle Institute (section Basilicata). "Ferran3dina" has been realized through the free platform "App inventor 2" . This suite features a quick and simple interface for the realization of very complex applications and also it does not require the knowledge of programming languages. After created the graphics and added contents you proceed to the creation of the basic logical scheme that allows operation. For each monument there is a descriptive card (Fig.5) with some information such as the location on google maps, directions, photos, opening hours, etc.) and the link for the 3D visualization of the object on "Sketchfab" 6 website. When we upload our 3D models we proceeded to decoding web links related to the models of $Q R$ codes. The $Q R$ Code can be inserted

${ }^{3}$ Dji Phantom Vision 2 plus:

http://www.dji.com/product/phantom-2-vision-plus

${ }^{4} \mathrm{http}: / / \mathrm{www}$.basilicastle.it/pages/Home.html

${ }^{5} \mathrm{https}$ ://ai2.appinventor.mit.edu/

${ }^{6} \mathrm{https}: / /$ sketchfab.com/ everywhere, from brochures to books, from the website informative panels to the map of the city of Ferran3dina, in correspondence of its monuments made in 3D.
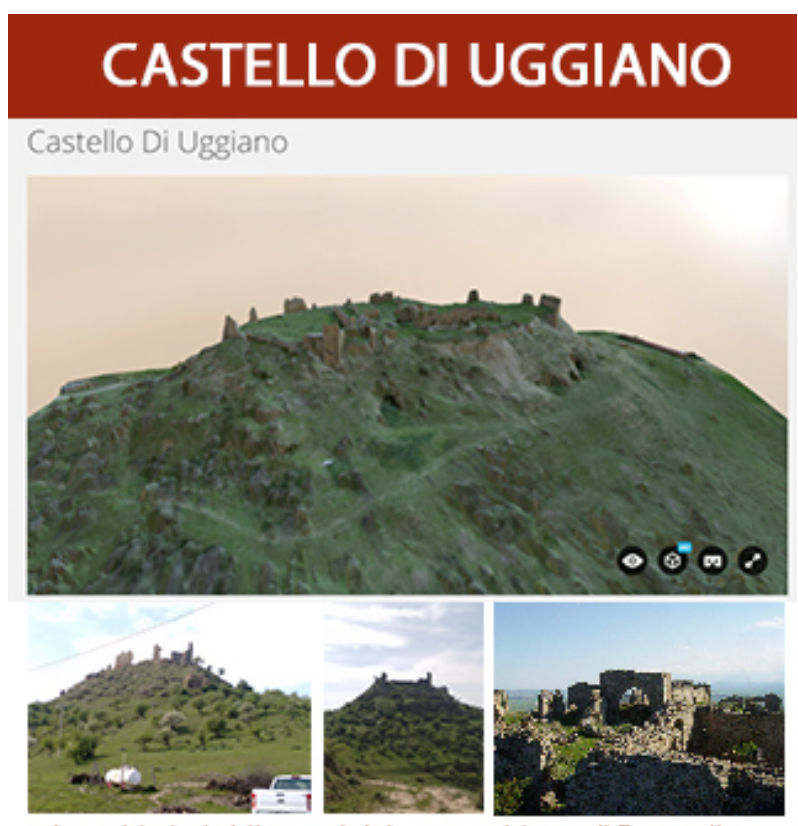

A pochissimi chilometri dal centro abitato di Ferrandina (Matera, Basilicata) è presente un complesso fortificato di età medievale di notevole importanza: il castello di Uggiano. Esso sorge su una collina 420 metri sul livello del mare a controllo delle valli del torrente Vella e del fiume Salandrella. Dalle rovine delle sue torri è ancora tuttora possibile dominare un'estesissima area che va dalla prospicente costa jonica della Basilicata fino ai

Figure 5: Screenshot from "Ferran3dina". Datasheet of the castel of Uggiano.

\section{Conclusions}

The city of Ferrandina presents an important cultural heritage but little valued. Each monument chosen by us for its historical value and importance, inserted inside in the APP "Ferran3dina", has requested a bibliographical search and a deep study. The creation of the APP for Android through the online platform free "App Inventor" does not require a deep or specific computer knowledge, allowing its use even to beginners. One of the strengths is the card of each monument is precisely in the visualization in 3D of the same, realized through the use of drones and SFM techniques. The processing of these three-dimensional models requires, however, a deep practical knowledge in the use of the drone and the Structure from Motion technology. Through new technologies, students, researchers and tourists can take advantages from 3D digital contents observing historic buildings, archaeological sites, artifacts, etc. They allow exploration of the assets in a new, fast, complete and intriguing perspective. In our case, the 3D models were realized used to create innovative digital content, virtual tours and to improve the communication of information of the cultural heritage of the city of Ferran3dina. The digital cultural offerings must be planned on key points such as storytelling, emotional experience related to cognitive processes. The elements created by augmented reality fascinate the user without forgetting the historical and scientific reference. The 
technology has to be a real support to learning traditional knowledge, the dissemination and the promotion of the cultural heritage.

\section{References}

ALBERTI, L., 1595. Descrittione di tutta Italia, Bologna.

BRUNO, F., BRUNO, S., DE SENSI, G., LUCHI, M.L., MANCUSO, S. and MUZZUPAPPA, M., 2010. From 3D reconstruction to virtual reality: A complete methodology for digital archaeological exhibition. Journal of Cultural Heritage, 11, pp. 42-49. DOI: 10.1016/j.culher.2009.02.006

BÖHLER, W., 2006. Comparison of 3D laser scanning and other 3D measurement techniques. In: M. BALTSAVIAS, A. GRUEN, L. VAN GOOL and M. PATERAKI, eds, Recording, Modeling And Visualization of Cultural Heritage. London: Taylor \& Francis Group, pp. 89-100. DOI: 10.1002/oa.1156

CAPRIOLI, M. and SCOGNAMIGLIO, A., 2009. Low cost methodology for 3D modelling and metric description in architectural heritage. Proceedings 3D-ARCH 2009: 3D Virtual Reconstruction and Visualization of Complex Architectures, XXXVIII/5-W1.

COLOMINA, I. and MOLINA, P., 2014. Unmanned aerial systems for photogrammetry and remote sensing: A review. ISPRS Journal of Photogrammetry and Remote Sensing, Volume 92, pp. 79-97. DOI:10.1016/j.isprsjprs.2014.02.013

DE ReU, J., Plets, G., Verhoeven, G., BATS, M., CherRetté, B., DE MAEYeR, W., DE SMEDT, P., DECONYNCK, J., HERREMANS, D., LALOO, P., VAN MEIRVENNE, M. and DE CLERCQ, W., 2013. Towards a three-dimensional cost-effective registration of the archaeological heritage. Journal of Archaeological Science, 40(2): pp. 1108-1121. DOI: 10.1016/j.jas.2012.08.040

FORTE, M., DELL' UNTO, N., JONSSON, K. and LERCARI, N., 2015. Interpretation Process at Çatalhöyük using 3D. 20th Annual Meeting of the European Association of archaeologists (EAA2014), 10-14 September 2014, Istanbul, Turkey.

HÖRR, C. and BRUNNETT, G., 2013. Boon and Bane of High Resolutions in 3D Cultural Heritage Documentation. Bock, H.G. et al. (eds.) Scientific Computing and Cultural Heritage. Springer-Verlag Berlin Heidelberg, pp. 31-39. DOI: 10.1007/978-3-642-28021-4_4

KOURTZELLIS, Y., 2009. A Critical Approach to Digital Three-Dimensional Representation of Monuments [Kritiki prosegisi ton psifiakon 3D anaparastaseon mnimeion]. Archaiologia kai texnes, 113, pp.11-16.

LASAPONARA, R., MASINI, N., PECCI, A., PERCIANTE, F., POZZI, D., RIZZO E., SCAVONE M. and SILEO M., 2016. Qualitative evaluation of COSMO SkyMed in the detection of earthen archaeological remains: the case of Pachamacac (Peru)", Journal of Cultural heritage, 2016, in press.

LISANTI, N. and BARBONE, N., 1987. Ferrandina recupero di una identità culturale (Catalogo della mostra, MaggioLuglio 1987), Galatina, Congedo Editore.

MASINI, N., BISCIONE, M., DANESE, M., PECCI, A., DANTONIO, A. and SCAVONE, M., 2014. Nuove tecnologie per la tutela e la valorizzazione del patrimonio fortificato: l'Atlante Digitale dei Castelli di Basilicata, in Fortificazioni, memoria, paesaggio. Convegno scientifico in occasione dei cinquant'anni di attività dell'Istituto Italiano dei Castelli, 1964-2014. Riassunti delle relazioni, a cura di Vittorio Foramitti ed Enrico Lusso, Editrice Universitaria Udinese srl, Udine, p. 137.

NEITZEL, F. and KLONOWSKI, J., 2011. Mobile 3d mapping with a low-cost UAV system, Int. Arch. Photogramm. Remote Sens. Spatial Inf. Sci., XXXVIII-1/C22, pp. 39-44. DOI: 10.5194/isprsarchives-XXXVIII-1-C22-39-2011

NEX, F. and REMONDINO, F., 2013. UAV for 3D Mapping Applications: A Review. Applied Geomatics, 6, pp.1-15. DOI: $10.1007 / \mathrm{s} 12518-013-0120-\mathrm{x}$

PALESTINA, C., 1994. Ferrandina. Volume primo. La terra di Oblano, dagli insediamenti enotri alla città di Ferrante, Venosa, Appia 2 editrice.

PALESTINA, C., 1996. Ferrandina, Volume quinto, territorio - viabilità - platee - masserie, Venosa, Appia 2 editrice.

PECCI, A., SCAVONE, M., MASINI, N., SILEO, M., DANTONIO, A. and MARZIO, C., 2015. "Innovative technologies for cultural heritage: the unmanned aerial vehicles" in REUSO 2015. III CONGRESO INTERNACIONAL SOBRE DOCUMENTACIÓN, CONSERVACIÓN Y REUTILIZACIÓN DEL PATRIMONIO ARQUITECTÓNICO Y PAISAJISTICO, a cura di L. Palmero Iglesias, Editorial UPV, Valencia, pp. 586-593.

PROTOSPATA L., 1731. Rerum in Regno Neapolitano Gestarum, ab anno Sal. 860 usque ad '1102 Breve Chronicon, in "Raccolta di varie Croniche, Diari ed altri opuscoli così italiano, come latini appartenenti alla storia del Regno di Napoli", Tomo II, Napoli, p. 102.

REMONDINO, F., and EL HAKIM, S., 2006. "Image-based 3D modelling: a review", in The Photogrammetric Record, $21-$ 115, pp.269-291. DOI: 10.1111/j.1477-9730.2006.00383.x 

"FERRAN3DINA"

SALERNITANUS R., 1804. Chronicon, in Reum italicarum scriptores, Tomo VII, p. I Muratori, Città di Castello, MDCCCIV, p. 187.

VOSSELMAN, G., and MAAS, H.G. 2010. Airborne and terrestrial laser scanning. Dunbeath, Whittles Publishing. 10.1080/17538947.2011.553487 


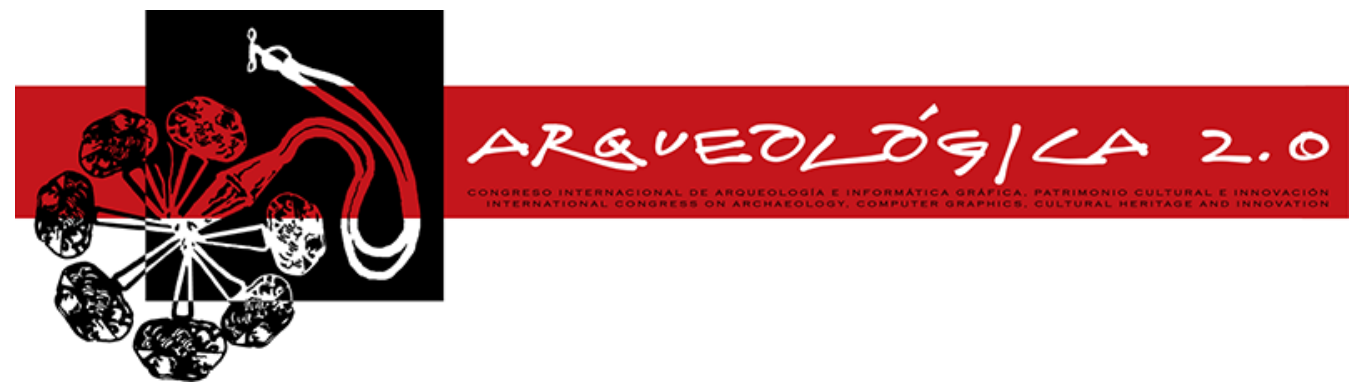

Proceedings of the $8^{\text {th }}$ International Congress

on Archaeology,

Computer Graphics,

Cultural Heritage and Innovation

'ARQUEOLÓGICA 2.0'

in Valencia (Spain)

Sept. $5-7,2016$

\title{
3D DIGITISATION AND RECONSTRUCTION OF A CAPITAL IN NORTH- WESTERN GAUL: INTERIM RESULTS ON THE CITY OF ALET
}

\author{
Yann Bernard ${ }^{a,{ }^{*}}$, Jean-Baptiste Barreau ${ }^{a}$, Catherine Bizien-Jaglin ${ }^{b}$, Laurent Quesnel ${ }^{a}$, Loïc \\ Langouët $^{b}$, Marie-Yvane Daire ${ }^{a}$ \\ a Laboratoire Archéosciences UMR 6566 CReAAH, 35000 Rennes, France. yann.bernard@univ-rennes1.fr; laurent.quesnel@univ- \\ rennes1.fr, jean-baptiste.barreau@univ-rennes1.fr, marie-yvane.daire@univ-rennes1.fr; \\ ${ }^{\text {b } C e n t r e ~ R e ́ g i o n a l ~ d ' A r c h e ́ o l o g i e ~ d ' A l e t, ~ B P ~} 6035413$ Saint-Malo, France. langouet.loic@wanadoo.fr, catherine.bizien- \\ jaglin@wanadoo.fr
}

\begin{abstract}
:
The City of Alet is an important archaeological site in Brittany because it was in the late Iron Age the capital of the Coriosolites. The remains, scattered today in a neighbourhood of Saint-Malo, are highly heterogeneous. Because of its great archeological interest, it has become since 2015 the subject of experimentation in digital archeology. From 3D scanning and Ground Penetrating Radar experimentation, we started a 3D reconstruction of city including several levels of uncertainty and fuelling archaeological thoughts, the results of which are still in discussion.
\end{abstract}

Key words: coastal and island archaeology, 3d scanning, ground penetrating radar, $3 \mathrm{~d}$ reconstruction

\section{Introduction}

\subsection{Archeological context}

The archaeological excavations carried out between 1971 and 1985 by L. Langouët (1987) at the foot of the promontory of Alet, ancient settlement previous to the modern town of Saint-Malo (Brittany France) (Fig. 1), helped to locate the Roman port of Reginca which is mentioned in the 'Peutinger Map', a medieval copy of an ancient road document. Located at the junction of several river and sea routes, the site of Reginca occupies a prominent place in the Normano-Breton Gulf, which is extended by the Rance and stands as a major traffic artery to penetrate far into the inland region. The artefacts found during the excavation, show diverse and sometimes remote origins which attest commercial activities throughout antiquity.

\subsection{Framework context}

In close cooperation with the research team CeRAA (Centre Régional Archéologique d'Alet), leader of the archaeological researches on the site of Alet, the Common Cultural Connections (CCC's) recently provided an opportunity to develop an interdisciplinary approach on the $3 \mathrm{D}$ digitalisation of the site and first reconstruction developments. The aim of the CCC' project is to enhance understanding of the shared cultural heritage of the three European partner regions through an innovative mobile exhibition (Daire and Momber 2014); then, the reconstruction of the Alet ancient port was developed as an illustration of the late prehistoric and roman saling roads and contacts along the Channel-Atlantic façade of Europe.

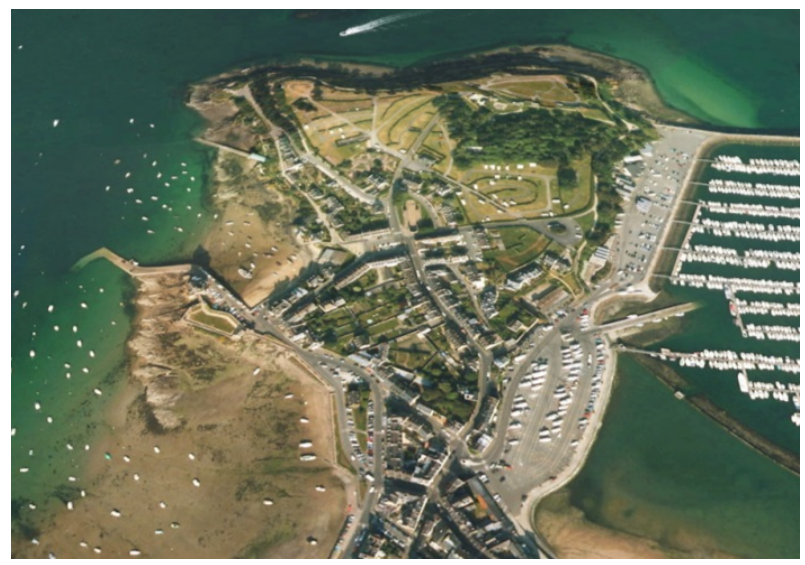

Figure 1: Google Earth view of the modern town of Saint-Malo.

\subsection{Diversity of the data sources : The benefits of an interdisciplinary approach}

The specificity of the Alet ancient city case study is the diversity of complementary sources of data available: underwater and terrestrial archaeology, historic sources (texts, ancient maps, photos and drawings), geophysical surveys and monitoring, environmental studies, etc. Each of them, taken independently, was not sufficient to draw a complete and accurante view of the past of this site. But, by combining the data, it became then possible

“Corresponding Author: Yann Bernard, yann.bernard@univ-rennes1.fr 
to propose a historic re-construction of the roman city, built on precise evidences completed by some hypothetical reconstructions.

\section{3D Laser and magnetic surveys}

\subsection{D laser survey}

In January 2015 and in the context of the WDCAH project (Barreau et al. 2013 and 2014), several archaeological structures (on the terrestrial and intertidal domain), previously excavated by the CeRAA team were scanned (Fig. 2). The scans were performed with a Focus3D X 330 particularly on the remains of an old retention pond which allowed, thanks to an ingenious pumping system, to provide potable water to the City.

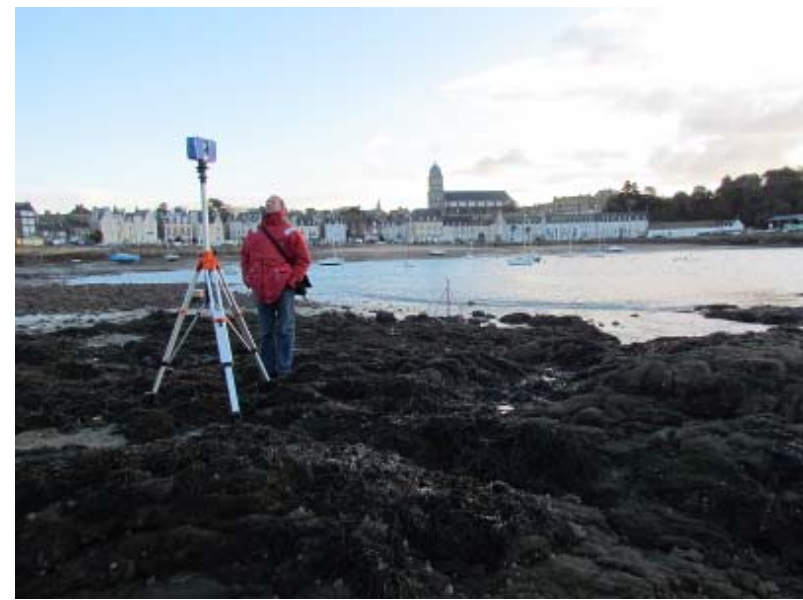

Figure 2: 3D laser survey of the seashore (doc. Y. Bernard).

\subsection{Ground Penetrating Radar}

Alongside terrestrial scanning, we also tried, in June 2015 , to detect buried remains. We used a Stream EM which is a multi channel Ground Penetrating Radar solution dedicated to utility locating and mapping (Conyers 2012). The results, difficult to read because of bomb craters from the Second World War, are studied and evaluated (Fig. 3).

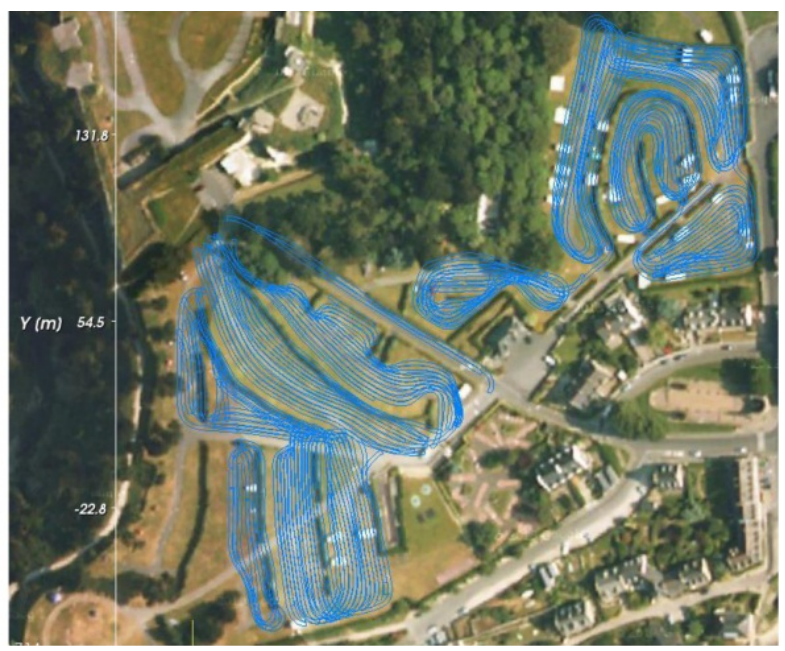

Figure 3: Area covered with the G.P Radar (doc. ABEM France).

\section{3D Modeling}

With the large volume of textual data and images (Fig. 4) from several decades of archaeological research, a 3D reconstruction work could begin. This was done with $3 \mathrm{ds}$ Max 2015/VRay 3 and involved both buildings that vegetation.

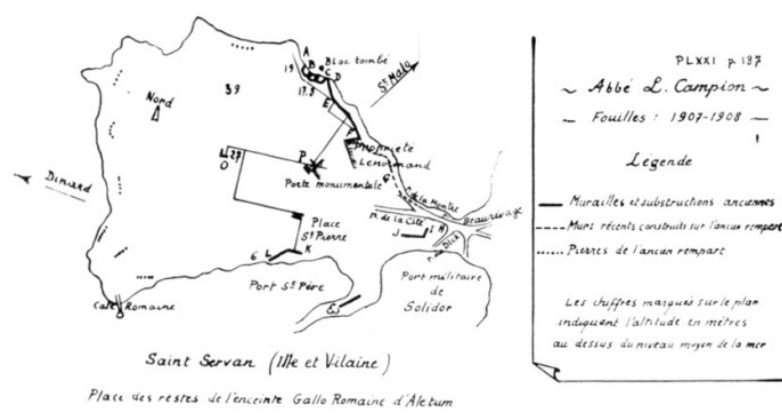

Figure 4: Map of the remains of the Alet urban boundary walls drawn by Abbé L. Campion in 1908 (Dos 1969).

The digitisation of the remains has been also integrated (Fig. 5). The alluvial cordon failure, known by archaeologists, was also considered for the reconstructions (Fig. 6 and 7).

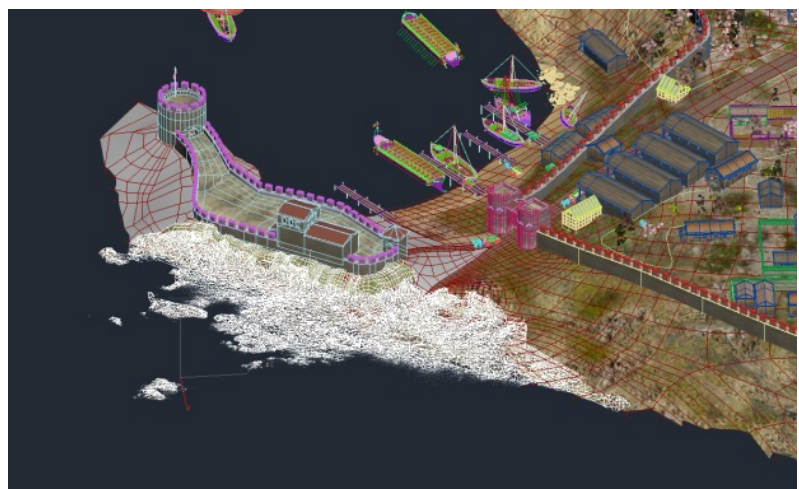

Figure 5: Mesh resulting from laser survey of the seashore archaeological features included in 3D model (white object) (doc. Y. Bernard, CNPAO, CCC's project).

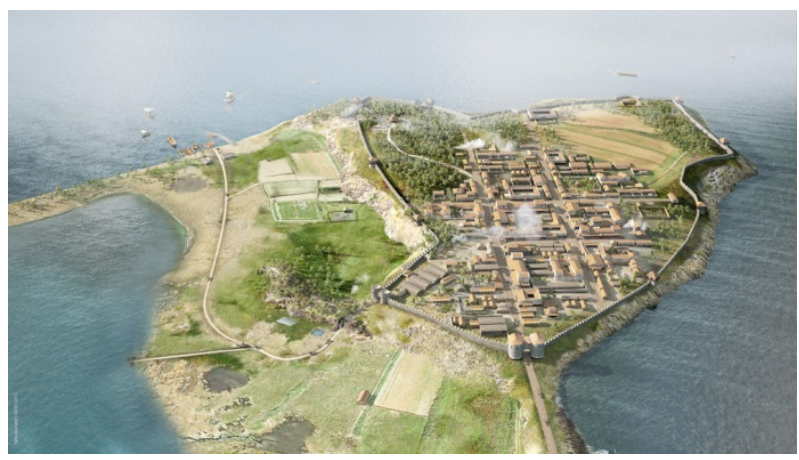

Figure 6: $3 \mathrm{~d}$ reconstitution of the Ancient city and port of Alet, before the break of the alluvial cordon during the 4th cent. $A D$ (doc. Y. Bernard, CNPAO, CCC's project).

In addition to our reconstitution, we used a graphical representation of the amount of historical/archaeological evidence of elements represented (Fig. 8). The scale of colors is adapted from the project Byzantium 1200 (Öner and Berger 1998) and from a table which represents the 
grade of evidence for the representation of elements in virtual archeology (Resco and Figueiredo 2014).

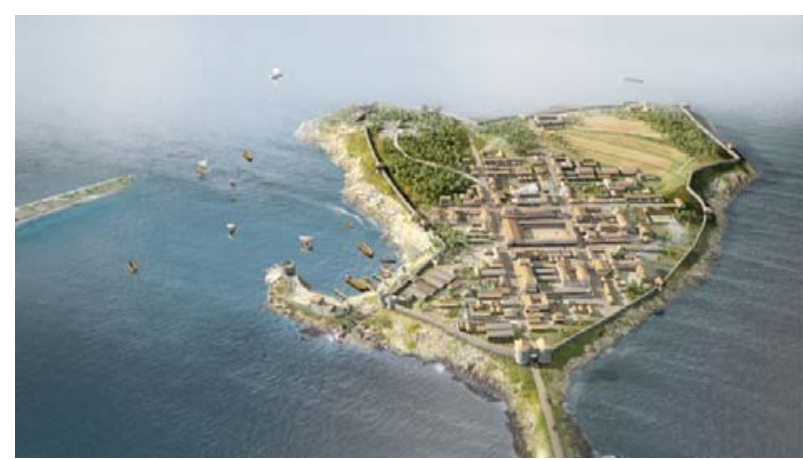

Figure 7: $3 \mathrm{~d}$ reconstitution of the Ancient city and port of Alet, after the break of the alluvial cordon during the 4 th cent. $A D$ (doc. Y. Bernard, CNPAO, CCC's project).

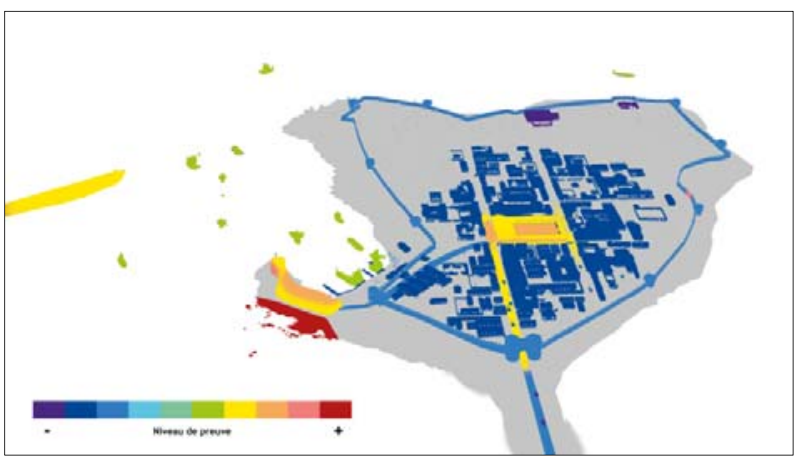

Figure 8: Ranking of the reconstitution this rendering shows the city as color coded according the grade of

historical/archaeological evidence (doc. Y. Bernard, CNPAO, CCC's project).

\section{Conclusion and future works}

\section{1. $3 \mathrm{~d}$ model as a dynamic compilation of knowledge}

The $3 d$ reconstitutions developed from a wide range of data synthesize the state of knowledge at any given time. The sense of affirmation caused by the photorealistic rendering can be qualified by the graphical commentary system highlighted above. $3 d$ files that make up the scene can be modified to adapt to new contributions and scientific discoveries.

\subsection{Future works: the 3D reconstruction applied to ancient/roman armorican cities}

The Alet case study presented above has to be considered as a preliminary work, essential in the improvement of the methodological process. Our aim is now to develop such approach in a wider geographical and culturel scope, covering the territory or Armorica (i.e. Western France area during the Roman Empire); our objective will be to propose $3 D$ reconstruction of the main roman cities, in order to allow comparative approach within the very large frame work of the Roman Empire territory.

\section{Acknowledgements}

The CCC' project is co-funded by the Creative Europe Programme of the European Union. It is led by the MAT (Maritime Archaeology Trust, Southampton, UK) and involves the Prehistory department of the Universtiy of Cantabria (Santander, Spain), and the CReAAH (Centre de Recherche en Archéologie, Archéosciences, Histoire, Rennes, France). We also want to thank the company ABEM France for the loan of the Stream EM multi channel Ground Penetrating Radar used in Alet.

\section{References}

BARREAU, J.B., GAUGNE, R., BERNARD, Y., LE ClOIREC, G. and GOURANTON, V., 2013. The West Digital Conservatory of Archaeological Heritage project. Proc. of Digital Heritage Int. Congress 2013, Vol. 1, pp. 547-554

BARREAU, J.B., BERNARD, Y., PETIT, Q., BEUCHET, L., PETIT, E., PlATEN, V., GAUGNE, R., LE RUMEUR, J. and GOURANTON, V., 2014. Combination of 3D scanning, modeling and analyzing methods around the castle of Coatfrec reconstitution, 5th International Conference EuroMed, pp. 418-426

CONYERS, L.B., 2012. Interpreting Ground-penetrating Radar for Archaeology. Left Coast Press. 220 pages.

DAIRE, M.Y. and MOMBER, G., 2014. What is the Common Cultural Connections Project? Available: http://commonculturalconnections.maritimearchaeologytrust.org/uploads/images/Posters/CCC_Leaflet_Teachers_act 4.pdf.

DOS, A., 1969. Cinq campagnes de fouilles archéologiques à la Cité d'Alet à Saint-Servan-sur-Mer. Annales de Bretagne Vol. 76, No. 1, pp. 229-245. DOI : 10.3406/abpo.1969.2515

LANGOUËT, L., 1987. Les fouilles archéologiques de la zone des cathédrales d'Alet. Saint-Malo : Dossiers du Centre Régional d'Archéologie d'Alet. 140 pages.

ÖNER, A.T. and BERGER, A. 1998. Byzantium1200 project. Available : http://www.byzantium1200.org

RESCO, P.A. and FIGUEIREDO, C., 2014. Escala de evidencia histórica | Scale of historical evidence Available: https://parpatrimonioytecnologia.wordpress.com/2014/07/21/escala-de-evidencia-historica-scale-of-historicalevidence. 


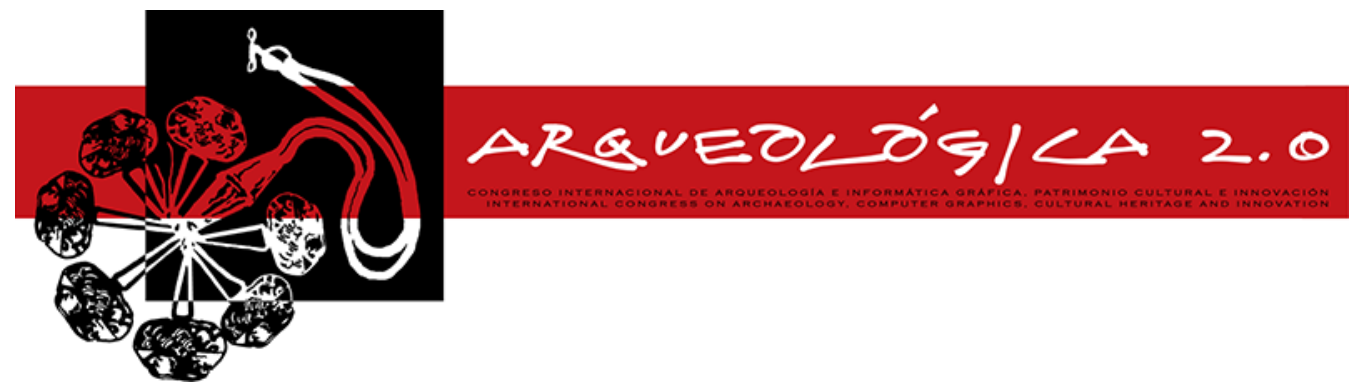

Proceedings of the $8^{\text {th }}$ International Congress

on Archaeology,

Computer Graphics,

Cultural Heritage and Innovation

'ARQUEOLÓGICA 2.0'

in Valencia (Spain),

Sept. $5-7,2016$

\title{
THE ROLE OF TANGIBLE INTERACTION FOR COMMUNICATING QUALITATIVE INFORMATION OF BUILT HERITAGE
}

\author{
Eslam Nofal ${ }^{a, b,},{ }^{*}$, Vanessa Boschloos ${ }^{c}$, Hendrik Hameeuw ${ }^{c}$, Andrew Vande Moere $^{a}$ \\ ${ }^{a}$ Research[x]Design, Department of Architecture, KU Leuven, Kasteelpark Arenberg 1, 3001, Leuven, Belgium. \\ eslam.nofal@kuleuven.be; andrew.vandemoere@kuleuven.be \\ ${ }^{\mathrm{b}}$ Department of Architecture, Assiut University, 71516, Assiut, Egypt. \\ ${ }^{c}$ Antiquity Department, Royal Museums of Art and History, Jubelpark 10, B-1000 Brussels, Belgium. v.boschloos@kmkg-mrah.be; \\ h.hameeuw@kmkg-mrah.be
}

\begin{abstract}
:
Each built heritage artifact possesses multiple types of information, varying from simple, factual aspects to more complex qualitative and tacit qualities and values like the architectural symbolism of a monument. This paper investigates how tangible interaction can enable the communication of qualitative information of built heritage to lay visitors. Through a comparative, field study in a real-world museum context, we examined how the tangible characteristics of an interactive prototype museum installation influence how visitors perceive a particular story. The communicated story relates a historical journey in ancient Egypt to the physical and architectural characteristics of the entrance colonnade at the Djoser Complex in Saqqara. The first preliminary findings indicate how tangible interaction is able to engage museum visitors more to accomplish additional efforts, facilitating a vivid understanding of cultural values and architectural qualities of built heritage.
\end{abstract}

Keywords: Tangible interaction, physical visualization, qualitative information, built heritage, cultural learning, Saqqara.

\section{Introduction}

Our heritage sites and monuments are not just physical objects, but also communicate particular meanings and values over time. The built heritage can therefore be characterized as a communication process, in which each artifact potentially carries different types of information that visitors are invited to perceive and interpret differently (Kepczynska-Walczak and Walczak 2015). These information types tend to vary from factual or quantitative information (e.g. monument functions or building date), which are relatively easy to represent, to more tacit qualities and values (e.g. architectural qualities, cultural values, symbolic meaning of a monument) that due to their abstract and subjective character are typically more challenging to transfer to visitors. Recent digital technology advancements have enabled various innovative opportunities for more engaging, informative and potentially enjoyable way of communicating heritage information. As a result, built heritage information has already been represented via a variety of paradigms, such as virtual reality (VR) for visualizing the virtual reconstruction of ancient worlds, or augmented reality (AR) for immersing users in historical stories. We believe that tangible interaction is also a promising paradigm for communicating heritage information, which has the added quality to be relatively affordable, collaborative and requiring little experience or skills. For instance, particular qualities of tangible interaction have been demonstrated in a wide range of applications in different realms, such as its effectiveness for collaborative and participative processes in public space in comparison to touch interfaces (Claes and VandeMoere 2015), and its touch and manipulation affordance in interactive exhibits, which attracts more visitors and prompts them for further exploration (Ma et al. 2015).

In comparison to graphical user interfaces (GUIs), tangible user interfaces (TUIs) are relatively intuitive and they do not only afford objects in an abstract physical form, but they can also incorporate particular material attributes (e.g. size, shape, texture, color, weight) that to convey information in addition to the digital representation (Macaranas et al. 2012). The feel of these physical attributes can aid recall, and can be perceptually re-accessed (Seo et al. 2015). It is no surprise then that tangible interaction has been exploited to communicate heritage information, such as providing immersive and more engaging experiences to support intuitive handling and to fit in with outdoor heritage environments (Ciolfi et al. 2013), or allowing visitors to explore background information in museum context (Schneegass et al. 2014). These studies focused on the engagement level and content personalization more than

“Corresponding Author: Eslam Nofal, eslam.nofal@kuleuven.be 
the level of understanding and knowledge gain that leads to cultural learning. Cultural learning is an informal learning style (Ibrahim et al. 2015), its setting stimulates users into thinking to explore and realize the cultural value. This style suits users who seek knowledge for pleasure or those who seek knowledge based on genuine motivation; such as enjoyer or general visitor.

For our study, we aimed to investigate how visitors can be provided with a meaningful and interactive experience that stimulates people to think, discover and make meaningful connections with built heritage without any external help. We are particularly interested in discovering ways how tacit and qualitative information can be indirectly and intuitively communicated in an informal cultural learning context. In order to discover the causal effect of tangible interaction on the sensemaking of the visitors, we developed a comparative, field study in a real-world museum context. This paper reports on the first findings of our preliminary study, providing the first hints towards how tangible interaction influences knowledge gain and user engagement.

\section{Context}

The Djoser pyramid complex is a funerary complex in Saqqara designed by Imhotep, one of the greatest architects in ancient Egypt. It was built for pharaoh Djoser around $2630 \mathrm{BCE}$, and is believed to be the world's oldest large-scale stone structure. For the purpose of this research, we have chosen an historical story of how the pharaoh journeyed along the Nile to visit each of the nomes (the territorial divisions of ancient Egypt) and their local Gods, and how this story was translated in the physical architecture of the entrance colonnade of this complex: it has been suggested that each niche (the space created between adjacent columns) in the entrance colonnade represents a shrine where the nome gods of ancient Egypt were accommodated during the Heb-Sed (a festival celebrating the continued rule of the king through rituals that symbolically rejuvenate him) (Hermann 1932). This working hypothesis is plausible because the number of niches and nomes are equal (42). The architect Imhotep may have designed the architectural layout of the colonnade to portray the Nile river; the end chamber could represent the delta; and the processing of pharaoh Djoser along the corridor and passing by each nome shrine may evoke a ritualized version of the pharaoh's journey along the Nile to visit each of the nomes and their local gods.

\section{Methodology}

For the aim of this study, we developed three different interactive installations (and experimental conditions) in order to compare the causal influence of the tangible interaction on the sensemaking of the visitors, as shown in Figure 1. Each condition consisted of an interactive navigation (input) and a passive representation (output) element. For the navigation, a map of ancient Egypt with its territorial divisions of 42 nomes was used as the main interaction method, either via touch screen (Touch-Dix) or via a tangible interactive surface featuring a movable 3D-printed statue of pharaoh Djoser on the map (TangDix and Tang-Phys). Each condition contained a representation view of the entrance colonnade that dynamically changed according to the user interaction.
This view varied from a digital display showing a walkthrough in a rendered 3D model of the colonnade (Touch-Dix and Tang-Dix) to a 3D, physical rendition of the colonnade that was semi-attached to the installation (Tang-Phys), as summarized in Table 1.

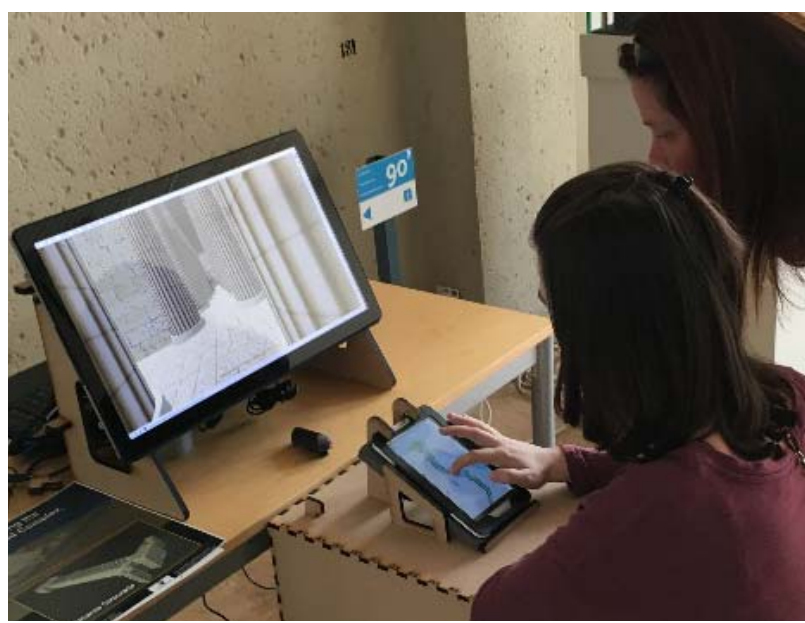

a)

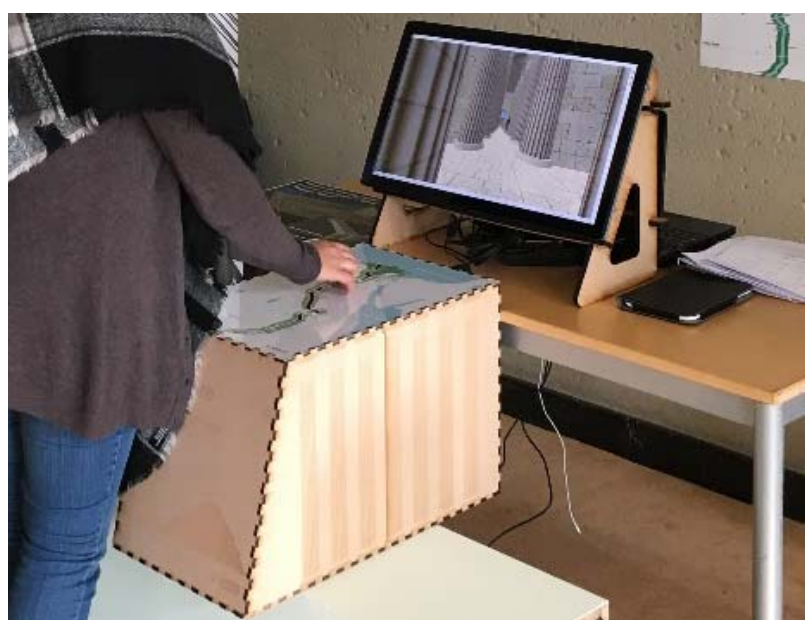

b)

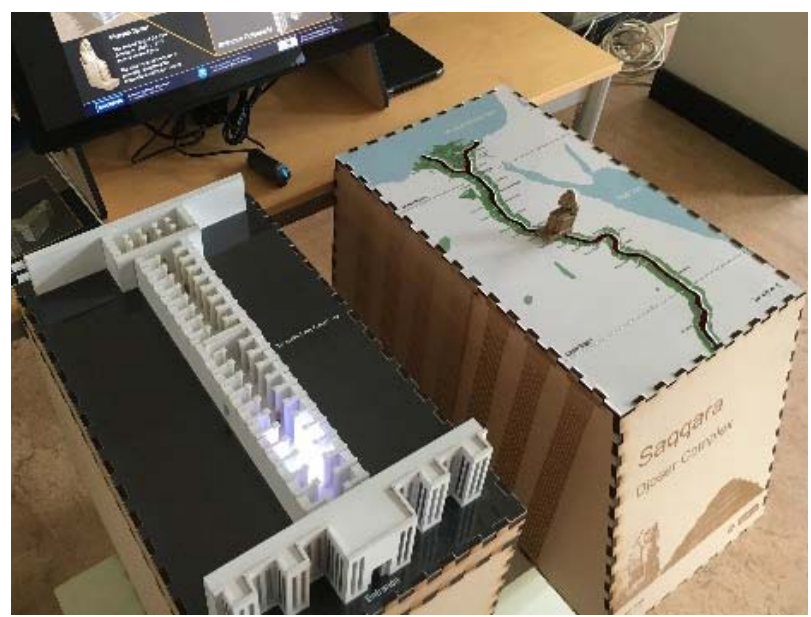

c)

Figure 1: Different conditions for communicating the architectural story of the entrance colonnade of Djoser Pyramid Complex: a) Touch-Dix; b) Tang-Dix; c) Tang-Phys.

We carried out a two-day pilot study at the Antiquity Department of the Royal Museums of Art and History in Brussels (in the exhibition rooms of the Egyptian 
Collection), to estimate general usability issues like whether museum visitors would be sufficiently intrigued by the interactive designs to start interacting with them, and whether they would intuitively understand the functionalities of the interactive features. This museum comprises the largest collection of Egyptian antiquities in Belgium. During the study, each condition was introduced with a brief explanation about the general context of the building (i.e. location and historical period) and about their purpose of interaction (i.e. exploring the architectural symbolism of the entrance colonnade). Visitors were allowed to participate individually or in groups, and as such included couples and dozens of children on a museum school trip. All of the participants signed an informed consent form to confirm that they voluntarily participate in this study, and the results of this research can be used only for scientific purposes. All the interactions were observed, logged and video recorded. The experiment finished with a semi-structured ad hoc interview that was audio-taped, and which focused on the comprehension of the meaningful relationship between the map and the colonnade. The interview also included questions about how the colonnade looked like, in order to capture how people perceived the architectural characteristics of the space (e.g. height, fluting of the columns) that were not explicitly relevant to understand the story, yet still are valuable heritage qualities to be appreciated or remembered. Next to measuring the level of appreciation via open questions, visitors also filled in a user experience questionnaire (ueq-online.org), covering both classical usability aspects (i.e. efficiency, perspicuity, dependability) and user experience aspects (i.e. originality, stimulation)

Table 1: Navigation and representation means of the three experimental conditions

\begin{tabular}{c|c|c|c} 
& Touch-Dix & Tang-Dix & Tang-Phys \\
\hline Navigation & touch screen & $\begin{array}{c}\text { tangible } \\
\text { installation }\end{array}$ & $\begin{array}{c}\text { tangible } \\
\text { installation }\end{array}$ \\
Representation & $\begin{array}{c}2.5 \mathrm{D} \text { digital } \\
\text { display }\end{array}$ & $\begin{array}{c}2.5 \mathrm{D} \text { digital } \\
\text { display }\end{array}$ & $\begin{array}{c}\text { 3D physical } \\
\text { rendition }\end{array}$
\end{tabular}

Touch-Dix. The navigation technique is via touch screen (7 inch tablet computer), dragging 'you are here' icon on the map causes a corresponding walk-through (position and rotation) in the colonnade representation displayed on the larger digital screen (Figure 1.a). The connection between the map on the touch screen and the rendered 3D model of the colonnade on the digital display was accomplished via the Edddison plugin (edddison.com), which simplifies the controlling of 3D applications.

Tang-Dix. A 3D printed statue of pharaoh Djoser was physically moved along the Nile river through a tangible installation of ancient Egypt map. This movement causes a corresponding walk-through (position and rotation) in the colonnade representation displayed on the digital display (Figure 1.b). This link is also attained via the tracking properties of the same plugin Edddison.

Tang- Phys. The same tangible installation of the previous condition is used as a navigation technique. Moving the statue along the Nile river causes a sequence illumination in the physical rendition of the colonnade, each nome with its corresponding niche (Figure 1.c). This condition has been experimented in two different setups; a) fixed: the colonnade mock-up is fixed in the installation, users can only look at it and they may touch it, and b) graspable: users in this condition are allowed to grasp the colonnade mock-up, touch it, look through it, etc.

\section{Results and Discussion}

The pilot study involved 13 participants (i.e. 3 individuals and 10 groups varying between 2 and 10 visitors). Participants varied in terms of gender, age range, and the motivation behind their museum visit (e.g. school or family visit, local or international tourists, or museum staff). Most of the participants expressed a personal interest in information related to cultural heritage, they regularly visited museums, and they claimed to have general knowledge about the Egyptian heritage. But most of them were not familiar with interactive installations.

\subsection{Comprehension and Perception}

In the condition of Touch-Dix, we discovered that participants paid more attention to navigate in the touch screen than the second display that showed the 3D representation of the colonnade. This behavior naturally lead to relatively poor comprehension of the relationship between the map and the colonnade. In contrary, the condition Tang-Phys enabled visitors to understand the general meaning of the story behind the architecture of the entrance colonnade because of the clear link between the movement of the statue along the Nile and the corresponding lights in the physical colonnade. As a result, they appreciated the interaction method because they found it provokes visitors to do an extra effort, which facilitates their understanding. However, in condition Tang-Dix, some participants had only understood that meaning during the interview after asking the question about the corridor's representation.

All of the participants described the colonnade as a linear space with a lot of columns and unclosed chambers (niches). Dimensionally, participants in all conditions estimated its height as a double normal height which is relatively correct $(6.60 \mathrm{~m})$, while their perception of the length of the corridor varied from the real length (in fifties) to overestimations in hundreds. It is worth mentioning that in the condition of Tang-Phys, participants perceived the proportions and an overview of the space better than in the conditions of digital display. For instance, some of the participants in that condition mentioned correctly that the columns were attached to walls. They also better perceived the number of the columns (42). On the other hand, in digital display conditions (Touch-Dix and Tang-Dix), participants had better perception of the architectural details and styles. Some of the participants described the columns as rounded columns with vertical grooves. Unexpectedly, nobody in Tang-Phys perceived the fluting columns.

\subsection{Engagement and Likeability}

Individuals spent remarkably less time in interaction than groups; discussion in groups prompted them to explore more, which in terms increased the interaction time. On the other hand, in conditions of screen display (TouchDix and Tang-Dix), the time of interaction was clearly longer than in Tang-Phys. With regard to the design 
likeability, participants generally appreciated Tang-Dix condition, and they found it interesting. Tang-Phys was considered fun and more suitable for children. In contrast, they seemed not to appreciate Touch-Dix that much, but this was probably due to some ergonomics issues. It is acknowledged the touch screen should be larger for fairer comparison.

\section{Conclusion}

In this work-in-progress paper, we described the design, implementation and comparison between three different conditions for a novel communication of built heritage qualitative information in a real-world museum context. We showed how these conditions achieve different forms of engagement. The findings of our preliminary study indicated how tangible interaction stimulates museum visitors to accomplish additional efforts, facilitating an understanding of cultural values and architectural qualities of built heritage.
Future directions include a more thorough study with a larger number of participants, taking into consideration the ergonomic and technical limitations of the pilot study. The study will be followed by quantitative analysis of the user experience questionnaire and a qualitative analysis of the observation and participants' answers of the interview based on existing learning models.

\section{Acknowledgements}

We would like to thank the Antiquity Department of the Royal Museums of Art and History in Brussels; Luc Delvaux and Eric Gubel for their support and assistance during the museum experiment. We would like also to thank all the volunteers for their participation during their museum visit. The corresponding author gratefully acknowledges the PhD scholarship funded by the Egyptian Ministry of Higher Education.

\section{References}

CIOLFI, L., PETRELLI, D., GOLDBERG, R., DULAKE, N., WILLOX, M., MARSHALL, M. and CAPARRELLI, F., 2013. Exploring historical, social and natural heritage: challenges for tangible interaction design at Sheffield General Cemetery. In: NODEM 2013: Beyond Control - The Collaborative Museum and Its Challenges.

CLAES, S. and VANDEMOERE, A., 2015. The role of tangible interaction in exploring information on public visualization displays, In Symposium on Pervasive Displays (PerDis'15), pp. 201-207. DOI: 10.1145/2757710.2757733

HERMANN, A., 1938. Führer durch die Altertümer von Memphis und Sakkara, Berlin, p.32.

IBRAHIM, N., ALI, N.M., and YATIM, N.F.M., 2015. Factors facilitating cultural learning in virtual architectural heritage environments: end user perspective. ACM Journal on Computing and Cultural Heritage (JOCCH), 8 (2), Article 8. DOI: $10.1145 / 2660776$

KEPCZYNSKA-WALCZAK, A. and WALCZAK, B. M., 2015. Built heritage perception through representation of its atmosphere. Ambiances Experiential Simulation. Available http://ambiances.revues.org/640 [2/21, 2016].

MA, J., SINDORF, L., LIAO, I., and FRAZIER, J., 2015. Using a tangible versus a multi-touch graphical user interface to support data exploration at a museum exhibit, Conference on Tangible, Embedded, and Embodied Interaction (TEl'15), pp. 33-40. DOI: 10.1145/2677199.2680555

MACARANAS, A., ANTLE, A. N. and RIECKE, B. E., 2012. Bridging the gap: attribute and spatial metaphors for tangible interface design, Conference on Tangible, Embedded and Embodied Interaction (TEl'12), pp. 161-168. DOI: $10.1145 / 2148131.2148166$

SCHNEEGASS, S., KNITTEL, J., RAU, B. and ABDELRAHMAN, Y., 2014. Exploring exhibits: Interactive methods for enriching cultural heritage items, In Poster session at International Conference on Tangible, Embedded and Embodied Interaction (TEl'14).

SEO, J.H., ARITA, J., CHU, S. L., QUEK, F. and ALDRIEDGE, S., 2015. Material significance of tangibles for young children, Conference on Tangible, Embedded, and Embodied Interaction (TEl'15), pp. 53-56. DOI: $10.1145 / 2677199.2680583$ 


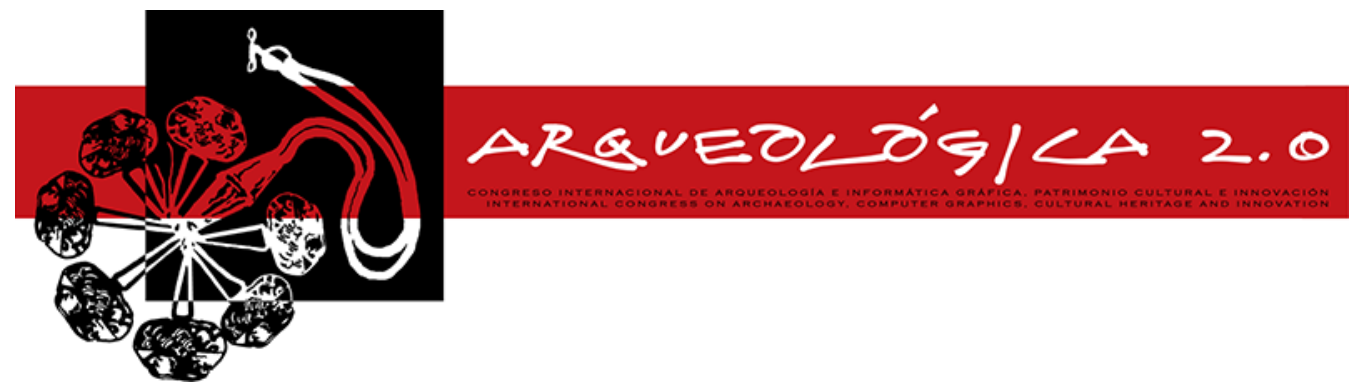

Proceedings of the $8^{\text {th }}$ International Congress

on Archaeology,

Computer Graphics,

Cultural Heritage and Innovation

'ARQUEOLÓGICA 20'

in Valencia (Spain),

Sept. 5 - 7, 2016

\title{
TRAZANDO RUTAS EN LA EDAD DEL BRONCE TUROLENSE: PERSPECTIVAS DE TRABAJO
}

\author{
TRACING ROUTES IN TERUEL'S BRONCE AGE: WORK PERSPECTIVES
}

\author{
Joaquín Jiménez, Teresa Orozco, Agustín Diez
}

Departamento de Prehistoria y Arqueología, Universidad de Valencia, Facultad de Geografía i Historia (Edificio Departamental. $1^{\mathrm{a}}$ y $2^{\mathrm{a}}$ planta) Av. Blasco Ibañez, 28, 46010, Valencia, España. jojipuer@alumni.uv.es, teresa.orozco@uv.es, agustin.diez@uv.es

\begin{abstract}
:
The goal of this work is studying the structure of the territory during the Bronce Age, in the province of Teruel, using GIS tools. So we have localized the most relevant archaelogical sites, and we have elaborated a database with the purpose of crossing it with the DTM from the IGN, corresponfing to the province of Teruel. With all this we have created in QGIS and gvSIG an Archaeological Information System of the area. Using the MDT we have calculated friction maps, with a doule objective: establishing an isotropic cost zone around each ones of the archaeological sites, and also establishing the more effective communication routes between them. The isotropic acumulated cost maps have been useful to create isochronic cost maps which allows us to have an approach to the catchment area of the sites. These maps are suitable for creating a more accurate image adding the topographic variable to the one given by the Thiessen polygons.
\end{abstract}

Key words: Bronce Age, Teruel, GIS, landscape archaelogy, isocronic acumulated cost, least cost routes

\section{Resumen:}

En este trabajo intentamos visualizar la estructura del territorio durante la Edad del Bronce en Teruel mediante herramientas SIG. Para ello, se ha procedido a localizar diversos yacimientos realizando una base de datos, que se ha cruzado con los MDT 200 del IGN correspondientes a la provincia de Teruel, para crear con QGIS y gvSIG un Sistema de Información Arqueológica de la zona. A partir del MDT se han calculado diversos mapas de fricción, con un doble objetivo: establecer una zona de costes isotrópicos alrededor de cada uno de los yacimientos y establecer las vías de comunicación más efectivas entre ellos. El mapa de coste acumulado isotrópico ha servido para crear mapas isócronos de costes de desplazamiento, que proporcionan una aproximación al área de captación de los yacimientos. Estos mapas sirven para enriquecer la imagen obtenida con los polígonos Thiessen al tener en cuenta la variable topográfica.

Palabras clave: Edad del Bronce, Teruel, SIG, arqueología del paisaje, coste acumulado isócrono, rutas de menor coste

\section{Introducción}

Los estudios de Francisco Burillo y Jesús Picazo entre otros, han venido a poner de manifiesto la complejidad y los cambios espacio temporales que tuvieron lugar en tierras turolenses durante el segundo milenio a.C., además de las intensas relaciones de este área con los territorios circundantes (especialmente el litoral levantino donde se extiende el llamado Bronce Valenciano), con los que comparte afinidades culturales y socioeconómicas. La intención de este trabajo es estudiar el registro arqueológico de los hábitats conocidos y ver si existe una relación entre ellos, para establecer un estado de la cuestión acerca de la Edad del Bronce en Teruel. Con este fin, se han analizado la estructura del territorio y el poblamiento, en las diferentes fases de la Edad del Bronce, utilizando herramientas informáticas como QGIS, y gvSIG.

\section{Metodología}

Tras realizar una base de datos con los yacimientos, se ha cruzado con los MDT 200 (Modelo Digital del Terreno) del ICN correspondientes a la provincia de Teruel, para crear con QGIS un modelo gráfico de la zona, con el fin de establecer relaciones entre yacimientos prehistóricos. En primer lugar se ha calculado una capa raster que indica la pendiente, para a continuación crear un mapa de fricción (Nuninger et al. 2006: 2-28). Se ha utilizado la fórmula $T=0.0277^{\star} R^{\star} P+0.6115^{\star} R$ donde $T=$ Mapa de Tiempo (segundos), $\mathrm{R}=\mathrm{MDT}$ (en metros) y $\mathrm{P}=$ Mapa de pendientes. A este mapa de fricción le hemos aplicado el algoritmo de tratamiento SAGA Coste acumulado

*Corresponding Author: Agustín Diez, agustin.diez@uv.es 
isotrópico, elaborando un mapa de costes temporales de desplazamiento. La función de reclasificado convierte el mapa en intervalos de tiempo, que permiten crear una aproximación al área de captación de cada yacimiento, que tenga en cuenta la variable topográfica, por lo que resulta más precisa que la resultante de aplicar únicamente los polígonos Voronoi (Ramírez et al. 1993: 222). El análisis se ha centrado en los yacimientos del Bronce Medio, realizando un análisis de rutas de menor coste para los asentamientos de ese momento. Se ha utilizado gvSIG, calculando el coste isotrópico para cada yacimiento por separado, estableciendo las rutas de menor coste entre los yacimientos. Con ello se ha intentado crear una aproximación a las posibles vías de comunicación y a la articulación del territorio durante esta fase cultural.

\section{La edad del bronce en teruel: poblamiento y territorio}

Los trabajos de Picazo y Burillo, principalmente, proporcionan dataciones $\mathrm{C} 14$ que han permitido afinar en la periodización de la Edad del Bronce en Teruel planteando una división tripartita:

- Bronce Antiguo 2000/1900-1600 a.C. (2450-1900 cal BC)

- Bronce Medio 1600-1300/1250 a.C. (1900-1400 cal $\mathrm{BC})$

- Bronce Reciente o Tardío 1300/1250-1100 a.C. (1500-1150 cal BC) (Burillo y Picazo, 1991-92)

Los yacimientos de hábitat considerados quedan enmarcados en una de las tres fases propuestas (Fig. 1). Desde inicios del II milenio a.C. asistimos a una intensificación de la ocupación del territorio. El estudio realizado para el Bronce Antiguo y Medio (Picazo 1991: 79-108), muestra que el poblamiento tiende a la concentración (Fig. 2). Son poblados estables de tipo aglomerativo en posiciones elevadas con defensas naturales y/o artificiales. Su extensión es reducida.

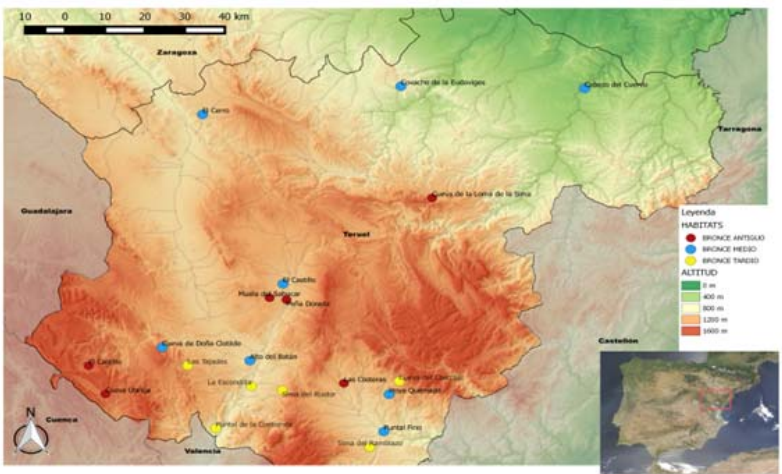

Figura 1: Hábitats de las diferentes fases. Elaboración propia sobre MDT del IGN.

Se observa una ausencia aparente de jerarquización en el hábitat. En el transcurso del Bronce Medio se detecta la emergencia de una serie de asentamientos cuyas dimensiones destacan sobre la media y que presentan ubicaciones privilegiadas en cuanto a recursos: el Puntal Fino (Sarrión) y El Castillo (Alfambra), de unos 3500 metros ${ }^{2}$. Éstos se ajustan al modelo de una distribución primada (Haggett 1976: 135): se encuentran en zonas clave de la red de comunicaciones y con mayores recursos potenciales, por lo que se consideran asentamientos privilegiados económicamente.

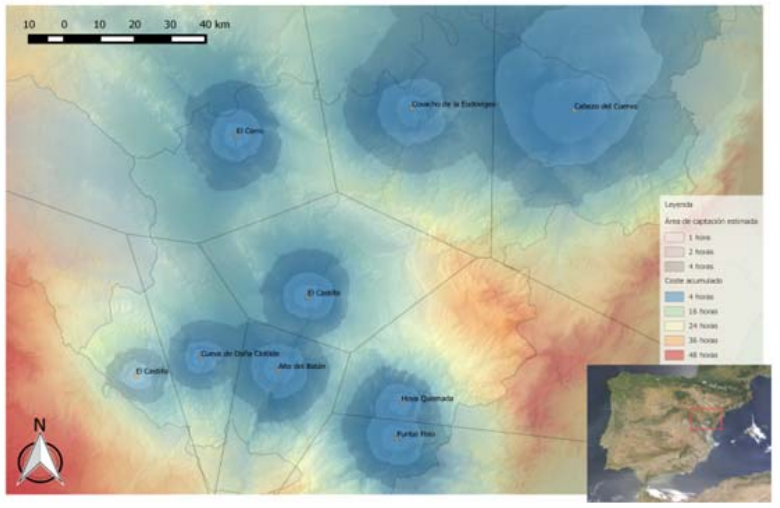

Figura 2: Mapa de coste isotrópico, área de captación teórica en base al coste de desplazamiento y comparación con polígonos Voronoi, para el Bronce Medio. Elaboración propia sobre MDT del IGN.

\section{Análisis territorial con herramientas GIS}

A la luz de los datos proporcionados por los estudios de Picazo, Burillo y otros, hemos comprobado algunas de las conclusiones a las que llegan dichos autores. Los índices de Clark-Evans (Clark y Evans 1954) arrojan en todas las fases estudiadas valores próximos a 1, por lo que la dispersión de los yacimientos es aleatoria y no existe ninguna jerarquización apreciable del territorio. Por ello se han estudiado con QGIS las áreas de captación de los distintos hábitats y momentos (Figs. 2 y 3 ), en base al coste temporal del desplazamiento sobre el relieve (coste isotrópico).

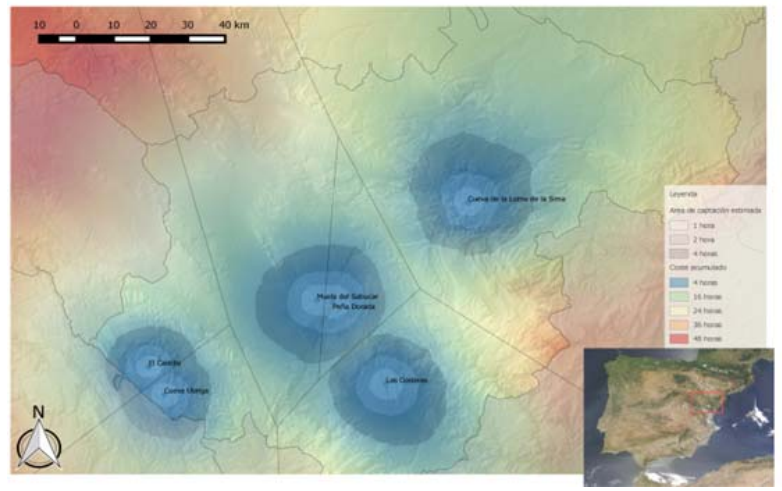

Figura 3: Mapa de coste isotrópico, área de captación teórica en base al coste de desplazamiento y comparación con polígonos Voronoi, para el Bronce Antiguo. Elaboración propia sobre MDT del IGN.

El análisis de las vías de comunicación teóricas se ha calculado con gvSIG (Fig. 4), siguiendo las propuestas de R. López (2005: 95-111). Los primeros resultados muestran la conexión con el litoral levantino. Se ha propuesto la existencia de unas rutas de trashumancia estacional que conectarían las tierras altas de Teruel con el litoral levantino, por lo que estas conexiones podrían haber conectado a estos grupos de un modo estable (Burillo y Picazo 1997). Finalmente se puede apreciar en el Bronce Tardío (Fig. 5) el alto grado de despoblación que sufre la parte norte de la provincia de 
Teruel y la disolución de la estructuración territorial incipiente, del período previo.

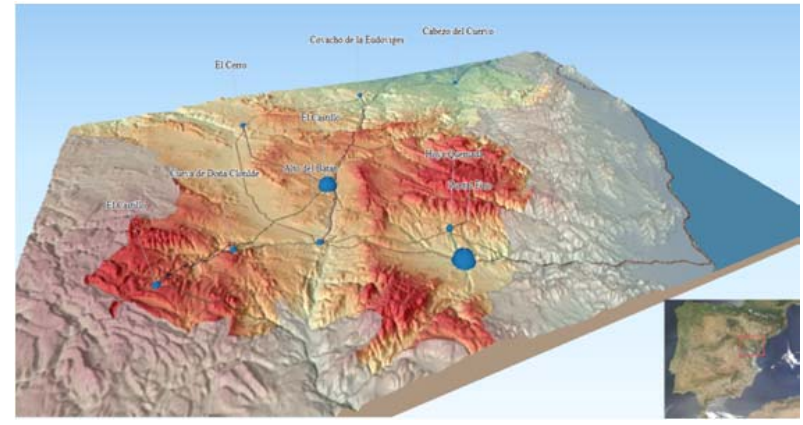

Figura 4: Mapa de caminos calculados siguiendo la ruta de mínimo coste para el Bronce Medio. Elaboración propia sobre MDT del IGN.

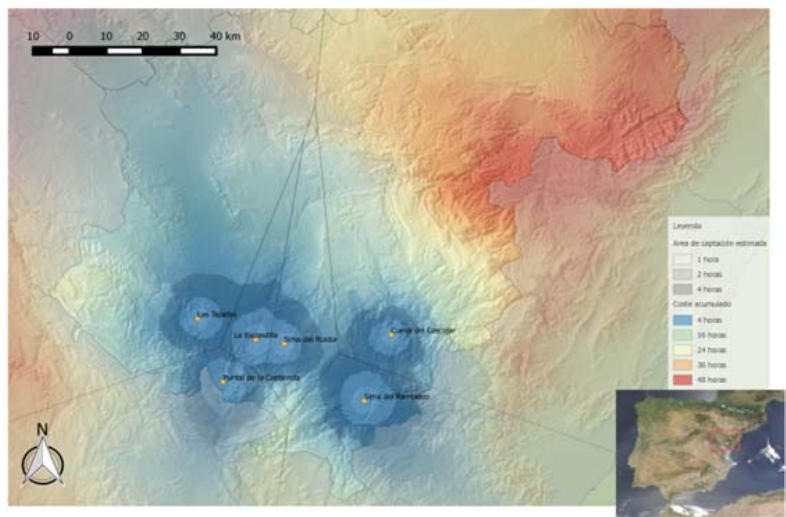

Figura 5: Mapa de coste isotrópico, área de captación teórica en base al coste de desplazamiento y comparación con polígonos Voronoi, para el Bronce Tardío. Elaboración propia sobre MDT del IGN

\section{Valoración y futuros trabajos}

Durante el Bronce Antiguo, entre 2000- 1600 a.C. se produce un desarrollo y consolidación de la economía agraria, un establecimiento en poblados estables en altura y la generalización de los objetos de cobre (aunque aún escasos). La jerarquización territorial es aparentemente inexistente. No obstante, comienzan a apreciarse algunas diferencias incipientes entre las culturas materiales de dos grupos regionales: Mijares, más vinculado al mundo levantino y Alfambra. Serán estos dos ámbitos geográficos separados, con evoluciones divergentes durante el Bronce Medio. Aunque algunos elementos permiten observar cierta continuidad de los grupos sociales en la fase siguiente.

Entre el 1600 y el 1100 a.C se aprecia en la provincia de Teruel el desarrollo de grupos estructurados social y territorialmente, con dos centros que ejercerán de cabeceras regionales (Puntal Fino y El Castillo de Alfambra). Las vinculaciones de estos grupos con Levante son fuertes así como las relaciones con el sur catalán. Estas comunidades que ven su momento álgido durante el Bronce Medio, entran en una crisis, cuyos efectos son evidentes en el despoblamiento, la desarticulación territorial y el debilitamiento de las relaciones existentes. Se experimenta una caída demográfica, así como el abandono de un modelo económico y social que tendía a la intensificación e incremento de la complejidad (Burillo y Picazo 1994/96). Durante el Bronce Tardío, la ruptura se hace evidente y todas las tradiciones anteriores se irán diluyendo hasta desaparecer completamente del registro arqueológico. Las nuevas sociedades emergentes, pertenecerán a un modelo cultural diferente, que incluso introducirá una nueva forma de entender las prácticas funerarias, y que cristalizará en la etapa siguiente, durante la Primera Edad del Hierro.

Los resultados de esta fase del trabajo, nos indican las posibilidades que tiene esta forma de análisis para un territorio como la provincia de Teruel. Es por ello que en las siguientes fases se pretende ampliar el área de estudio a las zonas aledañas de Castellón y Valencia, así como incluir mayor número de yacimientos en el estudio. También es intención extender la investigación a la etapa anterior, la Edad del Cobre, así como a la posterior de la Edad del Hierro, con el propósito de analizar la evolución de este territorio en un amplio marco temporal y espacial.

\section{Referencias}

BURILLO, F. y PICAZO, J., 1991-92. Cronología y periodización de la edad del Bronce en la provincia de Teruel, Kalathos, 11-12, pp. 43-89.

BURILLO, F. y PICAZO, J., 1994/96. El Bronce Medio y la transición al Bronce Tardío en Teruel, Gala, 3-5, pp. 59-75.

BURILLO, F. y PICAZO, J., 1997. El sistema ibérico turolense durante el segundo milenio A. C., Saguntum: P. L. A. V., 30 , pp. $29-58$

CLARK, P.J. y EVANS F.C., 1954. Distance to nearest neighbour as a measure of spatial relationships in populations. Ecology, 35, pp. 445-453.

HAGGET, P. 1976: Análisis locacional en la geografía humana. Barcelona, 416 páginas.

LÓPEZ, R., 2005: Cálculo de rutas óptimas mediante SIG en el Territorio de la ciudad celtibérica de Segeda. Propuesta metodológica, Salduie, 5, pp. 95-111.

NUNINGER, L. y SANDERS, L., 2006. La modèlisation des rèseaux d'habitation en archèologie : trois expèriences, M@ppemonde 83, pp. 2-28. http://mappemonde.mgm.fr/num11/index.html

PICAZO, J., 1991. Contribución de análisis estadísticos para la diferenciación de grupos culturales durante la Edad del Bronce en el Sur del Sistema Ibérico, Archeologia e Calculatori, 1; pp. 79-108. 
RAMÍREZ, J.L., CISNEROS, M. y DIEZ, A., 1993. Evolución de los patrones de asentamiento en la comarca de Liébana desde la prehistoria hasta la antigüedad, Aplicaciones Informáticas en Arqueología: teorías y sistemas, pp. 219-232. 


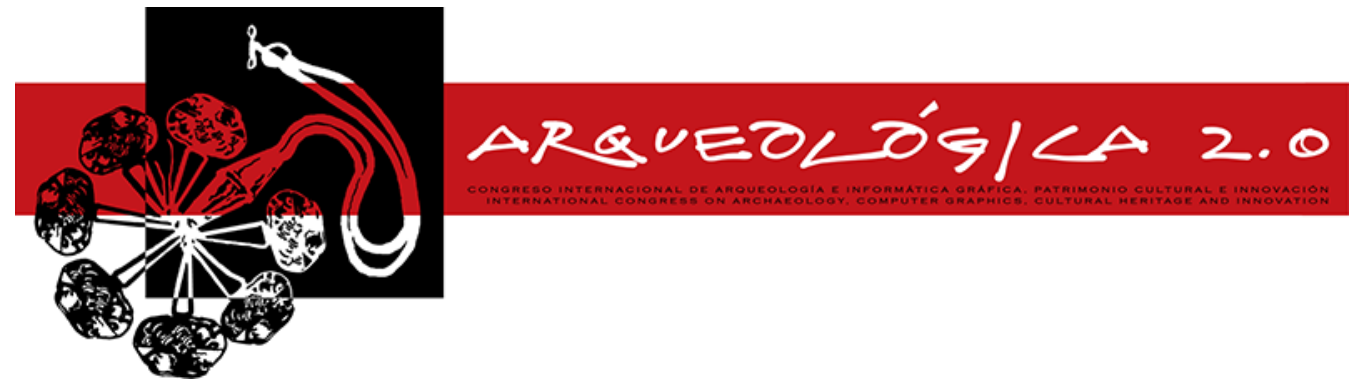

Proceedings of the $8^{\text {th }}$ International Congress

on Archaeology,

Computer Graphics,

Cultural Heritage and Innovation

'AROUEOLÓGICA 2.0'

in Valencia (Spain),

Sept. $5-7,2016$

\title{
PUTTING 3D MODELS INTO CONTEXT - THE SCHACHERMEYR POTTERY COLLECTION AND THE DEFC APP
}

\author{
Seta Štuhec ${ }^{a,},{ }^{*}$ Edeltraud Aspöck ${ }^{a}$, Anja Masur ${ }^{a}$, Peter Andorfer $^{b}$, Ksenia Zaytseva $^{b}$ \\ ${ }^{a}$ Austrian Academy of Science, Institute for Oriental and European Archaeology (OREA), Fleischmarkt 20-22, 1010 Vienna, Austria. \\ seta.Stuhec@oeaw.ac.at; edeltraud.Aspoeck@oeaw.ac.at; anja.masur@oeaw.ac.at \\ ${ }^{\mathrm{b}}$ Austrian Academy of Science, Austrian Centre for Digital Humanities, Sonnenfelsgasse 19, 1010 Vienna, Austria. \\ peter.Andorfer@oeaw.ac.at; ksenia.Zaytseva@oeaw.ac.at
}

\begin{abstract}
:
In order to overcome the different knowledge schemas of research on Neolithic and Chalcolithic sites of Greece and Anatolia, an open access Django-based database called DEFC App (Digitizing Early Farming Cultures Application) has been developed. The 3D models of the Schachermeyr sherd collection are one of the many resources that will be integrated into the database. The present contribution focuses on these 3D models and their metadata and on how they are contextualized within the DEFC App database and beyond. Additionally, we discuss the 3D model provenance metadata that should accompany the 3D models in order to assure their transparency.
\end{abstract}

Key words: digital archaeology, online site database, 3D model, data integration, metadata, legacy data, linked open data

\section{Introduction}

The Schachermeyr pottery collection was left to the Austrian Academy of Science by Fritz Schachermeyr in order to serve everyone interested in studying the Neolithic pottery of Greece. With this intention the collection has been made available to the public and with the recent development in technology it can finally reach the broadest possible audience in the form of digital 3D models.

The 3D models will be presented within an open-access Django-based database called DEFC App (DEFC App 2016; GitHub DEFC App 2016) that has been created in the framework of the Digitizing Early Farming Cultures (DEFC) project. The purpose of this application is to integrate research data from Neolithic and Chalcolithic sites and finds of Greece and Anatolia (Aspöck and Masur 2015). Both areas were usually researched in isolation from each other, which resulted in fragmented data, organized according to different knowledge schemas. In collaboration with the Aegean Anatolian Prehistoric Phenomena (AAPP) research group (ÖAW, OREA), an app has been created, which aims to overcome this fragmentation and will finally allow collaborative research throughout the whole area. Therefore the existing digital datasets are being harmonised and analogue data from publications (AlramStern 1996) are being digitised. Furthermore, a selection of 90 representative sherds from the Schachermeyr pottery collection (Schachermeyr 1991) was digitised using a Breuckmann SmartScan HE 5 Megapixel Color 3D Scanner (Fig. 1).
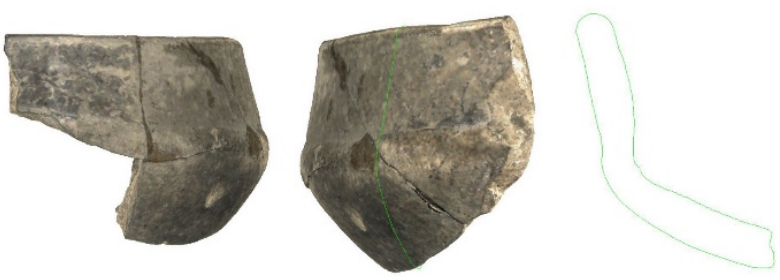

Figure 1: A textured 3D model and its cross-section of a sherd from the Schachermeyr pottery collection.

All data will be made available through the DEFC App that can be accessed through the project homepage. This app, which complies with standards of data sharing and interoperability, must allow easy access, data connectivity and data reuse.

The present contribution focuses on the $3 D$ models of the sherds and their associated metadata. First, the 3D models will be presented in the context of the DEFC App data model. Afterwards, we will discuss the standards of the necessary metadata and paradata that accompany these 3D models in order to ensure their transparency.

\section{DEFC App data model}

The DEFC App data model meets the particular requirements of dealing with data of different granularity. This means that some data sets are very detailed

"Corresponding Author: Seta Štuhec, seta.Stuhec@oeaw.ac.at 
containing many sub-levels (such as the documentation of modern archaeological excavations), wereas other data sets comprise broad archaeological data (e.g. old reports and other legacy data). The DEFC App data model therefore connects different levels of excavation processes, geographical location and chronological periodisation, while also keeping the complex relationships between the data objects. To meet the needs of all possible users, a clear conceptual data model that is based on the most probable relationships between archaeological objects has been defined with the following main model classes (Fig. 2):

- Site (location where archaeological research took place/observations were made);

- Research event (project and type of archaeological research that was carried out);

- Area (particular part of the site within a certain time span - period);

- Finds (artefacts, animal and plant remains found in a certain area);

- Interpretation (archaeologist's interpretation of areas/finds etc.).

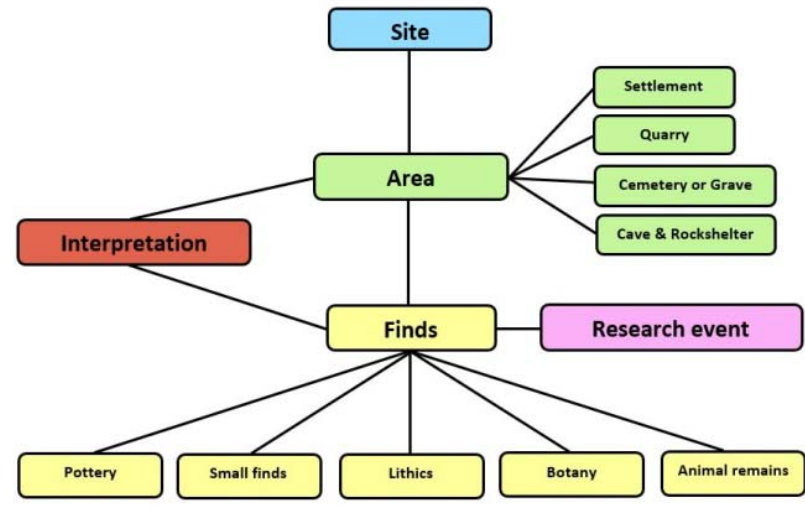

Figure 2: DEFC App conceptual data model.

Each of these classes is defined through several properties, most of them linked to a carefully curated set of controlled vocabulary that has been ordered in thesauri. To properly link the 3D models from the Schachermeyr pottery collection with the DEFC App database classes, the work on the sherds conducted by E. Alram-Stern (Schachermeyr 1991) was used to gather the assets metadata. The publication includes information that will allow us to link the 3D models to the location where they were found. The "Site" class includes the coordinates that will be displayed on the app's map (Fig. 3).

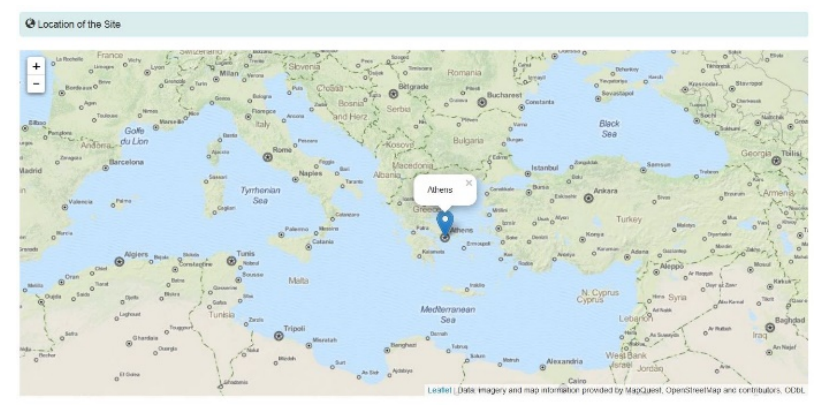

Figure 3: DEFC App map display.
Furthermore, the 3D models will be linked to the research event during which the sherds were collected ("Research event" class). The dating of the sherds will be carried out through the "Area/period" class and finally they will be included in possible interpretations ("Interpretation" class). The "Finds" class includes several detailed properties, where the form, decoration and other characteristics of the ceramic can be described. In addition, the database is linked to a Zoterobased reference library (Zotero 2016) collected by the AAPP research group. In this way it becomes possible to link the 3D models to the corresponding literature.

After this necessary first phase of literature research, the $3 \mathrm{D}$ ceramic models will be attributed with more detailed information concerning their form and decoration. These data were gathered by the AAPP research group. At present, these metadata are - together with other Greek pottery databases made by the AAPP research group stored in Access databases. To integrate the latter with the DEFC App, both the DEFC App as well as the pottery Access databases are being mapped to the CIDOC Conceptual Reference Model (CRM) ontology (CIDOC-CRM 2014). After this mapping, all data will be stored in a triple store with a SPARQL endpoint. By mapping the various databases to the CIDOC CRM, it becomes possible to integrate all these different data sources since it is clear which classes and properties of the initial databases correspond. At this point, this new metadata can also be connected to the 3D sherd models.

\section{3D metadata}

The content of the paragraphs above can be classified as the so-called "heritage asset identification"-part of 3D metadata according to the recommendations of the 3D ICONS guidelines (3D ICONS 2016). In this section we will look into the $3 \mathrm{D}$ model creation metadata (often called paradata) that should accompany the 3D models to asure their transparency. One of the bigger problems when using digital substitutes for scientific research is namely their critical evaluation. When we use a 3D model, we must be sure that it is reliable to a given extent (especially if it was created by someone else), i.e. we have to be sure that the $3 \mathrm{D}$ model corresponds within a certain accuracy to the physical object. This can be achieved by carefully documenting the capture/creation and processing procedures of the 3D data. In this way advantages and disadvantages posed by hardware and software of data processing can be considered and the 3D model's quality can be assessed.

When deciding on which data to include with the digital Schachermeyr models, we considered the standards recommended by 3D ICONS, the Archaeological Data Service (ADS) Guides to Good Practice (ADS 2016) and the IANUS project (IANUS 2016). Additionally, the CIDOC CRMdig extention (Theodoridou 2016) has been taken into account, since it is planned to link also these 3D metadata with the DEFC App directly.

First, the "administrative metadata" will be added:

- Project name: the name of the scanning project;

- Actor: the person who captured 3D data and the person who did the post-processing; 
- Time of capture: when were the data captured and when were they processed;

- Copyright;

- Digital asset ID: the file name;

- File format;

- URI/ID.

Additionally, provenance metadata (3D model creation and processing) will be included in the "activity" part of the metadata schema. Activity consist of two parts. The first part represents the creation of the 3D models:

- Type of activity: which 3D acquisition method was applied (e.g. 3D structure light scanning);

- Digital device: the hardware for the 3D capturing. In the case of $3 D$ scanning, the metadata that should be recorded are:

o Scanning device;

o Texturing device: scanner camera or external camera;

o Computer device;

o Accompanying software (and pre-set parameters);

- Capture conditions record of any external activities that might have influenced the $3 D$ capture procedure (e.g. weather).

The second part of the activity log documents the 3D model post-processing workflow. In our case several software packages were used in order to prepare the 3D models for the final upload to the DEFC App. Each step will be documented as follows:

- Software: the post-processing software and its version;

- Action: the processing steps that have been carried out (e. g. hole filling, polishing, texturecolour conversion, decimation, compression)
- Import/export file format.

Since most instruments already perform a lot of automatic processing during the capturing stage, these processes will be documented in separate *.TXT files which are automatically generated by the scanners that are used. This will ensure a very complete paradata coverage.

\section{Conclusion}

Fritz Schachermeyr left his collection to the Austrian Academy of Science so that it could serve researchers, students and all parties interested in studying the Neolithic pottery of Greece. Therefore the collection has been opened to the public. Since the collection has been digitised, the sherds are now finally available to the broadest possible audience. Moreover, these digital sherd surrogates are not going to be presented as a plain collection of separate $3 D$ models, but will be incorporated within an open access database DEFC App as a part of a rich dataset

Furthermore, using the ontologies CIDOC CRM and the CRMdig extention, additional information on the sherds themselves as well as information about the 3D model creation will be available.In this way we wish to ensure the context, accessibility, sharing and transparency of these 3D data.

\section{Acknowledgements}

This work was supported by the Austrian Academy of Sciences initiative go!digital under Grant ACDH 2014/22 and by the ARIADNE EU-funded project under Grant FP7-313193. We want to thank the members of the AAPP research group for their contributions to the data model and thesauri. Many thanks also to Matej Durčo (ÖAW ACDH) for the technical support.

\section{References}

3D ICONS, 2016. 3D ICONS Guidelines. Available: http://3dicons-project.eu/eng [13/03, 2016].

ALRAM-STERN, E., 1996. Die Ägäische Frühzeit“. Band 1: Das Neolithikum in Griechenland. Veröffentlichungen der mykenischen Kommission 16.

ARCHAEOLOGICAL DATA SERVICE (ADS), 2016. Guides to good practice. Available: http://guides.archaeologydataservice.ac.uk/g2gp/Main [13/03, 2016].

ASPÖCK, E. and MASUR, A., 2015. Digitizing Early Farming Cultures: Customizing the Arches Heritage Inventory \& Management System. In: GUIDI, G., SCOPIGNO, R., TORRES, J. C. and GRAF, H., eds., 2015 Digital Heritage International Congress, 28 September - 2 October 2015, Granada, pp. 463-464. DOI: 10.1109/DigitalHeritage.2015.7419549

CIDOC-CRM, 2014. CIDOC Conceptual Reference Model homepage. Available: http://www.cidoc-crm.org/ [07/04, 2016].

DEFC APP, 2016. DEFC App homepage. Available: http://defc.digital-humanities.at/ [13/03, 2016].

GITHUB DEFC APP, 2016. DEFC App source code. Available: https://github.com/acdh-oeaw/defc-app [11/04, 2016].

IANUS, 2016. Research Data Center: Archaeology \& Ancient History. Available: http://www.ianus-fdz.de/ [13/03, 2016].

THEODORIDOU, M., 2016. CIDOC CRMdig model. Available: http://www.ics.forth.gr/isl/index main.php?l=e\&c=656 $[13 / 03,2016]$.

SCHACHERMEYR, F. (†),1991. Sammlung Fritz Schachermeyr: Die neolithische Keramik Thessaliens. Aus dem Nachlaß bearbeitet von Eva Alram-Stern. Veröffentlichungen der Mykenischen Kommission 13.

ZOTERO, 2016. Zotero DEFC online library. Available: https://www.zotero.org/defc-orea-oeaw [13/03, 2016]. 


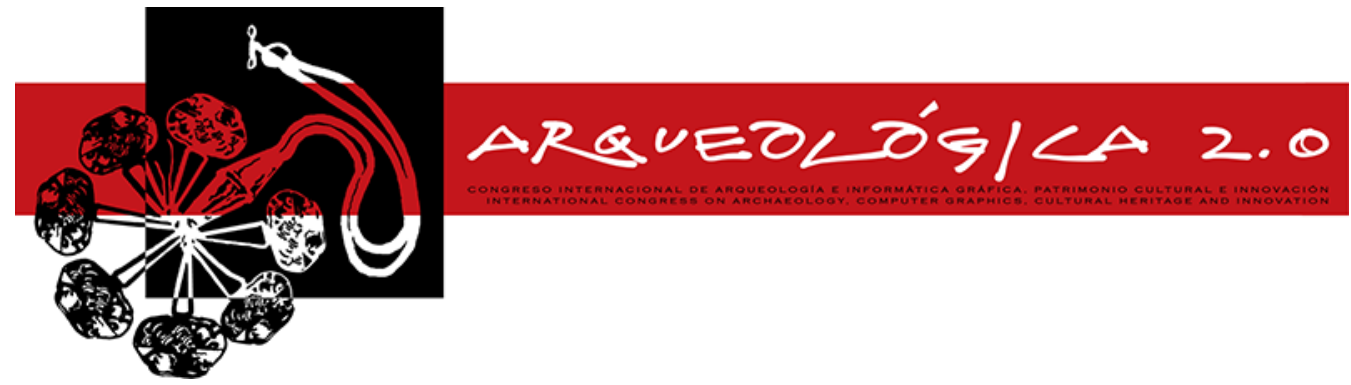

Proceedings of the $8^{\text {th }}$ International Congress

on Archaeology,

Computer Graphics,

Cultural Heritage and Innovation

'ARQUEOLÓGICA 20'

in Valencia (Spain),

Sept. 5-7, 2016

\title{
PORTUS LUPIAE. 3D MODELING AND VISUAL NARRATIVE FOR RECONSTRUCTING A LONG MARITIME HISTORY
}

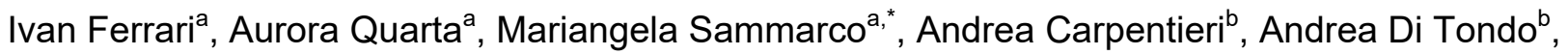 \\ Roberto Leone ${ }^{c}$ \\ ${ }^{a}$ Department of Cultural Heritage, University of Salento, Via Dalmazio Birago 64, 73100 Lecce, Italy. if.ivan@libero.it; \\ aurora.quarta@gmail.com; mariangela.sammarco@libero.it \\ ${ }^{b}$ Insynchlab, Via L. Settembrini, 20, 73100 Lecce, Italy. info@insynchlab.net \\ ${ }^{c}$ Melchioni Elettronica Sud s.a.s, Via Taranto, 68-74, 73100 Lecce, Italy. info@onboardcamera.it
}

\begin{abstract}
:
The fast evolution of digital technologies and techniques of data recording have had a great impact on archaeological research. The first effect of this revolution was an increased number of strongly technologically oriented projects and applications. Among all available solutions, the use of 3D models is particularly relevant for the reconstruction of sites and monuments poorly preserved, often destroyed by natural causes or human action. These digital replicas are, at the same time, a virtual environment that can be used as a tool for the interpretative hypotheses of archaeologists and an effective medium for a visual description of the cultural heritage as it crosses linguistic barriers. In this paper, methodology, aims and outcomes of a virtual reconstruction of the ancient harbour at St. Cataldo (Lecce, south Italy) carried out by Portus Lupiae Project of the University of Salento, are offered as case study for a virtual reconstruction of a long maritime activity. The use of 3D technologies for teaching and research as well as the post-processing and implementation of data generate a new digital workflow for sharing local culture.
\end{abstract}

Key words: 3D modeling, virtual heritage, ancient harbour, digital storytelling, drones, visual narrative

\section{Introduction}

Virtual Reality and 3D modeling have been applied to archaeology for more than three decades now (Remondino and Campana 2014). Much has been written on the potential of these tools for archaeological research (Niccolucci 2002) and most projects involving these technologies focus on the communicational aspects of 3D modeling in various media - internet, museum installations, etc. (Gabellone 2011), or technological improvements of $3 \mathrm{D}$ modeling tools and their use as a tool for scientific investigation (Hermon and Nikodem 2008).

The experience here presented regards a multidisciplinary research improved by the University of Salento to investigate the coastal area and the waters off the Bay of St. Cataldo, the main harbour of the Roman town of Lupiae, modern Lecce in southern Italy, and to further describe the construction of the coastal infrastructures and their historical context. The oldest pier is dated back by literary sources (Pausanias, Description of Greece, 6.19.9) to the era of Emperor Adrian, while archival documents provide detailed descriptions of the ancient structure up to the XVI century. The roman pier was reduced in size in 1901, and the ancient construction material partially re-used in a twentieth-century breakwater that was directly founded on the earlier structure, and is still preserved in shallow water (Fig. 1).

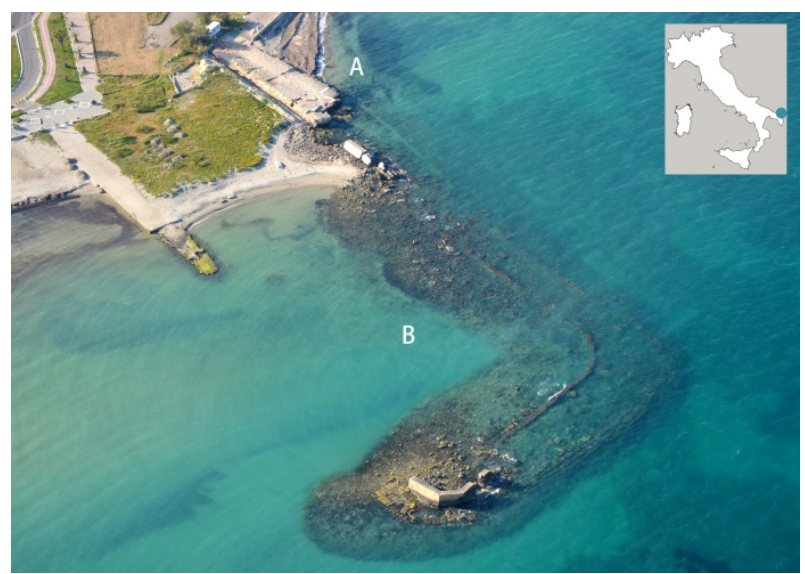

Figure 1: General aerial view of the ancient harbour at St. Cataldo. A: the roman pier; B: the new breackwater.

The project "Portus Lupiae" started in 2009 as an experience of archaeological excavation, using different technologies such as aerial photo mapping, GPR survey,

`Corresponding Author: Mariangela Sammarco, mariangela.sammarco@libero.it 
carbon-14 analysis, micropapaeonthological studies, computer vision and photogrammetry (Sammarco and Marchi 2012; Ferrari and Quarta in press). Starting point for this archaeological work was to collect all graphic and photographic documentation available for this monument, consisting mostly of archival documents, ancient maps (Fig. 2), historical photographs and publications from the 1880 s.

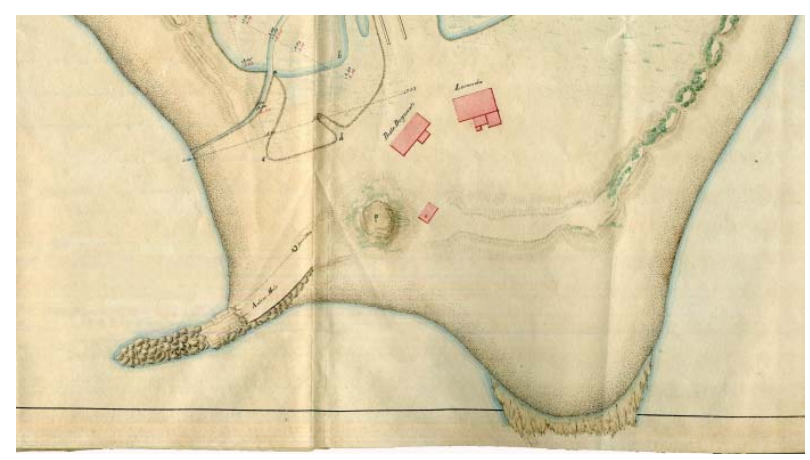

Figure 2: Detail of historical map (1881) showing the original bending shape of the roman pier (from State Archive of Lecce).

A two-years long archaeological excavation allowed to dig up the roman pier, that can be actually observed along the beach. The monument shows a compact structure and consists of two outer walls $15 \mathrm{~m}$ distant from each other (Fig. 3). The two curtains are made by large squared limestone blocks and filled with hydraulic concrete made with a strong mortar mixed with a local stone aggregate.

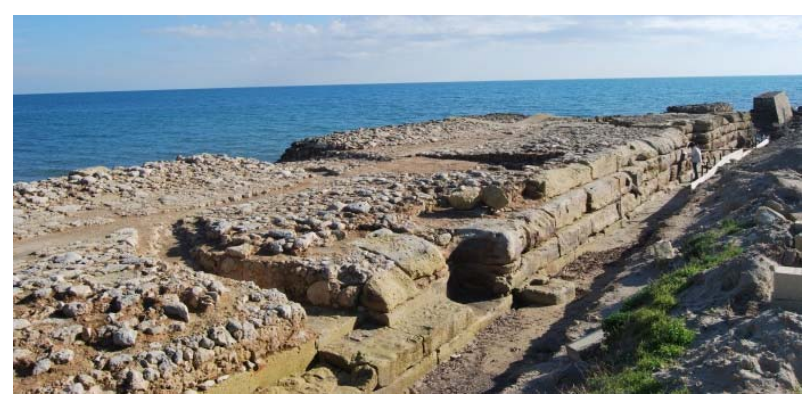

Figure 3: Current conditions of the roman pier.

The pier has been used until Middle Age, when it was a very active commercial port along the Adriatic coast. A significant trade activity is documented throughout the $\mathrm{XVI}$ and the XVII century, mostly to embark olive oil. When this activity decreased during the XVIII century, the harbour was progressively abandoned.

The new breakwater (Fig. 1) is L-shaped, begins at the root of the ancient pier and extends $190 \mathrm{~m}$ seaward. It laids on a wide submerged foundation consisting of large-size squared limestone blocks.

\section{From field to screen: archaeological $\mathbf{3 d}$ modeling}

\subsection{The virtual model of the roman pier}

First step for the digital modeling of the roman pier was to acquire a direct survey of the monument; then, an image-based 3D model developed using "structure for motion" argorithm has been realized (about 200 photos have been taken, part of them by UAV platforms) using the software Agisoft PhotoScan.

This first phase of construction of the model triggered a cognitive process which allowed us to understand the complexity of the monument and its interaction with the ancient environment. A first question concerned the original planimetric extension of the structure; analyzing the ruins both emerged and submerged, currently 140 $\mathrm{m}$ long, it was clear that the pier was much more longer and that it has been affected by continuous sea erosion process; no archaeological evidences could yet confirm how long the pier was in ancient time.

However, two architecturall features appeared to be definite: the slightly bending-shape and the width of the platform that increases in its advance into the sea. A further topic of discussion was the presence of two blocks projecting from the inside face of the pier $\sim 75 \mathrm{~cm}$, presenting circular-shaped holes $\sim 33 \mathrm{~cm}$ in diameter. At first misinterpreted as mooring rings, these two blocks are placed $220 \mathrm{~cm}$ below the hypothetic quay floor and just above the sea level; furthermore, they do not present any traces due to rope rubbing.

Thus, the virtual model (Fig. 4) offered a interpretative sintesys showing these blocks used as support for wooden poles connected to machines for loading and unloading cargo from the ships.

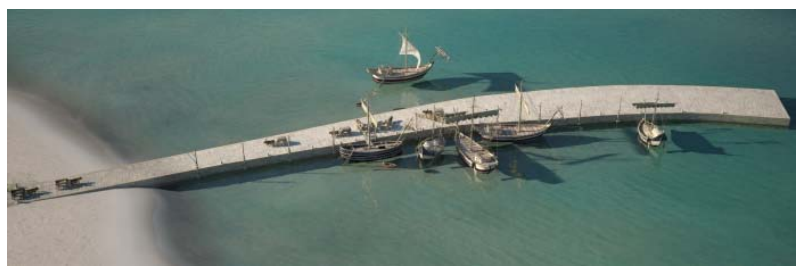

Figure 4: 3D model of the pier of roman age; aerial view.

\subsection{The virtual model of the modern pier and the underwater groundworks}

The 3D model intended both to reconstruct in elevation the missing parts of the L-shaped breackwater and to rediscover digitally the massive underwater foundations well visible in shallow water (Fig. 5).

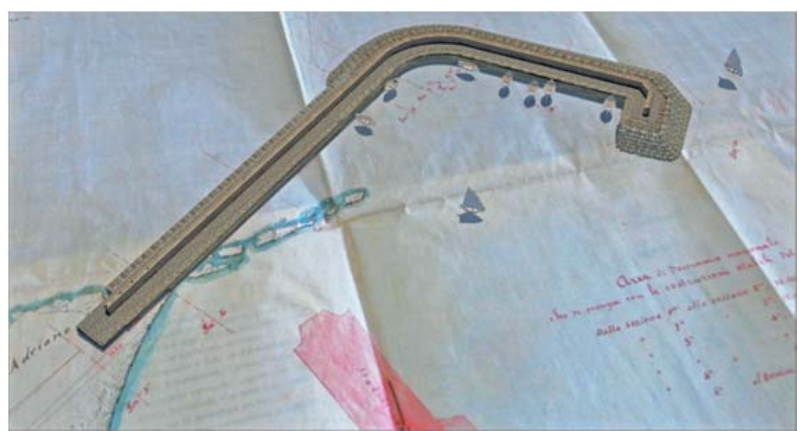

Figure 5: 3d model of the modern L-shaped breakwater; a project plan (1901) provides a ground to the virtual object.

The work tools used are Maxon Cinema 4D, a licensed cross-platform software for modeling, rendering and animation of interactive 3D contents, and Adobe After Effects for compositing and post-production.

In addition, historical maps have been elaborated to be used as a 'visualscape' for the location of the model. The 
massive underwater groundworks has been rebuilt using the measurements provided in archival documents while the preserved outer walls were reconstructed using dimensions recorded on site and textured using photos taken on site, as well.

\section{In progress: visual narrative and digital storytelling for reconstructing a long maritime history}

The final outcome of the processing and post-processing phases is a 3.5-minute video, in which the virtually rebuilt harbour of St. Cataldo is shown in its landscape (Fig. 6). The visual narration starts with a controlled glide of the drone over the monument; adopting the wireframe technique the architectural evolutive pattern is shown. Then, gradually a realistic texture of building materials fade in, enhancing the perception of the structure and the realistic virtual model appears. A further phase of character animation (using profiles representing different people who operated there at the time) recreates workactivities bound with the port facilities. A narrator explains the progression of events.

We are currently working to develop a complete virtual timeline digitizing new contents (drawings, historical photographs, ancient maps ect.) usefull for designing the audiovisual narratives and making further 3D virtual models: a medieval tower, a chapel, the lighthouse. So, new shorter sections of this long maritime history will be written and replied into visual narrations.

\section{Final observations}

In conclusion, the virtual long life history of the ancient harbour of St. Cataldo, the main coastal outcome of the Roman town of Lupiae, modern Lecce (Italy) demonstrates how 3D modeling could be extremely useful for interpreting, monitoring and promotion of archaeological sites, offering a 'sixth sense' for understanding remains from the past.

The "digital experience" here reported offers a new creative perspective for local cultural heritage, presenting a mature interpretation of reality. By creating such virtual workflow of contents, we also intend to increase the access that general public has to the culturale heritage, promoting a better sharing and communication of archaeological and historical informations. The techniques applied enable the viewer to gain a variety of historical themes; that's why we assume that the outputs of this application are not limited to the mentioned heritage sites, rather the techniques could be applied to different multi-layered historical contexts.

\section{Acknowledgements}

The authors are grateful to Prof. Giuseppe Ceraudo and Prof. Carla Maria Amici (University of Salento), coordinators of the research project, for their support to this "digital experience", and to Dr. Giovanni Vinci e Dr. Laura Masiello (Soprintendenza Archeologia della Puglia) for the economic support.
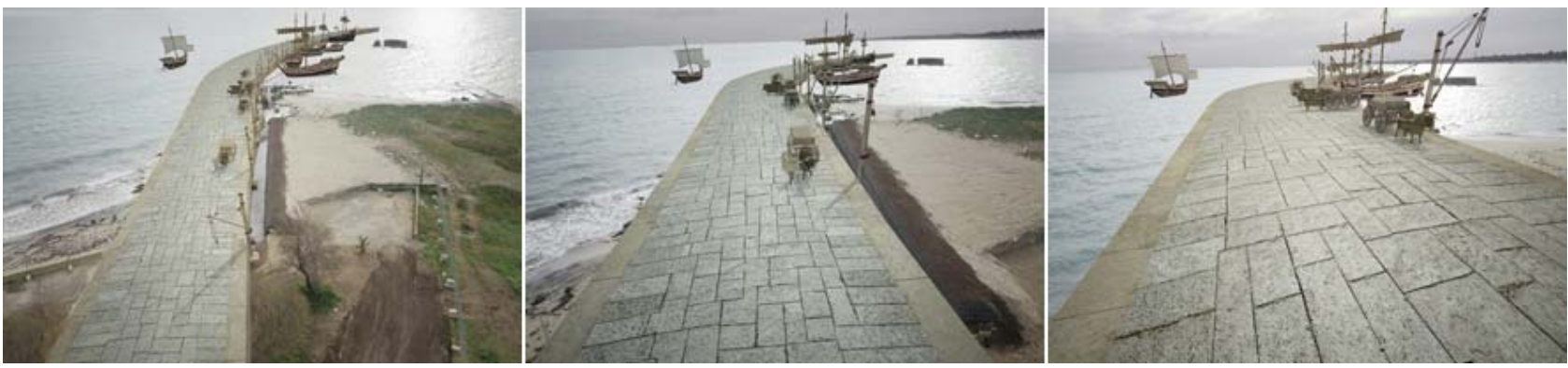

Figure 6: Visual synthesis of the narrativ process. The realistic model of the roman pier appers in its natural landscape.

\section{References}

FERRARI, I. and QUARTA, A., in press. II molo romano di San Cataldo (Le). Nuovi dati per una proposta ricostruttiva. 2nd International Conference of Aerial Archaeology. "From Aerostats to Drones: aerial imagery in Archaeology" (Rome, 3-5 February 2016). Poster session.

GABELLONE, F., 2011. The reconstructive study in archaeology: case histories in the communication issues. SCIRES-IT SClentific RESearch and Information Tec.hnology, 1, Issue 1, CASPUR-CIBER Publishing, http://caspurciberpublishing.it, DOI 10.2423/i22394303v2n2p99, pp. 53-78.

HERMON, S. and NIKODEM, J., 2008. 3D modelling as a scientific research tool in archaeology. In: A. POSLUSCHNY, K. LAMBERS AND I. HERZOG, eds., Layers of Perception. Proceedings of the $35^{\text {th }}$ International Conference on Computer Applications and Quantitative Methods in Archaeology (Berlin, April 2-6), Kolloquien zur Vor- und Frühgeschichte, Vol. 10, Bonn (CD-Rom)

NICCOLUCCI, F., 2002. Virtual Archaeology between Scientific Research and Territorial Marketing. Proceedings of the VAST EuroConference (Arezzo, November 2000). BAR International Series, vol. 1075, Oxford.

REMONDINO, F. and CAMPANA, S., eds, 2014. 3D Recording and Modelling in Archaeology and Cultural Heritage. Theory and best practices. BAR International Series, vol. 2598, Oxford. 
SAMMARCO, M. and MARCHI, S., 2012. Tra terra e mare: ricerche lungo la costa di San Cataldo (Lecce). Con un'Appendice litostratigrafica di S. MARGIOTTA. Journal of Ancient Topography, XXII,Congedo Editore, Galatina, pp. 107-132. 


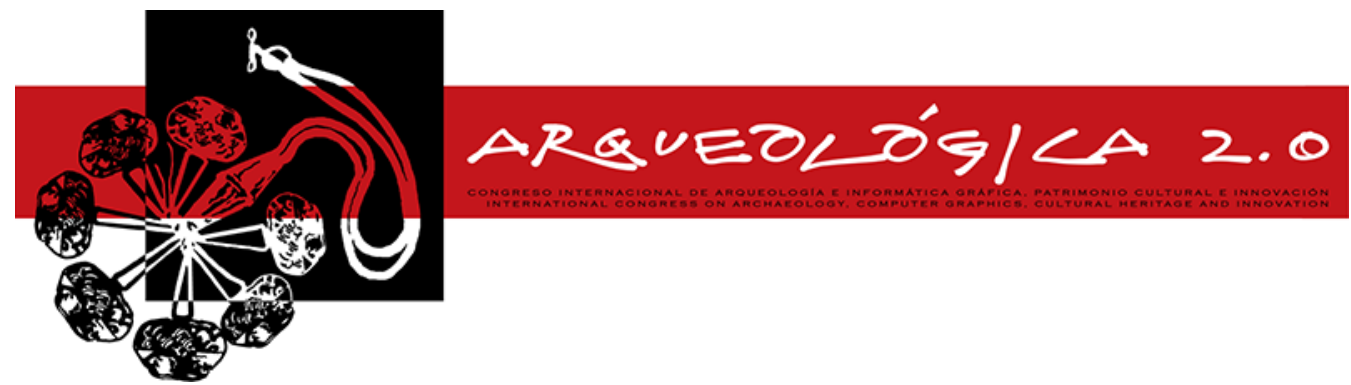

Proceedings of the $8^{\text {th }}$ International Congress

on Archaeology,

Computer Graphics,

Cultural Heritage and Innovation

'ARQUEOLÓGICA 2.0'

in Valencia (Spain),

Sept. $5-7,2016$

\title{
3D MODELING AND VIRTUAL APPLICATIONS FOR THE VALORIZATION OF HISTORICAL HERITAGE
}

\author{
Elisa Farella ${ }^{a,{ }^{,}}$, Fabio Menna $^{\mathrm{b}}$, Fabio Remondino $^{\mathrm{b}}$, Massimiliano Campi $^{\mathrm{a}}$ \\ ${ }^{a}$ Dept. of Architecture, Federico II University, Naples, Italy. elisa.farella88@gmail.com; campi@unina.it \\ b 3D Optical Metrology (3DOM) unit, Bruno Kessler Foundation (FBK), Trento, Italy. $\underline{\text { fmenna@fbk.eu; remondino@fbk.eu }}$
}

\begin{abstract}
:
A large amount of 3D digital models, acquired with reality-based techniques or modelled with CAAD methods, are today part of archaeological studies. This new form of heritage documentation has deeply changed the traditional way of representing, studying and visualizing the remains of the past. At the same time, 3D digital documentation is rarely shared and easily accessible, so as the historical iconographic sources, text documents and other information used for interpreting remains and for validating 3D reconstructions. This paper describes the first results of an interdisciplinary project of 3D documentation and valorization of historical heritage, carried out in the archaeological site of Pausilypon (Naples, Italy). The final aim is to realize an integrated virtual tour of the site, developed in Unity 3D, based on 3D surveying products. This tour proposes a new way of presenting and visualizing results of archaeological studies and 3D documentation, collecting and overlapping different types of data in a unique and interactive virtual environment. Besides $360^{\circ}$ equi-rectangular panoramic image and 3D models, heterogeneous material will help users to understand the interpretative process followed for the hypothetical CAAD reconstruction. These results will be mainly shared via web, for a larger dissemination of the work and for supporting future research on the site. In addition, for promoting the knowledge of the archaeological remains, a simplified and immersive tour will be developed for Virtual Reality devices.
\end{abstract}

Key words: Cultural Heritage, Documentation, 3D Modelling, 3D Reconstruction, Visualization, Valorization, Virtual Tour

\section{Introduction}

The drawing of ancient monuments has been, for centuries, a powerful instrument of knowledge in architecture and archeology. The development of several sensors and techniques for 3D digital surveying and documentation (Remondino 2011) is changing, in last years, the traditional way of recording and representing reality, following a new desire of visualizing and knowing the world through its three dimensions. This innovation has proved to be particularly relevant in those disciplines based on vision and on representation of archaeological artifacts as instruments for discovering and recomposing their ancient aspect. Traditional twodimensional documentation (plans, sections, photos, etc.) is, in fact, always a partial representation of a conservative condition and it is the result of a work of selection, simplification and interpretations of artifacts. Nowadays technological evolution allows to produce and to preserve in digital archives a huge amount of geometrical, colorimetric and volumetric information, freezing the actual condition of remains. The aim of this paper is to show the developed methodology not only to acquire 3D digital information with multi-technique procedures, but also to share products. Besides the recent evolution of reality-based techniques and CAAD modelling tools, in last years the development of Virtual
Reality (VR) applications is changing the traditional way to communicate and to disseminate archaeological results. In the presented case study, the interactivity and contents of applications are customized for different types of users, specifically scientists and non-expert users, respectively with research and promotional purposes.

\section{Case study}

The presented case study is the archaeological site of Pausilypon (Naples, Italy), where a project of 3D documentation, hypothetical reconstruction and virtual fruition of the area was carried out. The site (Fig. 1) preserves the remains of a spectacular maritime villa of Roman period, organized on three-level terraces. Bestpreserved structures are on the upper terrace: a Theatre $(47 \times 22 \mathrm{~m})$ and an Odeon (23×25m).

On the lower terrace, thermal baths are the only artifacts today visible. The ancient villa was much more extended, but today only a little part is preserved or recognizable. The hypothetical reconstruction of the site is, for this reason, very difficult but also very important. So far the project is mainly focused on the two theatres of the public area. The Theatre, built following the Greek rules (above the natural slope of the hill), could host up

‘Corresponding Author: Elisa Farella, elisa.farella88@gmail.com 
to 2.000 people. On the opposite side of this area, there is a smaller Odeon which was originally covered.

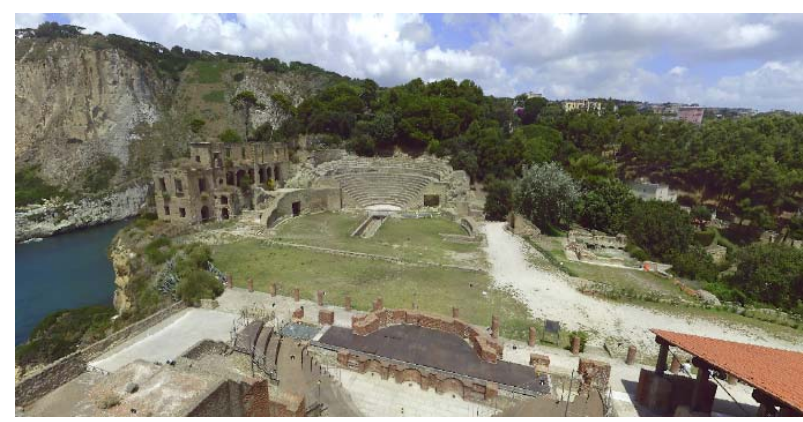

Figure 1: General view of the archaeological area in Pausilypon.

\section{3D reality-based surveying and modelling}

The survey of the area (ca 1 ha) required a multitechnique procedure. The entire area was firstly surveyed with a TOF laser scanner (Faro Focus 3D), planning and acquiring 29 medium resolution scans. This instrument has a range noise less than $1 \mathrm{~mm}$ for measurements up to $25 \mathrm{~m}$. The scans alignment and registration were carried out with the proprietary software, using printed checkerboard targets and spheres, distributed within the field of view of the instrument. The final point cloud is of about 338 million points (Fig. 2). The main difficulties of the TLS survey were the handling of the large quantity of data as well as the colouring of the point cloud due to overlapping scans and low-res embedded camera.

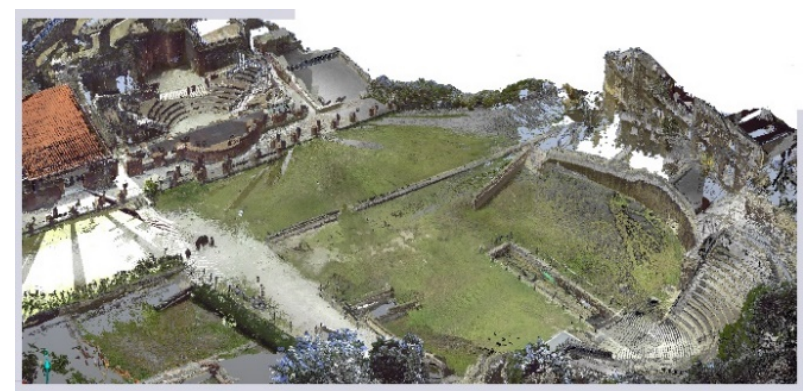

Figure 2: Laser scanning point cloud.

The site's survey was also accomplished using terrestrial photogrammetry (Nocerino et al. 2014), in order to close gaps and to improve texture information of the TLS data. The photogrammetric acquisitions (ca 140 images) were performed with a Nikon D7000, coupled with a $24 \mathrm{~mm}$ lens, keeping a mean GSD less than $5 \mathrm{~mm}$ for a 1:50 drawing scale. The project was scaled using a scale bar located on the field and the final dense point cloud contains ca 30 mil. points (Fig. 3). The main difficulties were associated to the complex and large scenario, the vegetation occluding some areas of the site as well as the textureless surfaces.

The integration of TLS and photogrammetric point clouds was carried out keeping the laser data as reference. The resulting merged point cloud was the base of the site's documentation and conservation whereas it was decimated at $5 \mathrm{~cm}$ sampling step for VR and valorization purposes. The generated polygonal model presented topological errors due to different and complex surfaces, required a long post-processing phase and was finally textured for the successive valorization steps.

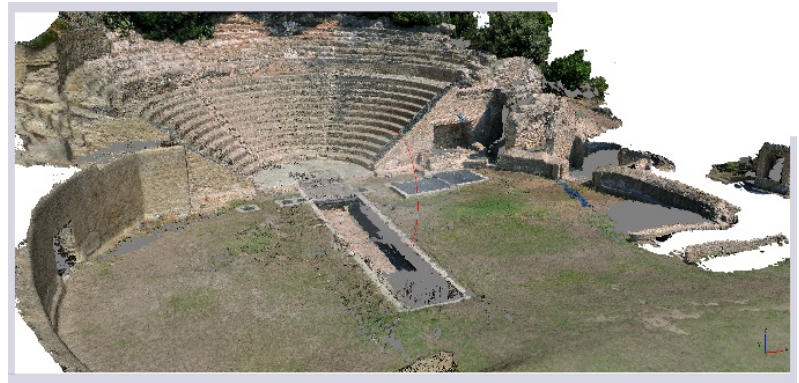

Figure 3: Photogrammetric dense point cloud.

\section{Hypothetical 3D reconstruction}

Recomposing the ancient aspect of artifacts has always been one of the main goal of archaeological studies. This practise showed to be powerful in communicating the value of fragmented spaces and architectures, difficult to recognize in their shapes and functions. The reconstructive process followed in this project started from the reality-based 3D models previously described, at the moment only for the Theatre. Initially geometrical features and constraints were extracted with planar sections from 3D models and compared with different descriptions and two-dimensional drawings of the area elaborated in different time periods, to analyse main differences between actual and previous conditions. Different sources (Fusco et al. 1842; Gunther 1913; Alvino 2001) describe the finding of the actual remains, the ancient aspect of the area and the first relevant restoration work of the 19th century. There were used to assemble the CAAD-based 3D hypothetical reconstruction of the structures (Fig. 4) which is taking into account the level of coherence between parts and elements today visible and corresponding descriptions and representations in the different periods (Guidi et al. 2014). In the final 3D reconstructive models, the use of different methods of representation will underline the different level of reliability of our hypothesis, based on the iconographical and bibliographical sources.

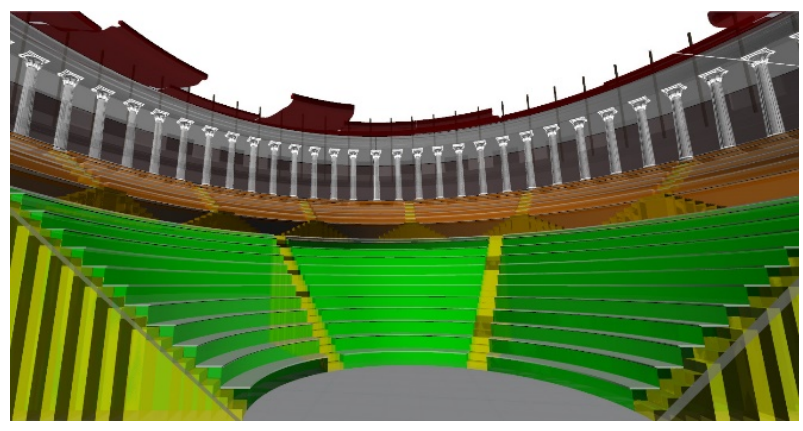

Figure 4: The CAAD-based hypothetical reconstruction of the Theatre based on the reality-based 3D model.

\section{The virtual tour of Pausilypon}

The development of a virtual tour of the site is the final step of the project with a disseminative and a promotional goal, considering different kinds of users (scientists and non-experts) and needs. 
A first enriched virtual tour for scientists, based on the Unity3D engine and the aforementioned 3D contents, will be shared via web, accessible online and open. The 3D informations and references could in fact help researchers, not only for comparisons but also for validating theories and reconstructive hypoteses. Inside the virtual tour, user will be able to navigate and interact with different virtual environments:

- $360^{\circ}$ equi-rectangualar panoramic images, acquired in different positions within the site. In every image, user can immersively explore the actual condition of the site. The visualization of the present state of this heritage is essential to compare and verify the achieved 3D results (Fig. 5).

- 3D reality-based data, overlapped to the panoramic images. The user can visualize the 3D data with its levels of details, holes, incoherences, geometrical and colorimetric results. This phase is important to evaluated results and data used for the following steps.

- References and other sources. This step represents the interpretative phase. Besides previous elements, other information (texts, bibliographical sources, historical drawing and photos, etc.) are part of this 3D environment. Principal geometries of $3 \mathrm{D}$ reconstructive model are also showed in this part, to verify coherence between our choices and corresponding references (Fig. 6).

- In this scaenario scientists working on similar task and research field can easily visualize and compare all data used in this project and can evaluate the realiability of the final 3D reconstructive model proposed.

- Final 3D virtual / hyphotetical reconstruction, overlapped to panoramic images.

- This environment contains starting and ending data (actual and original aspect of artifacts) of this project.

This last scaenario will be available also for a second simplified tour for not-expert users.

These contents will be shared for an immersive and interactive navigation through VR devices, with the main aim of promoting the knowledge of the historical heritage for its preservation.

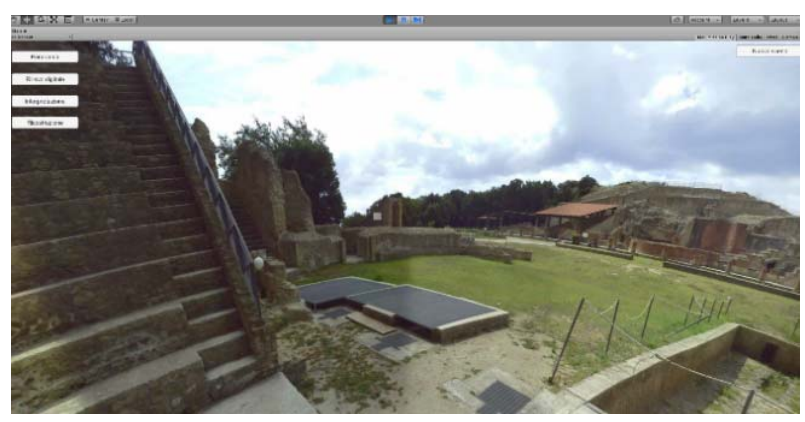

Figure 5: A panoramic view of the site inside Unity 3D gaming engine.

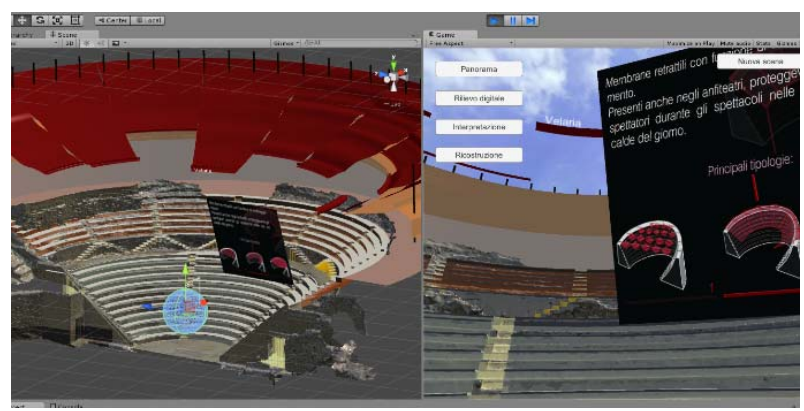

a)

b)

Figure 6: Virtual environment in Unity 3D with 2D and 3D data: a) scene planning; b) gaming view.

\section{Conclusions}

The paper presented the on-going work for the 3D documentation and valorization of the Pausilypon site. After the 3D documentation and modeling phase, the digital products were inserted in a game engine for valorization and communication purposes.

Virtual applications are indeed showing, in last years, their capabilities to offer ineditos scenarios in the traditional way of exploring and interacting with real or modelled worlds.

Moreover immersive experiences could attract and increase interests of a large part of younger and nonexperts users.

The last developed tour proposes a virtual immersive navigation into $360^{\circ}$ panoramic images and, through user input, it offers the chance of visualizing the hypotetical reconstruction elaborated in this project.

\section{References}

ALVINO, F., 2001. La collina di Posillipo. Napoli: Grimaldi \& C. Editori, 201 pages.

FUSCO, G.M., FUSCO, V. and TROJANO, A., 1842. Giunta al commento critico sul frammento inedito di Fabio Giordano intorno alle grotte del Promotorio di Posillipo. Napoli: Tipografia di Matteo Vara. Available at: https://books.google.it/books/reader?id=MoUGLAiR 9oC\&hl=it\&printsec=frontcover\&output=reader\&pg=GBS.PA10

GUIDI, G., RUSSO, M. and ANGHELEDDU, D., 2014. 3D survey and virtual reconstruction of archaeological sites. Digital Applications in Archaeology and Cultural Heritage, 1, pp.55-69. doi:10.1016/j.daach.2014.01.001

GUNTHER, R.T., 1913. Pausilypon. The imperial villa near Naples, with a description of the submerged foreshore and with observations on the tomb of Virgil and on other Roman antiquities on Posilipo. Oxford: University Press, 294 pages. Available at: https://archive.org/details/pausilyponimperi00gunt 
NOCERINO, E., MENNA, F. and REMONDINO, F., 2014. Accuracy of typical photogrammetric networks in cultural heritage 3D modeling projects. The International Archives of the Photogrammetry, Remote Sensing and Spatial Information Sciences, Volume XL-5. doi:10.5194/isprsarchives-XL-5-465-2014

REMONDINO, F., 2011. Heritage Recording and 3D Modeling with Photogrammetry and Laser Scanning. Remote Sensing, 3, pp. 1104-1138. doi:10.3390/rs3061104 


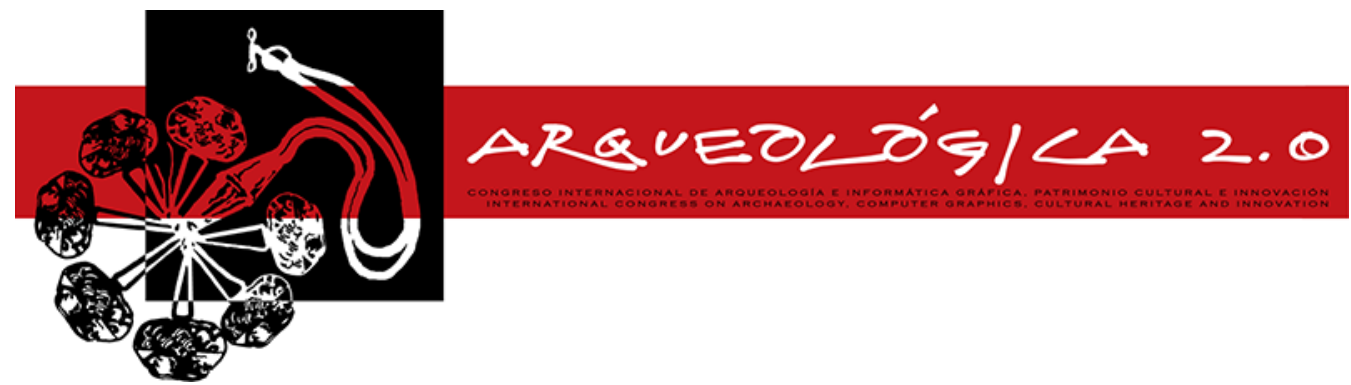

Proceedings of the $8^{\text {th }}$ International Congress

on Archaeology,

Computer Graphics,

Cultural Heritage and Innovation

'AROUEOLÓGICA 2.0'

in Valencia (Spain),

Sept. $5-7,2016$

\title{
TRABAJOS 3D REALIZADOS EN LA PUERTA 1 DEL COMPLEJO ARQUEOLÓGICO DE PERDIGÕES (PORTUGAL): ESTADO DE LA CUESTIÓN
}

\author{
3D WORKS IN THE ARCHAEOLOGICAL COMPLEX OF PERDIGÕES - GATE 1 (PORTUGAL): STATE OF THE ART
}

José L. Caro

Dpto. Lenguajes y Ciencias la Computación, Universidad de Málaga, ETSI Informática, 29071 Málaga, España. jlcaro@uma.es

\begin{abstract}
:
The University of Malaga has been excavating since 2008 at the Archaeological Complex of Perdigões. The incorporation of $3 \mathrm{D}$ technologies to archeology is now a fact and in this project has been used. This article aims to present the works taken place in the archaeological complex of Perdigoes related to the use of 3D technologies.

Key words virtual archaeology, digital archaeology, archaeological record, cultural heritage, documentation, 3D reconstruction, enclosures, Neolithic, calcolithic

\section{Resumen:}

La Universidad de Málaga lleva excavando en un proyecto internacional desde 2008 en el Complejo Arqueológico de Perdigões. La incorporación de las tecnologías 3D a la arqueología es hoy en día un hecho y en este proyecto no ha sido menos. El presente artículo tiene como objetivo presentar los trabajos realizados en el Complejo Arqueológico de Perdigões en lo que se refiere al uso de técnologías 3D.
\end{abstract}

Palabras clave: arqueología virtual, arqueología digital, documentación arqueológica, patrimonio cultural, reconstrucción 3D, recintos de fosos, Neolítico, calcolítico

\section{Introducción}

Durante los últimos años el número de recintos de fosos detectados en el suroeste de la península ibérica se ha incrementado (Valera y Pereiro 2013; Delibes et al. 2014). Debido a las características arquitectónicas que los definen, fosos y fosas excavadas sobre el sustrato geológico, y sobre todo las grandes dimensiones que pueden llegar a tener, son yacimientos arqueológicos de difícil difusión a diferencia de los henges (UK) cuyo foso está abierto y se ha mantenido su bank.

El equpo de investigación PERUMA (www.perma.es) lleva lustros estudiando el fenómeno de los recintos de foso y desde 2008 lleva realizando campañas arqueológicas en el Complejo Arqueológico de Perdigões (Reguengos de Monsaraz - Portugal). En este yacimiento estamos desarrollando y poniendo a prueba una metodología para el estudio del fenómeno y, en términos más concretos, sobre el llamado sector $L$ que ocupa la puerta 1. Una parte metdológica importante del estudio ha sido desarrollada usando tecnologías de la información y las comunicaciones y entre éstas, en el presente artículo, nos centraremos las que usan tecnologías 3D.

\section{Complejo Arqueológico de Perdigões}

El Complejo Arqueológico de Perdigões (Fig 1) se localiza en el Concelho de Reguengos de Monsaraz, a unos $2 \mathrm{~km}$ al NW del núcleo urbano, en el Alentejo portugués (distrito de Évora). Complexo Arqueológico dos Perdigões (Reguengos de Monsaraz, Portugal) está compuesto por un total de 12 fosos cuya cronología abarca desde el neolítico (los más interiores) al calcolítico los exteriores. Posee, además, un área en la que existen sepulcros funerarios, un crómlech y un menhir, ocupando en total una superficie de cerca de 16 ha de extensión.

El equipo de investigación PERUMA, surgido dentro del seno del Área de Prehistoria de la Universidad de Málaga, ha venido realizando actividades arqueológicas en el sitio, tras ser invitado en 2006 a participar en el Programa Global de Investigação Arqueológica dos Perdigões (INARP), coordinado por el Núcleo de Investigação Arqueológica (NIA) de ERA-Arqueologia.

El sector L, asignado al equipo se sitúa en una de las puertas del yacimiento, la denominada puerta 1. En el período 2008-2009 se realizaron prospecciones geofísicas que proporcionaron una ajustada definición de la planta del yacimiento (Márquez et al. 2008, 
Márquez et al. 2011). Durante los años 2009 y el 2010 se excava Foso 1, para lo que se aprovechó un sondeo ya iniciado por ERA en 1997 (Lago et al. 1998). Las campañas 2011 y 2012 consistieron en excavaciones en extensión, que acabaron configurando un gran corte (L1) con forma rectangular, dimensiones de $34 \mathrm{~m} \times 30 \mathrm{~m}$ (Suárez et al. 2012).

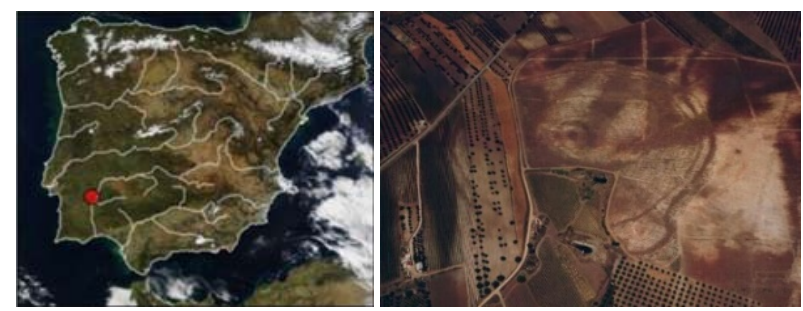

Figura 1: Localización del yacimiento y vista aérea (Lago et al. 1998).

\section{Trabajos digitales 3D realizados en Perdigoes: Una metodología para el estudio y puesta en valor}

Durante las campañas sobre la puerta 1 se ha ido desarrollando y perfeccionando una metodología que emplea medios digitales, tanto para el registro, estudio como para su futura difusión. En este apartado deseamos exponer metodológicamente el flujo de trabajo y herramientas desarrolladas durante los últimos 9 años cuyo objetivo es el registro, estudio, difusión y puesta en valor (Pavlidis et al. 2007). Todo ello siguiendo la filosofía de la carta de Londres (Denard 2012).

El flujo de trabajo y productos resultantes que describiremos en los siguientes apartados son: prospecciones geofísicas, microtopografía, fotogrametría y reconstrucciones.

El primer elemento metodológico usado como futura base para la elaboración modelos 3D sobre yacimientos de este tipo es la prospección geofísica (Márquez et al. 2011). Se partía de una fotografía aérea (Lago et al. 1988) (no ortofotográfica) del yacimiento que delimitaba algunos fosos pero no era suficiente para encajarla sobre el terreno por falta de precisión. Las prospecciones geomagnéticas dieron como resultado un magnetograma detallado en el que se puso de relieve la cantidad de fosos, hoyos y otras estructuras como puertas o imbrices mostrando la complejidad del yacimiento (Fig. 2).

La microtopografía del terreno (Fig. 2) permitió darle volumen, mediante un modelo digital del terreno (DTM Digital Terrain Model), a todas las estructuras del yacimiento e hizo posible el encaje de la microtopografía en una topografía actualizada y una nueva fotografía aérea proporcionando la base cartográfica necesaria para situar con rigor científico el resto de los elementos (Denard, 2012).

La técnica fotogramétrica ha sido usada para la documentación desde un punto de vista científico del patrimonio arqueológico, histórico y artístico y se ha convertido en un referente (Caro et al. 2016) siendo una competencia a técnicas más caras (Habbib et al. 2004) y pudiéndose usar para sistemas de realidad aumentada (Portales et al. 2009). Metodológicamente hablando se ha usado como marco teórico la fotogrametría y los algoritmos SFM (Structure from Motion). Para el desarrollo de las experiencias nos hemos decantado por la herramienta Photoscan de Agisoft (AGISOFT 2014).

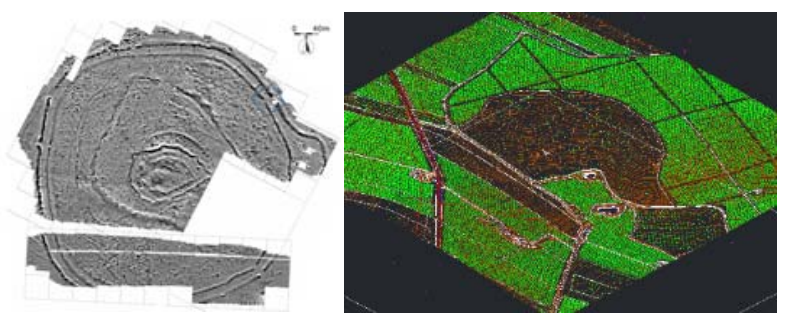

Figura 2: Geomagnética de Perdigões y sector L (izq) (Marquez et al. 2011) y microtopografía (der.).

Las primeras experiencias que realizamos estuvieron relacionadas con la aplicación de la fotogrametría con el objetivo de generar restituciones que apoyaran el dibujo y registro así como la planimetría general. Se obtuvieron como resultado unas plantas sintéticas de grandes extensiones entre las que destacamos la planta de 2012 que aportó la visión completa del corte (Fig. 3).

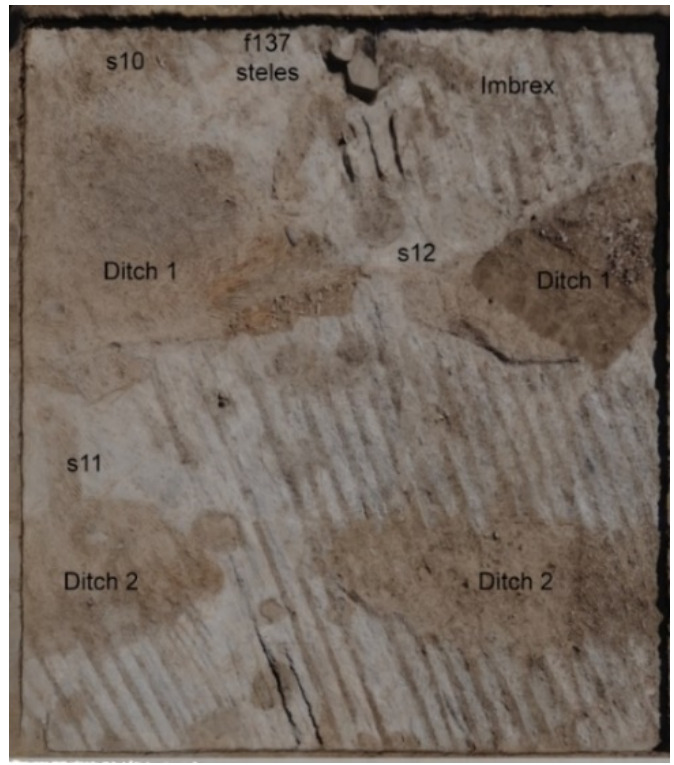

Figura 3: Aspecto general del entorno de la Puerta 1 del Foso 1 (fotogrametría) (Caro et al. 2016).

Un segundo ámbito de aplicación lo realizamos en "micro" elementos usando un ídolo cerámico y una pesa de telar decorada (Fig. 4) siendo mayor la necesidad de tomas fotográficas para una fotogrametría de detalle.

Por último, con toda la información obtenida mediante las técnicas anteriores estábamos en disposición de ofrecer adelantos en lo que se refiere a la reconstrucción para una mejor comprensión del yacimiento. Para abordar esta tarea se han emprendido dos caminos bien diferenciados. Por un lado, la reconstrucción basada en las plantas y estructuras usando software de render tradicional $y$, en segundo lugar, usando game-engines.

Así, siguiendo métodos de render y basándonos en los estudios realizados sobre la misma se realizó una reconstrucción tentativa de la puerta 1 levantando una de las estelas. En la Figura 5 podemos observar 
algunas de las fases de trabajo para obtener el resultado final. A partir de estos mismos modelos se ha abordado el uso para recreación y naviegación en entorno inmersivo e game-engines. El uso de las game engine en el modelado y difusión del patrimonio está en vigor debido a las características de estos sistemas (Bruno et.al. 2010; Svana 2010; Merlo et.al. 2012; Caro y Hansen 2015). Incluso pueden ser empleados como sistemas de tipo story tellers representando la vida cotidiana o algún tipo de escenificación histórica, gracias a las posibilidades de incorporación elementos animales y humanos animados.

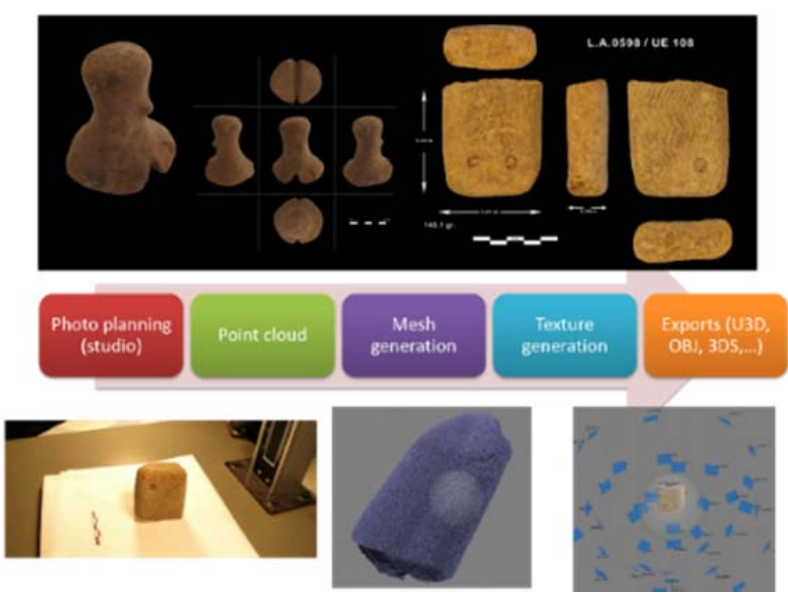

Figura 4: Selección de piezas para el modelado de artefactos (ídolo-izquierda-, pesa de telar-derecha-).
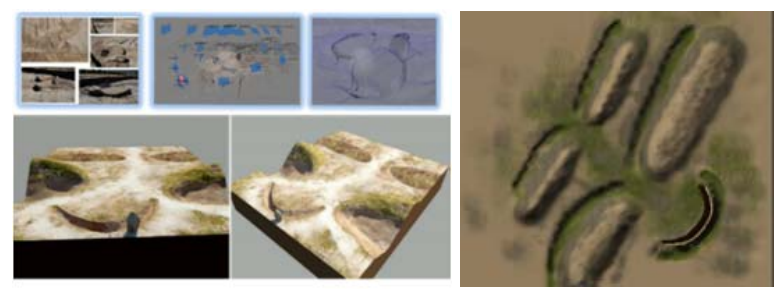

Figura 5: Algunas fases de reconstrucción de la puerta 1 de Perdigões (izq.) y su render en Unity3D (der.).
Usando proporciona Unity3D panteamos el modelado de la puerta 1 para una paseo virtual en un mundo inmersivo (Fig. 5).

\section{Conclusiones y Trabajo Futuro}

En el presente artículo hemos desarrollado la metodología digital que está poniendo en práctica el equipo PERUMA en el seno de Complejo Arqueológico de Perdgiões. Pretendemos con el mismo mostrar las diferentes herramientas empleadas que abarcan desde el proceso de detección del yacimiento hasta la puesta en valor del mismo. Conviene reincidir en que los yacimientos de tipo recintos de fosos son de difícil puesta en valor y protección debido a su singularidad. Todas son estructuras en negativo que están totalmente rellenas de forma antrópica.

La metodología empleada: prospecciones geofísicas, modelos digitales del terreno (foto aérea y microtopografía) y registro fotogramétrico proporcionan un marco necesario para una correcta recreación de los mismos mediante una base científica y en ellos seguiremos incidiendo en nuevos yacimientos que puedan ser estudiados así como en el propio caso de estudio en sucesivas campañas arqueológicas.

En el futuro incorporaremos y testearemos otras herramientas al flujo de trabajo. Las más reseñables son, por un lado, las herramientas dedicadas a la teledetección como LiDAR empleada para estudios del paisaje Un segundo campo que abordaremos es la recreación física usando impresoras $3 \mathrm{D}$ de los modelos obtenidos tanto de piezas singulares como de espacios y la conexión de las game-engines con sistemas de realidad virtual y realidad aumentada que proporcionen información enriquecida al visitante de forma física.

\section{Agradecimientos}

Este trabajo ha sido apoyado por el Ministerio de Economía y Competitividad (España) con la subvención al PROYECTO I+D+I HAR2014-53692-P: Arqueología y Patrimonio en los recintos de fosos, teledetección, caracterización y protección en yacimientos del suroeste de la Península Ibérica

\section{Referencias}

AGISOFT, 2014. Photoscan [online] http://www.agisoft.ru/products/photoscan [consult: 10-09-2014]

BRUNO, F., BRUNO, S., DE SENSI, G., LUCHI, M.L., MANCUSO, S., y MUZZUPAPPA, M., 2010. From 3D reconstruction to virtual reality: A complete methodology for digital archaeological exhibition. Journal of Cultural Heritage, 11(1), 42-49. DOI:10.1016/j.culher.2009.02.006

CARO, J.L., MÁRQUEZ, J.E., y JIMÉNEZ-JÁIMEZ, V., 2016. Using digital photogrammetry to produce 3D models at prehistoric ditched enclosures: Perdigões as a case study. In: H. Kamermans, W. de Neef, and C. Piccoli, eds., The Three Dimensions of Archaeology. XVII World UISPP Congress (pp. 61-72). Burgos: Archaeopress Archaeology.

CARO, J.L. y HANSEN, S., 2015. From Photogrammetry to the dissemination of archaeological heritage using game engines: Menga case study. Virtual Archaeology Review, [S.I.], v. 6, n. 12, p. 58-68, oct. 2015. ISSN $1989-9947$. Available at: <http://polipapers.upv.es/index.php/var/article/view/4159>. DOI:http://dx.doi.org/10.4995/var.2015.4159.

DELIBES, G., GARCÍA, M., DEL OLMO. J. y SANTIAGO, J., 2014. Recintos de fosos calcolíticos del valle medio del Duero: Arqueología Aérea y Espacial. Universidad de Valladolid

DENARD, H., 2012. The London charter for the computer-based Visualisation of cultural Heritage (Version 2.1 february 2009). In: A. Bentkowska-Kafel, H. Denard, and D. Baker, (Eds.), Paradata and Transparency in Virtual Heritage (pp. 73-80). Ashgate. 
HABIB, A.F., GHANMA, M.S., AL-RUZOUQ, R.I., y KIM, E.M., 2004. 3D Modelling of Historical Sites using LowCost Digital Cameras. In: XXXVth Congress of ISPRS. International Society for Photogrammetry and Remote Sensing.

LAGO, M., DUARTE, C., VALERA, A., AlBeRgARIA, J., AlMEIDA, F., CARVALHO, A.Y. y REIS, S.,1998. Povoado Pré-Histórico dos Perdigões (Reguengos de Mosaraz). Relatório final dos trabalhos de salvamento arqueológico. Relatórios Era, 1, ERA-Arqueologia, Lisboa (Portugal).

MÁRQUEZ, J.E., JIMÉNEZ, V. y MATA, E., 2008. Excavaciones en el yacimiento de Perdigões (Reguengos de Monsaraz, 2080-2010). Universidad de Málaga (España). Apontamentos de Arqueologia e Património 2: 41-48.

MÁRQUEZ, J.E., VALERA, A.C., BECKER, H., JIMÉNEZ, V. y SUÁREZ, J., 2011. El Complexo Arqueológico dos Perdigões (Reguengos de Monsaraz, Portugal). Prospecciones Geofísicas - Campaña 2008-09. Trabajos de Prehistoria 68, nº 1: 175-186. DOI: http://dx.doi.org/10.3989/tp.2011.11065.

MERLO, A., DALCÒ, L. y FANTINI, F., 2012. Game engine for Cultural Heritage: New opportunities in the relation between simplified models and database. Virtual Systems and Multimedia pp. 623-628. DOI: http://dx.doi.org/10.1109/vsmm.2012.6365993.

PAVLIDIS, G., KOUTSOUDIS, A., ARNAOUTOGLOU, F., TSIOUKAS, V. y CHAMZAS, C., 2007. Methods for 3D digitization of Cultural Heritage. In: Journal of Cultural Heritage, 8(1), 93-98. DOI:10.1016/j.culher.2006.10.007

PORTALÉS, C., LERMA, J.L., y PÉREZ, C., 2009. Photogrammetry and augmented reality for cultural heritage applications. The Photogrammetric Record, 24(128), pp. 316-331. DOI:10.1111/j.1477-9730.2009.00549.x

SUÁREZ, J., CARO, J.L., MATA, E., MÁRQUEZ, J.E. y JIMÉNEZ, V., 2012. Excavaciones en extensión de la Universidad de Málaga (UMA) en el yacimiento de Perdigões (Reguengos de Monsaraz, Portugal). El sondeo L1. Campañas 2011-2012. In: VI Encuentro de Arqueología del Suroeste Peninsular, pp. 521-549.

SVANA, D., 2010. Environment re-creation methods for virtual heritage using a game engine with discernment of visual learning cues. Norwegian University of Science and Technology. [online] http://www.divaportal.org/smash/get/diva2:418961/FULLTEXT01.pdf [Consult: 10-08-2014]

VALERA, A.C., y DO PEREIRO, T., 2013. Novos recintos de fossos no sul de Portugal: o Google Earth como ferramenta de prospecção sistemática.In: Arqueologia em Portugal. 150 anos. Retrieved March 13, 2014, from https://www.academia.edu/5221647/Novos_recintos_de_fossos_no_sul_de_Portugal_o_Google_Earth_como_ferram enta_de_prospeccao_sistematica 


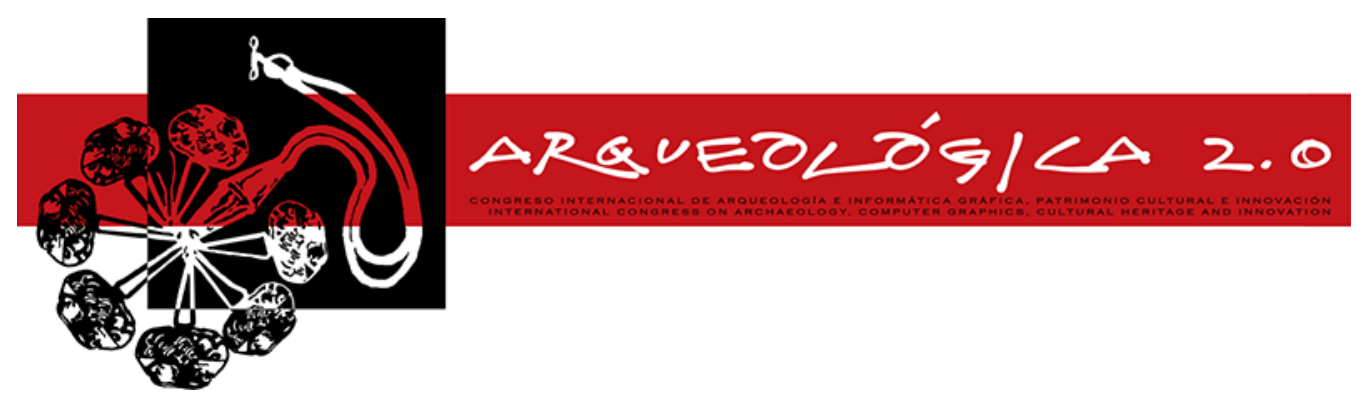

Proceedings of the $8^{\text {th }}$ International Congress

on Archaeology,

Computer Graphics,

Cultural Heritage and Innovation

'AROUEOLÓGICA 2.0'

in Valencia (Spain),

Sept. $5-7,2016$

\title{
3D SURVEY AND HBIM FOR THE KNOWLEDGE AND VALORIZATION OF ARCHEOLOGICAL HERITAGE. THE CASE STUDIES OF THE CAPUA AND TELESIA AMPHITHEATRES
}

\author{
Domenico lovane ${ }^{\star}$, Valeria Cera \\ Dept. of Architecture, University of Naples "Federico II", via Forno vecchio, 36, 80134, Naples, Italy. domenico.iovane@unina.it; \\ valeria.cera@unina.it
}

\begin{abstract}
:
Survey in Archaeology is aimed to represent, map and model the existent. The reality based modern techniques allow to acquire a large amount of geometric, colorimetric and volumetric informations on which deepen analysis of past artifacts. This paper describes the first phase of a work aimed to a better understanding of two Roman amphitheatres in Campania, the Capua and Telesia ones. The survey campaign, conducted by the integration of different techniques, from laser scanner to GPS, from total station to digital photogrammetry, allowed a full investigation about the construction of the two examples, in order to explain the differences and uniqueness. At the same time, the research purpose is to display and disseminate the results, structured according to the Historic Building Information Modeling. The structuring into three-dimensional families of parametric objects, connoted by various information that identifies them on time, allows the transmission of an in-depth systematized knowledge. This is able to communicate with the various professionals involved in the conservation and protection of cultural heritage. Parametric modeling is applied in the study for the remains of the two archaeological sites and also in the reconstruction of their original form.
\end{abstract}

Key words: virtual archaeology, cultural heritage, documentation, 3D modelling, 3D survey

\section{Introduction}

The modern techniques and 3D digital survey methodologies, with the development of more efficient sensors, allow the documentation, preservation and digital representation of sites and architectures with extraordinary geometrical and visual results (Remondino 2011). They are transforming the traditional approach to the study of the artifacts, based on two-dimensional drawings. The Three-dimensional models obtained are widely used in those areas where the display of the third dimension is particularly effective, as in archaeological studies that are governed by the fragmentary and paucity of remains. From these premises, the present study starts to aim at deepening the knowledge of some examples of the typical Roman entertainment architecture: the amphitheatres. Their development occurred throughout the Empire with variations in size and shape. Our case studies are the amphitheaters of Telesia and Capua Antica, located in Campania, a region of southern Italy. The purpose is to show, from the developed methodology to capture digital 3D information with integrated methodologies, the critical inferences that the acquired data have allowed to develop and the procedure to systematize and share the results, expanding the degree of knowledge and detail.

\section{Case studies}

The amphitheater of Telesia (Fig.1), the city currently known as San Salvatore Telesino, is located in the west, just outside the city gate. It's built in a natural valley arranged and adapted for that purpose. The building is entirely made of concrete and the construction scheme is made of approximately 64 radial wedges. The major axis of the arena is 67.80 meters in size and minor one is of 42.10 meters in size. The construction technique of the amphitheater, known as "quasi reticolato", allows to date the complex as built in the first half of the first century B.C. (Adam 2011), like the Pompei one. But when we see the architectural technique, we can notice that it would be the first example of "cavea sostruita" on a common system made of vaults cast on radial wedges. The Pompeian one has its substructure on the embankment instead.

The second amphitheater is the Capua one (Fig. 2), it is located in Santa Maria Capua Vetere, one of the most important cities of the Campania, which Tito Livio called "urbs maxima opulentissimaque Italiae" (the largest and richest city of Italy), and Cicero called "altera Roma" (second Rome). The size of the complex are: major axis, with N-S orientation, 167 meters; lower axis, with E-W orientation, 137 meters. The height of the façade was approximately 46 meters. It was divided into four levels:

`Corresponding Author: Domenico lovane, domenico.iovane@unina.it 
the first three have 80 rhythmic arches while the last one has a sequence of openings placed on axis of the underlying arches (Golvin 1988).

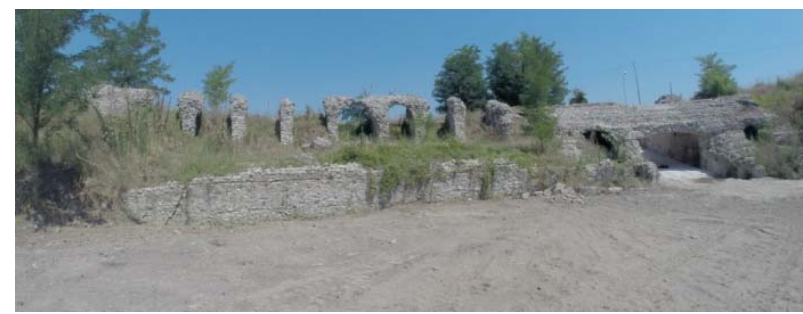

Figure 1: General view of the Telesia amphitheatre.

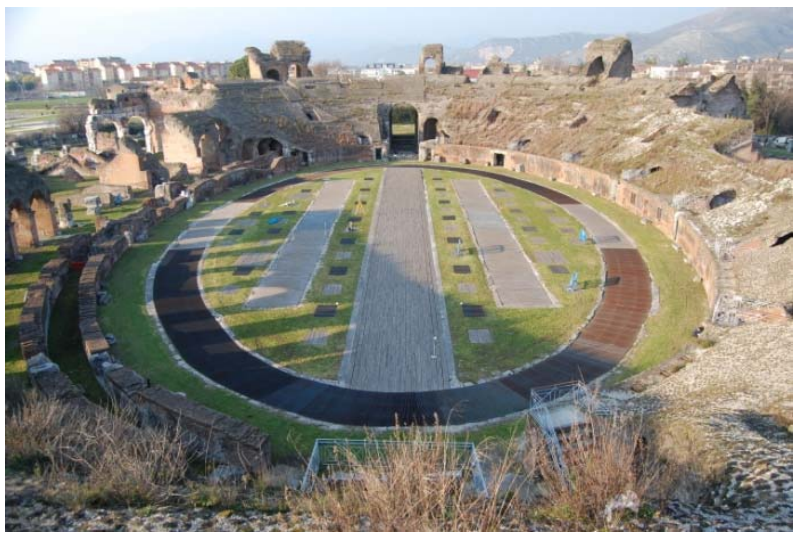

Figure 2: General view of the Capua amphitheatre.

\section{Multi-technique surveying}

The geometrical-dimensional data of the subject of study were captured by integrating different surveying methodologies.

The detection of the amphitheater of the ancient Capua was carried out using the GNSS mode and classifying it into the WGS84 system (reported to the Regional Network of GNSS Campania). A digital terrestrial photogrammetric survey phase was conducted by collecting image and location data. The equipment used is a NIKON D40 camera and a Laser Total Station TOPCON GPT-3000. Another survey phase was carried out by using a laser scanner CAM2 Focus3D Faro with a spatial resolution of $6 \mathrm{~mm}$ to $6 \mathrm{~m}$, medium quality. This system produced 56 scans. The alignment and the registration of the scans were made by its proprietary software using plain and spherical targets. The result was a pointcloud made by approximately $250 \mathrm{mln}$ of vertices (Fig. 3).

To capture the amphitheater of Telesia we used the range imaging technique of digital photogrammetry. The photographic acquisitions were made by a NIKON D40 camera equipped with a $18 \mathrm{~mm}$ lens with constant focal length.The arena was captured by 62 frames which produced a pointcloud of 49765 vertices. The gate was captured by 58 shoots instead and the obtained pointcloud was made by approximately 218882 vertices (Fig. 4).

\section{Surveying to discover}

Combining different surveying methodologies we were able to document the conservation status for both complexes and to provide a scientifically rigorous base in order to develop deeper analysis. The survey in Telesia has allowed to increase the studies on the geometry of the arena. Obtaining the axis size $(42.10 \mathrm{x}$ 67.80 meters) and applying the mathematical rules related to the ellipse we proceeded to determine algebraically the coordinates of the foci. Then we applied the definition of ellipse: if you take any point on the ellipse, the sum of the distances to the focus points is constant (PF1 + PF2 = 2a constant). So we took any point from the arena perimeter and we noticed that we were not able to satisfy the above definition. Therefore, it was possible to affirm with certainty that the figure that defines the geometry of the arena is an oval. The redesign and overlapping an ellipse and an oval on the amphitheater plan confirmed our thesis (Fig. 5).

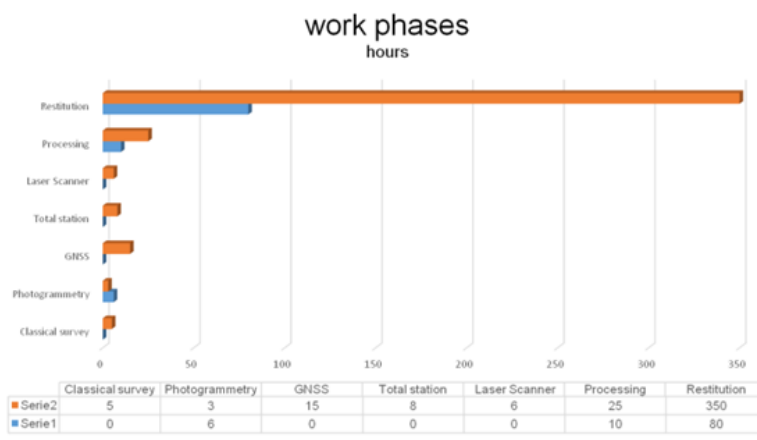

Figure 3: Comparative study of work phases: In blue Amph. Telesia, in red Amph. Capua Antica.

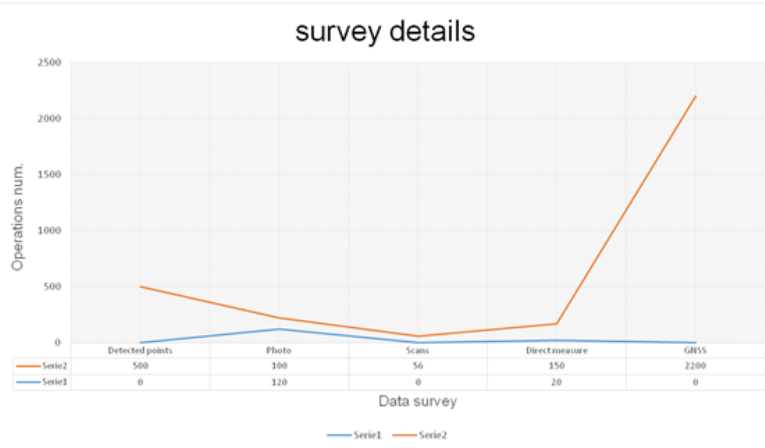

Figure 4: Comparative study of survey data.

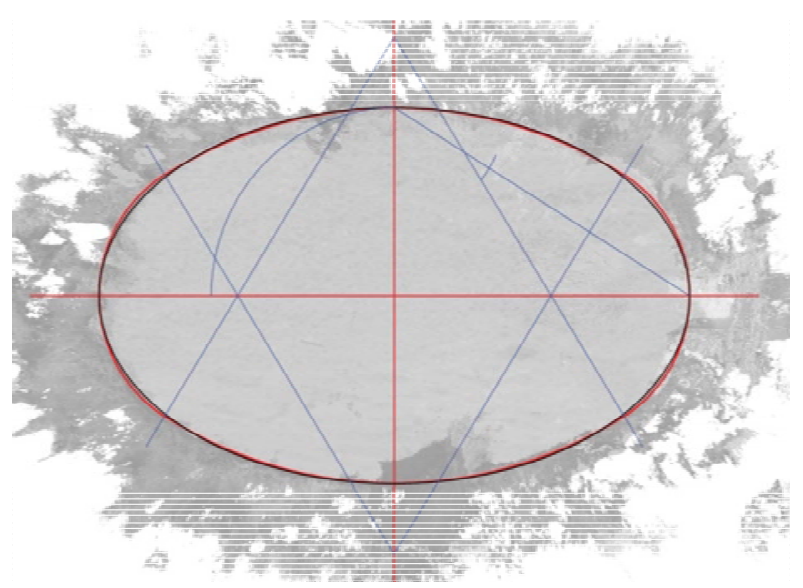

Figure 5: Geometric study about the Telesia's arena. In red the ellipse, in black the oval, in blue the construction lines of the oval. 
The detection of the amphitheater of the ancient Capua was carried out using the GNSS mode and classifying it into the WGS84 system (reported to the Regional Network of GNSS Campania). A digital terrestrial photogrammetric survey phase was conducted by collecting image and location data. The equipment used is a NIKON D40 camera and a Laser Total Station TOPCON GPT-3000. Another survey phase was carried out by using a laser scanner CAM2 Focus3D Faro with a spatial resolution of $6 \mathrm{~mm}$ to $6 \mathrm{~m}$, medium quality. This system produced 56 scans. The alignment and the registration of the scans were made by its proprietary software using plain and spherical targets. The result was a pointcloud made by approximately $250 \mathrm{mln}$ of vertices (Fig. 3).

To capture the amphitheater of Telesia we used the range imaging technique of digital photogrammetry. The photographic acquisitions were made by a NIKON D40 camera equipped with a $18 \mathrm{~mm}$ lens with constant focal length.The arena was captured by 62 frames which produced a pointcloud of 49765 vertices. The gate was captured by 58 shoots instead and the obtained pointcloud was made by approximately 218882 vertices (Fig. 4).

\section{Surveying to discover}

Combining different surveying methodologies we were able to document the conservation status for both complexes and to provide a scientifically rigorous base in order to develop deeper analysis. The survey in Telesia has allowed to increase the studies on the geometry of the arena. Obtaining the axis size $(42.10 \mathrm{x}$ 67.80 meters) and applying the mathematical rules related to the ellipse we proceeded to determine algebraically the coordinates of the foci. Then we applied the definition of ellipse: if you take any point on the ellipse, the sum of the distances to the focus points is constant $\left(P F_{1}+P F_{2}=2 a\right.$ constant $)$. So we took any point from the arena perimeter and we noticed that we were not able to satisfy the above definition. Therefore, it was possible to affirm with certainty that the figure that defines the geometry of the arena is an oval. The redesign and overlapping an ellipse and an oval on the amphitheater plan confirmed our thesis (Fig. 5).

The survey of Capua antica was carred out for the whole archeology area including the first amphitheatre too, which is samller and older than the one we're studying. We noticed the existence of differences between the alignments of amphitheaters plans. Especially, the large amphitheater follows the major axis aligned in northsouth direction while the small one, according to the same alignment, has a rotation towards the west of approximately $5^{\circ}$. Becaude of the high degree of precision of current instrumentation it is possibile to estimate this rotation but it is believed to be almost imperceptible or equal to zero in relation to the reduced degree of precision of the instrumentation of that period. However it is present and characterizing the archaeological complex. (Fig. 6).

The new discoveries, made possible by the survey, are an interesting progress in the state of knowledge relating to amphitheaters presented in this paper. In addition, the results have allowed us to start a further stage of work, currently on-going, consisting in modeling the whole anfiteatrale complex. The purpose of modeling is not limited to the simple reconfiguration of the morphology of the two amphitheatres. It wants to be a container of much more detailed and differentiated informations. The work is conducted in the context of Historic Building Information Modeling HBIM (Murphy et al. 2012). The point clouds were imported in a BIM software and segmented to locate, to map and to classify all observed architectural elements (arches, columns divided into base, shaft, capital, busts, etc). All these elements will be modeled from the cloud, involving not only sizing parameters but also informations regarding the construction geometry, color, material, state of preservation. The result will be a complete $3 \mathrm{D}$ model, which can be interrogated and investigated in all its aspects. In this first step, it has already been possible to find as, in relation with the parameters set for the acquisition of data, the cloud obtained by laser scanner enables a better reading of the points compared to that returned by digital photogrammetry (Fig.7). Finally, the union of these data will allow not only the spread of general knowledge of the sites to the general public therefore visualization but simultaneously the realization of an enriched documentation for experts who want to participate with cataloging, preservation or restoration.

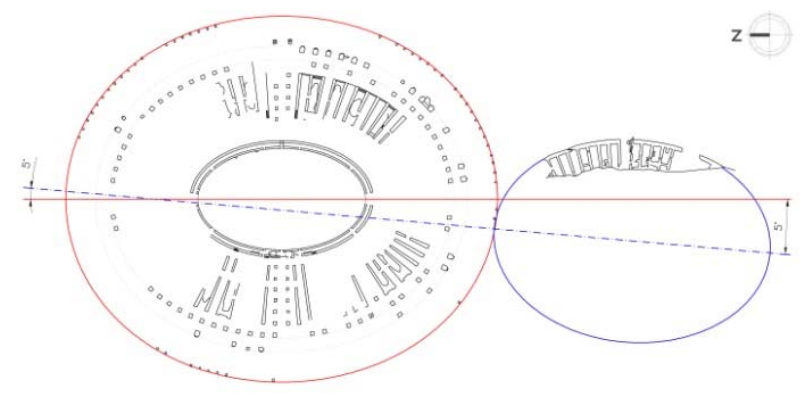

Figure 6: The $5^{\circ}$ rotation between the two amphitheatres of Capua Antica.

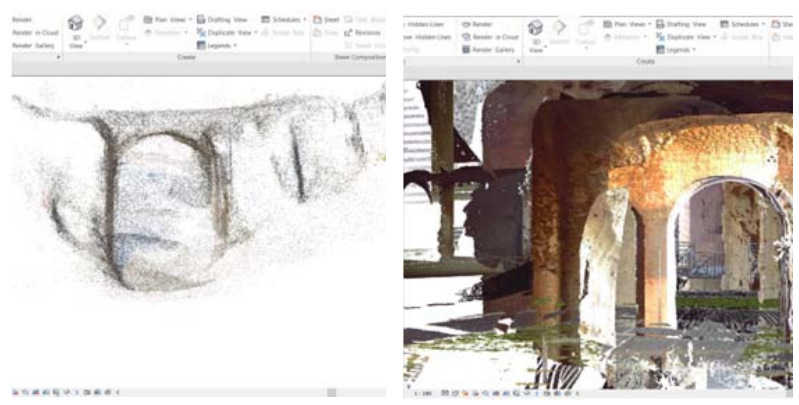

Figure 7: Differences between the two poincloud (TLS and photogrammetry) into software BIM.

\section{Conclusions}

The paper shows the on-going work of documentation and valorization of two evidences of the complex of Roman amphitheatres in Campania, Italy. The potential of surveying technologies - capable of acquiring in rapid time a large amount of metric and colorimetric data, highly accurate - in union with the most recent and smart modeling practices, Building Information Modelling - now applied to the historical heritage - made it possible to deepen the knowledge of representative architecture of the Roman Empire. The image based and range based tecniques allow to investigate the artifacts of the past, discovering underlying geometry, construction 
techniques, guiding principles not otherwise detectable. At the same time, the 3D models made by these methodologies become the basis for new forms of heritage documentation: parametric queried models, profoundly innovative than the traditional way of representing, studying and displaying the remains of the past. Thanks to parametric modeling you can overcome the limits of conservation experts, who are very often not able to manipulate the data of point clouds used as a simple display devices. It allows to reach a rationally systematized documentation, that allows to communicate with the various professionals involved in the preservation and protection of cultural heritage.

\section{References}

ADAM, J.P., 2011. L'arte di costruire presso i romani, materiali e tecniche, Milano, Longanesi. ISBN 978-88-304-0855-5

GOLVIN, J.C., L'Amphithéâtreromain: Essai sur la théorisation de sa forme et de sesfonctions, 2 voll., De Boccard, Paris, 1988. ISSN 0339-1736

MURPHY, M., MCGOVERN, E. and PAVIA, S., 2013. Historic Building Information Modelling - Adding intelligence to laser and image based surveys of European classical architecture. ISPRS Journal of Photogrammetry and Remote Sensing, 76 (2013), pp. 89 -102. ISSN: 0924 - 2716

REMONDINO, F., 2011. Heritage Recording and 3D Modeling with Photogrammetry and Laser Scanning. Remote Sensing, 3, pp. 1104-1138. DOI:10.3390/rs3061104. 


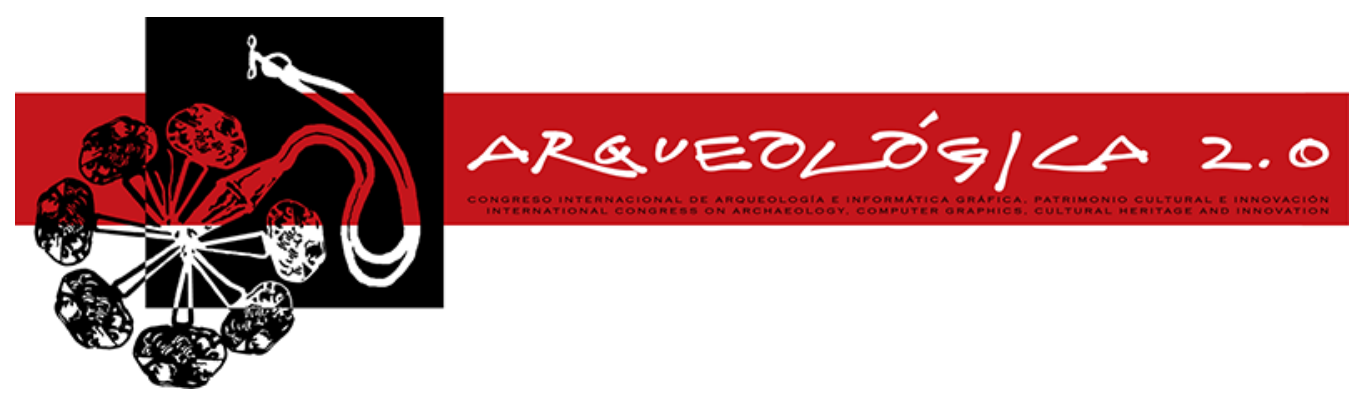

Proceedings of the $8^{\text {th }}$ International Congress

on Archaeology,

Computer Graphics,

Cultural Heritage and Innovation

'ARQUEOLÓGICA 2.0'

in Valencia (Spain),

Sept. $5-7,2016$

\title{
NUEVAS PUERTAS VIRTUALES AL MUNDO DE LA PRESERVACIÓN Y DIFUSIÓN DEL PATRIMONIO HISTÓRICO MILITAR. UN COMPROMISO POR EL FUTURO DE LA INVESTIGACIÓN Y EL CONOCIMIENTO
}

\section{NEW VIRTUAL GATES TO THE WORLD OF PRESERVATION AND DIFFUSION OF THE MILITARY-HISTORICAL HERITAGE. A COMMITMENT TO THE FUTURE OF RESEARCH AND KNOWLEDGE}

\author{
Margot Gil-Melitón ${ }^{a}$, José Luis Lermab \\ ${ }^{a}$ Máster SEAV en Arqueología y Patrimonio Virtual. Grado en Ingeniería en Geomática y Topografía. Investigadora en el Museo \\ Nacional del Ejército, Alcázar de Toledo, Unión s/n, 45001 Toledo, Spain. margot@ingheritag3d.com \\ ${ }^{\mathrm{b}}$ Grupo de Investigación en Fotogrametría y Láser Escáner (GIFLE). Departamento de Ingeniería Cartográfica, Geodesia y \\ Fotogrametría. Universitat Politècnica de València, Spain. jllerma@cgf.upv.es
}

\begin{abstract}
:
The use of techniques employed in fields so indispensable and developed for the earth sciences such as geomatics and surveying, and the application of information \& communication technologies (TIC), have transcended the scope of museums to the point that they are now responsible for their democratization.

Physical conservation is no longer enough for a resource as valuable as cultural heritage. It needs to be complemented by a digital preservation in all its forms. It is essential and necessary for its proper safeguard. Geometrical documentation, three dimensional (3D) reconstruction and 3D modelling are affective techniques to achieve the key targets for investigation, education, diffusion and preservation of pieces of historical armament.

Both heritage and virtual archaeology are fundamental pillars to delve into the future of education and knowledge. It is said that "Research begins when somebody has doubts about a specific topic and is pushed to find the means to resolve it". We bet for a culture which prepares us for researching, and we will try to show through this project how research can contribute to society.
\end{abstract}

Key words: virtual archaeology, cultural heritage, documentation, 3D reconstruction

\section{Resumen:}

El uso de las técnicas empleadas en campos tan imprescindibles y desarrollados en las ciencias de la tierra, como son la geomática y la topografía, y la aplicación de las tecnologías de la información y la comunicación (TIC), han ido transcendiendo al ámbito de los museos, de tal forma, que están siendo responsables de su democratización.

Un recurso tan valioso como es el patrimonio cultural ya no se conforma con una conservación física, debe complementarse de una preservación digital en todas sus formas, siendo básico y necesario para su adecuada salvaguarda. La documentación geométrica, la reconstrucción tridimensional (3D) y el modelado 3D son métodos eficaces para alcanzar unos objetivos clave en la investigación, educación, difusión y preservación de piezas de armamento histórico.

Tanto el patrimonio como la arqueología virtual son pilares fundamentales a la hora de profundizar en el futuro de la educación y el conocimiento. Se dice que "la Investigación comienza cuando uno tiene dudas sobre un tema determinado y es impulsado a buscar medios de satisfacerlo". Apostamos por una cultura que nos prepare para investigar, y desde este proyecto vamos a intentar demostrar lo que la investigación puede aportar a la sociedad.

Palabras clave: arqueología virtual, patrimonio cultural, documentación, reconstrucción 3D

‘Corresponding Author: Margot Gil-Melitón, margot@ingheritag3d.com 


\section{Introducción}

La investigación que se desarrolla en este artículo se centra en la documentación geométrica, la reconstrucción $3 \mathrm{D}$ y en el modelado 3D, a partir de fotogrametría digital de objeto cercano. Estos procesos se aplicarán en piezas y planos de armamento histórico pertenecientes a diferentes colecciones y épocas. Todo ello localizado en los fondos del Museo del Ejército de Toledo (MUSEJE).

Con el uso y la aplicación de tecnologías innovadoras y sin contacto, se irán obteniendo modelos tridimensionales de cada una de las diferentes piezas históricas seleccionadas. A partir de los datos obtenidos, podremos, además de ir elaborando un catálogo documental y 3D con fines de investigación, difusión, preservación y educación, mostrar y poner en conocimiento un amplio abanico de resultados:

- Estudios exhaustivos de conservación.

- Seguimiento y evaluación de cambios.

- Estudios preventivos de restauración.

- Análisis estructurales.

- Conversión en 3D de dibujos y grabados.

- Reconstrucciones virtuales a partir de antiguos planos de construcción y armamento.

- Digitalización de antiguos mapas y su posterior reconstrucción virtual.

- Museos virtuales.

- Museos sin barrera.

- Restauración virtual.

- Ingeniería inversa.

- Fines de investigación.

- Fines educativos.

- Interactivos.

- Aplicaciones multimedia.

- Simulaciones.

- Generación de animaciones.

- Infografías (paneles y cartelería).

- Juegos serios.

- Ejecución de réplicas/facsímiles.

- Procesos de impresión 3D.

- Generación de prototipos (educación e investigación).

- Realidad aumentada y realidad virtual.

En el caso concreto del armamento histórico y desde el punto de vista de la ingeniería, estos métodos a utilizar aportan beneficios y capacidades infinitas.

¿Qué nos pueden ofrecer la documentación geométrica, el modelado 3D y la reconstrucción 3D en factores como la conservación, preservación, presentación y difusión del patrimonio histórico militar?

- Poner a disposición del MUSEJE modelos virtuales de sus piezas, para la creación de una plataforma en red que permita ver e interactuar con objetos de su colección en 3D, con el propósito de acercar cada vez más al público a los museos y a sus exposiciones.
- Desarrollo cultural y tecnológico para un museo sin barreras. Creación de réplicas a través de los modelos virtuales para personas con discapacidad y grupos infantiles, dentro del área de ver y tocar (AVYT) del Museo, dando así un apoyo a la educación e investigación.

- Acercar nuestro legado patrimonio al resto del mundo y así poder colaborar, intercambiar e incluso interactuar con diferentes piezas de museos internacionales.

- Fomentar la digitalización 3D.

- Conocer la historia de los objetos a través de una serie de herramientas de navegación enriquecidas con 3D.

- Transformación de los museos en lo que a funciones básicas se refiere.

- Bibliotecas de objetos 3D interactivos.

- Puesta en valor del talento en beneficio del legado arqueológico y patrimonial.

- Opciones para un futuro departamento de innovación

- Ser fiel a la Carta de Londres (The London Charter 2009), documento internacional de referencia en los campos del patrimonio cultural y las TICs, y a los Principios de Sevilla (Principles of Seville 2013).

En resumen, además de una gran variedad de productos, estas tecnologías, ponen a nuestra disposición, datos que pueden marcar hipótesis históricas y que de no ser por la facilidad de estudio digital, en la mayoría de los casos no sería posible debido a la difícil o imposible manipulación de estas obras de arte.

Tenemos un gran reto por delante. Todos y cada uno de los objetos elegidos para este trabajo, son piezas emblemáticas pertenecientes a personajes relevantes dentro de la historia política y militar de nuestro país. Nos enfrentamos, por tanto, a una gran variedad de texturas y materiales tan complejos como son los metales, las piedras preciosas, el marfil, el hueso, los esmaltes, etc. Sin olvidarnos del efecto que la luz hace sobre ellos.

Este trabajo se enmarca en el Proyecto Fin de Máster SEAV en Arqueología y Patrimonio Virtual con especialidad en documentación geométrica, restauración virtual y técnicas no destructivas. Dicho trabajo ha derivado en un proyecto de investigación dentro del campo del patrimonio cultural mueble, en concreto, en el del patrimonio histórico militar.

\section{Toma fotogramétrica y procesamiento del armamento histórico}

Actualmente el proyecto se encuentra en una fase previa de toma de datos en los talleres del Museo del Ejército (Fig. 1). Debido a la dificultad de la toma fotográfica, trabajamos a $25 \mathrm{~cm}$ del objeto (Fig. 2), la toma fotogramétrica se realiza con filtro polarizador y bajo una cabina de luz para evitar los reflejos. Se ha decidido realizar la toma de imágenes y parte del 
procesado fotogramétrico de cada pieza, antes de ser retiradas y sustituidas por otras. De esta forma garantizamos la correcta alineación de fotografías y la posterior reconstrucción del modelo 3D.

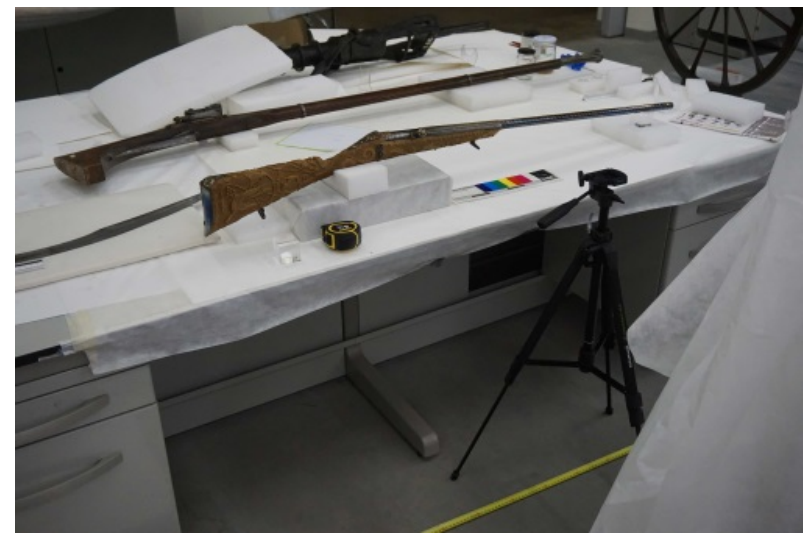

Figura 1: Zona de trabajo para la toma fotogramétrica en los Talleres del Museo del Ejército

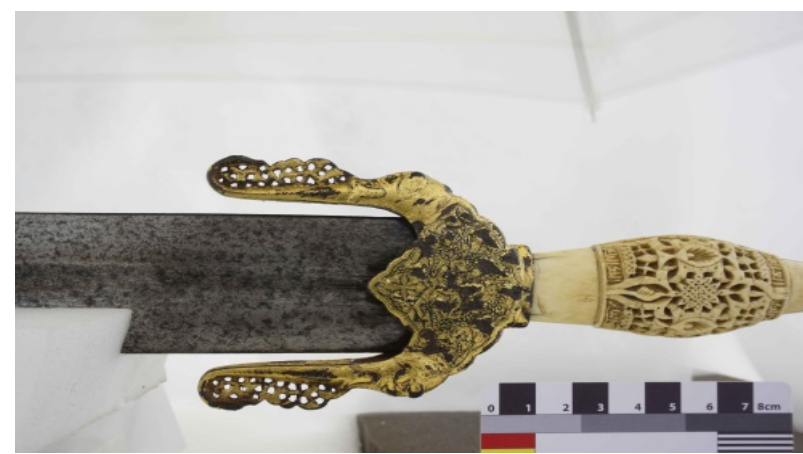

Figura 2: Espada Jineta de Ali-Atar (Museo del Ejército)

La mayoría de las piezas están en la primera fase del procesado fotogramétrico con el programa Agisoft PhotoScan Pro. A continuación se muestran varias resultados del modelado 3D desarrollado: escopeta de Espartero (M.E.M., n. ${ }^{\circ}$ Inv. 40267) (Fig. 3); espada Jineta de Ali-Atar (M.E.M., n. ${ }^{\circ}$ Inv. 22904) (Fig. 4).

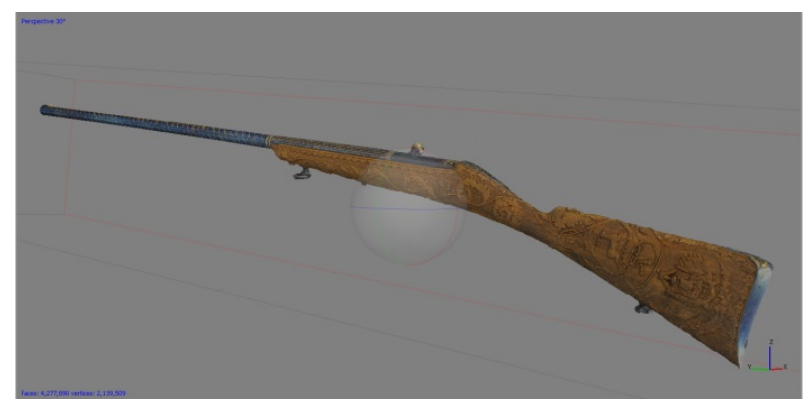

Figura 3: Escopeta de Espartero (Museo del Ejército). Modelo fotogramétrico en malla.

La espada nazarí, se piensa que pudo pertenecer a AliAtar, alcaide de Loja. Su empuñadura esta lujosamente decorada en marfil y oro (Fig. 3a). Asimismo, el filo de la espada dificulta sustancialmente el proceso de reconstrucción 3D. Nótese que para un objeto tan pequeño la complejidad del proceso de captura fue notable. En total se capturaron 539 fotografías de las cuales 281 pertenecen a la empuñadura.

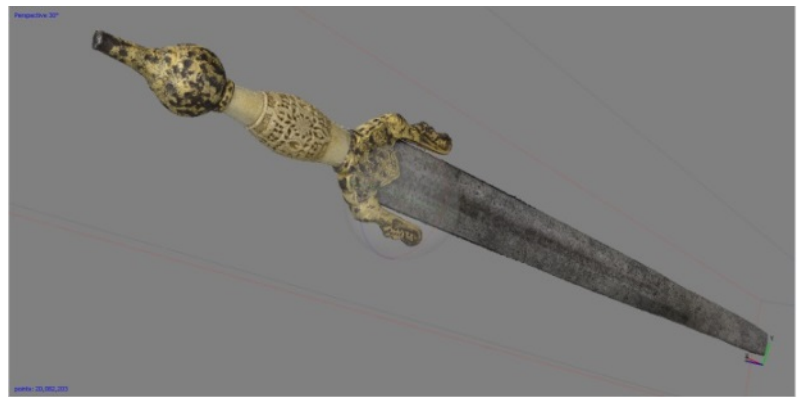

(a)

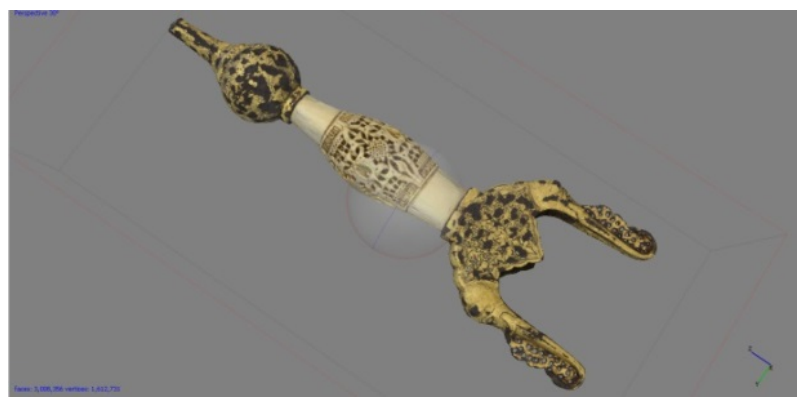

(b)

Figura 4: Espada Jineta de Ali-Atar (Museo del Ejército): a) Nube de puntos densa; b) Modelo fotogramétrico en malla de la empuñadura

\section{Conclusiones}

Este trabajo en curso muestra resultados preliminares del levantamiento fotogramétrico desarrollado en el MUSEJE. La finalidad de los productos derivados es múltiple. Sin embargo, la dificultad de la reconstrucción 3D del patrimonio histórico militar no es baladí.

El proyecto demuestra la importancia de las técnicas de documentación geométrica para la democratización de los Museos. Contribuye a mejorar los procesos de investigación, abriendo una nueva línea de estudio, a partir de la cual, reconstruiremos el pasado a través de la virtualidad, pudiendo así marcar y confirmar hipótesis históricas.

Las acciones futuras van orientadas en ofrecer soluciones fotogramétricas de vanguardia que faciliten las labores de difusión y preservación del patrimonio histórico militar, sin que esté limitado al material armamentístico.

\section{Agradecimientos}

Al Museo del Ejército de Toledo por permitirnos investigar en sus dependencias. A D. Germán Dueñas Beraiz, Conservador Jefe del Departamento de Armas del Museo, por su confianza, apoyo y orientación en el campo del armamento, y a todo el personal que se está viendo involucrado en el desarrollo de este trabajo, por su colaboración y toda la ayuda prestada. 


\section{Referencias}

PRINCIPLES OF SEVILLE, INTERNATIONAL PRINCIPLES OF VIRTUAL ARCHAEOLOGY, 2013. Available: http:// www.arqueologiavirtual.com/carta/wp-content/uploads/2012/03/BORRADOR-FINAL-FINAL-DRAFT.pdf [3/10/2015].

THE LONDON CHARTER for the computer-based visualization of cultural heritage, (2009. Available: http://www.londoncharter.org [4/10/2014]. 


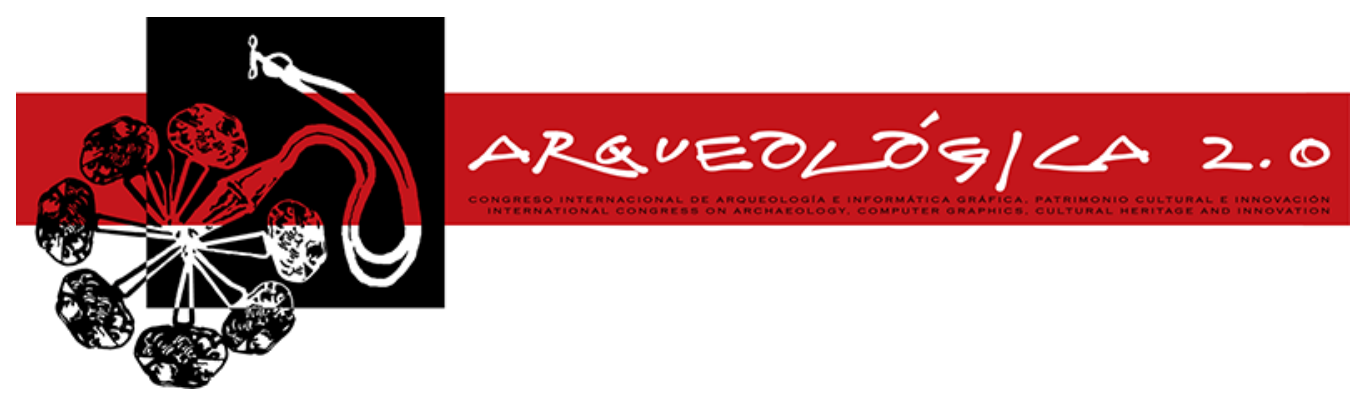

Proceedings of the $8^{\text {th }}$ International Congress

on Archaeology,

Computer Graphics,

Cultural Heritage and Innovation

'ARQUEOLÓGICA 2.0'

in Valencia (Spain),

Sept. 5-7, 2016

\title{
PHILANTHROPIC FOUNTAIN OF KORNAROU SQUARE: USING SFM TO CALCULATE THE FOUNTAIN'S GEOMETRIC CHARACTERISTICS IN ORDER TO DETERMINE ITS INELASTIC DYNAMIC RESPONSE
}

\author{
Alexandros Lyratzakis ${ }^{*}$, Panagiotis Parthenios, Maria Stavroulaki \\ School of Architecture, Technical University of Crete, Kounoupidiana, 73100 Chania, Crete Greece. alyratzakis@isc.tuc.gr; \\ parthenios@arch.tuc.gr; mstavr@mred.tuc.grfig
}

\begin{abstract}
:
This paper proposes the use of Structure from Motion (SFM) techniques to survey inaccessible monument structures and presents its application on capturing Kornarou Square's philanthropic fountain in Heraklion, Crete. A series of aerial and terrestrial photos of the fountain were combined in order to build the 3D geometry of the monument using Agistoft's Photoscan. This 3D model was used to study the dynamic behavior of the fountain. Its response was determined through multiple inelastic dynamic analyses. The analysis results were summarized in the average dynamic curve.
\end{abstract}

Key words: 3D photoscan, multi step dynamic analysis, virtual archaeology, digital archaeology, structure from motion

\section{Introduction}

In recent years, the rapid development of the capacities of Personal Computers offered new "tools" to contemporary scholars / engineers. Methodologies which a decade ago required specialized, high cost equipment and time-consuming processing of the results, can now be implemented within a short period by using ordinary equipment. The 3D Photo Scanning constitutes such a methodology, according to which, through the use of a conventional camera and PC can be produced a detailed 3D model of any structure. The Photoscan applications are varied and as long as technological progress opens up new capabilities, the applications will be multiplied.

A field, in which the Photo Scanning is predominantly used, is the geometric documentation of monuments (De Reu et al. 2013; Koutsoudis et al. 2014). The lack of architectural drawings in combination with the difficult approach of several monumental structures, led to the search for alternative surveying methods. Photoscan is an interesting alternative proposal to deal with these issues.

The aim of this paper is the utilization of the computational capabilities of contemporary computers, by applying demanding procedures such as Photoscan and multi-step dynamic analysis. The Photo Scanning is applied to the Philanthropic fountain of Kornarou square, a 18th century"s Turkish sebil located in Heraclion, Crete. The fountain"s approach closer than $7 \mathrm{~m}$ is not possible due to surrounding space"s rehabilitation. The purpose of the study is the construction of an accurate model in order to measure in accuracy the outer dimensions of the fountain. Subsequently, according to these dimensions, a simplified finite element model of the fountain was constructed. The estimation of the actual response of the building is made through multiple dynamic analyses.

\section{Philanthropic fountain of Kornarou square}

During the Turkish occupation, the ottomans" squirearchy felt very strongly the need for finding water for the needs of the citizens, the people"s of the suburbs and their religious demands. During this period, in several Heraklion"s squares, philanthropic fountains were built, while other simpler ones were erected in various streets in the centre of the town. Quite a few of them are preserved in good condition.

Philanthropic fountain of Kornarou square is the last preserved of this kind which was built by Hadji Ibrahim aga in 1776. Kornarou square"s Sebil is of a circular type building with a domes and around the walls there are windows, in front of each one of them there exist a tap with a stone basin for the water to be collected (Fig. 1). Up to 2013, the funtain was used as a traditional coffeehouse.

\section{Data collection}

The fieldwork is separated into two steps. The first involves the terrestrial and aerial photo shooting of the Sebil. The photo shooting was performed performed following the $3 \times 3$ rules. A terrestrial "ring" of photo

*Corresponding Author: Alexandros Lyratzakis, alyratzakis@isc.tuc.gr 
shoots were taken, fully zoomed out, around the Sebil with a DSLR Sony SLT a58 at 20.4 MP with an 18-55 $\mathrm{mm}$ lens. The camera was placed on a tripod at a constant height $1.7 \mathrm{~m}$ and an average distance of 7 meters from tha fountain. For the photo shooting of the roof, a low cost Parrot minidrone along with a Smartphone (Sumsumg Galaxy S5) were used. The total number of photographs that has been used for the generation of the 3D model of the monument was 54 (42 terrestrial photos and 12 aerial photos). The photo shooting was chosen to take place late in the afternoon when lighting conditions were optimal for the monument.

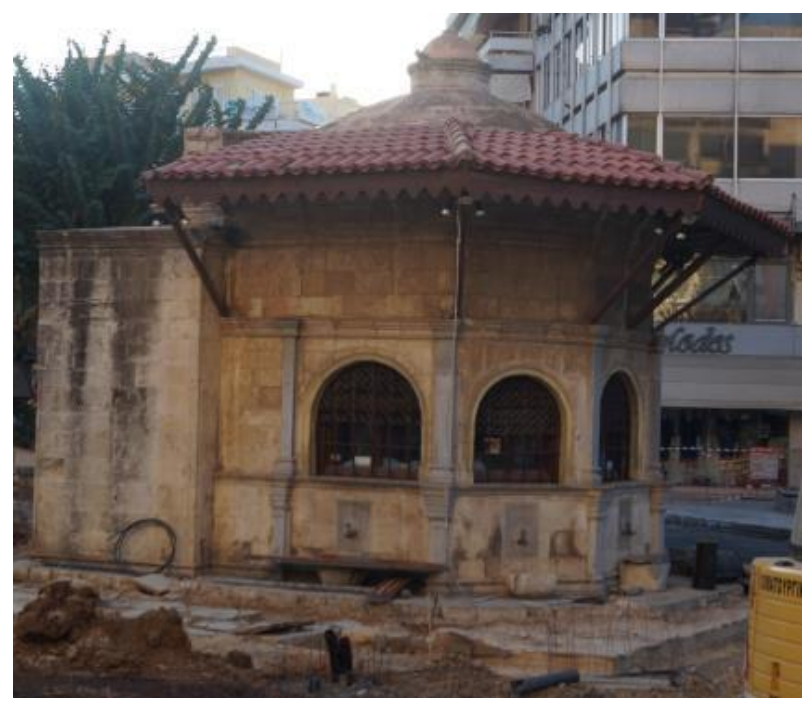

Figure 1: Philanthropic fountain of Kornarou square.

\section{3D model generation}

A 3D model can be generated in an automated threestep process, using Agisoft Photoscan (AgiSoft LLC; Parthenios et al. 2015). Primarily, a pre-processing of the implemented photographs is recommended, in order to improve the quality of the model. Therefore, the areas in the images with "moving" objects or shadows were masked.

The first step of the 3D model"s processing includes the images" aligning. During this step a 3D sparse point cloud (17551 points) was generated representing the geometry of the scene (Fig. 2). The alignment of the pictures carried out according to the following arrangements i) Accuracy: high ii) Pair preselection: Generic. Subsequently, a dense cloud (4.408.941 points) was built in order to increase the model"s accurate.

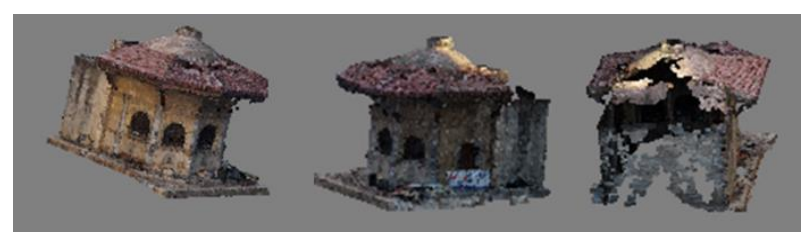

Figure 2: Dense cloud.

During the second step, the final mesh was created based on the model that resulted from the densification. The mesh was carried out according to the following options: i) Surface type: Arbitrary, ii) Source data: Dense cloud iii) Polygon count: High. For the closure of the gaps, the tool "close holes" (tools-> mesh-> close holes) was used at level: $100 \%$. In the final step, the texture model was built (generic mapping mode and max indensity) (Fig. 3).

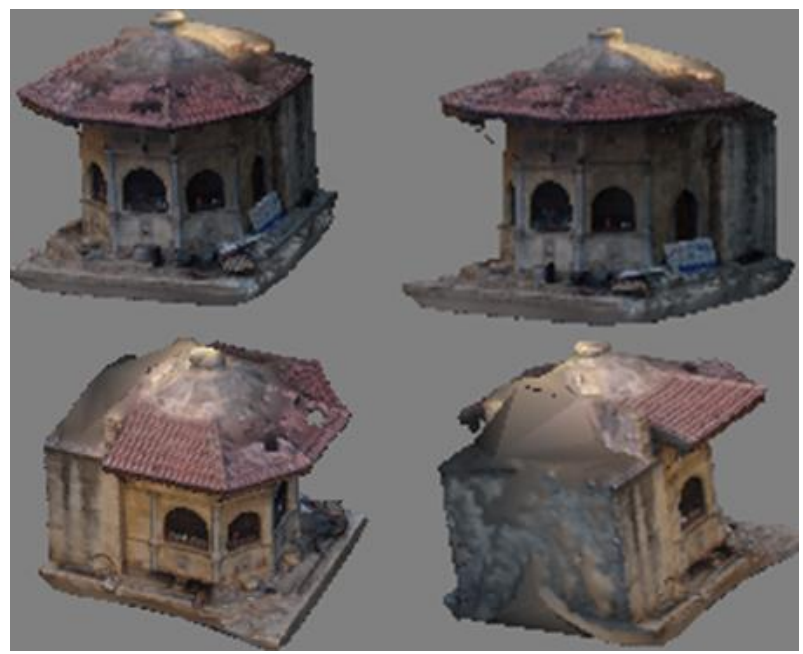

Figure 3: Final Agisoft Model.

\section{Finite element Model}

The model was exported to .dxf file from Agisoft in order to be imported to Autocad as a mesh. Nevertheless, the mesh model could not be used for dynamic analyses with the finite element software Msc Marc. The most important reasons for this inability are: a) Due to being nonuniform and full of blanks, Agisoft"s mesh can not be used as a finite element"s mesh (model in not suitable form) and b) The model includes several non-structural items such as the wooden roof and the fountain's decorative elements (eg marble columns).

Manual scaling was performed on the original model, based on the dimensions of the western gate of the fountain. The gate's actual width was measured equal to $1.4 \mathrm{~m}$ and Photoscan model's gate's width is equal to $1.02 \mathrm{~m}$. According to these dimensions, a scale $1.4 / 1.02$ was performed to the model to calculate all the fountain"s dimensions. A simplified solid model was constructed, based on the original (Fig. 4). Overall 6396 3D solid elements were used for the finite element meshing of the model (Fig. 5).

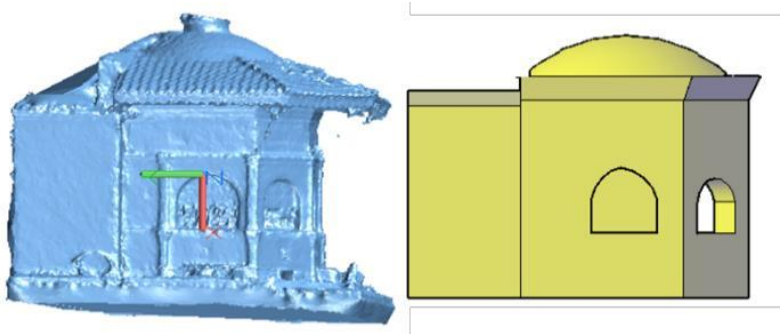

Figure 4: Left: Agisoft"s mesh Right: Solid model.

\section{Mechanical properties of masonry}

In this model, the compressive strength of the masonry which consists of dimensioned natural stone units and general purpose mortar was calculated according to Eurocode 6. The compression strength of stones ( $\mathrm{fb}$ ) and the mortar (fm) were assumed equal to $0.5 \mathrm{MPa}$ and 
35MPa respectively (Greek type unreinforced masonry). Based on these values the compressive strength of the masonry is equal to $2.2 \mathrm{MPa}$ and the tensile strength alongside the joints and vertically to the joints is equal to $\mathrm{ft} \perp=0.25 \mathrm{Mpa}$ and $\mathrm{ft} / /=0.125 \mathrm{MPa}$ respectively. The Young"s modulus is calculated equals to $E=2.2 \mathrm{GPa}$ (EC6 2005). For the Poisson's ratio $v=0.25$ is used. For the description of the inelastic behavior of the masonry the parabolic yield criterion Drucker-Prager is used.

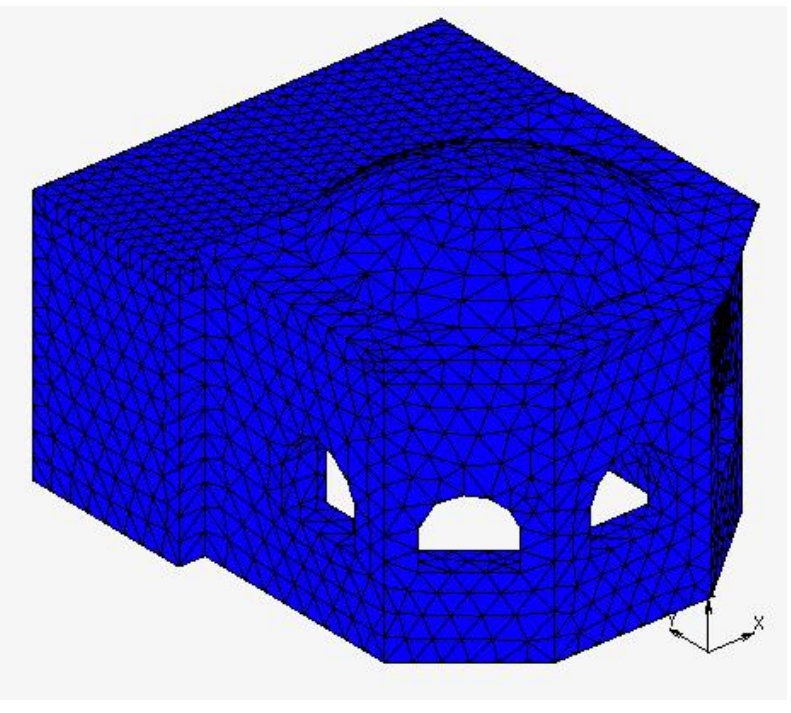

Figure 5: FE Model (MSC Marc)

\section{Multi-step dynamic analysis}

In order to study the response of the fountain, the method of the Multi-step dynamic analysis, was selected. Initially, an accelerogram is selected as reference and then in order to create milder and more powerful ground movements the record is modified by multiplying the amplitudes of accelerations with a single coefficient. So new accelerograms are created and the model is resolved with each of them.

Subsequently, a measure concerning the response of the structure, like the base shear, the node drifts, and the inter-storey displacements, is defined as Damage Measure. It is extracted from the inelastic dynamic analysis and is depicted in a graph in relation to the intensity of the seismic stimulation.

The response of the structure depends to a great extent on the selected recording (frequency, content and duration) for which the analysis was carried out; therefore more recordings are needed in order to estimate the response of the structure more accurately. The seismic input is defined through a poper set of acceleration time histories like recorded accelerograms.

In this case, the selection of the earthquake records is based on the following criteria (lervolino et al. 2008; Katsanos and Sextos 2013): i) earthquakes that occurred in Greece and Turkey; ii) compatibility with the type 1 spectrum shape of Eurocode 8 and iii) records from earthquakes with magnitude $M S \geq 5$. The acceleration time histories data were obtained from Peer Berkeley Strong-motion Database. Thirty seismic recordings with a gradual escalation of their intensity in 15 steps $(0,1 \mathrm{~g}-0,2 \mathrm{~g}-\ldots-1.5 \mathrm{~g})$, were used. The Peak Ground Acceleration as a measure of the accelerogram escalation and the maximum peak displacements of the dome as Damage Measure were used

As confirmed in the results of dynamic analysis, the seismic response for the same level of intensity varies widely between the different seismic loadings. It is observed that the spectral acceleration is significantly altered in each examined accelerograms (Fig. 6).

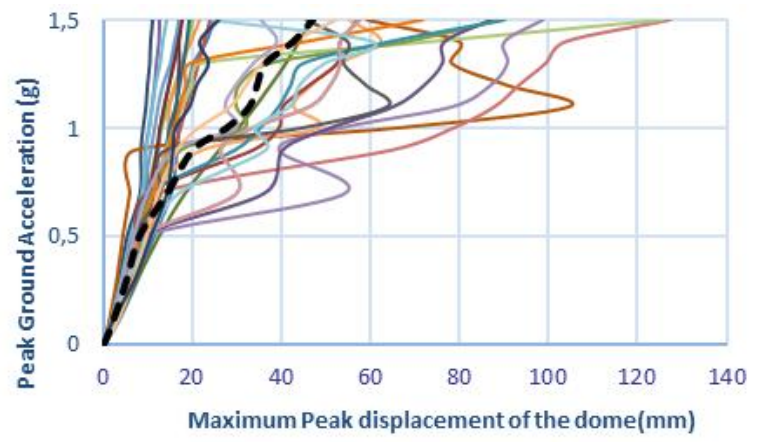

Figure 6: Multi-step dynamic analysis curves.

\section{Concluding remarks}

The present study attempted to capture the inaccessible Philanthropic fountain of Kornarou square, exclusively through photographs. The study aimed to create an accurate 3D model by Photoscan, the dimensions of which will be able to be used to design a finite element model. Although the goal was achieved, there is considerable scope for improvement of the methodology.

The results of the analysis of terrestrial photographs were satisfactory in exporting an accurate model. On the other hand, the aerial photoshooting with minidrone, did not have the same results. The Agisoft did not recognise the drone"s photos due to their poor quality. The use of a drone equiped with higher quality camera would solve these problems.

The geometric characteristics of the fountain were calculated with high accuracy, by making it possible to construct a representative finite element model, which was subjected to multi-step dynamic alalysis. The analysis results are summarized in Multi-step dynamic analysis curves. It is observed that the response of the structure varies among various earthquakes with the same intensity. Furthermore due to the large movements, the fountain might need retrofit.

It becomes clear that the application of Photoscan and FE software, contributes to cultural heritage buildings' study. In order to facilitate and combine this software, the creation of a middleware is required which will be able to automatically convert the Photoscan"s nonuniform mesh to FE mesh.

\section{References}

AGISOFT LLC, 2011. AgiSoft PhotoScan User Manual: Standard Edition, Version 0.8.4. AgiSoft LLC, 2014 
DE REU, J., Plets, G.,VerhoeVEN, G., DE SMEDT, P., BATS, M., CheRRetté, B., DE MAEYER, W., DECONYNCK, J., HERREMANS, D., LALOO, P., VAN MEIRVENNE, M. and DE CLERCQ, W., 2013. Towards a three-dimensional cost-effective registration of the archaeological heritage, 40, pp.1108-1121 DOI: 10.1016/j.jas.2012.08.040

EC6, 2005. EUROCODE 6: design of masonry structures-part 1-1: general rules for reinforced and unreinforced masonry structures, E, European Committee for Standardization (CEN), Brussels, Belgium.

IERVOLINO, I., GALASSO, C., COSENZA, E., 2009. REXEL: computer aided record selection for codebased seismic structural analysis 8:339-362. DOI:10.1007/s10518-009-9146-1

KATSANOS, E.I., and SEXTOS, A.G., 2013. ISSARS: An integrated software environment for structure-specific earthquake ground motion selection. Advances in Engineering Software, on-line, DOI: 10.1016/j.advengsoft.2013.01.003

KOUTSOUDIS, A., VIDMAR, B., IOANNAKISA, G., ARNAOUTOGLOUA, F., PAVLIDIS, G. and CHAMZAS, C., 2014. Multi-image 3D reconstruction data evaluation. Journal of Cultural Heritage, 15(1), pp.73-79 DOI:10.1016/j.culher.2012.12.003

PARTHENIOS, P., PETINARELIS, A., LOUSA, S. and EFRAIMIDOU, N., 2015. Three modes of a monument's 3D Virtual Reconstruction. The case of Giali Tzamisi in Chania, Crete, Digital Heritage 2015, Granada, Spain, pp. 75-78 


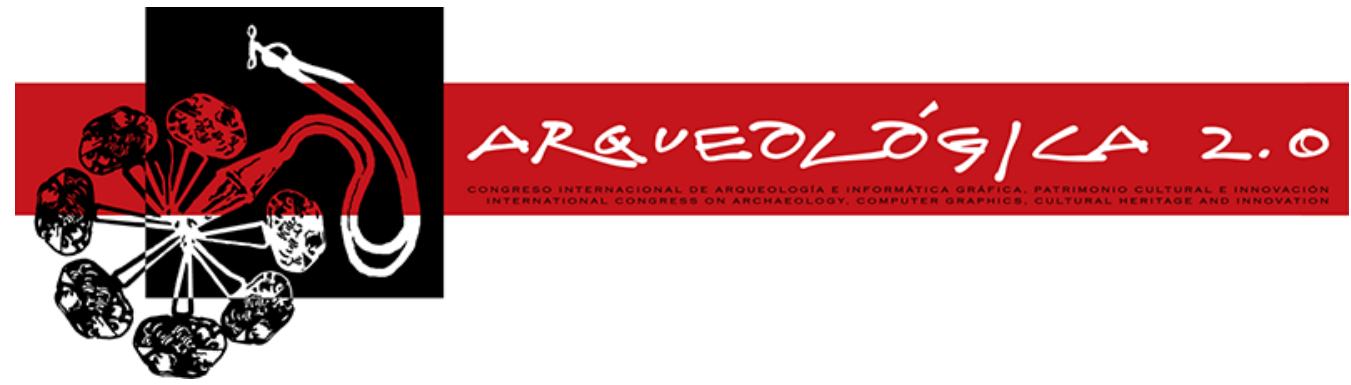

Proceedings of the $8^{\text {th }}$ International Congress

on Archaeology,

Computer Graphics,

Cultural Heritage and Innovation

'ARQUEOLÓGICA 20'

in Valencia (Spain),

Sept. 5-7, 2016

\title{
COMBINING STRUCTURE FROM MOTION TECHNIQUES WITH LOW COST EQUIPMENT FOR A COMPLETE 3D RECONSTRUCTION OF A 13TH CENTURY CHURCH
}

\author{
THE CASE OF TRANSFORMATION OF THE SAVIOUR CHURCH IN MESKLA, IN CRETE ISLAND \\ Panagiotis Parthenios, Theano Androulaki", Evangelia Gereoudaki, Giorgos Vidalis \\ School of Architecture, Technical University of Crete Campus, Kounoupidiana, 73100, Chania, Greece. parthenios@gmail.com; \\ theano.and@gmail.com; elizagere@gmail.com; g.d.vidalis@gmail.com
}

\begin{abstract}
:
The use of 3D digitization and modelling in documenting heritage sites has increased significantly over the past few years. This paper presents the process of a monument's virtual 3D reconstruction using Structure from Motion techniques with common, user friendly, low cost equipment. The byzantine church of the Transformation of the Saviour in Meskla, Crete, aged back to the 13th c., has been photographed by two student groups and the two models were merged into one unified 3D scene.The detailed and high quality products of the 3D modelling can be used for educational and research purposes but also for the touristic promotion of the area through light, easy to use, 3D visualizations on the web.
\end{abstract}

Palabras clave: virtual archaeology, structure from motion, cultural heritage, documentation, 3D reconstruction

\section{Introduction}

\subsection{Team and objective of research}

The following research was realised during the postgraduate programme "Space, Design and Built Environment: Integrated conservation of historical built environment with advanced technology and materials", in the School of Architecture in Technical University of Crete for the documentation and the production of digital 3D models of a byzantine church through automatic photogrammetric software. The aim is the use of the 3D models for educational, touristic and research development in Cultural Heritage.

\subsection{Historical information}

The church is dedicated to the feast of the Transformation of the Saviour, lies at the northern part of the Meskla settlement, ca. $20 \mathrm{Km} \mathrm{SW}$ of Chania, in Crete Island. The ground-plan of the monument displays a typical example of a small single-aisled church, thus an architectural form that was very popular on the island of Crete during the era of the Venetian occupation. The iconographical programme of the church follows the typical concept of the single-aisled fresco painted churches of Crete. The church was initially erected in the middle of the 13th c. as it is implied by the first layer of frescoes that was discovered at the apsis. As it is concluded by the dedicatory inscription, the church was renewed and re-painted on the 15th of May 1303 by the painters Theodoros-Daniel and Michael Veneris.

\subsection{Existing similar work}

The use of 3D digitization and modelling in documenting heritage sites and monuments has increased significantly over the past few years. This is mainly due to advances in Laser scanning techniques, 3D modelling software, image-based-modelling techniques, computer power and virtual reality. There are many approaches currently available. Some examples of scanned cultural heritage models are developed at the following projects: The Digital Michelangelo Project: 3D Scanning of Large Statues, Three modes of a monument's 3D Virtual Reconstruction and The Cultural Electronic Network Online( http://cenobium.isti.cnr.it/).

\section{Process, tools and methodology}

\subsection{Existing software research}

The starting point of the research was the investigation of the available software, that offers the possibility to process image data and generate $3 \mathrm{D}$ model data via common, user friendly, low cost equipment. Photosynth, Autodesk 123D Catch, Agisoft Photoscan software were used.

"Corresponding Author: Theano Androulaki, theano.and@gmail.com 


\subsection{Work on site}

Two teams were formed, to photoscan the interior and exterior of the monument, following the CIPA $3 \times 3$ rules. The photo sets required sufficient overlap areas, in order to combine later the 2 outcomes in one file.Team A photographed the interior with a digital camera, model Canon EOS 450D (Fig.1) and team B the exterior with an Olympus E 330. Low ISO setting is needed to avoid the production of image noise. No flash was used because it introduces abrupt local exposure variation, leading to errors during point cloud processing.

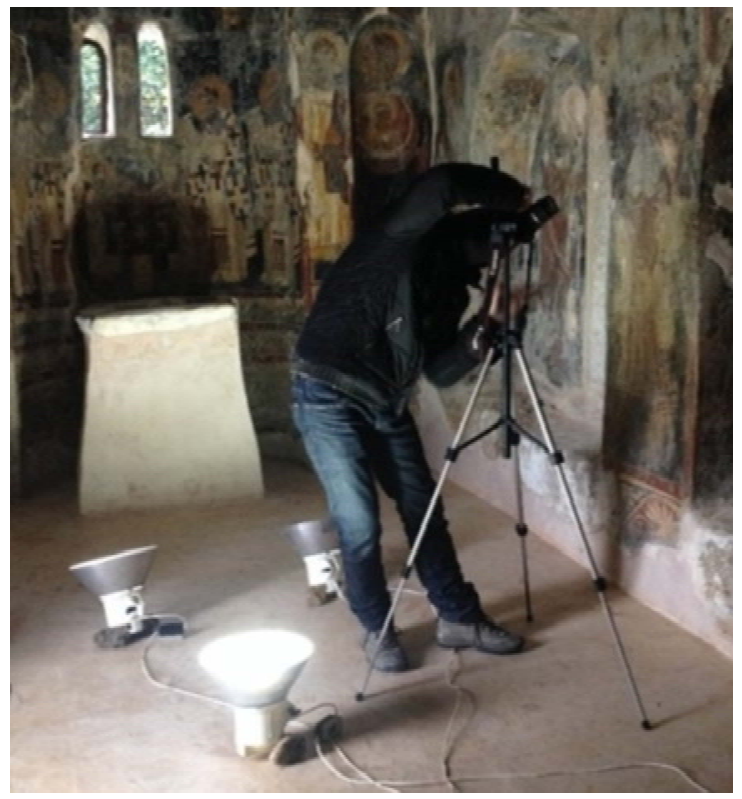

Figure 1: Process of photoshooting in the church.

Team A: The lighting conditions in the interior were poor. In order to take the proper photos, the interior space was photographed using a tripod and three headlamp lights. The lights were placed on the floor to achieve the sufficient level of light for the roof and the dark corners. The goal was the detailed and high quality images of the wall and roof paintings. Team B: The photo shooting included shots around the church and the roof (Table 1).

\begin{tabular}{c|c|c}
\multicolumn{2}{c}{ Table 1: Camera's settings } \\
Setting & Team A & Team B \\
\hline ISO & 100 & 100 \\
Focal length (mm) & $18-55$ & 14 \\
Aperture & F/3.5 - F/5.6 & $F / 5.6-\mathrm{F} / 8.00$ \\
Exposure time & $1 / 25-1.6$ & $1 / 80-1 / 160$
\end{tabular}

Furthermore, the overall length of the church's facade and the door opening were measured, in order to bring the resulted models into the right scale.

\subsection{Agisoft Photoscan}

The data processing was executed in the PC's of the Digital Media Lab at the School of Architecture, using Agisoft Photoscan software. The procedure would outpout two different point clouds and models that would be combined into one file. The workflow followed four steps: Align photos, Build Dense Cloud, Build Mesh, Build Texture. The products of the process were two 3D models, interior and exterior (Figs. 2 and 3). The files sizes are $512 \mathrm{Mb}$ of the interior and $77 \mathrm{Mb}$ of the exterior. According to the settings of the workflow different sized files can be produced, depending on the preferable use and desired quality (Table 2). A lower quality, smaller file size would be more appropriate for internet applications, while a higher quality, larger file size with higher level of detail could be used for further research, such as studying the frescos, or inspecting the monument's pathology (eg. through its inelastic dynamic response).

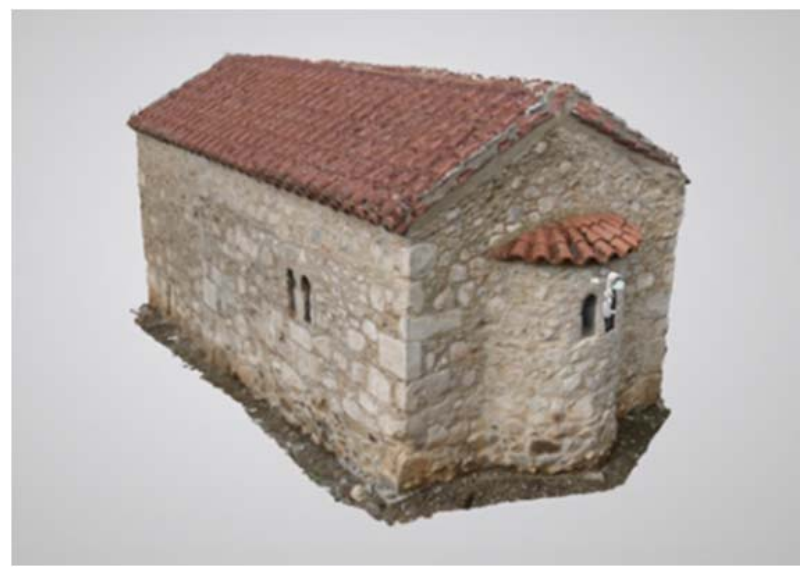

Figure 2: Exterior view of the church's 3D model.

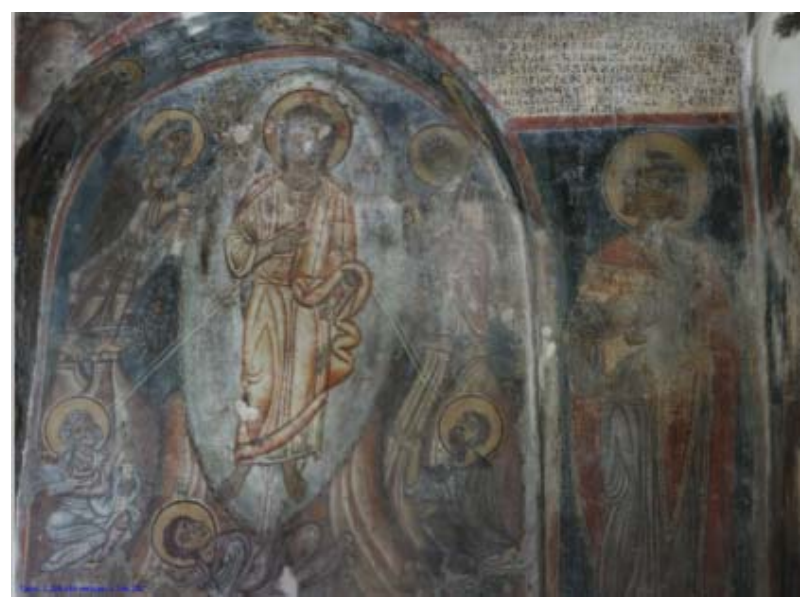

Figure 3: High precision view of a wall painting of the 3D model's interior.

\section{Import and assembly in 3ds Max}

The 3D files exported from Agisoft were a file with obj format and a jpeg image of the texture. The obj file was imported in 3ds Max. Each file was rescaled. The adjustment of the scale was realised manually according to the measurements of the facade. The coordinate system of the 3D models was also manually repositioned. The rescaled models were merged. Using the large size files from Agisoft the merged obj model in 3ds max was $256 \mathrm{Mb}$. Even though the professional version of Agisoft would have been able to provide accurate scaling and georeferenced positioning, the scope of this study was to use only free tools, thus due to using the Standard edition we had to perform these manually, based on physical measurings. This method 
proved adequate for the purpose of our study. The total model was rendered as it was, with no additional lights, using default settings producing high accuracy images of both the interior and exterior.

Table 2: Agisoft Photoscan settings and results

\begin{tabular}{c|c|c} 
Workflow & INTERIOR & EXTERIOR \\
\hline Align photos & 269 images & 55 images \\
Accuracy: High & & \\
Pair selection: Disabled & $\begin{array}{c}\text { Est. Time } \\
180 \text { min }\end{array}$ & $\begin{array}{c}\text { Est. Time } \\
6 \text { min }\end{array}$ \\
Advanced Settings: Default & & \\
Values & $\begin{array}{c}136,282 \\
\text { points }\end{array}$ & $\begin{array}{c}44,351 \\
\text { points }\end{array}$ \\
Point Cloud Output: & Cloud
\end{tabular}

Build Dense Cloud

\begin{tabular}{c|c|c}
\hline Quality: Medium & Est. Time & $\begin{array}{c}\text { Est. Time } \\
10 \mathrm{~min}\end{array}$ \\
Depth Filtering :Aggressive & $90 \mathrm{~min}$ & \\
& $\begin{array}{c}48,789,557 \\
\text { points }\end{array}$ & $\begin{array}{c}2,920,700 \\
\text { points }\end{array}$ \\
Dense Point Cloud Output: & Build Mesh
\end{tabular}

\begin{tabular}{c|c|c}
\hline $\begin{array}{c}\text { Surface Type: Arbritary } \\
\text { Source Data: Dense Cloud }\end{array}$ & Est. Time \\
$\begin{array}{c}130 \mathrm{~min} \\
\text { Face Count : Medium }\end{array}$ & $\begin{array}{c}\text { Est. Time } \\
3 \mathrm{~min}\end{array}$ \\
Interpolation:Disabled & $\begin{array}{c}2,288,685 \\
\text { faces }\end{array}$ & $\begin{array}{c}136,870 \\
\text { faces }\end{array}$ \\
\hline \multicolumn{2}{c|}{ Build Texture } & Est. Time \\
Mapping Mode: Generic & Est. Time \\
Blending mode: Mosaic & $5 \mathrm{~min}$ & \\
Texture size/count: 6.000x1 &
\end{tabular}

\section{Issues}

During the whole process a number of issues arose. Team A, responsible for the interior, faced several lighting problems. In addition to the headlights placed on the floor, the two doors of the church had to be open during the photoshooting in order to light also with the natural daylight. This caused problems to the merge of the interior and exterior model at the openings creating noise around them. Team B, responsible for the exterior faced several problems during the photographing process. The surrounding area didn't offer the proper perspective to photograph the roof. As a result the exterior 3D model produced in Agisoft was produced with several gaps on the roof as the photos weren't correctly overlapped. Team B tried to shoot from a higher level using a ladder but the gradient of the surroundings wouldn't help. To solve this problem the team is in the process of using a drone. During the process of the union in $3 \mathrm{ds}$ Max, noise from the exterior model was placed in the interior and vise versa, so it had to be removed.

\section{Internet applications}

The resulted 3D model of the church's interior and exterior space was exported successfully to WebGL (Fig. 4) and is available to be viewed on the web without the need of any special software or plugin under the following address: https://skfb.ly/NnNR

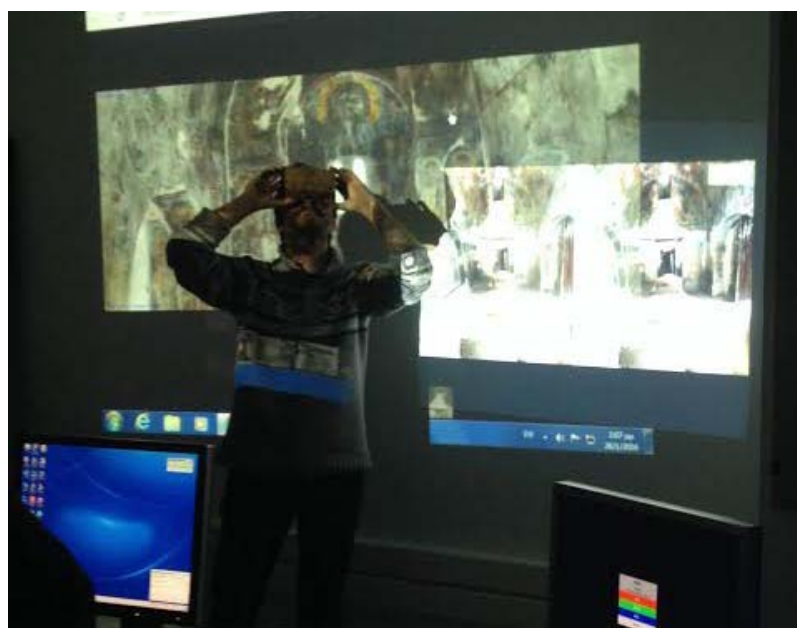

Figure 4: Use of the Oculus in the lab.

\section{Results - Evaluation}

This method proved to be a fast, low cost and flexible technique of 3D modelling which can potentially be used for digital documentation by people with no technical background.

This practice allows a full and detailed compilation of data referring to the monument and a complete 3D model which can be edited from distance. The accuracy and precision of the results are remarkable and allow further use of the 3D models for recording and visualization of detailed wall paintings and in order to study the pathology and the structural behavior of monuments. The products of the $3 \mathrm{D}$ modelling can be used for educational and research purposes but also for the touristic promotion of the area.

\section{Acknowledgements}

We would like to thank Ephorate of Antiquities of Chania for their help during the study of the byzantine church of the Transformation of the Savior in Meskla and the students of the class: Androulaki Theano, Gereoudaki Evangelia, Vidalis Giorgos, Digalaki Tatiana-Christi, Ntoura Magdalini, Chadjidakis Giorgos and Spyrou Eleytherios.

\section{References}

AGISOFT LLC, 2011. AgiSoft PhotoScan User Manual: Standard Edition, Version 0.8.4. AgiSoft LLC

BILA, Z., REZNICEK, J. and PAVELKA, K., 2013. Range and Panoramic Image Fusion Into a Textured Range Image For Cultural Heritage Documentation, ISPRS Annals of the Photogrammetry, Remote Sensing and Spatial Information Sciences, Volume II-5/W1, 2013 XXIV International CIPA Symposium, 2 - 6 September 2013, Strasbourg, France 
EL-HAKIM, S., BERALDIN, J.A. and PICARD, M., 2002. Detailed 3D Reconstruction of Monuments Using Multiple Techniques, published in Proceedings of the Intern. Workshop on Scanning for Cultural Heritage Recording Complementing or Replacing Photogrammetry,.September 01-02, 2002.Corfu, Greece pp.58-64.NRC 44915.

PARTHENIOS, P., PETINARELIS, A., LOUSA, S. and EFRAIMIDOU, N., 2015. Three modes of a monument's 3D Virtual Reconstruction. The case of GialiTzamisi in Chania, Crete, 2015 Digital Heritage International Congress, Granada, Spain, pp. 75-78.(DOI: 10.1109/DigitalHeritage.2015.7413838 Conference: 2015 Digital Heritage)

REMONDINO, F., EL-HAKIM, S., GIRARDI, S., RIZZI, A., BENEDETTI, S. and GONZO, L., 2009. 3D virtual reconstruction and visualization of complexarchitectures - the "3D-Arch" project Proceedings of the ISPRS Working Group V/4 Workshop 3D-ARCH "Virtual

SCOPIGNO, R., CALLIERI, M., CIGNON, P., CORSINI M., DELLEPIANE, M., PONCHIO, F. and RANZUGLIA, G., 2011. 3D Models for CH: Beyond Plain Visualization, ISTI-CNR,pp. 48-55.Issue No.07 - July (2011 vol.44)pp: 48-55

PHOTOSCAN AGISOFT, http://www.agisoft.ru (5/24/2016) 


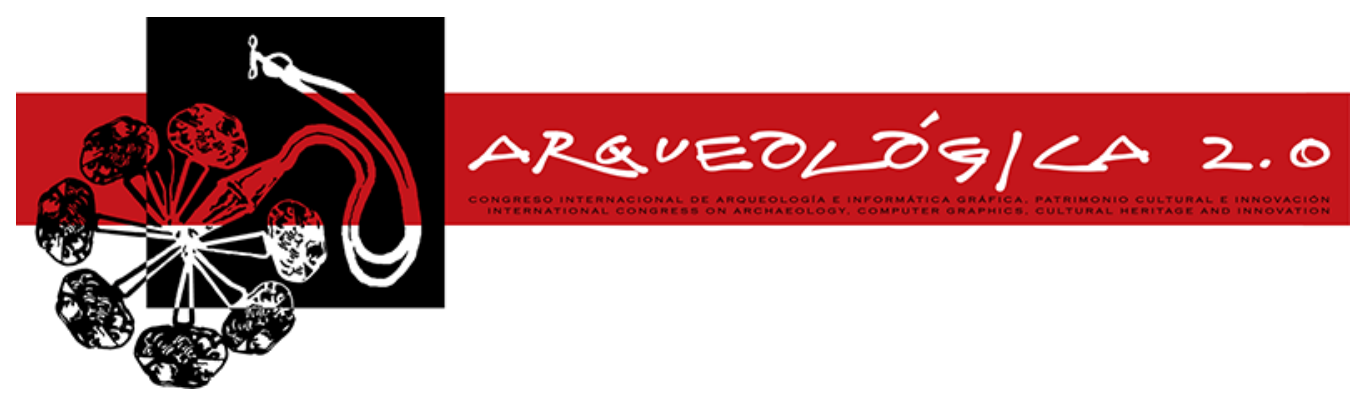

Proceedings of the $8^{\text {th }}$ International Congress

on Archaeology,

Computer Graphics,

Cultural Heritage and Innovation

'ARQUEOLÓGICA 2.0'

in Valencia (Spain),

Sept. $5-7,2016$

\title{
THE SOUTH AFRICAN HERITAGE RESOURCES INFORMATION SYSTEM (SAHRIS): DEVELOPMENT AND CHALLENGES THROUGH MANAGEMENT OF CULTURAL HERITAGE RESOURCES THROUGH AN INTEGRATED WEB-BASED PLATFORMF
}

\author{
Clinton Jackson“, Dr Ragna Redelstorff \\ South African Heritage Resources Agency, 111 Harrington Street, PO Box 4637, Cape Town 8000, South Africa. \\ cjackson@sahra.org.za; rredelstorff@sahra.org.za
}

\begin{abstract}
:
The South African Heritage Resources Agency (SAHRA) is a statutory body created to implement the National Heritage Resources Act No.25 of 1999 and is responsible for the identification and management of the national estate of South Africa. In 2013, the South African Heritage Resources Information System (SAHRIS) was developed to create an inventory of the national estate and facilitate the management of heritage resources.

The SAHRIS platform is an interactive system that provides a collaborate space through which government officials, heritage practitioners, developers and researchers can engage with the management of the national estate of South Africa. Core functions include an online application system, in which public users and governement officials collaborate and communicate; an archive of heritage sites and resources; protect heritage sites and resources that are threatened by development or mining activities; a collections management system for the effective management of heritage objects.

Despite its progressive efficiency, users of SAHRIS encounter challenges such as difficult navigatibility due to it serving a variety of users and applications. Furthermore, although it is a public domain and should therefore allow free access to all records, privacy of certain documents and records is important in order to protect researchers' interests and heritage resources from loitering and destruction. The advantage of a digital system is that it is work in progress and open to continuous improvement.
\end{abstract}

Key words: drupal, cultural heritage, documentation, heritage resource management, collaborative spaces

\section{Introduction}

The South African Heritage Resources Agency (SAHRA) is a statutory body created in terms of the National Heritage Resources Act (NHRA), No. 25 of 1999 (South Africa, Department of Arts and Culture 1999). This legislation replaced the previous National Monuments Act, No. 28 of 1969, and engaged with the need to incorporate heritage resources management with the consitutional recognition of the cultural rights of South Africans as expressed in the post apartheid period (Ndlovu 2011).

SAHRA is mandated in terms of this act to identify and manage South African heritage resources, which are part of the national estate of South Africa. The national estate is a composition of declared heritage objects (e.g., artworks, military objects), archaeological and palaeontological resources, meteorites, historical structures (e.g., buildings, monuments), maritime and underwater cultural heritage (e.g., shipwrecks) as well as burial grounds and graveyards.
The NHRA specifically states within its opening statement that SAHRA is "to introduce an integrated and interactive system for the management of the national heritage resources" (South Africa, Department of Arts and Culture, 1999). This specific mandate was achieved through the creation of the South African Heritage Resources Information System (SAHRIS). SAHRIS has provided an integrated web-based platform that not only achieves the goals of Section 39 of the NHRA to develop and maintain an inventory of the national estate but to also engage in more complex matters pertaining to the general management of heritage resources such as the permitting of research involving activities on heritage sites and export and destructive analysis of heritage resources; the commenting on development applications; and the logging of heritage crimes (Smuts 2015).

\section{What is SAHRIS?}

SAHRIS was created in order to address the opening statement of the NHRA. It provides a platform through

*Corresponding Author: Clinton Jackson, cjackson@sahra.org.za 
which heritage resources can be identified, recorded, managed and protected.

SAHRIS covers three main functions, namely, i) to serve as a repository of information on identified heritage sites; ii) to serve as a collections management platform for heritage objects; iii) as an integrated platform for complete heritage management (Smuts et al. 2016).

These integrated functions allow for the protection of heritage resources that are threatened by development or mining activities.

\section{Development}

The initial conceptualisation of SAHRIS began in the mid 2000's and was finalised in 2011 when it was recommended that SAHRA investigate the use of Free Open Source Sofware (FOSS) (Hill 2011). Owing to its large user base, integration of GIS functions, and existing catalogue of modules, Drupal was selected as the content management system (CMS) of SAHRIS. It was launched internally in 2012 and the final developed version released to the public in 2013.

The system made it possible to integrate the legislated mandate for heritage management with a full data collection system that could act as an inventory of the national estate of South Africa. This synergy has gone a long way in populating the database of the national estate. Since its public implementation, the number of users and sites, heritage objects and cases created on SAHRIS, has increased considerably, reflecting the public's increased engagement with heritage resources (Fig. 1). The aim is to have every existing heritage object and site occurring in South Africa recorded on SAHRIS with the help of its users, e.g. when researchers discover and excavate new archaeological or palaeontological resources or sites.

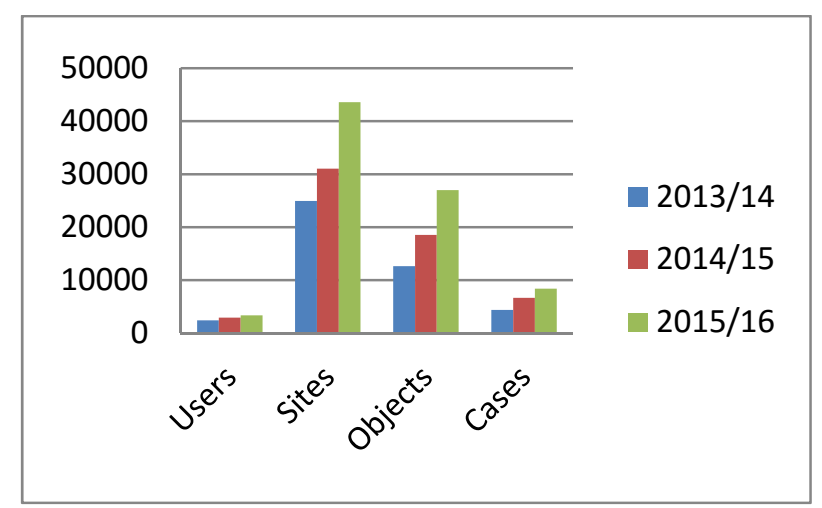

Figure 1: The use of SAHRIS has increased steadily per year since its launch indicated by the increased number of users and created cases, sites and objects on SAHRIS.

\section{SAHRIS as an inventory of the national estate}

The NHRA mandates SAHRA under section 39 to create a database that records all heritage resources that are deemed to be conservation worthy or that are afforded general protection under the NHRA (South Africa, Department of Arts and Culture, 1999)

\section{Protecting heritage resources that are threatened by development or mining activities}

Development is a necessity that benefits both the economy (e.g., by mining resources) and the general public (e.g. job creation, by building infrastructure for electricity creation and distribution, houses, hospitals, roads etc.). However, within any development footprint area, archaeological and palaeontological heritage resources may occur. The aim is to create a complete platform that includes all heritage sites and resources that developers can use to be alerted to the occurrence of heritage resources during the early stages of planning. The developer and SAHRA then use SAHRIS to interact and resolve conflicts by e.g. recording and mitigation of a heritage site or resources by a qualified archaeologist or palaeontologist. This ensures that mitigated heritage resources are accessioned in museums and still available to the public and researchers.

Furthermore, logging development applications on SAHRIS allows officials to examine the cumulative impact of development on heritage resources in South Africa, thereby allowing for more informed decisions (Fig. 2).

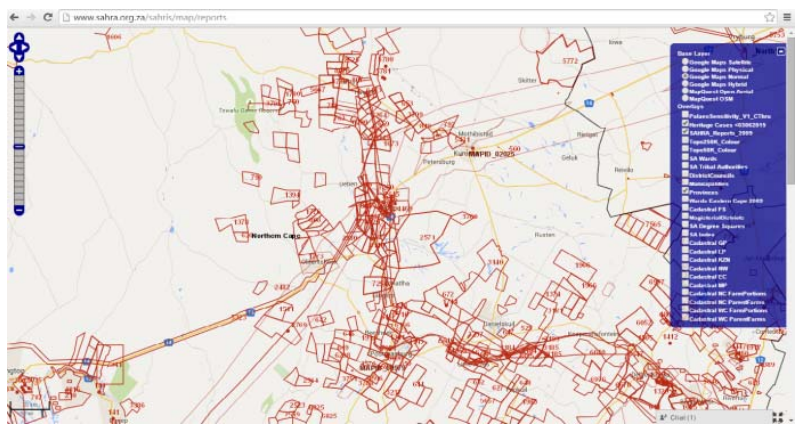

Figure 2: Cululative impact of development applications in Kathu, Northern Cape Province.

\section{Collaborative spaces}

SAHRIS also creates a collaborative space through which associated governmental departments can engage on matters that pertain to the management of heritage resources as is called for by both the National Environmental Management Act.

The logging of heritage cases on SAHRIS allows for the immediate and convenient access to a record of decisions taken as well as the transparency provided by the display of case particulars.

Taking the idea of collaborative spaces further, SAHRIS provides a platform for researchers to share information whilst still maintaining a level of privacy that can protect both the integrity of the resource they are studying as well as their own research topic.

\section{SAHRIS and Heritage Management in South Africa}

The promulgation NHRA instituted a three tier system of heritage management in South Africa. This means that the responsibility of managing heritage resources is split between National, Provincial and Local (Municipal) 
levels. SAHRA as the national body is responsible for the assessment of Provincial Heritage Resources Authorities (PHRA) and the devolution of powers to the PHRAs in terms of the NHRA (Hine and Khumalo 2015).

The adoption of SAHRIS amoungst the PHRAs allows for this devolution to take place whilst also allowing for effective and immediate monitoring. To date three of the PHRAs have been deemed fully competent to handle all aspects of the NHRA including archaeological resources. SAHRA is managing permitting and development applications on behalf of the remaining PHRAs.

\section{Shortcomings of HRM in SA}

The main shortcoming is the communication and engagement of researchers and SAHRA, and the lack of willingness to apply for permits. SAHRA does not have the financial and staff capabilities to follow up on transgressions of the NHRA. Streamlining processes via new, updated and relaxed policies may make the researchers' job easier and thereby motivate them to apply for permits. SAHRA recognises that only with the important help of researchers does it gain information on the existence and locations of heritage resources and sites to fill SAHRIS' database. Even more challenging is for SAHRA to follow up on developers to ensure they apply and comply with comments issued by SAHRA, such as employing a professional archaeologist/palaeontologist to monitor excavation works prior to construction or mining operations and report back on the finds.

\section{Challenges facing SAHRIS}

\subsection{Complexity}

A large criticism levied against the system has been the complexity of use. The system answers to a variety of uses and users, i.e., developers, researchers, heritage officers and other government officials use it for their applications, helping to create an inventory repository of the national estate by creating object and site records, and using the interactive map to record positions of sites and resources. This diversity of usage compromises the ability of the general public and officials to navigate and make effective use of the system. Indeed research conducted amongst the officials who make the most use of the system has shown that $35 \%$ of users are dissatisfied with the navigability of the platform (Jackson 2016).

\subsection{Intellectual property and Licensing}

The public nature of information loaded onto SAHRIS is guided by the Promotion of Access to Information Act (Act 2000) (PAIA) and Section 31 of the National Environmental Management Act (NEMA, Act of 1999), which invokes the right of the public to access records (Wiltshire 2013).

However, this legislated mandate does not apply to research data that have been donated for use on SAHRIS. In order to protect the intellectual property of the authors and still maintain the public nature of the system it was decided to license all content on SAHRIS under the Creative Commons Attribution-ShareAlike License (CCBYSA). This allows users to explore and make use of the data on SAHRIS as long as the original author is cited and the data are not sold (Wiltshire 2013).

Whilst the general disclaimer for use of the website states that any information placed online will be a matter of public record, should the data be readily accessible to the public, especially where it includes research proposals and methodologies that are required by officials to process permit applications? Provision have been made for the secure upload of this information on SAHRIS, however this was done out of a reaction to concern raised by members of the academic community. SAHRA's own policy remains silent regarding to access to this information in relation to the provisions made in PAIA.

\subsection{Conservation and information in the public domain}

One of the core tenets of SAHRIS is the publically accessible nature of the site information available on the system. Section 39(6) of the NHRA expresses the public nature of the inventory, ensuring that it is available to any member of the public, provided that information can be kept private should its disclosure negatively impact on any person's economic interests, privacy, or on the conservation of a heritage resource or site (South Africa, Department of Arts and Culture, 1999).

SAHRIS requires that sites are geocoded when being captured, and while the functionality exists for the capturer to confine the visibility of a site to nominated individuals (Jackson, 2015), the question remains as to whether this is sufficient, especially considering that by default all sites are recorded publically. In the case of archaeological or palaeontological resources that are open to public visitation the risk of looting remains high; should these resources be accessable on an online platform (Chirikure 2013) However, closing access to these records would prevent developers and heritage practitioners from being able to consult the site location data during planning and management. This matter requires further investigation before a policy decision can be made.

\subsection{Uptake of SAHRIS amoungst provincial authorities}

During the roll out of SAHRIS each of the PHRAs were visited in order to provide training, however it was soon discovered that four of the nine PHRAs had sporadic, throttled or unstable internet connections. SAHRA attempted to engage with the matter by dealing with the State Information Technology Agency (SITA) under whom most of the PHRAs IT requirements were handled, however this was not successful and it became evident that internet access in these offices were treated as a non essential service despite the roll out of web based system that would enable them to fulfil their legislated mandate (Wiltshire and Smuts 2014). In fact even amongst the functional PHRAs there has been resistance to the adoption of SAHRIS and to date it is only SAHRA and one of the PHRAs that have fully adopted SAHRIS. One PHRA even went as far as 
attempting to develop their own system which replicates the functions of SAHRIS (Heritage Western Cape, 2015).

\subsection{Daily work with SAHRIS from a Heritage Officer's perspective}

When working with SAHRIS on a regular basis some drawbacks are noticeable. One of them is the inefficient workflow between the different tabs and pages, again due to the complexity of the system.Furthermore, a guided map or tabs would facilitate the application process. Additionally, automated responses would solve time constraint issues when working with deadlines. As an example, users are not being automatically notified by updates or status changes or when a permit report is due. If an applicant forgets to change the status to "submitted" or leaves it in "draft", the $\mathrm{HO}$ fails to pick it up and process it in good time, which becomes problematic when working according to a tight schedule.

\section{Conclusion}

SAHRIS has changed the manner in which heritage resources are managed in South Africa and opened up new possibilities for heritage management within the digital sphere. However, this shift has not been without its problems. Challenges include the complex nature of the system in its attempt to accommodate a wide variety of uses, which impacts the ability to easily navigate it. Furthermore, the questions of privacy and conservation are matters that require unpacking in order to ensure that a balance is reached between the publics' right to access heritage information and the need to conserve these finite resources. However, such difficulties are far outweighed by the positive results experienced since the systems launch, and SAHRA remains dedicated to the constant improvement of the system and will engage with users in order to ensure that heritage continues to be managed in the digital sphere in South Africa.

\section{References}

CHIRIKURE, S. 2013. Heritage conservation in Africa: The good, the bad, and the challenges. South African Journal of Science. 109(1-2):1-3. DOI: 10.1590/sajs.2013/a003.

DEPARTMENT OF ARTS AND CUTURE, SOUTH AFRICA, 1999. National Heritage Resources Act 25 of 1999. Government Gazette, 506 (19974), Pretoria, Government Printers.

HERITAGE WESTERN CAPE. 2015. Heritage Western Cape Annual Report 2014/2015. Western Cape Provincial Government: Cape Town.

HILL, P. 2011. SAHRA: Review and Analysis of SAHRA's IT Function. Unpublished internal document. IM Governance.

HINE, P. and KHUMALO, N. (2015). Evaluating the current state of heritage resources management in South Africa. Paper presented at the ASAPA Biennial Conference, 01-03 July, University of Zimbabwe, Harare.

JACKSON, C and SMUTS, K. 2015. The use of SAHRIS as a tool for collaborative research with a focus on the spatial analysis of rock art sites and motifs. Paper presented at the ASAPA Biennial Conference, 0103 July, University of Zimbabwe, Harare.

JACKSON, C. 2016. SAHRIS User Satisfaction Survey Report. Unpublished internal document. South African Heritage Resources Agency.

NDLOVU, N. 2011. Legislation as an Instrument in South African Heritage Management: Is It Effective? Conservation and Management of Archaeological Sites. 13(1):31-57. DOI: 10.1179/175355211X13097877338932.

SMUTS, K. 2015. SAHRIS as a tool for reporting, tracking and managing cases of heritage crime in South Africa. South African Museums Association Bulletin, (37): 17-31.

SMUTS, K., MLUNGWANA, N. and WILTSHIRE, N. 2016. SAHRIS: South Africa's integrated, web-based heritage management system. Journal of Cultural Heritage Management and Sustainable. In Press.

SMUTS, K.,and WILTSHIRE, N. 2014. Challenges facing heritage management in South Africa ashighlighted by the implementation of a web-based national heritage management system. Proceedings of the 11th Congress of the PanAfrican Association for Prehistory and Related Field. In Press.

WILTSHIRE, N.G. 2013. The use of SAHRIS as a state sponsored digital heritage repository and management system in South Africa. ISPRS Annals of the Photogrammetry, Remote Sensing and Spatial Information Sciences. (II-5/W1): 325-330. DOI: 10.5194/isprsannals-II-5-W1-325-2013. 


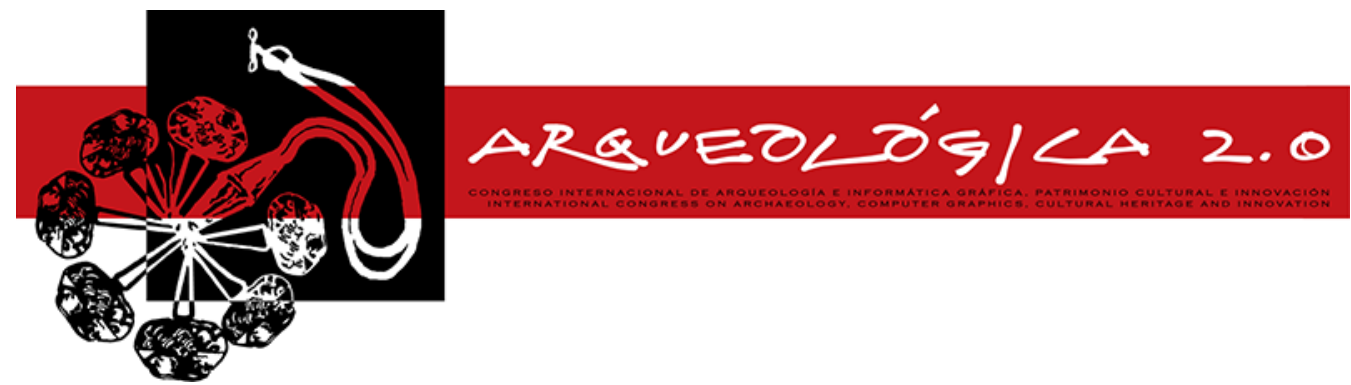

Proceedings of the $8^{\text {th }}$ International Congress

on Archaeology,

Computer Graphics,

Cultural Heritage and Innovation

'ARQUEOLÓGICA 2.0'

in Valencia (Spain),

Sept. $5-7,2016$

\title{
AUTHENTICITIES AND VIRTUAL REALITY THE CASE STUDIES JUPITER COLUMN AND KALEIDOPHONIC DOG
}

\author{
AUTENTICIDADES Y REALIDAD VIRTUAL. LOS ESTUDIOS DE CASO COLUMNA DE JUPITER Y \\ KALEIDOPHONIC DOG \\ Jesús Muñoz , Franziska Schaaf, Ralf H. Schneider, Caroline Y. Robertson-von Trotha \\ ZAK | Centre for Cultural and General Studies, Karlsruhe Institute of Technology (KIT), Rüppurrer Str. 1a, Haus B, 76137 Karlsruhe, \\ Germany. jesus.morcillo@kit.edu; franziska.schaaf@kit.edu; ralf.schneider@kit.edu; caroline.robertson@kit.edu
}

\begin{abstract}
:
The common notion of digital replicas is mostly dominated by the idea that a digital 3D reconstruction should be as faithful to the original artefact as possible. However, the resulting 3D models need often too many computing resources for displaying, so that it is barely possible to experience them with accuracy in a virtual environment. In order to make complex 3D replicas more accessible, the polygonal mesh has to be decimated at the expense of the details loosing "authenticity" in an "auratic" sense. Against this background, we test a pluralistic notion of authenticity that relies more on conserving meanings rather than on conserving physical features by contextualizing 3D objects in VR environments. For this purpose, we use two case studies, the Ladenburg's Jupiter Column (II AD), and the audio-kinetic sculpture Kaleidophonic Dog (1967) by Stephan von Huene.
\end{abstract}

Key words: virtual archaeology, kaleidophonic dog, jupiter column, synesthetic documentation, authenticities

\section{Resumen:}

El concepto habitual de réplicas digitales está mayoritariamente dominado por la idea de que la reconstrucción 3D ha de ser tan fiel al artefacto original como sea posible. No obstante, los modelos 3D resultantes son a menudo tan complejos que es casi imposible experimentarlos con detalle en un entorno virtual al requerir demasiados recursos computacionales para su representación gráfica. Para hacer más accesibles las réplicas 3D hay que diezmar la red poligonal a costa de los detalles perdiendo "autenticidad" en un sentido "aurático". Con este trasfondo probamos una noción pluralística de autenticidad que consiste más en la conservación de siginificados que en la conservación de características físicas contextualizando objetos $3 \mathrm{D}$ en entornos de realidad virtual (RV). Con este fin usamos dos ejemplos, la Columna de Júpiter (II A.D.) y la escultura audiocinética de Stephan von Huene Kaleidophonic Dog (1967).

Palabras clave: arqueología virtual, kaleidophonic dog, columna de júpiter, documentación sinestésica, autenticidades

\section{Introduction}

In the "Nara Declaration" (1994) authenticity is described to rely on "thruthful and credible values" (ICOMOS 1994). This implies a variable approach that overcomes the object-related and classic notion of the "original's aura" as the essential form of cultural tradition (Benjamin 1935). The widely spread use of optical and computer based technologies for the documentation of cultural heritage in recent years has favored the conceptual enhancement of authenticity as a working criterion for faithful and accurate documentations within the framework of virtualization, but we seldom find projects that consider authenticity as a "layered concept" in a consistent way, e.g., by taking into account the check list of the "Nara Grid" (Van Baalen 2008) for the re-creation of meaning in different social contexts. Rather, in the
"Seville Charter" (2012), which directly addresses virtual archaeology, we find a predominant aura-related notion of authenticity. According to the "Principles of Seville" on virtual archaeology, which actually enhance and update the guidelines formulated in the "London Charter" (2009), "authenticity must be a permanent operational concept in any virtual archaeology project" (§ 4), i.e., a requirement for virtualizing original objects. But that doesn't mean that there is no place for other interpretations. Even if the "Principles of Seville" do not explicitly relate to the ambitious definition of authenticity formulated in the "Nara Declaration" (1994), we can infer that some aspects of it are present in $\S 4.1$ such as the idea that "archaeology is complex and not an exact and irrefutable science", and therefore, "it must be openly committed to making alternative virtual interpretations provided they afford the same scientific validity." In this sentence, the authenticity is determined in a similar way

*Corresponding Author: Jesús Muñoz, jesus.morcillo@kit.edu 
as proposed in the "Nara Declaration", i.e., through „thruhtful and credible values" related to the presumably original context (cf. Nara 1994, § 9). "The Nara Document on Authenticity" (1994) goes beyond that considering time, space and cultural aspects as key factors of authenticity. But even here, authenticity is considered as an abstract entity linked to the original context or contexts of the past and not as a variable quality that changes depending on different uses and social memories, including present and future projections.

Based on two case studies on digital cultural heritage, we will argue that contextual enhancement and new forms of virtual interaction are needed in order to reenact all the possible meanings and "authenticities" of the object. For this purpose, we follow theoretical and practical approaches on authenticity in the field of virtual archaeology and cultural heritage (e.g. the idea of "progressive authenticities", Lowenthal 2008) and art conservation with a special focus on core strategies for the conservation of media art such as emulation, reinterpretation and digital re-enactment (cf. Variable Media Network 2004; Rinehart and Ippolito 2014, Muñoz Morcillo et al. 2014).

\section{The Case Studies Jupiter Column and Kaleidophonic Dog}

The Jupiter Column of Ladenburg was used to test interdisciplinary research methods that make perceptible the various dimensions of cultural heritage. Built roughly 200 AD, destroyed shortly thereafter and then reconstructed and changed, this typical landmark in the Roman provinces was accidentally discovered in the 1970s, buried in a former well (Heukemes 1975). For the $3 \mathrm{D}$ reconstruction of the column, different methods were used. Researchers at the KIT-Institute of Photogrammetric and Remote Sensing (IPF) provided a photogrammetric reconstruction based on 700 photographs with a resolution of 36 megapixels using Agisoft (Fig. 1a and 1b), one of the most popular and efficient photogrammetric software, achieving a photographic looking model with original colors and a very high resolution. Researchers of the Heidelberg University FCGL (Forensic Computational Geometry Laboratory) applied structured light using the Breukmann SmartSCAN-3D-HE with an extreme high resolution but no texture information. This procedure in combination with geometrical filters helped for deciphering an overwritten inscription. (Fig. 1c). Finally, a web application for contextualizing the results using geodata and 3D annotation was developed by the Geoinformatics Research Group at the Heidelberg University (http://ors.geog.uni-heidelberg.de/musieke). Against this background, the spatio-temporal distribution and the speculations on the varying purposes of the statue put the general question of authenticity of cultural heritage to the fore. The object itself demanded a processual display, because of its complex record of findings and interpretations. Using 3D annotations and geodata in connection with a web application, researchers and the general public can not only examine the 3D reconstructed Jupiter Column, they also can understand, in which place the column was found, where it was supposed to have been before, and where similar sculptures were located, allowing a study of the Jupiter Column as a type.

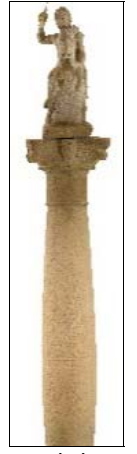

(a)

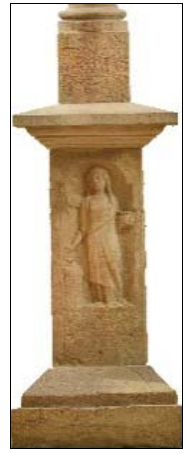

(b)

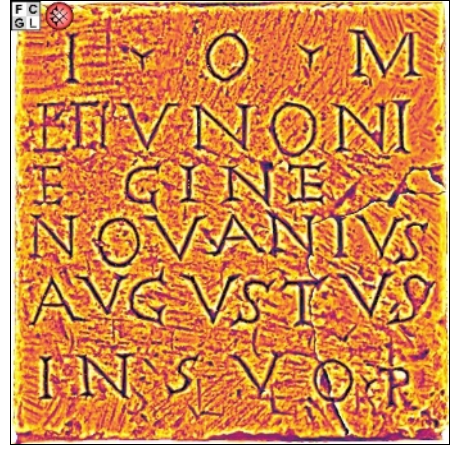

(c)
Figure 1: (a) and (b) Ortho perspective of the photogrammetric reconstructed Jupiter Column in two sections. Photo: IPF/KIT; (c) Detail of the inscription, digitized by applying structured light. Fictive colors. Photo: FCGL/Heidelberg University.

In our accompanying research, we found that both computer scientists and heritage professionals acknowledge "the original" and attributions of its auratic qualities. However, researchers in our sample stressed the importance of exact and accurate methods in digital reproductions. It can be said, that in creating digital versions, the "aura" of the original is replaced by the zeal and effort of the "accurate" and "geometrically exact" scientific research process. Moreover, the same researchers evoked the necessity to transmit scientifically produced knowledge to a larger audience. Hence, accurate, realistic, sustainable, and manageable representations help both to determine what the original artefact potentially was and to reveal its processual nature, providing thus a basis for further research and public communication. This notion of providing knowledge about and access to the artefact is congruent with the above-mentioned definition of the "Nara Declaration" (1994) demanding a transparent and therefore "credible" presentation of the sources of information.

The audio-kinetic sculpture Kaleidophonic Dog (1967, Fig. $2 a$ ) by the US-american-german artist Stephan von Huene (1932-2000) was virtualized for documentation and conservation purposes using VR-technologies as part of a methodological approach to a new kind of "informational preservation" (cf. Muñoz-Viñas 2011, p. $25)$. It consists of 8 wooden pipes, a xylophon, a wooden drum, a cymbal, and a wooden dog lying on his back and covered with red leather, with movable front legs, mouth and head. The 21 kinetic and acoustic parts are regulated by valves and bellows within a complex pneumatic system actioned by both a vacuum and a blowing motor. For this case-study, an interdisciplinary team composed of KIT-members of the Intelligent Sensor-Actuator-Systems Laboratory (ISAS) and the ZAK applied photogrammetric reconstruction based on 380 photos using VisualSFM, fine modelling in the 3D modelling software Blender as well as two game engines -Unity for testing and Unreal for the final implementation of sound and kinetic parameters-, and VR technologies for a lifelike experience of the results (Fig. 2c). We decided to include full sensory perception, such as spatial, kinesthetic, and acoustic experience levels, since they also transport important information for under- 
standing cultural assets. At the KIT, we address this issue with the tests on an Oculus- and Kinect-based VRsystem, developed by the ISAS Laboratory that allows the user for freely walking in a virtual environment (Faion et. al. 2012). We used this system for the virtual reenactment of media art into an "e-Installation". An eInstallation is a virtualized media artwork that reproduces all synaesthesia and interaction levels of the artwork identified as relevant for the production of meanings (Muñoz Morcillo et al. 2014). It consist of the 3D model of the artwork, the inner logic - i.a. audio-visual, haptic, and sensor information- embedded in a game engine, and the appropriate tracking and VR-system to immersively experience the results. Based on a documentation of the artwork, which followed the pluralistic and multiperspective approach of the "Variable Media Questionaire" (by Ippolito, Depocas et al. 2003), we opted for the use of new textures for UV mapping the 3D model instead of following the photogrametric information of the original. The manual texturing was formalistic nearer to the creation process of the artwork than using reconstructed textures, since the artist also covered 3D objects (i.e., hand carved wooden parts) with 2D surfaces (i.e., leather pieces, cf. Newmark 1972; Danieli 1968). In this sense, the making of the "virtual" Kaleidophonic Dog focuses on "the craftsman's contribution to preserving authenticity" as described in "The Nara Grid" (Van Balen 2008, p. 40).

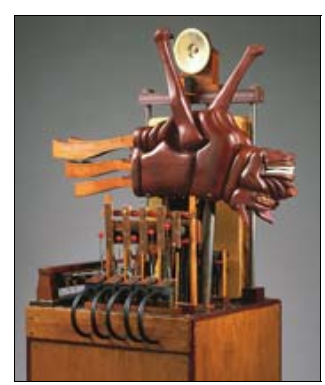

(a)

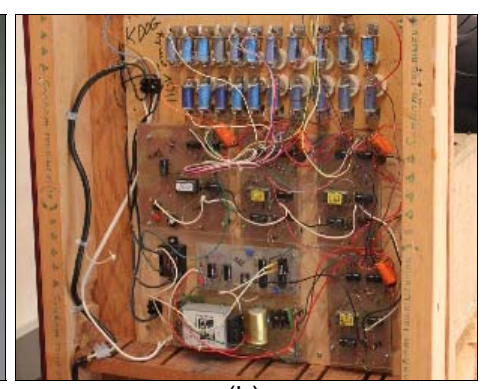

(b)

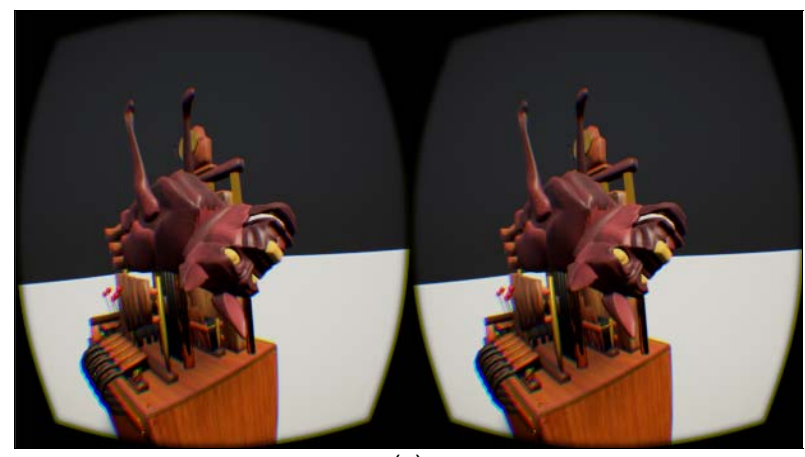

(c)

Figure 2: (a) Kaleidophonic Dog (1967). Photo: Artist's State;

(b) EPROM circuits for the control of the instruments and kinetic parts; (c) VR-version in Unreal. Photos: ZAK-ISAS/KIT.

As for the composition -a pseudo haphazard mixture of sounds-, there are two historically documented versions: the first one worked with five punched tapes in different length that activated the bellows of the instruments and kinetic parts, and the second one based on EPROMcircuits and relais (Fig. 2b). As the artist described (Kipphoff and Altner, p. 58), there are aesthetical differences between the pneumatically and the electrically regulated sculpture: the first version with punched tapes was much more "sensuous" because of the fully pneumatic control, therefore it had a more noticeable corporeal presence. Changing some parameters in the game engine, the reproduction of this different versions is also possible. The composition principle itself was virtualized making a mixture of migration of the original binary code stored in the EPROMs and emulation of the timing and counter information of the circuits by blueprint programming these parameters in Unreal. The mentioned parameters were retrieved for the first time thanks to the virtualization effort.

\section{Interim Findings: Authenticities}

The "over-authenticity" of 3D objects such as the Jupiter Column promises an additional value for research activities. If those $3 \mathrm{D}$ objects are also embedded in convenient multimodal virtual environments, a pluralistic approach to the "authenticities" and "meanings" involved is possible, as the virtual re-enactment of the Kaleidophonic Dog and its multi-versional representation demonstrate. The preservation of media art in practice promotes a concept of authenticity in terms of continuity of representation, critical analysis and decision-making models for future challenges.

In the field of archaeology, we also need a pluralistic concept of authenticity. As the case study Jupiter Colum shows, researchers and the general public can greatly profit from digitally reconstructed cultural artefacts that reveal layers of meanings and historical speculations in time-space annotations. The idea of the relative irrelevance of the physical source for the documentation of its meaning in a truthful sense is even clearer in the field of "informational preservation" as we see in the case study Kaleidophonic Dog or in the "digital conservation" in general. The source can be understood as its absolute physical condition but the authenticity is the result of the faithful transmission of its meanings that does not rely on the physical source but in its contextualization and creation processes. A transmission procedure based on scientifically testable virtualizations cannot utterly ensure the conservation of every meaning layer of an artwork, but is not necessarily worse than the transmission of ancient texts, which authenticity mainly relies on criticism and philological analyses.

Furthermore, the virtualization of the Kaleidophonic Dog was a complex knowledge process that allowed us to document the audio-kinetic composition principle of the artwork by studying the electronics: the documentation made during the virtualization process revealed the timing and counter parameters for the first time.

\section{Conclusions}

The interim results of the two projects discussed provide interesting findings for a reassessment of criteria for contextualizing 3D models: 1 . there are more than only one authentic result regarding the $3 \mathrm{D}$ reconstruction using different methods: every result is a valid one, and the sum of them enhances the perceptible informational basis of the original; 2 . we need several contextualization layers in order to understand the meanings of the objects through time and cultural contexts; and 3 . the discovery of new documentation 
aspects through virtualization processes supports an investigative notion of authenticity.

Last but not least, these experiences in VR archaeology and digital re-enactment of media art encourage some emendations in $\S 4.4$ of the Seville Charter regarding authenticity in the sense of the Nara Declaration and the media art conservation theory: VR-Archaeology "must be openly committed to making alternative virtual interpretations provided by scientific validity", whereby scientific validity should be based on truthful and credible values for different versions of an object, different uses through time as well as different cultural contexts and memories, and maybe even future projections of meanings.

\section{Acknowledgements}

This interim analysis on authenticity and virtual archaeology wouldn't be possible without the cooperation with interdisciplinary teams, whose members we thank here: Dr. Andreas Hensen (Museum
Lobdengau in Ladenburg), Prof. Dr. Christian Witschel (Heidelberg Center for Cultural Heritage, $\mathrm{HCCH}$ ), Dr. Hubert Mara (FCGL - Forensic Computational Geometry Laboratory), Dr. Thomas Vögtle (Institute of Photogrammetric and Remote Sensing, IPF), Prof. Dr. Bernhard Höfle (GIScience / Geoinformatics Research Group), Florian Faion, Antonio Zea, and Prof. Dr. Uwe D. Hanebek (Intelligent Sensor-Actuator-Systems Laboratory, ISAS), as well as the e-Installation-students Sophie von Schmettow, Lian Xizhe, Miriam Jöchner, and the research fellow Mercedes Morita (Laboratory of Ablation, Cleaning and Restoration with Laser - Optics Research Center of La Plata, Argentina). For support during the documentation of the Kaleidophonic Dog we also thank the engineer and art restorer Prof. Werner W. Lorke (iO Interdisziplinäre Objekte) and the art critic Dr. Petra Kipphoff von Huene.

This work was supported by the Stadt Karslruhe ("Interdisziplinärer Kulturtopf") and the HEiKA-Research fonds.

\section{References}

BENJAMIN, W., 2006. Das Kunstwerk im Zeitalter seiner technischen Reproduzierbarkeit. Frankfurt am Main: Suhrkamp.

DANIELI, F.A., 1968. West Coast Grotesque: Stephan von Huene. Art Forum, Januar 1968, pp. 50-52.

DEPOCAS, A., IPPOLITO, J. and JONES, C., (eds.) 2003. The Variable Media Approach - Permanence through Change. New York: Guggenheim Museum Publications. See http://variablemediaquestionnaire.net/ [6/1, 2016]

FAION, F., FRIEDBERGER, S., ZEA, A. and HANEBECK, U.D., 2012. Intelligent sensor-scheduling for Multi-KinectTracking. Proceedings of the 2012 IEEE/RSJ, IROS, October 2012, Vilamoura, Algarve, Portugal.

HEUKEMES, B., 1975. Die Jupitergigantensäule von Ladenburg in antiker Zeit und heute - dreimal zerstört und zweimal wiederhergestellt. Denkmalpflege in Baden-Württemberg 4, Heft 2, pp. 39-43.

INTERNATIONAL FORUM OF VIRTUAL ARCHAEOLOGY, 2012. Principles of Seville. International Principles of Virtual Archaeology. Final Draft. SEAV (Sociedad Española de Arqueología Virtual). Online document: http://www.arqueo logiavirtual.com/carta/wp-content/uploads/2012/03/BORRADOR-FINAL-FINAL-DRAFT.pdf [3/30, 2016].

INTERNATIONAL COUNCIL ON MONUMENTS AND SITES, 1994. The Nara Document on Authenticity. ICOMOS/ ICCROM/UNESCO: Nara.

KIPPHOFF VON HUENE, P. and ALTNER, M., (eds.) 2012. Stephan von Huene - Die gespaltene Zunge. Texte \& Interviews. Split Tongue. Text \& Interviews. München: Hirmer.

LOWENTHAL, D., 2008. Changing Criteria of Authenticity. In: Pamela Jerome (ed.), An Introduction to Authenticity in Preservation, APT Bulletin 39, no. 2/3, p.4.

MUÑOZ, J., FAION, F., ZEA, A., HANEBECK, U.D. and ROBERTSON-VON-TROTHA, C.Y., 2014. e-Installation: Synesthetic Documentation of Media Art via Telepresence Technologies, Preprint: http://archiv.org/abs/1408.1362 [4/15, 2016]. Revised version in: Bosteranu, Maria; Crăciun, Cerasella (eds.), 2016, Space and Time Visualisations, Springer Verlag (in press). See also http://www.e-installation.org [6/1, 2016].

MUÑOZ-VIÑAS, S., 2011. Contemporary Theory of Conservation. Oxford: Elsevier.

NEWMARK, D., 1972. An Interview with Stephan von Huene on his Audio-Kinetic Sculptures. Leonardo 5, pp. 69-72.

RINEHART, R. and IPPOLITO, J., 2014. Re-collection. Art, New Media, and Social Memory. Cambridge: The MIT Press.

VARIABLE MEDIA NETWORK, 2004. Seeing Double. Emulation in Theory and Practice (Solomon R. Guggenheim Museum; Daniel Langlois Foundation). Online Document http://www.variablemedia.net/e/seeingdouble/ [6/1, 2016].

VAN BALEN, K., 2008. The Nara Grid: An Evaluation Scheme Based on the Nara Document on Authenticity. APT Bulletin 39, no. 2/3 39: pp. 39-45. 


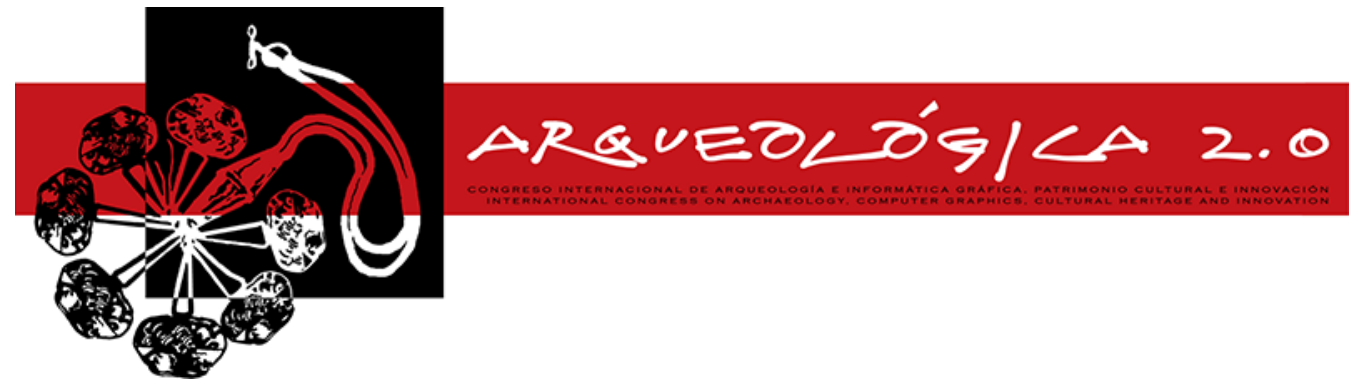

Proceedings of the $8^{\text {th }}$ International Congress

on Archaeology,

Computer Graphics,

Cultural Heritage and Innovation

'AROUEOLÓGICA 2.0'

in Valencia (Spain),

Sept. $5-7,2016$

\title{
SURVEYING DAMAGE TO HISTORIC BUILDINGS IN MEINONG EARTHQUAKE
}

\author{
Ren-Zuo Wang ${ }^{\mathrm{a},{ }^{*}}$, Heng-Chen Chang ${ }^{\mathrm{b}}$, Meng-Chieh Lee ${ }^{\mathrm{c}}$ \\ ${ }^{a}$ Associate Research Fellow, National Center for Research on Earthquake Engineering, Taipei, Taiwan. rzwang@ncree.org.tw \\ ${ }^{\mathrm{b}}$ Research Assistant, National Center for Research on Earthquake Engineering, Taipei, Taiwan. sis81818@hotmail.com \\ ${ }^{c}$ Associate Professor, Department of interior design, National Taichung University of Science and Technology, Taichung, Taiwan. \\ MCJL@nutc.edu.tw
}

\begin{abstract}
:
In this paper, according to survey damage to historic building in Meinong earthquake, five damage models for Chinese temple, the state temple of the Martial God are proposed. These temples were built during 1600s. These five damage models are separation of column from wall (M1), roof damage (M3) wall cracks (M5), surface peeling (M6), and Tilt column (M8). Taiwan free field strong earthquake network is used to analyze seismic data from three free field stations. These stations are close to the state temple of the Martial God. Due to forward directivity effect, the stations' maximum ground acceleration amplitude is dependent of distance between epicenter and station. Modal analysis using finite element method (FEM) is used to detect weak positions of Martial God temple. Weak positions of numerical results are close to site failure positions of Martial God temple.
\end{abstract}

Key words: Meinong earthquake, Chinese temple, damage model, free field strong earthquake network, FEM.

\section{Introduction}

Taiwan is located in Circum-Pacific seismic zone. According to statistics data of earthquake records, Taiwan may occur a strong earthquake per 15-year to 20-year. It is possible to have large disasters under region with intense and frequent seismic activities. Economic losses and casualties cause by natural disasters. In addition, cultural heritages and historic buildings may be destroyed. Intense typhoon occurrence can be predicted, but intense earthquake occurrence can't be predicted. On February 6, 2016, an earthquake with a moment magnitude of 6.6 in southern of Taiwan caused by some cultural heritages damage. It seems to be a problem with maintained Taiwan's cultural heritages and historic buildings under seismic.

In Taiwan, few researchers are to study seismic resisting capability of historic buildings. When time passing, structures' earthquake-resisting capacity of monuments is less than modern architectures. On the other hand, the materials of early construction are mostly timbers and bricks. Timbers are hard to prevent deterioration than other materials. Bricks are also broken away when some earthquakes occurs. Moreover, in Taiwan's building codes, there are not enough articles to provide information of structures' earthquake-resisting capacity of monuments. Although many researchers in Taiwan have provided technologies of seismic disaster prevention for general buildings, but in terms of historical buildings, there are short of analytical techniques to introduce more new technology, such as measurement and assessment of seismic evaluation and early warning system.

This earthquake caused some cultural heritages damage especially close to epicenter. Therefore, we choose 30 historic monuments (Table 1) to survey damage models and conduct disaster data collection.

Table 1 Number of monument survey sites

\begin{tabular}{c|c}
3 Level Historic Monuments of Taiwan & Amount \\
\hline National Historic Monuments & 12 \\
County Historic Sites & 17 \\
Historic Buildings & 1
\end{tabular}

\section{Damage Models of historic monuments}

In Meinong earthquake, the wood structure and the brick mixed constructions have severely damaged. In Taiwan, historic monuments have three types such as national historic monuments, county historic sites and historic buildings. In this paper, damage models of historic monuments are classified as nine damage models (see Table 2). Most of historic monuments are Chinese temples. They are traditional wooden frame type (Chuang et al. 2006). One of them is the state temple of the Martial God. Figure 1 shows damage models of the

"Corresponding Author: Ren-Zuo Wang, rzwang@ncree.org.tw 
state temple of the Martial God. They are separation of column from wall (M1), roof damage (M3) wall cracks (M5), surface peeling (M6), and tilt column (M8).

Table 2 Damage models of 3 level historic monuments

\begin{tabular}{|c|c|c|c|c|}
\hline \multirow{2}{*}{\multicolumn{2}{|c|}{ Damage models }} & \multicolumn{3}{|c|}{ Number of monument sites } \\
\hline & & \multirow{2}{*}{$\begin{array}{c}\begin{array}{c}\text { National } \\
\text { Historic } \\
\text { Monuments }\end{array} \\
10\end{array}$} & \multirow{2}{*}{$\begin{array}{c}\text { County } \\
\text { Historic } \\
\text { Sites }\end{array}$} & \multirow{2}{*}{$\begin{array}{c}\begin{array}{c}\text { Historic } \\
\text { Buildings }\end{array} \\
1\end{array}$} \\
\hline M1 & $\begin{array}{l}\text { Separation of } \\
\text { column from } \\
\text { wall }\end{array}$ & & & \\
\hline M2 & Tilt wall & 5 & 3 & None \\
\hline M3 & Roof damage & 7 & 3 & None \\
\hline M4 & $\begin{array}{l}\text { Separation of } \\
\text { beam from } \\
\text { Wall or column }\end{array}$ & 4 & 14 & 1 \\
\hline M5 & Wall cracks & 18 & 12 & 2 \\
\hline M6 & $\begin{array}{l}\text { Surface } \\
\text { peeling }\end{array}$ & 5 & 6 & None \\
\hline M7 & $\begin{array}{l}\text { Separation of } \\
\text { dowel from wall }\end{array}$ & 2 & 4 & 1 \\
\hline M8 & Tilt column & 3 & 1 & None \\
\hline M9 & $\begin{array}{l}\text { Land } \\
\text { subsidence }\end{array}$ & None & 2 & None \\
\hline
\end{tabular}

The damage events of $M 1$ at the state temple of the Martial God are the most damage in these five damage Models. The maximum displacement of gap between column and wall is $5 \mathrm{~cm}$.

In roof damages (M3), different roof positions have different kind of damages. Figure 1 shows grave collapse from eaves in the state temple of the Martial God and the beam supporting the roof was broken.

In Fig.1, M5 is wall cracks at the top of door. This type of cracks is occurred at the corner of beams and door. M6 is the surface peeling of stone wall next to the gate. It didn't affect the structure stability. M8 occurs at the stairs and the column almost separated from its original position.

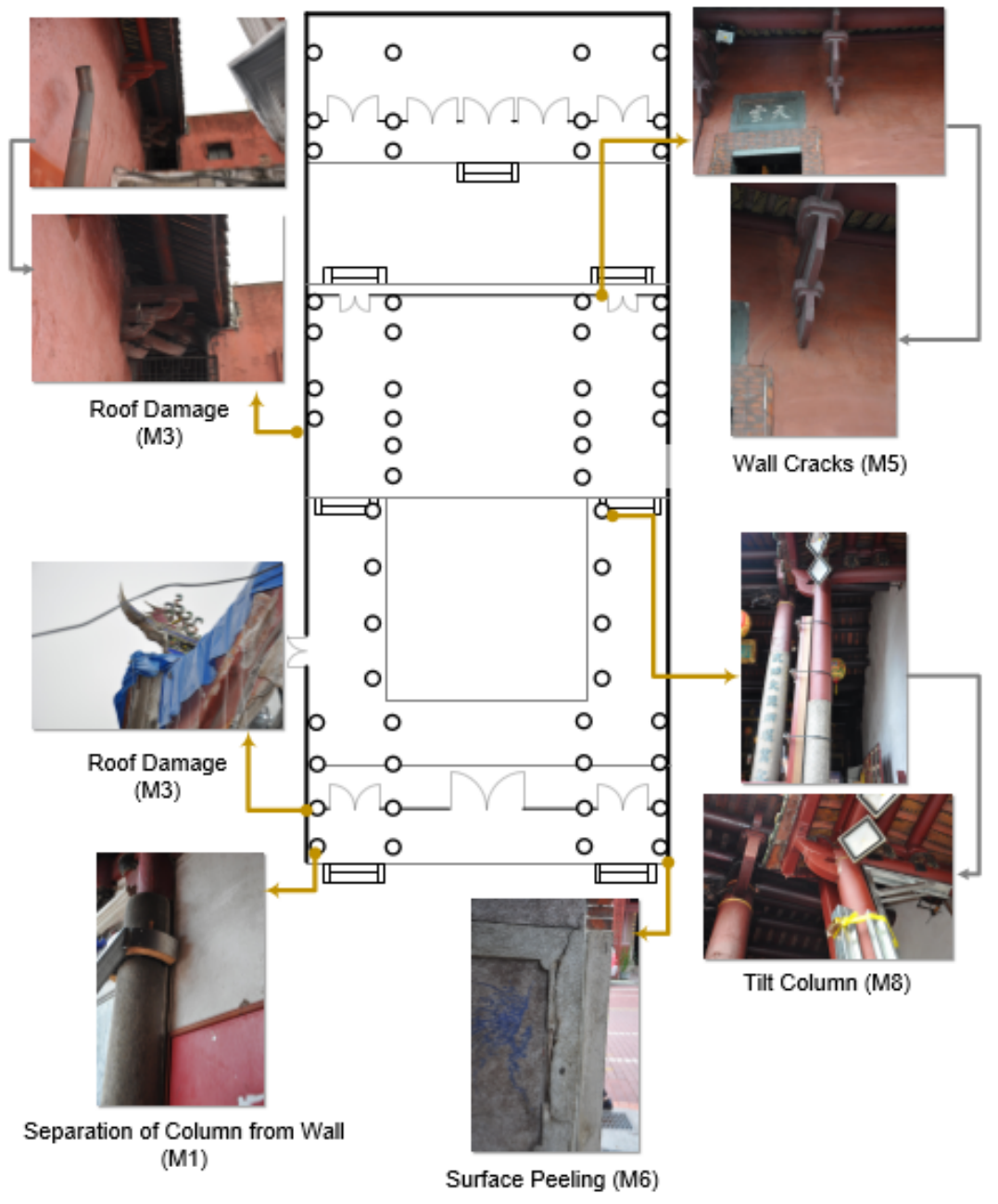

Figure 1: Damage Models of the State Temple of the Martial God. 


\section{Strong Motion Observation Stations}

According to CWB's free field strong earthquake network, three free field stations are close to the state temple of the Martial God. These three stations are CHY067, CHY085, and CHY097 (as Fig. 2). Table 3 shows more information of these free field stations. They are including GPS, distances between stations and epicentre, impulse per mass, maximum ground acceleration, and first frequency for three components. Figure 3 shows the earthquake response spectrum at CHY085. CHY085 is the closest station from the state temple of the Martial God. Figure 4 shows acceleration time histories at CHY085 for Z, NS and EW components. The impulse per mass of earthquake can be computed as:

$$
\begin{aligned}
& J=\int \mathbf{F} d t=\int \operatorname{ma} d t \\
& \frac{J}{m}=\int \mathbf{a} d t=\int|a| d t
\end{aligned}
$$

Where

$J=$ impulse, $\mathbf{F}=$ force vector, $m=$ mass, $\mathbf{a}=$ acceleration vector, $\mathrm{a}=$ acceleration.
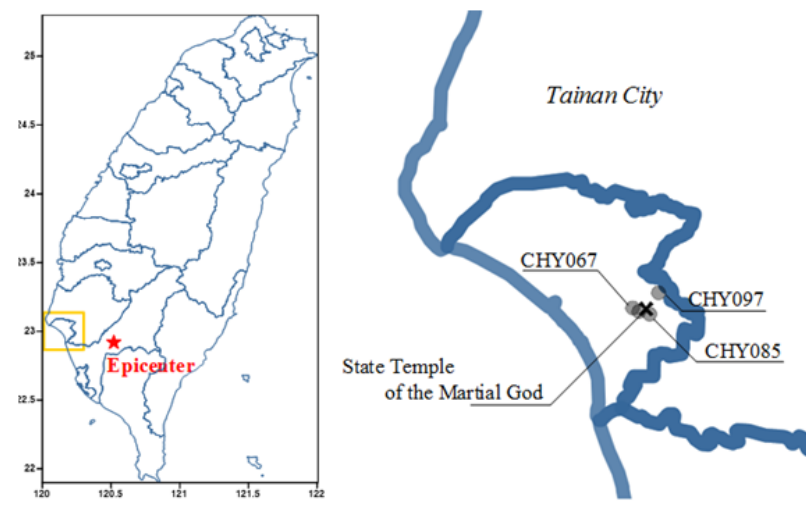

Figure 2: Positions of the state temple of the Martial God and three free filed stations.

\begin{tabular}{|c|c|c|c|c|c|c|c|}
\hline \multirow{2}{*}{$\begin{array}{l}\text { Free } \\
\text { Field } \\
\text { Stations }\end{array}$} & \multirow{2}{*}{$\begin{array}{c}\text { Epicetera } \\
\text { Distance } \\
(\mathrm{km})\end{array}$} & \multicolumn{3}{|c|}{$\begin{array}{c}\text { Impulse per } \\
\text { Mass } \\
\text { (cm/s) }\end{array}$} & \multicolumn{3}{|c|}{$\begin{array}{c}\text { Max. Ground } \\
\text { Acceleration } \\
\text { Amplitude (gal) }\end{array}$} \\
\hline & & $Z$ & NS & $E W$ & $Z$ & NS & $E W$ \\
\hline -Y067 & 34.67 & 399 & 528 & 707 & 78 & 147 & 208 \\
\hline †Y08 & 33.31 & 310 & 487 & 572 & 90 & 163 & 232 \\
\hline CHY097 & 33.13 & 257 & 455 & 545 & 48 & 125 & 127 \\
\hline
\end{tabular}

Table 3: Information for Taiwan strong motion observation

In Table 3, the impulses per mass at $\mathrm{CHY} 067$ are large than other station impulses. Due to resonance effect caused by topographic effect, the maximum ground acceleration and impulse per mass are at CHY085 station in EW direction. Since forward directivity effect by fault, PGA in this area is more than 200 gal (Lee et al. 2001).

In Fig. 5, modal analysis using FEM is proposed. Site weak positions (WPs) of FEM such as roof M3, M5 and M8 in Figs. 1 and 5 are close to site positions of the state temple of the Martial God.

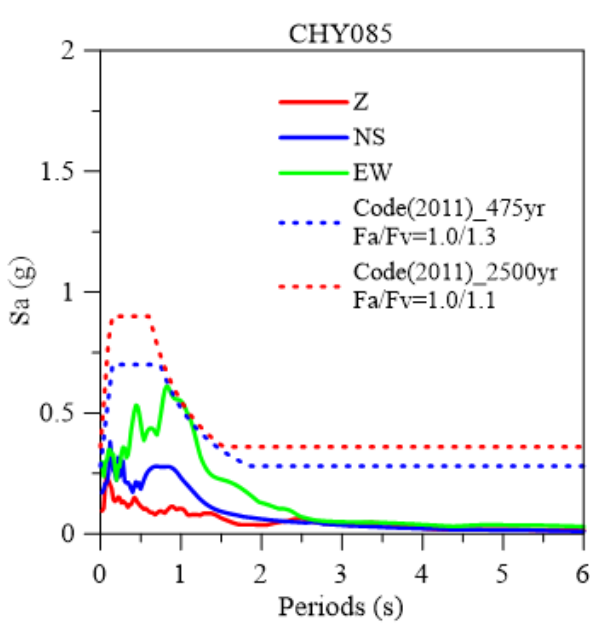

Figure 3: earthquake response spectrum at CHY085.

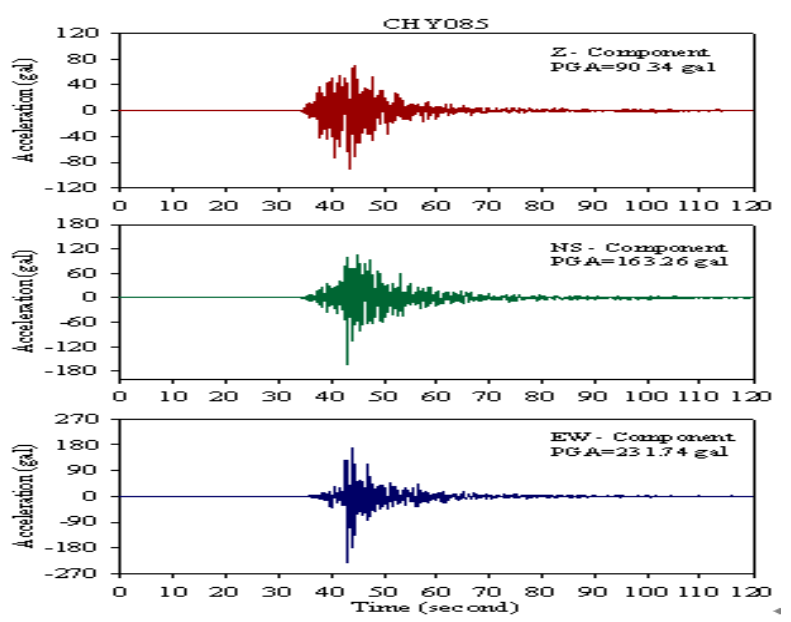

Figure 4: Acceleration signal at CHY085.

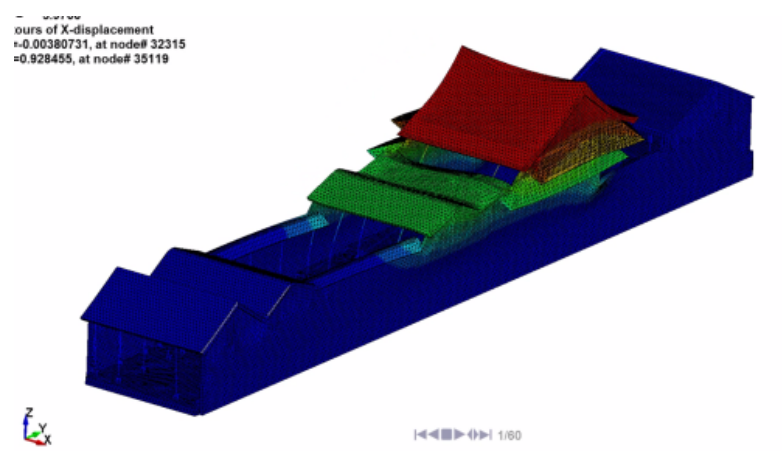

Figure 5: Finite element analysis of state temple of the Martial God in X direction.

\section{Conclusion}

Five damage models for wood and brick mixed constructions are proposed. Damage model relationships with strong motion observation stations are established. Modal analysis using FEM is used to find the weak positions (WPs) of the Martial God temple. WPs of FEM analysis are close to site positions of Martial God temple such as roof M3, M5 and M8 in Fig. 1. 


\section{References}

Central Whether Bureau, Geophysical Database Management System. Message posted to ftp://gdms.cwb.gov.tw/

CHUANG, T.F., CHEN, C.Y., LIN, Y.Y., and CHEN J.W., 2006. Numerical analysis for the behavior of traditional wooden frame under earthquake excitation-Illustrated by Yu-shan-Kuan. MingDao Journal, 2(2), pp. 69-105 (in Chinese).

LEE, C.T., CHENG, C.T., LIAO, C.W., and TSAI, Y.B., 2001. Site classification of Taiwan free-field strong-motion stations. Bulletin of the Seismological Society of America, 91 (5), pp. 1283-1297. 


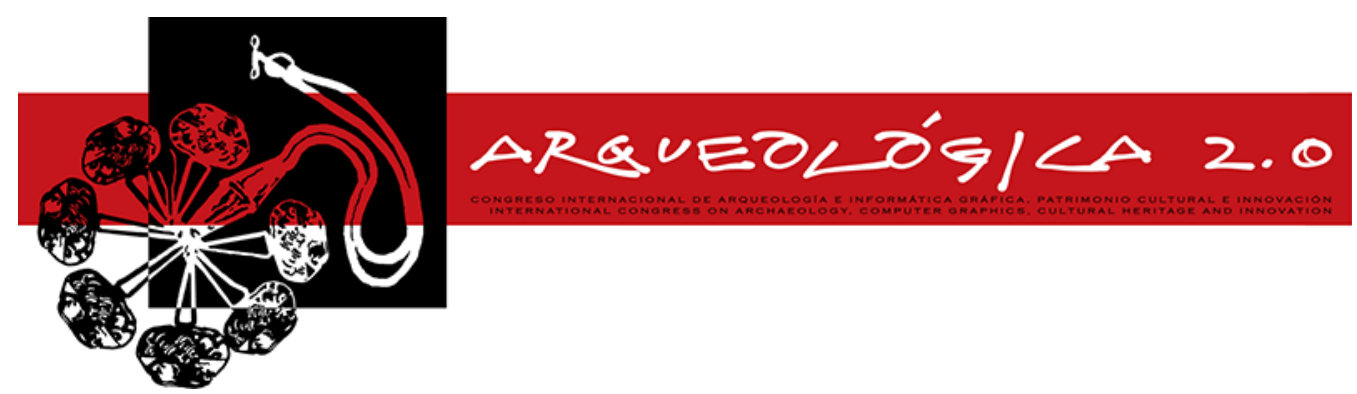

Proceedings of the $8^{\text {th }}$ International Congress on Archaeology, Computer Graphics, Cultural Heritage and Innovation 'ARQUEOLÓGICA 2.0' in Valencia (Spain), Sept. 5-7, 2016

\title{
ESTRATEGIAS PASIVAS EN EDIFICIOS ECLESIÁSTICOS CANARIOS CONSTRUIDOS ENTRE LOS SIGLOS XV Y XVI
}

\author{
PASSIVE STRATEGIES IN CANARIAN ECCLESIASTICAL BUILDINGS BUILT BETWEEN THE FIFTEENTH AND \\ SIXTEENTH CENTURIES
}

\author{
Sara Pérez
}

Departamento de Construcción y Tecnología Arquitectónicas, Escuela Técnica Superior de Arquitectura de Madrid, Universidad Politécnica de Madrid, Avenida de Juan de Herrera, 4, 28040 Madrid, España. saraperezespinosa@gmail.com

\begin{abstract}
:
Historical and experimental research of the Canarian churches built during the Spanish conquest of the archipelago which evolved until the eighteenth century, according to the hypothesis that wants to confirm the existence of passive strategies in the built heritage which is still standing today. From a technical perspective, it is made an analysis of the environment of each building. It carried out a critical analysis of external conditions that includes climatic, bioclimatic and orographic factors and social factors, which affect on the Canarian ecclesiastical architectural typologies. Once it is completed the identification and preliminary study of each case, every church is individually analyzed from assays "in situ" and representation and digital simulation. It've been made climatic studies, 2D digitalisations and thermal and acoustic "in situ" assays, using, among other tools, a thermal camera and a sound pressure level meter respectively.
\end{abstract}

Key words: cultural heritage, virtual architecture, data acquisition, 2D digitalisation, sound pressure assay, thermal assay

\section{Resumen:}

Investigación histórico-técnica de los templos eclesiásticos canarios construidos durante la conquista del archipiélago y evolucionados hasta el siglo XVIII, en función a la hipótesis que quiere confirmar la existencia de estrategias pasivas en el patrimonio construido que continúa en pie hoy. Desde la lógica técnica y el contexto físico en el que se desarrollan los edificios se realiza un análisis crítico de los agentes externos, tanto climáticos, bioclimáticos y orográficos como sociales, que afectan a las tipologías arquitectónicas eclesiásticas canarias. Tras la identificación y estudio previo de cada caso, se procede al análisis individual a partir de ensayos in situ y representación y simulación digitales. Se hacen estudios bioclimáticos, ensayos térmicos y acústicos, con cámara térmica y sonómetro y levantamientos bidimensionales.

Palabras clave: patrimonio cultural, arquitectura virtual, adquisición de datos, digitalización 2D, ensayo acústico, ensayo térmico

\section{Introducción}

El planteamiento y la investigación de nuevas formas de ver y pensar la arquitectura desarrollada por las sociedades del pasado son ineludibles para la mejora de las actuaciones futuras. La arquitectura es continente de una función social y a partir de ella se genera y articula interna y externamente, es decir, que se debe comprender como un fenómeno social y no como un hecho aislado, sin contexto. Por tanto, esta investigación propone que el entorno debe ser el condicionante del tipo de arquitectura adecuado a él, aportando en la construcción de cada edificación una serie de estrategias bioclimáticas pasivas.

Esta búsqueda de la relación existente entre la tipología arquitectónica y su entorno haciendo uso de diferentes estrategias pasivas, se estudia a partir de la arquitectura eclesiástica de las Islas Canarias, debido a los patrones estereotipados de las edificaciones de uso religioso cristiano y en el periodo comprendido entre la conquista, donde se crean los primeros templos, y el XVIII, siglo donde concluyen las principales ampliaciones de éstos.

\subsection{El qué y el porqué}

En el archipiélago canario los templos construidos en los periodos comprendidos entre el siglo XV y el XVIII comenzaron siendo pequeñas salas de culto cristiano construidas a lo largo del territorio según se iban conquistando las islas. Estos primeros edificios, de pequeñas dimensiones, disponían de una sola estancia que tenía un doble uso, confesional y jurídicoadministrativo, como sede del gobierno de cada zona. 
A medida que la feligresía crecía los templos se ampliaban, creciendo a lo alto y a lo ancho, primero a partir de capillas que se adosaban al cuerpo primitivo y luego creando nuevas naves.

El fenómeno de evolución de las capillas en ermitas, y éstas, a su vez, en iglesias atiende fundamentalmente a la configuración de numerosas poblaciones rurales y aisladas, constituyendo el templo como único edificio religioso que se tenía cerca, en un tiempo de grandes dificultades de comunicación.

\subsection{Las variables de estudio}

Para demostrar la existencia de estrategias pasivas sobre el patrimonio eclesiástico, se han determinado varias variables de estudio para el análisis de todos los templos, que son las siguientes:

- Factores climáticos, bioclimáticos, orográficos y demográficos.

- Cambios en la configuración constructiva y ampliación de los templos.

- Porcentaje de huecos de la envolvente del edificio.

- Sistema constructivo de los paramentos exteriores.

- Relación de los materiales constructivos.

- Espesor de los paramentos exteriores.

- Capacidad aislante acústica de los paramentos exteriores.

- Capacidad aislante térmica de los paramentos exteriores.

\section{Método}

\subsection{Diseño}

Como arranque de la investigación se realizó una revisión crítica a modo de reseña historiográfica del estado de la cuestión.

Tras esta reseña historiográfica, para cumplir con el objetivo de esta investigación, la metodología de trabajo se ha dividido en dos grandes bloques:

\subsubsection{FASE 1 Recopilación y estudio bibliográfico de la documentación técnica}

Esta fase se ha dividido asimismo en dos. La primera analiza e identifica el patrimonio eclesiástico construido en Canarias entre el siglo XV y el siglo XVIII. En esta fase se han investigado todos los templos que a priori cumplían con las características de estudio (42), considerando el sistema constructivo de cada uno, la cronología de su construcción y la relación de materiales constructivos. La segunda fase analiza la información estadística y geográfica del entorno en el que se sitúa cada templo, considerando la información necesaria a partir del condicionante social, la información geográfica y la información bioclimática.

\subsubsection{FASE 2 Modelado y desarrollo de los ejemplos de estudio}

Una vez seleccionados los ejemplos se realiza el levantamiento $2 \mathrm{D}$ y $3 \mathrm{D}$ de cada muestra válida para su posterior simulación y caracterización a partir de tomas de datos in situ, tanto en el exterior como en el interior del templo:

- Temperatura ambiente

- Cálculo de los porcentajes de humedad

- Fotografía térmica sobre los paramentos

- Ensayo acústico

\subsubsection{FASE 3 Simulación 3D}

A partir de los datos adquiridos y sobre el levantamiento tridimensional de cada ejemplo se realizarán pruebas e hipótesis mediante simulación. Esta fase aún está por concluir.

\subsection{Población y muestra}

Con la relación de templos analizados en la fase previa, se seleccionaron los ejemplos suficientes para su investigación en profundidad, atendiendo a las siguientes pautas:

- Estar en uso religioso continuo, se excluyen los templos cerrados indefinidamente.

- No contar con reconstrucción total posterior al siglo XVI.

- No contar con reconstrucción parcial mayor a un $50 \%$ posterior al siglo XVI.

- No contar con ampliaciones posteriores al siglo XVIII.

\section{Resultados}

\subsection{Selección de muestras}

Con el fin de corroborar la existencia de estrategias pasivas en los templos eclesiásticos canarios construidos durante el periodo de la conquista castellana que han ido evolucionando hasta el siglo XVIII, se están analizando, observando, investigando, comprobando y clasificando la totalidad de los templos existentes, es decir, cuarenta y dos templos.

La elección final de las muestras (Fig. 1) que se están investigando se justifica a partir de las reedificaciones o destrucciones totales que han sufrido quince de estos templos, quedando fuera del estudio. En la actualidad, dos de los veinticinco templos de estudio están cerrados al público por rehabilitación. Éstos no se han tenido en cuenta para la toma de datos in situ, pero sí se está siguiendo su rehabilitación por si fuera de interés para la investigación.

La mayoría de muestras válidas de estudio se registran en las islas de La Palma y de Tenerife, quedándose con sólo un ejemplo las islas de El Hierro, La Gomera, Fuerteventura y Lanzarote. 


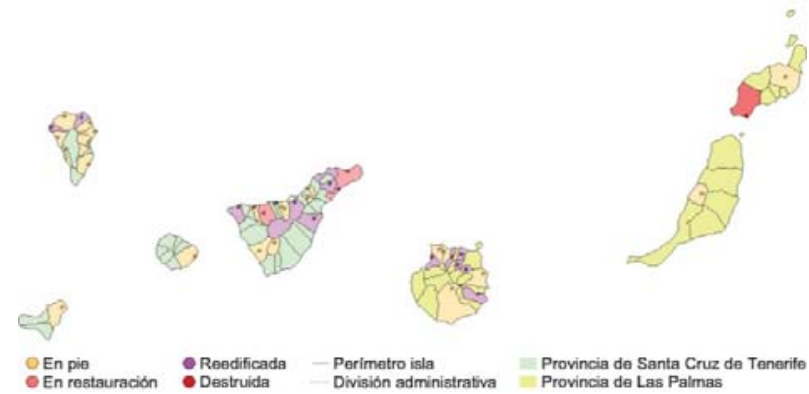

Figura 1: Mapa de muestras sobre el archipiélago canario, diferenciando los templos en pie, en fase de restauración, destruidos y reedificados.

\subsection{Recolección de los datos}

Para el análisis del comportamiento acústico (UNE EN ISO 140-5:1999) se ha utilizado un sonómetro (Ono Sokki LA-500) y se han tomado muestras del nivel de presión acústica continuo equivalente ponderado $A$ (LAeq) con un sistema de toma de datos igual a todos los templos (Fig. 2):

- Se ha dispuesto el sonómetro, colocado sobre trípode, en paralelo al suelo y en dirección al centro del templo.

- Las tomas acústicas se han realizado en Leq, en cada apertura hacia el exterior, en el centro del templo y en el altar, para, a partir de estas tomas, determinar el valor acústico medio.

- Se realizan dos ensayos en cada edificio, uno en invierno y otro en verano.

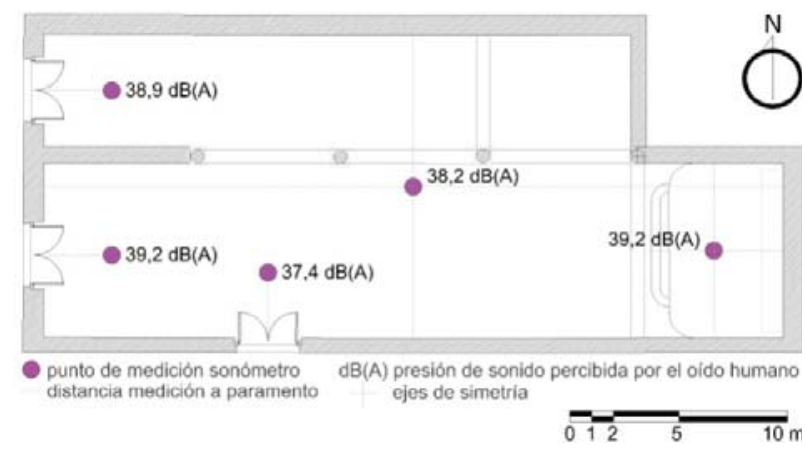

Figura 2: Mapa de ensayo acústico interior en la iglesia matriz de Santa Úrsula, en Adeje, isla de Tenerife. Siglo XVI.

Para el análisis del comportamiento térmico (UNE-EN ISO 6946:2012, UNE-EN ISO 15927-1:2006) se han utilizado un medidor de temperatura ambiente $y$ porcentaje de humedad y una cámara térmica por infrarrojos (FLIR ThermaCAM BCAM) (Fig. 3). Con estos instrumentos se analizan los paramentos que dan a exterior, desde el interior del edificio, como desde el exterior. Se analizan tanto los paramentos verticales como las cubiertas (Fig. 4), huecos de ventana y puertas, según emisividad de cada material, temperatura ambiente interior y exterior y porcentaje de humedad relativa.
La siguiente fase prevista es la simulación tridimensional $\mathrm{BIM}$, volcando datos reales y completando virtualmente los comportamientos térmico-acústicos anuales.

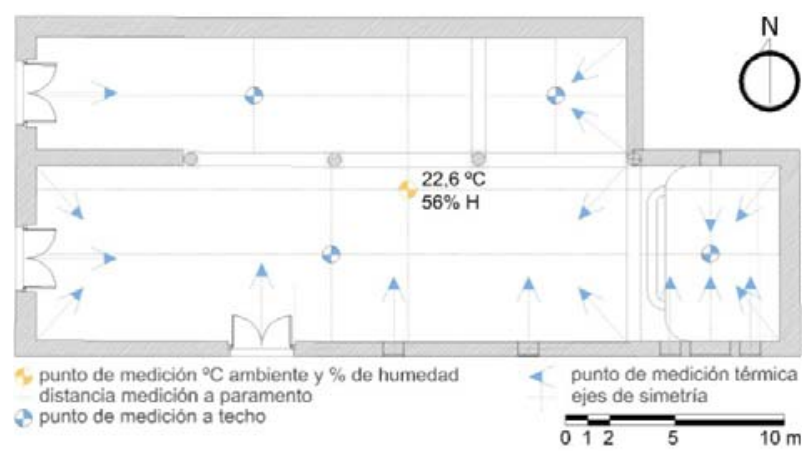

Figura 3: Mapa de ensayo térmico interior en la iglesia matriz de Santa Úrsula, en Adeje, isla de Tenerife. Siglo XVI.

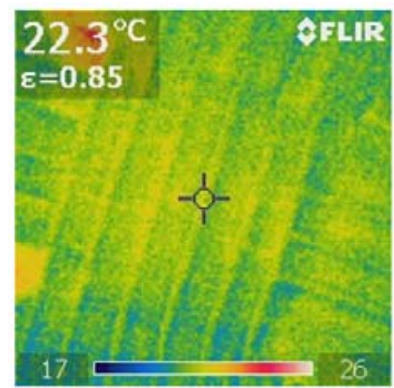

a)

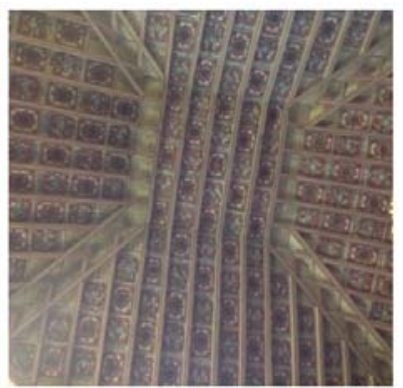

b)
Figura 4: Cubierta de la iglesia matriz de Santa Úrsula, en Adeje, isla de Tenerife. Siglo XVI: a) fotografía con cámara térmica; b) fotografía con cámara digital.

\section{Primeras Conclusiones}

Las islas presentan morfologías variadas que generan microclimas diferentes a los que debe adecuarse la estructura de cada templo. Se han analizado los factores climáticos propios de cada una de ellas detectando cambios de temperatura suaves entre invierno y verano en cada muestra, alta radiación solar en general, pero una gran diferencia de temperaturas medias entre ellos, en función a la altitud, orografía y distancia al mar.

Este estudio se ha completado analizando todos los factores climáticos y bioclimáticos en función a las posibles estrategias pasivas dentro de la situación geográfica de cada muestra válida. Se aprecian diferencias de comportamiento térmico y acústico en los templos debido al entorno construido inmediato entendiéndose como una estrategia pasiva más. El azote del viento, la radiación solar y el procentaje de humedad son los factores más determinantes de los que se protegen los templos. En éstos, la naturaleza de la superficie, el color, la composición y la estructura, provocan diferentes fenómenos de calentamiento y enfriamiento jugando un papel muy importante.

\section{Referencias}

ACHA, C. and NEILA, J., 2014. Arquitectura Bioclimática y Construcción Sostenible. DAPP. 
CARRIÓN, A., 2001. Diseño acústico de espacios arquitectónicos. UPC. Barcelona.

DE LA PEÑA, D., 2001. La Iglesia de San Marcos Evangelista de Icod y vida del Siervo de Dios fray Juan de Jesús.

LIMA, L. and ALEJANDRO, J., 2010. Arquitectura, ilustración e ideal eucarístico en los templos de Canarias (17551850).

MANUEL, R.L., 2000. Acústica arquitectónica aplicada. Madrid.

MAÑANA-BORRAZÁS, P., 2002. Arqueotectura 1: Bases teórico-metodológicas para una Arqueología de la Arquitectura.

MARZOL, M.V., 1993. Los factores atmosféricos y geográficos que definen el clima del archipiélago canario. Revista de Historia de Canarias. Aportaciones en homenaje al profesor Luis Miguel Albentosa, pp. 151-176. 


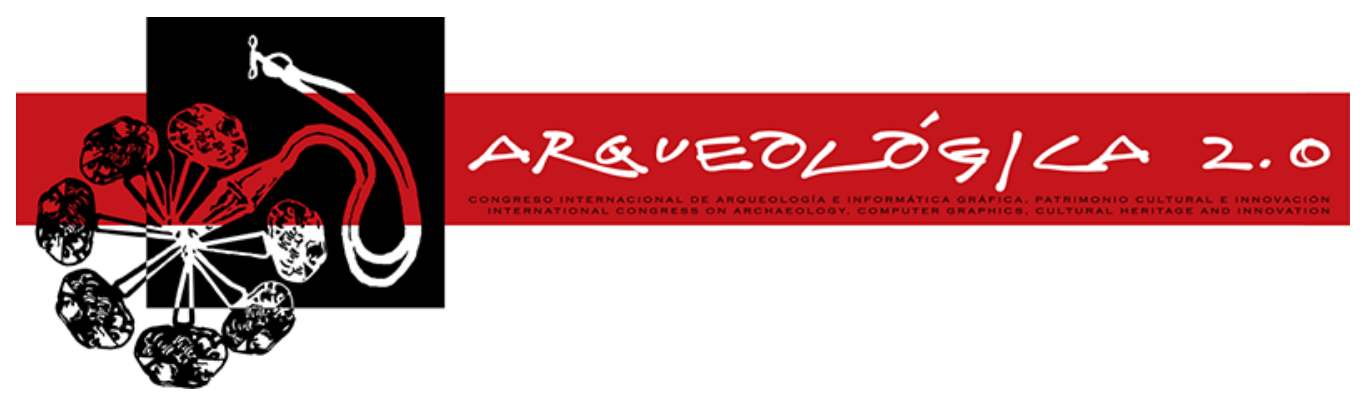

Proceedings of the $8^{\text {th }}$ International Congress

on Archaeology,

Computer Graphics,

Cultural Heritage and Innovation

'ARQUEOLÓGICA 2.0'

in Valencia (Spain),

Sept. $5-7,2016$

\title{
DISCRETE AND CONTINUOUS MONITORING TO CHARACTERISED THE THERMO-HYGROMETRIC STATE OF WALL-BUILDING MATERIALS IN OSTIA ANTICA ARCHEOLOGICAL SITE
}

\section{CARACTERIZACIÓN TERMOHIGROMÉTRICA DE MATERIALES DE CONSTRUCCIÓN DEL LUGAR ARQUEÓLOGICO DE OSTIA ANTICA MEDIANTE TOMA DE DATOS DISCRETA Y CONTINUA}

\author{
Fernando J. García-Diego ${ }^{\mathrm{a}, \mathrm{b}}$, Claudia Scatignoc, ${ }^{\mathrm{c}}$, Paloma Merello $^{\mathrm{d}}$ \\ ${ }^{a}$ Department of Applied Physics, Universitat Politècnica de València, Av. de los Naranjos s/n, Valencia 46022, Spain. \\ figarcid@upvnet.upv.es \\ ${ }^{\mathrm{b}}$ Centro de Tecnologías Físicas, Universitat Politècnica de València, Av. de los Naranjos s/n, Valencia 46022, Spain. \\ c Department of Earth Science, University of Rome “Sapienza”, Piazzale Aldo Moro 5, 00185, Rome, Italy. claudia.scatigno@uniroma1.it \\ ${ }^{d}$ Accounting Department, University of Valencia, Avd.Tarongers s/n,46000 Valencia, Spain. paloma.merello@uv.es
}

\begin{abstract}
:
Nowadays, the procedures and instruments for measuring temperatures on the air and materials surface are normed and amply used, through direct and indirect techniques, with the aim to evaluate the conservation status of ancient buildings. In this work, two monitoring procedures are discussed in order to characterise materials, bricks and mortar aligned with "opus caementicium" technique, that make up the framework of "Casa di Diana" Mithraeum, a roman building (130 CE) sited in an Italian archaeological site (Ostia Antica, Rome). In this sense, for one year the wall-building materials and the surrounding air were monitored with two different procedures: a direct multi-points measurement with several handheld instrument which different physical systems conduced in predetermined periods and a long-term monitoring campaign with sensors specially developed placed along the walls. Preliminary data analyses show that the discrete monitoring with punctually procedure gives important information like the evaporating and condensing risk for both materials and areas particularly critical associated at lower level $(0-70 \mathrm{~cm})$. Continuous monitoring allows the individuating of punctual characteristics in time and space, planning recovery actions, although it requires more data treatment. Preliminary data treatments show the potentiality and advantages of both methodologies: general information and more data treatment with automatic method and specific information and more time spends in data adquisition with a manually proceeding.
\end{abstract}

Key words: indoor monitoring, thermos-hygrometric measurements, archaeological site, materials surface and air measures, preventive conservation

\section{Resumen:}

En la actualidad, con el objetivo de evaluar el estado de conservación de edificios antiguos, los procedimientos e instrumentos para la medición de temperaturas del aire de y de la superficie de los materiales están estandarizadas y son ampliamente utilizados a través de técnicas directas e indirectas. En este trabajo, se discuten dos procedimientos de control con el fin de caracterizar los materiales, ladrillo y mortero, colocados con la técnica de "opus caementicium", que constituyen el marco del Mitreo de la "Casa di Diana", un edificio romano (130 dC) situado en el yacimiento arqueológico italiano (Ostia Antica, Roma). En este sentido, durante un año los materiales de construcción de muros y el aire circundante fueron monitorizados con dos procedimientos diferentes: uno mediante medición manual directa de múltiples puntos con varios instrumentos, realizado en períodos predeterminados y una campaña de monitorización continua a largo plazo con sensores especialmente desarrollados para este fin emplazados en las paredes. Análisis preliminares muestran que el sistema discreto aporta información importante de riesgo, como la evaporación y la condensación, tanto para los materiales como para las zonas especialmente aquellas más críticas (zona baja, 0-70 cm). La monitorización continua permite la individuación de las características puntuales en tiempo y en espacio, aunque requiere de un tratamiento de datos más extenso. Los análisis preliminares muestran la potencialidad y las ventajas de ambos métodos: información general con el método automático y un tratamiento de datos más extenso e información específica con un mayor consumo de tiempo en la toma de datos con un procedimiento manual.

"Corresponding Author: C. Scatigno, claudia.scatigno@uniroma1.it 
Palabras clave: monitorización interior, mediciones termohigrométricas, lugar arqueológico, materiales y superficie, conservación preventiva

\section{Introduction}

In term of technology building materials performance (Cardinale et al. 2010) or to individuate changing occurred along the time or to assess the rising damp or masonry (Sandrolini and Franzoni 2006), thermohygrometric buildings investigation is a practice amply available in the preventive conservation (Grinzato 2010). In the archaeological contest, where the building materials suffer of harsh climatic conditions, the environment monitoring temperature $(T)$ and relative humidity $(\mathrm{RH})$ is the first step to evaluate the status of historic materials (Merello et al. 2013). In the literature, very few works present a methodology based on the combination of complementing monitoring techniques, and they are mainly focused on moisture analysis of buildings, or for air pollution (Nava et al. 2010). In this work, a combination of two monitoring systems, discrete and continuous, was applied on Casa di Diana Mithraeum, a roman building (130 A.D.), sited in Ostia Antica, characterised by several conservation problems (Scatigno et al. 2016). The first method is based on multi-point measurements within a systematic measurement in predetermined locations on wallbuilding materials and the second method based on continuous measurements through an array of sensors, both performed in a sufficient number of walls, in order to represent different climatic zones in the building. Specifically, the manually method was performed with a multi-handheld instruments to individuate behavioural differences between mortar and bricks, measures repeated in different seasons throughout the year. The automatic approach, consists of 28 thermo-hygrometric sensors linked each other and positioned along walls surface, in order to record the air thermo-hygrometric near the building materials.

Data treatment was performed with Principal Component Analysis (PCA) and multivariate statistical analysis individuating advantages of both procedures and data were stored in Burrito software (Fernández-Navajas et al. 2013). The main goal of the paper is to determine the potentiality and advantages of both methodologies with preliminary data treatments.

\section{Materials and method}

\subsection{Discrete monitoring ( $T, \mathrm{RH})$}

\subsubsection{Instrumental technology}

Three different instruments were used. The Protimeter Surveymaster (SM BLD5360) that evaluates the conditions of moisture both on the surface by a conductive method and under surface layer of about 19 $\mathrm{mm}$ by an electromagnetic method using a needle electrodesanda non-invasive inspection through radio frequency technique (RFE). The electromagnetic method measures with two different modes: by LED scale, identifying degrees of dampness below the surface and by directly $\mathrm{RH}$ percentage values. A Multimeter PM 2521 Philips (PT100 probe) and IR Thermometer TESTO 810 were used for the contact and air temperature measurements, respectively.

\subsubsection{Multi-point measures}

A measurement in predetermined locations on wallbuilding materials of each wall was performed. In order to measure both brick and mortar and reveal differences along the vertical wall, a multi-point set was individuate, for a total of 22 measurements/walls.

\subsubsection{Recorded data}

The measurements, along the entire year, started on spring of 2014 and precisely from the exact day of the beginning equinox/solstice, obtaining a matrix of 3290 data.

\subsection{Continuous monitoring ( $T, \mathrm{RH})$}

\subsubsection{Instrumental technology}

The instrumental technology consists of multiple sensors (DS2438 - Maxim Integrated Products, Inc., Sunnyvale, CA, USA dual sensors and $\mathrm{HIH}-4000$ - Honeywell International, Inc., Minneapolis, MN, USA) that can be used in the system simultaneously with only one data line (1-wire communication protocol) (García-Diego and Zarzo 2010).

\subsubsection{Positioning sensors}

A total of 28 probes were installed, 27 in the interior along the wall) and one placed on the sill of a window as an outdoor climate control.

\subsubsection{Recorded data}

The continuous monitoring campaign system was started since the 29th June 2014 and finished the 31th August 2015, obtaining matrix of 5.342.400 data.

\section{Results and discussion}

\subsection{Discrete Monitoring}

Regarding $\mathrm{T}$, the air temperature $(\mathrm{Ta})$ is hotter than contact temperature (Tc) measured for both brick and mortar, especially in summer facilitating evaporating and condensing processes (Fig. 1a). Regarding RH, considering the average value for each one season, in general the brick has moisture content greater mortar, from $2 \% \pm 0.5$ up to $15 \%$, value reached in the summer time (Fig. 1b). PCA data treatment reveals that there is also a difference between the surface and inside material $(19 \mathrm{~mm})$. Podia are particular cases: the values are closed to saturation. The data collection takes a couple of weeks for each campaign.

\subsection{Continuous Monitoring}

In general, T remains stable between July and the end of October. During the winter season, there was greater amplitude than in summer-autumn. $\mathrm{RH}$ shows more 
fluctuation. Two clear groups were found for $\mathrm{T}$ and $\mathrm{RH}$ in a preliminary data treatment with PCA. For each parameter the sensors clustering according if their positions were in protected area, closed, (sensors situated away from openings, window and frontal walls to these, where the outdoor exchanges are frequent) or placed in area more ventilated (near to openings: window and main entrance presence).
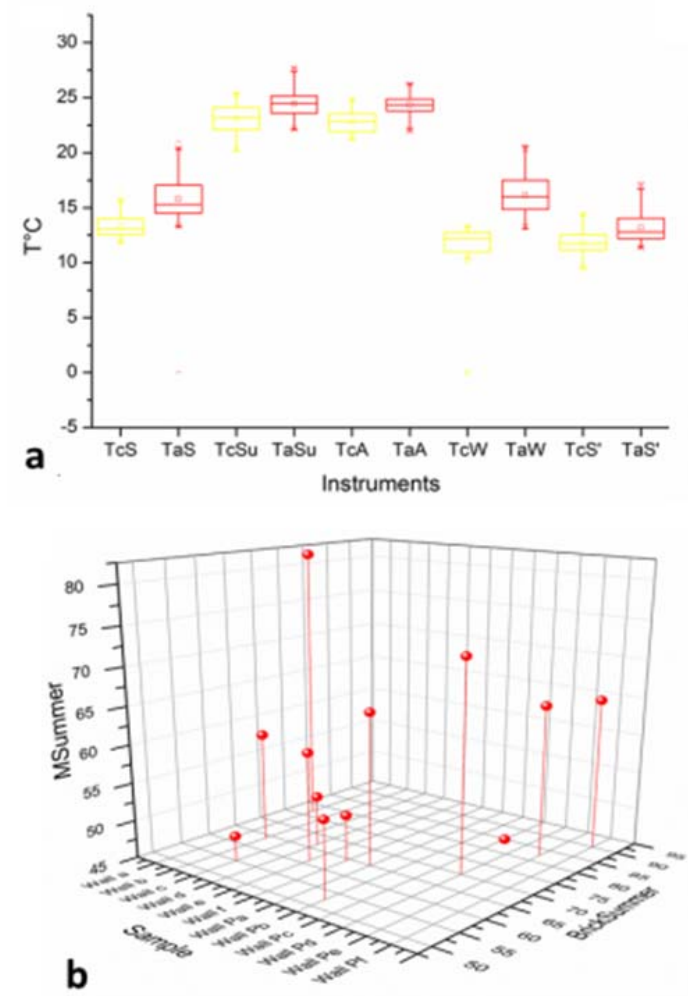

Figure 1: a) Box chart. $T$ (contact and air measurements) in the seasons ("S" pring, "S" ummer, "A" utumn, "W" inter, "S" Spring 15 "); b) 3D Scatter. RHaverage (mortar and brick). The graph shows the RH behaviour in the different walls.

\section{Conclusions}

We have compared to two innovative monitoring procedures completely different one from each other. The data analysed reveal the potentiality and disadvantages of each one. The discrete monitoring, thought a detailed mapping measurements and the employment of different instruments, was built to study the materials building and to correlate the indoor environment with the materials, representing a full method. The wall surface measured with and without contact instruments was investigated in order to put into light the risk of particular phenomena like the evaporating and condensing, to which depend damages caused by the salt efflorescences. This method employs a strategy that consists of a fixed number of measures repeated in selected days for one year. The advantages are widely discussed. The disadvantage is the manually procedure and the time spent into measuring, which can be considerably reduced by the continuos monitoring. The continuous monitoring is the practice more used into characterising the microclimate campaigns. The innovative of the method used consists into sensors technology: dimensions sensors $(0.5 \mathrm{~cm})$, high memory of data storing (10 years and more) and high frequency of data recording (1 minute). Also the data store is innovative (Fernández-Navajas et al. 2013) and used in others historical building (Merello Giménez 2013). This monitoring procedure allows to characterise the trends of physical parameters $(T, R H)$ and individuate the episodes that occur during the year and can compromise the conservation and safeguard of ancient buildings. The procedure was allowed to individuate differences between Mithraeum and pre-Mithraeum. The disadvantage is the data treatment during its manipulation. This last statement is surpassed thanks to software used (Fernández-Navajas 2013).

\section{Acknowledgements}

The authors would like to thank the staff of the archaeological area of Ostia Antica for the permission to work in this house. This work is partially supported by the projects HAR2013-47895-C2-1-P and HAR201347895-C2-2-P from MINECO.

\section{References}

CARDINALE, N., ROSPI, G. and STAZI, A., 2010. Energy and microclimatic performance of restored hypogeous buildings in south Italy: The "Sassi" district of Matera. Build Environ. http://dx.doi.org/10.1016/j.buildenv.2009.05.017

FERNÁNDEZ-NAVAJAS, A., MERELLO, P., BELTRÁN, P. and GARCíA-DIEGO, F.J., 2013. Software for storage and management of microclimatic data for preventive conservation of cultural heritage. Sensors. http://dx.doi.org/10.3390/s130302700

GARCÍA-DIEGO, F. and ZARZO, M., 2010. Microclimate monitoring by multivariate statistical control: The renaissance frescoes of the Cathedral of Valencia (Spain). Journal of Cultural Heritage http://dx.doi.org/10.1016/j.culher.2009.06.002

GRINZATO, E., 2010. Humidity and air temperature measurement by quantitative infrared thermography. Quantitative InfraRed Thermography Journal http://dx.doi.org/10.3166/qirt.7.55-72

MEREllo, P., PÉReZ, M.C., GARcíA, F.J., FERNÁNDEZ, Á., PÉREZ, J., BARÓ, J.L., CURIEL, J., D'ANTONI, P., RIBERA, A. and FERRAZZA, L., 2013. Ariadne's house (Pompeii, Italy) wall paintings: A multidisciplinary study of its present state focused on a future restoration and preventive conservation. Materiales de Construcción http://dx.doi.org/10.3989/mc.2012.00812

NAVA, S., BECHERINI, F., BERNARDI, A., BONAZZA, A., CHIARI, M., GARCÍA-ORELLANA, I., LUCARELLI, F., LUDWIG, N., MIGLIORI, A., SABBIONI, C., UDISTI, R., VALLI, G. and VECCHI, R., 2010. An integrated approach to 
assess air pollution threats to cultural heritage in a semi-confined environment: The case study of Michelozzo's Courtyard in Florence (Italy). Sci Total Environ. http://dx.doi.org/10.1016/j.scitotenv.2009.07.030

SANDROLINI, F. and FRANZONI, E., 2006. An operative protocol for reliable measurements of moisture in porous materials of ancient buildings. Build Environ http://dx.doi.org/10.1016/j.buildenv.2005.05.023

SCATIGNO, C., PRIETO-TABOAdA, N., PREITE, M., CONTE, A.M., GARCÍA-DIEGO, F.J. and MADARIAGA, J.M., 2016. Analitycal techniques for the characterisation of historical building materials: Case study "Casa di Diana" Mithraeum (Archeological site in Ostia Antica, Italy). In: Wythers MC (ed) Advances in Materials Science Research, Nova Science Publishers, Inc. edn, New York 


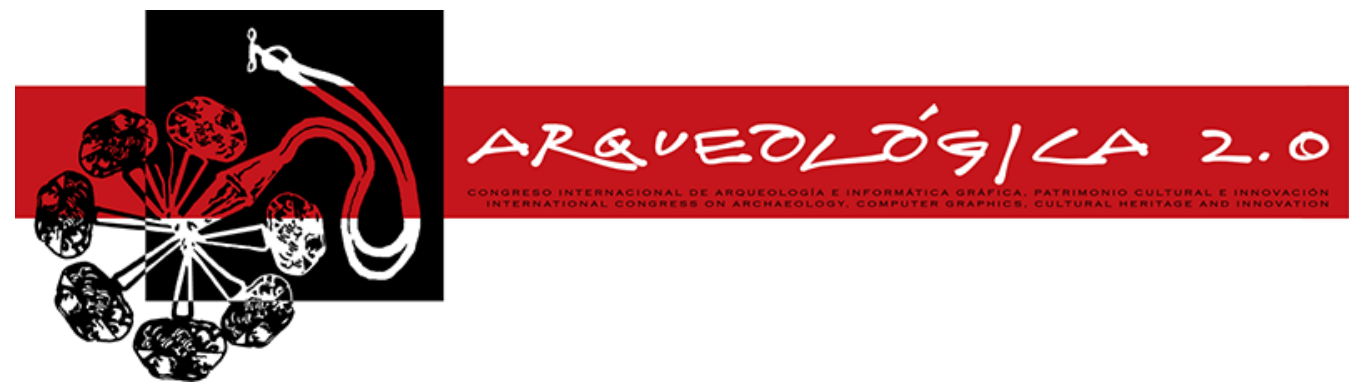

Proceedings of the $8^{\text {th }}$ International Congress

on Archaeology,

Computer Graphics,

Cultural Heritage and Innovation

'ARQUEOLÓGICA 20'

in Valencia (Spain),

Sept. 5-7, 2016

\title{
VIRTUAL CITIES INHABITED BY AUTONOMOUS CHARACTERS: A PIPELINE FOR THEIR PRODUCTION
}

\author{
Ana Paula Cláudio a, ${ }^{\star}$, Maria Beatriz Carmo ${ }^{a}$, Alexandre Antonio de Carvalho ${ }^{a}$, Willian Xavier ${ }^{a}$, Rui \\ Filipe Antunes ${ }^{a, b}$ \\ ${ }^{a}$ BiolSI - Biosystems \& Integrative Sciences Institute, Faculdade de Ciências, Universidade de Lisboa, Campo Grande, 1749-016 \\ Lisboa, Portugal. apclaudio@fc.ul.pt; mbcarmo@fc.ul.pt; fc47014@alunos.fc.ul.pt; fc34918@alunos.fc.ul.pt; rfantunes@fc.ul.pt
}

${ }^{\mathrm{b}}$ MIRALab, University of Geneva, Switzerland.

\begin{abstract}
:
Creating 3D reconstruction of the past is a challenging task requiring a vast set of technical skills, with teams usually including historians, 3D artists and IT technicians. In this paper, we describe our combined efforts to work under a low-budget pipeline to make a 3D simulation of the medieval village of Mértola in the south of Portugal. The work we describe in this paper is part of a larger project called "BIHC - Bio- Inspired Human Crowds" whose partial objectives are the development of a set of tools for the animation of 3D reconstructions of cultural heritage sites. We have focused on developing a lightweight model of the village that would allow the incorporation of virtual autonomous inhabitants in a simulation running in real-time and visitable by online audiences in both i) bird's-eye and ii) first-person points of view. The contribution of this paper is the identification of a set of tools and stages that can be used to obtain the final interactive environment recreating the inhabited ancient village.
\end{abstract}

Key words: virtual archaeology, digital archaeology, cultural heritage, 3D reconstruction, 3D data interoperability

\section{Introduction}

Amongst the daunting difficulties of creating 3D simulation of ancient sites are the costs associated with these types of simulations. One of our goals was to address this issue by building upon a pipeline of tools and methods available for free in an educational setting or with campus licenses, and basing it upon volunteer work. This work resulted from a multidisciplinary team of volunteers, including archaeologists from the Campo Arqueológico de Mértola, and students and teachers from Faculdade de Ciências da Universidade de Lisboa working as part of their curricular activities.

The former group of participants have provided useful insights and historically relevant guidelines about the architecture and culture of the ancient site. This input included information about the civil housing and military structures in the urban landscape, such as the defensive wall and the watchtower. Based on this information, students' activities were then organized by teachers in such a way as to include tasks that would allow the modeling of these features of the urban scene.

As a result, initially, a sample of a few houses was built using Autocad (www.autodesk.com) and later textured using 3ds Max (www.autodesk.com) and Photoshop (creative.adobe.com). Students have made three versions of each house. These variations allow us to integrate different levels of detail: i) a lightweight version with a geometry of a reduced number of polygons, to be visible at a distance; ii) a second version, where houses only have the exterior walls but have a higher definition with detailed roofs and doors, to be seen at close range; iii) another version, also in high definition, with the interior walls and props, allowing a visit using a firstperson point-of-view. This restricted set of houses provided us with templates to use with CityEngine (www.esri.com) to create general areas of the village where we did not have much available information. A second group of students used Autocad to model the iconic watchtower, again as part of their curricular program. Finally, a third group is currently modeling the agglomerate of fifteen houses of the Alcáçova (citadel) in 3ds Max. The model of the defensive wall is being improved based on a more accurate description.

The second step of this reconstruction departed from these architectural structures and entailed using CityEngine to generate the combined landscape. This part of the simulation comprised of the architectures described as well as the topographical features and vegetation of the site. Finally, this $3 D$ model was exported to a format compatible with Unity3D (unity3d.com), a software tool to develop videogames. Then, animated virtual characters were incorporated and some simple behaviors were implemented.

`Corresponding Author: Ana Paula Cláudio, apclaudio@fc.ul.pt 
The models of the characters and their basic animations were obtained from specialized software companies like Daz 3D (www.daz3d.com/) and Mixamo Fuse (wwwmixamo.com/fuse). Their movements were accomplished utlizing the physical engine and algorithms that are incorporated in Unity3D; some scripts were used to tune movements and behaviors (e.g. character following another character; donkey following a man).

Virtual models that reproduce ancient civilizations anchored in credible historical information are being used widely. The virtual recreation of historical places that no longer exist or that are considerably damaged is usually based on 3D modeling tools or procedural modeling (Muller et al. 2006; Dylla et al. 2010; Saldaña and Johanson 2013). Some authors include virtual humans in the environment; see Anderson et al. (2010) for a review about serious games for cultural heritage.

Our approach explores the interoperability of 3D software tools to combine the models of the scenario with animated virtual characters to obtain an interactive application. For the time being, the virtual characters in the scenario have simple intelligent behaviors that will be improved by algorithms inspired in Artificial Life.

\section{Creating the Virtual Scenario}

The creation of the virtual scenario comprised of terrain generation, modeling the buildings (houses, the watchtower and the defensive wall) and their integration into the same environment. Figure 1 highlights the main components used in the pipeline. We applied the geographic processing capabilities of the ArcGIS platform (desktop.arcgis.com) to import the model of the terrain and 3D modeling tools to draw some of the buildings. These models were then exported to CityEngine, where more houses were added by procedural modeling. Afterwards, the complete virtual environment was exported in the format .fbx, to Unity, where the virtual characters were integrated.

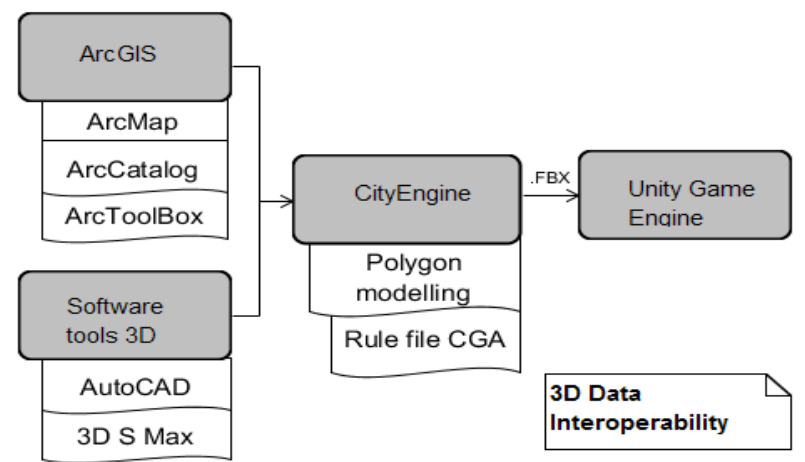

Figure 1: Pipeline overview

\subsection{Terrain Generation}

To obtain the model of the terrain, several steps were carried out. OpenTopography (opentopo.sdsc.edu/datasets) offers raster datasets for digital terrain models (DTM). The data on the area of Merrtola was selected and captured as an image in GeoTIFF format. This file was imported to the ArcGIS platform and processed with ArcMap, ArcCatalog and ArcToolBox tools.

With ArcCatalog, we accessed the WebFeatureService (mapas.dgterritorio.pt) to get spatial data. The shapefile used in this step was also used to export the coordinates of the region of interest in KML format in order to capture an image on Google Earth to apply as a texture to the terrain. With ArcMap, this image was georeferenced and combined with the above GeoTIFF image. Finally, the ArcToolbox generated the digital elevation model of the terrain (height map). The height map and the image with the texture were imported into CityEngine. An additional step was required to import the terrain model into Unity, as explained later.

\subsection{Modeling the Buildings}

To model the buildings, we used two approaches: 3D modeling tools to draw buildings for which there was more information available and procedural modeling to create similar models for general areas of the village.

AutoCAD was used to build models with different levels of detail, which were later exported to 3 ds Max to be textured. These models were imported into CityEngine, in .obj format with the texture in an .mtl file. Actually, CityEngine imports data in several formats to provide interoperability with tools that work with $3 \mathrm{D}$ models.

Models can be imported into CityEngine as static models or as shapes. Static models can also be converted into shapes (Fig. 2), however they cannot be modified, neither their individual vertices nor their textures. They can only be scaled and positioned by translations or rotations, while shapes can be modified by grammar operations described in CGA files.

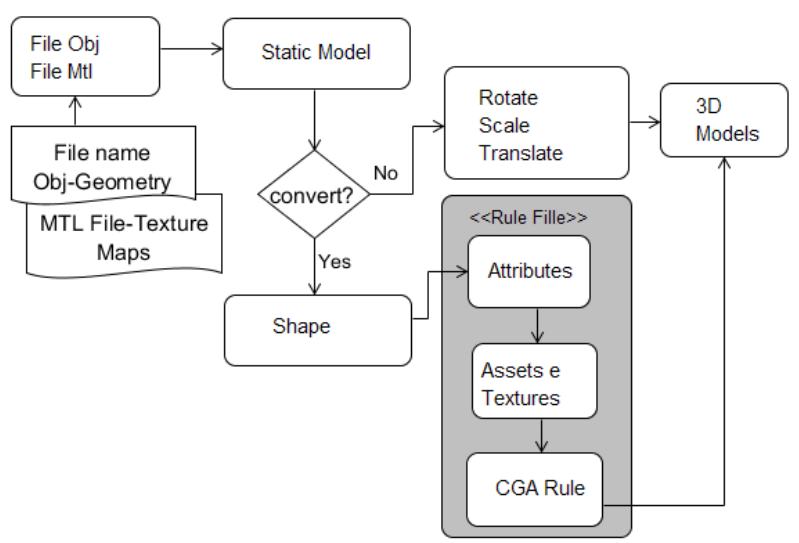

Figure 2: The pipeline inside CityEngine.

\subsection{Combining the 3D elements}

The virtual urban environment integrates several layers: for the terrain, the static models (comprising objects imported from 3D modeling tools) and the shapes. The shape layers include the models generated by applying grammar rules. These include buildings and streets generation, as well as landscape creation with tree models from a vegetation library (www.arcgis.com/apps/CEWebViewer/viewer.html?3dW ebScene $=6015 \mathrm{f7d} 48 \mathrm{dff} 4 \mathrm{b3084de76bcf22c5bca). \quad We}$ used the layer alignment feature to combine all the layers: "align graphic to terrain", "align static model" and "align terrain to shape".

The complete virtual 3D CityEngine model (Fig. 3) was exported to Unity using the .fbx format. To ensure navigation in real-time, it is necessary to have a lightweight model. Considering this, some elements, like 
the houses, were modeled with different levels of detail, and set in distinct layers before being exported to the .fbx file. This way, the Unity game engine can reproduce models that are away from the camera with less polygons while the ones that are closer are displayed with more polygons to attain a more realistic effect.

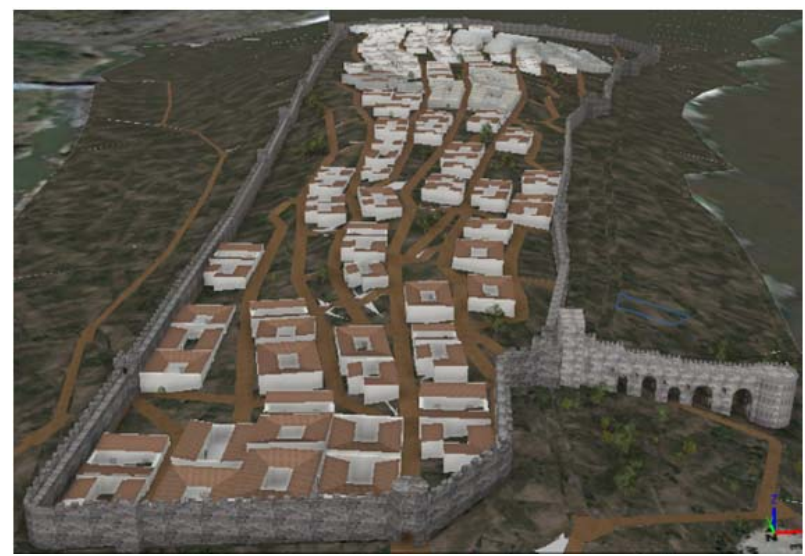

Figure 3: Virtual urban environment in CityEngine.

\section{Inserting the Animated Characters}

For the time being, three models were included in the Unity scenario: a man, a child and a donkey. The first one, together with a skeleton and a set of basic animations, was obtained from Daz 3D Studio that supports several export formats compatible with Unity The animations were obtained from Mixamo Fuse (e.g., walk, run, sit on a bench, climb stairs). The model of the donkey, including a skeleton and a set of animations, was obtained from Arteria3D (arteria3d.myshopify.com).

To ensure that the movements of the characters are credible, two factors are important: the quality of the animations and the reproduction of the laws of physics, a responsibility of the physics engine included in Unity. The physical engine uses colliders to deal with physical collisions. So, to guarantee that characters move on the ground and do not exhibit unnatural movements, like trespassing walls, it is mandatory to define the colliders for every mesh corresponding to elements in the scenario that may be in the way of a moving character, such as other characters, houses, walls or trees.

Also the terrain needs a collider to ensure the virtual characters will move on top of it, preventing the gravity force (implemented by the physics engine) from making them fall vertically and disappear from the scene.

To export the terrain from CityEngine to Unity, a process analogous to the one described in Saldaña and Johanson (2013) was adopted. First, the terrain in CityEngine was saved to a .png file which was converted to the raw format using Photoshop; then the Unity option
"Terrain" was used to import this file, and so a "Terrain Collider" was associated with the ground.

The basic animations of the characters were combined with some scripts included in Unity that implement simple artificial intelligence algorithms, such as the $A^{*}$ algorithm for choosing the shortest path between two points and a script called "follow target" used, for instance, to make the donkey follow the man (Fig. 4).

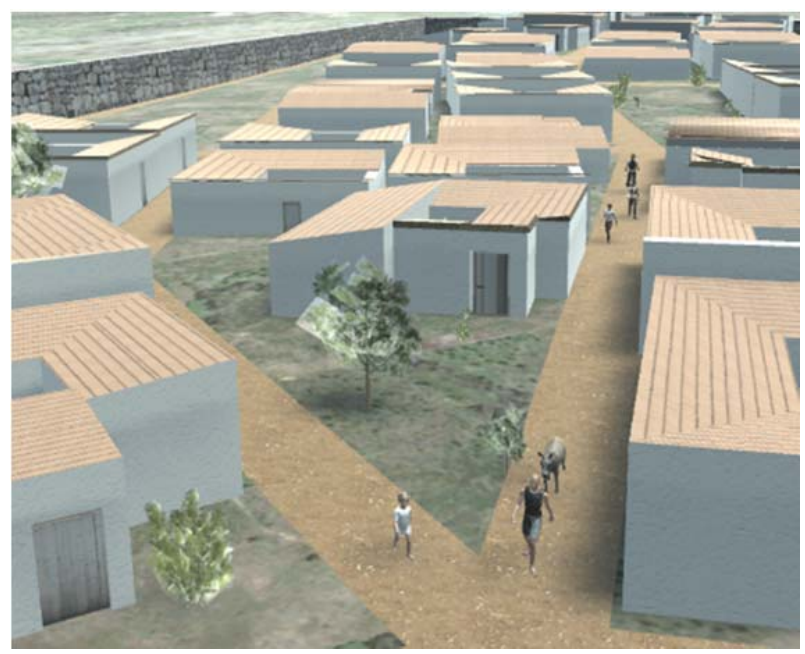

Figure 4: Virtual environment with virtual characters in Unity.

\section{Conclusions and future work}

Currently the virtual model of the medieval village of Mértola is being improved whilst taking into consideration that a balance between realism and number of polygons needs to be attained, because it is necessary to obtain a lightweight model that supports interaction in real-time.

Concerning the virtual inhabitants, algorithms inspired in Artificial Life are being developed to obtain a generative model for heterogeneity and spontaneity in behavioral animation of small, medium and large gatherings of virtual characters.

\section{Acknowledgements}

This project was funded by the EU Horizon 2020 research and innovation programme under the Marie Skłodowska-Curie grant agreement No 655226 (fellowship to Dr. Rui Filipe Antunes). We acknowledge the support of BiolSI R\&D unit (UID/MULTI/04046/2013), Portugal, the information provided by the team of Campo Arqueológico de Mértola and the students that have produced 3D models. Proofreading by Piki Productions.

\section{References}

ANDERSON, E.F., McLOUGHLIN, L., LIAROKAPIS, F., PETERS, C., PETRIDIS, P. and FREITAS, S., 2010, Developing serious games for cultural heritage: a state-of-the-art review. Virtual Reality, 14.4, pp: 255-275.

DYLLA, K., FRISCHER, B., MULLER, P., ULMER, A. and HAEGLER, S., 2010. Rome Reborn 2.0: A Case Study of Virtual City Reconstruction Using Procedural Modeling Techniques. CAA 2009, Making History Interactive. 37th Proceedings of the CAA Conference, March 22-26, 2009, Williamsburg, Virginia (Archaeopress: Oxford, 2010), pp. 62-66. 
MULLER, P., WONKA, P., HAEGLER, S., ULMER, A. and GOOL, L., 2006. Procedural Modeling of Buildings. ACM Transactions On Graphics, Jul, Vol. 25, pp. $614-623$.

SALDAÑA, M. and JOHANSON, C., 2013. Procedural modeling for rapid-prototyping of multiple building phases. International Archives of the Photogrammetry, Remote Sensing and Spatial Information Sciences, Fev., Vol. XL5/W1. 


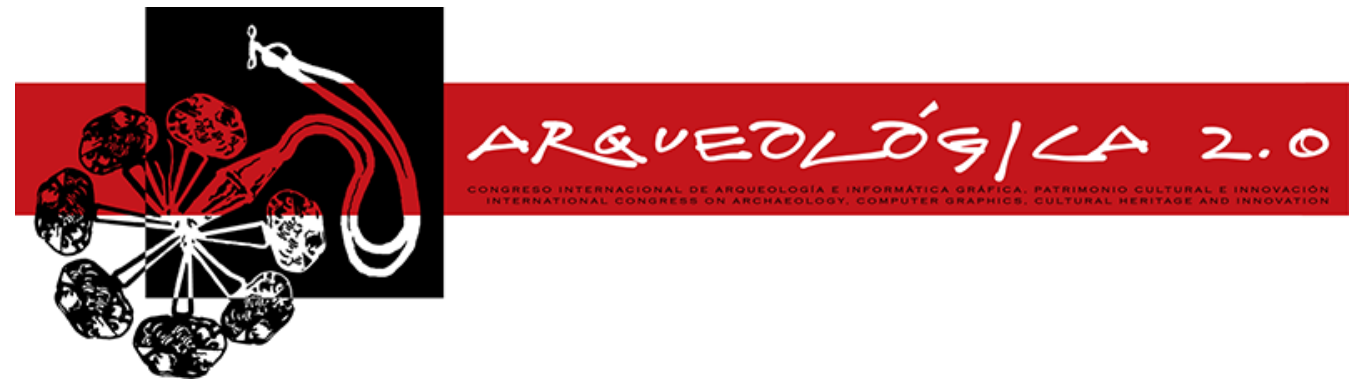

Proceedings of the $8^{\text {th }}$ International Congress

on Archaeology,

Computer Graphics,

Cultural Heritage and Innovation

'ARQUEOLÓGICA 2.0'

in Valencia (Spain),

Sept. $5-7,2016$

\title{
PRELIMINARY DATA OF CFD MODELING TO ASSESS THE VENTILATION IN AN ARCHAEOLOGICAL BUILDING
}

\section{MODELIZACIÓN MEDIANTE CFD DE PARA EVALUAR LA VENTILACIÓN EN UN EDIFICIO ARQUEOLÓGICO, DATOS PRELIMINARES.}

\author{
Fernando J. García-Diego ${ }^{\mathrm{a}, \mathrm{b}}$, Claudia Scatigno ${ }^{\mathrm{c}^{*}}$, Paloma Merello ${ }^{\mathrm{d}}$, Eliseo Bustamante ${ }^{\mathrm{e}}$. \\ ${ }^{a}$ Department of Applied Physics, Universitat Politècnica de València, Av. de los Naranjos s/n, Valencia 46022, Spain. \\ fjgarcid@upvnet.upv.es \\ ${ }^{b}$ Centro de Tecnologías Físicas, Universitat Politècnica de València, Av. de los Naranjos s/n, Valencia, Spain. 46022. \\ c Department of Earth Science, University of Rome "La Sapienza", Piazzale Aldo Moro 5, 00185, Rome, Italy. \\ claudia.scatigno@uniroma1.it \\ ${ }^{d}$ Accounting Department, University of Valencia, Avd.Tarongers s/n,46000 Valencia, Spain. paloma.merello@uv.es \\ e Department of Construction Engineering and Civil Engineering Projects, Universidad Politècnica de València, Camino de Vera s/n. \\ 46022 Valencia, Spain. elbusgar@doctor.upv.es
}

\begin{abstract}
:
The present study addresses the influences of wind flow structure, as an important factor responsible of material damage (erosion contributing) on "Casa di Diana" Mithraeum, a roman building (130 A.D.) sited on Ostia Antica (archaeological site, Rome - Italy), through the Computational Fluid Dynamics (CFD) simulations and direct measurements for its verification and validation (V\&V). In this preliminary work, we present results relating to $3 \mathrm{D}$ reconstruction (geometry of the entire building) and the mesh importing on Fluent software. In general, the data check confirms, with $\pm 10 \%$, a good agreement (model) between the numerical solutions and direct measurements data by portable sensor. For this, the model proposed could be applied on similar cases, buildings characterised by different "boundary conditions", to predict without direct measurements, the air movement in these ventilated spaces.
\end{abstract}

Key words: computational fluid dynamics (CFD), ventilation, archaeological site, preventive conservation, 3D reconstruction

\section{Resumen:}

El presente estudio aborda la influencia de la acción del viento en la estructura puesto que dicha acción es un factor relevante y responsable del daño material (contribuye en la erosión) del mítreo de la "Casa de Diana", un edificio romano (130 A.C.) situado en Ostia Antica (sitio arqueológico, Roma, Italia), mediante las simulaciones de la dinámica de fluidos computacional y las mediciones de campo para su verificación y validación (V\&V). En este trabajo preliminar, se presentan los resultados de un reconstrucción 3D (geometría del edificio entero) y del mallado importado al software Fluent. En general, la inspección de los datos confirma, con $\pm 10 \%$, un buen ajuste (modelo) de las soluciones numéricas y de las mediciones de campo adquiridas mediante un sensor portátil. Para ello, el modelo propuesto puede ser aplicado en casos similares, edificios caracterizados por diferentes condiciones de contorno, para predecir sin las mediciones de campo el movimiento del aire en estos espacios ventilados.

Palabras clave: dinámica de fluidos computacional (DFC), ventilación, sitio arqueológico, conservación preventiva, reconstrucción 3D

\section{Introduction}

The study on evaluation of historical buildings indoor conditions is constantly increasing, especially in terms of the adequacy of natural microclimate (D'Agostino and Congedo 2014) and to enjoy the works art by visitors (psycho-physical wellness) (Corgnati and Perino 2013). The effect of ventilation strategies on the microclimate was used to investigate also indoor environment, like crypt (D' Agostino et al. 2013), place under harsh climatic conditions.

“Corresponding Author: Claudia Scatigno, claudia.scatigno@uniroma1.it 
A three dimensional (3D) computational fluid dynamics (CFD) model and direct measurements for verification and validation $(\mathrm{V} \& \mathrm{~V})$ of CFD has been developed to assess the ventilation issues of an historic building sited in Ostia Antica (archaeological site, Rome - Italy) in order to assess the influence of wind in terms of material building conservation (erosion and faciliting evaporation processes) that suffer of several problems (Scatigno et al. 2016a, Scatigno et al. 2016b), and to evaluate the air quality (exchange air).

The aim of the study was to find a solution able to provide a proper microclimate for the conservation of the building, studying the airflows and developing in a future a global plan for conserving and protecting the site.

The preliminary results show a good agreement (model) between the numerical solutions and direct measurements data by portable sensor.

The direct measurements give the punctually information on air movement, the CFD simulation, on the contrary, allows to offer illustrative graphic screens and precise values in the full indoor space of the archaeological site.

The prediction model, offers the whole knowledge of the "real" air ventilation with a "virtual" method.

For all of this, the model proposed could be applied on similar cases, buildings characterised by different "boundary conditions", to predict without recourse to direct measurements, the air movement in these ventilated spaces.

\section{Methodology}

\subsection{Building description}

The Casa di Diana Mithraeum, made of bricks and pozzolanic mortar (wall-building materials), is comprised of two inter-communicating rooms (pre-Mithraeum and Mithraeum) and several openings (windows and main door) which expose small areas to sunlight and outer air. Despite, being defined as such structurally comparable to a semi-confined environment, really the framework presents a very characteristic microclimate, similarly to a hypogeum (Scatigno et al. 2016a). No ventilation systems are found, thus the ventilation is natural and comes from several openings, especially from one window, sited at west side (pre-Mithraeum room), of significant dimensions $(1.48 \times 1.16 \mathrm{~m})$.

\subsection{CFD techniques}

CFD techniques consist of the solution of a set of partial differential equations. These equations are the equation of continuity, the conservation of momentum (or NavierStokes Law) and the energy. Equation 1 integrates these equations in a single equation:

$$
\frac{\partial}{\partial t}(\rho \varphi)+\operatorname{div}\left(\rho u \varphi-\Gamma_{\varphi} \operatorname{grad} \varphi\right)=S_{\varphi}
$$

Where:

$$
\begin{aligned}
& \rho=\text { the density of the fluid (air) } \\
& \varphi=\text { the variable of interest } \\
& t=\text { the time }
\end{aligned}
$$

$$
\begin{aligned}
& \rho \\
& u=\text { the velocity vector } \\
& \Gamma \varphi=\text { the diffusion coefficient of } \varphi \\
& S \varphi=\text { the source term of } \varphi
\end{aligned}
$$

In this work, from the different CFD commercial software, we have chosen ANSYS FLUENT and GAMBIT (the pre-processor of Fluent). In this way, ANSYS FLUENT has been already used for the study of the ventilation in different types of buildings (FlagaMaryanczyk et al. 2014, Xu et al. 2013).

CFD software also requires some Boundary Conditions $(B C)$ to perform the CFD simulations. In this vein, and using the suitable sensors, the pressure and the air velocity at the windows, doors and holes were measured as well as the temperatures at the walls, floor and air. By different BCs and meshed, CFD simulations were performed. In this work, the standard $\mathrm{k}-\varepsilon$ turbulence model and wall functions were used in all these computations (D'Agostino and Congedo, 2014). Unfortunately, the numerical results are obtained from a limited number of cases, i.e., these measured inputs determined by the meteorology of the day of the field experiments.

\subsection{Field measurements}

In order to verify the model, the direct measurements were performed in only one day with non-extreme meteorological conditions (in March of 2016) with one sensor moved in different points to map the area, considering the more ventilated area (near to openings: principal entrance, windows) and the centre of two rooms (within other four central points).

\section{Preliminary results}

The "Casa di Diana" Mithraeum presents a complex geometry. The building is built on two different levels, due to the presence of structures like the altar and "podiae", seats for the Romans that assisted the sacrificial ritual of the killing the bull, which are about seventy centimeters above the pedestrian level.

For this, the geometry phase was conducted with special attention.

The Figure 1 and 2 show the phases of geometry building through the GAMBIT. The Figure 3 shows the next phase, the importation into FLUENT.

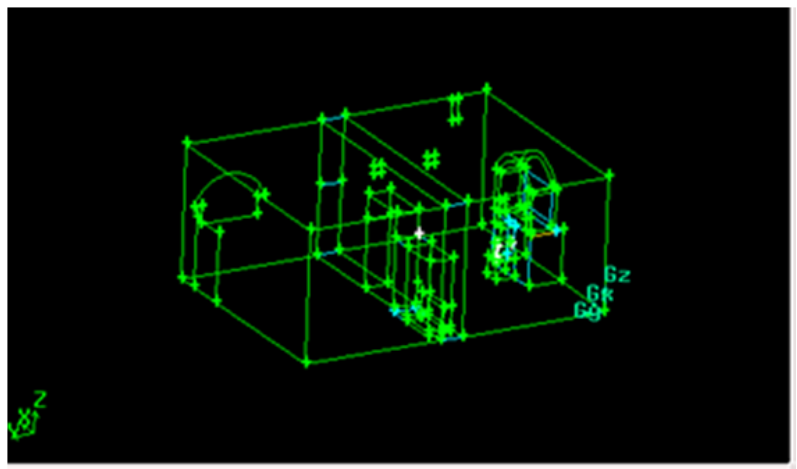

Figure 1: Phases of geometry building (point cloud), made by Gambit software 


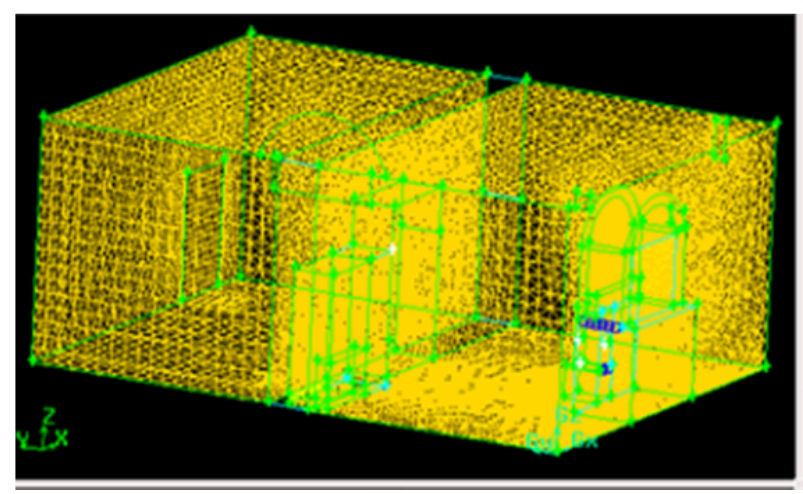

Figure 2: Phases of geometry building (meshes) made by Gambit software

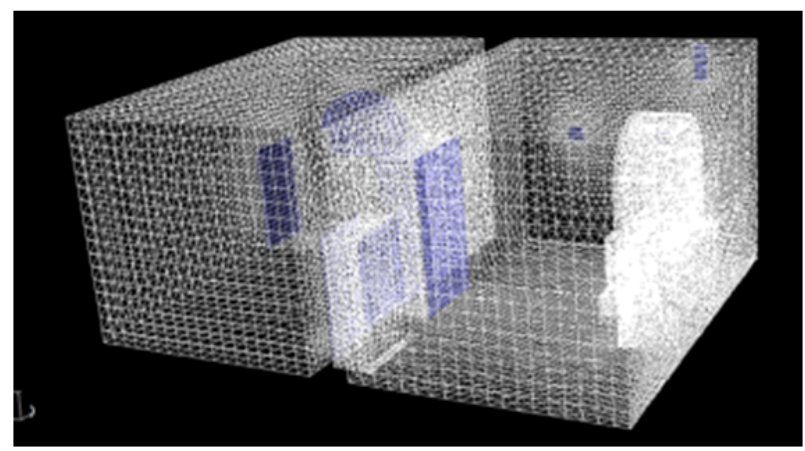

Figure 3: Mesh importing in Fluent. The blue areas indicate the openings (main entrance and windows) and the access into two inter-communicating rooms.

At the first view, the ability of the CFD simulations to predict airflow in archaeological site was clear.

A significant difference was found between two rooms. In particular, in a corner area of the pre-Mithraeum room, the air valocities change. During the experiment, the airflow rates, which pass through the wholes, is small: no relevant wind gusts are detected during this day as consequence no indoor air velocities changes appear neither in direct measurements with sensors or in CFD results. Of course, seasonal changes and several wind gusts could modify the nature of indoor microclimate of the monument. Next field measurements will be carried out in different seasons and in extreme meteorology to compare results.

\section{Conclusions}

In this preliminary work, we present the results relating to $3 \mathrm{D}$ reconstruction (geometry of the entire building) and the preliminary meshes to study the convergence of the results.

Regarding the air monitoring, a preliminary data checking reveal that the indoor air velocity values are in a very low range of values, as consequence the resulted percentage is a very small magnitude. In this vein, the most important question is the good fit in the comparative results (CFD and measurements) and that the trend of results is accomplished.

In general, the data check confirms, with $\pm 10 \%$, a good agreement (model) between the numerical solutions and direct measurements data by portable sensor. In some cases, a more significate difference was found.

This work confirms that CFD modeling can help in a better control of the indoor microclimate of archeological buildings. However, there will be necessary next field measurements in different seasons and in extreme meteorological events as well some measurements and computations including the presence of people in the historical building in order to analyze their influence.

\section{Acknowledgements}

The authors would like to thank the staff of the archaeological area of Ostia Antica for the permission to work in this house. This work is partially supported by the projects HAR2013-47895-C2-1-P and HAR201347895-C2-2-P from MINECO.

\section{References}

CORGNATI, S.P. and PERINO, M., 2013. CFD application to optimise the ventilation strategy of Senate Room at Palazzo Madama in Turin (Italy). Journal of Cultural Heritage

D' AGOStinO, D., CONGEDO, P.M. and CATALDO, R., 2013. Ventilation Control using Computational Fluid-dynamics (CFD) Modelling for Cultural Buildings Conservation. Procedia Chemistry. doi: http://dx.doi.org/10.1016/j.proche.2013.03.012

D'AGOSTINO, D. and CONGEDO, P.M., 2014. CFD modeling and moisture dynamics implications of ventilation scenarios in historical buildings. Build Environ. doi: http://dx.doi.org/10.1016/j.buildenv.2014.05.007

FLAGA-MARYANCZYK, A., SCHNOTALE, J., RADON, J. and WAS, K., 2014. Experimental measurements and CFD simulation of a ground source heat exchanger operating at a cold climate for a passive house ventilation system. Energy Build. doi: http://dx.doi.org/10.1016/j.enbuild.2013.09.008

SCATIGNO, C., MORICCA, C., TORTOLINI, C. and FAVERO, G., 2016a. The influence of environmental parameters in the biocolonization of the Mithraeum in the roman masonry of Casa di Diana (Ostia Antica, Italy). Environ Sci Pollut Res. http://dx.doi.org/10.1007/s11356-016-6548-x

SCATIGNO, C., PRIETO-TABOADA, N., PREITE, M., CONTE, A.M., GARCÍA-DIEGO, F.J. and MADARIAGA, J.M., 2016b. Analitycal techniques for the characterisation of historical building materials: Case study "Casa di Diana" Mithraeum (Archeological site in Ostia Antica, Italy). In: Wythers MC (ed) Advances in Materials Science Research, Nova Science Publishers, Inc. edn, New York 
XU, G., LUXBACHER, KD., RAGAB, S. and SCHAFRIK, S., 2013. Development of a remote analysis method for underground ventilation systems using tracer gas and CFD in a simplified laboratory apparatus. Tunnel Underground Space Technol 


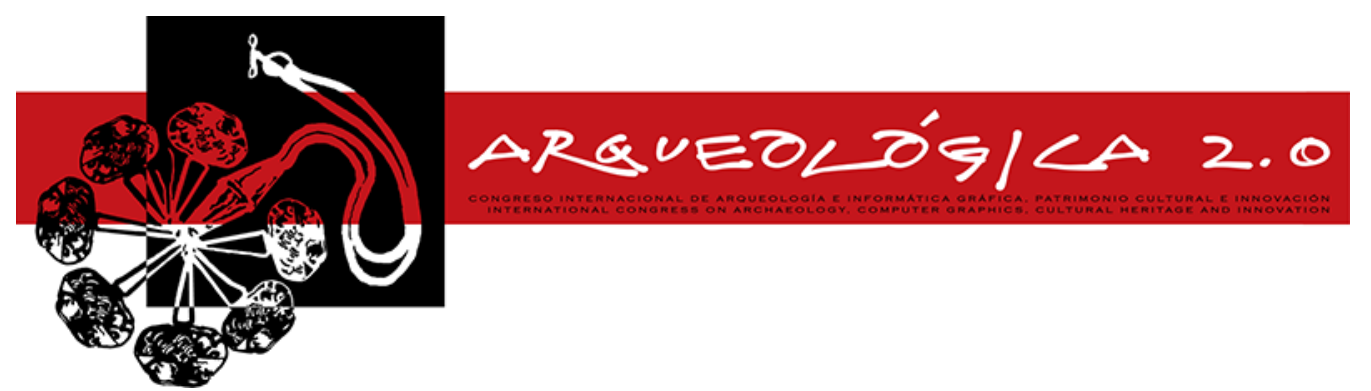

Proceedings of the $8^{\text {th }}$ International Congress

on Archaeology,

Computer Graphics,

Cultural Heritage and Innovation

'ARQUEOLÓGICA 2.0'

in Valencia (Spain),

Sept. $5-7,2016$

\title{
THE CIRCUS MAXIMUS: DIACHRONIC RECONSTRUCTIONTHROUGH THE APPLICATIONOF NEW TECHNOLOGIES
}

\author{
Domenica Dininno \\ Dipartimento di Filologia, Letteratura e Linguistica - University of Pisa, Italy. mimma.dininno@gmail.com
}

\begin{abstract}
:
The area occupied by the Circus Maximus in Rome is currently undergoing some restoration, archaeological surveys and a re-opening to the public. The targeted excavations have uncovered a great amount of new information, which needs to be reviewed and analyzed in order to address many problems still unsolved. The project hereafter presented is an investigation conducted by the University of Pisa in collaboration with the Bruno Kessler Foundation of Trento, Italy. The project aims to study the Circus with a new methodological approach for the site, i.e. photogrammetry and a relational database. It aims to create a graphic model with attached database accessible bythe Soprintendenza for measurements, mappings, future restorations, consultations and fruition.
\end{abstract}

Key words: cultural heritage, documentation, 3D reconstruction, valorization, Circus Maximus

\section{History of Circus and tophographical grading}

The Circus Maximus in Rome is the largest building dedicated to shows of all time. It is an exceptional structure, at the centre of the Roman "sporting" passion for centuries, it has an unbroken continuity of life, at least from the archaic period to the present day (Fig. 1) It is a unique area containing a well- known building, remained in use until 549 AD (Ciancio Rossetto 2001).

Many Latin authors agree that, since the protohistoric age, the area between the Palatine and Aventine, called Valle Murcia, was the seat of worship such as the games in honor of Conso, in which there were chariot races. However, it was only in regia age, in particular with Tarquini, who according to tradition were organized circus games on the site, the place was outlined and the first wooden chairs were arranged for the public. The oldest roads in the region consisted of two streets, which were to go into the valley of the circus following the slopes of the Palatine and Aventine, avoiding the swampy valley: the vicus and the vicus lugarius Tuscus.

In the last centuries of the republic, the Valley was gradually placed urban-architectural profile and with partially set structures.

On the side towards the Aventine several temples were built, all places out of the pomerio, of plebeian character and often linked to commercial functions: in particular, the temple of Ceres, Free and Free, Spurrier probably built by Crassus in $493 \mathrm{BC}$. The building, along with that of Flora stood alongside the clivus Publicus (current clivo of Publici) above carceres of Circus Maximus, it quickly became the real political center and the archive of the populace.
At the opposite end of the circus was to be the Temple of Mercury, patron of merchants, which is also very old (founded in 495 BC), that of Venus Obsequens (295 BC) and the Venus Verticordia (which replaced an archaic shrine of Fortuna virilis, attributed to Servius Tullius).

During the age of Caesar, to meet the new requirements and allow a greater usability, the surrounding road network was redesigned.

The plan of the circus in the first century B.C. was probably less complicated than the construction of the Imperial period (Bigot 1908).

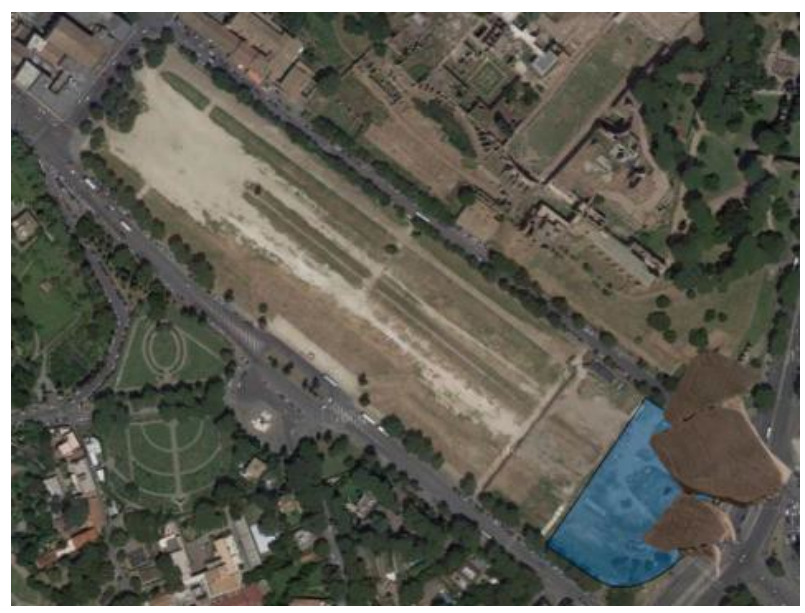

Figure 1: The Circus Maximus in Rome: whit blue indicates the actual archaeological area, with the overlap of the marble tables of the FUR.

The circus was large $621 \mathrm{~m}$ and wide $118 \mathrm{~m}$. The auditorium would have been unified, the two long sides being connected together by the short side opposite to 
carceres, in the shape of crescent moon (Ciancio 2002). There were steps sloping on each other, as in theaters, divided into three areas: the bottom with stone seats and the upper with wood. The total capacity was probably around 150,000 people. The building was destroyed by several fires under Nero (Marcattili 2006) and Domitian. It was later rebuilt by Trajan in 100-104, when it saw its most important building phase. In year 80 , a triple arch was placed in the center of the circus hemicycle, in remembrance of the victories of Vespasian and Titus in the Jewish War (Golvin 2002). The circus was then enlarged by Caracalla and restored by Constantine (Brandizzi 1991) up in order to contain up to 300,000 spectators.

In the Middle Ages the area around the circus was gradually burying and was used as an agricultural area. During the Fascism period (Muñoz 1934), due to the construction of the archaeological walk, the Circus Maximus was liberated of all the warehouses and industrial buildings that were placed around it. Only in 1975 excavations were carried out and the area assumed the archaeological area dignity for the part related to hemycicle (Ciancio 1986), while the remaing is used for public events.

Various transformations and destructions have made difficult the understanding of the heritage site itself. The whole area is currently undergoing restoration and reopening to the public with the project "Environmental regeneration and enhancement of the archaeological remains of the Circus Maximus and the related public spaces in Via dei Cerchi and Piazza di Porta Capena" which included archaeological surveys and small surveys in the still visible remains of the Circus Maximus (Fig. 2).

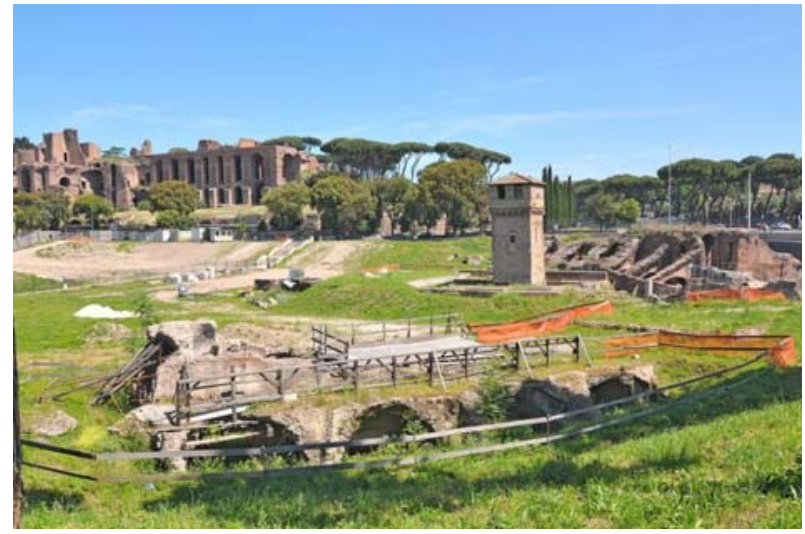

Figure 2: The Circus Maximus in Rome as visible today.

\section{The project}

The project, named "The Circus Maximus in the urban arrangement of the region $\mathrm{XI}$ : diachronic reconstruction and topographical development through the application of new technologies" is conducted by the University of Pisa in collaboration with the Bruno Kessler Foundation of Trento, Italy. The project investigates the Circus with a new methodological approach for the site, i.e. photogrammetry (Nocerino at al. 2014), 3D modelling and a relational database. The investigation, through a total review of historical data and new surveys, aims totackle the study of how the construction of the building has changed the topography of the Regio X
(Colini 1934). The final digital product will the contain collected historical data of the ruins in one accessible portal/informatics system. The global aim is to demonstrate how new technologies can change the practical and daily work and the way of thinking archaeology.

\section{Working methodology}

The first step was to collect data of all the traceable archeological knowledge, published and unpublished, about the Regio XI where the Circus is placed: the iconographic, cartographic, cadastral, epigraphic, as well as the chronicles of medieval and modern finds often unpublished. For this purpose, given the quantity of material and its heterogeneous source, a relational database was selected as best solution to organize, displayand access all the material. The preparation of the database will be essential for classification, mapping and evaluation of the area occupied bythe Circus in its various stages of life.

The database was completed with direct and indirect surveying operations: the archaeological survey is an essential part in the comprehension of ancient structures and monuments. With photogrammetric acquisitions (Luhmann et al. 2006) we obtained a three-dimensional photo-realistic relief of the existing situation (Fig. 3). Digital photogrammetry (Mikhaikl et al. 2001) after comparing costs and benefits, proved to be the best solution for the project's needs: Photogrammetry helped to engage the various stages in different contexts at the same site, discovered at different times; Photogrammetry helped to integrate the old data, derived from previous excavations or surveys.

This indirect surveying was coupled with CAD rendering to reconstruct also areas which could not easily be reproduced through traditional graphic (Remondino et al. 2014).

The methodological choice was motivated by the hybrid and complex nature of the archaeological site - an educational excavation but also a public work of urgent nature: the restoration works were urgent and this forced to speed the archeological research and, subsequently, the graphic recording of the structures and findings.

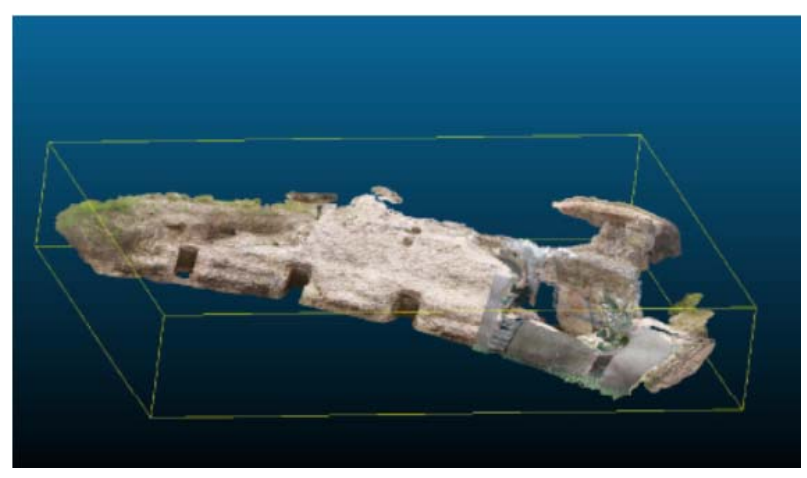

Figure 3: The overlap of photogrammetric survey of cavea side Aventino before and after restoration.

\section{Actual results and outcomes}

So far the accomplished results consist in a metric photorealistic 3D rendering (Fryer et al. 2007), useful for grasping the Circus's racecourse aspects not easily 
reproduced through traditional graphic. It is also connected to the realized database for measurements, mappings for future restorations. The three-dimensional restitution helped to produce drawings and maps that highlight certain changes. These are still essential working tools for critical reading of the structural characteristics of the circus and its relationship with the surrounding buildings (Fig. 4).

Such 2D/3D data, in the future, may form the basis for bringing together the idea of reconstruction of the topographyof the Regio XI and its main monuments.
The final results will be accessible bythe Soprintendenza for consultations and for developing restoration and fruition policies (interactive computer workstation present in the museum, virtual reality with Oculus, etc.).

\section{Acknowledgements}

This work was supported by the Soprintendenza Archeologica Capitolina, prof. Paolo Liverani and the 3DOM unit of FBK Trento.

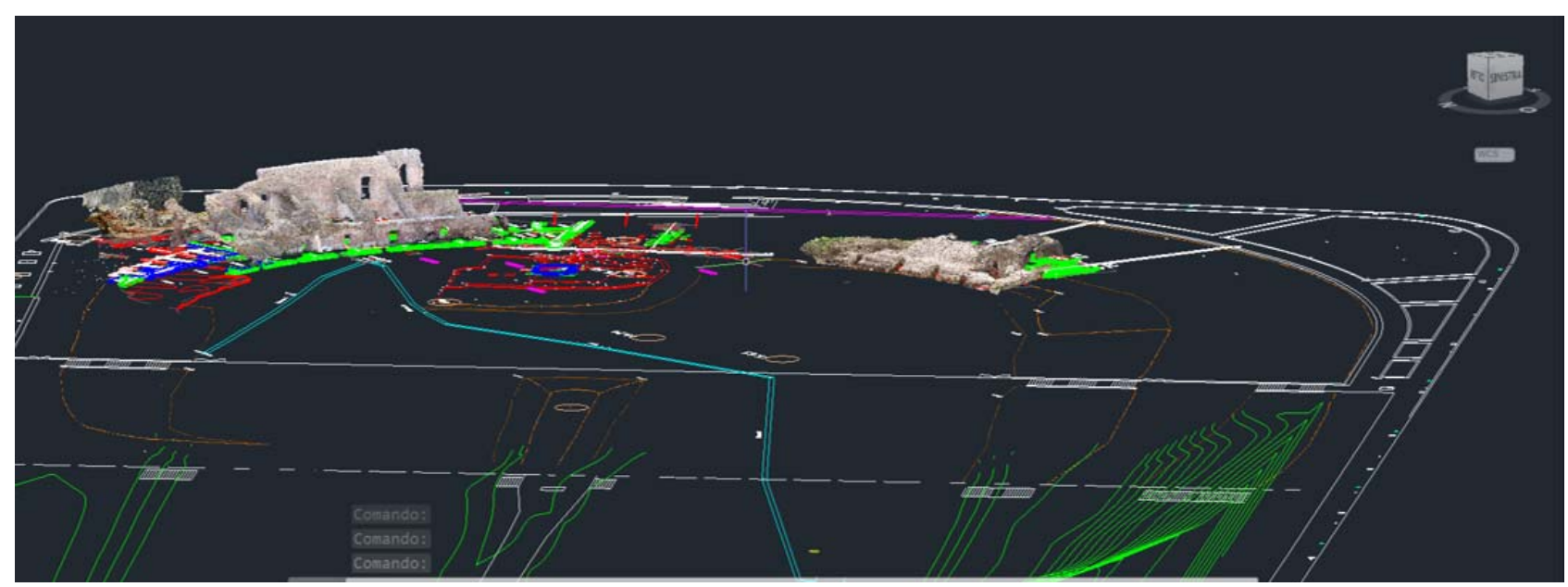

Figure 4: Photogrammetric survey of Circus

\section{References}

BIGOT, P., 1908. Recherche des limites du Grand Cirque, «bc», 36, pp. 241-253.

BRANDIZZI, P., 1991. L'emiciclo del Circo Massimo nell'utilizzazione post classica, «mefra», 103, 1, pp. 7-40.

CIANCIO, P., 1986. Circo Massimo Scavi e indagini, «bc», 91/92, pp. 542-545.

CIANCIO, P., 2001. II Circo Massimo: la creazione di un modello architettonico, in El Circo en Hispania Romana, Madrid, pp.13-25.

CIANCIO, P., 2002. Circo Massimo. Risultati delle indagini archeologiche nell'area centrale, «bc», 103, pp. $186-189$.

COLINI, A.M., 1934. Regione XI - Circus Maximus, «bc», 62,pp. 175-177.

FRYER, J., MITCHELL, H. and CHANDLER, J., 2007. Applications of 3D Measurement from Images, Whittles Publishing.

GOLVIN, J.C., 2002. Les immages du cirque, source de connaissance de son architecture? Leur importance pour la restitution des edifices de la spina, in El Circo en Hispania Romana, Merida, pp. 41-54.

LUHMANN, T., ROBSON, S. and KYLE, S., 2006. Close Range Photogrammetry: Principles, Techniques and Application, Whittles Publishing.

MARCATTILI, F., 2006. Ara Consi in Circo Massimo, «mefra», 118, 2, pp. 621-651.

MIKHAIKL, E., BETHEL, J. and MCGLONE, J., 2001. Introduction to Modern Photogrammetry, J. Wiley and Sons .

MUÑOZ, A., 1934. La via del Circo Massimo, Bibliotheca d'arte editrice, Roma.

NOCERINO, E., MENNA, F. and REMONDINO, F., 2014. Accuracy of typical photogrammetric networks in cultural heritage 3D modeling projects. The International Archives of the Photogrammetry, Remote Sensing and Spatial Information Sciences, Volume XL-5.

REMONDINO, F. and CAMPANA, S., 2014. 3D Recording and Modeling in archaeologyand cultural heritage, Archaeopress. 


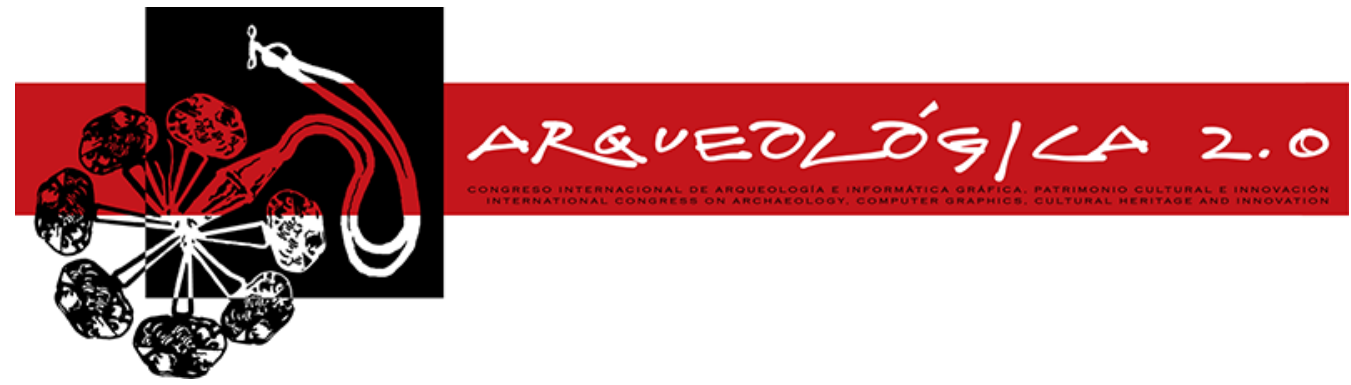

Proceedings of the $8^{\text {th }}$ International Congress

on Archaeology,

Computer Graphics,

Cultural Heritage and Innovation

'ARQUEOLÓGICA 2.0'

in Valencia (Spain),

Sept. $5-7,2016$

\title{
APLICACIÓN DE DIVERSAS TÉCNICAS DE DOCUMENTACIÓN PATRIMONIAL ARQUITECTÓNICA EN LA ALQUERÍA 'MAS DEL NOI'
}

\section{APPLICATION OF DIVERSE ARCHITECTURAL HERITAGE DOCUMENTATION TECHNIQUES ON THE 'MAS DEL NOI' FARMHOUSE}

\author{
Juan Pedro Carbonell-Rivera ${ }^{\mathrm{a},{ }^{,},}$, David Montalvá-España ${ }^{a}$, José Luis Lerma ${ }^{\mathrm{b}}$ \\ ${ }^{a}$ Máster Universitario en Ingeniería Geomática y Geoinformación, Universitat Politècnica de València, $C^{\circ}$ de Vera s/n, 46022 Valencia,
} España. juacarri@upv.es; damones2@upv.es

${ }^{\text {b } G r u p o ~ d e ~ I n v e s t i g a c i o ́ n ~ e n ~ F o t o g r a m e t r i ́ a ~ y ~ L a ́ s e r ~ E s c a ́ n e r ~(G I F L E) . ~ D e p a r t a m e n t o ~ d e ~ I n g e n i e r i ́ a ~ C a r t o g r a ́ f i c a, ~ G e o d e s i a ~ y ~}$ Fotogrametría. Universitat Politècnica de València, $C^{\circ}$ de Vera, s/n. Edificio 7i. 46022 Valencia, España. jllerma@cgf.upv.es

\begin{abstract}
:
For the study, documentation and conservation of architectural heritage, it is required to use all the available techniques, classic and new, that may contribute to provide a correct idea about the present condition of the construction, and tackle the possible actions for its appropriate maintenance.

This paper describes the usage of a terrestrial laser scanner for the recording and documentation of the 'Mas del Noi' at the Campus of Vera, Universitat Politècnica de València. First, classical techniques are used for the graphical recording, sketches and topographic radiation. Afterwards, it is shown the indirect process implemented for the massive 3D data acquisition from laser scanning and photogrammetry, modelling of the point cloud and 3D printing to materialize the final results. The detection of alterations by multispectral and thermal imagery is also included.
\end{abstract}

Key words: architectural heritage, digital documentation, cultural heritage, documentation, 3D model, 3D printing

\section{Resumen:}

En el proceso de estudio, documentación y conservación del patrimonio arquitectónico se hace necesaria la utilización de todas las técnicas disponibles, tanto clásicas como modernas, que puedan aportar una idea acertada del estado actual en que se encuentra la construcción, y abordar las posibles actuaciones para su adecuado mantenimiento.

En este artículo se presentan los trabajos realizados mediante el uso de un escáner láser 3D para el registro y la documentación del 'Mas del Noi' en el campus de Vera de la Universitat Politècnica de València. Se aborda la realización de un registro gráfico mediante técnicas clásicas, dibujo a mano alzada y radiación topográfica. Posteriormente se muestra el proceso indirecto implantado a partir de la toma masiva de datos 3D mediante láser escáner y fotogrametría, el modelado de la nube de puntos y la materialización del resultado final en una impresión 3D. También se incluye la detección de patologías mediante imágenes multiespectrales y térmicas.

Palabras clave: patrimonio arquitectónico, documentación digital, patrimonio cultural, documentación, modelo 3D, impresión 3D

\section{Introducción}

La documentación del patrimonio cultural no consiste únicamente en la toma in situ de los datos necesarios para su registro en detalle, sino que también involucra los procedimientos necesarios que permiten procesar, gestionar y archivar esta información, para su presentación y recuperación posterior en un determinado momento de la vida del mismo.

Las diferentes técnicas que se pueden aplicar no se deben considerar excluyentes, ni prevalecer unas sobre otras. Así las más actuales no reemplazan a otras ya conocidas sino que resultan complementarias y pueden aportan nuevos niveles de información que serán de aplicación durante el proceso de conservación. De este modo, en la ejecución del proyecto se ha planteado metodológicamente la aplicación de un gran abanico de técnicas de documentación gráfica, que se complementan y que permiten obtener un registro geométrico exhaustivo.

A continuación se abordará el caso de estudio, desarrollando las técnicas clásicas de documentación

‘Corresponding Author: Juan Pedro Carbonell-Rivera, juacarri@upv.es 
realizadas, dibujo a mano alzada y radiación topográfica. Seguidamente se hará referencia al proceso de toma de datos láser y su posterior tratamiento de los datos, así como a la detección de patologías en zonas de especial interés mediante fotografía multiespectral y térmica, para finalizar exponiendo los resultados y productos finales obtenidos.

\section{Caso de estudio}

El 'Mas del Noi' (Fig. 1) se caracteriza por ser uno de los edificios más antiguos del Campus de Vera. En la actualidad, la alquería alberga en su interior la fundación CEDAT (Servicio de atención al alumno con discapacidad). Está compuesto por varias construcciones unidas por sus fachadas generando así una composición singular(Conselleria de Medi Ambient, Aigua 2008).

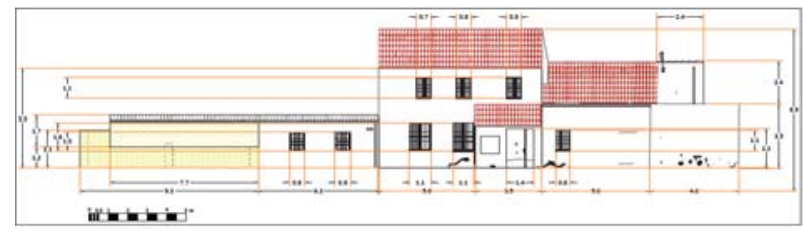

Figura 1: Dibujo CAD de la cara oeste de la alquería.

\section{Técnicas clásicas de documentación}

En general el objetivo es representar y acotar de manera proporcional elementos constructivos fundamentales en planta, alzado y sección, así como elementos característicos en 3D para tener una idea general de la construcción. Por ello, la metodología de trabajo planteada para la modelización de edificios históricos mediante técnicas topográficas y fotogramétricas, contempla distintas fases distribuidas en el tiempo y dependientes unas de otras.

Inicialmente, se ha de llevar a cabo una planificación general del proyecto, contemplándose para ello, tanto los trabajos topográficos como fotogramétricos que van a ser necesarios. En esta fase se hace necesaria la correcta planificación de las redes topográficas de apoyo. Las cuales deberán permitir la obtención de suficientes puntos para definir la estructura básica, medir los puntos de apoyo necesarios para orientar y proyectar las fotografías y definir un sistema de referencia común y estable para todo el proyecto.

Para ello, es necesario realizar una visita a campo en la que se realizan dibujos a mano alzada del edificio a documentar, en el que se remarcarán las patologías constructivas. Estos se materializan de forma digital en un archivo en formato CAD dividiéndolos en alzado, planta y perfiles (véase Figura 1)

En cuanto a la planificación de los trabajos fotogramétricos, se deberán analizar el número y situación de las tomas fotográficas teniendo en cuenta aspectos como el formato, la resolución de la cámara y la escala de trabajo, las características del objetivo y sus distorsiones, la ubicación y orientación de los paneles para determinar el horario más adecuado para la realización de las tomas, la presencia de obstáculos y zonas ocultas intentando garantizar una cobertura completa.
Para el desarrollo de este trabajo se ha utilizado una cámara Canon EOS $1100 \mathrm{D}$, que equipa un Sensor CMOS 18MP APS-C con procesador DIGIC 5 de 14-bit con una resolución de 12 megapíxeles y una sensibilidad ISO 100-6400.

A continuación se realiza la materialización, observación, cálculo y compensación de las redes topográficas planteadas. En primer lugar se hace necesario la materialización en el terreno de diferentes bases topográficas a las que se dan coordenadas utilizando técnicas GNSS siempre que los obstáculos en el entorno de las bases no provoque efectos multicamino (Pascual et al. 2007) que desaconsejen el uso de esta tecnología (Cielo descubierto). En este proyecto se realizaron mediciones GNSS utilizando un receptor Trimble R8 que posee una precisión en medición estática en horizontal de $3 \mathrm{~mm}+0.1 \mathrm{ppm}$ RMS, y en vertical de $3.5 \mathrm{~mm}+0.4 \mathrm{ppm}$ RMS.

En el caso de no tener buena visibilidad a las diferentes constelaciones GNSS, se utilizarán técnicas de medición clásicas. Para tal fin se utilizó una estación total Leica TS02 para estos fines, que posee una precisión a prisma de $1.5 \mathrm{~mm}+2 \mathrm{ppm}$, pudiendo realizar medidas a cualquier tipo de superficies con una precisión de $2 \mathrm{~mm}+2 \mathrm{ppm}$. El uso de esta tecnología es muy recomendable para la fase de toma de puntos por radiación. Una vez definida la red topográfica base que cubra todo el perímetro del edificio (véase Tabla 1) se realizarán mediciones al edificio utilizando la técnica clásica de radiación para la realización de un levantamiento en formato CAD de las diferentes vistas del edificio.

Tabla 1 Muestra de coordenadas de la red topográfica con estación total.

\begin{tabular}{c|c|c|c} 
Punto & $Y(m)$ & $Y(m)$ & $Z(m)$ \\
\hline 1000 & 729086,329 & 4373512,69 & 50,759 \\
1001 & 729067,473 & 4373519,12 & 50,802 \\
1002 & 729055,908 & 4373524,83 & 50,918 \\
1003 & 729064,057 & 4373538,81 & 51,012
\end{tabular}

En este archivo debe cerciorarse que todas las patologías y elementos registrados en los primeros planos obtenido de los bocetos (véase Figura 1) estén representados en ese plano CAD obtenido a partir de la técnica de radiación.

Una vez realizada la red topográfica, y posterior radiación, se puede llevar a cabo la toma, verificación y obtención de las distintas fotografías necesarias para cubrir todo el objeto (véase Figura 2). En esta fase se han de tener en cuenta dos condicionantes muy importantes y que pueden entrar en conflicto: la necesidad de una cobertura completa y redundante y la necesidad de minimizar el número de fotografías necesarias para aumentar el rendimiento del trabajo, por lo que se deberá buscar un equilibrio entre ambos (Pérez García et al. 2011)

\section{Documentación con escáner láser}

La aplicación del escáner láser terrestre de media distancia se utiliza cada día más en labores de 
documentación patrimonial. Su uso está justificado en proyectos de levantamiento fotogramétrico en donde las dimensiones son grandes y sobre todo con geometría compleja. Por ello, ha supuesto un avance gracias al registro de información de manera rápida y exhaustiva, permitiendo generar documentación de fácil divulgación científica (Lerma et al. 2010)

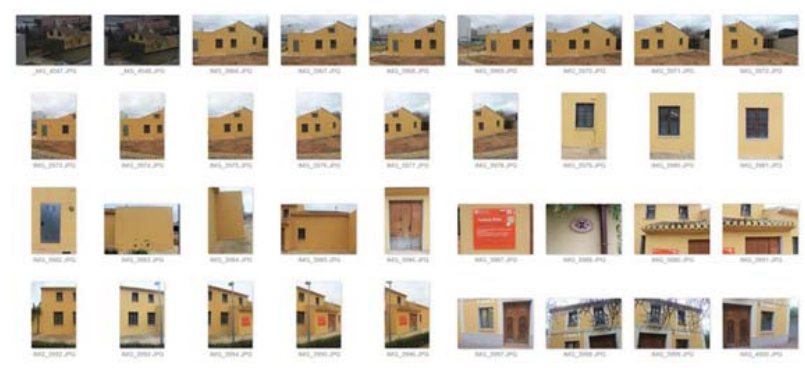

Figura 2: Muestra de imágenes.

\section{Documentación con escáner láser}

La aplicación del escáner láser terrestre de media distancia se utiliza cada día más en labores de documentación patrimonial. Su uso está justificado en proyectos de levantamiento fotogramétrico en donde las dimensiones son grandes y sobre todo con geometría compleja. Por ello, ha supuesto un avance gracias al registro de información de manera rápida y exhaustiva, permitiendo generar documentación de fácil divulgación científica (Lerma et al. 2010)

En primer lugar se definieron las posiciones óptimas del láser escáner. Posteriormente se realizó la toma de datos con un láser escáner Leica $\mathrm{P} 40$, que posee una precisión de alcance de $1.2 \mathrm{~mm}+10 \mathrm{ppm}$ a una velocidad de escaneo de 1 millón de puntos por segundo con alcances de hasta $270 \mathrm{~m}$.

Una vez realizada la toma de datos se procedió al registro (alineación) y georreferenciación de las estaciones mediante el programa 3DVEM - Register GEO. Los procesos de tratamiento de las nubes de puntos, generación de mallado y texturizado se han efectuado mediante el software 3DReshaper (véase Figura 3).

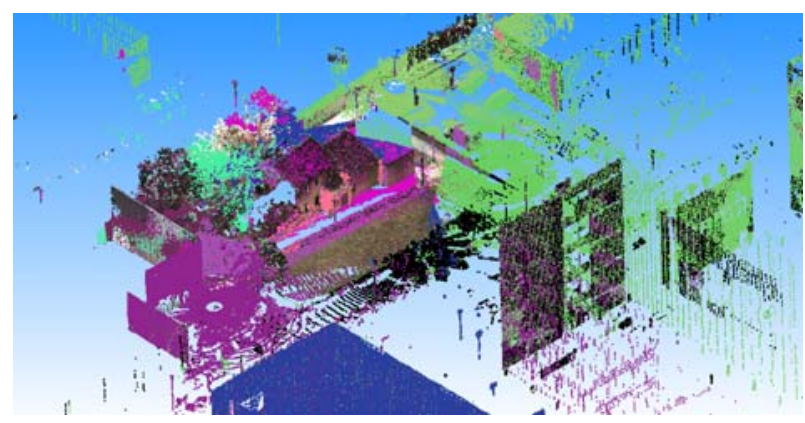

Figura 3: Visualización de la nube de puntos bruta.

A continuación se ha realizado un proceso de filtrado de la nube de puntos con el fin de reducir el ruido producido por el láser escáner y centrarse solo en el edificio de studio (Fig. 4). Este proceso se ha de realizar de forma iterativa hasta que el nivel de detalle sea el correcto, eliminándose todos los posibles errores groseros, además de otros elementos (Mañana-Borrazás et al. 2008).

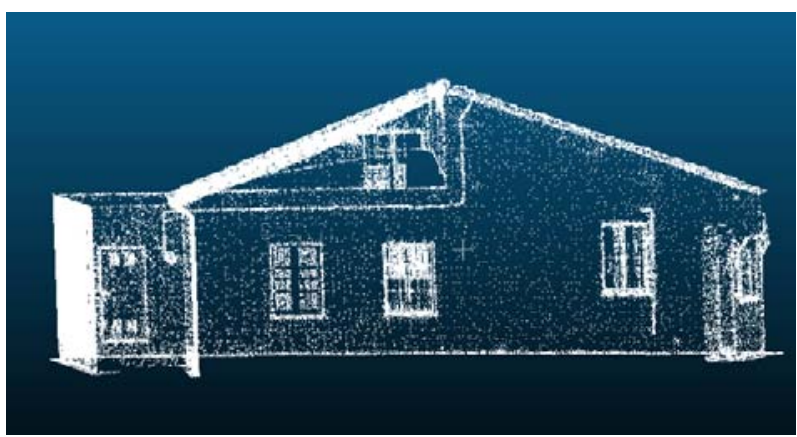

Figura 4: Selección de puntos.

Seguidamente se realiza un mallado de la nube de puntos, rellenado de huecos y optimización del modelo (Lerma García et al. 2008).

Debemos obtener un modelo 3D óptimo respecto a la precisión de la nube de puntos bruta utilizada (véase Figura 5).

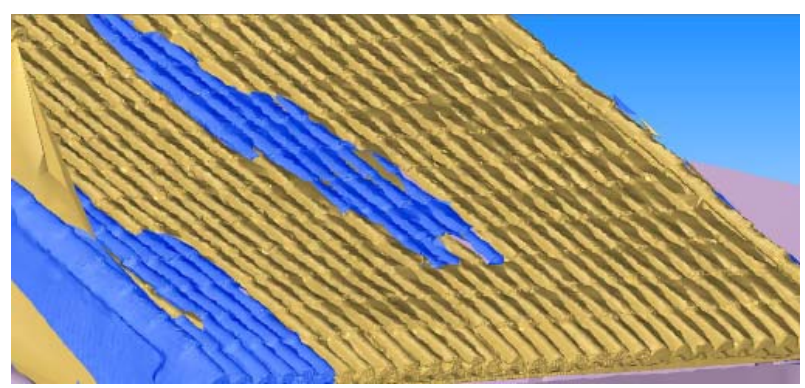

Figura 5: Modelado óptimo del tejado de la alquería.

El último paso en el proceso de creación de un modelo 3D a partir de una nube de puntos es la texturización del modelo a partir de las imágenes digitales.

\section{Imágenes multiespectral y térmica}

Para la documentación de zonas de especial interés y de alto valor patrimonial se realizó la adquisición de diferentes fotografías con diferentes rangos del espectro electromagnético (véase Figura 6) para la detección de patologías. Ejemplificamos esta técnica utilizada sobre un respiradero, un elemento único y de alto valor patrimonial en la alquería 'Mas del Noi'.
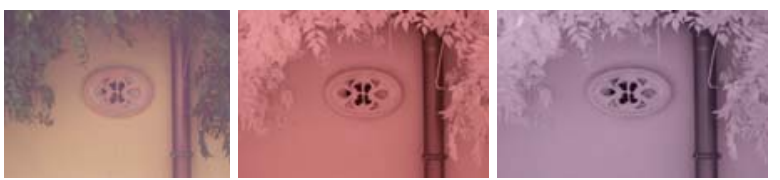

Figura 6: Toma fotográfica en el espectro visible (izquierda), utilizando un filtro IR de paso bajo (centro) y utilizando un filtro de paso alto (derecha).

En esta documentación se tomaron cinco fotografías, una toma fotográfica sin filtro, y cuatro tomas fotográficas utilizando diferentes filtros, espectro visible, ultravioleta, infrarrojo de paso alto e infrarrojo de paso bajo. Para el procesamiento de toda esta información se utilizó la técnica estadística de componentes principales (Vicent Garcia et al. 1996) para reducir la dimensionalidad del conjunto de datos.

El análisis de componentes principales (ACP) busca la proyección según la cual los datos queden mejor 
representados en términos de mínimos cuadrados. El ACP se emplea sobre todo en análisis exploratorio de datos y para construir modelos predictivos. EI ACP comporta el cálculo de la descomposición en autovalores de la matriz de covarianza, lo que provoca que en los primeros componentes resultado se obtenga la mayor parte de la información reflejada en cada banda (RGB) de las diferentes tomas fotográficas realizadas (Figura 7 )

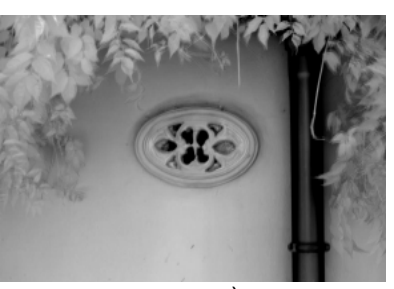

a)

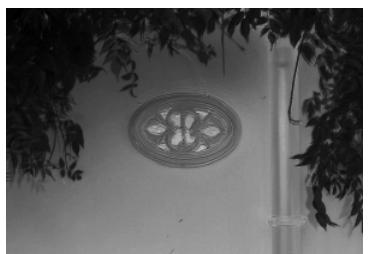

c)

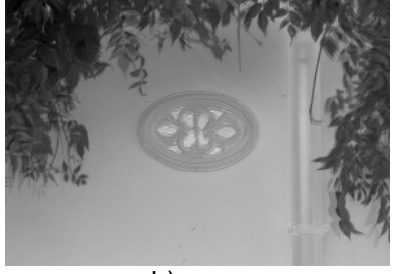

b)

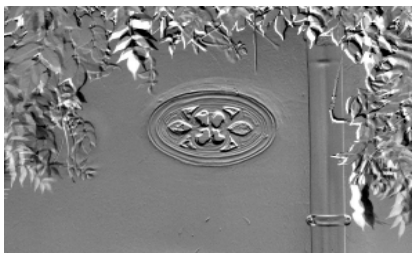

d)
Figura 7: Componentes principales: a) Primer componente; b) Segundo componente; c) Tercer componente; y d) Cuarto componente.

Este comportamiento del método provoca que en las bandas secundarias, se observen las diferencias entre las diferentes tomas, como es el movimiento de las hojas en la parte superior y lateral de la Figura 7. Igualmente podemos observar en la parte superior del respiradero cómo se ha detectado una ondulación que corresponde con la presencia de una capa de yeso, que difiere del material constructivo empleado en la fachada.

En lo referente a la termografia, resulta de especial interes puesto que con esta técnica se pueden observar materirales 0 patologías que no podrian ser descubiertas a simple vista (Fig. 8) y facilitan la delimitación de otras como podría ser el caso de humedades(Gayo 2002). Una de las caracteristicas más importantes es que esta técnica es no destructiva puesto que no necesita contacto físico con el objeto de estudio. El problema es que puede verse gravemente afectada por elementos externos, como pueden ser cambios climáticos de presión, temperatura y humedad.

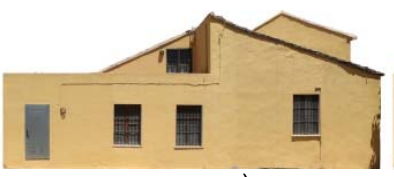

a)

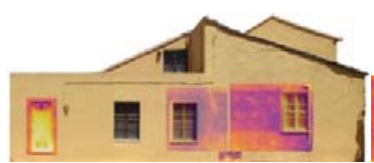

c)

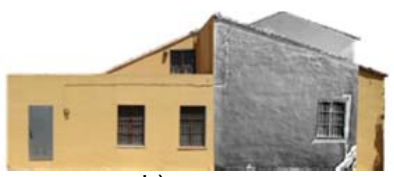

b)

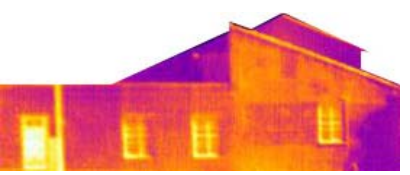

d)
Figura 8: Mosaicos de la cara sur del 'Mas del Noi: a) Visible (RGB); b) RGC con multiespectral; c) RGB con incrustaciones de imágenes térmicas; d) Térmico.
Para este estudio termográfico, se utlizó la camara FLIR ThermaCAM B4 con una resolucion de $320 \times 240$ pxeles, preparada para trabajar en un rango de temperaturas comprendido entre $-20 \mathrm{C}^{\circ}$ y $120^{\circ} \mathrm{C}$.

\section{Resultados}

A continuación se muestran parte de los resultados alcanzados en el proyecto de documentación patrimonial. Se han clasificado en dos grandes grupos, bidimensionales (2D) y tridimensionales (3D).

\subsection{Resultados bidimensionales}

El primer resultado generado se trata de la generación de mosaico de cada una de las fachadas del edificio. Para ello, se tuvieron que rectificar las imágenes previamente (Fig. 9).

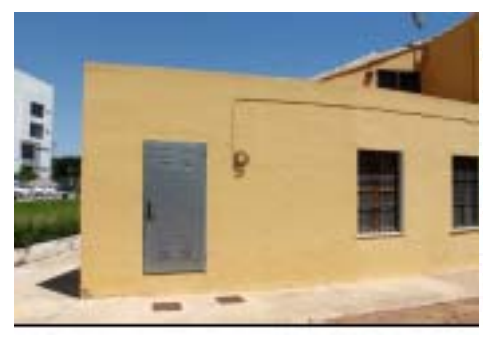

a)

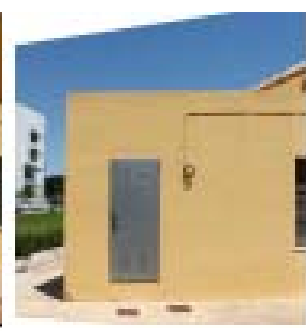

b)
Figura 9: Proceso de rectificación 2D: a) Imagen original RGB; b) Imagen rectificada recortada RGB.

Posteriormente, se ha unido las imágenes rectificadas. Puesto que el proyecto se caracteriza por la integración de múltiples técnicas en un resultado final, se han generado distintos mosaicos en función de las técnicas utilizadas, destacando no solo las imágenes visibles sino también las imágenes multiespectrales y térmicas.

\subsection{Resultados Tridimensionales}

Tras la generación de la malla (Fig. 10) a partir de los datos de la nube de puntos obtenidos con el láser escáner, se ha procedido a la maquetación y la impresión de maquetas 3D mediante una impresora de la marca Multimaker.

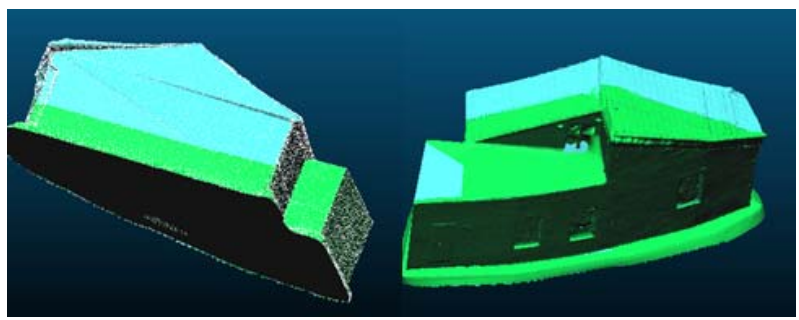

Figura 10: Vistas 3D de la malla de triángulos. Nótese que el volumen está cerrado.

Para ello, esta empresa facilita un software denominado Cura (Fig. 11), el cual está diseñado con un interfaz sencillo y a la vez completo para generar un producto final acorde con nuestros objetivos.

\section{Valoraciones finales}

La utilidad de este tipo de modelos y técnicas, la inclusión en diferentes documentos estándar, accesibles 
a través de la web e incluso adaptables a sistemas de realidad aumentada no sustituyen la tradicional documentación, pero sí aportan un grado más de percepción, tanto para la documentación patrimonial como para la sensibilización del estado actual del patrimonio.

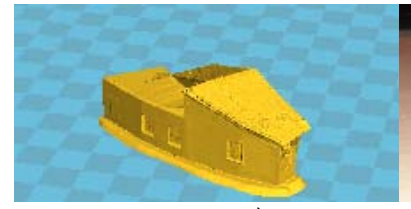

a)

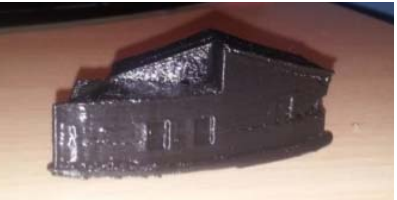

b)
Figura 11: Impresión 3D:a) Generación del objeto 3D mediante CURA; b) Muestra de impresión.

La digitalización por medio del láser escáner tiene como principal virtud de servir de una base sólida y precisa para la obtención de una documentación y un archivo digital de calidad y detalle en un momento concreto de la vida de un elemento patrimonial, que posibilita la preservación digital de ese elemento. Sin embargo, no sustituye a las técnicas más convencionales puesto que estas aportan una información muy valiosa para los productos finales, como puede ser la inclusión de datos RGB o la generación de perfiles para el estudio del edificio en secciones.

Por ello, se concluye que no existe una técnica única que pueda englobar todos los proyectos de documentación y conservación, y que la mejor solución a optar es la interoperabilidad de las distintas técnicas. De esta manera, se podrán generar resultados acordes con los objetivos del proyecto.

\section{Agradecimientos}

Especial reconocimiento a la empresa Leica Geosystems, S.L. por la cesión del láser escáner Leica P40 utilizado en este proyecto.

\section{Referencias}

CONSElLERIA DE MEDI AMBIENT, AIGUA, U.IH., 2008. Plan de Acción Territorial de Protección de La Huerta de Valencia. Available at: http://www.upv.es/contenidos/CAMUNISO/info/U0549942.pdf.

GAYO, E., 2002. La Humedad Como Causa de Patologías En Monumentos: Desarrollo de Nuevas Técnicas de Análisis No Destructivo Basadas En Termografía Infrarroja. Universidad Complutense de Madrid, Servicio de Publicaciones.

LERMA, J.L., VAN GENECHTEN, B., HEINE, E. y SANTANA, M., 2008. Theory and Practice on Terrestrial Laser Scanning: Training Material Based on Practical Applications; [Prepared by the Learning Tools for Advanced ThreeDimensional Surveying in Risk Awareness Project (3DRiskMapping)]. Ed. UPV, Univ. Politécnica de Valencia. Available at: https://books.google.de/books?id=-0nRXwAACAAJ.

LERMA, J.L., CABRELLES, M., NAVARRO, S. y SEGUÍ, A.E., 2010. Modelado fotorrealístico 3D a partir de procesos fotogramétricos: láser escáner versus imagen digital. Cuadernos de arte rupestre. [Online], pp. 85-90. Available at: http://carmesi2.regmurcia.com/recursos/arterupestre/6/LermaCAR2012_06_08.pdf.

MAÑANA-BORRAZÁS, P., RODRÍGUEZ PAZ, A. y BLANCO-ROTEA, R., 2008. Una experiencia en la aplicación del Láser Escáner 3D a los procesos de documentación y análisis del Patrimonio Construido: su aplicación a Santa Eulalia de Bóveda (Lugo) y San Fiz de Solovio (Santiago de Compostela). Arqueología de la Arquitectura [Online] 5. Available at: http://arqarqt.revistas.csic.es/index.php/arqarqt/article/view/87/84.

PASCUAL, J.P., CASCO, N.A. y MURAVCHIK, C.H., 2007. Antena de Microtira para GPS con Mitigación del Multicamino. XII Reunión de Trabajo en Procesamiento de la Información y Control [Online]. Available at: https://www.researchgate.net/profile/Carlos_Muravchik/publication/237340757_Antena_de_Microtira_para_GPS_con _Mitigacin_del_Multicamino/links/556dc1d508aefcb861da98a5.pdf.

PÉREZ, J.L., MOZAS, A.T., CARDENAL, F.J. y LÓPEZ, A., 2011. Fotogrametría de bajo coste para la modelización de edificios históricos. Virtual Archaeology Review, pp. 121-125. http://doi.org/10.4995/var.2011.4633

VICENT, J.M., MONTERO, I., RODRÍGUEZ, Á.L., MARTÍNEZ, M.I. y CHAPA, T., 1996. Aplicación de la imagen multiespectral al estudio y conservación del arte rupestre postpaleolítico. Trabajos de Prehistoria 53, pp. 19-35. http://doi.org/10.3989/tp.1996.v53.i2.390 


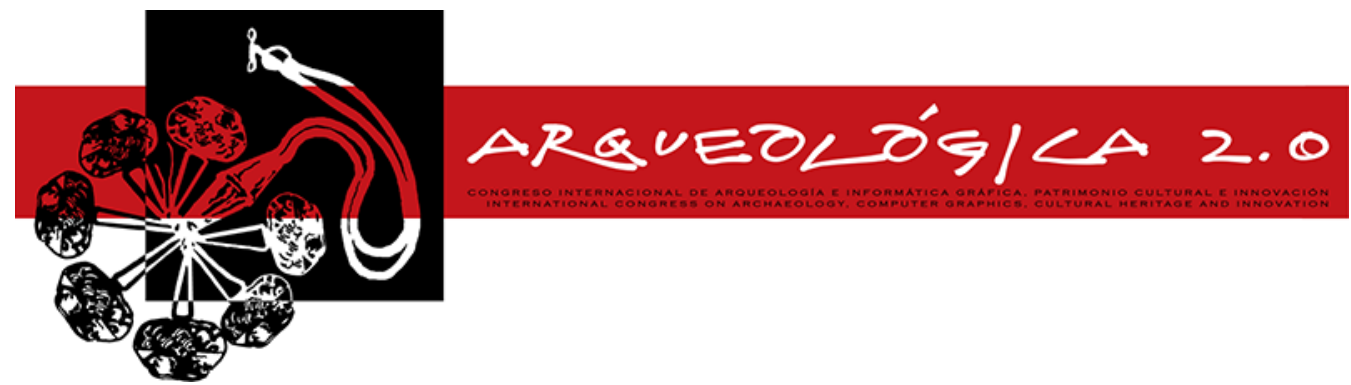

Proceedings of the $8^{\text {th }}$ International Congress

on Archaeology,

Computer Graphics,

Cultural Heritage and Innovation

'ARQUEOLÓGICA 2.0'

in Valencia (Spain),

Sept. 5- 7, 2016

\title{
EL PALACIO DE LOS NIÑOS DE DON GOME (ANDÚJAR, JAÉN), GESTIONADO DESDE UN PROYECTO H-BIM
}

\author{
THE PALACE OF THE CHILDREN OF DON GOME (ANDÚJAR, JAÉN), MANAGED THROUGH THE HBIM PROJECT
}

\author{
Álvaro García, Enrique Nieto*, Juan José Moyano
}

Departamento de Expresión Gráfica e Ingeniería en Edificación, Escuela Técnica Superior de Ingeniería de Edificación, Universidad de Sevilla, Avenida Reina Mercedes, 4a , 41012 Sevilla, España. alvaro andi@hotmail.com; jenieto@us.es; jmoyano@us.es

\begin{abstract}
:
The document aims to clarify an efficient methodology for the study of the built heritage. This methodology comprises the historical, construction and evolutionary aspects regarding the heritage, and also includes the chronology of interventions carried out in the historic building. The collection and manipulation of graphic information and related data will be based on a 3D interoperable graphic model which allows managing the information integrated in it, regarding the disciplines related to the conservation process and Heritage Rehabilitation. Furthermore, the system will widen the management of coming information in heritage maintenance, thus fulfilling its life cycle. The case study focuses on the Palace of the Children of Don Gome, a historic building located Andujar, Jaen (Spain). This work compiles and organises data in order to enable an analysis based on a Heritage or Historic Building Information Model called the "HBIM Project". In addition, this model will employ precise techniques for the acquisition of real geometries, such as photogrammetry, so as to generate a model including all relevant and accurate information about a building of significant historical and architectural value.
\end{abstract}

Key words: HBIM project, historic building information modelling, patrimonial information model, photogrammetric restitution, architectural archaeology, BIM.

\section{Resumen:}

El documento pretende exponer una metodología eficiente para el estudio del patrimonio construido, que englobe sus aspectos histórico, constructivo y evolutivo, incluida la cronología de las intervenciones llevadas a cabo en el edificio histórico. La recopilación y manipulación de la información, gráfica y de datos relacionados, se sustentará en un Modelo gráfico 3D interoperable, que permita una gestión de toda la documentación integrada en el mismo desde todas los campos disciplinares relacionados con el Proceso de Conservación y Rehabilitación Patrimonial. El sistema permitirá además ampliar la gestión de la información que se obtiene en el mantenimiento del patrimonio, cumpliendo así su ciclo de vida.El caso de estudio se centra en el "Palacio de los niños de Don Gome", un edificio histórico situado en la localidad de Andújar, Jaén (España). El trabajo constituye una compilación y ordenación de datos que permiten un análisis basado en un Modelo de Información Patrimonial, denominado "Proyecto HBIM". Además, se sustentará en técnicas precisas para la adquisición de las geometrías existentes, como es la fotogrametría, a fin de generar un modelo que contenga toda la información relevante y fiel sobre un edificio de importante valor histórico y arquitectónico.

Palabras clave: Proyecto HBIM, historic building information modelling, modelo de información patrimonial, restitución fotogramétrica, arquelogía de la arquitectura, BIM.

\section{Introducción}

El sistema BIM (Building Information Modeling), permite un flujo de trabajo organizado durante las diferentes etapas de un proyecto: programa, diseño, construcción, operación y demolición (Eastman et al. 2011). Concebido como un núcleo contenedor de datos (database), relacionada a una representación gráfica asentada en un modelo 3D paramétrico, facilitará la gestión de la información durante el ciclo de vida del edificio. En cambio, su aplicabilidad al Patrimonio Arquitectónico se encuentra condicionada debido a las peculiaridades propias del edificio histórico. El gran hándicap de las construcciones históricas es su complejidad, al introducir geometrías irregulares, materiales no homogéneos, alteraciones y daños en paramentos por el transcurrir del tiempo. Ello plantea nuevos desafíos en el modelado digital 3D y simulación de actuaciones estructurales en función de las diferentes hipótesis (Barazzetti et al. 2015). Aunque la

*Corresponding Author: Enrique Nieto, jenieto@us.es. 
constante evolución del sistema BIM ha introducido capacidades avanzadas para incorporar información proveniente de otros sistemas fiables, y muy precisos, para la adquisición de una geometría fiel: las técnicas fotogramétricas y el escaneo 3D (Nieto et al. 2013).

\section{Información gráfica fiel al Patrimonio}

Las vistas métricas, junto a perspectivas 3D del modelo, y los esquemas de datos relacionados con los elementos representados son esenciales en proyectos de intervención (Rehabilitación, Reconstrucción, Restauración) basados en la tecnología BIM, y que definimos como proyecto H-BIM (Nieto and Moyano 2014, 2016). Lo habitual es que esta información gráfica sea insuficiente y debe integrarse con los nuevos datos acaecidos, en la elaboración del proyecto y durante la misma intervención. Deben surgir nuevos estudios multidisciplinares del edificio histórico para completar la falta de datos en ciertas áreas específicas, así como corregir imprecisiones de las planimetrías existentes (Fai et al. 2011, 2013).

En el campo de la preservación histórica del edificio, el proyecto debe sustentarse en un modelado $3 \mathrm{D}$ fiel a las geometrías reales. Las medidas tomadas con herramientas tradicionales de medición deben ser colmadas con técnicas de levantamiento más completas, como es el escaneo 3D, y complementadas con la fotogrametría para precisar los relieves y las texturas del material. Actualmente el software BIM puede incorporar nubes de puntos procedentes de las anteriores técnicas, como referencia fiel en la fase de modelado (Nieto et al. 2014). En estudios anteriores se ha experimentado con equipos manuales Escáner 3D (Artec) y software de fotogrametría (Photoscan Agisoft, 123DCatch Autodesk) para la toma de la geometría de piezas arquitectónicas de gran valor (capiteles y tallas del Cenador de Carlos V). Posteriormente, se crearon bibliotecas de objetos paramétricos (GDL) con la geometría y textura no manipulada; base documental disponible para futuras investigaciones o intervenciones en el patrimonio arquitectónico (Nieto et al. 2013).

La gestión de todos los cambios sustanciales a lo largo de la historia y su registro mediante la vinculación a una base de datos actualizable será fundamental para el mantenimiento y la protección del Patrimonio (Brumana et al. 2013). Es por ello, que este artículo se centra en el estudio histórico, evolutivo y constructivo de un edificio de carácter patrimonial, gestionado desde un Modelo de Información Patrimonial; es decir, un análisis de compilación y ordenación de datos basado en un "Proyecto HBIM".

\section{La arquitectura de la Casa-Palacio}

El edificio analizado, conocido como "la casa de los niños de Don Gome", se encuentra en el municipio de Andújar, provincia de Jaén (España). El edificio fue la casa que la familia Gome de Valdivia construyó en el siglo XVII, junto a lo que en su día fue entrada a la muralla, conocida como puerta de la Virgen María. La parte central de la casa es una Portada-Torre que articula todo el conjunto del edificio, de indudable valor castrense, entre el manierismo y el barroco (Fig.1a). La puerta principal, tapiada durante varios siglos, sería abierta el año 1989, en su última intervención. A día de hoy el acceso sigue siendo la puerta secundaria, por no haberse completado el proceso de restauración interior de la torre (Fig.1b).

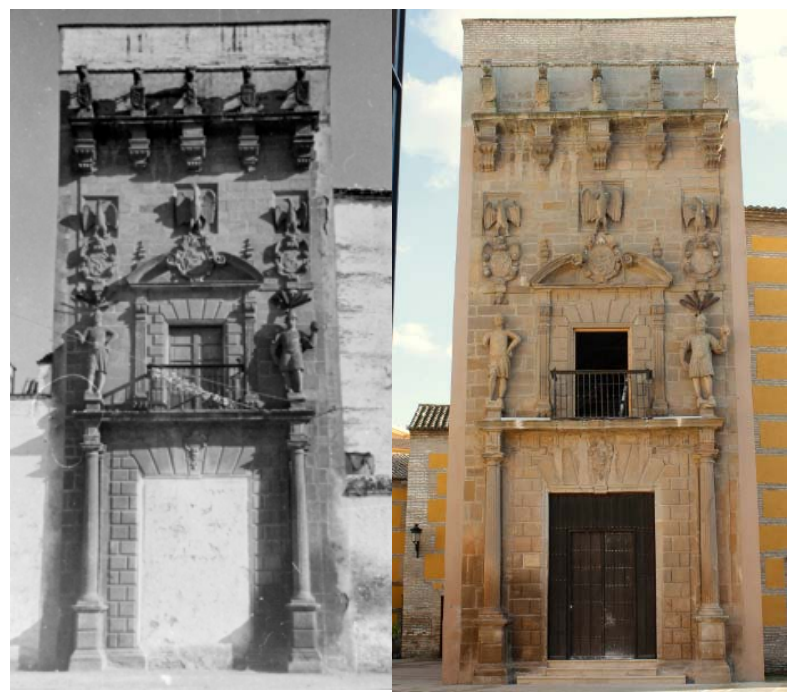

Figura 1: (a) Fachada con la puerta tapiada, principios S. XX.

(b). Imagen reciente con la puerta incorporada en el vano.

La unidad constructiva se va a ver alterada por posteriores transformaciones y añadidos. Va ser la última intervención, en el año 1989, la de mayor calado, una restauración parcial, muy discutida por los trabajos llevados a cabo. Se plantea la restauración del conjunto atendiendo a fines estructurales para consolidar el edificio y evitar su progresivo deterioro (Fig. 2).

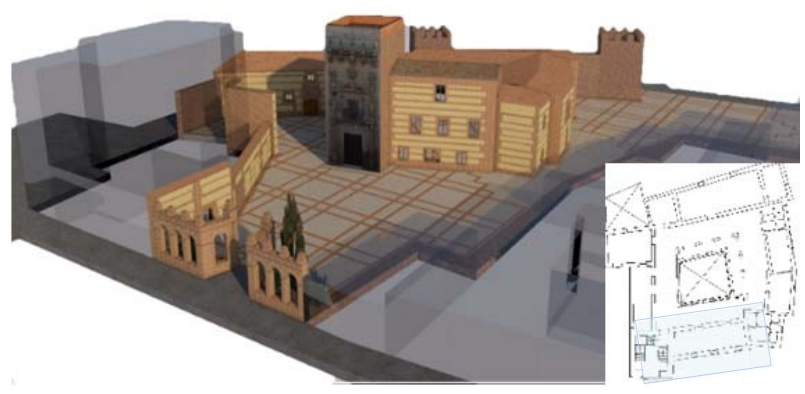

Figura. 2: (a) Conjunto palaciego, con la Zona marcada modelada a LOD-300. Motor Cine Render de ArchiCAD. Autor: Álvaro García.

\section{Proceso del Modelado BIM}

Teniendo en cuenta el tamaño del inmueble, se ha optado por un modelado a nivel LOD-100, para todo el entorno, cerramientos y cubiertas, exceptuando la cubierta de la torre y estructura de la nave norte (Fig. 3). En esta zona llegaremos a un nivel de desarrollo LOD300. Para la realización de las vigas del artesonado, se ha optado por la herramienta Perfil, ya que la misma genera una sección de corte (2D) que después es utilizada para la extrusión de la pieza con la herramienta Viga. Para el modelado de elementos singulares, como canecillos (Fig. 4), se recurre a técnicas fotogramétricas. Ello ha facilitado la obtención de la geometría real de las piezas, en forma de nube de puntos, que de otra forma serian imposibles de modelar con exactitud. Se ha empleado el software Photoscan al permitir, a partir de una serie de fotografías, la generación de un modelo 3D para después exportarse al proyecto HBIM. 


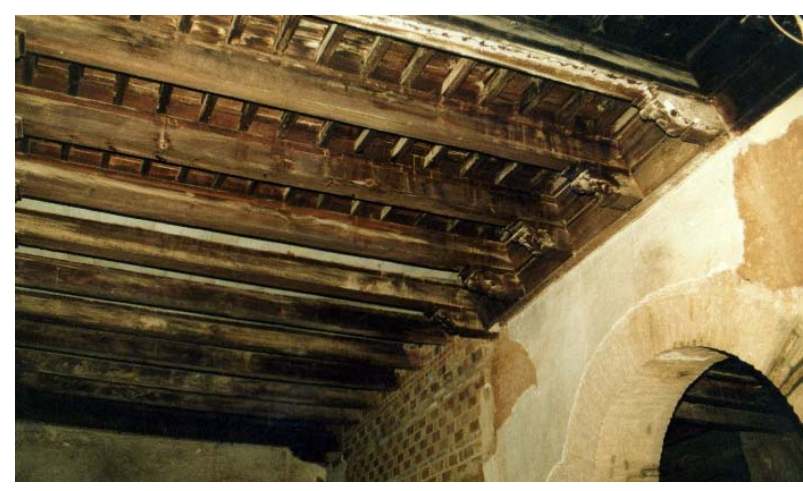

Figura 3: La Nave Norte antes de 1989. Fotos: Iván Jimenez.

Se han realizado diferentes tomas fotográficas que envuelven al elemento evitando zonas no barridas; se disminuye así la fase de cierre de huecos para facilitar al software la generación de una maya más aproximada a la realidad del objeto. Para la obtención de un canecillo del artesonado se han utilizado 53 fotografías (Fig. 4).

Después de ser tratadas las imágenes, se ha seguido el flujo de trabajo preestablecido: orientar fotos, crear nube de puntos, crear malla y por último crear textura. Los puntos de control han facilitado escalar el objeto.
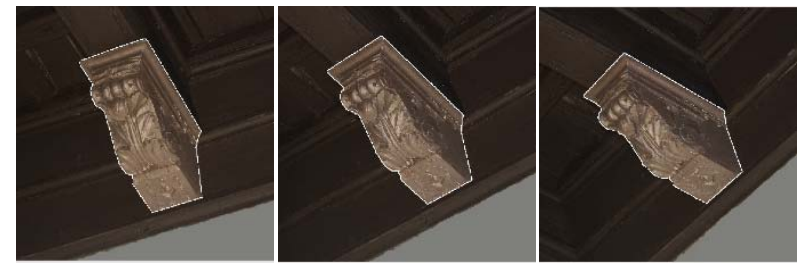

Figura 4: Creación de máscaras en las fotografías a los canecillos, software Photoscan. Autor: Álvaro García.

Para la exportación a ArchiCAD se emplea la extensión $3 d s$, para que el propio software lo convierta en un objeto paramétrico insertado en la biblioteca incrustada. Una vez en su posición se ha modificado el material de la superficie de los canecillos y demás elementos del artesonado (vigas y molduras del techo) (Fig. 5).

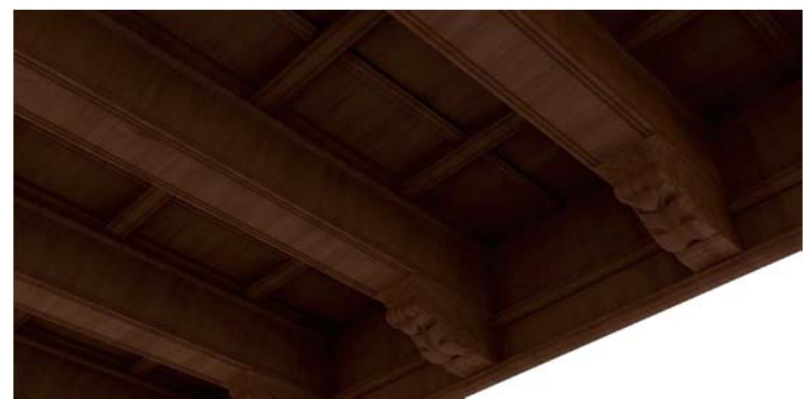

Figura 5: Artesonado completo del salón de la nave. Modelado y renderizado en ArchiCAD. Autor: Álvaro García.

\section{Tablas inventario del artesonado}

Se ha generado un inventario de todos los elementos del artesonado de las plantas baja y primera. Se trata de una clasificación tipológica contenida en el proyecto HBIM que comprende elementos singulares de gran valor histórico, como son los canes datados del siglo XVII. Las tablas creadas incorporan ítem de información por columna en referencia a los objetos incluidos en ella: ID, cantidad, longitud, anchura, altura, estado de conservación, datación y patologías (Fig. 6).

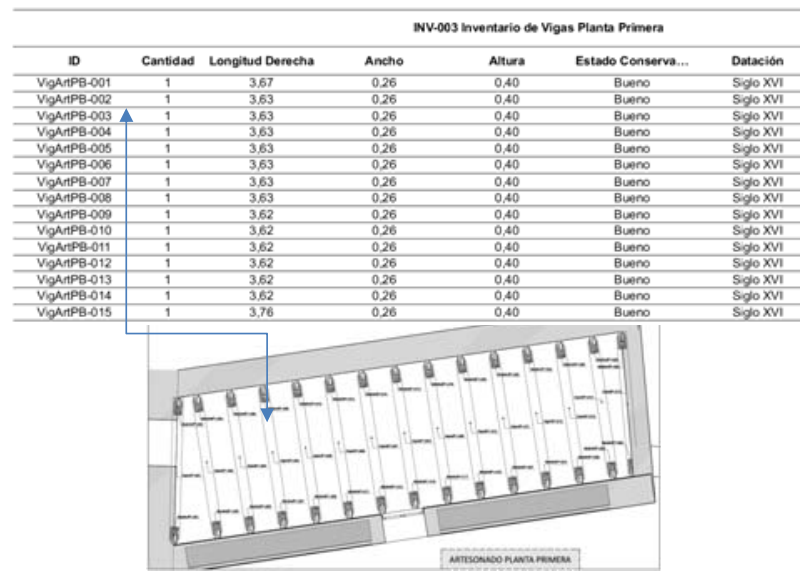

Figura 6: Identificación de vigas y canecillos del artesonado, y vinculación con las tablas del Proyecto HBIM.

Uno de los objetivos de este proyecto es demostrar la eficiencia de este sistema de gestión de datos que, apoyándose en un grupo multidisciplinar de profesionales, nos arrojará toda la información vital de nuestro inmueble de manera instantánea, para llegar a convertirse en interoperable con plena eficacia.

\section{Conclusiones}

La investigación histórica, documental y gráfica, es fundamental e indispensable para la correcta elaboración de un proyecto de rehabilitación del edificio patrimonial o HBIM, con la obtención de un modelo gráfico de datos fiel a la realidad. Las plataformas BIM son pués eficaces para recoger los procedimientos que engloban aspectos constructivos y crono-evolutivos de la historia del edificio. Por lo que, todos los elementos originales estarían catalogados previamente a su demolición, pasando por el tamiz crítico del grupo de trabajo multidisciplinar y optimizando la conservación de todas aquellas piezas arquitectónicas susceptibles de ser recuperadas.

Así mismo, al tratarse de un sistema de trabajo multidisciplinar, la riqueza de los datos implantados en el modelo no tiene comparación con los métodos actuales. Su fácil modificación y el hecho de fusionar los datos aportados en cualquier listado con los propios del elemento al que están referenciandos, hace que los procesos de mantenimiento se lleven de una manera más ordenada, clara y fácil a tiempo real.

\section{Referencias}

BARAZZETTI, L., BANFI, F., BRUMANA, R., ORENI, D., PREVITALI, M. and RONCORONI, F., 2015. HBIM and augmented information: towards a wider user community of image and range-based reconstructions, ISPRS - 
International Archives of the Photogrammetry, Remote Sensing and Spatial Information Sciences, XL-5/W7, pp.35-42. DOI:10.5194/isprsarchives-XL-5-W7-35-2015.

BRUMANA, R., A., GEORGOPOULOS, D., ORENI, A,. RAIMONDI, A. and REGGIANI, 2013. HBIM for documentation, dissemination and management of built heritage. The case study of St. Maria in Scaria d'Intelvi. International Journal of Heritage in the Digital Era, 2(3), pp. 433-451. DOI: 10.1260/2047-4970.2.3.433.

EASTMAN, C., TEICHOLZ, P., SACKS, R. and LISTON, K., 2011. BIM Handbook: A guide to building information modeling for owners, managers, designers, engineers, and contractors. John Wiley \& Sons, Inc. Fai, S., Graham, K., Duckworth, T., Wood, N. and Attar, R., 2011. Building Information Modeling and Heritage Documentation. CIPA 2011 Conference Proceedings: XXIIIrd International CIPA Symposium, 8 pp. 305-349.

FAI, S., FILIPPI, M. and PALIAGA, S., 2013. Parametric Modelling (BIM) for the Documentation of Vernacular Construction Methods: A BIM Model for the Commissariat Building, Ottawa, Canada. ISPRS Annals of the Photogrammetry, Remote Sensing and Spatial Information Sciences. XXIV International CIPA Symposium, II-5/W1, pp. 115-120. DOI: 10.5194/isprsannals-II-5-W1-115-2013.

FAI, S., GRAHAM, K., DUCKWORTH, T., WOOD, N. and ATTAR, R., 2011. Building information modelling and heritage documentation. 18th International Conference on Virtual Systems and Multimedia, XXIII CIPA Symposium, 2011 Prague, Czech Republic, pp. 12-16.

NIETO, J., MOYANO, J., RICO, F. and ANTÓN, D., 2013: La necesidad de un modelo de información aplicado al patrimonio arquitectónico. Libro de Actas del $1^{\circ}$ Congreso nacional BIM - EUBIM 2013, Valencia, pp. 21-32. DOI: 10.13140/2.1.1096.5763.

NIETO, J. and MOYANO, J., 2014. El Estudio Paramental en el Modelo de Información del Edificio Histórico o "Proyecto HBIM". Virtual Archaeology Review, 5(11), pp. 73-85.

NIETO, J., MOYANO, J. and FERNÁNDEZ-VALDERRAMA, P., 2014b. Implementación de las nuevas técnicas de levantamiento en el sistema BIM (Building Information Modeling). XII Graphic Expression applied to Building International, Madrid, At Vol.I, pp. 327-337. DOI: 10.13140/2.1.2573.4727.

NIETO, J., MOYANO, J., RICO, F. and ANTÓN, D., 2016. Management of built heritage via HBIM Project: A case study of flooring and tiling.Virtual Archaeology Review, 7(14), pp. DOI: http://dx.doi.org/10.4995/var.2016.4349. 


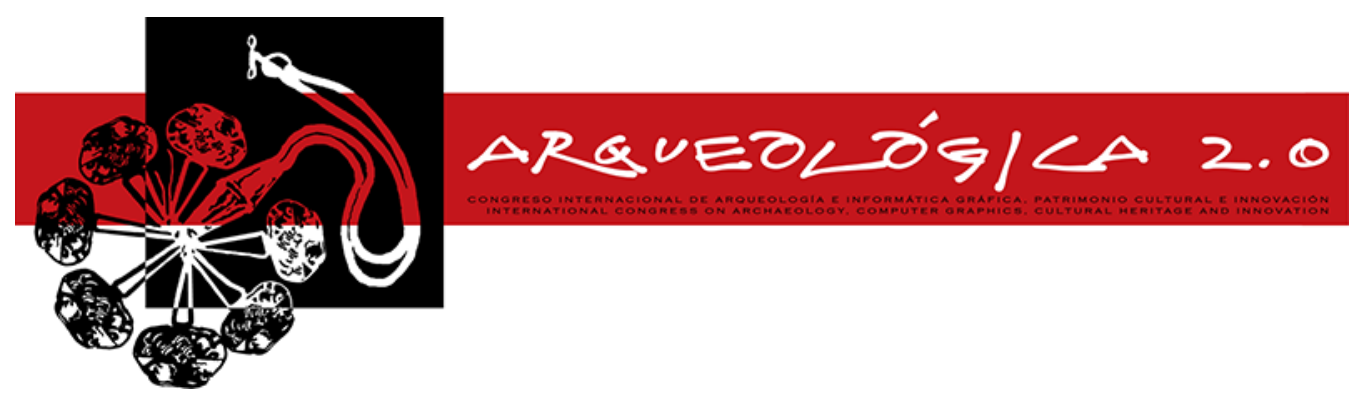

Proceedings of the $8^{\text {th }}$ International Congress

on Archaeology,

Computer Graphics,

Cultural Heritage and Innovation

'ARQUEOLÓGICA 2.0'

in Valencia (Spain),

Sept. $5-7,2016$

\title{
THE WESTERN HIGH GATE OF MEDINET HABU: PHOTOGRAMMETRIC 3D MODELLING \& DOCUMENTATION
}

\author{
LA ALTA PUERTA OCCIDENTAL DE MEDINET HABU: MODELADO 3D FOTOGRAMÉTRICO Y DOCUMENTACIÓN \\ Owen Murray ${ }^{\mathrm{a},{ }^{*}}$, Hilary McDonald ${ }^{\mathrm{b}}$, Jennifer L.Kimpton ${ }^{\mathrm{c}}$ \\ ${ }^{a}$ OMM Photography, 10960 - 74 Ave NW, Edmonton AB, Canada. omurray@ommphoto.ca

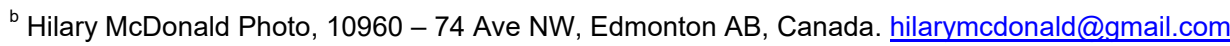 \\ ${ }^{\mathrm{c}}$ Oriental Institute, University of Chicago,1155 East 58th Street, Chicago Illinois, USA. jkimpton@uchicago.edu
}

\begin{abstract}
:
This paper discusses the 3D photogrammetric modelling and documentation of the Western High Gate at Medinet Habu by the University of Chicago's Oriental Institute, Epigraphic Survey Project. It provides an overview of technique and approach, along with a discussion of measurement methods and accuracy.
\end{abstract}

Key words: 3D modelling, documentation, photogrammetry, Medinet Habu, Oriental Institute, The Epigraphic Survey

\section{Resumen:}

Este artículo discute el modelado 3D y la documentación fotogramétrica de la alta puerta occidental en Medinet Habu por el Instituto Oriental del Universidad de Chicago, Proyecto Levantamiento Epigráfico. Proporciona una visión general de la técnica y el enfoque, junto con una discusión de los métodos de medición y precisión.

Palabras clave: modelado 3D, documentación, fotogrametría, Medinet Habu, Instituto Oriental, La Encuesta Epigráfica

\section{Introduction}

The Western High Gate of Medinet Habu (Fig. 1) is located in Luxor, Egypt, on the west bank of the Nile and is one of two fortified gates in the great girdle wall that surrounds the Medinet Habu temple complex. It was first investigated and recorded in 1931/32 by Uvo Hölscher during the 5th campaign of the University of Chicago's Oriental Institute (Hölscher and Nelson 1934).

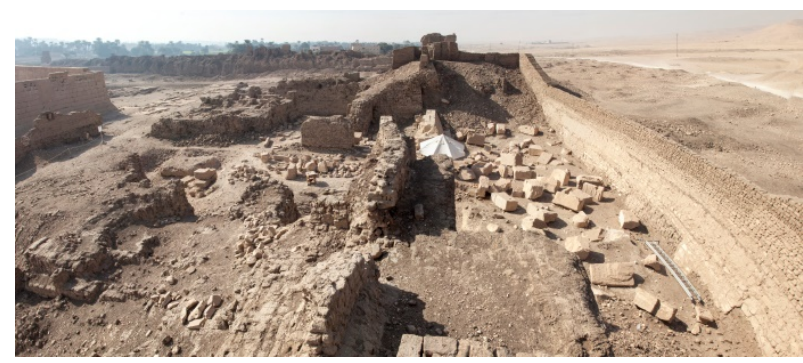

Figure 1: Overview of the Western High Gate at Medinet Habu from the North (McDonald 2016).

Unlike the east gate, whose stone architecture remains largely intact, the west gate was attacked towards the end of the 20th dynasty, with large blocks toppled from the upper courses of the structure and subsequently buried under rubble and debris. It was then likely razed to the ground along with portions of the adjoining girdle wall during the 21st - 24th dynasties and used as a stone quarry. As such, a few foundation blocks of the south tower are all that remain in situ of the stonework, though large sections of supporting mud brickwork are still in place.

Conversely, the supporting mud brickwork of the east gate was destroyed during a 'clearing' of the temple complex during the late 1800's.

Although their dimensions differ, Hölscher's excavation of the foundation of both gates revealed them to be of very similar construction - the western gate being slightly larger - and this, paired with an analysis and comparison of in situ east gate blocks with those excavated from the rubble and debris at the west gate allowed him to conclude that, "the west gate closely resembled the east gate in construction and surfaces intended for display" (Hölscher 1951). The two gates thus provide a sort of inverse impression of one another; the study of each allowing a better understanding of their whole appearance and function in antiquity.

‘Corresponding Author: Owen Murray, omurray@ommphoto.ca 
The 3D modelling of the Western High Gate undertaken as part of the 2015/16 Epigraphic Survey Project (Chicago House) was a continuation of Hölscher's explorations and conclusions, serving as the best means of thoroughly documenting the area before further excavations under the guidance of Oriental Institute researcher Jen Kimpton, and further research, publication and development of the area for tourism under Chicago House Director Ray Johnson.

\section{Technique \& Approach}

As drone and UAV technology permissions are next to impossible to obtain in Egypt, the 3D model of the western high gate relied on a camera mast system. A $7 \mathrm{~m}$ aluminum pole, as well as scaffolding were used to obtain the desired heights, angles and overlap required to accurately build the model. 3006 photos were taken with a Nikon D700 and fixed $28 \mathrm{~mm}$ lens and assembled using Agisoft Photoscan. As Photoscan had no issues determining the make of camera and lens used, no additional camera calibrations were performed.

To facilitate project execution, the overall area was divided into 20 sections (Fig. 2), or chunks. Before field photography of any section began, a series of chunk points were determined and nailed in place using either reflective tape or reinforced tinfoil plaques. These chunk points were labelled sequentially and placed in corner points and along the boundaries of each section, as well as on any prominent features within that section. The points were photographed and a written description noted for each to aid in their total station survey post photography. The section was also cleaned of any garbage and three rulers $(2 \times 50 \mathrm{~cm}, 1 \times 1 \mathrm{~m})$ used for scale calibration were placed, in varied locales within that section. To aid in acquisition, the photos required to build the model were grouped into three different types (Fig. 3); Topos, Overviews and Details.

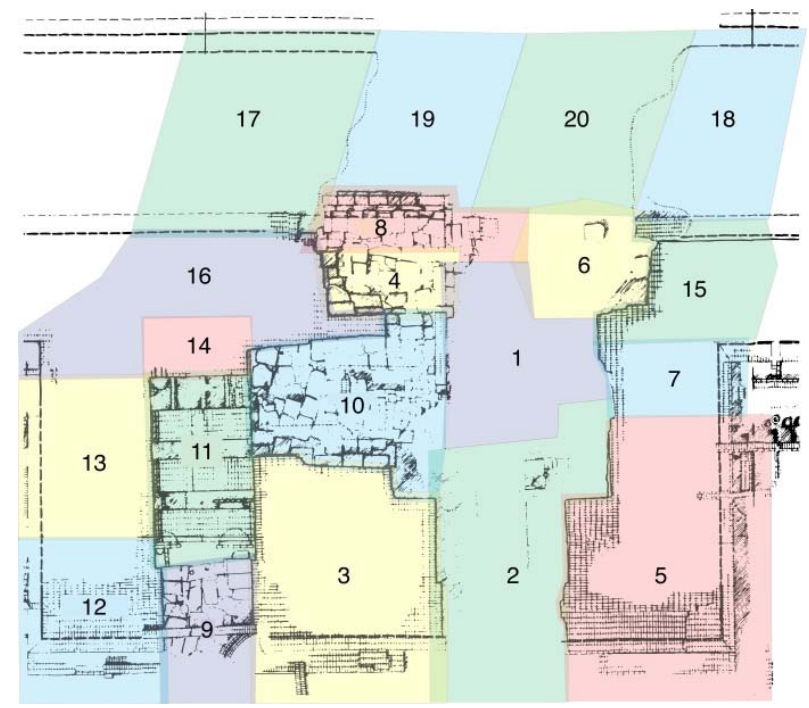

Figure 2: Map of the Western High Gate area divided into 20 sections (Hölscher and Kimpton 2016).

Topos were shot at a height of $4 \mathrm{~m}$ above ground with the camera angled looking straight down, flush, or parallel, to the ground. This cartographic perspective provided an easily aligned framework in which the other two types of photographs could be further inserted and aligned.

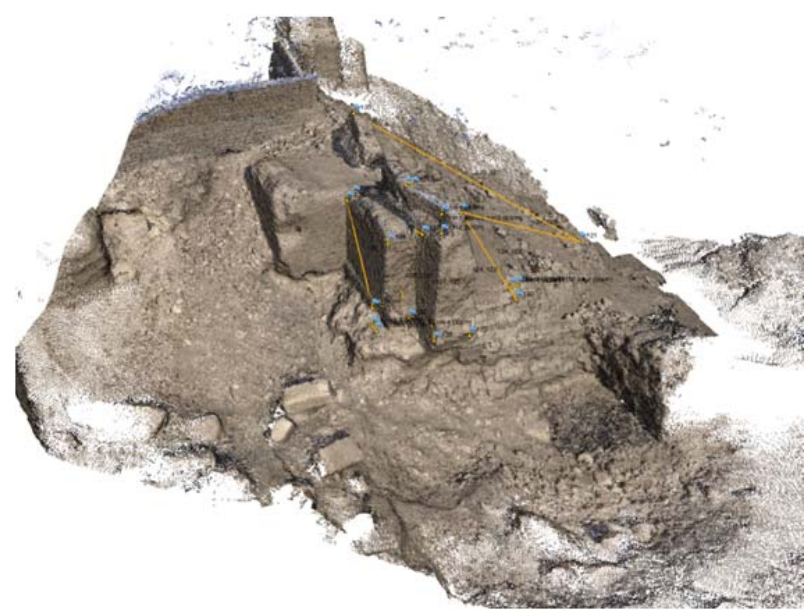

Figure 3: Survey/Chunk points measured (Murray and McDonald 2016).

Overviews were shot with the pole positioned perpendicular to the ground but the camera inclined downwards at roughly a $45^{\circ}$ angle, and taken just along, or outside, the borders delineating the section, looking inwards to capture the interior of that section. These overviews were taken at positions of $13 \mathrm{~m}, 7 \mathrm{~m}, 4 \mathrm{~m}$, and $2 \mathrm{~m}$ as dictated by the height of the features the section contained. A final handheld pass of the section was also included in these photos with the camera positioned perpendicular to the ground, but parallel to any wall or block features. The perspective and positioning of these type of photos allowed the geometry of individual sections to be captured easily as well as providing a suitable degree of overlap between sections aiding in their ability to align with one another (Fig. 4).

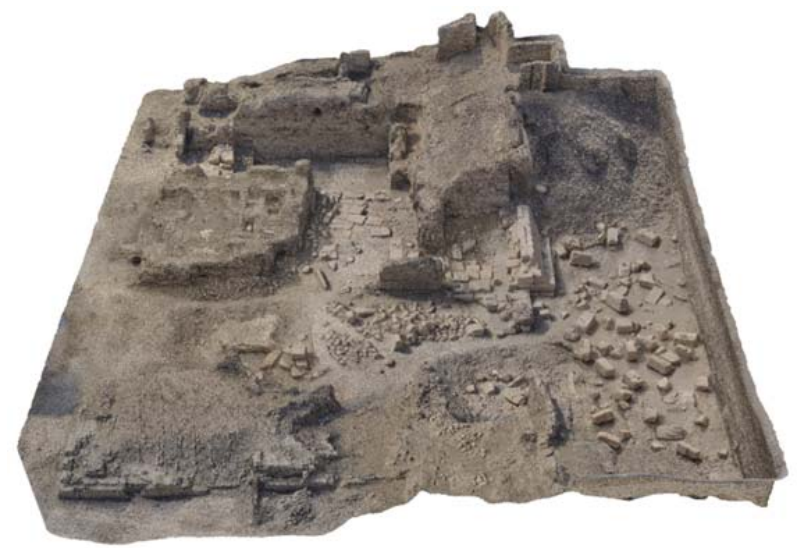

Figure 4: Overview of the Western High 3D Model as seen from the North (Murray and McDonald 2016).

Details were taken of any features within the section with unusual or obtuse geometry (in relation to the ground) such as undercut mudbrick structures, oddly positioned block fragments, etc that could not be adequately captured by the series of standardized overview photographs. This meant that many details were taken from a low level looking up; camera positioned perpendicular to ground but inclined upwards at approximately $20^{\circ}-30^{\circ}$. 
Special attention was paid to the time of day and raking light in regards to prominent mudbrick wall features, and in several sections photos taken at different times of day (generally early morning/late afternoon) were combined so as to achieve the best possible lighting result for that section. In a similar vein, attention to shadow cast by the pole often dictated the manner of movement for the Topo type photographs (camera aligned to the East, moving East-West in strips) so as to avoid this cast shadow.

Photos were shot in RAW format and catalogued and developed in Lightroom. Processing generally involved minor colour temperature calibration and major highlight and shadow recovery so as to 'flatten' the photo, making it have less contrast than the conditions in which it was shot, and show as much detail in shadow areas as possible. Processed photos were exported as high resolution jpegs and then imported in Agisoft Photoscan for construction of the 3D model.

Sections took approximately $1-2$ days to photograph on site, consisting of anywhere from $80-320$ images depending on the intricacy of the features involved in the section. At the end of each day a low resolution "daily" model of the section was created to check that accurate and adequate coverage was provided by the sequence of photos taken.

\section{Discussion}

After a majority of the sections had been photographed, it was pointed out that a margin of error could be introduced into each section model as well as the overall model by including total station survey points. This stands to reason, as the accuracy of the measurements are only as accurate as the surveyor taking them - and in some cases, chunk points established on difficult to obtain corners and features would result in a margin of error greater than the normal $+/-0.5 \mathrm{~mm}$. A control test of this concept was conducted on section 15 , as it provided a good representation of the terrain encountered within the overall west gate area.

Model 15 was assembled 3 times; first using a combination of 14 surveyed chunk points for that section, along with scale bar calibration of three rulers (2 $x 50 \mathrm{~cm}, 1 \times 1 \mathrm{~m})$, the second time using just the 14 surveyed chunk points for that section, and the third time using just the scale bar calibration of three rulers. The distance between 8 points in each of the models was measured and the 3 different models were compared against one another, as well as against the same points measured independent of Photoscan, in Autocad, as well as against the distance ground truthed by hand using a tape measure. Table 1 and Table 1 cont'd list the results between the 3 different model builds and difference in results compared to the Autocad measurements.

\section{Conclusions}

Although it was initially thought the inclusion of chunk point total station measurements would improve the accuracy of the section 15 model, it appears this is not the case, with the scale bar calibration model having a slight edge over both combined scale bar and chunk point model, as well as just the chunk point model.
Table 1: Section 15 measurement comparisons in metres. SB = Scalebar, $\mathrm{CP}=$ Chunk Point.

\begin{tabular}{c|c|c|c|c|c}
$\begin{array}{c}\text { Points } \\
\text { Measured }\end{array}$ & $\begin{array}{c}\text { Autocad } \\
(\mathrm{m})\end{array}$ & $\begin{array}{c}\text { SB \& } \\
\text { CP } \\
\text { Model } \\
(\mathrm{m})\end{array}$ & $\begin{array}{c}\text { SB \& } \\
\text { CP Diff. } \\
(\mathrm{m})\end{array}$ & $\begin{array}{c}\text { Model } \\
(\mathrm{m})\end{array}$ & $\begin{array}{c}C P \\
\text { Diff. } \\
(\mathrm{m})\end{array}$ \\
\hline $120-121$ & 9.8423 & 9.846 & 0.0037 & 9.844 & 0.0017 \\
$121-124$ & 8.2365 & 8.247 & 0.0105 & 8.252 & 0.0155 \\
$122-124$ & 4.5305 & 4.578 & 0.0475 & 4.573 & 0.0425 \\
$123-124$ & 4.5980 & 4.653 & 0.0550 & 4.649 & 0.0510 \\
$127-133$ & 3.6318 & 3.619 & 0.0128 & 3.619 & 0.0128 \\
$128-132$ & 3.1382 & 3.155 & 0.0168 & 3.154 & 0.0158 \\
$129-127$ & 3.6914 & 3.175 & 0.0236 & 3.716 & 0.0246 \\
$130-131$ & 3.9118 & 3.923 & 0.0112 & 3.926 & 0.0142
\end{tabular}

Table 1 cont'd: Section 15 measurement comparisons in metres. $\mathrm{SB}=$ Scalebar, $\mathrm{CP}=$ Chunk Point.

\begin{tabular}{c|c|c|c} 
Points Measured & SB $(m)$ & SB Diff. $(m)$ & Tape $(m)$ \\
\hline $120-121$ & 9.827 & 0.0153 & 9.844 \\
$121-124$ & 8.231 & 0.0055 & 8.236 \\
$122-124$ & 4.569 & 0.0385 & 4.574 \\
$123-124$ & 4.644 & 0.0460 & $\mathrm{~N} / \mathrm{A}$ \\
$127-133$ & 3.612 & 0.0198 & 3.164 \\
$128-132$ & 3.148 & 0.0098 & 3.166 \\
$129-127$ & 3.708 & 0.0166 & 3.754 \\
$130-131$ & 3.916 & 0.0042 & 3.194
\end{tabular}

Regardless of model assembly method, it would appear that measurements within a vertical dimension lose accuracy over a certain degree. It seems that measurements over a $45^{\circ}$ angle of inclination are inaccurate at approximately $1 \%$ of the total distance measured, whereas those $\leq 45^{\circ}$ have an inaccuracy of only $0.1-0.2 \%$ of the total distance measured. One interpretation of this data is that the placement of vertically aligned scale bars in a ' $z$ ' plane - and the resulting number of projections of those points within the model - were not numerous enough to ensure the same level of accuracy as those within ' $x$ ' and ' $y$ ' planes. Trials in subsequent field seasons and surveys will be conducted to test this premise.

Since preparing and recording chunk points within the context of each section is/was time consuming, and the results are worse to negligible between this method and scale bar calibration, subsequent seasons and model assemblies will rely solely on scale bar calibration. Total station survey points will be used, though only in accurately georeferencing the finished model and positioning it within a global context.

Overall, despite the inability to use drone and UAV technology, the camera mast system and photogrammetric approach utilizing Agisoft Photoscan delivered results that were accurate, resulting in a model agreeable to all involved. The use of these 3D modelling and documentation techniques will continue, with a possible survey of the east gate being done for comparison and more comprehensive understanding of 
the High Gates of Medinet Habu initiated by Hölscher and now furthered by Kimpton.

\section{Acknowledgements}

This work was supported by a USAID grant as part of the Development \& Management of Western Medinet Habu as a New Open-Air Museum \& Tourist Site project.

\section{References}

HÖLSCHER, U., 1951. The Mortuary Temple of Ramses III, Part II. In: T. GEORGE ALLEN, and E.B. HAUSER, eds, The Excavation of Medinet Habu - Volume IV. Chicago: The University of Chicago Press, Oriental Institute Publications Volume LV, pp. 4-10.

HÖLSCHER, U. and NELSON, H.H., 1934. Work in Western Thebes, 1931 - 33. In: J.H. BREASTED, and T. GEORGE ALLEN, eds, Oriental Institute Communications, No.18. Chicago: The University of Chicago Press, Oriental Institute Publications, pp. 92-101. 


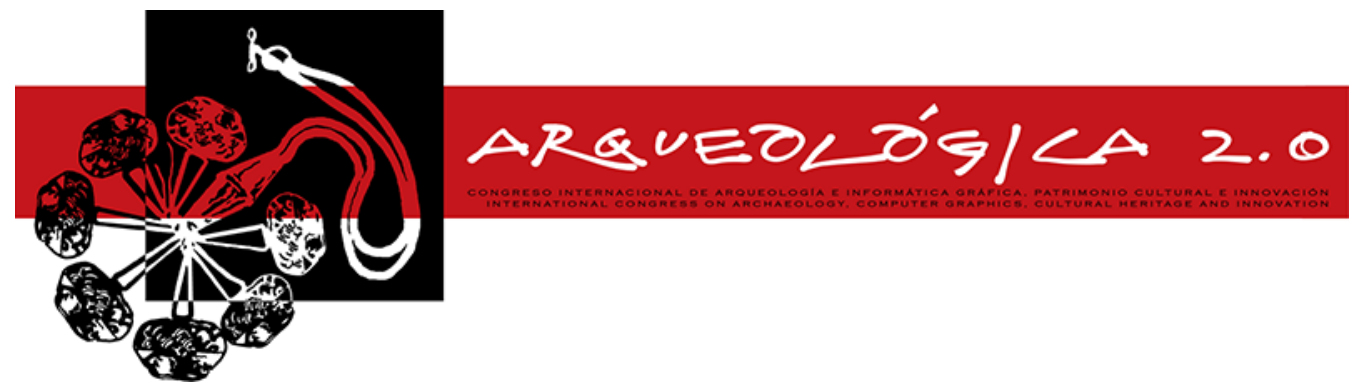

Proceedings of the $8^{\text {th }}$ International Congress

on Archaeology,

Computer Graphics,

Cultural Heritage and Innovation

'ARQUEOLÓGICA 2.0'

in Valencia (Spain),

Sept. $5-7,2016$

\title{
PROPUESTA DE ANÁLISIS TRIDIMENSIONAL APLICADO A LA INTEGRACIÓN DE LAS DIFERENTES ACTUACIONES ARQUEOLÓGICAS REALIZADAS EN CUEVA DE LA COCINA (DOS AGUAS, VALENCIA)
}

\section{TRIDIMENSIONAL ANALYSIS PROPOSAL TO INTEGRATE DIFFERENT ARCHAEOLOGICAL FIELDWORK CONDUCTED AT CUEVA DE LA COCINA (DOS AGUAS, VALENCIA)}

\author{
Agustín Diez ${ }^{a}{ }^{,}$, Oreto García ${ }^{a}$, Martina Basile ${ }^{b}$, Alfredo Cortell ${ }^{a}, N$ efeli Tsa ${ }^{a}$ \\ a Departament de Prehistòria i Arqueologia, Universitat de València, 46010, Spain. agustin.diez@uv.es; oreto.garcia@uv.es; \\ alfredo.cortell.nicolau@gmail.com; nemesis.soul@hotmail.com \\ b Universita de Roma, La Sapienza, Italy. martina1811@tiscali.it
}

\begin{abstract}
:
At this document we present a computer protocol, designed for the development of a digital environment which will allow virtual reconstruction of both, the stratigraphic information and the material record found at Cueva de la Cocina (Dos Aguas, Valencia). By this we also mean to relate the most recent fieldwork at the site to that carried on during the 1970 s. The first interventions inside the cavity date back to the first half of the XX century, when a complex sequence, which comprehended layers mainly related to the last hunter-gutherers and the first farmers, was identified. Accurateness, both describing and gathering precise information of the site was not a priority according to the methodology of older excavations. However, the fieldwork directed by Javier Fortea during the 1970s was meticulously registered using tridimensional notes of the information referring to the excavated layers and the recovered findings, although an analysis and interpretation of the site was never undertaken. Nowadays, we intend to integrate that information into a virtual working environment, so that, using specific software, data can be digitally processed for its 3D visualization and further analysis. Resorting to different statistical analysis and graphic representation packages has also been required. The results presented here refer to virtualization of the tridimensional information of one of the units excavated during the 2015 campaign, along with two adjacent units of the intervention developed by Javier Fortea. Thus, we try to show an example not only of the different potentialities that digitalization offers when registering detailed information of the excavated record, but also of its usefulness as a working tool in order to recover older interventions.
\end{abstract}

Key words: virtual 3D, archaeological fieldwork, spatial analysis, Cocina Cave

\section{Resumen:}

Presentamos en este trabajo el protocolo de trabajo diseñado para la creación de un entorno digital que permite la recreación virtual de la información estratigráfica y el registro material recuperado en Cueva de la Cocina (Dos Aguas, Valencia) con el fin de correlacionar los trabajos de campo actuales con aquellos llevados a cabo en la década de los 70 del pasado siglo. Los primeros trabajos en la cavidad se remontan a la primera mitad del siglo XX cuando se identificó una amplia secuencia que englobaba niveles de ocupación prehistóricos principalmente relacionados con los últimos cazadores-recolectores y el primer neolítico. Estos trabajos se realizaron siguiendo metodologías que adolecían de una rigurosa descripción y documentación. Sin embargo, los trabajos dirigidos por Javier Fortea en la década de los 70 del siglo XX fueron meticulosamente documentados mediante la anotación tridimensional de la información referida a las capas excavadas y los hallazgos recuperados, aunque posteriormente no se avanzó en el análisis e interpretación de la secuencia del yacimiento. En la actualidad nos hemos propuesto integrar esta información en un entorno de trabajo virtual con el fin de proceder al tratamiento de los datos mediante software específico para su visualización 3D y el análisis posterior de los mismos a través de paquetes de análisis estadístico y de representación gráfica. Los resultados presentados se refieren a la recreación de la información tridimensional de uno de los sondeos excavados durante la campaña 2015 y dos cuadros adyacentes de la actuación efectuada por Javier Fortea. Tratamos de ofrecer de este modo un ejemplo no solo de las potencialidades que ofrece la informatización para la documentación pormenorizada del registro excavado sino también de su uso como herramienta de trabajo para recuperar intervenciones anteriores.

Palabras clave: realidad virtual, excavación arqueológica, análisis espacial, Cueva de la Cocina

*Corresponding Author: Agustín Diez Castillo, adiez@uv.es 


\section{Introducción}

Las posibilidades que ofrece un entorno de análisis 3D para el análisis de una intervención arqueológica son de gran interés para el avance metodológico en la sistematización de la información generada. En este trabajo presentamos los primeros resultados de la aplicación del protocolo de trabajo diseñado con el fin de integrar la información de las diferentes actuaciones de campo en Cueva de la Cocina (Dos Aguas, Valencia) (Fig. 1). Concretamente vamos a describir la metodología diseñada para introducir la información tridimensional de dos actuaciones que cuentan con un registro detallado, si bien atendiendo a diferentes tipos de toma de datos. La Cueva de la Cocina es una amplia cavidad, de aproximadamente unos $300 \mathrm{~m}^{2}$, abierta en el Barranco de la Ventana, en el municipio de Dos Aguas. El yacimiento fue objeto de diferentes intervenciones a lo largo del siglo XX llevadas a cabo siguiendo las propuestas metodológicas al uso en cada uno de los momentos (Pericot 1945; Fortea 1973; Fortea et al. 1987; García et al. 2015). Las primeras actuaciones tuvieron lugar en los años 40 bajo la dirección del profesor Luís Pericot, y lógicamente adolecen de una sistematización en la toma de datos, si bien es cierto que disponemos de la descripción pormenorizada de los trabajos realizados a través de los minuciosos diarios de campo que describen día a día las características generales de la secuencia de los diferentes sondeos, así como de los hallazgos efectuados. La cavidad proporcionó una interesante secuencia prehistórica principalmente atribuida al denominado Mesolítico final de la secuencia regional (6.600-5700 cal BC), además de ocupaciones posteriores desde el Neolítico antiguo a la Edad del Bronce (García et al. 2014; García et al. 2015). Las excavaciones efectuadas en la década de los 70 (1974 a 1981) fueron dirigidas por el profesor Javier Fortea, el cual utilizó un protocolo de registro de campo acorde con las modernas técnicas introducidas ya en estos momentos en la arqueología (Laplace y Méroc 1954, VV.AA. 1976:39, Petit 2009).

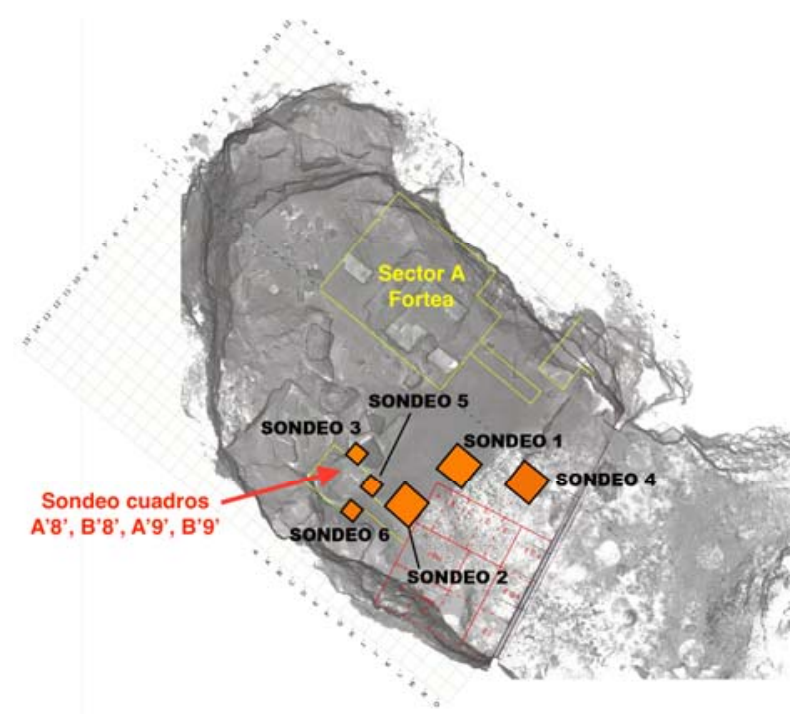

Figura 1: Planta de la cavidad con indicación de la situación del sondeo 3 (actuación 2015) y el sondeo que afecta a los cuadros A'8', B'8', A'9' y B'9' (intervención de Fortea).
La minuciosidad de la intervención de Fortea nos permite ahora proceder a su análisis global en el contexto de un proyecto que incorpora el análisis virtual de todas las intervenciones. En el presente trabajo procederemos a presentar la restitución estratigráfica 3D de uno de los sondeos excavados por Fortea (el sector correspondiente a sus cuadros A'8', B'8', A9', B'9' y su comparación con la información obtenida a partir de la reciente intervención en la cavidad, en un sondeo inmediato a estos cuadros. El objetivo en este artículo, más que indagar en la interpretación arqueológica, reside en comparar el procesamiento de las diferentes estrategias de registro de datos en el laboratorio mediante técnicas de virtualización 3D.

\section{Metodología}

Gracias al riguroso sistema de registro tridimensional puesto en práctica por el profesor Javier Fortea y su equipo, hemos podido recuperar información de cerca de 10000 registros. Este equipo fue uno de los primeros en generalizar el uso del denominado método LaplaceMéroc (VV.AA. 1976:39). De éste modo, Fortea ideó un sistema de registro fotográfico a través del levantamiento de una estructura fija que permitía la toma de fotografías verticales con una cámara Hasselblad 6X6. Sobre las fotografías se numeraban los hallazgos que quedaban a su vez registrados en un inventario en papel milimetrado, donde se consignaban las coordenadas $\mathrm{X}, \mathrm{Y}, \mathrm{Z}$ de los mismos. Los datos referidos al subcuadro de la excavación (se realizaba una subdivisión en 9 subcuadros de $33 \times 33 \mathrm{~cm}$ ), y al estrato arqueológico, quedaban igualmente reflejados. La excavación avanzaba a medida que se producía el levantamiento de materiales. Fortea realizó igualmente un segundo sondeo de menor tamaño en el que los materiales quedaron consignados por capas (8 capas de aproximadamente $10 \mathrm{~cm}$ ) y atendiendo a 4 sectores de $50 \times 50 \mathrm{~cm}$. En este caso los diferentes materiales asociados quedan asignados a la capa y al subsector, atendiendo a las indicaciones del registro de campo. La precisión de la toma de datos efectuada por Fortea nos ha permitido plantear el proyecto de análisis de esta excavación teniendo en cuenta además los datos aportados por las recientes actuaciones en la cavidad por parte de nuestro equipo de trabajo. Las excavaciones de Fortea no fueron estudiadas pormenorizadamente en su día, únicamente disponemos de un avance de resultados sobre el registro de los restos arqueológicos (Fortea et al. 1987).

El primer paso, lógicamente, ha consistido en la digitalización de toda la información registrada por el equipo de Fortea. En la mayor parte de los casos los registros estaban completos lo que significa que se había anotado el cuadro, el sector, la capa, las tres coordenadas y la descripción, un número de inventario e incluso observaciones. En otros casos, la información se refería exclusivamente a cuadro, sector y capa. Siempre se contaba con las cotas iniciales y finales de cada capa. Los sectores eran 9 en la zona de la excavación principal, pero en el sector que se presenta en este trabajo eran 4 de $0,5 \times 0,5 \mathrm{~m}$. En todos los casos, las coordenadas horizontales estaban referidas a los límites del cuadro excavado. Por ello, ha sido necesario crear un sistema que automatice la generación de las coordenadas dentro del yacimiento. 
En los casos en los que no teníamos coordenadas de los hallazgos se ha procedido a generar un volumen de cada sector y capa, dentro del cual se han generado de forma aleatoria las coordenadas de los hallazgos con una rutina en la que intervienen los paquetes de $R$ : ( $R$ Core Team 2015) rgl -para generar el volumen- (Adler et al. 2016), alphashape 3d (Lafarge y Pateiro-López 2016) -para generar los hallazgos dentro del volumen- y VecStatGraphs3D (Felicisimo et al. 2016) y K3est -para el tratamiento estadístico-, siguiendo la propuesta metodológica realizada por los autores de este último (Felicisimo et al. 2014).

\section{Trabajos futuros}

Los resultados generados permiten relacionar la secuencia descrita por Fortea con la documentada en el sondeo 3, excavado en el verano de 2015 (Fig. 2). Hemos podido confirmar la existencia de unos niveles superiores con material neolítico y unos niveles inferiores mesolíticos, en los que desaparece la cerámica y se documentan los triángulos tipo cocina. De la misma forma, se ha podido comprobar que la distribución de los materiales documentados por Fortea (Figs. 3 y 4 ) y la documentada por nosotros es uniforme. En definitiva, el trabajo que se presenta es un primer paso en la documentación integral de los trabajos arqueológicos en Cueva de Cocina.

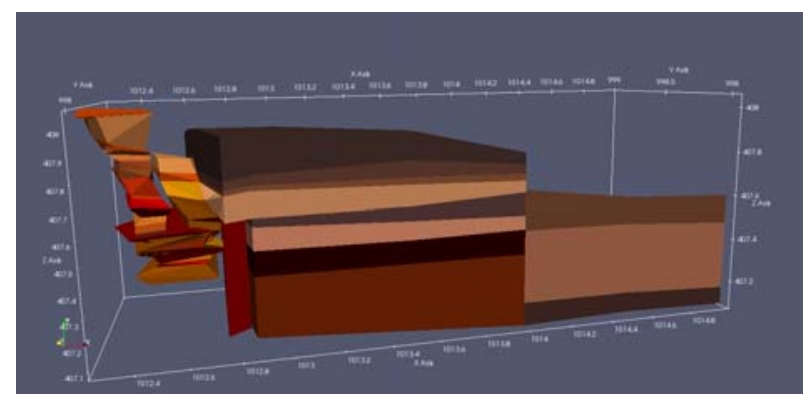

Figura 2: Vista 3D en Paraview (Henderson 2006) de la reconstrucción de los volúmenes de las Unidades Estratigráfica excavadas por Fortea (primer plano) y del sondeo 3 (García et al. 2015).

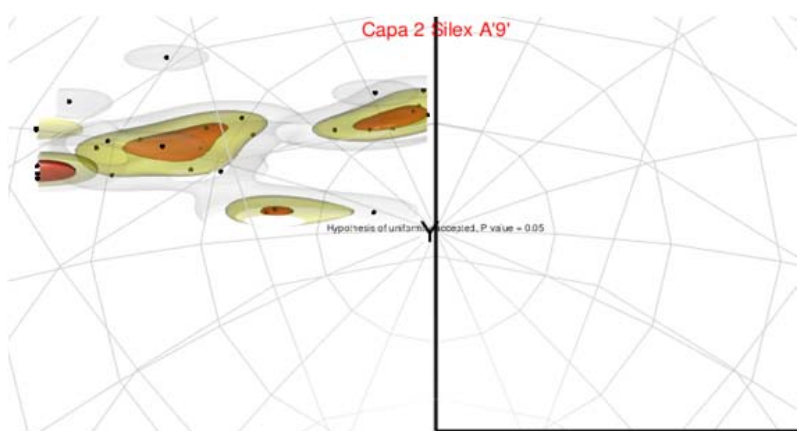

Figura 3: Vista 3D de la distribución de sílex en la capa 2 del cuadro A'9' excavado por Fortea realizada con VecStatGraphs3D (Felicísimo et al. 2014).

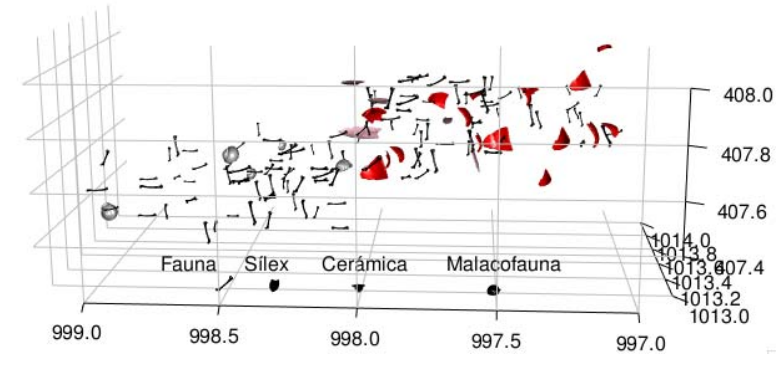

Figura 4: Distribución 3D de los materiales recuperados por Fortea en la capa 1 (en rojo las cerámicas).

\section{Agradecimientos}

El trabajo presentado se ha llevado a cabo en el marco del proyecto "MESO COCINA: los últimos cazarecolectores y el paradigma de la neolitización en el mediterráneo occidental" (HAR2012-33111), y el proyecto HAR2015-68962 "EVOLPAST: Dinámicas evolutivas y patrones de variabilidad cultural de los últimos caza-recolectores y el primer neolítico en el este peninsular (7000-4500 cal BC)", subvencionados por el Ministerio de Economía y Competividad, Gobierno de España. Los trabajos de campo (Campaña 2015) se han llevado a cabo dentro del programa de investigaciones del SIP-Museu de Prehistòria de la Diputación de Valencia.

\section{Referencias}

ADLER, D., MURDOCH, D., NENADIC, O., URBANEK, S., CHEN, M., GEBHARDT, A., BOLKER, B., CSARDI, G., STRZELECKI, A. y SENGER, A., 2016. Rgl: 3D Visualization Using OpenGL. R package version 0.95.1441. Disponible: https://CRAN.R-project.org/package=rgl [2/14/2016].

FELICÍSIMO, A., RUIZ, J.C., POLO, M.E., CUARTERO, A. y GARCÍA, P., 2014. VecStatGraphs3D: Vector analysis using graphical and analytical methods in 3D. $R$ package version 1.6. Disponible: https://CRAN.Rproject.org/package=VecStatGraphs3D [2/14/2016]

FORTEA, J., 1973. Los complejos microlaminares y geométricos del Epipaleolítico mediterráneo español. Salamanca: Universidad de Salamanca (Memorias del Seminario de Prehistoria y Arqueología, 4), 545 páginas.

FORTEA, J., MARTÍ, B., FUMANAL, P., DUPRÉ, M. y PÉREZ RIPOLL, M., 1987. Epipaleolítico y neolitización en la zona oriental de la Península Ibérica, En: Premières Communautés Paysannes en Méditerranée Occidentale. Actes du Colloque International du CNRS (Montpellier, 1983) (J. Guilaine, J: Courtin, J.-L. Roudil, J.-L. Vernet, dirs.), Paris, pp. 599-606.

GARCÍA, O., JUAN, J., McClURE, S.B, DIEZ, A. y PARDO, S., 2015. Avance de resultados de los nuevos trabajos arqueológicos en Cueva de la Cocina (Dos Aguas, Valencia): campaña de 2015. Saguntum (PLAV), 47, pp. 251-255. DOI: 10.7203/SAGVNTVM.47.7195

GARCÍA, O., JuAN, J., McCluRE, S.B., PASCUAL, J.LI., MARTí, B., PÉREZ, M., BERNABEU, J., PARDO, S., MOLINA, LI., CARRIÓN, Y. y DIEZ, A., 2014. Los últimos caza-recolectores en Cueva de la Cocina (Dos Aguas, 
Valencia). En: R. SALA, coord, Los cazadores y recolectores del Pleistoceno y del Holoceno en Iberia y el estrecho de Gibraltar. Burgos: Universidad de Burgos/Fundación Atapuerca, pp. 370-372. DOI: 10.13140/RG.2.1.1517.6809

HENDERSON, A., 2006. The ParaView Guide: A Parallel Visualization Application. Nueva York: Kitware Inc., 340 páginas.

LAFARGE, T., PATEIRO-LÓPEZ, B., POSSOLO, A. y DUNKERS, J.P., 2014. R Implementation of a Polyhedral Approximation to a 3D Set of Points Using the a -Shape. Journal of Statistical Software 56, no. 4 (2014). DOI: 10.18637/jss.v056.i04

LAFARGE, T. y PATEIRO-LÓPEZ, B., 2016. Alphashape3d: Implementation of the 3D Alpha-Shape for the Reconstruction of 3D Sets from a Point Cloud. $R$ package version 1.2. Disponible: https://CRAN.Rproject.org/package=alphashape3d [2/14/2016].

LAPLACE, G., y MÉROC, L., 1954. Application des coordonnées cartésiennes à la fouille d'un gisement. Bulletin de la Société préhistorique de France 51(Fasc. 1/2), pp.58-66. DOI: 10.3406/bspf.1954.12427

PERICOT, L., 1945. La Cueva de la Cocina (Dos Aguas). Nota preliminar. Archivo de Prehistoria Levantina, 2, pp. 3971.

PETIT, M.A., 2009. La introducció a Catalunya del mètode Laplace-Méroc d' enregistrament i anàlisi de l' excavació estratigràfica mitjançant l' ús de les coordenades cartesianes. En Els Pirineus i les àrees circumdants durant el tardiglacial: mutacions i filiacions tecnoculturals, evolució paleoambiental (16000-10000 BP): XIV Col. loqui Internacional d'Arqueologia de Puigcerdà. Puigcerdà-10-12 de novembre de 2006: homenatge al professor Georges Laplace. Institut d'Estudis Ceretans, pp. 51-64.

R CORE TEAM, 2015. R: A language and environment for statistical computing. Disponible: https://www.R-project.org/ [2/10/2015].

VV. AA., 1976: La Labor del Servicio de Investigación Prehistórica y su museo en el pasado año 1975. Valencia: Museu de Prehistòria de València, 62 páginas. 


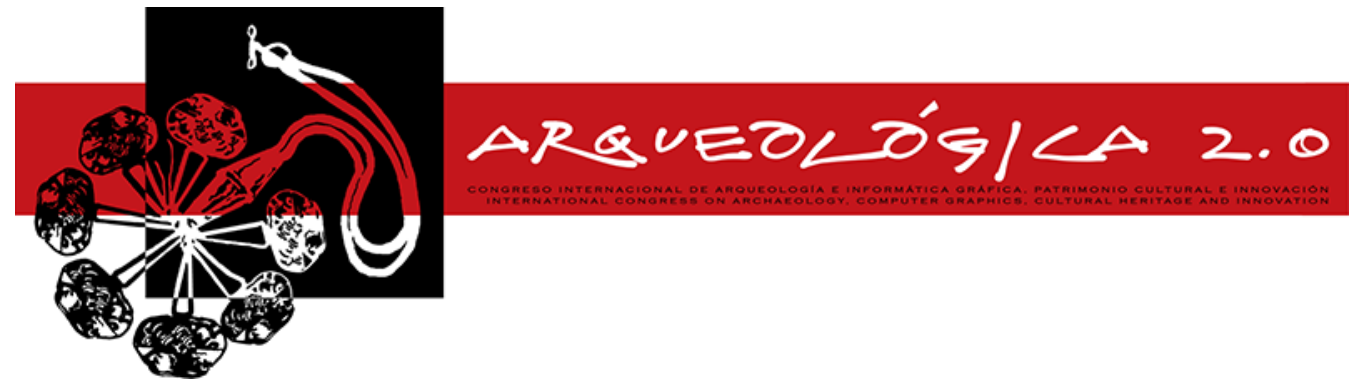

Proceedings of the $8^{\text {th }}$ International Congress

on Archaeology,

Computer Graphics,

Cultural Heritage and Innovation

'ARQUEOLÓGICA 2.0'

in Valencia (Spain)

Sept. $5-7,2016$

\title{
TRABAJOS DE DOCUMENTACIÓN DIGITAL DE GRABADOS RUPESTRES EN EL TÉRMINO MUNICIPAL DE ALCÁZAR DE SAN JUAN (CIUDAD REAL, ESPAÑA)
}

\section{DIGITAL DOCUMENTATION OF PETROGLYPHS IN THE MUNICIPALITY OF ALCÁZAR DE SAN JUAN (CIUDAD REAL, SPAIN)}

\author{
Víctor Manuel López-Menchero, ${ }^{a, *}$, Ángel Marchante ${ }^{b}$, Matthew L. Vincent ${ }^{c}$, Ángel Javier Cárdenas ${ }^{a}$ \\ y Jorge Onrubia ${ }^{a}$

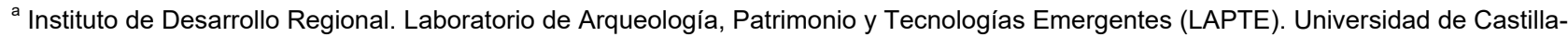 \\ La Mancha, Avda. Camilo José Cela s/n, 13071, Ciudad Real. España \\ ${ }^{\mathrm{b}}$ Universidad de Las Palmas de Gran Canaria, España \\ ${ }^{\mathrm{C}}$ Centro de Estudios de Arqueología Virtual. ITN-DCH Fellow. Universidad de Murcia, España
}

\begin{abstract}
:
In recent years, several historical rock art sites have been located in Alcazar de San Juan. Given its fragility, one of the most important and urgent tasks being undertaken within the framework of the DIPAR research project is the documentation of these sites. Among the various techniques used to this, two stand out above the rest: the application of digital photography at night, and three-dimensional documentation.
\end{abstract}

Key words: digital photography, 3D, archaeological heritage, rock art, photogrammetry, documentation

\section{Resumen:}

En los últimos años se ha localizado en Alcázar de San Juan un interesante conjunto de estaciones rupestres con grabados de época histórica. Dada su fragilidad, una de las tareas más importantes y urgentes que se están acometiendo en el marco del proyecto de investigación DIPAR es su documentación. Entre las distintas técnicas empleadas para ello, dos destacan por encima de las demás: la fotografía digital nocturna y el registro tridimensional.

Palabras clave: fotografía digital, 3D, patrimonio arqueológico, arte rupestre, fotogrametría, documentación

\section{Introducción}

El municipio de Alcázar de San Juan se encuadra geográficamente en la cuenca alta del Guadiana, en pleno centro de La Mancha. Posee un extenso término municipal, lo que favorece la presencia de un vasto y rico patrimonio arqueológico, legado de las distintas culturas y civilizaciones que a lo largo de la Historia se han asentado en estas tierras. Entre ese patrimonio, algunos investigadores han localizado, en los últimos años, al menos tres estaciones rupestres con grabados: Pozos de Navarro, Pozo del Empego y Pozo de Tello. Todas ellas inéditas y carentes, por tanto, de ningún tipo de documentación o investigación al respecto. Actualmente, la Universidad de Castilla-La Mancha está trabajando de forma intensiva en la documentación de todas estas estaciones. Dichos trabajos se enmarcan dentro de un proyecto de $\mathrm{I}+\mathrm{D}+\mathrm{i}$ titulado "Sistema de
Documentación Integral del Patrimonio Rupestre (DIPAR)".

\section{La documentación del arte rupestre}

Hasta la fecha, los sistemas tradicionales de documentación de arte rupestre han tenido como fin último la obtención de calcos de los motivos representados, al objeto de facilitar su correcta visualización y consecuentemente su interpretación. Es evidente que la correcta visualización de los motivos es esencial para acometer su posterior interpretación con unas mínimas garantías. Precisamente por ello, un calco incompleto o impreciso puede conducir a interpretaciones erróneas por parte de su autor pero también por parte de aquellos otros investigadores que consulten esos mismos calcos (Tufte 1999: 72-73). Como complemento al calco, el uso de la fotografía ha sido una constante en los trabajos de documentación de

`Corresponding Author: Victor Manuel Lopez-Menchero, victor.lopezmenchero@uclm.es 
arte rupestre desde principios del siglo XX. En el caso concreto de los grabados rupestres, tradicionalmente se ha apostado por el uso de pinturas, tiza u otros componentes para destacar los motivos antes de realizar la toma fotográfica ya que permiten mejorar la visibilidad de los petroglifos resaltando su interior o su contorno (Seoane-Veiga 2006: 36-37 Antczak y Antczak 2007; Rey y Eiroa 2009-2010). En otras ocasiones se ha perseguido conseguir el calco directo del original mediante técnicas invasivas como el frottage o el calco sobre plástico (Seoane-Veiga 2005; Cortón 2011: 163165). Las desventajas e inconveniente mostrados por todos estos procedimientos ya han sido suficientemente tratados por diversos autores, que han centrado sus críticas en la falta de objetividad o fidelidad de estas técnicas así como en el deteriroro que muchas de ellas provocan en los grabados (Bednarik 1979; Rogerio 2007; San Nicolás 2012: 29-30). Es por ello que resulta prioritario elaborar una metodología de trabajo que minimice esos riesgos al tiempo que incremente los niveles de objetividad de la información obtenida. Entre las múltiples técnicas que se están ensayando para conseguir alcanzar ese objetivo, en el presente artículo nos detendremos únicamente en dos: la fotografía digital nocturna y el registro tridimensional.

\section{Fotografia digital nocturna}

Uno de los mayores problemas a los que debemos enfrentarnos en el arduo proceso de documentar grabados rupestres es su falta de visibilidad. Muchos de ellos han sufrido un proceso de erosión tal que resultan prácticamente imperceptibles al ojo humano en las horas centrales del día, tornándose visibles únicamente al amanecer y especialmente al atardecer, cuando la luz incide en ellos de forma rasante. Este fenómeno natural puede ser reproducido de manera controlada por la noche mediante el uso de luz artificial. Desde hace años diversos investigadores han podido constatar las bondades que el trabajo nocturno ofrece en las tareas de documentación de grabados rupestres gracias a la posibilidad de controlar las condiciones lumínicas (Soto y Rey 1996; Cortón 2011: 165-166; Ugalde 2011: 3334). No obstante, la metodología más adeduada de trabajo para la toma de fotografías nocturnas apenas ha sido objeto de discusión por parte de la comunidad científica, lo que ha limitado el alcance de esta técnica.

Para llenar este vacio el equipo de tabajo ha desarrollado una metodología propia cuyos resultados consideramos satisfactorios y reproducibles por otros grupos de investigación. Para ello se ha empleado unicamente una cámara réflex Nikon D90 con 2 objetivos (objetivo NIKKOR 18-105 mm VR + objetivo Tamron F004N SP AF 90 mm F/2.8 Di VC USD MACRO
1:1), una linterna LED táctica (con zoom, XM-L de 1600 lúmenes) y un trípode.

La linterna táctica dada su potencia, versatilidad, resistencia, durabilidad y precio se ha mostrado como el sistema de luz artificial más adecuado. Especialmente si tomamos en consideración que durante la toma fotográfica es necesario mover, siguiendo una órbita parabólica, el punto de luz alrededor del motivo o panel que se quiere fotografiar. Para ello es necesario configurar la cámara sin flash, en enfoque manual, con una apertura del diafragma que puede oscilar entre f/28 y $f / 36$ al objeto de lograr una mayor profundidad de campo, una sensibilidad 100 ISO que permite lograr una mayor nitidez, y un tiempo de exposición en torno a los 8 segundos, suficiente para que entre una cantidad de luz adecuada y para poder mover la fuente de luz artificial alrededor del petroglifo. Dado el tiempo de exposición seleccionado, cualquier ligero movimiento de la cámara, por muy sutil que sea, provocará que la fotografía salga "trepidada" por lo que el disparo se debe efectuar bien con el temporizador de la propia cámara o bien con un disparador remoto, siendo en cualquier caso el uso del trípode imprescindible. Para evitar el efecto de sombras duras y desiguales se ha optado por mover la linterna en órbita parabólica de 180 grados alrededor del motivo, a unos 10-20 centímetros del suelo durante el tiempo que dura la exposición. Este procedimiento evita las típicas oclusiones en las zonas que quedan totalmente en sombra en la fotografía nocturna convencional como consecuencia de la proyección de las propias paredes del grabado 0 de alguna irregularidad en la superficie de la roca. Además permite documentar paneles completos de más de un metro de longitud usando como fuente de iluminación una simple linterna (Figs. 1 y 2 ).

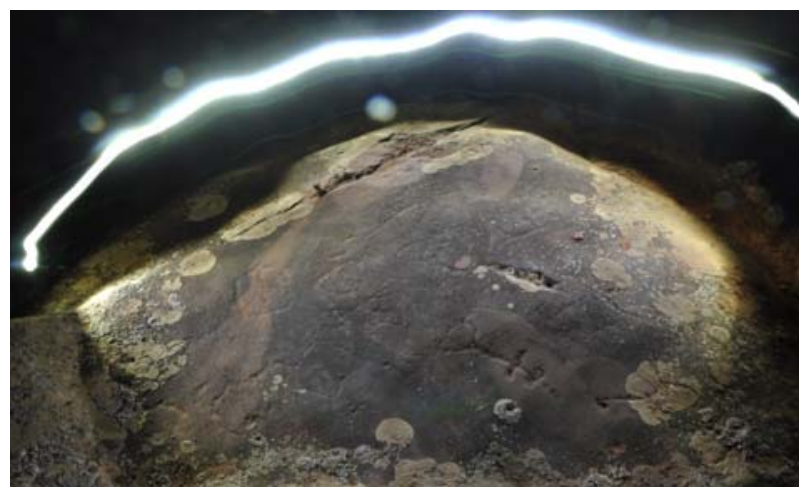

Figura 1: Al objeto de conseguir una iluminación uniforme el foco de luz debe moverse describiendo una órbita parabólica de 180 grados alrededor del motivo o del panel. El haz dejado por la linterna debe quedar fuera del encuadre de la fotografía. Estación rupestre de Pozos de Navarro.

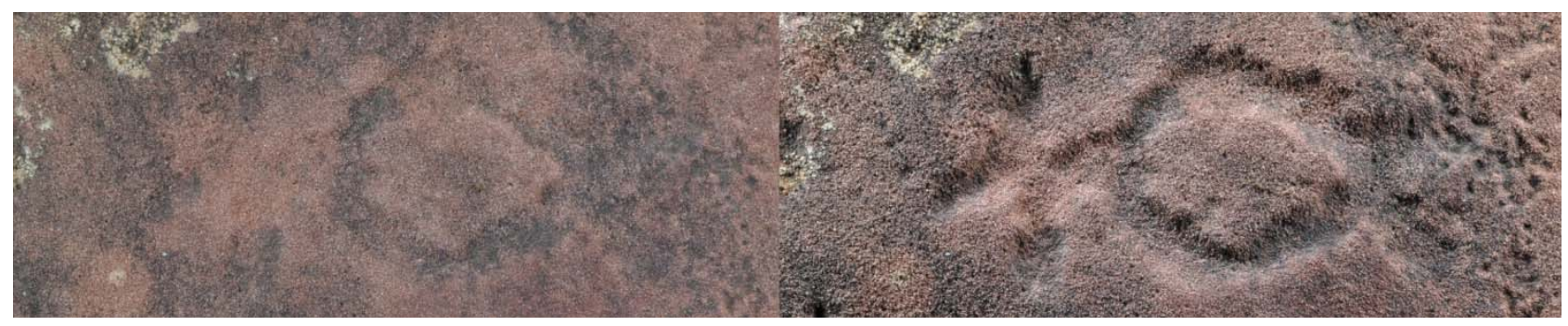

Figura 2: La fotografia de la izquierda muestra el aspecto del petroglifo con una luz plana, acorde con el nivel de visibilidad diurno que suele presentar. La fotografia de la derecha muestra los resultados obtenidos tras aplicar la metodologia de iluminación y registro desarrollada por el equipo de trabajo. Estación rupestre de Pozo del Empego 


\section{El registro tridimensional}

A pesar de la utilidad y del potencial de la fotografía digital nocturna, debemos ser conscientes de sus limitaciones como sistema de registro por sí solo, en la medida que todo grabado posee una naturaleza tridimensional que la fotografía no es capaz de captar. La posibilidad de documentar de forma métrica tridimensional aquello que posee 3 dimensiones es fundamental a la hora de alcanzar unas cotas óptimas de información registrada.

La dificultad de acceso que presentan muchas estaciones rupestres así como la necesidad de implementar sistemas de documentación de bajo coste que permitan documentar a gran escala el inmenso número de motivos y paneles que existen en España nos induce a apostar por la fotogrametría como técnica de documentación tridimensional prioritaria. Una vez obtenidos los modelos tridimensionales es posible aplicar filtros o shaders que aumentan la visibilidad de los petroglifos digitalizados. En este caso, hemos utilizado el software gratuito Meshlab con el shader de Radiance Scaling, que reproduce en cierta medida los resultados que podríamos obtener con la metodología de Reflectance Transformation Imaging (RTI), pero sin el complicado proceso que implica la adquisición RTI (Fig. 3).

\section{Conclusiones}

El arte rupestre es una de las manifestaciones culturales más importantes y extendidas de la Humanidad. Sin embargo, como hemos podido comprobar con las estaciones rupestres de Alcázar de San Juan, no siempre la teoría coincide con la práctica. Multitud de enclaves con grabados rupestres, especialmente de época histórica, se encuentran completamente abandonados y en serio peligro de desaparición. Precisamente por ello, debemos ser capaces de desarrollar metodologías de trabajo útiles y eficaces, implementables a gran escala, y consecuentemente de bajo coste y relativa sencillez. Solamente sí somos capaces de documentar con rigor el arte rupestre en su conjunto, podremos desentrañar los misterios que aún permanecen irresolutos en torno a esta intrigante manifestación cultural.

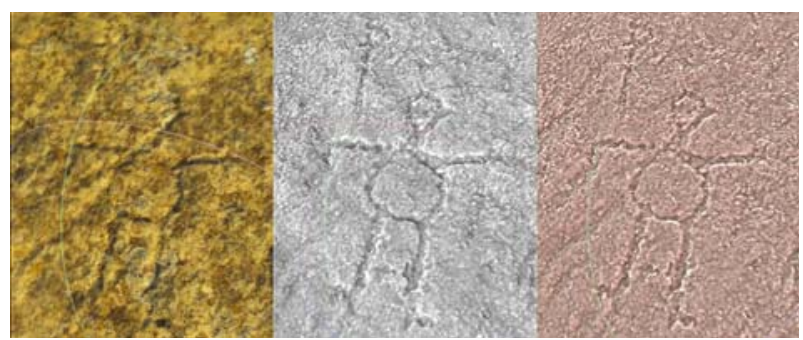

Figura 3: La imagen de la izquierda muestra el resultado de la digitalización del antropomorfo de los Pozos de Navarro antes de aplicar ningún tipo de shader. La imagen central muestra el resultado obtenido tras la aplicación en Meshlab del Labertian

Radiance Scaling, mientras que la imagen de la derecha muestra el resultado tras la aplicación del shader Lit Sphere Radiance Scaling.

\section{Agradecimientos}

La Junta de Comunidades de Castilla-La Mancha y el Fondo Europeo de Desarrollo Regional a través del proyecto «Sistema de documentación integral del patrimonio rupestre» (POIl-2014-005-P) han hecho posible este trabajo. Deseamos asimismo mostrar nuestro más sincero agradecimiento a los investigadores que nos pusieron sobre la pista de estos enclaves: D. Jesús Lizcano, D. Ángel Vaquero y D. Juan Ángel Ruiz.

\section{Referencias}

ANTCZAK, M.M. y ANTCZAK, A. (eds.). 2007. Los Mensajes confiados a la Roca. Sobre el inventario de petroglifos de la Colonia Tovar de Peter Leitner. Editorial Equinoccio. Universidad Simón Bolívar. Caracas.

BEDNARIK, R.G., 1979. The Potential of Rock Art Patination Analysis in Australian Archaeology, en The Artifact. 4, pp. 14-38.

CORTÓN, N. CARRERA, F., DE LA PEÑA, A., NEIRA, A., y BERNALDO DE QUIRÓS, F., 2011. Avance al estudio de los petroglifos de Peña Fadiel (Filiel, Lucillo de Somoza, León), en Férvedes: Revista de investigación, 7, pp. 105114.

REY, J. y EIROA, J.J., 2009-2010. Arte de la Edad del Broncelos grabados ruprestres de Cova da Bruxa y Laxe das Rodas (Muros, A Coruña): actuación arqueológica y revisión interpretativa, en Anales de prehistoria y arqueología, 25-26, pp. 77-118.

ROGERIO, M.A., 2007. Una propuesta no invasiva para la documentación integral del arte rupestre. CSIC - Instituto de Recursos Naturales y Agrobiología de Sevilla (IRNAS).

SAN NICOLÁS. M., 2012. Documentación gráfica del Arte rupestre postpaleolítico para un plan de gestión, en Jornadas técnicas para la gestión del arte rupestre, patrimonio mundial. Comarca de Somontano de Barbastro, pp. 23-43.

SEOANE-VEIGA, Y., 2005. Metodología de reproducción de grabados rupestre en Galicia. Levantamiento de calcos sobre plástico, en Cuadernos de estudios gallegos, 52(118), pp. 81-115.

SEOANE-VEIGA, Y., 2006. Novos petroglifos no Monte de Rego Novo (Amoedo-Pazos de Borbén), en Cuadernos de Estudios Gallegos, 53(119): pp. 31-52.

TUFTE, E.R., 1999. Envisioning Information. Graphics Press, Cheshire, Conneticut.

UGALDE, M.F., 2011. Registro de los petroglifos de Catazho (Morona Santiago), en Investigaciones arqueológicas en Azuay y Morona Santiago, INPC, pp. 13-45. 


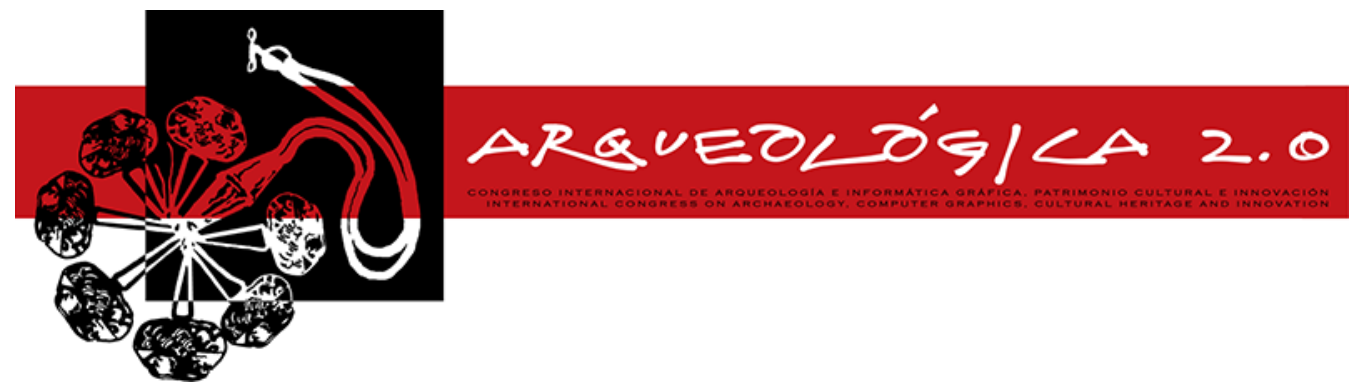

Proceedings of the $8^{\text {th }}$ International Congress

on Archaeology,

Computer Graphics,

Cultural Heritage and Innovation

'ARQUEOLÓGICA 2.0'

in Valencia (Spain),

Sept. $5-7,2016$

\title{
EXTRACTING SPATIAL INFORMATION OF HERITAGE GARDENS FROM BOUNDARY PAINTINGS BASED ON 3D MAPPING TECHNOLOGIES
}

\author{
USO DE TECNOLOGIAS DE MAPEO 3D PARA LA EXTRACCION DE INFORMACION ESPACIAL DE JARDINES \\ HISTORICOS CHINOS A PARTIR DE PINTURAS DE ESTILO “LINEA REGLADA” (JIEHUA)
}

\section{Chen Yang}

Department of Landscape Architecture, College of Architecture and Urban Planning, Tongji University, 1239 Siping Road, 200092 Shanghai, China. chen.yang@tongii.edu.cn

\begin{abstract}
:
Boundary paintings, or jie hua, is a traditional Chinese painting style originally created for architectural design. Today, boundary painting is valuable for historic conservation since it provides accurate depictions of heritage gardens. However, this valuable evidence has not been fully decoded and used in conservation practices, because there is no effective method to translate these artworks into spatial information that can be directly applied. Therefore, the aim of this research is to demonstrate how to use 3D mapping technologies to decode boundary paintings and translate them into spatial indicators and parameters for spatial conservation of heritage gardens. This approach will be explored through building 3D virtual models of heritage gardens based on the spatial information extracted from historical boundary paintings. Some indicators, such as visual openness, connectivity and intelligibility, will be explored in the process to represent spatial patterns of heritage gardens. At the same time, aerial images of specific gardens will be captured from existing environment using UAV in accordance with the viewpoints in boundary paintings. These images will be compared with boundary paintings of the same garden to confirm spatial patterns and to detect changes. The outcome of this research will be a staged guide to decode boundary paintings and provide indicators for spatial pattern conservation in heritage gardens. This guide will be interested by landscape conservators, heritage planners and digital program developers.
\end{abstract}

Key words: heritage garden, boundary painting, 3D mapping, spatial pattern, 3D reconstruction

\section{Introduction}

The term heritage garden refers to a garden that is recognised as a place of historic and cultural significance. For example, the Summer Palace in China and the Palace of Versailles in France are typical heritage gardens in different cultural contexts. As a kind of cultural landscape, heritage gardens are the result of the accumulation of cultural values and attributes overlaying natural systems, in their tangible and intangible dimensions (Yang et al.2015). They constitute a key resource in enhancing community identity and fostering local economic development (UNESCO 2011). Today, urban sprawl and uncontrolled tourism development means heritage gardens are changing with increasing speed. Important historical information is being lost through destructive changes, and as a result, the cultural continuity of the past is challenged (Eetvelde and Antrop 2004).

Spatial patterns are the essential attribute of heritage gardens. A spatial pattern of a garden is a perceptual structure, placement, or arrangement of garden features. The essence of spatial pattern is the methodology used for spatial problems (Alexander 1977). Spatial patterns of heritage gardens contain not only historic values, but also rich wisdom and knowledge of land use. It is therefore the key attribute in conservation practices. Spatial pattern of heritage landscape has been highlighted within many landscape convention programs, such as the Cultural Landscape Inventory in the U.S. National Park Service (1998), the Historic Landscape Characterisation programme in England (Aldred and Fairclough 2003; Clark et al. 2004) and the cultural landscape evaluation of the UNESCO World Heritage Convention (UNESCO 2009).

However, the lack of objective methods and reference to recognise and protect spatial patterns of heritage gardens has become a significant reason for the loss of historical information. In China, spatial patterns of heritage gardens are fading away as the result of landscape changes, and there is no reference to control changes in an acceptable way. Therefore, it is necessary to explore new resources and methods for spatial pattern protection.

Boundary painting, or jie hua, is a spatial style of painting in China, which is a valuable resource for spatial pattern recognition in heritage gardens. Boundary painting refers to the accurate depiction of architectural forms in a fineline style aided by the ruler (Britannica 2016). It was originally invented in the Jin Dynasty (265- 
$420 \mathrm{CE})$ to record architectural forms and became an independent style of painting in the Tang Dynasty (618907 CE). However, the significance of boundary painting has not been realised, and boundary painting has not been fully decoded into applicable spatial references.

The development of 3D mapping technologies provides great potential on the decipherment of boundary paintings. Modelling the past and future of heritage landscapes and buildings to assess development impacts is one of the contemporary topics of digital heritage conservation (Short 2007; Vanegas et al. 2010). In China, boundary paintings have been explored mostly in qualitative ways. The artists, styles, painting techniques and historical contexts of boundary paintings are the main topics in exploration. There are rarely studies focusing on quantitatively translating boundary paintings to provide accurate references in conservation practices. Therefore, the overarching aim of this research is to explore an innovative approach combing boundary paintings and 3D mapping technologies to extract spatial information of heritage gardens. The objectives of this research are:

1. To identify the main features of heritage gardens through pattern analysis of boundary paintings.

2. To identify the main indicators of spatial pattern of heritage gardens in China based on 3D GIS.

3. To build a staged guide to extract spatial information from boundary painting of heritage gardens.

\section{Project Proposal}

\subsection{A case study of Slender West Lake}

This research will examine the case of Slender West Lake to demonstrate how to use 3D mapping technologies to extract spatial information from boundary paintings. Slender West Lake is located in Yangzhou City, Jiangsu Province, in east-central China (Fig. 1). It covers 12.23 square kilometres of protected areas. It was designed as a National-level Scenic and Historic Interest Area by the State Council of the People's Republic of China in 1988.

During the Qing dynasty (1645-1912 CE), Yangzhou was one of the most prosperous cities in the empire (Finnane 2004). Between 1775 and 1795, salt merchants, scholars and officials built a large number of gardens on the lakeside to please the visiting emperors and to cater for their own social and cultural practice. At the height of the Qing Dynasty, Emperors Kangxi and Qianlong visited Slender West Lake during their southern inspections. There were more than a hundred gardens and public buildings along the three-kilometre water course. In this period, court painters visited Yangzhou with emperors to record gardens in Slender West Lake for documentary purpose, which provide valuable information for conservation research today.

\subsection{Data source, type and collection methods}

Three types of data will be collected in this research. Firstly, boundary paintings of Slender West Lake in the Qing Dynasty will be collected as the major data (Table 1). Secondly, documentary evidence, including historic maps, local historic chronicles of Yangzhou and Slender
West Lake will be collected as complementary dataset (Table 1). These two datasets will be collected from local management authorities, libraries, and museums and the Department of Archive in Yangzhou. Thirdly, existing condition of Slender West Lake will be examined through site observations. Spatial features will be recorded by hand-drawing maps, photograph and laser scanning devices. These datasets will be integrated into a GIS database for later analysis.

Table 1 Boundary paintings and documentary evidence of Slender West Lake

\begin{tabular}{|c|c|}
\hline Sources & Documents \\
\hline \multirow{4}{*}{$\begin{array}{l}\text { Local } \\
\text { chronicles }\end{array}$} & The Eminent Sites of Pingshan, 1742 \\
\hline & $\begin{array}{l}\text { The Imperial Grace of the southern Tours, } \\
\qquad 1771\end{array}$ \\
\hline & $\begin{array}{c}\text { Chronicle of the Painted Barques of } \\
\text { Yangzhou, } 1795\end{array}$ \\
\hline & $\begin{array}{l}\text { Illustrations of the famous Sites of Yangzhou, } \\
\qquad 1822\end{array}$ \\
\hline \multirow[t]{2}{*}{ Artworks } & $\begin{array}{l}\text { Atlas of Great Landscapes of the Gardens in } \\
\text { the South of Yangtze River, } 1760\end{array}$ \\
\hline & Illustrated Gazetteer of Pingshan Hall, 1765 \\
\hline Master plans & $\begin{array}{c}\text { Master Plan of Slender West Lake Scenic and } \\
\text { Historic Interest Area } 2005\end{array}$ \\
\hline \multirow[t]{3}{*}{$\begin{array}{l}\text { Professional } \\
\text { reports }\end{array}$} & $\begin{array}{l}\text { Brief Report on the } 1978 \text { investigatory } \\
\text { excavation of the ancient wall of Yangzhou, } \\
1979\end{array}$ \\
\hline & $\begin{array}{l}\text { Archaeological Survey Report of the Historic } \\
\text { City of Yangzhou, 1987-1998 }\end{array}$ \\
\hline & $\begin{array}{l}\text { Research on Cultural Landscape Value of } \\
\text { Slender West Lake in Yangzhou, } 2011\end{array}$ \\
\hline $\begin{array}{c}\text { Aerial } \\
\text { photographs }\end{array}$ & $\begin{array}{c}\text { Aerial Photo of Slender West Lake Scenic and } \\
\text { Historic Interest Area, } 2008\end{array}$ \\
\hline \multirow[t]{2}{*}{$\begin{array}{l}\text { Topographical } \\
\text { maps }\end{array}$} & $\begin{array}{c}\text { Archaeological Map of the Historic City of } \\
\text { Yangzhou, } 1973\end{array}$ \\
\hline & $\begin{array}{l}\text { Topographical Map of Slender West Lake } \\
\text { Scenic and Historic Interest Area, } 2005\end{array}$ \\
\hline
\end{tabular}

\section{Expected Outcomes}

The expected outcome of this research will be a decoding guide including three stages: Firstly, garden features in boundary paintings will be identified and grouped into different categories (Fig. 2); Secondly, the scale of each garden feature will be identified through referring-on local architecture styles during the same period; thirdly, based on the spatial information extracted from boundary paintings, digital terrain models of heritage gardens will be built in an ESRI ArcScene 10.2.2 platform. Lastly, the virtual model will be analysed by spatial analysis tools in ArcGIS, which leads to a group of indicators and parameters on spatial patterns.

\section{Acknowledgements}

This work was supported by Tongji Architectural Design (Group) Co., Ltd. and Key Laboratory of Ecology and Energy-saving Study of Dense Habitat (Tongji University), Ministry of Education under Grant [number 2015KY06]. 


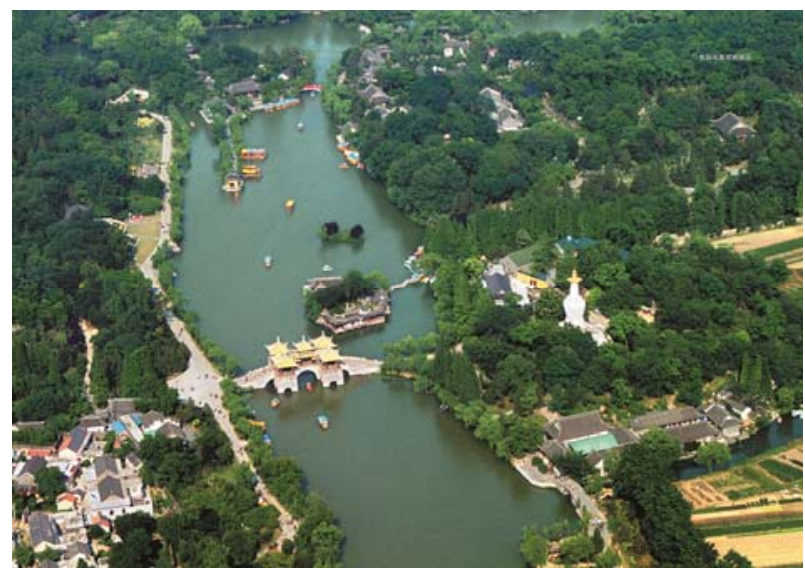

Figure 1: View of Slender West Lake, 2009, photography by Mao, Yongkuan.

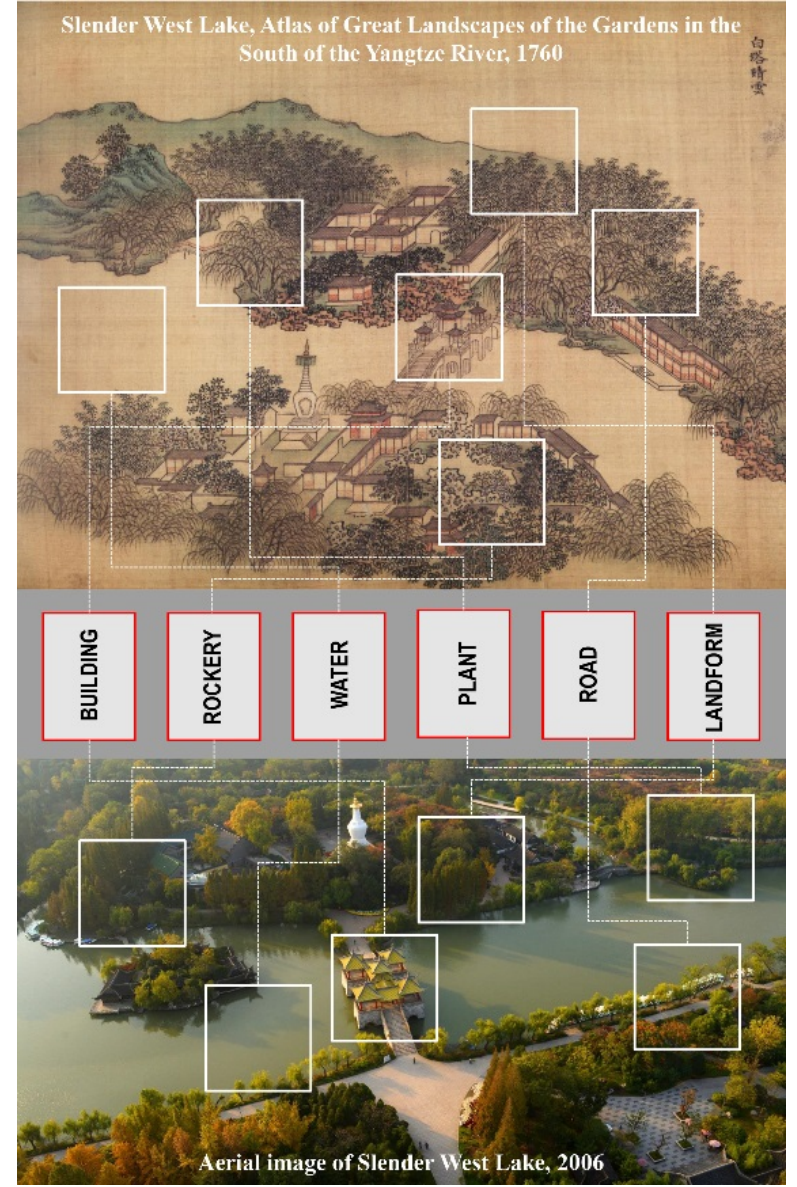

Figure 2: Feature analysis: (top) boundary painting of White Stupa area in Slender West Lake, Atlas of Great Landscapes of the Gardens in the South of the Yangtze River, 1760; (bottom) aerial image of White Stupa area in Slender West Lake, 2006, Mao.

\section{References}

ALDRED, O., and FAIRCLOUGH, G., 2003. Historic Landscape Characterisation: Taking Stock of the Method. Taunton: English Heritage and Somerset County Council.

ALEXANDER, C., 1977. A Pattern Language: Oxford University Press.

BRITANNICA, E., 2016. Gongbi, Chinese painting Encyclopedia Britannica.

CLARK, J., DARLINGTON, J. and FAIRCLOUGH, G., 2004. Using Historic Landscape Characterisation, English Heritage's review of HLC Applications 2002-03. London: English Heritage \& Lancashire County Council.

EETVELDE, V.V. and ANTROP, M., 2004. Analyzing structural and functional changes of traditional landscapes - two examples from Southern France. Landscape and Urban Planning, 67(1-4), 79-95. doi:10.1016/s01692046(03)00030-6

FINNANE, A., 2004. Speaking of Yangzhou: A Chinese City, 1550-1850. Cambridge (Massachusetts) and London: Published by the Harvard University Asia Center. Distributed by Harvard University Press.

SHORT, M., 2007. Assessing the Impact of Proposals for Tall Buildings on the Built Heritage: England's Regional Cities in the 21st Century. Progress in Planning, 68(3), 97-199.

UNESCO, 2009. World Heritage Cultural Landscapes: A Handbook for Conservation and Management. Paris, France: World Heritage Centre, United Nations Educational, Scientific and Cultural Organisation.

UNESCO, 2011. Recommendation on the Historic Urban Landscape. Retrieved from Paris, France.

VANEGAS, C. A., ALIAGA, D. G., WONKA, P., MÜLLER, P., WADDELL, P. and WATSON, B., 2010. Modelling the Appearance and Behaviour of Urban Spaces. Paper presented at the Computer Graphics Forum.

YANG, C., SIM, J. and LAWSON, G., 2015. Deciphering Historic Landscapes: A Case Study of Slender West Lake in Yangzhou, China. Landscape Research, 41(1), 95-112. doi:10.1080/01426397.2015.1041468 